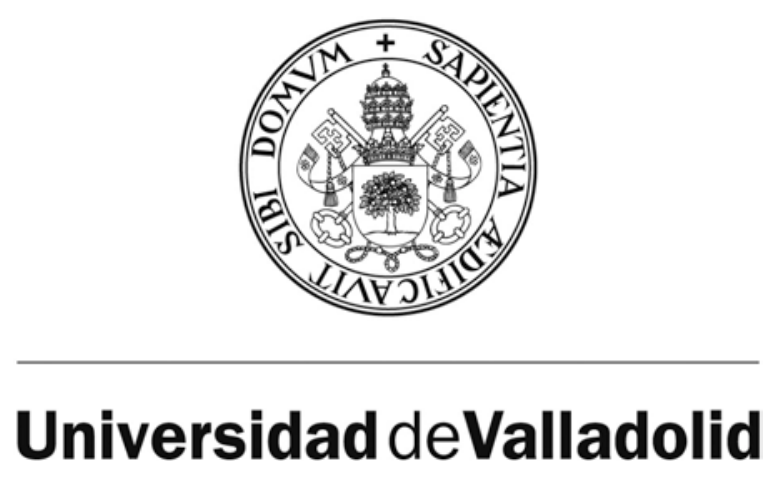

FACULTAD DE CIENCIAS SOCIALES, JURÍDICAS Y DE LA COMUNICACIÓN DEPARTAMENTO DE HISTORIA MODERNA CONTEMPORÁNEA Y DE AMÉRICA. PERIODISMO. COMUNICACIÓN AUDIOVISUAL Y PUBLICIDAD

TESIS DOCTORAL:

\title{
ARTE Y COMUNICACIÓN. PROPAGANDA POLÍTICA Y TRANSMISIÓN DE MODELOS SOCIALES EN LA OBRA DE EDUARDO VICENTE
}

Presentada por Isabel Rodrigo Martín para optar al grado de doctora por la Universidad de Valladolid

\author{
Dirigida por: \\ Dr. D. Raúl Eguizábal Maza
}

Ponente:

Dra. Dña. Ana Belén Sebastián Morillas 


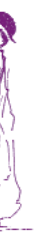
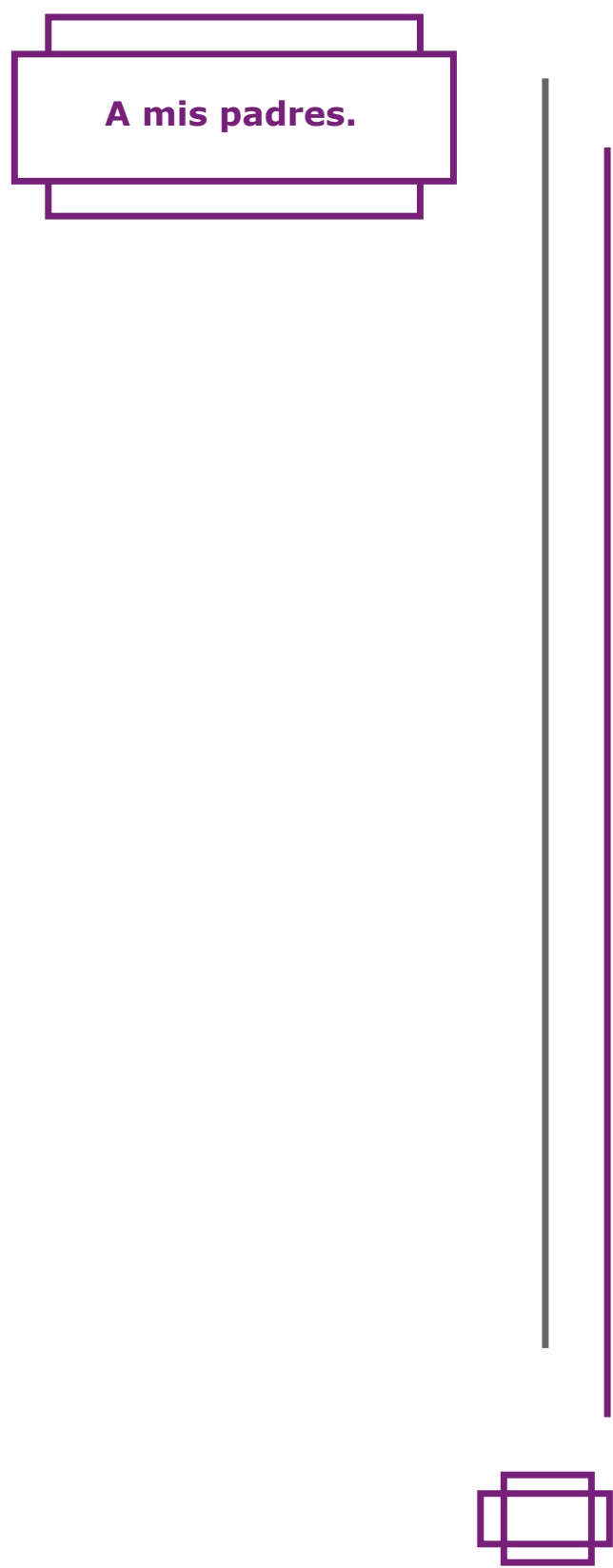



\section{Agradecimientos.}

Me gustaría agradecer en primer lugar a D. Raúl Eguizábal Maza la dirección de esta tesis doctoral, así como la pasión transmitida por el estudio y la investigación del arte y la comunicación. Sin su visión crítica y su esfuerzo personal, este trabajo de investigación no hubiese sido posible. De su mano he padecido y disfrutado de la exigencia académica, el rigor científico y la pasión por las cosas bien hechas.

A Dña. Ana Belén Sebastián Morillas, por su labor como ponente.

Por otra parte, me gustaría agradecer también a mis padres, que me enseñaron que la vida no consiste en un sprint final, sino que se trata de una carrera de fondo, donde hay que disfrutar y aprender de cada obstáculo encontrado en el camino. Sin su apoyo incondicional no sería la persona que soy hoy en día.

A Ángel Luis Navarro, quien me acompaña en la aventura de la vida, compartiendo conmigo las ilusiones y los retos que se nos plantean.

También quiero agradecer a Luis Rodrigo Martín su paciencia, apoyo y entusiasmo en todos nuestros proyectos.

Querría mostrar mi más sincero agradecimiento a D. Francisco Hernando Manso por la revisión crítica de los documentos que componen este trabajo de investigación.

A todos aquellos que entienden que el arte es un elemento de compromiso, un ejercicio de responsabilidad y un acercamiento al conocimiento, sin límites, sin fronteras y sin exclusividades.

No querría cerrar este apartado de agradecimientos sin acordarme de todas aquellas personas que han descubierto junto a mi a Eduardo Vicente y me han acompañado durante los últimos años. Los ánimos dados y las sonrisas han sido un gran aliciente para redactar esta tesis doctoral. 
Interés de esta investigación.

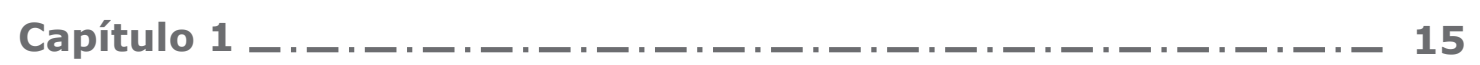
Introducción Metodológica.

1.- Marco general e interés por el estudio $-\cdot \cdot \cdot-\cdot \cdot \cdot-\cdot \cdot \cdot-\cdot 19$

2.- El estado de la cuestión $-\cdot \cdot \cdot \cdot \cdot \cdot \cdot-\cdot \cdot \cdot \cdot \cdot-\cdot \cdot \cdot-\cdot \cdot \cdot-\cdot 31$

3.- Punto de partida $-\cdot \cdot \cdot-\cdot \cdot \cdot-\cdot \cdot \cdot-\cdot \cdot \cdot \cdot \cdot \cdot-\cdot \cdot \cdot-\cdot \cdot-33$

4.- Delimitación del objeto de estudio $-\cdot-\cdot-\cdot \cdot \cdot-\cdot-\cdot \cdot \cdot-\cdot 35$

5.- Fases iniciales del objeto de estudio $-\cdot \cdot \cdot-\cdot \cdot \cdot-\cdot \cdot \cdot-\cdot \cdot \cdot 39$

6.- Formulación de la hipótesis y de los objetivos $\_\cdot-\cdot-\cdot-\cdot \cdot \mathbf{4 1}$

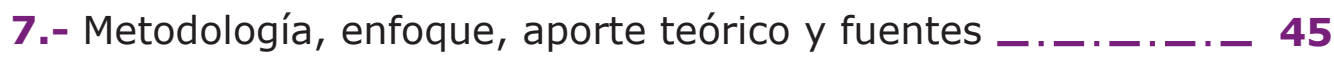

8.- Fuentes documentales $-\cdot-\cdot \cdot \cdot-\cdot \cdot \cdot-\cdot \cdot \cdot \cdot-\cdot \cdot \cdot-\cdot-\cdot 59$

- Notas $-\cdot \cdot \cdot-\cdot \cdot \cdot-\cdot \cdot \cdot-\cdot \cdot \cdot-\cdot \cdot \cdot-\cdot \cdot \cdot-\cdot-\cdot \cdot \cdot-\cdot \cdot \cdot-\cdot-61$

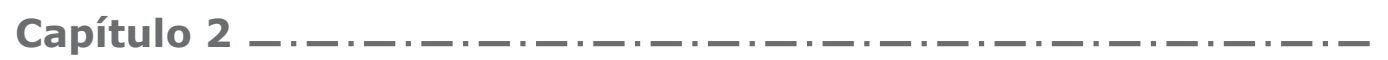

Propaganda política. La imagen como transmisora de ideología.

1.- Concepto de propaganda $-\cdot \cdot \cdot-\cdot \cdot \cdot-\cdot-\cdot \cdot \cdot-\cdot-\cdot \cdot-\cdot-67$

2.- Definiciones de propaganda $-\cdot-\cdot-\cdot-\cdot-\cdot-\cdot-\cdot \cdot \cdot-\cdot \cdot-71$

3.- Propaganda y comunicación $-\cdot-\cdot-\cdot \cdot \cdot-\cdot \cdot \cdot-\cdot \cdot \cdot-\cdot-\cdot 75$

4.- Propaganda y publicidad $\_\cdot-\cdot-\cdot \cdot \cdot-\cdot \cdot \cdot-\cdot-\cdot \cdot \cdot \cdot-\cdot 79$

5.- Técnicas de la propaganda 


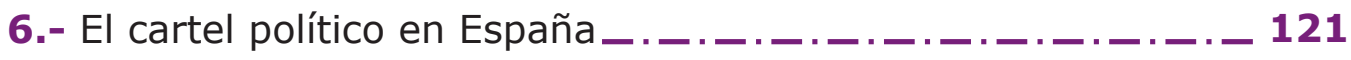

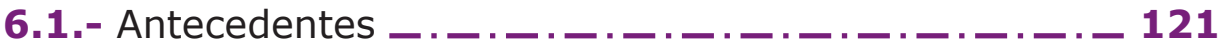

6.2.- El arte de la guerra

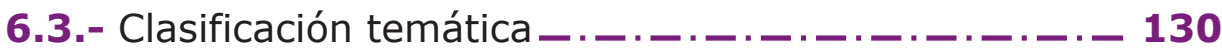

6.4.- Editores y lugares de impresión _........... 134

6.5.- Cartelistas destacados

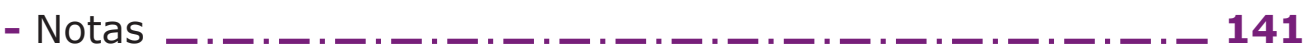

Capítulo 3

La imagen como transmisora y representativa de modelos sociales

1.- La imagen como transmisora y representativa de modelos sociales

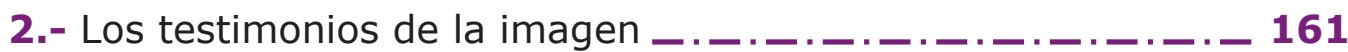

3.- Iconografía e iconología

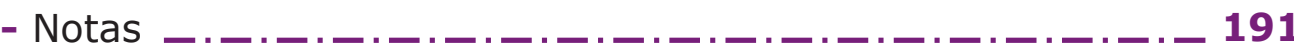

Capítulo 4

Eduardo Vicente entre la pintura y la ilustración gráfica.

Contexto social y estudio experimental

1.- Eduardo Vicente y sus entornos más próximos: Segovia y

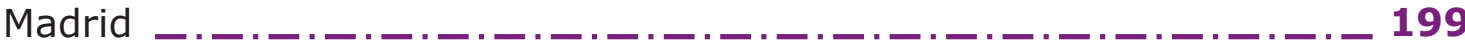

1.1.- Eduardo Vicente (1909-1968) _............. 199

1.2.- Turégano - Segovia _.................... 202

1.3.- Madrid - Villa y Corte (1890-1936) _......... 204

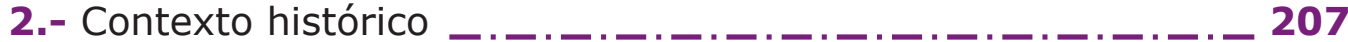

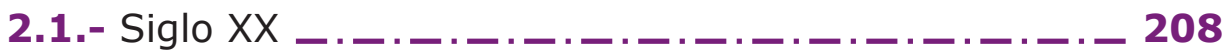

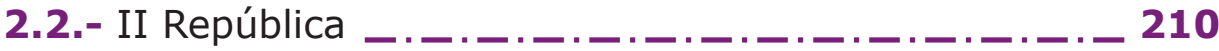

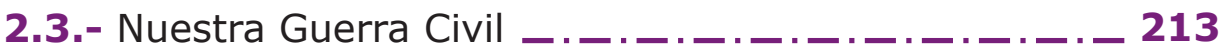


2.4.- Posguerra $-\cdot-\cdot \cdot--\cdot \cdot-\cdot \cdot--\cdot-\cdot \cdot-\cdot--\cdot \cdot-215$

3.- Contexto Cultural $-\cdot-\cdot-\cdot-\cdot \cdot \cdot-\cdot--\cdot-\cdot-\cdot \cdot-\cdot \cdot--\cdot \mathbf{2 1 9}$

3.1.- Manifestaciones literarias $-\cdot-\cdot-\cdot \cdot--\cdot \cdot--\cdot \cdot-\mathbf{2 1 9}$

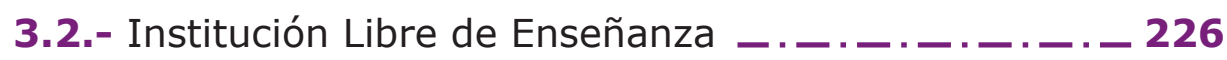

3.3.- Las Misiones Pedagógicas $-\cdot-\cdot-\cdot-\cdot \cdot-\cdot-\cdot \cdot--227$

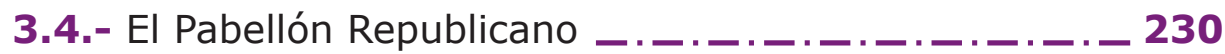

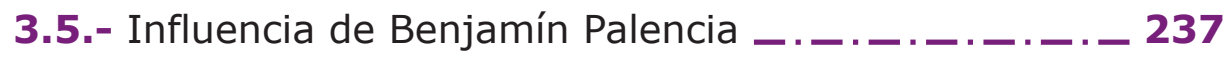

4.- Contexto Económico $-\cdot-\cdot-\cdot \cdot-\cdot \cdot-\cdot-\cdot-\cdot-\cdot-\cdot-\cdot-\cdot-\cdot 241$

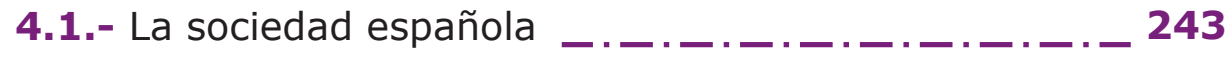

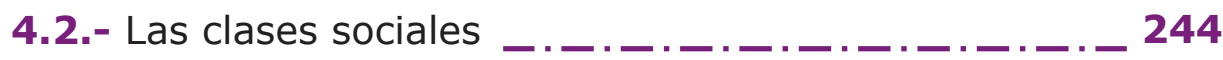

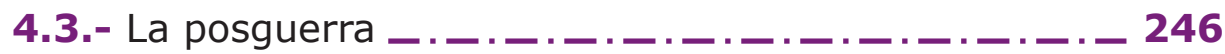

5.- Estudio experimental _-

6.- Fases de la investigación $-\cdot-\cdot \cdot-\cdot \cdot--\cdot-\cdot \cdot \cdot-\cdot-\cdot \cdot-255$

- Notas $-\cdot-\cdot \cdot \cdot-\cdot \cdot-\cdot-\cdot \cdot \cdot-\cdot \cdot \cdot-\cdot \cdot \cdot-\cdot \cdot--\cdot \cdot \cdot \cdot-\cdot-323$

Conclusiones $-\cdot-\cdot \cdot \cdot-\cdot \cdot-\cdot \cdot--\cdot \cdot \cdot-\cdot \cdot \cdot-\cdot \cdot-\cdot-\cdot \cdot--\cdot \cdot-325$

- Notas $-\cdot-\cdot \cdot \cdot \cdot \cdot-\cdot \cdot-\cdot \cdot \cdot-\cdot-\cdot \cdot \cdot-\cdot-\cdot \cdot \cdot-\cdot \cdot \cdot--\cdot-341$

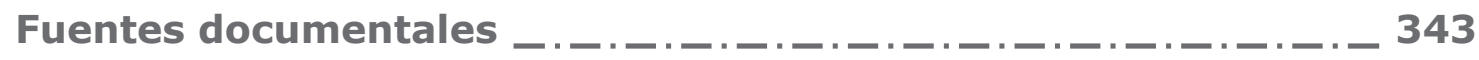

1.- Bibliografía $-\cdot-\cdot \cdot \cdot-\cdot \cdot \cdot \cdot-\cdot \cdot \cdot-\cdot \cdot \cdot-\cdot \cdot-\cdot \cdot \cdot \cdot--\cdot 347$

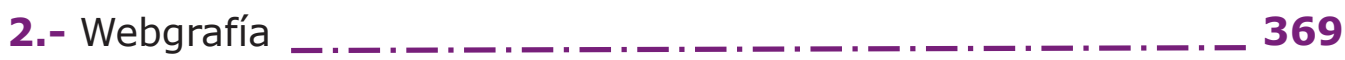

- Notas $-\cdot-\cdot \cdot \cdot-\cdot-\cdot-\cdot \cdot-\cdot \cdot \cdot-\cdot \cdot \cdot-\cdot-\cdot \cdot \cdot--\cdot-\cdot-\cdot-371$ 


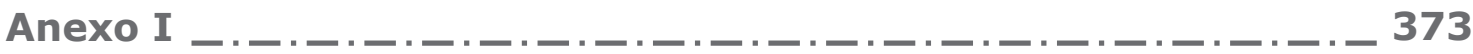
Cronología vital y artística

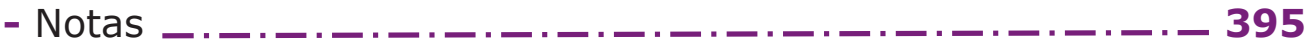

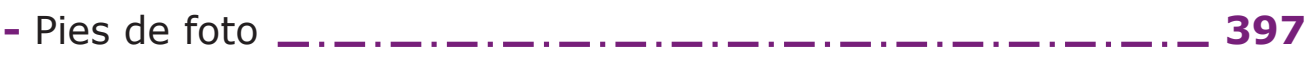

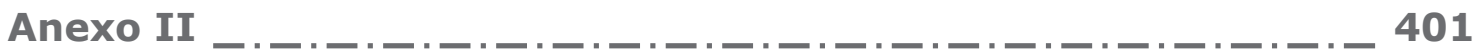
Fichas de estudio

- Notas $-\cdot-\cdot-\cdot \cdot \cdot-\cdot \cdot \cdot-\cdot \cdot \cdot-\cdot-\cdot \cdot \cdot-\cdot \cdot-\cdot-\cdot-\cdot-\cdot \cdot-415$

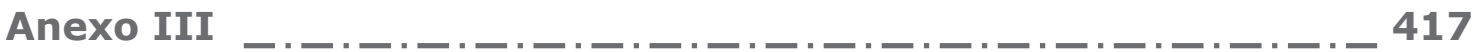

Fichas individuales de cada obra analizada.

- Retratos $-\cdot-\cdot-\cdot \cdot \cdot-\cdot-\cdot-\cdot \cdot \cdot-\cdot-\cdot \cdot-\cdot \cdot \cdot-\cdot-\cdot-\cdot \cdot-421$

- Carteles $-\cdot-\cdot \cdot \cdot-\cdot \cdot \cdot-\cdot \cdot \cdot \cdot-\cdot \cdot \cdot-\cdot \cdot \cdot \cdot \cdot-\cdot \cdot \cdot-\cdot-\cdot-441$

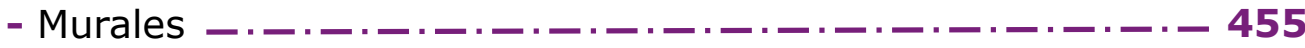

- Ilustraciones $-\cdot-\cdot \cdot \cdot-\cdot \cdot \cdot-\cdot \cdot \cdot-\cdot \cdot-\cdot \cdot \cdot-\cdot--\cdot \cdot \cdot-473$

- Otras obras $-\cdot-\cdot \cdot \cdot-\cdot-\cdot-\cdot \cdot \cdot-\cdot \cdot \cdot-\cdot \cdot-\cdot \cdot-\cdot \cdot-\cdot-\cdot-683$

- Notas $-\cdot-\cdot \cdot \cdot-\cdot \cdot \cdot-\cdot-\cdot-\cdot \cdot \cdot-\cdot \cdot \cdot-\cdot-\cdot \cdot \cdot \cdot \cdot \cdot-\cdot \cdot \cdot-799$ 


\section{Interés de esta investigación.}

El conocimiento de la obra de un artista, cualquiera que sea, implica siempre una necesidad de abundar en la investigación de todas aquellas circunstancias que le rodean y que condicionarán su legado en, al menos, dos sentidos: por una parte en tanto que conformarán su personalidad, sus formas de percepción de la realidad, su posicionamiento ético, moral y político $y$, en segundo lugar, porque esa época y sus tendencias afectarán a su producción artística, técnicas, materiales y formas de expresión, incluso temáticas.

El estudio de la obra de Eduardo Vicente podría justificarse simplemente por su interés artístico, pero al abordarlo en esta tesis desde un prisma multidisciplinar y enfocándolo bajo la lente de la capacidad comunicativa y propagandística de su obra, el estudio toma un renovado valor. El compromiso y la creencia en la defensa de una posición a medio camino entre la ética y la política, así como las circunstancias propias de su vida y de sus influencias culturales configuran un conjunto de obras que merece ser examinado por la repercusión que tuvieron, no solo en el plano artístico sino también en el comunicativo, propagandístico y representativo de la cultura, sus agentes y los modelos sociales que la articulan.

Este será precisamente el enfoque de la presente investigación. Por una parte se aborda el estudio, desde un enfoque eminentemente teórico, de la comunicación y la propaganda, las relaciones y vínculos que surgen entre ambos conceptos, así como sus notas características y diferenciadoras. En un segundo lugar abordaremos el estudio de la imagen como objeto de conocimiento, analizando y evaluando su función como vehículo de saberes, transmisor de creencias, valores, modelos de comportamiento, normas sociales, modas y modos de posicionamiento ante la realidad, la cultura y sus agentes.

El estudio teórico se completa y fundamenta mediante el análisis de una segunda fase, de carácter experimental, en la cual se recopila una muestra significativa de la obra de Eduardo Vicente, se cataloga estableciendo categorías significativas que nos permitan abundar en un conocimiento más profundo de su trascendencia cultural y de su influencia social. Fruto del establecimiento de esas categorías podemos analizar en profundidad una serie de índices e indicadores referidos al contenido, la técnica y la función de cada una de sus obras. En la presente tesis doctoral se prestará especial atención 
al tercero de estos indicadores, el referido a la función social, donde podremos completar el estudio poniéndolo en relación con el papel propagandístico y generador de significados de la imagen.

Se presenta por tanto en las siguientes páginas un estudio científico completo que aborda el estudio de una muestra significativa de la obra de un artista significativo pero poco estudiado y que servirá para poner en valor la obra de Eduardo Vicente en el contexto de su época y en relación con otros artistas en los que la academia se ha detenido con mayor atención; y lo hacemos desde una doble vertiente, por una parte mediante la articulación de una primera fase de investigación cuantitativa que se completará y tomará sentido pleno con otra posterior fase de investigación cualitativa.

Mediante la investigación cuantitativa podremos tomar porcentajes comparativos y representativos de los diferentes aspectos que hemos estudiado. El enfoque cualitativo nos habilitará para poder detectar connotaciones ideológicas y significados culturales y sociales, así como conocimientos relativos a las condiciones de producción y recepción de la obra artística analizada.

Parece evidente que, en una cultura eminentemente audiovisual como la actual, el estudio de la imagen y sus repercusiones se hace necesario en tanto que son formadoras de conocimiento y moldeadoras de sensibilidades, actitudes y compromisos. La imagen, como formadora de las actitudes, atiende a sus tres componentes esenciales: el componente cognitivo que tendrá como objetivo el conocimiento de las creencias y valores socialmente establecidos, el componente afectivo que permitirá organizar la realidad en términos de gusto o disgusto, agrado o desagrado y el componente conductual que determinará la tendencia o disposición de los ciudadanos para reaccionar en una dimensión determinada. En definitiva, las obra gráfica constituye un medio eficaz para transmitir ideología y representar los modelos sociales.

La presente tesis doctoral quiere trasciender el análisis de una obra concreta y de un artista determinado, permite establecer puentes e inferencias significativas entre la recogida de datos y la construcción de imágenes expresivas y significativas que dotan de significados el entramado cultural y social en el que se producen y se consumen. Se convierte en un modelo de análisis aplicable a cualquier periodo histórico, bajo cualquier perspectiva 
artística y tomando como referencia la obra de cualquier agente cultural de una cierta relevancia.

El análisis de contenido que articula toda la investigación trata de superar los defectos de los cuales tradicionalmente adolecen este tipo de enfoques mediante la contextualización de los datos, en procesos culturales complejos, por lo que los resultados y conclusiones de esta tesis suponen un avance en el conocimiento, no solo de una determinada obra, sino que arrojan luz sobre un periodo histórico convulso de nuestra historia. No se limitan nuestras conclusiones al estudio técnico-artístico de la obra de Eduardo Vicente sino que se trata de encontrar las causas que la originan y las consecuencias que se derivan de su exhibición y publicación. Por todo ello se hace necesario y a la vez se enriquece el conocimiento del periodo histórico en el que se enmarca, prestando especial atención al entorno político, económico, cultural y científico que determina y connota la obra.

Pensamos que toda persona busca que su vida se guie por un camino de coherencia y responsabilidad, más aún cuando esa persona forma parte de la élite cultural de un determinado país. Los años en los que se desarrolla la vida de Eduardo Vicente fueron posiblemente los años más difíciles de la historia moderna de España. Unos tiempos duros para el ejercicio responsable de los derechos y el sostenimiento coherente de las posiciones ideológicas. Precisamente por todo ello la trayectoria vital e intelectual de Eduardo Vicente debe ser puesta en valor, estudiada y dada a conocer como ejercicio máximo de responsabilidad creativa, de arte al servicio de la integridad.

El compromiso, cada vez menos extendido en las modernas sociedades que se basan en la impostura, nos parece un requisito indispensable de la intelectualidad. Eduardo Vicente es un ejemplo de compromiso. Su obra defiende su pensamiento y su pensamiento se define mediante su obra. El intelectual debe comprometerse, en el sentido que sea, pero con decisión, es un ejercicio de responsabilidad. El intelectual debe ser la vanguardia del pensamiento y de la ideología, entre otras cosas porque se considera que solo pueden pertenecer a ella las clases mejor formadas y más preparadas de cada momento social. Mal futuro cabe esperar de una sociedad en la que ni siquiera sus mejores hombres y mujeres son capaces de comprometerse política, social y culturalmente. El mundo desencantado provoca un alejamiento de la defensa de las posturas ideológicas pero ello implica también una cesión en 
los derechos y en la individualidad, en definitiva, una renuncia voluntaria a parcelas de la libertad en lo individual que se magnifica en lo social y que arrasa con lo cultural.

El intelectual debe estar en permanente sintonía con el desarrollo social y cultural donde se inscribe su obra, pero también donde se interpreta y conforma. Es evidente que no tiene la misma trascendencia una ejecución pictórica, literaria o artística cuando se produce en un momento o en otro, más allá de sus características específicas. En este sentido consideramos que el artista debe posicionarse, comprometerse con la historia, ejercer su libertad creativa en sintonía con los acontecimientos que le toque vivir, ser crítico o defensor en función de su opinión y trayectoria; en definitiva ser valiente para avalar con su pensamiento y su obra los cambios sociales.

También pensamos que el arte es mucho más que simple estética, que las implicaciones sociales y culturales pueden trascender en un momento determinado el valor estético de la misma. Desde tal convencimiento entendemos que este tipo de estudios que se aproximan al arte desde la comunicación, y que se inspiran en la trascendencia social y cultural de artista y obra completan la construcción de la historia de los territorios y fundamentalmente de los pueblos. Es posible que haya una historia escrita con mayúsculas, una historia oficial construida desde el rigor de los acontecimientos, pero no menos cierto es que existe otra historia, la de las gentes, la de los pensamientos y sentimientos recogidos por el artista y expresados en primera y en segunda persona. La historia de los países es la historia de sus gentes y Eduardo Vicente supo plasmar y transmitir con enorme acierto todo ese sentir.

El artista nace y se hace. En el caso de E. Vicente concurrieron una serie de circunstancias favorables y junto a su voluntad firme. Es innegable la existencia de unas cualidades y una predisposición para inclinarse hacia el arte; pero, además, tuvo la suerte de nacer en el seno de una familia que valoraba la cultura y tenía interés y admiración por todo lo referido a los aprendizajes. Su hermano mayor, Esteban fue un modelo a seguir, el Museo del Prado -próximo a la vivienda familiar- un lugar donde instruirse, los amigos y lugares de tertulia fuentes donde beber, el Madrid de su época un motivo para sus obras, las Misiones Pedagógicas un desafío -mezcla de aventura y espíritu misionero-, el momento histórico-social, guerra y 
posguerra, un aliciente para su imaginación, el apoyo de personas como Eugenio $D$ 'Ors una vitamina económica, su ideología política marco delimitador del contenido de muchos de sus cuadros, y su personalidad e intereses el cariz propio a su obra: su sello, su impronta.

Y, al igual que la muerte le sorprendió tempranamente en la soledad de su estudio y su cuerpo estuvo dos días en el anonimato, así el cuerpo de su obra parece haber dormitado en el olvido sin que casi nadie haya reivindicado, en su justa medida, el valor de su obra y las aportaciones que conlleva. Una vez más, como en el caso de tantos grandes artistas, a Eduardo Vicente hay que reconocerle su valía y recrearnos en su legado. "Más vale tarde que nunca". Esperemos que esta tesis doctoral suponga, de momento, un mínimo avance en el conocimiento, reconocimiento y valoración de una persona con innegable compromiso artístico, cultural e ideológico. 



\title{
П] Capítulo 1
}

\author{
Introducción Metodológica
}

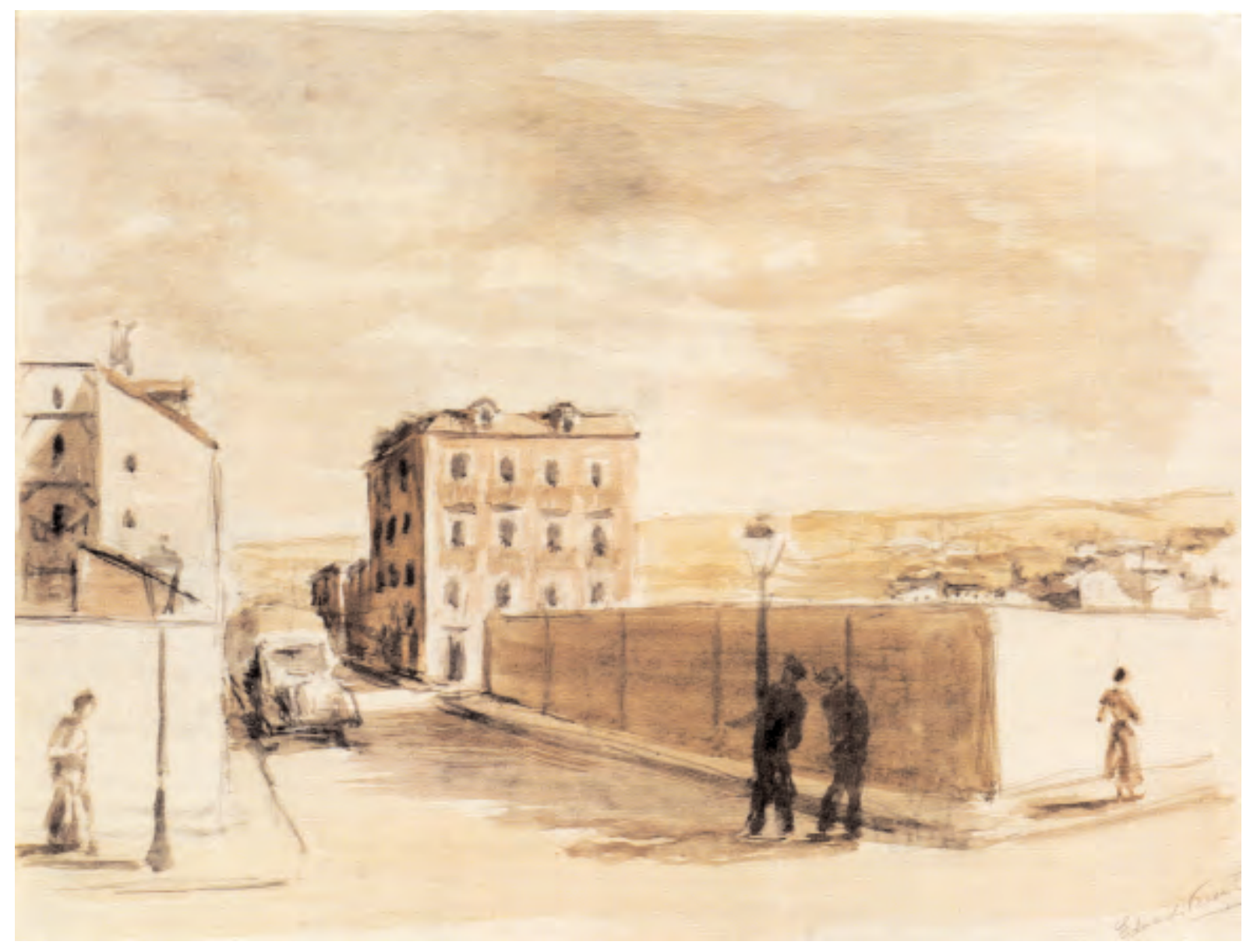

Afueras de Madrid. 1955. Madrid. Acuarela sobre papel. Colección particular. Eduardo Vicente 

C6... desde que las ciencias humanas se reconocieron como tal, "el saber y el hacer" se desafían mutuamente como objetivos 91

Martínez Gastey, P. (1999:223)

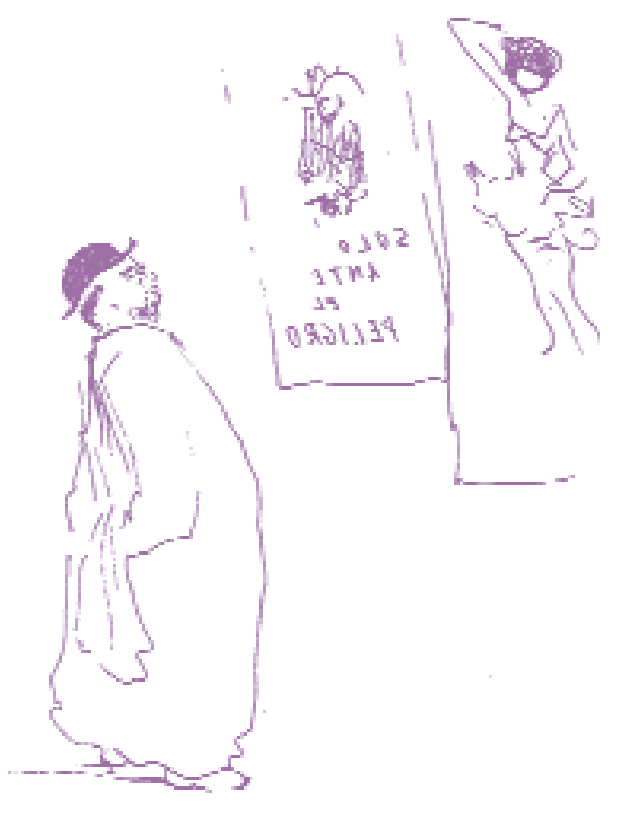





\section{Marco general e interés del fenómeno a estudiar.}

\section{La imagen como medio de conocimiento.}

Desde la antigüedad la imagen ha cumplido diferentes funciones, a saber, en un primer momento podemos considerar a la imagen como un medio de expresión que han utilizado los hombres para comunicar los hechos o conceptos, así como sus afectos y deseos, por otro lado, la imagen es también un medio de información, que da a conocer a los otros las formas y modos de vida de una época determinada, como también todo lo relacionado con las ideologías dominantes o con las expectativas de aquellos que construyen las imágenes. Finalmente la imagen se construye como un medio de representación; van a ser precisamente los estudios iconográficos los que nos permiten conocer la realidad, tanto física como social (Cuadro 1).

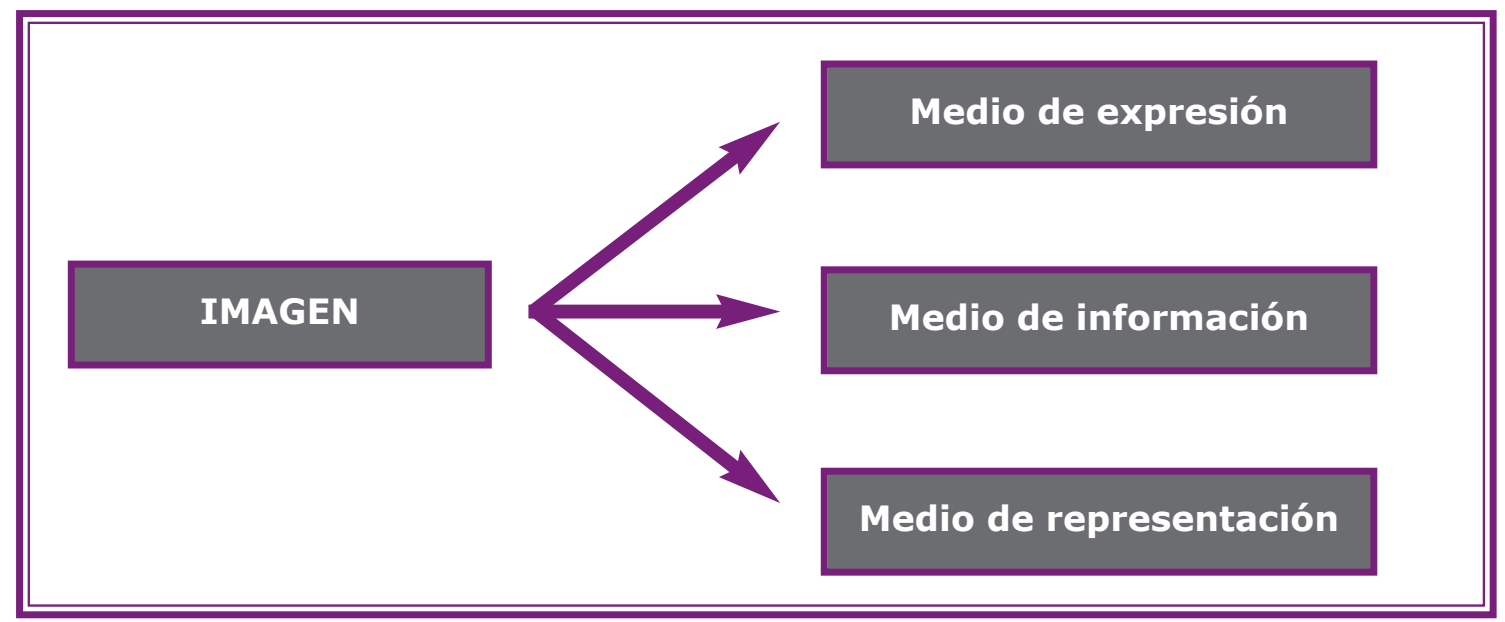

Cuadro 1. Elaboración propia

"Manifestándose así la imagen de la naturaleza de Leonardo en todos sus aspectos como un punto de transición metódicamente necesario: solamente por medio de la visión artística la abstracción científica conquista su legitimidad y su propio camino". 2

Cassier, E. (1951:200)

Las imágenes, de cualquier índole, se posicionan como un elemento importante de la teoría del conocimiento. Así el estudio iconográfico se convierte en un instrumento fundamental de dicha teoría.

Las imágenes se constituyen como una representación de la realidad en el paradigma de una nueva forma de conocer, o mejor dicho, en un instrumento de conocimiento que nos permitirá comprender y aprender cuestiones de carácter conceptual, ideológico, social y cultural. 
Si leemos con atención la cita anterior de Cassier podremos extraer varias consecuencias que nos van a dar algunas pautas en nuestro estudio de investigación

En primer lugar, contemplamos al ser humano a partir del acto de observar, de mirar las imágenes, situándole así como sujeto principal del proceso de conocimiento, en segundo lugar se produce la circustancia concreta de la importancia de la visión, una visión cargada de muchas simbologías y afectos que le van a permitir conquistar diferentes ámbitos del saber artístico y también científico.

En este proceso de transformación entre la imagen y el conocimiento se sitúa nuestra investigación estableciendo un diálogo entre lo real y lo simbólico, entre el arte y la ciencia, entre la imagen y todas las connotaciones que nos ayudan a conocer al artista y a la situación política y social en la que vivió Eduardo Vicente. Así, el hombre no sólo ve y observa sino que mira y ahí define su individualidad, pues el mirar implica la dimensión cultural e intencional de cada individuo que interactúa con el entorno cultural e ideológico.

Ahora bien, continuando en la introspección del proceso de mirar las imágenes, todo lo anteriormente dicho sustenta la estructura básica que genera la dialéctica central que motiva esta forma de explicar el conocimiento: la revelación frente a la observación rigurosa de la obra del artista, la manifestación divina frente a la fuerza de la razón que se impone con argumentos lógicos, el paso de la cultura escolástica a la humanística, o dicho de otra forma más analítica y concreta, ver o mirar implica una relación conceptual y aún metafísica entre el sujeto que realiza la acción de mirar y la imagen que contempla.

Así observar o mirar las imágenes tiene su traducción en la dimensión cultural que va a permitir definir las diferentes individualidades. La imagen u objeto a observar constituye el objeto final que es conocer, profundizar en el saber de todo aquello que rodea al hombre.

La observación y su vinculación con la experimentación hace su primera presencia en la actividad artística, definida como una "observación empírico-sensible" (Cassier, E. 1951:78). Esta experimentación tendrá función final de refutar la hipótesis, contrastarla, es decir, será el paso a esa observación empírico-sensible a "la intuición pura" asignando una nueva 
"jerarquía a la sensibilidad".

Es así cómo consideramos la observación de las imágenes y cómo ésta pasa a formar parte de la teoría del conocimiento y aquí es donde entra en juego el arte, en nuestro caso la obra del pintor Eduardo Vicente, que es la tarea que nos ocupa. Es justamente ese desplazamiento de la revelación a la observación. Es esa idea que señala Gombrich con claridad.

"...para la Edad Media, el esquema es la imagen; para el artista posmedieval, es el punto de partida para correcciones, ajustes, adaptaciones, el medio para hurgar en la realidad y para luchar con lo particular". 3

Gombrich, E.H. (2002:148)

Nos situamos pues ante una nueva forma de conocer en la que el hombre es parte central de ella, tal como reflejan las palabras de Cassier:

"Nicolás de Cusa es para Leonardo el representante más que de un determinado sistema filosófico, de un nuevo modo y de una nueva tendencia de investigación". 4

Cassier, E. (1951:78)

Con estas palabras Cassier confirma esencialmente que lo que se produce es una nueva tendencia de investigación. En este ir y venir, entre los conceptos de conocimiento y visión, nos indica que ambos van unidos pues se van defendiendo en un juego de incidencias que conforma el nuevo saber.

Por tanto conocer, investigar, ver, observar, mirar ..., en definitiva lo que estamos haciendo es identificar una filosofía en la que la visión se convierte en el máximo exponente, es decir, estamos identificando lo que podríamos denominar como una nueva cultura de la narrativa visual.

En este proceso de conocer, no podemos dejar de lado este otro aspecto de la visión que atañe indiscutiblemente a la dimensión cultural, pues mirar, como ya hemos expuesto, lleva implícito la individualidad del que mira, es decir, quién y qué se mira en las imágenes seleccionadas, cómo y en qué dirección en definitiva, implica la intencionalidad de los creadores que, conscientemente o no, nos lleva a explorar otros caminos. 
"Pues no hay que olvidar que, en nuestra cultura ver significa también saber vivir". 5

\section{Starobinski, J. (2002:portada interior)}

El estudio de la obra artística de Eduardo Vicente nos va a permitir por un lado, analizar esa primera función informativa, en la que nos transmite la ideología de la época en la que vivió y los ideales con los que se comprometió, y por otro, su obra será una fiel representación de las normas y los valores sociales de la España de ese periodo histórico en el que vivió el artista (Cuadro 2).

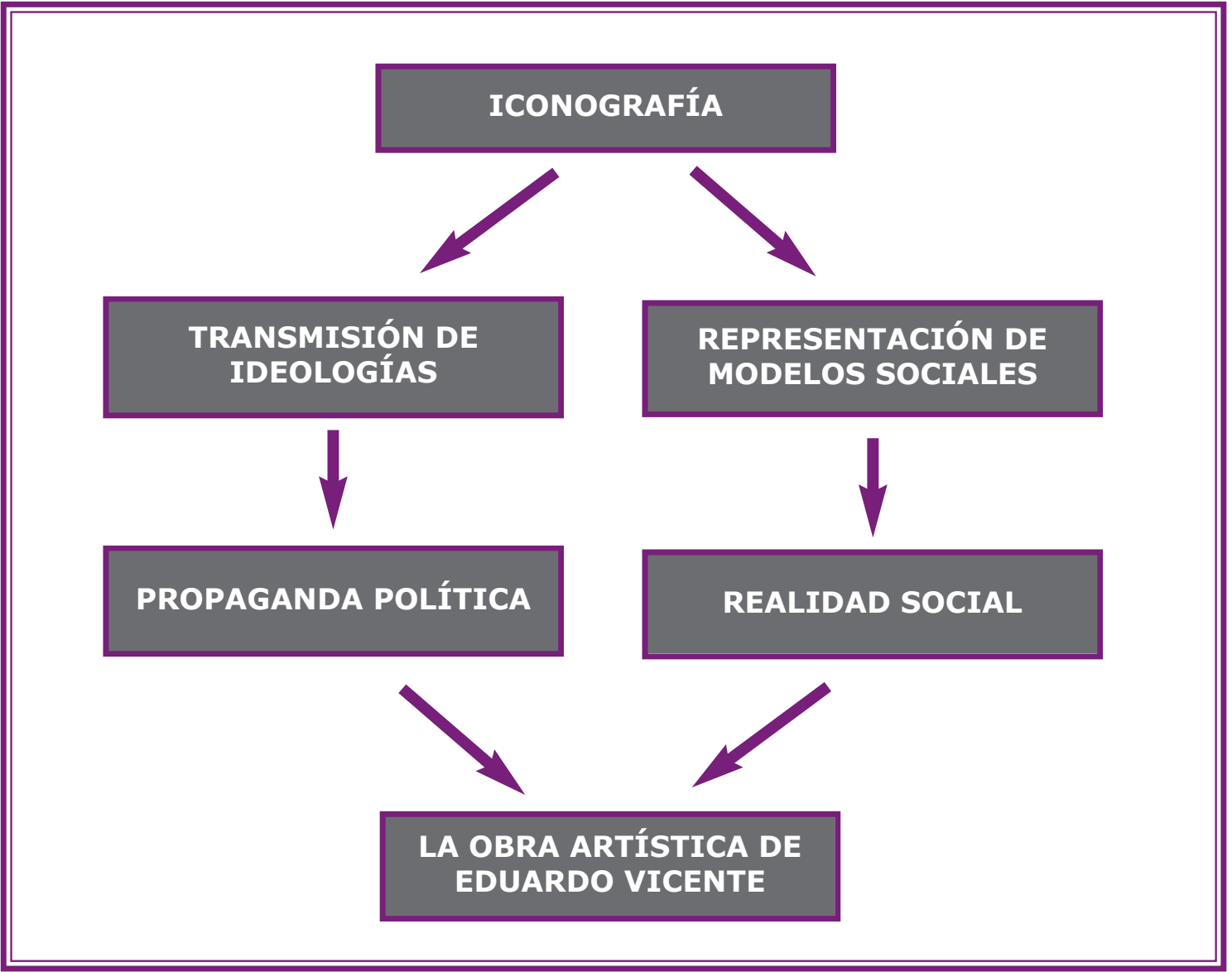

Cuadro 2. Elaboración propia 
El estudio iconográfico de la obra de Eduardo Vicente lo vamos a dividir en dos partes, por un lado lo centraremos en la función transmisora de ideología, donde prestaremos atención al valor propagandístico de su obra y, por otro lado a la función representadora de modelos sociales a través del análisis de las imágenes que reflejan la realidad social.

\section{ideología.}

\section{Propaganda política. La imagen como transmisora de}

"Donde hay autoritarismo hay propaganda". 6

Eguizábal, R. (1998:109)

Para comenzar este apartado nos atrevemos a adoptar la cita del profesor Eguizábal y darla, aún, una mayor dimensión: donde hay poder hay propaganda. Porque el "poder" tiende a prevalecer y por tanto necesita actuar de forma propagandística para seguir existiendo y no duda en adoctrinar y utilizar todas las herramientas necesarias para seguir ejerciendo el control y disfrutar de todos los beneficios, privilegios que conlleva. Por este motivo, un primer acercamiento al concepto de propaganda podría ser relativo a su dependencia del poder.

De forma intuitiva cabría pensar por tanto que la propaganda se deriva del poder en una relación de jerarquía que podríamos representar de la siguiente manera (Cuadro 3):

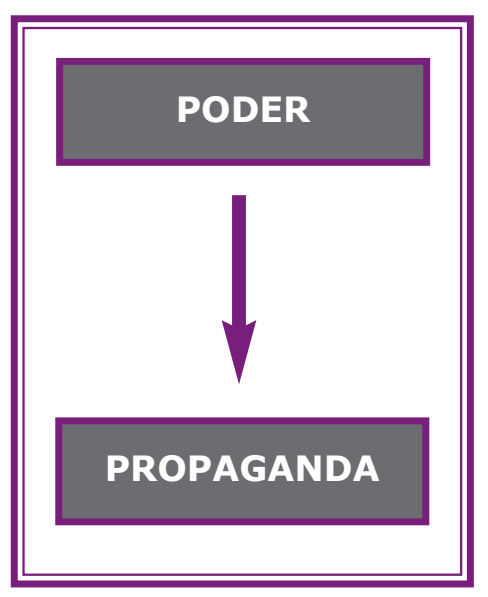

Cuadro 3. Elaboración propia 
No obstante, al contemplar con mayor grado de reflexión la naturaleza de las influencias entre los conceptos de poder y propaganda lo hacemos en una relacción bidireccional de determinación mutua basada en la cercanía en lugar de en la jerarquía (Cuadro 4):

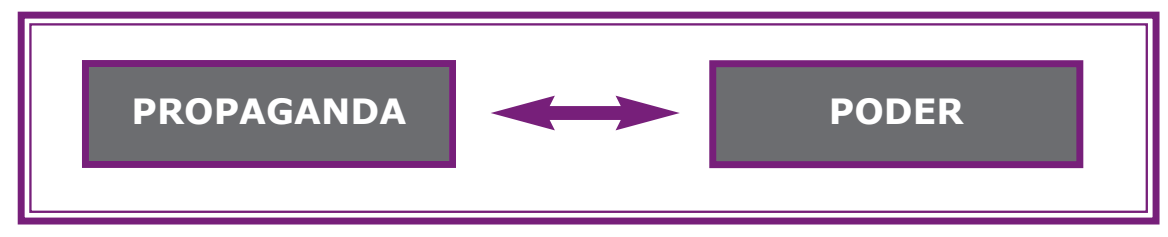

Cuadro 4. Elaboración propia

Hablar del poder no es sencillo, más bien al contrario. A lo largo de la Historia las formas de organización social han evolucionado y se han ido adaptando a diferentes tipos de ciudadanos y de territorios, por lo que la casuística es prácticamente infinita. En efecto, el ejercicio del poder no siempre se desempeña de la misma manera. Hay grandes diferencias entre la democracia, la cooperación y la dictadura pues existe una franja muy grande que va a determinar, en gran medida, la intensidad propagandística de sus discursos y sus acciones, en cualquier ámbito de las manifestaciones sociales.

En general, se observa una relación directa entre el autoritarismo y la propaganda. Es decir, a mayor autoritarismo mayor intensidad propagandística (Cuadro 5).

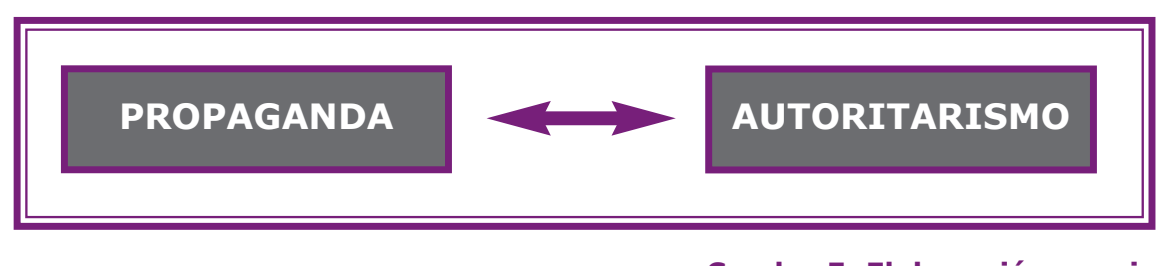

Cuadro 5. Elaboración propia

Las manifestaciones propagandísticas se dan en todos los ámbitos de representación social. Así las podemos encontrar en al menos los siguientes ámbitos:

El poder político. 
* El poder económico.

* El poder social.

Sus manifestaciones pueden ser tan numerosas como variadas; desde la formulación de una ley que recoja el espíritu propagandístico de la ideología a perpetuar hasta una obra de arte que intente expresar las ideas de la causa a la que representa.

"Prácticamente cualquier cosa es susceptible de volverse propaganda, el arte, la escuela, los libros, la moda y, por supuesto, la información y la publicidad". 7

Eguizábal, R. (1998:109)

Por regla general las manifestaciones propagandísticas tienen una intención comunicativa pues no sólo pretenden informar de los hechos o los conceptos a transmitir sino que además conllevan de forma más o menos implícita otras intenciones que superan la mera transmisión de datos para persuadir, seducir, fascinar y modelizar. En definitiva, para conseguir llegar a los receptores y lograr su adhesión (Cuadro 6).

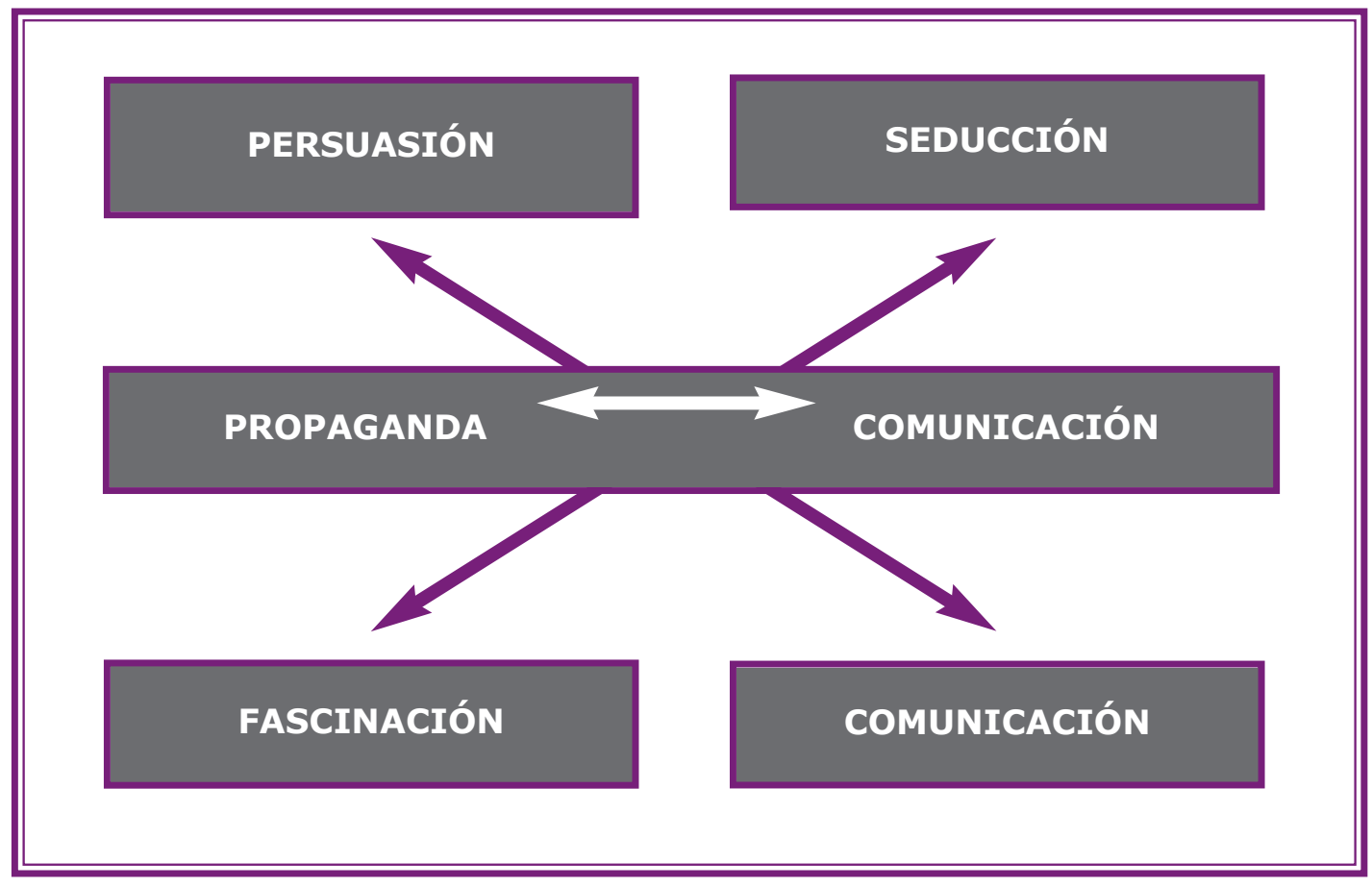

Cuadro 6. Elaboración propia 
La diferencia entre la propaganda y otros tipos de comunicación no la encontramos en los medios o vías de influencia que, como podemos observar en el cuadro anterior, son las mismas que para cualquier comunicación de otra naturaleza sino en las intenciones y en las formas de manifestación de sus códigos.

Así, siguiendo este razonamiento, podemos establecer una primera diferencia entre publicidad y propaganda. Mientras la primera se presenta frente a los receptores de forma descubierta y utilizando los códigos que se le han asignado, la propaganda se oculta o se disfraza en periodismo, educación, literatura, arte, diseño, música, etcétera. En los dos casos hay similitud en la intención comunicativa ya que ambas pretenden ser capaces de crear, modificar o reforzar comportamientos o actitudes, pero la diferencia fundamental estriba en las formas o modos de realizarla y en la consideración del receptor como miembro del proceso comunicativo.

"La propaganda constituye un caso extremo de acción estratégica y manipulativa, frente al ámbito de la acción comunicativa emancipadora entre iguales: por ello orienta radicalmente hacia el universo del tener ( $y$ por ello reifica, cosifica, cristaliza y simplifica las ideas como dogmas y mercancías) en lugar de constituir una proyección hacia el ser en el ámbito de lo social". 8

Vázquez Mendel, M.A. (2004:13)

Las imágenes propagandísticas, con su finalidad de actuar sobre los sujetos a los que se dirige, lo hacen en una doble vertiente, hacia lo personal y hacia lo social. En definitiva pretenden conseguir modelos de sujetos integrados en la cultura dominante, según el orden establecido y que representen los modelos de acción que de ellos se espera y desea (Cuadro 7). 


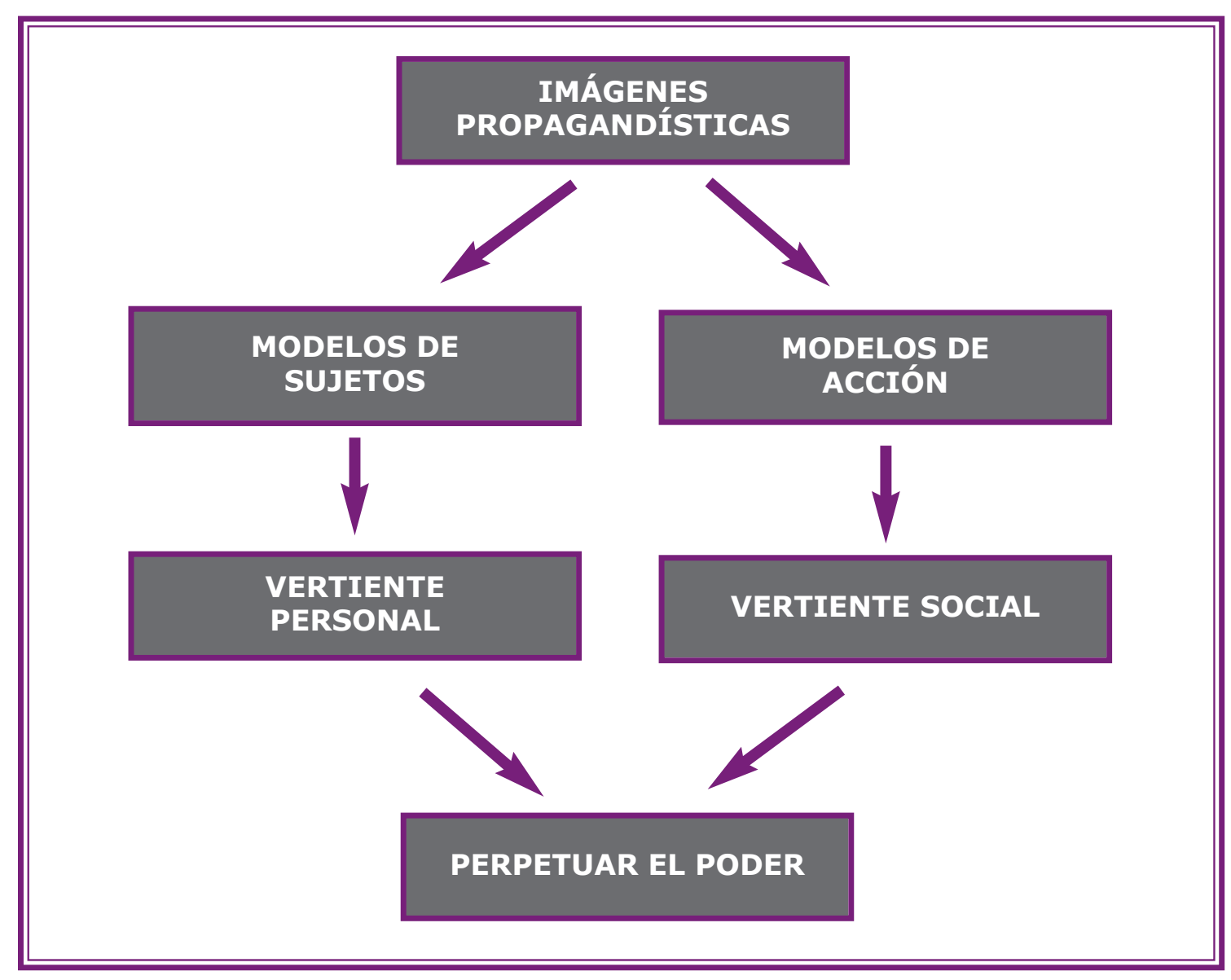

Cuadro 7. Elaboración propia

Por tanto, debemos entender la propaganda como una comunicación interesada que, pese a las diferentes formas en que se camufla, se distingue por poseer como última finalidad la perpetuación del poder y de quienes lo ostentan. 


\section{La realidad social. La imagen como transmisora de modelos sociales.}

No resulta ninguna novedad en la historia del arte, la existencia de un arte que se declare al servicio de una ideología y sirva para presentar la realidad social del momento en que se produce la obra, puesto que en diferentes periodos de la historia podemos encontrar unas obras de arte al servicio de la monarquía o de una religión determinada.

La Reforma Católica en el Concilio de Trento, en su Decreto de Imágenes, propuso la propagación de las ideas a través del arte, en la medida en que propugnaba que él debía llevar el mensaje de la verdad católica. Esta concepción es coincidente con la de Lenin de que las ideas del comunismo debían ser propagadas por medio del arte.

En realidad, cualquier dogma que imponga una presencia totalitaria en su política cultural tenderá a la uniformidad estética, identitaria, por una simple razón de seguridad y dominio.

Las técnicas de dominio implementadas por parte del Estado respecto a sus ciudadanos se alimentaban de formas estéticas y se desarrollaban programas culturales para poner las artes al servicio del poder y representar la realidad según imponía la ideología dominante.

Aunque no se pueda hablar de un dominio total del régimen en el poder, pues las manifestaciones artísticas también tienen sus mecanismos de escape y consiguen transgredir el poder y conseguir la expresión de sus propias ideas, en algunos casos contrarias a las propuestas como "concretas".

En este margen de libertad que se concede al artista, podemos situar la obra de Eduardo Vicente, que utilizó su obra para reaccionar contra la ideología del régimen totalitario del general Franco.

La obra de este artista es una excelente muestra para conocer los modelos sociales que imperaban en la época en que vivió Eduardo Vicente (1909/1968). 
Sus cuadros costumbristas nos dan información de los oficios que existían en Madrid y los estilos de vida de esa época. Los retratos de personajes famosos tenían la intención de inmortalizar y dar testimonio de las actuaciones que estos personajes realizaban en diferentes ámbitos de representación social, las escenas reflejadas en numerosos murales, que servían de decoración de salones de distintos establecimientos, nos presentan el ambiente y las costumbres del Madrid de la época, el papel de la mujer, las escenas familiares, las de la guerra civil española, la soledad, la crueldad en épocas difíciles y un largo etcétera. Todos ellos constituyen la temática que iremos desgranando a medida que avancemos en este trabajo de investigación.

El arte es un espejo que refleja los cambios sociales de cada periodo. Temas como los derechos humanos, la nostalgia de los periodos de abundancia, el deseo de libertad, entre otros temas, están presentes en las imágenes del artista, y es que las tendencias sociales y las imágenes de las manifestaciones artísticas se retroalimentan.

La obra de Eduardo Vicente resúme el espíritu de un tiempo histórico determinado. Ambos, arte y tiempo, se necesitan.

"... al igual que los textos o los testimonios orales, las imágenes son una forma importante de documento histórico. Reflejan un testimonio ocular". 9

Burke, P. (2005:17)

Las imágenes representativas de modelos sociales, al igual que sucedía en las imágenes portadoras de ideología, también se dirigen al sujeto como ser individual y en su vertiente social, como ciudadano de una sociedad (Cuadro 8). 


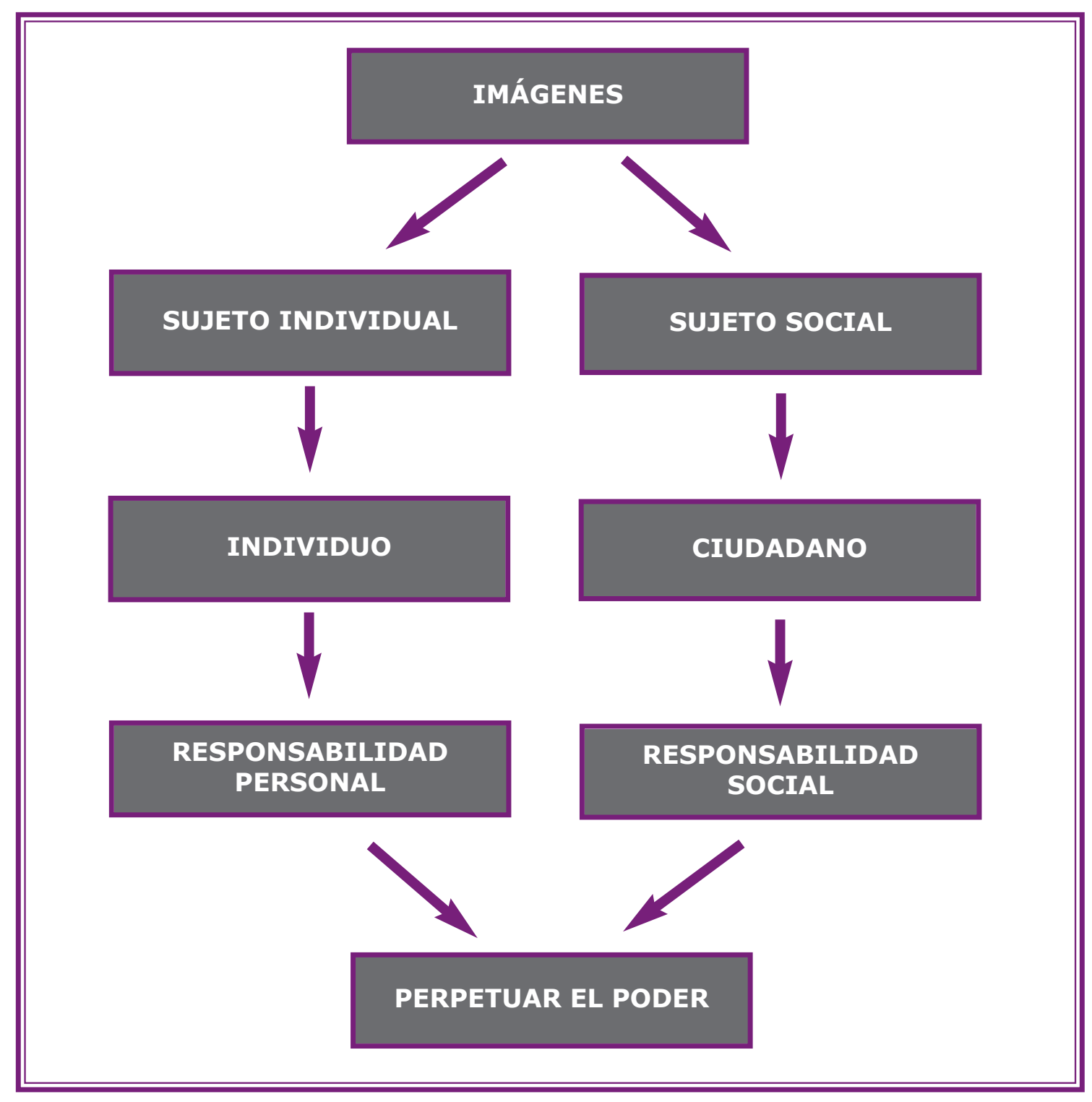

Cuadro 8. Elaboración propia

El estudio iconográfico nos facilitará un mayor conocimiento de la realidad social, de la cultura dominante y de los modos y estilos de vida de la sociedad en la que se centra nuestro estudio de investigación. 


\section{El estado de la cuestión.}

Al comenzar la investigación nos vimos en la necesidad de hacer un profundo repaso de los estudios realizados con anterioridad. Nuestra voluntad es poder superar algunos defectos o lagunas que hemos encontrado, en relación a nuestro objeto de estudio y que, básicamente, se refieren a las siguientes cuestiones:

* Falta de claridad en los estudios iconográficos ya que la mayoría de los encontrados se centran fundamentalmente en el conocimiento de la composición gráfica y artística.

La ausencia de estudios que abarquen las dos dimensiones que hemos otorgado a la imagen como transmisora de ideología y representativa de modelos sociales y que se concreten en la obra de un artista reconocido.

Estudios parciales sobre la iconografía centrados en alguna manifestación concreta como el cartel de guerra, la publicidad institucional,... y no un estudio global que analice un periodo histórico y sus manifestaciones sociales.

- La inexistencia de un modelo de análisis que nos permita el estudio de la imagen, de su poder y eficacia en la transmisión de ideología, así como en la representación de los modelos sociales y las pautas de conducta.

* Se echa en falta, en los estudios anteriores, una visión crítica del papel que la imagen ha tenido y tiene en la construcción de la realidad, quedándose la mayoría de ellos en una descripción analítica de los hechos, acontecimientos y diferentes manifestaciones.

* Se observa, con demasiada frecuencia, que la imagen, como transmisora de ideología y representativa de modelos sociales, se ha utilizado como medio para perpetuar el poder desde el poder, ejerciendo el papel de agente socializador encargado de transmitir la cultura, los ideales, las normas, las actitudes y valores a los ciudadanos, y se olvidan otras funciones que también cumplen las imágenes como la denuncia, reivindicación, formación, demostración, solidaridad, y la contribución a la transformación de la realidad social. Este hecho nos ha permitido definir dos funciones distintas de la propaganda (Cuadro 9). 


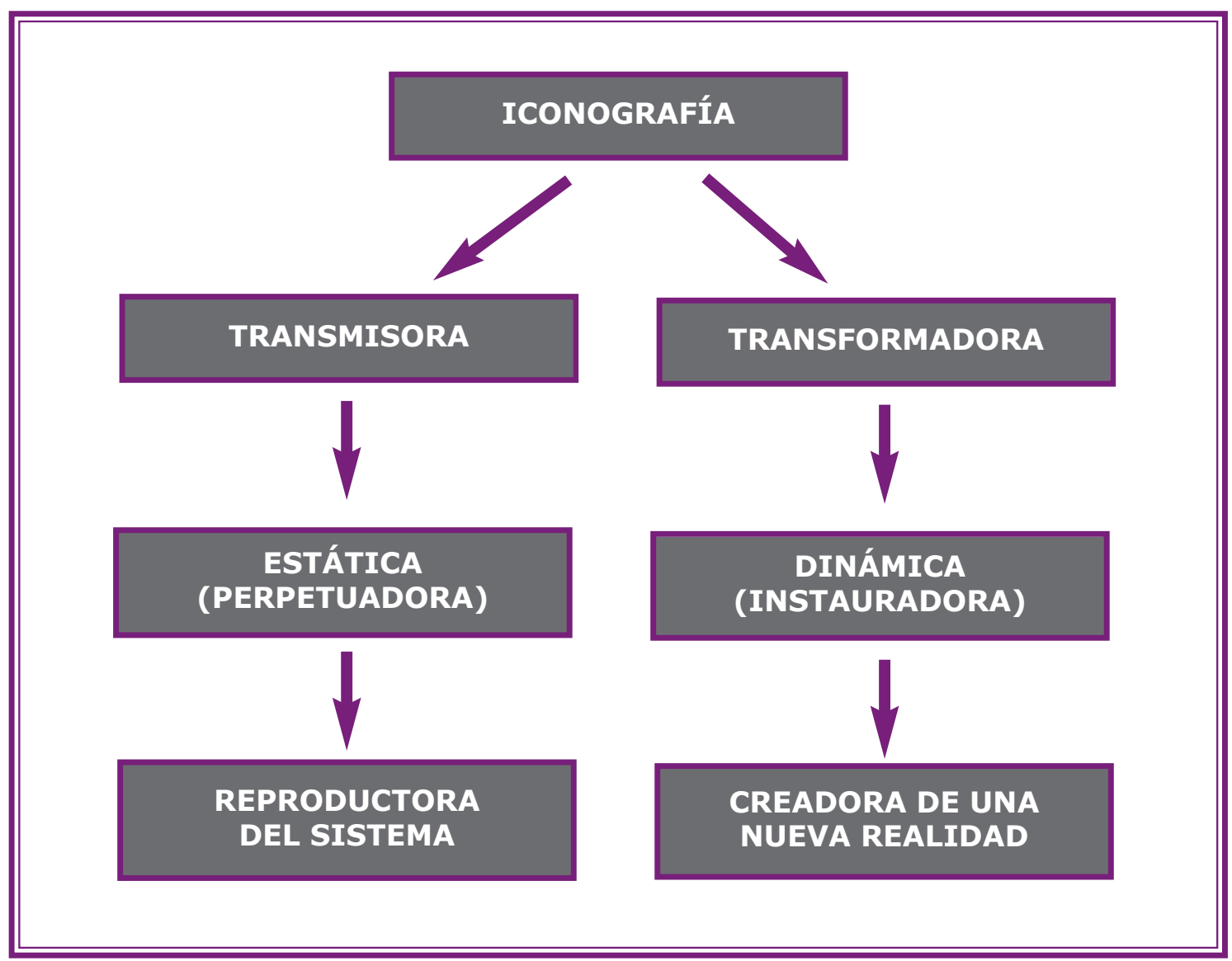

Cuadro 9. Elaboración propia

* El estudio de la imagen como transmisora de ideología y su concreción en la vida y obra del artista Eduardo Vicente servirá para reivindicar su influencia, su implicación y su creación artística, a la vez que nos permitirá un conocimiento de una parte de la historia de nuestro país que, por diferentes motivos, ha estado relegada al olvido o, al menos, ha quedado en un segundo plano tanto en el campo académico como en el social. 


\section{Punto de partida.}

Nuestro punto de partida está basado en los aspectos que hemos señalado en el repaso al estudio de la cuestión que llevamos a cabo en páginas precedentes y queda concretado en los siguientes puntos:

La urgencia de comprobar el valor de la imagen como parte esencial de la teoría del conocimiento.

La necesidad de diferenciar claramente las dos vías de investigación de la iconografía como transmisora (reproductora) y transformadora (educadora) de la realidad social.

La carencia de estudios que expliquen el valor iconográfico en un periodo histórico determinado y que abarque la mayoría de las manifestaciones sociales.

La importancia de descubrir la vida y la obra de un artista poco conocido, Eduardo Vicente, que vivió y sirvió con sus pinceles al bando republicano porque se sentía humanamente solidarizado con la causa que representaba.

Poner en valor su obra, difundirla y contribuir, en la medida de nuestras posibilidades, a su conocimiento. 



\section{Delimitación del objeto de estudio.}

El estudio de la imagen como transmisora de ideología y representativa de modelos sociales así como su presencia en cualquiera de las manifestaciones sociales nos obliga a recurrir a diferentes áreas del saber. Este abordaje multidisciplinar nos va a permitir tener una perspectiva global del fenómeno analizado, superando los estudios parciales y las visiones particulares que se han venido realizando en los estudios iconográficos. Los resultados obtenidos en esta investigación pretenden generar un análisis que nos permita entender la realidad social en un periodo histórico determinado y el papel que desempeñan las imágenes de la obra de Eduardo Vicente en la construcción de la realidad, en sus relaciones, sus creaciones y sus interrelaciones.

Nuestro objeto de estudio consta de dos partes bien definidas, de naturaleza distinta pero complementaria.

En la primera parte se hará un recorrido teórico que nos permita comprender toda la dimensión de la comunicación propagandística, sus orígenes, sus causas y consecuencias, sus finalidades y todas sus manifestaciones. Este primer acercamiento nos abrirá un amplio abanico de posibilidades de afrontar su estudio, nos mostrará, también, sus limitaciones. Podemos señalar claramente los límites que separan la propaganda de otros tipos de comunicación; límites que en algunas ocasiones no estarán bien definidos, se nos mostrarán confusos y difusos, dificultando notablemente su estudio.

Este primer esfuerzo en la conceptualización del fenómeno propagandístico nos servirá para llegar a un buen conocimiento del fenómeno a estudiar y su diferencia con otros relacionados como publicidad política o religiosa que, en algunas ocasiones, pueden llegar a confundirse. Así estableceremos una diferenciación clara entre comunicación política y comunicación propagandística, que nos ayudará a entender mejor la realidad social que vamos a afrontar.

En esta primera parte (Cuadro 10) del objeto de estudio también se hará un recorrido teórico sobre la importancia de la imagen, sus funciones y el papel que desempeña en la representación de la realidad social y su relación intrínseca con la teoría del conocimiento. 


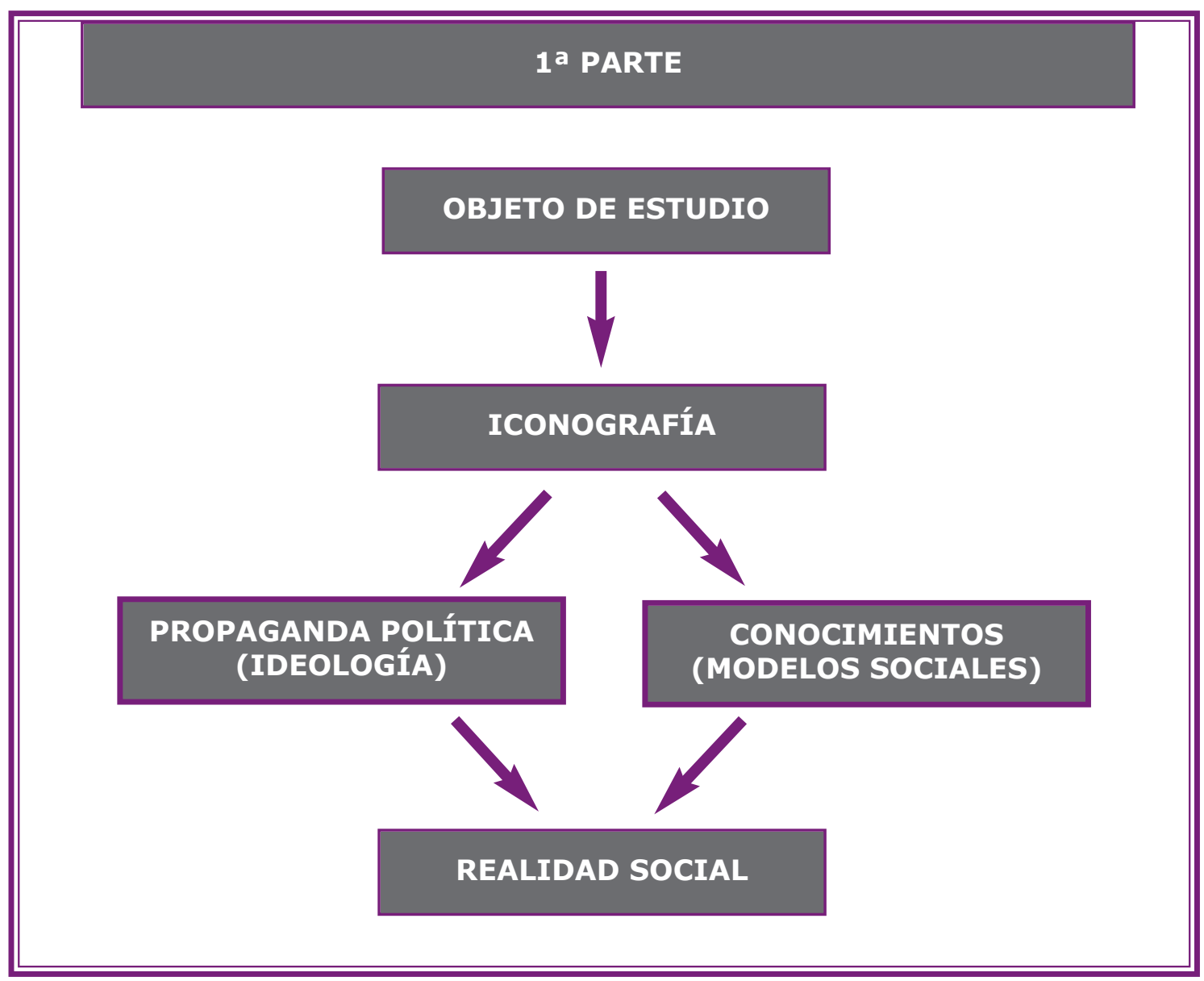

Cuadro 10. Elaboración propia

La segunda parte (Cuadro 11) de nuestra investigación se centrará en el estudio de un hecho concreto. La vida y obra de Eduardo Vicente, en un tiempo determinado (1909-1968), años difíciles, revueltos, que iremos comprendiendo con el estudio de las imágenes, su finalidad y todos los mecanismos que utilizó para hacerse visible e invisible y permitir que sirviera para muy diversos fines, tan variados como el cuidado y apoyo de las personas necesitadas, para expresar ideologías, burlar las normas establecidas por el nuevo poder establecido por la fuerza; es decir, resumiendo, las restricciones a la libertad impuestas por el bando ganador de la Guerra Civil Española. 


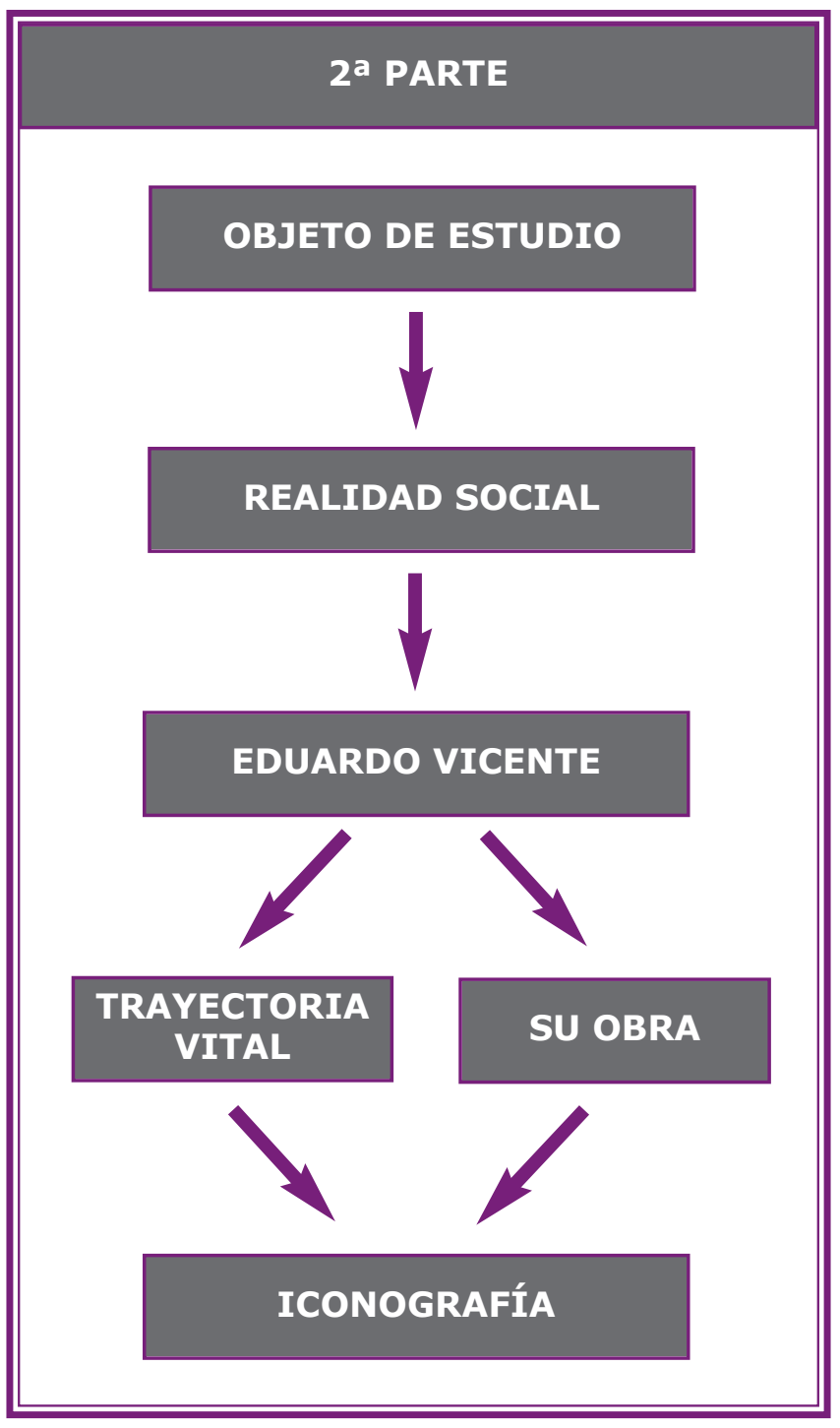

Cuadro 11. Elaboración propia

Por tanto, el objeto de estudio de la presente tesis queda definido, finalmente, en los siguientes términos.

Arte y comunicación. Propaganda política y transmisión de ideología en la obra de Eduardo Vicente. 



\section{Fases iniciales del objeto de estudio.}

1.- Aproximación teórica a la comunicación propagandística.

2.- Delimitación de la propaganda con respecto a otros tipos de comunicación.

3.- La propaganda, entendida en su acepción más amplia, es un fenómeno presente en toda la historia de la humanidad que, a pesar de la amplitud de aspectos que comporta, es fácilmente identificable y se la puede delimitar como objeto de estudio en su evolución diacrónica.

4.- Desde la idea ya señalada por Domenach, J.M. que la propaganda es polimórfica y cuenta con recursos casi ilimitados, haremos un recorrido por los diferentes medios de transmisión que utiliza la propaganda, el cartel político, la publicidad política y comercial, las instituciones sociales como la educación que a través de sus agentes socializadores contribuyen a perpetuar la ideología dominante y otras manifestaciones sociales y artísticas, del mundo del arte, de la música, de la literatura, del diseño, de la moda...

5.- Aproximación teórica de la imagen como elemento importante en la teoría del conocimiento.

6.- Definir las distintas funciones que desempeña la imagen: expresión, información y representación, que nos permiten comprender cuestiones de carácter conceptual, ideológico y social.

7.- Delimitación de un periodo histórico y de un personaje: Eduardo Vicente. Su vida y obra constituyen un auténtico documento, tanto por su obra como por su implicación personal en la historia del momento social en el que vivió.

Finalmente se realizarán las conclusiones que deberán responder a los objetivos planteados y contrastarán la hipótesis planteada en este estudio de investigación. 



\section{Formulación de la hipótesis y de los objetivos.}

\section{HIPÓTESIS}

A la hora de establecer la formulación de la hipótesis para la presente investigación y una vez delimitado el objeto de estudio, es necesario tener en cuenta que, al ser un fenómeno tan complejo, nos vemos obligados a concretarlo e identificarlo para hacerlo comprensible.

Así pues, al definir la hipótesis partimos de la afirmación de Kerlinger, F.N. que proponía que la hipótesis debe definirse siempre como:

"Declaración conjetural de las relaciones entre dos o más variables". 10

\section{Kerkinger, F.N., M. A. (1970:51)}

Este autor identifica los dos requisitos imprescindibles que tienen que tener las hipótesis acertadas, es decir, aquellas que hacen posible extraer conocimientos significativos:

1.- Las relaciones entre variables.

2.- Comprobar las implicaciones que permiten probar las relaciones.

Añade, a éstos dos criterios subordinados: que las hipótesis descubren la compatibilidad con el conocimiento actual y que se enuncian tan económicamente como sea posible.

Medawar, P.B., describe la hipótesis y su función de la siguiente manera:

"Todos los avances del entendimiento científico, a cualquier nivel, empiezan con una aventura especulativa, una preconcepción imaginativa de lo que pudiera ser cierto, una preconcepción que siempre y necesariamente va un poco más lejos (algunas veces mucho más lejos) de cualquier cosa de la cual tenemos autoridad lógica y fática para creer en ella. Es la invención de un mundo posible o de una fracción minúscula de ese mundo. Se expone entonces la conjetura a la crítica para encontrar si tal mundo imaginario se parece al real o no. Sin embargo el razonamiento científico es en todos los niveles una interacción entre dos episodios de pensamiento, un diálogo entre dos voces, una imaginaria y crítica la otra; un diálogo, si se quiere, entre lo 
posible y lo real, entre proyecto y práctica, conjetura y crítica, entre lo que puede ser verdad y lo que es el caso de hecho". 11

Medawar, P.B. (1972:138)

El estudio iconográfico en un contexto histórico delimitado por la vida del artísta Eduardo Vicente nos obliga a delimitar y concretar los recursos, técnicas, medios y manifestaciones sociales y culturales que configuraron la historia política y social del periodo analizado y el papel que la imagen tuvo para transmitir la ideología y representar los modelos sociales y estilos de vida.

Por consiguiente en este estudio se hace necesario analizar algunas de las variables más influyentes que utilizó la propaganda para conseguir sus efectos.

La identificación y comprobación de la implicación de dichas variables, justificarán y permitirán extraer conclusiones que ayuden a clasificar aspectos poco estudiados y a veces confusos de la propaganda como fenómeno comunicativo.

En consecuencia, teniendo en cuenta lo anteriormente expuesto, partimos de las siguientes premisas:

1.- La iconografía es un fenómeno comunicativo que informa y persuade.

2.- La iconografía estará directamente relacionada con la cultura en la que poder cumplir sus funciones expresivas, informativas y representativas.

3.- Utiliza todos los medios, técnicas y recursos a su alcance para perpetuar el poder.

4.- El estudio iconográfico permite conquistar diferentes ámbitos del saber artístico y científico.

5.- Observar con rigor las imágenes constituye el punto de partida para conocer y comprender la realidad física y social, ejerciendo un claro desplazamiento de la revelación al análisis. 
6.- Las imágenes seleccionadas en nuestro estudio llevan implícitamente la intencionalidad de su autor que con su obra nos conduce a explorar diferentes ámbitos de la época en la que se produjeron.

7.- La base de la eficacia de las imágenes tiene su orígen en la creatividad con que se generan y en la que se produjeron.

8.- La imagen, además de cumplir las funciones anteriormente expuestas, tiene el poder de ejercer en el observador un acto de experiencia y esta va a cumplir la función de comprobar si los objetivos planteados y la hipótesis de partida son realistas y aportan novedades importantes para el conocimiento.

Teniendo en cuenta todos estos aspectos, nuestra hipótesis quedaría definida en los siguientes términos:

La obra iconográfica de Eduardo Vicente cumplió la función comunicativa de transmitir la ideología republicana y a su vez sirvió para transmitir las actitudes, valores y normas de la sociedad del periodo analizado.

\section{OBJETIVOS}

Del planteamiento de la hipótesis, necesariamente, se derivan una serie de objetivos generales y otros, con un carácter más específico, que pretenden señalar qué queremos investigar, para posteriormente definir cómo lo vamos a realizar.

En definitiva lo que pretendemos conseguir mediante esta formulación de los objetivos es una planificación rigurosa del trabajo de investigación.

Desde ese primer punto de vista más genérico formulamos los siguientes objetivos generales:

Descubrir el interés del uso de la imagen como documento histórico. 
* Comprobar el valor de la imagen como documento político, económico, artístico y social.

Analizar las posibilidades de la imagen para la lectura de las estructuras del pensamiento y representación de una determinada época.

Desde estos objetivos generales se derivan una serie de objetivos específicos que podemos formular de la siguiente manera:

Analizar el contexto histórico, político y educativo comprendido entre los años 1909 y 1968 (años en los que vivió Eduardo Vicente).

Comprobar el pensamiento ideológico y social, con la visión o sensación que producen las imágenes de la obra del pintor Eduardo Vicente.

Utilizar las imágenes como fuente de investigación para conocer y valorar la obra del pintor como transmisora de ideologías.

- Descubrir las técnicas implementadas por parte del Estado respecto a sus ciudadanos y observar cómo éstas se alimentan de las formas estéticas y se desarrollan con programas culturales para poner las artes al servicio del mismo.

Conocer a través de las imágenes los valores, actitudes y normas de la cultura de un periodo histórico determinado.

Ayudar a captar la sensibilidad colectiva de una época a través de la interpretación de las imágenes de la obra del pintor Eduardo Vicente.

* Reconocer el legado artístico de Eduardo Vicente y su dedicación y compromiso con sus ideales políticos. 


\section{Metodología, enfoque, aporte teórico y fuentes.}

Para el estudio de las imágenes, como fenómeno comunicativo, hay que recurrir obligatoriamente a la Historia del Arte, a la Teoría General de la Comunicación Social y a la vez a la historia de los Medios de Comunicación y a la Historia Universal. Las imágenes existen desde que existe el hombre y sus manifestaciones son tan variadas como numerosas.

Las imágenes forman parte de una cultura y no pueden entenderse si no se tiene un conocimiento de la misma, por eso el estudio iconográfico de la obra del pintor Eduardo Vicente hay que situarlo en la época en la que vivió.

Por consiguiente, este estudio iconográfico no debería referirse sólo a lo que es manifiestamente tal sino a todo el complejo sistema de comunicación humana en un contexto social determinado, donde cada mensaje puede cumplir una función propagandística o representar un modelo social determinado.

Teniendo en cuenta todas estas consideraciones previas y fundamentales, su estudio ha de ser necesariamente multidisciplinar.

Para abordar el estudio de la imagen tenemos que partir de la Historia de la Comunicación Social, y al estudiar los canales de la propaganda estamos estudiando la Historia de los Medios y los soportes en los que se propaga. Es más, estudiar la imagen nos lleva a detenernos en el arte, la música, la arquitectura, la literatura, etcétera.

Desde otro punto de vista, al acercarnos a los contenidos nos vemos obligados a recurrir a la historia de las ideas políticas y a conocer las normas sociales y los estilos de vida. La Sociología y la Psicología Social nos aportarán datos relevantes en este sentido.

Por todo, ello contemplamos la Propaganda dentro de un contexto de la Historia de la Comunicación con todos los supuestos a los que nos hemos referido con anterioridad, con la única peculiaridad de prestar atención a las imágenes que se produjeron en ese momento y que tenían la función de persuadir a las masas. Excluímos aquí las imágenes de persuasión de masas orientadas a la venta de bienes y servicios que serían el objeto del estudio de la publicidad. 
La propaganda política se vale de la experiencia y de los medios de la publicidad. Y así la Historia de la Publicidad se convertirá en un apoyo imprescindible en nuestro estudio.

En las investigaciones sobre la historia de la publicidad del profesor Eguizábal podemos leer:

"La publicidad,... debe ser también ligada a factores políticos e ideológicos pero nunca debe ser confundida con la propaganda. La diferencia fundamental, más allá de los objetivos de difusión ideológica de la propaganda, es que lo característico de ésta ha sido su tendencia a la simulación de sus intenciones y de sus medios, frente a la vocación pública y abierta de la actividad anunciadora y publicitaria. Publicitar es hacer público, y lo primero que anuncia la publicidad es su propia naturaleza, su mensaje de pertenencia a un género.

No obstante, así como existen diferencias, no falta tampoco las coincidencias. Ambas son manifestaciones de un poder". 12

Eguizábal, R. (1998:14)

Nuestro estudio de la propaganda abarca múltiples aspectos de la vida social, desde la educación a la política, desde la religión a la guerra y, por supuesto, a la comunicación social en general.

Por esta razón, necesitamos recurrir a una teoría de las ciencias sociales que se caracteriza por su indeterminación. En este sentido Mouly, M. ${ }^{13}$ identifica las siguientes características de una buena teoría que pueda servir como criterios adecuados:

* Un sistema teórico debe permitir que se puedan probar empíricamente.

La teoría debe ser compatible tanto con la observación como con teorías previamente validadas.

Deben establecerse las teorías en términos sencillos.

En este sentido Maslow, J.A. (1954) señala las nueve funciones de la ciencia que quedan reflejadas en el siguiente cuadro: 
1.- Su función indagadora de problemas, formuladora de cuestiones, animadora de presentimientos, productora de hipótesis.

2.- Su función examinadora, comprobadora, certificadora; tratar y comprobar hipótesis; repetición y comprobación de experimentos; compilación de hechos.

3.- Su función organizadora, teorizadora, estructuradora; búsqueda de generalizaciones cada vez más amplias.

4.- Su función acumuladora de historia erudita.

5.- Su faceta tecnológica; instrumentos, métodos, técnicas.

6.- Su faceta administrativa, ejecutiva y organizativa.

7.- Sus funciones editora y educativa.

8.- Sus aplicaciones al uso humano.

9.- Su apreciación, disfrute, celebración y glorificación.

Las imágenes y su contemplación merecen nuestra más profunda admiración y respeto, pues son, sin lugar a dudas, una herramienta imprescindible para la construcción del pasado puesto que son un producto del tiempo en el que fueron creadas pero, a la vez, sirven para disfrutarlas y poder ser nuevamente recreadas y repensadas $y$, en cierta forma, condicionan el futuro en tanto que configuran la representación de la realidad y la percepción de la misma.

Las investigaciones en humanidades, como es la nuestra, y en los límites de metodologías cualitativas se presentan escurridizas y complicadas de abordar. Aspectos como la creatividad artística, la mirada, enmarcadas en variables de análisis epistemológicas y socioculturales, políticas o económicas, se hacen difíciles de cuantificar o, más bien, es improbable y con falta de rigor cualquier intento cuantificador, pues debemos evitar que ciertos paradigmas o modelos 
de investigación nos Ileven a los límites que Gombrich pudiera señalar como futuribles:

"...las eruditas notas a pie de página referentes a manuales litográficos cederán el paso a tablas estadísticas que correlacionen el tamaño de las pinturas con las fluctuaciones en las inversiones, todo ello respaldado por ordenadores, claro está". 15

Gombrich, E.H. (2004:186)

En el estudio cuantitativo señalamos únicamente el número total de piezas que componen la obra del artista estudiado y su clasificación en las distintas categorías.

Nuestro estudio se inscribe, fundamentalmente, en un modelo cualitativo, en el que podemos asumir que vamos a caminar por arenas movedizas, especulativas pero, por otro lado, libres en cuanto a propuestas creativas en el modo de afrontar el estudio, siendo esa, asimismo, la actitud esencial en toda investigación. No se trata de buscar y abordar nuevos temas como de indagar sobre aspectos poco transitados. Además de describir hechos y exponerlos vamos a trabajar con las ideas, y más que limitarnos a fechas vamos a tratar de construir una síntesis nueva de esas ideas. El enfoque analítico y descriptivo recoge el cruce de diferentes disciplinas como la historia del arte, y la iconografía que permite y sustenta la investigación.

En el ejercicio de indagaciones y pesquisas no renunciamos y, claro está, es nuestra obligación, apelamos a instrumentos de rigor para abordar dicho estudio. Los textos de los principales teóricos de nuestro campo de investigación, remitiendo a la tradición teórica, los documentos originales de las ideas estudiadas del período en cuestión, las reflexiones, así como la documentación visual y los análisis comparativos de la misma, serán nuestros principales instrumentos.

En esa idea de comunión entre los posibles lazos y relaciones variables que ha presentado el arte y la investigación científica, es en el que se inscribe los márgenes teóricos de nuestra tesis, cobra mayor sentido esta metodología que permite transitar por modelos de pensamiento en la parte del conocimiento visual que le corresponde, más allá de fechas y hechos; es ese: 
"escribir la historia del arte en función de soluciones a problemas" ${ }^{\mathbf{1 6} .}$

\section{Gombrich, E.H. (2004:186)}

El problema de los giros en los procesos del crear y la mirada, efectivamente, cómo, por qué y qué respuestas dan los artistas ante los problemas de carácter creativo, y cómo utilizan su obra para perpetuar las ideas políticas, religiosas, o los modelos sociales que son encrucijadas del conocimiento, de naturaleza epistemológica.

Asimismo, no queremos dejar de señalar, -como última anotación a nuestras propuestas en el aspecto del enfoque de estudio- que la perspectiva señalada como modo para abordar el estudio que nos proponemos, cercano a los postulados metodológicos de Panofsky, de Gombrich y la Escuela Warburg, también tengan su por qué y una prolongación en el ámbito educativo. Separándonos, por otro lado,

"...del paradigma hegeliano que nos invita a buscar el significado sintomático del cambio estilístico. Este paradigma ha contribuido indudablemente a la popularidad de los estudios históricos del arte en el contexto de la educación liberal. Expone la promesa de una historia sin lágrimas, un curso de exploración en el que el Partenón pueda ser diagnosticado como una expresión del espíritu griego y en el que una visión de la catedral de Chartres ahorre al estudiante la molestia de leer los enrevesados argumentos a los escolásticos" 17

Gombrich, E.H. (2004:186)

Pero nosotros preferimos esa "empresa común en zona inexplorada", a pesar de los fantasmas:

"Desde luego, todos hemos empleado fórmulas de encantamiento y todos hemos disparado contra fantasmas inexistentes, pero al menos deberíamos adiestrarnos, nosotros y a nuestros estudiantes, en ese espíritu de crítica y de autocrítica que es lo único que logra que las búsquedas intelectuales valgan la pena. Una de las consecuencias más indeseables de la industria académica es, me parece a mí, una cierta atrofia de la discusión, como si una vigorosa crítica pudiera poner en peligro las posibilidades de promoción de un colega". 18 
Esperamos que los fantasmas a los que nos enfrentemos no sean en esencia inexistentes o no tengamos la tentación de crearlos en exceso, o carezcamos de la agudeza de descubrirlos y excluir los errores en nuestra tesis planteada. Pero, sobre todo, esperamos y deseamos que este trabajo y este recorrido nos sirva para ejercitarnos en el manejo y reflexión de la ideas y que este viaje, esta experiencia, pueda ser revertida en un mayor conocimiento, lo que, sin duda, hará que valga la pena.

Para el estudio y análisis de la obra de Eduardo Vicente nos centraremos principalmente en las aportaciones de Panofsky (1892-1968) ya que su influencia sigue siendo un referente imprescindible en la mayoría de los estudios histórico-artísticos de los últimos años. Panofsky inaugura una escuela historiográfica con la que pretende recuperar, la unidad de la obra de arte, como el mismo señala:

"Un buen estudio del contenido no sólo es útil para la comprensión Histórica de una obra de arte, sino también enriquece y clarifica la expresión estética de una forma peculiar" 19.

Panofsky, E. (1930:30)

En nuestro estudio partimos de los tres niveles de significado que propone Panofsky:

1.- Nivel Pre-Iconográfico.- Reconocimiento.

2.- Nivel Iconográfico.- Significado.

3.- Nivel Iconológico.- Sentido Profundo.

(Niveles que desarrollamos más exhaustivamente en el capítulo 3).

Contemplamos además, distintos enfoques psicoanalíticos, estructuralistas y de la Historia del Arte y de todos ellos extraemos unas cuantas reflexiones generales que nos van a ser muy útiles en el estudio de las imágenes que componen la obra del artista Eduardo Vicente y su valor propagandístico y representativo de modelos sociales.

* Las imágenes dan acceso no ya directamente al mundo social sino más bien a las visiones de ese mundo propias de una época. 
El testimonio de las imágenes debe ser situado en un "contexto" o, mejor dicho, en una serie de contextos: cultural, político, religioso, económico...

* El testimonio de una serie de imágenes es más fiable que el de una imagen individual.

* En el caso de las imágenes el investigador se ve obligado a leer entre líneas, fijándose en los detalles, en las ausencias y presencias y todo aquello que pueda ser utilizado para extraer información.

A modo de síntesis proponemos la metodología que queda reflejada en el siguiente gráfico (Cuadro 12):

\section{OBRA DE EDUARDO VICENTE}

CUANTITATIVO

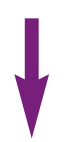

ANALÍTICO

CONFIRMATIVO

DEDUCTIVO
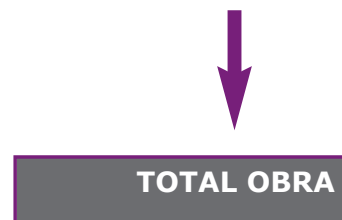

CATEGORÍAS:

- Aspectos formales

- Contenido

- Aspectos técnicos

- Función: Transmisora de

Ideología; Representativa

de modelos sociales

\section{CUALITATIVO}

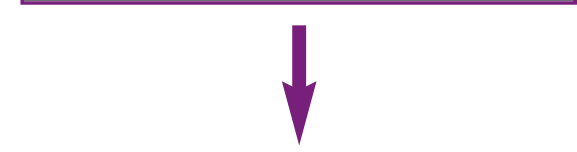

DESCRIPTIVO

EXPLORATIVO

INDUCTIVO

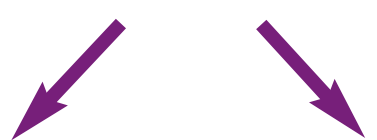

MODELOS SOCIALES

VALOR PROPAGANDÍSTICO

- Affliación

- Formación

- Participación

- Escenas de guerra

- ...
Roles sociales: Masculino;

Femenino; Infancia

- Clases sociales

- Profesiones

- Ocio y entretenimiento:

Cafés; Tabernas; Fiestas

populares; Fiestas taurinas 
El objeto de estudio de nuestra investigación se llevará a cabo en dos fases consecutivas. En la primera fase partiremos de una introducción general y necesaria para centrar el objeto de estudio (Capítulos 2 y 3 ). En la segunda fase, tomaremos como referente a un artista, Eduardo Vicente, un periodo de España, de 1909 a 1969, en el que iremos desgranando el papel de la propaganda política y su función transmisora de ideología (Capítulo 4). Finalmente, concluiremos con el capítulo 5 donde comprobaremos si se han alcanzado los objetivos que definimos en la introducción metodológica y llevaremos a cabo la verificación de la hipótesis propuesta como punto de partida.

La primera de las fases del estudio se centrará en un plano teórico conceptual que nos permitirá definir de forma clara y precisa la imagen, así como establecer claramente las semejanzas y diferencias con otros tipos de comunicación (Capítulo 2). La iconografía como representativa de la realidad social nos llevará a la reconstrucción de la cultura de la época (Capítulo 3).

Por tanto, en esta primera fase nos centraremos en una visión general del fenómeno estudiado que necesariamente establecerá las perspectivas, los límites y los anclajes en los que nos apoyaremos para llevar a cabo un estudio más en profundidad en la segunda fase de la investigación.

Esta primera fase constituye una visión general del objeto de estudio, tal como queda reflejado en el siguiente gráfico (Cuadro 13). 


\begin{tabular}{|c|c|c|}
\hline Capítulo & 2 & 3 \\
\hline $\begin{array}{l}\text { Estudio } \\
\text { Etapa }\end{array}$ & Teórico conceptual & $\begin{array}{l}\text { Teórico conceptual } \\
\text { descriptivo }\end{array}$ \\
\hline Tarea & Revisión conceptual & $\begin{array}{l}\text { Contextualización } \\
\text { histórica y evolución } \\
\text { de la imagen }\end{array}$ \\
\hline Finalidad & $\begin{array}{l}\text { Definición de la } \\
\text { propaganda política y } \\
\text { concrección de sus } \\
\text { límites con otros tipos } \\
\text { de comunicación, } \\
\text { especialmente la política } \\
\text { y la publicidad }\end{array}$ & $\begin{array}{l}\text { Estudio y reflexión del } \\
\text { papel de la imagen } \\
\text { como transmisor de } \\
\text { ideología y representativo } \\
\text { de modelos sociales }\end{array}$ \\
\hline $\begin{array}{l}\text { Soporte } \\
\text { Teórico }\end{array}$ & $\begin{array}{l}\text { - Teoría de la Comunicación } \\
\text { - Historia General de las } \\
\text { CC. Sociales. } \\
\text { - Historia de los Medios } \\
\text { de Comunicación } \\
\text { - Historia Universal } \\
\text { - Historia de la Publicidad } \\
\text { - Teoría de la Cultura }\end{array}$ & $\begin{array}{l}\text { - Historia } \\
\text { - Teoría de la Comunicación } \\
\text { - Teoría de la Publicidad } \\
\text { - Teoría de la Cultura } \\
\text { - Sociología } \\
\text { - Historia del Arte } \\
\text { - ... }\end{array}$ \\
\hline
\end{tabular}

Cuadro 13. Elaboración propia

En la segunda fase, nos centraremos en el estudio de la vida y la obra del artista Eduardo Vicente. Los pasos que seguiremos en esta segunda fase quedan representados en el siguiente gráfico (Cuadro 14). 


\begin{tabular}{|c|c|c|c|}
\hline Capítulo & 4 & 5 & Anexo \\
\hline $\begin{array}{l}\text { Estudio } \\
\text { Etapa }\end{array}$ & $\begin{array}{l}\text { Teórico histórico, } \\
\text { cualitativo y } \\
\text { cuantitativo } \\
\text { descriptivo }\end{array}$ & Conclusiva & Documentos \\
\hline Tarea & $\begin{array}{l}\text { Contextualización } \\
\text { historia y } \\
\text { descripción. } \\
\text { Trabajo } \\
\text { experimental }\end{array}$ & $\begin{array}{l}\text { Grado de } \\
\text { cumplimiento de } \\
\text { los objetivos } \\
\text { generales y } \\
\text { específicos y } \\
\text { verificación de la } \\
\text { hipótesis }\end{array}$ & $\begin{array}{l}\text { - Datos } \\
\text { bibliografícos } \\
\text { - Hojas de registro } \\
\text { del trabajo } \\
\text { experimental } \\
\text { - Ficha individual } \\
\text { del análisis de las } \\
342 \text { obras } \\
\text { iconográficas del } \\
\text { artista }\end{array}$ \\
\hline Finalidad & $\begin{array}{l}\text { Conocer y } \\
\text { describir la vida } \\
\text { y obra del artista } \\
\text { Eduardo Vicente } \\
\text { y su contribución } \\
\text { a las ideas } \\
\text { republicanas de } \\
\text { la España y la } \\
\text { representación de } \\
\text { la realidad social } \\
\text { (1909-1969) } \\
\text { Análisis y } \\
\text { resultados de la } \\
\text { muestra analizada }\end{array}$ & $\begin{array}{l}\text { Comprobar cómo } \\
\text { a través del arte } \\
\text { y de la participación } \\
\text { en las actividades } \\
\text { culturales se } \\
\text { puede contribuir } \\
\text { a la perpetuación } \\
\text { o revocación del } \\
\text { poder establecido. } \\
\text { Nuevas vías de } \\
\text { investigación }\end{array}$ & $\begin{array}{l}\text { Ejemplificaciones } \\
\text { del papel de la } \\
\text { imagen y su } \\
\text { función } \\
\text { propagandística } \\
\text { y representativa } \\
\text { de los modelos } \\
\text { sociales }\end{array}$ \\
\hline $\begin{array}{l}\text { Soporte } \\
\text { Teórico }\end{array}$ & $\begin{array}{l}\text { - Historia del Arte } \\
\text { - Teoría de la } \\
\text { Cultura } \\
\text { - Historia de la } \\
\text { Educación } \\
\text { - Teoría e Historia } \\
\text { de la Publicidad } \\
\text { - Psicología Social } \\
\text { - Sociología } \\
\text { - Literatura }\end{array}$ & & \\
\hline
\end{tabular}


Es precisamente la naturaleza multidisciplinar del asunto objeto de investigación, la que se configura como la mejor justificación de la necesidad de estudiar la imagen y sus múltiples posibilidades.

El hecho de tener que recurrir a diferentes disciplinas y extraer de ellas conclusiones precisas nos proporcionará una visión global del valor de los estudios iconográficos, con la seguridad de que las disciplinas en las que se basa cuentan con una tradición amplia y sus teorías están basadas en investigaciones rigurosas y aceptadas por la comunicad científica (Cuadro 15).

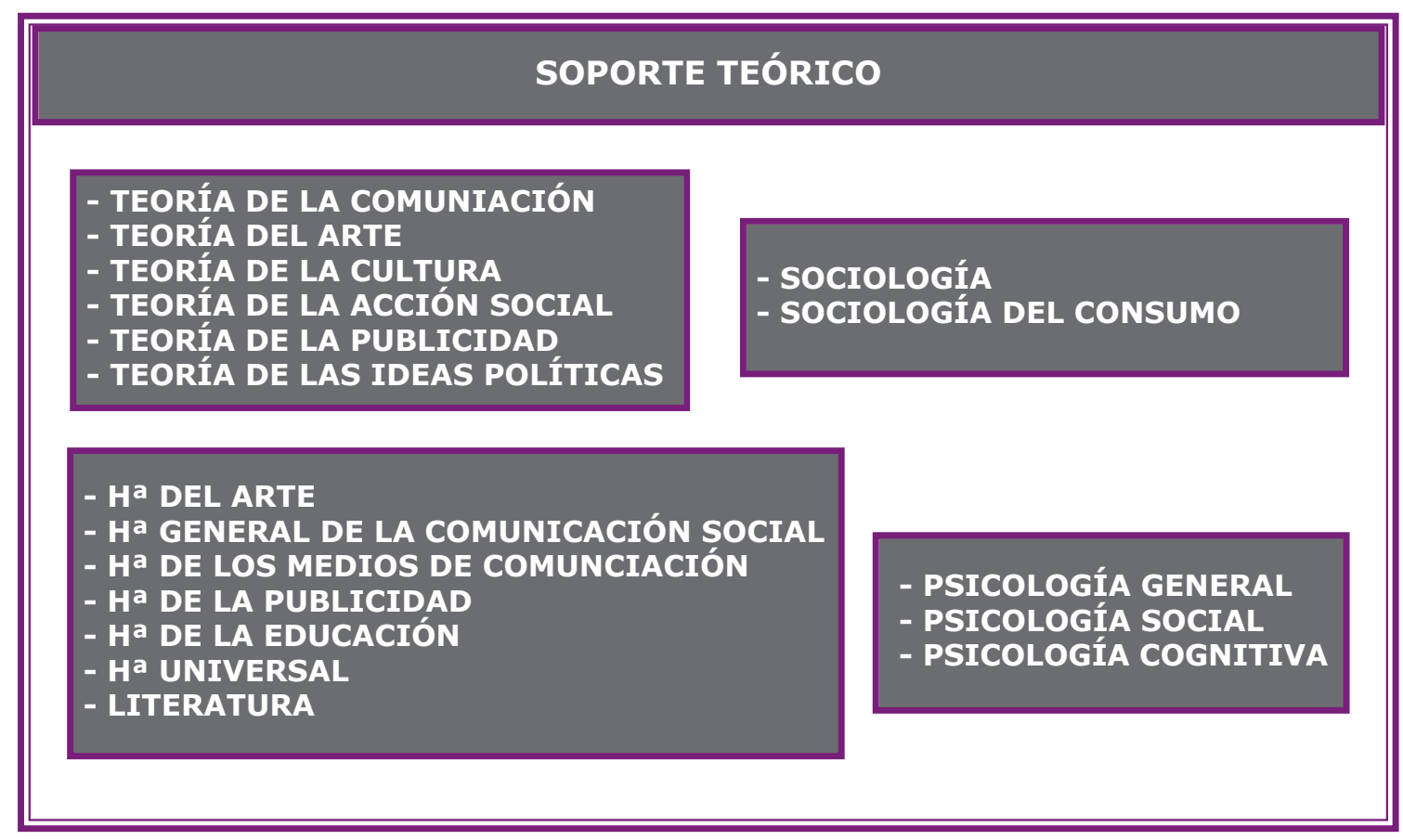

Cuadro 15. Elaboración propia

La visión global que conseguimos con el carácter multidisciplinar del estudio se verá ampliada y completada por los diferentes enfoques específicos que, con una mayor profundidad, se van a realizar a lo largo del trabajo de investigación.

De esta manera, cabe señalar que, mediante el estudio teórico conceptual, conseguimos definir y delimitar correctamente el objeto de estudio con gran rigurosidad. 
Mediante el estudio teórico descriptivo podremos crear un marco contextualizador del objeto de estudio que lo enriquece y fundamenta.

El análisis histórico-social nos llevará a conocer la evolución que ha sufrido la imagen a lo largo de la historia y nos permitirá analizar su función propagandística a la vez de constituir un fiel reflejo de la realidad en el periodo histórico señalado.

Así, el investigador debe conocer al sujeto y sus interrelaciones, por lo que es imprescindible recurrir la psicología general, cognitiva y social.

La psicología general en tanto que estudia al individuo y su conducta.

La psicología cognitiva, en cuanto que considera la imagen como parte de la comunicación con su respectiva influencia en la adquisición de los valores, las actitudes y las normas de los ciudadanos.

La psicología social, considerará tanto al emisor como al receptor de la imagen como sujetos que interactuan con la realidad social y establecen relaciones interpersonales que conforman, en muchas ocasiones, los estilos de vida de cada momento histórico.

También se hace necesario recurrir a la sociología porque nos va a permitir estudiar el comportamiento de los grupos sociales y sus interacciones. La integración del individuo en un grupo social condiciona y, en algunos casos, determina las ideas, las opiniones e incluso las ideologías.

En ningún caso, debemos perder un enfoque que, desde la teoría de la comunicación, nos posibilite investigar las imágenes, pues estas no pueden estudiarse de forma aislada, deben incluirse dentro de la teoría de la comunicación, pues como señalamos al principio del capítulo, los estudios iconográficos son una forma concreta de comunicación.

La politología y el estudio de las ideas políticas deberán ser áreas del saber básicas para comprender la propaganda en cuanto que ésta se destina a la instauración o perpetuación de estructuras de poder y por tanto de una innegable naturaleza política. 
Por último, durante toda la investigación se recurrirá a la observación. Acudir a la ejemplificación corresponde a una doble necesidad, por una parte de reafirmar todas las ideas expuestas de forma teórica y, por otra, de ilustrar las características del periodo analizado, comprobando el papel que desempeña la imagen en la configuración de la realidad social.

La última parte del trabajo consistirá en la verificación de la hipótesis planteada así como una constatación del grado de cumplimiento de los objetivos formulados, tanto generales como específicos . 



\section{Fuentes documentales.}

"La mayoría de las investigaciones, en cualquier campo de actividad, están sustentadas en una serie de datos que se obtienen fundamentalmente de las fuentes de información y las obras de referencia". 20

Marcos Recio, J.C. (2007:36)

En esta cita encontramos una clara diferencia entre fuentes de información y obras de referencia.

Las fuentes de información han sido definidas por diferentes autores, así, en el Manual de fuentes de información podemos leer:

"Se consideran fuentes de información a los materiales o productos originales o elaborados, que aportan noticias o testimonios a través de los cuales se accede al conocimiento, sea éste el que sea". 21

Carrizo Saimero, G., Irueta-Goyone, P., López de Quintana, E. (1994:30)

Las fuentes de información nos ofrecerán multitud de informaciones, estudios en profundidad, análisis comparativos, etcétera. Y las obras de referencia nos aportarán las informaciones puntuales sobre un fenómeno más concreto y más delimitado, que quedará recogido en la bibliografía utilizada en el trabajo de investigación.

Las fuentes documentales que se utilizan para el estudio de la propaganda y de los modelos sociales, a través de la imagen, no son distintas a las que se deben manejar en cualquier otro estudio de cualquier otro proceso comunicativo.

\section{Fuentes Primarias.}

Textos bibliográficos:

Respecto a los textos centrales en nuestra investigación, vamos a establecer una clasificación entre aquellos que se centran en los aspectos epistemológicos específicos que se posicionan en el valor y las funciones de la imagen como motor de las transformaciones en el crear y sus procesos; así como en la importancia en la transmisión de ideologías y aquellos que 
centrados en variables socioculturales que sirven para conocer la sociedad del momento en que tiene lugar nuestra investigación y contextualizan y completan las argumentaciones de los datos obtenidos en el estudio.

* Textos especializados sobre el uso de la imagen como documento histórico, el método iconográfico, los usos de la imagen, y los relacionados con todo lo que concierne a la creación artística y su función social.

* Textos bibliográficos y revistas profesionales del ámbito comunicativo, histórico, sociológico, político y de temática socio-cultural, que nos aportan las bases teóricas necesarias y se constituyen en el punto de partida de nuestro trabajo de investigación.

* La obra artística del pintor Eduardo Vicente:

* Como transmisora de ideología: retratos, carteles, escenas de guerra, religiosas y mitológicas.

垱 Como representativa de modelos sociales: Tipos y costumbres, murales.

Material impreso: campañas propagandísticas, carteles de guerra, anuncios publicitarios, otras obras de arte..., que servirán para ejemplificar los datos obtenidos a lo largo de la investigación

\section{Fuentes Secundarias.}

Medios de comunicación social, fundamentalmente, prensa y revistas, cine, informes... También, recurriremos a la historia oral, para recabar testimonios de personas que vivieron en la España del periodo analizado y que nos aportan vivencias, experiencias y que en ocasiones serviran para clarificar aspectos de nuestro estudio.

Así pues, nuestras fuentes documentales no son otras que las de cualquier otro investigador. Pero dada la complejidad del fenómeno propagandístico, que, de hecho, abarca casi infinitos aspectos de la vida social, se hace necesario acotar y sistematizar los instrumentos en relación a la temática abordada en nuestro estudio. 


\section{Notas}

1.- Martínez Gastey, P. (1999) "La investigación cualitativa" en La fuerza de la publicidad. Cuadernos cinco días. Madrid. p.223.

2.- Cassier, E. (1951). Individuo y cosmos en la filosofía del renacimiento. Emecé. Buenos Aires. p. 200.

3.- Gombrich, E.H. (2002). Arte e ilusión. Estudio sobre la psicología de la representación pictórica. Debate. Madrid. p.148.

4.- Cassier, E. (1951). Individuo y cosmos en la filosofía del renacimiento. Emecé. Buenos Aires. p. 73.

5.- Starobinsky, J. (2002). El ojo vivo, trad. Julián Mateo Ballorca. Cuatro. Valladolid. (palabras del editor en la portada interior).

6.- Eguizabal Maza, R. (1998). Historia de la Publicidad. Eresma \& Celeste ediciones. Madrid. p. 109.

7.- Eguizabal Maza, R. (1998). Historia de la Publicidad. Eresma \& Celeste ediciones. Madrid. p. 109.

8.- Vázquez Medel, M. A. (2004) "Los efectos de la propaganda: una aproximación desde la Teoría del Emplazamiento" en Propaganda y Comunicación. Una aproximación plural. Comunicación Social. Sevilla. p. 16.

9.- Burke, P (2005). Visto y no visto. El uso de la imagen como documento histórico. Trad. Teófilo de Lozolla. Crítica. Barcelona. p.17.

10.- Kerlinger, F.N. (1970). Fouendations of Behavioural Research. Holf, Rimehart and Winston. Nueva York. p. 51.

11.- Medawar, P.B. (1972). The hope of progress. Methuen, Londres. p.138.

12.- Eguizábal Maza, R. (1998). Historia de la Publicidad. Eresma \& Celeste ediciones. Madrid. p. 14.

13.- Mouly, G.H. (1978) citado por: Cohen, L. y Manion, L. (1990). Métodos de investigación educativa. La Muralla, S.A. Madrid. p.41. 


\section{Notas}

14.- Maslow, J.A. (1954). Motivation and personality. Harper and Row. Nueva York. Citado por: Cohen, L. y Manion, L. (1990). Métodos de investigación educativa. La Muralla, S.A. Madrid. p. 41.

15.- Gombrich, E.H.(2004). Ideales e ídolos. Ensayos sobre los valores en la historia y en el arte. Debate, Barcelona. p. 186.

16.- Gombrich, E.H.(2004). Ideales e ídolos. Ensayos sobre los valores en la historia y en el arte. Debate, Barcelona. p. 186.

17.- Gombrich, E.H.(2004). Ideales e ídolos. Ensayos sobre los valores en la historia y en el arte. Debate, Barcelona. p. 186.

18.- Gombrich, E.H.(2004). Ideales e ídolos. Ensayos sobre los valores en la historia y en el arte. Debate, Barcelona. p. 188.

19.- Panofsky, E. (1930). Hercules an Scheidewegw and andere antike Bildstoffe inder nevaren Kunst, Studien der Bibliothek. Warburg, XVIII. Leipziy_Berlin. Citado en Holly, M.A. Panofsky and the Foundations of Art History. Cornell University. Press $1^{\text {a }}$ Ed. 1984 p. 30.

20.- Marcos Recio, J.C. (2007) "Las fuentes de la información al servicio de la publicidad. Investigación y Planificación". en Nuevas Tendencias en la Publicidad del siglo XXI. Comunicación Social. Sevilla-Zamora. p.36.

21.- Carrizo Saimero, G., Irueta-Goyone, P., López de Quintana, E. (1994). Manual de fuentes de información. Cegal. Madrid. p.30. 


\section{|] Capítulo 2}

\section{Da imagen como transmisora de ideología.}

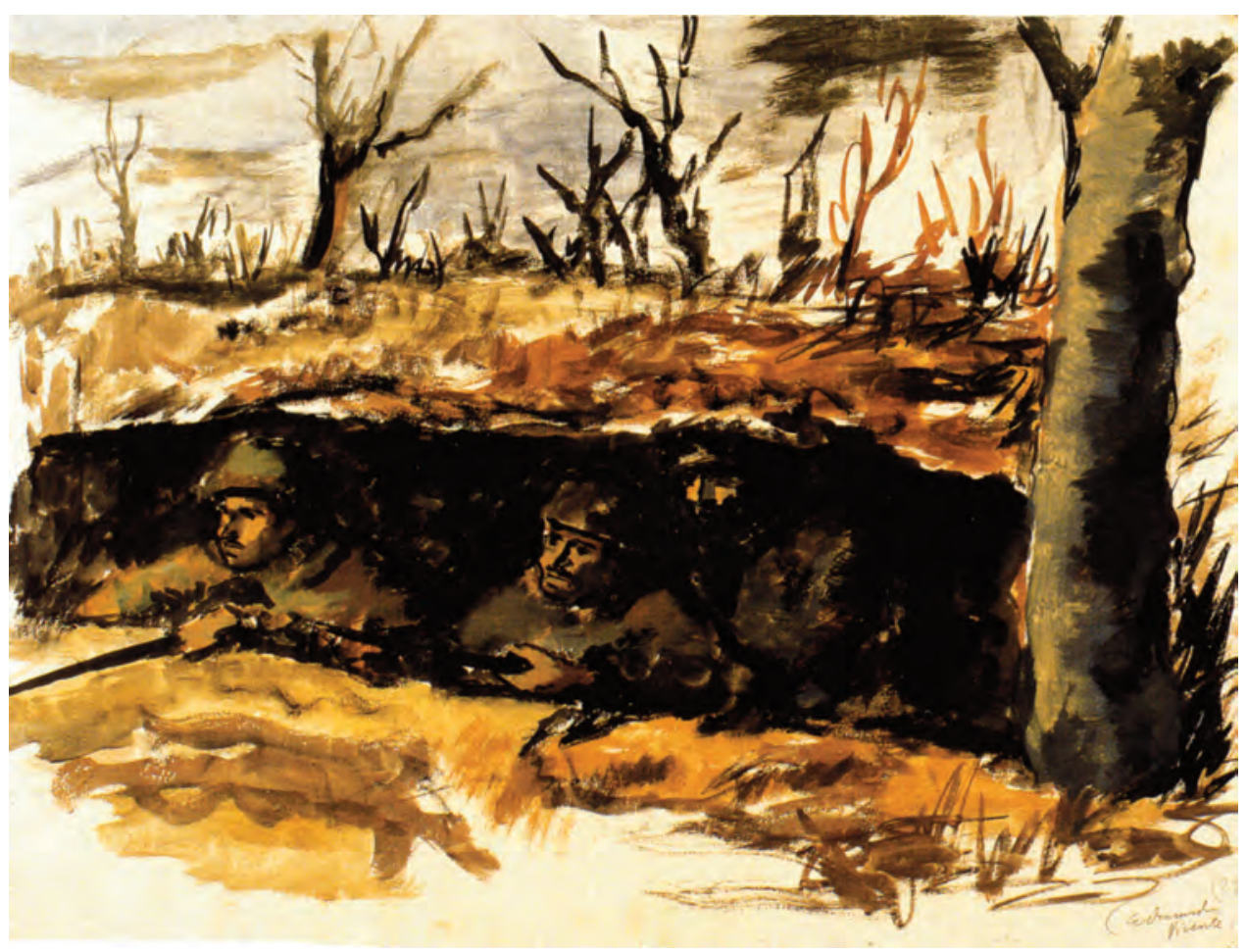

Tres soldados vigilando desde una trinchera. 1937. Barcelona.

Acuarela sobre papel. Museu Nacional d'Art de Catalunya (Gabinete de Dibuixos i Gravats).

Eduardo Vicente 

En el proceso histórico, que va de la propaganda a la publicidad, hubo un tiempo en que ambas coexistían, con sus propias características. Es en la segunda mitad de nuestro siglo cuando se produce la confusión en la medida en que el consumo reina y la ideología declina $\Omega^{1}$

Ferrer, E. (2004:23)

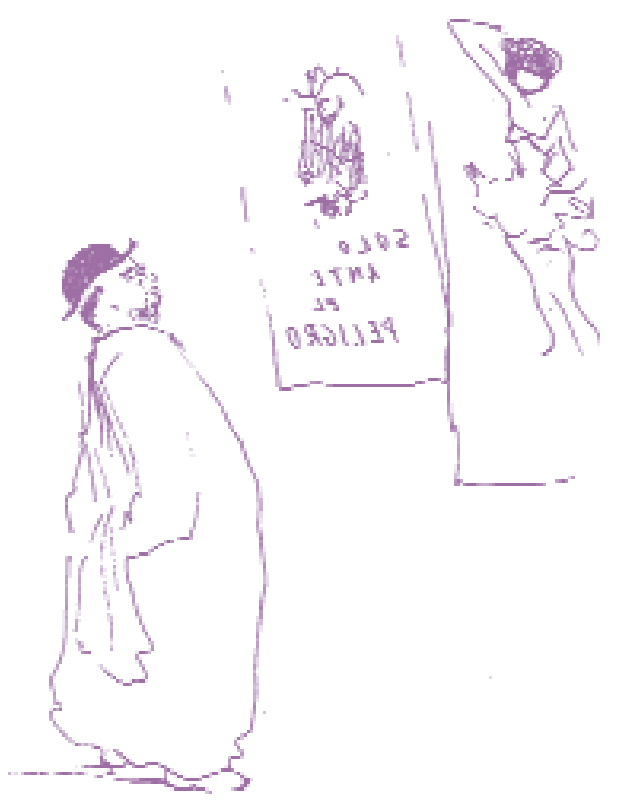





\section{Concepto de propaganda.}

La propaganda política es uno de los fenómenos dominantes en la primera mitad del siglo $X X$. Sin ella serían inconcebibles las grandes conmociones de nuestra época, la revolución comunista y el fascismo. Fue en gran parte gracias a la propaganda como Lenin y Hitler impusieron sus modelos totalitarios. Tanto el bolchevismo soviético como la toma de poder y la invasión del 1940 por parte del régimen nazi hunden sus raíces en la innovadora utilización de la propaganda.

"Los dos hombres que han marcado más profundamente, aunque de manera muy distinta, nuestra reciente historia son, antes que hombres de estado y jefes militares, dos genios de la propaganda que proclamaron la supremacía de esta arma moderna. "Lo principal, dijo Lenin, es la agitación y la propaganda en todas las capas del pueblo". Hitler, por su parte, afirmó; "La propaganda nos permitió conservar el poder y nos dará la posibilidad de conquistar el mundo". 2

Domenach, J. M. (1968:2)

Es cierto que los estudios de la propaganda se circunscriben principalmente a los regímenes totalitarios y sitúan su momento de esplendor en el siglo $X X$, con el bolchevismo, el fascismo o el nazismo, pero no debe olvidarse que la propaganda ha existido siempre y sigue existiendo en la actualidad, a pesar de la implantación progresiva de los sistemas democráticos, pues, hoy día, podemos encontrar numerosas muestras de comunicación que presentan rasgos reconocibles e identificables con lo que en su día se denominó "propaganda".

Los poderes políticos, económicos, religiosos o de cualquier otro tipo siguen produciendo un tipo de comunicación que bien podría llamarse "propaganda", sobre todo si al estudiar la comunicación tenemos en cuenta el pasado y la historia de la propaganda como generadores de sentido de los hechos y acontecimientos que se producen en el devenir de una sociedad en un momento determinado.

El vocablo con que se la designa es contemporáneo del fenómeno. La palabra propaganda es uno de esos términos arbitrariamente extraídos de las fórmulas del latín pontifical; fue empleado por la Iglesia en los tiempos de la Contrarreforma (de propaganda fide) y casi no rebasó los límites del 
vocabulario eclesiástico (Colegio de la Propaganda) hasta que, a fines del siglo XVIII, irrumpió la lengua laica. Pero aún entonces conservó su resonancia religiosa, que solo en el siglo XX perdió definitivamente.

Si recurrimos a las referencias etimológicas del término "propaganda", nos encontramos en un primer lugar con el prefijo "pro" que indica, siempre, lo que está por delante en el espacio y/o en el tiempo; por otro lado la raíz de "propaganda" proviene del indoeuropeo "pack" que significa atar, fijar, asegurar, amarrar, de la que derivará la palabra "pax" con el significado de acuerdo o vínculo y, también, otros derivados como pacto o pagar, que tienen sobre todo un carácter cuantitativo, que significan cantidad pactada o acordada.

Una característica curiosa de la palabra propaganda consiste en ser de las pocas que en español, hoy día, conservan la forma del gerundio latino "propagandum", manteniendo vivo su efecto de potencialidad, es decir, que no se termina ni en su acción, ni en sus efectos, es decir que continúa activa, como expresa M. A. Vázquez Medel:

"propaganda es lo que ha de ser propagado, sin que su difusión agote ese principio y esa pulsión a seguir existiendo y propagando un proyecto, unas ideas, unas creencias... La propaganda nunca se sacia: es imperialista, holística, universal, expansiva... Es una violencia que sólo se detiene en presencia de una violencia más fuerte" $\mathbf{3}$

Vázquez Medel, M.A. (2004:20)

También cabe destacar que el verbo "propagar" tiene una acepción genética que significa multiplicar por generación o por otra vía de producción, por lo que propaganda apunta a esa acción productora y reproductora de ideología. Como recuerda Brown:

"Aludía a la práctica del jardinero de introducir en la tierra los esquejes frescos de una planta para multiplicarla". 4

Brown, J. A. C. (1991:10)

Por lo tanto, se acentúa la idea de una transformación mediante el 
empleo de técnicas artificiales.

Vemos pues cómo, con estas breves referencias etimológicas, la propaganda puede ser analizada, tanto por sus acciones, como por sus efectos.

La articulación de los poderes fácticos de los entornos sociales, especialmente aquellos de naturaleza política y religiosa, ha recurrido reiteradamente a la propaganda como forma de extenderse y perpetuarse. No obstante, durante el siglo XX esta utilización se hace aún más evidente en tanto que se aprovecha de los avances propios de la ciencia de la comunicación que irrumpen con fuerza en las clásicas distribuciones de poderes de las estructuras estatales. El cuarto poder, vinculado a la comunicación, es un medio propicio, pero no único, para que la propaganda se convierta en un fenómeno configurador y perpetuador de esquemas y sistemas de poder. 



\section{Definiciones de propaganda.}

Las definiciones de propaganda que se manejan hoy en día poco tienen en común con su primer sentido apostólico, unas hacen referencia a la propaganda como una herramienta para ejercer influencia en la opinión y en la conducta de la sociedad, otras, se centran en el lenguaje de la propaganda destinado a la masa. Emplean palabras u otros símbolos a los cuales sirven como vehículo la radio, la prensa y la cinematografía principalmente. La finalidad es ejercer influencia en la actitud de las masas en puntos que están sometidos a la propaganda y que son objeto de opinión.

Son muchas las definiciones que encontramos de propaganda. El diccionario de la Real Academia Española la describe como:

"la acción o efecto de dar a conocer una cosa con el fin de atraer adeptos o compradores". 5

R.A.E. (1992:1667)

Esta definición no se ciñe a las características más específicas de lo que entendemos por propaganda, más bien se ajusta a lo que se entiende por publicidad. Más rigurosas son otras definiciones.

Para Jacques Ellut, la propaganda es un:

"Conjunto de métodos utilizados por un poder político o religioso con el fin de obtener efectos ideológicos o psicológicos". 6

Ellut, J. (1976:6)

Manuel Ángel Vázquez Medel considera la propaganda como:

"Una dinámica de desplazamiento, que arranca a aquellos a quienes quiere convertir en adeptos de su lugar, de su ámbito, de su plexo; que los traslada a otro espacio real o simbólico en el que se crea una nueva comunidad interpretante cerrada; que debilita los nexos y las relaciones con el mundo de la vida y potencia un hilo conector con el absoluto de la idea o la causa". 7

Vázquez Medel, M. A. (2004:16) 
En esta misma línea podemos encontrar definiciones de otros autores. De ellas seleccionamos las siguientes:

"La propaganda es la expresión de una opinión o una acción por individuos o grupos, deliberadamente orientada a influir opiniones o acciones de otros individuos o grupos para unos fines predeterminados y por medio de manipulaciones psicológicas". 8

Edwards,V. (1938:40)

"La propaganda aventajará con su impetuoso avance, de muy lejos a la organización, a fin de conquistar el material humano indispensable para esta última. Siempre he sido enemigo de la organización precipitada y pedante, que produce inertes y mecánicos resultados. Por esta razón, lo mejor es dejar que una idea se difunda desde un centro y por medio de la propaganda durante un espacio de tiempo dado, y luego explotar cuidadosamente en busca de dirigentes entre los seres humanos que acudieron a la cita". 9

Hitler, A. (1925:279)

"Intento sistemático de un individuo o varios de controlar actitudes $y$, por consiguiente, las acciones de grupos de individuos mediante el empleo de la sugestión". 10

Doob, L.W. (1948:240)

"La propaganda, en cuanto modo comunicativo, es una forma de comunicación intencional, cuyo objetivo es el adoctrinamiento o manipulación ideológica del receptor". 11

Eguizábal, R. (2007:33)

"La propaganda, en el terreno de la comunicación social, consiste en un proceso de diseminación de ideas a través de múltiples canales con la finalidad de promover en el grupo al que se dirige los objetivos del emisor no necesariamente favorables al receptor; implica pues un proceso de información y un proceso de persuasión". 12 
Emma Rodero Antón en su artículo "Concepto y técnicas de la propaganda y su aplicación al nazismo", después de revisar diferentes definiciones de propaganda, elabora una que, según la autora, reúne las características especificas de la propaganda.

"Se entiende por propaganda la acción sistemática y reiterada, ejercida por medios orales, escritos o icónicos, sobre la opinión pública, con una finalidad persuasiva, principalmente mediante la sugestión y técnicas psicológicas similares, para imbuir una ideología/ doctrina o incitar a la acción mediante la canalización de actitudes y opiniones, al presentarse la realidad tergiversada, seleccionada e interpretada con un reduccionismo valorativo y con una carga emocional. La propaganda se mueve en una estructura sociocultural determinada, sin la cual no pueden comprenderse sus repercusiones psicológicas y culturales". ${ }^{13}$

Rodero, E. (2000:658)

En esta definición, recopilatoria de muchas otras, se recogen las líneas básicas en que se sustenta la propaganda:

La acción sistemática y reiterada, tanto en el tiempo como en el contenido del mensaje.

* La pluralidad de medios que utiliza para la transmisión de los mensajes.

Dirigida a la "muchedumbre". (no al individuo sino al "hombre masa")

* Su carácter sugestivo.

* Realidad tergiversada. (generalmente simplificada aplicando un reduccionismo totalitario).

* Importante carga emocional.

* El mensaje debe contener una sola idea suficientemente clara y comprensible para toda la población. 

3 Propaganda y comunicación.

Del estudio de todas estas formas de definir la propaganda podemos concluir que en la mayoría de los casos existe una relación directa con la comunicación intencionada, o mejor dicho la propaganda es una forma de comunicación y, como tal, presenta los mismos elementos que cualquier otro tipo de comunicación: (emisor, mensaje y receptor) y una serie de características especiales y diferenciadoras, que a lo largo de este trabajo iremos desgranando, analizando y describiendo (Cuadro 1).

"Cuando hablamos de propaganda nos estamos refiriendo a un sistema de comunicación humana en una sociedad donde cada mensaje, ya sea hablado, escrito, icónico, etc., cumple la función de transmitir una determinada ideología. Existe pues, una estrecha relación entre propaganda y comunicación". ${ }^{14}$

Martín Requero, M.I. (2000:29)

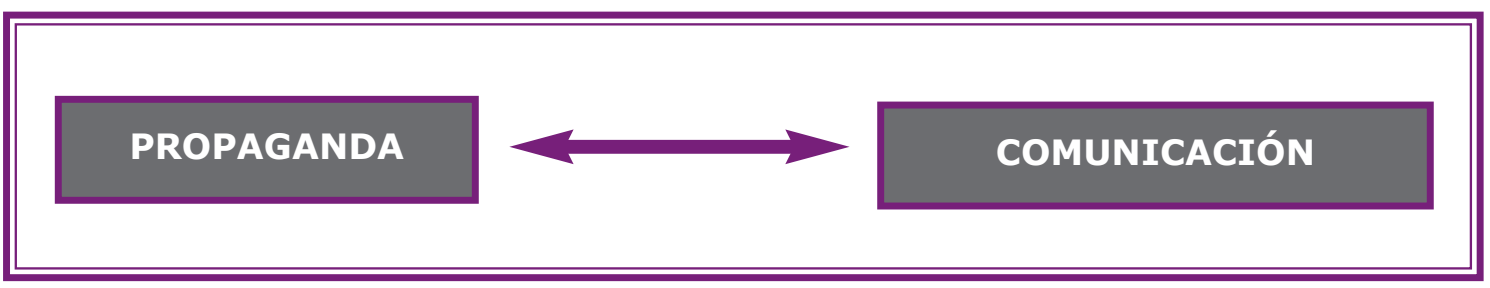

Cuadro 1. Elaboración propia

Si consideramos la propaganda como fenómeno comunicativo tenemos, obligatoriamente, que recurrir a los dos procesos comunicativos que podemos diferenciar: la información y la persuasión.

El concepto de información podemos definirlo como el proceso de comunicación destinado a que el emisor haga compartir al receptor determinados datos o conocimientos.

El proceso persuasivo se centra principalmente en la respuesta del receptor, ya que la finalidad del proceso comunicativo es que el mensaje conforme la conducta del receptor según la intencionalidad del emisor. Así un aspecto esencial de la propaganda es la persuasión:

"promover una dependencia interactiva emisor-receptor con el objetivo de influir sobre él. Por ello, una propaganda es un proceso de persuasión a su 
vez basado en técnicas psicológicas y en la sugestión". 15

Pizarroso, A. (1993:27)

Por tanto, la diferencia entre información y persuasión radicaría únicamente en la "intencionalidad", incluso podríamos afirmar que toda comunicación es informativa y persuasiva, pues una información, como fenómeno comunicativo, pura y aisladamente de cualquier tipo de influencia no existe en la realidad social (Cuadro 2). Además el sujeto que informa espera siempre una respuesta del receptor; es más, todo proceso comunicativo tiene como objetivo principal obtener respuesta.

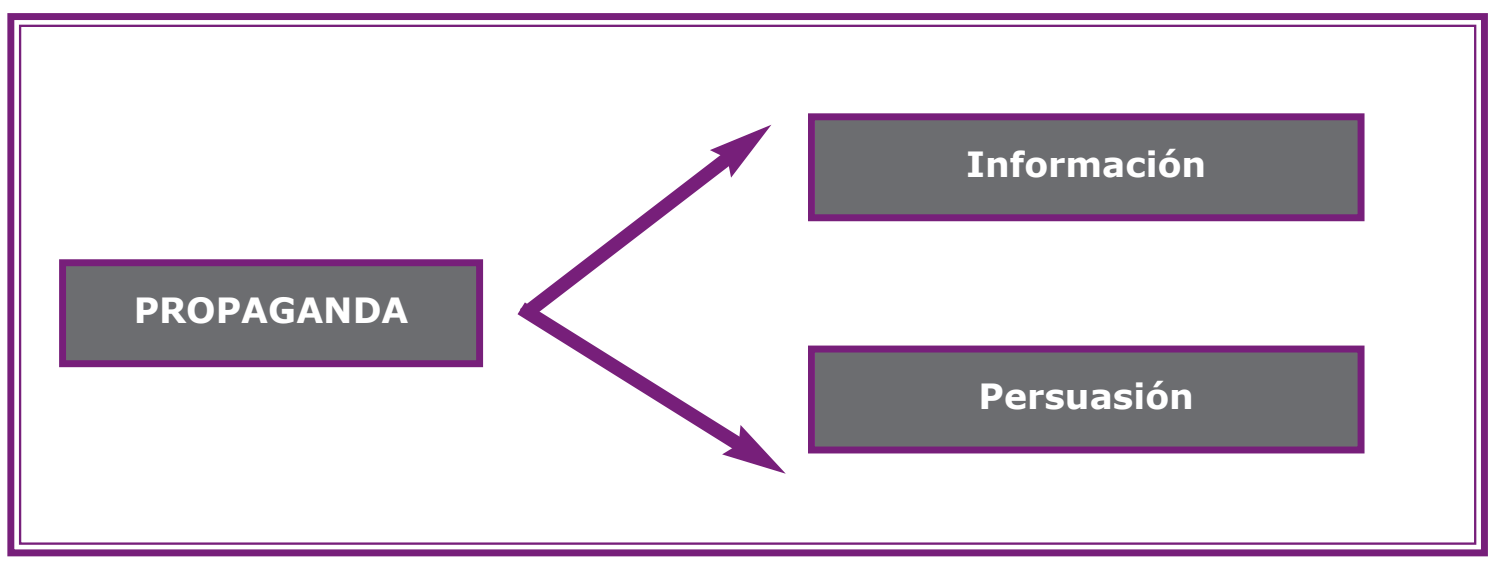

Cuadro 2. Elaboración propia.

Podemos afirmar que la persuasión como fenómeno comunicativo es inherente al ser humano, desde el momento que éste comparte espacios y tiempos con los otros, es decir, la convivencia con sus congéneres en la ciudad es la que determina que, para vivir de forma pacífica y armoniosa, se necesitan reglamentos y normas de conducta, esto es simplemente política: un conjunto de códigos y preceptos que todos deben asumir y cumplir para permitir el funcionamiento y el progreso social. Es decir se necesita una organización social y en estas organizaciones actúa la propaganda, pues esta necesita de entornos sociales complejos. Asimismo la propaganda es inherente a la organización estatal. Nos encontramos pues como Estado y Propaganda aparecen de forma inseparable. La propaganda necesita de la política para poder existir. 
"La propaganda no se realiza de manera aislada, sino que exige una política coherente y el coordinarse con esta política. Hacia fines de la Primera Guerra Mundial, Lord Northcliffe había conseguido hacer comprender a su gobierno que la propaganda de guerra a su cargo no era posible sin que se definiese una política precisa traducida en actos en el presente y que se asignasen objetivos para lo por venir". ${ }^{\mathbf{1 6}}$

Domenach, J. M. (1968: 39)

En una primera aproximación podríamos equiparar propaganda y persuasión o, mejor dicho, considerar la propaganda como una comunicación persuasiva. Ahora bien, el concepto de persuasión no es, en absoluto, preciso, es más funciona como una etiqueta que aglutina diferentes vías de influencia cognitivas, afectivas y conativas, que utiliza cualquier tipo de comunicación (Cuadro 3). Así podemos diferenciar convicción, persuasión, seducción, fascinación y modelización.

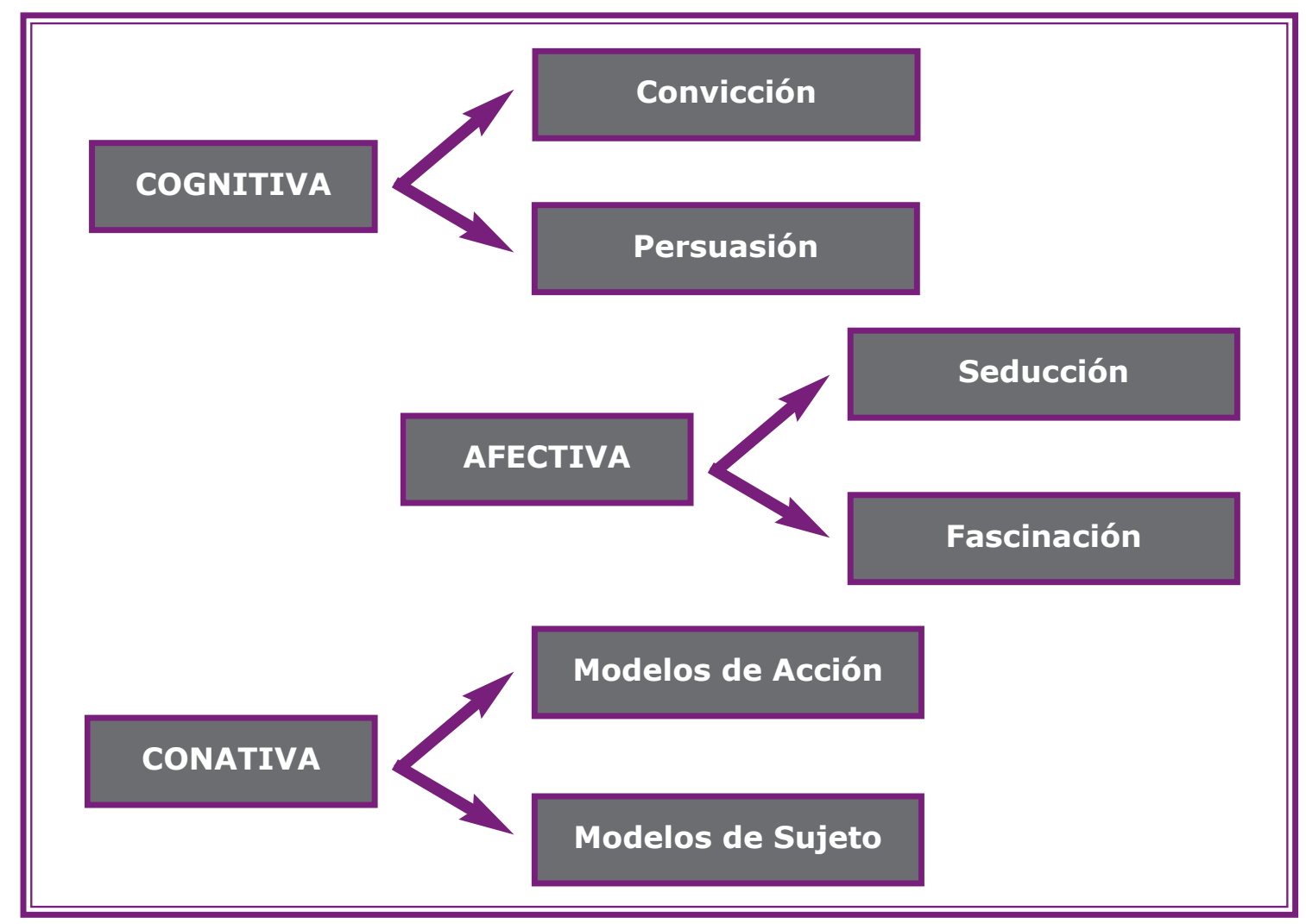

Cuadro 3. Vías de influencia de la comunicación. 
La convicción y la persuasión se dirigen al receptor como un ser racional que utiliza la inteligencia y el razonamiento lógico para decodificar la información. En esta primera vía de influencia observamos una diferencia sustancial entre la publicidad y la propaganda, esta última suele utilizar la amenaza, la ira, la culpa e incluso el miedo, empleando la sugestión para dominar la voluntad del receptor y dirigiendo sus conductas en una dirección determinada,

"sin proporcionar evidencia ni base lógica alguna para su aceptación, exista o no dicha base". ${ }^{17}$

Brown, (1991:24)

La propaganda, rara vez argumenta, se limita a realizar afirmaciones en favor a las tesis que defiende. Presenta las afirmaciones como verdades absolutas apelando, para ello, a las emociones y a los sentimientos, provocando una fuerte presión emocional.

La publicidad se dirige a un consumidor racional a través de la información, la argumentación, la demostración, los testimonios, la hiperatribución, etc., con la finalidad de hacer visibles los atributos de los productos anunciados y resolver los problemas funcionales con los que se enfrenta el ciudadano consumidor.

La seducción y la fascinación se dirigen a la parte emocional del ser humano. La primera se asienta en los sobresignificados y valores simbólicos de los objetos y de los hechos, se actúa sobre ellos y se les dota de características capaces de hacer sentir a las personas que los posean, dando así un sentido al mensaje; mientras que la segunda lo hace a través de la fuerza fascinadora que presentan las imágenes y sus posibilidades tecnológicas, así también con las palabras escritas o dichas de viva voz.

Por último la modelización actúa sobre los receptores presentando modelos de sujetos y modelos de acciones de conducta para su aprendizaje vicarial y para servir de modelos de identificación social. 
4 Propaganda y publicidad.

La propaganda y la publicidad de siempre se encuentran muy cercanas, incluso en algunas ocasiones se solapan o se confunden.

A continuación señalamos los aspectos que ambas comparten y las que las diferencian de forma sustancial.

Las vías de influencia que hemos señalado anteriormente de la propaganda coinciden, en gran medida, con las de la comunicación publicitaria, es decir ambos tipos de comunicaciones comparten las mismas herramientas para llegar a sus receptores, tal como queda reflejado en el siguiente cuadro (Cuadro 4).

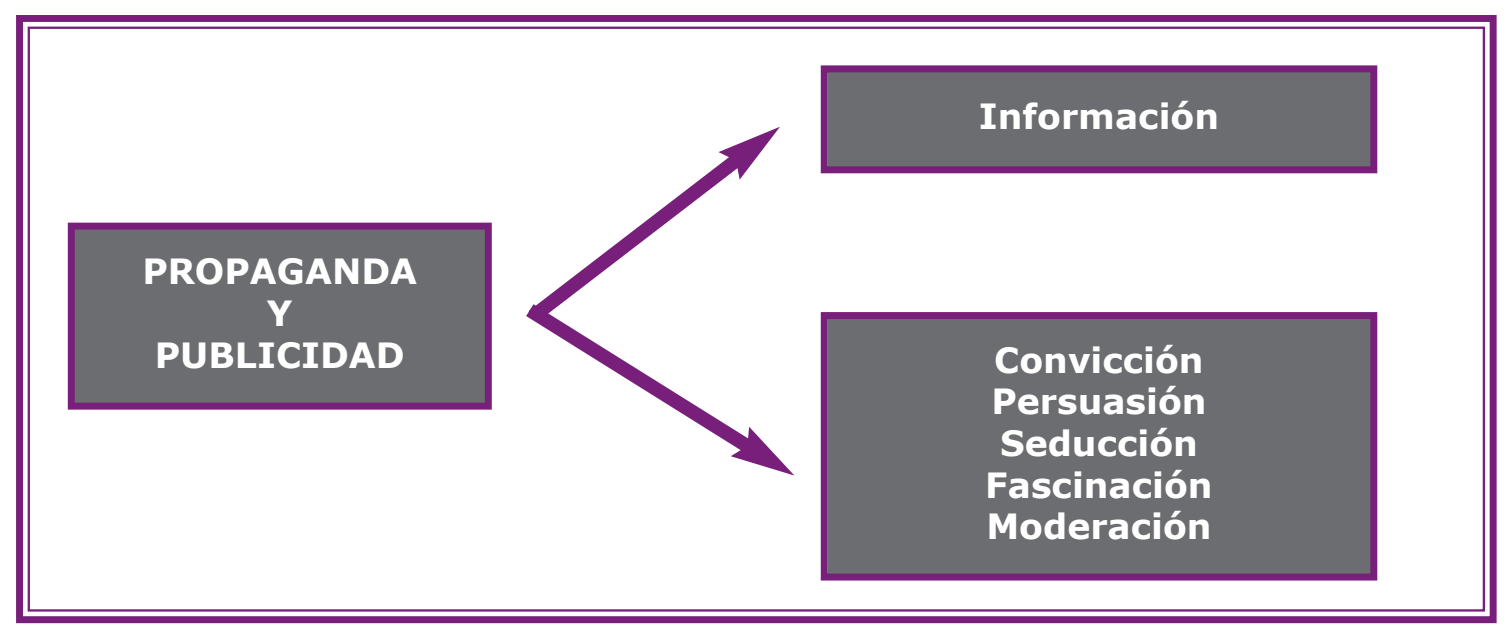

Cuadro 4. Elaboración propia

Pero lo cierto es que la propaganda también es un fenómeno mucho más complejo puesto que, además de la modificación, creación o reforzamiento de las actitudes y respuestas conlleva otras actividades como el control de la información, la dirección de la opinión pública, la manipulación, positiva o negativa, de conductas y la creación de los modelos de manifestarse una sociedad (Cuadro 5). 


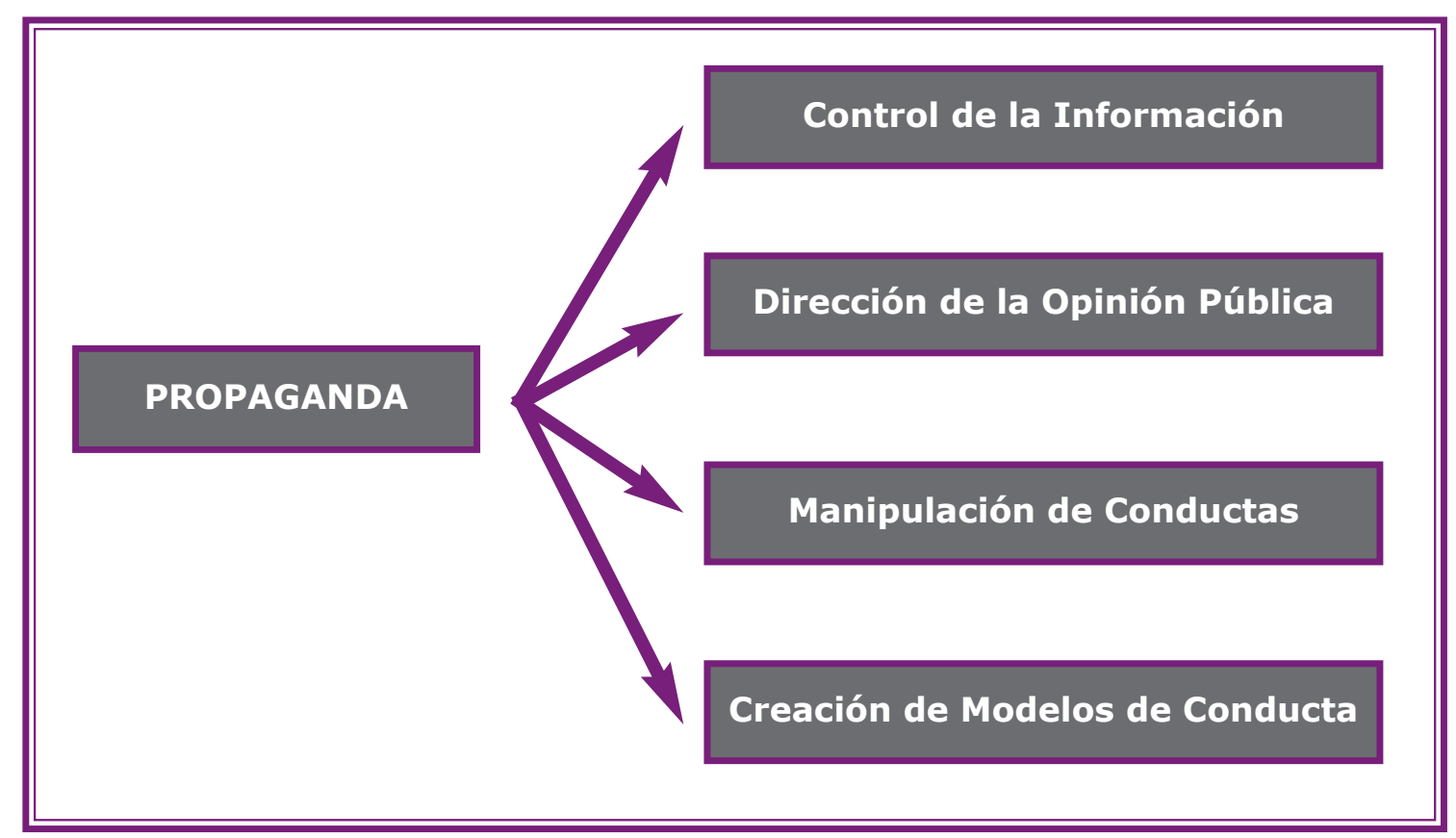

Cuadro 5. Elaboración propia

El estudio sistemático de la propaganda nos ha permitido encontrar muchas otras diferencias con la comunicación en general y con la publicitaria en particular. A modo de síntesis presentamos los siguientes cuadros (Cuadros 6 y 7) en el que podemos ver de forma resumida las diferencias encontradas entre ellas.

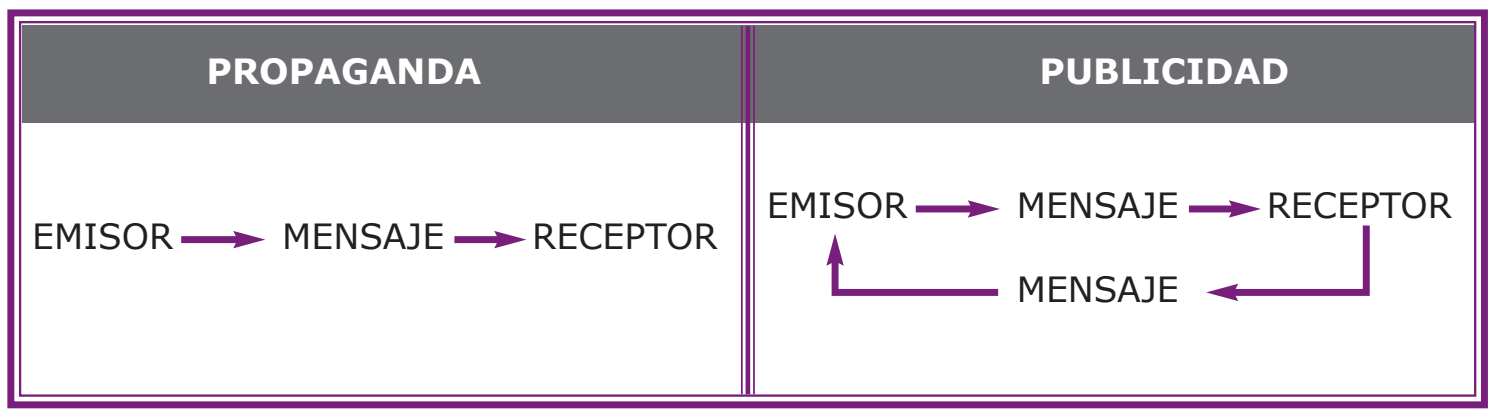

Cuadro 6. Elaboración propia 


\begin{tabular}{|c|c|}
\hline PROPAGANDA & PUBLICIDAD \\
\hline $\begin{array}{l}\text { - Unidireccional } \\
\text { - Monológica } \\
\text { - Mensaje cerrado } \\
\text { - Comunicación pasiva } \\
\text { - Sin crítica } \\
\text { - Verdad Absoluta } \\
\text { - Violenta } \\
\text { - Impuesta } \\
\text { - Sin espacio para la reflexión } \\
\text { - Escenarios Totalitarios } \\
\text { - Carácter solapado de sus objetivos } \\
\text { - Es la antitesis del pensamiento libre } \\
\text { - Control absoluto del pasado y del } \\
\text { presente para preparar el futuro } \\
\text { - Recurre a la intimidación, la amenaza } \\
\text { y el miedo para conseguir adeptos } \\
\text { - Enmarcada en un plano ideológico y } \\
\text { político }\end{array}$ & $\begin{array}{l}\text { - Bidireccional } \\
\text { - Dialógica } \\
\text { - Mensaje Abierto } \\
\text { - Comunicación activa } \\
\text { - Con crítica } \\
\text { - Verdad relativa } \\
\text { - Pacífica } \\
\text { - Propuesta } \\
\text { - Aabierta a otras posibilidades y } \\
\text { planteamientos } \\
\text { - Entornos de competencia } \\
\text { - Manifestación clara de los objetivos } \\
\text { - Respeta la libertad de pensamiento } \\
\text { - Los tres tiempos -pasado, presente y } \\
\text { futuro- es patrimonio de la ciudadanía } \\
\text { - Utiliza la argumentación, la demostración } \\
\text { y la retórica para convencer } \\
\text { - Enmarcada en un escenario de mercado } \\
\text { y de consumo }\end{array}$ \\
\hline
\end{tabular}

Cuadro 7. Elaboración propia

La propaganda podemos compararla con la publicidad en cuanto tiende a crear, modificar o confirmar actitudes y opiniones y usa algunos de los medios propios de ésta; pero se distingue de ella porque persigue un fin ideológico y no comercial. Las necesidades o las preferencias que suscita la publicidad están relacionadas a un producto particular, mientras que la propaganda sugiere o impone creencias o reflejos que a menudo modifican el comportamiento, el psiquismo y aún las convicciones religiosas o filosóficas. La propaganda por consiguiente, influye en la actitud fundamental del ser humano. En este sentido podríamos compararla con la educación; pero las técnicas que emplea habitualmente $y$, sobre todo, su deseo de convencer y subyugar, sin formar, la hacen su antítesis. 
La propaganda es por tanto un conjunto de acciones esencialmente de naturaleza comunicativa. No obstante, también utiliza, otro tipo de acciones que no lo son. Lo que sí comparten todas las acciones propagandísticas es un carácter ideológico (político o religioso).

"Los desfiles o la moda (la ropa "a lo Mao", la barba castrista, el mono azul republicano) son en ocasiones herramientas propagandísticas. Pero también lo puede ser la pintura y el cine, como lo han sido en la Rusia soviética o en la Alemania nazi. El periodismo, el arte plástico y la arquitectura, la música y la literatura, las vestimentas, los comics, etc., puestos al servicio de una ideología se constituyen como instrumentos de propaganda". 18

Eguizabal, R. (2007:33)

Vemos pues, cómo la propaganda utiliza todas las técnicas y recursos a su alcance para conseguir sus objetivos y obtener sus pretensiones. Así, empleará los medios convencionales: folletos, carteles, medios de comunicación social y también el uso del "acontecimiento" y todos los símbolos para lograr, como ya ocurrió en otras épocas históricas (como la Revolución francesa o la dictadura del General franco, por citar tan sólo un par de ejemplos) que todo se vuelva propaganda: la forma de vida, la manera de vestir, las fiestas, los mitos y los símbolos, incluso las formas de comunicación social.

"La propaganda es polimórfica y cuenta con recursos casi ilimitados". 19

Domenach, J. M. (1968: 19) 
5 Técnicas de la propaganda.

La mayor parte de las técnicas que emplea la propaganda se sustentan en mecanismos muy simples y comunes a la mente humana:

"La mayoría de la gente quiere creer que los problemas son sencillos en vez de complejos, quiere que se confirmen sus prejuicios, quiere sentir que no está marginada, lo que implica que los otros sí lo estén, y necesitan señalar a un enemigo que cargue con sus frustraciones". 20

Brown, J.A.C. (1991: 25)

Las técnicas que utiliza la propaganda fueron objeto de análisis científico y explicadas en los años posteriores a la primera Guerra Mundial, después de haber sido utilizadas en la contienda abundantemente y por todos los participantes en el conflicto.

J.M. Domenach (20) fue el encargado de difundirlas en "La propagande politique", obra en la que formula cinco leyes concretas o reglas de uso, a título de principios rectores deducibles de los hechos históricos entonces recientes, siguiendo en parte una obra anterior de P. Quentin (1943) del mismo título. Tales leyes son las que todo propagandista político, especialmente en tiempos de guerra, ha tenido de hecho en cuenta a la hora de producir su desinformación sistemática y remitirla, o imponerla, a los medios. Domenach las ilustra con detalle, pero aquí nos limitamos a dar alguna indicación sobre cada una, sólo a efectos de disponer de un marco sobre la forma que adopta la propaganda.

1.- La primera ley es la de la simplificación y del enemigo único. Consiste en dividir su doctrina y sus argumentos en algunos puntos que serán definidos tan claramente como sea posible. Toda una gama de fórmulas está a disposición del propagandista: manifiestos, profesiones de fe, programas, declaraciones, catecismos, los que, bajo una forma generalmente afirmativa, enuncian una cierta cantidad de proposiciones en un texto breve y claro.

Las tres grandes campañas propagandísticas que han modificando significativamente el mundo: la fe católica, la Revolución Francesa y el Marxismo, se esforzaron por resumir sus ideas de forma clara y concisa. Así la fe Católica redactó el Credo, donde se condensa toda su ideología, La Revolución Francesa definió la Declaración de los Derechos del Hombre y del 
Ciudadano, en la que se refleja la ideología y sigue siendo hoy en día un testimonio de los principios que defendía. Tanto el Credo Católico, como en la Revolucionaria Declaración de Derechos, están redactados con frases cortas y muy rítmicas, fáciles de memorizar y repetir al pie de la letra. Por último, encontramos el Marxismo, con el manifiesto comunista, texto sustancialmente más extenso que los anteriores pero que, al igual que ellos, condensa toda su doctrina así como sus efectos.

Para conseguir una mayor simplicidad las obras propagandísticas suelen utilizar un lenguaje asociado a los valores y creencias profundamente arraigados por el público, sin proporcionar información de apoyo o de razón. Con frecuencia apelan a nociones tales como el honor, la gloria, el amor a la patria, el deseo de conseguir la paz, la libertad y hacen referencia a los valores familiares. Recurren a fórmulas breves y concisas como los eslóganes, así recordamos el "grito de guerra" del régimen nazi: Heil Hitler, Ein Volk, ein Reich, ein Führer ,el,"Creer, obedecer, combatir", de Mussolini, el "todo el poder para los soviets", del socialismo soviético, el iArriba España!, "España, una, grande y libre" del General Franco, y símbolos como el puño en alto, el saludo fascista, etc.

Esta ley indica que se busca siempre la individualización del líder o del grupo de pertenencia o bien del grupo adversario. En este último caso, el enemigo se personaliza en un rostro concreto a quien atribuir todos los males, la violencia y los desastres que padecen los ciudadanos.

2.- Ley de la exageración y desfiguración. La exageración de las noticias es un procedimiento periodístico frecuentemente utilizado por la prensa partidista que hace resaltar todas aquellas informaciones que le son favorables, así utiliza cualquier acontecimiento en su favor y lo transforma en pruebas amenazantes. El emisor propagandístico maximiza su eficacia en los medios transmitiendo información ya valorada, ampliada o desfigurada en favor de su causa. Destacar lo interesante, descontextualizar frases, adaptarse al nivel lingüístico del receptor y huir de los detalles son, entre otros, algunos modos de ilustrar esta ley.

Domenach, explica esta ley poniendo claros ejemplos de su utilización por el régimen nazi: 
"La propaganda hitleriana se sirvió sistemáticamente de la noticia como medio para dirigir los espíritus. Las "informaciones" importantes no se daban nunca en bruto. Cuando aparecían ya estaban preparadas, cargadas de un potencial de propaganda. Un ejemplo de esto lo da la manera cómo la prensa alemana presentó una huelga declarada en los Estados Unidos y que nos refiere Walter Hagemann. No se decía: "los huelguistas rechazan un laudo arbitral de Roosevelt", sino "los huelguistas responden con un rechazo del laudo arbitral a la estúpida política social de Roosevelt". Como se ve, la exageración comienza en la etapa de la información y se acentúa, generalmente, en el título y en el comentario". 22

Domenach, J. M. (1968: 25)

3.- Ley de orquestación. La primera condición de una buena propaganda es la repetición incesante de los temas principales. Esta ley se refiere a la repetición incansable de los temas básicos de la campaña propagandística. No obstante, esta reiteración debe ser presentada de forma orquestada para que no derive en un discurso monótono, por lo que hay que adecuar su estructura y presentación al medio o canal en el que se va difundir. En este sentido también se fijará en las herramientas que utiliza habitualmente la publicidad para llegar a los consumidores y producir un cambio de actitud. Esta misma idea la conoce y refleja Hitler cuando escribía:

"El éxito de un anuncio, se debe a la persistencia y asiduidad con que se emplea". 23

Hitler, A. (1925:94)

La orquestación de un tema determinado consiste en su repetición por todos los órganos de propaganda en formas adaptadas a los diversos públicos, que deben ser tan variadas como sea posible. "Para un público diferente, siempre un matiz diferente", prescribía una de las directivas de Joseph Goebbels, ministro de la propaganda del régimen nazi, quien pronto toma conciencia de la importancia de esta técnica que ya había descubierto la Iglesia Católica.

"Con una repetición suficiente y la comprensión psicológica de las personas implicadas, no sería imposible probar que de hecho un cuadrado es 
un círculo. Después de todo ¿qué es un cuadrado y un círculo? Son meras palabras, y las palabras pueden moldearse hasta descifrar las ideas". ${ }^{24}$

\section{(cit. en Pratkanis y Aronson 1994:77)}

Por tanto la condición esencial de una buena orquestación es, en todos los casos, adaptar con cuidado y delicadeza el tono y la argumentación a los diferentes públicos. Esto, que en principio parece sencillo, en la práctica resulta con frecuencia muy difícil para propagandistas de formación intelectual, que no pueden hablar el lenguaje que conviene a las clases sociales más bajas como los campesinos o los obreros. En este sentido, podemos comprobar cómo Hitler era un auténtico maestro por el arte con que variaba sus discursos para provocar los efectos deseados.

"... ante sus antiguos compañeros evocaba el heroísmo de las luchas pasadas; ante los campesinos, hablaba de la dicha familiar; ante las mujeres, de sus deberes de madres alemanas, etc. Napoleón, a quien puede considerarse uno de los precursores de la propaganda moderna, especialmente por su habilidad en la concisión y el slogan, sabía también dirigirse tanto a sus tropas como a los académicos o a los musulmanes de Egipto en los términos adecuados". 25

Domenach, J. M. (1968: 28)

Las técnicas más habituales que se utilizan en esta ley son: los ataques apabullantes al rival, la apariencia de diversidad en las fuentes de información, el lanzamiento de "globos sonda" y el silenciamiento de los temas incómodos entre otros.

4.- Ley de transfusión. Los mensajes propagandísticos no surgen de la nada sino que, por regla general, la propaganda opera siempre sobre un sustrato ya existente, bien sea una mitología nacional (la Revolución Francesa, los mitos germánicos, etc.), o de un simple complejo de odios y de prejuicios tradicionales: "fobias" o "filias" diversas.

Un principio conocido por todo orador público con un mínimo de experiencia es el de no contradecir frontalmente a una muchedumbre, comenzando por declararse de acuerdo con ella, para colocarse en su 
corriente, antes de doblegarla. Se trata de la capacidad de recoger el apoyo popular apelando a sentimientos e ideas ya enraizados en el colectivo. Primero se investiga el sustrato preexistente de emociones, fobias, mitos y gustos; después se apela a ellos adaptando el mensaje y maximizando su eficacia.

Teniendo en cuenta todas estas consideraciones sería erróneo, por lo tanto, pensar que la propaganda puede ser un instrumento todopoderoso que oriente las masas en cualquier dirección. Aún en los casos más extremos de "atiborramiento de los cráneos" o de "lavado de cerebros" siempre se hace en un sentido bien determinado.

5.- Ley de unanimidad y de contagio. Desde la existencia de la sociología se conoce la gran importancia que tiene la presión del grupo en la configuración de la opinión individual y los múltiples conformismos que nacen en las sociedades. Esta presión que ejercen los grupos también ha sido confirmada por los psicólogos modernos y especialmente por los especialistas norteamericanos en opinión pública. Es conocido por todos aquellos que practican los "sondeos de opinión" que una persona puede tener sobre un mismo tema dos opiniones muy distinta $y$, a veces, hasta contradictorias, según opine como miembro de un grupo social (Iglesia, partido, etc.), o bien a título personal. Está claro que dos opiniones contrarias subsisten en el espíritu del sujeto sólo por la presión de los diversos grupos sociales a los que pertenece. La mayoría de los hombres desean, ante todo, estar en armonía con sus semejantes, rara vez osarán perturbar la armonía que reina en torno de ellos expresando una idea contraria a la de la generalidad; de aquí la importancia que adquiere la opinión de la mayoría que, incluso cuando no hay certeza, se llega a considerar como un principio general digno de ser aceptado y respetado por todos. Por todo ello, se infiere que muchas de las opiniones públicas son en realidad una suma de conformismos, mantenidos porque el sujeto cree que su opinión es también unánimemente compartida por todos los que le rodean. La tarea de la propaganda será entonces la de reforzar esa unanimidad, incluso la de crearla artificialmente. Se basa en el principio de presión sobre el individuo por parte del grupo, que trata de homogeneizar las opiniones de sus miembros. Crear un clima y una ilusión de unanimidad social sobre el tema en cuestión, a fin de controlar las actitudes individuales, es el objetivo principal de muchas de las campañas propagandísticas. El recurso a manifestaciones, desfiles, banderas, uniformes, bandas de música, 
héroes, escritores, artistas y deportistas, es siempre eficaz.

Estas cinco leyes que Domenach expone conforman el marco general de las directrices que inspiran las campañas propagandísticas. Por otro lado nos gustaría reseñar la aportación que la historiadora belga Anne Morelli 26 expone en su libro "Principios elementales de la propaganda de guerra" donde traduce tales directrices "formales" a contenidos concretos, y los resume en los "diez mandamientos de la propaganda de guerra", que todo propagandista debe conocer, de la siguiente manera:

1.- Nosotros no queremos la guerra.

2.- El adversario es el único responsable de la guerra.

3.- El enemigo tiene el rostro del demonio.

4.- Enmascarar los fines reales de la guerra presentándolos como causas nobles.

5.- El enemigo provoca atrocidades a propósito, si nosotros cometemos errores es involuntariamente.

6.- El enemigo utiliza armas no autorizadas.

7.- Nosotros sufrimos muy pocas pérdidas, las del enemigo son enormes.

8.- Los artistas e intelectuales apoyan nuestra causa.

9.- Nuestra causa tiene un carácter sagrado.

10.- Los que ponen en duda la propaganda de guerra son unos traidores.

Morelli repasa cómo se utilizaron, por parte de todos los contendientes cada uno de estos "mandamientos" en las dos guerras mundiales y, más recientemente, en el conflicto de la antigua Yugoslavia. 
Queda de manifiesto que reiteradamente los dirigentes de cualquiera de los frentes, en cualquiera de las guerras, manejan los mismos argumentos y las mismas falsedades, con la intención de conseguir arrastrar a la población a la defensa irracional de posiciones ideológicas que con dramática frecuencia se traducen en una apología de la locura y la muerte.

Muchos otros autores han hablado de las diferentes técnicas propagandísticas utilizadas a lo largo de la historia y nos atrevemos a afirmar que sus aportaciones están contempladas, en mayor o menor medida, en las leyes y principios que aquí hemos referido.

\section{Recursos utilizados por la propaganda:}

Son tantos y tan variados los recursos utilizados por la propaganda, que nos es imposible detallarlos con profusión y exhaustividad; no obstante, y conscientes de las limitaciones, a continuación presentaremos un breve e interesante, al menos a nuestro juicio, recorrido por aquellos recursos que se han ultilizado con mayor frecuencia y notoriedad.

* Material impreso. Dentro del material impreso destacamos:

El libro es un instrumento básico en la propaganda; aunque resulta costosa la lectura, los libros han sido piezas claves en la historia de la propaganda. Recordemos la importancia del Manifiesto comunista (Fig. 1 y 2) uno de los tratados políticos más influyentes de la historia, encargado por la Liga de los Comunistas a Karl Marx y Friedrich Engels entre 1847 y 1848, y publicado por primera vez en Londres el 21 de febrero de 1848. También resulta incuestionable la trascendencia de las obras de Lenin, (publicadas entre los años 1895 y 1923), y Stalin sobre la propaganda comunista, así como la gran la tirada del Mein Kampf (Mi Lucha) (Fig. 3), de Adolf Hitler. Todos ellos son libros de palpitante actualidad y sin duda unas de las obras claves para comprender el panorama político, económico y social de un momento histórico determinado. Todos ellos circulan por el mundo habiendo sido traducidos prácticamente a todos los idiomas y habiendo alcanzado las cifras de varios millones de ventas. 

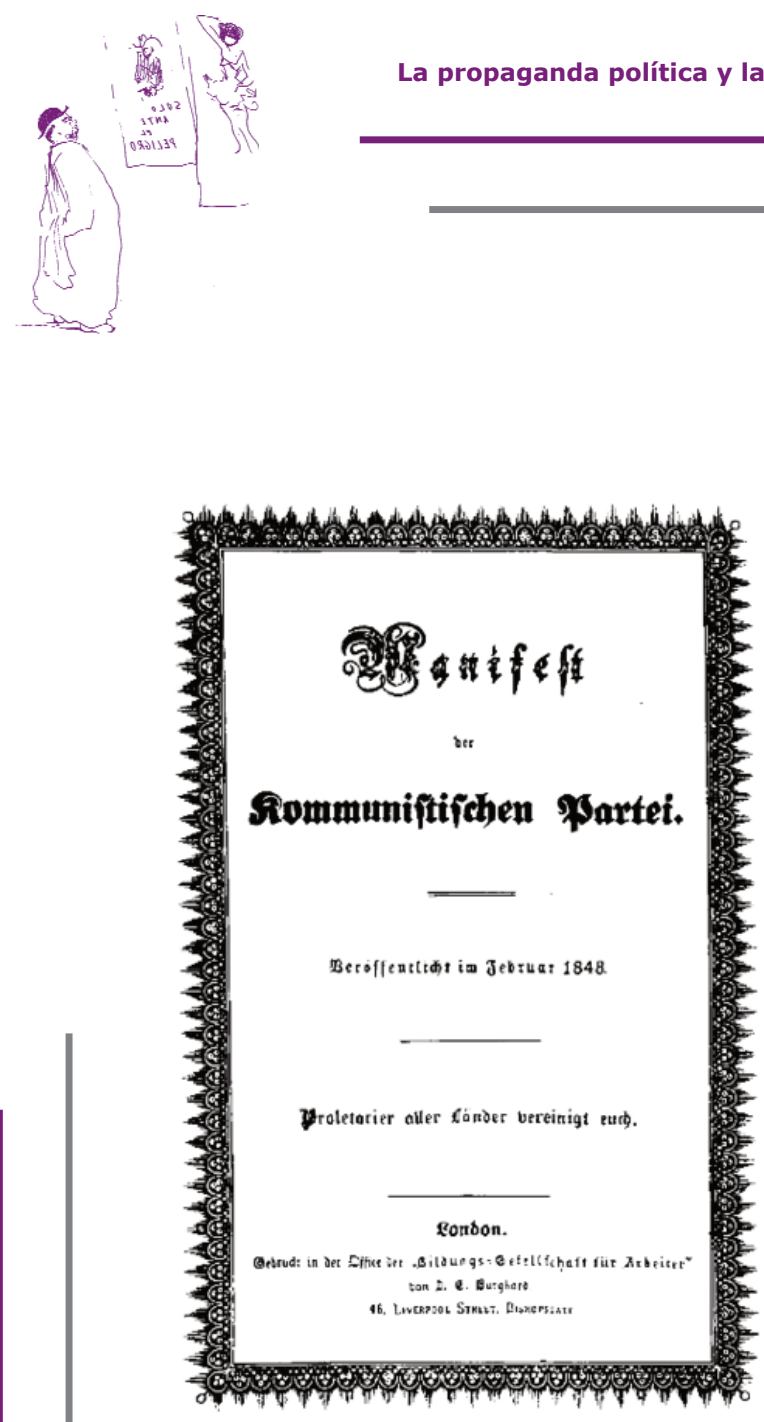

Fig. 1 y 2.

Distintas portadas del Tratado Comunista de Karl Marx.

Fig. 3.
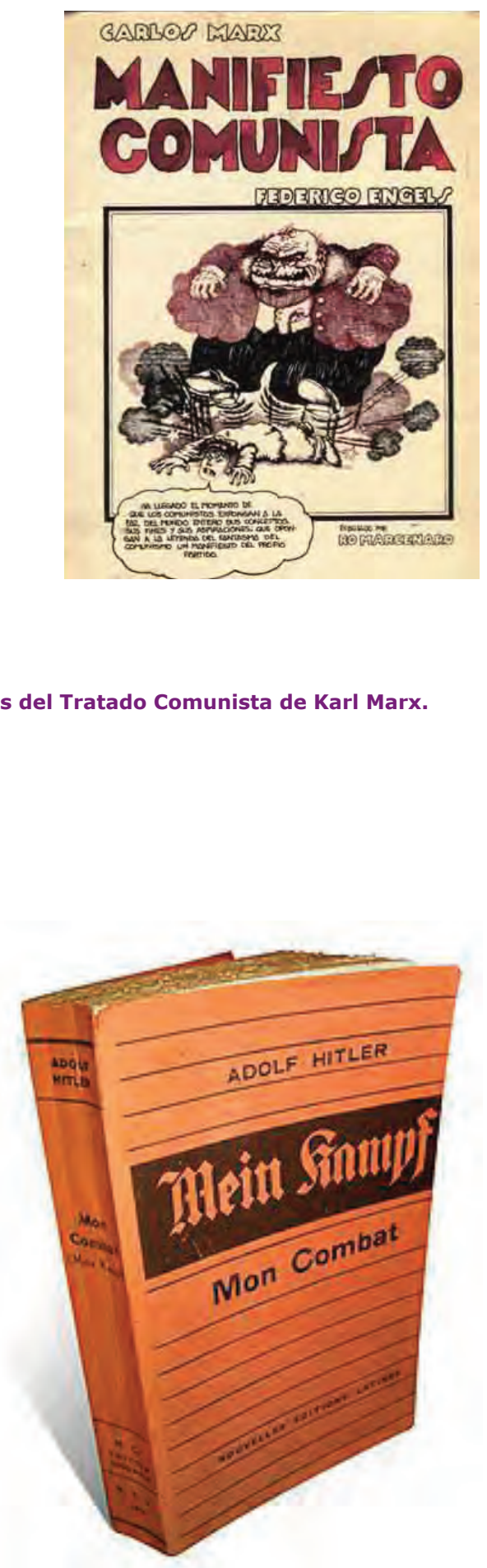
* El panfleto. El término panfleto, es de origen incierto, aunque es probable que provenga de la forma anglo-latina panfletus. Ha designado a lo largo de la historia diversas formas de texto. En Inglaterra, a partir del siglo XVII, tomó el significado de "libelo" o "escrito polémico" y, un siglo más tarde, tanto en Francia como en Inglaterra, pasó a designar directamente a un instrumento escrito de controversia política. Fue el arma predilecta de la propaganda en el siglo XIX, utilizado más tarde por los comunistas.

Podríamos definirlo como libelo de carácter agresivo y/o humorístico, artículo o publicación relativamente breve de contenido político y de aparición espasmódica y discontinua, generalmente impreso de modo urgente y en calidad exigua. Escrito de oposición, irónico y violento de distribución manual y habitualmente clandestina.

El panfleto político, parafraseando a Courier, es "veneno impreso", es una maldición, es un texto de agitación que expresa un léxico subterráneo ausente en los medios de comunicación oficial.

El término panfleto político hace referencia a una manifestación escrita urgente asociada con una finalidad política o ideológica predeterminada, inmersa en una tradición de ausencia de respeto hacia los poderes instaurados. Supone un espacio de escritura militante, breve y direccionado, inserta en un horizonte de sentidos compartidos vinculados con una lucha determinada e inmediata que representa una situación concreta de descontento. El panfleto político circula de mano en mano, y su propia materialidad denota la urgencia de su propósito y el compromiso de sus artífices (Fig. 4, 5 y 6).

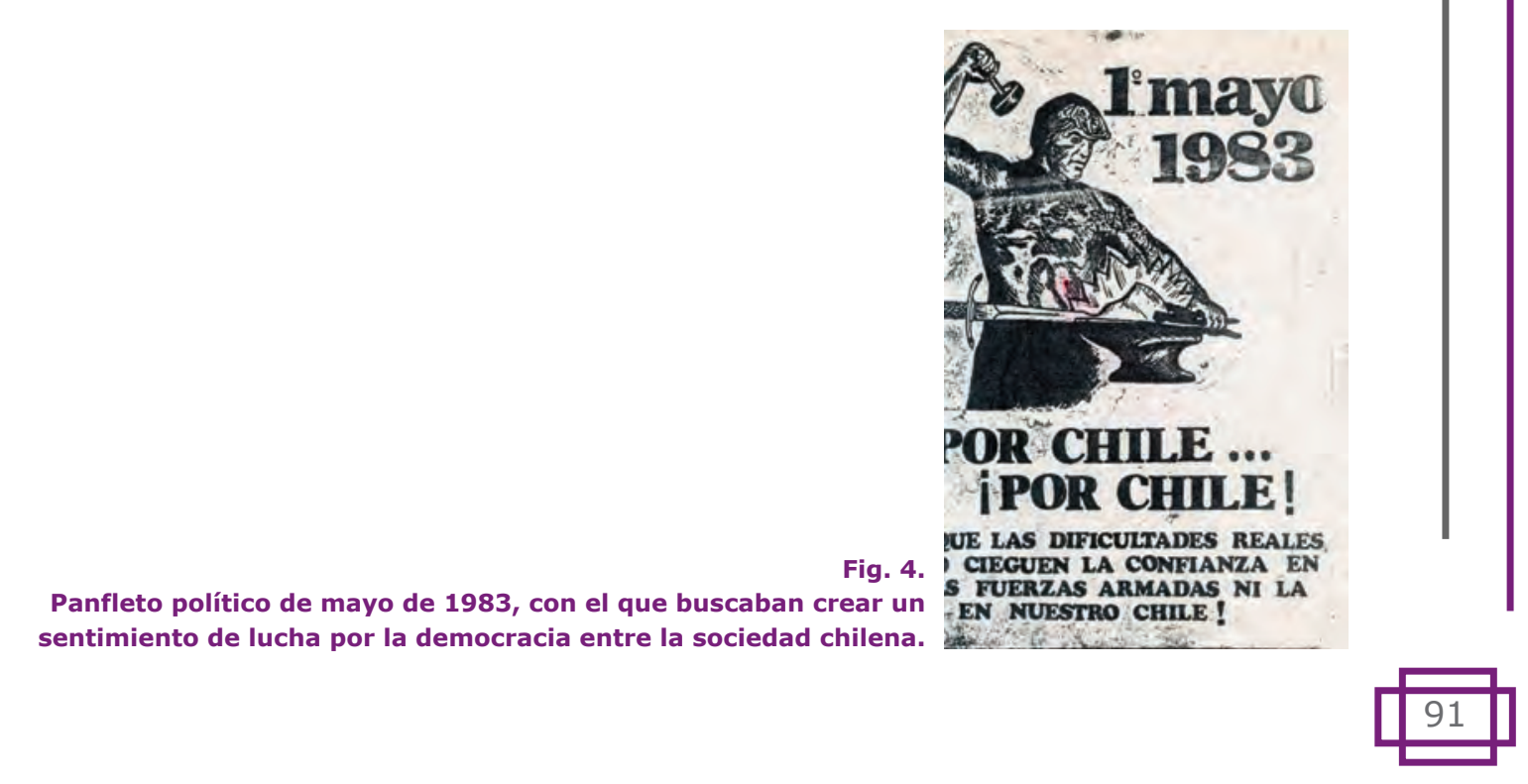




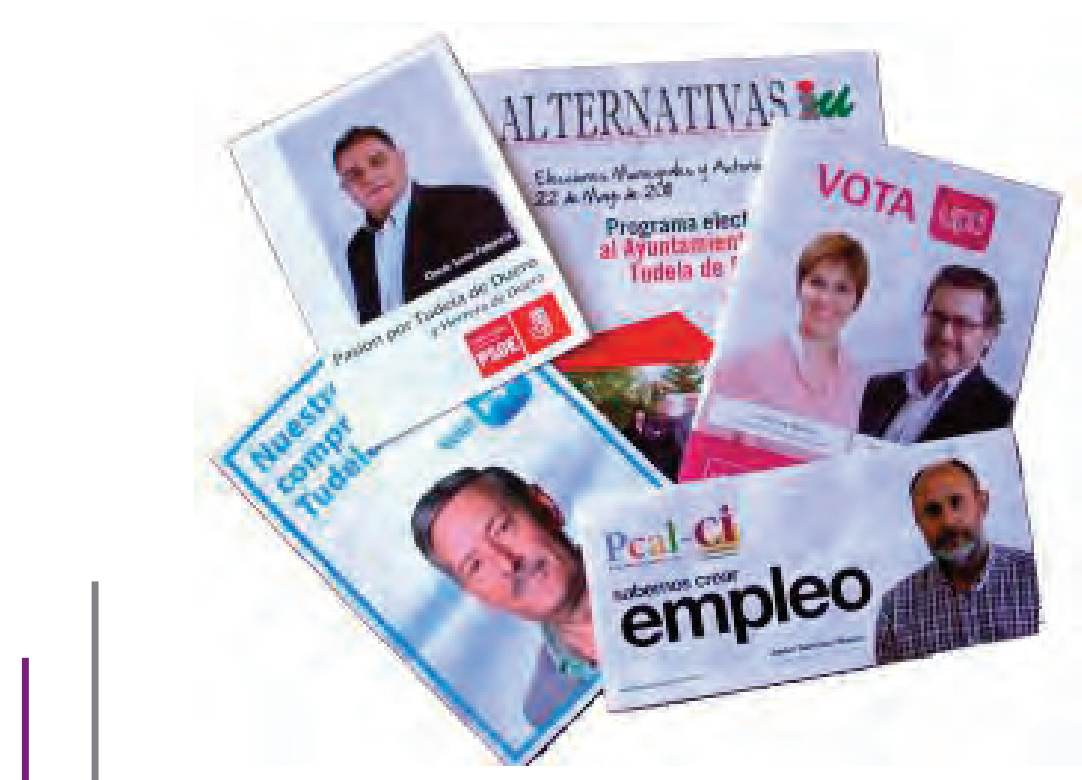

Fig. 5 y 6.

Los panfletos son utilizados por los distintos partidos políticos para resumir los puntos fuertes de sus programas electorales y pedir el voto ciudadano.

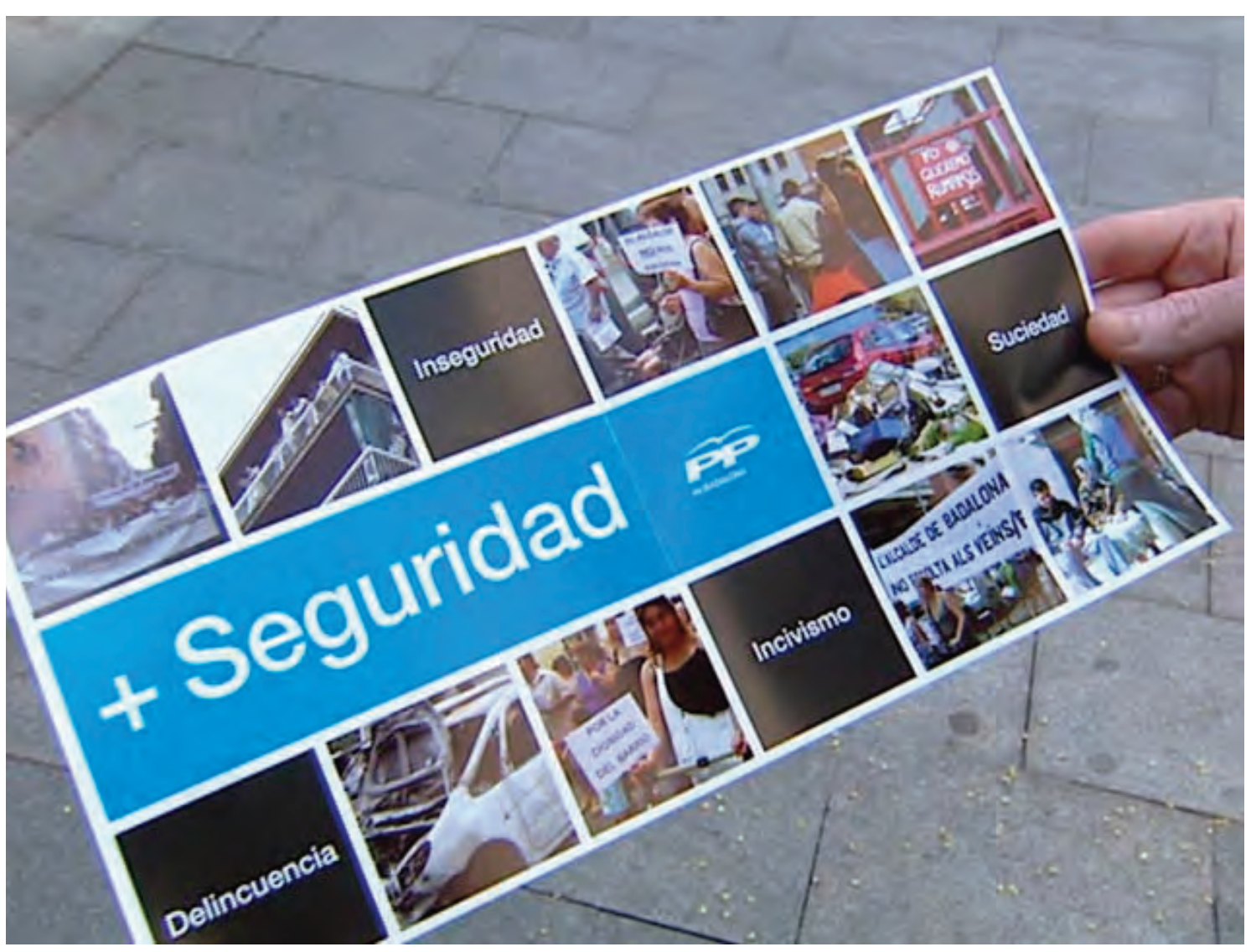


* El periódico. Este medio de comunicación ha sido y sigue siendo el instrumento principal de la propaganda impresa. Comprende varias modalidades, desde los de gran tirada hasta los más modestos periódicos de barrio o de fábrica; incluso puede ser distribuido y expuesto (periódicos murales). El periódico, por su propia naturaleza, es un medio ideal para la configuración del pensamiento político y la determinación de tendencias de pensamiento. La información presentada como objetiva, real y verídica, junto a sus secciones de análisis y contextualización de la misma desde las firmas de prestigiosos colaboradores, conforman un instrumento ideal para la transmisión de premisas de contenido ideológico, además el periódico suele ser visto por una gran parte de la población como un instrumento de reflexión y análisis de la actualidad al que se le otorga una gran credibilidad (Fig. 7, 8, 9 y 10).
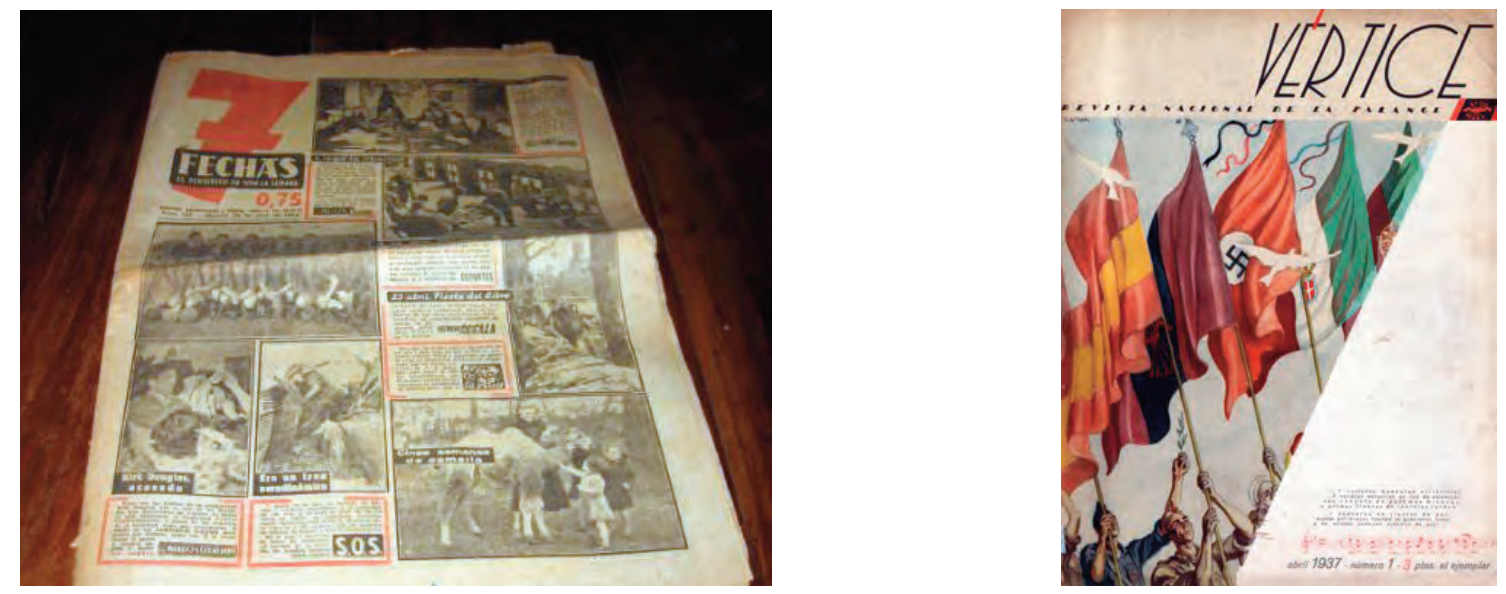

Fig. 7, 8, 9 y 10. Imágenes correspondientes a distintas publicaciones realizadas por el bando Nacional (arriba) y por el bando Republicano (abajo).
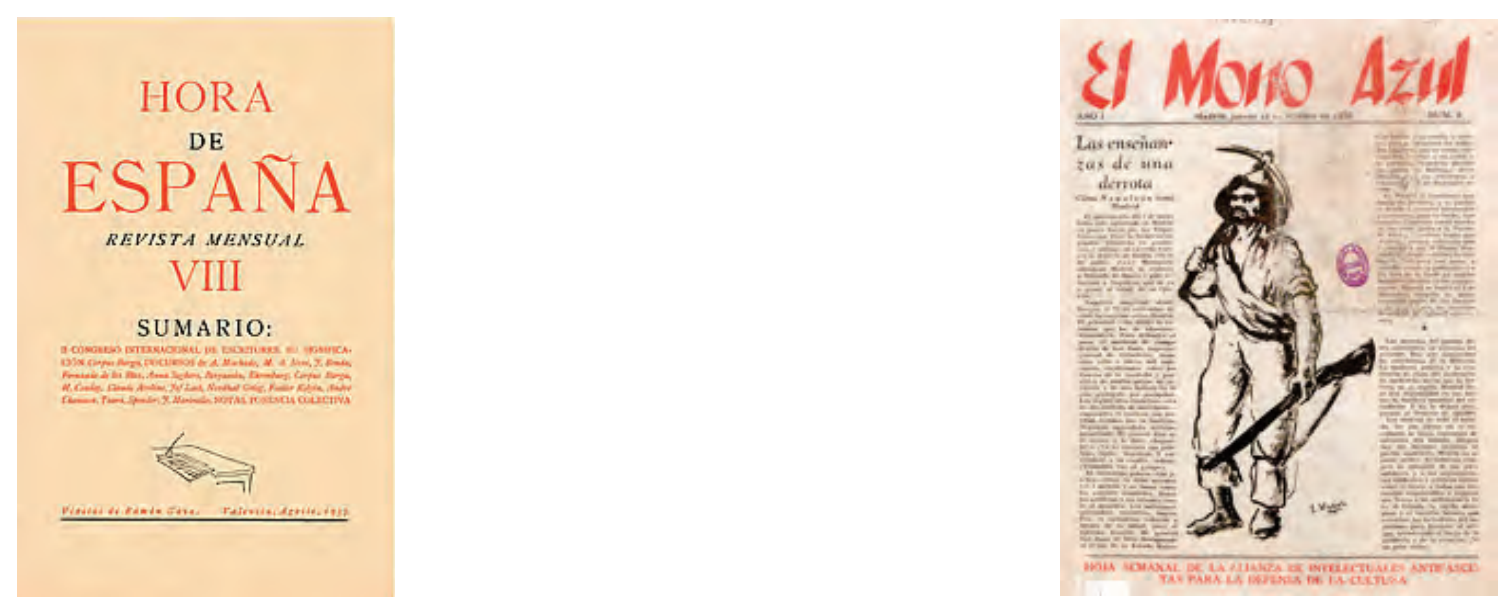


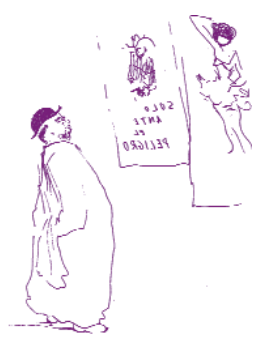

* El cartel. Es un aviso que comunica un evento futuro o una acción presente, generalmente de grandes dimensiones para que sea capaz de llamar la atención del público al que va dirigido (Fig. 11, 12, 13, 14 y 15).

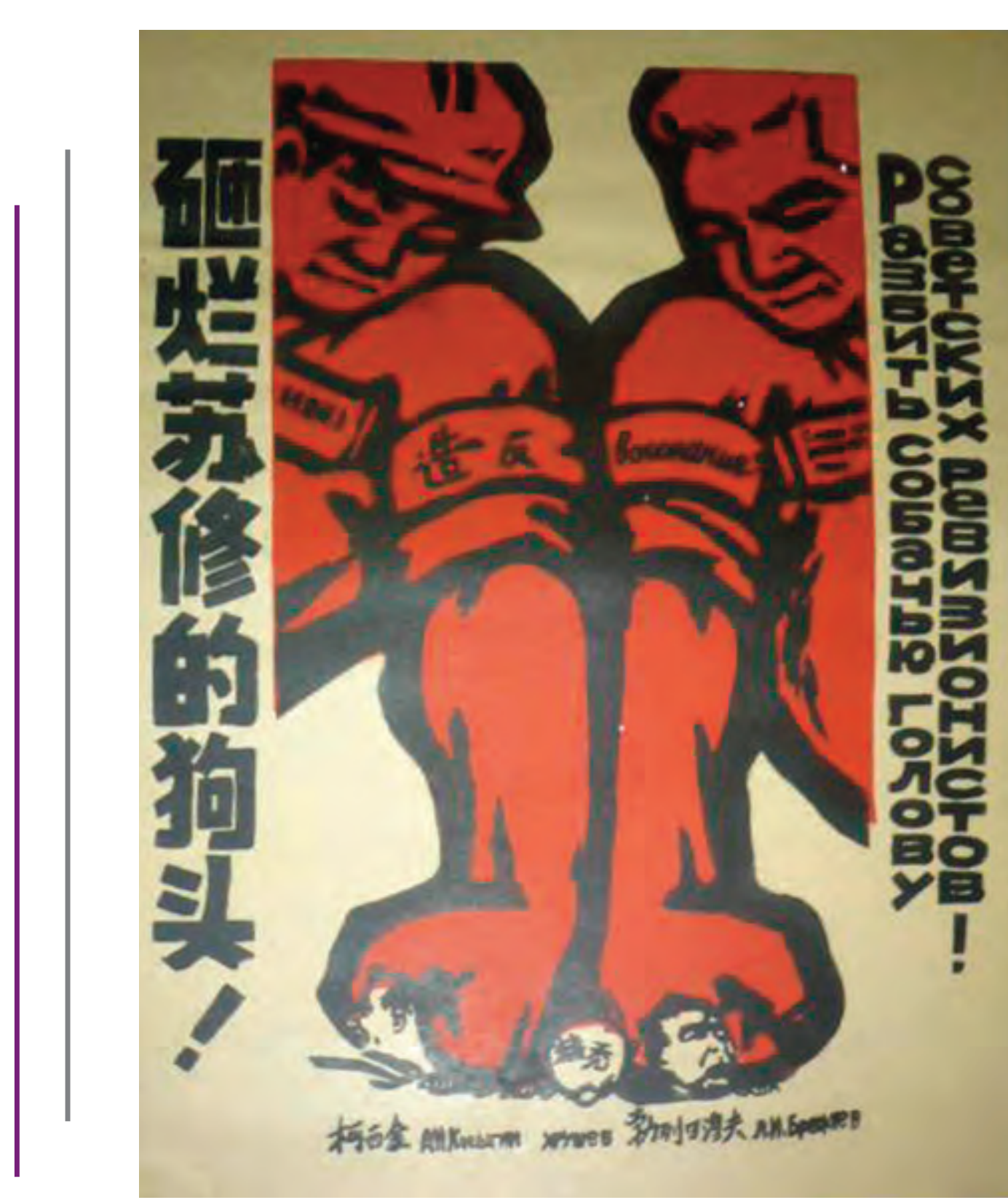

Fig. 11.

Cartel Político de la Revolución China. 
Fig. 12.

Reclutamiento de soldados para el ejército de Estados Unidos.
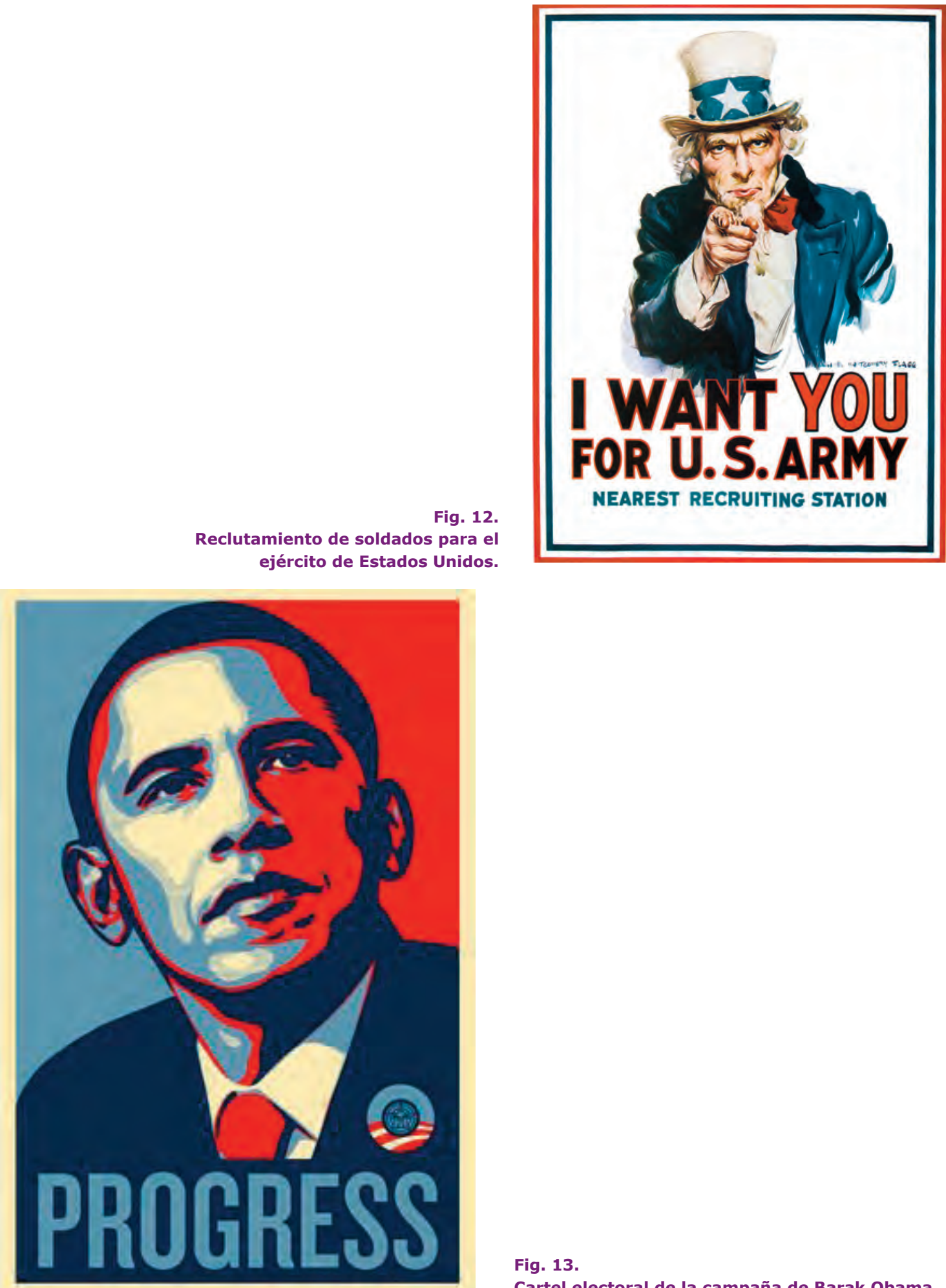

Fig. 13.

Cartel electoral de la campaña de Barak Obama. 

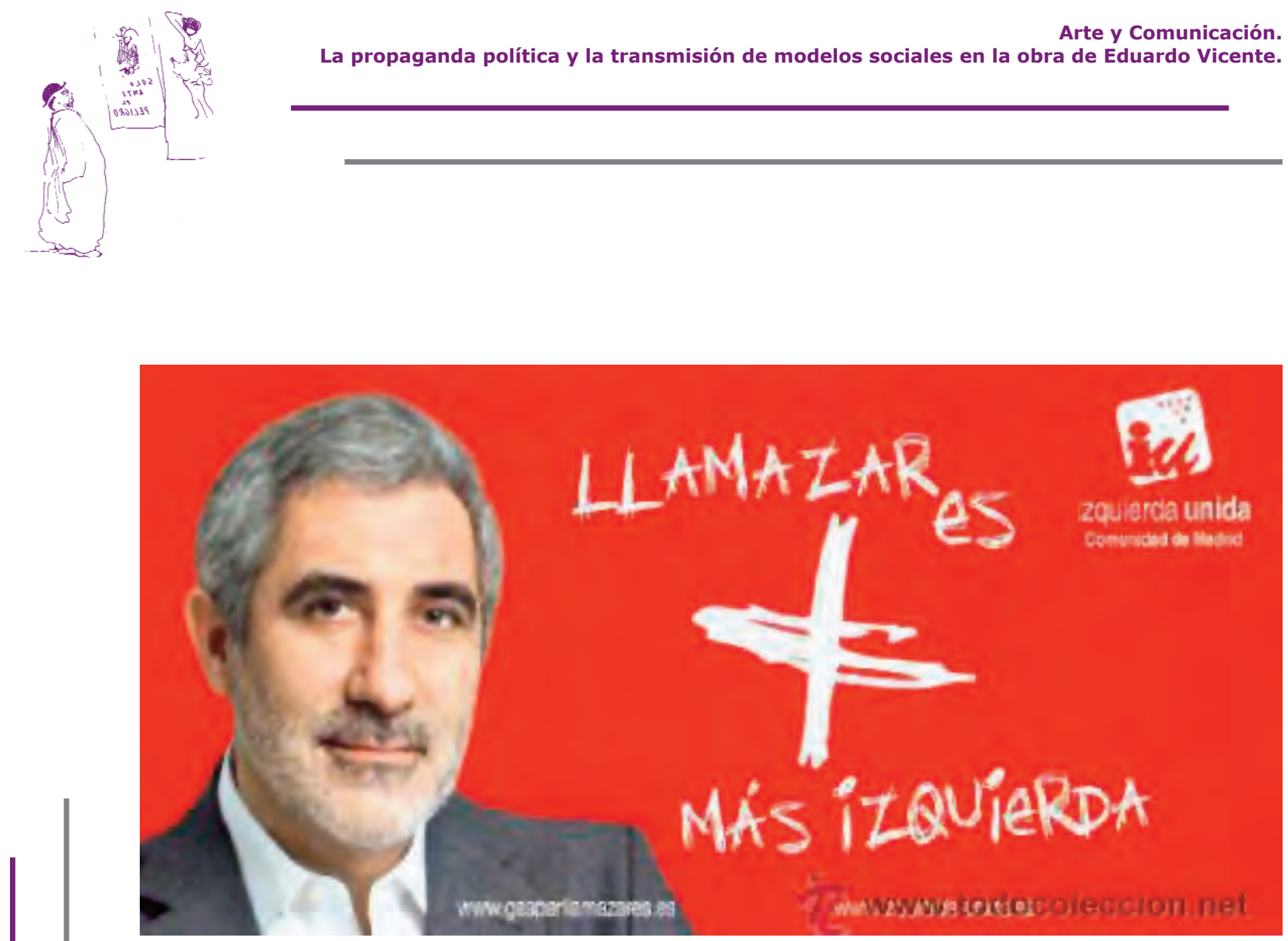

Fig. 14 y 15.

Ejemplos de creatividad en vallas publicitarias de los partidos progresistas españoles.

\section{la mayor tasa de paro de Europa 4 millones de desempleados} Por todo
lo logrado. PSOE $\left[\begin{array}{ll}\text { Motivos } \\ \text { para creer }\end{array}\right.$ 
El volante propagandístico. Es un papel impreso, generalmente del tamaño de media cuartilla, que se distribuye directamente de mano en mano a las personas en las calles y en el cual se anuncia, pide, cuestiona o hace constar algo. Su mensaje es breve y conciso, por lo cual se diferencia del tríptico y del folleto, aunque se acepta que el volante es un cierto tipo de folleto breve. Se conoce en inglés como flyer. Para crear un volante efectivo es necesario que el mensaje sea presentado de manera atractiva para que el lector se anime a leer el texto completo. Para lograr ésto es recomendable no dar demasiada información. Es bueno acompañar imágenes pero, también, con mesura. No es recomendable usar demasiados tipos o fuentes de letra diferentes entre sí, pero sí se puede lograr un efecto interesante cambiando el tamaño de las mismas. No se deben usar solamente letras mayúsculas, a menos que sea en los títulos o subtítulos. Los párrafos deben distribuirse para facilitar su lectura y es bueno que existan suficientes espacios en blanco para dar una sensación de balance. El color del papel puede incrementar el impacto del mensaje, aunque la tinta del texto sea de un solo color (Fig. 16 y 17).

\section{Guardó als valors}

a Baltasar Garzón Real

LLOC: TEATRE CAPRI HORA: $19: 30 \mathrm{H}$

DIA: 24 DE GENER DE 2011 ORGANITZA

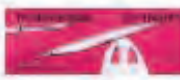
COL LABORA:
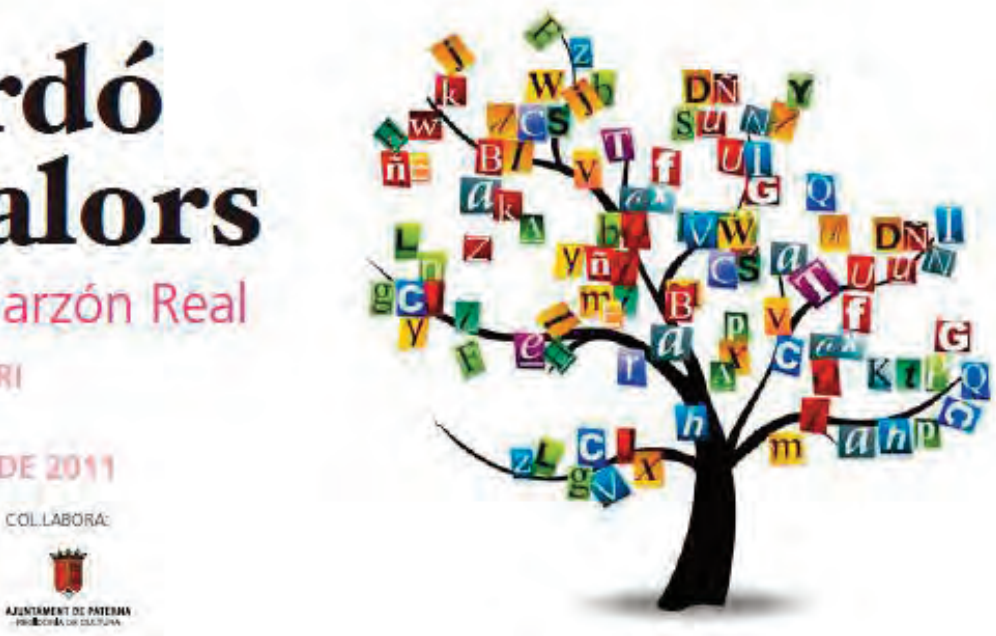

Fig. 16.

Volatina para una conferencia o miting político. 


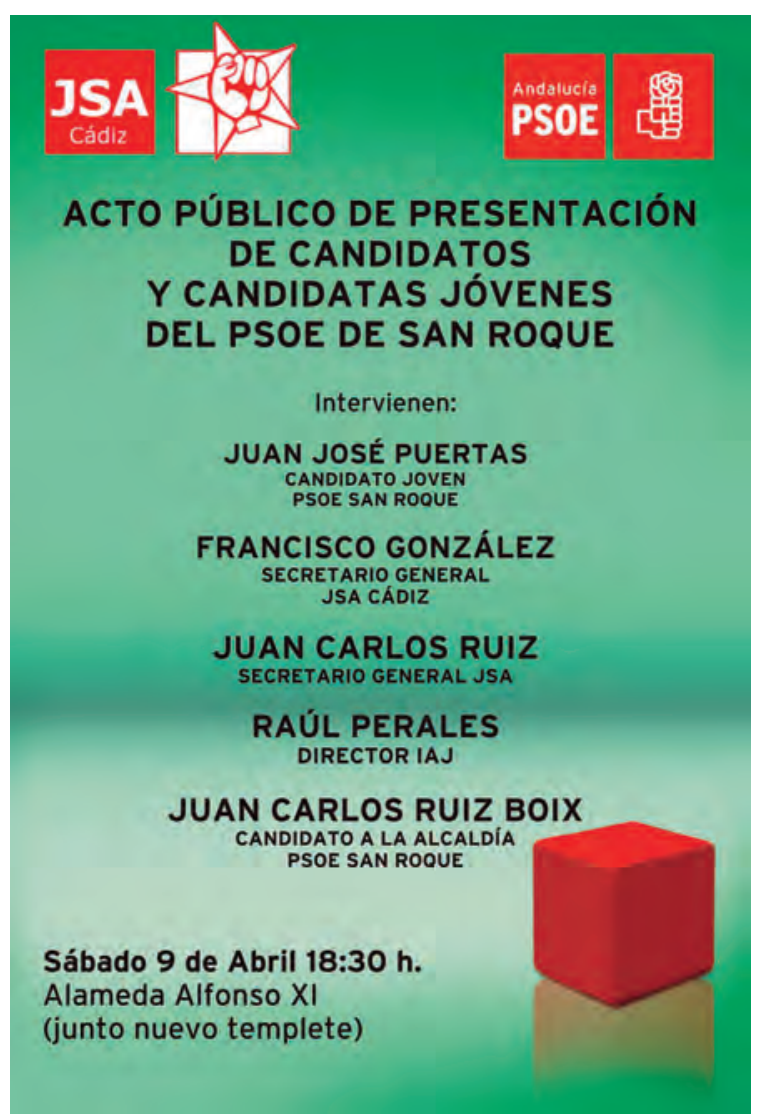

Fig. 17.

Volatina para publicitar un acto público en el que se presenta a los nuevos candidatos.

\section{La oratoria para la construcción de mensajes propagandísticos:}

La palabra hablada constituye una herramienta muy eficaz en la transmisión de los mensajes propagandísticos y ha sido utilizada en incontables ocasiones en la historia de la humanidad como arma en las contiendas bélicas así como en la construcción de los discursos políticos con el fin de atraer a las masas hacia posiciones ideológicas y actitudinales próximas al emisor de los mismos. Para conseguir mayor efectividad con estos discursos deben presentar una serie de características entre las que cabe destacar en primera instancia que deben ser claros, con enunciaciones primarias y lo más sencillos posibles, para que sea fácilmente comprensibles por todos y cada uno de los ciudadanos sin que requiera demasiado esfuerzo.

Ejemplo de todo lo anterior son los discursos pronunciados por Hitler en donde la simplicidad y el reduccionismo se configuraban como elementos 
articuladores de todo el discurso. Mediante estas sencillas operaciones se conseguían relatos de una simplicidad pasmosa que, unidos a la fuerza de la intimidación y la cuidada puesta en escena, conseguían atraer a las masas y su adhesión inquebrantable. En este mismo sentido podemos ilustrar esta tendencia a la claridad y la simplificación en la siguiente expresión utilizada para desprestigiar el papel de la iglesia católica como líder de opinión y ejemplo de moralidad:

"Si los rezos y oraciones del pueblo ruso no evitaron que perdieran la guerra, entonces no sirven para nada". ${ }^{27}$

Hitler, A. (1925: 228)

En esta misma línea, y desde una ideología completamente antagónica, encontramos la labor propagandística del líder de la revolución cubana, Fidel Castro, que con su retórica atrae a las masas incluso horas de escucha activa. Como podemos observar en la siguiente cita, el reduccionismo a la simplicidad extrema es un recurso que se utiliza en cualquier evento propagandístico por su efectividad y su capacidad para llegar a todos los estratos sociales, fundamentalmente a aquellos de menor formación intelectual entre los que la efectividad se multiplica.

"En el transcurso de la madrugada habrá quedado atrás el Año 49 de la Revolución y entraremos de lleno en el año 50, que simbolizará el medio siglo de resistencia heroica.

Proclamemos al mundo con orgullo este récord que nos hace acreedores al más justo de los reclamos: que se respete el derecho a la vida y a la sana alegría de nuestra Patria.

Por ese derecho lucharemos hasta la muerte. Para los cubanos, hace más de un siglo, Martí lo proclamó: "iPatria es humanidad!". $\mathbf{2 8}$

Castro, F. (2007)

Para hacer más eficaz el discurso propagandístico y poder llegar con claridad a las masas se utiliza en las reuniones públicas el altavoz. Además de 
amplificar la difusión de los mensajes suma la posibilidad de poder desplazarse a voluntad del propagandista. A lo largo de la historia de la humanidad podemos encontrar innumerables ejemplos de la utilización de diferentes técnicas de amplificación del sonido entre las que destacaremos su utilización en múltiples contiendas bélicas (especialmente significativa durante la guerra civil en China).

Con frecuencia se instala en un camión o cualquier otro medio de transporte que permita su desplazamiento entre diferentes localidades. Durante la campaña electoral de junio de 1950, el partido socialista belga usó camiones equipados en esa forma; se detenían de pronto en una localidad y después de algunos discos que ponían sobre aviso a la población, un orador exponía ante el micrófono las consignas propagandísticas. Este método tenía la ventaja de permitir entrar en contacto, en cualquier lugar, con mucha población que no asistía habitualmente a reuniones políticas o actos de carácter ideológico. En Viet-Nam, el gobierno francés utilizó también camiones con altavoces pero, en este caso, se complementaba mediante la organización de un bazar ambulante que servía para atraer a la población.

En la actualidad el altavoz sigue utilizándose en casi todas las campañas electorales, configurándose como un elemento clave de la estrategia propagandística.

La radio es un instrumento de difusión de la palabra. Las radioemisoras, principalmente las de onda corta, fueron utilizadas durante la primera guerra mundial, y aún en el momento actual son utilizadas como uno de los principales instrumentos adoctrinadores, con fines de propaganda interior y exterior. Se ha comprobado que la voz humana confiere a la argumentación vida y presencia, cualidades de las que carece un texto impreso, y que aplicadas a un relato lo refuerzan considerablemente. En los Estados Unidos se elaboraron diferentes análisis que trataban de examinar las voces de los locutores en función de su poder de seducción. En las modernas democracias occidentales, las regulaciones de los periodos electorales contemplan la posibilidad de que la radio, entre otros medios de comunicación, ponga espacios a disposición de los diferentes partidos políticos para que puedan utilizarlo con fines propagandísticos al objeto de difundir su programa e intenciones y se posibilite de esta forma que los ciudadanos emitan un voto informado y responsable. No obstante, y fuera de los periodos electorales y de su 
legislación, el medio radio es utilizado de forma sistemática por las diferentes estructuras de gobierno para tratar de atraer a la población hacia sus posiciones ideológicas, tratando de moldear la opinión pública hacia los intereses partidistas en la búsqueda de un doble objetivo: por una parte conseguir la implantación pacífica de sus políticas reduciendo el conflicto social y, en una segunda instancia, tratando de perpetuarse en la ostentación de los poderes.

En los conflictos bélicos es frecuente también la utilización de la radio como medio para dirigirse a la población extrajera convirtiéndose con frecuencia en un importante elemento de contraporpaganda. La influencia de la radio puede acrecentarse aún más mediante la "audición colectiva". El sentimiento de masa acrecienta los efectos de los discursos propagandísticos como señalábamos en páginas anteriores y la utilización de la radio responde a este mismo planteamiento.

El canto es también un vehículo de propaganda. Las canciones y cantos pueden ser soporte ideológico y propagandístico en cualquiera de sus múltiples formas. Así, podemos encontrar revolucionarios políticos, épicos, nacionalistas, canciones satíricas, que suelen ser un arma para llevar a cabo la oposición a un sistema establecido. Algunos de los ejemplos más evidentes de la utilización de los cantos como soporte para la inclusión de mensajes propagandísticos son los siguientes: La Marsellesa y La Internacional, el éxito de las canciones satíricas divulgadas por las emisiones francesas de la B.B.C. durante las dos guerras mundiales. También son muy conocidas las canciones de la Guerra Civil española donde ambos bandos aprovechaban para insertar los mensajes que hablaban de su excelencia y de la maldad del bando contrario. Las canciones de la guerra civil no son simples composiciones musicales, representan la otra lucha de dos bandos irreconciliables, la lucha de las palabras y de las ideas, o más bien de la representación de cada bando. Eran cantadas por los combatientes de ambos bandos. Muchas de ellas aún permanecen en la memoria colectiva de los españoles. Estas canciones servían para levantar la moral en las trincheras, para difundir mensajes ideológicos, dar motivos y razones para la lucha, potenciar el sacrificio, etcétera.

A modo de ejemplo señalamos la letra de una conocida canción republicana titulada: "Campesinos" y otra falangista compuesta por Fernando Moraleda "Soy Falangista", "Campesinos". 


\section{"Campesinos"}

Los campos heridos de tanta metralla, los pueblos sangrantes de tanto dolor, y los campesinos sobre la batalla, para destrozar al fascismo traidor. Dejando el arado tirado en la tierra, tomando el fusil para pelear, marchamos alegres hacia las trincheras,

para que en España haya libertad. Somos los campesinos, hoy somos los soldados. iAdelante!

Gritan nuestros fusiles, gritan nuestros arados. iAdelante!

iAdelante! iAdelante!

La sangre que corre valiente a diario ha de ahogar un día en su tempestad

a los enemigos del proletariado, y a los enemigos de nuestra unidad. Ya llegará el día de nuestra victoria; la Paz por el mundo se paseará, talleres y campos cantando la gloria de los que cayeron por la libertad.

Somos los campesinos, hoy somos los soldados. iAdelante!

Gritan nuestros fusiles, gritan nuestros arados. iAdelante! iAdelante! iAdelante!

\section{"Falangista soy"}

Falangista soy, Falangista hasta morir o vencer $Y$ por eso estoy al servicio de España con placer. Alistado voy con la juventud a la lid de nuestra fe

Mi camisa azul y el escudo con el yugo y el haz.

Garantía son

en la España inmortal que triunfará.

Cuando se enteró mi madre de que yo era de las JONS, me dio un abrazo y me dijo:

"iHijo mío de mi alma así te quería yo!

Falangista valeroso

y con este patrimonio, la Justicia, el Pan, la Patria y una España Grande y Libre que soñaba José Antonio".

Cuando estoy en las trincheras dando la cara a muerte, si muero sólo lo siento, madrecita de mi vida porque no volveré a verte.

Pero sé que si me matan, de la tierra en que yo muera, se alzará como una espiga roja y negra, de la pólvora y la sangre, mi bandera. 


\section{El poder de la imagen.}

* La imagen es, sin duda, el instrumento de mayor impacto y el más eficaz. Su percepción es inmediata y no exige ningún esfuerzo. Si se la acompaña con una breve leyenda, remplaza ventajosamente a cualquier texto o discurso. De aquí el conocido dicho popular que "una imagen vale más que mil palabras". La imagen es susceptible de portar significados relativos a lo racional $y$, fundamentalmente, a lo emocional, por lo que se constituye como un elemento excepcional para conseguir adoctrinamientos y la transmisión de modelos de comportamiento. Cualquier entramado de poder ha recurrido a lo largo de la historia al empleo de imágenes como aglutinadoras de la esencia de su naturaleza y, a un tiempo, como manifestación externa de su propia existencia y poder.

Hay muchas clases de imágenes: fotos, caricaturas y dibujos satíricos, emblemas y símbolos, retratos de los mandos militares y políticos, incluso, composiciones que tratan de relacionar conceptos como el del mando militar y la santidad, el valor y la entrega, la miseria y el enemigo, etcétera (Fig. 18, $19,20,21,24,25$ y 26$)$.

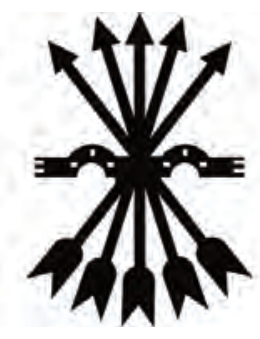

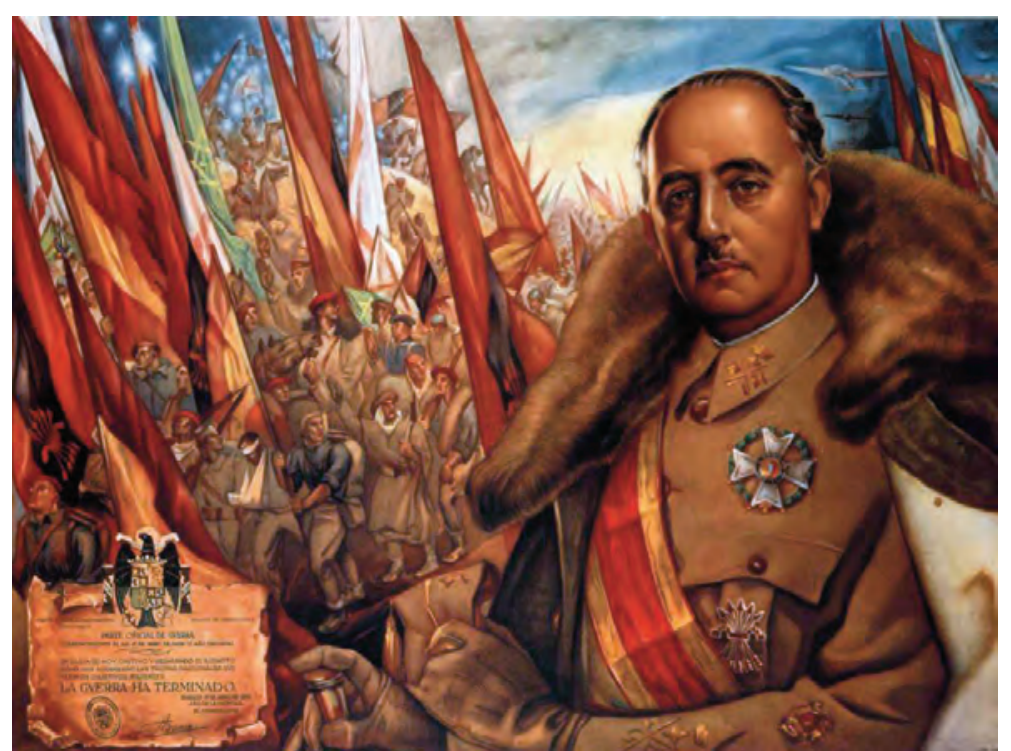

Fig. 18 y 19.

La imagen del General Franco (autor de figura 18, Paco Rivera), del escudo franquista y del Yugo y las Flechas, presentes en la bandera de La Falange, se convirtieron en los símbolos más representativos de la dictadura española. 


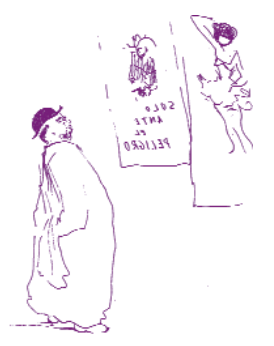
La propaganda política y la transmisión de modelos sociales en la obra de Eduardo Vicente.

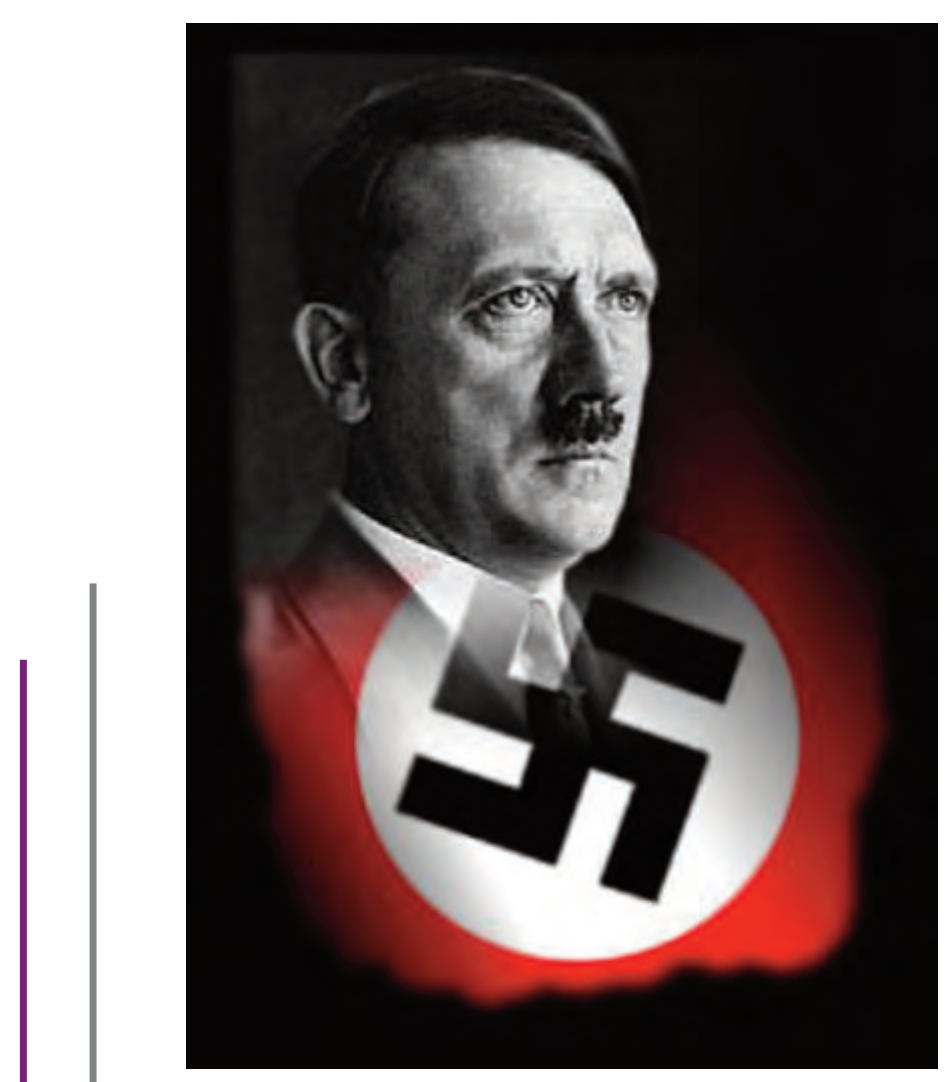

Fig. 20.

Imagen de Adolf Hitler, que junto con la cruz esvática representaron el régimen Nazi.

Fig. 21.

Un jóven empuñando una bandera Repúblicana.

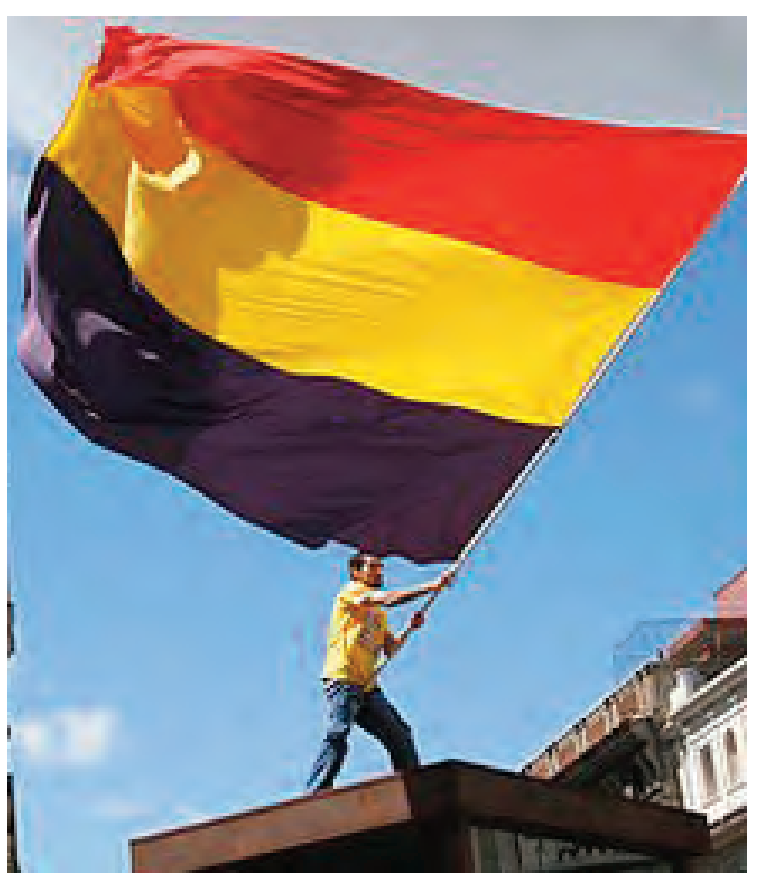



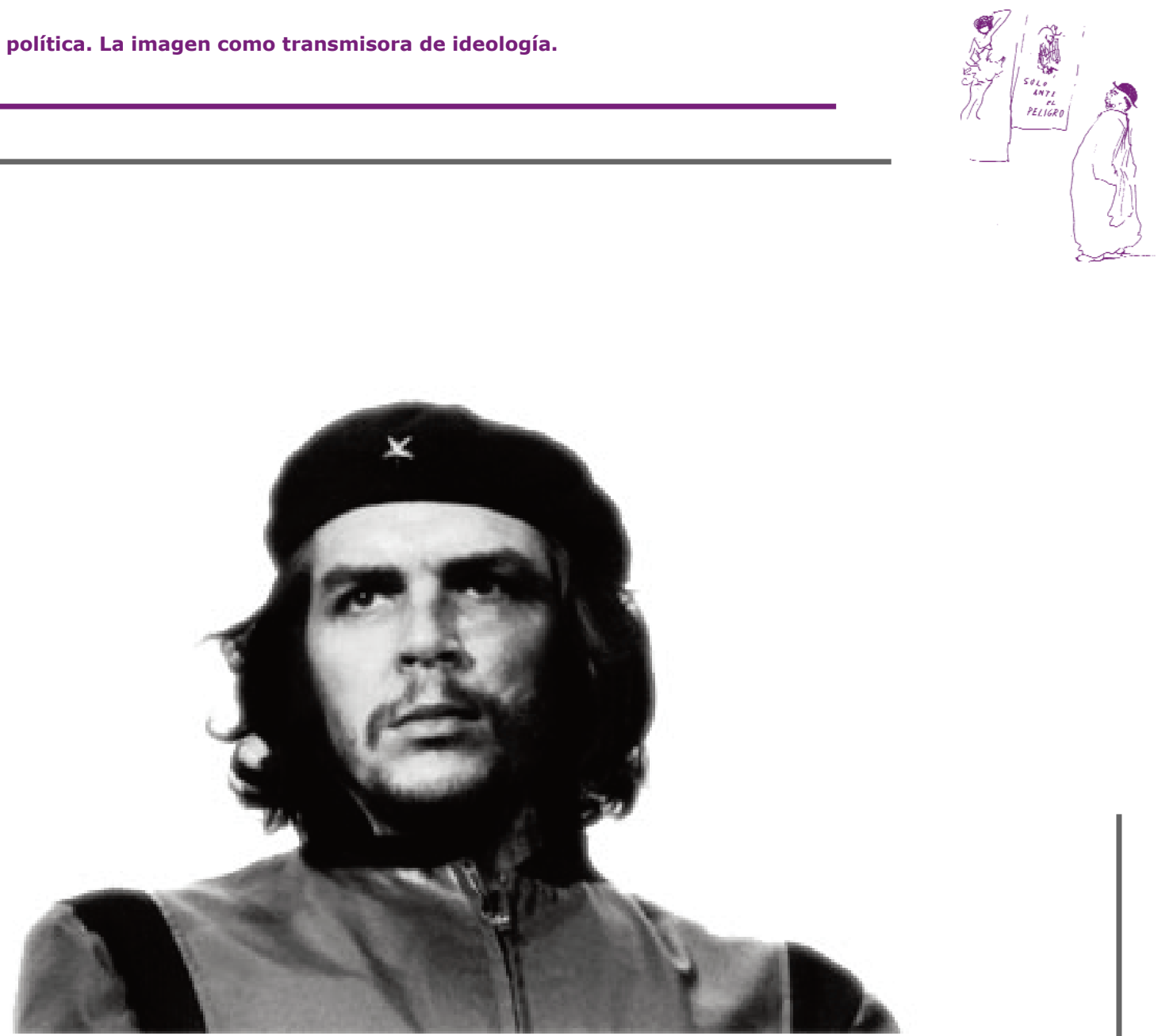

Fig. 22 y 23

La imagen del Che Guevara tomada por el fotógrafo cubano Alberto Korda durante el funeral de las víctimas del atentado terrorista a el barco Le Coubre, el 5 de marzo de 1960, se ha convertido en un icono revolucionario.

Fig. 24.

Ernesto Guevara también se convierte en un icono del Pop Art, de la mano de Andy Warhol.
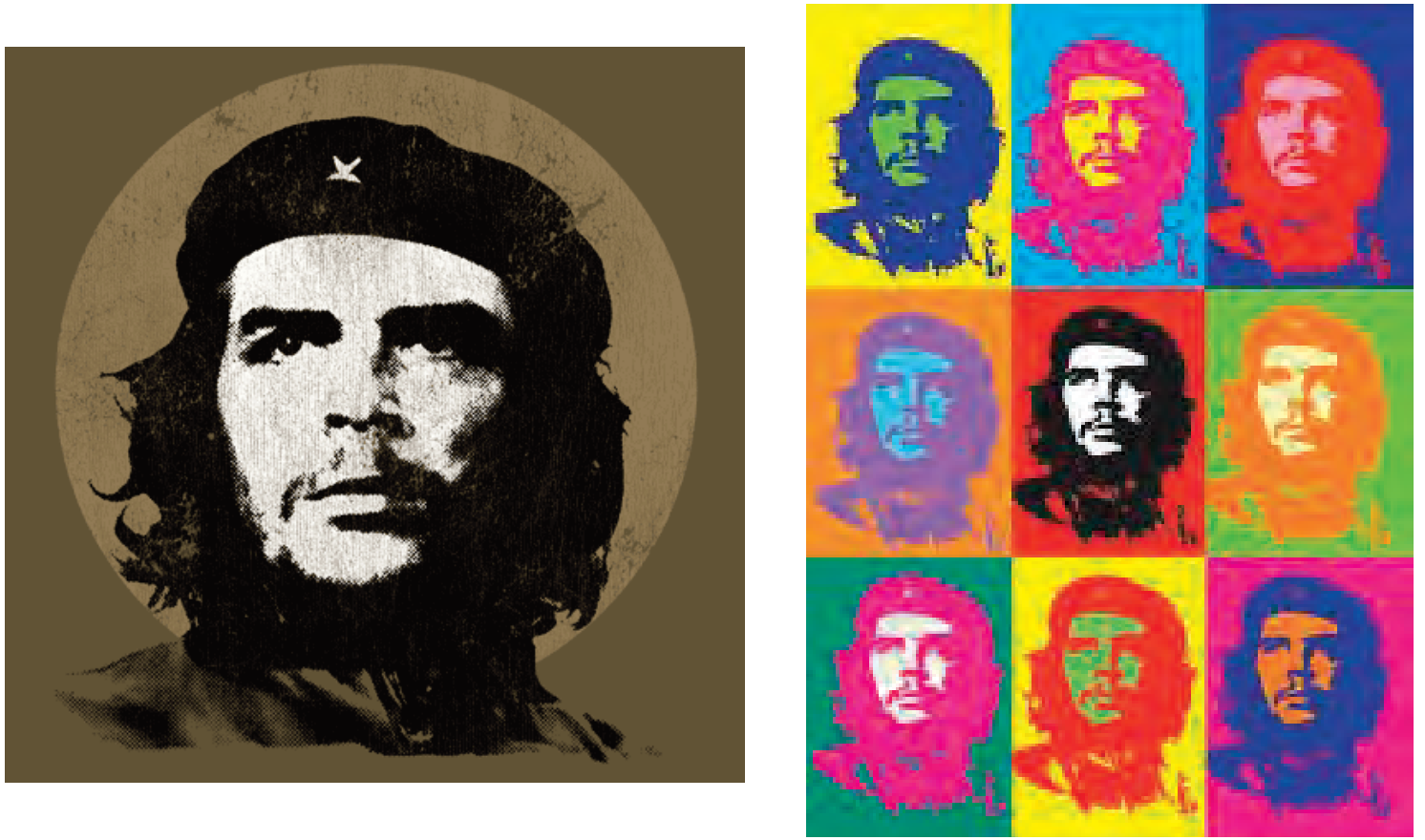
Arte y Comunicación.

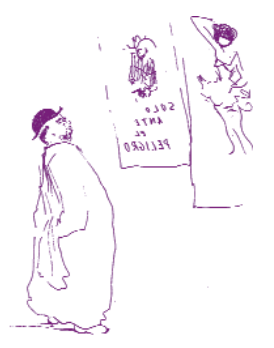
La propaganda política y la transmisión de modelos sociales en la obra de Eduardo Vicente.

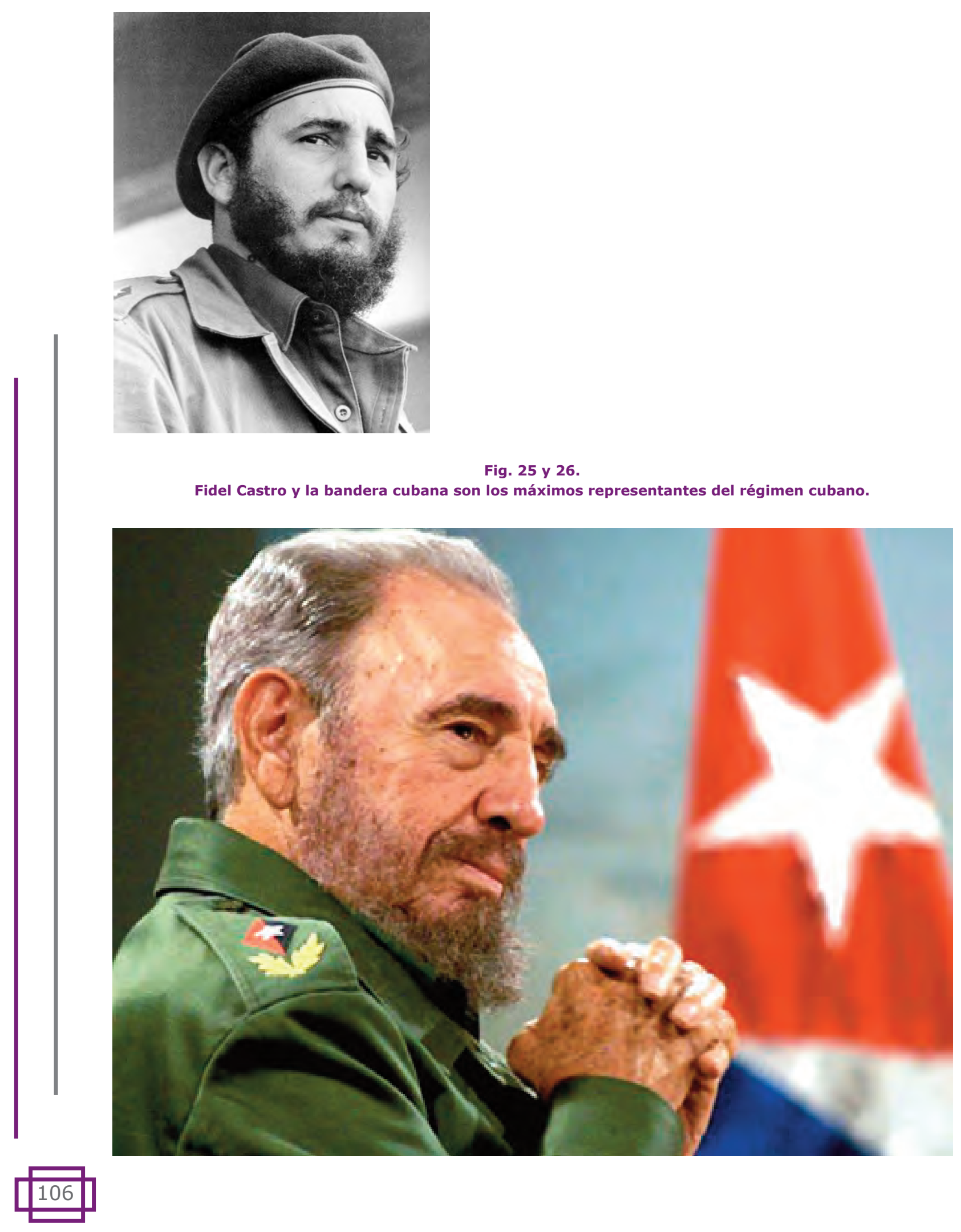




\section{El espectáculo es un medio excelente insertar propaganda.}

* El teatro. Cualquier espectáculo que se dirija a una masa es susceptible de convertirse en un vehículo para la transmisión de la propaganda. En este sentido cabe destacar el importante papel que a lo largo de los años ha desempeñado el teatro para promocionar determinadas ideologías. En este sentido, vinculado a la instauración de nuevos valores políticos y ciudadanos, resaltamos el papel del teatro en la Revolución Francesa. Así mismo, el teatro recobró su eficacia de propaganda durante la Revolución bolchevique. En ambos casos las obras se salpicaban de sketchs muy simples, preparados para diversos auditorios, (ejército, campesinos, población civil, etc.), y en los que se ensalzaban los méritos y el porvenir de los obreros y campesinos revolucionarios, en contraste con la torpeza de sus enemigos. Con la misma intención de ridiculizar al enemigo se representan farsas inspiradas en el folklore.

Con frecuencia el teatro inspiró la técnica de la propaganda (Fig. 27 y 28); así sucedió con los coros hablados que se originaban en las manifestaciones, o incluso en las "conferencias dialogadas" en las que participaban Hitler y Mussolini donde, además de la presencia del líder, se encontraba un actor que se encargaba de desempeñar, más o menos groseramente, el papel de contradictor.

También en la España del General Franco el teatro se convirtió en una herramienta eficaz para perpetuar las ideas del Nacional Catolicismo.

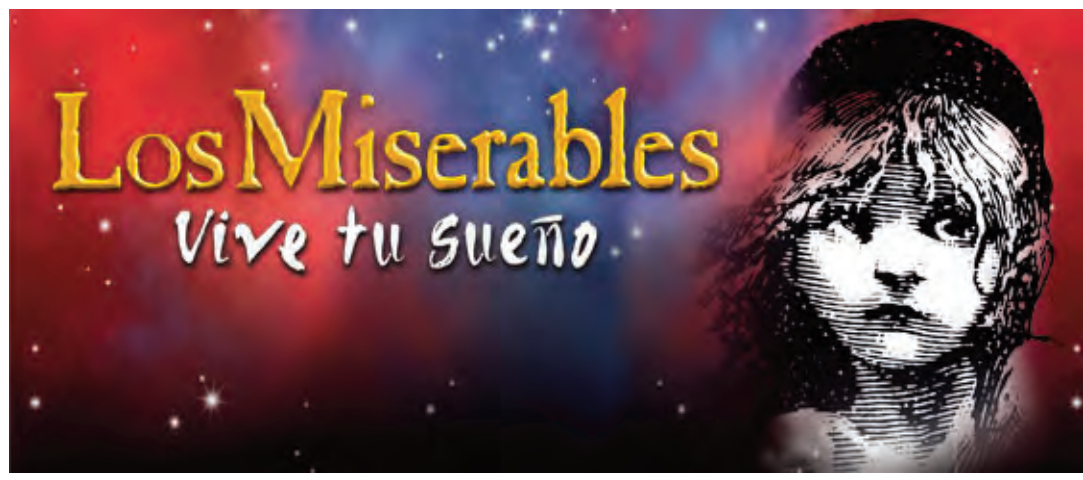

Fig. 27 y 28. Las obras de teatro de la actualidad nos siguen mostrando la barbarie de algunos régimenes políticos.

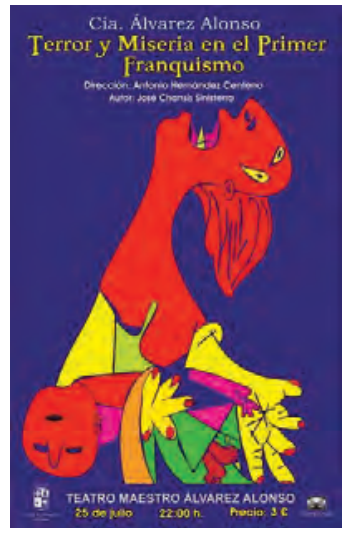


* Los desfiles militares y los mítines políticos se convertían en espectáculos para las masas. En ellos se utilizaban todos los signos propagandísticos con carrozas decoradas representando escenas ideales del porvenir y del bienestar nacional, mostrando la esperanza de los ciudadanos que colmaba sus aspiraciones mediante la demagogia y la identificación de un enemigo común. No faltaban, tampoco, figuras y escenas carnavalescas que encarnaban a los enemigos con la finalidad de mostrar su maldad, devolviendo la unidad y garantizando el poder y la seguridad para los amigos y, la violencia, la exclusión social y el miedo para los enemigos (Figuras 29, $30,31,32$ y 33$)$.

Con frecuencia los desfiles militares y los mítines políticos eran una puesta en escena, una representación de los valores ideológicos y políticos que sustentan un determinado régimen. Un espectáculo en el que la forma prima en muchas ocasiones sobre el fondo y donde se expone la fuerza y la claridad de un movimiento en busca de la adhesión entusiasta de una masa. Al igual que ha sucedido históricamente con la iglesia y sus procesiones, los desfiles y mítines son una expresión de la devoción y la fuerza social, del apoyo de la masa al proyecto ideológico y por ende un elemento de retroalimentación.
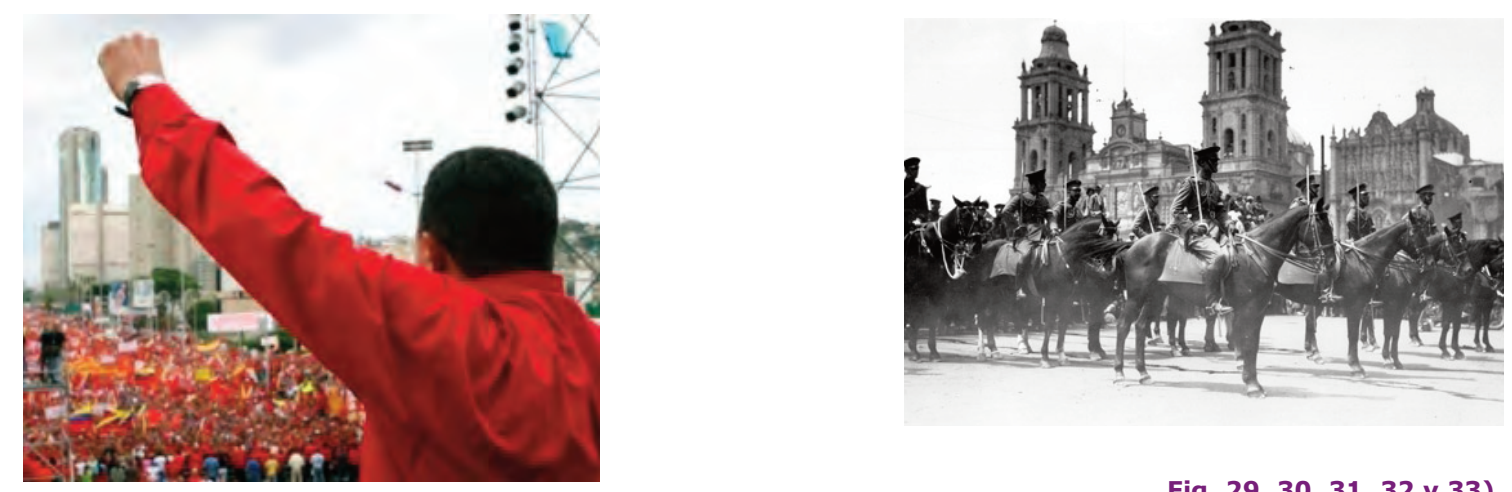

Fig. 29, 30, 31, 32 y 33). Distintas imágenes de mítines políticos y desfiles
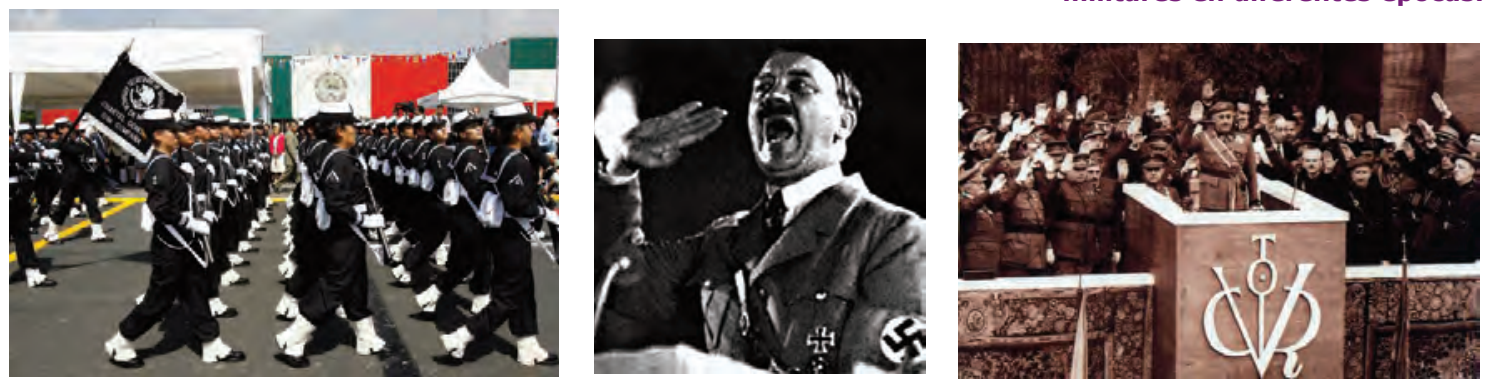
El cine es un instrumento de propaganda particularmente eficaz, bien sea cuando es utilizado por su valor documental, ya que, reproduce la realidad con cierta fidelidad de ahí que le confiera una autenticidad indiscutible o, bien como el teatro, para propagar determinada ideología, a través de una vieja leyenda, un tema histórico o un texto moderno (Fig. 34, 35, 36, 37 y 38).

Las películas de historias más o menos inventadas y ciertos reportajes pertenecen a la primera categoría. En la segunda, los nazis habían realizado un modelo de propaganda antisemita con El judío Süss. En esta misma línea, podemos encontrar la mayor parte de la producción cinematográfica elaborada en la URSS o en las democracias populares donde su esencia es la propaganda y exaltan la epopeya militar de la lucha contra los fascistas alemanes o las grandes tareas de la construcción socialista.

El cine, que se hace en España a partir de julio del 36, va a estar producido por organizaciones políticas y por sindicales. Fundamentalmente, va a ser un cine documental, informativo, de guerra. Algunas de esas organizaciones sindicales son la UGT (de tipo socialista) y la CNT (de tipo anarquista). Hay otras entidades, como Film Popular, la Subsecretaría de Propaganda o la Generalitat Catalana, que se dedican a filmar algunos títulos. Desde 1936, los dos bandos empiezan a usar el cine como medio de propaganda. En el bando franquista, se crearía el Departamento Nacional de Cinematografía. Al concluir la guerra civil, numerosos profesionales del cine marcharían al exilio.

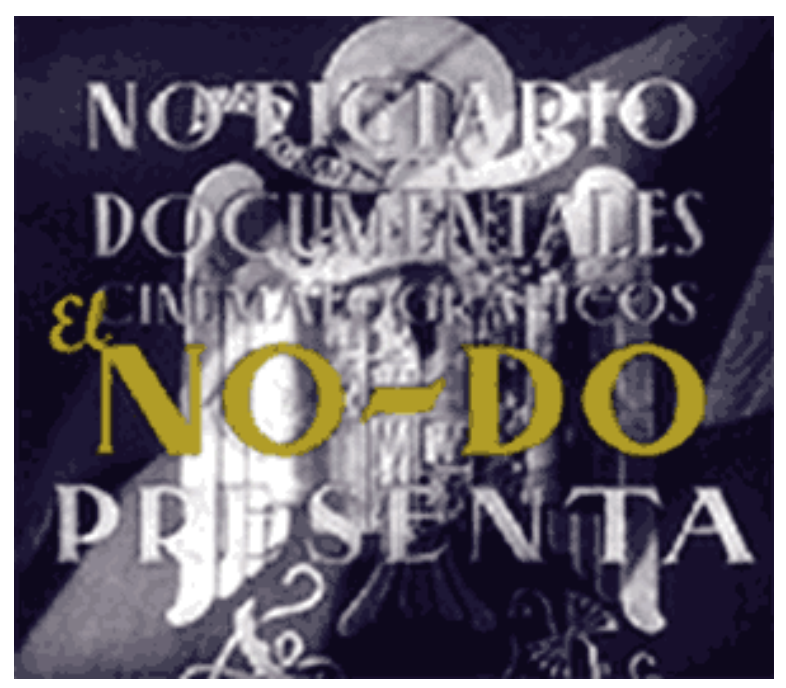




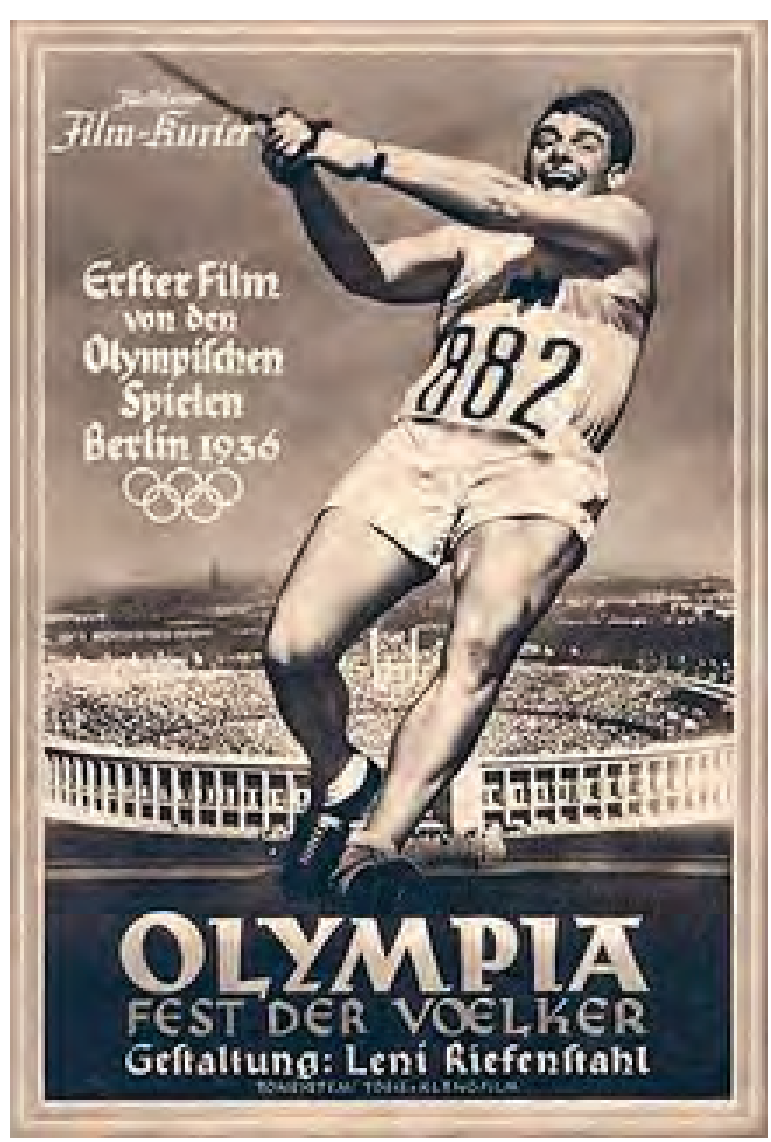

Fig. 35.

Cartelera de la película "Olimpia " de la Cineasta alemana Leni Riefenstahl.

Fig. 36.

Fotograma de la película "El gran dictador" en la que parodian al régimen nazi.

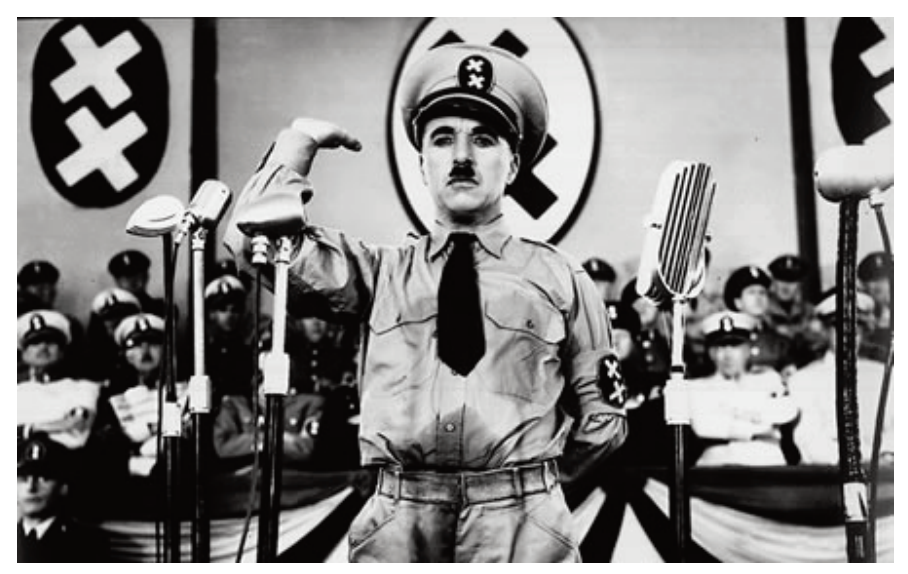



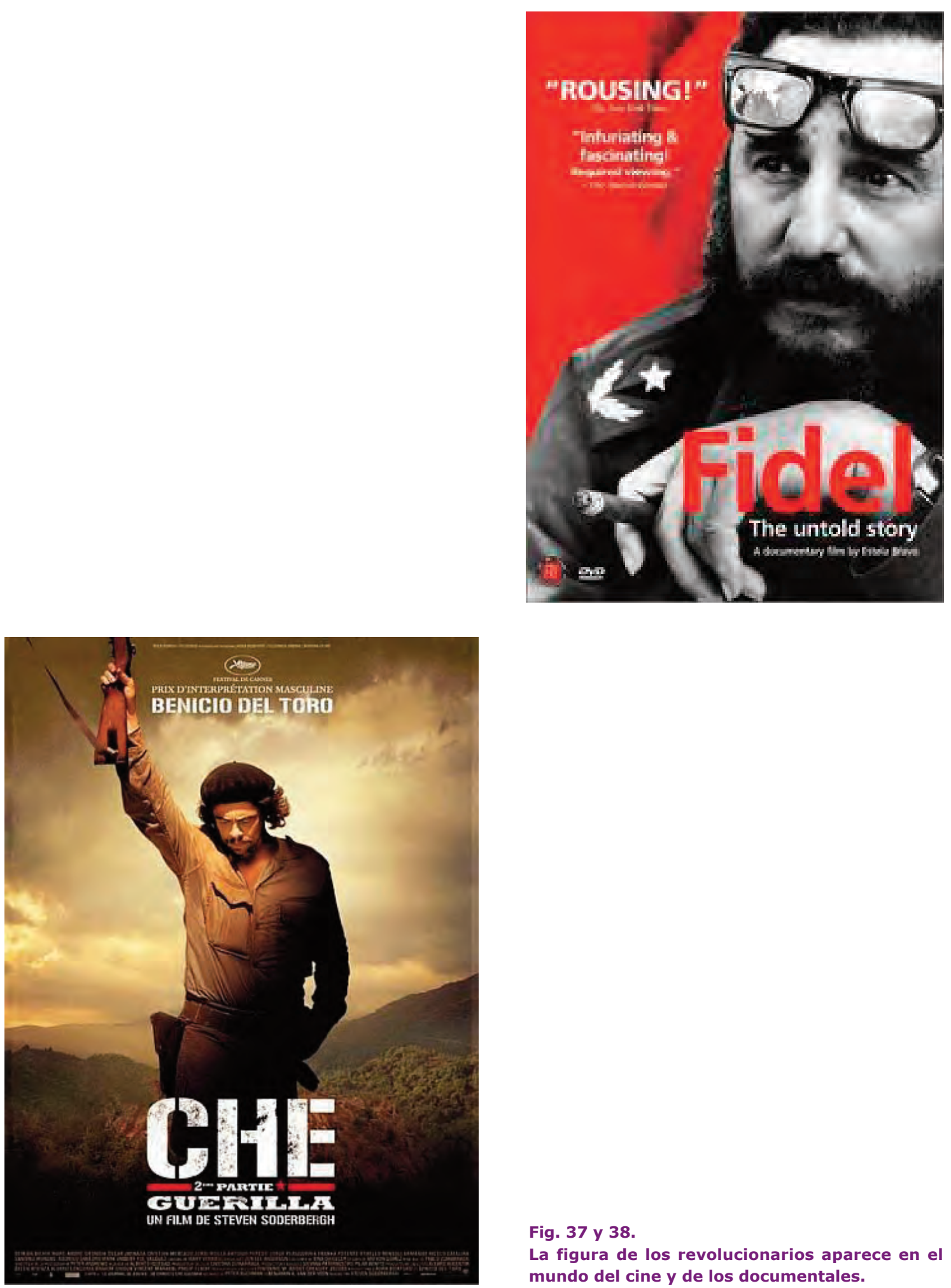

Fig. 37 y 38 .

La figura de los revolucionarios aparece en el mundo del cine y de los documentales. 
* La publicidad actúa también como propaganda.

Aunque anteriormente ya comentábamos que la propaganda puede compararse con la publicidad en cuanto tiende a crear, transformar o confirmar opiniones y usa algunos de los medios propios de ésta, se distingue de ella porque persigue un fin político y no comercial; también podemos observar cómo la publicidad en algunos casos ejerce una función propagandística. Este fenómeno lo vemos claramente en la publicidad comercial española después de la guerra civil, donde los productos y las empresas son portadoras de los valores de la ideología dominante. Basta un recorrido por la publicidad española de los años posteriores a la guerra civil para darnos cuenta cómo es utilizada la publicidad por parte de los poderes políticos. Una fórmula que se pone de moda son los "saludas", expresión básica de adhesión pública al glorioso ejercito vencedor, a su caudillo y al nuevo régimen. Con este tipo de publicidad los anunciantes trataban de configurarse una imagen corporativa próxima a los valores sociales dominantes. El discurso publicitario de contenido propagandístico no se dirige por tanto única y exclusivamente a los potenciales consumidores de sus productos sino a un público mucho más amplio en la intención de configurar una imagen más global que pudiera retraer beneficios de otra índole y que conectara con un determinado sentir popular, en muchos casos impuesto por las armas, pero absolutamente predominante.

"CALVO Y MUNAT. Fontaneros, sanitarios. Saludan al glorioso ejército vencedor, a I invicto caudillo y a sus clientes y amigos. iViva España!".

"PERFUMERÍA GAL dirige un entusiasta saludo al glorioso Ejército español, liberador de Madrid y de España, y al preclaro héroe que lo acaudilla.

Saturados de patriótica emoción, saludamos a España y a su glorioso Caudillo en estas horas promesa de grandezas"

"SEDERÍAS CARRETAS IVIVA FRANCO! IARRIBA ESPAÑA!

Estos "saludas", según Carlos Velasco Murviedro, no persiguen ninguna función comercial, tal y como se muestra a continuación: 
"La profesión pública de fe a un régimen que llegaba y que necesitaba y exigía de los ciudadanos adhesión inquebrantable a sus principios y realizaciones". 29

Velasco, C. (1988: 12-22)

Estos "saludas" constituían un listado oficial de lo que más tarde sería la reserva espiritual del occidente cristiano.

"Los iViva España!, iArriba España!, iFranco, Franco, Franco!, la utilización de la simbología del nuevo Estado - banderas, águilas imperiales, brazos alzados - abundan en la publicidad comercial en un momento en que el miedo a la represión ante la tibieza política o el entusiasmo indisimulado de la victoria lleva a la adhesión pública e incondicional a la nueva España: la auténtica, la nacional, la Una, Grande y Libre, según declama sin rubor la publicidad del momento". 30

Marchamalo, J. (1996:18)

Veamos algunos ejemplos (Fig. 39, 40, 41, 42, 43 y 44):

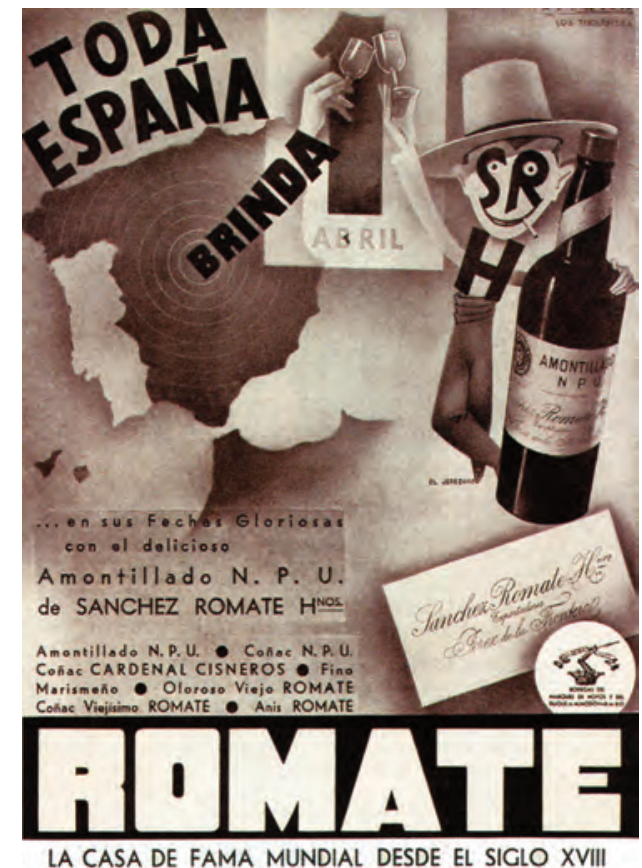

LA CASA DE FAMA MUNDIAL DESDE EL SIGLO XVIII
Fig. 39.

Anuncio publicado en Horizonte, marzo-abril de 1940, no extra: "Un año de paz en España". Hemeroteca Municipal de Madrid. 

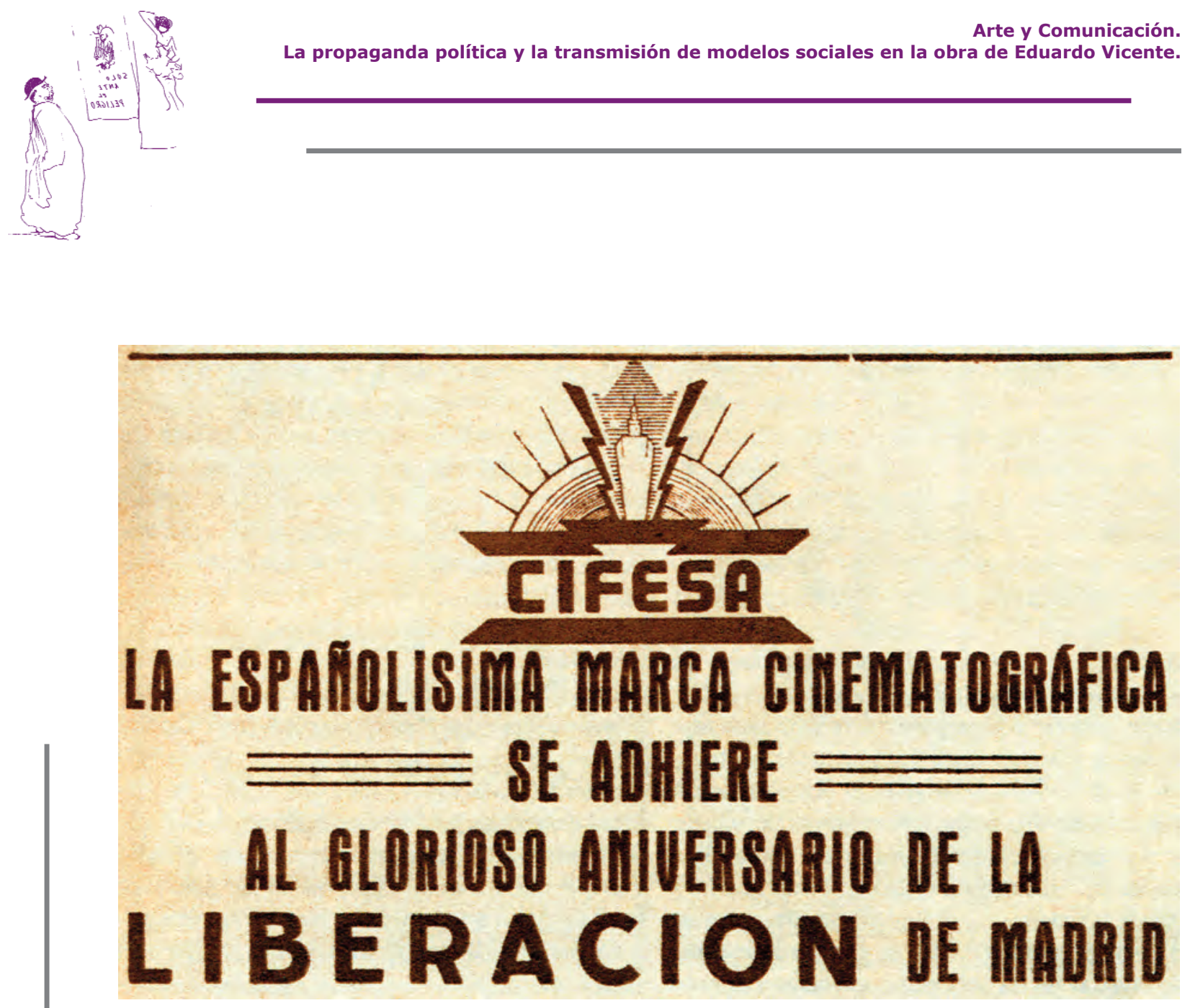

Fig. 40.

Fotos, 28 de marzo de 1940. Hemeroteca Municipal de Madrid.

Fig. 41. ABC, 12 de abril de 1939. Hemeroteca Municipal de Madrid. repetían en los distintos anuncios publicitarios.

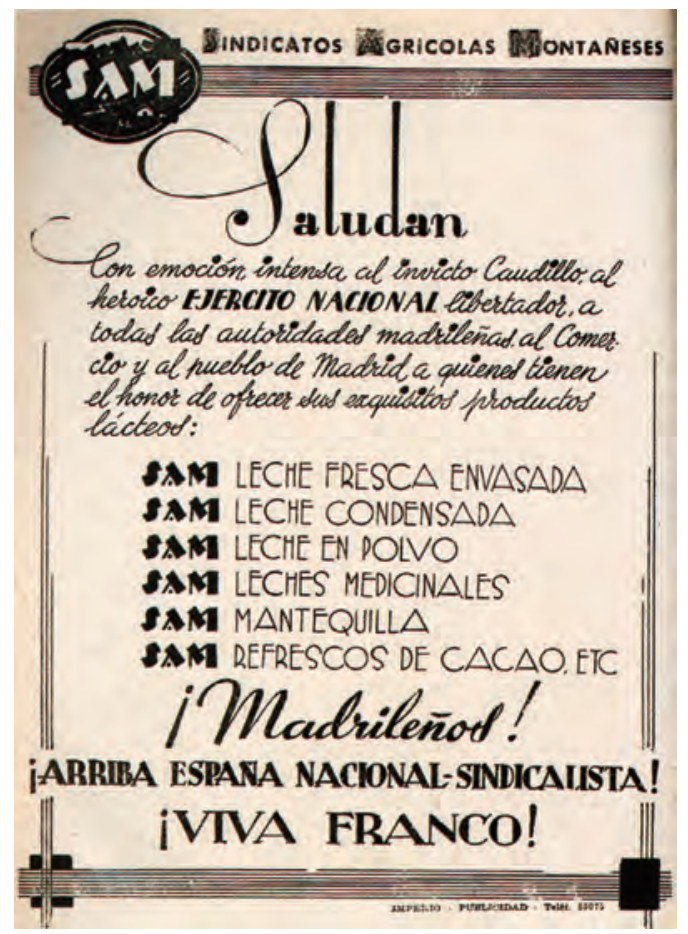


Fig. 42.

Cartel, 1939, 103x71,2. Hemeroteca Municipal de Madrid
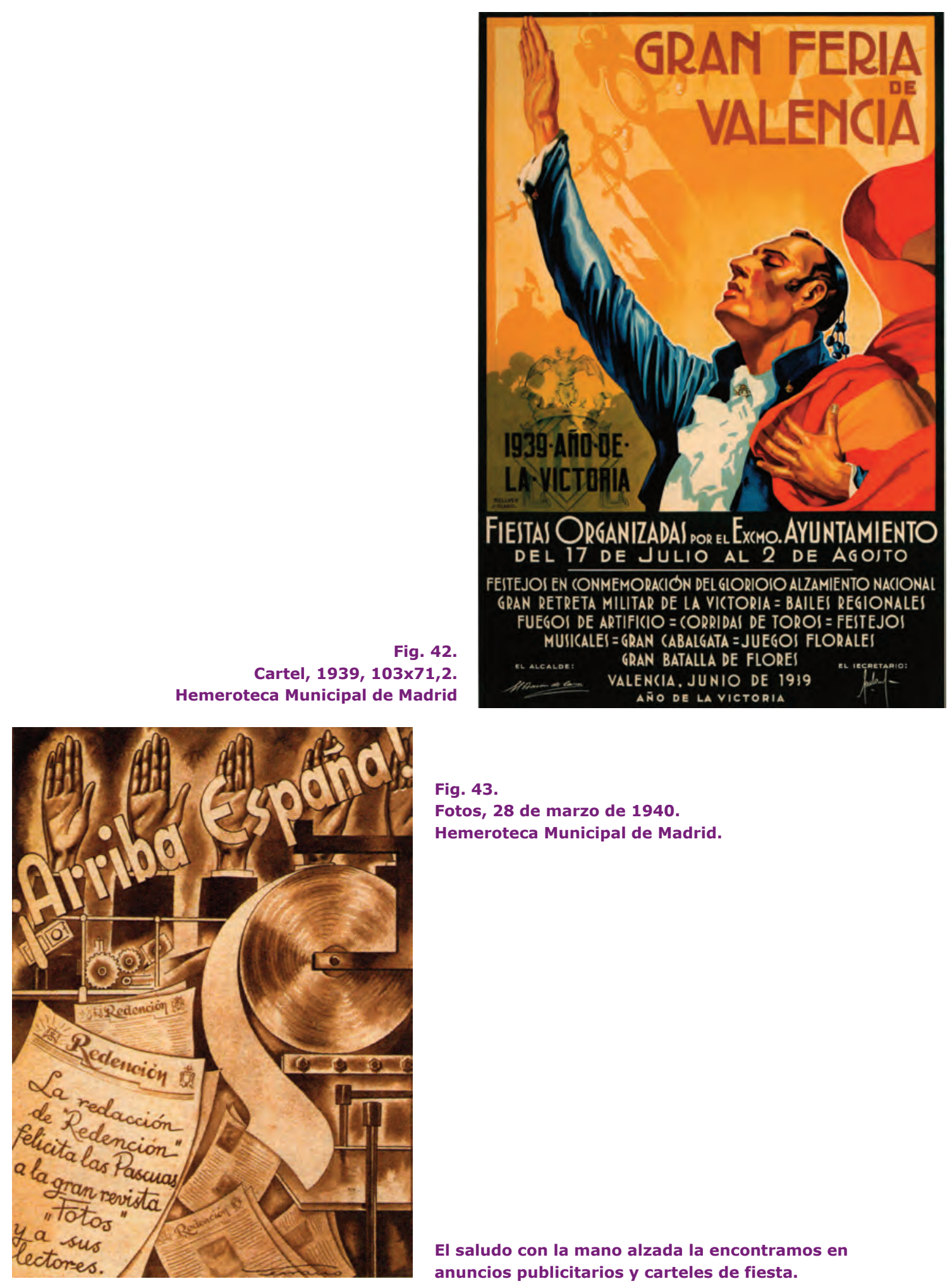

Fig. 43.

Fotos, 28 de marzo de 1940.

Hemeroteca Municipal de Madrid.

El saludo con la mano alzada la encontramos en anuncios publicitarios y carteles de fiesta. 


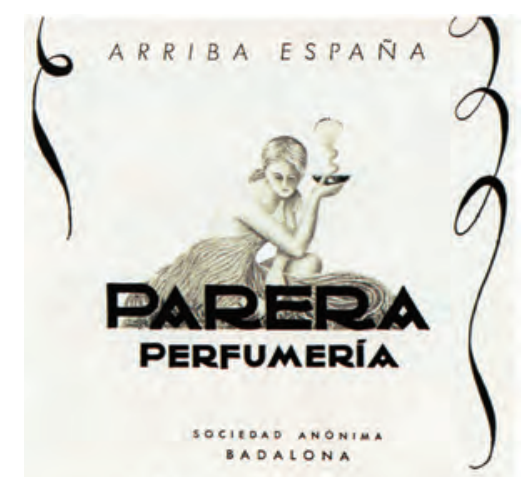

Aclama

al Invicto caudillo FRANCO a la Gloriosa Nueva España, Vietorioso Ejército.

\section{Saluda}

a todos sus Clientes, Amigos $Y$ a los Consumidores de sus

"VARON de Perfumería

"GONG" - "COCAINA EN FLOR"

"VERDADERA", etc.

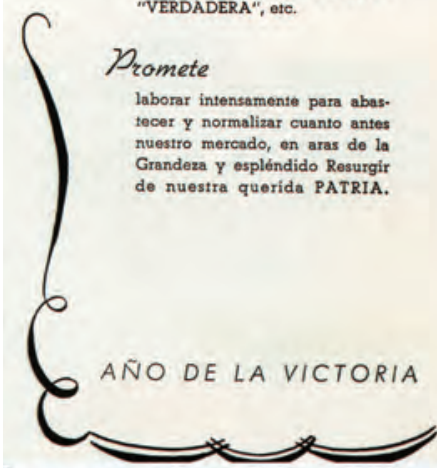

También la publicidad, como hacía el teatro y otros medios, no perdía ocasión para desprestigiar todo aquello que tenía que ver con el enemigo (Figura 45).

Fig. 45.

Horizonte, mayo de 1939. Hemeroteca Municipal de Madrid. La sombrerería Brave, era uno de los muchos negocios que desprestigiaban al bando perdedor de la Guerra Civil Española, en sus anuncios publicitarios.
Fig. 44.

Anuncio publicado en Vértice, mayo de 1939.

Hemeroteca Municipal de Madrid.

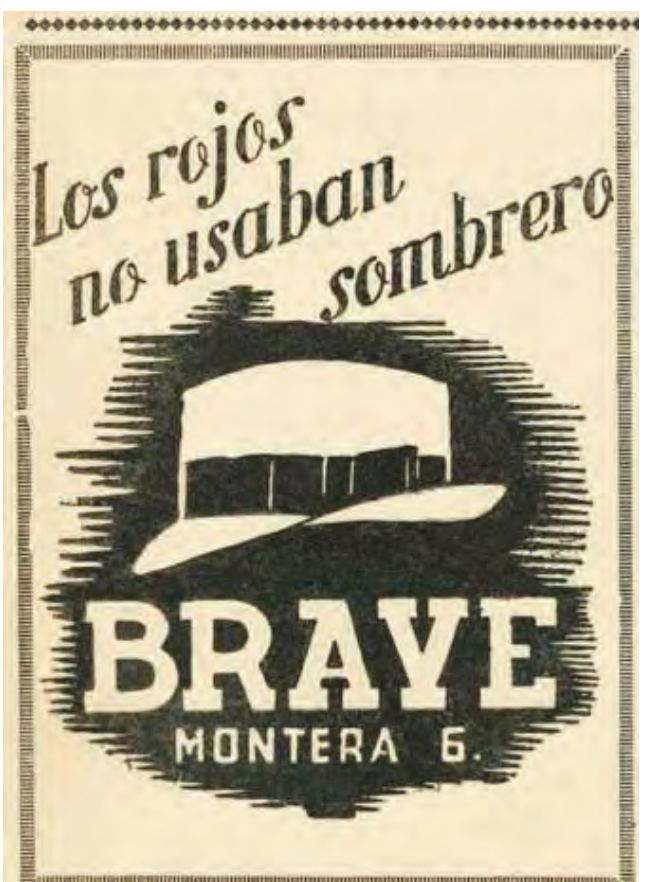




\section{La educación y su función propagandística.}

La educación como institución socializadora al servicio de los ciudadanos cumple la función comunicativa de transmitir los conocimientos de anteriores generaciones, a la vez que propaga los valores, actitudes y normas sociales de cada periodo histórico.

Los sistemas educativos se convierten de inmediato en un elemento muy tentador para los aparatos propagandísticos en cuanto que ofrecen la posibilidad de adoctrinar a una masa enorme que, según el desarrollo del territorio, suele comprender prácticamente a toda la base de la pirámide poblacional, en un ambiente reglado, bajo un sistema jerarquizado. Si a todo esto le unimos la doble ventaja desde el punto de vista propagandístico de que los receptores de los mensajes son un público infantil que no suele tener ideas preconcebidas y por tanto se limita la resistencia a la permeabilidad de los mensajes propagandísticos y, en segundo lugar, que ese público de carácter infantil es el futuro del grupo social y que en unos poco años serán los que se distribuyan por todo el entramado social perpetuando las estructuras y modelos de poder.

La propaganda política leninista convierte a la escuela en uno de los pilares de su propaganda total. Después, los "seminarios políticos", las "escuelas de perfeccionamiento" y los "círculos de estudio" formaran centenas de miles de "propagandistas" o "agitadores". Las obras de Marx, Engels, Lenin.- Stalin y el "Compendio de Historia del P. C. "libro de cabecera de todos los comunistas", fueron la base de la enseñanza en la Unión Soviética.

En España, en el periodo de nuestro estudio que se corresponde con los años que vivió el artista Eduardo Vicente (1906-1969), caben destacar tres momentos muy significativos e importantes en la Historia de la educación de nuestro país:

- El inicio del siglo XX. Claves de la modernización pedagógica.

- La educación en la II República. El proyecto de modernizar España.

- La Educación en el franquismo. La educación como aparato ideológico del Estado. 
En cada uno de los tres periodos señalados podemos observar la gran importancia que los gobiernos de la nación concedieron a la Educación, fundamentalmente porque no dudaron en aplicar la fuerza que ésta tiene como herramienta propagandística y su capacidad para influir en la formación de los ciudadanos que pudieran perpetuar o cambiar los modelos establecidos.

El ejemplo más claro y evidente lo encontramos en la educación de la dictadura franquista que se convirtió en una clara manifestación propagandística. El poder político establecido por las armas utilizó a la escuela como el agente social capaz de adoctrinar a sus ciudadanos y todas las medidas promulgadas en el ámbito de la educación tenían la intencionalidad de convertir la escuela en un lugar de adoctrinamiento político-religioso. Esta función propagandística de la institución escolar se convirtió en eje sobre el que gravitaba todo el proyecto educativo sin tomar en consideración las nuevas didácticas y prácticas educativas que se habían experimentado en la época anterior. Lo importante era que la Educación sirviera a la ideología dominante y la escuela se configuró como el lugar de transmisión de la propaganda del régimen dictatorial de Franco (Fig. 46, 47, 48, 49, 50, 51 y 52).

"La educación primaria inspirándose en el sentido católico, consustancial con la tradición escolar española, se ajustará a los principios del Dogma y de la Moral católica y a las disciplinas del Derecho canónico vigente". ${ }^{31}$

BOE. 18 de julio de 1945

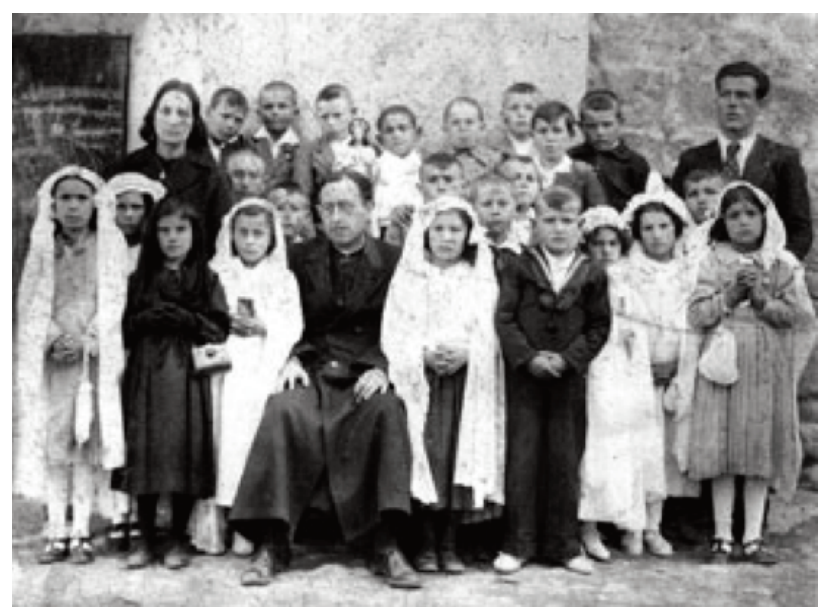

Fig. 46.

La escuela como transmisora de ideologías. 
"La formación del espíritu nacional, como esencial disciplina que ha de iluminar y enfervorizar el alma de nuestros niños y nuestros jóvenes". ${ }^{32}$

\section{Ibáñez Martín, J. (1945)}
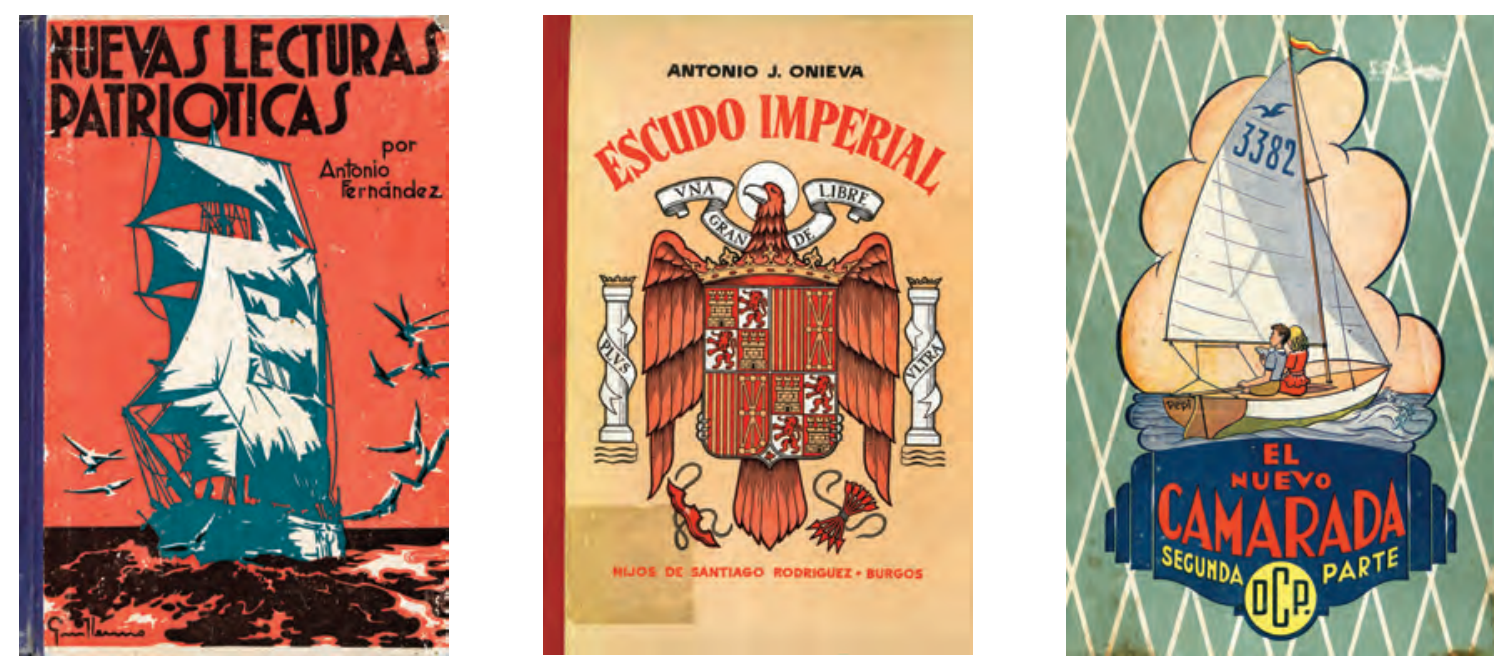

Fig. $47,48,49,50,51$ y 52 .
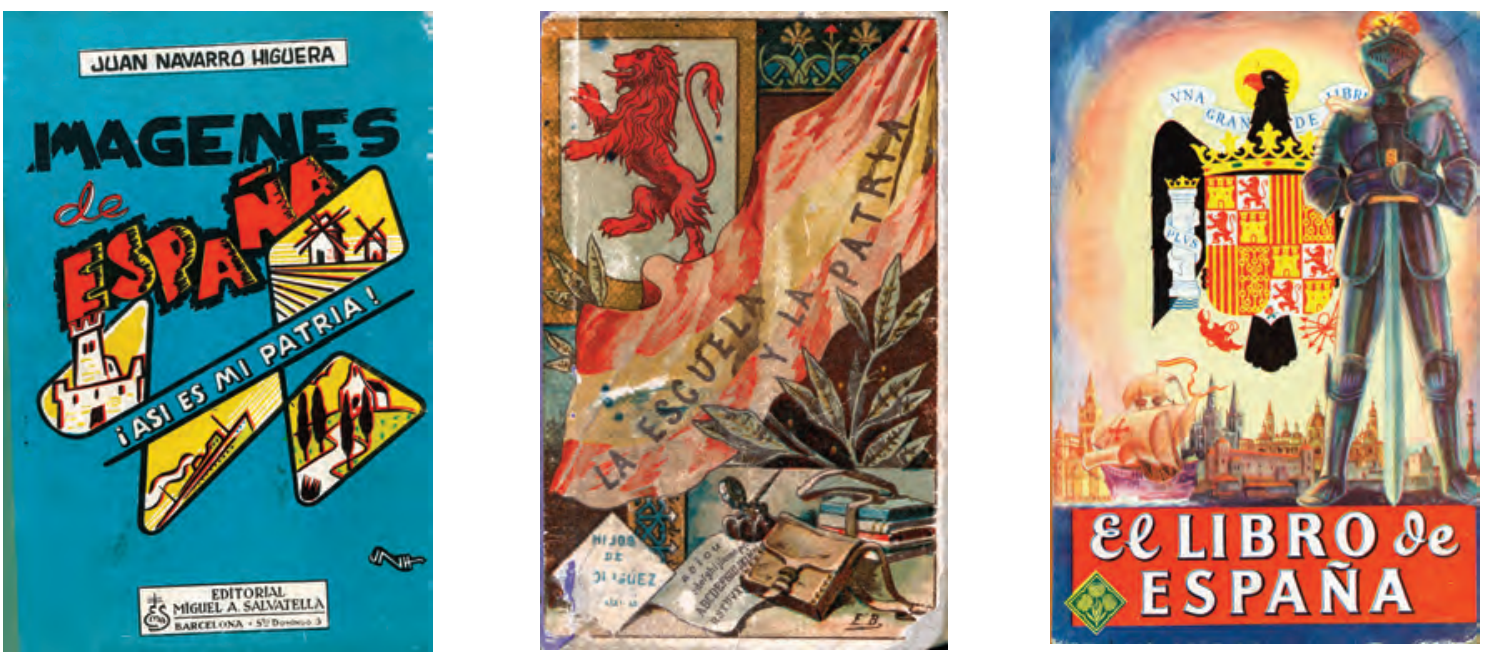
Después de esta rápida revisión de algunos de los principales vehículos de propaganda trataremos de investigar sobre el cartel como soporte informativo, ya que el objetivo de nuestra investigación es comprobar cómo en la obra del artista Eduardo Vicente existen carteles políticos que se usaron como vehículo de transmisión ideológica. 


\section{El cartel político en España.}

\section{1.- Antecedentes.}

El cartel como soporte informativo alcanza un extraordinario desarrollo en las últimas décadas del siglo XIX, pero serán los primeros años del siglo XX donde se concede una gran importancia al uso del cartel como soporte vinculado a la actividad publicitaria y política.

En el siglo XIX confluyen una serie de factores económicos, técnicos y artísticos que van a conformar el cartel como el medio informativo más eficaz en ese momento histórico.

Dese el punto de vista económico, es en el siglo XIX cuando comienza la primera Revolución Industrial que trajo consigo un aumento extraordinario de la fabricación de productos que, a su vez, generó rivalidad entre empresas que entraban en competencia en los mismos mercados. La existencia de un mercado competitivo en el que las mercancías necesitan de un plus para que obtengan éxito comercial impulsó la necesidad de acudir a técnicas que convirtieran esas mercancías en objetos más atractivos a los ojos de los consumidores. Esta nueva situación económica en la que por primera vez en la historia el ritmo de producción de bienes y servicios de consumo era superior a la capacidad de consumo trajo como consecuencia la creación de diferentes mecanismos de difusión para promocionar, publicitar y vender los productos fabricados. $Y$ es, precisamente, en este momento donde comienza el desarrollo del cartel como medio de comunicación de masas.

En relación a los avances tecnológicos que favorecieron la profusión del empleo del cartel como herramienta de comunicación cabe destacar que, en la segunda mitad del siglo XIX, se suceden una serie de avances técnicos, como la aparición, en primer lugar, de la litografía, que permitió la reproducción masiva de carteles y, posteriormente, el offset, que propició el abaratamiento de los costes con una garantía de calidad en cuanto la reproducción. El cartel se configuraba así como un medio capaz de atraer la atención, suscitar cierta fascinación mediante sus mensajes de carácter seductor, ofreciendo una importante cobertura en tanto que la relación entre el número de ejemplares y su coste resultaba atractiva para los anunciantes.

En el campo artístico, se producen una serie de factores que favorecen y condicionan el desarrollo del cartel. Nos estamos refiriendo básicamente al 
auge de corrientes artísticas como el Modernismo y posteriormente el Art Déco que dieron una gran importancia a las artes gráficas y la consideración del arte no sólo como obras para ser contempladas sino, también, con posibilidades de ser aplicadas a otros campos.

Así, el cartel nace como arte aplicado que emplea la técnica del dibujo, enriquecida con colores, y se pone al servicio de la industria y de la política. Desde el principio se vio, claramente, que el cartel podía cumplir dos funciones: una comercial y otra social como podemos observar en las siguientes citas:

"... el cartel combina la quirografía del dibujo con trazos gruesos y su posterior impresión mecánica, con fines multiplicadores, al servicio de los intereses comerciales". 33

Gubern, R. (1997:24)

"Los carteles son manifestaciones democráticas y populares que sirve como indicadores de la cultura nacional y contribuyen a educar el gusto y a dirigir las aficiones del pueblo". 34

Blanco y Negro. (1902: no 573)

Es precisamente esta función social la que permitirá al cartel ser mucho más que un simple medio para vender productos. El cartel se constituye como un elemento básico a la hora de exponer la trascendencia social de un producto, servicio o ideología por lo que su función trasciende del mero reclamo publicitario, convirtiéndose en un medio capaz de enseñar, educar y seducir. Jordi y Arnau Carulla señalan las cuatro funciones que ejerce el cartel a lo largo del siglo XX:

- La popularización del arte.

- La democratización de la sociedad.

- El desarrollo de la sociedad de consumo.

- La incorporación del ocio a la vida cotidiana. 
En relación a las funciones que cumple el cartel podemos establecer siguiendo a F. Enel ${ }^{35}$ dos niveles diferentes.

Un primer nivel explicito que remite a:

- Información y comunicación.

- Persuasión.

- Economía.

Otro segundo nivel que tiene en cuenta los mecanismos psicosociales del receptor:

- Función compensativa.

- Ambiental.

- Educativa.

- Estética.

- Creadora.

Abraham Moles ${ }^{36}$ en su obra, El afiche en la sociedad urbana, señala las mismas funciones que Enel, pero incluye además la función de propaganda.

En definitiva, a la hora de plantear una investigación rigurosa sobre los carteles, además de tener en cuenta al emisor y receptor, es imprescindible tomar en consideración el contexto histórico, económico, social y político en que se produce. Toda investigación científica que tenga por objeto de estudio el cartel debería por tanto tener una doble dimensión, por una parte la referida a las variables internas que configuran la obra $y$, por otra, una segunda dimensión contextual que se ocupe de las variables externas al cartel que lo dotan de sentido y significado. 
característica de ejercer un impacto en la sociedad al mismo tiempo que la reflejaba". 37

Carulla, J. y Carulla, A. (1998:11)

"... el cartel constituye una imagen colectiva en profundidad de la comunidad en acción". 38

McLuhan, M. (1974:29)

Cuando hablamos de cartel como soporte informativo y comercial no podemos obviar algunos artistas que consiguieron transformar el carácter meramente comercial del cartel publicitario para elevarlo a la categoría de obra de arte dotando a sus obras de un interés estético que, en muchas ocasiones trasciende a su propio valor documental o mercantil. En este sentido, nombres como Chéret (Fig. 53 y 54), Cappiello, Tolouse-Lautrec (Fig. 55 y 56), Mucha, Cassandre, entre otros, consiguieron trasladar estas manifestaciones artísticas al espacio público de la ciudad, para uso y disfrute de sus ciudadanos.

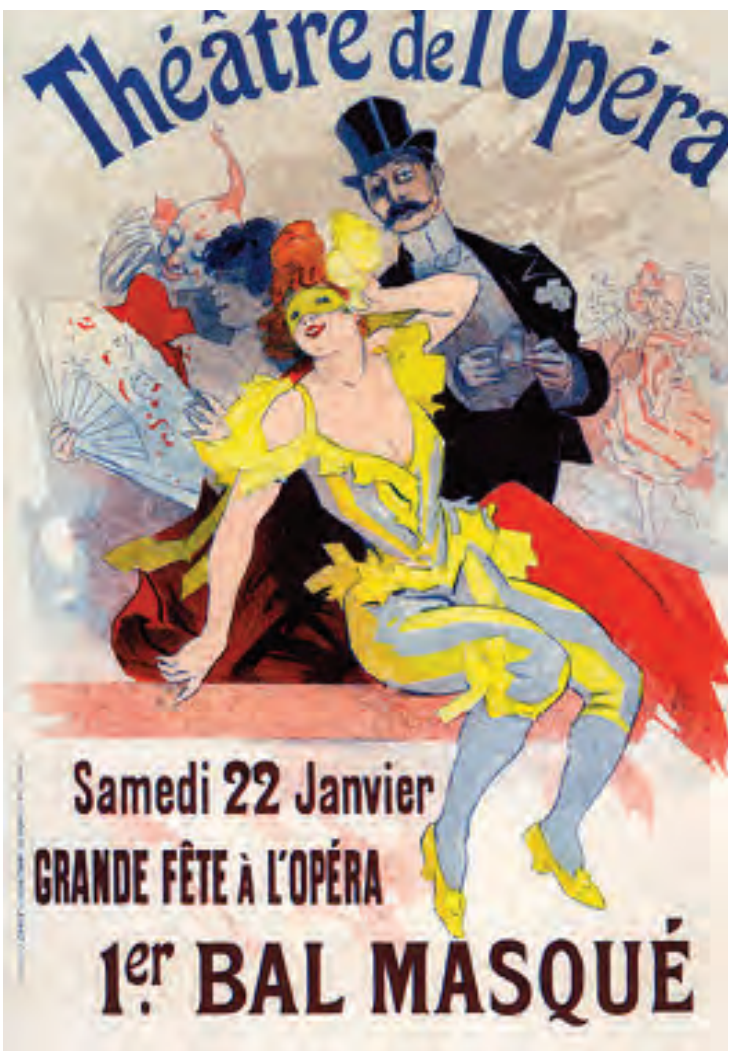

Fig. 53.

"Théâtre de l'Opéra". Cheret. 
Fig. 54.

"L'Amant des Danseuses". Cheret.

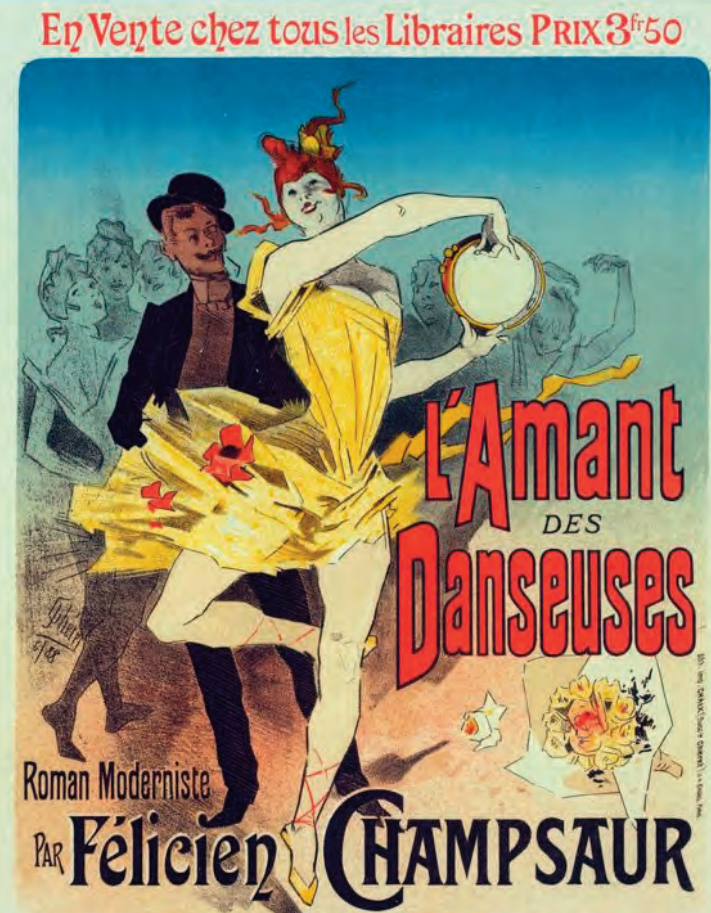

-E. DENTU - EditeUR, 3,Place de Valois. PARIS

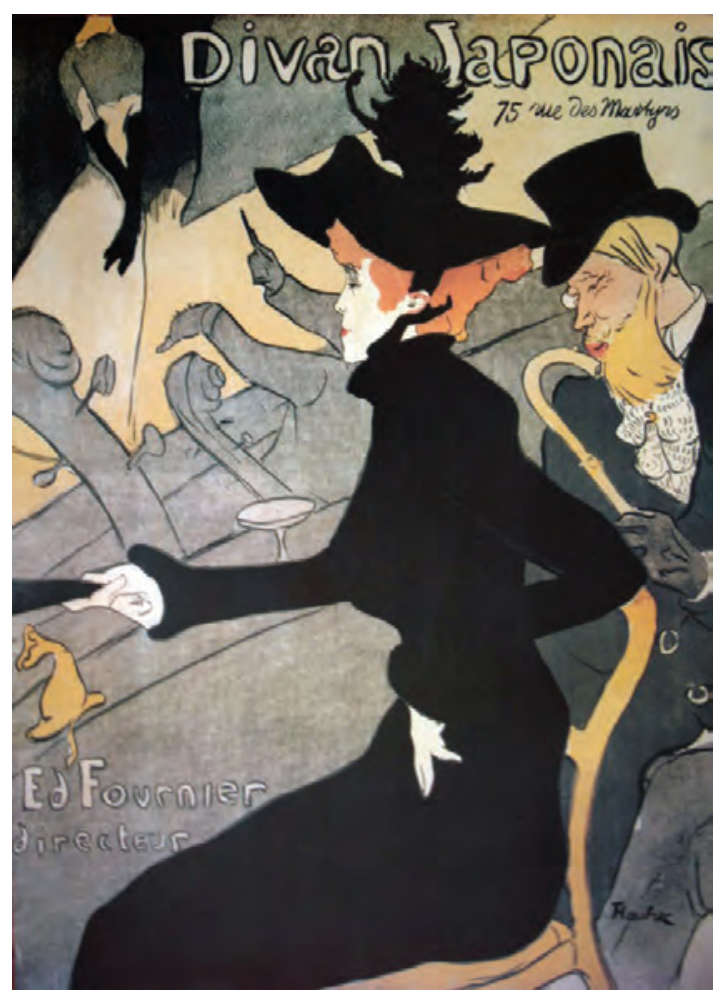

Fig. 55.

"Divan Japonais". Tolouse-Lautrec. 

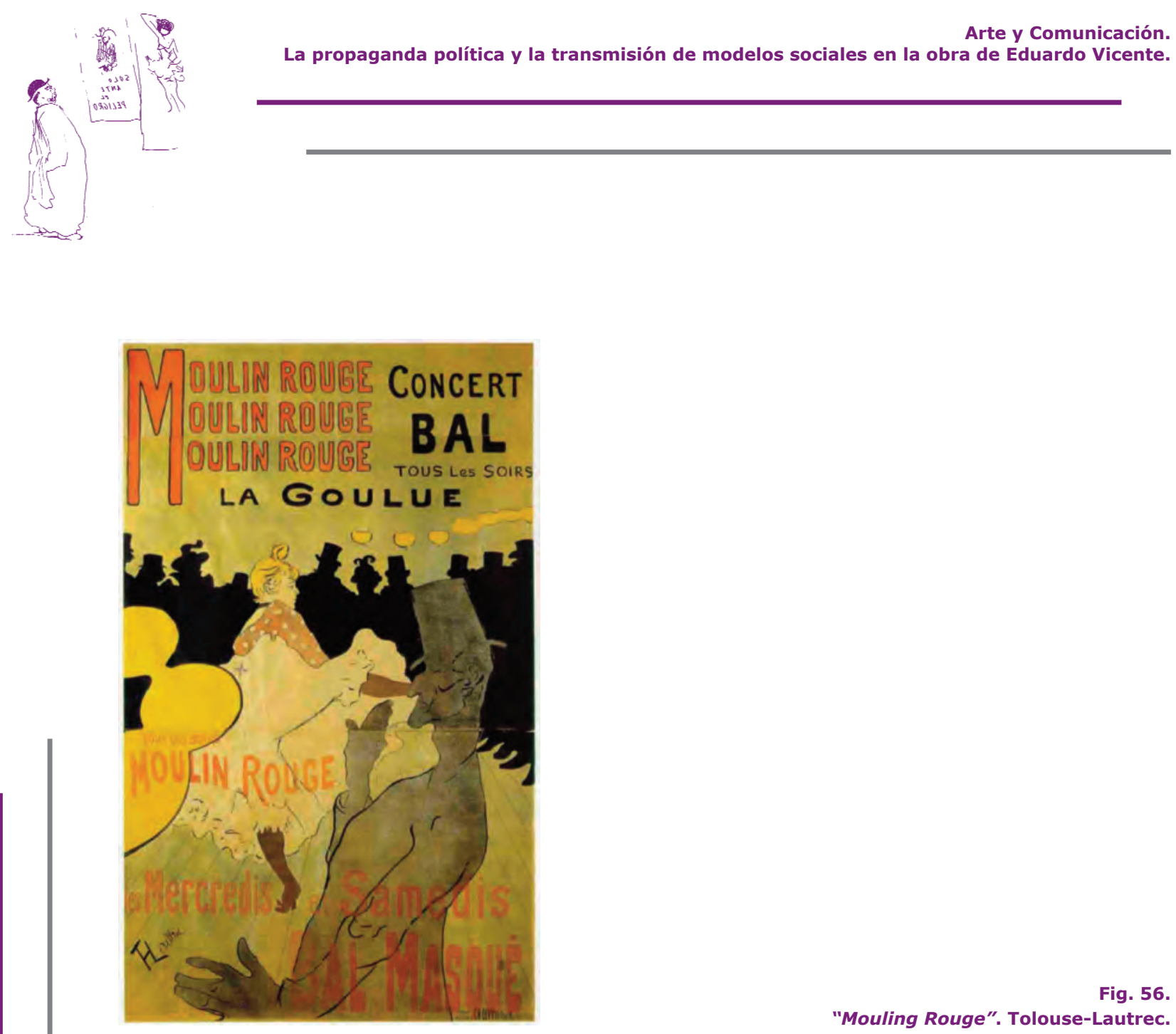

Fig. 56.

"Mouling Rouge". Tolouse-Lautrec.

Nos encontramos en este momento ante los inicios de lo que hoy en día se empieza a denominar el consumo cultural, donde el arte convive en los espacios urbanos y se realizan diferentes actividades pensadas para acometer una transformación cultural. Pretende la creación de un ágora contemporánea, un espacio físico y mental de encuentro e intercambio entre ciudadanos y artistas. Para ello utiliza la obra de arte como herramienta de transformación social y territorial.

"El cartel cumple, dadas sus características específicas, por ser "un grito en la pared", una función eminentemente social, ya que va dirigido pese a su carácter artístico no sólo a un público visitante de museos y galerías, sino también a un público que pasea por la calle y continuamente recibe su reclamo". 39

Julian, I. (1993:17)

La función estética, en un primer momento supeditada a la función comercial del cartel consiguió convertirse en un elemento básico a la hora de captar la atención de los consumidores, pero además, en una segunda 
instancia se configuró como un elemento publicitario más que dotaba de una mejor imagen a los productos que publicitaba aumentando consiguientemente la percepción de su valor y calidad, siendo el germen del consumo social en el que prima a un mismo nivel la consideración que del producto tiene el comprador como de quienes le rodean.

\section{2.- El Arte de la Guerra.}

La Guerra Civil española condicionó la obra de toda una generación de artistas e intelectuales que entendían que sus trabajos debían de responder a un posicionamiento ético y no solo estético, en el que la ideología política debía de expresarse.

La actividad artística que se produce en España entre 1936 y 1939 atiende a exigencias extraculturales. No debemos olvidar sus raíces sociales, la guerra y la revolución. Debido a la creciente politización de la cultura, nos encontramos con un arte de tendencia y cualquier planteamiento objetivo o que no fuera político era rechazado.

En el mismo momento en que el artista se posiciona a un lado u otro del conflicto toma conciencia de que su producción artística no puede ser pura o neutral, sino que debería estar al lado del pueblo a fin de contribuir a lograr la nueva cultura y la nueva sociedad por la que luchaba. Así el arte se convierte en un elemento de utilidad pública y los artistas en trabajadores al servicio de la sociedad. Tanto una como otra ideología en contienda expresaban de la misma forma el deber de los intelectuales y artistas de servir a la causa mediante sus obras.

El arte debe concebirse, en tiempos de guerra, como algo colectivo, enraizado en el pueblo, como afirma André Gide en el Congreso Internacional de Escritores:

"... el arte al perder el contacto con la realidad y la vida, se convierte en artificio...siempre es por la base, por el suelo, por el pueblo, como un arte recobra fuerza y se renueva". 40

Gide, A. (1936: 19) 
También debe ser revolucionario y como tal cumplir con su función social.

"...ya que la revolución no se expresa única y exclusivamente por la correcta expresión gráfica o literaria de un símbolo, sino que comporta la manifestación de unas categorías perfectamente definidas". $\mathbf{4 1}$

Julián, I. (1993:88)

El arte en esta época según Inmaculada Julián González ${ }^{42}$ debe cumplir diferentes funciones, a saber:

- "Recoger el momento que se vivía en la calle y en los frentes.

- Impartir dado el momento las consignas e indicaciones necesarias a la población.

- Llevar a cabo campañas culturales en los frentes.

- Difundir entre la población realizaciones artísticas.

- Llevar el arte a la calle.

- Revitalización del arte popular. "

Estas mismas funciones cumplía el cartel político puesto que se dispuso a informar y a formar, tomando partido. Podemos decir, de modo general, que el cartel de guerra fue un arte de propaganda y de educación. Tareas que creo cumplió a la perfección en aquellos años tan conflictivos.

Los organismos políticos estimularon la publicación de carteles y hojas ilustradas de propaganda, boletines, etc., que exaltaban el espíritu y el sentido de la lucha. Las publicaciones que más destacaban en la llamada zona nacional son Vértice y Jerarquía, ilustrando sus números Teodoro y Álvaro Delgado, José Caballero, J.J. Acha, J. Olasagasti y Carlos Saenz de Tejada. En la zona republicana señalamos Hora de España y Mono Azul, en las que sobresalen las colaboraciones de importantes artistas como: Bardasano, Helios Gómez, Miguel Prieto y Eduardo Vicente. 
Las exigencias propagandísticas y de formación política de las masas exigen cuadros, grabados, carteles, esculturas y productos artísticos monumentales, en general cualquier soporte susceptible de transmitir una idea o ideología.

El cartelismo fue la actividad más desarrollada en la época, alcanzando gran diversidad de estilos y planteamientos revolucionarios. Renau fue el primero en plantearse la función social de su producción y la necesidad de involucrarse de forma explícita en el conflicto con su obra.

"En el caso concreto de España, es curioso contemplar cómo el hecho violento de la guerra despierta al artista de su inerte letargo". 43

Renau, J. (1937:33)

Así los artistas se incorporaron a diferentes organizaciones y sabían que tenían un papel protagonista en la sociedad del momento, cuyas tareas pueden resumirse en:

- Estar al servicio de la revolución, al lado del pueblo luchando por una nueva sociedad.

- Llevar a cabo una obra revolucionaria, tanto en los aspectos formales como en los de contenido.

- Su obra debía estar al servicio del pueblo, por lo que debía tener un carácter crítico y pedagógico.

- Estar dispuesto a participar en los planes de enseñanza y las actividades culturales que se programasen con la finalidad de proteger y ampliar el patrimonio cultural.

- Estar a disposición para colaborar en cualquier actividad para la que fuese requerido.

Estas actividades fueron realizadas de forma sobresaliente por muchos artistas del momento que no dudaron en hacer de la función propagandística o trasmisora de valores ideológicos y sociales tema central de su producción artística. 


\section{3.- Clasificación temática.}

En relación a la clasificación temática hay que tener en cuenta que el cartel tiene como finalidad principal fijar en la mente de los ciudadanos las consignas y los deberes, mantener la moral y prevenir de los peligros.

La producción cartelista en esta época se ajustó perfectamente a los acontecimientos sociales y militares que se estaban produciendo; en este sentido, nos aventuramos a proponer la siguiente clasificación:

- Los relativos a la actividad militar, el reclutamiento y la movilización, las consignas de guerra, el fortalecimiento de la disciplina e, incluso, normas para la instrucción, no faltando los que se referían a la intervención extranjera (Fig. 57).

- Los relacionados con la economía de guerra, especialmente el trabajo en la retaguardia y la agricultura (Fig. 58).

- Los que contienen mensajes ideológicos, los fascistas y, especialmente, los referidos al antifascismo, que son abundantes al presentarse como una norma básica de actuación. Están también los vinculados a los grupos anarquistas y la revolución (Fig. 59).

- Los que presentan caricaturas de personajes o grupos del otro bando.

- Los que pretenden concienciar contra las actividades subversivas que puedan minar la moral y favorecer el triunfo del enemigo (Fig. 60).

- Los carteles de prensa, que anuncian publicaciones o son periódicos murales (Fig. 61).

- Los dedicados a la educación de adultos (Fig. 62).

- Los relacionados con las actuaciones de ayuda y solidaridad y las asociaciones que se ocupan de ello. Aquí cabría indicar el elevado número de los dedicados a los niños y a las mujeres; los primeros como objeto de protección y las segundas por su valiosa contribución al esfuerzo bélico (Fig. 63). 
Fig. 57.

"Les milicies, us necessiten!". Arteche.

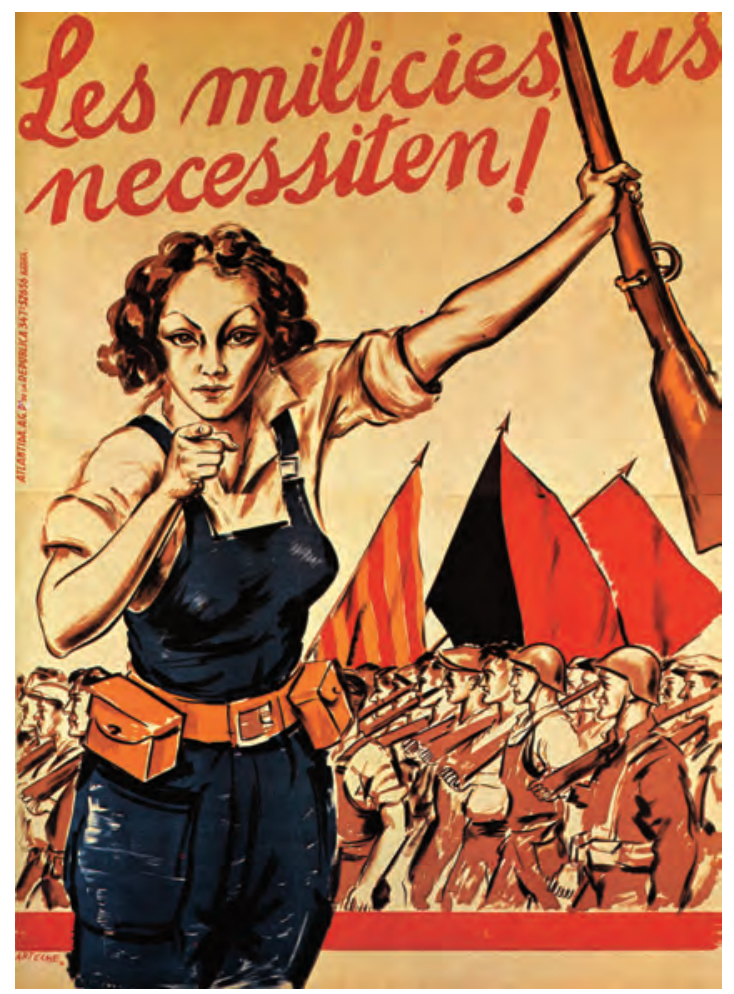

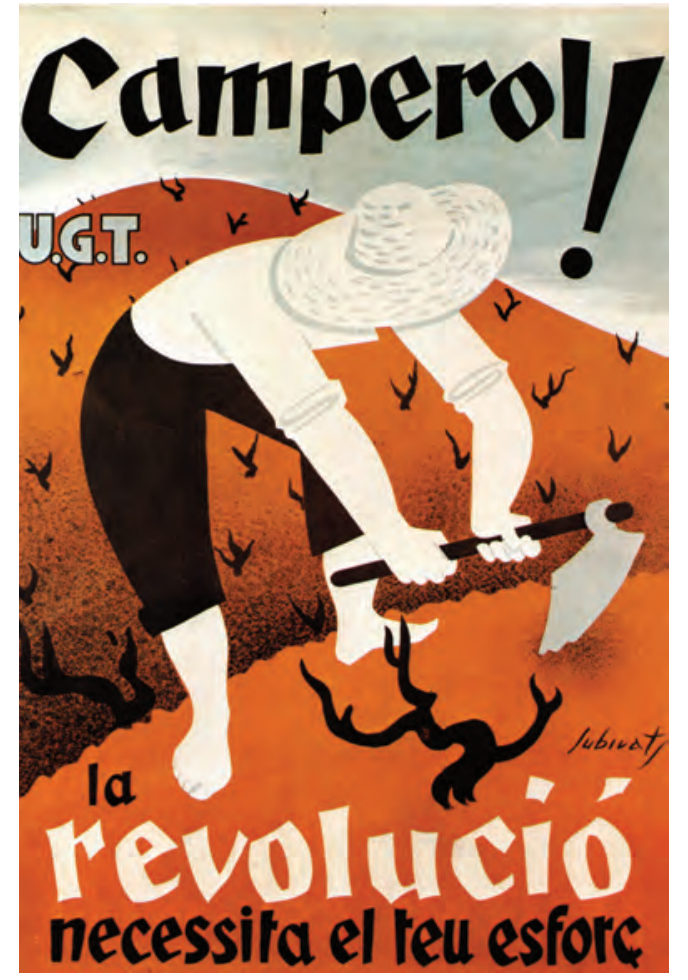

Fig. 58.

"Camperol! La revolució necesita el teu esforç". Josep Subirats. 


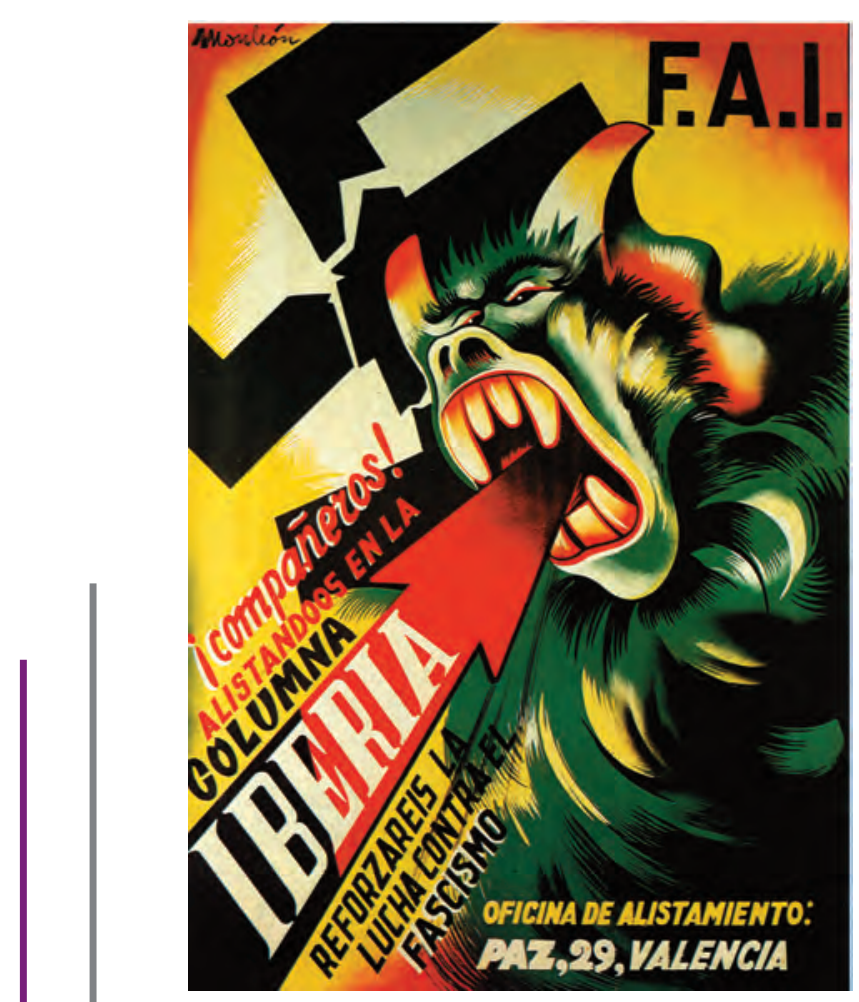

Fig. 59.

"¿Compañeros! Alistandoos en la Columna Ibérica reforzareis la lucha contra el fascismo. Monleón.

Fig. 60. "S.E. el generalísimo". Cañavate.

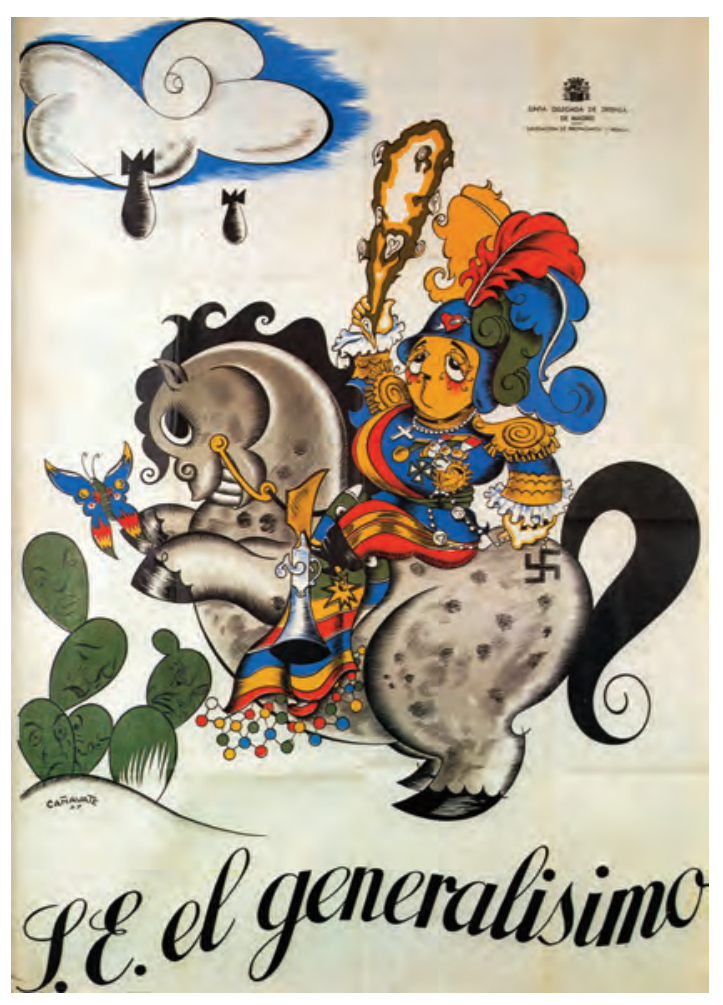


Fig. 61.

"Nueva República". Anónimo.
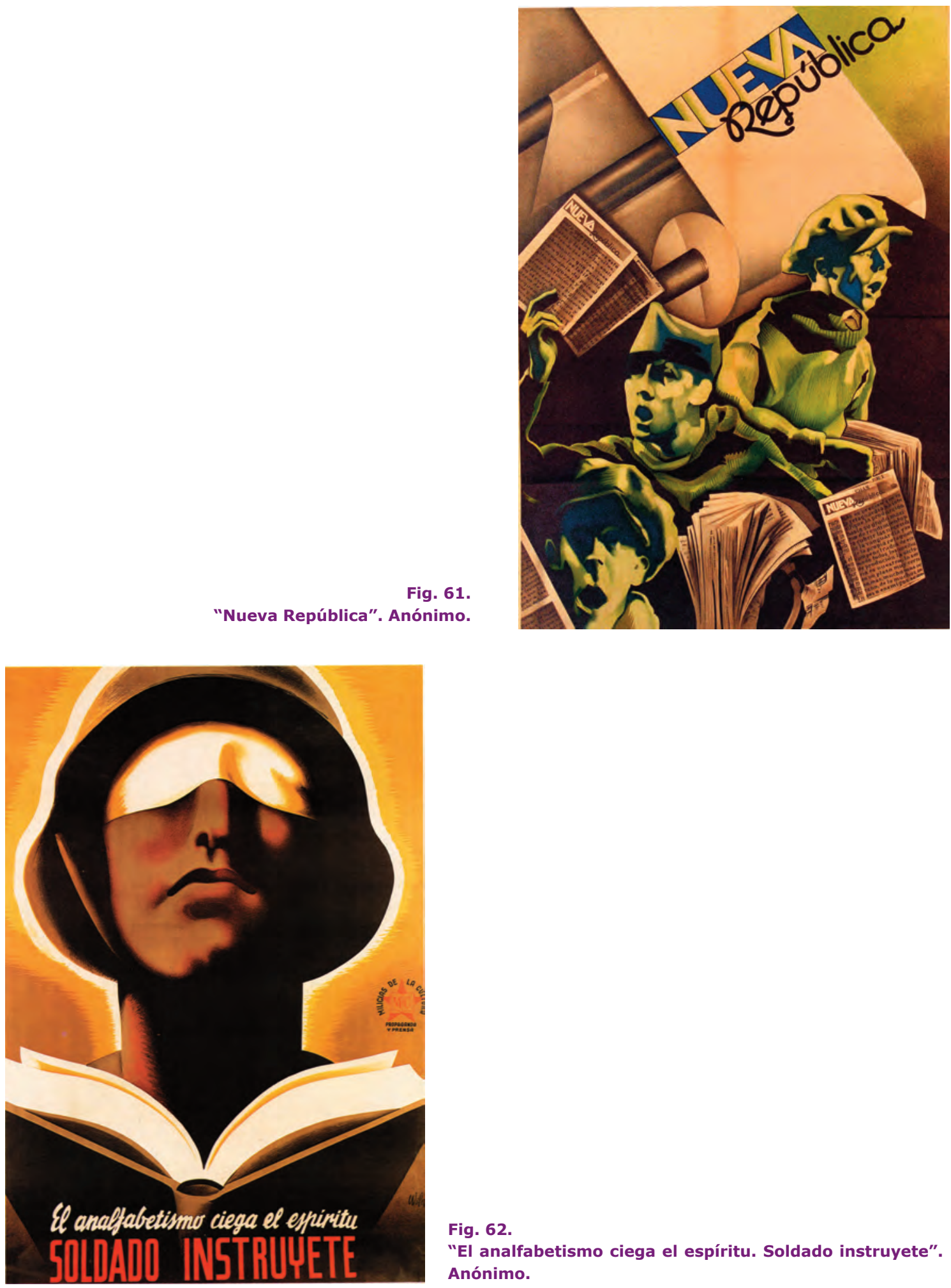

Fig. 62.

"El analfabetismo ciega el espíritu. Soldado instruyete". Anónimo.
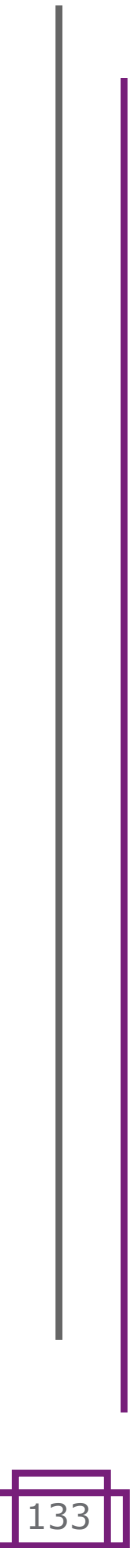


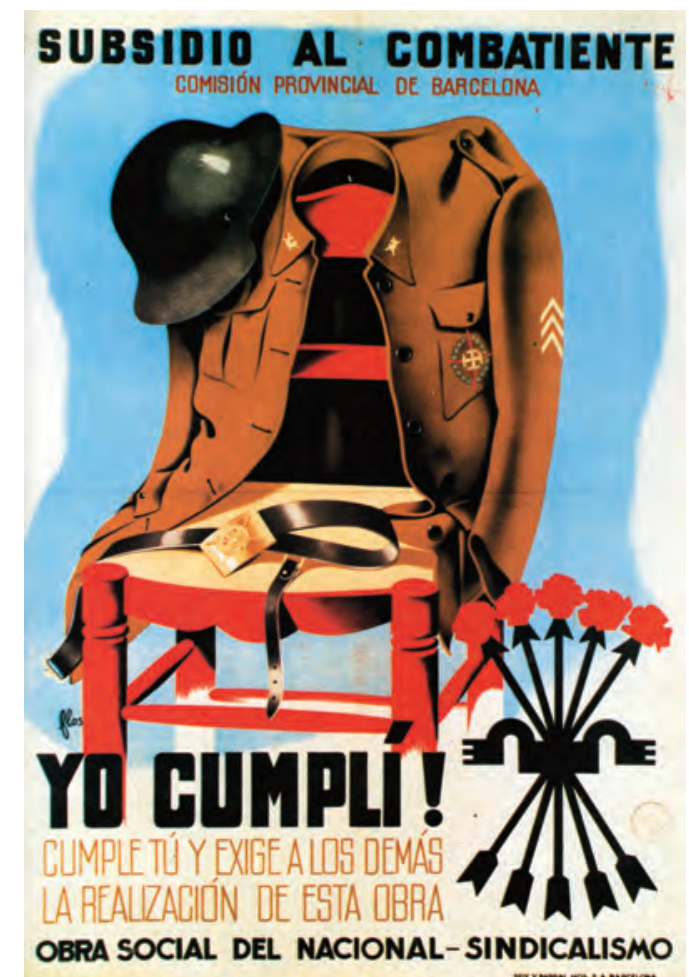

Fig. 63.

"Subsidio al combatiente. Yo cumplí! Cumple tú y exige a los demás la realización de esta obra. Flos.

\section{4.- Editores y lugares de impresión.}

Los lugares de impresión donde se llevaron a cabo la mayoría de estas obras fueron fundamentalmente tres ciudades: Madrid, Barcelona y Valencia. No es de extrañar, pues se trataba de tres urbes en las que las artes gráficas estaban desarrolladas $y$, además, se trata de los territorios que resistieron durante más tiempo, por lo que las instituciones públicas y privadas republicanas tuvieron sus órganos directivos y por tanto de propaganda. Aunque no llegaron a alcanzar el nivel de producción de las ciudades anteriormente citadas también cabe destacar el elevado número obras que salieron de Bilbao, Castellón, Gijón, Santander, París, Moscú y Leningrado.

Sus editores fueron de lo más variado, destacando instituciones públicas como el Ministerio de Instrucción Pública y del Ministerio de Propaganda, además del Ejército de la República. Entre las entidades privadas cabe citar a los sindicatos y partidos políticos, especialmente CNT-AIT, UGT, PCE o Juventudes Libertarias, organizaciones como Altavoz del Frente o las Asociaciones de Amigos de la Unión Soviética. 


\section{5.- Cartelistas destacados.}

Todas las circunstancias que hemos comentado anteriormente afectaron directamente a la producción artística, se presentaban unas nuevas exigencias, a las que el artista se tuvo que adaptar y lo hizo a través de los numerosos cambios formales, el surrealismo y los últimos restos del cubismo desaparecieron, dando paso al realismo como estilo dominante y a la sencillez expresiva.

Renau, influido por el cartelismo soviético posrevolucionario, utiliza la técnica del fotomontaje. Bardaso emplea una técnica más tradicional, no utiliza ni el fotomontaje ni imágenes gráficas sino que se basa exclusivamente en el dibujo. Un dibujo simple y poco terminado, como a brochazos, de gran fuerza expresiva.

El grabado y el dibujo a tinta también fueron formas de expresión propicias. Sobresalen en esta disciplina Antonio Rodríguez Luna, Arturo Souto, Miguel Prieto, Eduardo Vicente, Ramón Puyol o Victorio Macho.

Algunos continuaron elaborando imágenes similares a las que habían hecho en años anteriores a 1936. Arturo Souto, por ejemplo, sigue en la línea del expresionismo social; Ramón Puyol, continúa su línea de realismo político v carácter sentimental.

Cada artista se suma a la tendencia en función de sus posibilidades creativas.

A la hora de estudiar los carteles políticos españoles nos encontramos con una cierta desproporción entre el número de carteles republicanos y nacionales. La diferencia es el fiel reflejo de la distinta importancia que cada bando concedió al cartel político: fundamental para los republicanos, que contaban con mayor número de imprentas en su lado, y casi inexistente para los nacionales (Fig. 64, 65, 66, 67, 68, 69, 70 y 71).

Como cartelistas importantes en el bando franquista destacamos: Caballero, Cabanas, Quintanilla, Valverde y Carlos Sáenz de Tejada, entre otros. En el bando republicano, nombramos en primer lugar a Josep Renau, conocido internacionalmente y que fue, seguramente, el más grande. Su producción no fue muy numerosa dado que atendía muchas actividades 
relacionadas con la cultura, a Marti Bas, Riba Rovira, Parrilla, Melendreras, Cañavate, Ramón Puyol, Bardasano, y otros muchos, además de los numerosos carteles anónimos que se conservan.

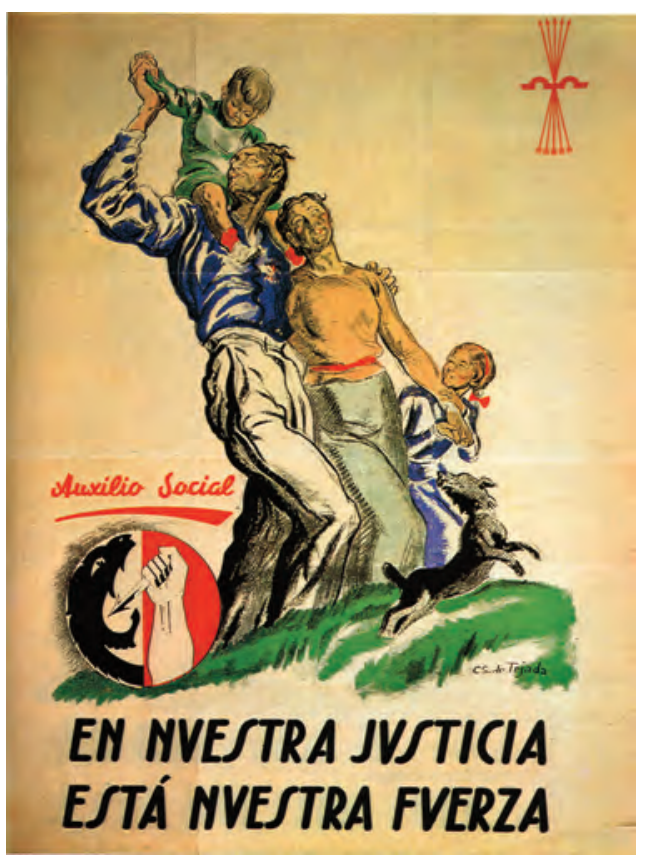

Fig. 64.

"En nuestra justicia está nuestra fuerza". Carlos Sáenz de Tejada.

Fig. 65.

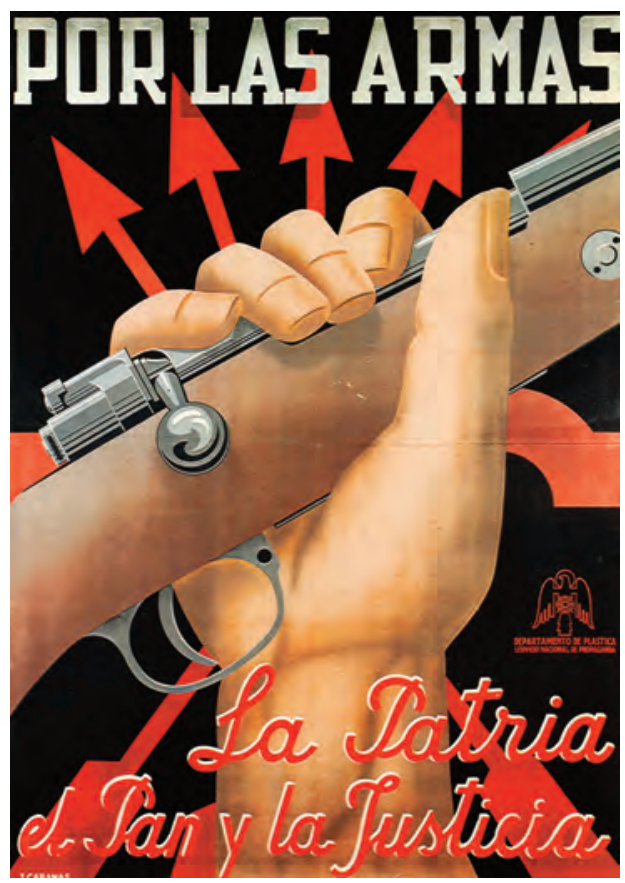



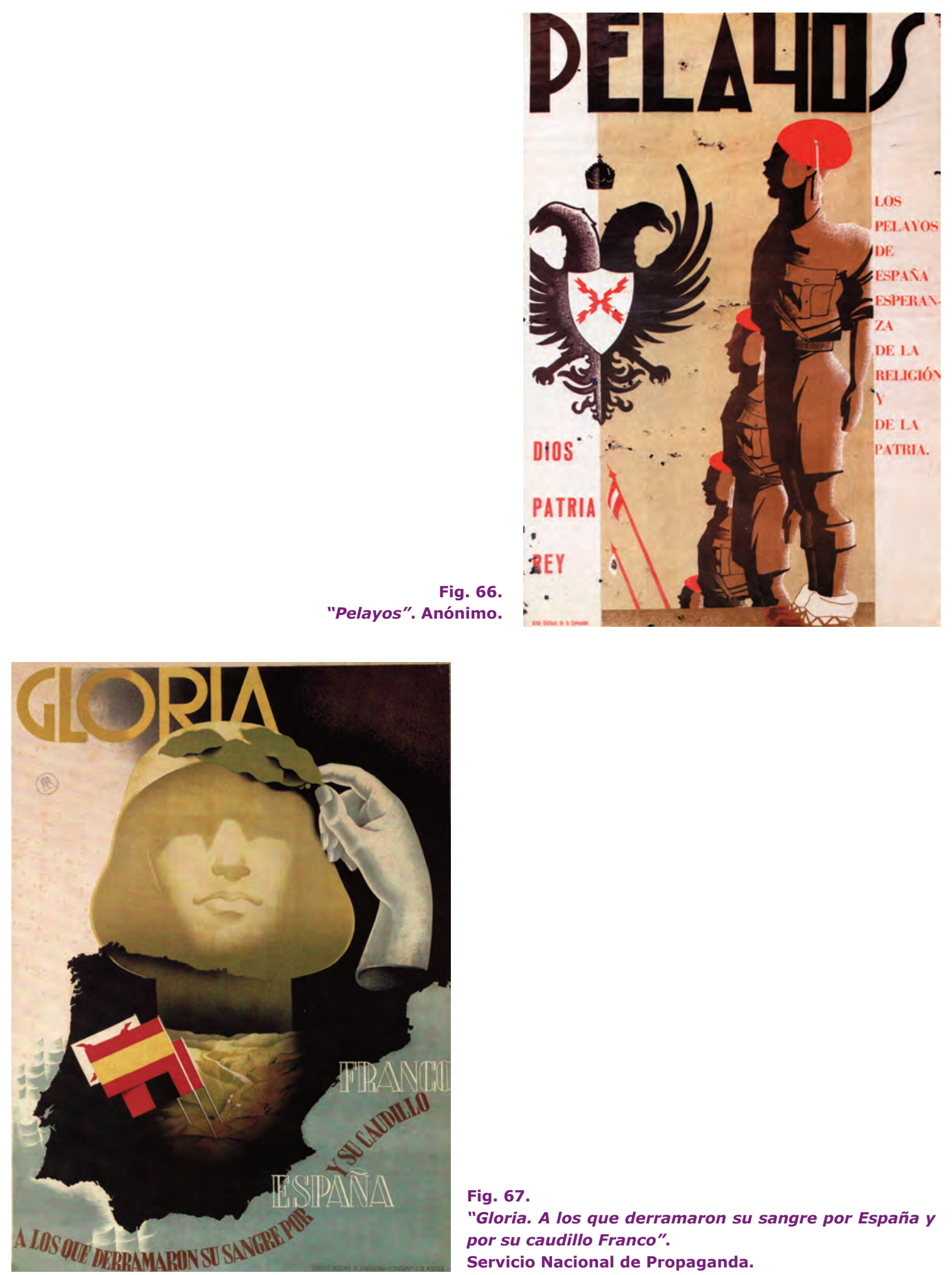

Fig. 67.

"Gloria. A los que derramaron su sangre por España y por su caudillo Franco".

Servicio Nacional de Propaganda.

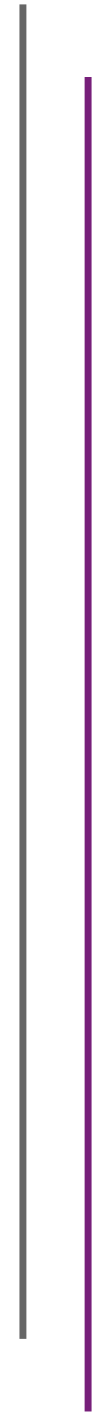


Arte y Comunicación.

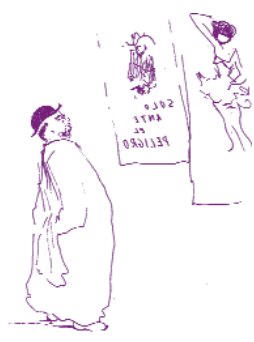

La propaganda política y la transmisión de modelos sociales en la obra de Eduardo Vicente.

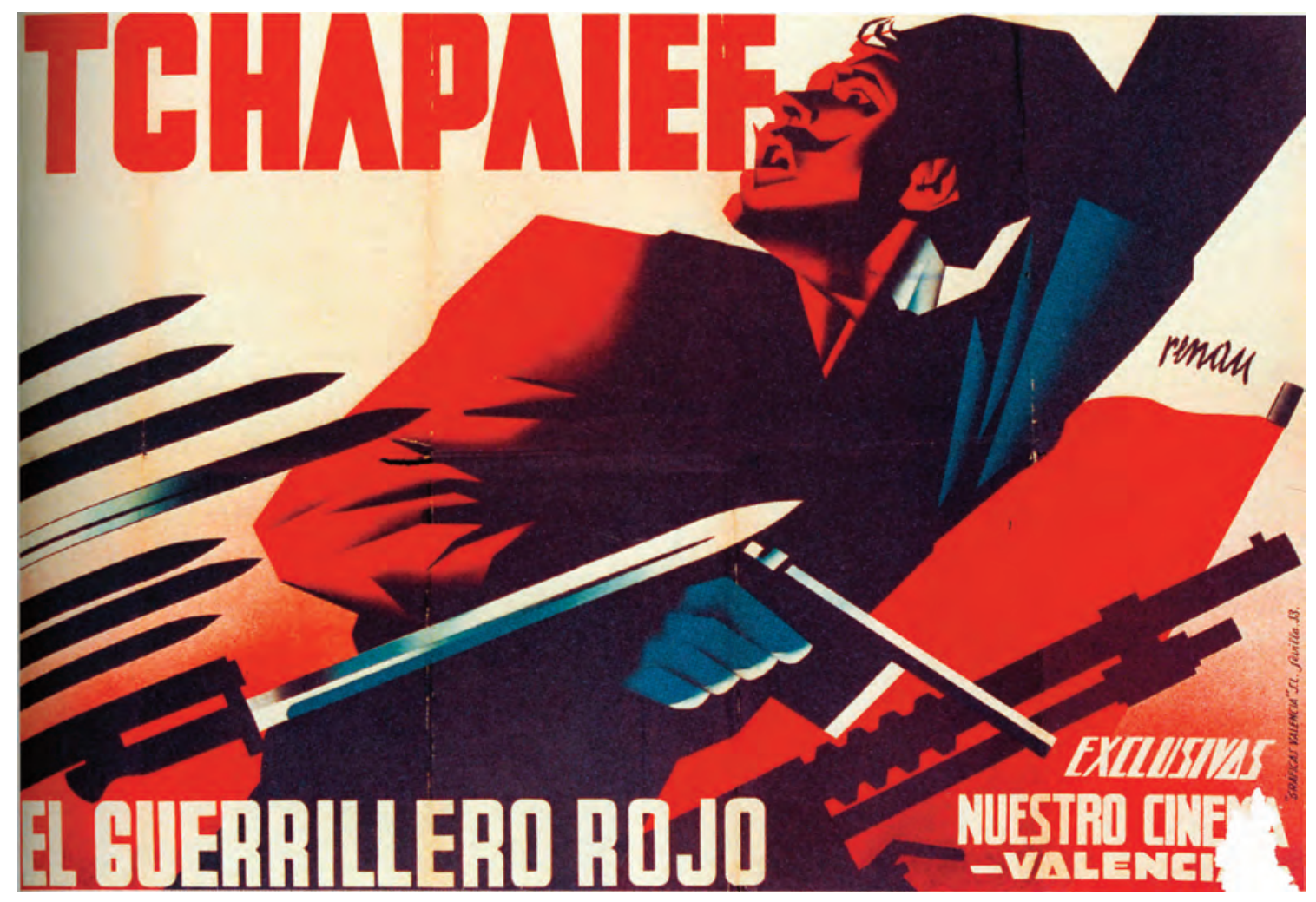

Fig. 68.

"Tchapaief. El guerrillero rojo". Renau.

Fig. 69.

"Combatid! Nos gritan las mujeres de la U.R.S.S. Os ayudaremos hasta el triunfo definitivo". Bardasano.

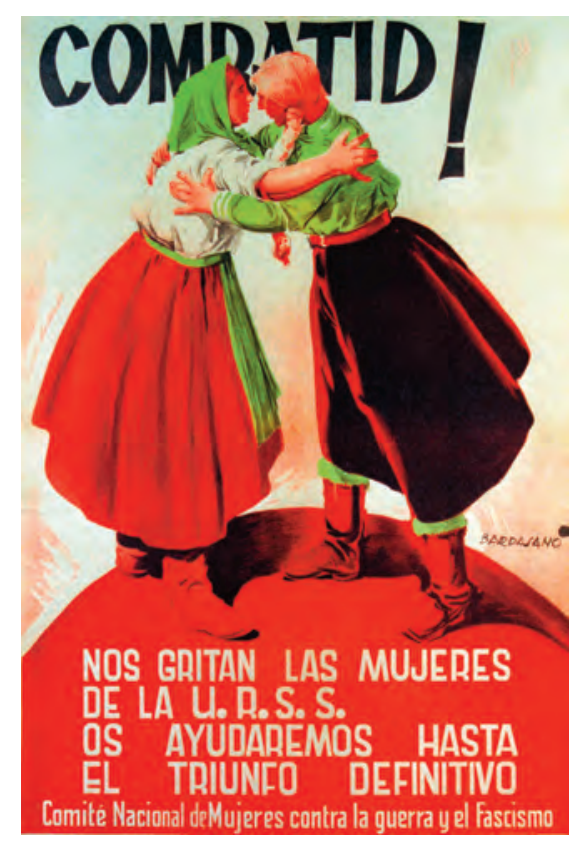


Fig. 70.

"Front Popular!". Martí Bas.
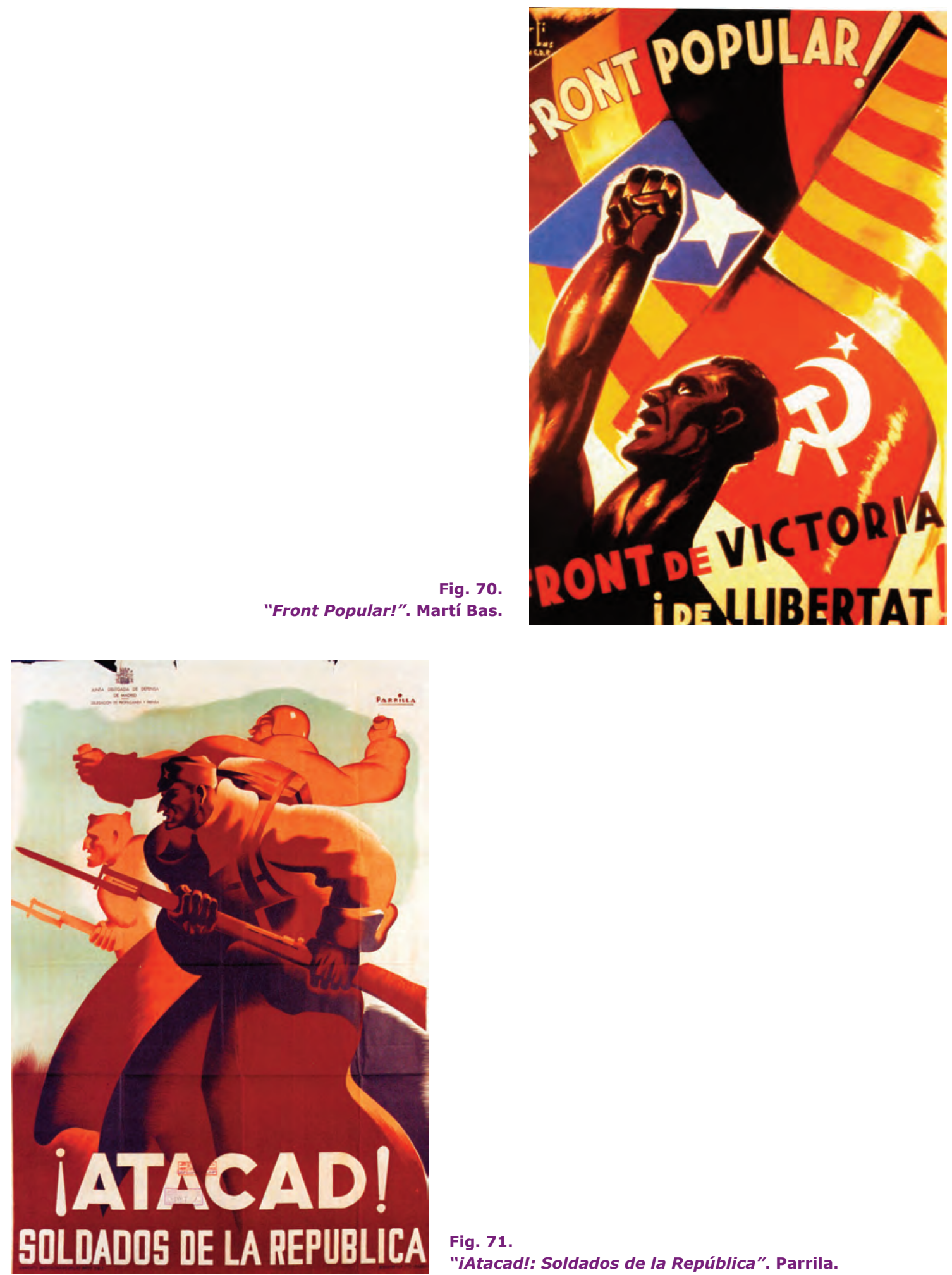

Fig. 71.

"iAtacad!: Soldados de la República". Parrila. 
En nuestro trabajo de investigación nos detenemos en la obra de Eduardo Vicente, hombre comprometido con el bando republicano, que colaboró con el Consejo de Sanidad de Guerra y con el Comisariado del Grupo de Ejércitos de Valencia, junto con Renau, Arreño y Ballester. En 1937 fue uno de los firmantes de la "Ponencia Colectiva" redactada en Valencia, participó en la exposición de París de 1937, en las Misiones pedagógicas, colaboró como ilustrador en algunas revistas y realizó carteles y grabados para diferentes organizaciones republicanas. Sus trabajos sobre la guerra fueron dibujados con el sentido de la instantánea de las fotografías. Los grabados por otra parte aportan un amplio repertorio de la España más profunda y popular. Sus obras se caracterizan por un estilo expresionista de carácter social y bélico. Aspectos que trataremos de forma exhaustiva en el Capítulo IV de esta tesis doctoral.

En definitiva, podemos afirmar que el cartel es, sin lugar a dudas, uno de los medios de expresión más vivos y enérgicos que llegan a la población de forma directa y comprensible. Constituye parte de la realidad urbana y política y es en palabras de Vicent Marc:

"el verdadero periódico del mundo por su carácter directo, su texto voluntariamente conciso destinado a ser leído rápidamente y a contrastar la opinión". 44 


\section{Notas}

1.- Ferrer, E. (2004) "Publicidad y propaganda". Revista Digital Independiente Voz Universitaria. 31 de julio de 2004. pp. 23.

2.- Domenach, J. M. (1968) Le propagande politique. EUEBA. Editorial Universitaria de Buenos Aires. Cuarta edición. p. 2.

3.- Vázquez Medel, M. A. (2004) "Los efectos de la propaganda: una aproximación desde la Teoría del Emplazamiento" en Propaganda y Comunicación. Una Aproximación plural. Comunicación Social. Sevilla. p. 20.

4.- Brown, J. A.C. (1991) Técnicas de persuasión. Alianza Editorial. Madrid. p. 10.

5.- R.A.E. (1992) Diccionario de la Lengua Española. Espasa Calpe. Vigesima primera edición. Tomo II. Madrid. p. 1667.

6.- Ellul, J. (1976) Histoire de la Propagande. P. U. F. 2a edición. Paris. p. 6.

7.- Vázquez Medel, M. A. (2004) "Los efectos de la propaganda: una aproximación desde la Teoría del Emplazamiento" en Propaganda y Comunicación. Una Aproximación plural. Comunicación Social. Sevilla. p. 16.

8.- Edwards, V. (1938) Group Leader's Guide to Propagande analysis. Columbia University. Press. Nueva York. p. 40.

9.- Hitler, A. (1925) Mi lucha. Antalbe. $1^{\text {a }}$ edición. Barcelona. p. 279.

10.- Dood, L.W. (1948) Public Opinion and Propaganda. Henry Holt and Co., Nueva York. p. 240.

11.- Eguizábal, R. (2007) Teoría de la Publicidad. Cátedra. Madrid. p. 33.

12.- Pizarroso, A. (1999) "La historia de la propaganda: una aproximación metodológica", en Revista Historia y Comunicación Social, no 4. Universidad Complutense. Servicio de Publicaciones. Madrid. p. 147. 


\section{Notas}

13.- Rodero, E. (2000) "Concepto y técnicas de la propaganda y su aplicación al nazismo" en las Actas del III Congreso Internacional Cultura y Medios de comunicación. Publicaciones Universidad Pontificia. Salamanca. p. 658.

14.- Martín Requero, M.I. (2000) "Propaganda política y educación. Las imágenes de los textos escolares en la escuela Franquista (1939/1975)", en Publifilia. Revista de Culturas Publicitarias. Colegio Universitario de Segovia. p. 29.

15.- Pizarroso, A. (1993) Historia de la propaganda. Eudema. Madrid. p. 27.

16.- Domenach, J. M. (1996) La propaganda política. EUBEDA. Editorial universitaria de Buenos Aires. Cuarta edición. p. 39.

17.- Brown, J. A.C. (1991) Técnicas de persuasión. Alianza Editorial. Madrid. p. 24.

18.- Eguizábal, R. (2007) Teoría de la Publicidad. Cátedra. Madrid. p. 33.

19.- Domenach, J. M. (1996) La propaganda política. EUBEDA. Editorial universitaria de Buenos Aires. Cuarta edición. p. 19.

20.- Brown, J. A.C. (1991) Técnicas de persuasión. Alianza Editorial. Madrid. p. 25.

21.- Domenach, J. M. (1968) Le propagande politique. EUEBA. Editorial Universitaria de Buenos Aires. Cuarta edición.

22.- Domenach, J. M. (1968) Le propagande politique. EUEBA. Editorial Universitaria de Buenos Aires. Cuarta edición. p. 25.

23.- Hitler, A. (1925) Mi lucha. Antalbe. $1^{\text {a }}$ edición. Barcelona. p. 94.

24.- Pratkanis, A. y Aronson, E. (1994) La era de la propaganda. Uso y abuso de la persuasión. Paidós Comunicación. Barcelona. p. 77. 


\section{Notas}

25.- Domenach, J. M. (1968) Le propagande politique. EUEBA. Editorial Universitaria de Buenos Aires. Cuarta edición.

26.- Morelli, A. (2001) Principios elementales de la propaganda de guerra. Edición Hiru. Hondarribia. 2001; original francés 2001.

27.- Hitler, A. (1925) Mi lucha. Antalbe. $1^{\text {a }}$ edición. Barcelona. p. 228.

28.- Castro F. (2007) "Mensaje de fidel al pueblo de cuba". 31 de diciembre del 2007 http://www.cuba.cu/gobierno/discursos/ (01/08/2011).

29.- Velasco, C. (1988) "Publicidad y política en la guerra civil" en la Revista Historia 16, no 143. Madrid. p. 12-22.

30.- Marchamalo, J. (1996) Bocadillos de Delfín. Editorial Grijalbo. Barcelona. p. 18.

31.- B.O. E. del 18 de julio de 1945.

32.- Ibáñez Martín, J. (1945) "Discurso de presentación de la Ley de Educación de 17 de julio de 1945 a las Cortes Españolas".

33.- Gubern, R. (1997) "Medios icónicos de masas" en Historia 16, Madrid. p. 54.

34.- Blanco y Negro (1902) "Concurso de carteles para las fiestas de mayo". Madrid. no 573. 26-04-1902.

35.- Enel, F. (1974) El cartel: lenguaje, funciones, retórica. Editorial Fernando Torres. Valencia. p. 30 y sig.

36.- Moles, A. (1976) El afiche en la sociedad urbana. Paidós. Buenos Aires. p. 23.

37.- Carulla, J. y Carulla, A. (1997) La publicidad en 2000 carteles. Vol. I. Postermil. Barcelona. p. 11. 


\section{Notas}

38.- McLuhan, M. citado por Enel, F. (1974) El cartel: lenguaje, funciones, retórica. Editorial Fernando Torres. Valencia. p.29.

39.- Julián, I. (1993) El cartel republicano en la Guerra Civil Española. Ministerio de Cultura. Dirección General de Bellas Artes y Archivos. Instituto de Conservación y Restauración de Bienes Culturales. Madrid. p. 17.

40.- Gide, A. (1936) cita recogida por Martí Ibañez, F. en "Por un arte revolucionario" en Tiempos Nuevos, 1-12- 36.

41.- Julián, I. (1993) El cartel republicano en la Guerra Civil Española. Ministerio de Cultura. Dirección General de Bellas Artes y Archivos. Instituto de Conservación y Restauración de Bienes Culturales. Madrid. p. 88.

42.- Idem.

43.- Renau, J. (1937) La función social del cartel publicitario. Tipografía Moderna. $1^{a}$ edición. Valencia. p. 33.

44.- Marc, V. en Restany, P. (1968) Un manifieste de la nouvelle peinture: Les noveaux Realistes. Planeta. Paris. p. 58. 


\section{|] Capítulo 3}

La imagen como transmisora y representativa de modelos sociales.

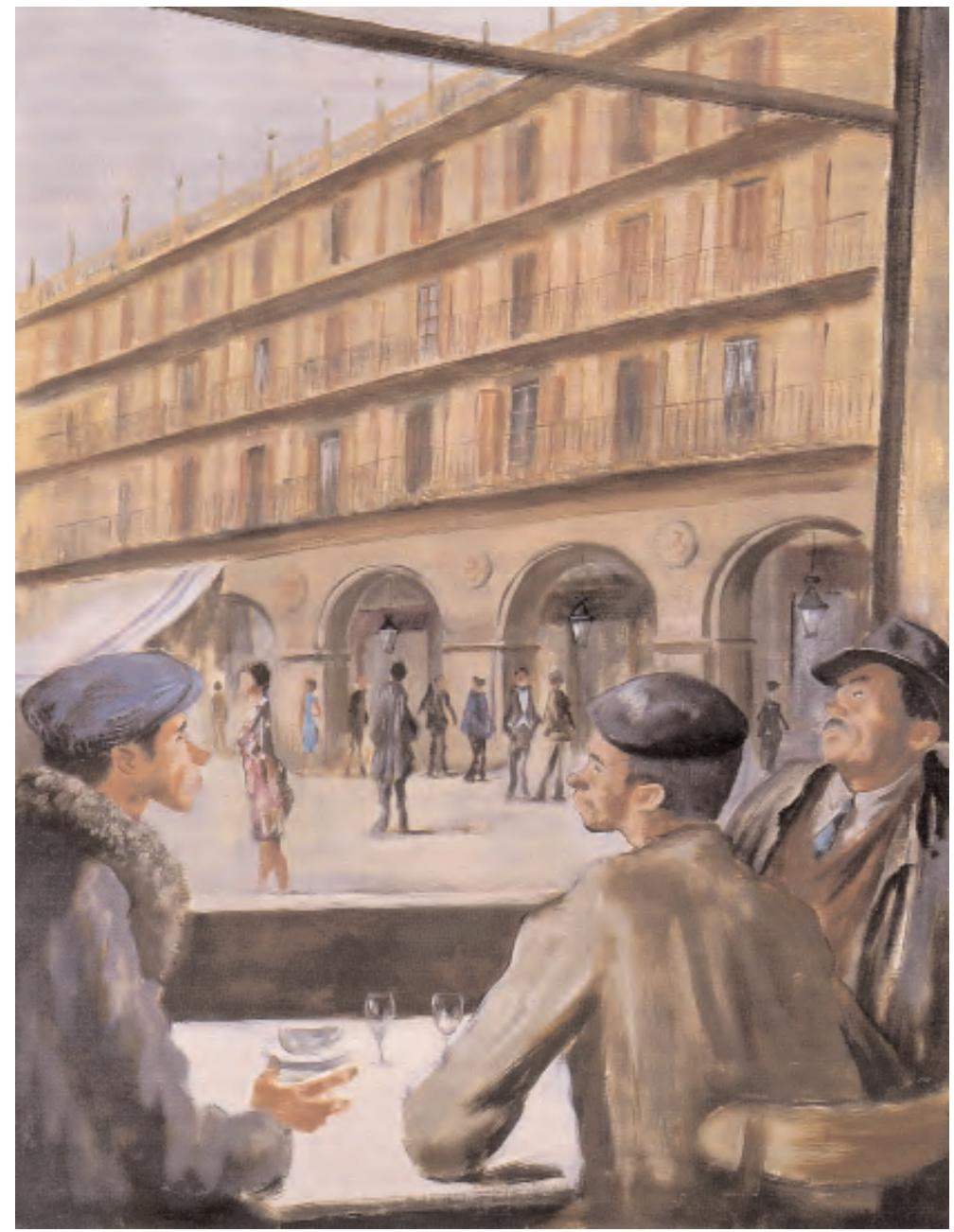

Bebedores en la Plaza Mayor. 1960-65. Madrid. Oleo sobre lienzo. Museo Municipal.

Eduardo Vicente 

C su cuarto de sonrisa, un susurro, una miradita. Se va. (las instantáneas tiendas de campaña que el aire y la luz ponen a nuestro estar aquí $y$ allá convienen con todo $y$ no con él). El ve a los otros en su tienda de luz y aire, pero los otros no lo ven a él.

Siempre anda fuera de su tienda, su fondo. No tiene ambiente general. $\Omega S^{1}$

Ramón Jiménez, J.R. (1950:Solapas interiores)

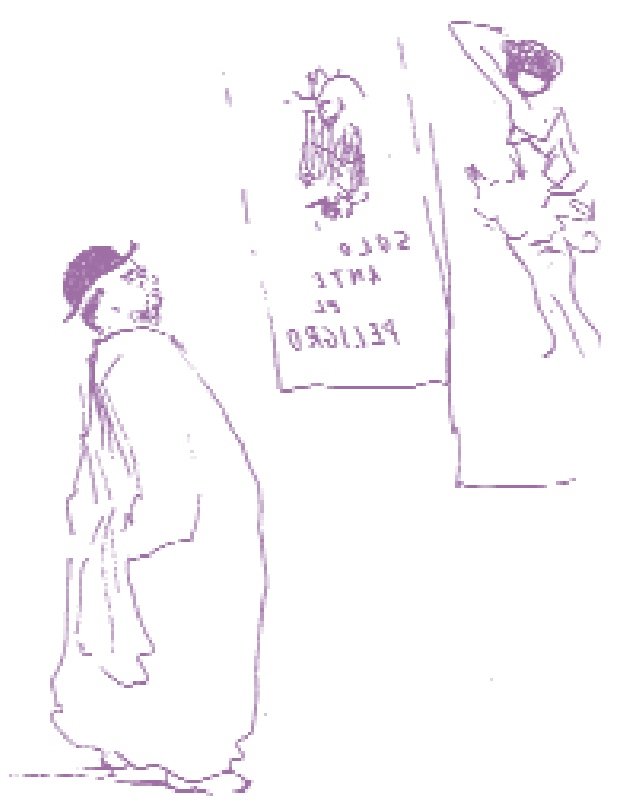





\section{La imagen como transmisora y representativa de modelos sociales.}

El empleo de la imagen como fuente documental ha sido objeto de estudio por numerosos investigadores. Aunque, en muchos casos, los testimonios de las imágenes se consideraban, por parte de los historiadores, como documentos de índole inferior a los textos escritos y a los testimonios orales, también es verdad que, cada vez más, las imágenes sirven para conocer acontecimientos políticos, tendencias económicas, estructuras sociales, así como para el estudio del pensamiento, la historia de la vida cotidiana, la historia de la cultura material, e incluso la estética y las modas de culto al cuerpo, entre otros muchos temas.

Todos estos ámbitos de conocimiento no habrían podido llevarse a cabo, si solamente nos hubiéramos limitado a las fuentes tradicionales como los textos escritos o los documentos oficiales conservados en los diferentes archivos.

Las imágenes se han ido abriendo un importante camino como fuente documental y sirven de guía de estudio para conocer diferentes épocas y acontecimientos dignos de ser comprendidos y valorados.

El empleo de las imágenes se remonta al siglo XVII, como señala Francis Haskell (1928-2009) ${ }^{2}$ en su obra titulada Historia de las imágenes, donde las pinturas de las catacumbas de Roma fueron testimonio de la historia del cristianismo primitivo $y$, en el siglo XIX como testimonio de la historia social.

El Tapiz de Bayeux (Fig. 1), fue un referente importante como fuente histórica en el siglo XVIII. Este tapiz y su testimonio ha sido utilizado en numerosas ocasiones por los historiadores especializados en la conquista de Inglaterra por los normandos y en los acontecimientos que sucedieron en ella.

Fig. 1.

Detalle de la muerte del rey Harold durante la batalla de Hasting, del tapiz de Bayeux. Musée de la Tapisserie, Bayeux.

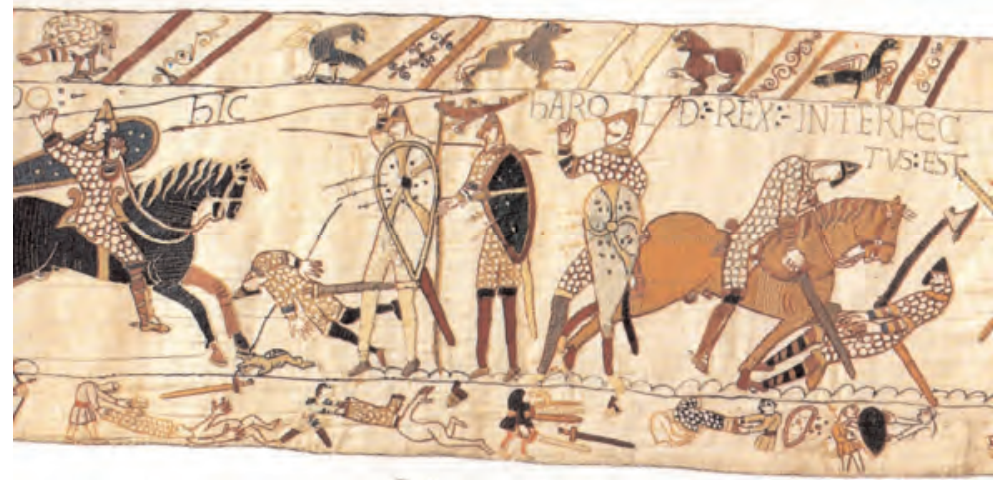


Los cuadros de Joseph Vernet, de los puertos de los mares franceses, (Fig. 2, 3, 4 y 5) fueron muy alabados por un crítico de arte, según el cual, si otros pintores hubieran sido como Vernet, sus cuadros serían muy útiles porque:

"en sus cuadros podría leerse la historia de las costumbres, las artes y las naciones". 3

Lagrange, L. (1864:77)

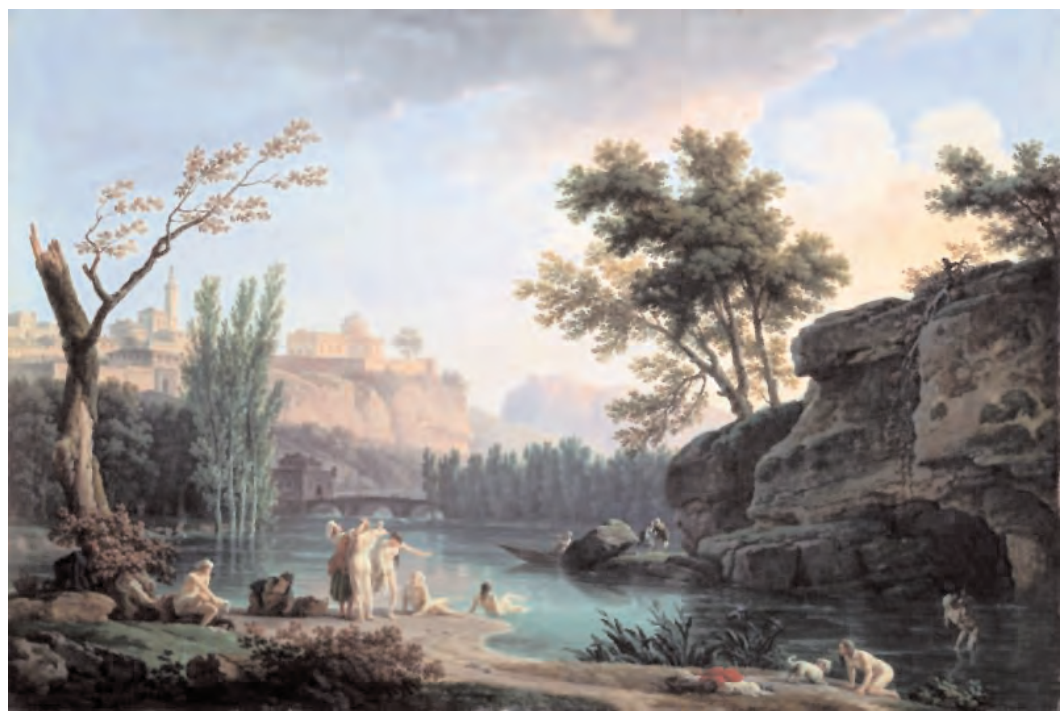

Fig. 2.

Fig. 3.

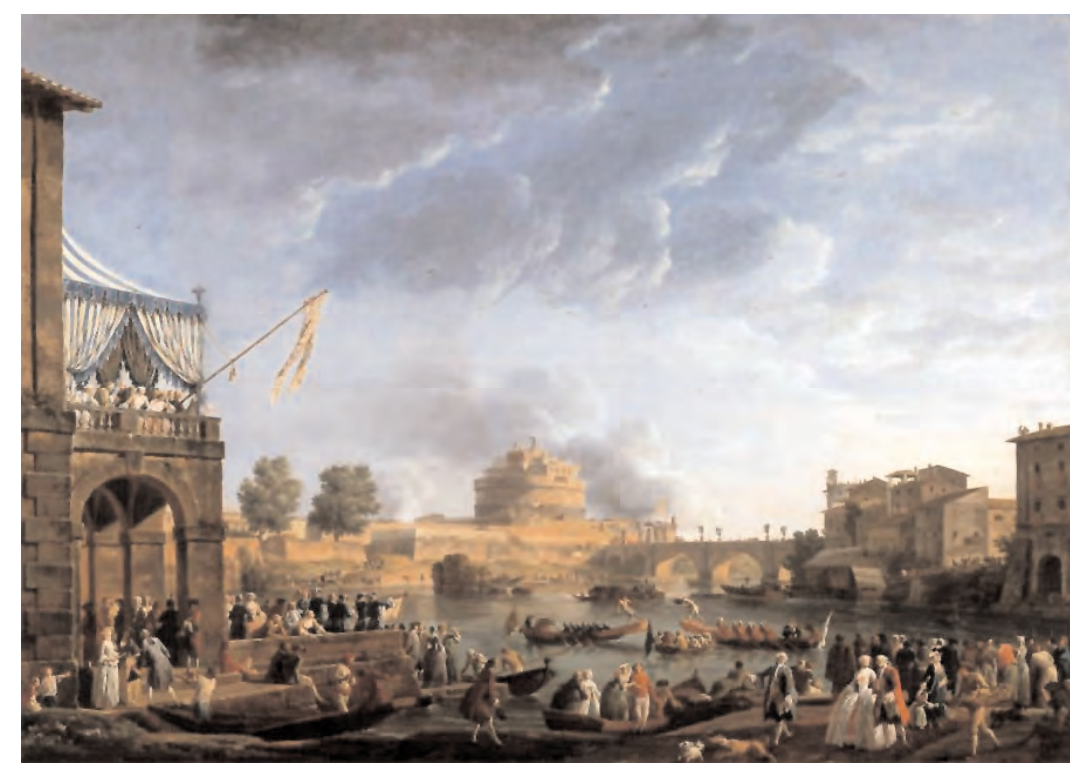




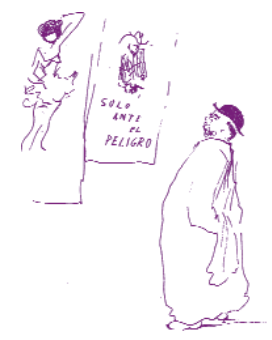

Fig. 4.
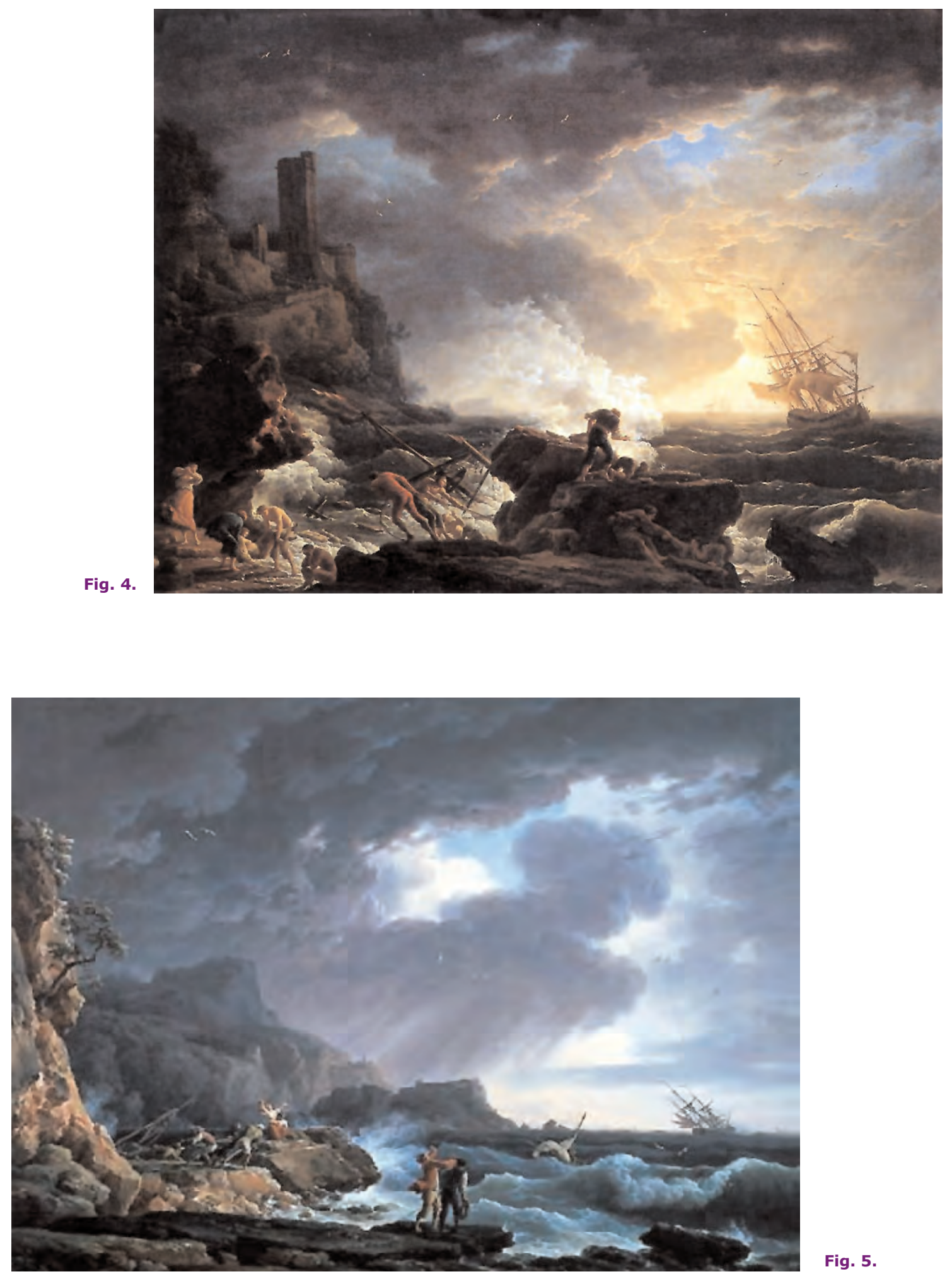

Fig. 5.

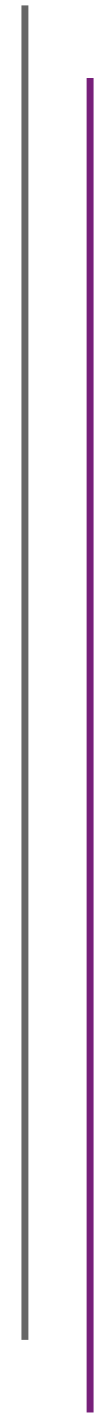

Fig.

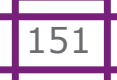


Las imágenes servirán para la reconstrucción de la cultura, los edificios, las gentes y las actividades que realizaban; también sus vestidos, el mobiliario, los paisajes urbanos y todos los utensilios que se usaban y se colocan en su contexto social original (Fig. 6, 7, 8 y 9).

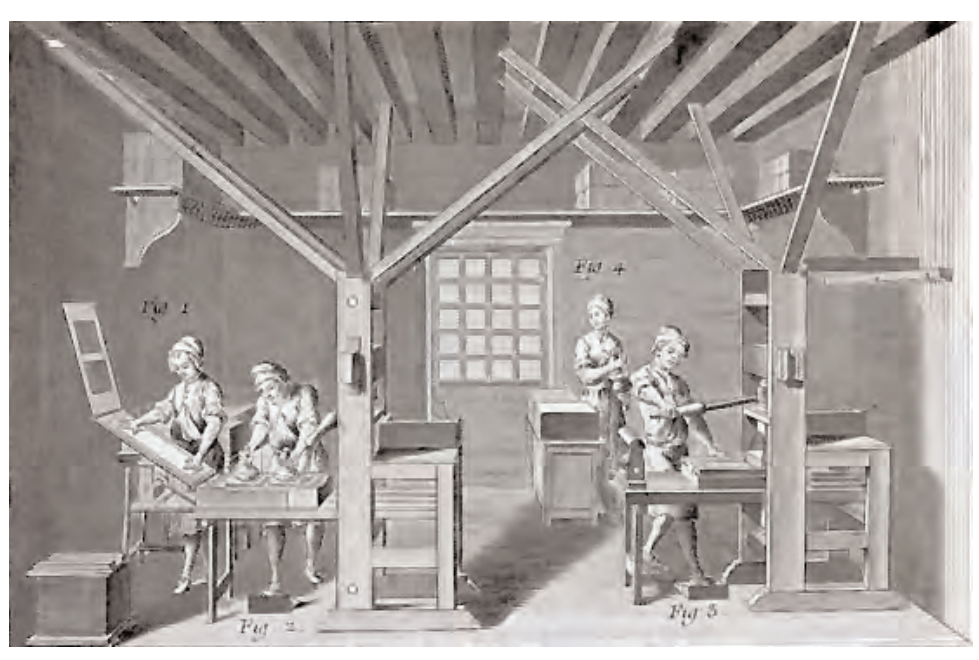

Fig. 6.

Grabado de la sala de

composición de una imprenta.

Fig. 7.

Milagro en Rialto, Vittore Carpaccio.óleo sobre lienzo. Galleria dell'Accademia.

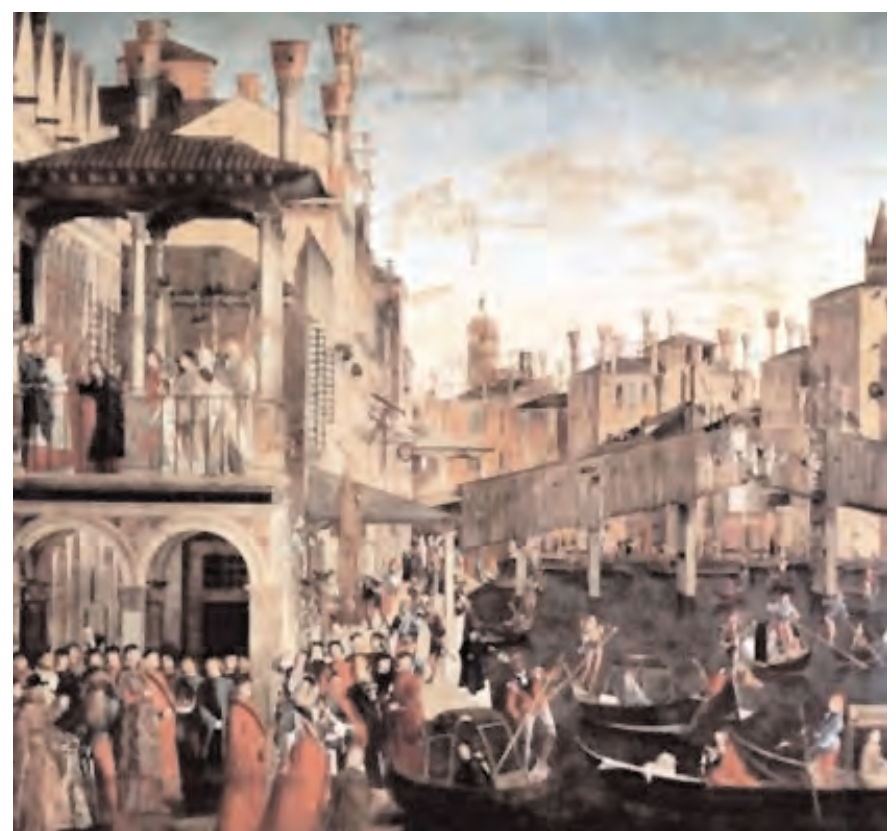




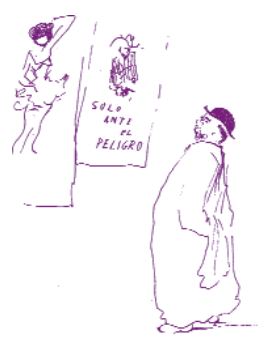

Fig. 8.

La Escuela de Atenas. Rafael Sanzio (1510-1511)
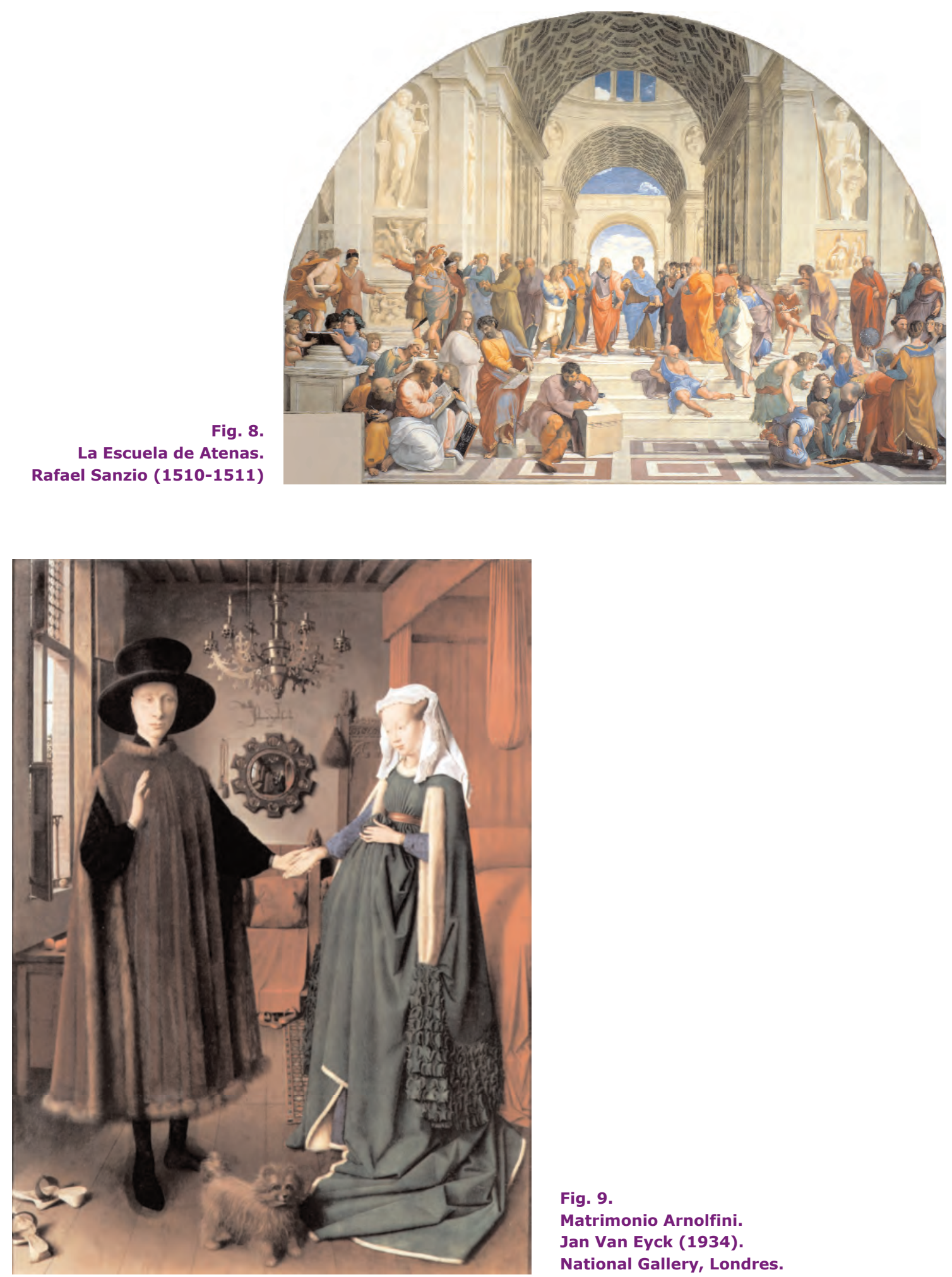

Fig. 9.

Matrimonio Arnolfini.

Jan Van Eyck (1934).

National Gallery, Londres.

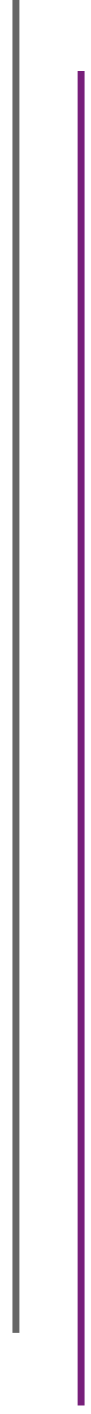


"Las imágenes son una guía para el estudio de los cambios experimentados por las ideas de la enfermedad y de la salud y, todavía son más importantes como testimonios de cambio experimentado por los cambios de belleza, o de la historia de la preocupación por la apariencia externa tanto por parte de los hombres como de las mujeres. Del mismo modo, la historia de la cultura material sería prácticamente imposible sin el testimonio de las imágenes, que también han supuesto una contribución importante a la historia de las mentalidades". 4

Burke, P. (2005: 12)

Los especialistas en historia de la cultura Jacob Burckhardt (1818-1897) y Johan Huizinga (1872-1945) basaban sus estudios de la cultura italiana y de los Paises Bajos en las pinturas de artistas como Rafael o Van Eyck, (Fig. 10, $11,12,13,14$ y 15), y en los textos de Burckhardt ${ }^{5}$ que calificaba las imágenes como:

"Testimonios de las fases pretéritas del desarrollo del espíritu humano" y de objetos "a través de los cuadros podemos leer las estructuras de pensamiento y representación de una determinada época".

Fig. 10. Retrato de Baltazar Castiglione.

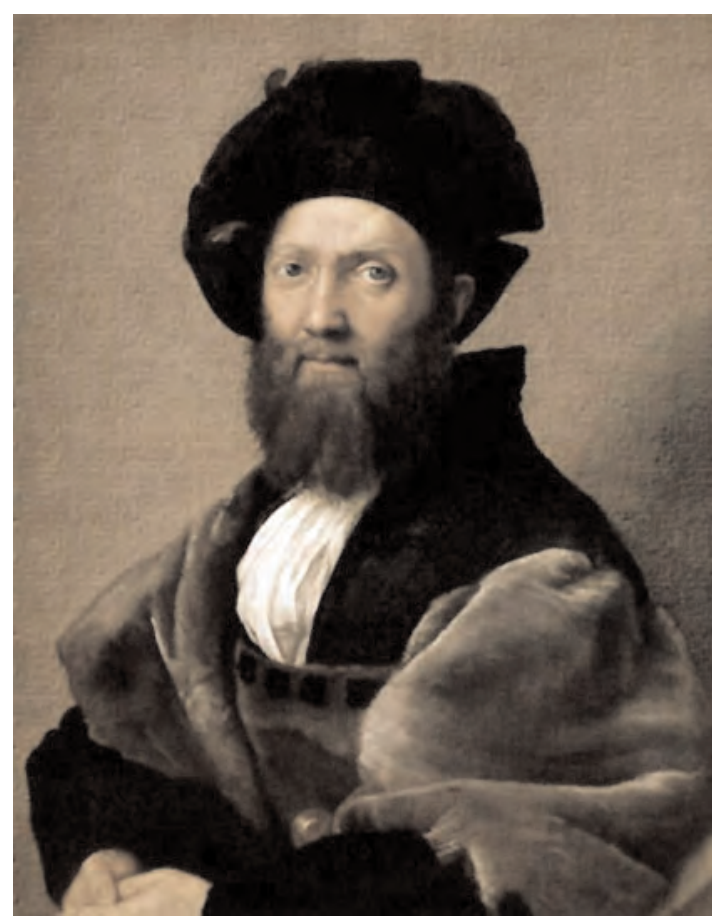




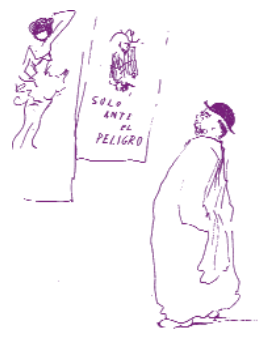

Fig. 11.

La Sagrada Familia con San Juan. Llamada "La Perla". Rafael Sanzio.

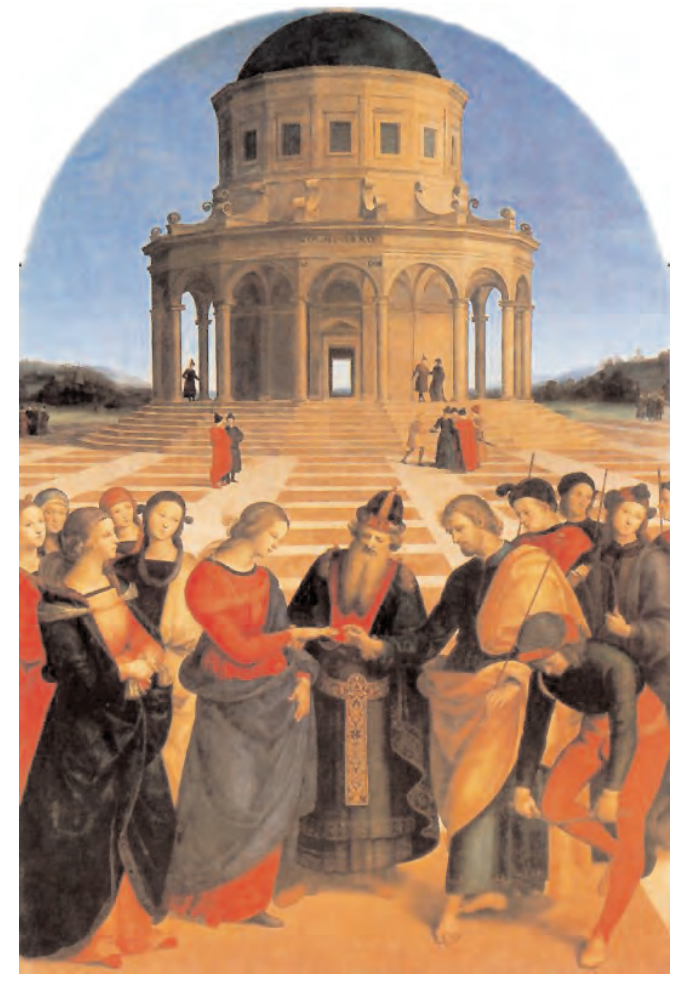

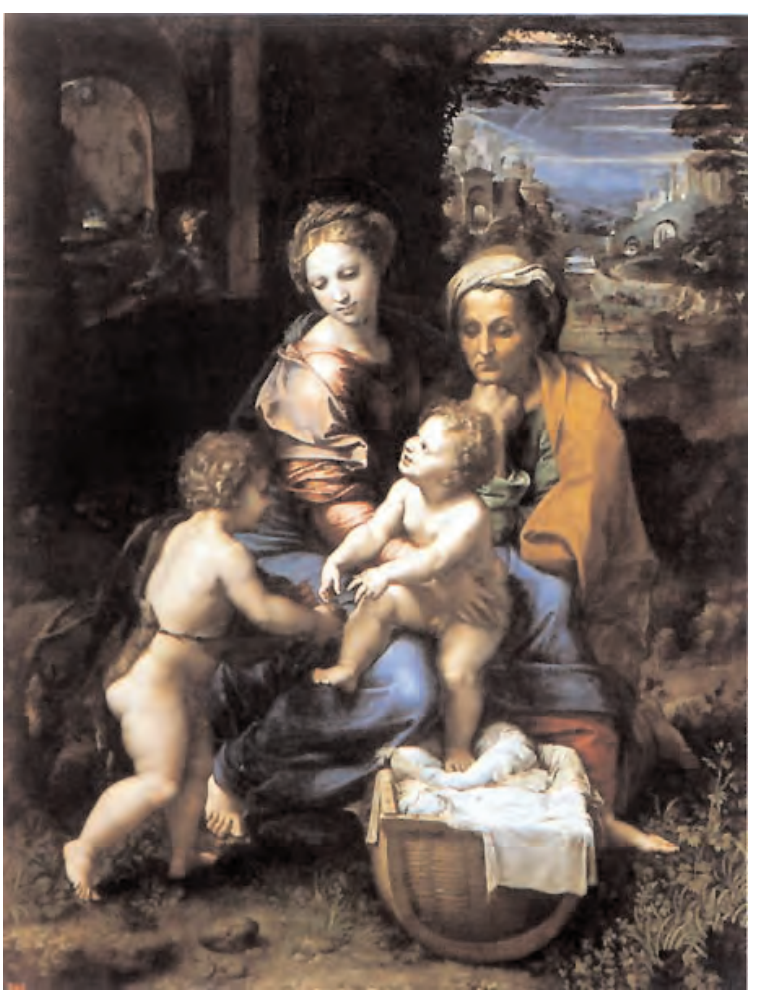

Fig. 12.

Los desposorios de la Virgen.

Rafael Sanzio.

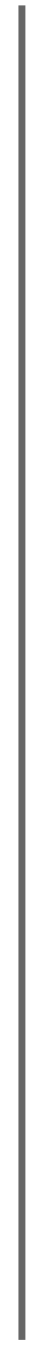

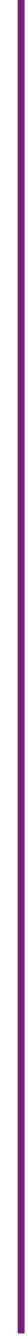


Arte y Comunicación.

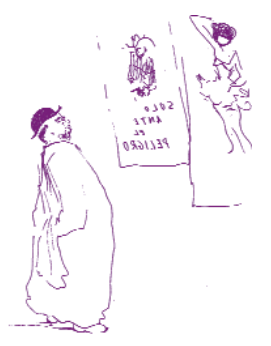
La propaganda política y la transmisión de modelos sociales en la obra de Eduardo Vicente.

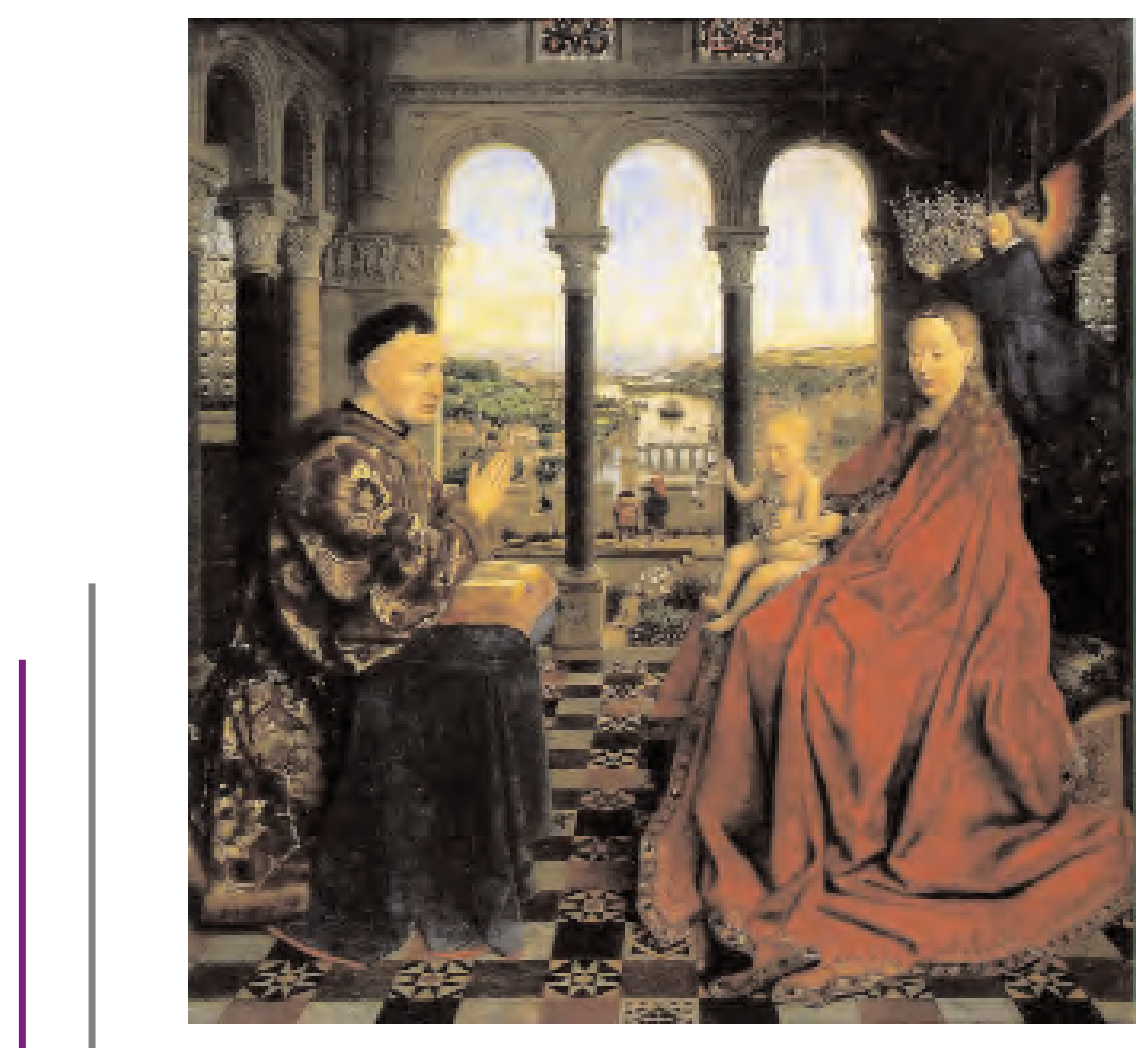

Fig. 13.

La Virgen del Canciller Rolin. Jan Van Eyck (1435).

Fig. 14.

Virgen con niño, con Santos y donante Cartujo. La Virgen del Canónigo. Jan Van Eyck (1441).

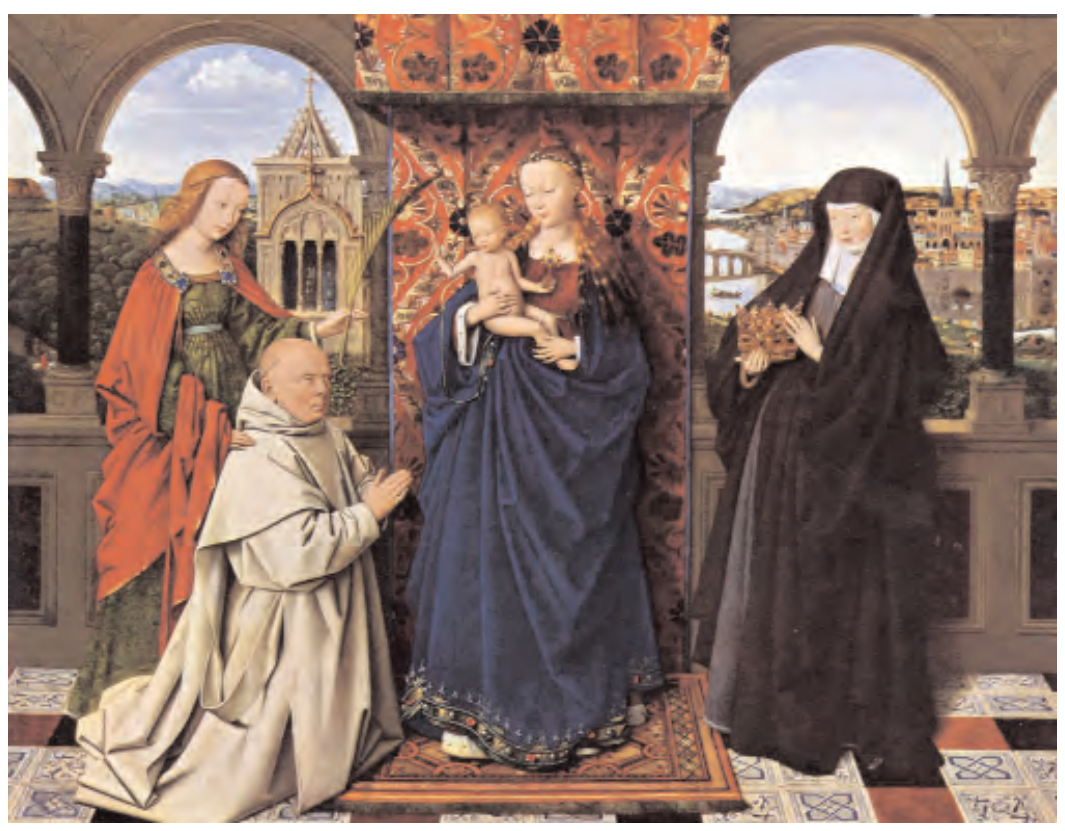



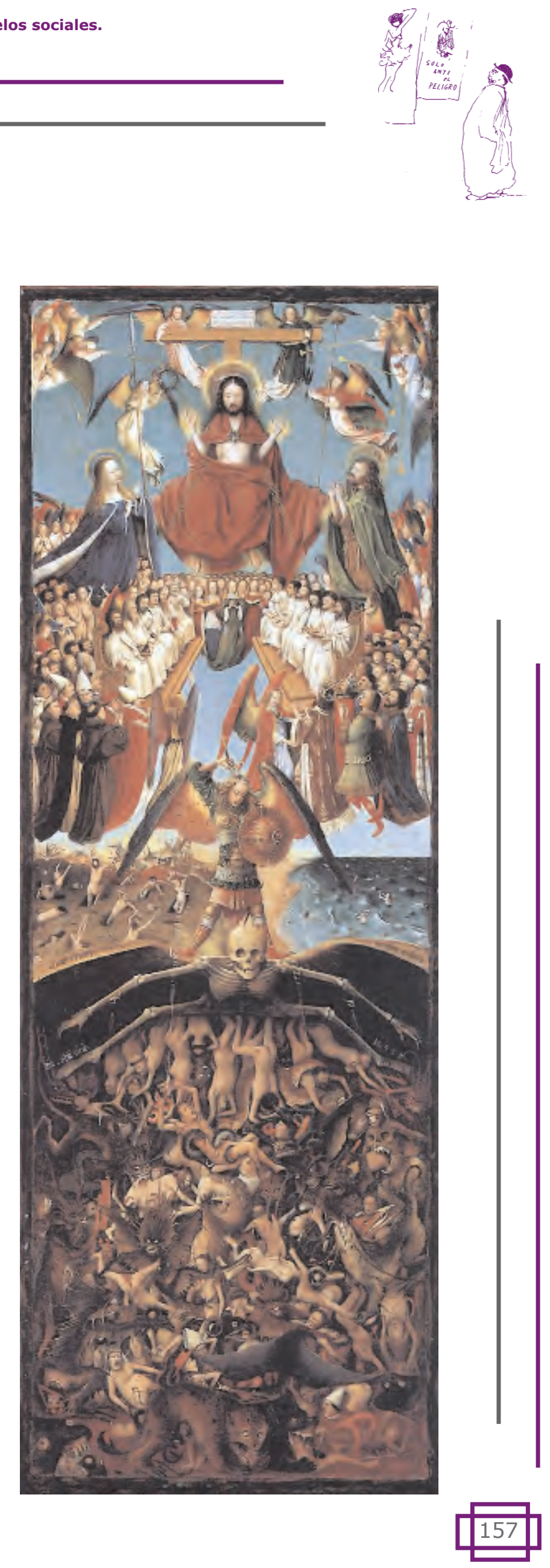
Huizinga pronunció en 1905 la lección inaugural en la Universidad de Groning, cuyo título: "El elemento estético del pensamiento histórico" era una clara defensa de la imagen y de la creación artística como una manera de formar imágenes que servían como fuente de conocimiento.

Otro académico de la generación de Huizinga, Aby Warburg (18661929) se dedicó al estudio de la cultura y utilizaba, en sus investigaciones, tanto las imágenes como los textos escritos.

El Instituto de Warburg fomentaba la imagen, como comenta la historiadora Frances Yates (1899-1981) que frecuentaba el Instituto a finales de los años treinta:

"Iniciada en la técnica de Warburg consistente en utilizar los testimonios visuales como documento histórico". 6

Yates, F. A. (1975:4)

Otros autores como Gilberto Freyre (1900-1987), Philippe Ariès (19141982), entre otros muchos, van concediendo a la imagen el lugar que le corresponde, no sólo como testimonio sino también como fuente para compartir las experiencias y los conocimientos no verbales de las diferentes culturas.

No obstante habrá que esperar hasta los inicios de los ochenta para que el arte, con sus imágenes, comiencen a ser reconocidos como fuente importante para la investigación; así como lo confirman las actas de un congreso de historiadores americanos celebrado en 1985 y dedicado a los "testimonios del arte". Tras ser publicado un número especial del Journal of interdisciplinary history, este congreso despertó tal interés que sus actas se volvieron a publicar en formato de libro escrito por los autores Robert I. Rotberg y Theodore K. Rabb. ${ }^{7}$

A partir de este momento, Simon Schama, participante en el congreso anteriormente citado, se hizo famoso por la utilización de testimonios visuales en sus investigaciones. Sus estudios abarcan desde la cultura holandesa del siglo XVII hasta un interesante recorrido de las actitudes occidentales ante el paisaje durante varios siglos. 
El uso de la imagen como documento histórico se convierte en una fuente imprescindible para compartir las experiencias y los conocimientos no verbales de la cultura de cualquier momento. En definitiva las imágenes nos permiten imaginar el pasado de un modo más vivo; al situarnos frente a la imagen nos situamos frente a la historia.

"El hecho de que las imágenes fueran utilizadas en las diversa épocas como objetos de devoción o medios de persuasión y para proporcionar al espectador información o placer, hace que puedan dar testimonio de las formas de religión, los conocimientos, las creencias, los placeres, etc, del pasado". 8

Burke, P. (2005:17) 



\section{Los testimonios de la imagen.}

Antes de comenzar una investigación utilizando la imagen como fuente importante y testimonio de una época, es conveniente definir la imagen y su importancia en la comunicación humana.

El término "imagen" se utiliza para referirse a un conjunto de fenómenos o de realidades materiales e inmateriales diferentes. El concepto puede ser aplicado de forma general, tanto en la comunicación diaria como en la artística, didáctica y científica.

Son muchas las definiciones que encontramos del término "imagen":

"Naturaleza de las cosas, lo permanente e invariable de ellas". 9

R.A.E. (1975:677)

"Figura, representación y apariencia de una cosa. Representación viva y eficaz de una cosa, de una intuición o visión poética, por medio del lenguaje". 10

R.A.E. (1970:731)

"Representación mental de una cosa percibida por los sentidos". 11

Casares, J. (1973:462)

"Representación de un objeto en dibujo, pintura, escultura, etc." 12.

Moliner, M. (1984:90)

En todas estas definiciones la imagen se nos presenta como un tipo de copia más o menos exacta de la realidad, un calco, un recuerdo. Es decir, que el concepto de representación está continuamente presente en estas acepciones, como lo está en la definición de A. Moles que concibe la imagen como:

"Un soporte de la comunicación visual que materializa un fragmento del medio óptico (universo perceptivo) susceptible de persistir a través del tiempo, y que constituye uno de los principales componentes de los 
mas-media". 13

Moles, A. (1973:47)

Un soporte que materializa un fragmento del universo perceptivo es, ante todo, una cosa real y tangible en el que se destaca, por encima de cualquier otro rasgo, la materialidad y se deja en segundo término la función de representación o de réplica. De esta definición de Moles podemos extraer las ideas de materialidad (aspecto fabricado de la imagen) y de independencia con respecto a los temas u objetos representados.

En el caso de algunas imágenes, solemos hablar de una reproducción o de una copia de la realidad, concediéndola todo el crédito que la realidad misma tiene.

Sin embargo, toda copia o representación es siempre parcial y no puede ser de otra manera. La realidad es como es, poliédrica, tridimensional y solamente perceptible por el conjunto de nuestros sentidos, estando estos inmersos dentro ella.

La realidad es siempre viva, dinámica y cambiante.

La imagen supone "congelar" un mínimo aspecto de esa realidad en unas pocas dimensiones cerradas y limitadas.

"Toda imagen supone una reducción quirúrgica de la realidad a la que extirpan rasgos del carácter". ${ }^{\mathbf{1 4}}$

Zunzunegui, S. (1989:136)

Además la imagen constituye una visión del mundo basada en una serie de partículas inconexas e independientes ${ }^{15}$, como señala Berger refiriéndose a la fotografía:

"La imagen fotográfica, a diferencia de la memoria, no preserva significados, sino que ofrece apariencias, a las que se otorga una importante credibilidad en función de la inmediatez, tomadas al margen de su significado". 16 
Todo lo anteriormente expuesto, no supone que queramos negar el valor de la imagen, sino lo que pretendemos es situar su aportación cognoscitiva en el nivel que le corresponde y reivindicar su papel como otra alternativa útil para la construcción de lo que estamos denominando realidad. como:

Por tanto, consideramos la imagen, en palabras de Justo Villafañe

"una selección de la realidad". 17

Villafañe, J. (1985:23)

La selección de la realidad es uno de los hechos que constituyen la naturaleza icónica.

Una de las características fundamentales de todo lenguaje icónico es su grado de isomorfismo (similitud de forma) en relación a las características de los referentes, dicho grado varía a lo largo de una amplia escala:

"Una gama continua de formas va de los medios menos isomórficos a los que lo son más; incluye elementos intermedios como los sonidos onomatopéyicos del lenguaje, los ideogramas, las alegorías y otros símbolos convencionales". 18

Arnheim, R. (1976:247)

Es ese grado de isomorfismo el que explica, en principio, la mayor universalidad de los lenguajes icónicos respecto al lenguaje hablado, mucho más arbitrario y por consiguiente más sujeto a convenciones. Aunque en este trabajo defenderemos que la cuestión del parecido o similitud está también sujeta a convenciones y que, por lo tanto, la iconicidad, como nos lo advierte Joan Costa, es en buena medida resultado de la subjetividad y la personalidad creativa de quienes manejan las técnicas de producción icónica y de cómo las usan. Lo que nos parece fuera de toda duda es que existe una relación objetivable, mensurable, entre determinados tipos de imágenes y sus referentes: 
"Una fotografía en color es más icónica que una fotografía en blanco y negro; un retrato es más icónico que una caricatura .. un mapa o el plano de una ciudad son menos icónicos que una fotografía aérea; un esquema, un diagrama o un organigrama apenas son icónicos de aquello que representan; una fórmula química o matemática o una página escrita son todavía menos icónicos, menos semejantes a lo que representan -grado cero de iconicidad". 19

Costa, J. (1992:65)

Así, una escala de iconicidad mide el grado de isomorfismo que una imagen guarda con su referente. Una escala de iconicidad intenta mostrar en una forma ordenada los diferentes grados de correspondencia que pueden darse entre ambos términos. Advertimos no obstante que, en el análisis de la relación entre imagen y realidad, no se puede reducir esta a una mera cuantificación de la iconicidad entre una y otra. Una imagen, independientemente de su grado de iconicidad o abstracción, es también una forma de representación que sirve para modelizar la realidad gracias, precisamente, a que posee equivalentes estructurales de cualquier situación de realidad y a que estos, aún siendo necesariamente "visuales", no son siempre "icónicos", baste pensar en las relaciones de orden espacio-temporal que imperan en la realidad y sus formas de representación mediante imágenes.

Una escala de iconicidad, para resultar de alguna utilidad, debe cumplir dos objetivos: debe dejar claras las diferencias entre cada nivel, para lo cual cada nivel deberá tener una formulación lo más particular posible y, al mismo tiempo, cada nivel debe abarcar el mayor número de imágenes. En otras palabras, la escala de iconicidad más operativa será aquella que, con menor número de niveles, consiga abarcar el mayor número de imágenes posible. De cualquier manera, cualquier escala que se proponga tiene siempre que mostrarse reduccionista respecto a los aspectos que son posibles aislar en una imagen y que permitirían situarla en uno u otro nivel, se presupone en principio una definición de "iconicidad" a la que tal escala deberá ajustarse y, en esta misma definición, reside como veremos la eficacia o no de la clasificación resultante. Para nuestros fines, tomaremos en consideración las propuestas por Conrado Maltese (1970), Abraham Moles (1973) y Justo Villafañe (1985), centrando nuestra atención preferentemente en aquellos niveles que hagan referencia a la bidimensionalidad del soporte, es decir, 
aquellos que tratan de la imagen plana.

De acuerdo a esto, la primera observación es que las escalas que hemos propuesto como modelos difieren entre sí fundamentalmente por dos motivos:

* El número de niveles.

Los criterios utilizados para determinar el grado de iconicidad correspondiente a cada nivel.

A continuación analizamos las escalas más interesantes para nuestra investigación:

\section{Conrado Maltese (1970)}

En Semiología del mensaje objetual (1970) Maltese propone una escala basada en un catálogo de las propiedades táctiles y visuales que pueden ser cubiertas por un determinado repertorio de signos:

"...pedir un repertorio de signos es lo mismo que pedir un repertorio de procedimientos para instituir equivalencias entre una parte $y$ un todo $y$ entre un conjunto definido y un conjunto llamado a sustituirlo". 20

\section{Maltese, C. (1970: 164-165)}

Lo que viene a ser lo mismo que instituir un "repertorio de procedimientos de codificación" que, en el caso de la imagen, se traduce en las técnicas empleadas para construir signos icónicos que dupliquen las propiedades táctiles y ópticas del referente, aumenten sólo las ópticas o que, aún siendo sólo visuales, sustituyan simbólicamente (por medio de sinestesias) las propiedades táctiles. Tales propiedades son:

\section{Táctiles:}

1. Forma en el espacio.

2. Tamaño. 
3. Peso.

4. Dureza.

\section{Visuales:}

5. Forma de los contrastes de claroscuro.

6. Forma de los contrastes cromáticos.

De acuerdo a esto, la escala que propone el autor, queda de la siguiente manera (Cuadro 1):

0 . Objeto de referencia.

1. Duplicado (comunicación de 6 propiedades sobre 6 de la experiencia visivo-táctil de referencia).

2. Reproducción (comunicación directa de 5 propiedades sobre 6).

3. Facsímil/modelo (comunicación directa de 4 propiedades sobre 6: peso y dureza pueden ser, por ejemplo, considerados no interesantes).

4. Representación plana óptica a colores (comunicación directa de 2 propiedades sobre 6 y reducción a dos dimensiones de la propiedad 1).

5. Representación plana óptica en negro (comunicación directa de una propiedad sobre 6 y reducción a dos dimensiones de la propiedad 1 ).

6. Proyecciones geométricas (comunicación sustitutiva o indirecta de las propiedades 1 y 2: por ejemplo una proyección ortogonal. Si completadas por el color representan sustitutivamente también las 5 y 6 ).

7. Representación simbólica plana integra (comunicación sustitutiva de las propiedades 1,5 y 6 ).

8. Representación simbólica plana sumaria (comunicación sumaria de las propiedades 1 y 6 ).

9. Representación simbólica plana reducida (comunicación esquemática sustitutiva de las propiedades 1 y 6 ).

10. Representación simbólica plana esquemática (comunicación esquemática de sólo la propiedad 1).

11. Abstracción sígnica 


\section{Abraham Moles (1973).}

La escala de iconicidad más conocida es la que Abraham Moles (1973) plantea dividida en trece grados que van desde la máxima iconicidad (el propio objeto que se designa en tanto especie o signo ostensivo en la definición de Umberto Eco) hasta aquellas imágenes de iconicidad nula (descripción del objeto mediante palabras o fórmulas algebraicas). El principio que rige esta escala decreciente radica en que el "grado de iconicidad" de una forma es inverso a su "grado de abstracción", comparando siempre la imagen con el objeto (Cuadro 2).

\begin{tabular}{|c|c|c|c|}
\hline \multicolumn{4}{|c|}{ Escala de iconicidad decreciente } \\
\hline Nivel & Definición & Criterio & Ejemplos \\
\hline 12 & El referente físico mismo & & Objeto en vitrina o en exposición \\
\hline 11 & $\begin{array}{l}\text { Modelo bi- o tridimensional a } \\
\text { escala }\end{array}$ & Colores y materiales arbitrarios & Reconstrucción ficticia, maqueta \\
\hline 10 & $\begin{array}{l}\text { Esquema bi- o tridimensional } \\
\text { reducido o aumentado }\end{array}$ & $\begin{array}{l}\text { Colores y materiales escogidos según } \\
\text { criterios lógicos }\end{array}$ & $\begin{array}{l}\text { Mapas en } 3 \text { dimensiones,globo } \\
\text { terráqueo }\end{array}$ \\
\hline 9 & $\begin{array}{l}\text { Fotografía o proyección realista } \\
\text { en un plano }\end{array}$ & $\begin{array}{l}\text { Proyección perspectiva rigurosa, } \\
\text { medios tonos y sombras }\end{array}$ & Catálogos ilustrados, posters \\
\hline 8 & $\begin{array}{l}\text { Dibujo, fotografía de alto } \\
\text { contraste }\end{array}$ & $\begin{array}{l}\text { Continuidad del contorno y cierre de } \\
\text { la forma }\end{array}$ & $\begin{array}{l}\text { Afiches, catálogos, fotografías } \\
\text { técnicas }\end{array}$ \\
\hline 7 & Esquema anatómico & $\begin{array}{l}\text { Corte en la carrocería o envoltorio; } \\
\text { respeto por la topografía; cuantificación } \\
\text { de elementos y simplificación }\end{array}$ & $\begin{array}{l}\text { Corte anatómico, corte de un } \\
\text { motor, plano de conexiones } \\
\text { eléctricas, mapa geográfico }\end{array}$ \\
\hline 6 & Representación "estallada" & $\begin{array}{l}\text { Disposición perspecpectiva artificial } \\
\text { de piezas según sus relaciones de } \\
\text { vecindad topográfica }\end{array}$ & $\begin{array}{l}\text { Objetos técnicos en manuales de } \\
\text { ensamble o reparación }\end{array}$ \\
\hline 5 & Esquema de principio & $\begin{array}{l}\text { Sustitución de los componentes por } \\
\text { símbolos normalizados; paso de la } \\
\text { topografía a la topología; } \\
\text { geometrización }\end{array}$ & $\begin{array}{l}\text { Mapa de conexiones de un } \\
\text { receptor de TV, mapa } \\
\text { esquematizado del Metro }\end{array}$ \\
\hline 4 & $\begin{array}{l}\text { Organigrama o esquema de } \\
\text { bloque }\end{array}$ & $\begin{array}{l}\text { Los elementos son cajas negras" } \\
\text { funcionales, conectadas lógicamente; } \\
\text { presentación de funciones lógicas }\end{array}$ & $\begin{array}{l}\text { Organigrama de una empresa, } \\
\text { flujograma de un programa } \\
\text { computacional }\end{array}$ \\
\hline 3 & Esquema de formulación & $\begin{array}{l}\text { Relación lógica, no topológica, en un } \\
\text { espacio no geométrico, entre } \\
\text { elementos abstractos. Los lazos son } \\
\text { simbólicos y todos los componentes, } \\
\text { visibles. }\end{array}$ & $\begin{array}{l}\text { Fórmulas químicas desarrolladas, } \\
\text { sociogramas }\end{array}$ \\
\hline 2 & Esquema en espacios complejos & $\begin{array}{l}\text { Combinación en un mismo espacio de } \\
\text { representación de elementos } \\
\text { esquemáticos pertenecientes a } \\
\text { sistemas diferentes }\end{array}$ & $\begin{array}{l}\text { Fuerzas y posiciones geométricas } \\
\text { en una estructura metálica; } \\
\text { esquema de estática; } \\
\text { representación sono }\end{array}$ \\
\hline 1 & $\begin{array}{l}\text { Esquema de vectores en } \\
\text { espacios puramente abstractos }\end{array}$ & $\begin{array}{l}\text { Representación gráfica en un espacio } \\
\text { métrico abstracto, de relaciones entre } \\
\text { tamaños vectoriales }\end{array}$ & $\begin{array}{l}\text { Gráficos vectoriales en } \\
\text { electrotécnica }\end{array}$ \\
\hline $\mathbf{0}$ & $\begin{array}{l}\text { Descripción en palabras norma- } \\
\text { lizadas o fórmulas algebráicas }\end{array}$ & $\begin{array}{l}\text { Signos abstractos sin conexión } \\
\text { imaginable con el significado }\end{array}$ & Ecuaciones y textos. \\
\hline
\end{tabular}

Cuadro 2. Moles, A. 


\section{Justo Villafañe (1985).}

Por su parte, Villafañe propone una escala de iconicidad para la imagen fija-aislada que, a nuestro entender, resulta la más interesante por dos motivos: aparece estructurada de acuerdo a un criterio de iconicidad que, aunque similar en muchos puntos al esgrimido por Moles, tiene la virtud de hacer referencia únicamente a las imágenes sobre superficie plana o bidimensional, como ocurre con el dibujo; por otro, los niveles de clasificación permiten distinguir perfectamente las funciones asociadas a cada nivel. Así, la "descripción" requerirá de imágenes pertenecientes a los niveles superiores de la escala, mientras que la función informativa puede situarse en un nivel más bajo, etc. Lo que con ello se deja entrever es que, en cada caso, la iconicidad no es una relación que se mueve entre el signo y el "objeto real", como quería Moles, sino que, en cada caso, es la función adscrita al signo la que determina el contenido que deberá ser vehiculado por aquel:

"El plano del metro no necesita 'informar' del color de las estaciones, ni el pictograma clavado en la puerta de un lavabo representando una mujer, nos indica si ésta es joven o vieja. Ahora bien, la maqueta que tiene que presentar un arquitecto al que le han encargado el proyecto de una nueva línea del metro, o la foto de una mujer archivada en una agencia matrimonial, deberán poseer otro tipo de datos visuales mucho más elaborado para poder cumplir su función primordial: la descripción". $2 \mathbf{1}$

Villafañe, J. (1985:43)

Escala de iconicidad que propone Villafañe (Cuadro 3):

\section{Grado}

11.- La imagen natural: Restablece todas las propiedades del objeto. Existe identidad. (Cualquier percepción de la realidad sin más mediación que las variables físicas del estímulo)

10.- Modelo tridimensional a escala: Restablece todas las propiedades del objeto. Existe identificación pero no identidad. (La Venus de Milo)

9.- Imágenes de registro estereoscópico: Restablece la forma y posición de los objetos emisores de radiación presentes en el espacio. (Un holograma) 
8.- Fotografía en color: Cuando el grado de definición de la imagen esté equiparado al poder resolutivo del ojo medio.

7.- Fotografía en blanco y negro: Igual que el anterior.

6.- Pintura realista: Restablece razonablemente las relaciones espaciales en un plano bidimensional. (Las meninas de Velázquez).

5.- Representación figurativa no realista: Aún se produce la identificación, pero las relaciones espaciales están alteradas. (El Guernica de Picasso, una caricatura).

4.- Pictograma: Todas las características sensibles, excepto la forma, están abstraídas. (Siluetas. Monigotes).

3.- Esquemas motivados: Todas las características sensibles abstraídas. Tan sólo restablecen las relaciones orgánicas. (Organigramas. Planos).

2.- Esquemas arbitrarios: No representan características sensibles. Las relaciones de dependencia entre sus elementos no siguen ningún criterio lógico. (La señal de tráfico que indica "ceda el paso").

1.- Representación no figurativa: Tienen abstraídas todas las propiedades sensibles y de relación. (Una obra de Miró).

Cuadro 3. Villafañe, J.

A esta escala de iconicidad se asocian determinadas funciones de la imagen (Cuadro 4).

\begin{tabular}{|l|l|}
\hline Grado de nivel de realidad & Función Pragmática \\
\hline 11.- Imagen natural & Reconocimiento \\
\hline 10.- Modelo tridimensional a escala & Descripción \\
\hline 9.- Imagen de registro estereoscópico & \\
\hline 8.- Fotografía en color & \\
\hline 7.- Fotografía en blanco y negro & \\
\hline 6.- Pintura realista & Artística \\
\hline 5.- Representación figurativa no realista & \\
\hline 4.- Pictogramas & Información \\
\hline 3.- Esquemas motivados & \\
\hline 2.- Esquemas arbitrarios & \\
\hline 1.- Representación no figurativa & Búsqueda \\
\hline
\end{tabular}


Donde, como vemos, se distingue entre descripción e información: ésta implica discriminar la parte más importante de los contenidos que se quieren comunicar, lo que conllevaría una mayor abstracción a fin de que algunos elementos secundarios de la imagen no distraigan de los elementos principales.

En definitiva estas escalas no son más que formulaciones teóricas de los distintos niveles de realidad.

Por otro lado y desde la etimología de la palabra "imago-inis", podemos acercarnos a algunas de las características de este concepto. Este sustantivo latino equivale a "retrato" y evoluciona desde una tripe vertiente: reproducción, representación e imitación, siempre en contacto con las formas "imari" o imitari" 22.

Pero también pertenece a la misma raíz de "magia", o arte de realizar cosas maravillosas en contra de las leyes naturales, comportando elementos de hechizo, sugestión, fascinación, poder cautivador, etcétera.

Así pues la imagen es el continuo juego entre lo real/irreal, la presencia y la ausencia, el pasado congelado en el presente para el futuro.

La imagen es un fenómeno de representación y de percepción de algo que existe por sí mismo, ya que la realidad no suele crear imágenes (si exceptuamos el reflejo producido por el agua).

La imagen la crea el hombre, la elabora contando con unos medios técnicos determinados, con todas las posibilidades y limitaciones de los mismos pero nunca es fiel a su totalidad, nunca abarca la realidad a la que recuerda.

En la aparición de la imagen probablemente juega un papel relevante el reflejo de la figura humana como motor desencadenante de la producción icónica, así lo sugiere Gubern, R. ${ }^{23}$ en la Ilamada "hipótesis del lago". El hombre se veía confrontado con su propia imagen, es decir, con la repetición de su propia figura (lo mismo y lo otro) reflejado en las aguas del lago.

Siguiendo este mismo sentido mítico encontramos la explicación de Gibson ${ }^{24}$ que nos habla del acto gráfico fundamental. 
Mucho antes de que existiese el concepto de representación como lo entendemos hoy, es lógico pensar que los hombres observasen con asombro y extrañeza el trazo que un dedo podía dejar sobre el barro o sus huellas sobre la arena; es, precisamente, a este trazo lineal que puede dejarse sobre casi todas las superficies, excepto la del agua, a lo que Gibson denomina acto gráfico fundamental.

Este trazo puede realizarse a través de dos sistemas opuestos, pero a la vez complementarios: trazando un canal (con distintos materiales: palo, dedo...) o dejando un depósito (de diferentes materiales: tizas, pigmentos...). A estos trazos podemos considerarlos como imagen que es huella de su acto producto. Nos estamos refiriendo a lo que podríamos llamar "prehistoria de la imagen", época lejana donde las imágenes eran el trabajo de artesanos. Estas primeras imágenes participaban de una especie de magia en la medida que eran muy escasas y constituían un reflejo de la realidad.

Posteriormente, en la historia de la imagen podemos distinguir tres etapas siguiendo la división propuesta por Moles: 25

Primera etapa: corresponde a las técnicas de grabado sobre cobre, madera, litografía, etc, y en la que aparece la imprenta permitiendo la multiplicidad de imágenes, aunque estas siguen aún muy limitadas.

Segunda etapa: Coincide con el descubrimiento de la trama fotográfica (finales del siglo XIX), época del triunfo de la imagen.

Tercera etapa: corresponde al momento en el que Moles estudiaba la historia de la imagen, (1991), cuando se empieza a tomar conciencia de su uso y su utilidad en el campo de la comunicación.

Desde esta tercera fase, señalada por Moles hasta la actualidad podemos observar cómo el aumento de la imagen ha sido espectacular, ya que las posibilidades tecnológicas han permitido que puedan realizarse y reproducirse con gran facilidad y perfección, lo que ha permitido que su uso se extienda a todos los ámbitos de la comunicación.

La imagen suele hacerse con un fin determinado, ya sea informativo, persuasivo, didáctico..., y según la función que queramos dar a la imagen, 
tenemos la posibilidad intencional de manipulación de la realidad a la que hace referencia. Esta manipulación estará dirigida a conseguir el efecto pretendido: informar, motivar, adornar, explicar, etcétera.

El tema de nuestro estudio estará orientado hacia la comunicación a través de las imágenes de la obra del pintor Eduardo Vicente (imágenes fijas) y el papel social que desempeñan; por lo que la reflexión acerca de las imágenes irá dirigida no solamente a descubrir los diferentes aspectos que determinan la imagen en sí mismo, sino también a analizar lo que significan como transmisoras de ideologías y representativas de los valores sociales.

"La imagen es una cristalización de lo real sensorial". 26

Moles, A. (1991:13)

La imagen es imagen de alguna cosa, que en un principio pretende sostener relación con lo "real" que es su punto de referencia objetivo; en cualquier caso la imagen es siempre un testigo de algo.

Toda imagen es figurativa en la medida en que se presenta como un soporte de comunicación.

Nuestro estudio será, por una parte "fenomenológico", en tanto que analizaremos las imágenes de la obra del pintor Eduardo Vicente, diferenciando sus tipos, formas, colores, tamaños, técnicas..., y por otro lado "funcional" ya que lo que nos interesa es conocer el papel que desempeñan estas imágenes como transmisoras de ideologías y de los valores sociales del momento en que se produjeron, lo que nos permite comunicar y conocer el mundo que nos rodea.

Por tanto, el estudio de la obra de este artista, lo haremos desde un punto de vista en el que contemplaremos un conjunto de imágenes de "comprensión" y de "comunicación". Dejaremos sin analizar la imagen artística, pues este sería ya otro objeto de estudio.

Para finalizar atenderemos a la expresión de la imagen como "una cristalización de lo real sensorial", en palabras de Moles, convenientemente 
materializada en un mensaje que llega al receptor y le traslada significados, explicaciones, comentarios, actitudes, valores y normas sociales.

En este sentido prestaremos atención al papel que las imágenes cumplen como vehículo de transmisión de valores y de ideología en el período histórico en que vivió Eduardo Vicente.

Analizaremos los roles sociales, los personajes y su implicación en la vida social y cultural del momento, las costumbres, los oficios, las escenas y todos los mensajes en los que exista transmisión ideológica, por que las imágenes son la expresión de un pasado. Nos remitimos a Fontcuberta para apoyar nuestras reflexiones:

"Toda imagen es físicamente una huella, el resultado de un trasvase o de un intercambio (un depósito de tinta, un efecto de carga eléctrica o magnética, una reacción química). En síntesis, una diferente modulación de información almacenada, de "memoria". Solo la consciencia histórica nos permitirá calibrar entre huellas directas y diferidas, matizar los diferentes grados intermedios". 27

Fontcuberta, J. (1994:79)

En este sentido hay que considerar que todo espectador entra en contacto con la imagen desde una perspectiva ideológica que forma parte de su competencia global, sin que importe demasiado que sea o no consciente de ello. Por tanto, la imagen deberá ser contemplada como dotada de cierta competencia ideológica y como dice. U. Eco ${ }^{28}$, la competencia ideológica puede jugar un papel importante en la actualización de los mensajes transmitidos por las imágenes.

Solamente así puede explicarse de forma satisfactoria que la contemplación de una imagen en diferentes ocasiones nos transmita alternativas distintas.

No debemos olvidar que la imagen es también lenguaje.

Se considera lenguaje al recurso de comunicación utilizado por un emisor para transmitir cualquier información a un receptor. 
Todo lenguaje se basa en la utilización de un cierto código que ambas partes (emisor y receptor) conocen y les resulta comprensible.

El lenguaje visual se apoya en signos cuyo significante es de carácter visual, y en el existen diferentes tipos de signos: la señal, el indicio, el icono y el símbolo. A la hora de analizar el fenómeno del lenguaje de las imágenes conviene distinguir, como en el lenguaje escrito, tres aspectos sobre el que se articulan los diferentes tipos de signos: el léxico, la gramática y el estilo.

Por lo general, los artistas no inventan imágenes sino que recurren al patrimonio artístico de la cultura en la que están inmersos, en ocasiones, algunos creadores introducen modificaciones que permiten renovar el repertorio aportando a la cultura una mayor dimensión.

Dado que el objeto inmediato de la iconografía es la imagen, para poder conocer su significado y su importante papel comunicador, así como agente socializador que contribuye a la formación de los ciudadanos, el investigador tiene que dominar las leyes y los elementos que la rige. En este sentido M. A. Castiñeiras ${ }^{29}$ establece cuatro grandes campos de estudio (Cuadro 5):

El estudio de los temas y motivos. Consistente en el análisis de la obra basado en una distinción de su contenido.

El estudio de los elementos figurativos que utiliza el autor para describir o expresar una idea: simple figura, personalización y atributo.

El estudio de los modos de expresar el contenido: símbolo, alegoría y narración.

Las relaciones entre texto e imagen 
El lenguaje visual tiene una característica propia que le hace distinto de los demás lenguajes. Consiste en la relación que existe entre "icónico" y "realidad", proporcionándole credibilidad. Esta particularidad específica del lenguaje visual es la que le convierte en el más eficaz de todos en la función comunicativa; de aquí la importancia y empleo masivo de la imagen visual en todos los ámbitos de la comunicación social. Es tan abundante la presencia de la imagen que empieza a hablarse de "una civilización de la imagen" e incluso se ha popularizado el proverbio: "una imagen vale más que mil palabras".

"... el importante papel que en la actualidad la imagen ha alcanzado en aspectos tan fundamentales de la vida del hombre, como aprendizaje o ocio, explica en parte el desinterés de nuestra sociedad por la palabra y la lectura". 30

Castiñeiras González, M. A. (1998:39)

La mayoría de las informaciones que el hombre contemporáneo, habitante de las grandes urbes, recibe se analizan a través de los sentidos de la vista y el oído. De ellas, más del $80 \%$, específicamente a través del mecanismo de la percepción visual. De aquí que sea correcto hablar de la "civilización de la imagen" para referirse al universo comunicativo contemporáneo.

El incremento espectacular que ha experimentado el lenguaje visual viene acompañado de la alta rentabilidad comunicativa y del desarrollo vertiginoso que han experimentado las diversas técnicas de representación gráfica, sobre todo en cuanto al grado de fidelidad reproductiva, a la memorización y transmisión de imágenes y al consecuente desarrollo de los medios audiovisuales de la comunicación.

Ahora bien el lenguaje visual no nos interesa exclusivamente por sí mismo, como conjunto de signos, sino como recurso o instrumento aplicado a la creación artística. Es decir, prestamos atención al lenguaje en función del objeto perseguido con su uso (creación) y de los efectos y consecuencias que con ese uso se consigue (contemplación), o dicho de otra manera, la obra de arte se convierte en una herramienta de enseñanza y de aprendizaje. 
Por esto nuestro trabajo de investigación no es un estudio de la imagen que se limite a establecer los mecanismos ópticos, las formas de percepción, ni los elementos morfológicos y dinámicos; tampoco se ciñe al análisis semántico de las expresiones visuales. Nuestra concepción es pragmática, es decir, consideramos que la obra se produce con intención comunicativa y en esta, la imagen visual es uno de los factores constitutivos del proceso de comunicación. Además el estudio se hará relacionándolo con todos los otros fenómenos que participan de forma activa en el mismo hecho comunicativo.

No analizaremos la imagen como una entidad con significado propio y relacionado con otros objetos comunicativos, sino que estudiaremos una situación social generadora de necesidades comunicativas que son satisfechas con diferentes objetos artísticos, entre ellos los visuales, foco prioritario de este trabajo de investigación.

De este modo, si el significado de una imagen se manifiesta por el uso que se hace de ella. Para conocer ese significado deberán conocerse todas las circunstancias sociales, culturales, políticas y económicas que concurren en el acto de comunicación.

Si queremos averiguar el valor y las funciones que ha cumplido y cumple la obra artística del pintor Eduardo Vicente en el periodo comprendido entre 1906 y 1968, obligatoriamente debemos recurrir a la historia pues nos proporcionará los datos del contexto social en el que vivió el artista, datos necesarios para poder interpretar de forma correcta su obra.

Estudiar la obra de Eduardo Vicente nos ayudará a conocer mejor esa parte de la historia de España. Esperamos que el fruto de este trabajo aporte conocimiento acerca del papel de las obras de arte como transmisoras de ideología y representativa de las actitudes, valores y normas de la sociedad en un periodo concreto.

Finalmente, debemos considerar, a la hora de enfrentarnos al estudio de la imagen, la conveniencia de hacer una distinción entre iconografía e iconología para posteriormente conocer los métodos de estudio de la imagen y proponer el que vamos a utilizar en esta investigación. 


\section{Iconografía e iconología.}

Se llama Iconología a la rama de la simbología y de la semiología que estudia las denominaciones visuales del arte, por ejemplo la representación de las virtudes, vicios y otras cosas morales o naturales, con la figura o apariencia de personas.

Por extensión, se trata de la ciencia que estudia las imágenes, emblemas, alegorías y monumentos con que los artistas han representado a los personajes mitológicos, religiosos o históricos, y se diferencia de la iconografía en que ésta tiene por fin la simple descripción de imágenes, mientras que la iconología las estudia en todos sus aspectos, las compara y las clasifica, llegando incluso a formular leyes o reglas para conocer su antigüedad y diversos significados e interpretaciones.

La iconología considerada en toda su amplitud puede dividirse en tres ramas en razón del objeto representado:

* Iconología pagana. Comprende las imágenes propias de la idolatría o religiones no cristianas.

Iconología profana o civil. Comprende las figuras de personajes históricos que no sean objeto de culto religioso.

Iconología religiosa. Se refiere a Dios, ángeles, santos y otras imágenes procedentes de la religión.

La Iconografía (palabra compuesta de icono y grafe -descripción-) es la descripción de las temáticas de las imágenes y también el tratado o colección de éstas.

Los matices de su diferencia conceptual con la iconología son a veces poco precisos.

Mientras que la iconografía es esencialmente descriptiva, la iconología profundiza hasta alcanzar el significado último de las imágenes. Se busca el significado histórico, filosófico, social...

Al igual que el término iconografía es conocido desde hace siglos, el de Iconología se remonta hasta el propio Platón que le da el significado de 
lenguaje figurado. Más cercano en el tiempo aparece en 1593, en Roma un libro publicado por Cesare Ripa con el título "Iconología" ${ }^{31}$. Consistía en un catálogo de imágenes referentes a virtudes, vicios, dioses, cada uno de ellos acompañado por una figura femenina que los representa. Muchos artistas lo tomaron como fuente de representación de estos temas. Sin embargo, su intención era claramente iconográfica. No fue hasta finales del siglo XVII y principios del XVIII cuando algunos autores lo toman como representación alegórica y ya en el siglo XIX se incluye con este significado en los diccionarios. Aby Warburg consideró que sólo tras un estudio profundo del pasado se podían explicar muchas de las grandes obras renacentistas. Él y sus discípulos E. Panofsky, F. Saxl, y E. Wind incorporan este método a sus estudios.

Iconografía es la ciencia que estudia el origen y formación de las imágenes, su relación con lo alegórico y lo simbólico, así como su identificación por medio de los atributos que casi siempre les acompañan. Esta ciencia tiene su origen en el siglo XIX y fue desarrollada a lo largo del XX. El gran estudio de la Iconografía y su desarrollo podemos encontrarlo en un grupo de iconógrafos famosos afincados en Hamburgo durante los años inmediatamente anteriores a la toma del poder de Hitler. De este grupo formaban parte Aby Warburg (1866-1929), Fritz SaxI (1890-1948) Erwin Panofsky. (1892-1968) y Edgar Wind (1900-1971) todos ellos académicos con excelente formación y variados intereses en el campo de la literatura, la filisofia y la historia. Las aportaciones de la escuela de Warburg, en relación al estudio de las imágenes, podemos resumirlas en los tres niveles de interpretación correspondientes a otros tres niveles de significado formulados por Panofsky que no se quedaron en la mera descripción y clasificación de los distintos temas y aspectos formales de las obras de arte (iconografía), sino que quiso averiguar el significado de la obra en su condición de documentos culturales (iconología).

\section{Métodos de estudio.}

W.E. Kleinbauer ${ }^{32}$ propone una interesante clasificación basada en dos puntos de vista que en su opinión resumían las diferentes propuestas de los investigadores en el estudio de las imágenes.

El primer punto de vista se centra en la perspectiva intrínseca que consiste en el estudio de la obra desde dentro y, por lo tanto, a partir de la descripción y de análisis de sus cualidades inherentes, es decir, todo lo 
relacionado con la forma y con el contenido. En este sentido abarca el estudio de las propiedades físicas: forma, tamaño, color, que responderían al interrogante ¿cómo?, a los problemas de atribución, que contestarían al ¿quién?, a los datos de temporalidad ¿cuándo), a su proveniencia ¿dónde?, así como a las características formales: temática, simbolismo y función.

El segundo punto de vista se ocupa de la vertiente extrínseca que considera la obra de arte desde fuera y tiene por tanto un campo de actuación mucho mayor. Así podemos considerar las circunstancias espacios temporales, la propia biografía del artista, problemas artísticos relacionados con la psicología y el psicoanálisis, así como los determinantes sociales, políticos, culturales e intelectuales propios de una historia social, de una historia de las ideas y de la historia de las mentalidades.

Pero la obra de arte constituye un todo, es forma y contenido, significado y significante, elementos que pueden separarse sin desvirtuarse. De ahí que las palabras de Hegel adquieran un importante significado:

"El contenido forma un todo con la forma figurada, y esa unidad constituye su aspecto esencial". 33

Hegel, G.W.F. (1979:53)

En su Introducción a la estética (1828) Hegel concede un valor inestimable al arte en la historia de la cultura, puesto que los artistas han utilizado su obra como "un medio para tener conciencia de las ideas e intereses más sublimes del espíritu". De esta manera los pueblos, a través de las creaciones artísticas, han puesto de manifiesto "la filosofía y la religión estarían concretadas en las formas creadas". ${ }^{34}$

Las aportaciones de Hegel tienen su reconocimiento en muchos historiadores del arte, entre los que destaca Panofsky que concibe la obra de arte como un ente orgánico en el que tanto la forma como el contenido forman una unidad, y el estudio del contexto ayuda a entender el significado.

Es precisamente Panofsky el que crea una nueva escuela historiográfica cuyo principio se basa en la consideración de la unidad de la obra de arte, como él mismo señala: 
"Un buen estudio del contenido no sólo es útil para la comprensión histórica de una obra de arte, sino que también enriquece y clarifica la experiencia estética de una forma peculiar". 35

Panofsky, E. (1930:26)

Erwin Panofsky fue un estudioso importante en el desarrollo de la metodología de la Historia del arte que postuló, como dijimos anteriormente, tres niveles en el acercamiento a las imágenes.

El primer nivel preiconográfico, es el meramente descriptivo y contesta a la pregunta ¿qué veo? Después viene el iconográfico o convencional y finalmente el iconológico o de significado. Estos tres niveles generan un conocimiento de una imagen artística que va de la superficie a la profundidad.

Según Panofsky, el primer paso para la apreciación del arte es simplemente observar una imagen y decir qué vemos, antes que intentemos atribuirle un significado.

El segundo nivel iconográfico de interpretación tiene que ver con nuestro conocimiento del mundo: podemos nombrar a las personas, reconocer situaciones e inferir estados emocionales. Según el bagaje cultural que tengamos podemos identificar una imagen de una figura masculina clavada en una madera como la Crucifixión o podemos decir que 13 hombres sentados en una mesa representan "La última cena". En palabras de Panofsky, la iconografía tiene que ver con temas convencionales y por eso implica un trabajo especializado sobre la imagen porque hay que indagar en un universo cultural. La iconografía muestra que ciertas formas son, por ejemplo, santos o dioses o alegorías particulares. Los santos, como los "dioses paganos", generalmente tienen un atributo que los identifica.

El tercer nivel o iconológico es el más profundo y significativo. La iconología busca relacionar el sentido simbólico de los objetos y figuras en el arte con lo político, poético, religioso, filosófico y tendencias sociales de la personalidad, periodo o país que se estudia. La iconología interpreta y ubica una imagen en relación al horizonte cultural de una época. Para llegar al tercer nivel se tiene que pasar necesariamente por los dos primeros, el 
primario y el iconográfico. Y, por supuesto, requiere de un conocimiento más especializado que implica adentrarse en las disciplinas histórica, filosófica, científica, etcétera. Según Panofsky una imagen artística brinda, en una forma condensada, los valores intelectuales y culturales de un grupo social. Por esta razón insistía en que las imágenes forman parte de una cultura total y no pueden entenderse si no se tiene un amplio conocimiento de esa cultura.

Es en este tercer nivel en el que las imágenes proporcionan a los historiadores de la cultura un testimonio útil y de hecho indispensable (Cuadro 6).

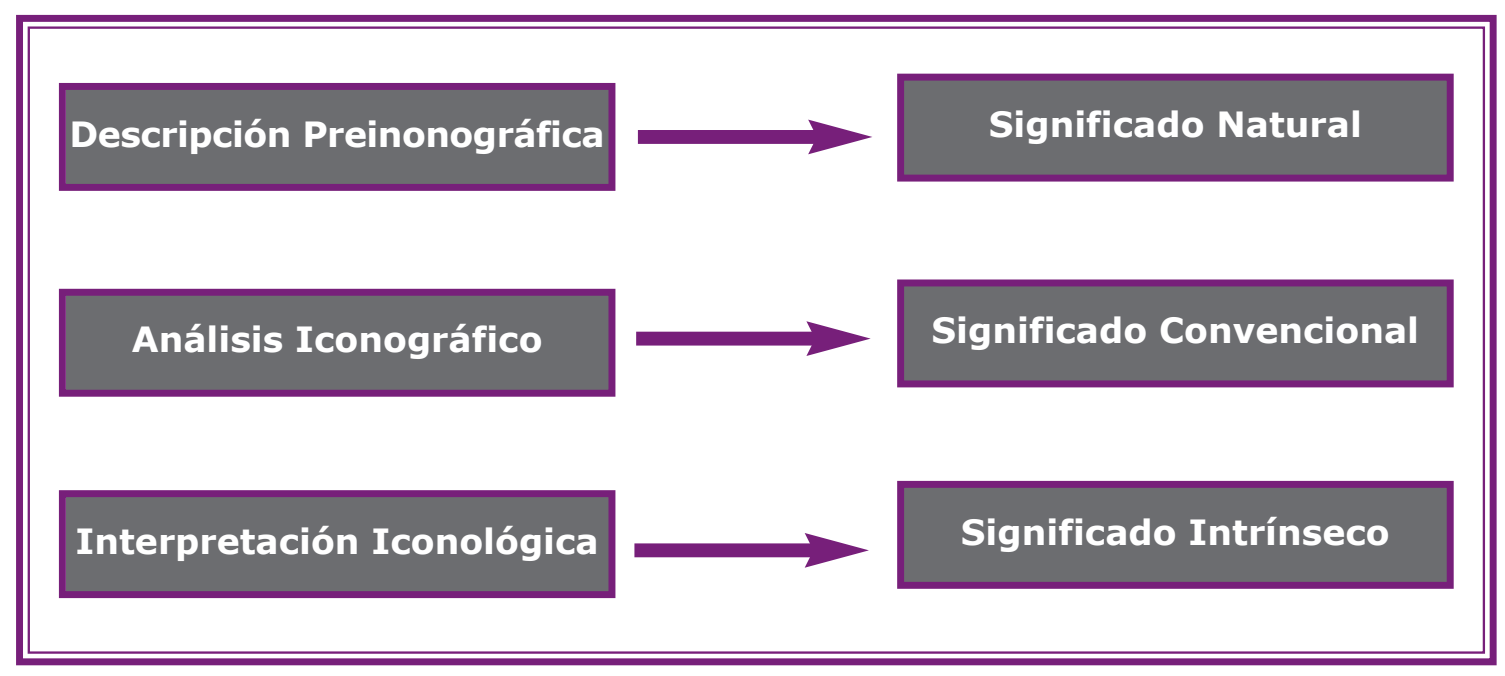

Cuadro 6. Niveles de interpretación. Panofsky (1939).

Estos tres niveles plásticos de Panofsky se corresponden con los tres niveles literarios que distinguía mucho antes el filólogo clásico Friedrich Ast 36 (1778-1841) pionero en el arte de la interpretación de los textos "hermenéutica" (Cuadro 7). 


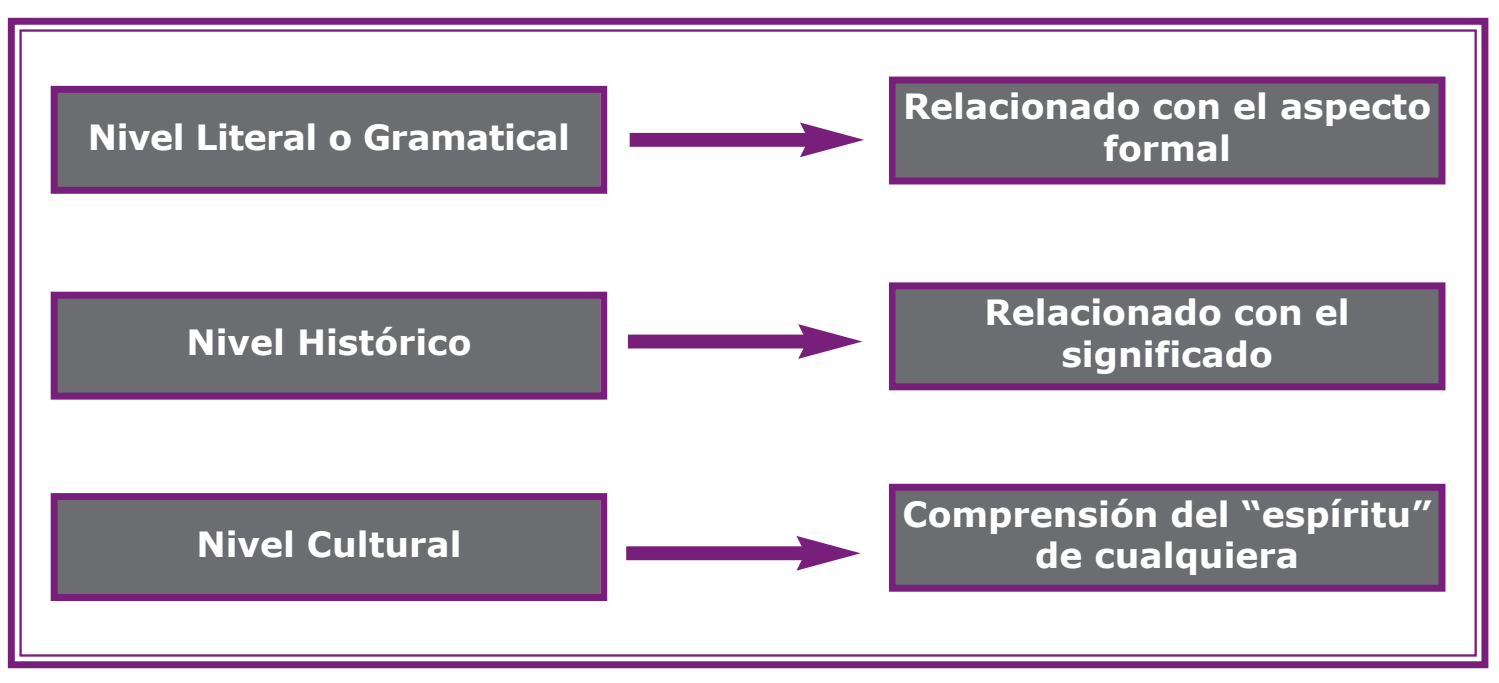

Cuadro 7. Elaboración propia a partir de F. Ast.

En definitiva lo que hizo Panofsky y sus colegas fue aplicar al mundo de las imágenes una tradición alemana de interpretación de textos.

Panosfsky insiste en que las imágenes forman parte de una cultura total y no pueden entenderse si no se tienen conocimientos de esa cultura, y para interpretar el mensaje es preciso estar familiarizado con los códigos culturales.

El esquema tripartito de Panofsky se mueve de las partes al todo, y del todo a las partes. Se trata pues de una interpretación circular y orgánica cuyo mayor énfasis está en el contenido y en el contexto de la obra de arte.

Así con la lectura iconográfica e iconológica, la historia del arte se convierte en una descodificación de símbolos. Panofsky distingue dos tipos de símbolos, los símbolos ordinarios, propios de la iconografía y símbolos en el sentido de Cassirer, constitutivos de la iconología ${ }^{37}$.

1.- Símbolos ordinarios. Se trata de imágenes que pueden descifrarse a través del conocimiento de la tradición visual y textual. Así conocemos el significado de la Cruz, la Torre de Babel o la Paloma del Espíritu Santo. 
2.- Símbolos cassirianos. Son los que forman parte de las condiciones psicológica, culturales, sociales, políticas, filosóficas y espirituales que actúan sobre el artista y que utiliza en sus obras, unas veces de forma consciente y otras inconscientemente.

La aportación más novedosa de Panofsky, es sin duda alguna, el haber sabido ofrecer un método aplicable a diferentes campos de investigación histórica. Panofsky no se deja llevar por la mera contemplación de las obras de arte sino que intenta buscar las causas y las consecuencias de las mismas, así como el significado de las imágenes y su relación con la situación histórica en la que se producen. La obra de arte deja de ser una creación intemporal y comienza a tener su tiempo concreto. Un tiempo concreto en el que se unifican arte y pensamiento, donde las obras de arte son vistas como imágenes y como ideas. Por esta razón, el análisis de las imágenes necesita recurrir a diferentes fuentes y disciplinas como la historia social, la psicología, etcétera, En definitiva el estudio de las obras de arte debe hacerse siempre desde una perspectiva integral.

Otro de los grandes estudiosos del método iconográfico fue Guy de Tervarent, $^{38}$ cuya preocupación por la Iconología le llevó a estudios de naturaleza iconográfica que quiso sistematizar, postulando estos análisis en cuatro estadios fundamentadas en el mundo de las imágenes, las cuales nos presentan formas visuales o motivos iconográficos que, una vez identificados, se convierten en temas iconográficos. Un estudio más profundo nos trasladará al origen visual o literario, desarrollando su manifestación en el espacio y el tiempo.

Así, el método de análisis podemos resumirlo en los siguientes apartados:

Las fuentes del propio artista, mentor, comitente...

La literatura de la época o en la época.

Identidad con obras artísticas anteriores ya conocidas.

Elementos que configuran la obra de arte. 
Está claro que la Iconología debe apoyarse en la Iconografía para poder identificar y clasificar la imagen que se estudia, ver su origen y evolución en el tiempo. Sin embargo, esta última puede constituir por sí sola un propio método.

Lo que se deja de manifiesto es que en el estudio de la obra de arte se hace imprescindible la aplicación de distintos métodos y análisis para que podamos comprender en su totalidad lo que significó en su tiempo.

\section{Posibilidades y limitaciones de los métodos.}

Las críticas, a estos métodos señalados, han sido muy numerosas. Las más generales hacen referencia a que estos métodos no tienen en cuenta la calidad artística de la obra de arte, y se fija en muchos otros datos que están relacionados con el contenido de la obra. Otras críticas giran en torno a la idea que los iconólogos tienden a ver, en las obras de arte, muchos más simbolismos que los que en realidad pretendió mostrar el artista. Esta crítica la hace el propio Panofsky diciendo:

"Hay que reconocer que existe cierto peligro en el hecho que la iconología pueda comportarse no como etnología en contraposición de etnografía, sino como astrología en contraposición a la astrografía". 39

Panofsky, E. (1979:51)

Estas críticas han exigido al estudioso saber discernir entre lo que es intencionado y lo que pueda ser inconsciente en la obra de arte.

Profundizando en todas estas críticas, E. H. Gombrich ha señalado las cuatro limitaciones de los estudios iconológicos que, según él, necesitan una profunda revisión:

* La trampa de la interpretación fácil está sustentada con numerosas citas y notas a pie de página que sirven para convencer al lector de una demostración que se ha elaborado con anterioridad.

*a imagen visual debe estudiarse teniendo en cuenta las distintas funciones que las diferentes sociedades y culturas la asignan, de tal manera 
que la forma de una representación no puede ser separada de su función y de las necesidades de la sociedad que las produce y las demanda. Al entender el arte como mensaje y comunicación, Gombrich considera que tanto la forma como la función de las obras de arte tienen que estar continuamente adaptándose a las transformaciones sociales. Esta relación entre la forma y la función en el arte abre nuevas vías de investigación histórica que forzosamente deben discurrir por los cauces de la sociología y la antropología.

Dentro de la visión de la obra de arte como mensaje, Gombrich apunta la dificultad de determinar el significado de la obra de arte por el carácter abierto y polisémico de la imagen, cuya comprensión es susceptible de diferentes interpretaciones en función de los receptores del mensaje y de la época en que se estén contemplando. De ahí la afirmación de Umberto Eco, de que las líneas de significación de una obra de arte están abiertas por el camino de su continua recepción.

\section{"Hemos visto, pues, que:}

1) las obras "abiertas" en cuanto en movimiento se caracterizan por la invitación a hacer la obra con el autor;

2) en una proyección más amplia (como género de la especie "obra en movimiento"), hemos considerado las obras que, aun siendo físicamente completas, están, sin embargo, "abiertas" a una germinación continua de relaciones internas que el usuario debe descubrir y escoger en el acto de percepción de la totalidad de los estímulos;

3) toda obra de arte, aunque se produzca siguiendo una explícita o implícita poética de la necesidad, está sustancialmente abierta a una serie virtualmente infinita de lecturas posibles, cada una de las cuales lleva a la obra a revivir según una perspectiva, un gusto, una ejecución personal". 40

Eco, U. (1992:44)

Vemos pues, como son tres los niveles de intensidad en que se presenta un mismo problema. El tercer nivel es el que interesa a la estética como formulación de definiciones formales; y sobre este tipo de apertura, de la obra acabada, la estética contemporánea ha insistido mucho. Veamos, por 
ejemplo, la siguiente afirmación de L. Pareyson, la que consideramos como una de las más valiosas páginas de fenomenología de la interpretación:

"La obra de arte... es una forma, un movimiento concluso, que es como decir un infinito recogido en una concreción; su totalidad resulta de una conclusión y, por consiguiente, exige que se la considere no como el hermetismo de una realidad estática e inmóvil, sino como la apertura de un infinito que se ha completado recogiéndose en una forma. La obra tiene por esto infinitos aspectos, que no son sólo "partes" suyas o fragmentos, porque cada uno de ellos contiene la obra entera y la revela en determinada perspectiva. La variedad de las ejecuciones tiene, pues, su fundamento en la compleja naturaleza, tanto de la persona del intérprete cuanto de la obra que debe ejecutarse... Los infinitos puntos de vista de los intérpretes y los infinitos aspectos de la obra se responden, se encuentran y se aclaran recíprocamente de tal modo que determinado punto de vista logra revelar la obra entera sólo si la toma en ese determinado aspecto, y un aspecto particular de la obra, que la revele entera bajo una nueva luz, debe esperar el punto de vista capaz de captarlo y proyectarlo...

Y esto permite, pues, afirmar que:

...todas las interpretaciones son definitivas en el sentido de que cada una de ellas es, para el intérprete, la obra misma, y provisionales en el sentido de que cada intérprete sabe que debe siempre profundizar la propia. En cuanto definitivas, las interpretaciones son paralelas, de modo que una excluye las otras, aun sin negarlas". $\mathbf{4 1}$

\section{Pareyson, L. (1954:119)}

* En último lugar Gombrich señala, una vez más, el problema del significado intencional que consiste en saber con exactitud lo que el autor pretendió que significase. Por lo que hay que considerar por una parte el significado de la obra en sí misma y, por otra, las posibles implicaciones, siempre abiertas a numerosas interpretaciones. En este sentido Umberto Eco reivindica, lo que él denomina "intentio operis":

"el texto (imagen) es un dispositivo concebido con el fin de producir su lector modelo". 42 
Una vez analizadas las limitaciones y dificultades de los métodos que se encargan del estudio de las imágenes, E. Gombrich formula una serie de reglas que deberían seguir todos los investigadores que se enfrentan a la difícil tarea de interpretar las obras de arte.

1.- La primacía de los géneros. El investigador debe establecer los géneros y tenerlos en cuenta a la hora de hacer sus interpretaciones.

2.- La ley del decoro. Decoro significa "lo adecuado" e implica que existe una conducta adecuada en las diferentes circunstancias y, por supuesto unos temas adecuados a los contextos en los que se producen.

3.- La falacia del diccionario. Si utilizamos los diccionarios de imágenes con independencia del contexto estaremos analizando imágenes muertas y sus interpretaciones no servirán para nada.

Estas tres reglas sirven a Gombrich para hacer una dura crítica del mal uso de la iconología como método para interpretar la obra de arte:

"Deberíamos exigir al iconólogo que después de cada uno de sus vuelos volviera a la base y nos explicara si los programas del tipo de los que ha disfrutado reconstruyendo pueden documentarse con fuentes primaria o sólo con las obras de sus colegas iconólogos. De lo contrario corremos el peligro de estar construyendo un modo mítico de simbolismo, casi igual a como el Renacimiento construyó una ciencia ficticia de los jeroglíficos basada en la falsa idea de partida acerca de la escritura egipcia". 43

Gombrich, E. H. (1994:48)

Este breve repaso sobre el valor de la imagen y sus posibilidades como fuente de investigación nos sirve para situarnos ante la obra del pintor Eduardo Vicente, sabiendo que su obra nos va a permitir compartir las experiencias y los conocimientos no verbales de la cultura dominante en los años que vivió el pintor, años comprometidos, difíciles pero llenos de posibilidades culturales y artísticas como tendremos ocasión de contemplar en el capítulo IV de este trabajo de investigación. 
Queremos ser rigurosos en nuestro estudio, por lo que evitaremos interpretaciones fáciles y simplistas, nos centramos en los aspectos fundamentales, haciendo una síntesis precisa que nos permita eliminar los aspectos accesorios de las ideas centrales. Así compartimos las palabras de E. Cassirer, referidas al valor de la representación artística.

"En el acto de la visión y la representación artística se separa lo contingente de lo necesario, en él sale a la luz la esencia de las cosas que encuentra su expresión visible en la forma artística. También aquí la teoría científica de la experiencia -tal como la acuñaron Kepler y Galileo está directamente subordinada al concepto y a la exigencia fundamental de exactitud que había establecido y asegurado la teoría del arte". ${ }^{44}$

Cassirer, E. (1951:205)

Partimos del concepto de obra abierta definido por U. Eco y de las posibilidades que nos da esa abertura que ofrece un sin fín de posibilidades de interpretación y significación, tarea que esperamos concluir evitando las dificultades y limitaciones que los estudiosos del tema han definido y hemos señalado anteriormente.

"...la obra de arte (imagen) es un mensaje fundamentalmente ambiguo, una pluralidad de significados que conviven en un solo significante". 45

Eco, U. (1992:15)

"...la obra como de una "forma", es decir, como de un todo orgánico que nace de la fusión de diferentes niveles de experiencia precedente: ideas, emociones, disposiciones a obrar, materias, módulos de organización, temas, argumentos, estilemas fijados de antemano y actos de invención. Una forma es una obra conseguida: el punto de llegada de una producción y el punto de partida de un consumo que, al articularse, vuelve siempre a dar vida a la forma inicial desde diferentes perspectivas". ${ }^{\mathbf{4 6}}$

Eco, U. (1992:18)

También partimos de la importancia de las imágenes y del papel que desempeñan en las representaciones visuales en la vida política, religiosa y 
cultural del momento histórico en que son producidas, constituyendo así un documento histórico de gran valor. Nuestro estudio se centra en las imágenes y no en el arte, es preciso aclarar este tema, pues nuestra intención en ningún momento pretende hacer una valoración o crítica artística, sino centraremos en el valor de las imágenes que utilizó el artista y el papel propagandístico y representativo de los modelos sociales del periodo histórico en el que vivió. 



\section{Notas}

1.- Jiménez, J.R. en Vicente, E. (1950) Tipos de la Calle. Afrodisio Aguado, S.A. Solapas interiores.

2.- Haskell, F. (1993) History and its Images. New Haven, p. 123.

3.- Lagrange, L. (1864) Les Vernet et la pinture au VIII siècle. $2^{\mathrm{a}}$ edición París, p.77.

4.- Burke, P. (2005) Visto y no visto. Es uso de la imagen como documento histórico. Crítica. Barcelona, p. 12.

5.- Burckardt. Citado en Burke, P. (2005) Visto y no visto. Es uso de la imagen como documento histórico. Crítica. Barcelona, p.13.

6.- Yates, F. A. (1975) Shaskespeare's Last Plays. Londrés, p. 4.

7.- Rotberg, R. I. y Rabb, T. K. (eds) (1988) Arts and History: Images and Their Meanins. Cambridg.

8.- Burke, P. (2005) Visto y no visto. Es uso de la imagen como documento histórico. Crítica. Barcelona, p. 17.

9.- Real Academia Española. (1975) Diccionario Manual Ilustrado. Espasa Calpe. Madrid, p. 677.

10.- Real Academia Española (1970) Diccionario de la Lengua Española. 19a edición. Madrid, p. 731.

11.- Casares, J. (1973) Diccionario ideológico de la Lengua Española. $2^{\mathrm{a}}$ edición. Gustavo Gili. Barcelona, p. 462.

12.- Moliner, M. (1984) Diccionario de uso del español. Tomo II. Gredos S. A. Madrid, p. 90.

13.- Moles, A. (1973) en Imagen y Comunicación de F. Torres. Valencia, p. 47. 


\section{Notas}

14.- Zunzunegui, S. (1989) Pensar la imagen. Cátedera Universal del País Vasco, p. 136.

15.- Sontag, S. (1980) Sobre la fotografía. Edhasa. Barcelona.

16.- Bercer, J. (1975) Modos de ver. Gustavo Gili. Barcelona, p. 15.

17.- Villafañe, J. (1985) Introducción a la teoría de la imagen. Pirámide. Madrid, p. 24.

18.- Arnheim, R. (1976) El pensamiento visual. EUDEBA. Buenos Aires ,p 247.

19.- Costa, J. (1992) Imagen pública. Una ingeniería social. Fundesco. Claves de Comunicación social. Madrid, p. 65.

20.- Maltese, C. (1970) Semiología del mensaje objetual. Alberto Corazón Editor, Madrid, 1972, pp. 164 y 165.

21.- Villafañe, J. (1985) Introducción a la teoría de la imagen. Ediciones Pirámide, Madrid, p. 43.

22.- Corominas, J. (1974) Diccionario crítico etimológico de la lengua castellana. Gredos. Madrid, p. 990.

23.- Gubern, R. (1987) El simio informatizado. Fundesco. Madrid.

24.- Gibson, J. (1966) The senses considered as perceptual systems. Hougton mifflin. Boston.

25.- Moles, A. (1991) La imagen, comunicación functional. Trillas. Mexico.

26.- Moles, A. (1991) La imagen, comunicación functional. Trillas. Mexico, p. 13.

27.- Fontcuberta, J. (1994) El beso de Judas. Fotografía y verdad, ed. Gustavo Gili, Barcelona, p. 79. 


\section{Notas}

28.- Eco, U. (1981) Lector in fabula. Lumen, Barcelona, pp. 120 y ss.

29.- Castiñeiras González, M. A. (1998) Introducción al método iconográfico. Ariel, S. A. Barcelona, p. 41.

30.- Castiñeiras González, M. A. (1998) Introducción al método iconográfico. Ariel, S. A. Barcelona, p. 39.

31.- Ripa, C. (1996) Iconología. I-II, trad. Lat. J y Y. Barja; trad. It. R. M. Marino Sánchez-Elvira y F. García Romero, Madrid. (1ª ed. 1987).

32.- Kleinbauer, W. E. (1971) "Modern Perspectives" in Western Art History. Nueva York, p. 37.

33.- Hegel, G.W. F. (1979) Introducción a la estética. Ed. Península. Barcelona, p. 53.

34.- Hegel, G.W. F. (1979), op.cit. p 10.

35.- Panofsky, E. (1930) citado en Holly, M. A. (1984) Panofsky and the Foundations of Art History, Cornell University Press $1^{\text {a }}$ edición, p. 26.

36.- Friedrich, A. (1778-1841) citado por Burke, P. (2005) Visto y no visto. Es uso de la imagen como documento histórico. Crítica. Barcelona, p. 45.

37.- Panofsky, E. (1992) Estudio sobre iconografía. "Introducción". Alianza Editoral. Madrid, p, 22.

38.- Tervarent, G. (1981) De la méthode iconologique, en Académie Royale de Belgique. Tome XII.4, Bruselas.

39.- Panofsky, E. (1979) El significado de las artes visuales. Alianza Editorial. Madrid, p. 51.

40.- Eco, U. (1992) Obra abierta. Paneta Agostini. Barcelona. p. 44. 


\section{Notas}

41.- Pareyson, L. (1954) Estetica. Teoria della formatività. Edizioni di «Filosofia», Turín. p. 119.

42.- Eco, U. (1995) Interpretación y sobreinterpretación. University Press. Cambridge. p. 68.

43.- Gombrich, E.H. (1994) Imágenes simbólicas. Alianza Editorial. Madrid. 1994. p. 48.

44.- Cassirer, E. (1951) Individuo y cosmos en la filosofía del Renacimiento. Ed.: Emecé, Buenos Aires, 1951, p. 205.

45.- Eco, U. (1992) Obra abierta. Paneta Agostini. Barcelona. p.15.

46.- Eco, U. (1992) Obra abierta. Paneta Agostini. Barcelona. p. 18. 


\section{|] Capítulo 4}

Eduardo Vicente entre la pintura y la ilustración gráfica. Contexto social y estudio experimental.

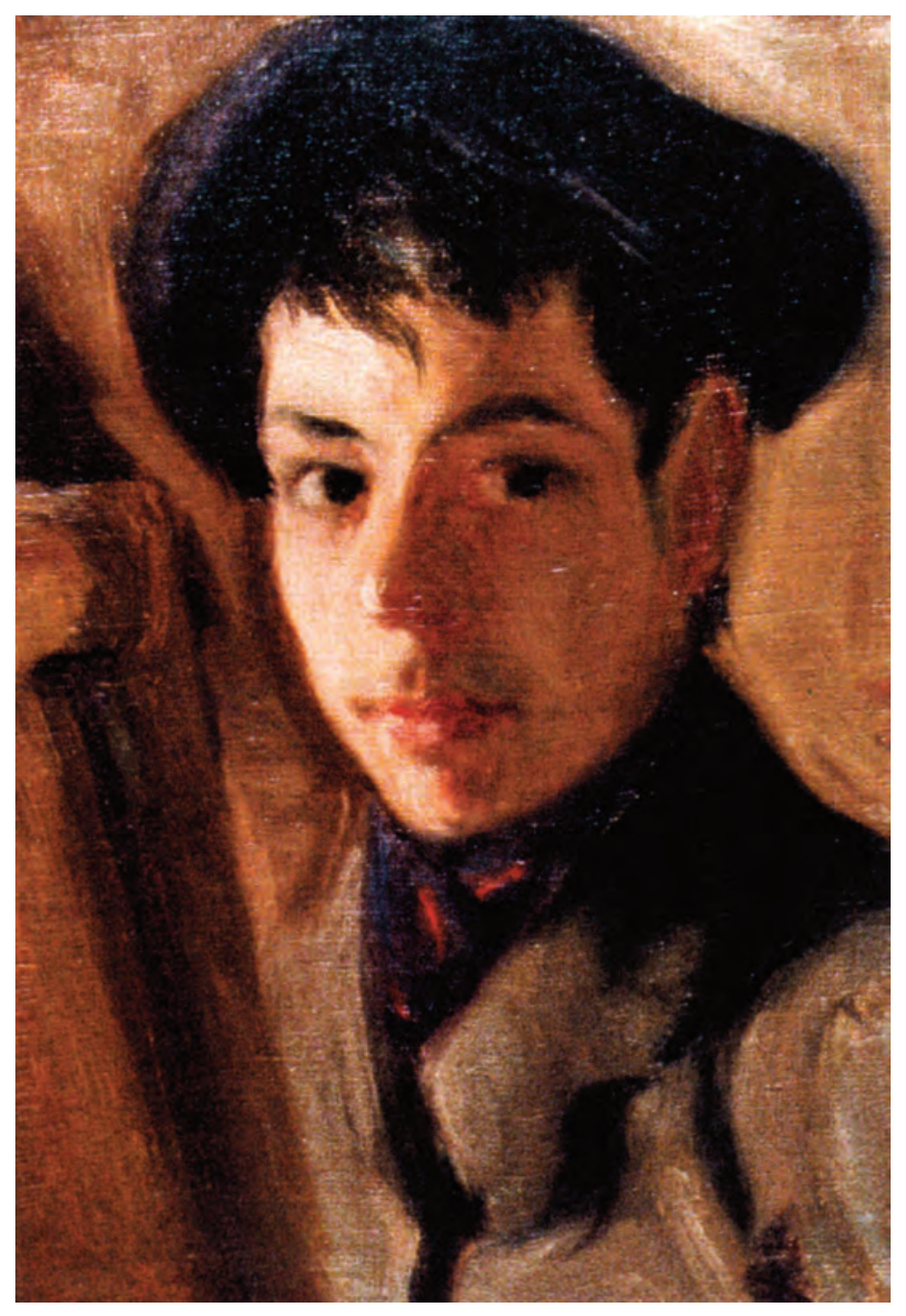

Autorretrato. 1928. Segovia. Mural. Hotel "Las Sirenas", Segovia.

Eduardo Vicente 





\section{Eduardo Vicente y sus entornos más próximos:} Segovia y Madrid.

\section{1.- Eduardo Vicente (1909-1968).}

Nacido en la familia formada por Toribio Vicente -Guardia Civil- y Sofía Pérez. Poco antes de nacer Eduardo (Fig. 1), el matrimonio se había trasladado a vivir a Madrid desde el pueblo segoviano de Turégano. Pueblo éste donde había visto la luz -1903- su hermano mayor Esteban Vicente, pintor y escultor, pionero del expresionismo abstracto en España.

En los primeros años de su infancia heredó la pasión por el dibujo y la pintura de su padre, con quién disfrutó de incontables visitas a los principales museos de Madrid.

Decide abandonar sus estudios en quinto de bachillerato, para matricularse en la Escuela de Bellas Artes de San Fernando.

Junto con su hermano Estaban y Juan Bonafé (hijo), comienza su andadura dentro del mundo de las artes plásticas, alquilando su primer estudio artístico en la calle del Carmen. En 1924 entra a trabajar como pintor ayudante en los talleres escenógrafos Amorós y Mignoli.

Un año más tarde cambia su estudio de la calle del Carmen por otro situado en el Paseo del Prado. Es en este estudio, cuando Eduardo Vicente comienza a participar en tertulias, otorgando una gran importancia a estas reuniones con artistas y literatos, una pasión que le acompañará durante el resto de su vida.

Con 19 años, Eduardo Vicente inaugura su primera exposición en el Salón de arte del Ateneo de Madrid. Gracias a esta muestra pictórica, Eduardo comienza a perfilarse como uno de los grandes pintores españoles del siglo $X X$.

Acompañado del pintor inglés Christopher Hall, realiza una serie de viajes por toda España, que le sirvieron para conocer los distintos paisajes de la Península Ibérica, así como a sus gentes y costumbres.

Es en 1931, cuando le encargan la creación y la dirección del Museo Ambulante de las Misiones Pedagógicas, lo que le supone un nuevo reto, y un cambio de rumbo en su carrera. Junto con sus amigos Ramón Gaya y Juan 
Bonafé, realizan copias de las grandes obras históricas del arte español y recorren los pueblos de todo el país divulgando la cultura artística y acercando estas obras a las personas, que de haber sido de otra manera, nunca hubiesen conocido.

En 1936, pide su relevo en las Misiones Pedagógicas para volver a Madrid e involucrarse de nuevo en la vida artística de la España de los años 30. La Guerra Civil Española, supondrá en la vida de Eduardo Vicente, al igual que en la vida de todos los españoles una ruptura completa. Con el conflicto bélico en plena expansión, Eduardo Vicente tuvo que decidir su posición política y optó por poner su talento artístico a disposición de los Servicios de Propaganda del Ejército Republicano donde comenzó su labor cartelística.

A pesar de que fueron años muy complicados, Eduardo Vicente, tuvo tiempo de participar en la Exposición Internacional de París (1937) dentro del Pabellón Español, donde los grandes artistas del país decidieron que éste se convirtiera en un escaparate de la barbarie que se estaba viviendo en España con la guerra.

Al finalizar el conflicto bélico, Vicente, decide continuar viviendo en el país que ama y descarta la posibilidad del exilio, a pesar de la derrota del bando Republicano y del futuro que se avecinaba para todos los que estuvieron a favor de las ideas del bando perdedor.

La mala época que atravesaba el país, le hizo dedicarse a la pintura industrial, y dejar de lado su faceta artística, trabajando al servicio de los distintos contratistas de obra que había en Madrid durante el periodo de la posguerra.

Poco a poco, Eduardo Vicente, comienzó a recuperar su antigua vida, donde la pintura era una pasión, más que solamente una forma de conseguir dinero. La gran amistad que le unía con el director literato de la Editorial Espasa Calpe, José María de Cossío, le lleva a convertirse en el ilustrador de distintas colecciones que publicaba dicha editorial, así como a ser el ilustrador oficial de la columna taurina que tenía la editorial.

Otra de sus grandes amistades, la que mantiene con Eugenio D'ors le abre las puertas de la Galería Biosca, situada en la calle Génova de Madrid, 
donde la sociedad madrileña comienza a hacerse eco de este artista. D'ors crea un equipo de artistas renovadores llamado "Academia Breve de Crítica y Arte" y le lleva a participar en "El primer Salón de los Once", junto con otros artítas como Benjamín Palencia, Manolo Hugué, Zabaleta...

La crítica le hizo conseguir en 1943 su tercera Medalla Nacional de Arte y realizó dos exposiciones de gran importancia, una en la Galería MIR de Zaragoza y otra en la Galería Mateu de Valencia.

Un año más tarde, le encargan realizar el mural decorativo para el baptisterio de la Catedral de Orihuela, en Murcia, y es invitado a participar en el "II Salón de los Once".

A mediados de los años cuarenta comienza a quedar patente la renovación plástica que estaban realizando los artistas contemporáneos dándose las primeras pinceladas de lo que sería el arte moderno en España. Eduardo Vicente participó en tres exposiciones en las que se pudieron comprobar estos cambios. El Museo Nacional de Arte Moderno, acogió las muestras tituladas: "Floreros y Bodegones", "Autorretratos de pintores españoles actuales" y "Antología de las mejores obras expuestas en Madrid".

La Academia de Bellas Artes de San Fernando le otorgan la beca Conde de Cartagena, brindándole la oportunidad de viajar a Estados Unidos. De esta manera, aprovecha esta portunidad para dejar constancia, al igual que lo había hecho en Madrid en años anteriores, de las escenas de barrio y los ciudadanos de Harlem, Brooklin y Broadway. Retaros que le sirvieron para realizar varias exposiciones a su vuelta a España.

La Galería Hugo de Nueva York, le otorga la oportunidad de realizar su primera exposición en los Estados Unidos. Eduardo Vicente comienta a tener un gran reconocimiento internacional y más adelante realiza una segunda exposición en la Galería Painting-Library, también en Nueva York. También fue invitado a mostrar su obra en la Exposición Internacional del Instituto Carneggie de Pittsburg.

El comisario Pérez Comendador, selecciona a este pintor madrileño para participar dentro de la Exposición de Arte Español, de Alejandría y El Cairo. Muestra en la que sus obras acompañan a las de artistas de la talla de Dalí, Vázquez Díaz y Zuloaga. 
Gracias al prestigio que le otorga el trabajo bien hecho y las buenas críticas, se convierte en un referente dentro del arte contemporáneo español de esa época y tienen el honor de ser nombrado miembro del Jurado de la Primera Bienal Hispanoamericana de Arte celebrada en el Palacio de Bibliotecas y Museos del Paseo de Recoletos de Madrid. También tuvo una gran participación en la Bienal de Venecia donde acude con una importante muestra. El Instituto Internacional de Boston en la capital española y la Casa de América de la provincia andaluza dieron cobijo a grandes obras de Eduardo Vicente.

Otra de las ciudades que le sirvieron a este artista para retratar a sus gentes, y sus calles fue París, ciudad a la que realizó dos viajes en 1957 y donde toma contacto con los movimientos artísticos europeos de la época.

Los Salones del Casino de Madrid acogen, en 1964, un banquete que sirve para homenajear al artista, al que asistieron las personalidades más destacadas de la vida cultural de ese momento.

Un año más tarde, viaja a Guadalajara para pintar los murales que decoran el coro de la iglesia de Brihuega. Regresa a Madrid para terminar las pinturas de la sala Reflectorio del Banco Urquijo. Durante los últimos años de su vida, Eduardo Vicente, se dedica a pintar varios murales más de iglesias y edificios destacados dentro del territorio nacional. El más importante fue el que realizó en la sede Vicente Lluch, Agente de Aduanas.

La última exposición que pudo inaugurar Eduardo Vicente fue en mayo de 1968, en la Galería Quixote de Madrid, coincidiendo, una vez más con las fiestas de San Isidro.

El 9 de mayo de 1968, con 59 años de edad, le sorprende la muerte en su estudio, en la más absoluta soledad puesto que nadie se entera de la noticia hasta dos días después.

\section{2.- Turégano - Segovia.}

El pueblo de Turégano tenía por aquel entonces alrededor de 1200 habitantes. Pueblo rural, castellano viejo, que alternaba las labores cerealistas propias del campo con pequeñas tiendas de ropa y comestibles situadas bajo los soportales de su plaza mayor; cabecera de zona, referente y fuente de suministro de una docena de pueblos aledaños. 
Conocido y famoso, además, por sus ferias de ganado -especialmente, en el mes de Noviembre, la de San Andrés- en la cual la localidad se veía, año tras año, desbordada por la concurrencia de los más afamados "tratantes" de ganado mular y asnal. El colorido, la algarabía, el mercadeo y las transaciones rompían por aquellas fechas el silencio del resto del año.

Acabada la feria, monotonía. La rutina de uno de tantos pequeños pueblos de Castilla la Vieja. La escasez de recursos, la cultura ramplona de la mano con el analfabetismo, las privaciones, los comadreos vecinales, la pobreza de ánimo, los lutos, las fiestas, el aguardiente matinal,... y las solanas. Sobre todo las solanas, por aquello de que el sol, el aire y la saliva eran gratis y confortaban tanto al cuerpo como al espíritu.

Pueblo religioso, metódico y con arraigadas tradiciones ancestrales; la costumbre era la norma. Respetuoso con los mayores, sumiso ante los imperativos religiosos, fiel a las cofradías, acrítico excepto con el vecino de enfrente, receloso ante los cambios y conservador; eso sí muy conservador. Pueblo que apenas sufrió cambios desde que estuviera encerrado en su Castillo el que fuera secretario de Felipe II, Antonio Pérez.

A finales de la Edad Media estuvo vinculado a la Corona y a la Iglesia como lo testimonia, aún, su Iglesia-Castillo y la decena de parroquias, con distintas advocaciones, repartidas por el núcleo urbano.

Tenía, y gozaba, Turégano a principios del siglo XIX de algunos privilegios como cabecera de zona: médico, botica, veterinario, secretario y puesto de la Guardia Civil donde prestaba servicios a la Patria el padre de Eduardo.

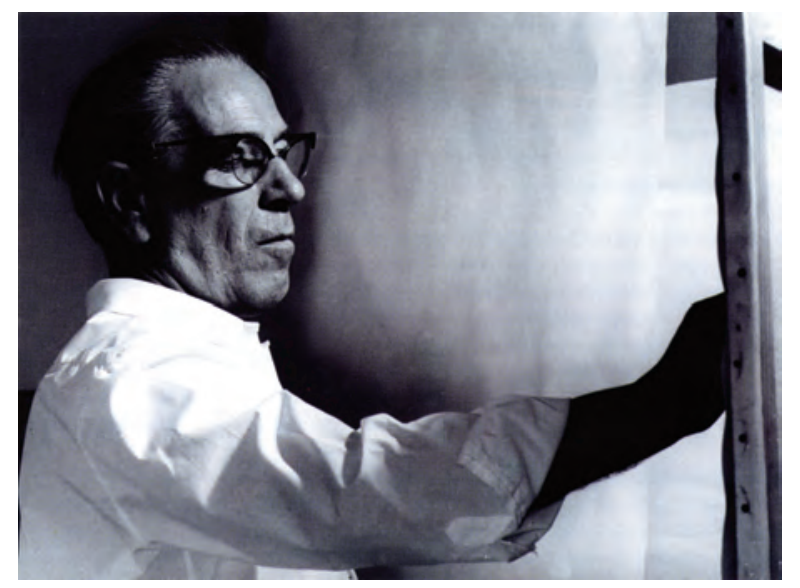




\section{3.- Madrid - Villa y Corte $(1890-1936)$.}

Madrid era, a finales del siglo XIX y principios del XX una ciudad preindustrial; de oficios variopintos - supeditados a una estructura familiar 0 gremial-, de valores tradicionales y de una nobleza ya rancia que se resistía a morir.

No obstante, era a su vez la capital de un nuevo estado liberal, un mundo de negocios. Centro, por tanto, de la Administración, la Política, la Bolsa y las Instituciones culturales y científicas del país, empezando por la Universidad.

Las corrientes culturales de la época intentaban abrirse camino, darse a conocer y obtener reconocimiento mediante la integración en las tertulias y la participación en instituciones tipo: Ateneo, Residencia de Estudiantes o la asistencia a conferencias y publicaciones esporádicas en periódicos y revistas. Un Madrid que por entonces aspiraba a codearse con lo que en Francia se denominó "la belle époque parisien", en Austria "la Viena de fin de siglo" o en Alemania "el Berlín de Weimar". Era el Madrid de la Edad de Plata, al igual que tuvimos nuestro Siglo de Oro. Madrid, centro de la creación cultural y científica de España. A finales de siglo se abren los nuevos locales del Ateneo de Madrid, lugar donde se debatían los grandes problemas de la España del momento y se aportaban soluciones más o menos radicales. Podemos decir que fue la cuna de los inspiradores de la Institución Libre de Enseñanza.

Fueron muchos los que sintieron la llamada de la capital de España: Leopoldo Alas "Clarín", Emilia Pardo Bazán, Benito Pérez Galdós, Miguel de Unamuno, Pío Baroja, los hermanos Antonio y Manuel Machado, Juan Ramón Jiménez, Ramón María del Valle Inclán, Francisco Giner de los Ríos, Santiago Ramón y Cajal...). Periódicos como "El Imparcial", "El Liberal", "El Sol",... fueron plataforma y notarios de su pensamiento y obras.

Madrid era la caja de resonancia de los avatares y vaivenes de España. Algunos de los integrantes de la llamada generación del "98" (Azorín, Baroja, Maeztu, Unamuno, Valle Inclán) pusieron de manifiesto la decadencia de España, el fin de sus colonias, la inseguridad política, la precariedad de sus estructuras atrapadas en las redes del caciquismo, el proteccionismo férreo que impedía el despegue industrial -que, ya, otros países europeos habían 
llevado a cabo-, lo rudimentario de nuestra agricultura, la escasez de comercio, la crisis cultural, el analfabetismo de la mayoría de la población,... realidad que había quedado enmascarada por el "casticismo" de la segunda mitad del siglo XIX y que, ya, Ángel Gavinet entre otros, pionero del "98", había denunciado en su -"idearium español"-1891- y aportado soluciones para salir de tal aletargamiento y penuria.

Era el Madrid de las reuniones y tertulias: "El Café de Madrid" en la Calle de Alcalá, "El Café de Fornos", "La Horchatería de Candela",... lugares frecuentados por lo más granado, a nivel cultural, de España. Pío Baroja, gran analista y crítico social, nos retrata así el ambiente de aquellos cafés:

"Como puede verse, la vida del café, por la mañana, por la tarde y por la noche, es bastante cambiante; su ambiente recoge el clima artístico de nuestro tiempo; en la variedad de públicos está desde el funcionario mediocre hasta el investigador prestigioso, pasando por el pintor, por el escultor, por el escritor y por el poeta". 2

Gómez-Santos, M. (1955:165)

No es pues de extrañar que la capital de España fuese imán, santo y seña, para quienes con inquietudes culturales o aspiraciones de mejora económica estuviesen abiertos a lo que Madrid ofrecía. 



\section{Contexto Histórico.}

Eduardo Vicente nace, como sabemos, a principios del siglo XX. Época de intrigas políticas y sociales en España. Una España, sumida en el atraso agrario y en el recuerdo nostálgico de lo que fue su imperio colonial. Una España convulsionada políticamente.

Cercana está, aún en el tiempo, la época de la Restauración - Reinado de Alfonso XII, 1875-1885-, la regencia de su esposa María Cristina 18851902, la alternancia o turnismo en el poder de los partidos políticos: conservadores, representados por Antonio Cánovas del Castillo y que aglutinaba a moderados, unionistas, católicos, nobleza, terratenientes, alta burguesía industrial, funcionariado militar y civil, etcétera; y liberales comandados por Práxedes Mateo Sagasta y en cuyas filas militaban los progresistas, demócratas, clases medias y profesionales. Estos, más los grupos marginados de las esferas de poder como eran los distintos bandos carlistas y las variopintas secciones republicanas configuraban el panorama político de España. Dicho sea de paso, de una España donde era notorio el analfabetismo y en la cual el caciquismo político era la tónica dominante en las elecciones.

Un final de siglo en el que si bien no habíamos puesto los cimientos de la industrialización, cuando otros como Francia o Inglaterra estaban en pleno desarrollo, y sin embargo en el que afloran movimientos anarquistas como la Federación de Trabajadores Regionalistas de España -FTRE-, en Cataluña y Andalucía, que aunque se disolvió a finales de los noventa, la masa proletarial se encuadró posteriormente en la Confederación Nacional del Trabajo -CNT-. Igualmente nace el Partido Socialista Obrero Español -PSOE, 1879- de manos de Pablo Iglesias y, a su vez, se funda en 1888 la Unión General de Trabajadores -UGT-.

Es a su vez un periodo de nuestra historia en el que germinan los nacionalismos y regionalismos. En 1901, Prat de la Riba y Francesc Cambó fundan la Lliga regionalista; anteriormente se habían aprobado "las bases de Manresa" por las cuales se defendía la Organización Confederal de España y la Soberanía de Cataluña en política exterior. Sabino Arana, por su parte, crea en 1895 el Partido Nacionalista Vasco -PNV-. Y, aunque con menor fuerza y virulencia, Alfredo Brañas y Manuel Murgía sientan las bases ideológicas del nacionalismo gallego. Hechos, todos ellos, que enmarañaron el panorama político español. 
Para colmo de males, en el exterior, la Paz de Zanjón de 1878 sólo había aplazado el problema de Cuba. Bajo el liderazgo del cubano José Martí, apoyado por EEUU, se inició la insurrección de la isla. En los gobiernos tanto de Cánovas como de Sagasta se intentó solucionar el problema pero la voladura del acorazado "Maine" en el puerto de la Habana provocó la guerra contra EEUU. Las batallas de Cavite y Santiago evidenciaron la desigualdad de fuerzas y dejaron patente la precariedad de nuestras tropas y armamento militar; y que el patriotismo y el coraje español no eran suficientes para movernos por el mundo.

En 1898 se firmó la Paz de París por la que España reconocía la independencia de Cuba, Puerto Rico y Filipinas, a la vez que cedía a EEUU las islas Guam.

Un año después España vendía a Alemania las Marianas, Carolinas y Palaos. Seguidamente, en 1890, a EEUU las islas Sibutú y Cagallán. Era el fin del Imperio colonial español.

Termina el siglo XX con una España en precario. Una España con un grado altísimo de analfabetismo, con economía rural y dispersa, carente de unas bases sólidas para abordar la industrialización, socialmente fraccionada y políticamente dividida y a la espera de la mayoría de edad del nuevo rey - mientras tanto bajo la regencia de su madre María Cristina-. Los albores del siglo XX no eran, pues, nada halagüeños.

\section{1.- Siglo $X X$.}

Con la llegada del nuevo siglo se restaura la Monarquía -Alfonso XIII, 1902 - 1931-. Las esperanzas puestas en el Rey eran muchas, los problemas pendientes también.

España seguía siendo un país de base agraria -más del $60 \%$ de la población-. El país Vasco y Cataluña eran los únicos focos industriales con perspectivas de futuro y que atraían población del resto de las regiones. En ellos, fundamentalmente, comenzaron a nacer las Sociedades Anónimas capaces de aglutinar el capital necesario para el despegue económico; paralelamente se fue desarrollando la Banca, tan incipiente como necesaria. Sin embargo eran muchas las regiones donde el peso de las pequeñas 
empresas familiares y la tradición e intereses de los gremios se resistían a morir.

Así pues, nos encontramos ante un tejido social compuesto por una clase alta integrada por latifundistas, banca, alta burguesía y la élite política; una clase media formada por comerciantes, funcionarios, medianos y pequeños industriales, oficiales del ejército y clero; y la clase baja donde se daban cita obreros, pequeños agricultores, jornaleros, etc. Cada uno con sus particulares intereses.

El nuevo Monarca, Alfonso XIII inició su gobierno interviniendo directa y personalmente en la vida política. Él, no las elecciones, determinaba el turnismo de los partidos y realizaba el nombramiento de los mandos militares del ejército.

Tiempos difíciles. Las reformas propuestas por Maura (cambio del sistema electoral o la Ley de administración local) condujeron a la tristemente famosa "Semana trágica de Barcelona". Igualmente sucedió a Canalejas pues encontró una fuerte oposición a sus reformas en materia sociolaboral y a la secularización de la vida política. La vida social y política tomó tintes de dramatismo -especialmente, a partir del asesinato de Canalejas- debido a las sucesivas fragmentaciones de los partidos democráticos y al impacto que supuso el comienzo de la primera guerra mundial -1914-1918-.

Todo ello desembocó en una gran crisis durante los meses de Julio y Agosto de 1917: malestar e inconformismo de los militares, convocatoria de huelga general, conflictividad social, recrudecimiento de la cuestión catalana. Y para colmo de males se reavivó el problema marroquí: Abd-El-Krim trajó en jaque y derrotó a las tropas españolas en la batalla de Annual ocasionándonos importantes pérdidas económicas y, sobre todo, de vidas humanas; además de poner en evidencia la simplicidad del ejército español y la incompetencia de la clase política.

Todo este cúmulo de circunstancias provocaron la Dictadura de Miguel Primo de Rivera -1923-1930-, dictadura plenamente consentida y aprobada por el Rey. Pero ni el Directorio Militar que se estableció hasta 1925 ni el Directorio Civil dieron solución a los problemas tradicionales que afligían a la Patria. En consecuencia, Primo de Rivera carente de apoyos, incluso dentro del 
ejército, dimite en Enero de 1930. Ni el sucesor por él propuesto -Dámaso Berenguer- ni el sucesor de éste -Aznar- pudieron enderezar el timón de la nación. Las ansiadas elecciones municipales celebradas el 12 de Abril de 1931 dieron como resultado una mayoría de base republicana en las poblaciones que se consideraban puntos neurálgicos de la nación. Ante estos hechos, Alfonso XIII sale de España. Comienza la II República.

\section{2.- II República.}

La segunda República fue un intento de profunda renovación política, económica y cultural dentro de un marco constitucional.

La salida de Alfonso XIII deja a España nuevamente sin Monarca. Acto seguido, proclamada la II República, se forma un Gobierno Provisional presidido por Niceto Alcalá Zamora -en este Gobierno estaban presentes las fuerzas firmantes del "Pacto de San Sebastián"-. Enseguida se atienden a una serie de problemas que desde hacía tiempo estaban enquistados, así: se establece la jornada laboral de ocho horas, se deroga la Ley de Jurisdicciones, se suprime la Academia Militar de Zaragoza, se determina la Ley del retiro, se suprime la religión en las Escuelas, ...

Pronto surgieron dificultades, más problemas que reformas o soluciones. Por una parte Francesc Maciá proclamó la república catalana -y se creó la Generalitat- y sobre todo se vivió un clima de contradicciones y descontento con alteraciones frecuentes del orden público -hecho por el que se creó el Cuerpo de guardias de asalto-, reiteradas huelgas promovidas por la CNT -especialmente en Sevilla, País Vasco y Cataluña-, se agudizó el problema religioso que motivó la quema de muchos conventos en Madrid, así como la vejación de religiosos.

En este ambiente, enrarecido, se convocan elecciones a Cortes Constituyentes -en Junio de 1931- y resultan vencedores la conjunción republicano-socialista (excepto en el País Vasco y Navarra).

La nueva Constitución -aprobada en Diciembre de 1931- convertía a España en un estado democrático y laico, con una única cámara, un Presidente de la República nombrado por seis años, establecía el sufragio universal -incluidas las mujeres-, subordinación de la propiedad al interés 
público, ... En definitiva, un Estado "integral" pero que, a su vez, permitía la autonomía de municipios y regiones.

Entre 1931-1933 fue una época de profundas reformas -bienio progresista-, con Manuel Azaña como Jefe de Gobierno y Alcalá Zamora como Presidente de la República. Para mejorar los rendimientos del campo se aprobó la Ley de Bases de la Reforma Agraria, merced a la cual se daba vía libre a la expropiación de fincas no explotadas directamente por los propietarios y entrega en arrendamiento a los labradores; y para descentralizar la política se pusieron en práctica las Autonomías Regionales -concretamente, la autonomía catalana llegó a funcionar con Francesc Maciá como presidente-.

Pero el nuevo marco político y las reformas que se iniciaron no eran del agrado ni de la Iglesia, ni del ejército ni tampoco de los grandes propietarios. Ya en 1932 el general Sanjurjo intentó un golpe de Estado. Por su parte la Confederación Española de Derechas Autónomas, lideradas por Gil Robles, -CEDA- estableció un programa con el fin de anular las reformas llevadas a cabo por el Gobierno en el poder, es decir las izquierdas. Los antirrepublicanos y nacionalistas, liderados por José Antonio Primo de Rivera- fundaron la Falange Española, sólida oposición al régimen. Y para colmo de males se produjeron las gravísimas revueltas en "Casas Viejas" -Enero de 1933- que terminaron con la masacre de numerosos jornaleros y una durísima represión. Hechos todos ellos que determinaron la dimisión de Azana y la convocatoria de elecciones en Noviembre de 1933.

Estas nuevas elecciones dieron el triunfo a la CEDA y al Partido radical de Lerroux -aunque ninguno de ellos con mayoría-. Los sucesivos gobiernos revisaron y anularon las reformas de Azaña.

Otra vez vuelta a empezar en un clima social cada vez más tenso que culminó con la revolución de Octubre de 1934: huelga general, rebelión de los mineros de Asturias, creación de "comités revolucionarios", etcétera. Ante esta situación, Niceto Alcalá Zamora disolvió las Cortes y convocó elecciones para Febrero de 1936.

Es sabido que, de cara a las elecciones, republicanos, regionalistas, socialistas y comunistas se unieron y formaron el llamado Frente Popular, bajo un programa reformista y democrático. Las derechas no consiguieron hacer 
una candidatura única a nivel nacional, ni siquiera unificar un programa electoral. La consecuencia fue que las elecciones del 16 de Febrero dieron el triunfo a las izquierdas. España quedó con un nuevo dibujo político conforme a los resultados; así Madrid, Cataluña, Asturias y la periferia del Mediterráneo quedaron bajo el control del Frente Popular, mientras que las dos Castillas, Navarra y Aragón de las derechas.

Nuevamente, el Gobierno trató de restaurar la política del primer bienio pero otra vez resurgió el desorden público con huelgas y quema de conventos. Inconformismo y caos era la tónica dominante.

Mola, en contacto con los carlistas, se erigió en el director de una conspiración. La chispa del levantamiento la provocó el asesinato de Calvo Sotelo -el 13 de julio de 1936- por un grupo de guardias de asalto como represalia al cometido por la derecha en la persona del teniente José del Castillo. El Alzamiento Nacional estaba a la vuelta de la esquina.

El tiempo de la II República fue una época tormentosa, mezcla de muchos intereses e ideologías por lo cual la efectividad de las numerosas reformas previstas y algunas puestas en práctica no pudieron llevarse a cabo. Sin embargo, no todo fue negativo pues se impulsó la educación -se creó el Ministerio de Instrucción Pública-, la Institución Libre de Enseñanza alcanzó gran notoriedad e influencia -se fundó la Junta de ampliación de estudios que establecía viajes para que el profesorado pudiera viajar y residir en el extranjero-; nació el Centro de Estudios Históricos así como la Fundación Francisco Giner de los Ríos, ... y, lo más importante, se dio un gran avance contra el analfabetismo dictaminando que la educación debería ser libre, gratuita y basada en la coeducación, con respeto a la variedad lingüística de España. La reforma de la Escuelas Normales de Profesores coadyuvó a esta iniciativa.

Podemos, incluso, hablar de este periodo histórico como "la Edad de Plata de nuestra cultura" pues fueron muchas las artes que brillaron con luz y nombres propios. En Arquitectura e Ingeniería civil muchas de nuestras ciudades arreglaron sus vías centrales, en Madrid se construyó el Palacio de Comunicaciones y el Círculo de Bellas Artes, se desarrolló la Ciudad Lineal, ... también en Barcelona, por ejemplo, se termina la Vía Layetana. En Pintura es de todos conocido el renombre que adquieren Picasso, Miró y Dalí; y otros 
como Ignacio de Zuloaga o Daniel Vázquez. Otro tanto podemos decir de Pablo Gargallo y Julio González en escultura, o Joaquín Turina y Manuel de Falla en música.

Mención aparte en este periodo merece la "Generación del 98" en literatura; autores como Ramiro de Maetzu, Miguel de Unamuno, Antonio Machado, Azorín y Ramón María del Valle Inclán abanderaron un estilo serio, profundo y renovador de las letras frente a un Modernismo, ya , caduco y un teatro comercial de la época -triunfal, por cierto- en el que se movían autores como Pedro Muñoz Seca o Carlos Arniches. No se puede dejar de lado otra generación inmediatamente posterior como es la de "1914", en la cual dejaron su huella e influencia social y política hombres de la talla de Ortega y Gasset, Manuel Azaña o Gregorio Marañón. Sin olvidar, claro está, nuestra "generación del 27" con Federico García Lorca, Luis Buñuel, Rafael Alberti, Dámaso Alonso, Vicente Alexaindre, etc.

En definitiva, podemos hablar de una "Edad de Plata" de nuestra cultura en esta época, compuesta no por un ramillete de elegidos sino por un haz de nombres y obras de enorme influencia en la vida social, cultural y política.

\section{3.- Nuestra Guerra Civil}

La victoria republicana en las elecciones de Febrero de 1936 frustró las expectativas de las derechas. No aceptaron la derrota en las urnas, máxime cuando dos años antes los de izquierdas habían intentado derrocar a su gobierno legítimo. Por tanto las intrigas y conspiraciones se sucedían y en el ambiente social se respiraba intranquilidad. Era evidente que se estaba preparando un pronunciamiento.

El 17 de Julio de 1936 se inició la sublevación en Melilla, Marruecos y Canarias; el día 18 estalló en la Península. Pronto se convirtió en una guerra civil e, incluso, se internacionalizó el conflicto. España quedó dividida en dos bandos: las izquierdas -Madrid, Cataluña, Levante, la franja cantábrica, Castilla la Nueva, Extremadura y gran parte de Andalucía-; y las derechas que triunfaron en Castilla la Vieja, León, Navarra, Galicia, parte occidental de Aragón, Baleares, Canarias y algunas provincias andaluzas. En Madrid, por tanto, fracasó la sublevación y quedó en zona republicana. 
Madrid fue el objetivo clave en los primeros momentos. Mola debía tomar la capital por el norte y Franco por el sur; pero los milicianos detuvieron al General Mola en la sierra de Guadarrama y los republicanos resistieron gracias al apoyo de las Brigadas Internacionales y los tanques y aviones soviéticos. Se estabilizó el frente, al tiempo que se sucedían las tropelías y asesinatos ya iniciados en -Paracuellos del Jarama- y que tuvieron continuidad contra los aristócratas, burgueses, militares, religiosos, ...

En Marzo de 1937, Mola inició la ofensiva contra Vizcaya -momento del tristemente célebre bombardeo de Guernica por la legión "Cóndor" alemana. Este frente del Norte poco a poco fue perdiendo fuerza y consistencia.

Pero la clave de la victoria final de los sublevados estuvo en el frente del Este. A pesar de tomar la iniciativa los republicanos -el General Vicente Rojo logró entrar en Teruel-, sin embargo en la durísima batalla del Ebro hubieron de replegarse. Franco tomó fácilmente Tarragona y a continuación Barcelona.

El resto de la guerra -hasta el 1 de Abril de 1939- fueron represalias, escaramuzas y un avance implacable de Franco hacia Madrid que fue dejando por el camino un reguero de sangre - no tantos como escribe José María Gironnella, un millón de muertos, en su obra Los Cipreses creen en Dios- y un nutrido arsenal de odio y rencor en el corazón de los españoles. La resistencia a ultranza de Juan Negrín adolecía de una falta de unidad entre las distintas facciones de izquierdas.

Si cruenta fue la guerra -150.000 muertos, 30.000 represaliados, 30.000 fusilados, 500.000 exiliados, 400.000 heridos- no menores fueron sus consecuencias: España quedó sometida a una Dictadura militar con pérdida de las libertades políticas, aislada internacionalmente y bajo control policial; campos abandonados, infraestructuras inutilizadas, carente de industrias y con escasez de reservas de oro - las no muchas que había se encargó la URSS de llevárselas por los pingues servicios prestados al bando republicano durante la contienda-. España se convirtió una vez terminada nuestra guerra en una autarquía bajo el espectro de la II Guerra Mundial.

Ambos bandos tuvieron sus colaboradores o apoyos internacionales, 
así: a los republicanos les prestó ayuda México, la URSS -a cambio de oro-, Francia suministró algunas armas y, de manera especial, las Brigadas Internacionales; a los sublevados Alemania, Italia y Portugal -importante fue el petróleo de la TEXACO y los camiones de la General Motors-.

A nivel interno, la economía, las artes, la música, las ciencias, las letras, ... también se pusieron de parte de uno u otro bando. Así algunos dieron su oro, animales, grano, joyas o dinero por la causa; otros como Miguel Hernández pusieron su ingenio y poesía; Federico García Lorca fue fusilado por su ideología de izquierdas, Rafael Alberti. Y en la zona nacional José María Pemán, Luca de Tena, Pedro Muñoz Seca. Por su parte, Eduardo Vicente puso su ingenio a través de sus carteles, a favor del Bando Republicano.

\section{4.- Posguerra.}

Uno de Abril -día de la Victoria Nacional- Comienzo de la posguerra. El régimen de Franco se asentó sobre las bases de la Falange, la Iglesia y el Ejército, especialmente. Podríamos añadir, también, el apoyo de familias políticas compuestas por Monárquicos (carlistas y donjuanistas) y, posteriormente, tecnócratas (básicamente del Opus Dei).

Enseguida comenzaron a dictarse leyes: Ley de la Represión de la Masonería y el Comunismo, Ley para la Seguridad del Estado... Ramón Serrano Suñer se convirtió en los primeros tiempos en una pieza clave del régimen y la Falange y el Movimiento Nacional fueron enseñas y referentes básicos en la vida de los españoles proyectadas en organismos como: OJE, Sección Femenina, SEU, etc; con distintivos como el vocabulario empleado, los saludos, canciones, uniforme, etc. Una época y un estilo de vida.

La Ley de Cortes -aprobada en 1942- o el Fuero de los españoles -aprobado en 1945- fueron guiños virtuales de apertura incapaces de enmascarar la auténtica dictadura. Ni siquiera la Ley de Sucesión a la Jefatura del Estado - 1947- que consideraba a España como un Reino hizo desdecirse a Don Juan Carlos de Borbón de su condena al régimen en el conocido Manifiesto de Lausana. España era una dictadura bajo el control personal de la figura del Caudillo. Los grupos de guerrilleros -MAQUIS- echados al monte no fueron una oposición lo suficiente fuerte como para inquietar al sistema. 
España, pues, quedó sumida en un aletargamiento, enquistamiento, obsesionada en aumentar la producción nacional -autoabastecerse- para no tener que realizar importaciones. Quedó aislada internacionalmente. Época de hambre y carencia de libertades.

La creación del SNT -Sindicato Nacional del Trigo- produjo efectos contrarios a los deseados ya que la falta de libertad para comercializar los productos del campo, al estar fijados oficialmente los precios, llevó a una carestía de los mismos y con ello al estraperlo. Cada cual intentó sacar de sus pertenencias -especialmente de orden alimenticio- la mayor ganancia posible y abundaron las ventas y reventas de productos de primera necesidad como la carne, queso, café, tabaco, garbanzos, etc. La CGST -Comisaría General de Abastecimientos y Transportes- no resolvió el problema y mucho menos la medida de las Cartillas de Racionamiento- que hicieron más notoria la escasez y promovieron una picaresca propia de nuestros siglos XVI y XVII-. En definitiva, el excesivo intervencionismo perjudicó a la agricultura y ahogó a la industria la cual no pudo desarrollarse libremente por el excesivo control del INI a través de sus empresas filiales.

Y no sólo fue la economía. La educación y las costumbres fueron sometidas a una censura férrea auspiciada y bendecida por la iglesia. Bajo esta estructura social apenas cabía otra cosa que la sumisión y, en los casos extremos, la rebeldía que siempre tenía consecuencias negativas, tanto para los pocos que se atrevían a levantar la voz, la pluma o los pinceles como para sus familiares y allegados. A nivel de la masa trabajadora los Sindicatos Verticales establecían una dependencia directa de los mandos y los pocos derechos legítimos concedidos eran vendidos como favores y complacencias de los dirigentes. Y siempre de forma arbitraria y personal.

Este era el panorama nacional hasta 1950 con ligeras modificaciones hasta pasados los -60-. El enfrentamiento entre los dos grandes bloques -occidental, EEUU y oriental, URSS-, que tuvo como consecuencia la conocida guerra fría, llevó a nuestro país a firmar el Pacto de Madrid con los americanos por el que se nos prestó ayuda económica a cambio de la contraprestación de que pudiesen establecer bases militares en nuestro territorio. Por intereses, pero ya éramos algo internacionalmente. Se nos empezó a admitir en Organismos Internacionales, 1950, (FAO, UNESCO, ...), firmamos el Concordato 
con el vaticano -1953-, fuimos admitidos en la ONU -1955-, e ingresamos en la OECE -1958-. Años de una ligera apertura pero no exentos de presiones internas: huelgas de trabajadores, crisis universitarias, renacimiento de los nacionalismos, etc. Años en los cuales la supervivencia era el principal objetivo. Penuria económica y miseria intelectual. 



\section{Contexto Cultural.}

El siglo XIX termina con el desastre del 98. En 1898, España debe abandonar los últimos restos de su antiguo imperio colonial: Cuba, Puerto Rico y Filipinas. Se produce entonces un sentimiento de derrota y decadencia.

En 1902 comienza el reinado de Alfonso XIII y conservadores y liberales se turnan pacíficamente en el gobierno. El general Primo de Rivera asume el poder desde 1923 hasta 1930. La monarquía debilitada propicia que los republicanos apoyados por socialistas y grupos catalanistas de izquierda ganen unas elecciones municipales, hasta que en 1931 el rey deja el trono y se proclama la II República. El comunismo adquirió una fuerza notable y se fundó un movimiento inspirado en el fascismo, la falange.

En 1936 comienza la guerra civil, que dejará una huella muy profunda en la literatura de posguerra.

A nivel cultural en la $1^{a}$ parte del siglo XX en España se produce un desarrollo cultural extraordinario, en todos los géneros literarios: Modernismo, Noventayochismo, Vanguardias, Grupo del 27, Novecentismo...

\section{1.- Manifestaciones literarias.}

Aparece un grupo de jóvenes escritores imbuidos de ansias renovadoras. Azorín dice: " Un espíritu de protesta, de rebeldía, animaba a la juventud de 1898". Y cita a escritores como Ramiro de Maeztu, Pío Baroja, Miguel de Unamuno, Jacinto Benavente, Rubén Darío, Ramón Maria del Valle-Inclán, .Todos estos jóvenes son llamados despectivamente " modernistas", es decir, anticonformistas. Vivieron intensamente los acontecimientos históricos y los problemas de España y fueron especialmente sensibles al " desastre del 98".

Entre los escritores más destacados del 98 hubo algunos más interesados sobre la reflexión sobre España que por los aspectos puramente formales. Para tal fin utilizarán muy frecuentemente el género ensayístico, aunque también la novela, el teatro y la poesía.

A los jóvenes del 98 les animaba un espíritu de libertad y de reforma, un inconformismo ante la realidad que los rodeaba, que contribuye a que busquen en lo popular y en lo cotidiano la esencia de España (intrahistoria) Los noventayochistas se comprometen con esa realidad, que será el tema fundamental de su obra, e intentan cambiarla. 
Debemos tener en cuenta a Miguel de Unamuno, tanto en poesía como en novela y ensayo, a Ramón María del Valle Inclán, en poesía y como dramaturgo y novelista, a Pío Baroja en la novela y a Azorín en novela y ensayo. Al hablar de la lírica del 98, Antonio Machado es el poeta que sobresale.

El subjetivismo será la nota dominante en cuatro novelas: " Camino de perfección" de Baroja, " Amor y pedagogía" de Unamuno, " La voluntad" de Azorín, y " Sonata de Otoño" de Valle Inclán. Es una nueva forma de concebir la novela que rompe con la narrativa realista del siglo anterior.

La preocupación que por España sienten estos autores está en el fondo de toda su producción literaria, de ahí su enorme interés por el paisaje y los pueblos de España, por una parte, y por la otra, su constante buceo en su historia para descubrir sus valores esenciales y permanentes. En castilla, sus paisajes, sus pueblos, su historia externa y la historia callada y sencilla de sus gentes, ven los noventayochistas la esencia de España. Ellos mismos y su estilo se identifican con el paisaje castellano, austero y recio.

También sus inquietudes existenciales y, en algunos casos, religiosas, fruto del deseo de reflejar la verdad, son temas de sus obras: el sentido de la vida y de la muerte, la caducidad y el paso inexorable del tiempo, la presencia o ausencia de Dios como respuesta a las preguntas fundamentales sobre la existencia. Por eso, también son temas frecuentes los sentimientos de soledad, angustia y pesimismo que estas inquietudes producen en el autor.

La característica fundamental del estilo de estos escritores es la sobriedad. Huyen del retoricismo y de la grandilocuencia, y escriben con claridad y sencillez. Esto unido a la necesidad de profundizar en la esencia de los pueblos les lleva a utilizar palabras características del lugar, incluso arcaísmos. Como el subjetivismo impregna todas sus obras, aparece un léxico de carácter pesimista. En cuanto a la sintaxis, se caracteriza por la sencillez, como por ejemplo la prosa de Azorín, en la que predominan las oraciones simples.

Pío Baroja mantuvo una básica fidelidad a la novela. Puede decirse que en sus novelas cabe todo: encontramos política, humor, crítica social, aventuras... Principalmente lo que pretendía era reflejar la vida. Su técnica 
narrativa tenía como base, en primer lugar, la observación de la realidad y en segundo lugar, la espontaneidad al reflejar todo aquello que observaba...

Sus temas son muy variados; aunque prefería la acción, con protagonistas inconformistas que viven de espaldas a la sociedad. En unos casos, son personajes frustrados a causa del destino que les es adverso. Es frecuente, también, que los protagonistas tengan ideas semejantes a las de su creador ( anarquismo, anticlericalismo...) . Se ha dicho que el estilo de Baroja es descuidado; lo indudable es que su prosa es clara y espontánea, como en el resto de sus coetáneos, huye del lenguaje retórico. Su producción literaria es muy extensa, formada en su mayor parte por novelas, también escribió ensayos e hizo algún intento poético.

Una parte de su obra narrativa aparece agrupada en trilogías, entre las que destacamos:

* La lucha por la vida constituida por " La Busca" y " Mala hierba" en 1904 y " Aurora roja" en 1905.

La raza con "La dama errante" y " La ciudad de la niebla" en 1909 y " El árbol de la ciencia" en 1911.

Tierra vasca formada por " La casa de Aizgorri" 1900, " El mayorazgo de Labraz"1903 y "Zalacaín el aventurero" 1909.

Miguel de Unamuno se muestra en todos los géneros, con un estilo apasionado y vehemente, abundante en exclamaciones.

Entre sus novelas debemos citar:

* "Paz en la guerra", novela histórica, sobre el tercer enfrentamiento carlista.

* "Niebla", un intento de renovación de la técnica narrativa.

A todo ello sumar las típicas preocupaciones unamunianas: la consistencia de la persona, la angustia ante la muerte y el mas allá... etc., en el famoso trigésimo primer capítulo, Augusto, el protagonista, desesperado 
por un desengaño amoroso ha pensado en suicidarse. Sin embargo, habiendo leído cierto ensayo sobre el suicidio, decide consultar con su autor, el propio Unamuno. La espléndida conversación entre el novelista y su personaje, llega a ser violenta, y Augusto insinúa incluso la idea de matar a Unamuno, y éste, furioso, decide hacer que muera Augusto. El personaje, entonces, que poco antes había pensado en suicidarse, siente renacer unas inmensas ganas de vivir, y mientras ruega compasión dice a Unamuno que él también morirá, pues como él, también es un sueño, una invención de alguien.

"Abel Sánchez", la temática gira en torno a la envidia.

* "La tía Tula", obra en la cual la educación estrecha y la moral impuesta por la sociedad, a una mujer, le hacen perder al hombre del cual estaba enamorada.

- "San Manuel Bueno, Mártir", en la que se plantean los problemas de la salvación, la fe y la inmortalidad a través de la historia del cura de un pueblo que no cree en Dios, pero dedica su vida a las gentes del pueblo, para que sean felices esperando una vida mejor después de la muerte.

José Martínez Ruiz, Azorín, natural de Monóvar ( Alicante), destacó en novela y ensayo. Cursó los estudios de derecho pero se dedicó a la literatura y el periodismo. Evolucionó, a lo largo de su vida, desde posturas revolucionarias juveniles hasta un conservadurismo en todos los aspectos, incluido el religioso.

Los temas son muy variados, pero siempre centrados en las líneas generales que hemos visto en los autores del 98: los hombres de España, los paisajes de las tierras castellanas, las evocaciones de la propia infancia y juventud... Un aspecto muy importante es el estilo. Se caracteriza por una gran sencillez: frases cortas, orden riguroso, claridad, precisión... y por la utilización de palabras casi olvidadas. Todo ello hace de sus obras, incluidos sus ensayos verdaderas piezas maestras de la descripción.

En cuanto a sus obras, todas tienen en común la escasa trama argumental que las sustenta, a favor de la pintura de paisajes y caracteres, lo que aproxima sus obras novelísticas a los ensayos. En 1902 escribe Azorín " La voluntad", en ella aparece Antonio Azorín, cuyo apellido elegiría como 
seudónimo. Otras, "Los pueblos" y " Confesiones de un pequeño filósofo", donde recrea la vida en un internado religioso.

En Valle Inclán hay una mayor presencia de los rasgos característicos del modernismo; no obstante su evolución permitió superar esa fascinación por el lenguaje adornado y los ambientes exóticos.

Sus primeras novelas se agrupan en un ciclo, " Memorias del Marqués de Bradomín", que toman el título del protagonista. Cada una de ellas añade al sustantivo sonatas el nombre de una estación: Sonata de primavera, de estío de otoño y de invierno, donde nos presenta un mundo legendario y nostálgico.

El segundo ciclo narrativo es el de la trilogía " La guerra carlista", con Tirano Banderas, donde inventa la novela protagonizada por el dictador hispanoamericano.

Por ultimo, en una fase posterior, Valle Inclán, se dedica a novelar la historia española de finales del siglo XIX. Es el ciclo de "El ruedo ibérico, del que solo nos han llegado dos novelas completas: "La Corte de los milagros", y "Viva mi dueño".

Las ideas de los novecentistas tienen sus raíces en un reformismo burgués y en la defensa de los ideales republicanos. El Novecentismo supone la aparición de un nuevo tipo de intelectual, se hará gala de pulcritud, de una sólida preparación universitaria ampliada en el extranjero... de ahí que se haga un examen disciplinado y sereno de los problemas con pretensión de objetividad y con voluntad de claridad racionalista, orientada a la formación de minorías. Son frecuentes las declaraciones de antirromanticismo y de fervor por lo clásico. Atienden a lo universal, resistiéndose a encerrarse en lo nacional y prefieren lo urbano a lo rural.

El problema de España sigue estando muy presente, y aunque desde un punto de vista más riguroso y sereno, pervive entre los novecentistas una concepción centralista de España. Otros temas frecuentes son, la idea de la revolución desde el poder - regeneracionismo- y un carácter elitista.

En cuanto al estilo, huyen del sentimentalismo, lo romántico, la exaltación pasional, para orientarse hacia lo clásico, lo sereno. Por lo tanto se 
produce un abandono de las interjecciones, del tono apasionado y vehemente. Es característico el intelectualismo, una literatura para minorías que conduzca hacia el ideal de un arte puro, donde es fundamental la preocupación por el lenguaje y las formas.

Gabriel Miró escritor alicantino sorprende el contraste entre su vida gris de funcionario, sin anécdotas, y la intensa vida interior de la que es testimonio su obra. Son veintidós libros, donde predominan las narraciones cortas, en las que se recogen impresiones sobre tierras y gentes. Miró destaca por su asombrosa capacidad de captar sensaciones. Un temperamento voluptuoso y una sensibilidad exacerbada llenan las páginas de sus obras con una riqueza, un dominio del lenguaje, cuajado de imágenes vivísimas y una emoción contenida de belleza pocas veces igualadas. Su pasión por la obra bien hecha busca la perfección formal y la acción deja de ser el elemento fundamental y pasa a ser soporte para sus espléndidas descripciones.

De entre sus novelas, destacan sus dos obras maestras: " Nuestro Padre San Daniel" y " El obispo leproso". En ellas el autor adopta una actitud crítica, aunque no con una carga ideológica concreta. En ambas un ambiente opresivo, inmovilista, la inocencia, el amor y el anhelo de vivir se estrellan contra la intolerancia religiosa. Entre sus relatos breves destacan: " El libro de Sigüenza", donde el autor se oculta tras el protagonista y " Años y leguas", la misma estructura posee "El humo dormido".

Pérez de Ayala nació en Oviedo, estudió en varios colegios jesuitas y se licenció en derecho. Como corresponsal viajó por Europa y América. Durante la República fue embajador en Londres y luego se exilió en Buenos Aires, regresó en 1955 a Madrid, donde murió en 1962. La trayectoria de Pérez de Ayala desemboca en la novela intelectual. Se inició con un libro de versos, sin embargo sus ensayos y novelas son de mayor interés. Como novelista su trayectoria se divide en tres etapas:

Entre 1907 y 1913, publica varias novelas unidas por la figura del protagonista, que es un trasunto del propio autor. "Tinieblas en las cumbres", de corte erótico y tres años después " A.M.D.G" (Ad Maiorem Dei Gloriam) despiadada sátira del colegio donde se educó. Y siguen dos obras maestras: "La pata de la raposa", y "Troteras y danzaderas". 
* En 1916, salen a la luz sus "novelas poemáticas de la vida española", con tres relatos: "Prometeo", " Luz de domingo" y " La caída de los limones", donde ganan terreno las ideas inconformistas de la realidad española.

En 1921, la acción sirve de pretexto para que los personajes encarnen actitudes e ideas vitales sobre estética, moral, psicología, política... la novela se aproxima al ensayo. Así en "Belarmino y Apolonio", dos zapateros ilustran diversas actitudes ante la vida. "Luna de miel, luna de hiel" y " Los trabajos de Urbano y Simona", que giran en torno a los prejuicios españoles ante el sexo, y "Tigre Juan y el curandero de su honra", sobre el honor, el amor, la hombría y el donjuanismo.

El estilo del autor es fascinante, denso, pastoso, con una difícil mezcla de ironía y gravedad, así como de palabras populares y cultas. Pérez de Ayala lucha por conseguir una precisa transcripción de su pensamiento de sus paradojas, de su interioridad.

Entre 1939 y 1950, dadas las circunstancias, no podían servir de modelo más que las novelas de Baroja, y en concreto "La busca", ejemplo para muchos de los narradores de lo que se ha llamado generación del 40 .

Dos fechas podrían señalarse como significativas: 1942 con "La familia de Pascual Duarte" de Camilo José Cela, visión agria de realidades míseras y brutales calificada como tremendismo y 1945 con " Nada" de Carmen Laforet -Premio Nadal- , donde nos presenta a una muchacha que vive con unos familiares en un ambiente sórdido de mezquindad, de histeria, de ilusiones fracasadas, de vacío. Podría añadirse, 1947 con " La sombra del ciprés es alargada" de Miguel Delibes.

Serán características de la novela de posguerra: el reflejo amargo de la vida cotidiana, su enfoque desde la angustia existencial, con temas como: la soledad, la inadaptación, la frustración, la muerte... la abundancia de personajes marginales y desarraigados o desorientados y angustiados. De esta corriente participa Zunzunegui. Escapan a estas características los escritores que cantan a la victoria militar, en novelas como "La fiel infantería". 


\section{2.- Institución Libre de Enseñanza.}

Fundada en 1876 por un grupo de Catedráticos disconformes con las ideas políticas y culturales de la época; entre ellos, Francisco Giner de los Ríos, Gumersindo Azcárate, Nicolás Salmerón, etc. Habían sido separados de su Cátedra Universitaria por su negativa a ceñir sus enseñanzas a los dictámenes oficiales en materia religiosa, política y moral, especialmente. Cualquier alteración a los cánones oficiales era objeto de censura; máxime si ello conllevaba tintes de libertad.

Dada su situación de expulsados de los círculos influyentes en materia política y educativa fundaron un centro educativo privado en el cual poder exponer sus ideas, aplicar sus métodos de enseñanza -muchos de ellos tomados de las corrientes renovadoras de otros países europeos- y fomentar la investigación y el progreso en una España que estaba anquilosada y encorsetada en cánones tradicionales. En principio, la Universidad, de donde ellos procedían, fue el primer objetivo de análisis y reestructuración; después también la enseñanza primaria y secundaria.

No fueron, ellos, los únicos que participaron, en sus comienzos, en el proyecto pues a su lado estaban otros personajes de amplio calado intelectual como: Joaquín Costa, Augusto González Linares, Federico Rubio... todos ellos abiertos a una necesaria renovación educativa, cultural y social. Al igual que Manuel Bartolomé Cossio o Raimundo Rubio que se sumaron posteriormente.

De esta manera, la ILE, desde 1876 hasta 1936, fue el principal foco cultural español y, sobre todo, el cauce por el cual llegaban a nuestra patria las teorías e innovaciones pedagógicas y científicas de otros países. La ILE fue el viento fresco y rejuvenecedor de una cultura rancia, selectiva y formalista que como una maraña entretejía las esferas de poder e impedía el progreso y la participación del pueblo.

A través de "El BILI" -Boletín de la Institución Libre de Enseñanza- se daban a conocer las ideas, experiencias, opiniones y controversias de colaboradores extranjeros de la talla de Bertrand Russell, Henri Bergson, Charles Darwin, María Montessori, León Tolstoi y otros españoles como Juan Ramón Jiménez, Azorín (José Martínez Ruíz), Ramón Pérez de Ayala... 
Desde la Institución se emprendieron importantes reformas; especialmente en el terreno jurídico, educativo y social. Reformas, muchas de ellas, que otros intelectuales y políticos españoles de principios de siglo llevaban demandando. A tal efecto, se crearon Organismos como el Museo Pedagógico o la Junta de ampliación de estudios- de la que dependía, entre otras, la famosa Residencia de Estudiantes-.

Como ejemplo, algunas de actuaciones que llevaron a cabo fueron la creación de pensiones para ampliar estudios en el extranjero, la puesta en marcha y dinamización de colonias escolares de vacaciones, la Universidad de verano, las conocidas Misiones Pedagógicas, ... muchos de cuyos principios y actividades han sido recuperados en la actualidad. Todo ello quedó prohibido con el advenimiento de la Guerra Civil, aunque algunos exiliados intentaron dar continuidad a la Institución desde el extranjero.

"El mundo entero debe ser, desde el primer instante objeto de atención y materia de aprendizaje para el niño, como lo sigue siendo, más tarde para el hombre. Enseñarle a pensar en todo lo que le rodea y hacer activas las facultades racionales es mostrar el camino por donde se va al verdadero conocimiento, que surge después para la vida. Educar antes que instruir; hacer del niño, en vez de un almacén, un campo cultivable". ${ }^{3}$

Cossio, M. B. (1879:153-154)

\section{3.- Las Misiones Pedagógicas.}

Las Misiones Pedagógicas fueron un proyecto educativo español creado en el seno del Museo Pedagógico Nacional y de la II República e inspirado en la filosofía de la Institución Libre de Enseñanza. El 29 de mayo de 1931 se creó por Decreto del Patronato de Misiones Pedagógicas.

La Institución Libre de Enseñanza fue fundada en 1876 por Francisco Giner de los Ríos y un grupo de catedráticos expulsados de la Universidad por defender la libertad de Cátedra y negarse a ajustar sus enseñanzas a los dogmas oficiales en materia religiosa, política y moral.

La ILE se convirtió pronto en un símbolo de libertad intelectual y en el centro que ensayó la mayoría de las innovaciones pedagógicas que aparecieron 
posteriormente en España.

Desde un principio, las Misiones Pedagógicas y sus miembros se interesaron, además, por la cultura popular, recogiendo en sus viajes y excursiones romances, bordados, cerámicas y otros elementos de la vida rural española.

Realizaron actividades como:

Actividad Misionera.

Llevada a cabo por jóvenes intelectuales, artistas, escritores y, especialmente, inspectores de enseñanza primaria y maestros, bajo la dirección de Manuel B. Cossio.

\section{Servicio de Bibliotecas.}

Participaron activamente personas de la talla intelectual de María Moliner y Juan Vicens. Se repartieron, en muchos pueblos y aldeas, bibliotecas para adultos y niños.

\section{Servicio de Cine.}

José Val de Omar y Cristóbal Simancas fueron los principales encargados. Casi siempre era cine mudo, acompañado de un gramófono. Las películas eran de tres tipos: cómicas (de Charlot), de dibujos animados y documentales.

El Coro y el Teatro del pueblo.

Eran los encargados Alejandro Casona y Eduardo Martínez. Dirigían a un grupo de unos cincuenta estudiantes. Llevaban consigo un tabladillo de fácil montaje.

El Museo del pueblo.

Antonio Sánchez Barbudo, Ramón Gaya y Luis Cernuda fueron sus principales impulsores. Eran colecciones itinerantes de pintura; copias de 
cuadros de los pintores más famosos de la escuela española realizados por Juan Bonafé, Ramón Gaya y Eduardo Vicente. Los cuadros se transportaban en cajas fuertes de madera en camionetas y se exponían en los pueblos. El Museo permanecía una semana en cada localidad. A veces se dejaban algunas fotografías de los cuadros expuestas enmarcadas para las escuelas y centros obreros.

\section{Servicio de Música.}

Se dejaba en los pueblos un gramófono y una colección de discos, seleccionados por Óscar Esplá, que eran renovados de vez en cuando.

El Retablo de Fantoches.

El teatrillo se propuso cumplir las exigencias de un espectáculo culto sin renunciar a la cultura popular. Era dirigido por Rafael Dieste.

Se pretendía acercar el teatro al pueblo. Eran piezas breves elegidas entre pasos y entremeses del teatro clásico (Juan de la Encina, Lope de Rueda, Cervantes y Calderón de la Barca). El romance de "La loba parda", fue emblematico.

\section{Otras Actividades.}

El Patronato de las Misiones Pedagógicas organizó varios cursos para maestros a fin de intercambiar experiencias y realizar exposiciones escolares e invitaciones a aprovechar el medio como recurso.

Eduardo Vicente, pues, se involucró y participó activamente en las Misiones Pedagógicas y en la copia de cuadros del Museo del Prado, con el objetivo de acercar a los variopintos pueblos de España una parte de la cultura a través del museo ambulante. Fue para él una época comprometida y enriquecedora que le permitió, a su vez, tomar contacto y relacionarse con intelectuales y artistas como Juan Ramón Jiménez, Gerardo de Diego, Pedro Salinas, Cristina Mallo, Eugenio D Ors, Ortega y Gasset, etc.

Su vida quedó profundamente marcada por la Guerra Civil Española. Al igual que colaboró con las iniciativas de las Misiones Pedagógicas también lo 
hizo como ilustrados de algunas revistas y realizó carteles y grabados para diversas organizaciones republicanas.

\section{4- El Pabellón Republicano (1937).}

En una época tan convulsionada políticamente como la que estaba atravesando nuestro país en los años 30, los artistas españoles encontraron en la Exposición Internacional de 1937, inaugurada el 12 de julio, una forma magnífica para denunciar públicamenta las distintas situaciones por las que estaba pasando el pueblo español. El pabellón español o pabellón republicano (Fig. 2), como lo denominaban los propios artistas, se convirtió en un nuevo medio o soporte para hacer propaganda.

La comunicación propagandística se ponía en práctica en todos los rincones del pabellón español (Fig. 2), partiendo desde el propio edificio. Se trataba de un edificio situado en la Avenida Trocadero de París, y rodeado por otros pabellones de países de la talla de la URSS y la Alemania Nazi.

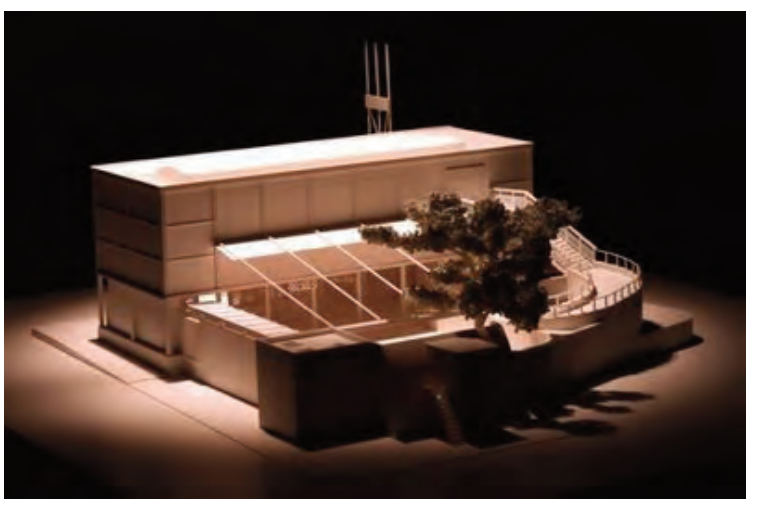

Fig. 2

Maqueta de Josep Lluís Sert del Pabellón de la República Española en la Exposición Internacional de París de 1937

El principal problema al que se enfrentaron Luis Lacasa y Josep Lluis Sert, los arquitectos encargados de diseñar el pabellón republicano, fue el de crear un edificio que sirviera como soporte propagandístico en sí mismo, que destacara del resto de los edificios de esta Exposición Universal, donde se pudiera denunciar la situación en la que se encontraba España en ese momento y en el que se pudiera reivindicar la legitimidad del Gobierno Republicano ante los ataques de la sublevación militar dirigida por Francisco Franco, haciéndose un especial hincapié en las propuestas de educación y de cultura. Para ello optaron por el diseño de un edificio construido a base de 
elementos muy modernos para su época (cerramientos de vidrio, vigas metálicas...), en donde no había espacio para las ornamentaciones y dónde se apostó por un conjunto de líneas y volúmenes puros. Todo ello envuelto en una gama de colores blancos, grises, negros y rojos, lo que hacía del pabellón un edificio capaz de transmitir una ideología muy marcada.

Las obras de arte que acudieron a formar parte de esta Exposición Internacional de 1937, se distribuyeron entre las tres alturas de las que conataba el edificio, se trataba de un pabellón de tres plantas casi sin paredes, así como de un patio donde se podía contemplar una escultura de Alberto Sánchez, de más de 12 metros de altura, titulada "El pueblo español tiene un camino que conduce a una estrella" (Fig. 3) (que presidía el exterior del pabellón), así como "La Montserrat" de Julio González, la "Cabeza de Mujer" de Pablo Picasso, "El Segador" de Joan Miró y "La Fuente de Mercurio" de Calder. Este patio, que se encontraba cubierto por una lona, servía también de auditorio.

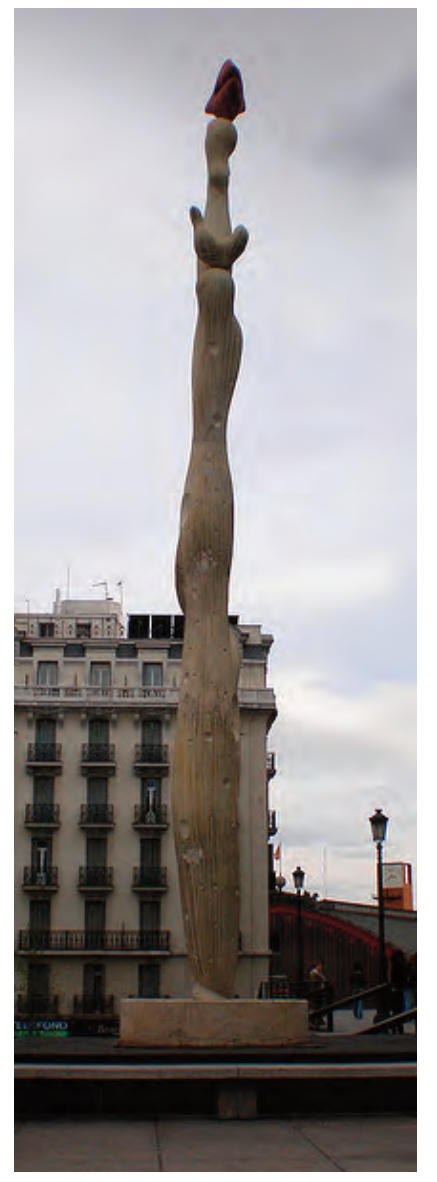


Tanto en la fachada del edificio, como en el interior del mismo, se pudieron contemplar diferentes exposiciones de fotomontajes, carteles, fotografías, paneles informativos... todo ello con el firme propósito de denunciar y hacer partíciples a todos los visitantes de la situación que estaba atravesando el gobierno repúblicano frente al bando nacional en España. Una de las obras más destacadas en este pabellón, fue la exposición del "Guernika" (Fig. 4) (por primera vez en su historia, actualmente se encuentra en el Museo de Arte Contemporáneo Reina Sofía de Madrid) de Pablo Picasso que se encontraba situado en el atrio de la planta baja. Cabe destacar la gran importancia de estas obras, porque una vez más, los pinceles se pusieron a favor de una causa, con la intención de realizar obras expresamente para ser expuestas en este edificio, dando una visión propia de los trágicos acontencimientos que se estaban viviendo a causa de la Guerra Civil Española

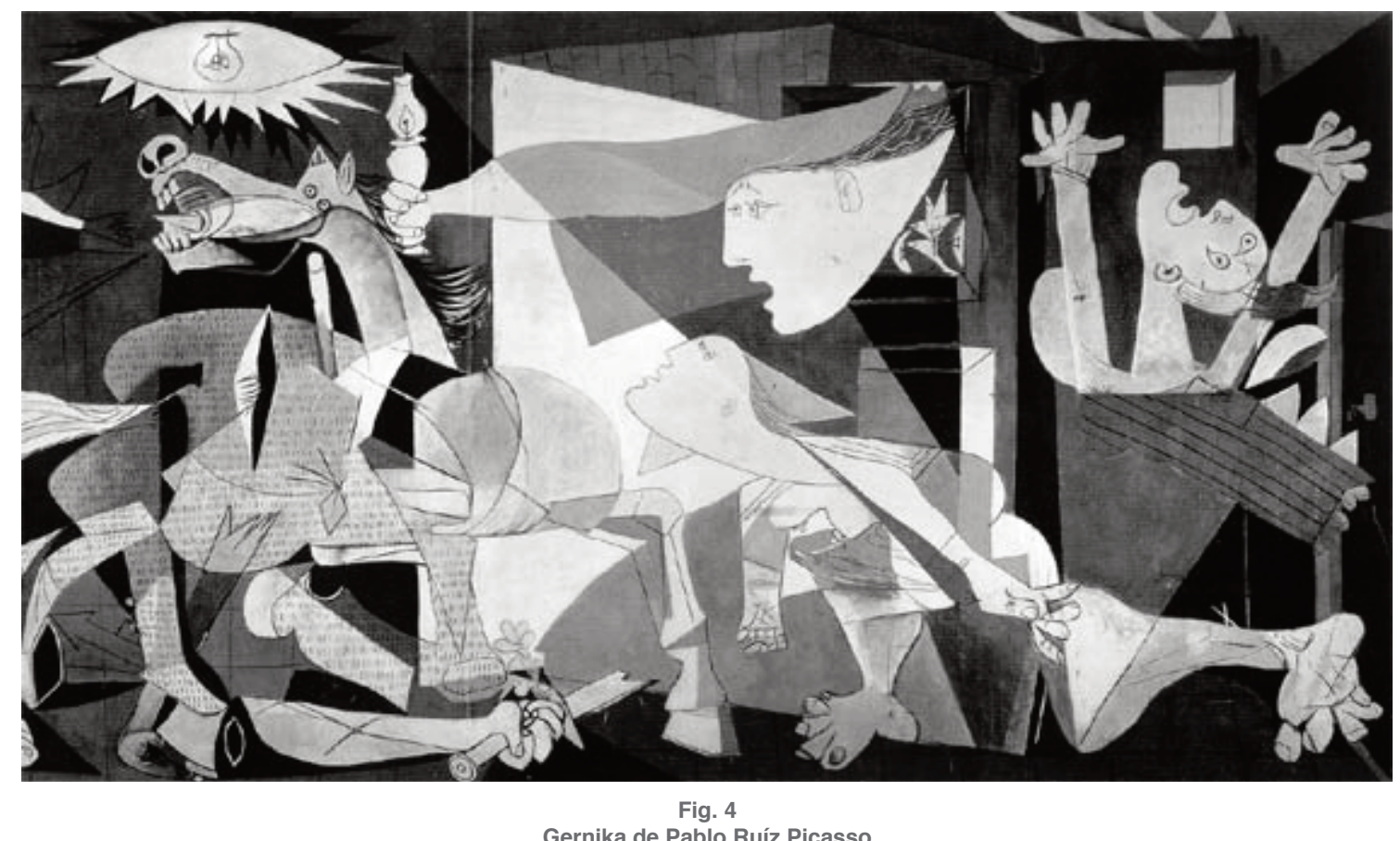

La ciudad de Barcelona, en 1992, con motivo de las Olimpiadas, encargó al estudio de arquitectos Ubac/Espinet, la realización de una réplica del Pabellón español de la Exposición Internacional de 1937, que fue destruido trás su finalización. En la actualidad, este emblemático edificio, alberga entre sus paredes el Centro de Estudios Históricos Internacionales y la Biblioteca del Pabellón de La República,que posee uno de los fondos más importantes a 
nivel mundial sobre la Seguda República, Guerra Civil, Franquismo, Exilio y Transición en España y, en especial, en Cataluña. Este edificio, fue donado por el Ayuntamiento de la ciudad a la Universidad de Barcelona donde, todavía hoy, se puede encontrar en su patio abierto una réplica del famoso "Guernika" de Picasso. Era también en esa planta donde los visitantes podían encontrar una serie de estanterías o vitrinas destinadas a la exibición de los diferentes folletos y publicaciones.

En este pabellón, no podia faltar la presencia de uno de los intelectuales más republicanos del momento como era Federico García Lorca que consiguió unir la intelectualidad a la libertad de la que hablaba en gran parte de su obra. El Servicio de Publicaciones del Pabellón Republicano, situado en la planta baja del edificio, albergó una gran fotografía del poeta junto a ejemplares de su obra "Llanto por la muerte de Igancio Sánchez". En uno de los fotomontajes que fueron expuestos durante la celebración de la exposición podían leerse unos versos de su "Romance de la Guardia Civil".

"Los caballos negros son. Las herraduras son negras.

Sobre las capas relucen manchas de tinta y de cera.

Tienen, por eso no lloran, de plomo las calaveras.

Con el alma de charol vienen por la carretera. Jorobados y nocturnos, por donde animan ordenan silencios de goma oscura y miedos de fina arena. Pasan, si quieren pasar, y ocultan en la cabeza una vaga astronomía de pistolas inconcretas. iOh ciudad de los gitanos! En las esquinas, banderas.

La luna y la calabaza con las guindas en conserva. iOh ciudad de los gitanos! ¿Quién te vio y no te recuerda? Ciudad de dolor y almizcle, con las torres de canela. Cuando llegaba la noche, noche que noche nochera, los gitanos en sus fraguas forjaban soles y flechas.

Un caballo malherido llamaba a todas las puertas. Gallos de vidrio cantaban por Jerez de la Frontera. El viento vuelve desnudo la esquina de la sorpresa, en la noche platinoche, noche que noche nochera.

La virgen y San José perdieron sus castañuelas,

y buscan a los gitanos para ver si las encuentran.

La virgen viene vestida con un traje de alcaldesa, de papel de chocolate con los collares de almendras. San José mueve los brazos bajo una capa de seda. 
Detrás va Pedro Domecq con tres sultanes de Persia.

La media luna soñaba un éxtasis de cigüeña.

Estandartes y faroles invaden las azoteas.

Por los espejos sollozan bailarinas sin caderas. Agua y sombra, sombra y agua por Jerez de la Frontera. iOh, ciudad de los gitanos! En las esquinas, banderas. Apaga tus verdes luces que viene la benemérita. iOh ciudad de los gitanos! ¿Quién te vio y no te recuerda?

Dejadla lejos del mar, sin peines para sus crenchas. Avanzan de dos en fondo a la ciudad de la fiesta. Un rumor de siemprevivas invade las cartucheras. Avanzan de dos en fondo. Doble nocturno de tela.

El cielo se les antoja una vitrina de espuelas. La ciudad, libre de miedo, multiplicaba sus puertas. Cuarenta guardias civiles entran a saco por ellas. Los relojes se pararon, y el coñac de las botellas se disfrazó de noviembre para no infundir sospechas.

Un vuelo de gritos largos se levantó en las veletas. Los sables cortan las brisas que los cascos atropellan. Por las calles de penumbra buyen las gitanas viejas con los caballos dormidos y las orzas de monedas. Por las calles empinadas suben las capas siniestras, dejando detrás fugaces remolinos de tijeras.

En el portal de Belén los gitanos se congregan. San José, lleno de heridas, amortaja a una doncella.

Tercos fusiles agudos por toda la noche suenan. La Virgen cura a los niños con salivilla de estrella.

Pero la Guardia Civil avanza sembrando hogueras, donde joven y desnuda la imaginación se quema. Rosa la de los Camborois gime sentada en su puerta con sus dos pechos cortados puestos en una bandeja. Y otras muchachas corrían perseguidas por sus trenzas, en, un aire donde estallan rosas de pólvora negra. Cuando todos los tejados eran surcos en la tierra. el alba meció sus hombros en largo perfil de piedra. iOh, ciudad de los gitanos! La Guardia Civil se aleja por un túnel de silencio mientras las llamas te cercan. iOh, ciudad de los gitanos! ¿Quien te vio y no te recuerda? Que te busquen en mi frente. Juego de luna y arena." 
El cine también estuvo presente en el pabellón republicano y venía de la mano de Luis Buñuel, quien fue nombrado coordinador de Propaganda al Servicio de la Información de la Embajada Española en la ciudad de París, tras el comienzo de la Guerra Civil. En el año 1937 fue el encargado de supervisar la producción y la realización de la película de propaganda "España leal en armas" y el Gobierno Republicano le encargó la programación cinematográfica del pabellón español. Un total de doce películas y documentales de género histórico, cultural y político fueron proyectadas en las instalaciones del Pabellón Republicano.

La planta primera se destinó a la trasmisión de ideologías mediante fotomontajes y carteles publicitarios, de esta manera las actividades económicas, las riquezas nacionales, la agricultura, la educación, las escuelas, la sanidad pública y las Misiones Pedagógicas eran los temas en torno a los cuales giraba la actualidad de ese momento.

Uno de los protagonistas indiscutibles de esta sección del pabellón español, era el cartelista Josep Renau (Fig. 5), encargado de dar a conocer la situación del momento en nuestro país dando un repaso por todas las regiones españolas en las que dejaba claro la actitud combatiente que se estaba Ilevando a cabo principalmente en el País Vasco y Cataluña. Una de las serie de obras más destacadas fue la dedicada a los desastres de la Guerra en donde los temas protagonistas eran la orfandad, las víctimas, la destrucción del patrimonio artístico y monumental, etcétera. Las imágenes se combinaban con los objetos y trajes más representativos de cada región y se completaban con distintos textos o citas literarias.

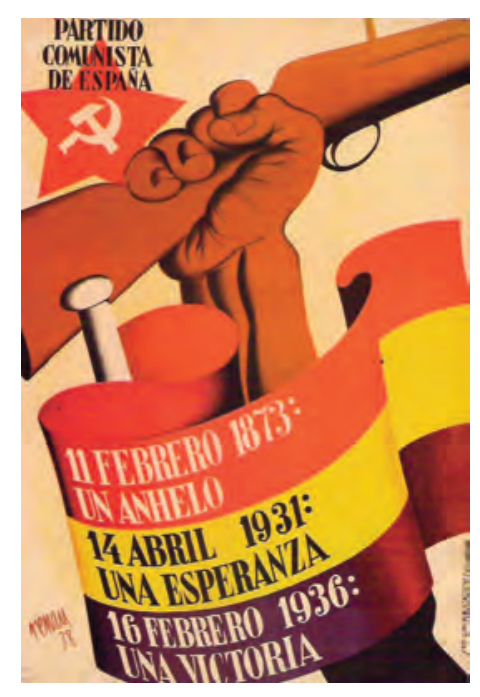


La segunda y última planta se destinó principalmente a las artes plásticas y a las artes populares. Esta sala estaba dividida de forma longitudinal por medio de unos paneles móviles que separaban de forma muy significativa las dos zonas de este piso. La entrada se hacía por la parte de las artes plásticas, haciendo un recorrido hasta las artes populares, zona de donde salía una escalera que conducía a los visitantes a la primera planta. Según se bajaban las escaleras se tenía enfrente "El payés catalán en revolución", un mural de grandes dimensiones del pintor catalán Joan Miró, que se encuentra desaparecido en la actualidad. Esta obra, representaba uno de los alegatos más valiosos expuestos en el pabellón republicano.

Miró relataba de la siguiente manera su experiencia en la Exposición Internacional de París:

"Participé en el Pabellón Español de la Exposición de París en 1937, porque me sentía humanamente solidarizado con lo que representaba... Presenté el gran panel del «Payés catalán en rebeldía» de grandes dimensiones, que pinté directamente subido en unos andamios en la misma sala del edificio... la ejecución de esta obra fue directa y brutal... Escogí este personaje, con una estrella azul proyectándose en la superficie, porque el payés con una hoz es un gran símbolo de Cataluña, personaje que echa sus raíces más profundas en la tierra, materializándose con ella." 4

Martín, F. (1983:173)

Otra de las colecciones más representativas con las que nos podíamos encontrar en este pabellón eran las 18 esculturas que el comisario de la exposición quiso dedicar a Emiliano Barral como homenaje póstumo a su figura, puesto que Barral había muerto en el frente español el 21 de noviembre de 1936.

Artistas como Solana, Horacio Ferrer, Ramón Gaya, Ramón Puyol, Eduardo Vicente, Gregorio Prieto, Francisco Mateos, Manuel Ángeles Ortiz, Enrique Climent y Pérez Mateo también tuvieron un papel muy importante dentro de la creación de las obras que se llevaron a esta Exposición Internacional de 1937. 


\section{4.- Influencia de Benjamín Palencia y de la Escuela de Vallecas.}

Las vanguardias, que comenzaban a tomar forma fuera de las fronteras españolas y que se iban convirtiendo en una fuente de inspiración para muchos autores, se convirtieron en el punto de inflexión para una serie de pintores españoles, que lucharon por la idea de una reforma en la producción artística española de esa época.

De esta manera, y como una forma de apostar por sus ideales, surge, en 1927, una renovación del arte español a manos de Alberto Sánchez y Benjamín Palencia (Fig. 6 y 7), quienes, dos años más tarde, formaron la "Escuela de Vallecas". Una corriente artística que se va a caracterizar por los paisajes castellanos y rurales sin olvidarse de sus gentes al igual que por mantener vivos los ideales de la Generación de 98.

Denominados "Escuela de Vallecas" por sus paseos diarios al barrio de Vallecas y sus habituales visitas al Cerro Almodóvar o "Cerro Testigo", como le denominan estos artistas, van a crear una serie de obras que se pueden insertar entre los periodos cubista y surrealista, donde lo más importante son las formas y las figuras de los paisajes reflejados en sus lienzos.

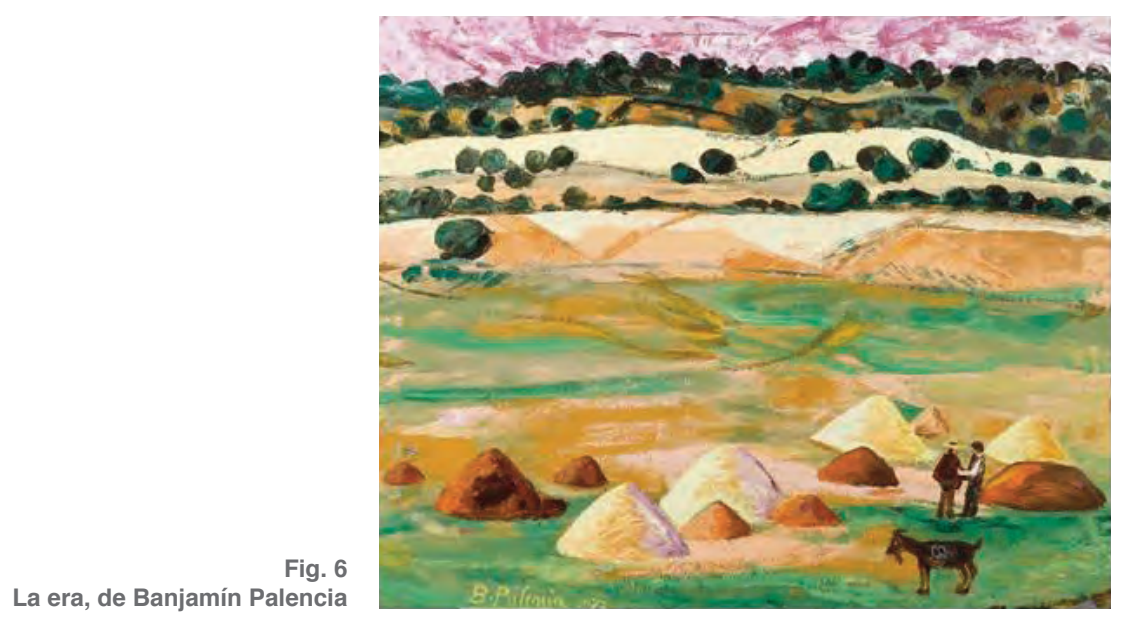

A la pasión y emoción que reflejan en cada una de sus obras y que muestran los ideales que defienden Alberto Sánchez y Benjamín Palencia, se une un nuevo grupo de artistas compuesto por: Juan Manuel Caneja, Maruja 
Mallo y Luis Castellanos, con los que se comprometen, de forma muy especial, grandes artistas literarios como fueron Luis Felipe Vivanco, Lorca y Alberti.

Los integrantes de la "Escuela de Vallecas", consiguen realizar un gran número de obras, todas ellas de una gran importancia y valor artístico. Sin embargo, todo esto, quedó al margen cuando en 1936 estalló la Guerra Civil Española, que logró la separación de uno de los mejores movimientos artísticos que se han conocido en este país.

El periodo comprendido entre 1936 y 1939, se caracterizó por las penurias que se pasaron en España a todos los niveles. La Guerra Civil, provocó un desajuste social, cultural, económico y por supuesto artístico, que influyó en los movimientos que habían surgido hasta el momento y se paralizó en gran medida la producción artística que estaba floreciendo en España antes del alzamiento militar.

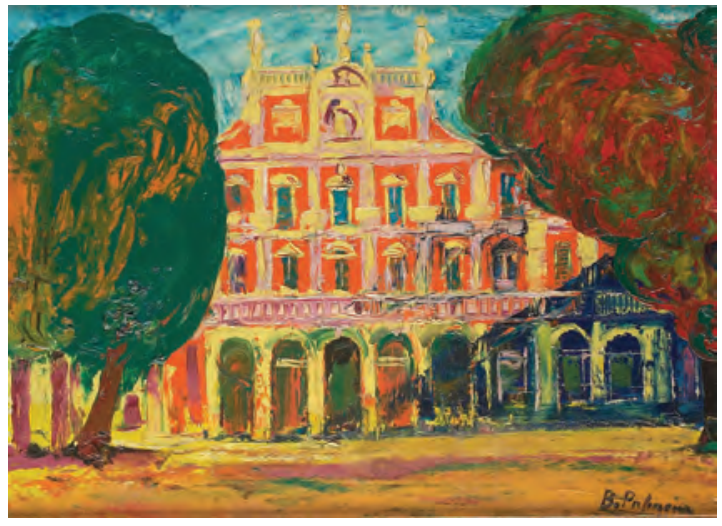

Fig. 7

Aranjuez, de Banjamín Palencia

Tras la finalización de la Guerra Civil y a pesar de la desestabilidad que existiría en España hasta muchos años después, Benjamin Palencia recuperó la ilusión por el arte, creando una nueva escuela. De esta manera consiguió reunir a una serie de estudiantes de la Escuela Bellas Artes, todos ellos discípulos de Vázquez Díaz, retomando la experiencia artística que había creado junto a Alberto Sánchez, antes de la Guerra Civil. La Segunda Escuela de Vallecas, que daría paso a la Escuela de Madrid, estuvo compuesta por Álvaro Delgado, Francisco San José, Carlos Pascual de Lara y Luis Castellanos. La proporción, los paisajes castellanos, los colores claros y las texturas magras fueron las bases en las que se forjó la formación de estos jóvenes artistas. 
Con una nueva escuela de formación pictórica creada por Palencia y la ilusión, renovada por este arte, Palencia continuó con su obra artística, la cual no abandonaría hasta 1980; año en el que falleció, después de más de 70 años dedicados a este arte. Dejó tras de sí una gran colección artística que evidencia la gran calidad de este artista de la vanguardia española.

Benjamín Palencia se puede considerar como uno de los artistas con un mayor compromiso con el arte de vanguardia, algo que puede demostrarse no sólo por las obras pictóricas realizadas a lo lago de su vida sino también por la cantidad de colaboraciones que realizó como director artístico en el Grupo de Teatro "La Barraca", así como por el gran número de exposiciones que realizó por toda España y en el extranjero. En 1974 ingresó en la Academia de Bellas Artes de San Fernando, igual que hizo unos años después en la Academia de San Jorge en Barcelona. 



\section{Contexto económico en la primera mitad del siglo XX.}

Para conocer la historia económica de España del siglo XX hemos de remontarnos, al menos, a la segunda mitad del siglo XIX cuando ya otros países de nuestro entorno -Francia, Alemania, etcétera- habían consolidado su despegue industrial.

En España la ruptura con el antiguo régimen se produjo de forma tardía. Además, la oposición a que entraran en nuestro país las ideas de "La Ilustración" se mantuvo durante mucho tiempo y perjudicó tanto al desarrollo cultural como al económico. En consecuencia, éramos una España rural sin apenas innovaciones en el campo, con los agravantes que suponían las estructuras derivadas del feudalismo: los señoríos jurisdiccionales, los mayorazgos, los bienes comunales, las tierras en manos muertas, etcétera. Las reformas propuestas por Melchor Gaspar Jovellanos en todos los índoles -incluída la Reforma Agraria- apenas sí se aplicaron y otras como las de Mendizábal fueron modificadas a poco de ser implantadas legislativamente. Igual podemos decir de la Desamortización de Madoz. Todo ello se tradujo en una tímida e incipiente industrialización que merced a las aportaciones de capitales extranjeros permitió iniciar la construcción del ferrocarril, propulsar la explotación de las minas, la creación de la Banca Nacional, etcétera, así como desarrollar una industria textil en Cataluña y siderúrgica, primero en Málaga y después en el norte peninsular.

Nos encerramos en nosotros mismos en un letargo económico de larga duración y consecuencias. Al efecto las palabras de Angel Gavinet "Sin perjuicio de buscar salida al excedente de nuestra producción, lo que más debe preocuparnos es producir cuanto necesitamos para nuestro consumo y alcanzar un bien al que pocas naciones puedan aspirar: la independencia económica".

Es, pues, una invitación a la autarquía. Cuando en nuestro entorno las ideas del liberalismo económico de Adam Smith estaban haciendo furor y propulsando las economías de los países limítrofes nosotros cerramos filas a la innovación y al comercio: en definitiva al progreso.

Desde finales del siglo XIX hubo en España un importante avance en la intervención del Estado -proteccionismo- Este arranca de la crisis agraria cuando coinciden los intereses agrarios con los industriales Presenta dos modalidades; elevación de las tarifas arancelarias y legislación de 
medidas favorecedoras de la iniciativa privada. Junto a las leyes arancelarias se fueron aprobando un extenso grupo de leyes que otorgaban exenciones y privilegios fiscales, subsidios, primas y pedidos directos de la Administración, hasta llegar, en el caso del carbón, a la obligatoriedad de su consumo.

La anulación de la franquicia arancelaria para el material ferroviario, en 1896 favoreció el desarrollo de la siderurgia. La intervención económica del Estado alcanzó su más alto nivel en los años 20. La política proteccionista y de intervención en economía alcanzó también un alto grado con la Dictadura de Primo de Rivera. En la segunda República se continuó con el proteccionismo, pero la política económica estuvo marcada por el reformismo: la ley para la Reforma Agraria, la de los jurados mixtos, el aumento de salarios o el establecimiento de un salario mínimo. A esta política económica llevada a cabo durante casi todo el primer tercio del siglo XX se la denominó nacionalismo económico. En algunos sectores nuevos; el apoyo público a la iniciativa privada fue esencial como en el sector químico, eléctrico y, sobre todo, naval.

La agricultura experimentó un crecimiento conforme avanzaba el siglo XX debido a tres factores: intensificación del uso del suelo, derivado de la progresiva eliminación del barbecho; la especialización de la producción, sobre todo en varias regiones de la cornisa cantábrica; y los cambios técnicos con la mecanización de las tareas agrícolas mediante incipientes modificaciones pero capaces de sustituir el éxodo rural. Se difundieron nuevos aperos de labranza y fue más frecuente el uso de fertilizantes químicos, frente al tradicional abono de origen orgánico.

En la consolidación industrial, el País Vasco fue el gran protagonista: el núcleo siderúrgico creció espectacularmente, Vizcaya aprovechó su hierro, la participación de los empresarios en las minas y la acumulación de capital, la facilidad para importar el carbón inglés (fletes) y la política arancelaria para conocer un alto desarrollo siderúrgico, con un máximo en 1914-1919. La típica concentración industrial siderúrgica se plasmó en 1902 con la aparición de "Altos Hornos de Vizcaya", la empresa siderúrgica más potente de España. A partir de 1900 y sobre todo de 1914 se desarrolla la industria metalúrgica de transformación con destino al ferrocarril y bienes de equipo, destacando Guipúzcoa. Por estas fechas se potencian las industrias eléctricas, navales y químicas, eso sí, con presencia de tecnología y capital extranjero. A este desarrollo industrial no fue ajeno la presencia de potentes bancos mixtos como 
el Bilbao y Vizcaya. En 1917 se crearon los Altos Hornos del Mediterráneo en Sagunto.

En Cataluña el sector más importante continuó siendo el textil. Tras el "desastre del 98" se produjo una recaída de la que se recupera pronto debido a las innovaciones tecnológicas aplicadas y al proteccionismo. La industria catalana va a conocer otro periodo de expansión en 1914, para volver a recaer en 1920. Este gran desarrollo económico se asienta en torno a Barcelona y el valle del Bajo Llobregat. Contrariamente a lo que ocurriera en el País Vasco la iniciativa no se debe al capital extranjero, sino al catalán, apareciendo apellidos como Rius, Güell, Muntadas, Ferrer, etc. En Cataluña también se desarrolla la industria de transformaciones metálicas, con menor empuje que las vascas debido a que dependía de su hierro. La química y la eléctrica Madrid participó también en este proceso de expansión industrial hasta convertirse en la tercera región industrial. Su industrialización está ligada al hecho de ser la capital de España y la sede de Administración Central, buscando muchas empresas los beneficios que la cercanía a la administración y el gran mercado, que era la capital, proporcionaban. Asturias y Cantabria también conocieron una expansión industrial, sobre todo del sector siderúrgico, ligado al carbón astur y leonés y al hierro vasco. También contarían ambas regiones con un sector bancario bastante importante -banco Santander. Por último, hay que destacar el inicio de la industrialización valenciana, unido a la acumulación de capital procedente de la exportación de cítricos.

Los Bancos, de esta época, se van a dedicar a un doble tipo de actividades; por un lado, a las comerciales (venta y compra de dinero) y con los ahorros captados invierten en las industrias más rentables. Este modelo mixto va a ser, en parte, responsable de la profundización de los desequilibrios sectoriales y regionales. Aparecen el Bilbao, Vizcaya, Banesto, Hispanoamericano, en las zonas donde la acumulación de capital es más importante; País Vasco, Cataluña, Madrid, Santander...

\section{1.- La sociedad española.}

Podemos decir que ni es agraria ni es industrial, sino que está a medio camino de ambas En el primer tercio del siglo XX asistimos a la verdadera transición demográfica, pasando de un modelo demográfico propio del 
Antiguo Régimen (altas tasas de natalidad y mortalidad) a otro propio del Nuevo Régimen demográfico (bajas tasas de natalidad y mortalidad). Como el descenso de la mortalidad fue más rápido que el de la natalidad, también asistimos a un aumento importante de la población (siete millones de personas entre 1900 y 1940). La distribución espacial de esta población continuó el modelo del XVIII y XIX; descenso del interior (salvo Madrid) y oeste; aumento del norte y este. También hubo importantes movimientos migratorios.

\section{2.- Las clases sociales.}

La oligarquía la componen la aristocracia y la alta burguesía. Su predominio político, económico y social va a ser indiscutible durante todo el siglo XIX, pero a partir de 1898 las clases medias y bajas le disputan esa hegemonía, por ello la conflictividad social y política aumenta tanto. La aristocracia se sigue localizando en el Centro y Sur de España; la alta burguesía se localiza en Cataluña, País Vasco y Madrid. Estas clases sociales copan los altos cargos del sistema bancario, mandan a estudiar a sus hijos a Inglaterra y nos traen el fútbol. Son aficionados a los concursos hípicos, al teatro, a la ópera y viven en los ensanches de las ciudades o en los barrios residenciales de la parte alta de las ciudades. Progresivamente la oligarquía se va haciendo más temerosa ante el empuje del movimiento obrero y se van aproximando al ejército del cual buscan su apoyo.

Las clases medias experimentaron un avance espectacular. En las ciudades su dominio era absoluto. Las clases medias o la pequeña burguesía estaba integrada por pequeños empresarios, comerciantes, agricultores medios, funcionarios y profesionales liberales, presentan una pluralidad mayor que la oligarquía en lo que se refiere a posturas políticas; conservadores, liberales o republicanos. Progresivamente, ayudados por los nuevos medios de transporte y de comunicación de masas, irán imponiendo su forma de vida al resto de la sociedad. La prensa, el asociacionismo (ateneos, tertulias, peñas, casinos, etc.) y la movilización de masas (manifestaciones, mítines, reuniones, ... ) son los instrumentos para imponer su forma de vida. Son bastante consumistas, se acercan progresivamente al mundo de la cultura y acuden a los espectáculos de masas: toros, fútbol, cine...

Las clases trabajadoras tienen un denominador común: la miseria y la pobreza. Pero las diferencias son tantas que hay que analizar por separado 
sus dos grandes sectores; el campesinado y el proletariado.- El campesinado está representado por la España rural; viven cercanos a la autosubsistencia, su forma de vida está más cercana a lo tradicional. No obstante, también hay muchas diferencias entre ellos. Los pequeños propietarios, dominantes en zonas de minifundio viven pendientes de las condiciones climáticas. Los pequeños arrendatarios y aparceros viven peor que éstos, pero existe un grupo de campesinos que son los que peor viven y más dificultades pasan; los jornaleros. Los jornaleros son los trabajadores del campo, Progresivamente la agitación social en el campo aumenta, de las dos ideologías del movimiento obrero, el anarquismo tiene más éxito ya que se compatibiliza mejor con el carácter individualista y rupturista de la sociedad. En cuanto a las acciones que realizan, destacar que están menos organizados que el proletariado y que acuden con menor frecuencia a la huelga como instrumento de presión, ya que los esquiroles, el paro y los trabajadores de los pueblos de al lado quitan eficacia a la huelga. Por el contrario utilizan más la acción directa; la quema de cosechas, los atentados contra la propiedad y las personas, los robos, etc. Los intentos revolucionarios menudean y siempre siguen el mismo esquema; toma del pueblo, comunicación a las autoridades y huída de estas; asalto y quema del registro de la propiedad y... llegada de la guardia civil o/y ejército, y vuelta a la normalidad. Sus reivindicaciones también se basan en principios clásicos; mejores condiciones de vida y de trabajo, mejor reparto de tierras y el principio de "la tierra para quien la trabaja": Todo ello englobado en la petición de una reforma agraria en profundidad, que no va a llegar hasta la segunda república.

El proletariado industrial constituye una fuerza emergente y progresiva. Se localiza en las zonas industriales: Cataluña, País Vasco, Madrid, Asturias, Cantabria, Valencia... Sus condiciones de vida y de trabajo son pésimas. Políticamente optan por el socialismo o marxismo, salvo en Cataluña que triunfa el anarquismo. Sus reivindicaciones empiezan siendo laborales y económicas, para pasar a ser también políticas. La novedad de las acciones colectivas desplegadas por los obreros a principios del siglo XX estriba en su carácter organizado y en su relación directa con las condiciones laborales de amplias masas obreras; los atentados terroristas anarquistas y las acciones descoordinadas desaparecen. Las movilizaciones comenzaron a reivindicar la jornada de ocho horas o el aumento salarial. La expresión más frecuente de estas luchas fue la huelga, que acabó muchas veces desembocando en la huelga general, ésta ya con carácter más político, pues pretendía el cambio de 
régimen. La primera huelga general convocada fue la de 1902 en Barcelona.

La UGT fue el gran sindicato de inspiración socialista. Se trata de un sindicato de orientación reformista y moderada, lo que le permitió recoger algunas de las aspiraciones sociales de los republicanos, aliados con los socialistas en 1910, cuando Pablo Iglesias accedió por primera al Parlamento español. Los más importantes dirigentes de la UGT fueron Julián Besteiro y Largo Caballero. La implantación básica de la UGT estaba entre los trabajadores de oficios de Madrid y en los trabajadores de las minas de Vizcaya y Asturias. De forma conjunta con el PSOE, la UGT promovió la creación de Centros Obreros que, desde 1905, desembocaron en las Casas del Pueblo, verdaderos centros de difusión de una cultura obrera alternativa a la burguesa de los ateneos y casinos. El movimiento anarquista del siglo XIX se escindió en dos tendencias; el partidario de la acción sindical y el partidario de la propaganda por el hecho. El primer sector se impuso y en 1910 se crea la Confederación Nacional del Trabajo (CNT). La CNT representa la organización obrera más importante de España hasta la guerra civil y, además, el principal sindicato anarquista del mundo. Se caracteriza por su independencia política (apoliticismo), su carácter revolucionario (apelación a la huelga general) y la práctica de la acción directa, en el sentido de rechazar toda mediación externa al sindicato en la solución de los conflictos laborales. A diferencia de la UGT, la central sindical CNT se caracterizaba por su escasa burocracia. La afiliación obrera y campesina a la CNT fue muy elevada desde 1919 hasta 1936, alcanzando durante el periodo de la segunda república más del millón de militantes. Su implantación geográfica estaba centrada en Cataluña y Andalucía. Entre sus líderes cabe destacar a Salvador Seguí, el Noi del Sucre o Ángel Pestaña, ambos representantes de una acción propiamente sindicalista y más moderada, frente a otro sector más radicalizado (la FAI) que se va a hacer con el control del sindicato a partir de 1931.

\section{3.- La posguerra.}

La victoria de Franco en la guerra civil supuso la instauración del Nuevo Estado, y una profunda ruptura en la historia de España. La plasmación económica de los planteamientos ideológicos del nuevo gobierno, tendría repercusiones económicas muy negativas tanto en el corto como en el largo plazo. A corto plazo, la puesta en marcha de dichas ideas condujo a una 
prolongada etapa de estancamiento y corte brusco en el proceso industrializador español que, pese a sus problemas, había ido aumentando en ritmo, volumen y diversidad desde las últimas décadas del siglo XIX. A largo plazo la discrecionalidad de las autoridades, cuando no la pura arbitrariedad, modificó profundamente las pautas de comportamiento de los agentes económicos. Consolidó como elementos relevantes de su actuación, la especulación, el tráfico de influencias e incluso la corrupción, todo ello disfrazado bajo justificaciones ideológicas ausentes de toda racionalidad económica. Al mismo tiempo permitió no ya el mantenimiento de actividades claramente incapaces de ser competitivas, sino la ampliación de su número y su inoperancia. No es vano afirmar que en durante el Franquismo eran más fáciles los buenos "negocios" que las buenas empresas.

Como en otros muchos aspectos, el Franquismo presentó el progreso económico y la mejora en el nivel de vida como logros propios para justificar su escasa legitimación. Lo cierto es que el régimen dictatorial supuso, en una primera etapa al menos, una prolongada detención en el ritmo de avance hacia una sociedad industrial iniciado mucho antes.

El decenio de los años cuarenta engloba los avatares de la agitada vida política, social y económica de la primera etapa del Franquismo. Ya durante la Guerra Civil, en sus últimos años, la maquinaria del régimen comienza a dar sus primeros pasos fijando e introduciendo las incipientes bases normativas y pautas a seguir en la característica política que se practicará plenamente poco tiempo después.

El marco en el que comienza este nuevo periodo, tras el punto de inflexión de la guerra, es desolador. No tanto por las destrucciones físicas y costes económicos directos que generó la guerra, - ampliamente utilizadas por el régimen como instrumento de propaganda para justificar sus fracasos -, cuanto por la desorganización general y la fragmentación de los mercados.

La producción agraria e industrial eran muy inferiores a las de 1935, las reservas de oro y divisas habían desaparecido, - utilizadas por los republicanos para financiar la adquisición de mercancías y material militar. El sistema monetario era un caos ante el aumento de la cantidad de dinero en circulación 
en las dos zonas contendientes, había una seria escasez de alimentos, materias primas y energía; y la red de transportes se encontraba seriamente deteriorada al haber sido unos de los objetivos militares prioritarios de las operaciones de ambos ejércitos.

Todos estos factores señalados, provocaron una espectacular distorsión en la estructura productiva con consecuencias negativas muy relevantes en los decenios posteriores. De esta forma, aun siendo apreciable, - y no menos dramático desde el punto de vista del ciudadano español -, el impacto directo del conflicto militar, éste no desempeñó un papel decisivo en el estancamiento de los años cuarenta. Fue la actuación económica de los vencedores la que tuvo una relevancia mucho mayor, como se demuestra al comparar la trayectoria española posterior a 1939 con la de los otros países europeos, beligerantes o neutrales, durante la Segunda Guerra Mundial.

El lapso temporal necesario para recuperar el nivel de actividad previo al conflicto fue extraordinariamente prolongado.. Por el contrario, la inmensa mayoría de los países europeos afectados por la Segunda Guerra Mundial, superaron ese máximo, en su caso anterior a 1939, antes de 1950. Cinco años después de acabadas las hostilidades. Es aquí donde radica la singularidad del caso español. En la lentitud de la recuperación tras 1940, fruto de causas comunes al resto de países europeos, y consecuencia también de causas autóctonas.

Respecto a las incidencias comunes; es evidente que la Segunda Guerra Mundial, afectó a España al igual que sucedió con otros países no beligerantes, pero también es indudable que podríamos habernos beneficiado de las ventajas que la contienda ofrecía. Los efectos negativos como, las restricciones al comercio, ruptura de relaciones, interrupción de comunicaciones, accesibilidad a mercados etc., incidieron especialmente por el lado de la oferta a las economías neutrales y no beligerantes. España con su equipo industrial sin haber sufrido demasiados daños, podría haber estimulado las exportaciones y favorecer la recuperación de su industria. Sin embargo, tal lógica empresa no se llevó a cabo, y esto fue así, no solo debido a circunstancias forzadas o inevitables que la coyuntura imponía, sino lo que es peor aún, por la terca y mal encaminada política llevada a cabo por las autoridades franquistas. Fue esta errada gestión, el caldo de cultivo básico para la ralentización del despegue de la economía española. 
Errores tales como la propia alineación de la España franquista con las potencias del eje, que colocaba al país bajo la frustrante situación de la escasez de materias primas y fuentes energéticas, - especialmente petróleo -, y bajo los recelosos ojos de las potencias vencedoras, mirando al país, con la desconfianza natural que se le tiene a un residuo fascista, como era España tras la Segunda Guerra Mundial. Debido a esta fría relación teñida de tintes ideológicos y políticos, España se vio privada de los préstamos aliados y de relaciones comerciales que permitiesen la importación de las aludidas materias primas tan necesarias. Otras claras equivocaciones se aprecian cuando las autoridades franquistas establecieron controles a la importación, y racionamiento de divisas, que no eran sino más y más obstáculos que substituían los criterios lógicos de asignación por criterios propios, políticos, de prestigio o "autosuficiencia", o incluso por los propios intereses de los que ostentaban el poder. El mercado de trabajo estaba seriamente regulado y sus rigideces eran muy notables. Los salarios se ajustaron a niveles inferiores a los de preguerra, disminuyendo el poder adquisitivo y, por tanto, influyendo en los bajos niveles de consumo y productos industriales básicos. La escasez de alimentos, símbolo que caracteriza inequívocamente los años de la posguerra española, ante una fijación de precios arbitraria, independiente de las condiciones de la oferta y la demanda, haría imprescindible el racionamiento, oficialmente establecido el 14 de mayo de 1939 por una orden del Ministerio de Industria y Comercio. La irrealidad de los precios oficiales provocaría de inmediato la aparición de un mercado negro (en el aceite y el trigo las cantidades desviadas hacia este mercado ilegal fueron iguales o superiores a las distribuidas a través de la regulación oficial), sin duda, el rasgo dominante de la vida en la España de los cuarenta. Hasta 1952, no seria posible acabar con el racionamiento del alimento del pueblo por excelencia: El pan. Los estrangulamientos provocados por la política de autarquía, de autosuficiencia hacia el exterior, acabarían siendo espectaculares. La lentitud de la recuperación, es un claro síntoma de ello.

Y adentrándonos de lleno en materia industrial, la política del Nuevo Estado no tendría efectos menos perversos. Empeñados en ignorar el coste de producción (y el de oportunidad), las ventajas de la especialización o la necesidad de adquirir una mayor competitividad, las autoridades impulsaron un fomento de las industrias consideradas de interés nacional en sus planteamientos políticos, distorsionando la asignación de recursos a través de una regulación tan rígida como arbitraria. Toda la maquinaria reguladora 
franquista desanimaba y retraía la inversión con gran contundencia y limitaba la capacidad de actuación e iniciativa del empresario.

La anulación de los mecanismos de mercado dentro del marco general aislacionista se llevó a cabo básicamente por dos vías. Por un lado, un férreo control del comercio exterior sometido a un régimen de completa intervención, para limitar en la mayor medida las importaciones ("... redimir a España de la importación de productos exóticos..."). y por otro, una activa política industrial para conseguir que España fuera una potencia económica y militar -no es casualidad pues, la importancia y el nùmero de los militares ocupando grandes cargos políticos o económicos, gestionando el poderoso ministerio de Industria y Comercio o decretando leyes tales como la "ordenación y defensa de la industria" de 1939 que clasificaba a las industrias según su valor militar- Tampoco fue ninguna casualidad la larga presencia (desde 1941 a 1963), como presidente y promotor del famoso Instituto Nacional de Industria (I.N.I, símbolo del intervencionismo estatal en la industria del Franquismo, y ejecutor del credo por excelencia de la "industrialización prioritaria": -producir e industrializarse a cualquier precio-), de José Antonio Suanzes, - militar e ingeniero naval, amigo personal de Franco y defensor de la industrialización a todo trance y autárquica -, que al igual que éste, la importancia de la eficiencia o la rentabilidad eran para él objetivos claramente secundarios frente al impulso de la industrialización.

EI I.N.I. se constituyó como una gran "empresa de empresas", cuya incumbencia se centraba en el apoyo, fomento, gestión y/o participación en aquellas empresas y manufacturas que a sus gestores les parecieran merecedoras de apoyo o patrocinio. Los sectores básicos fueron los más avalados, en especial energía (petróleo y electricidad con empresas como Calvo Sotelo, Endesa...) y siderurgia (Ensidesa). Otros sectores en los que intervino activamente fueron el transporte, la minería, la química... Como valoración final a la actuación del I.N.I, se puede decir que pese a la envergadura de su esfuerzo, su labor condujo a una ineficiente asignación de recursos y el consiguiente despilfarro de éstos. Además, como veremos más adelante, la financiación de sus proyectos se llevó a cabo gracias a una serie de "privilegios crediticios" que la permitieron acaparar un gran volumen de recursos financieros, con el consiguiente drenaje de la oferta de fondos para el conjunto de la actividad privada. En resumen, el empeño depositado en la creación de una robusta industria básica se difumina al ponerse de manifiesto la debilidad que ésta atesora a la hora de enfrentarse a un entorno competitivo. 
"El periodo de 1935-1950 resulta ser el único que puede explicar satisfactoriamente el atraso industrial de España."

Los años cincuenta constituyen un progresivo cambio en la política económica ya que se introducen algunas novedades que tendrán consecuencias positivas muy importantes. A pesar de que la política intervencionista y autárquica no se modifico sustancialmente hasta 1959, la introducción de pequeños cambios y una orientación diferente en la política económica, permitirán mayores niveles de crecimiento. Se toman nuevos caminos en lo referente a las relaciones comerciales exteriores, a la regulación de los mercados internos, e incluso a la política agraria (dejando de lado la penosa "política de suministros y racionamientos" del periodo anterior).

De entre los hechos acaecidos a nivel internacional en los comienzos de este nuevo decenio, que tuvieron una cierta influencia en el proceso de flexibilización y crecimiento de la economía, se pueden destacar entre otros: Los oportunos pactos con Estados Unidos a partir de 1951 (que aunque no tan cuantiosos como el famoso Plan Marshall, ayudaron a España a desbloquear el comercio exterior), la apertura exterior francesa frente a España en 1948, el voto a favor de nuestro país de la mayoría de los países hispanoamericanos, varios países de Europa occidental, norteamericanos y Árabes (nótese el hecho de que en 1949 el rey Abdulah de Jordania, visitó España, siendo el primer jefe de estado que lo hacia desde 1936).

Dicho sea de paso, fueron estos acontecimientos mundiales los que permitieron a España introducirse lentamente en el concierto de las naciones y no la actuación directa o la legislación de Franco. 



\section{Estudio experimental.}

La obra de Eduardo Vicente es muy amplia tanto en su contenido temático como en sus técnicas de expresión.

Nuestro estudio se centra principalmente en el contenido de la obra, ya que, como hemos expuesto, estamos investigando el valor de la imagen como transmisora de ideología y representativa de modelos sociales.

Una vez realizado el estudio teórico de la propaganda política (capítulo 2) y de la iconografía (capítulo 3), nos centramos en la obra del artista Eduardo Vicente y tratamos de realizar un análisis sistemático que nos permita alcanzar los objetivos y la hipótesis planteada.

Para ello partiremos del análisis de contenido, pues posee un conjunto de técnicas de análisis variadas y diversas que nos van a ser útiles en nuestro estudio.

En toda investigación de análisis de contenido, cualquiera que sea la técnica a utilizar, se debe proceder ordenadamente a una secuencia de etapas. A continuación presentamos las fases de nuestra investigación. 



\section{Fases de la investigación.}

1.- Preanálisis.- Fase correspondiente a la organización del trabajo y toma de decisiones:

Lectura flotante.

Recopilación del material.

* Localización de índices.

Elaboración de indicadores y establecimiento de categorías.

2.- Fase de explotación del material.- Fase de aplicación de las decisiones tomadas sobre el material a investigar. En este momento se buscan y reconocen los índices y se agrupan en categorías o códigos.

3.- Tratamiento e interpretación de los resultados.- Fase en la que se lleva a cabo el tratamiento estadístico y se obtienen los indicadores cualitativos y cuantitativos que describen el contenido de la obra analizada. Posteriormente se pasa a la interpretación de los datos obtenidos con la finalidad de demostrar o no los objetivos planteados y la hipótesis formulada en nuestro trabajo de investigación.

Todas estas fases, correspondientes al análisis de contenido, fueron representadas gráficamente por $\mathbf{L}$. Bardin ${ }^{\mathbf{1}}$ (Cuadro 1 ) en 1986 . Señalando las diferentes fases con los recorridos necesarios para llevar a cabo un trabajo de análisis e investigación. 


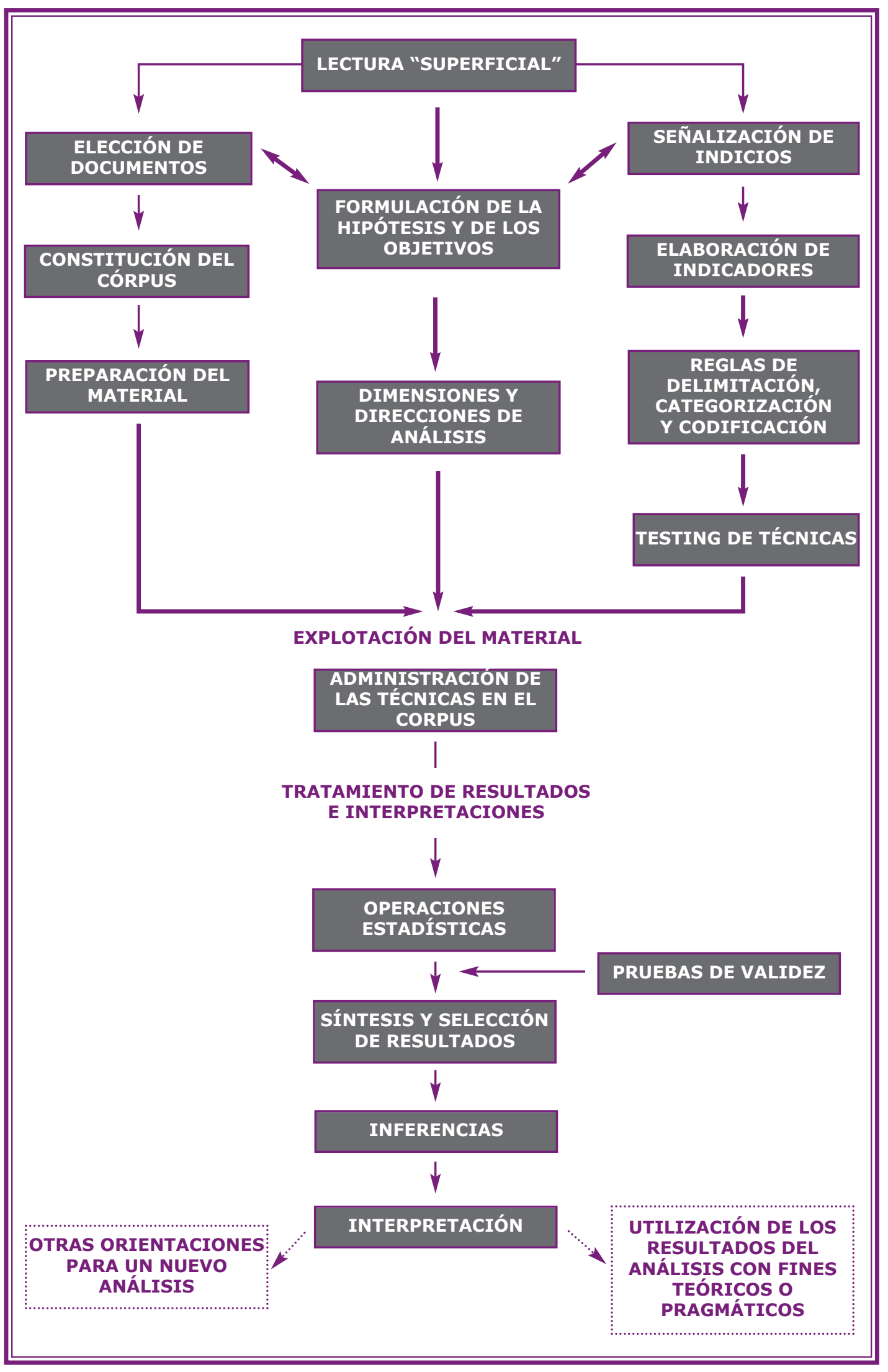


El análisis de contenido cumple una doble función:

- Una función heurística que enriquece el tanteo exploratorio y sirve para descubrir las imágenes existentes.

Una función de verificación. Conformando o invalidando la hipótesis trazada como punto de partida.

Así este método de análisis de contenido aplicado a nuestra investigación será un magnifico modelo para interpretar la obra artística de Eduardo Vicente bajo ciertas condiciones de organización y rigor.

El trabajo se inicia con una primera fase de descripción (enumeración, tipos de imágenes, contenido, aspectos formales y técnicos, función) y se culmina con una etapa de interpretación (significación de la obra artística como transmisora de ideología y representativa de modelos sociales).

El procedimiento que nos va a permitir el paso de una fase a otra es la cuantificación numérica y la inferencia, operación lógica por la cual se admite que una proposición es cierta en virtud de sus relaciones con otras proposiciones consideradas como verdaderas.

A continuación explicamos los pasos seguidos en nuestro trabajo de investigación:

Preanálisis. Este primer momento del trabajo de investigación podemos considerarlo como el periodo de intuiciones que tiene como objetivo sistematizar las ideas para llegar a un sistema de desarrollo de las operaciones y poder determinar un programa preciso a seguir. Consta de diferentes etapas, pero la realización de estas etapas no tiene por qué seguir un orden cronológico. Por ejemplo, elegir la muestra del trabajo a analizar puede ser anterior o posterior a la formulación de los objetivos, dependerá del tipo de investigación a realizar. En nuestro estudio, la muestra ha sido seleccionada a lo largo del proceso debido a la necesidad de buscar la obra del artista, y una vez que ya se habían definido los objetivos y formulada la hipótesis.

- Lectura flotante.- constituye el momento en el que tomamos contacto con el material que queremos investigar. De aquí surge la hipótesis 
y la selección de la muestra, en el caso que no se haya fijado anteriormente.

En nuestro caso, dicha lectura flotante se realizará sobre las obras del artista Eduardo Vicente, así como los conocimientos teóricos que hemos realizado sobre este tema

- Recopilación de material.- Es la constitución del "corpus" que pretende ser analizado a partir de un universo de documentos.

El "corpus" para el análisis corresponde a las obras de Eduardo Vicente que quedan agrupadas en las siguientes categorías (Cuadro 2):

\begin{tabular}{|c|c||}
\hline Categoría & Número de obras analizadas \\
\hline Retrato & 18 \\
\hline Cartel & 11 \\
\hline Mural & 15 \\
\hline Ilustración & 184 \\
\hline Otras obras & 114 \\
\hline
\end{tabular}

Cuadro 2. Elaboración Propia.

Retratos. La muestra está compuesta por dieciocho retratos, entre los que figuran diez personajes masculinos del mundo de la política, la literatura y un autorretrato, cinco mujeres y tres niñas, entre las que se encuentran sus dos hijas Mari Sol y Silvia Vicente (Fig. 8, 9, 10, 11 y 12).
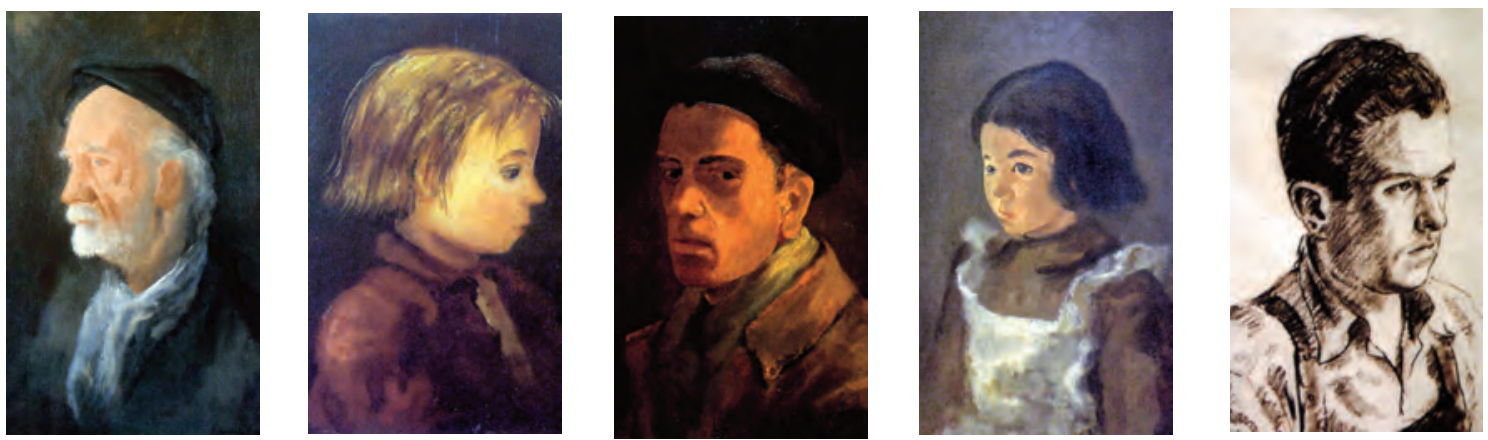

Fig. 8, 9, 10, 11 y 12. Retratos realizados por Eduardo Vicente. 
Carteles. Disponemos de once carteles, en su mayoría de carácter político, ya que el cartelismo fue la actividad más desarrollada en la época de la guerra civil, alcanzando gran diversidad de estilos y planteamientos revolucionarios. Los carteles de Eduardo Vicente se caracterizan por un estilo expresionista de carácter bélico y social y destacan por su fuerza y sencillez expresiva (Fig. 13, 14, 15, 16 y 17).
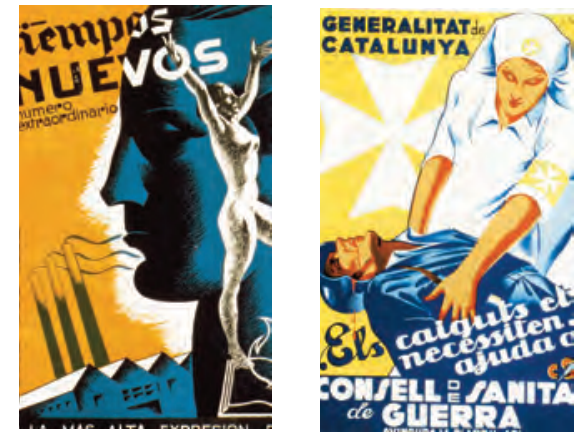
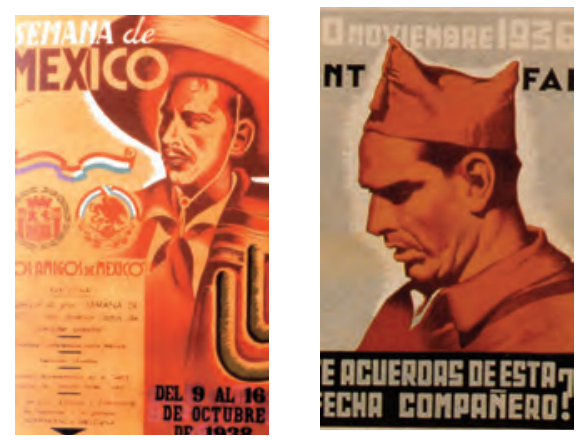

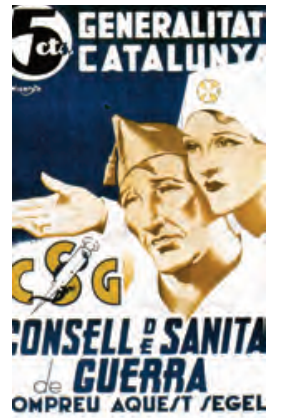

Fig. 13, 14, 15, 16 y 17.

Distintos carteles realizados durante la carrera artística de Eduardo Vicente.

Murales. Contamos con quince murales, de los cuales cinco son de carácter religioso y decoran diferentes iglesias y los otros son paisajes y escenas que sirven para la decoración de hoteles, bancos, restaurantes, cafeterías, Delegación de Hacienda y otras instituciones (Fig. 18, 19, 20, 21 y 22).
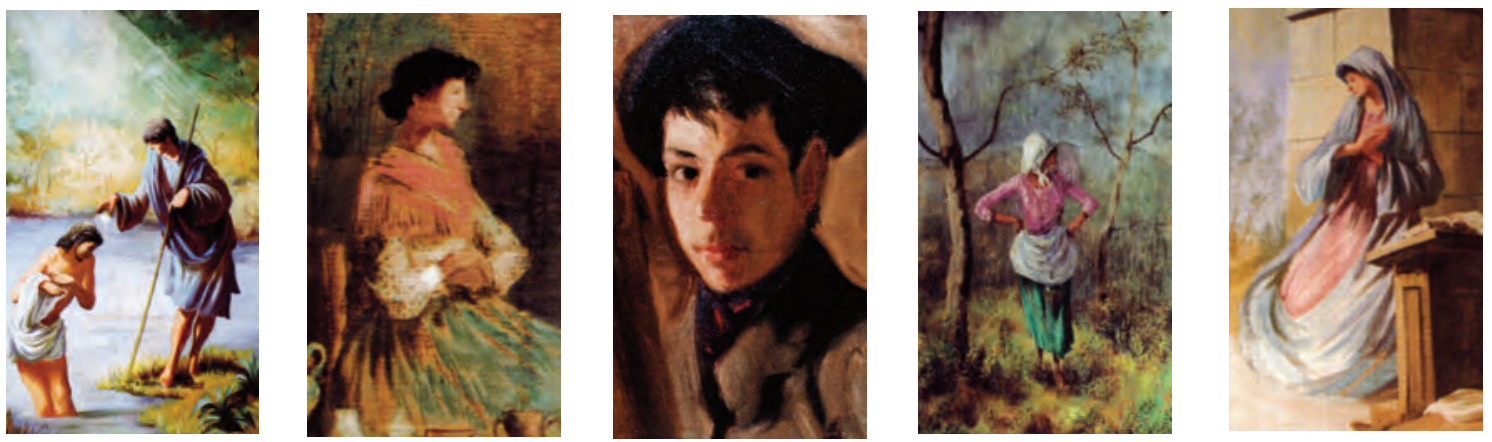

Fig. 18, 19, 20, 21 y 22.

Detalles de varios murales del artista Eduardo Vicente. 
Ilustraciones. Eduardo Vicente colabora con diferentes editoriales como ilustrador de obras de distintos autores. En la muestra seleccionada contamos con las ciento ochenta y cuatro ilustraciones de las obras seleccionadas en el cuadro adjunto (Cuadro 3) (Figuras 23, 24, 25, 26 y 27).
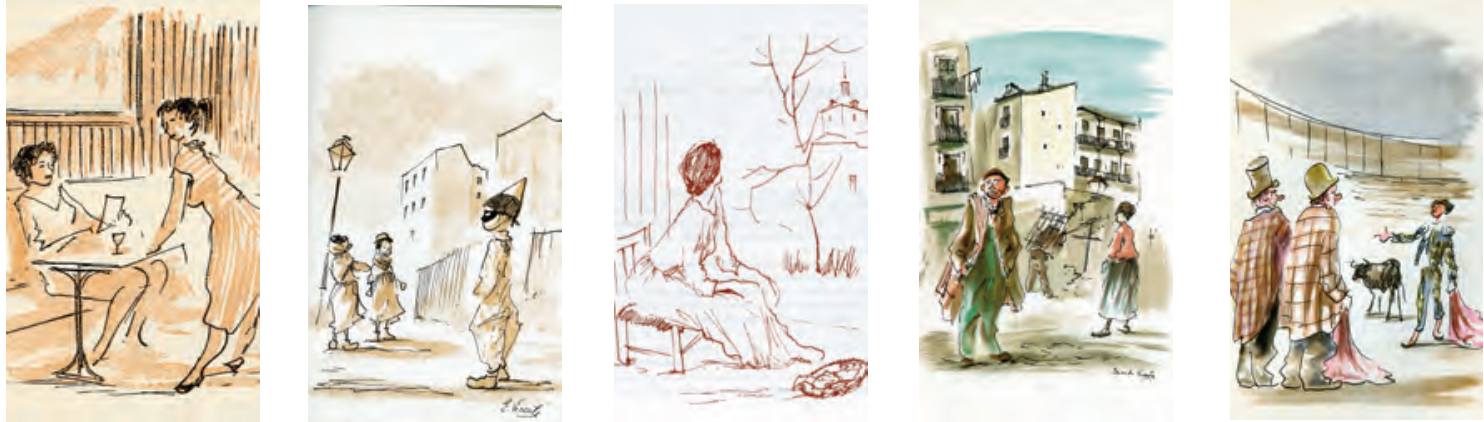

Fig. 23, 24, 25, 26 y 27.

Eduardo Vicente fue un referente en la ilustración editorial de la época.

\begin{tabular}{|c|c|c|c|c|c|c|}
\hline Portada & Autor & Título & Editorial & Año & Ilustradores & $\begin{array}{l}\text { Número de } \\
\text { ilustraciones } \\
\text { de Eduardo } \\
\text { Vicente }\end{array}$ \\
\hline 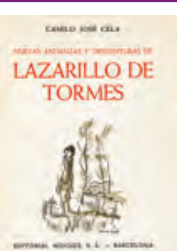 & $\begin{array}{c}\text { Camilo José } \\
\text { Cela }\end{array}$ & $\begin{array}{c}\text { "Nuevas } \\
\text { andanzas y } \\
\text { desventuras } \\
\text { de Lazarillo } \\
\text { de Tormes" }\end{array}$ & Noguer & 1944 & $\begin{array}{l}\text { Eduardo } \\
\text { Vicente }\end{array}$ & 14 \\
\hline 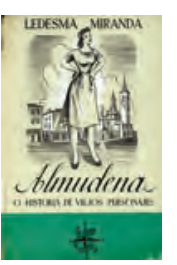 & $\begin{array}{l}\text { Ledesma } \\
\text { Miranda }\end{array}$ & $\begin{array}{c}\text { "Almudena } \\
\text { o historias } \\
\text { de viejos } \\
\text { personajes" }\end{array}$ & $\begin{array}{c}\text { Afrodisio } \\
\text { Aguado } \\
\text { S.A. }\end{array}$ & 1944 & $\begin{array}{c}\text { Eduardo } \\
\text { Vicente, } \\
\text { Emeterio Ruiz } \\
\text { Melendreras }\end{array}$ & 18 \\
\hline TPos DELCAUK & $\begin{array}{l}\text { Eduardo } \\
\text { Vicente }\end{array}$ & $\begin{array}{l}\text { "Tipos de } \\
\text { la calle" }\end{array}$ & $\begin{array}{c}\text { Afrodisio } \\
\text { Aguado S.A }\end{array}$ & 1950 & $\begin{array}{l}\text { Eduardo } \\
\text { Vicente }\end{array}$ & 42 \\
\hline
\end{tabular}




\begin{tabular}{|c|c|c|c|c|c|c|}
\hline Portada & Autor & Título & Editorial & Año & Ilustradores & $\begin{array}{l}\text { Número de } \\
\text { ilustraciones } \\
\text { de Eduardo } \\
\text { Vicente }\end{array}$ \\
\hline 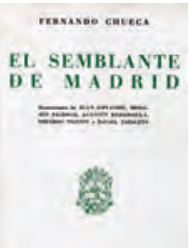 & $\begin{array}{c}\text { Fernando } \\
\text { Chueca }\end{array}$ & $\begin{array}{l}\text { "El } \\
\text { semblante } \\
\text { de Madrid" }\end{array}$ & $\begin{array}{c}\text { Instituto } \\
\text { de Estudios } \\
\text { Madrileños }\end{array}$ & 1951 & $\begin{array}{l}\text { Eduardo Vicente, } \\
\text { Juan Esplandíy, } \\
\text { Benjamín } \\
\text { Palencia, Agustín } \\
\text { Redondela, } \\
\text { Rafael Zabaleta }\end{array}$ & 9 \\
\hline E & $\begin{array}{l}\text { Marino } \\
\text { Gómez } \\
\text { Santos }\end{array}$ & $\begin{array}{l}\text { "Crónicas } \\
\text { del Café } \\
\text { Gijón" }\end{array}$ & $\begin{array}{l}\text { Biblioteca } \\
\text { Nueva }\end{array}$ & 1955 & $\begin{array}{c}\text { Eduardo } \\
\text { Vicente, César } \\
\text { González Ruano }\end{array}$ & 17 \\
\hline 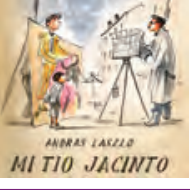 & $\begin{array}{l}\text { András } \\
\text { Laszlo }\end{array}$ & $\begin{array}{l}\text { "Mi tío } \\
\text { Jacinto" }\end{array}$ & $\begin{array}{l}\text { José Janés } \\
\text { Editor }\end{array}$ & 1956 & $\begin{array}{l}\text { Eduardo } \\
\text { Vicente }\end{array}$ & 44 \\
\hline 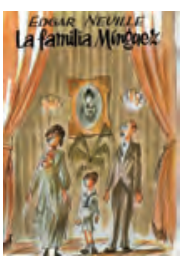 & $\begin{array}{l}\text { Edgar } \\
\text { Neville }\end{array}$ & $\begin{array}{l}\text { "La familia } \\
\text { Mínguez" }\end{array}$ & Taurus & 1956 & $\begin{array}{l}\text { Eduardo } \\
\text { Vicente }\end{array}$ & 9 \\
\hline $\begin{array}{l}\text { WAPEEORECFA } \\
\text { AHGULRR }\end{array}$ & $\begin{array}{l}\text { Edgar } \\
\text { Neville }\end{array}$ & $\begin{array}{c}\text { "La } \\
\text { piedrecita } \\
\text { angular" }\end{array}$ & Taurus & 1957 & $\begin{array}{l}\text { Eduardo } \\
\text { Vicente }\end{array}$ & 8 \\
\hline 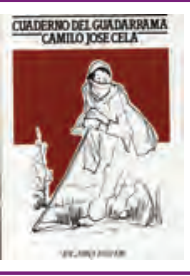 & $\begin{array}{l}\text { Camilo } \\
\text { José Cela }\end{array}$ & $\begin{array}{c}\text { "Cuadernos } \\
\text { de } \\
\text { Guadarrama" }\end{array}$ & Lumen S.A. & 1959 & $\begin{array}{l}\text { Eduardo } \\
\text { Vicente }\end{array}$ & 21 \\
\hline camparas de palo & $\begin{array}{l}\text { Baldomero } \\
\text { Isorna }\end{array}$ & $\begin{array}{c}\text { "Campanas } \\
\text { de palo" }\end{array}$ & $\begin{array}{c}\text { Maribel Artes } \\
\text { Gráficas }\end{array}$ & 1959 & $\begin{array}{l}\text { Eduardo } \\
\text { Vicente }\end{array}$ & 2 \\
\hline
\end{tabular}


Otras obras. En esta categoría incluimos el resto de las obras que componen la muestra, con un total de ciento catorce obras artísticas analizadas (Fig. 28, 29, 30, 31 y 32 ).
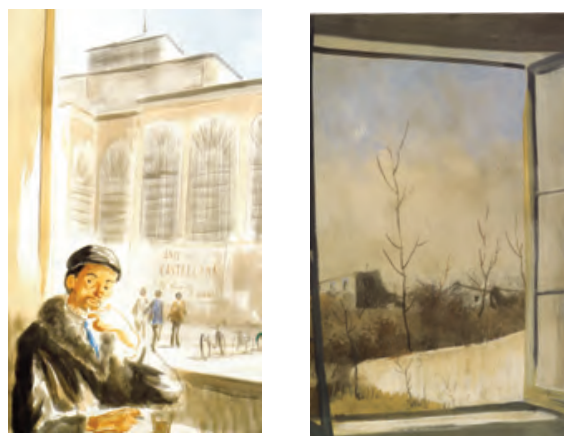
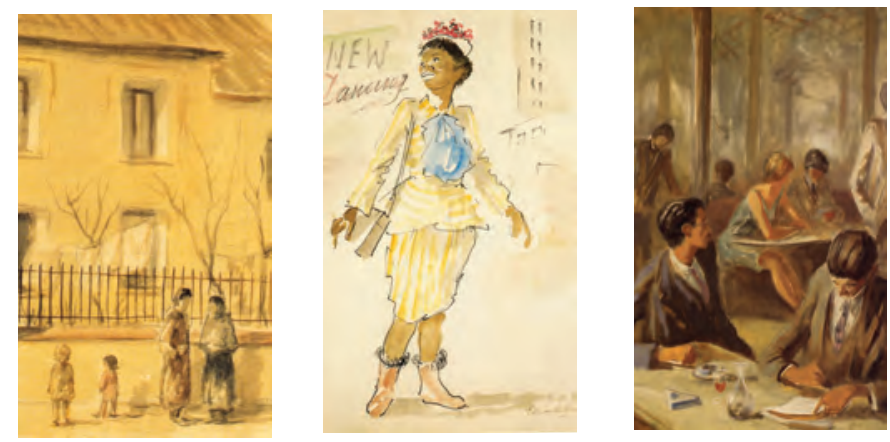

Fig. 28, 29, 30, 31 y 32.

Muestra de alguna de las obras de Eduardo Vicente realizadas en diferentes técnicas.

El total de la muestra seleccionada para su estudio y análisis asciende a un total de 342 obras. Esta cantidad constituye una representación exhaustiva y representativa de la obra de Eduardo Vicente.

- Localización de índices.- La localización de los índices se realiza atendiendo a diferentes criterios:

Variables externas de la obra en la que contemplamos:

* Título.

* Año.

* Tamaño.

Aspectos Técnicos de la obra en los que se atienden:

* Color dominante.

* Técnica de impresión.

* Plano de la imagen. 


\section{Contenido de la obra:}

* Personajes.

* Animales.

* Paisajes.

* Escenas.

* Gestos expresivos.- Para el análisis de este indicador hemos establecido dos categorías relacionadas con las emociones, así distinguimos entre emociones positivas y negativas.

Pese a que entendemos que las emociones, por su propia naturaleza, para ser interpretadas como positivas o negativas debemos tener en cuenta la subjetividad del investigador. Trataremos de objetivar y limitar las desviaciones propias de dicha subjetividad, tomando en consideración las normas y los valores, los usos y costumbres, así como las imposiciones éticas, morales y antropológicas.

En la categoría de emociones positivas hemos considerado todas aquellas imágenes que reflejan expresiones de felicidad, alegría, éxito, etcétera, o que aluden a comportamientos que están relacionados con el bienestar personal y con aquellas conductas que se adaptan a las normas sociales.

Por el contrario, a la categoría de emociones negativas se corresponderán aquellas imágenes que muestran el miedo, el dolor, la desolación, la rabia, la soledad, la muerte, etcétera, o aquellas escenas en las que sus personajes se encuentran en una situación trágica de marginación o exclusión social.

Esta división entre emociones positivas y negativas, que en teoría parece estar fácilmente delimitadas, en la práctica resulta muy difícil por la subjetividad que comentábamos anteriormente.

A pesar de encontrar esta dificultad, hemos decidido contemplar este indicador en nuestro análisis, pues definiendo de forma precisa las variables 
a tener en cuenta para incluirlas en una u otra categoría nos van a permitir obtener datos interesantes para conocer la realidad de la sociedad en este momento histórico analizado.

Después de un estudio exhaustivo de las imágenes de la obra de Eduardo Vicente, en relación a la transmisión de emociones, hemos decidido incluir en la categoría de emociones positivas: las escenas de ocio, familiares, de amigos, las fiestas, los oficios (como medio de ganarse la vida, sin diferenciar la valoración social de los mismos); y en la categoría de emociones negativas las relacionadas con: escenas de guerra (independientemente de si en estas escenas sus personajes se muestran más o menos felices o realizando conductas positivas, por considerar que la propia situación de guerra no es propia para dignificar la vida humana), situaciones de marginación social (prostitutas, vagos, vagabundos, maleantes...).

En definitiva, este indicador, con su margen de imprecisión y subjetividad, nos va a permitir obtener datos que servirán como punto de partida para poder realizar inferencias que nos lleve a una mejor interpretación de la imagen y de su valor como transmisor de las actitudes, valores y normas de la sociedad.

Función de la obra, variables internas o principales de nuestra investigación, que son las referidas a:

* Transmisora de ideología.

* Representativa de modelos sociales.

Con este estudio podemos comprobar cómo la obra artística, por una parte, informa y expresa y por otra, representa y crea. Teniendo en cuenta todos estos aspectos creemos acercarnos más al conocimiento y el valor que la obra artística de Eduardo Vicente ha tenido para reflejar los modelos sociales imperantes en la época en la que vivió y cómo puede servir de transmisión de una ideología determinada. 


\section{- Elaboración de indicadores y establecimiento de categorías para el análisis de la obra artística.}

Una vez señalados estos índices necesitamos elaborar los indicadores según los cuales se van a considerar los índices.

Estos indicadores nos van a permitir establecer una serie de categorías, es decir, clasificar, agrupar, codificar los elementos significativamente comunes. Para ello dividimos las obras artísticas en unidades operativas que posteriormente nos servirán para la descripción precisa, la interpretación y el tratamiento de los resultados. Los indicadores establecidos en función de los índices quedan definidos de la siguiente forma:

* Transmisión de ideología política y/o religiosa.

* Representativos de modelos sociales: Rol masculino y femenino, las clases sociales, la vida en el ámbito privado (hogar) y en el público (calle), las ciudades y los pueblos, sus gentes y sus costumbres, los oficios y profesiones como medio de subsistencia, el ocio (los toros, las fiestas, los bailes, el teatro, los lugares de alterne: cafés y tabernas)

Con estos indicadores queremos obtener datos sobre los modelos sociales y la ideología que las obras artísticas pretenden transmitir, así estamos de acuerdo con Valeriano Bozal al afirmar:

"la imagen..., no sólo es vehículo más o menos preciso de una ideología, es formadora de sensibilidad, a su través se fijan en nuestra mente tipos y motivos, modos de aproximarnos a la realidad" $\mathbf{8}$

Bozal, V. (1991:218)

Basta con observar la obra de Eduardo Vicente para comprender los modelos sociales, las pautas de conducta, las modas, los estereotipos propios de la época. 
2.- Fase de exploración de materiales.- Esta fase consiste en la aplicación sistemática de todas las decisiones formuladas en la fase del preanálisis.

La operación fundamental en esta etapa consiste en buscar las unidades de registro o unidades de significación, y el modo en que van a ser recogidas para que la información resulte de utilidad.

En esta fase confeccionamos unas unidades de registro para recoger la información de cada obra (Fichas 1, 2, 3 y 4). 
ANEXO III.

\section{VARIABLES EXTERNAS.}

\section{Título:}

Año:

Tamaño:

TIPO DE IMAGEN.

Retrato:

Cartel:

Mural:

Ilustración:

Otras Técnicas:

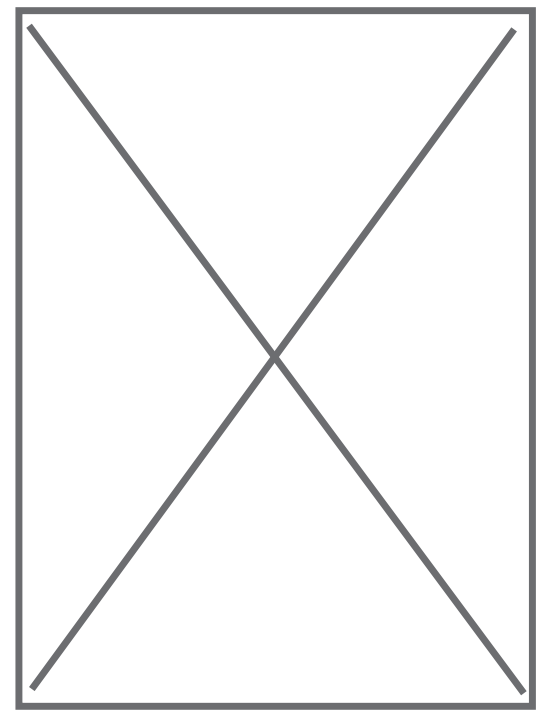

CONTENIDO.

Personajes:

Animales:

Gestos Expresivos:

Paisajes:

Escenas:

Función:

ASPECTOS TÉCNICOS.

Color dominante:

Técnica:

Plano de la imagen:

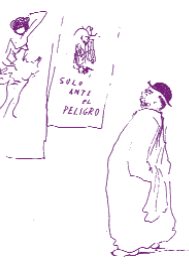




\section{Número total de cada tipo de imagen analizada}

\section{Contenido.}

- Personajes

- Animales

- Paisajes

- Escenas

\section{Aspectos técnicos.}

- Color dominante

- Técnica de impresión

- Plano de la imagen

\section{Función.}

- \% de propaganda política

- \% de propaganda religiosa

- \% de modelos sociales

Ficha 2.- Hoja de registro de los datos obtenidos en el análisis de cada tipo de imágenes: retratos, carteles, murales, ilustraciones y otras obras. 


\section{Total de la muestra}

\section{Contenido.}

- Personajes

- Animales

- Paisajes

- Escenas

\section{Aspectos técnicos.}

- Color dominante

- Técnica de impresión

- Plano de la imagen

\section{Función.}

- \% de propaganda política

- \% de propaganda religiosa

- \% de modelos sociales

Ficha 3. Hoja de registro de los datos obtenidos en el total de la muestra. 


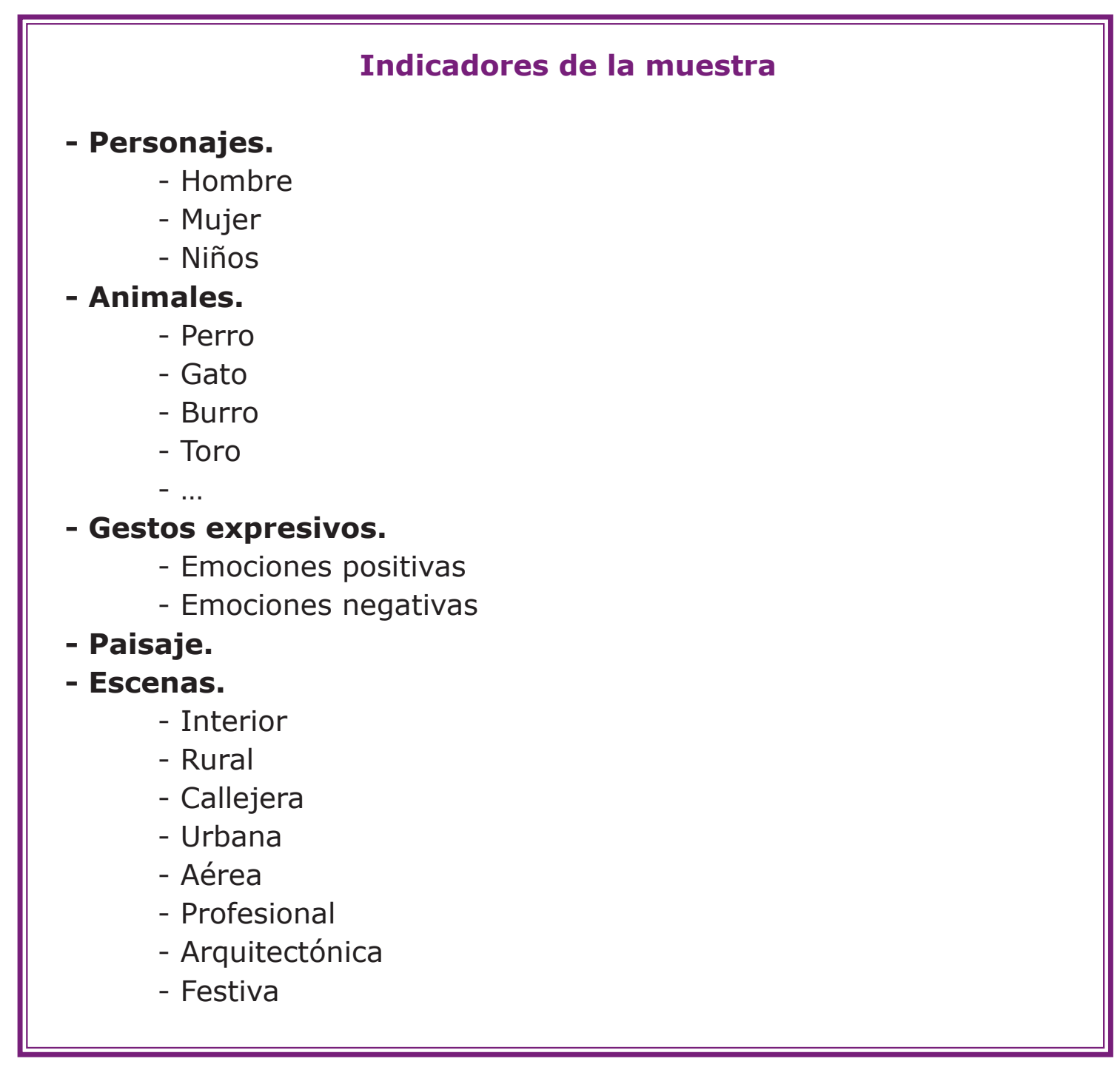

Ficha 4.- Hoja de registro de los diferentes indicadores selecionados para el análisis de los modelos sociales.

Con los datos obtenidos en las hojas de registro tenemos toda la información que hemos recogido en el análisis, dispuesta para su tratamiento o interpretación.

Las fichas individuales de cada obra analizada y las fichas resumen de cada tipo de imagen pueden consultarse en los ANEXO II y III. 
3.- Fase de tratamiento e interpretación de los resultados.- Una vez recopilado el material a analizar, hemos determinado dos fases diferentes para abordar el análisis y así poder obtener más datos sobre la obra del artista estudiado.

Una primera fase externa sobre los datos objetivos de la obra artística, en la que hemos señalado contemplado: Variables externas: título, tamaño y año. Tipos de imagen: retratos, carteles, murales, ilustraciones y otras obras. Aspectos técnicos: color, técnica de impresión y plano de la imagen (Cuadro 4).

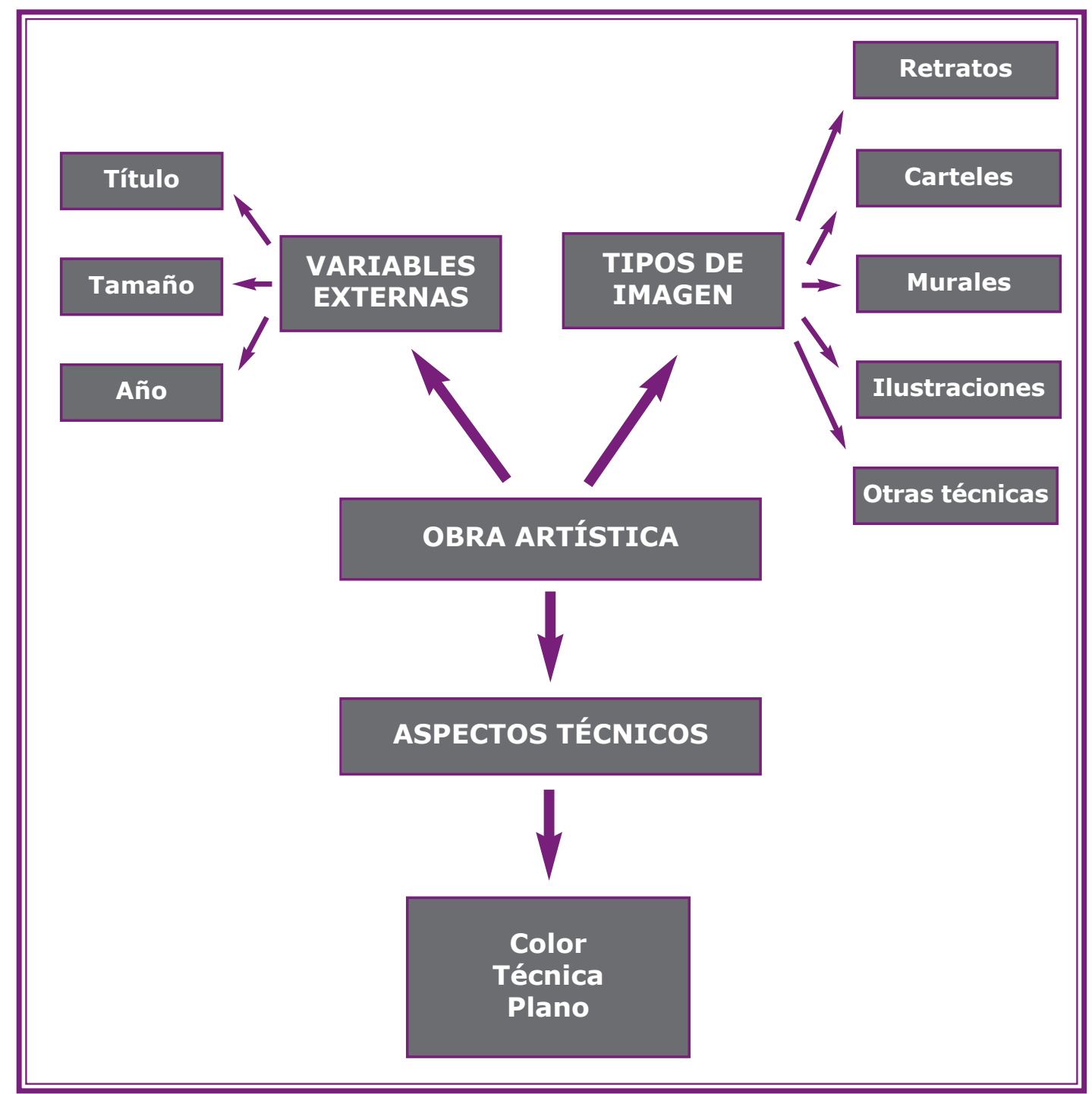

Cuadro 4. Primera Fase. Elaboración Propia. 
Una segunda fase interna en la que analizamos el contenido: personajes, animales, gestos expresivos, paisajes y escenas y la función que cumple la obra artística como transmisora de ideología y representativa de modelos sociales, aspectos esenciales en nuestro trabajo de investigación (Cuadros 5, 6 y 7 ).

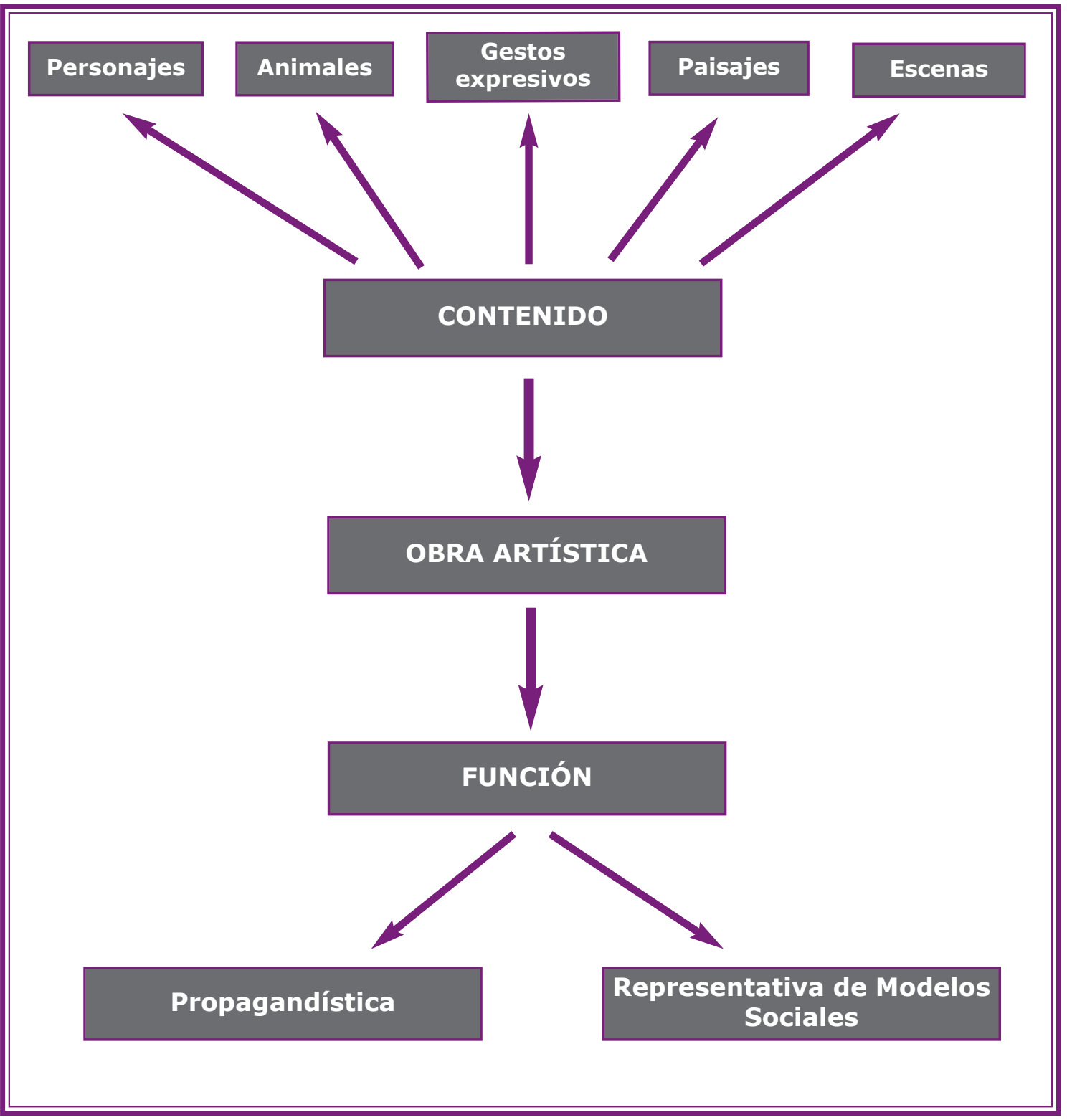

Cuadro 5. Segunda Fase. Elaboración Propia. 


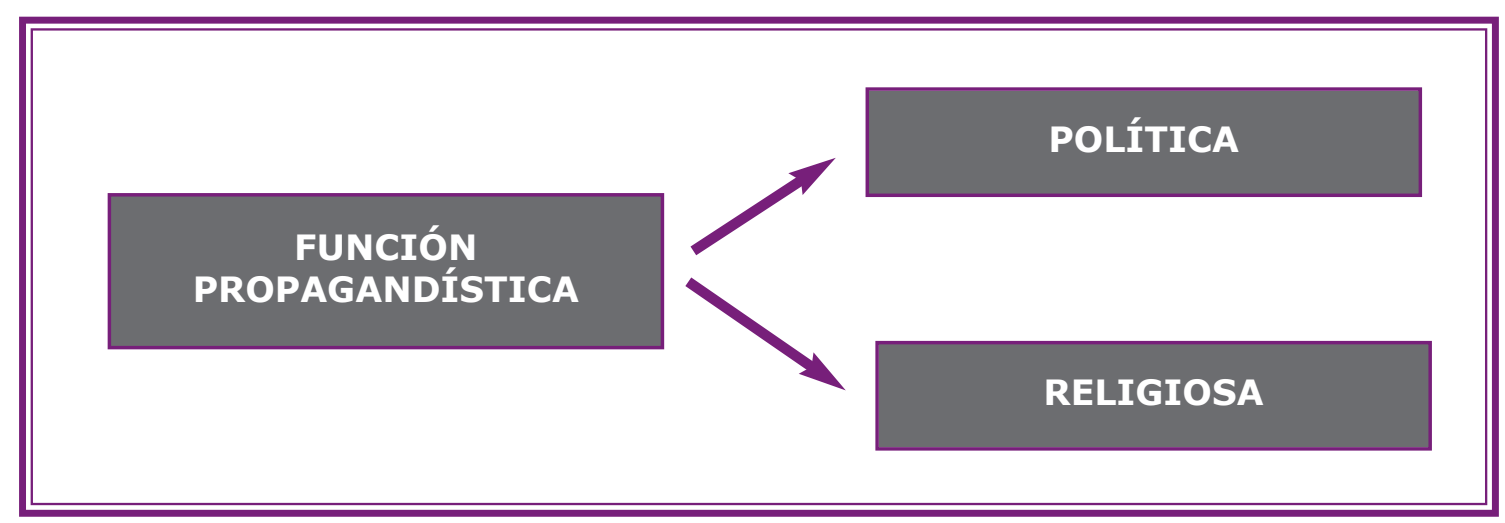

Cuadro 6. Elaboración Propia.

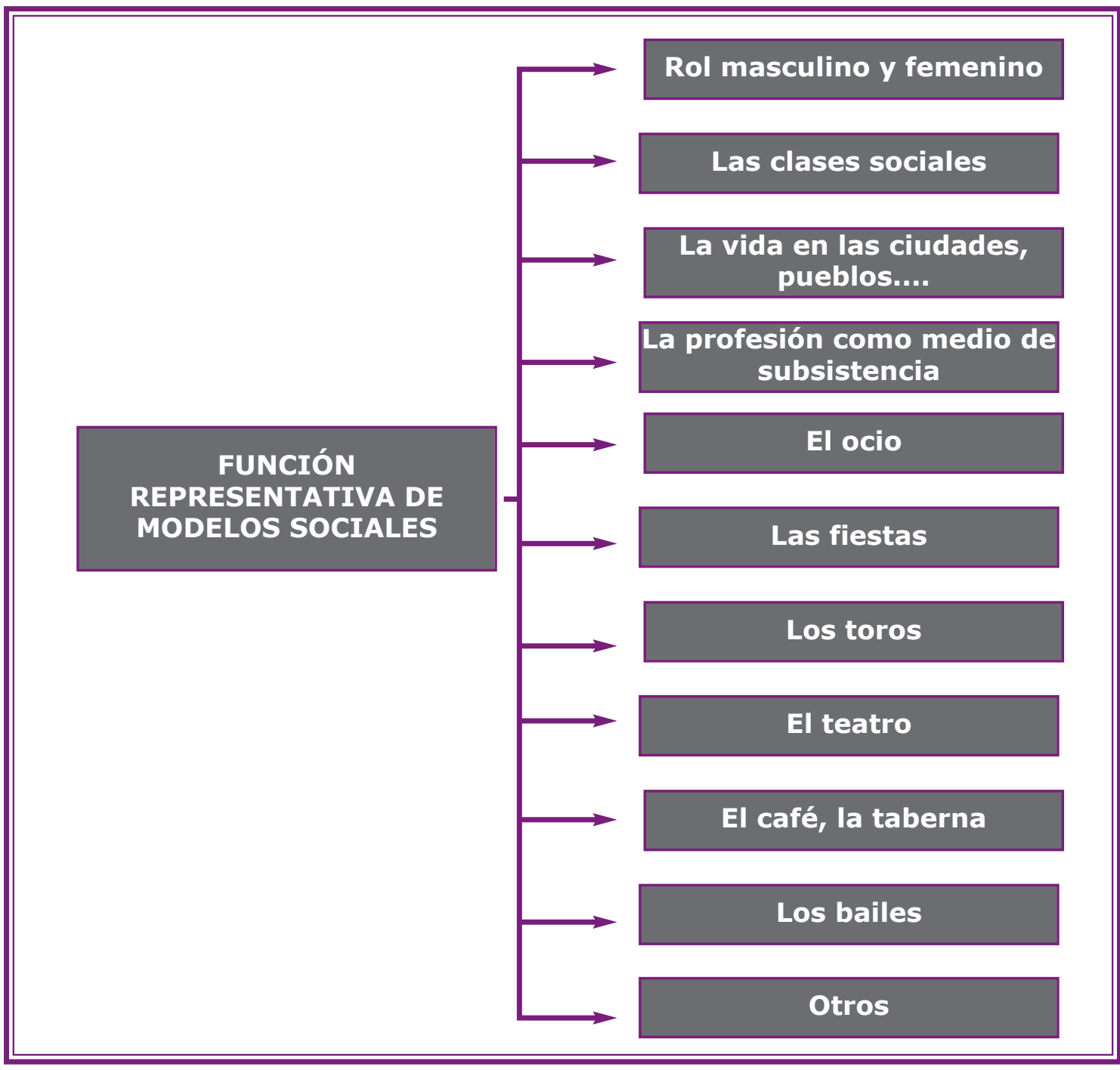


Una vez superada la fase del tratamiento de los datos pasamos a la interpretación de los datos obtenidos en el estudio y análisis de las 342 obras que constituyen la muestra seleccionada.

En esta fase se lleva a cabo el tratamiento estadístico de los resultados y se obtienen los indicadores cuantitativos que nos van a permitir describir el contenido del material analizado. También se obtienen los indicadores cualitativos que nos van a posibilitar la realización de inferencias que completen y enriquezcan los datos cuantitativos.

Datos y gráfica de la muestra analizada clasificada por categorías:

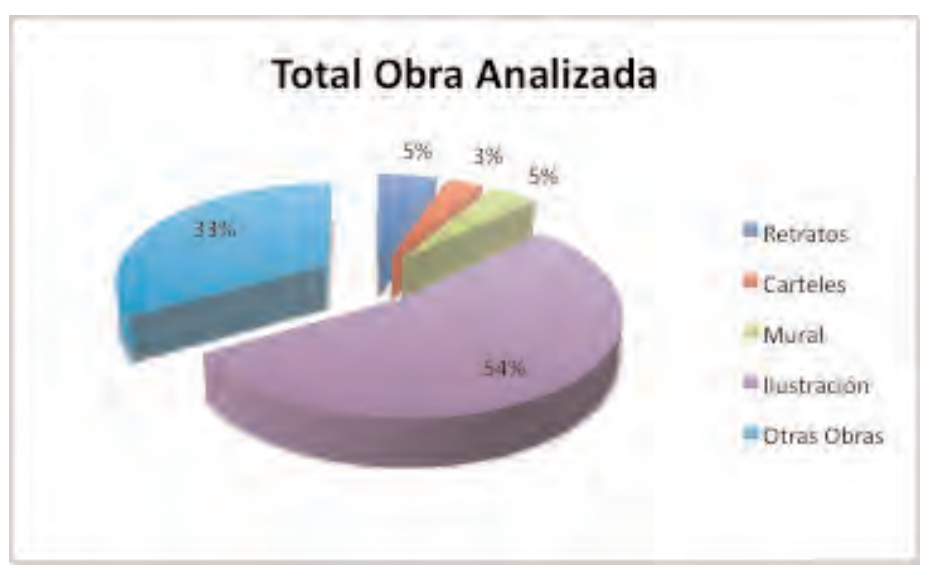

\section{Retratos.}

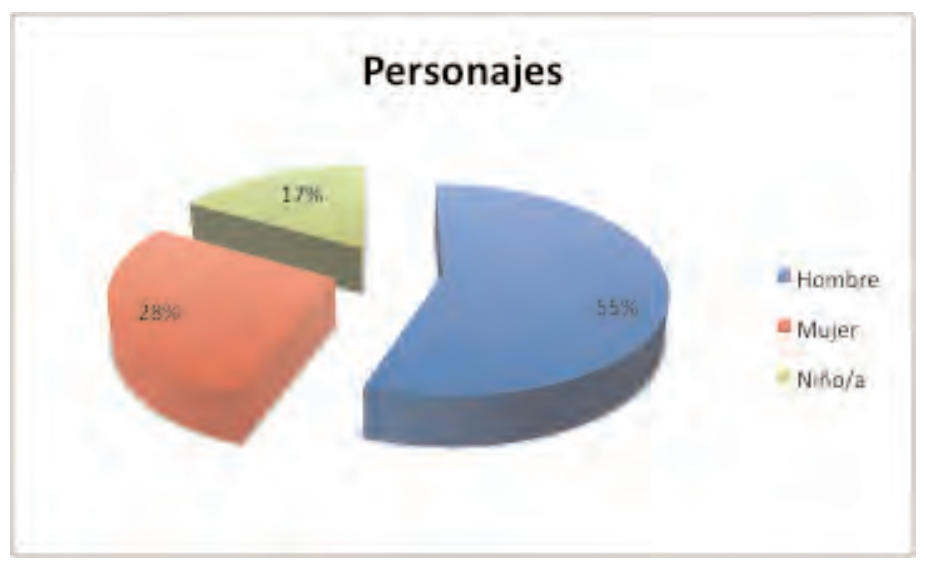



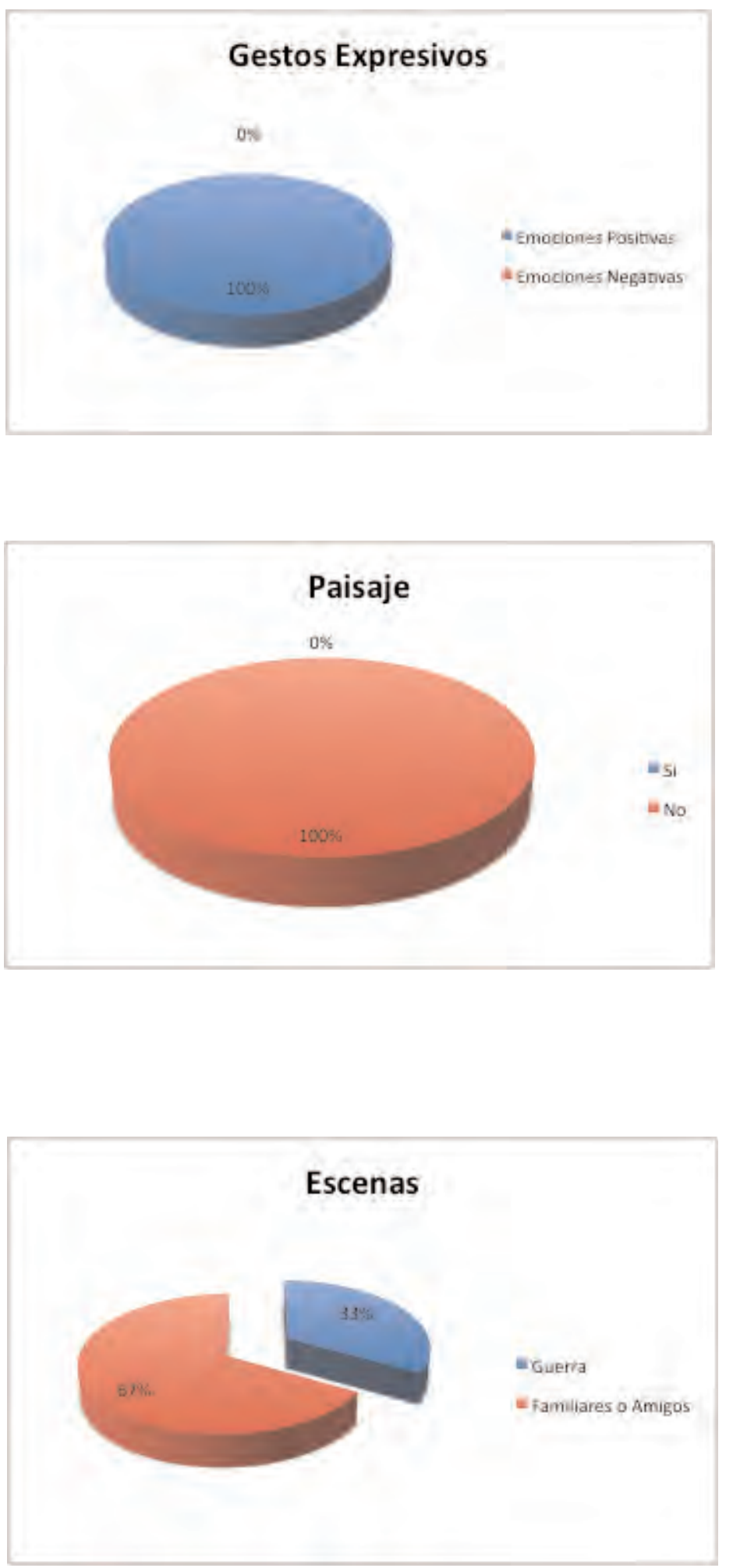

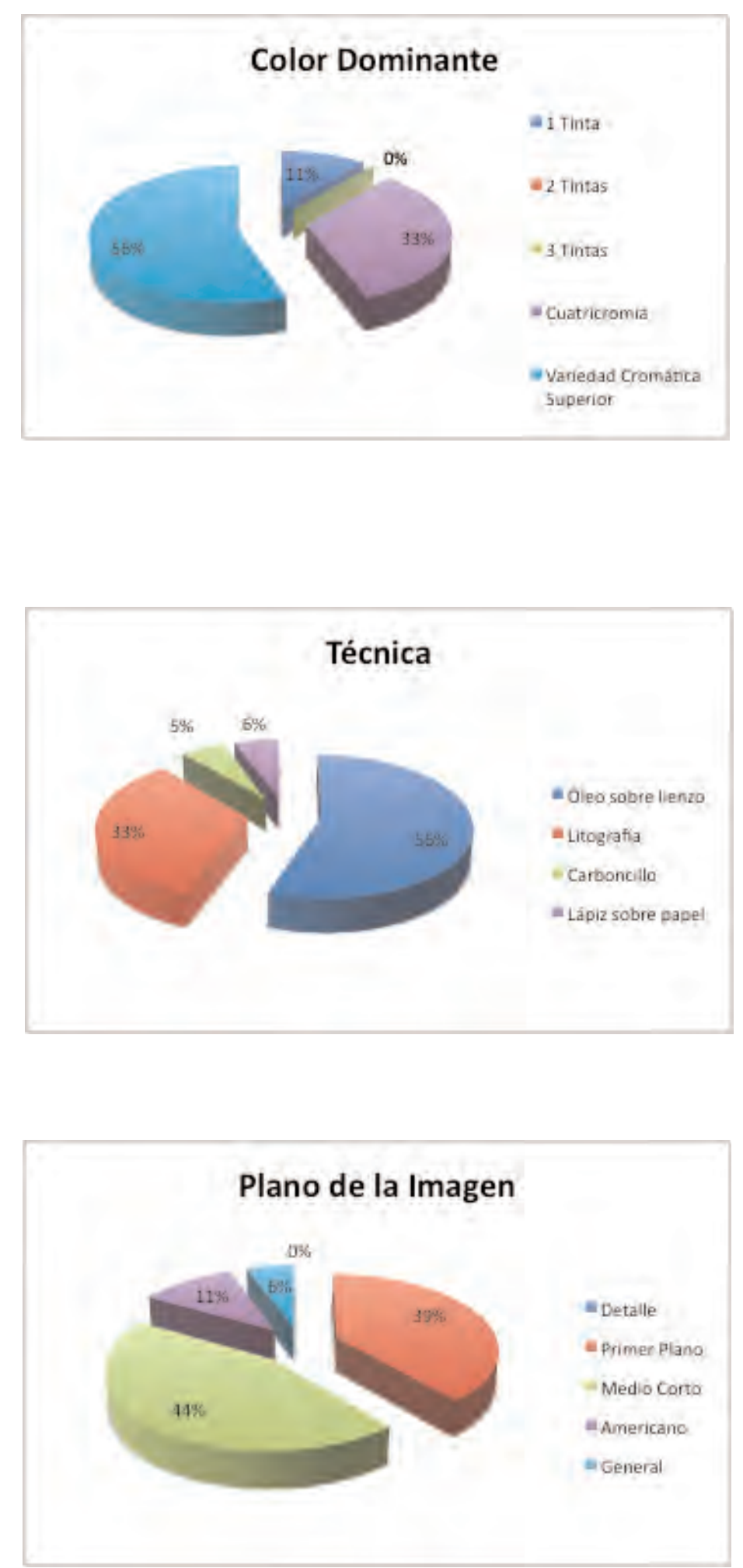


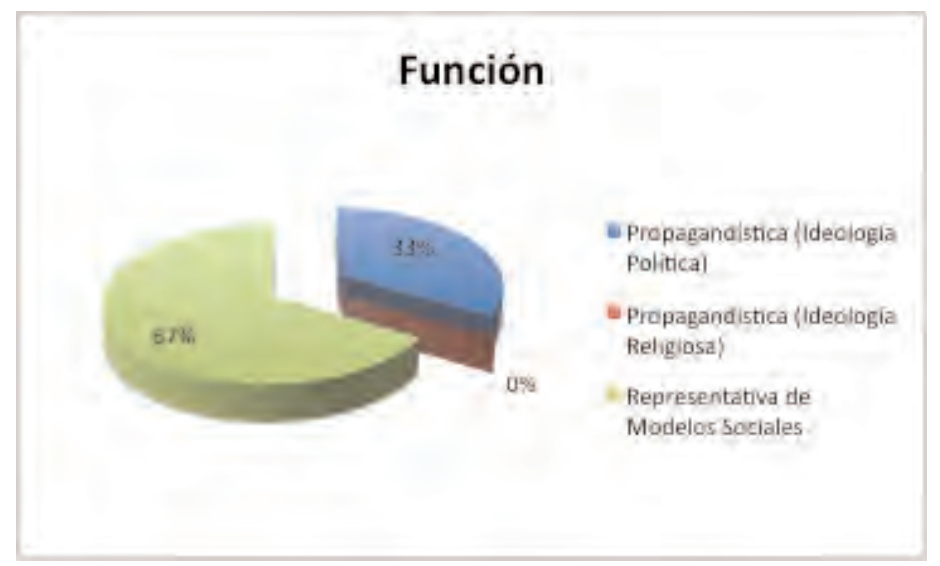

\section{Carteles.}
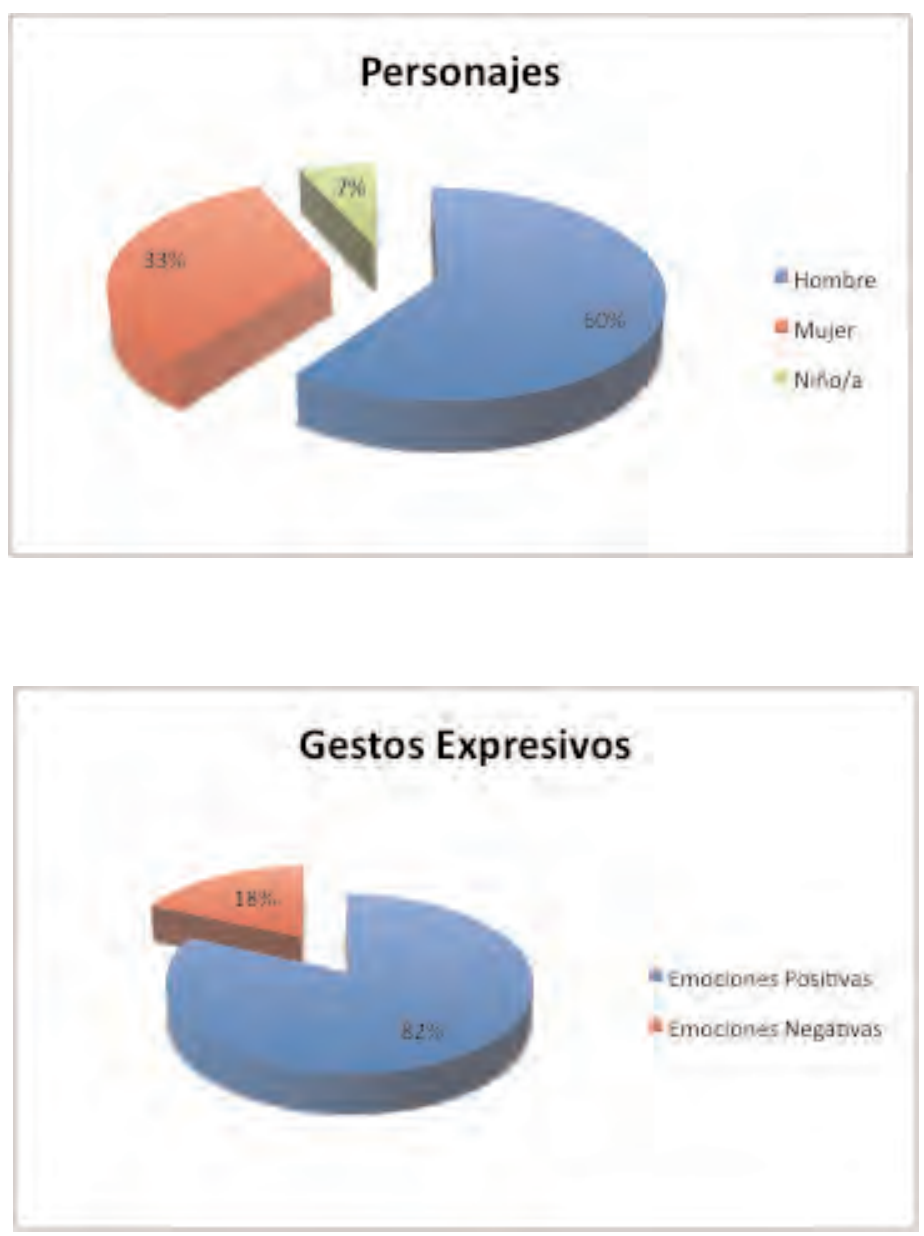

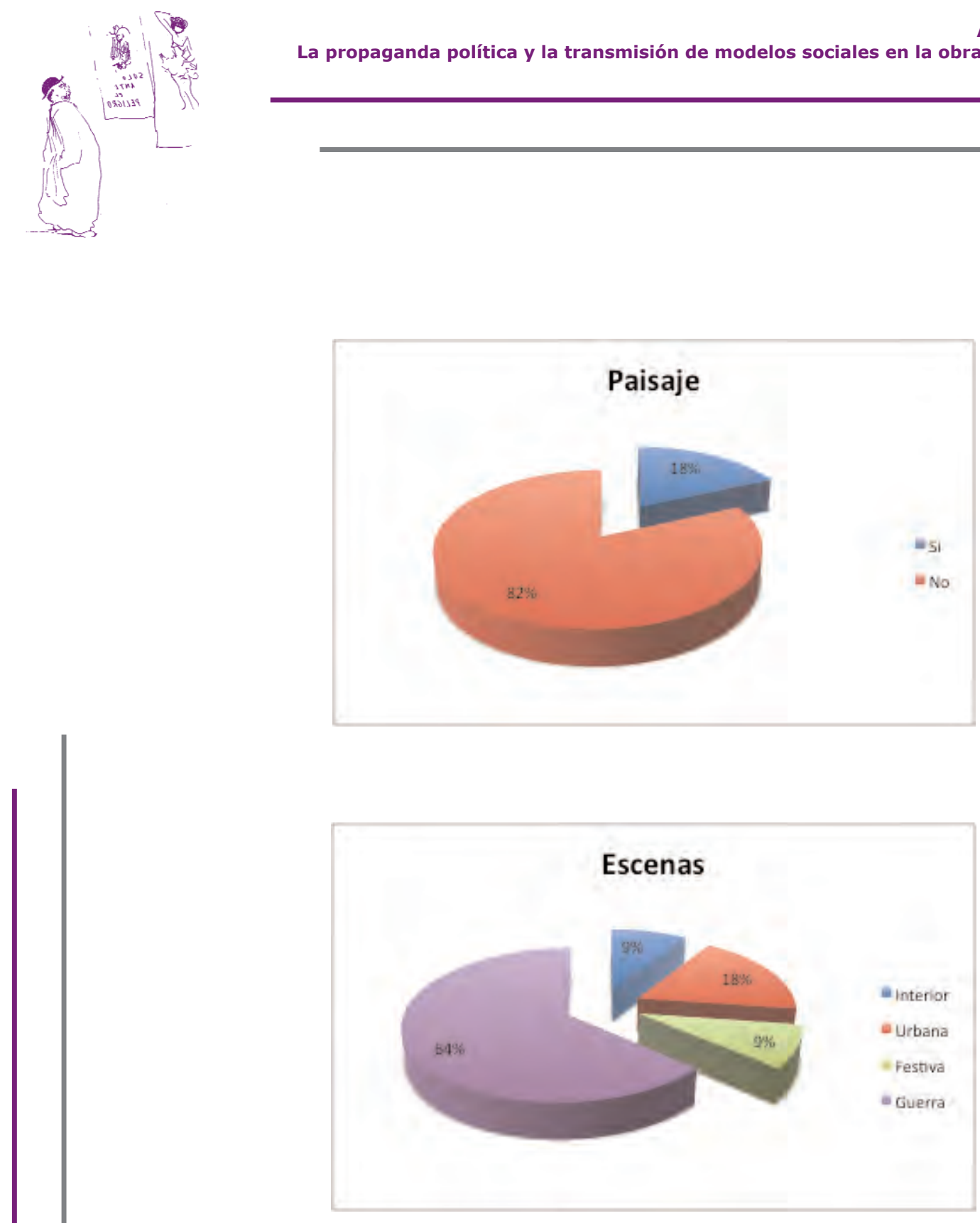

\section{Color Dominante}

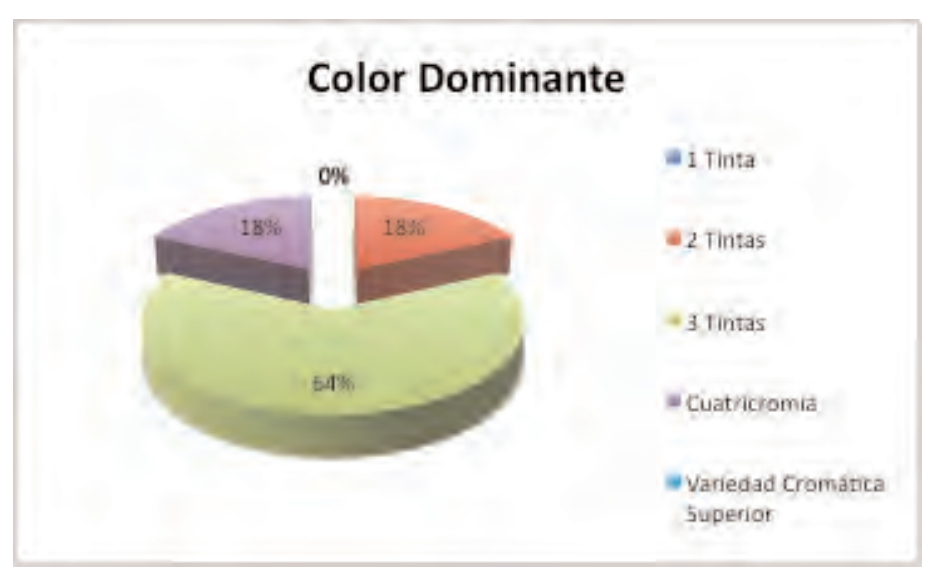



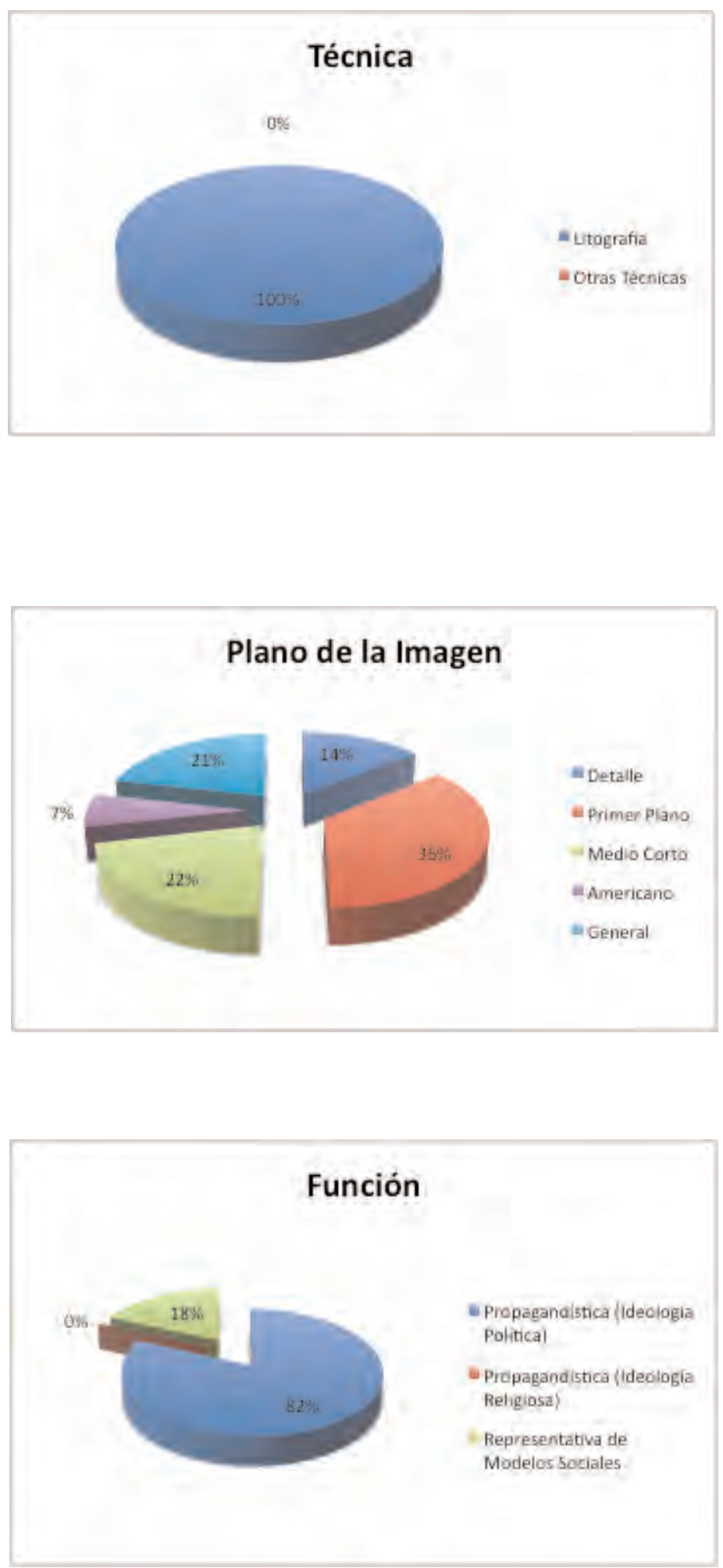


\section{Murales.}
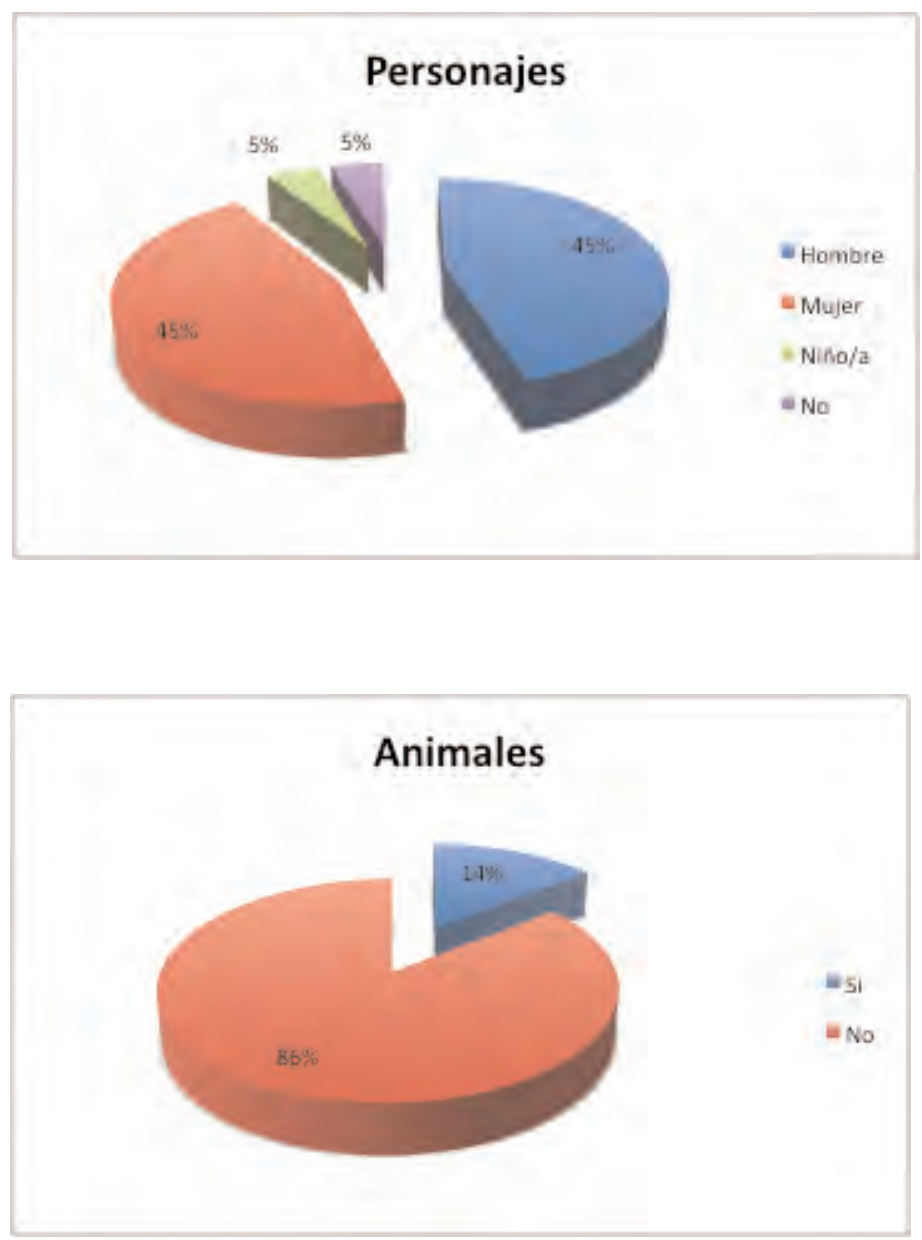

\section{Gestos Expresivos}

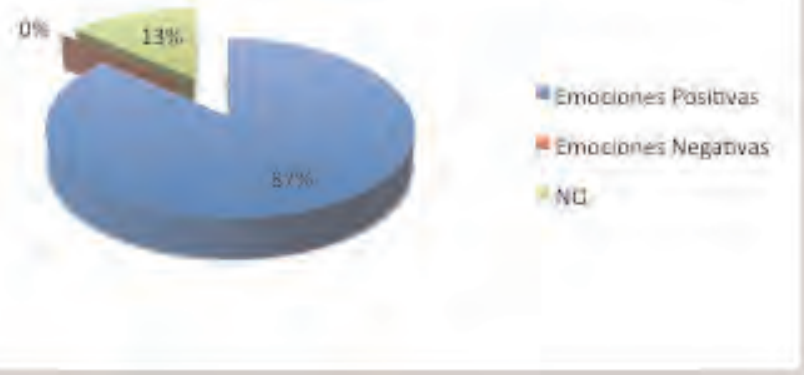



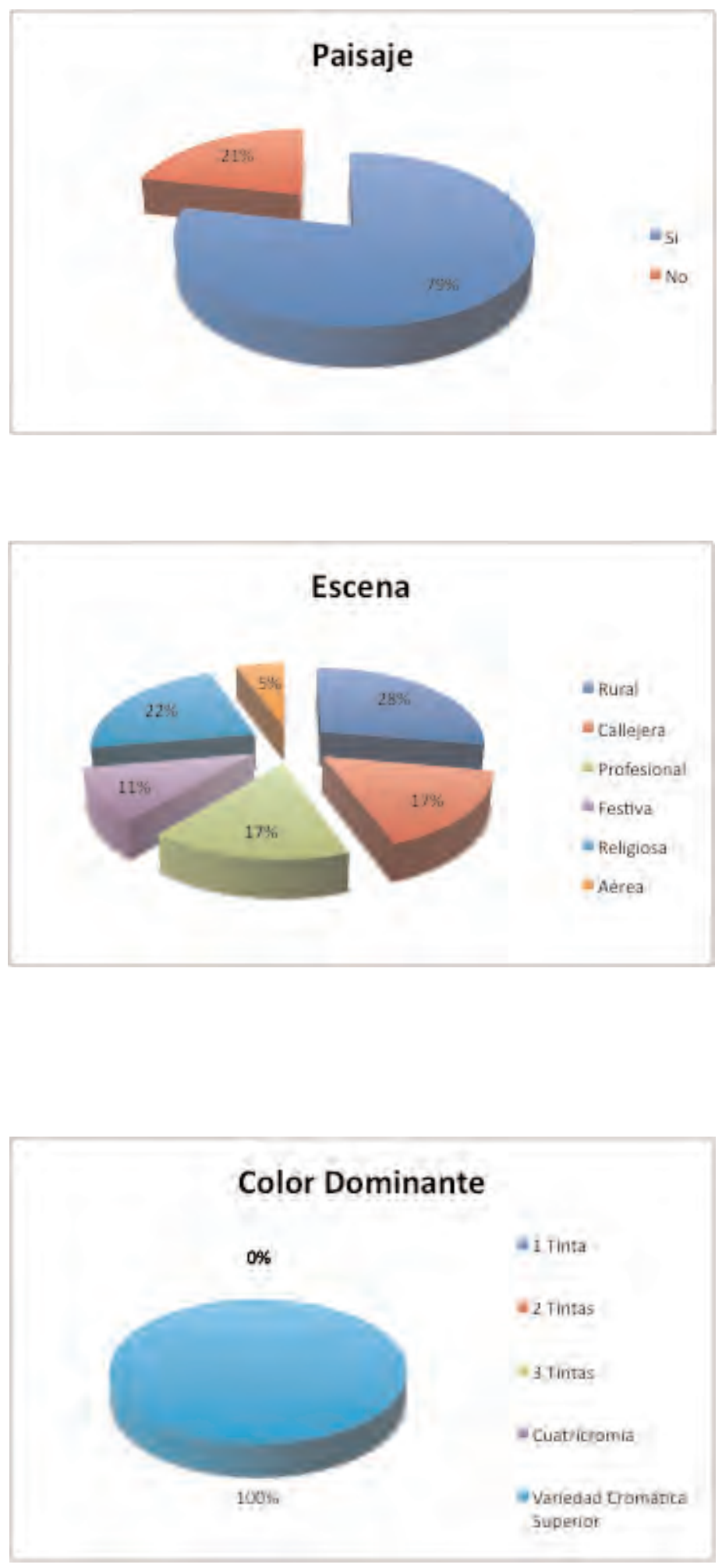

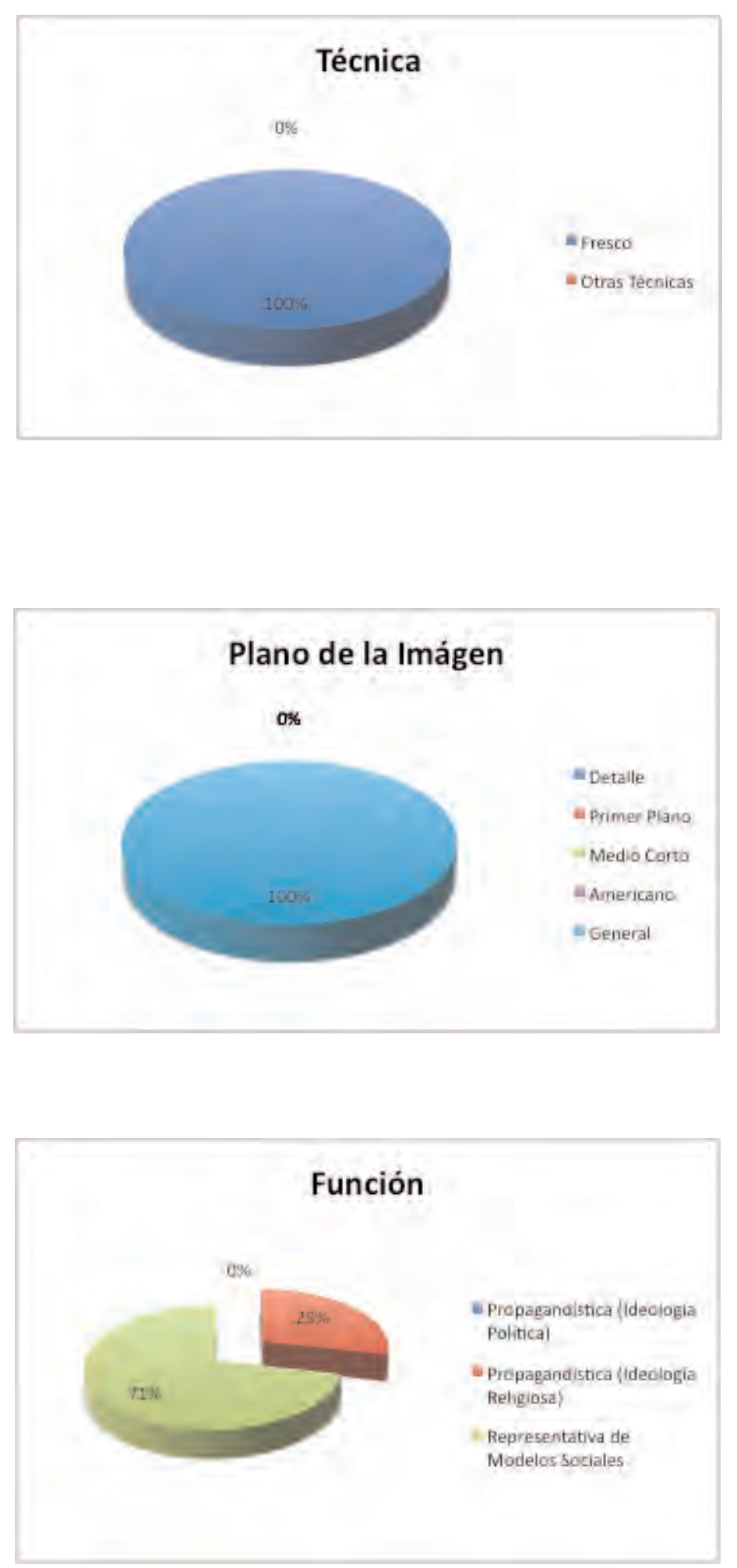


\section{Ilustraciones.}
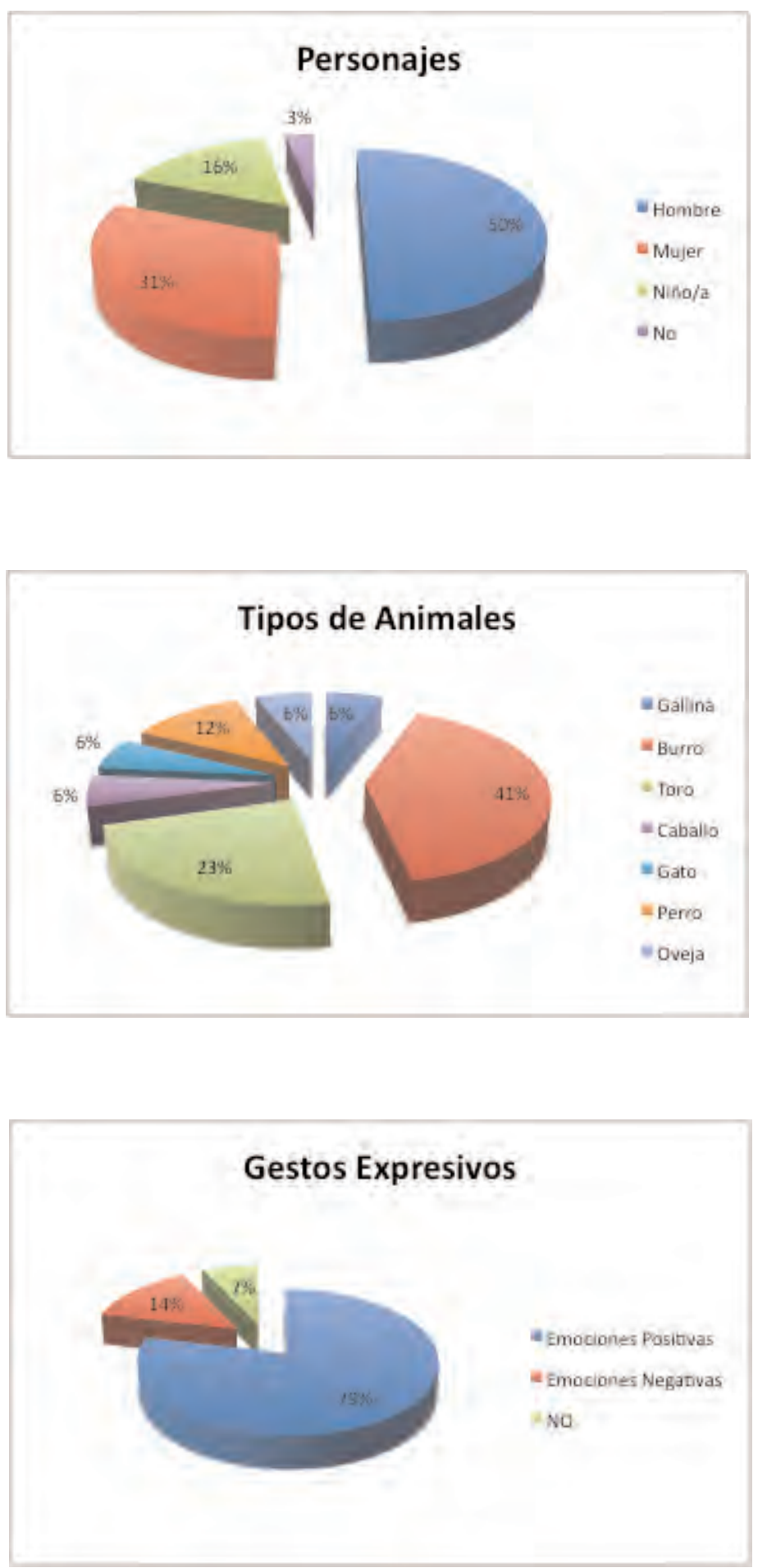

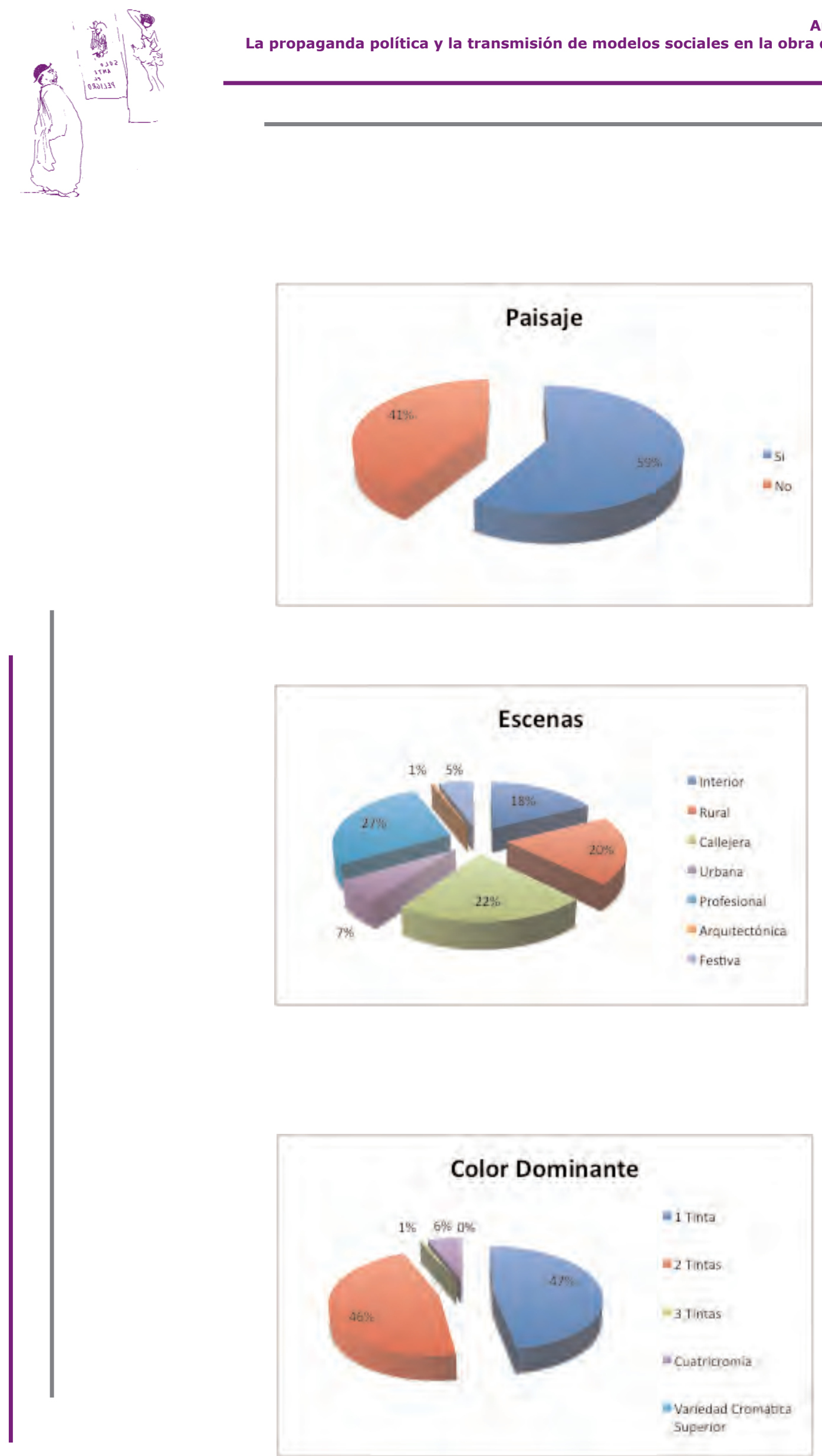

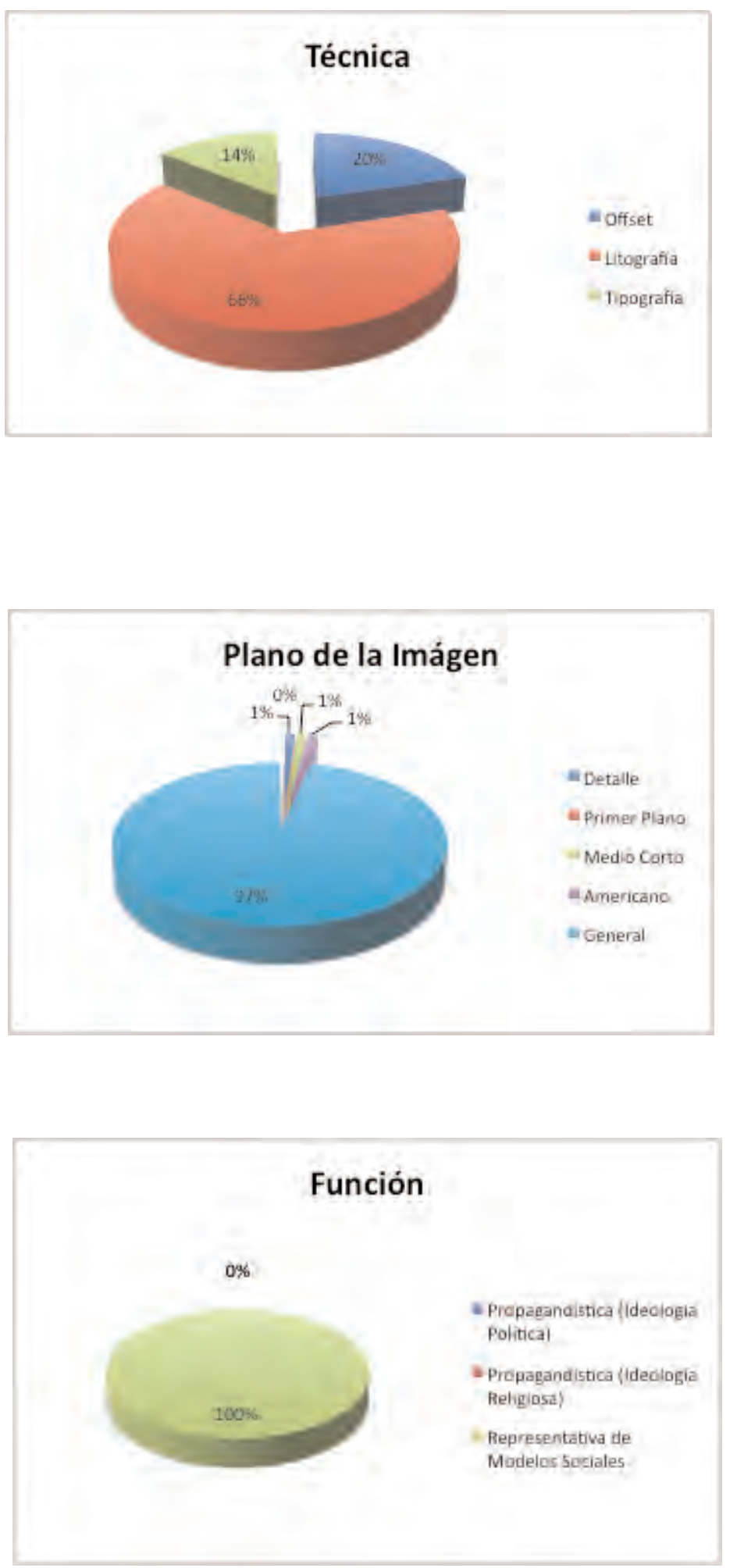


\section{Otras obras.}
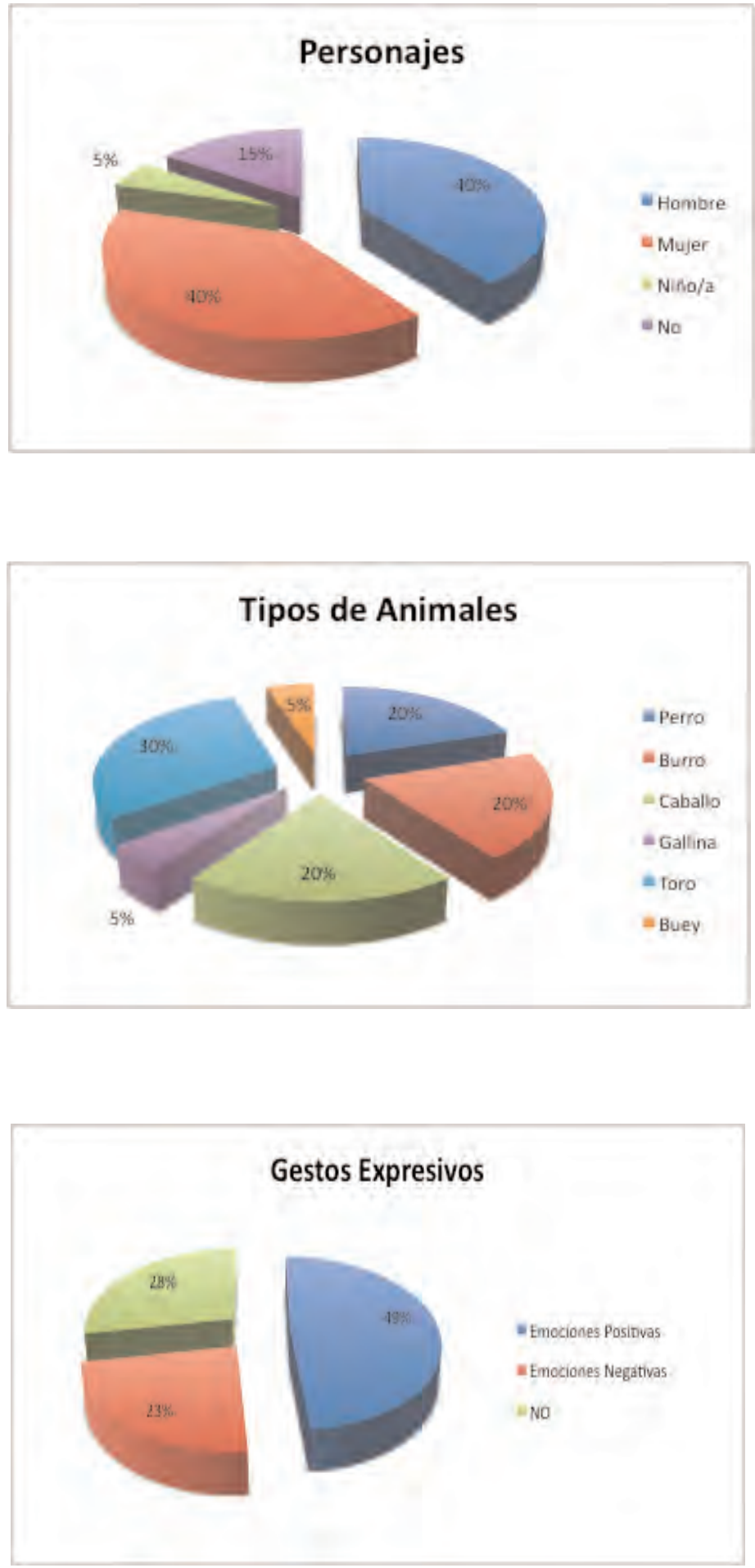

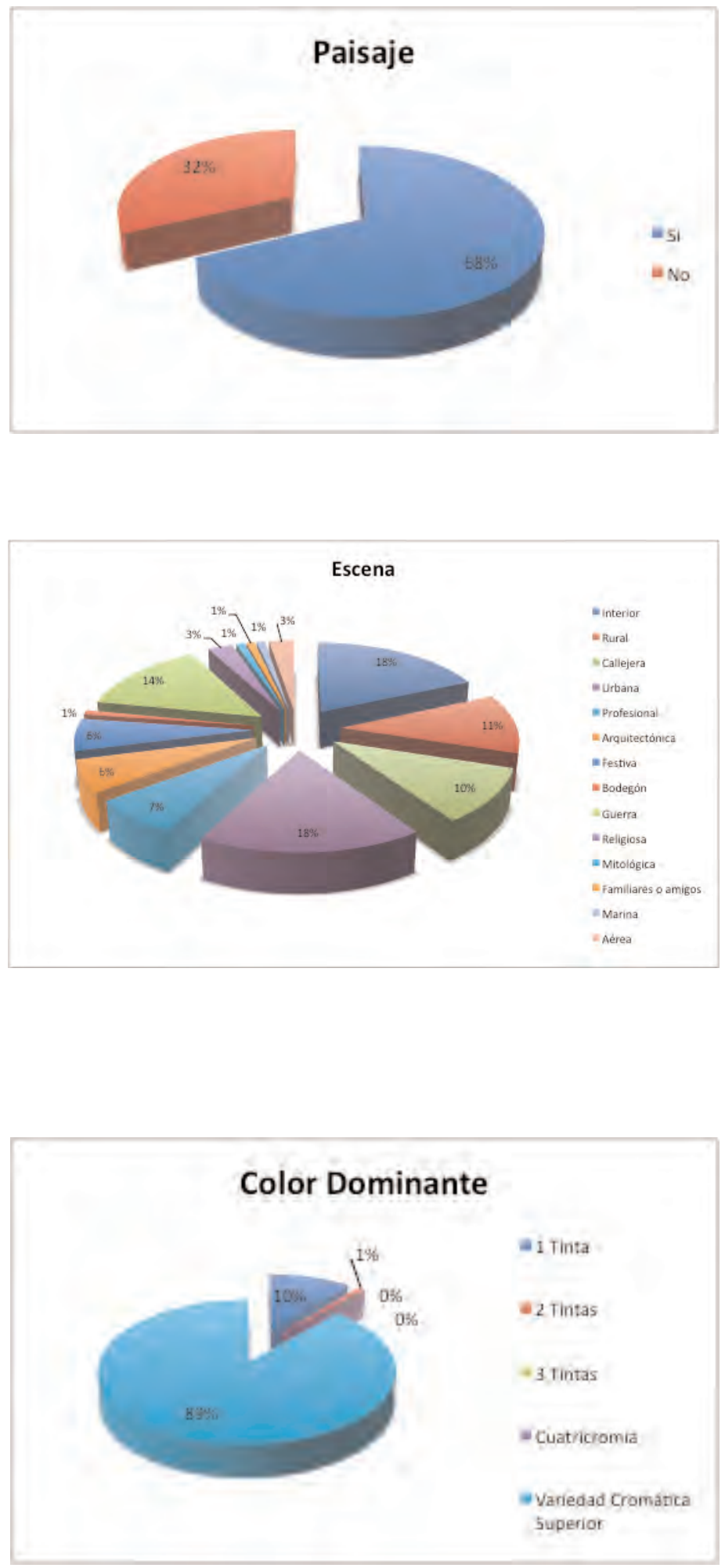

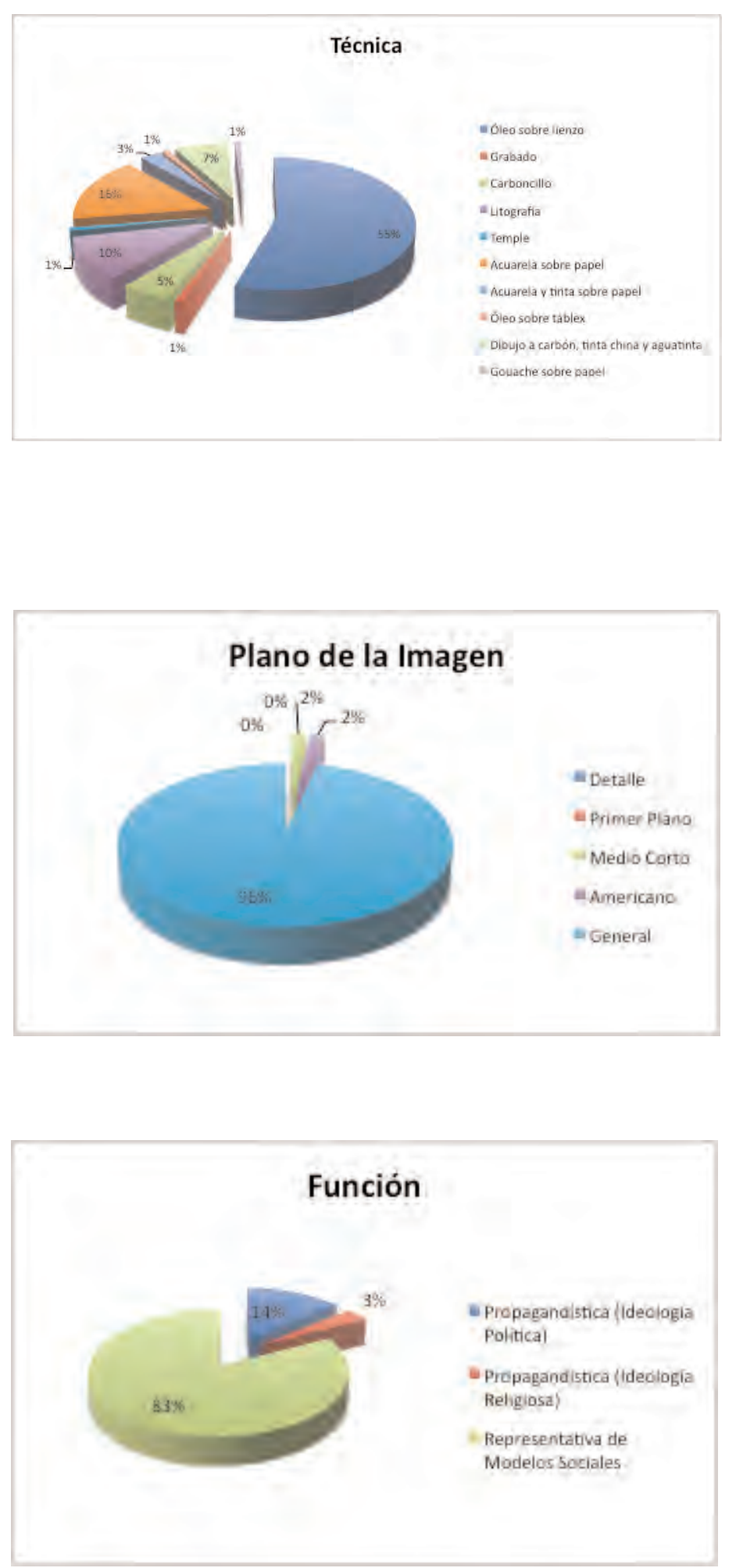


\section{Datos, gráficas y explicación de los resultados obtenidos del total de la muestra analizada.}

Contenido. En relación al contenido hemos seleccionado los diferentes indicadores: personajes, animales, gestos expresivos, paisajes y escenas.

\section{Personajes.}

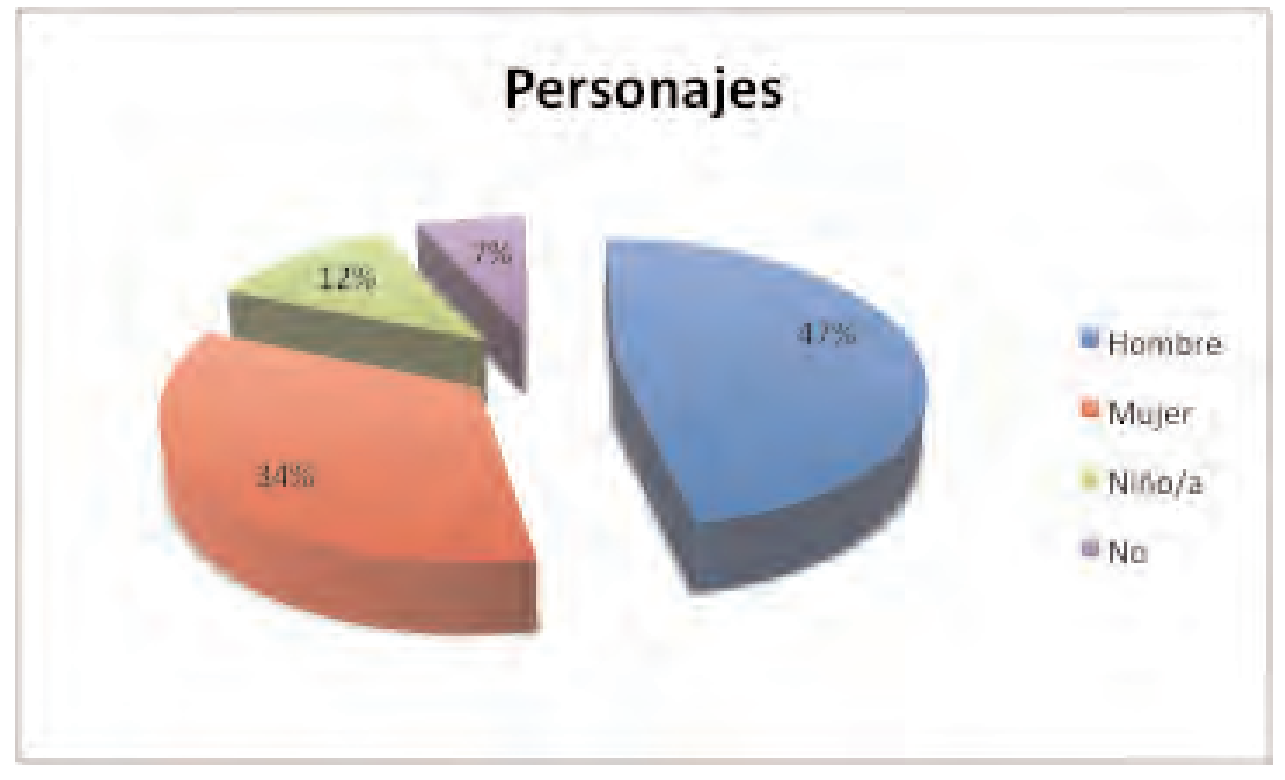

En la obra de Eduardo Vicente observamos una presencia mayor de personajes masculinos en todas las categorías analizadas: retratos $55 \%$, carteles el $60 \%$, murales el $45 \%$, ilustraciones el $50 \%$ y en otras obras el $40 \%$. Un $47 \%$ de hombres en el total de la muestra analizada.

En todas las categorías analizadas el número de hombres nunca es inferior al $40 \%$ en relación con la presencia femenina y de la infancia, destacando los carteles con un $60 \%$ y solamente en la categoría que hemos denominado "Otras obras" el número de mujeres y hombres es igual, llegando a tener ambos un 40\%. La representación de la infancia es muy inferior alcanzando únicamente un $5 \%$ del total representado

La presencia mayoritaria de personajes masculinos en la obra analizada puede justificarse por el papel que desempeñaban los hombres en este 
periodo histórico. Era una sociedad donde el hombre ejercía sus actividades dentro y fuera del hogar, por lo que tenía vida pública y privada. En el ámbito público realizaban su profesión y sus diversiones y en el ámbito privado del hogar representaban la autoridad, eran los cabezas de familia y todas las decisiones debían ser ejercidas o autorizadas por ellos. Por el contrario la mujer se quedaba relegada al ámbito privado, el hogar era su hábitat principal y sus acciones las relacionadas con las tareas domésticas, que eran consideradas exclusivamente femeninas (Fig. 33, 34, 35 y 36).

También, en este sentido, podemos destacar que Eduardo Vicente tuvo una implicación muy significativa en los círculos políticos y artísticos del momento, espacios dominados totalmente por los hombres.
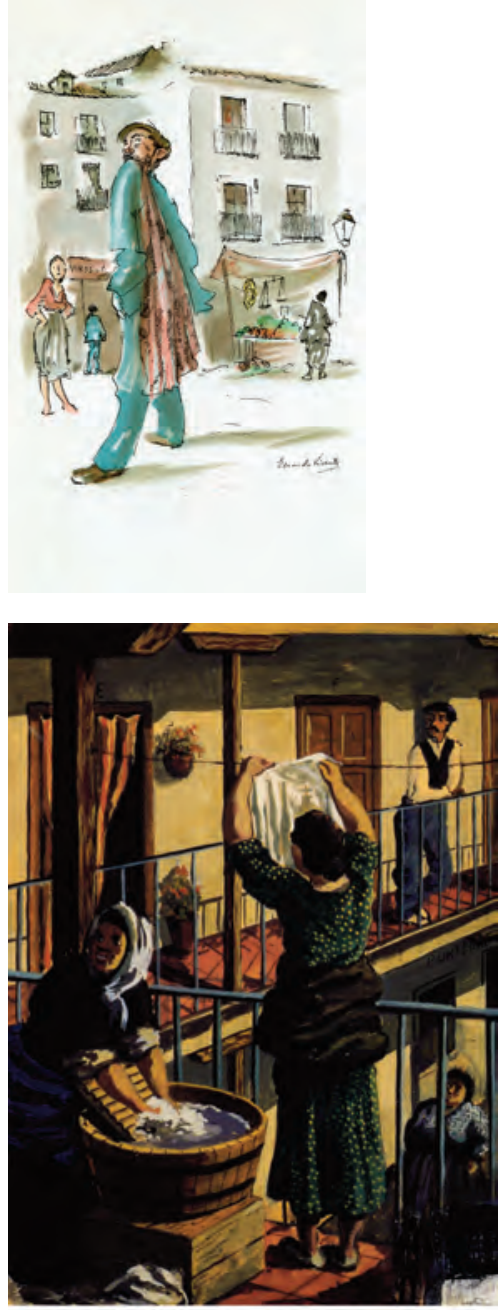
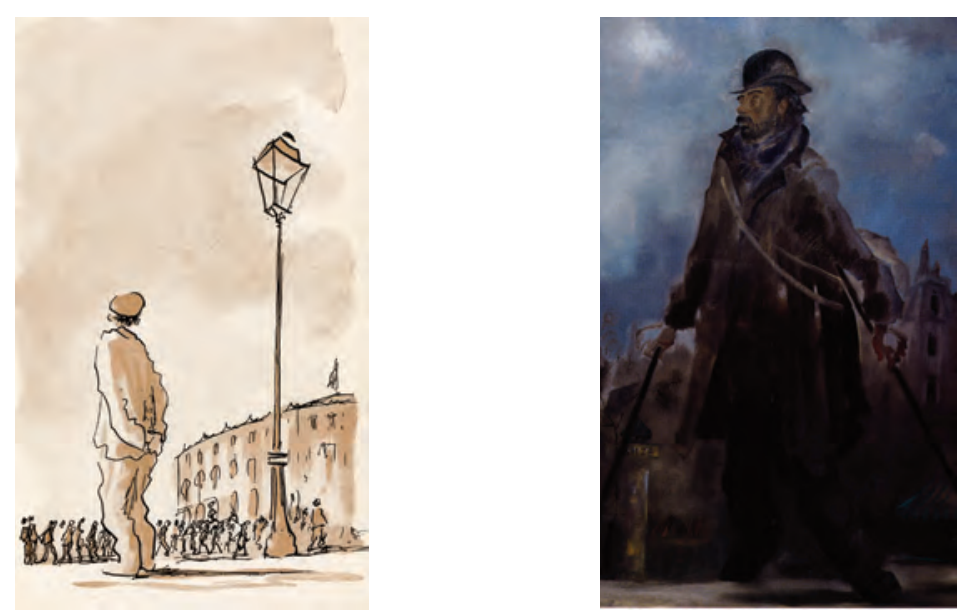

Figuras 33, 34, 35 y 36.

Distintos roles del hombre y la mujer de la época. 


\section{Animales.}

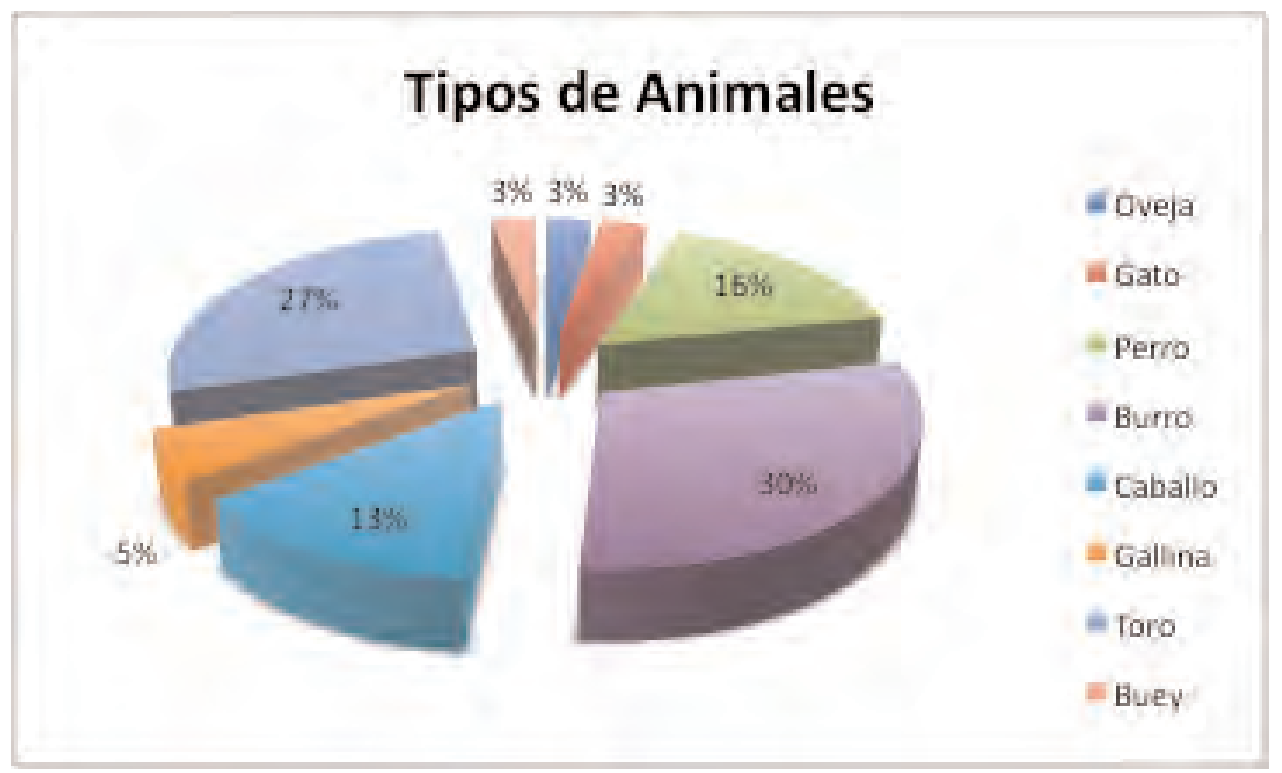

La presencia de animales ha sido un indicador a tener en cuenta en el análisis de la obra de Eduardo Vicente.

En este sentido podemos afirmar que en las categorías "Retratos" y "Carteles" no existe la presencia de ningún animal. En las demás categorías: murales, ilustraciones y otras obras, la presencia de animales es minoritaria, en ningún caso superan el $15 \%$ (murales $14 \%$, ilustraciones $9 \%$, y otras obras el $15 \%)$.

Los animales que aparecen en la obra son todos domésticos (Fig. 37, 38 y 39), la presencia del burro es la más numerosa alcanzando un porcentaje del $11 \%$, estos animales servían, en la época analizada, como medio de transporte para llevar las mercancías, así podemos ver cómo transportan vino y otras viandas.

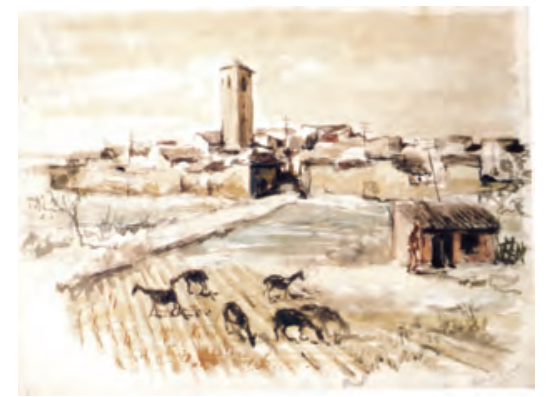

Fig, 37.

Animales pastando. 


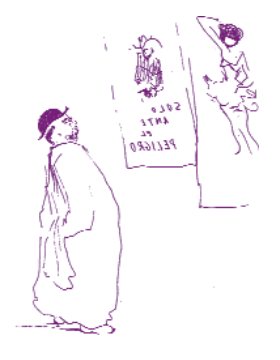

Fig. 38 y 39.

Los animales domésticos

forman parte de la obra

del artista.

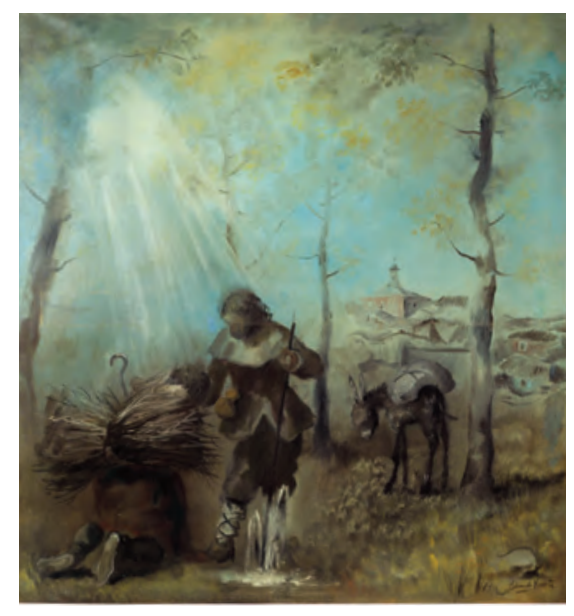

Los toros también están representados en la obra de Eduardo Vicente, con un porcentaje del $10 \%$, no olvidemos que el artista ejerció como ilustrador taurino para la editorial Espasa-Calpe. Podemos contemplar, en su obra, la fiesta taurina con escenas llenas de colorido (Fig. 40).

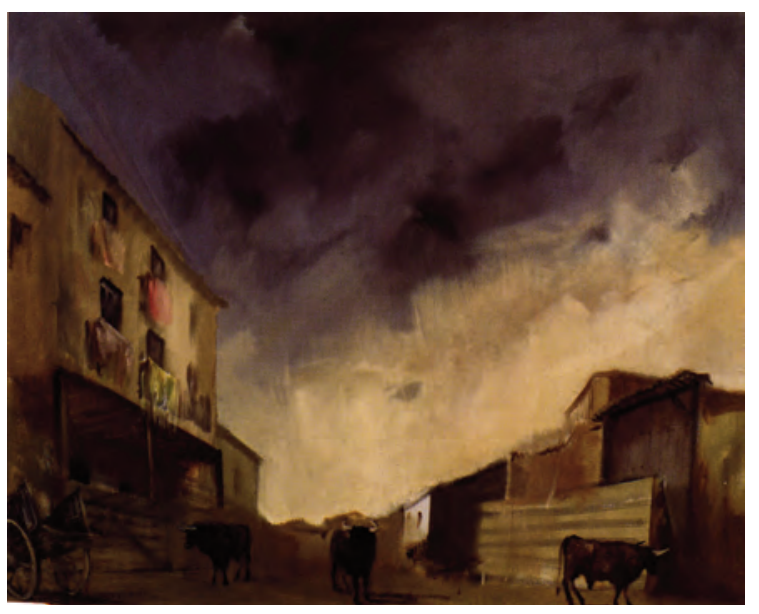

Fig. 40.

El caballo (5\%) y el buey (1\%) como animales de trabajo que utilizaban los labradores para realizar las tareas propias de la agricultura.

El perro (6\%) y el gato (1\%) como animales de compañía. La oveja $(1 \%)$ y la gallina $(2 \%)$ como animales para la subsistencia. 


\section{Gestos expresivos.}

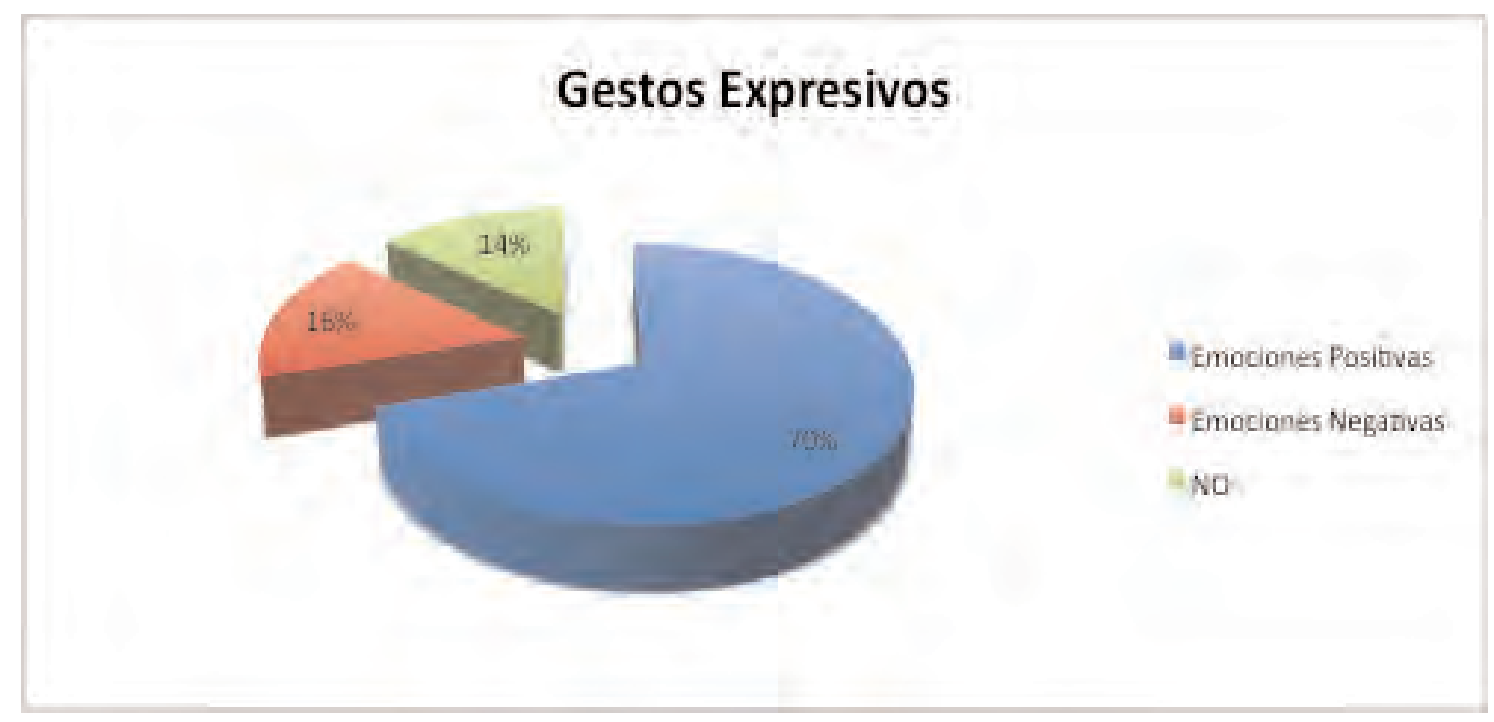

Para el análisis de los gestos expresivos hemos establecido dos categorías relacionadas con las emociones que transmiten. Las denominamos positivas y negativas, en función de que consideremos que reflejan el bienestar (paz, armonía, alegría, felicidad,...) y el malestar (miedo, tensión, ira, cólera, tristeza,,..$)$.

Esta tarea no ha sido fácil, pues es muy difícil ser objetivos en este sentido, ya que al contemplar la obra artística, cada uno de nosotros refleja sus propias emociones y sus experiencias previas, generalizando sus sensaciones y dándoles su propio significado.

A pesar de la dificultad señalada, sí podemos afirmar que la obra de Eduardo Vicente es una expresión mayoritaria de emociones positivas con un porcentaje del $70 \%$, como lo demuestran los datos obtenidos en todas las categorías estudiadas.

En los retratos, todos los personajes presentan gestos expresivos positivos (100\%), el artista intenta reflejar en su obra lo mejor de cada uno de ellos, y esto es así, porque todas las personas retratadas mantenían una relación emocional con el pintor. 
Los carteles presentan un porcentaje del $82 \%$ de gestos positivos, no olvidemos que estos formatos tenían una función propagandística e intentaban transmitir las bonanzas de la ideología a la que representaban. Las emociones negativas con $18 \%$ reflejan las dificultades y los peligros de un país en guerra.

En los murales podemos apreciar un $87 \%$ de emociones positivas y no aparecen, en ninguno, los gestos expresivos negativos, esto puede ser debido a que estos trabajos se realizaban por encargo y querían ser un elemento estético para la decoración.

En las ilustraciones también predominan los gestos expresivos positivos con un porcentaje de $89 \%$ frente a un $4 \%$ de expresiones negativas.

En la categoría denominada "otras obras" encontramos un $61 \%$ de gestos expresivos positivos, frente a un $11 \%$ de gestos expresivos negativos, casi el total de estos últimos corresponden a los cuadros que reflejan la crueldad de la guerra civil (Fig. 41, 42, 43 y 44).
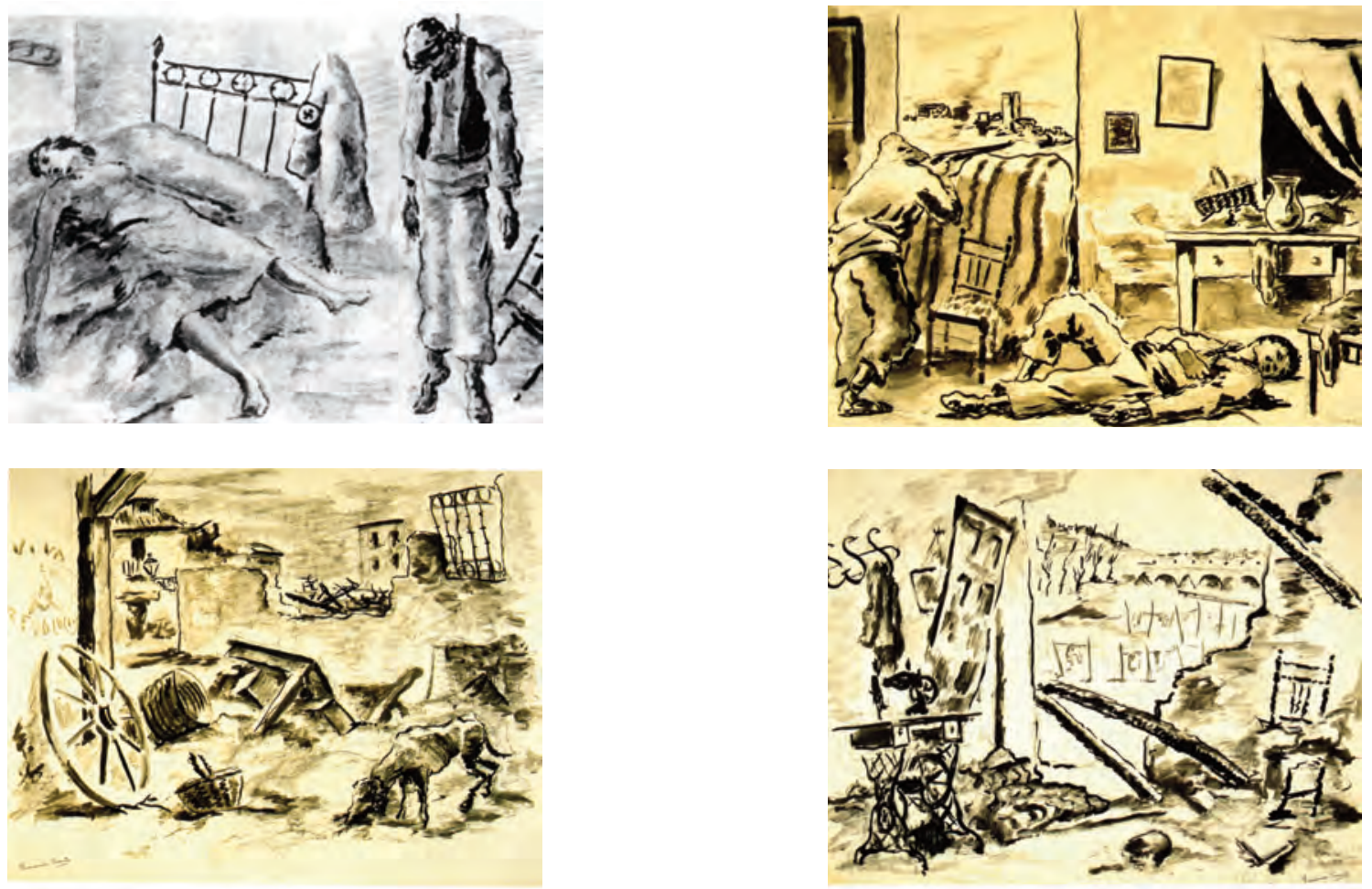

Fig. 41, 42, 43 y 44.

Eduardo Vicente no quiso que quedará en el olvido la barbarie de la Guerra Civil Española. 
El estudio de los gestos expresivos nos ha servido también para conocer algunos de los rasgos de personalidad de Eduardo Vicente, hombre vitalista, luchador, positivo que tuvo que adaptarse a la realidad del momento, pero que siempre permaneció fiel a su pensamiento e ideología.

\section{Paisajes.}

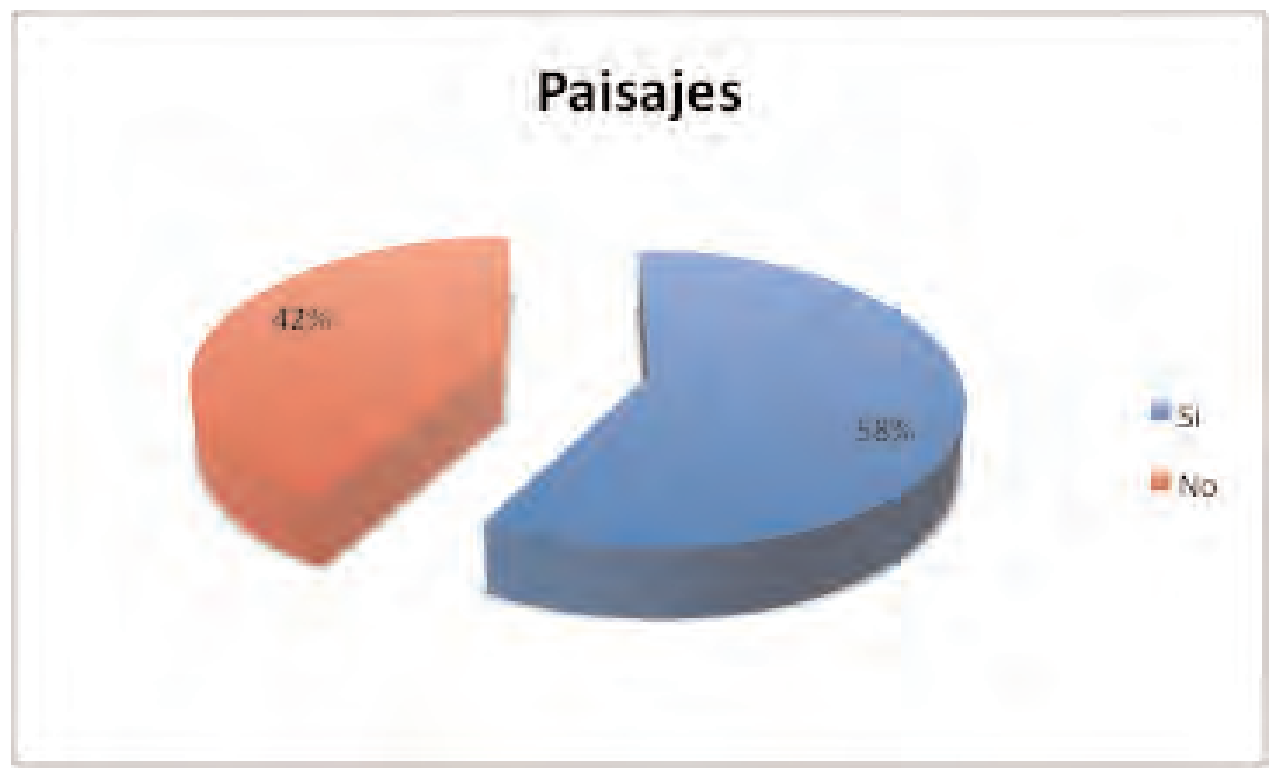

La existencia de paisajes en la obra de Eduardo Vicente es significativa ya que muchas de sus obras representan la realidad física como escenario de la composición gráfica. Los paisajes nos permiten conocer cómo eran las ciudades y sus alrededores, donde vivió y pintó el artista. Fue un artista que supo plasmar la vida cotidiana de Madrid. Su estilo de trazos ágiles y limpios, que interpretó con un sentido poético y con una gran delicadeza cromática las esencias de Madrid. Los escenarios que poblaron sus cuadros fueron esencialmente la Puerta del Sol, el Rastro, los descampados de las afueras de la ciudad, y los lugares próximos al Manzanares En estos paisajes urbanos, en los que aparecen figuras anónimas de la calle, plasmó sus grandes dotes para reproducir los ambientes de la ciudad, con una gran sensibilidad, un toque que resulta nostálgico, y una cierta carga expresionista. autores:

El Madrid pintado por Eduardo Vicente ha sido comentado por diferentes 
"El Madrid de Eduardo Vicente, su gran pasión, es innecesario ponerlo hoy sobre el tapete: Lo ha reflejado todo, y ha ido fijando a través de su obra tanto sus invariantes como sus radicales cambios". 9

Pérez Ferrero, M. (1968: 100

"Desde que en 1928 hizo su primera exposición en el Ateneo, ya aparece Madrid en sus cuadros como romántica variación: con una técnica que casi convierte el óleo en transparente acuarela, a la que siempre sería fiel, con colores muy matizados, pasta levísima, finísimos grises y un dibujo delicado sosteniéndolo todo como una arquitectura japonesa".10

Camoy, A. M. (1968: 32)

También nos deja información de otras ciudades, como París, Nueva York, Ámsterdam, Segovia y otros pueblos donde plasma el paisaje rural (Fig. 45, 46, 47, 48, 49 y 50).

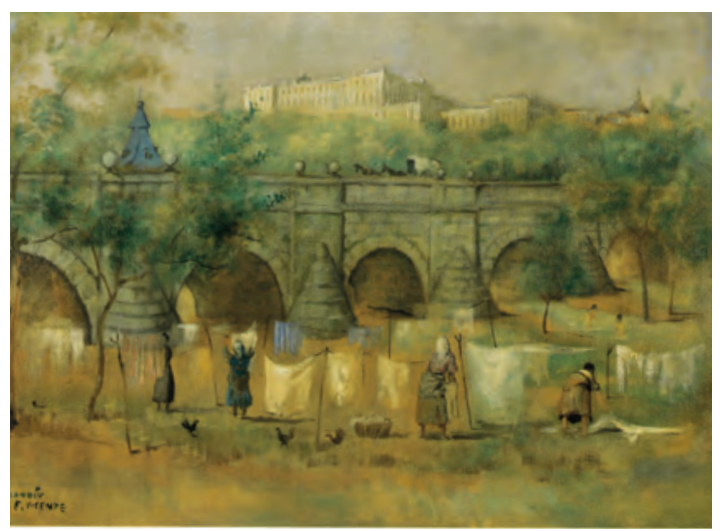

Fig. 45.

Puente de Segovia con lavanderas.

Fig. 46.

Madrid es la ciudad que más veces quedó plasmada en la obra de Eduardo Vicente

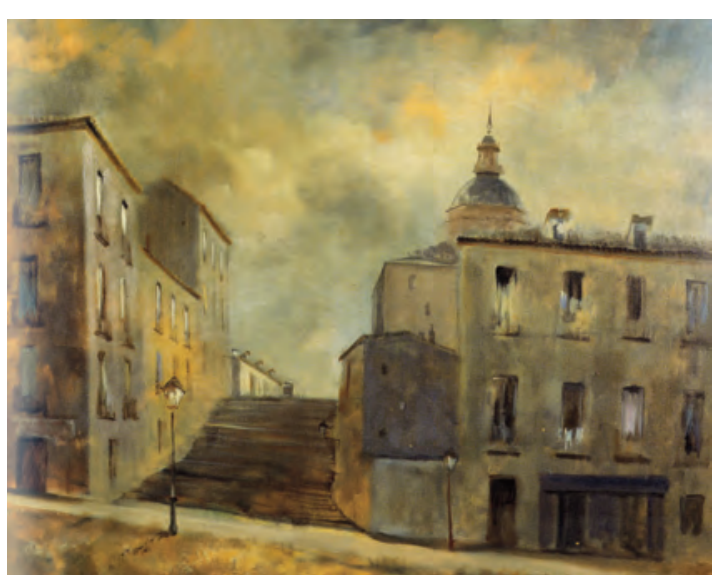


Eduardo Vicente entre la pintura y la ilustración gráfica. Contexto social y estudio experimental.

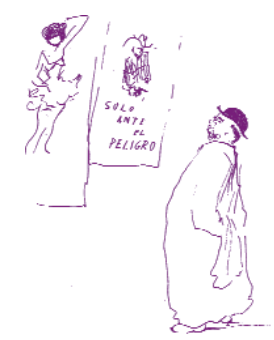

Fig. 47.

Paisaje pintado en uno de sus viajes a Nueva York
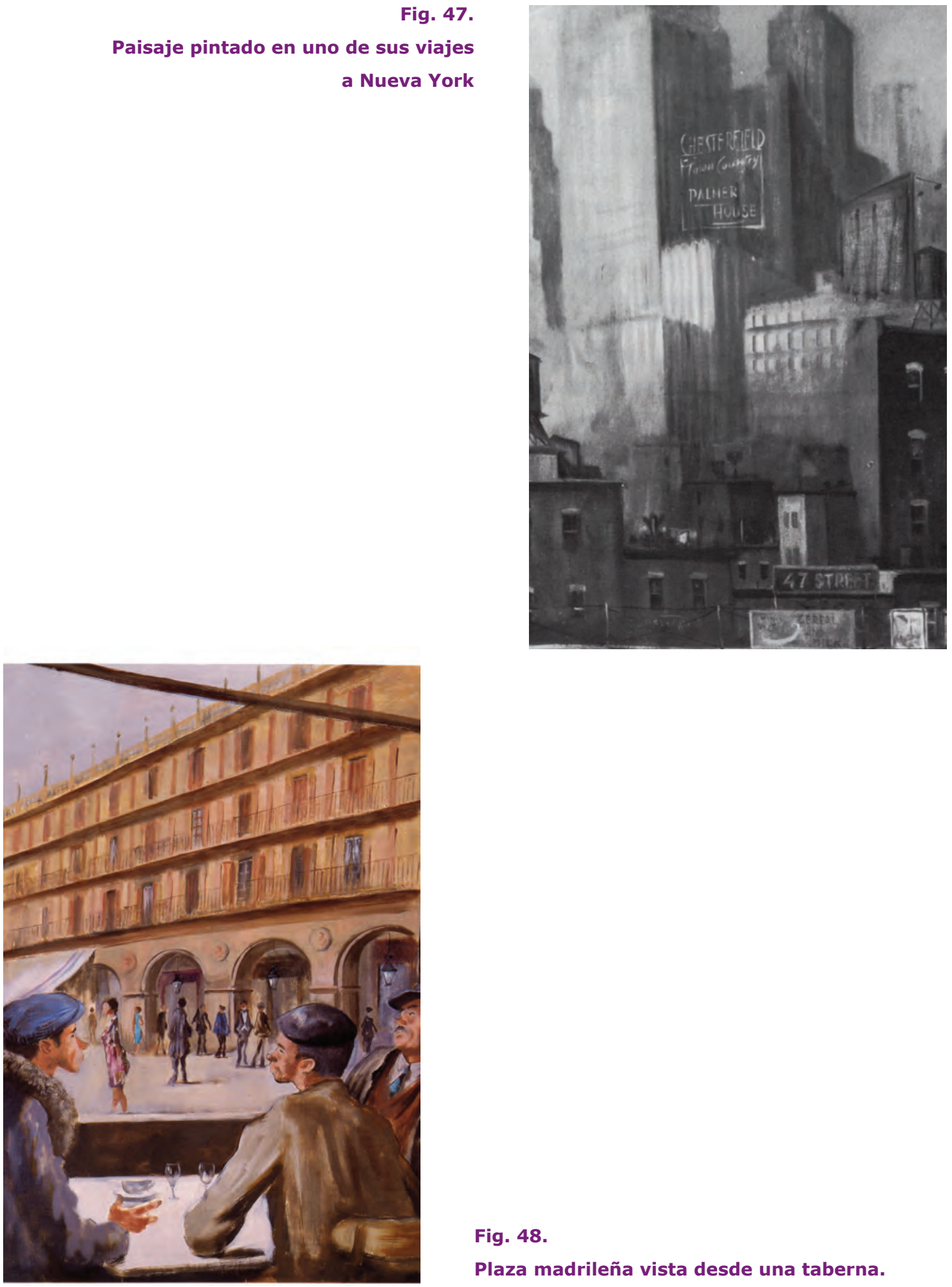

Fig. 48.

Plaza madrileña vista desde una taberna. 
Arte y Comunicación.

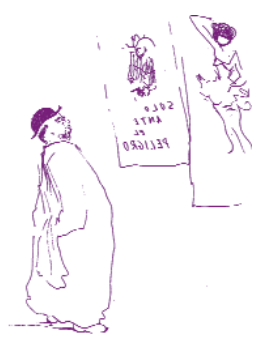
La propaganda política y la transmisión de modelos sociales en la obra de Eduardo Vicente.

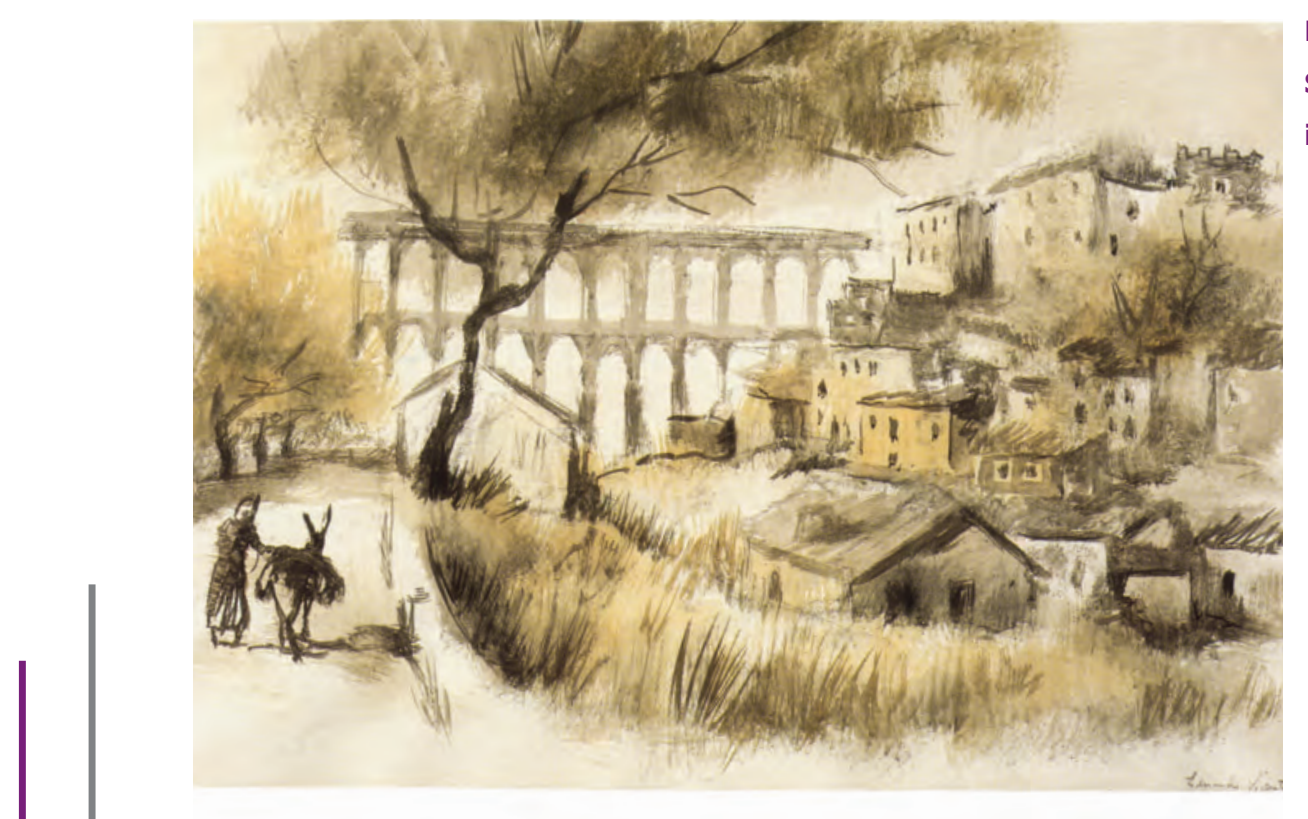

Fig. 49.

Segovia, recuerdo de la infancia del pintor.

Fig. 50.

Metro de París.

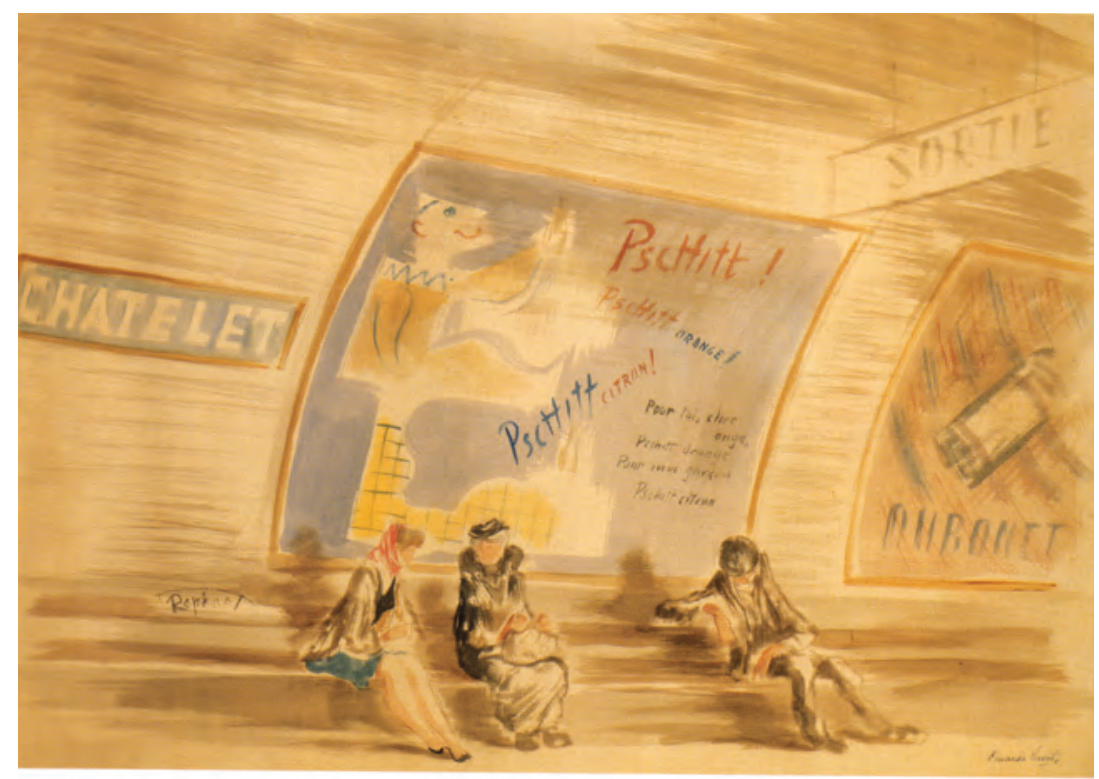


En todas las categorías, exceptuando los retratos, están plasmados los paisajes. Los murales son en los que alcanzan un porcentaje mayor, $79 \%$, seguido de "Otras obras" con un $68 \%$ y las ilustraciones con un $59 \%$. En los carteles sólo aparecen un $18 \%$ de paisajes que se utilizan como fondo destacando la figura en un primer plano.

\section{Escenas.}

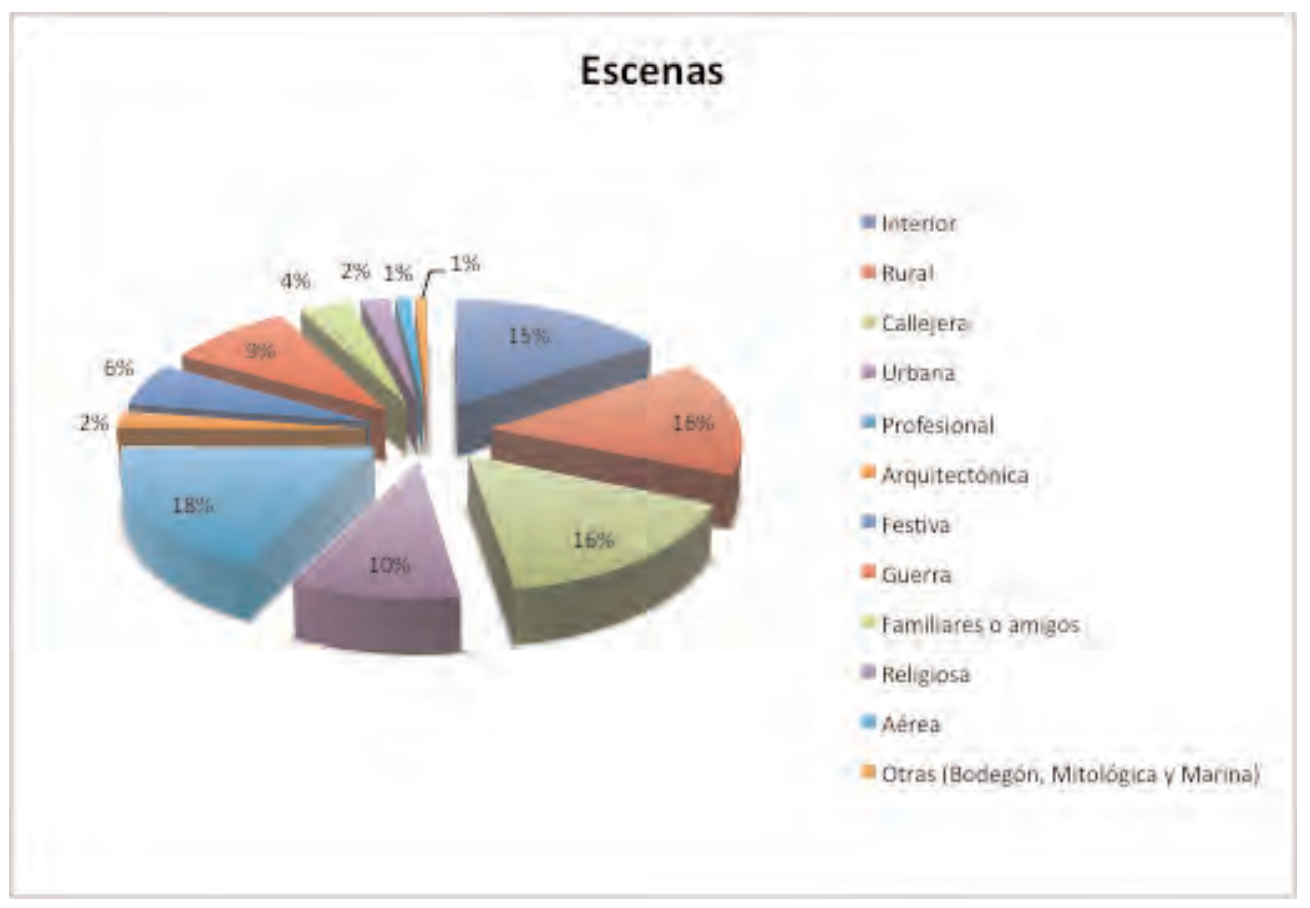

El estudio de las escenas que aparecen en la obra de Eduardo Vicente lo hemos dividido en diferentes categorías, un total de catorce, para poder explicar de forma más exhaustiva la riqueza de las composiciones del autor; así contemplamos escenas interiores y exteriores, rurales y urbanas, profesionales, festivas, arquitectónicas, de guerra, de familiares y amigos, religiosas, aéreas, bodegones, mitológicas y marinas.

De todas ellas destacamos las profesionales con un porcentaje del $18 \%$, al artista le gustaba plasmar los más variadas profesiones, así podemos ver en su obra al quesero, el viñatero, el bodeguero, el limpiabotas..., esta representación de las escenas profesionales son un indicador importante para entender la forma de vida y la cultura dominante en esta época analizada. 
Le siguen las escenas callejeras, las rurales y las interiores con un $16 \%$ de presencia cada una de ellas (Figuras 51, 52, 53, 54 y 55).

Las demás escenas alcanzan porcentajes inferiores a un $10 \%$.

El estudio de las escenas nos ha servido para conocer la vida de la calle, con los tipos de la calle como les denomino Eduardo Vicente en su obra publicada en 1950 en la que el propio artista comenta:

"... quiero decir que es necesario que el arte, y en mi caso concretamente el pictórico, sirva al futuro en el cuadro general de la cultura, el tejido de la vida humana en toda su complejidad, dentro de las limitaciones naturales que la materia expresiva impone tiránicamente". 11

Vicente, E. (1950:9)
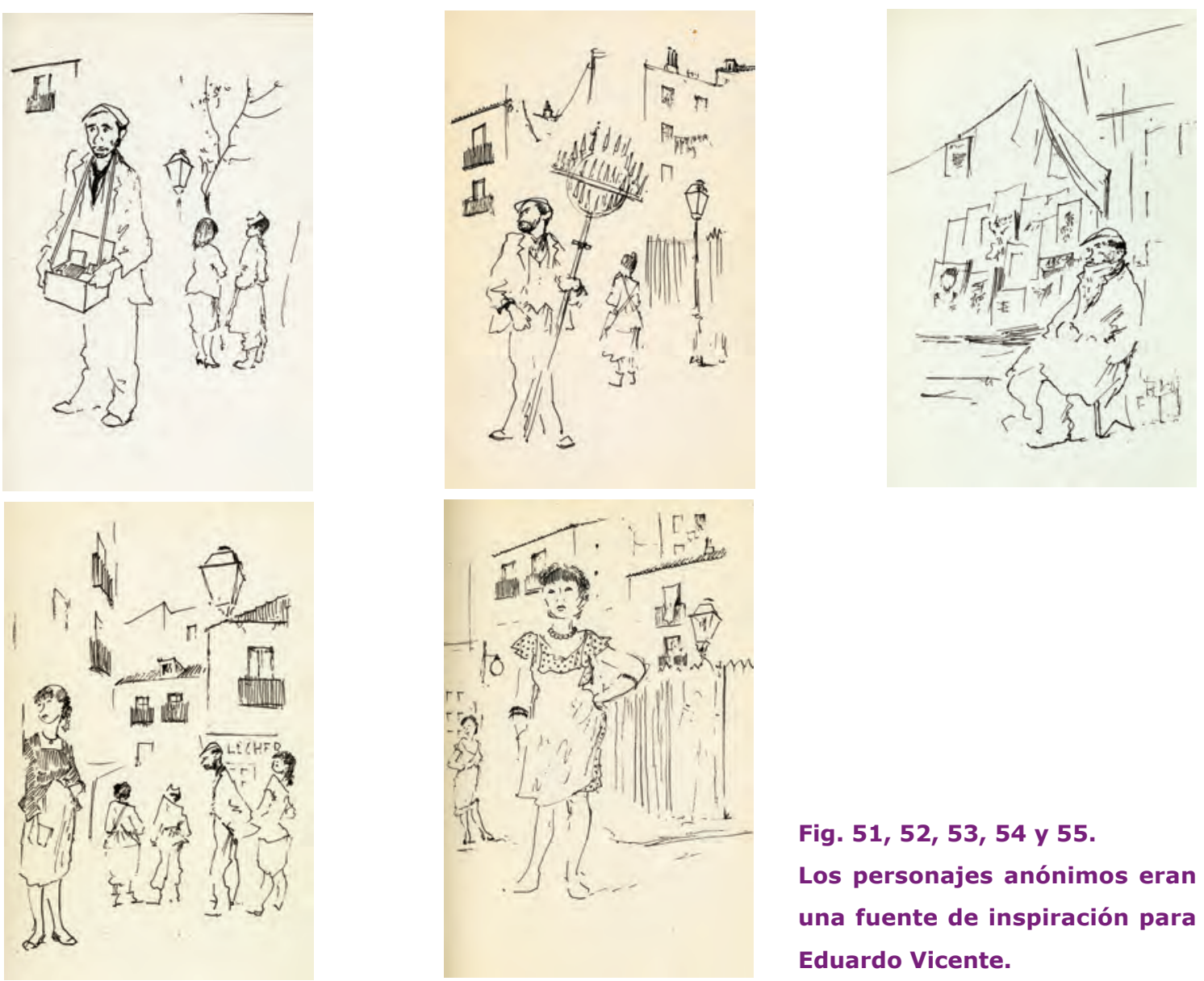

Fig. 51, 52, 53, 54 y 55 .

Los personajes anónimos eran una fuente de inspiración para Eduardo Vicente. 
La vida en los hogares, las reuniones de amigos y familiares, las fiestas, sus bailes, las corridas de toros y los encierros, muestran las formas de vida y la diversión y entretenimientos de esta etapa histórica (Fig. 56 y 57).
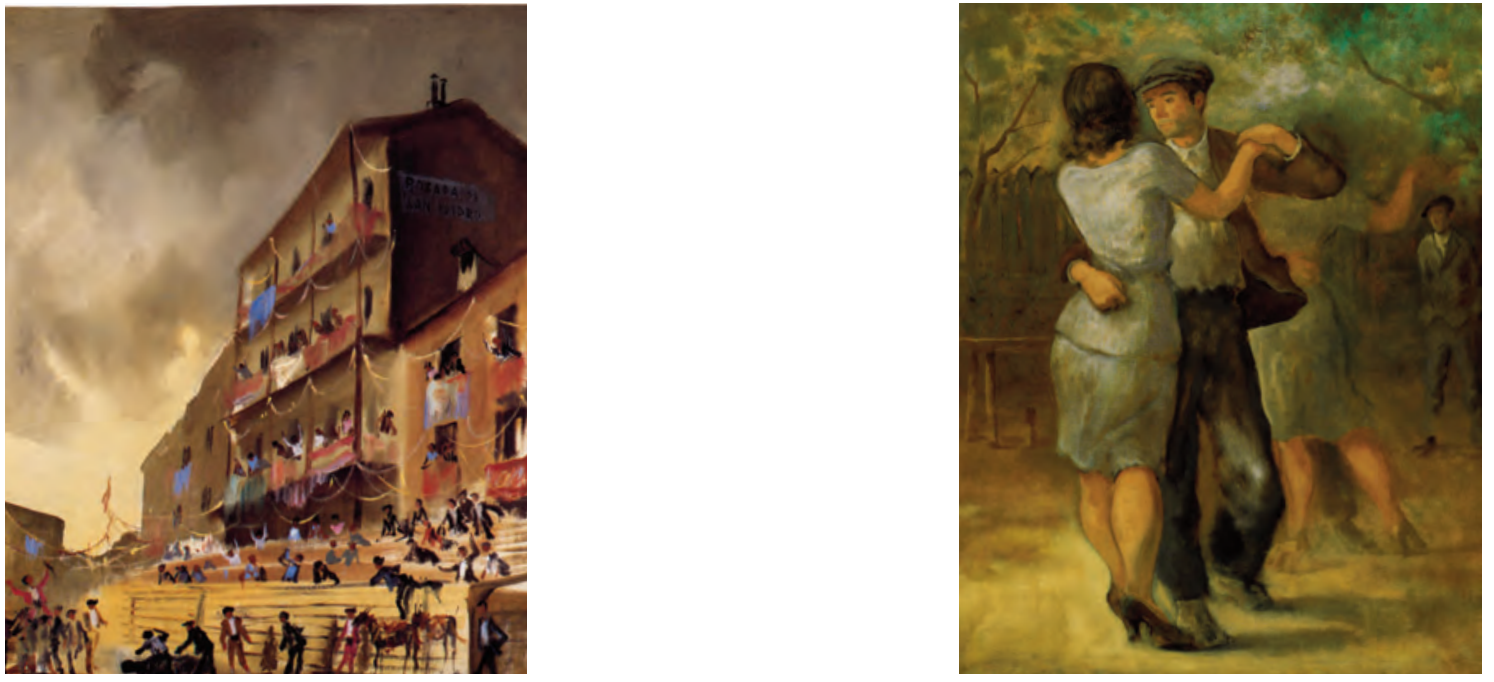

Fig. 56 y 57

Las fiestas populares está presentes en la obra del artista.

La guerra civil no pasa inadvertida para el artista, él quiere dejar constancia de la soledad, el dolor, el miedo y la muerte y denunciar con sus pinceles la existencia de un hecho trágico vivido por él y sus conciudadanos para servir de testigo y de denuncia de lo que no debe repetirse (Fig. 58 y 59).
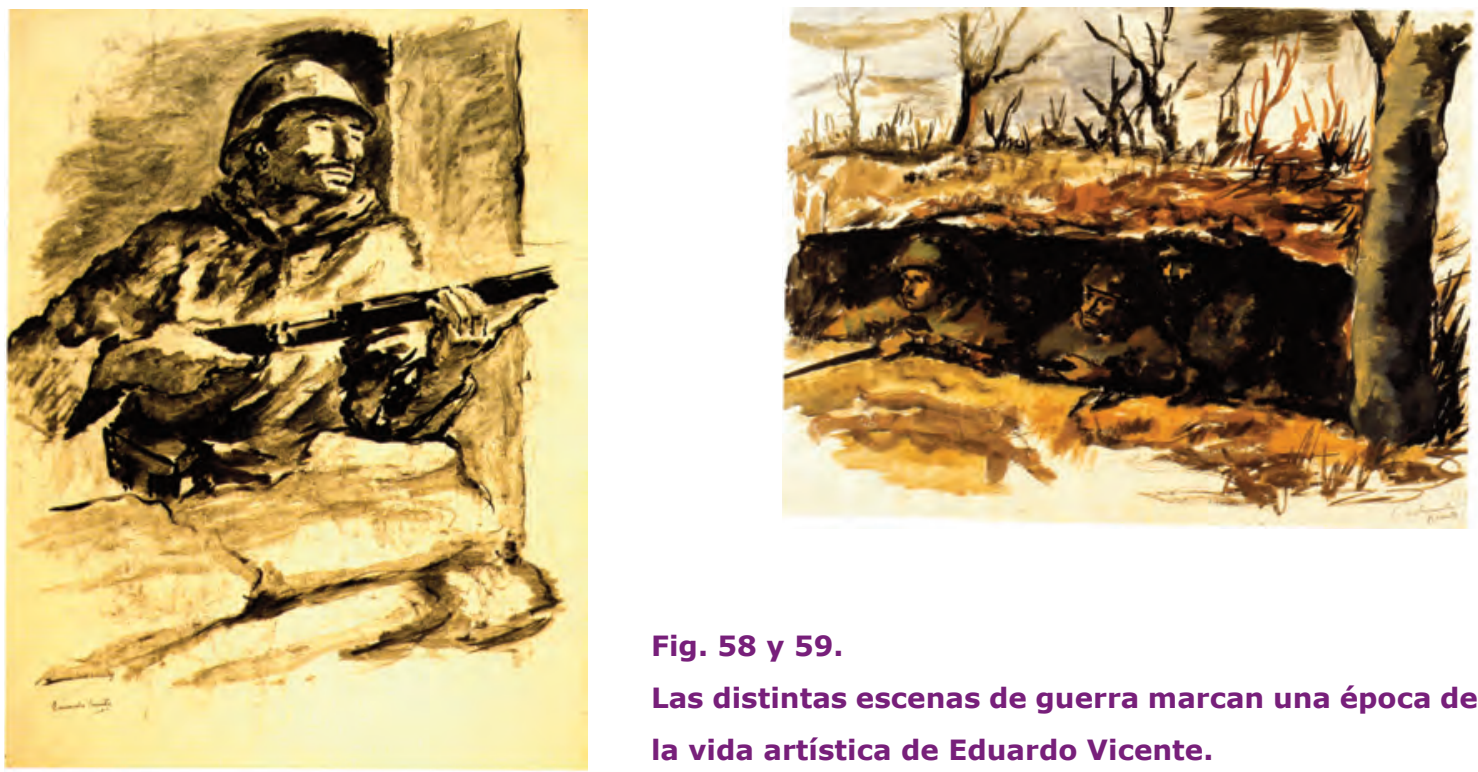

Fig. 58 y 59.

Las distintas escenas de guerra marcan una época de la vida artística de Eduardo Vicente. 
Las escenas arquitectónicas y religiosas tienen muy poca representatividad en torno al 4\%, y con una presencia insignificante quedan las cuatro restantes. Aéreas, bodegones, mitológicas y marinas.

\section{* Aspectos técnicos.}

Dentro de los aspectos técnicos hemos analizado el color dominante, la técnica de impresión y el plano de la imagen.

\section{Color dominante.}

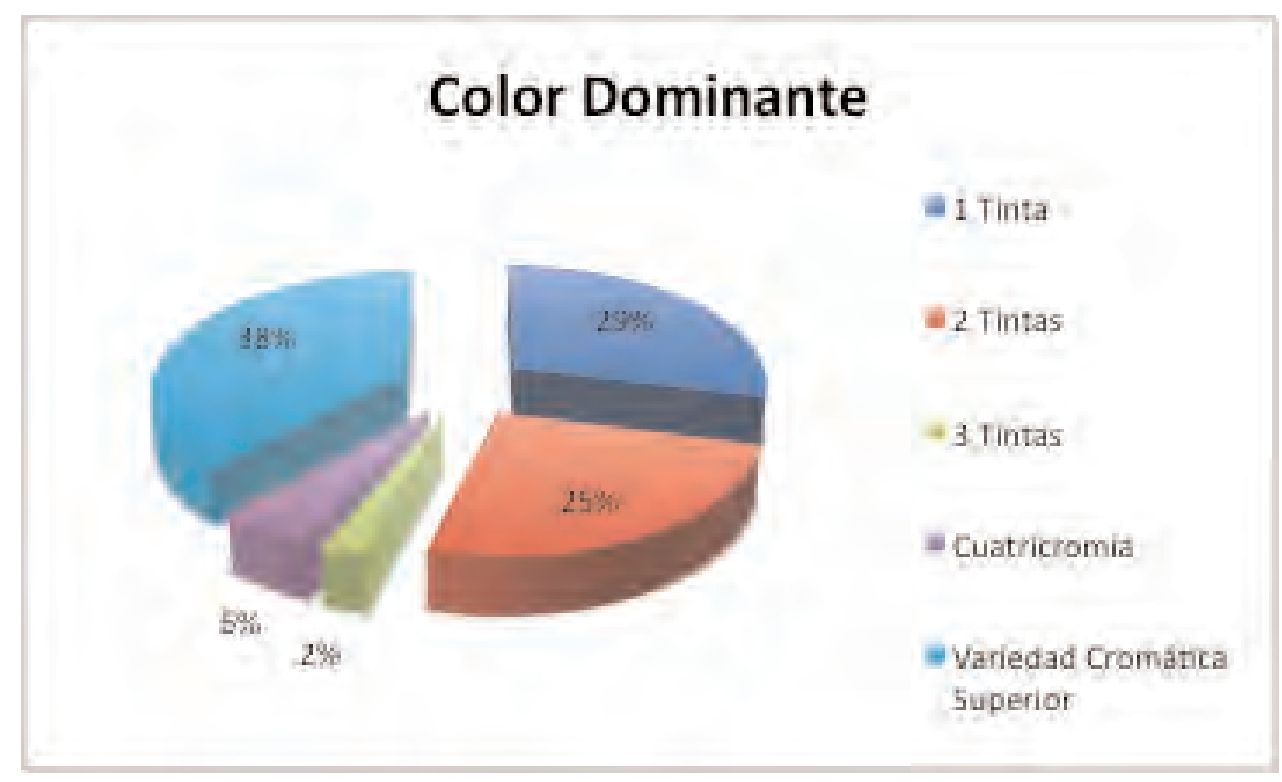

En la obra de Eduardo Vicente, en cuanto al uso del color, comprobamos que utiliza todas las posibilidades, desde el uso del blanco y negro hasta la cuatricromía.

El uso de una tinta alcanza un porcentaje del $29 \%$ y el de dos tintas un $25 \%$ lo que asciende a un total del $54 \%$, más de la mitad de la muestra seleccionada. La utilización de tres tintas con un $2 \%$ y la cuatricromía con un $6 \%$ representan un porcentaje del $8 \%$ de la muestra.

También cabe destacar que en un $38 \%$ de la muestra presenta una variedad cromática superior. 
La utilización del color puede explicarse fácilmente por las técnicas de impresión que existían en aquel momento, así como por el coste de las mismas.

\section{Técnica de impresión.}

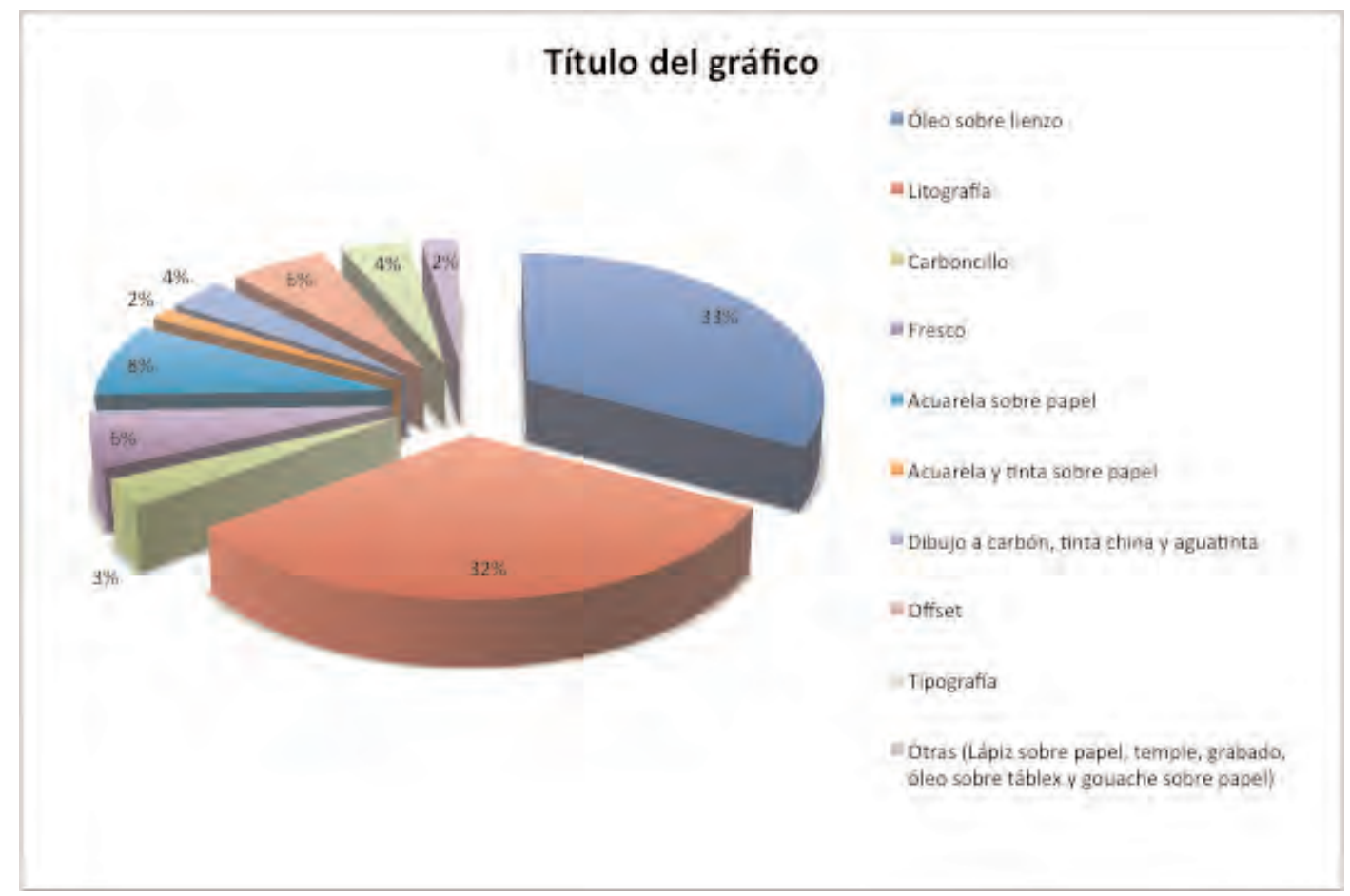

Eduardo Vicente fue un maestro en el manejo de las técnicas de impresión, aunque la mayoría de las obras analizadas están realizadas en óleo sobre lienzo $34 \%$ y en litografías con un 33\%, también podemos contemplar su dominio con la acuarela sobre papel, el fresco, el offset, la tinta china y aguatinta, la tipografía, los dibujos a carboncillo, el lápiz sobre papel y en menor medida, utilizó el temple, el grabado, el óleo sobre táblex y el gouache sobre papel.

Los tipos de obras determinan la técnica utilizada, así los retratos están realizados mayoritariamente en óleo sobre lienzo, con un 55\%, seguido de litografía con un 33\%, el resto de retratos están hechos usando carboncillo y lápiz sobre papel. 
Todos los carteles son tipografías $100 \%$, así como los murales que están todos pintados al fresco.

En las ilustraciones destacan las litografías con un porcentaje del $66 \%$, seguida del offsset con un $20 \%$ y tipografías con un $14 \%$.

En la categoría denominada "Otras obras" más de la mitad de la muestra analizada, 55\% es óleo sobre lienzo, le sigue la acuarela sobre papel, con un porcentaje del $16 \%$. En esta categoría están representadas la mayoría de las técnicas.

\section{Plano de la imagen.}

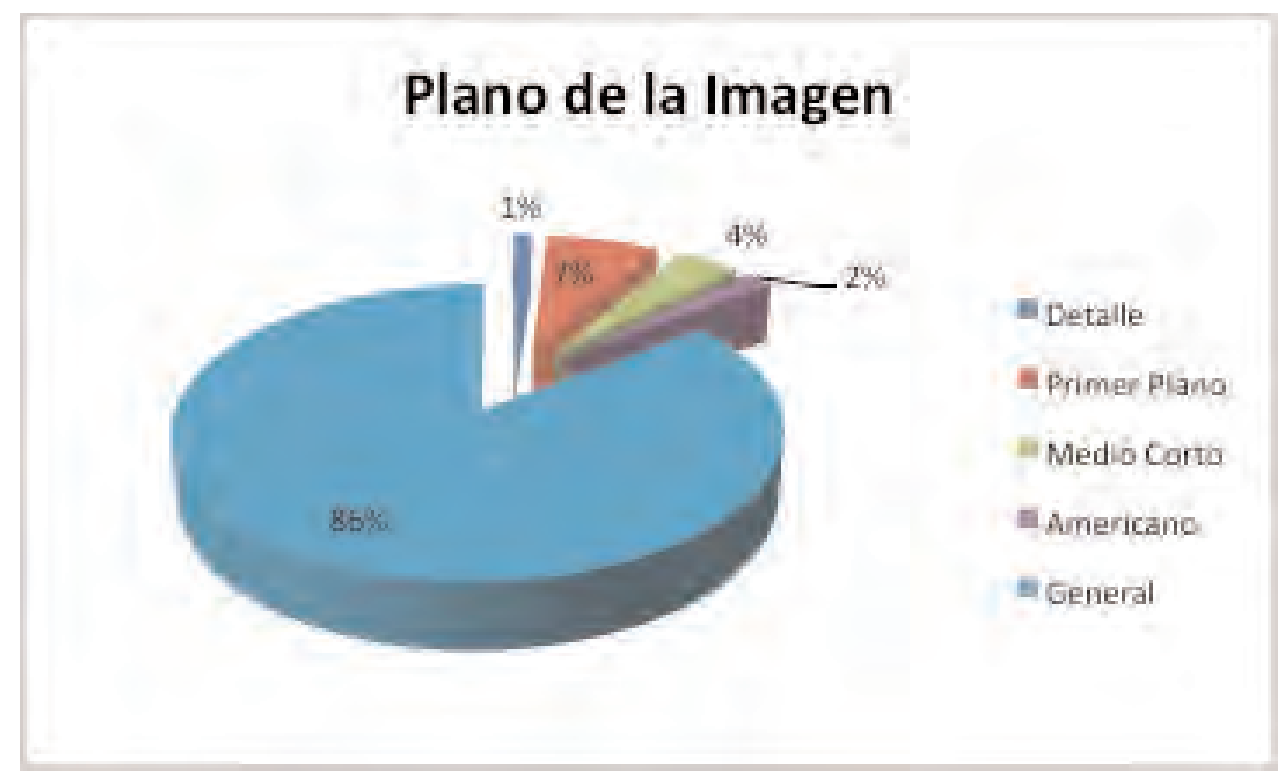

En relación al plano de la imagen cabe destacar, de manera significativa, el plano general, con un porcentaje del $86 \%$ del total de planos analizados, le sigue el primer plano con un $7 \%$, el medio corto con un $4 \%$, el americano con un $2 \%$ y el detalle con $1 \%$.

Al igual que sucedía con las técnicas de impresión que estaban 
determinadas por el tipo de obra, lo mismo ocurre con el plano de la imagen.

El plano general es el más usado en los murales con un porcentaje del $100 \%$, le sigue las ilustraciones con un $97 \%$ y la categoría "otras obras" con un $96 \%$.

En los carteles se emplean distintos planos: primer plano con un $36 \%$, el medio corto con un $22 \%$, el general con un $21 \%$, el detalle con un $14 \%$ y el americano con un $7 \%$.

En los retratos, el plano medio corto ocupa un 44\%, el primer plano un $39 \%$, el americano un $11 \%$ y por último el plano general con un $6 \%$.

\section{Función.}

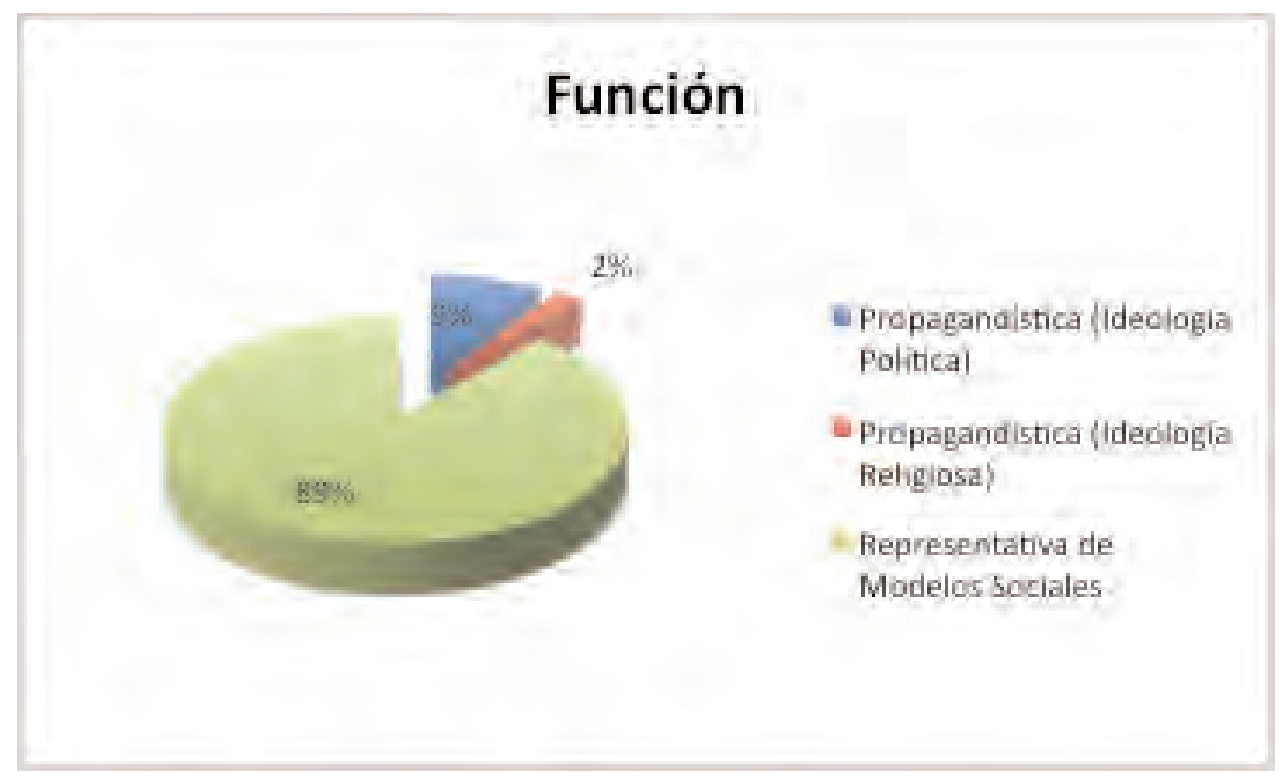

El estudio de la función que cumplen las obras de Eduardo Vicente constituye el objetivo principal de este trabajo de investigación. Ya hemos estudiado el valor propagandístico de la obra de arte (Capitulo 2) y el papel que desempeña la imagen como representativa de modelos sociales (Capitulo 3).

El resultado final de la obra analizada nos muestra que el $89 \%$ de la obra artística de Eduardo Vicente es representativa de modelos sociales, frente al $11 \%$ que cumple la función de propagandística, siendo el $9 \%$ transmisora de ideología política y un $2 \%$ de ideología religiosa. 
Haciendo una interpretación de los datos obtenidos por las categorías en las que hemos dividido la muestra del artista encontramos diferentes significados dignos de resaltar.

En los retratos encontramos que un $33 \%$ de los realizados representan la ideología que Eduardo Vicente defendió a lo largo de su vida, fue un hombre comprometido con el bando republicano, colaboró con el Consejo de Sanidad de Guerra y con el Comisariado del Grupo de Ejércitos de Valencia, e inmortalizó a figuras importantes del mundo de la política como Francisco Ascaso, Hans Beimar, Anselmo Lorenzo, Lina Odema, Frances Layret y Buenaventura Durruti (Fig. 60, 61, 62, 63, 64 y 65).
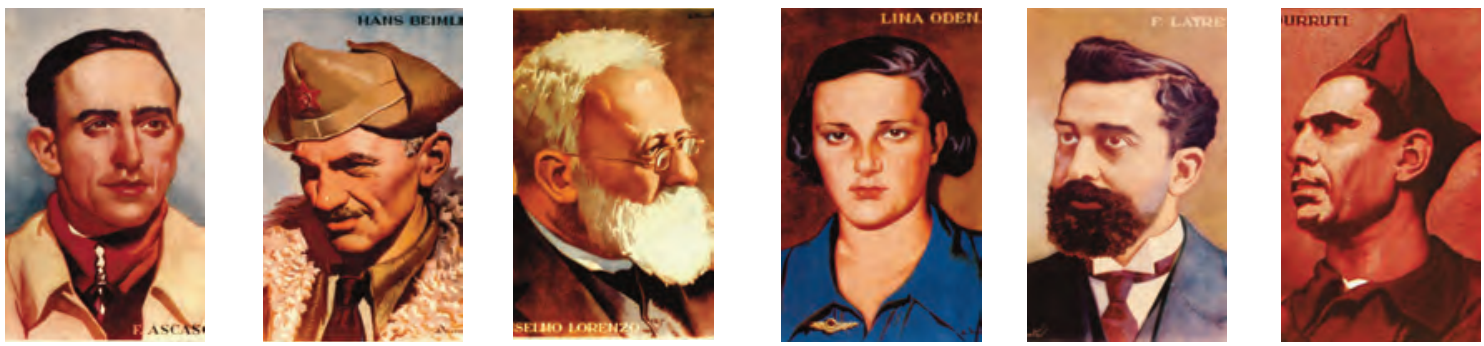

Fig. 60, 61, 62, 63, 64 y 65.

Representantes del bando republicano fueron inmortalizados en los carteles-retratos de Eduardo Vicente.

En esta categoría encontramos un $67 \%$ de personajes que representan los modelos sociales con dos retratos de su protector Pio Baroja y de sus amigos como el abogado Antonio García-Molina, al que vemos en la siguiente fotografía (Fig. 66).

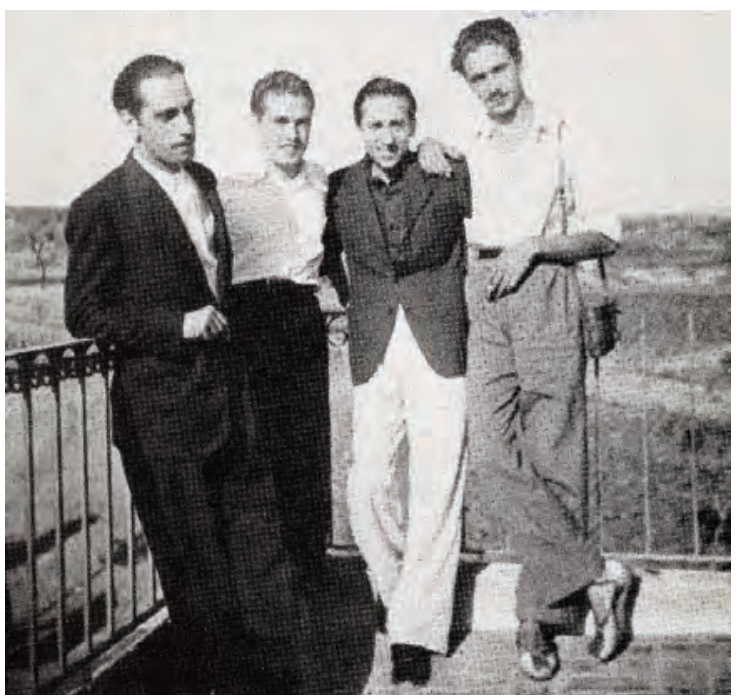

Fig. 66.

En la foto que aquí se reproduce aparecen (de izquierda a derecha) Eduardo Vicente, Antonio García-Molina, Gabriel Sijé y José María Franco 
También se sabe que retrató a Miguel Hernández, pero la obra está en paradero desconocido, a personajes famosos como Luis Hoyos Saínz, retrató a dos de sus hijas Mari Sol y Silvia, a personas conocidas y contamos con un autorretrato.

En los carteles destaca claramente la función de propaganda política con un porcentaje del $82 \%$ del total de la muestra frente a un $18 \%$ que son imágenes representativas de los modelos sociales propios del periodo analizado. Recordemos la implicación de Eduardo Vicente con el bando republicano colaborando con los cartelistas más famosos del momento (Fig. 67,68 y 69).
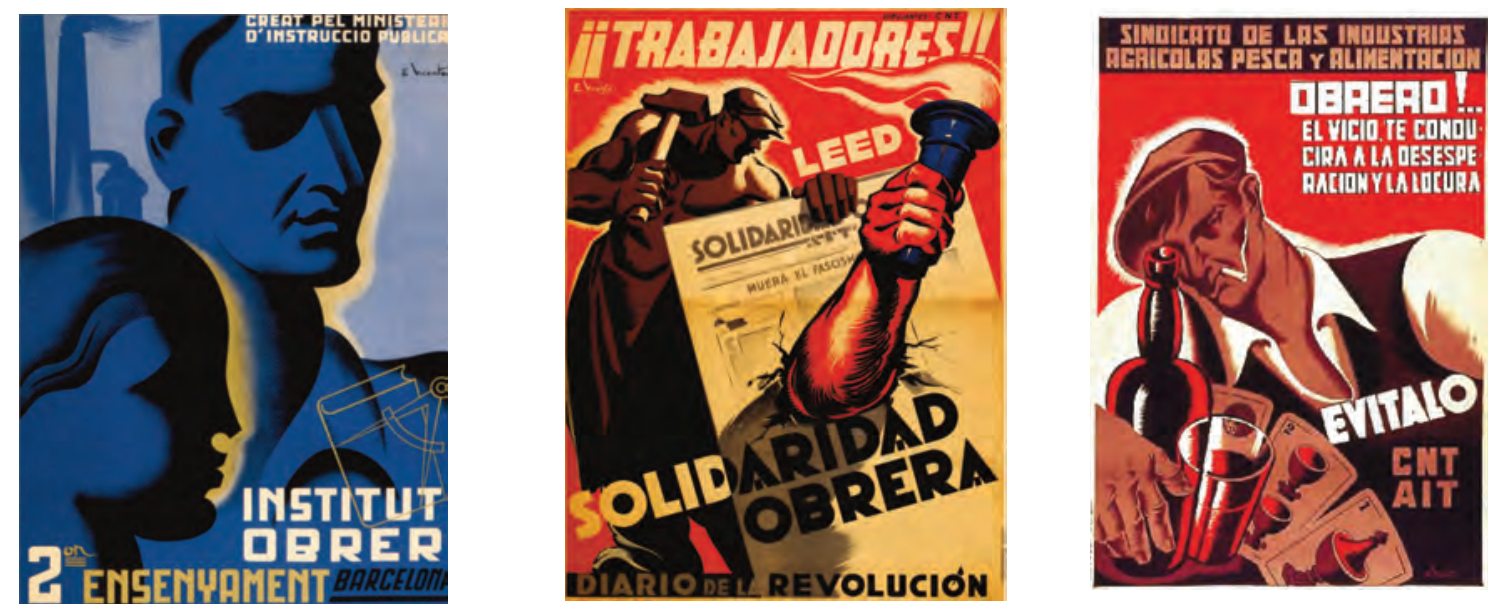

Figuras 67,68 y 69.

Carteles realizados durante el periodo de la Guerra Civil Española por Eduardo Vicente.

En los murales no aparece ninguna obra con función transmisora de ideología política, sin embargo nos encontramos con un porcentaje del $29 \%$ con ideología religiosa como los Bautismos de Cristo, que se encuentran en la Catedral de Orihuela y en la iglesia de la Encarnación, o la infancia de Cristo en la iglesia de Navacerrada (Madrid) (Fig. 70) o la Anunciación en la iglesia de Brihuela (Guadalajara) entre otras.

Fig. 70.

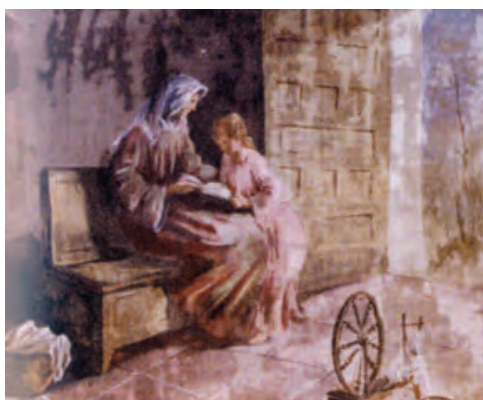


En las ilustraciones analizadas no hemos encontrado ninguna que cumpliera la función transmisora de ideología, ni política ni religiosa, presentando, por tanto, un $100 \%$ de ilustraciones que representan modelos sociales.

En lo que hemos denominado "Otras obras", el dominio de la función representativa de modelos sociales es absoluto, alcanzando un porcentaje de $83 \%$, frente a un $17 \%$ de función propagandística, siendo un $14 \%$ de ideología política y un $3 \%$ de ideología religiosa.

En definitiva podemos concluir que la obra de Eduardo cumple una doble función: propagandística y representativa de modelos sociales, en relación a la primera podemos afirmar que muchos de sus retratos, carteles y "otras obras" destacan por su transmisión de ideología política, en esta última categoría destacan las obras que dedicó a las escenas de guerra como: "Milicianos haciendo guardia", "Pasaron los fascistas", "Guardia durante el descanso" , y "Barrio bombardeado", Habitación destruida por un bombardeo" entre otros. Los murales y "otras obras" son transmisoras de ideología religiosa como: las obras dedicadas a San Isidro Labrador. En relación a la función representativa de modelos sociales se encuentran en las ilustraciones y "otras obras".

La obra de Eduardo Vicente nos ayuda a conocer la vida por dentro y por fuera, o dicho de otra forma la vida en el hogar y la vida social, el ámbito privado y el ámbito público. El artista supo dejar constancia de las expresiones emocionales que, a través de los gestos expresivos de sus personajes, nos hablaban de su situación, de sus miedos, de sus inquietudes y de sus aspiraciones.

Su obra es un testimonio gráfico que sirve para conocer las ciudades y su cultura habitada, sus calles y plazas llenas de gente que les da vida. Así podemos ver: "Gente en la puerta del Sol", "La puerta de Atocha", "La puerta de Toledo", "La Cava Baja", "La plaza de Santa Cruz", "La plaza de Lavapiés", "La calle de Esgrima" entre otras, que nos hablan del Madrid de su época, al igual que Fernando Chueca en su obra El semblante de Madrid, ilustrada entre otros por Eduardo Vicente (Fig. 71 y 72) podemos leer: 
"Y que poco hay que decir de la Plaza de Lavapíes, con su piso de cemento resquebrajado; con su boca del Metro, a la que, como parásita vegetación, se enredan mujerucas y chiquillos pedigüeños; su enorme columna metálica del transporte eléctrico; sus casas altas y bajas; algunas tiendas de nombre pintoresco, como la llamada "La Aduana de Lavapíes" y el barracón del Cine Olimpia, nombre fastuoso que nos recuerda a Zola y a Manet". 12

Chueca, F. (1991: 218)

La presencia de sus personajes, de esos tipos de la calle como le gustaba llamarlos, también son motivo de reflexión:

"Para el pintor de Madrid lo principal era el motivo humano, visto siempre, eso si, en su ambiente, tan identificado con el espíritu de la ciudad que ésta en lo que todavía retiene de castizo, se parecía milagrosamente a una composición de Eduardo Vicente". ${ }^{13}$

Campoy, A. M. (1968:29)

"Los tipos Madrileños de Eduardo Vicente se convierten, gracias a la penetración de su arte, en arquetipos. En esto se diría heredero directo del inmenso autor de teatro que se llamó Carlos Arniches, el cual sacaba a escena unos personajes: El honrado artesano, la mocita presumida, el galán pinturero, el chulón, el señor acomodado y castizo..., a los que luego, más o menos conscientemente, tomaban como modelos en dichos, maneras, en atuendos, los vivos y reales personajes de la calle". ${ }^{\mathbf{1 4}}$

Pérez Ferrero, M. (1968: 98)

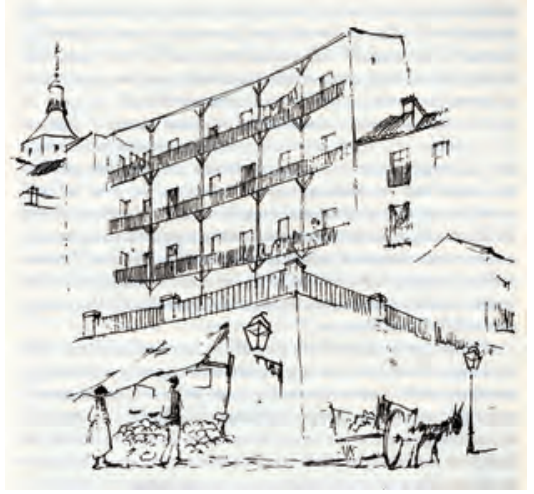

Fig. 71 y 72.

Escenas del barrio madrileño de Lavapiés. 
También deja testimonio gráfico de otras ciudades que impresionaron al artista y que nos expresa lo que sintió: Nueva York y sus gentes, personas de otras razas que fueron pintadas por $\mathrm{E}$. Vicente captando no sólo el aspecto físico sino el sentimiento (Fig. 73, 74 y 75).

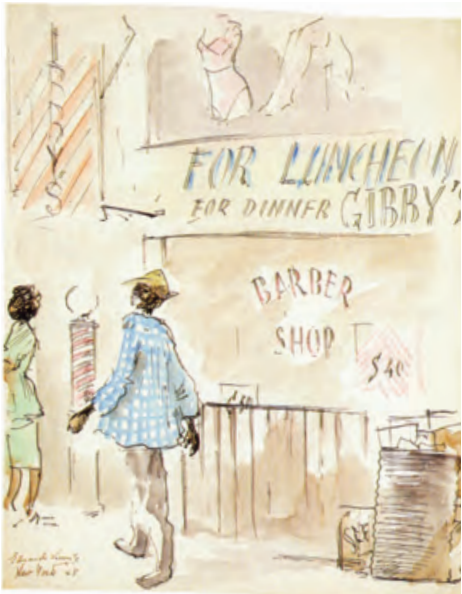

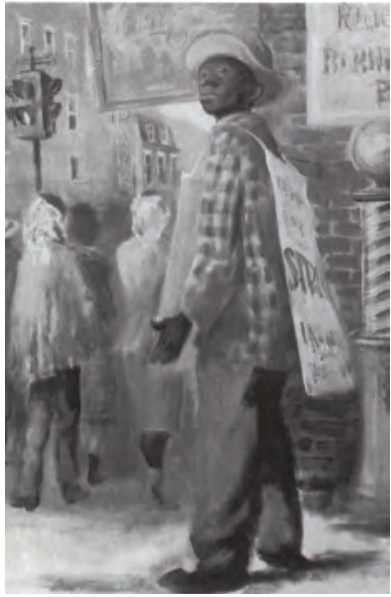

Fig. 73, 74 y 75 .

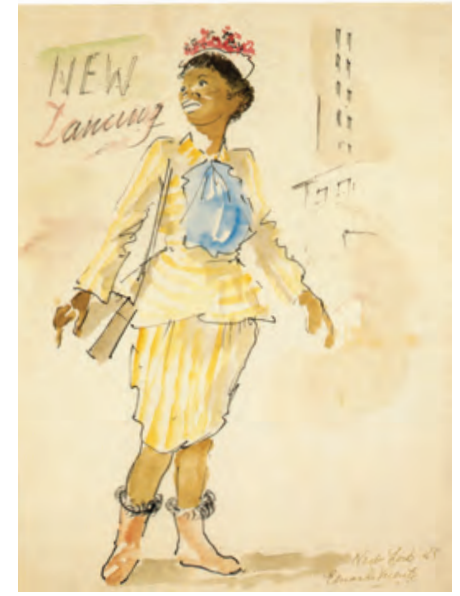

Retratos de los negros de Harlem, realizados durante su estancia en Nueva York.

París, ciudad de artistas y de tertulias en los cafés que le recordaban a las tertulias en los cafés de Madrid (Fig. 76 y 77).

Fig. 76 y 77.

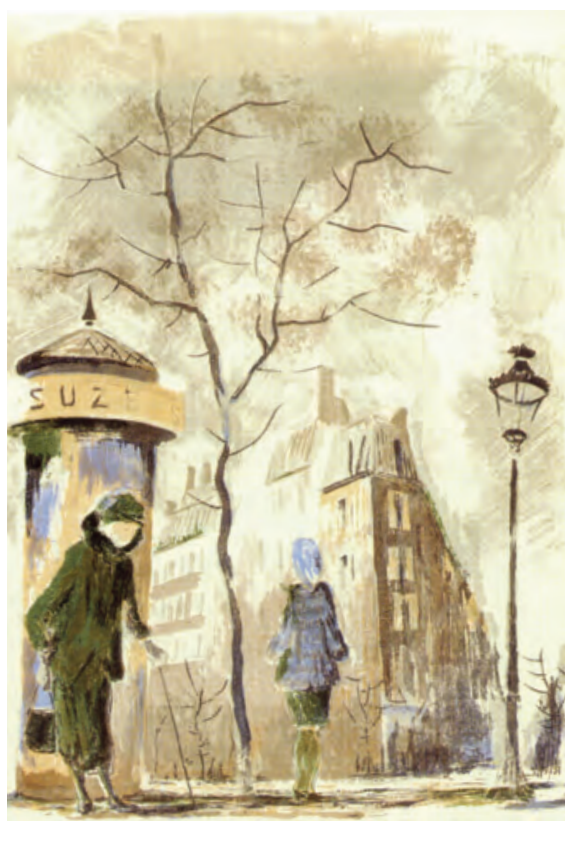

Paseos por París.

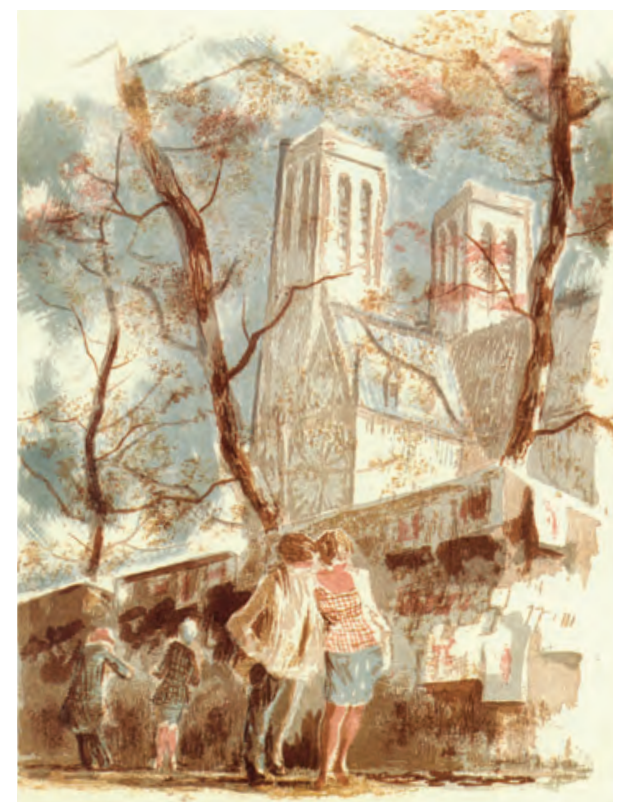




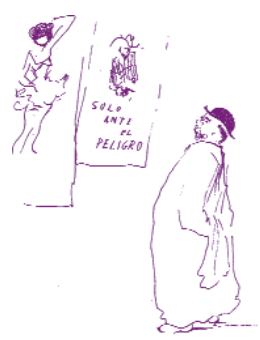

Segovia, ciudad en la que vivió su familia y él visitaba en los veranos (Fig. 78 y 79).
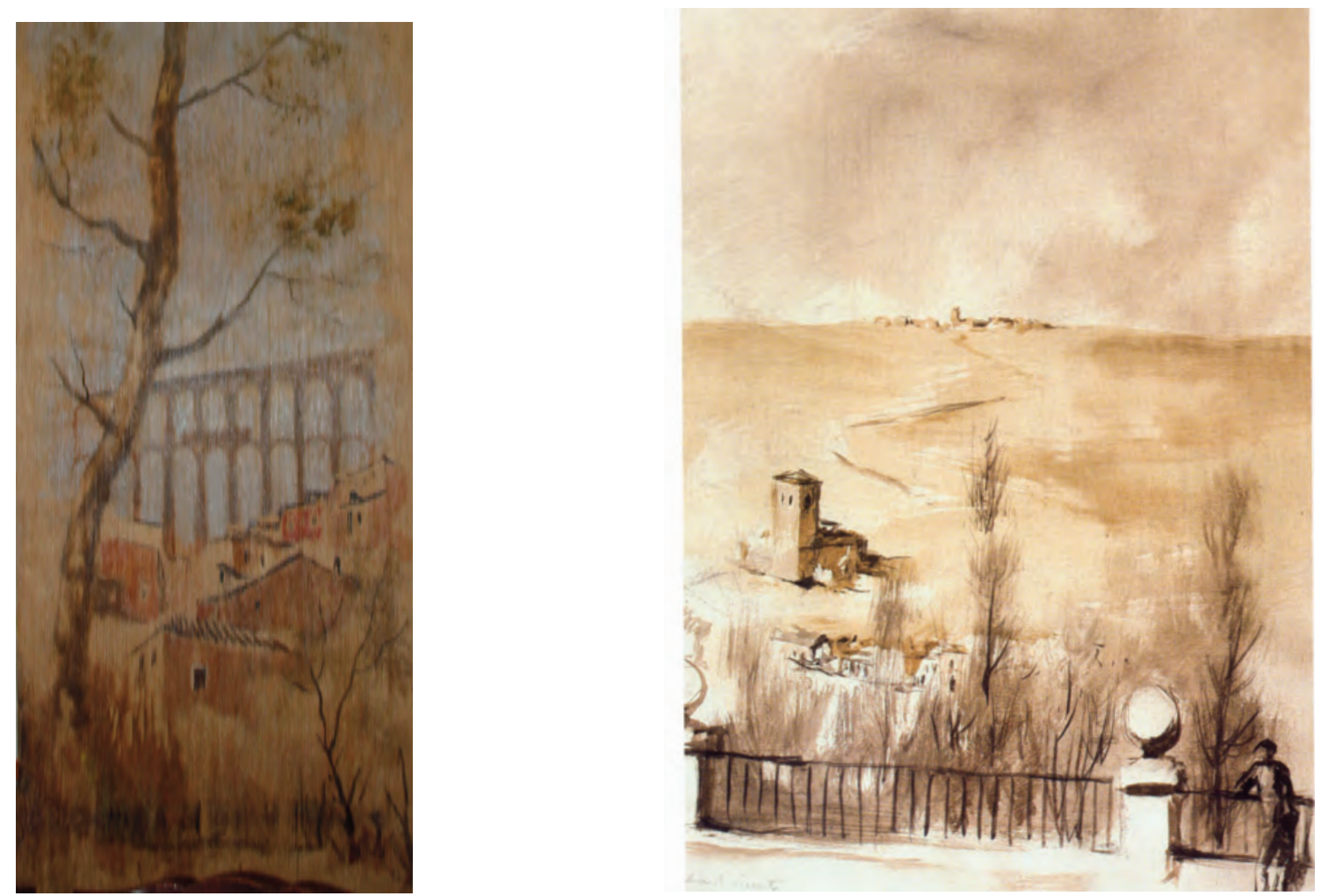

Fig. 78 y 79.

El acueducto y la iglesia de la Veracruz de Segovia quedaron plasmados en la obra del pintor Eduardo Vicente.

Amsterdam (Figura 80).

Fig. 80.

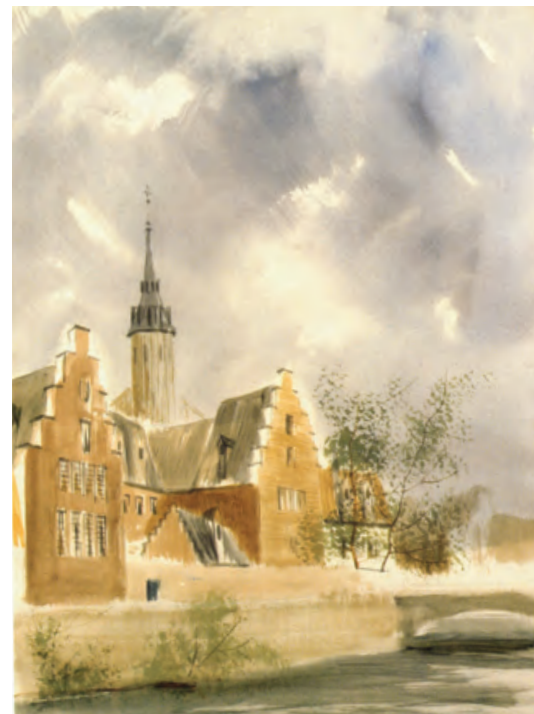

en uno de sus viajes. 
Y numerosos paisajes de pueblos y entornos rurales, así como las afueras de Madrid.

El artista observa la realidad y la plasma en su obra, le gusta reflejar al personaje y la actividad que realiza, así podemos contemplar la multitud de trabajos relacionados con la venta ambulante, una forma de subsistencia, que sirve para el mercado y su sistema económico. Sabe captar lo esencial del personaje, de los tipos de la calle como él los denomina en su obra publicada con el mismo título en la que podemos leer:

"Las artes plásticas fatalmente tienen que conformarse con su misión específica de dar la crónica sensible de la vida humana. Nada más y nada menos. Nada más, porque es inútil pretender llevar al lienzo una cadena de conceptos. $Y$ nada menos, porque en fuerza expresiva y representativa es inferior a todas las demás artes. En la pintura cabe el mundo en su totalidad, fijado y eternizado. Un cuadro, un dibujo, obligan a mantener domada la interpretación libre tan cara a la imaginación del sujeto que mira". 15

Vicente, E. (1950: 10)

Esta obra incluye 42 ilustraciones tituladas: dos traperos, dos tratantes, el mozo de cuerda, el ocioso, tratante de ganado, Plaza de Santa Cruz, pirulís, el barquillero, Navidad, el mielero, el quesero, dos novelas y cuentos, vendedor de coplas, dos vendedor ambulante, Vallecas, el aprendiz vidriero, gente en el Rastro, cabecera del Rastro, el limpia, un puesto en la calle Toledo, un puesto en el Rastro. Hombre anuncio, La proceridad, un vago, Plaza de Lavapíes, Cava baja, Mujeres al aire libre, esperando, la pipera, Puerta de Toledo, Calle de la Esgrima, pequeño mercado, hacia el Puente de Toledo, un hombre anuncio, barrios bajos, dos de gente en la puerta de Atocha y vendedor (Fig. 81, 82 y 83 ).

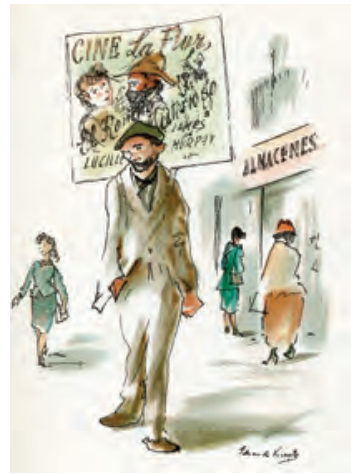

Fig. 81,82 y 83.

Tipos de la Calle.

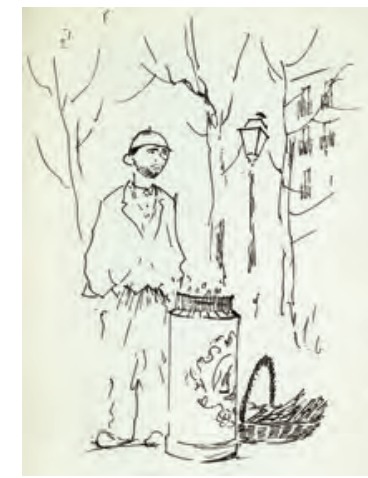


Calles y gentes que deambulaban por ellas, con su mercancía y con sus estribillos: "La miel de la Alcarria", "Las fresas de Aranjuez", "El queso recién elaborado", "Pirulís para los niños", para ganarse unas cuantas monedas para llevar a su casa.

Las calles repletas de hombres y mujeres vendiendo y comprando, en los puestos del Rastro y en otros mercados.

El Rastro (Figuras 84 y 85 ) aparece representado en varias obras, en este mercado podemos apreciar diferentes formas de comprar y vender, en palabras de Fernando Chueca:

"Pueden allí estudiarse las formas más elementales del comercio y las más astutas del chalaneo, ejercitadas por regatones, buhoneros, chamarileros y saldistas, mangones y cangalleros; las más legítimas manifestaciones de la humilde vocación de mercader junto con los más turbios monipodios". 16

Chueca, F. (1991: 191)
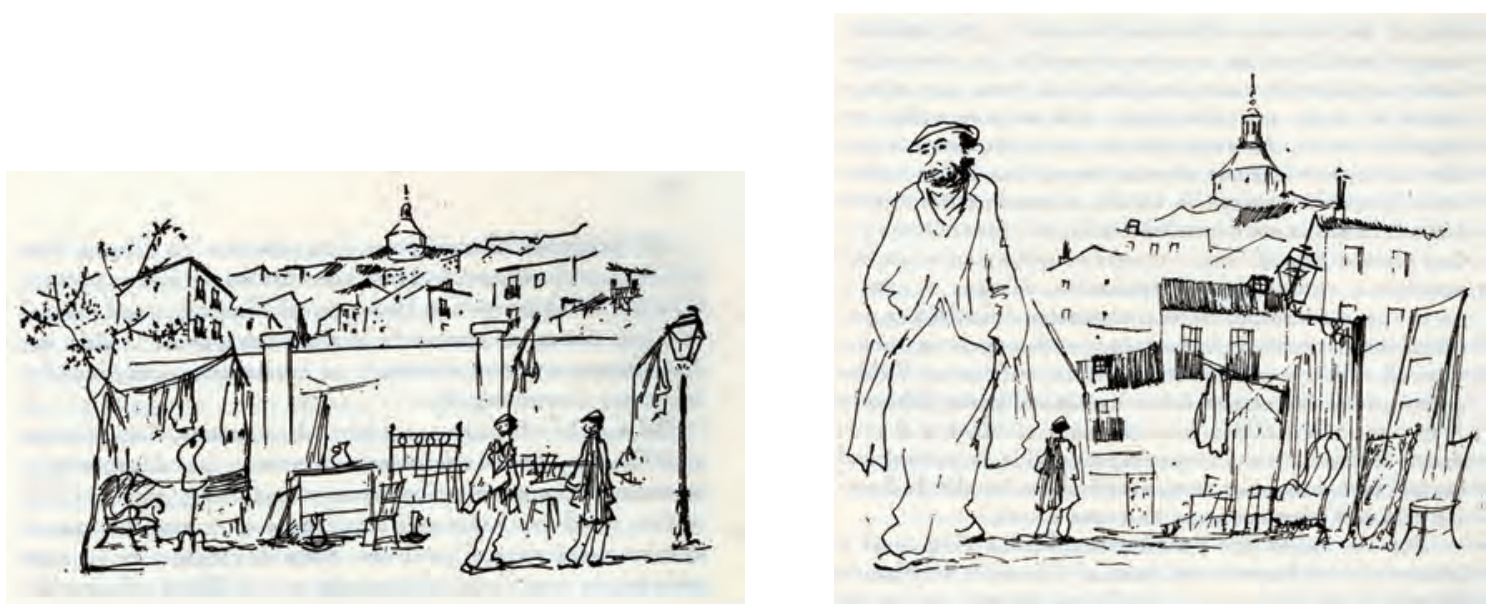

Fig. 84 y 85 .

Los puestos de EI Rastro y sus gentes

El papel de la mujer está muy representado en la obra de Eduardo Vicente. Las mujeres en sus hogares realizando las labores del hogar, propias de su condición femenina, cuidadora del esposo y de los hijos. También aparecen, en la obra artística, otras mujeres que tienen que ganarse la vida 
como pueden, vendiendo su cuerpo y ejerciendo la prostitución, como "Mujeres al aire libre", "Mujeres esperando" (Fig. 86 y 87 ).
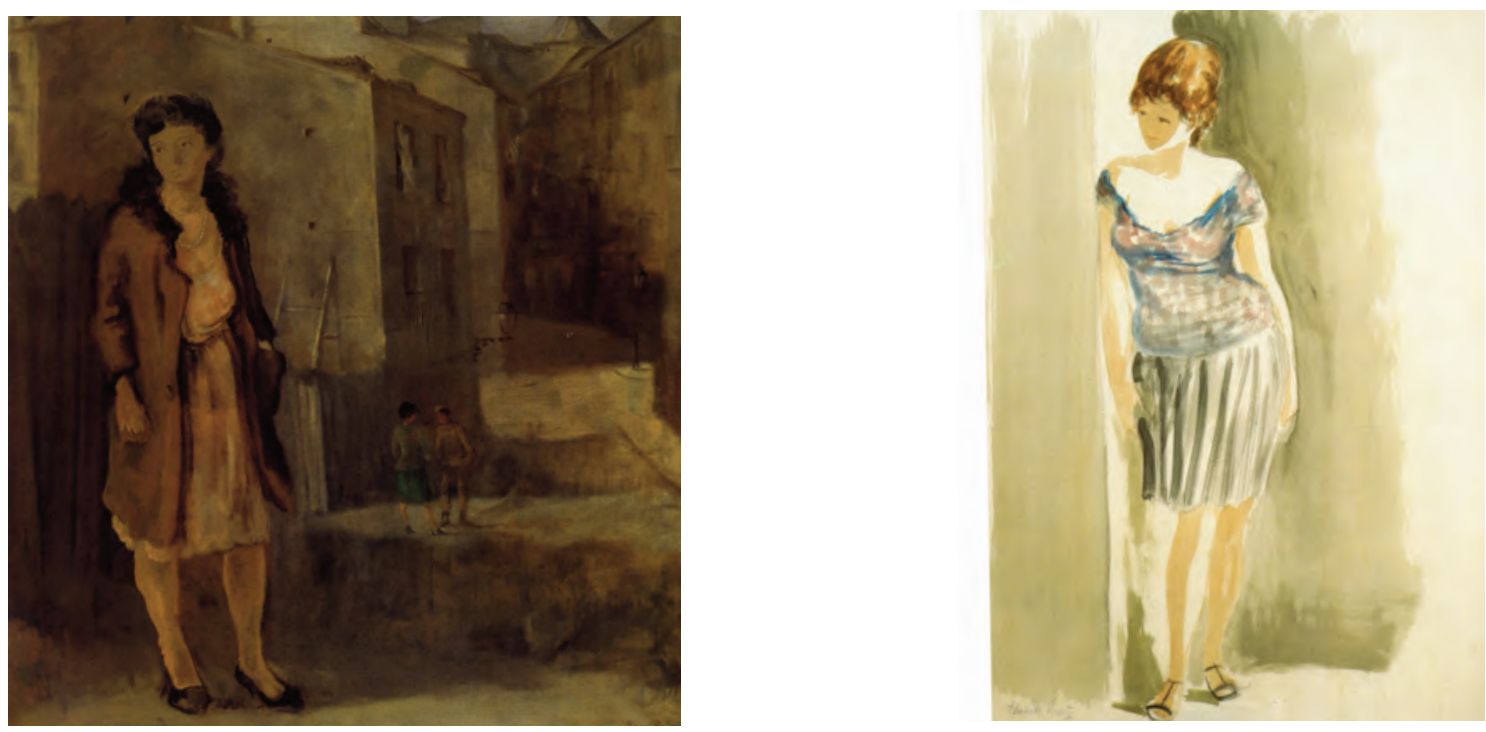

Fig. 86 y 87.

Las mujeres componen una parte importante de la obra de Eduardo Vicente.

Los hombres también están representados en su obra, con una presencia mayor que las mujeres y los niños, tal como quedó reflejado en el estudio experimental. Hombres en casa y en la calle, ejerciendo su profesión como medio de vida, tampoco se le escapan al artista esos personajes de la calle que no hacen nada, como "El ocioso", "El vago" (Fig. 88).

Fig. 88.

Ilustración del libro de Eduardo Vicente, Tipos de la calle.

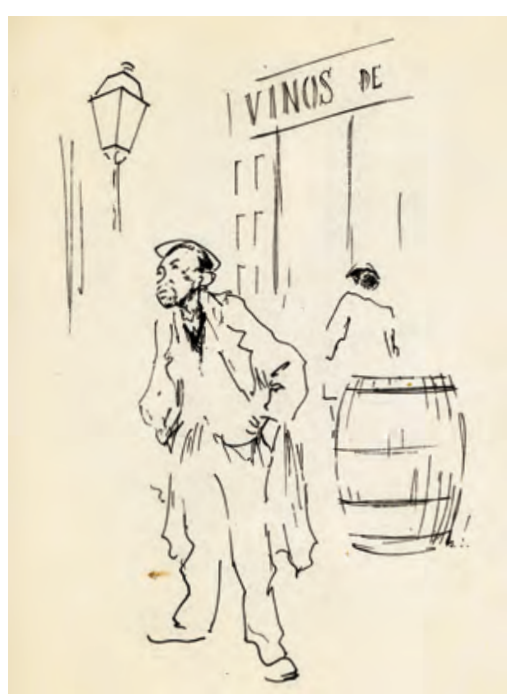


El ocio y la diversión también están representados en su obra.

Las fiestas de los toros, con sus diferentes manifestaciones: corridas de toros, encierros...

Las fiestas populares con sus bailes típicos. Son varías las obras de Eduardo Vicente que representa las fiestas con sus bailes populares como la imagen del año 1955 (Fig. 89), pero Eduardo Vicente es un observador nato de los cambios que iban apareciendo en la sociedad, así asiste a la explosión "ye-yé" (Fig. 90 y 91) y este nuevo cambio le proporcionó nuevos motivos para seguir creando y dejarnos un testimonio gráfico de lo que supuso este movimiento, como él mismo dice: "En este mundo tan curioso, tan sugestivo, al menos para mí".

"Y ahora, fiel a esa búsqueda constante, insaciable, el artista se ha zambullido con entusiasmo en el fenómeno "ye-yé", en el madrileño mundo "ye-yé" que tiene sus rasgos peculiares y autóctonos dentro del fenómeno internacional, porque el lugar imprime indiscutiblemente carácter. Por sus "boites", "drugstores" y "Piccadillys" bailantes, frenéticamente, ha paseado su mirada y su bloc de apuntes Eduardo Vicente. No importan los nombres extranjeros de los sitios. Bajo sus techos el rasgo local se advierte, si se avizora con tino". 17

Pérez Ferrero, M. (1968: 100)

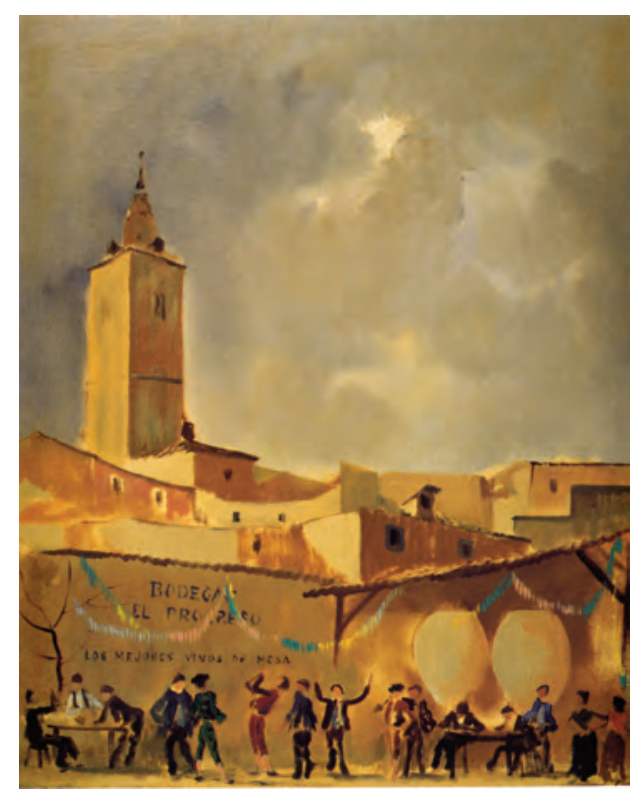

Fig. 89.

Fiesta en un pueblo. 
Arte y Comunicación.
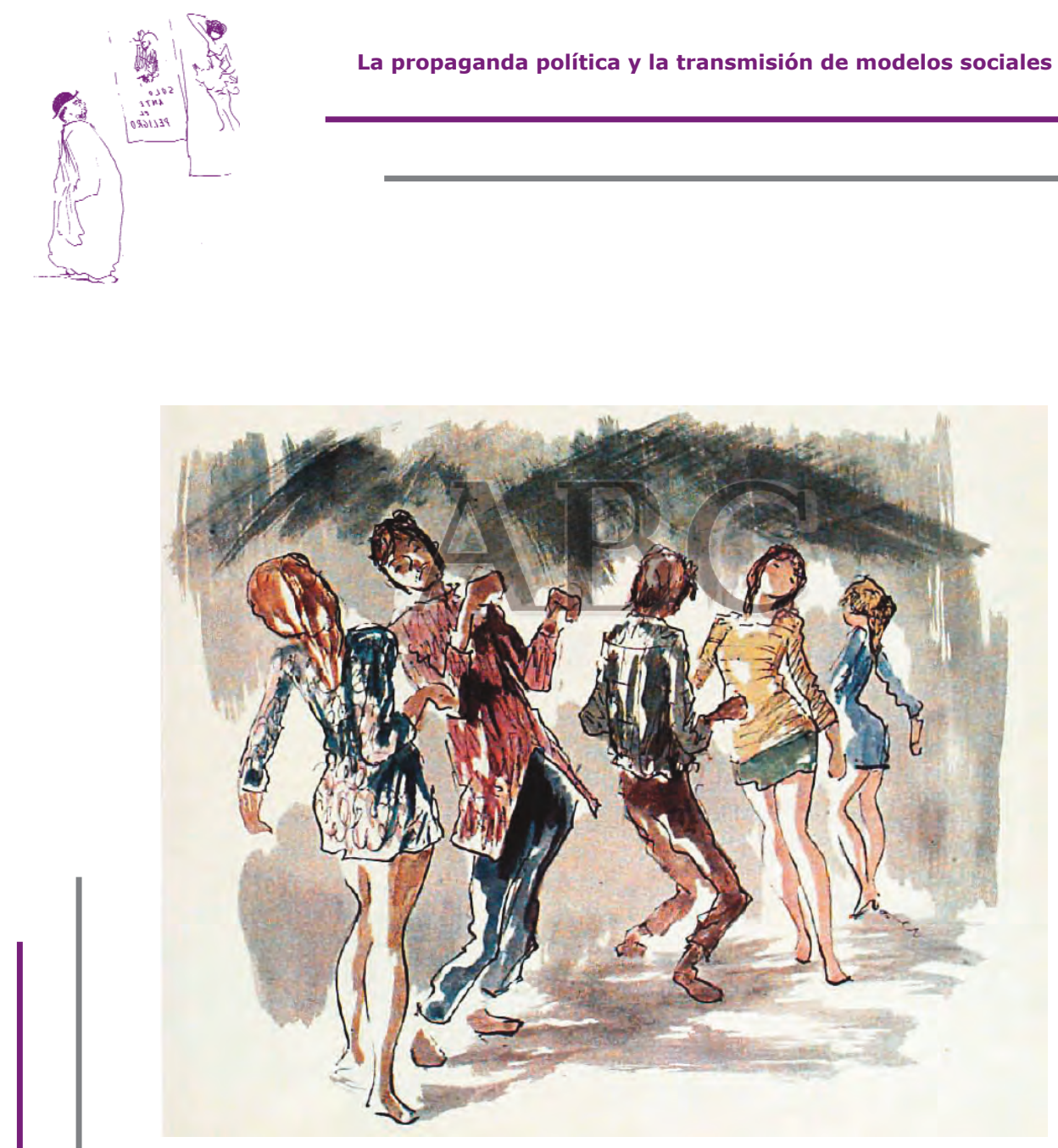

Fig. 90 y 91.

Generación "Ye-Ye".

Imágenes de Blanco y Negro. ABC.

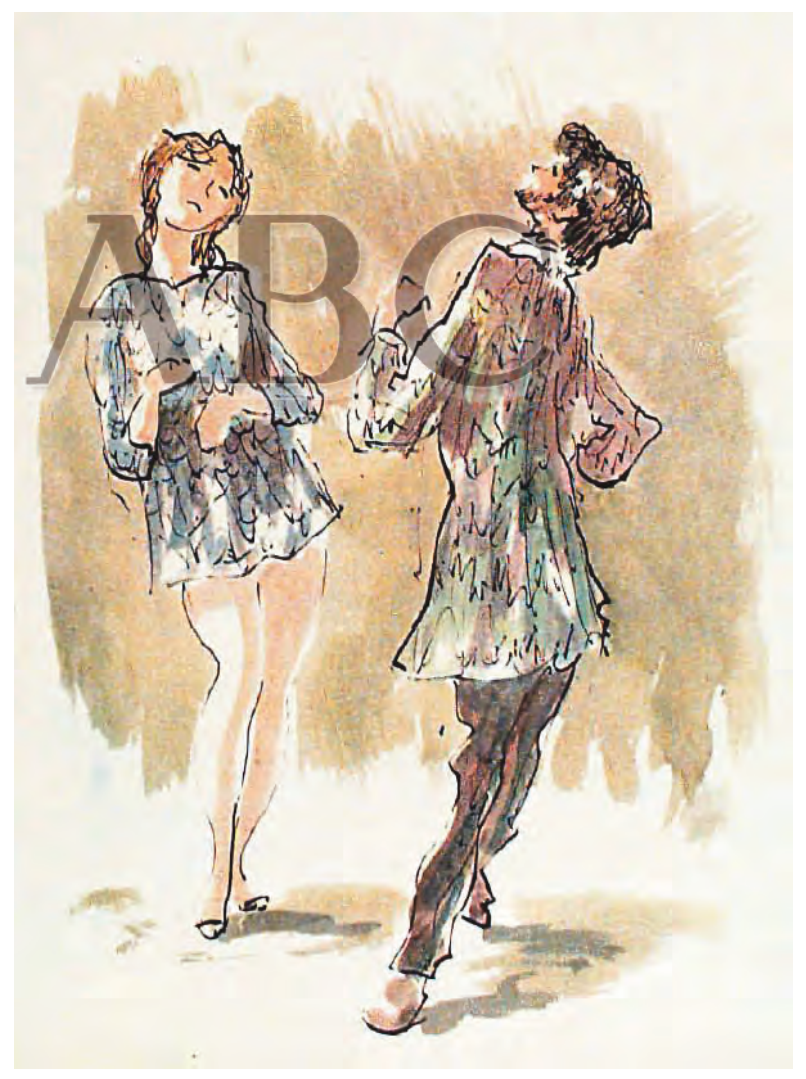


La vida en los cafés y tabernas. Aquí nos encontramos con dos establecimientos diferentes, los cafés reservados para personas más acomodadas y más cultas, donde acudían, no solo a beber sino a realizar intercambios culturales, políticos y económicos, allí se realizan las famosas tertulias. La obra "Crónicas del Café Gijón" (Fig. 92) de Marino Gómez Santos, nos cuenta el ambiente de este café y los personajes que acudían, cita en dos ocasiones a Eduardo Vicente:

"Eduardo Vicente, tipo barojiano por excelencia, escapado de la "Busca" en una noche madrileña, vive apartado de este grupo y va a sentarse junto al comediógrafo Luis Delgado Benavente" 18

Gómez Santos, M. (1955:143)

Esta obra está ilustrada por Eduardo Vicente y su obra gráfica refleja el ambiente y los personajes que acudían a estos establecimientos, forma parte de la historia de nuestro país, como refleja Ramón Gómez de la Serna:

"Pero la historia de un café - sea el que sea - es cosa atractiva para todos, cargada de eso que se llama entelequia.

Al ser descrito un café toma un aire mitológico, o mejor dicho mitománico, y se asoma uno a uno de los dramas más amenos de la vida, al drama de no querer morir, al meter jaleo para no morirse, al dar trascendencia a las cucharillas para agarrarse a ellas en último extremo" 19

Gómez de la Serna, R. (1955:184)

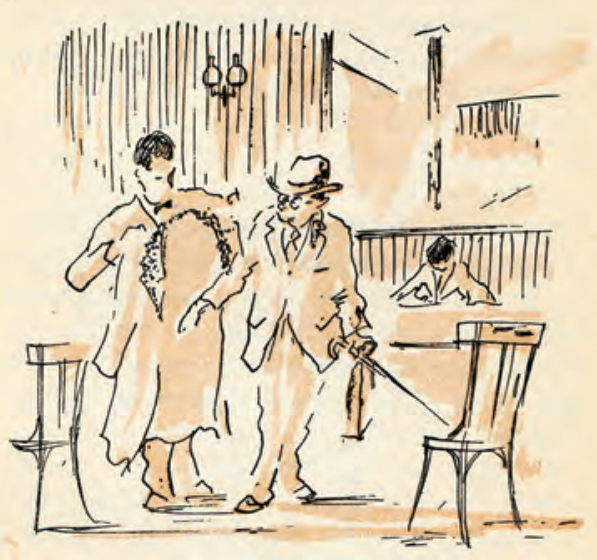

Fig. 92.

Ilustración del libro Crónicas del Café Gijón, de Marino Gómez de Santos. 
En estos famosos cafés de Madrid o de París encontramos representada a la mujer. Existen muchas imágenes en las que aparecen las mujeres, a las que aquí no se las excluye de la vida social (Fig. 93 y 94).

"Los cafés son lugares melancólicos hasta que aparecen en ellos las mujeres, que entran mirándose en los espejos, sabiendo que las miran. Ellas dan al café aquello que le faltaba y lo humanizan, salvándose del misogismo, liberándole de esa pobreza espiritual y física... Es todavía la época en que la mujer vive en sociedad un tanto cohibida. A los saraos va con los bailes calculados por su madre y los cumple rigurosamente, apuntándose en el carnet que lleva colgado de la muñeca. En el teatro está secuestrada dentro de la muralla de un palco". 20

Gómez Santos, M. (1955:31-32)

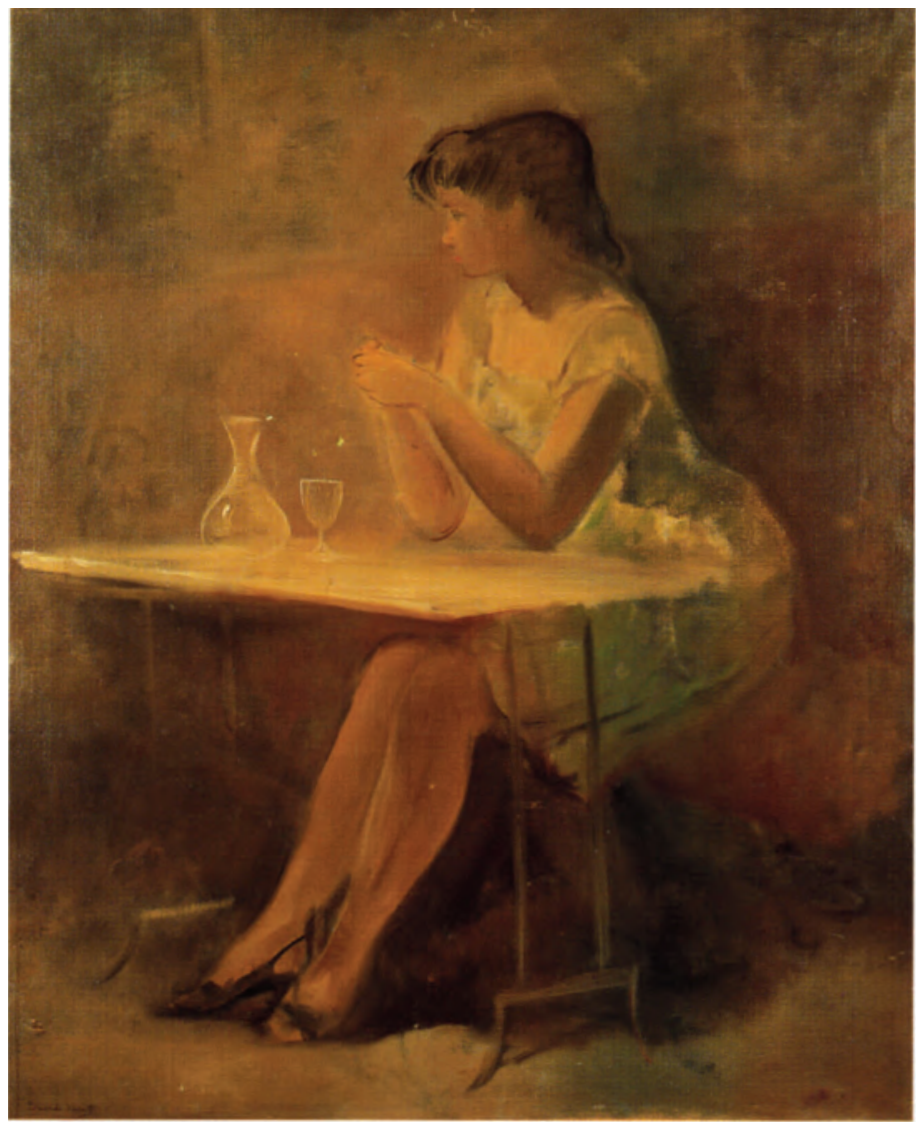

Fig. 93.

La mujer cobra importancia en las escenas de los cafés. 


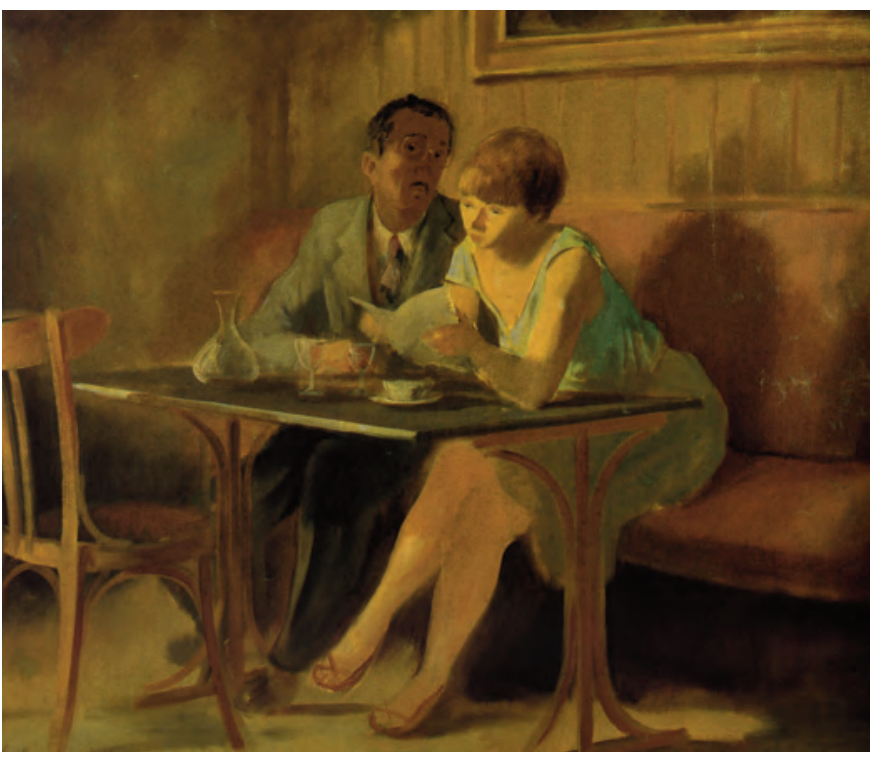

Fig. 94.

Pareja en un café madrileño.

En las obras donde están representadas las tabernas, encontramos diferencias con los cafés, en estas no aparecen personajes femeninos, son territorios exclusivos para hombres. Se aprecia la presencia de hombres de clases sociales más bajas, bebiendo vino y comentándose sus problemas (Fig. 95 y 96).

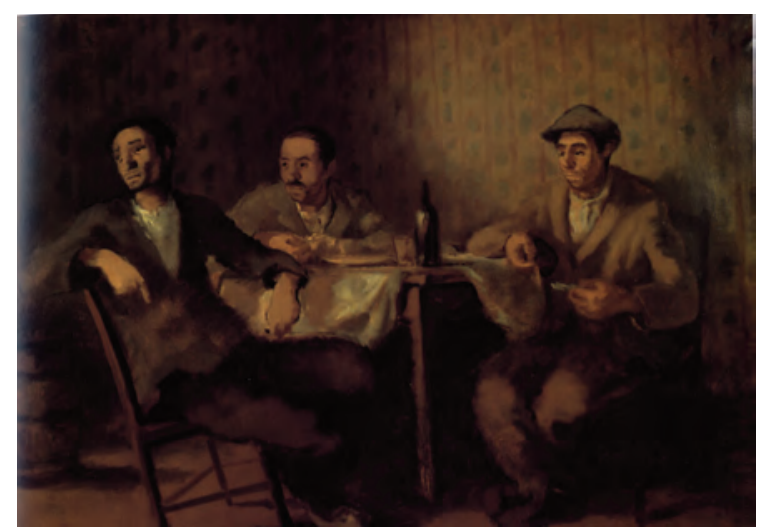

Fig. 95 y 96.

El ambiente de distintas tabernas marcó una época dentro de la obra de Eduardo Vicente.

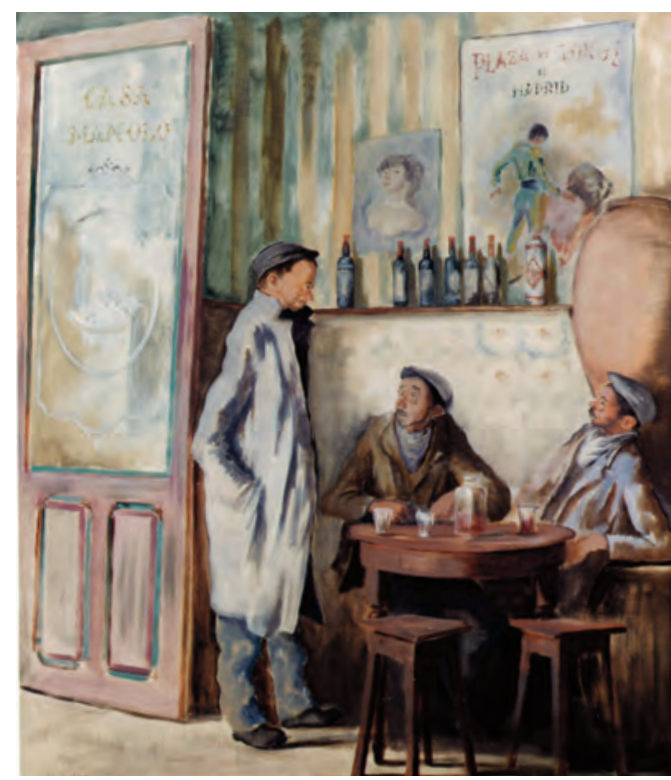


Esta distinción de clases sociales también se aprecia en otras representaciones, en las ilustraciones de la obra titulada La familia Mínguez, de Edgar Neville, ilustrada por Eduardo Vicente y publicada en 1956, se representa a una familia de clase alta, con hombres y mujeres bien vestidos, paseando por las mejores calles de Madrid, con una casa decorada de manera bien distinta a otras representaciones, como por ejemplo las corralas, el vestido marinero del niño impoluto, destaca sobre las vestimentas de otros niños de clases sociales más bajas, las sirvientas, vestidas como tal, para diferenciarse de las señoras (Fig. 97, 98, 99, 100 y 101).
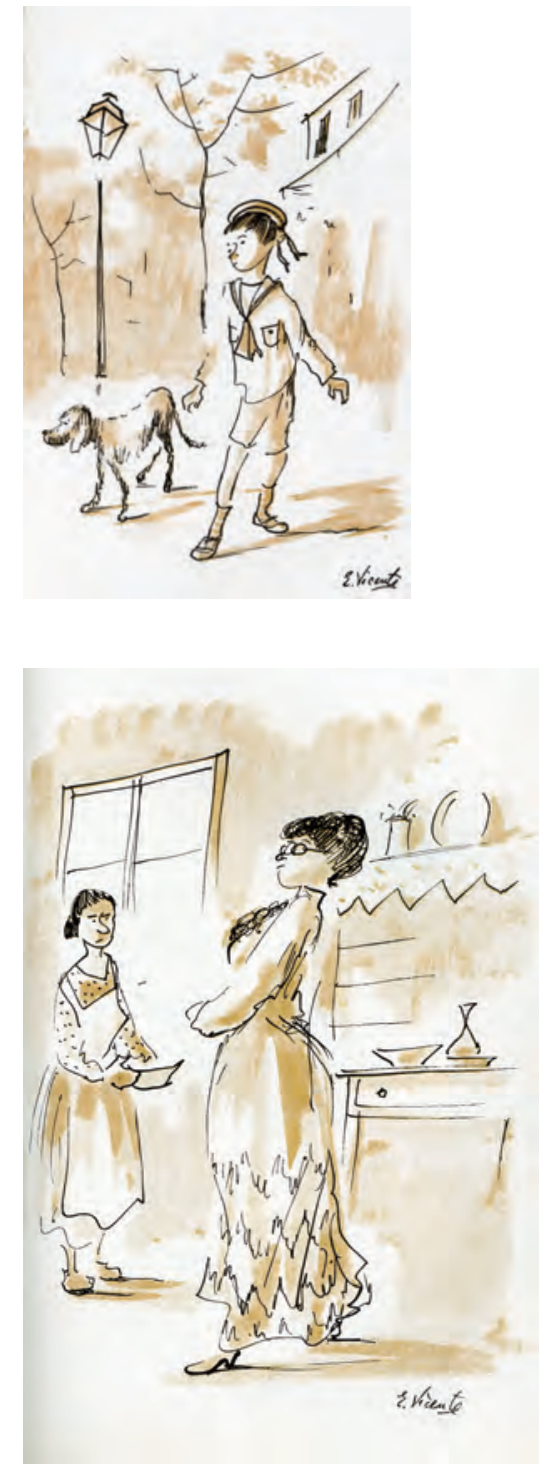
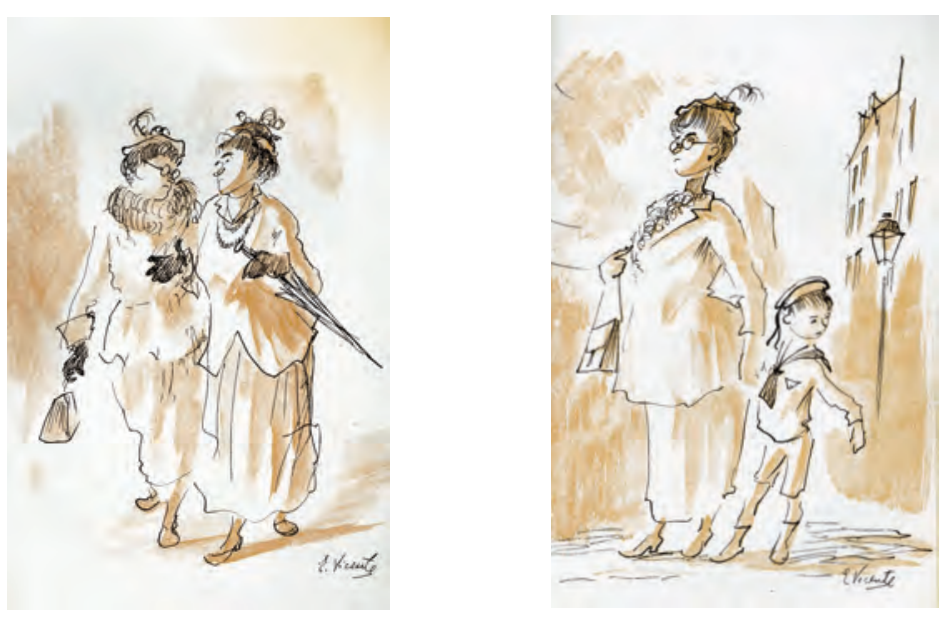

Fig. 97, 98, 99, 100 y 101.

Ilustración del libro La familia Mínguez, de Edgar Neville. 
"La historia de la familia Mínguez vale por un tratado de antropología hispánica. En este libro podrán los hombres de mañana darse cuenta de lo que fue una parte básica de la intimidad española cuando mediaba el siglo $X X$, con mucha más precisión que en las exhumaciones documentales de los eruditos. Todo es real en estos anales, desde la profunda intimidad de los protagonistas, hasta el detalle que parece banal y que, en verdad, pone su acento definitivo a las cosas. El argumento tragicómico está lleno de rendijas por donde la ternura asoma su temblor. Hay escenas de niños de graciosa y ejemplar sencillez, como hechas para oírlas con música de Schuman; y paisajes urbanos o interiores definitivos, pintaos con palabras leves, de una sencillez que nunca pasará". 21

\section{Marañon, G. (1956:12)}

Edgar Neville refleja con sus palabras la vida de una familia española y Eduardo Vicente la representa con sus ilustraciones sencillas pero cargadas de ternura y vitalidad siendo un fiel reflejo de la realidad.

A lo largo de este estudio son muchos los datos que podemos extraer de la obra de Eduardo Vicente, datos que nos ayudan a conocer la historia cultural, económica y social de la época en la que vivió el artista. Su obra se convierte en una magnifica representación de las actitudes, valores y normas de una época así como en una valiosa fuente de investigación. 



\section{Notas}

1.- Camón Aznar, J. (1968) ABC. Madrid. 21 de mayo de 1968. pp. 45.

2.- Gómez Santos, M. (1955) Crónica del Café Gijón. Biblioteca Nueva Madrid. p. 165.

3.- Cossio, M.B. (1879) "Carácter de la Pedagogía contemporánea: el arte del saber ver", en Boletín de la Institución Libre de Enseñanza. Año III, no 65 (31 de octubre de 1879). p.153-154.

4.- Martín, F. (1983) El pabellón español en la Exposición Universal en París en 1937. Sevilla. Universidad de Sevilla. 1983.

5.- Romero Cuesta, J. (1937) "Cómo realizan su labor de agitación los artistas de el Altavoz del Frente". Crónica no 380. Madrid. 21-2-1937. p. 9.

6.- Quilez Vicente, J. (1937) "La obra realizada por Carlos Esplá al frente del Ministerio de Propaganda". Crónica no 394. Pag. 6 - 8.

7.- Bardin. L. (1986) El análisis de contenido. Akal. Madrid. p. 77.

8.- Bozal, V. (1991) "Las imágenes de la enseñanza, la enseñanza de la imagen" en Revista de Educación , no 296. Ministerio de Educación y Ciencia. Madrid. pp. 217 - 245.

9.- Pérez Ferrero, M. (1968) "El mundo "Ye- Ye" de Eduardo Vicente" en revista Blanco y Negro. ABC. Madrid. p. 100.

10.- Campoy, A. M. (1968) "Arte y Artistas" en ABC. Madrid. 28/05/1968. p. 32

11.- Vicente, E. (1950) Tipos de la Calle. Afrodisio Aguado. S.A. Madrid. p. 9.

12.- Chueca, F. (1991) El Semblante de Madrid. Instituto de Estudios Madrileños. $2^{a}$ edición. p. 218. 


\section{Notas}

13.- Campoy, A. M. (1968) "Arte y Artistas" en ABC. Madrid. 28/05/1968. p. 29.

14.- Pérez Ferrero, M. (1968) "El mundo "Ye- Ye" de Eduardo Vicente" en revista Blanco y Negro. ABC. Madrid. p. 98.

15.- Vicente, E. (1950) Tipos de la Calle. Afrodisio Aguado. S.A. Madrid. p. 10.

16.- Chueca, F. (1991) El Semblante de Madrid. Instituto de Estudios Madrileños. $2^{\text {a }}$ edición. p. 191.

17.- Pérez Ferrero, M. (1968) "El mundo "Ye- Ye" de Eduardo Vicente" en revista Blanco y Negro. ABC. Madrid. p. 100.

18.- Gómez Santos, M. (1955) Crónica del Café Gijón. Biblioteca Nueva. Madrid. p. 143.

19.- Gómez de la Serna, R. (1955) en Gómez Santos, M. Colofón de Crónica del Café Gijón. Biblioteca Nueva. Madrid. p. 184.

20.- Gómez Santos, M. (1955) Crónica del Café Gijón. Biblioteca Nueva. Madrid. p. 32.

21.- Marañón, G. (1956) en Neville, E. Prologo de La familia Mínguez. Taurus. Madrid. p. 12. 


\title{
]|lConclusiones
}

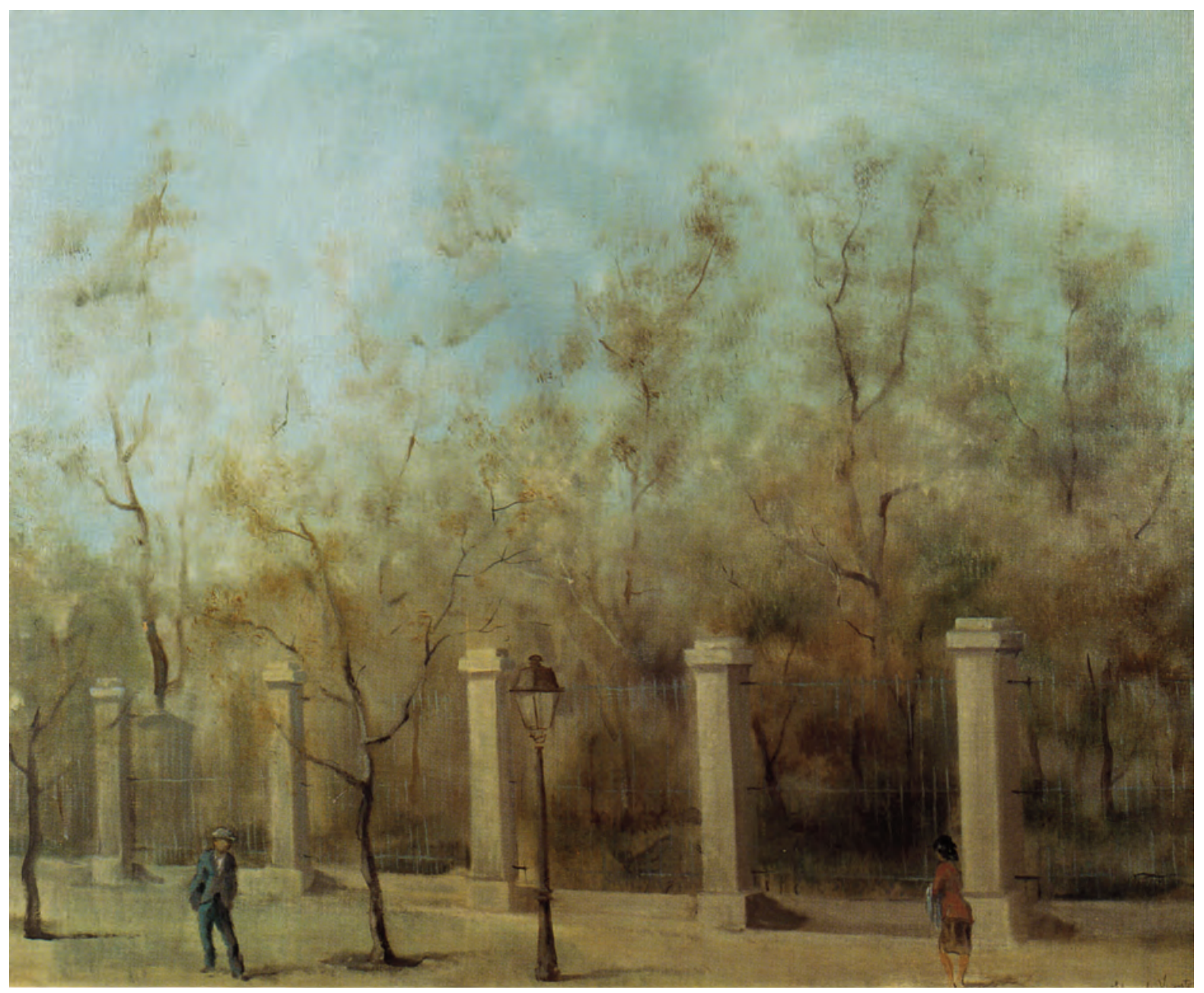

Vista del Jardín Botánico con figuras. 1955. Madrid.

Óleo sobre lienzo. Comunidad de Madrid.

\author{
Eduardo Vicente
}



La historia tradicional trabajaba con documentos escritos, rechazando u olvidando la existencia de otro tipo de documentación: objetos, pinturas, grabados, fotografías o carteles. No así la nueva historia que aprende de antropólogos y arqueólogos la importancia de las imágenes como fuentes documentales $99^{1}$

Eguizábal Maza, R. (2010:138)

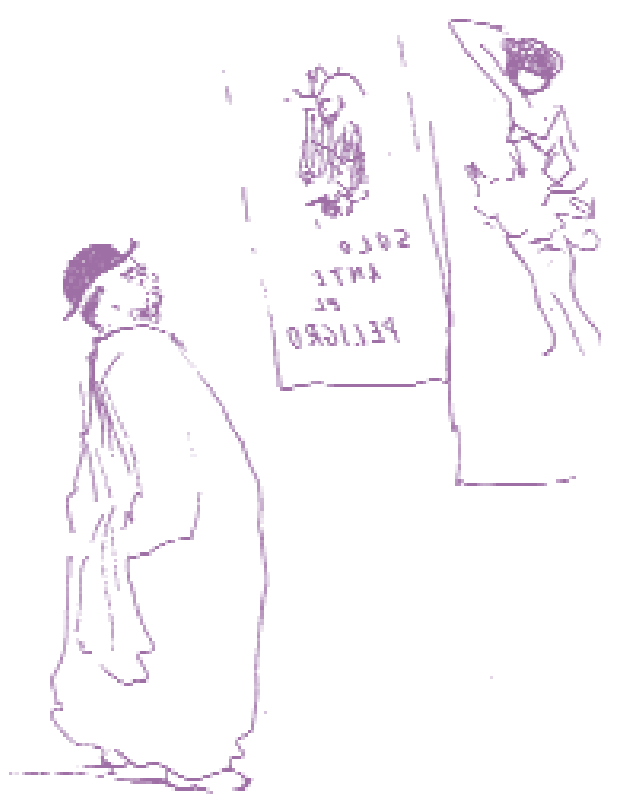





\section{Conclusiones.}

El objetivo principal de la presente tesis doctoral ha sido la investigación de las interacciones existentes entre la transmisión de ideología y la representación de normas y valores sociales en el seno de la obra artística de Eduardo Vicente. El enfoque de nuestro trabajo no podía por tanto ser otro que el derivado del conocimiento de la imagen, sus características y capacidadde influencia, tanto en los entornos sociales como en los individuales, desde la trascendencia psicológica referida a la interpretación del entorno como a su capacidad cultural para elaborar constructos sociales.

Desde el respeto más escrupuloso a la tradición académica, hemos pretendido aportar un giro sustancial a los estudios clásicos de la imagen introduciendo una nueva e importante variable, la comunicación, en el complejo entramado que configuran los nuevos procesos de crear y las nuevas formas de mirar la obra artística.

Abundando en esta idea, cabe destacar que, hemos pretendido mostrar que nuestras indagaciones sobre el valor de la imagen y las de su marco social y cultural permiten poner de manifiesto las diferentes formas de crear y los distintos modos de mirar o contemplar la obra y la intencionalidad del artista. Mediante el trabajo experimental creemos demostrar que el arte es una forma válida y que arroja la suficiente certeza como para ser tomado en consideración como elemento transmisor del conocimiento en la recreación de periodos históricos.

La obra artística, como medio de conocimiento, también ha supuesto un nuevo enfoque en el estudio de la realidad social. Por una parte, nos ha permitido descubrir el papel de la imagen como vehículo de transmisión de ideología política y religiosa y, por otra, como representativa de los modelos sociales, lo que nos habilita para explorar y comprender el complicado entramado social y cultural en el que se producen o en el que se contemplan las imágenes.

La obra de un artista debe ser investigada no sólo por lo que presenta, sino también por lo que representa. La capacidad transformadora del arte, vinculada a las pulsiones psicológicas de su creador, sus motivaciones y sus compromisos, forman un universo de representaciones que interactúa con los referentes sociales y culturales, contribuyendo a su formación y transformación. Es por esto que debemos de tener en cuenta otro cúmulo de variables, las 
que constituyen el universo del que contempla la obra, la interpreta y completa con su atribución de sentido y significado.

Este hecho se presenta en esta tesis doctoral como un dato concluyente, fundamentado en los postulados que conforman el pensamiento y se configura como un hecho central para poder comprender en su totalidad el importante papel que desempeña la obra artística como transmisora de ideología y representativa de modelos sociales.

Las indagaciones y análisis comparativos de la obra de Eduardo Vicente nos han permitido argumentar planteamientos y postulados relacionados con la obra artística y su poder comunicativo; con su importancia y su transcendencia; con el acto de crear y el acto de mirar, como bien explica E. H. Gombrich:

"Las formas del arte antiguo y moderno no son duplicados de lo que el artista tiene en la mente, como no son duplicados de lo que ve en el mundo exterior. En ambos casos son transposiciones a un medio adquirido, a un medio desarrollado por la tradición y las habilidades del artista y del contemplador". 2

Gombrich, E. H. (2002:314)

Así pues, una vez finalizados los diferentes capítulos que componen este trabajo de investigación:

- Capítulo 1.- Introducción Metodológica.

Capítulo 2.- Propaganda política. La imagen como transmisora de ideología.

Capítulo 3.-La imagen como representativa de modelos sociales.

* Capítulo 4.- Eduardo Vicente entre la pintura y la ilustración gráfica. Contexto social y estudio experimental.

Se hace necesario verificar la hipótesis con que comenzamos este trabajo, así como constatar el grado de consecución de los objetivos, tanto generales como específicos, que fueron definidos en el capítulo primero: 
Introducción metodológica, y que han servido de guía del trabajo de investigación.

\section{Verificación de la hipótesis.}

A lo largo del estudio teórico y práctico hemos podido observar cómo la obra de Eduardo Vicente es un fiel reflejo del periodo histórico en que él vivió y que, además de describir la realidad como solamente él sabía, donde unió la humanidad más sublime con aspectos más terrenales, y la calidad ética, cumplió y continúa cumpliendo una función propagandística, y representa con rigor los modelos de la sociedad del momento.

Nuestra hipótesis de partida quedó formulada en los siguientes términos:

La obra artística de Eduardo Vicente cumplió la función comunicativa de transmitir la ideología republicana y a su vez sirvió para transmitir las actitudes, valores y normas de la sociedad del periodo analizado.

Desde el capítulo 2, dedicado al estudio teórico de la propaganda: sus características y sus vinculaciones, hemos comprobado cómo Eduardo Vicente sirvió al bando republicano realizando carteles y grabados para distintas organizaciones. Además, sus obras sobre la Guerra Civil española son una denuncia del horror y la brutalidad de una guerra (como todas) sin sentido, donde todos los combatientes resultaron perdedores en mayor o menor medida. Vemos pues, cómo indiscutiblemente parte de su obra cumple esa función de propaganda política.

No obstante, su obra en mucho más profusa y variada. Eduardo Vicente, también pintó escenas religiosas. Fue un maestro en el manejo de los murales y tuvo muchos encargos para decorar diferentes ermitas, iglesias e incluso catedrales. Como es lógico, en estos trabajos la obra creada en los murales refleja escenas religiosas de la doctrina católica.

En el capítulo 3 se hace un significativo recorrido sobre el valor de la imagen como fuente de conocimiento. Nuestras indagaciones en este sentido nos Ilevan a constatar que la obra de Eduardo Vicente es un fiel reflejo de la sociedad en la que se produjo y es una clara representación de la cultura en 
el sentido más amplio y rico del término.

A lo largo del capítulo 4, donde se estudia la vida y obra de Eduardo Vicente, hemos podido cuantificar la función propagandística y la representativa de modelos sociales en cada una de las obras seleccionadas en nuestra investigación, organizadas por categorías para poder encontrar similitudes y diferencias significativas y representativas en cada una de ellas. Por otro lado, a través de la inferencia, se han podido estudiar diferentes aspectos de la sociedad del momento tales como: el papel del hombre y de la mujer, las clases sociales, las profesiones como medio de vida, la vida en diferentes ciudades y pueblos, las tradiciones y diversiones que ocupaban las horas de ocio de los ciudadanos de este periodo histórico.

Este valioso contenido cultural que atesora la obra de Eduardo Vicente actúa sobre la mente de los espectadores y sobre su conducta (dimensión individual), favorece el conocimiento y permite las relaciones interpersonales (dimensión colectiva), funciona como homologador cultural, define y determina consecuentemente los estilos de vida de los personajes representados (dimensión social) y, por último, cabe destacar que, desde una dimensión descriptiva, la obra artística determina y refleja la cultura de una sociedad en una etapa histórica determinada (Cuadro 1).

Dimensión Cognitiva

Dimensión Colectiva

Dimensión Social

Dimensión Descriptiva

\section{Desarrollo Individual}

Desarrollo Social

Modelos Sociales

Producción Artística 
Por todo lo expuesto, nos encontramos en condiciones de realizar un primer acercamiento a la hipótesis planteada al inicio de este trabajo de investigación. No obstante, antes de llegar a la exposición de las conclusiones finales y definitivas, es necesario comprobar el grado de consecución de los objetivos, tanto generales como específicos, que formulamos al inicio de la investigación, así como proponer nuevas vías de investigación surgidas a partir de los datos obtenidos en la presente tesis doctoral.

\section{Grado de consecución de los objetivos.}

Respecto a los objetivos, planteados en el capítulo 1, dedicado a la introducción metodológica, referidos básicamente al conocimiento del valor de la imagen en la obra artística de Eduardo Vicente y la función que cumplen como material comunicativo capaz de transmitir ideologías y representar las actitudes, valores y normas de la sociedad en que se produjeron, podemos afirmar que:

10.- La imagen sirve para conocer acontecimientos políticos, tendencias económicas y estructuras sociales, así como para el estudio del pensamiento, la historia de la vida cotidiana, la historia de la cultura, e incluso la ética y la estética que rigen en cada etapa histórica.

Sin el uso de las imágenes de las obras artísticas muchos de los ámbitos de conocimiento que hoy poseemos no habrían podido llevarse a cabo y no hubieran salido a la luz. Si únicamente se hubieran usado las fuentes tradicionales (textos escritos y documentos oficiales) pues en ellos no se pueden contemplar la cantidad de aspectos y detalles que contienen las imágenes por lo que necesariamente se pierde una información relevante a la hora de conocer e interpretar, pero fundamental para contextualizar.

La imagen, además de otras funciones, tiene la función vicarial donde es capaz de contener todos los elementos de cualquier realidad, por compleja que ésta sea.

20.- El estudio de la imagen ha puesto de manifiesto, de forma clara y rotunda, su importancia como fuente documental y su valor para conocer diferentes épocas y acontecimientos dignos de ser comprendidos y valorados. 
El uso de la imagen como documento histórico es una fuente imprescindible para compartir las experiencias y los conocimientos, no verbales, de la cultura de cualquier momento.

Así contemplar y estudiar la obra artística de Eduardo Vicente nos ha permitido recrear y conocer parte del pasado reciente de nuestro país.

30.- Las imágenes nos permiten la reconstrucción de la cultura en sus coordenadas espacio-temporales, es decir, la cultura en un país determinado y de una época concreta. Tienen la capacidad de presentarnos el ambiente de las ciudades y pueblos, los edificios por fuera y por dentro, sus gentes y las actividades que realizan; además de su vestuario, mobiliario y todos los utensilios que se usaban en el contexto social y cultural representado.

Por otra parte, la imagen se nos presenta como un soporte comunicativo, dando información de la ideología que representa y de los valores sociales del momento en que se produjeron, lo que permite comunicar y conocer el mundo que nos rodea.

Así, el arte se convierte en realidad, en paradigma de una nueva forma de conocer que se concentra en sí mismo y desencadena muchas posibilidades de estudio y análisis. Vemos pues, cómo los actos de ver y de observar la obra artística se consolidan como elementos mediadores de los modos de enseñar y de aprender.

En definitiva, el arte actúa como mediación del conocimiento, sabiendo que siempre el conocimiento resultante del estudio de cualquier obra artística constituye un acto de experiencia.

40.- El contexto histórico, político y cultural de España entre los años 1909 y 1968, años en los que vivió Eduardo Vicente, se caracterizó por ser un periodo convulso, en el que se dieron muchas circunstancias políticas y diferentes formas de gobierno: monarquía constituyente hasta 1923, dictadura (1923 - 1931), II República (1931 - 1936), conflicto bélico (1936 - 1939) y desde el año 1939 la Dictadura del General Franco. Se asistió, por tanto a la guerra civil y una larga posguerra, fueron años difíciles y comprometidos pero llenos de posibilidades creativas. 
En la actualidad se habla mucho de recurrir a la innovación y la creatividad para superar la crisis económica en la que estamos inmersos. Los años en los que vivió el artista también fueron tiempos de crisis económica, política y social y esta pudo ser la causa por la que Eduardo Vicente utilizó diferentes técnicas y formatos como medio de vida: pintor, ilustrador, grabador, muralista, etcétera. Su vida y su obra son un testimonio coherente de lucha y compromiso con sus ideales.

5.- El estudio experimental de la obra de Eduardo Vicente nos ha permitido cuantificarla en relación a la función que ésta cumple como transmisora de ideología y representativa de modelos sociales. Los datos numéricos nos presentan un porcentaje muy superior para la representación de modelos sociales con un $89 \%$, frente a un $11 \%$ de transmisión de ideologías, del total de la muestra; pero este dato numérico adquiere una mayor relevancia cuando los porcentajes se extraen de cada una de las categorías de las obras en que se dividieron para su análisis.

Desde esta nueva perspectiva, podemos afirmar que los carteles y retratos cumplen fundamentalmente una función propagandística, ya que los primeros se hicieron para la transmitir las ideas de diferentes organizaciones republicanas, y en los retratos están representados personajes de relevancia política, así como familiares y amigos del artista.

En los murales se representan escenas religiosas que sirven para la transmisión de ideología católica.

Y las ilustraciones y la categoría que hemos denominado "Otras obras", en su mayoría tienen la función de representar los modelos sociales.

Así, este estudio cuantitativo nos permite afirmar que el tipo de obra determina, en gran medida, la función que se pretende conseguir en el espectador de la obra.

6.- Las imágenes de la obra artística de Eduardo Vicente ponen de manifiesto el pensamiento ideológico y social de la época analizada, especialmente en las obras que el artista realizaba para diferentes organizaciones políticas y en los programas culturales, como las Misiones Pedagógicas, en las que participaba activamente poniendo el arte al alcance 
de todos los ciudadanos.

7.- Este trabajo de investigación, en el estudio teórico sobre la propaganda, nos ha permitido descubrir que la propaganda es inherente a la organización estatal. Es decir, Estado y propaganda aparecen siempre de forma inseparable.

El estado utiliza todas las técnicas y recursos a su alcance para conseguir sus pretensiones, a saber:

Los medios convencionales:

- Folletos

- Carteles

- Medios de Comunicación social

$-\ldots$

* El uso del "acontecimiento"

Los símbolos.

Las formas de vida.

La moda.

Las fiestas

Los mitos

Y determinados programas culturales para poner las artes al servicio de la propaganda.

En este último apartado es donde nos colocamos con la obra de Eduardo Vicente como transmisora de ideología.

8.- Las obras de Eduardo Vicente son un fiel reflejo de la cultura dominante en el periodo histórico en el que vivió.

A través de su obra, utilizando un enfoque cualitativo, hemos podido conocer las actitudes, los valores y las normas sociales. 
En este estudio cualitativo y por medio de la inferencia hemos comprobado cómo el arte se convierte en mediador del conocimiento y, a través suyo, hemos identificado diferentes aspectos para estudiar el contexto social y cultural de la época.

Los indicadores extraídos de la obra de Eduardo Vicente que hemos utilizado en el análisis han sido:

Los diferentes roles sociales:

- Masculino.

- Femenino

- La infancia

Las clases sociales.

La vidas en las ciudades que tuvieron un significado especial en la vida de Eduardo Vicente:

- Madrid y sus alrededores.

- París.

- Nueva York.

Las gentes y sus actividades en los que encontramos representados numerosos oficios.

- El ocio y entrenamiento:

- Los cafés y las tabernas.

- Fiestas populares

- Bailes tradicionales.

- El movimiento "Ye-yé" de los años 60

- Las corridas de toros.

- Los encierros.

El estudio de todos y cada uno de estos indicadores nos ha permitido el conocimiento de la realidad física y social de esta etapa histórica.

9.- Este trabajo de investigación sirve para dar a conocer el legado artístico de Eduardo Vicente, hombre de grandes convicciones, que supo vivir fiel a sus ideales y dejarnos una magnífica obra artística, poco conocida y, por este motivo, insuficientemente valorada. 
Con este trabajo queremos reivindicar su obra, digna de ser estudiada y reconocida por la comunidad artística y científica contribuir a su conocimiento para acercarle al lugar que le corresponde en la historia del arte de nuestro país.

Todas las imágenes analizadas en la obra artística de Eduardo Vicente pueden y deben de ser consideradas como "un acto comunicativo indirecto", no hay imposiciones, ni órdenes, no hay argumentación, nos encontramos ante la pura sugestión de la imagen.

El resultado de nuestro trabajo de investigación es especialmente profuso en la obtención de datos. Todos y cada uno de esos datos han sido analizados con rigurosidad, se han puesto en evidencia los componentes y las funciones de la imagen, se han clasificado y categorizado para convertirlas en expresivas y significativas. Nuestro trabajo enlaza en este punto con las ideas de Valeriano Bozal cuando señala la doble función de la imagen:

\section{"Las imágenes informan y expresan, representan y crean" $\mathbf{3}$}

Bozal, V. (1991:121)

No obstante, nuestro planteamiento aporta una tercera función pues, como hemos demostrado en las páginas precedentes, consideramos que las imágenes, además de informar y expresar, representar y crear, también conforman y deforman.

En definitiva, podemos concluir afirmando que esta investigación sobre la prolífica producción de Eduardo Vicente durante el periodo comprendido entre 1909 - 1968, le revela como un artista multifacético de primer orden que alternó la actividad propagandística con la asidua colaboración para la industria editorial, sin olvidar el cultivo de las artes plásticas. Su ingente legado está constituido por un amplísimo repertorio gráfico de indiscutible modernidad que lo erige como un referente esencial de la ilustración gráfica y de la pintura y le confirman como un artista de múltiples registros.

Con las consabidas limitaciones, esperamos haber efectuado una contribución al estado del conocimiento del artista cuyo estudio hemos abordado y, por extensión, pretendemos haber abierto nuevas vías de 
investigación, que podrían encaminarse al estudio de otras variables, que aunque las hemos constatado y medido en el análisis muestral (los aspectos formales, los técnicos y algunos indicadores del contenido) no han recibido cobertura en esta investigación, que se ha centrado principalmente en la función de la obra artística como transmisora de ideología y representativa de modelos sociales y que, definitivamente, merece una tarea investigadora adicional.

Con esta tesis doctoral consideramos que hemos iniciado una carrera investigadora que trataremos de ir construyendo desde un enfoque multidisciplinar, la rigurosidad del método científico y las motivaciones y curiosidades propias del investigador. Esperamos en un futuro inmediato poder explorar las nuevas vías de investigación identificadas con anterioridad y abrir otras nuevas en las interesantes relaciones entre la imagen y su contribución a la representación e interpretación de la realidad. Las relaciones entre la imagen y el poder y la utilización de las primeras al servicio de la promoción y mantenimiento de los segundos es, probablemente, una de esas cuestiones que, por mucho que pasen los años, siempre deberán ser estudiadas desde un punto de vista científico y crítico, más aún cuanto más complicadas sean las circunstancias socioeconómicas y políticas. Cualquier poder tiende a promover su perpetuación y la utilización de las imágenes, en una cultura eminentemente audiovisual, será uno de los medios más utilizados para alcanzar ese objetivo. Ampliar los horizontes del conocimiento de la imagen, sus relaciones con los poderes establecidos, y sus implicaciones sociales, culturales, económicas y políticas, son sin duda una necesidad permanente a la que la universidad debe dar respuesta. Consideramos modestamente que este trabajo ha servido, siquiera mínimamente, a este propósito. 

Notas

1.- Eguizábal Maza, R. (2010) "La historia del cartel como forma de historia cultural" en Otros fines de la Publicidad. Comunicación Social ediciones y publicaciones. Sevilla-Salamanca-Zamora. P. 138.

2.- Gombrich, E. H. (2002) Arte e ilusión .Debate. Madrid. p. 314.

3.- Bozal, V. (1991) "Las imágenes en la Enseñanza, la enseñanza de la imagen" en Revista de Educación. No 296. Servicio de Publicaciones del Ministerio de Educación y Ciencia. Madrid. p. 121. 



\section{[] Fuentes Documentales}

㕵 Bibliografía y Webgrafía.

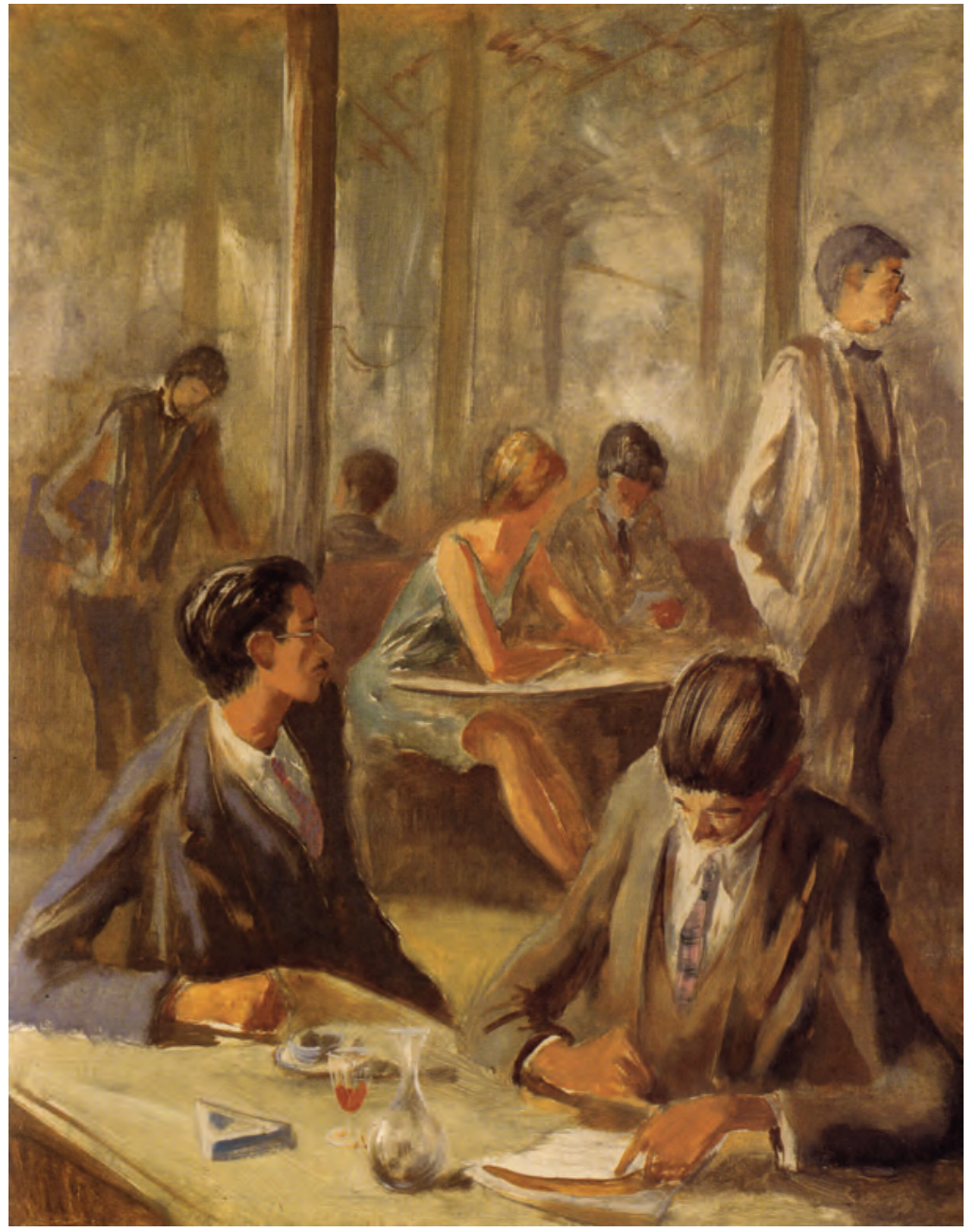

El Café Gijón. 1950. Madrid.

Óleo sobre lienzo. Colección Ángel de las Heras.

Eduardo Vicente 





\section{Bibliografía.}

- Abellá, R. (1978) Por el imperio hacia Dios. Crónica de una postguerra. Planeta. Barcelona.

- Aguilera Cerni, V. (1966). Ortega y D'Ors en la cultura artística española. Ciencia Nueva. Madrid.

- Aguilera Cerni, V. (1969). El arte impugnado. Cuadernos para el diálogo. Madrid.

- Aguilera Cerni, V. (1970). Iniciación al arte español de la postguerra. Península. Barcelona.

- Aguilera Cerni, V. (1975). La postguerra: documentos y testimonios. Ministerio de Educación y Ciencia. Madrid.

- Alcocer Garmendía, J.A. (1991). Qué es el mundo del cartel. Granada, E. y D. Madrid.

- Almagro, A. (1955). Constantes de lo español en la historia y en el arte. Imprenta Huertas. Madrid.

- Alvarado López, M.C. (2006). "Consideraciones para una historia de la publicidad social en España", en Publicidad y Cultura. La publicidad como homologador cultural. Comunicación Social. Sevilla.

- Alvarado López, M.C. (2008). "Nueva modernidad, nueva publicidad", en La publicidad en el contexto digital. Comunicación Social. Sevilla-Zamora.

- Aparici, R. y García Matilla, A. (1989). Lectura de imágenes. Ediciones de la Torre. Madrid.

- Aparici, R., Fernández Baena, J., García Matilla, A. y Osuna Acedo, S. (2006). La imagen. Análisis y representación de la realidad. Gedisa, S.A.. Barcelona.

- Aracil, A. y Rodríguez, D. (1982). El siglo XX. Entre la muerte del arte $y$ el arte moderno. Istmo. Madrid. 
- Aranguren, J.L. (1972). De Nonell a la última vanguardia. Galería Internacional de arte. Madrid.

- Aranguren, J.L. (1972). Treinta años de arte español (1943-1972). Guadarrama. Madrid.

- Aranguren, J.L. (1981). La filosofía de Eugenio d'Ors. Espasa Calpe. Madrid.

- Arnheim, R. (1976) El pensamiento visual. EUDEBA. Buenos Aires.

- Azcarte Ristori, J.M. (1978). Panorama del arte español del siglo $X X$. UNED. Madrid.

- Azcoaga, E. (1944). El auténtico lirismo de Eduardo Vicente. Madrid.

- Aznar Almazán, S. (1991). "Carteles y cartelistas" en Espacio, tiempo y forma. Serie VII. Historia del Arte.

- B. O. E. del 18 de julio de 1945.

- Babbie, E. (2000). Fundamentos de la investigación social. Parainfo. México.

- Bardin. L. (1986) El análisis de contenido. Akal. Madrid.

- Barthes, R. (1982). Investigaciones retóricas. I. La antigua retórica. Ediciones Buenos Aires. Barcelona.

- Barthes, R. (1986). Lo obvio y lo obtuso. Imágenes, gestos y voces. Paidós. Barcelona.

- Baudrillard, J. (1993). Cultura y simulacro. Kairós. Barcelona.

- Baudrillard, J. (2000). Pantalla Total. Anagrama. Barcelona.

- Benavides, J. y León, J.L. (1993). La crisis de la publicidad. Edipo. Madrid. 
- Bercer, J. (1975) Modos de ver. Gustavo Gili. Barcelona.

- Bernbach, B. (1999). La fuerza de la publicidad. Cuadernos Cinco Días. Madrid.

- Biescas, J.M. y Tuñón de Lara, M. (1980). España bajo la dictadura franquista (1939-1975). Labor. Barcelona.

- Blanco y Negro (1902) "Concurso de carteles para las fiestas de mayo". Madrid. no 573. 26-04-1902.

- Bonet, J.M. (1995). Diccionario crítico de las Vanguardias en España (1907-1936). Alianza Editorial S.A.

- Bonet Correa, A. (1981). Arte del franquismo. Cátedra. Madrid.

- Botti, A. (1992). Cielo y dinero. El nacionalcatolicismo en España. 1881-1975. Alianza. Madrid.

- Bouza, F. (1996). "Política y Comunicación". En El País. 3 de diciembre de 1996. Madrid.

- Bozal, V. (1966). El realismo, entre el desarrollo y el subdesarrollo. Ciencia Nueva. Madrid.

- Bozal, V. (1972). Historia del arte en España (Volúmen 2). Istmo. Madrid.

- Bozal, V. (1976). El intelectual colectivo y el pueblo. Comunicación. Madrid.

- Bozal, V. (1977). El lenguaje artístico. Península. Barcelona.

- Bozal, V. (1978). El arte del siglo XX. La construcción de la vanguardia. Cuadernos para el diálogo. Madrid.

- Bozal, V. (1987). Mímesis: las imágenes y las cosas. Visor. Madrid. 
- Bozal, V. (1989). El siglo de las caricaturas. Historia 16. Madrid.

- Bozal, V. (1991) "Las imágenes de la enseñanza, la enseñanza de la imagen" en Revista de Educación , no 296. Ministerio de Educación y Ciencia. Madrid.

- Bozal, V. y Llorens, T. (1976). España. Vanguardia artística y realidad social. 1936-1975. Gustavo Gili. Barcelona.

- Brihuega, J. (1981). Las vanguardias artísticas en España. 19091936. Istmo. Madrid.

- Brihuega, J. (1982). Manifiestos, proclamas, panfletos y textos doctrinales (Las vanguardias artísticas en España. 1910-1931. Cátedra. Madrid.

- Brown, J. A.C. (1991) Técnicas de persuasión. Alianza Editorial. Madrid.

- Bunge, M. (1970). La investigación científica. Su estrategia y su filosofía. Ariel. Barcelona.

- Bunge, M. (1972). Teoría y realidad. Ariel. Barcelona.

- Burke, P. (2005). Visto y no visto. El uso de la imagen como documento histórico. Trad. Teófilo de Lozolla. Crítica. Barcelona.

- Cabañas Bravo, M. (1996). La política artística del franquismo. El hito de la Bienal Hispano-Americana de Arte. CSIC. Madrid.

- Cabrera García, M.I. (1998). Tradición y vanguardia en el pensamiento artístico español (1939-1959). Universidad de Granada. Granada.

- Cacho Viu, V. (1997). Revisión de Eugenio d'Ors. Quaderns Crema. Barcelona. 
- Calvo Serraller, F. (1985). España. Medio siglo de arte de vanguardia. 1939-1985 (Volúmen 2). Fundación Santillana-Ministerio de Cultura. Madrid.

- Calvo Serraller, F. (1987). Imágenes de lo insignificante. El destino histórico de las vanguardias. Taurus. Madrid.

- Campoy, A.M. (1957). Pintores españoles contemporáneos. Omega. Barcelona.

- Campoy, A. M. (1968) "Arte y Artistas" en ABC. Madrid. 28/05/1968.

- Campoy, A.M. (1973). Diccionario crítico del arte español contemporáneo. Ibérico Europea de Ediciones. Madrid.

- Campoy, A. M. (1976). 100 maestros de la pintura española contemporánea. Ibérico Europea de Ediciones. Madrid.

- Cantalejo, R. (2008). Casino de la Unión, Segovia. Bibliografía Incompleta - Siglos XIX y XX. Segovia.

- Carey, J.W. (1965). "La publicidad: función institucional" en El impacto publicitario. Hispano-Europea. Barcelona.

- Carr, R. (1969). España 1808-1939. Ariel. Barcelona.

- Carr, R. (1996). La época de Franco (Historia de España Menéndez Pidal, $t X L I)$. Espasa. Madrid.

- Carr, R. (1999). España de la Restauración a la Democracia 18751980. Ariel-Historia. Barcelona.

- Carrizo Saimero, G., Irueta-Goyone, P., López de Quintana, E. (1994). Manual de fuentes de información. Cegal. Madrid. Barcelona.

- Carulla, J. y Carulla, A. (1995). España en 100 carteles. Postermil.

- Carulla, J. y Carulla, A. (1997) La publicidad en 2000 carteles. Vol. I. Postermil. Barcelona. 
- Carulla, J. y Carulla, A. (2000). El color de España. Postermil. Barcelona.

- Casares, J. (1973) Diccionario ideológico de la Lengua Española. 2a edición. Gustavo Gili. Barcelona.

- Cassier, E. (1951). Individuo y cosmos en la filosofía del Renacimiento. Emecé. Buenos Aires.

- Castellet, J.M. (ed) (1977). La cultura bajo el franquismo. Península. Barcelona.

- Castiñeiras González, M.A. (1998). Introducción al método iconográfico. Ariel, S. A. Barcelona.

- Cebrián, J.L. (2001). "La política del odio". En Documentos El País. 20 de septiembre de 2001. P.39. Madrid.

- Cela, C.J. (1944). Nuevas andanzas y desventuras de Lazarillo de Tormes. Noguer, S.A. Barcelona.

- Cela, C.J. (1959). Cuadernos de Guadarrama. Lumen, S.A. Barcelona.

- Cirlot, J.E. (1972). Arte del siglo XX. Labor. Barcelona.

- Chavarri, R. (1975). Mito y realidad de las Escuela de Vallecas. Ibérico Europea de Ediciones. Madrid.

- Chueca, F. (1951). El semblante de Madrid. Instituto de Estudios Madrileños. Madrid.

- Clark, E. (1989). La publicidad y su poder. Ed. Planeta. Barcelona.

- Corredor-Matheos, J. (1979). Vida y obra de Benjamín Palencia. Espasa Calpe. Madrid.

- Costa, J. (1977). El lenguaje fotográfico. Ed. CIAC, Biblioteca de la Comunicación. Barcelona. 
- Costa, J. (1992) Imagen pública. Una ingeniería social. Fundesco. Claves de Comunicación social. Madrid.

- Córdoba, P. (2008). La modernidad tipográfica truncada. Campgràfic Editors, S.L.

- Corominas, J. (1974) Diccionario crítico etimológico de la lengua castellana. Gredos. Madrid.

- Díaz, E. (1974). Notas para una historia del pensamiento español actual (1939-1973). Edicusa. Madrid.

- Díaz, E. (1987). Pensamiento español en la era de Franco. 19391985. EUDEMA. Madrid.

- Días Sánchez, J y Llorente Hernández, A. (2004). La crítica del arte en España (1939-1976). Istmo. Madrid.

- Diego, G. (1949). La pintura de Eduardo Vicente. Biblioteca José María Pereda. Universidad de California.

- Domenach, J. M. (1968) Le propagande politique. EUEBA. Editorial Universitaria de Buenos Aires. Cuarta edición.

- Dondis, D.A. (1978). La sintaxis de la imagen. Gustavo Gili. Barcelona.

- Dood, L.W. (1948) Public Opinion and Propaganda. Henry Holt and Co., Nueva York.

- Eco, U. (1981) Lector in fabula. Lumen, Barcelona.

- Eco, U. (1992) Obra abierta. Paneta Agostini. Barcelona.

- Eco, U. (1995) Interpretación y sobreinterpretación. University Press. Cambridge.

- Edwards, V. (1938) Group Leader's Guide to Propagande analysis. Columbia University. Press. Nueva York. 
- Egaña Casariego, F. (2005). "Una obra desconocida de Pedro Berruguete en Segovia: El primitivo retablo de la Cueva de Santo Domingo en Santa Cruz la Real", Goya, 309, Madrid.

- Egaña Casariego, F. (2008). Vaquero. Colegio Oficia de Aparejadores y Arquitectos Técnicos del Principado de Asturias \& Ediciones Trea, Gijón.

- Egaña Casariego, F. (2010). "El Concurso Internacional para el Faro de Colón. El proyecto español premiado", Goya, 331, Madrid, abril-junio, 2010.

- Eguizábal Maza, R. (1998). Historia de la publicidad. Ed. Eresma \& Celeste. Madrid.

- Eguizábal Maza, R. (2000). "Arte, publicidad y medios de comunicación" en Publicidad y Consumo: más de un siglo de historia. Instituto Nacional de Consumo. Santander.

- Eguizábal Maza, R. (2001). Fotografía Publicitaria. Cátedra. Madrid.

- Eguizábal Maza, R. (2002). "El arte al servicio de la técnica" en Publifilia. Revista de Culturas Publicitarias. n6. Colegio Universitario de Segovia. Segovia.

- Eguizábal Maza, R. (2002). Memoria de la seducción. Carteles del siglo XIX en la Biblioteca Nacional. Biblioteca Nacional de España. Madrid.

- Eguizábal Maza, R. (2007). "De la publicidad como actividad de producción simbólica" en Nuevas tendencias en la publicidad del siglo XXI. Martín Requero, M.I. y Alvarado López, M.C. (Coord.). Comunicación Social. Sevilla.

- Eguizábal Maza, R. (2007). Teoría de la Publicidad. Cátedra. Madrid.

- Eguizábal Maza, R. (2009). Industrias de la conciencia: Una historia de la Publicidad Social en España (1975-2009). Península. Madrid.

- Ellul, J. (1976) Histoire de la Propagande. P. U. F. 2a edición. Paris. 
- Enel, F. (1974) El cartel: lenguaje, funciones, retórica. Editorial Fernando Torres. Valencia.

- Faraldo, R.D. (1962). La Escuela de Madrid. Cigüeña. Madrid.

- Fernández, A. (1990). Historia del mundo contemporáneo. VicensVives. Barcelona.

- Ferrer, E. (2004) "Publicidad y propaganda". Revista Digital Independiente Voz Universitaria. 31 de julio de 2004.

- Ferrés, J. (2000). Educar en la sociedad del espectáculo. Paidós. Barcelona.

- Ferrés i Prats, J. (2008) La educación como industria del deseo. Un nuevo estilo comunicativo. Gedisa, S.A.. Barcelona.

- Florez, R. (1975). Eduardo Vicente. Artistas españoles contemporáneos. Servicio de Publicaciones del Ministerio de Educación y Ciencia. Bilbao. Barcelona.

- Fontana, J. (ed.) (1986). España bajo el franquismo. Crítica.

- Fontcuberta, J. (1994) El beso de Judas. Fotografía y verdad, ed. Gustavo Gili, Barcelona.

- Francés, J. (1945). Los dibujantes e ilustradores contemporáneos. Escuela de Artes y Oficios Artísticos de Madrid. Madrid.

- Franco Vene, G. (1983). Yo, Hitler. Nueva Lente. Madrid.

- Furones, M.A. (1980). El mundo de la publicidad. Salvat. Barcelona.

- Gaitán, J. y Piñuel, J.L. (1998). Técnicas de investigación en comunicación social. Elaboración y registro de datos. Síntesis. Madrid.

- Garreton, M. (1995). "Democracia y medios de comunicación, un marco general". En AA.VV. Los medios de comunicación, nuevas plazas para la democracia. Calandria. Lima. 
- García Felguera, M.S. (2000). El arte después de la guerra (Historia del Arte n.o 35). Historia 16. Madrid.

- García García, F. (1982). Creatividad e imagen en los niños. Ministerio de Educación y Ciencia. Madrid.

- García García, F. y otros (2007). Narrativa Audiovisual. Laberinto. Madrid.

- García Matilla, A. (1996). Los medios para la comunicación educativa. En APARICI, Roberto (Coord.)

- García Matilla, E. (1990). Subliminal:escrito en nuestro cerebro. Editorial Bitácora. Madrid.

- García Ochoa, L. (1983). "Benjamín Palencia, su entorno y su época" (Discurso de ingreso en la Real Academia de Bellas Artes de San Fernando). Madrid.

- Gaya Nuño, J. A. (1952). La pintura española del medio siglo. Ediciones Omega. Barcelona.

- Gibson, J. (1966) The senses considered as perceptual systems. Hougton mifflin. Boston.

- Gide, A. (1936) cita recogida por Martí Ibañez, F. en "Por un arte revolucionario" en Tiempos Nuevos, 1-12- 36.

- Gill, L.E. (1977). Publicidad y Psicología. Ed. Psique. Buenos Aires.

- Goffman, E. (1991). Los momentos y sus hombres. Paidós. Barcelona.

- Gombrich, E.H. (1994) Imágenes simbólicas. Alianza Editorial. Madrid. 1994.

- Gombrich, E.H. (2002). Arte e ilusión. Estudio sobre la psicología de la representación pictórica. Debate. Madrid. 
- Gombrich, E.H.(2004). Ideales e ídolos. Ensayos sobre los valores en la historia y en el arte. Debate, Barcelona.

- Gómez Santos, M. (1955). Crónica del Café Gijón. Biblioteca Nueva.

- González Martín, J.A. (1996). Teoría general de la Publicidad. Fondo de Cultura Económica. Madrid.

- González Martín, J.A. (1987-1988). "Publicidad, Modernidad y Posmodernidad", en Telos. Madrid.

- Gullón, R. (1955). Eduardo Vicente. Ayuntamiento de Reinosa. Casa de la Cultura Sánchez Díaz. Santander.

- Gubern, R. (1974). Mensajes icónicos en la cultura de masas. Editorial Lumen. Barcelona.

- Gubern, R. (1987) El simio informatizado. Fundesco. Madrid.

- Gubern, R. (1997) "Medios icónicos de masas". Historia 16, Madrid.

- Haskell, F. (1993) History and its Images. New Haven.

- Hegel, G.W. F. (1979) Introducción a la estética, Ed. Península. Barcelona.

- Heiber, H. (1988). Hitler. Salvat. Barcelona.

- Hitler, A. (1984). (Primera edición, 1925) Mi lucha. Antalbe. Barcelona.

- Hopkins, C.C. (1980). Mi vida en publicidad. Eresma (Clásicos publicitarios). Madrid.

- I.N.E. (1952). Principales actividades de la vida española en la primera mitad del siglo XX. Síntesis, Estadística. Madrid.

- Ibáñez Martín, J. (1945) Discurso de presentación de la Ley de Educación de 17 de julio de 1945 a las Cortes Españolas. 
- Isorna, B. (1959). Campanas de palo. Maribel, Artes Gráficas.

- Izard, M. (1973). Industrialización y obrerismo. Ariel. Barcelona.

- Jackson, G. (1981). Aproximación a la España contemporánea. 1898-1975. Grijalbo. Barcelona.

- Jiménez, J. R. (1950). Españoles de tres mundos. Visor Libros. Madrid.

- Juliá, S. (2004). Historia de las dos Españas. Taurus. Madrid.

- Julián, I. (1993) El cartel republicano en la Guerra Civil Española". Ministerio de Cultura. Dirección General de Bellas Artes y Archivos. Instituto de Conservación y Restauración de Bienes Culturales. Madrid.

- Kant, I. (1997). Crítica de la razón pura. Trad. Ribas, P. AlfaguaraSantillana. Madrid.

- Kaplún, M. (1985). El comunicador popular. CIESPAL. Quito.

- Kerch, D. y Crutchfield, R.S. (1972). Introducción a la Psicología Social. Ariel. Madrid.

- Kerlinger, F.N. (1970). Fouendations of Behavioural Research. Holf, Rimehart and Winston. Nueva York.

- Kleinbauer, W. E. (1971) Modern Perspectives in Western Art History. Nueva York.

- Knapp, M. L. (1988). La comunicación no verbal. El cuerpo y el entorno. Paidós Comunicación. Barcelona.

- Lagrange, L. (1864) Les Vernet et la pinture au VIIIa siècle. $2^{a}$ edición París.

- Laszlo, A. (1956). Mi tío Jacinto. José Janés. Barcelona.

- Larco, J. (1948). La pintura en España. Buenos Aires. 
- Leduc, R. (1986). Principios y prácticas de la publicidad. Ed. Deusto. Bilbao. Madrid.

- Leguineche, M. (1995). Los años de la infamia. Temas de hoy.

- León, J.L. (1992). La persuasión de las masas. Deusto. Bilbao.

- Leval, G. (1938). La reconstrucción social en España. Freedom Press. Londres.

- López Escobar, E. (1997). Modelos para el estudio de la comunicación colectiva. Editorial Enusa. Pamplona.

- Maltese, C. (1970) Semiología del mensaje objetual. Alberto Corazón Editor, Madrid, 1972.

- Marañón, G. (1956) en Neville, E. "Prologo de La familia Mínguez". Taurus. Madrid.

- Marc, V. en Restany, P. (1968) Un manifieste de la nouvelle peinture: Les noveaux Realistes. Planeta. Paris.

- Marchamalo, J. (1996). Bocadillos de delfín. GRIJALBO (Grijalbo Mondadori S.A.) Barcelona.

- Marcos Recio, J.C., García, A. y Nuño, V. (2004). Gestión de la documentación en la publicidad y en las relaciones públicas. Ed. Síntesis. Madrid.

- Marcos Recio, J.C. (2007) "Las fuentes de la información al servicio de la publicidad. Investigación y Planificación". en Nuevas Tendencias en la Publicidad del siglo XXI. Comunicación Social. Sevilla-Zamora.

- Marcos Recio, J.C. (2008). "La fotografía en la publicidad: archivos, bancos de imágenes y centros de documentación en el siglo XXI" en La publicidad en el contexto digital. Viejos retos y nuevas oportunidades. Pacheco Rueda, M. (Coord.). Ed. Comunicación Social. Sevilla-Zamora. 
- Martín Requero, M.I. (2000) "Propaganda política y educación. Las imágenes de los textos escolares en la escuela Franquista (1939/1975), en Publifilia. Revista de Culturas Publicitarias. Colegio Universitario de Segovia.

- Martín Requero, M.I. (2007). "Creatividad y nuevas tendencias de consumo" en Nuevas tendencias de la publicidad del siglo XXI. Comunicación Social. Sevilla-Zamora.

- Martínez Cachero, L.A. (1970). La emigración española a examen. ASE. Madrid.

- Martínez Gastey, P. (1999) "La investigación cualitativa" en La fuerza de la publicidad. Cuadernos cinco días. Madrid.

- Maslow, J.A. (1954). Motivation and personality. Harper and Row. Nueva York. Citado por: Cohen, L. y Manion, L. (1990). Métodos de investigación educativa. La Muralla, S.A. Madrid.

- Mattelart, A. (1994-1995). La invención de la comunicación. Bosch. Barcelona.

- Mattelart, A. (1993). La comunicación-mundo. Fundesco. Madrid.

- Mc. Quail, D. (1983). Mass comunication theory. An Introduction. Londres. Sage. (trad. Esp. Introducción a la teoría de la comunicación de masas. Barcelona. Paidós. 1985).

- McLuhan, M. citado por Enel, F. (1974) El cartel: lenguaje, funciones, retórica. Editorial Fernando Torres. Valencia.

- McLuhan, M. y Fiore, Q. (1988). El medio es el mensaje. Paidós. Barcelona.

- Medawar, P.B. (1972). The hope of progress. Methuen, Londres.

- Merani, A.L. (1979). Psicología genética. Ed. Grijalbo. México. 
- Meyer, W. (1991). Los creadores de imagen: poder y persuasión en Madison Avenue. Ariel. Barcelona.

- Miranda, L. (1944). Almudena o hitorias de viejos personajes. Afrodisio Aguado. Madrid.

- Moles, A. (1973) en "Imagen y Comunicación" de F. Torres. Valencia.

- Moles, A. (1976). El afiche en la sociedad urbana. Paidós. Buenos Aires.

- Moles, A. (1991) La imagen, comunicación functional. Trillas. Mexico.

- Moliné, M. (1988). La comunicación activa. Deusto. Bilbao.

- Moliner, M. (1984) Diccionario de uso del español. Tomo II. Gredos S. A. Madrid.

- Moragas, M. (1979). Sociología de la comunicación de masas. Propaganda política y opinión pública. Gustavo Gili. Barcelona. (volumen III).

- Morelli, A. (2001) Principios elementales de la propaganda de guerra, Edición Hiru. Hondarribia. 2001; original francés 2001.

- Moreno Galván, J. M. (1960). Introducción a la pintura española actual. Publicaciones Españolas. Madrid.

- Mouly, G.H. (1978) citado por: Cohen, L. y Manion, L. (1990). Métodos de investigación educativa. La Muralla, S.A. Madrid.

- Neville, E. (1956). La familia Mínguez. Taurus. Madrid.

- Neville, E. (1956). La piedrecita angular. Taurus. Madrid.

- Oejo, E. (1998). Dirección de arte. Ed. Eresma \& Celeste. Madrid.

- Ors, E. d'. (1945). Mis salones. Itinerario del arte moderno en España. Aguilar. Madrid. 
- Ors, E. d'. (1967). Menester del crítico de arte. Aguilar. Madrid.

- Ortega y Gasset, J. (1998). La rebelión de las masas. Ed. Tecnos. Madrid.

- Palencia, B. (1932). Los nuevos artistas españoles. Plutarco. Madrid.

- Panofsky, E. (1930). Hercules an Scheidewegw and andere antike Bildstoffe inder nevaren Kunst, Studien der Bibliothek. Warburg, XVIII. Leipziy_Berlin. Citado en Holly, M.A. Panofsky and the Foundations of Art History. Cornell University. Press $1^{\text {a }}$ Ed. 1984.

- Panofsky, E. (1979) El significado de las artes visuales. Alianza Editorial. Madrid.

- Panofsky, E. (1992) Estudio sobre iconografía. "Introducción". Alianza Editoral. Madrid.

- Pantorba, B. de (1980). Historia y crítica de las exposiciones nacionales de bellas artes celebradas en España. Jesús Ramón García Rama J. Madrid.

- Pareyson, L. (1954) Estetica. Teoria della formatività. Edizioni di «Filosofia», Turín.

- Payne, S.G. (1987). El régimen de Franco: 1936-1975. Alianza. Madrid.

- Peninou, G. (1976). Semiótica de la publicidad. Ed. Gustavo Gili. Barcelona.

- Pérez Ferrero, M. (1968) "El mundo "Ye- Ye" de Eduardo Vicente" en la revista Blanco y Negro. ABC. Madrid.

- Pericot, J. (1987). Servirse de la Imagen. Gredos. Madrid.

- Piaget, J. (2005). Psicología de la inteligencia. Crítica Editorial. Barcelona. 
- Picker, H. (1993). Hitler: anatomía de un dictador. Conversaciones de sobremesa. Grijalbo. Madrid.

- Pizarroso, A. (1993) Historia de la propaganda. Eudema. Madrid.

- Pizarroso, A. (1994). Historia de la Prensa. Centro de Estudios Ramón Areces. Madrid.

- Pizarroso, A. (1999) "La historia de la propaganda: una aproximación metodológica", en Revista Historia y Comunicación Social, no 4. Universidad Complutense. Servicio de Publicaciones. Madrid.

- Pose Porto, H. (2006). La cultura en las ciudades. Editorial GRAÓ de IRIF, S.L. Barcelona.

- Prat Gaballi, P. (1934). La publicidad racional. Labor, S.A. Barcelona.

- Prat Gaballi, P. (1939). El poder de la Publicidad. Juventud. Barcelona.

- Prat Gaballi, P. (1959). La publicidad combativa. Labor, S.A. Barcelona.

- Pratkanis, A. y Aronson, E. (1994). La era de la propaganda. Uso y abuso de la persuasión. Paidós Comunicación. Barcelona. 1994.

- Pratkanis, A. y Aronson, E. (1994) La era de la propaganda. Uso y abuso de la persuasión. Paidós Comunicación. Barcelona.

- Preston, P. (1978). España en crisis. Evolución y decadencia del régimen de Franco. Fondo de Cultura Económica. Madrid-México.

- Prieto Castillo, D. (1987). Discurso autoritario y comunicación alternativa. La Red de Jonás. Premia Editora. México.

- Qualterr, T. (1994). Publicidad y democracia en la sociedad de masas. Paidós. Barcelona. 
- Quirós, F. y Sierra, F. (2001). Comunicación, globalización y democracia. Crítica de la economía política de la comunicación y la cultura. Comunicación social. Sevilla.

- Ramonet, I. (1998). La tiranía de la comunicación. Debate. Madrid.

- Real Academia Española (1970) Diccionario de la Lengua Española. 19a edición. Madrid.

- Real Academia Española. (1975) Diccionario Manual Ilustrado. Espasa Calpe. Madrid.

- Reardon, K. (1983). La persuasión en comunicación. Paidós. Buenos Aires.

- Renal, J. (1980). Arte en peligro. 1936-39. Excmo. Ayuntamiento de Valencia. Fernando Torres-Editor, S.A. Valencia.

- Renau, J. (1937) La función social del cartel publicitario. Tipografía Moderna. $1^{\text {a }}$ edición. Valencia.

- Ricci Bitti, P. y Zani, B. (1990). La comunicación como proceso social. Grijalbo. México.

- Ripa, C. (1996) Iconología. I-II, trad. Lat. J y Y. Barja; trad. It. R. M. Marino Sánchez-Elvira y F. García Romero, Madrid. (1a ed. 1987).

- Rodero, E. (2000) "Concepto y técnicas de la propaganda y su aplicación al nazismo". En las Actas del III Congreso Internacional Cultura y Medios de comunicación. Publicaciones Universidad Pontificia. Salamanca.

- Rodrigo Martín, L. (Coord.) (2008). Publicidad y consumo. Nuevas modas, viejas causas y valores sociales. Comunicación Social. Sevilla-Zamora.

- Rodrigo Martín, L. (Coord.) (2011). Publicidad, innovación y conocimiento. Comunicación Social. Sevilla-Zamora. 
- Rotberg, R. I. y Rabb, T. K. (eds) (1988) Arts and History: Images and Their Meanins. Cambridg.

- Ruíz Melendreras, E. (Coord.) (1985). 100 años del cartel español. Publicidad comercial (1875-1975). Ayuntamiento de Madrid, Cámara de Comercio e Industria. Madrid.

- Ruíz Melendreras, E. (2003). "15 carteles para la historia", en Publifila. Revista de Culturas Publicitarias. n07. Colegio Universitario de Segovia. Segovia.

- Sánchez-Camargo, M. (1954). Pintura española contemporánea. La nueva escuela de Madrid. Ediciones Cultura Hispánica. Madrid.

- Sánchez-Camargo, M. (1954). Historia de la Academia Breve de Crítica de Arte. Homenaje a Eugenio d'Ors. Langa y Cia. Madrid.

- Satué, E. (1997). El diseño gráfico en España: historia de una forma comunicativa nueva. Alianza Madrid. Barcelona.

- Savater, F. (2002). Ética y ciudadanía. Editorial Montesinos.

- SedImayr, H. (1957). La revolución del arte moderno. Rialp. Madrid.

- Sontag, S. (1980) Sobre la fotografía. Edhasa. Barcelona.

- Starobinsky, J. (2002). El ojo vivo, trad. Julián Mateo Ballorca. Cuatro. Valladolid. (palabras del editor en la portada interior).

- Tamames, R. (1973). La República. La era de Franco. Alianza. Madrid.

- Tervarent, G. (1981) De la méthode iconologique, en Académie Royale de Belgique, Tome XII.4, Bruselas.

- Timoteo Álvarez, J. (1992). Historia y modelos de comunicación del siglo XX. Ariel. Barcelona. 
- Trapiello, A. (1994). Las armas y las letras. Literatura y guerra civil (1936-1939). Planeta. Barcelona.

- Tuñón de Lara, M. (1971). La España del Siglo XX. Tomo 1. Laia. Barcelona.

- Tusell, J. (1980). "El siglo XX", en Historia de España, Tomo XI. Carroggio. Barcelona.

- Tusell, J. (1984). Franco y los católicos. La política interior española entre 1945 y 1957. Alianza. Madrid.

- Tusell, J. (1992). Franco en la guerra civil, una biografía política. Tusquets. Barcelona.

- Tusell, J. y Martínez Novillo, A. (1991). Cincuenta años de arte. Galería Biosca 1940-1990. Tuner. Madrid.

- Ureña, G. (1982). Las vanguardias artísticas en la postguerra española. 1940-1959. Istmo. Madrid.

- Vallet, A. (1970). El lenguaje total. Editorial Luis Vives. Zaragoza.

- Vargas Llosa, M. (1994). Desafíos a la libertad. Aguilar, S.A. Grupo Santillana. Madrid.

- Vázquez Medel, M. A. (2004) "Los efectos de la propaganda: una aproximación desde la Teoría del Emplazamiento" en Propaganda y Comunicación. Una aproximación plural. Comunicación Social. Sevilla.

- Velasco, C. (1987). "Sucedáneos de posguerra", en Historia 16, no 137. Marzo de 1987.

- Velasco, C. (1988) "Publicidad y política en la guerra civil" en la Revista Historia 16, no 143. Madrid.

- Velasco, C. (1989). "Anuncios de posguerra", en Mensajes y Medios, no 9. Diciembre de 1989. 
- Velasco, C. (2000). "El consumo visto a través del cartel publicitario", en Publicidad y Consumo: más de un siglo de historia. Instituto Nacional de Consumo. Santander.

- Verdú, V. (2003). El estilo del mundo. La vida en el capitalismo de ficción. Anagrama. Barcelona.

- Vicente, E. (1950). Tipos de la calle. Afrodisio Aguado, S.A. Madrid.

- Vighi, F. (1979). Versos viejos. Edición no venal de la Caja de Ahorros y Monte de Piedad de Palencia. Palencia.

- Vilches, L. (1983). La lectura de la imagen. Paidós. Barcelona.

- Villafañe, J. (1985) Introducción a la teoría de la imagen. Pirámide. Madrid.

- VV.AA. (1990). Grandes personajes: Hitler. Castell. Barcelona.

- VV.AA. (1993). Carnavales. Colección de carteles del Círculo de Bellas Artes. Catálogo de la Exposición, Círculo de Bellas Artes. Madrid.

- VV.AA. (1999). 100 años de arte comercial en España. Catálogo de la Exposición, Obra Social y Cultural de Caja Segovia y Colegio Universitario de Segovia.

- White, D.J. (1983). Teoría de la decisión. Ed. Paidós. Barcelona.

- Wolf, M. (1994). La investigación de las comunicaciones de masas. Crítica y perspectivas. Instrumentos Paidós. Barcelona, Buenos Aires, México.

- Yates, F. A. (1975) Shaskespeare's Last Plays. Londrés.

- Zunzunegui, S. (1989) Pensar la imagen. Cátedera Universal del País Vasco.

- Diccionario de pintores y escultores españoles del siglo XX. Tomo XV. 

2 Webgrafía.

- http://www.elcultural.es/version_papel/ARTE/14181/Eduardo_Vicente $(05 / 05 / 2008)$

- http://www.museodelprado.muc.es (20/05/2008)

- http://www.bne.es (20/05/2008)

- http://bpsegovia.bcl.jcyl.es (20/05/2008)

- http://www.secc.es (20/05/2008)

- http://www.masdearte.com (20/05/2008)

- http://www.museoestebanvicente.es (20/05/2008)

- http://www.museoreinasofia.es (20/05/2008)

- http://www.muc.es (20/05/2008)

- http://www.unav.es (02/01/2009)

- http://eldoctorhache.wordpress.com (02/01/2009)

- http://www.arteespana.com (02/01/2009)

- http://www.artnet.com (02/01/2009)

- http://cipres.residencia.csic.es (02/01/2009)

- http://www.coleccionesrg.com (27/02/2009)

- http://www.arcadja.com (04/06/2009)

- http://www.residencia.csic.es (04/10/2009)

- http://www.salaretiro.com (04/10/2009)

- http://dialnet.unirioja.es (04/10/2009) 
- http://www.tallerdelprado.com (13/02/2010)

- http://pintura.aut.org (13/02/2010)

- http://www.artfacts.net (13/02/2010)

- http://comunidad-escolar.pntic.mec.es (13/02/2010)

- http://www.huelvainformación.es/article/ocio/692815/sera/eduardo/ vicente $(10 / 09 / 2010)$

- http://bpval.bcl.jcyl.es (30/03/2011)

- http://www.aab.es (30/03/2011)

- http://rabasf.insde.es (30/03/2011)

- http://www.cervantesvirtual.com (30/03/2011)

- http://www.foroxerbar.com/viewtopic.php (04/05/2011)

- http://www.books.google.com (30/05/2011)

- http://www.uva.es (01/08/2011)

- http://www.cuba.cu/gobierno/discursos/ (01/08/2011)

- http://www.pintura.aut.org (10/11/2011) 
Notas

1.- Marcos Recio, J.C. (2008). "La fotografía en la publicidad: archivos, bancos de imágenes y centros de documentación en el siglo XXI", en La publicidad en el contexto digital. Comunicación Social. Sevilla. 



\section{[]|Anexo I}

Cronología vital y Artística.

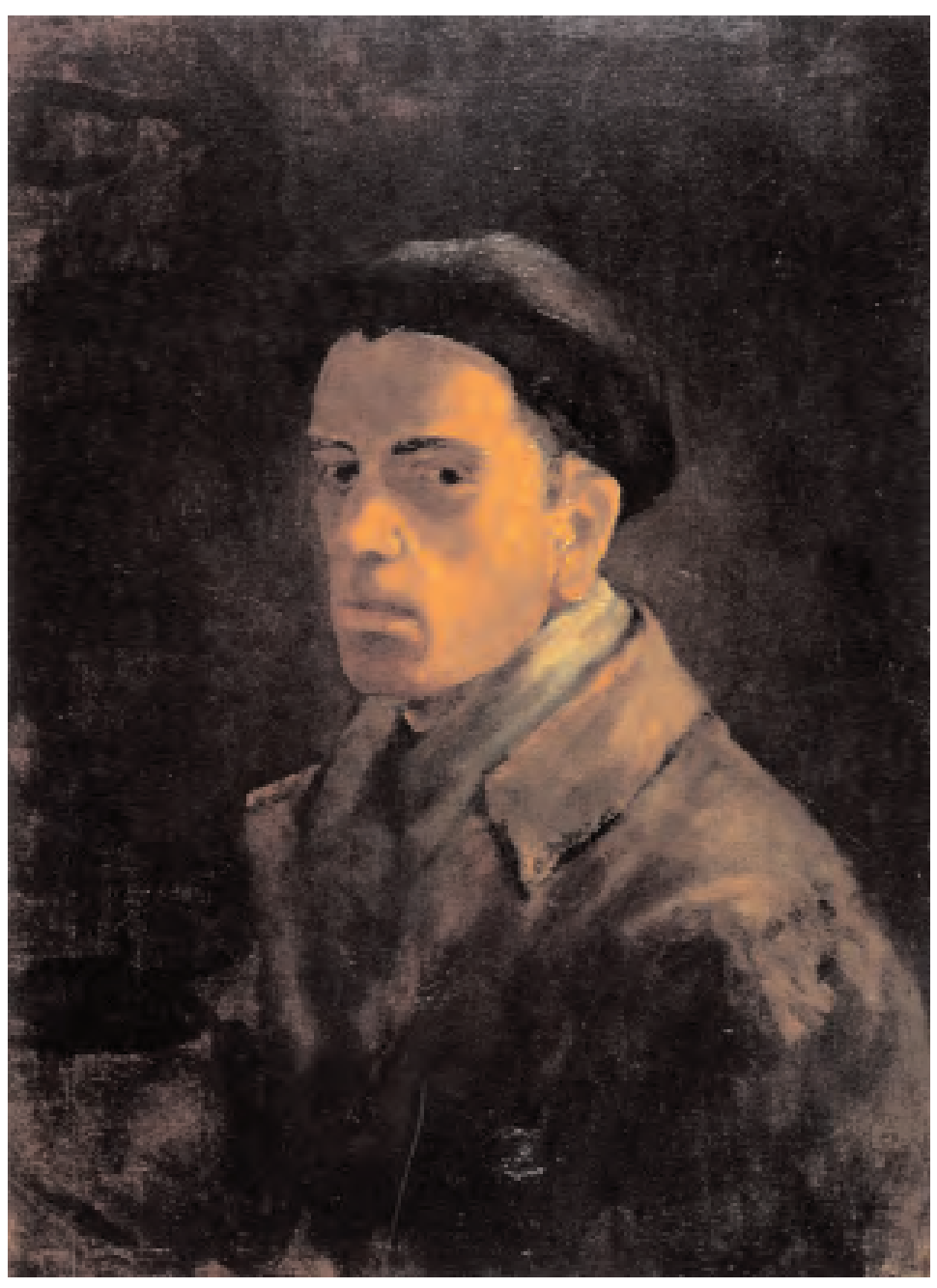

Autorretrato. 1946.

Óleo sobre lienzo. $65 \times 50 \mathrm{~cm}$.

Colección Ana Manrique, Valencia.

Eduardo Vicente 

\6 Siempre leve, temblando su pluma y su pincel ante ese mundo que cobija bajo esa capa de fino cristal que es su pintura. Gran tarea la de Eduardo Vicente al unir la humanidad más viril y recia y la tierra más terrena y desarbolada a la materia más irreal y flotante, con tonos trémulos, de alas de mariposa, de gasa angélica $99^{1}$

Camon Aznar, J. (1968:45)

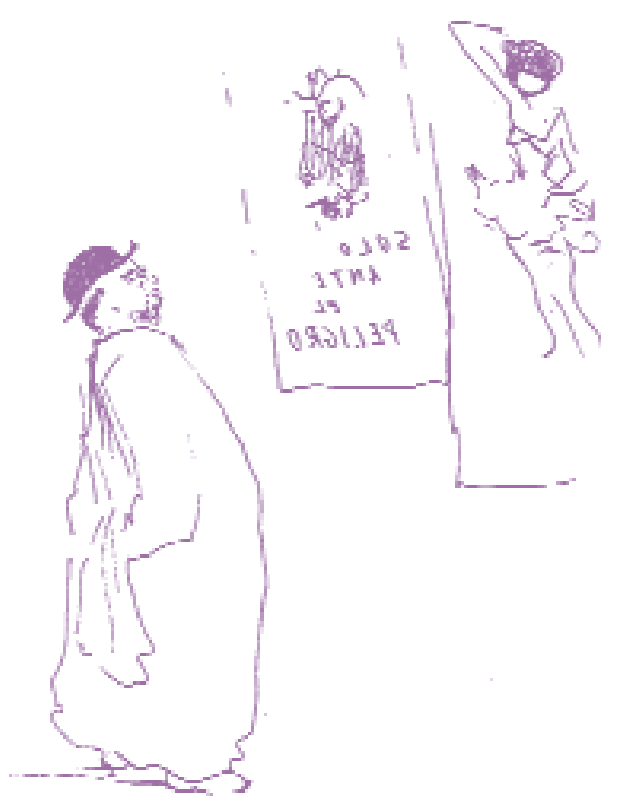





\section{Cronología vital y artística.}

\section{9 (Nacimiento e infancia)}

El cuartel de la Guardia Civil, situado en la calle Batalla de Salado de Madrid, ve nacer el 13 de octubre de 1909 a Eduardo Vicente.

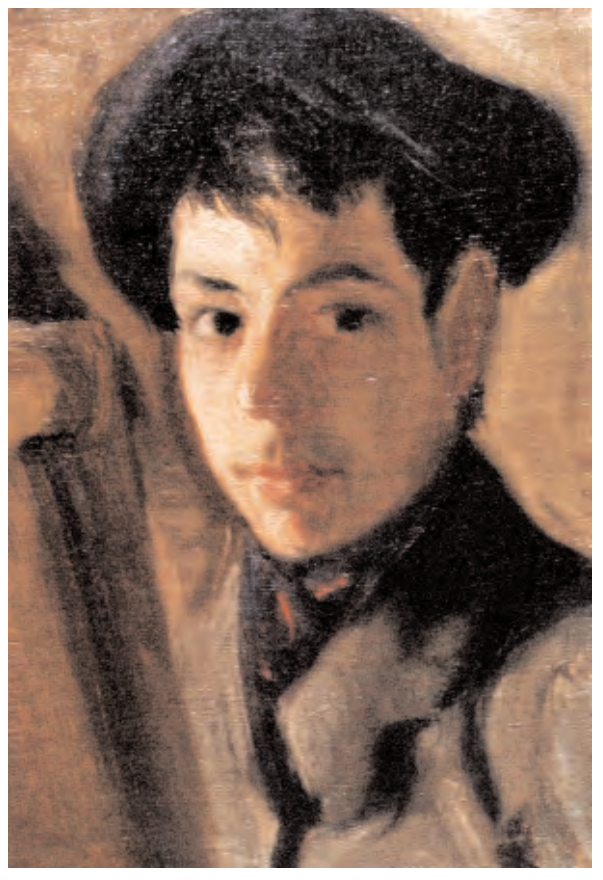

Figura 1.

Hijo de Toribio Vicente y Sofía Pérez, Eduardo Vicente heredó de su padre la pasión por el dibujo y la pintura, descubriendo en su infancia los principales museos de Madrid, acompañado siempre por su hermano, también pintor, Esteban Vicente.

Eduardo Vicente realiza sus primeros estudios en el colegio de Primera Enseñanza de la calle León, pasando luego al Instituto de San Isidro, situado en la calle Toledo, Instituto y estudios que decide abandonar en quinto de bachillerato, dando prioridad a la pintura que será su pasión el resto de su vida.

\section{4}

Se matricula y empieza a asistir a las clases de la Escuela de Bellas Artes de San Fernando, donde comienza a perfeccionar su técnica en el dibujo y la pintura.

Es en este año cuando Eduardo Vicente entra a trabajar como pintor ayudante en los talleres de los escenógrafos Amorós y Mignoni.

También, realiza sus primeros trabajos en la Calle del Carmen, donde tuvo su primer estudio artístico. Un estudio que compartía con su hermano Esteban y con el hijo de Juan Bonafé. 


\section{5}

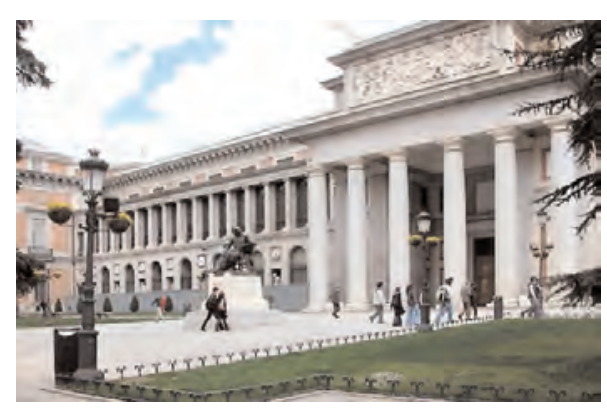

Figura 2.

Se traslada junto a su hermano mayor al antiguo estudio de Madrazo y Juan Gris en el Paseo del Prado. Lugar privilegiado para desarrollar su arte y creatividad, no sólo por las personas que habían ocupado el estudio con anterioridad, lo que les daría una motivación especial, sino también por encontrarse frente al Museo del Prado de Madrid, el cual alberga una gran e importante pinacoteca.

Este estudio les servirá para continuar con su labor artística y para celebrar reuniones y coloquios con los jóvenes artistas y escritores de la época como Bores y Pedro Flores, Pedro Salinas, Ortega y Gasset y Juan Ramón Jiménez entre otros; todos ellos personajes destacados en la historia de nuestro país.

Es entonces cuando en Eduardo Vicente crece un mayor interés por los motivos madrileños, no sólo paisajísticos sino también por su gente y su entorno, realizando sus primeras escenas de costumbrismo.

\section{8}

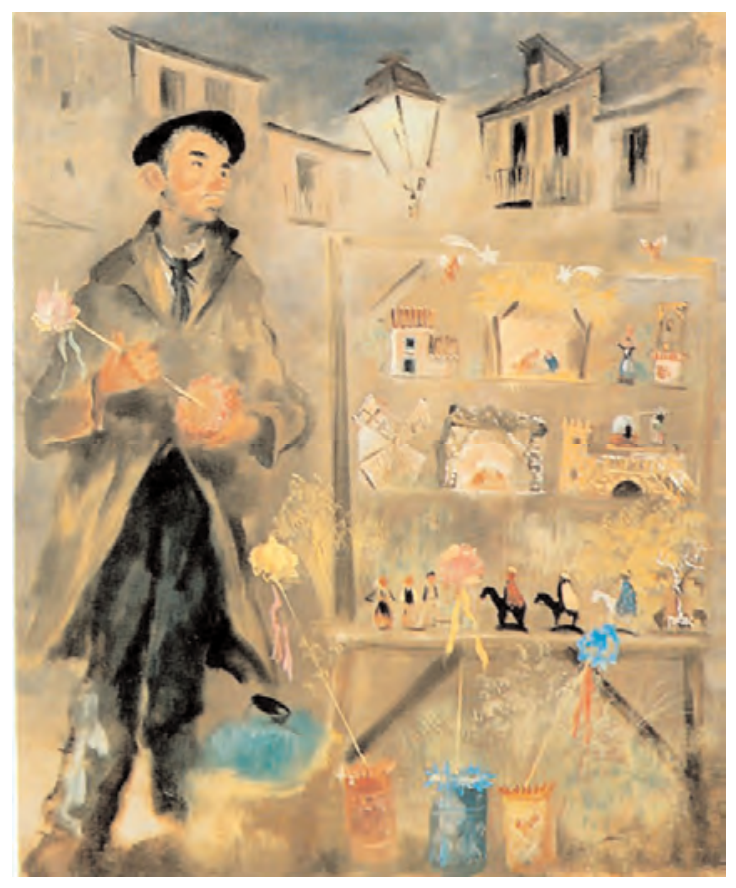

Figura 3.

El Salón de Arte del Ateneo de Madrid acoge su primera exposición. Una muestra artística donde se comienza a descubrir públicamente a uno de los grandes artistas españoles del siglo XX.

Tras la exposición realiza distintos viajes por toda España, dedicando un poco más tiempo a la zona levantina, con el fin de conocer los distintos paisajes y ambientes españoles, acompañado por el pintor inglés Christopher Hall, gran enamorado de las gentes, las costumbres y los paisajes españoles. 


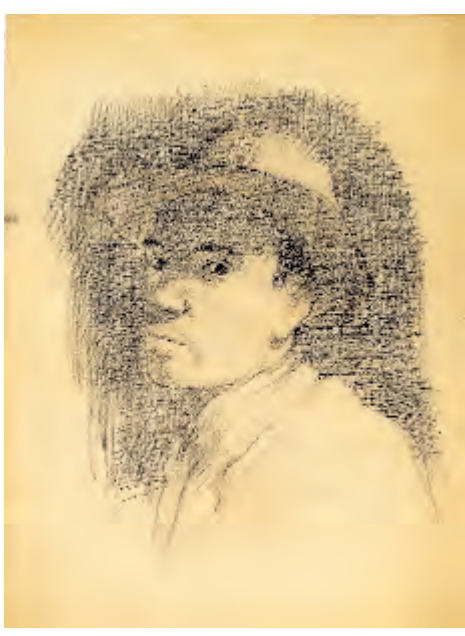

Figura 4.
La amistad y la pasión por la pintura que unía a Eduardo Vicente con su hermano mayor, Esteban, llevan al último a realizar un retrato de Eduardo.

Eduardo Vicente, también se convirtió en uno de los personajes que retrató el también pintor Ramón Gaya.

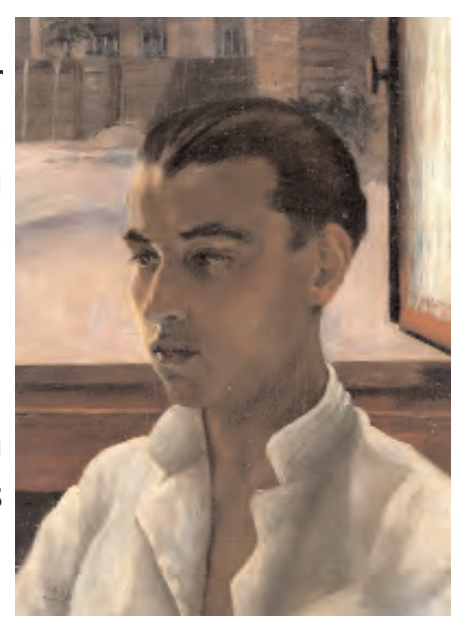

Figura 5

\section{1}

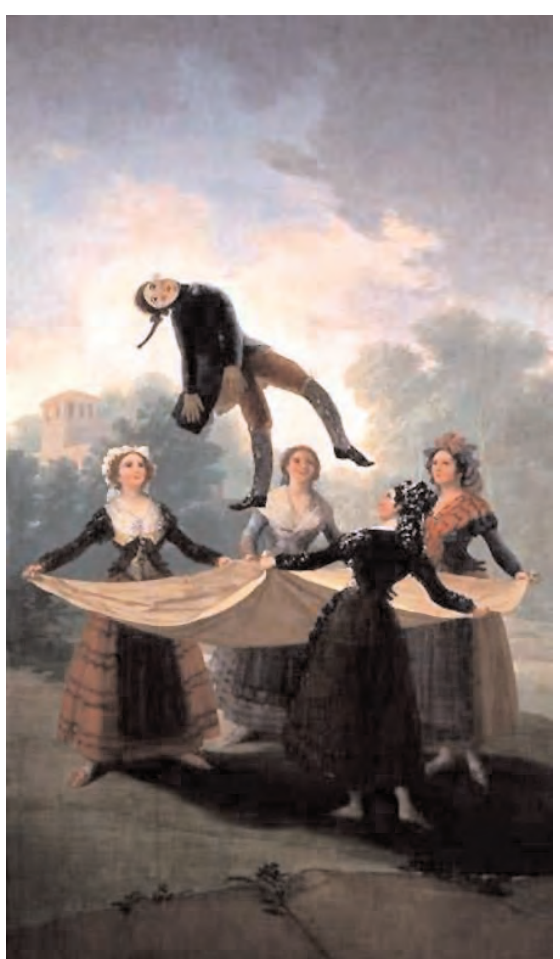

Figura 6.
Coincidiendo con el triunfo y la proclamación de la II República, le encargan la creación y la dirección del Museo Ambulante de las Misiones Pedagógicas. Eduardo Vicente, Ramón Gaya y Juan Bonafé copiaron las grandes obras históricas del arte español, ubicadas en el Museo del Prado, en la Academia de Bellas Artes de San Fernando y en Museo Cerralbo, para darlas a conocer.

"El pelele" de Francisco de Goya, fue uno de los cuadros copiados por Eduardo Vicente para darlo a conocer por las distintas provincias de España.

Durante varios años, estuvo recorriendo los pueblos de toda España para divulgar la importante herencia artística de mayor valor del país. 


\section{6}

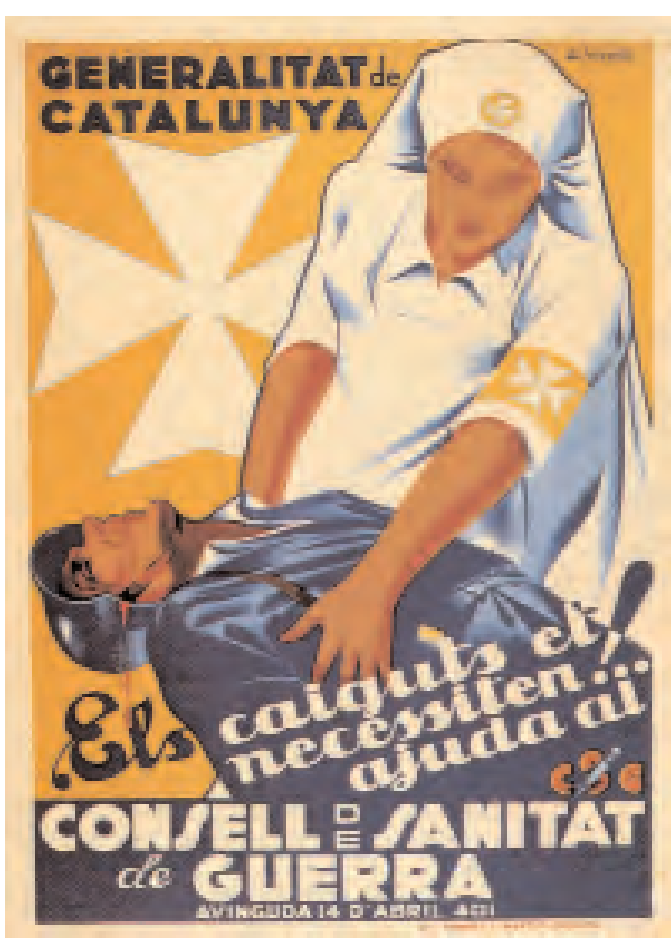

Figura 7.

A pesar de la motivación que le producía trabajar en las Misiones Pedagógicas, pide su relevo para volver a Madrid e involucrarse otra vez en la vida artística de la España de los años 30. Se instala en su nuevo estudio situado en Ópera (Plaza de Isabel II, en la actualidad), donde le sorprenderá la Guerra Civil Española el 18 de julio, día del Alzamiento.

Eduardo Vicente, decide enseguida su posición política y pone su talento artístico a disposición de los Servicios de Propaganda del Ejército Republicano donde comenzó su labor cartelísta. Vivió a caballo entre Madrid y Valencia, ciudades que le dieron cobijo al artista durante los largos años de la Guerra Civil.

\section{7}

En este año acontecen dos importantes hechos para Eduardo Vicente. Por una parte, tiene la oportunidad de participar en la Exposición Internacional de París, realizando una muestra con algunas de sus obras en el Pabellón Español, donde coincide con Aurelio Arteta, Gutiérrez Solana, Alberto Sánchez, Juan Bonafé, Ramón Gaya, Gregorio Prieto, Picasso, Miró, González y Calder.

Y por otra, el nacimiento en Valencia de su hija Marisol, fruto de su matrimonio con Ana Manrique.

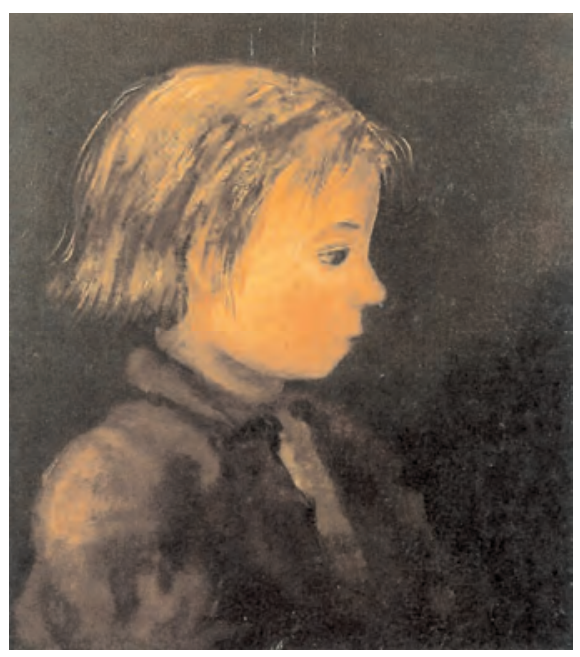

Figura 8. 
Con el final de la Guerra Civil y la derrota del bando republicano, Eduardo Vicente opta por continuar viviendo en su España natal y descartar la posibilidad del exilio, como hicieron muchos otros artistas de la época entre los que se encontraba, su hermano mayor, Esteban Vicente.

La mala época por la que atravesaba el país en esos momentos, le obliga a dedicarse a la pintura industrial estando al servicio de los distintos contratistas de obra que había en Madrid durante el periodo de posguerra.

\section{1}

El año 1941, será un punto de inflexión en la vida de este artista, pues recupera su vocación así como el reconocimiento de la crítica y del mundo artístico.

La amistad que unía a Eduardo Vicente con el director literario de la Editorial Espasa Calpe, José María de Cossío, le lleva a convertirse en el ilustrador de distintas colecciones y publicaciones de dicha editorial.

Es en este año cuando conoce a Eugenio D'ors que realizará una apuesta por este pintor desconocido, presentándosele a Aurelio Biosca, dueño de la Galería Biosca, situada en la calle Génova de Madrid, donde Eduardo Vicente vuelve, después de

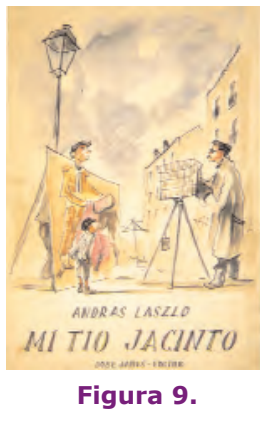
tantos años, a organizar una exposición con sus obras.

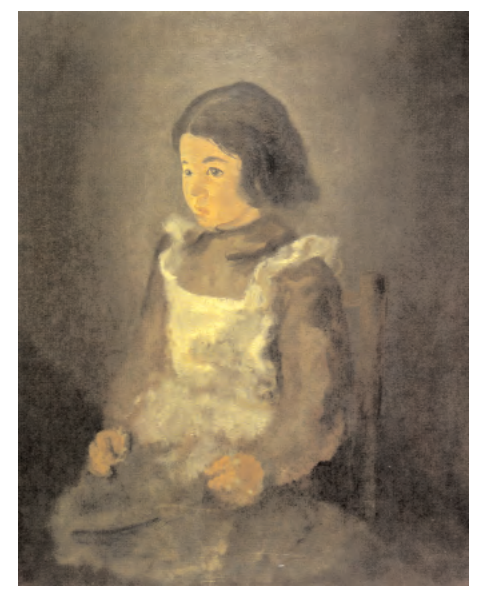

Otro de los acontecimientos de gran importancia para Eduardo Vicente fue el nacimiento de su segunda hija, Silvia Vicente Manrique.

Figura 10.

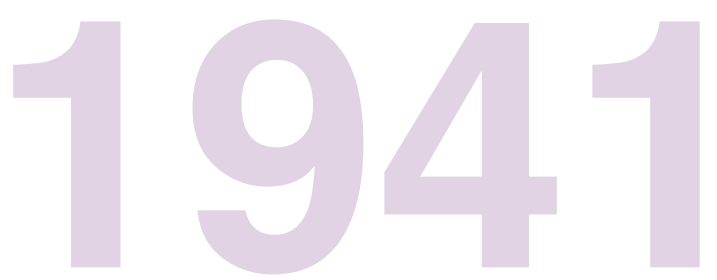




\section{2}

Eugenio D'ors crea un equipo de artistas renovadores llamado "Academia Breve de Crítica y de Arte", del que forma parte Eduardo Vicente desde el primer momento.

Gracias a D'ors, el artista madrileño participa con sus obras en "El Primer Salón de los Once", junto a grandes artistas de la época como: María Blanchard, Fujita, Grau Sala, Zabaleta, Olasagasti, Benjamín Palencia, Manolo Hugué, Pruna...

\section{3}

1943 fue un año muy productivo y de grandes reconocimientos para Eduardo Vicente, puesto que consiguió su tercera Medalla Nacional de Arte, y realizó dos exposiciones de gran importancia, una en la Galería MIR de Zaragoza y la otra en la Galería Mateu de Valencia.

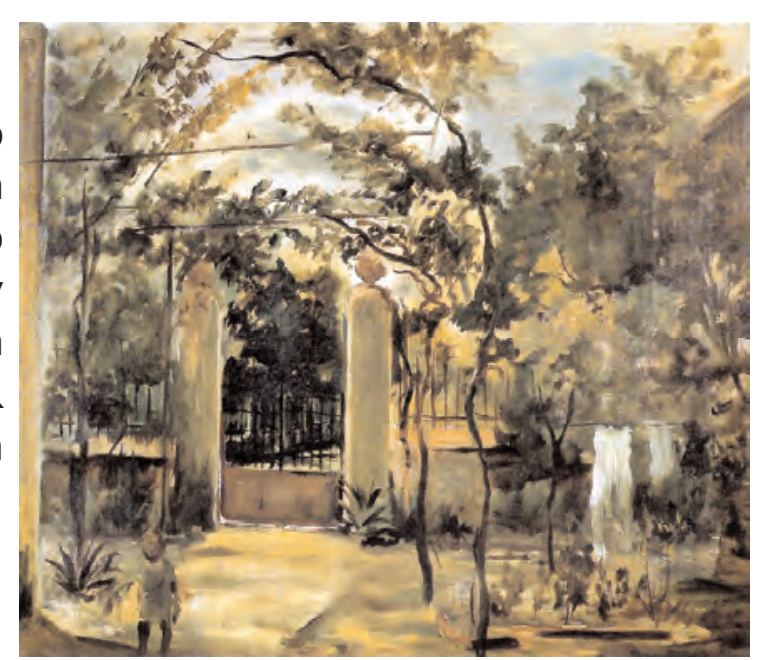

Figura 11.

\section{4}

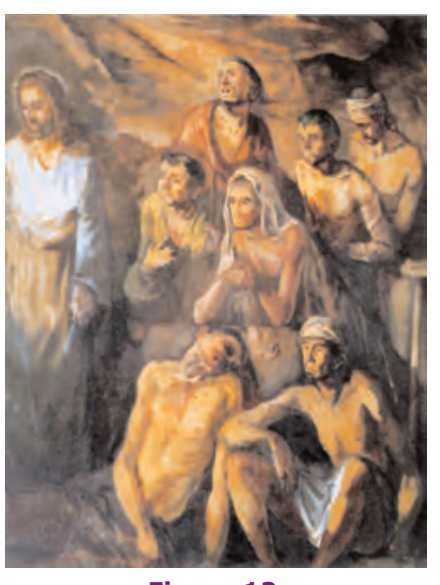

Figura 12.

Realiza un mural decorativo para el baptisterio de la Catedral de Orihuela, en Murcia. Una vez más, el artista madrileño, es invitado a participar en el "II Salón de los Once", junto a otros grandes artistas como: Gargallo, Torres García, Escassi, Palencia y Zabaleta.

Es en este mismo año, cuando Eduardo Vicente se convierte en un asiduo al Café Gijón de Madrid, donde conoce y comparte aficiones, ideas, inquietudes... con un gran número de intelectuales y artistas de la posguerra española, como: J. Suarez Carreño, 


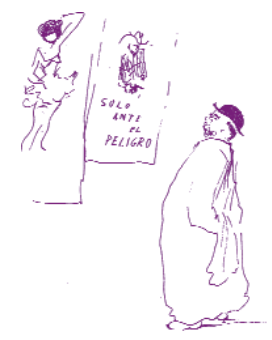

Francisco Arias o Cristino Mallo. Todos ellos, personas con una gran influencia e importancia en su vida.

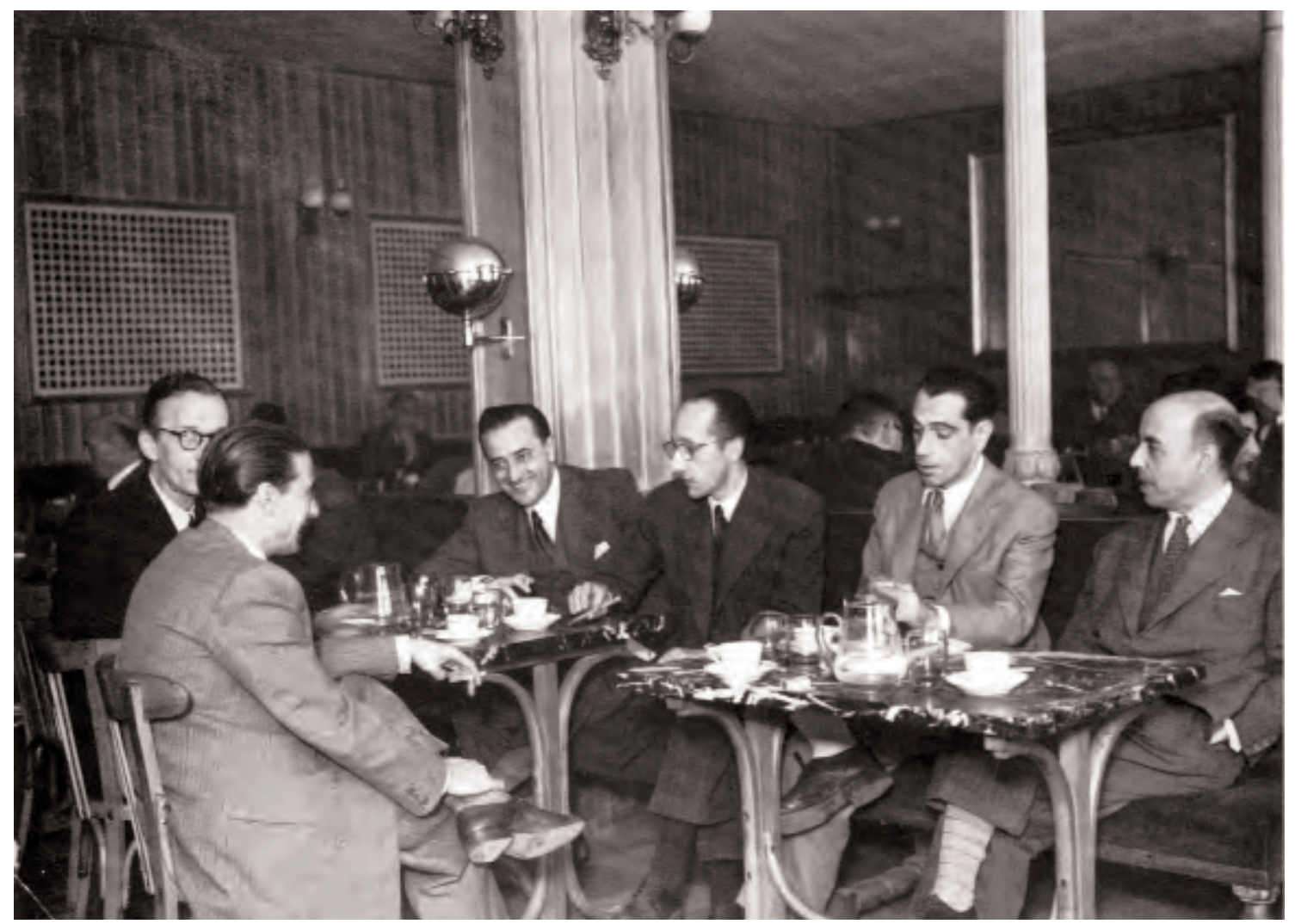

Figura 13.

Figura 14.

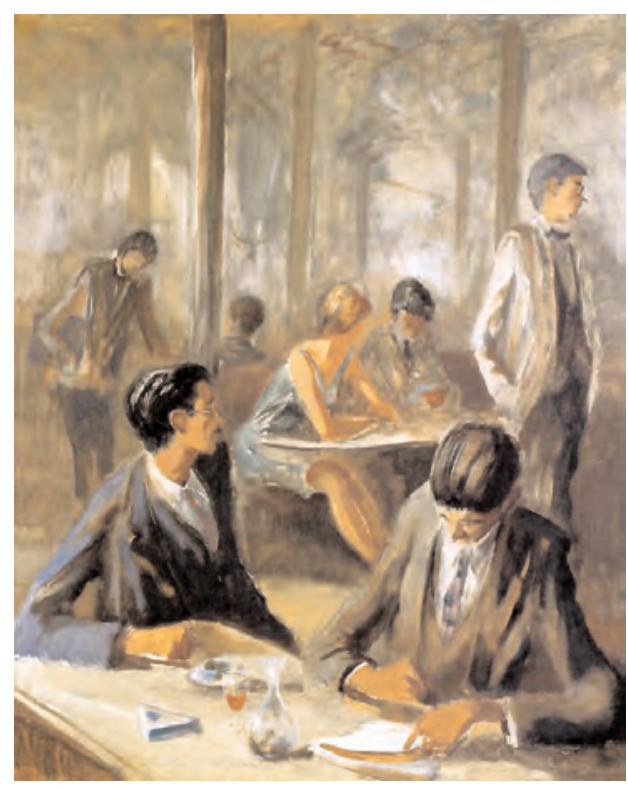




\section{5}

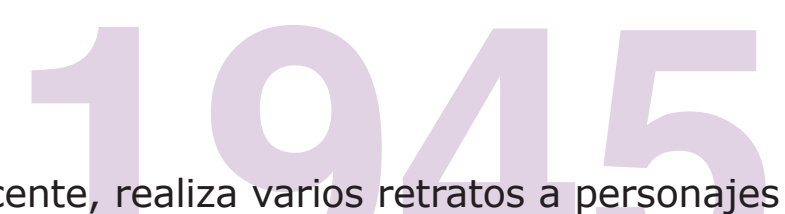

Durante este año, Eduardo Vicente, realiza varios retratos a personajes importantes de la época, así como a algunos de sus amigos.

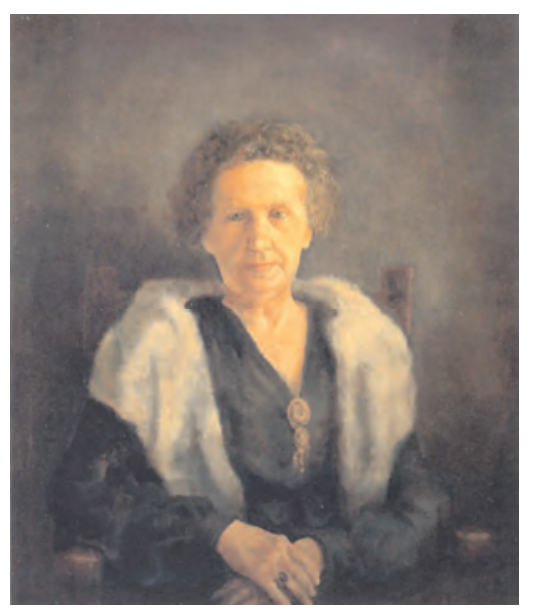

Figura 15

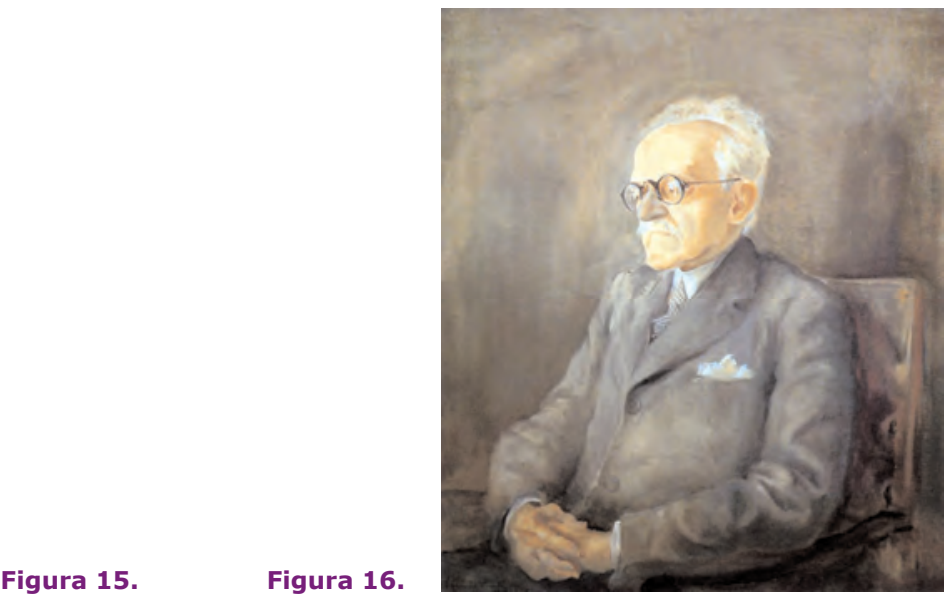

\section{6}

Se organizan varias exposiciones y comienzan a demostrar la renovación plástica que estaban experimentando los artistas de la época. Se ven los primeros pasos que daba el arte moderno en España. Eduardo Vicente participó en tres exposiciones donde quedaba reflejada la renovación de los artistas contemporáneos. El Museo Nacional de Arte Moderno, acogió las muestras de Eduardo Vicente tituladas: Floreros y Bodegones, Autorretratos de pintores españoles actuales y Antología de las mejores obras expuestas en Madrid.

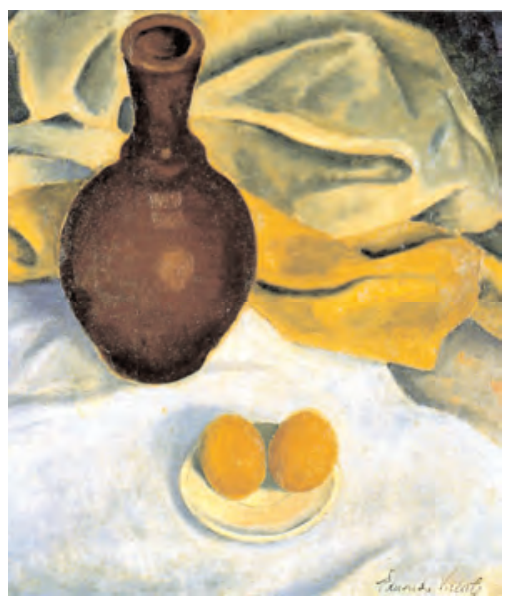

Figura 17.

Eugenio D'Ors vuelve a confiar en Eduardo Vicente y en sus obras para la Exposición de Arte Español que se realiza en Buenos Aires. Una vez más, el proteccionismo de D'Ors le otorga una magnífica oportunidad para dejar constancia de la importancia y calidad de sus obras. 


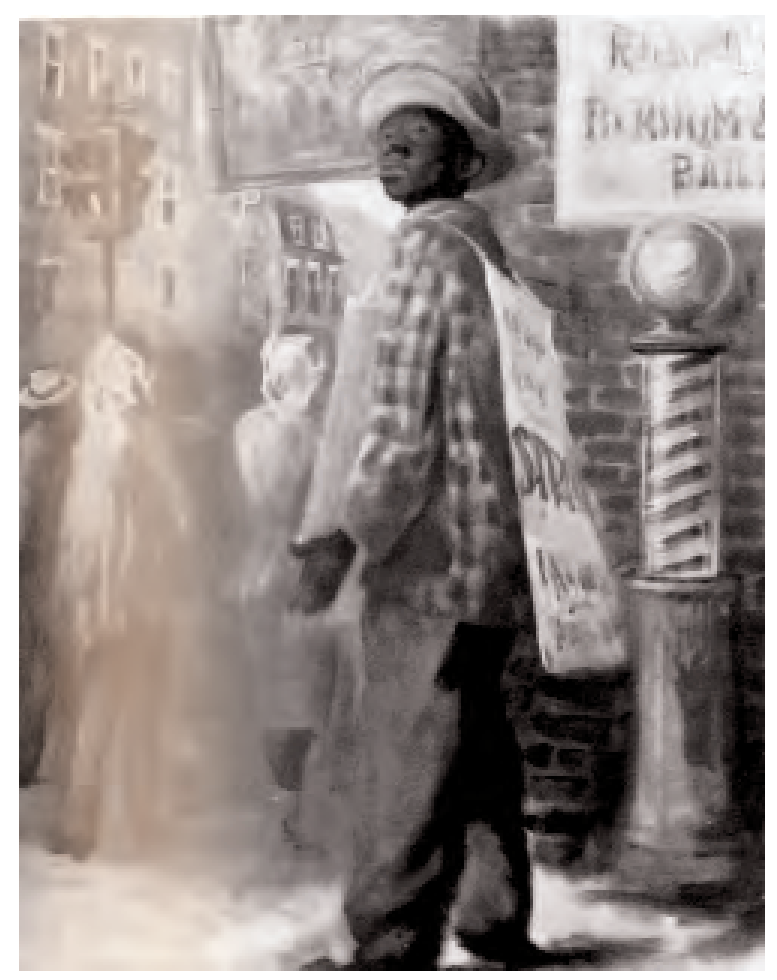

Figura 18.

A Eduardo Vicente le dan la beca Conde de Cartagena, concedida por la Academia de Bellas Artes de San Fernando, que le brinda la oportunidad de viajar a Estados Unidos y retratar a sus ciudadanos. De esta manera, el artista madrileño, aprovecha esta ocasión para dejar constancia, al igual que lo había hecho en Madrid en años anteriores, de las escenas de barrio y ciudadanos de Harlem, Brooklin y Broadway. Retratos que servirán para realizar varias exposiciones a su regreso al país natal.

Es también en este año, cuando Eduardo Vicente tiene la oportunidad de realizar su primera exposición en Nueva York, en la Galería Hugo.

\section{9}

A su vuelta a España, realiza varias exposiciones en territorio nacional entre las que destacan las muestras expuestas en la Galería Layetanas en Barcelona y la realizada en el Grupo Proel de Santander.

Año de nacimiento de otra de las hijas del artista, Alicia Vicente.

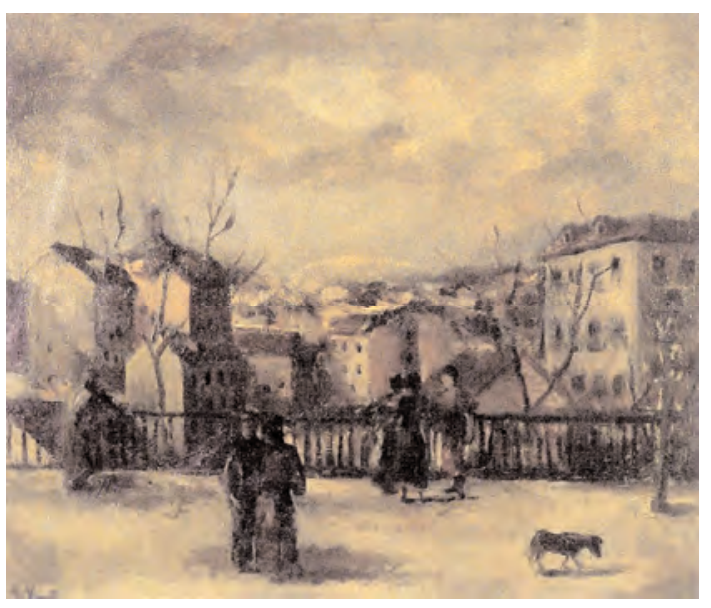

Figura 19. 


\section{0}

A Eduardo Vicente se le comienza a reconocer su valor artístico a nivel internacional. Realiza una segunda exposición en Nueva York, esta vez, en la Galería Painting-Library. Es invitado a mostrar su obra en la Exposición Internacional del Instituto Carneggie de Pittsburg, también en Estados Unidos.

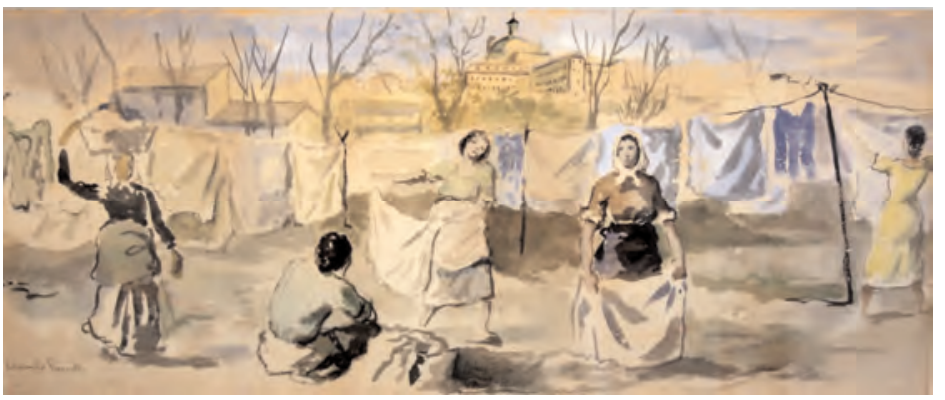

Figura 20.

De la mano del comisario Pérez Comendador, es seleccionado para participar dentro de la Exposición de Arte Español de Alejandría y El Cairo. Muestra en la que sus obras acompañan a las de artistas de la talla de Dalí, Vázquez Díaz y Zuloaga.

Comienza a decorar las paredes interiores del restaurante madrileño "El Schotis", con una serie de murales en los que se muestran, una vez más las costumbres y bailes de la sociedad madrileña.

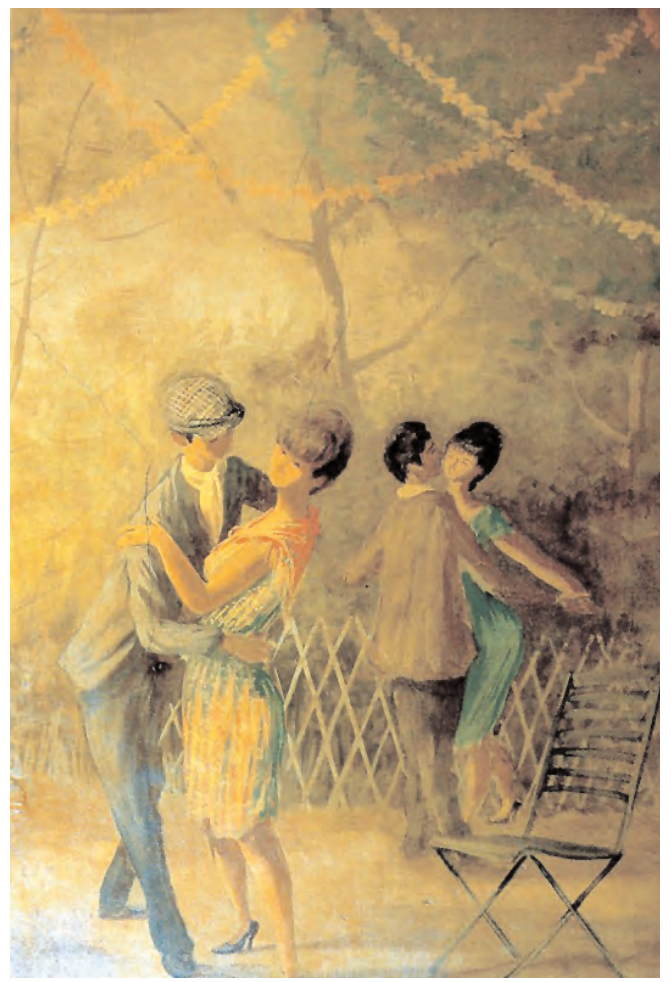

Figura 21. 
1951

Eduardo Vicente se consolida como un referente del arte contemporáneo español de la época y tiene el honor de ser nombrado miembro del Jurado de la Primera Bienal Hispanoamericana de Arte, celebrada en el Palacio de Bibliotecas y Museos del Paseo de Recoletos de Madrid. Tiene una gran participación en la Bienal de Venecia donde acude con una importante muestra. Madrid y Granada también fueron sede, en este año, de muestras del artista. El Instituto Internacional de Boston en la capital española y la Casa de América de la provincia Andaluza dieron cobijo a grandes obras de Eduardo Vicente.

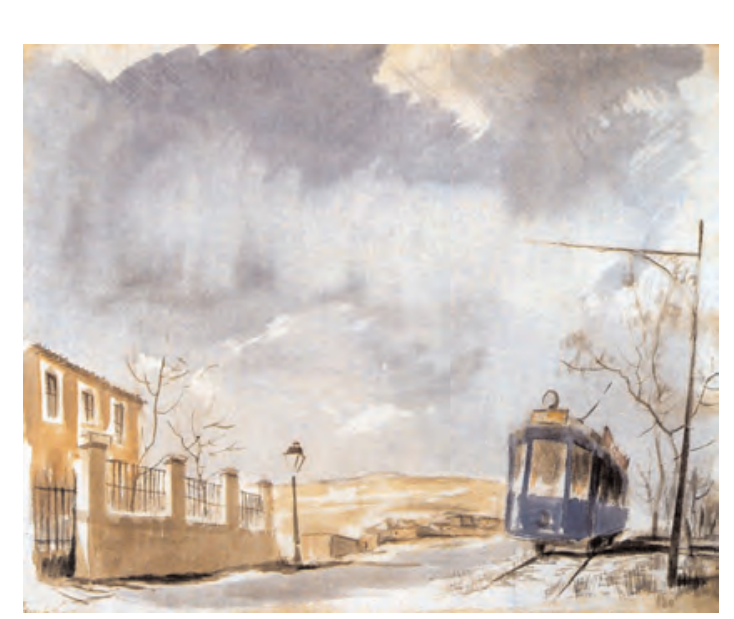

Figura 22.

\section{3}

El Museo Nacional de Arte Moderno de Madrid, acoge una muestra de Eduardo Vicente en las salas de la Dirección General de Bellas Artes. Realiza una exposición en la recién estrenada Galería Mayer de Madrid.

1955
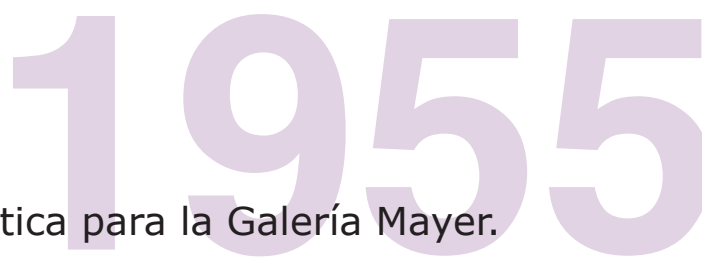

\section{7}

Realiza dos viajes a París donde toma contacto con los movimientos artísticos europeos de la época. Madrid, Cataluña y Asturias son escenario de varias exposiciones del artista. De este modo, la Galería Biosca, la Librería de Afrodisio Aguado, donde se presentan dibujos y aguatintas de Eduardo Vicente, la Galería Syra y la Sala de la Caja de Ahorros de Oviedo, con la exposición La nueva España, dan cobijo, una vez más, a las grandes obras realizadas por Eduardo Vicente. 

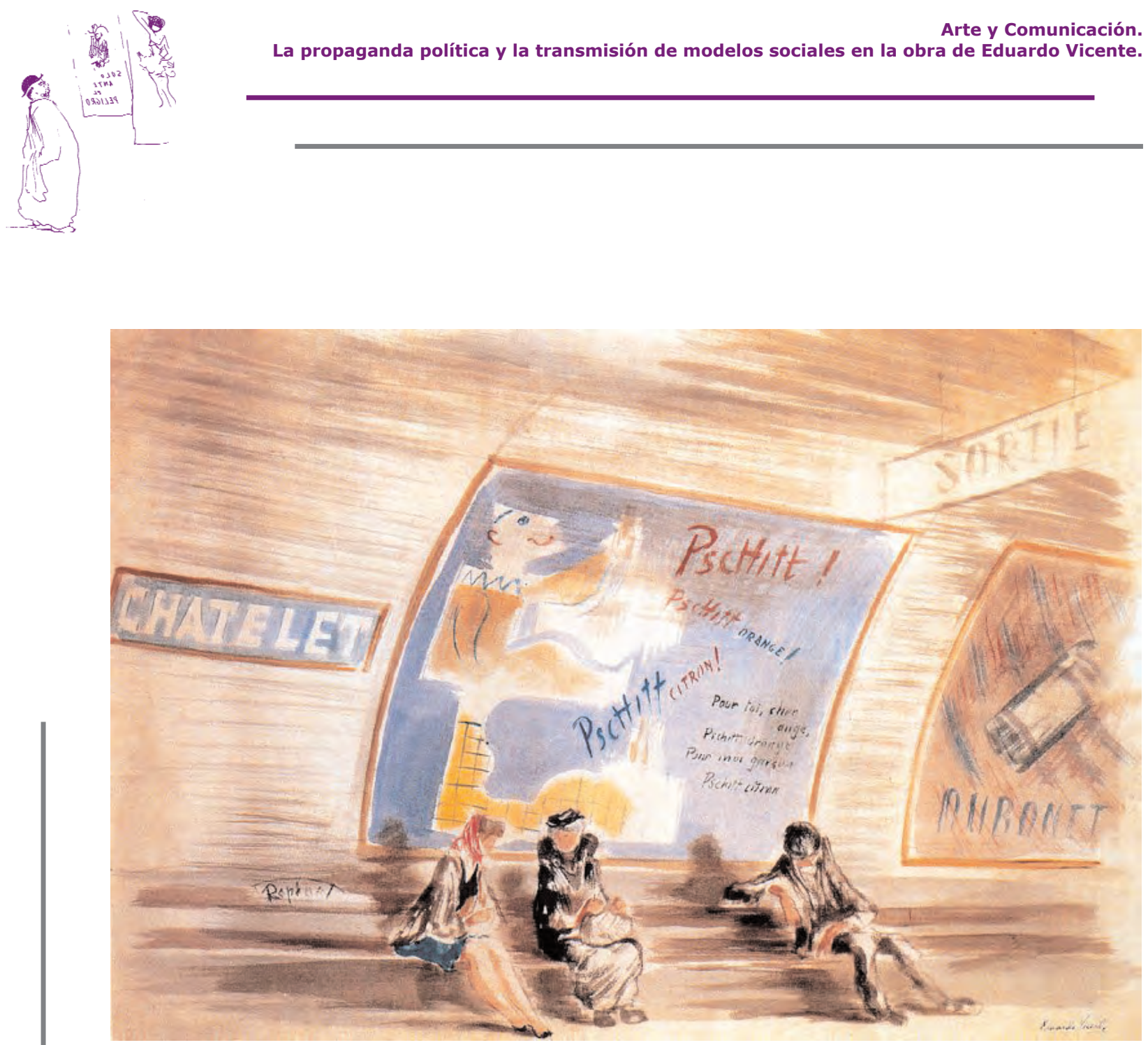

Figura 23.

1963

En el último mes del año lleva las litografías de su ciudad natal a la Galería Quixote, situada en la Plaza de España de Madrid. El Director del Museo Nacional de Arte Moderno y crítico de arte, Enrique Lafuente Ferrari, ofrece una conferencia Magistral en la clausura del evento.

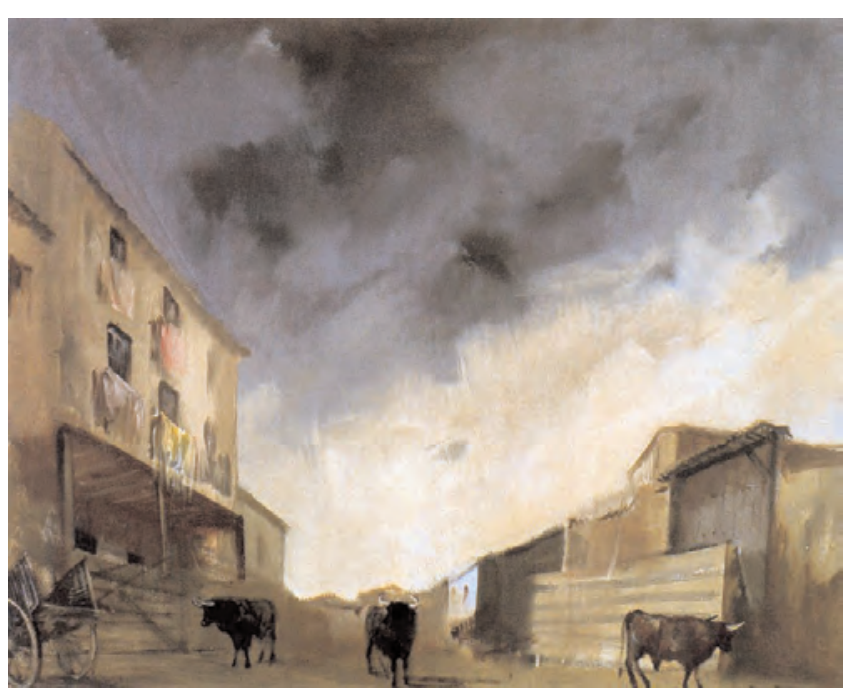

Figura 24. 
1964

El Museo de Bellas Artes de Bilbao y el Ateneo de Santander invitan al artista a organizar dos exposiciones en sus salones, con la repercusión que conlleva realizar muestras pictóricas en estos dos centros culturales.

Los salones del Casino de Madrid acogen un banquete que sirve para homenajear al artista y al que asistieron las personalidades más destacadas de la vida cultural de la época.

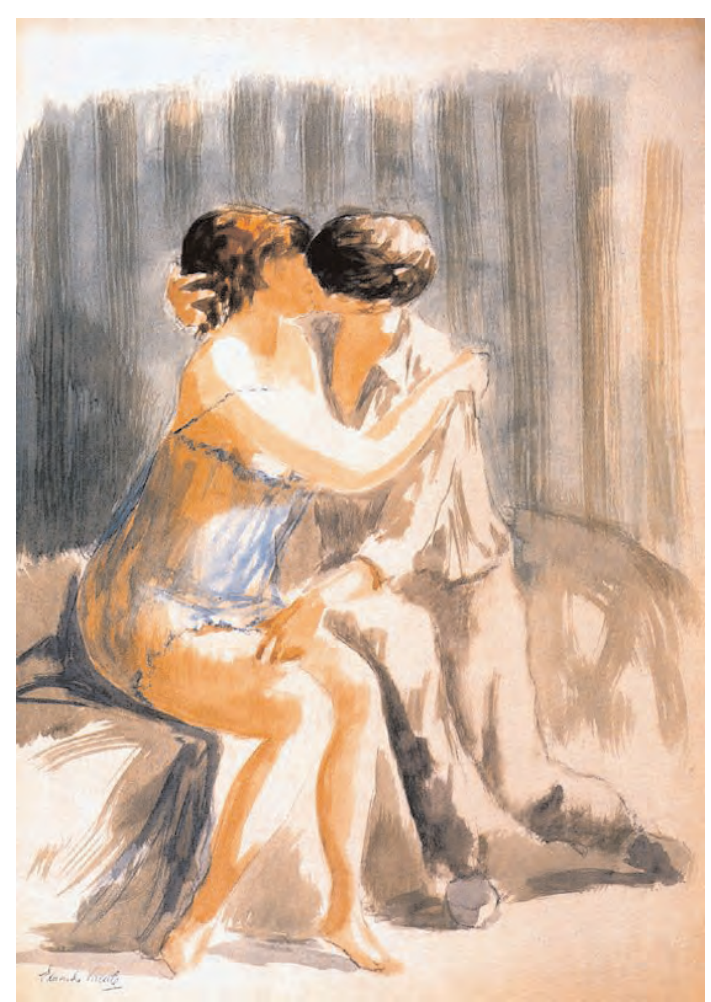

Figura 25.

\section{5}

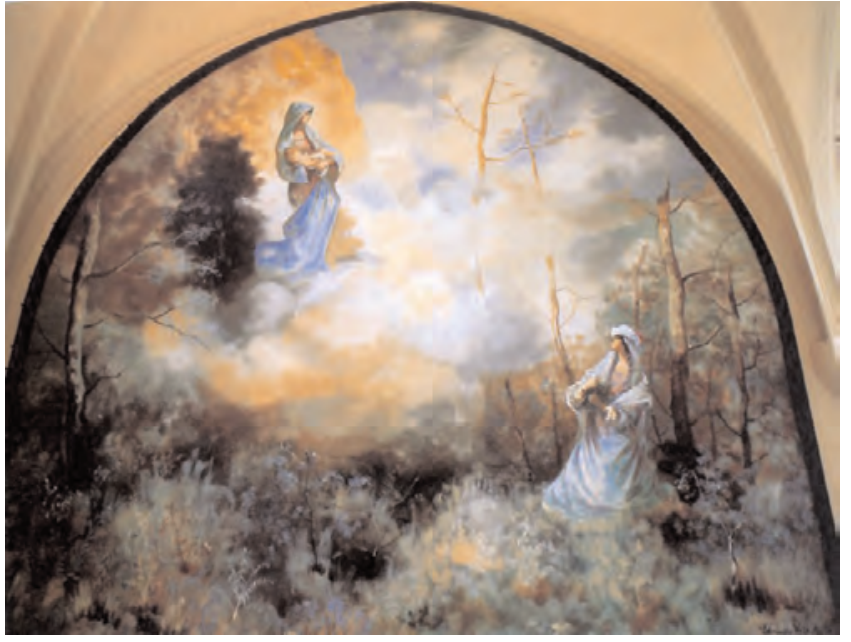

Figura 26.
Viaja a Guadalajara para pintar los murales que decoran el coro de la iglesia de Brihuega. Después, regresa a Madrid donde termina las pinturas de la sala refectorio del Banco Urquijo.

En mayo, coincidiendo con las fiestas de San Isidro, Eduardo Vicente expone en la Galería Quixote de Madrid una muestra con 100 dibujos de la vida cotidiana, uno de los temas 
preferidos del artista madrileño.

\section{6}

En esta ocasión, se desplaza a Logroño, donde pintará los murales del nuevo hotel Gonzalo de Berceo.

Realiza una exposición en Zaragoza, en la Galería Libros

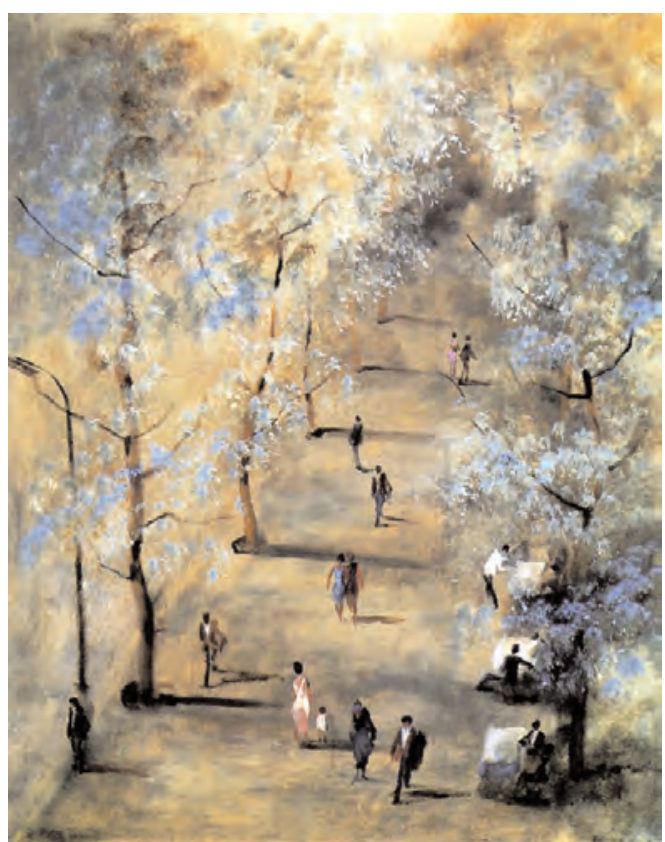

Figura 27.

1967

Se dedica a pintar varios murales más que decorarán diversos edificios madrileños. El más importante que realizó fue en la sede Vicente Lluch, Agente de Aduanas.

\section{8}

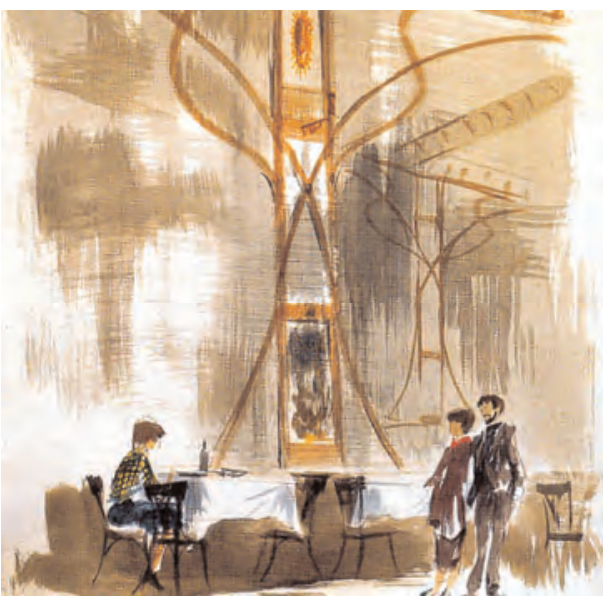

Figura 28.

La Galería Quixote de Madrid, acoge la última exposición que pudo inaugurar Eduardo Vicente, en mayo de 1968, coincidiendo, una vez más, con las fiestas de San Isidro.

El 9 de mayo, con 59 años de edad, le sorprende la muerte en su estudio, en la más absoluta soledad puesto que nadie se entera de la noticia hasta dos días después. 
1974

Fracasa el intento de instalar la Galería Eduardo Vicente, en el número 15 de la Puerta del Sol, en Madrid.

La Galería Giotto, situada en el Paseo de la Castellano, acoge la exposición Antológica de Eduardo Vicente después de su muerte. 



\section{SIN DEJARNOS NI SEÑAS NI ADIOS}

Se ha mudado Eduardo Vicente sin dejarnos ni señas ni adiós.

Sus amigos quedamos temblando como hojas que octubre arrugó.

Se ha quedado olvidado, yacente.

Era uno y ahora son dos:

ese rígido extraño testigo

y ese vuelo invisible en el sol.

El trasaba, y aguaba y pintaba, con levísimos toques de unción acuarelas felices y tristes, óleos tenues, fragantes de amor.

Arrabales, suburbios, madriles, parroquianos de frasca punzó, la muchacha que en cama de hierro se desviste olorosa a jabón.
Y qué cortos ahora sus viajes al París que del siempre hace hoy o a vivir con los negros de Harlem y a pintar sus tugurios de horror.

Su paleta, evapora, decanta, va a volar, a ser brisa el color.

El inventa su lila y su rosa, su aura verde que marzo insinuó.

El escónde la línea que tiembla, cimbreante, infalible de ardoz, tras la tierna apariencia indolente de sus manchas movidas de son.

Se habrá ido por esas praderas a cantar junto a King el pastor (pero ¿cómo olvidó aquí su cuerpo?) con sus pobres en la procesión. 

Notas

1.- Camón Aznar, J. (1968) ABC. Madrid. 21 de mayo de 1968. pp. 45.

2.- Diego, G. (1968) "Poema a la muerte de Eduardo Vicente". $A B C$. Madrid. 21 de mayo de 1968. pp. 45. 



\section{Pies de fotos.}

Figura 1.- Autorretrato de Eduardo Vicente en 1928. Hotel Sirenas. Segovia.

Figura 2.- Fotografía de la fachada principal del Museo del Prado de Madrid.

Figura 3.- Vendedor Navideño. Colección Museo Municipal. Madrid.

Figura 4.- Esteban Vicente (1930). Retrato de Eduardo Vicente. Grafito sobre papel. $65 \times 49 \mathrm{~cm}$.

Figura 5.- Ramón Gaya (1930). Retrato de Eduardo Vicente. Óleo sobre lienzo.

Figura 6.- Francisco de Goya (1791-1792). El Pelele $(267 \times 160 \mathrm{~cm})$. Museo del Prado. Madrid.

Figura 7.- ELS CAIGUTS ET NECESSITEN: AJUDA AL CSG. 1937. Consell de Sanitat de Guerra. Firmado en el ángulo superior derecho. Barcelona. $65 \times 45 \mathrm{~cm}$.

Figura 8.- Retrato de su hija Marisol Vicente Manrique. Óleo sobre lienzo $(40 \times 40 \mathrm{~cm})$. Colección Marisol Vicente. Valencia.

Figura 9.- Portada del libro "Mi tío Jacinto". 1956. Editor José Janés. Barcelona. Colección Nicanor Vares.

Figura 10.- Retrato de su hija Silvia Vicente Manrique. Óleo sobre lienzo $(75 \times 60 \mathrm{~cm})$. Colección Silvia Vicente. Madrid.

Figura 11.- Casa del pintor en Ciudad Jardín. Óleo sobre lienzo (59x69 cm.) Colección de Sagrario de Ulierte.

Figura 12.- Curación de los leprosos. Detalle. Catedral de Orihuela. Alicante.

Figura 13.- Fotografía tomada durante una tertulia en el Café Gijón 
(1952). (De izquierda a derecha: Alejandro Ferrant, hermano de Ángel, Cristino Mallo, Eduardo Vicente y Juan Morales. De espaldas: Francisco Arias).

Figura 14.- El café Gijón (1950). Óleo sobre lienzo (100x81cm). Colección de Ángel de las Heras. Madrid.

Figura 15:- Retrato de Lucía Sancho de Hoyos. Óleo sobre lienzo. $(8,5 \times 75,5 \mathrm{~cm})$ Colección particular. Madrid.

Figura 16.- Retrato de Luis de Hoyos. Óleo sobre lienzo. $(8,5 \times 75,5 \mathrm{~cm})$ Colección particular. Madrid.

Figura 17.- Bodegón (1928). Óleo sobre cartón. (54×42cm). Colección Sagrario Ulierte. Madrid.

Figura 18.- El negro y el Paisaje de Nueva York (1949).

Figura 19.- Vista de Las Vistillas. Óleo sobre lienzo $(65 \times 57 \mathrm{~cm})$. Colección particular.

Figura 20.- Lavanderas de las Vistillas. Gouache sobre papel (24,5x $58,5 \mathrm{~cm})$.

Figura 21.- El baile de La Bombilla (detalle mural). Restaurante "El Schotis". Madrid.

Figura 22.- Tranvía en las afueras. Acuarela sobre papel $(65 \times 54 \mathrm{~cm})$. Colección particular. Madrid.

Figura 23.- Metro de París (1960). Acuarela sobre papel $(90 \times 64 \mathrm{~cm})$. Colección Marisol Vicente Manrique. Madrid.

Figura 24.- Encierro. Óleo sobre lienzo $(81 \times 65 \mathrm{~cm})$. Colección Manolo Sancho. Madrid.

Figura 25.- El beso. Acuarela sobre papel $(101 \times 72 \mathrm{~cm})$. Colección particular. Madrid. 
Figura 26.- Aparición de la Virgen a la princesa Elima. Mural. Iglesia de Brihuega. Guadalajara.

Figura 27.- Paseo bajo los árboles (1965-1966). Óleo sobre lienzo (92×73 cm). Colección Fundación Santander Central Hispano.

Figura 28.- Café de París (1950-1955). Acuarela sobre papel. Colección particular. Madrid. 



\section{[] Anexo II}

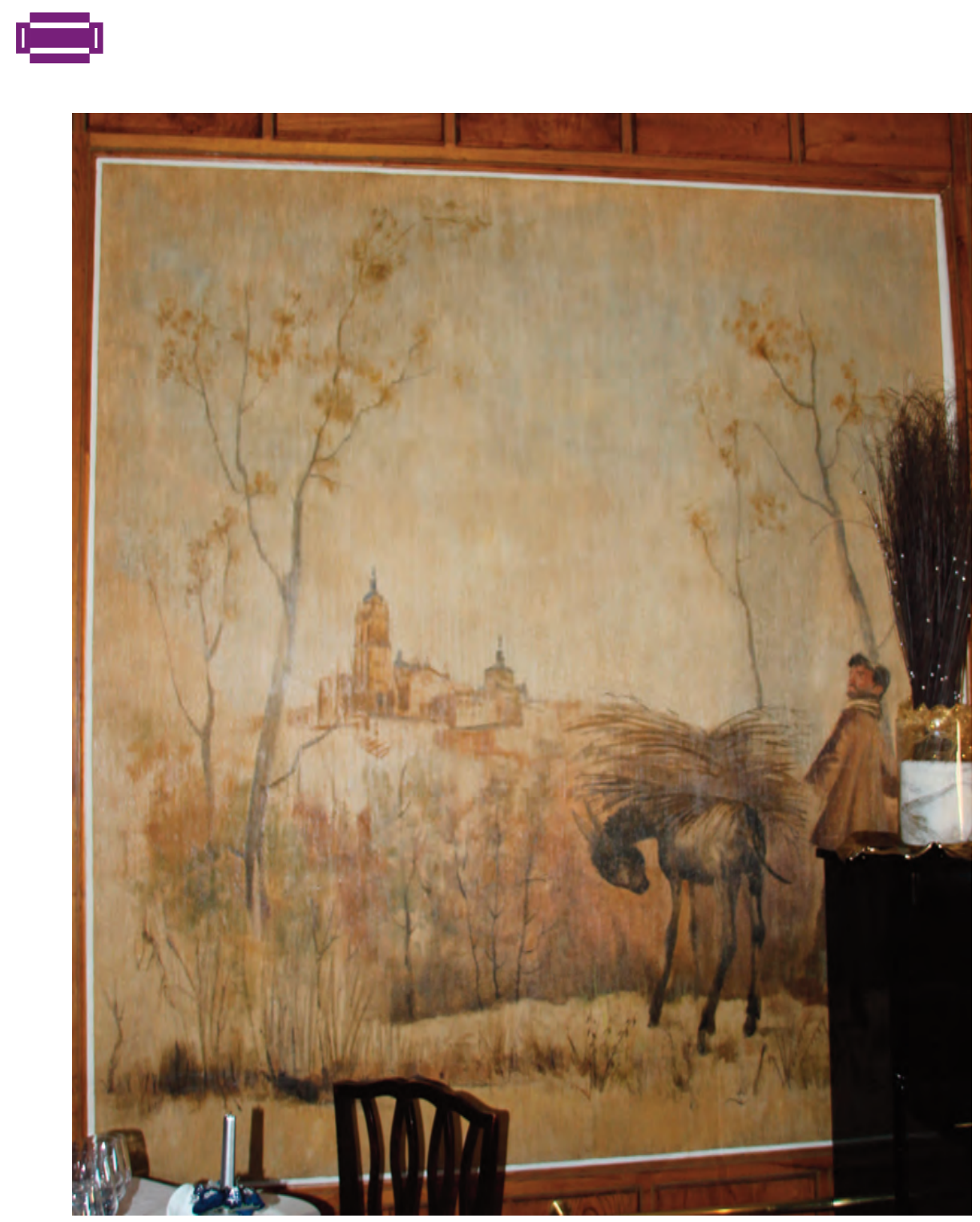

Mural. 1953.

Hotel Sirenas, Segovia.

Eduardo Vicente 

C6 La ocupación principal de Eduardo Vicente parace que es venir a borrar, a dejar, repudiar, irse, venir a irse. ¿Qué brocha, qué tubo busca para la tela del profundo poniente de la exaltante aurora?.

¿Adónde?. ¿Por qué vericuetos entre moles va, a qué tugurios sórdidos, cuevas deshabitadas, márgenes paradisíacos?. ¿Foro de Dostoyeswski interior, primeros planos de Fran Angélico?. Es difícil saberlo, como es difícil la relación de su ser natural con la vida, por desproporción, en cada caso, absoluta $99^{1}$

Jiménez, J.R. (1928:)

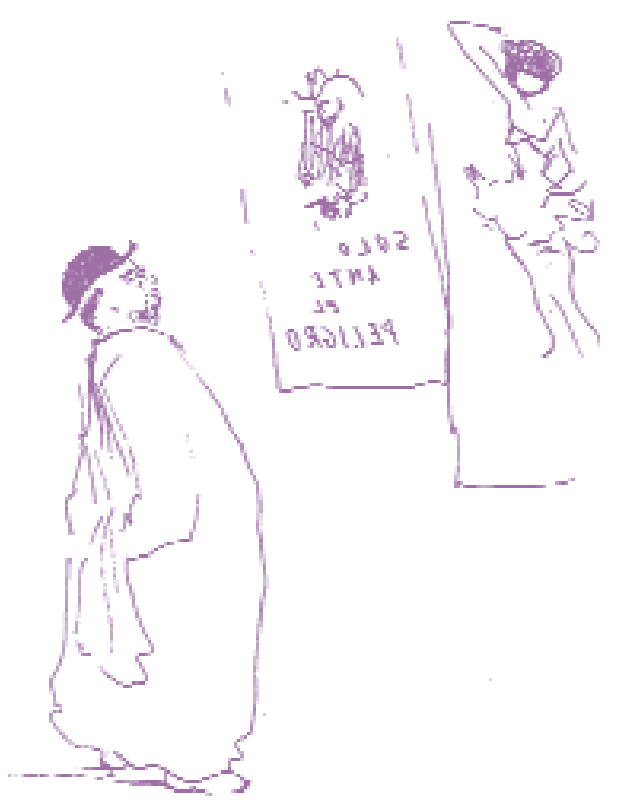



1 Ficha 2.

\section{Número total de Retratos}

\section{Contenido.}

- Personajes.- 18

- Animales.- 0

- Paisajes.- 0

- Escenas:

- Interior.- 0

- Guerra.- 6

- Rural.- 0

- Familiares o amigos.- 12

- Callejera.- 0

- Religiosa.- 0

- Urbana.- 0

- Aérea.- 0

- Profesional.- 0

- Bodegón.- 0

- Arquitectónica.- 0

- Mitológica.- 0

- Festiva.- 0

- Marina.- 0

Aspectos técnicos.

- Color dominante

- 1 Tinta.- 2

- Cuatricromía.- 6

- 2 Tintas.- 0

- Variedad Cromática Superior.- 10

- 3 Tintas.- 0

- Técnica de impresión

- Óleo sobre lienzo.- 10

- Acuarela sobre papel.- 0

- Litografía.- 6

- Acuarela y tinta sobre papel.- 0

- Carboncillo.- 1

- Óleo sobre táblex.- 0

- Lápiz sobre papel.- 1

- Dibujo a carbón, tinta china y aguatinta.- 0

- Fresco.- 0

- Gouache sobre papel.- 0

- Temple.- 0

- Offset.- 0

- Grabado.- 0

- Tipografía.- 0

- Plano de la imagen

- Detalle.- 0

- Americano.- 2

- Primer Plano.- 7

- General.- 1

- Medio Corto.- 8

\section{Función.}

- \% de propaganda política.- 6

- \% de propaganda religiosa.- 0

- \% de modelos sociales.- 12 


\section{Número total de Carteles}

\section{Contenido.}

- Personajes.- 15

- Animales.- 0

- Paisajes.- 2

- Escenas:

- Interior.- 1

- Guerra.- 7

- Rural.- 0

- Familiares o amigos.- 0

- Callejera.- 0

- Religiosa.- 0

- Urbana.- 2

- Aérea.- 0

- Profesional.- 0

- Bodegón.- 0

- Arquitectónica.- 0

- Mitológica.- 0

- Festiva.- 1

- Marina.- 0

Aspectos técnicos.

- Color dominante

- 1 Tinta.- 0

- Cuatricromía.- 2

- 2 Tintas.- 2

- Variedad Cromática Superior.- 0

- 3 Tintas.- 7

- Técnica de impresión

- Óleo sobre lienzo.- 0 - Acuarela sobre papel.- 0

- Litografía.- 11 - Acuarela y tinta sobre papel.- 0

- Carboncillo.- 0 - Óleo sobre táblex.- 0

- Lápiz sobre papel.- 0

- Dibujo a carbón, tinta china y aguatinta.- 0

- Fresco.- 0

- Gouache sobre papel.- 0

- Temple.- 0

- Offset.- 0

- Grabado.- 0

- Tipografía.- 0

- Plano de la imagen

- Detalle.- 2 - Americano.- 1

- Primer Plano.- 5 - General.- 3

\section{Función.}

- \% de propaganda política.- 9

- \% de propaganda religiosa.- 0

- \% de modelos sociales.- 2 


\section{Número total de Murales}

\section{Contenido.}

- Personajes.- 14

- Animales.- 2

- Paisajes.- 11

- Escenas:

- Interior.- 0

- Guerra.- 0

- Rural.- 5

- Familiares o amigos.- 0

- Callejera.- 3

- Religiosa.- 4

- Urbana.- 0

- Aérea.- 1

- Profesional.- 3

- Bodegón.- 0

- Arquitectónica.- 0

- Mitológica.- 0

- Festiva.- 2

- Marina.- 0

Aspectos técnicos.

- Color dominante

- 1 Tinta.- 0

- Cuatricromía.- 0

- 2 Tintas.- 0

- Variedad Cromática Superior.- 15

- 3 Tintas.- 0

- Técnica de impresión

- Óleo sobre lienzo.- 0

- Acuarela sobre papel.- 0

- Litografía.- 0

- Acuarela y tinta sobre papel.- 0

- Carboncillo.- 0

- Óleo sobre táblex.- 0

- Lápiz sobre papel.- 0

- Dibujo a carbón, tinta china y aguatinta.- 0

- Fresco.- 15

- Temple.- 0

- Gouache sobre papel.- 0

- Grabado.- 0

- Offset.- 0

- Tipografía.- 0

- Plano de la imagen

- Detalle.- 0

- Americano.- 0

- Primer Plano.- 0

- General.- 15

- Medio Corto.- 0

\section{Función.}

- \% de propaganda política.- 0

- \% de propaganda religiosa.- 4

- \% de modelos sociales.- 10 


\section{Número total de Ilustraciones}

\section{Contenido.}

- Personajes.- 175

- Animales.- 17

- Paisajes.- 108

- Escenas:

- Interior.- 32

- Guerra.- 0

- Rural.- 36

- Familiares o amigos.- 0

- Callejera.- 40

- Religiosa.- 0

- Urbana.- 12

- Aérea.- 0

- Profesional.- 51

- Bodegón.- 0

- Arquitectónica.- 1

- Mitológica.- 0

- Festiva.- 10

- Marina.- 0

Aspectos técnicos.

- Color dominante

- 1 Tinta.- 82

- Cuatricromía.- 10

- 2 Tintas.- 80

- Variedad Cromática Superior.- 0

- 3 Tintas.- 1

- Técnica de impresión

- Óleo sobre lienzo.- 0 - Acuarela sobre papel.- 0

- Litografía.- 42

- Acuarela y tinta sobre papel.- 0

- Carboncillo.- 0

- Óleo sobre táblex.- 0

- Lápiz sobre papel.- 0

- Dibujo a carbón, tinta china y aguatinta.- 0

- Fresco.- 0

- Gouache sobre papel.- 0

- Temple.- 0

- Offset.- 13

- Grabado.- 0

- Tipografía.- 9

- Plano de la imagen

- Detalle.- 2 - Americano.- 2

- Primer Plano.- 0 - General.- 176

\section{Función.}

- \% de propaganda política.- 0

- \% de propaganda religiosa.- 0

- \% de modelos sociales.- 183 


\section{Número total de Otras Obras}

\section{Contenido.}

- Personajes.- 91

- Animales.- 17

- Paisajes.- 78

- Escenas:

- Interior.- 21

- Guerra.- 16

- Rural.- 13

- Familiares o amigos.- 1

- Callejera.- 12

- Religiosa.- 3

- Urbana.- 20

- Aérea.- 3

- Profesional.- 8

- Bodegón.- 1

- Arquitectónica.- 7

- Mitológica.- 1

- Festiva.- 7

- Marina.- 1

\section{Aspectos técnicos.}

- Color dominante

- 1 Tinta.- 12

- Cuatricromía.- 0

- 2 Tintas.- 1

- Variedad Cromática Superior.- 102

- 3 Tintas.- 0

- Técnica de impresión

- Óleo sobre lienzo.- 62

- Acuarela sobre papel.- 18

- Litografía.- 12

- Acuarela y tinta sobre papel.- 3

- Carboncillo.- 6

- Óleo sobre táblex.- 1

- Lápiz sobre papel.- 0

- Dibujo a carbón, tinta china y aguatinta.- 8

- Fresco.- 0

- Gouache sobre papel.- 1

- Temple.- 1

- Offset.- 0

- Grabado.- 1

- Tipografía.- 0

- Plano de la imagen

- Detalle.- 0

- Americano.- 2

- Primer Plano.- 0

- General.- 111

- Medio Corto.- 2

\section{Función.}

- \% de propaganda política.- 16

- \% de propaganda religiosa.- 4

- \% de modelos sociales.- 95 

2 Ficha 3.

\section{Número total de la Muestra}

\section{Contenido.}

- Personajes.- 313

- Animales.- 19

- Paisajes.- 199

- Escenas:

- Interior.- 54

- Guerra.- 31

- Rural.- 54

- Familiares o amigos.- 13

- Callejera.- 55

- Religiosa.- 7

- Urbana.- 34

- Aérea.- 4

- Profesional.- 62

- Bodegón.- 1

- Arquitectónica.- 8

- Festiva.- 20

- Mitológica.- 1

- Marina.- 1

Aspectos técnicos.

- Color dominante

- 1 Tinta.- 96

- Cuatricromía.- 18

- 2 Tintas.- 83

- Variedad Cromática Superior.- 126

- 3 Tintas.- 8

- Técnica de impresión

- Óleo sobre lienzo.- 72

- Acuarela sobre papel.- 18

- Litografía.- 71

- Acuarela y tinta sobre papel.- 3

- Carboncillo.- 7

- Óleo sobre táblex.- 1

- Lápiz sobre papel.- 1

- Dibujo a carbón, tinta china y aguatinta.- 8

- Fresco.- 15

- Gouache sobre papel.- 1

- Temple.- 1

- Offset.- 13

- Grabado.- 1

- Tipografía.- 9

- Plano de la imagen

- Detalle.- 4

- Americano.- 7

- Primer Plano.- 26

- General.- 306

- Medio Corto.- 15

\section{Función.}

- \% de propaganda política.- 31

- \% de propaganda religiosa.- 8

- \% de modelos sociales.- 301 

3 Ficha 4.

- Personajes.

- Hombre.- 227

- Mujer.- 166

- Niños.- 33

- Animales.

- Perro.- 6

- Gato.- 1

- Burro.- 11

- Toro.- 10

- Oveja.- 1

- Caballo.- 5

- Gallina.- 2

- Buey.- 1

- Gestos expresivos.

- Emociones positivas.- 240

- Emociones negativas.- 55

- Paisaje.

- Si.- 199

- No.- 143

- Escenas.

- Interior.- 54

- Rural.- 54

- Callejera.- 55

- Urbana.- 34

- Profesional.- 62

- Arquitectónica.- 8

- Festiva.- 20

- Guerra.- 31

- Familiares o amigos.- 13

- Religiosa.- 7

- Aérea.- 4

- Bodegón.- 1

- Mitológica.- 1

- Marina.- 1 

ANEXO II.

Notas

1.- Jiménez, J.R. (1928). Españoles de tres mundos. Citado en: http://www.huelvainformación.es/article/ocio/692815/sera/eduardo/vicente $(10 / 09 / 2010)$ 



\section{]l]Anexo III}
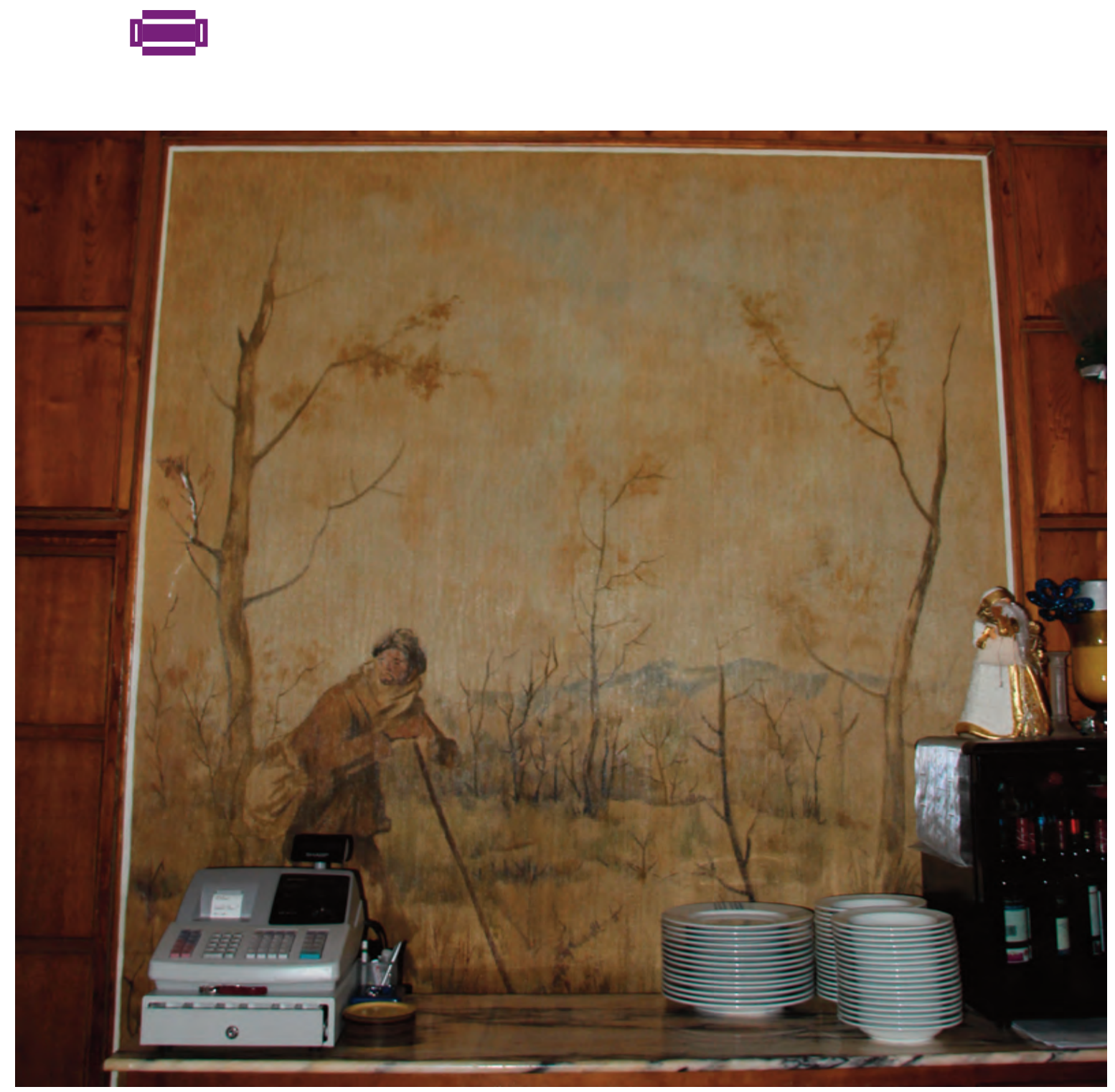

Mural. 1953

Hotel Sirenas, Segovia.

Eduardo Vicente 

$\checkmark C_{E s}$ como un gran carnaval, pero, en el fondo con una inquietud digna de observarse. A mí me basta con el espectáculo para captarlo $9 \mathcal{S}^{1}$

Eduardo Vicente (1968)

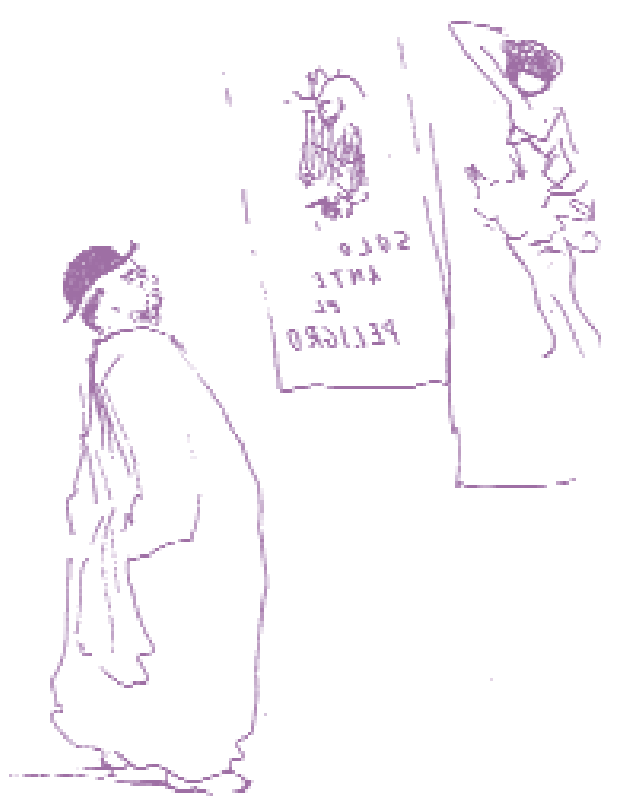





\section{[I Retratos}

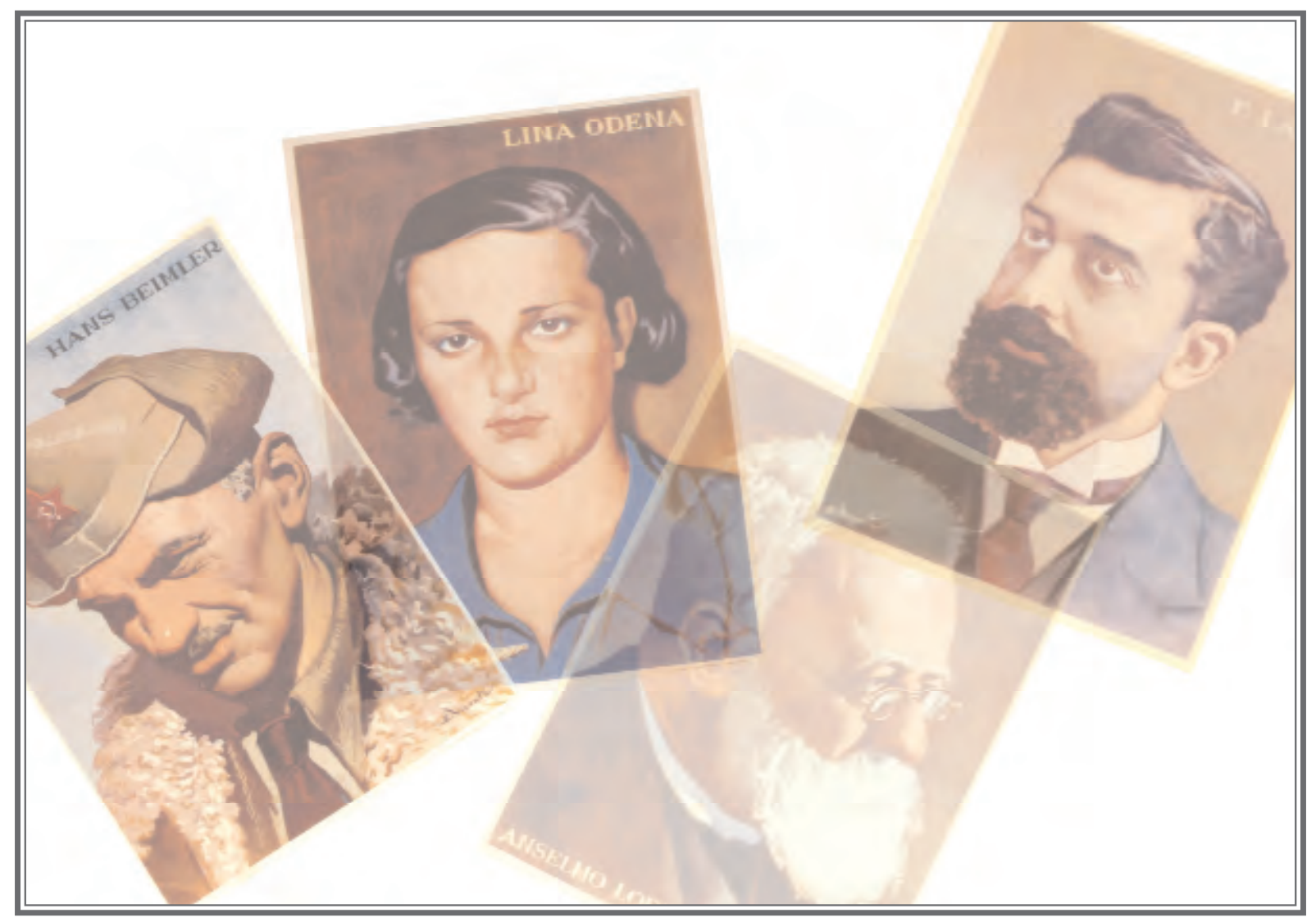

Afueras de Madrid. 1955. Madrid.

Acuarela sobre papel. Colección particular.

Eduardo Vicente 



\section{VARIABLES EXTERNAS.}

Título: Francisco Ascaso

Año: 1937

Tamaño: $28 \times 20 \mathrm{~cm}$.

\section{TIPO DE IMAGEN.}

Retrato: SI

Cartel: NO

Mural: NO

Ilustración: NO

Otras Obras: NO

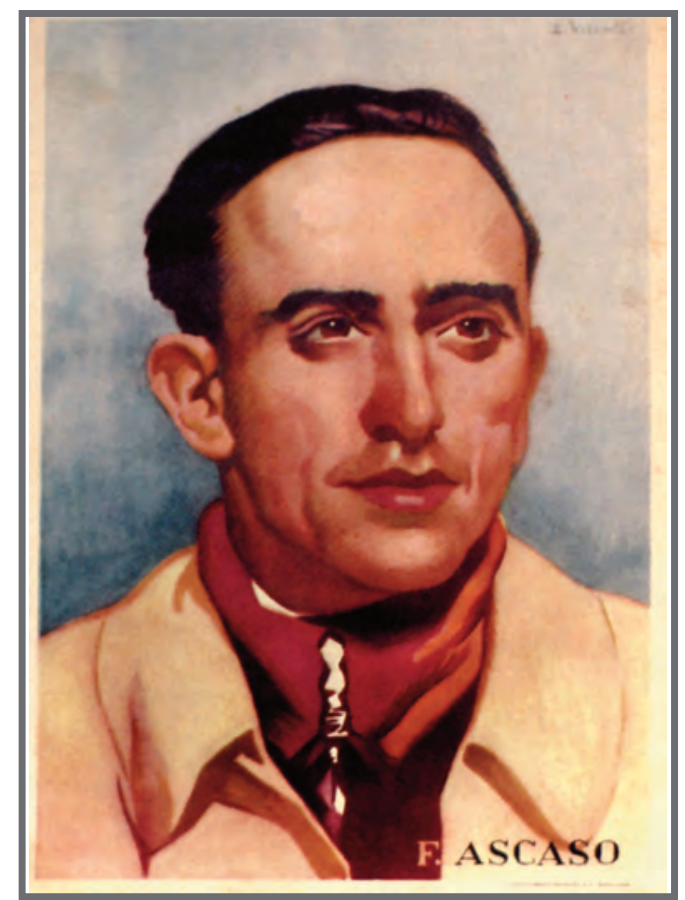

\section{CONTENIDO.}

Personajes: HOMBRE

Animales: NO

Gestos Expresivos: EMOCIONES POSITIVAS

Paisajes: NO

Escenas: GUERRA

Función: PROPAGANDÍSTICA (IDEOLOGÍA POLÍTICA)

\section{ASPECTOS TÉCNICOS.}

Color dominante: CUATRICROMÍA

Técnica: LITOGRAFÍA

Plano de la imagen: PRIMER PLANO 


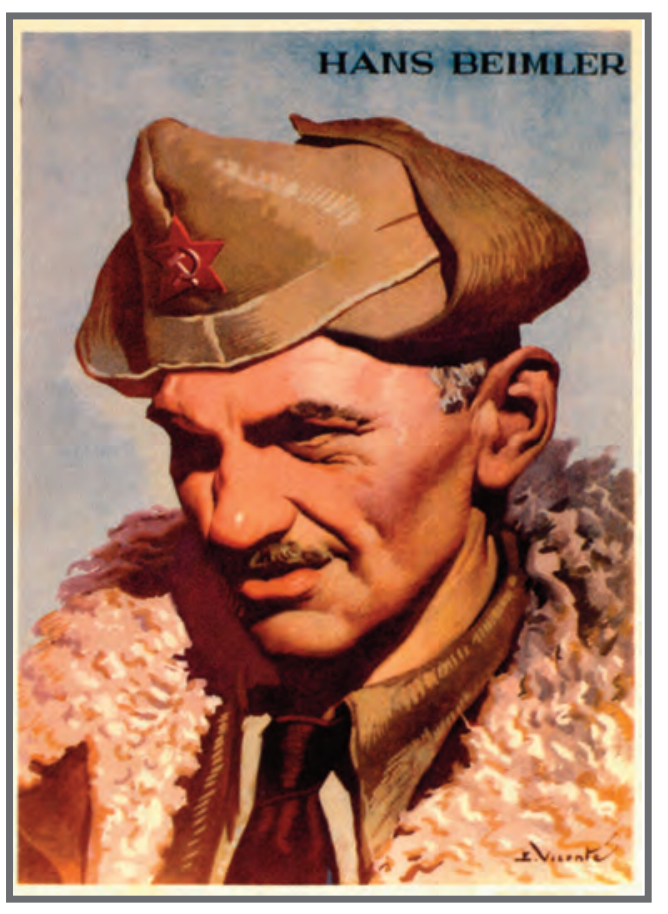

\section{VARIABLES EXTERNAS.}

Título: Hans Beimler

Año: 1937

Tamaño: 28 x $20 \mathrm{~cm}$.

\section{TIPO DE IMAGEN.}

\section{Retrato: SI}

Cartel: NO

Mural: NO

Ilustración: NO

Otras Obras: NO

\section{CONTENIDO.}

Personajes: HOMBRE

Animales: NO

Gestos Expresivos: EMOCIONES POSITIVAS

Paisajes: NO

Escenas: GUERRA

Función: PROPAGANDÍSTICA (IDEOLOGÍA POLÍTICA)

\section{ASPECTOS TÉCNICOS.}

Color dominante: CUATRICROMÍA

Técnica: LITOGRAFÍA

Plano de la imagen: PRIMER PLANO 


\section{VARIABLES EXTERNAS.}

Título: Anselmo Lorenzo

Año: 1937

Tamaño: $28 \times 20 \mathrm{~cm}$.

\section{TIPO DE IMAGEN.}

Retrato: SI

Cartel: NO

Mural: NO

Ilustración: NO

Otras Obras: NO

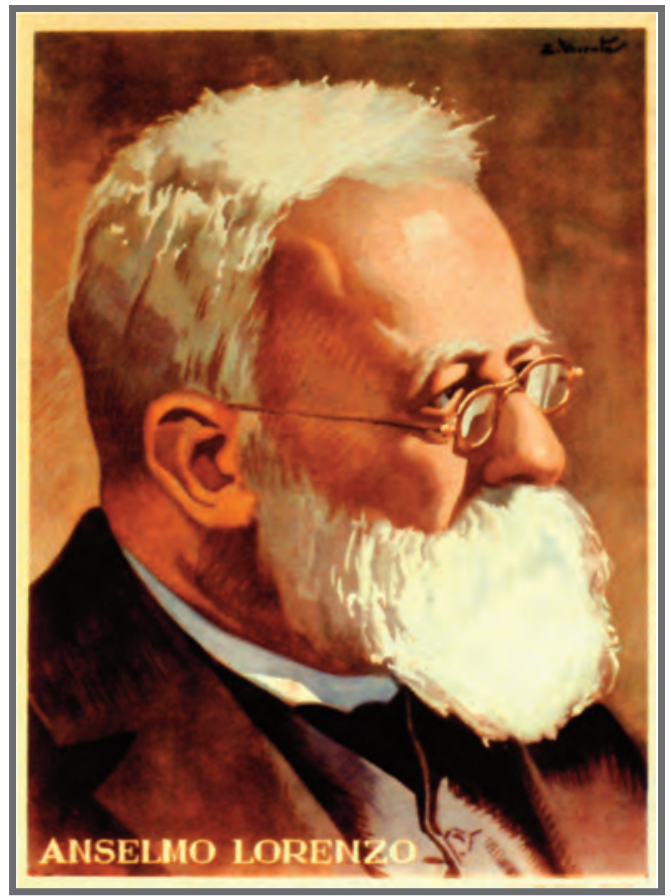

\section{CONTENIDO.}

Personajes: HOMBRE

Animales: NO

Gestos Expresivos: EMOCIONES POSITIVAS

Paisajes: NO

Escenas: GUERRA

Función: PROPAGANDÍSTICA (IDEOLOGÍA POLÍTICA)

\section{ASPECTOS TÉCNICOS.}

Color dominante: CUATRICROMÍA

Técnica: LITOGRAFÍA

Plano de la imagen: PRIMER PLANO 


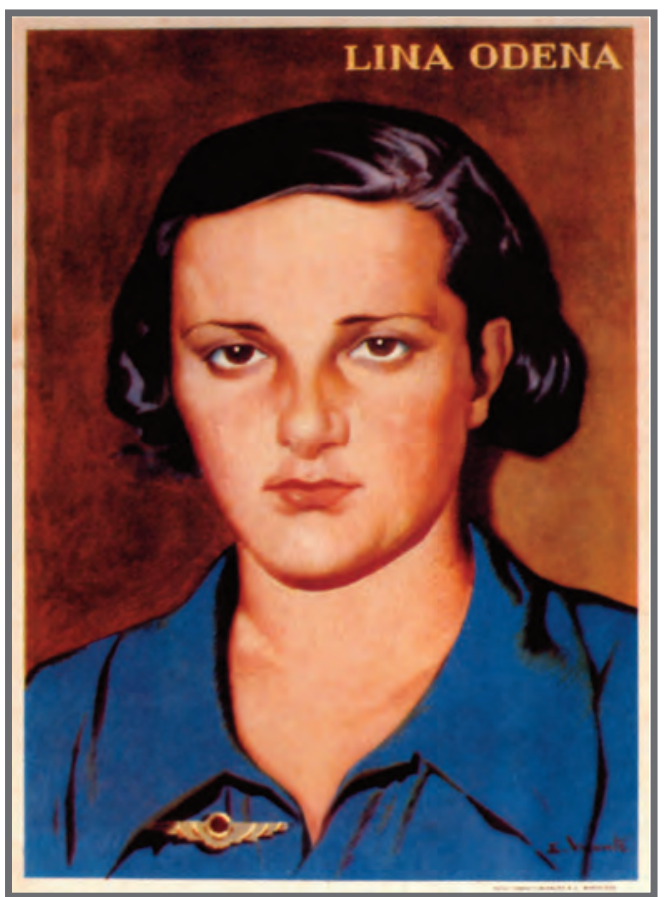

\section{VARIABLES EXTERNAS.}

Título: Lina Odena

Año: 1937

Tamaño: $28 \times 20 \mathrm{~cm}$.

\section{TIPO DE IMAGEN.}

Retrato: SI

Cartel: NO

Mural: NO

Ilustración: NO

Otras Obras: NO

\section{CONTENIDO.}

Personajes: MUJER

Animales: NO

Gestos Expresivos: EMOCIONES POSITIVAS

Paisajes: NO

Escenas: GUERRA

Función: PROPAGANDÍSTICA (IDEOLOGÍA POLÍTICA)

\section{ASPECTOS TÉCNICOS.}

Color dominante: CUATRICROMÍA

Técnica: LITOGRAFÍA

Plano de la imagen: PRIMER PLANO 


\section{VARIABLES EXTERNAS.}

Título: Francesc Layret

Año: 1937

Tamaño: $28 \times 20 \mathrm{~cm}$.

TIPO DE IMAGEN.

Retrato: SI

Cartel: NO

Mural: NO

Ilustración: NO

Otras Obras: NO

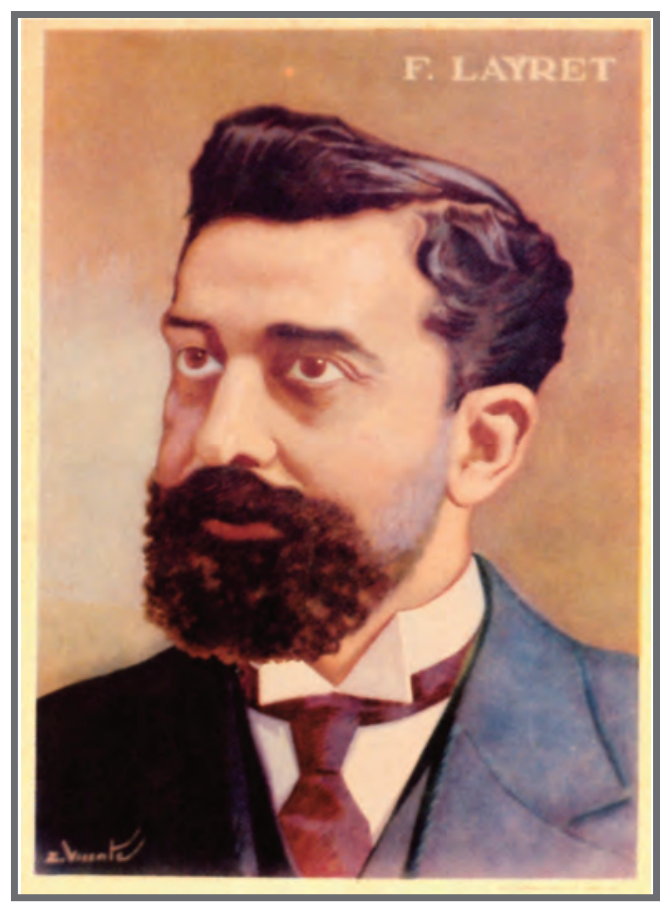

\section{CONTENIDO.}

Personajes: HOMBRE

Animales: NO

Gestos Expresivos: EMOCIONES POSITIVAS

Paisajes: NO

Escenas: GUERRA

Función: PROPAGANDÍSTICA (IDEOLOGÍA POLÍTICA)

\section{ASPECTOS TÉCNICOS.}

Color dominante: CUATRICROMÍA

Técnica: LITOGRAFÍA

Plano de la imagen: PRIMER PLANO 


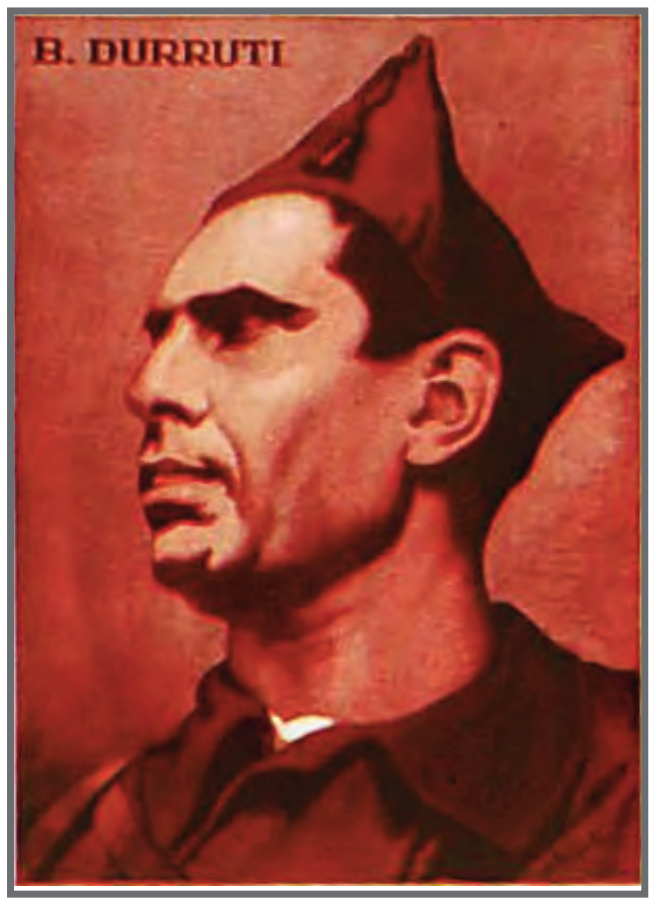

\section{VARIABLES EXTERNAS.}

Título: Buenaventura Durruti

Año: 1937

Tamaño: $28 \times 20 \mathrm{~cm}$.

\section{TIPO DE IMAGEN.}

Retrato: SI

Cartel: NO

Mural: NO

Ilustración: NO

Otras Obras: NO

\section{CONTENIDO.}

Personajes: HOMBRE

Animales: NO

Gestos Expresivos: EMOCIONES POSITIVAS

Paisajes: NO

Escenas: GUERRA

Función: PROPAGANDÍSTICA (IDEOLOGÍA POLÍTICA)

\section{ASPECTOS TÉCNICOS.}

Color dominante: CUATRICROMÍA

Técnica: LITOGRAFÍA

Plano de la imagen: PRIMER PLANO 


\section{VARIABLES EXTERNAS.}

Título: Sagrario Ulierte

Año: 1940

Tamaño: $99 \times 89 \mathrm{~cm}$.

\section{TIPO DE IMAGEN.}

Retrato: SI

Cartel: NO

Mural: NO

Ilustración: NO

Otras Obras: NO

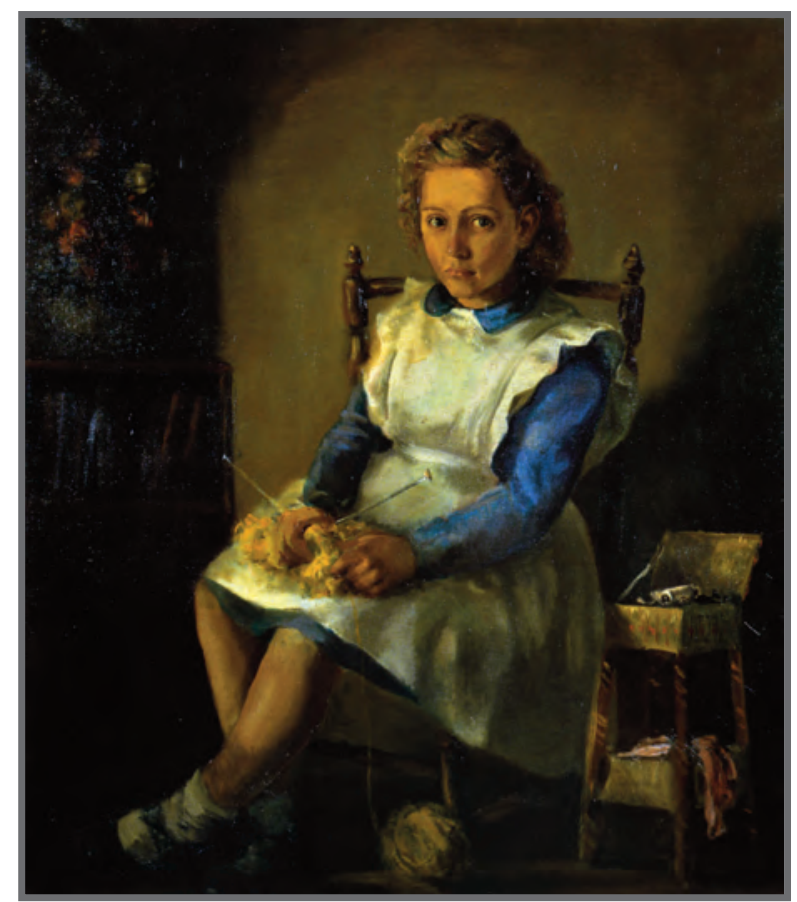

\section{CONTENIDO.}

Personajes: NIÑA

Animales: NO

Gestos Expresivos: EMOCIONES POSITIVAS

Paisajes: NO

Escenas: FAMILIARES O AMIGOS

Función: REPRESENTATIVA DE MODELOS SOCIALES

\section{ASPECTOS TÉCNICOS.}

Color dominante: VARIEDAD CROMÁTICA SUPERIOR

Técnica: ÓLEO SOBRE LIENZO

Plano de la imagen: GENERAL 


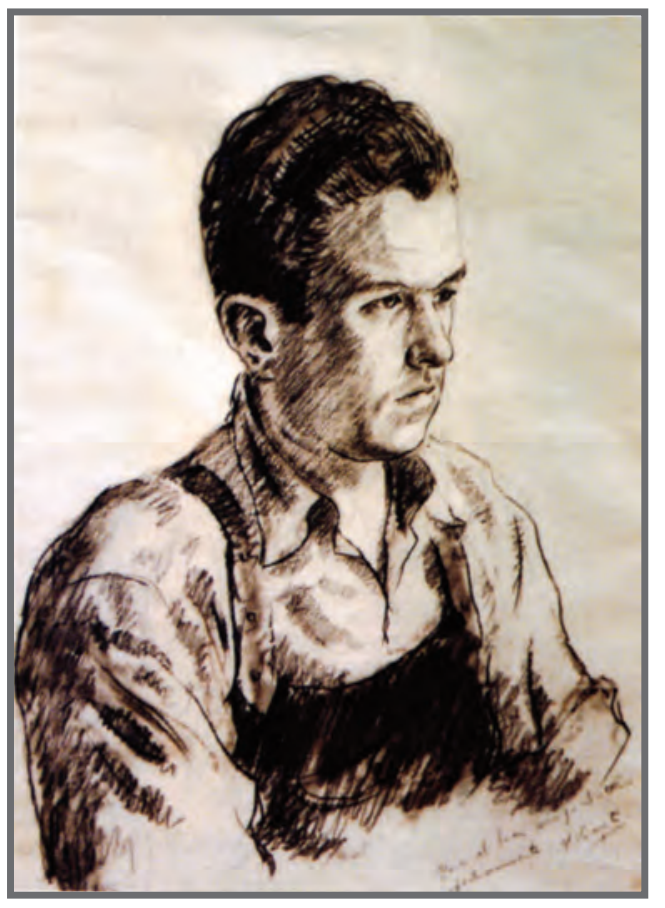

\section{VARIABLES EXTERNAS.}

Título: Antonio García-Molina

Año: 1942

Tamaño: DESCONOCIDO

\section{TIPO DE IMAGEN.}

Retrato: SI

Cartel: NO

Mural: NO

Ilustración: NO

Otras Obras: NO

\section{CONTENIDO.}

Personajes: HOMBRE

Animales: NO

Gestos Expresivos: EMOCIONES POSITIVAS

Paisajes: NO

Escenas: FAMILIARES O AMIGOS

Función: REPRESENTATIVA DE MODELOS SOCIALES

ASPECTOS TÉCNICOS.

Color dominante: 1 TINTA

Técnica: CARBONCILLO

Plano de la imagen: MEDIO CORTO 


\section{VARIABLES EXTERNAS.}

Título: María Pascual

Año: 1943

Tamaño: 65 x $50 \mathrm{~cm}$.

\section{TIPO DE IMAGEN.}

Retrato: SI

Cartel: NO

Mural: NO

Ilustración: NO

Otras Obras: NO

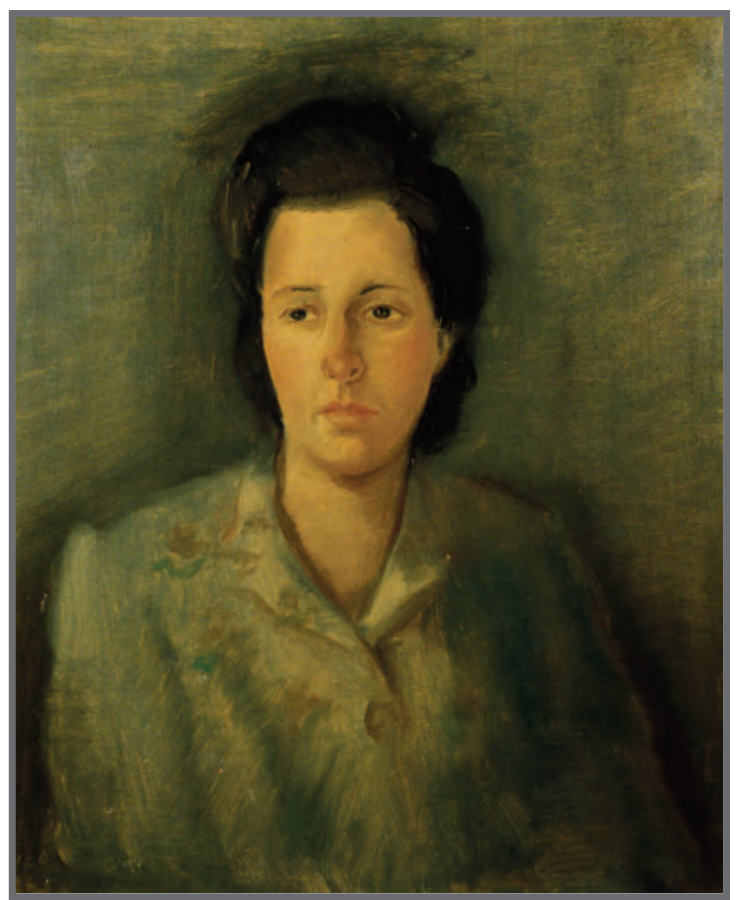

\section{CONTENIDO.}

Personajes: MUJER

Animales: NO

Gestos Expresivos: EMOCIONES POSITIVAS

Paisajes: NO

Escenas: FAMILIARES O AMIGOS

Función: REPRESENTATIVA DE MODELOS SOCIALES

\section{ASPECTOS TÉCNICOS.}

Color dominante: VARIEDAD CROMÁTICA SUPERIOR

Técnica: ÓLEO SOBRE LIENZO

Plano de la imagen: MEDIO CORTO 


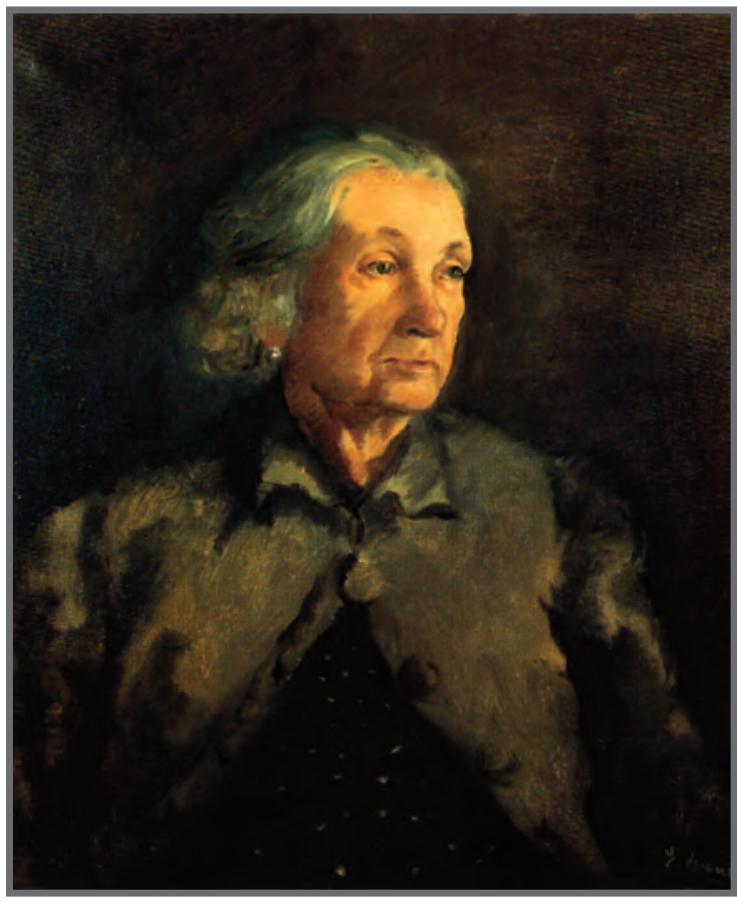

\section{VARIABLES EXTERNAS.}

Título: María Torres

Año: 1943

Tamaño: 68 x $58 \mathrm{~cm}$.

TIPO DE IMAGEN.

Retrato: SI

Cartel: NO

Mural: NO

Ilustración: NO

Otras Obras: NO

\section{CONTENIDO.}

Personajes: MUJER

Animales: NO

Gestos Expresivos: EMOCIONES POSITIVAS

Paisajes: NO

Escenas: FAMILIARES O AMIGOS

Función: REPRESENTATIVA DE MODELOS SOCIALES

\section{ASPECTOS TÉCNICOS.}

Color dominante: VARIEDAD CROMÁTICA SUPERIOR

Técnica: ÓLEO SOBRE LIENZO

Plano de la imagen: MEDIO CORTO 


\section{VARIABLES EXTERNAS.}

Título: Marisol Vicente

Año: 1943

Tamaño: $40 \times 40 \mathrm{~cm}$.

\section{TIPO DE IMAGEN.}

Retrato: SI

Cartel: NO

Mural: NO

Ilustración: NO

Otras Obras: NO

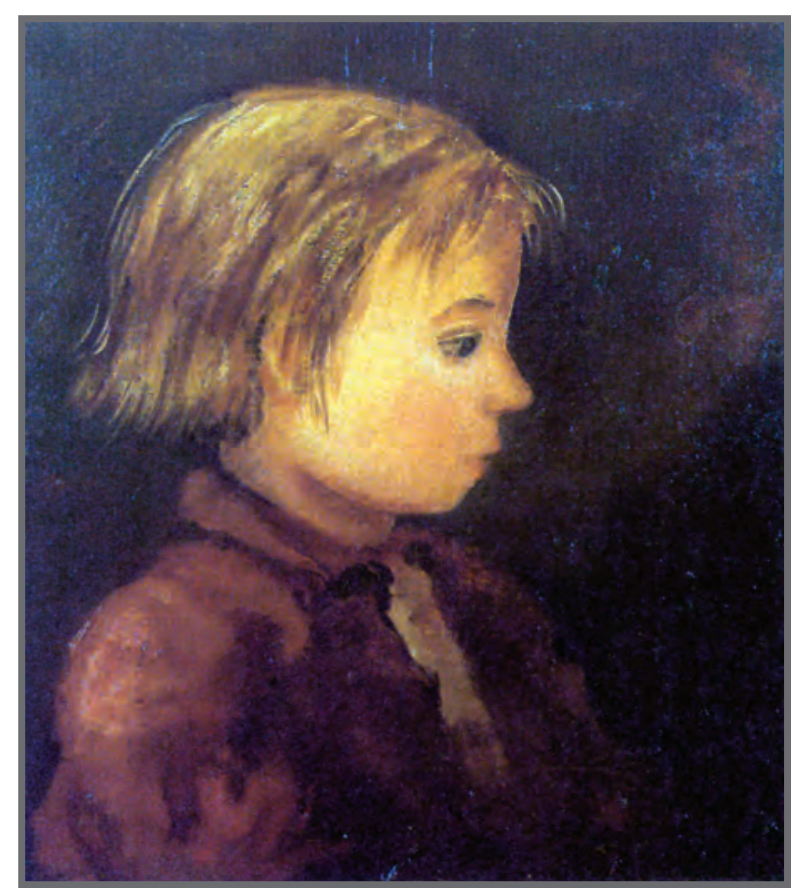

\section{CONTENIDO.}

Personajes: NIÑA

Animales: NO

Gestos Expresivos: EMOCIONES POSITIVAS

Paisajes: NO

Escenas: FAMILIARES O AMIGOS

Función: REPRESENTATIVA DE MODELOS SOCIALES

\section{ASPECTOS TÉCNICOS.}

Color dominante: VARIEDAD CROMÁTICA SUPERIOR

Técnica: ÓLEO SOBRE LIENZO

Plano de la imagen: MEDIO CORTO 


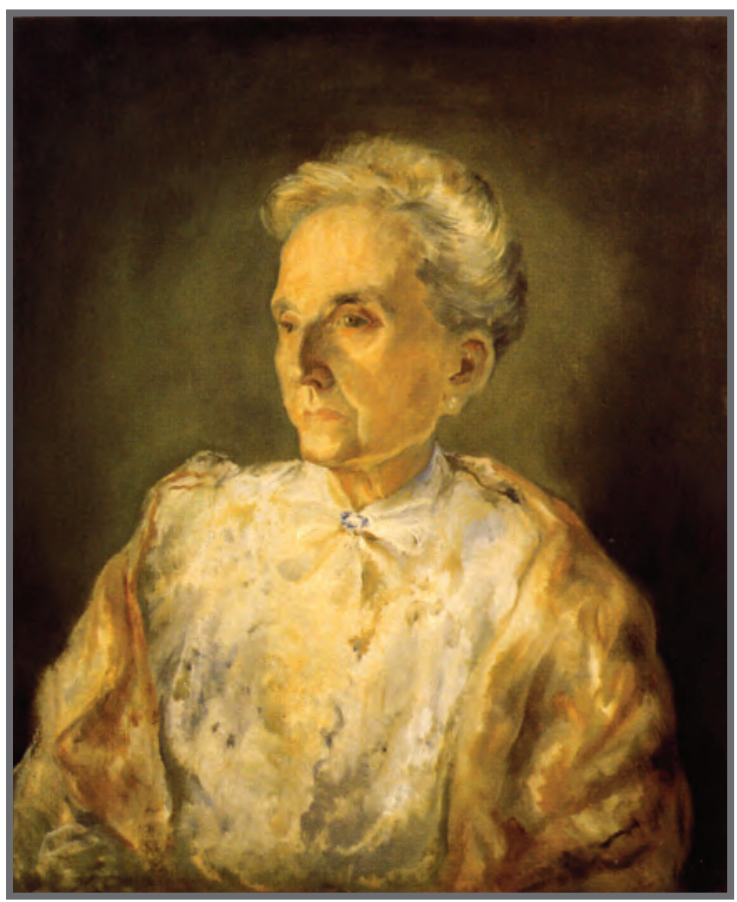

\section{VARIABLES EXTERNAS.}

Título: Consuelo Feijóo de Laya

Año: 1944

Tamaño: 65 x $54 \mathrm{~cm}$.

TIPO DE IMAGEN.

Retrato: SI

Cartel: NO

Mural: NO

Ilustración: NO

Otras Obras: NO

\section{CONTENIDO.}

Personajes: MUJER

Animales: NO

Gestos Expresivos: EMOCIONES POSITIVAS

Paisajes: NO

Escenas: FAMILIARES O AMIGOS

Función: REPRESENTATIVA DE MODELOS SOCIALES

\section{ASPECTOS TÉCNICOS.}

Color dominante: VARIEDAD CROMÁTICA SUPERIOR

Técnica: ÓLEO SOBRE LIENZO

Plano de la imagen: MEDIO CORTO 


\section{VARIABLES EXTERNAS.}

Título: Lucía Sancho de Hoyos

Año: 1945

Tamaño: $85,5 \times 75,5 \mathrm{~cm}$.

\section{TIPO DE IMAGEN.}

Retrato: SI

Cartel: NO

Mural: NO

Ilustración: NO

Otras Obras: NO

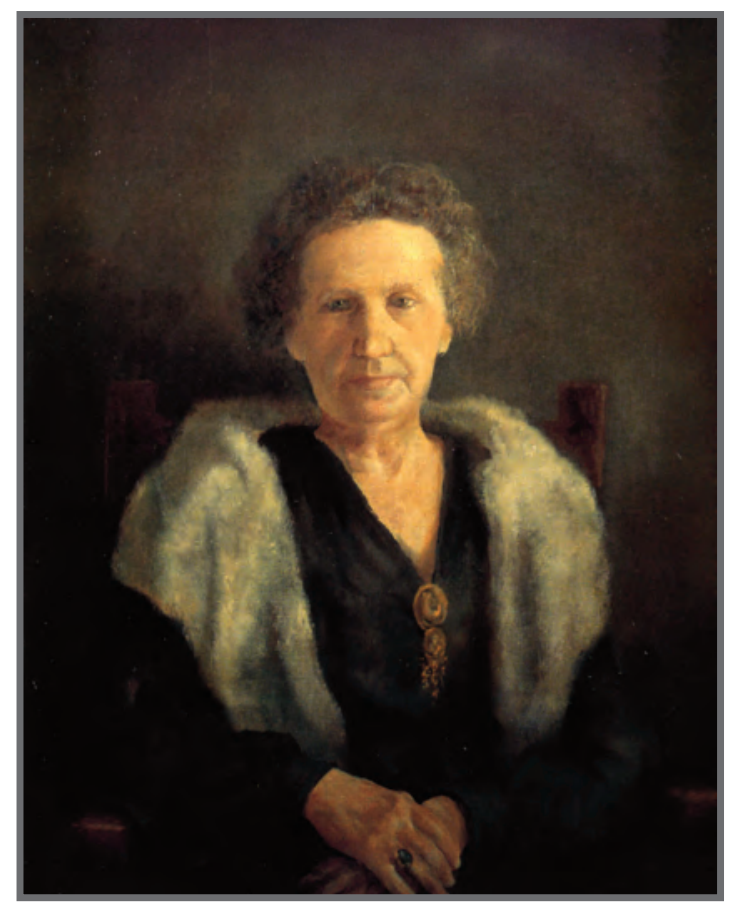

\section{CONTENIDO.}

Personajes: MUJER

Animales: NO

Gestos Expresivos: EMOCIONES POSITIVAS

Paisajes: NO

Escenas: FAMILIARES O AMIGOS

Función: REPRESENTATIVA DE MODELOS SOCIALES

\section{ASPECTOS TÉCNICOS.}

Color dominante: VARIEDAD CROMÁTICA SUPERIOR

Técnica: ÓLEO SOBRE LIENZO

Plano de la imagen: MEDIO CORTO 


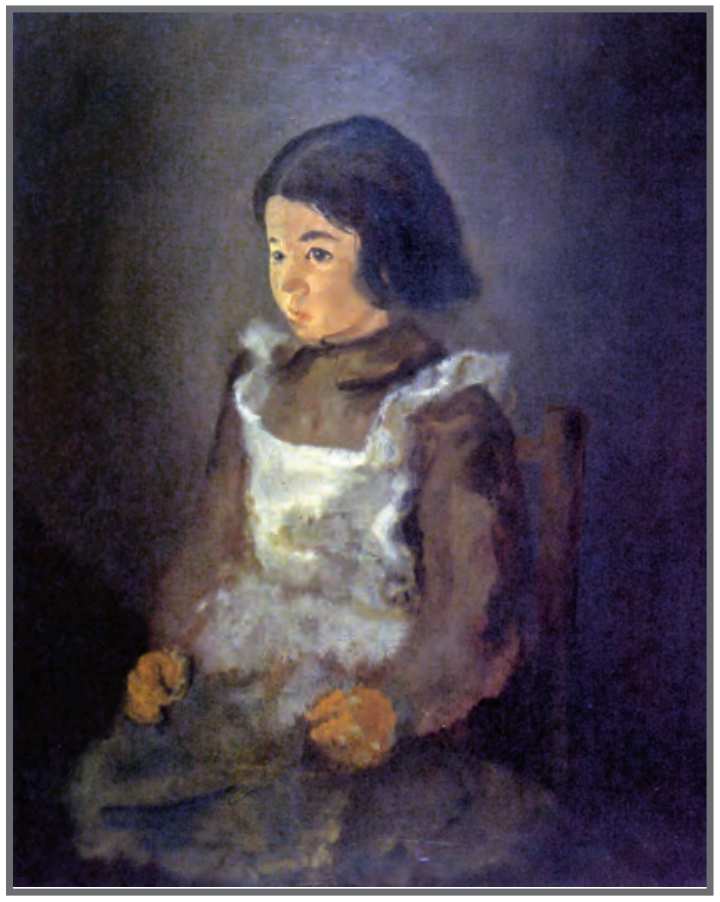

\section{VARIABLES EXTERNAS.}

Título: Silvia Vicente

Año: 1945

Tamaño: 75 x $60 \mathrm{~cm}$.

\section{TIPO DE IMAGEN.}

Retrato: SI

Cartel: NO

Mural: NO

Ilustración: NO

Otras Obras: NO

\section{CONTENIDO.}

Personajes: NIÑA

Animales: NO

Gestos Expresivos: EMOCIONES POSITIVAS

Paisajes: NO

Escenas: FAMILIARES O AMIGOS

Función: REPRESENTATIVA DE MODELOS SOCIALES

\section{ASPECTOS TÉCNICOS.}

Color dominante: VARIEDAD CROMÁTICA SUPERIOR

Técnica: ÓLEO SOBRE LIENZO

Plano de la imagen: AMERICANO 


\section{VARIABLES EXTERNAS.}

Título: Luis de Hoyos

Año: 1945

Tamaño: 85,5 x 75,5 cm.

\section{TIPO DE IMAGEN.}

Retrato: SI

Cartel: NO

Mural: NO

Ilustración: NO

Otras Obras: NO

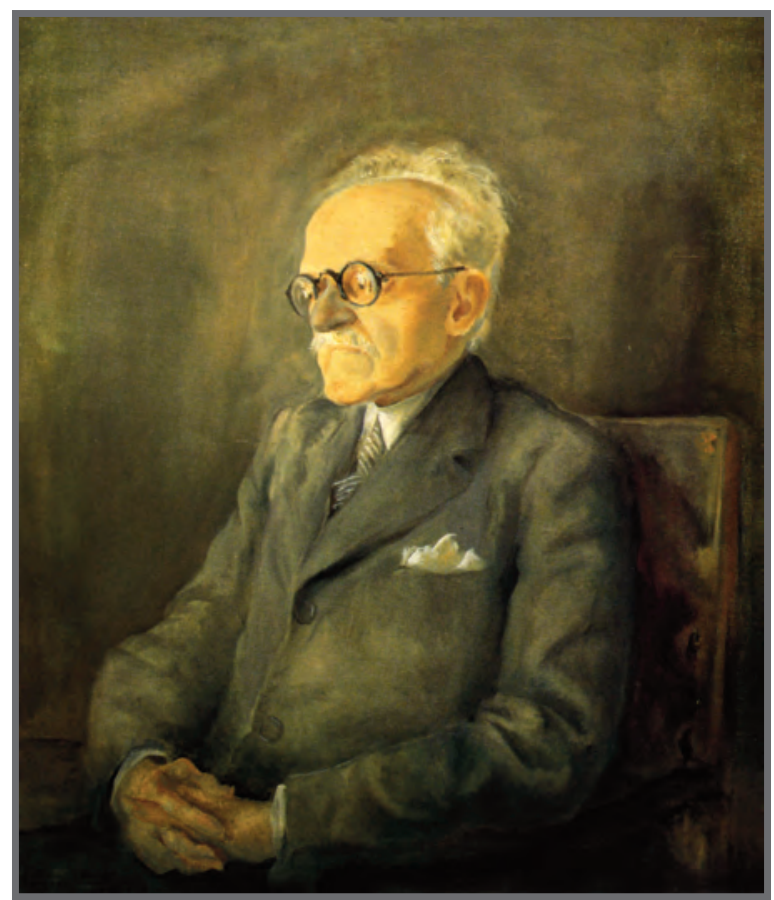

\section{CONTENIDO.}

Personajes: HOMBRE

Animales: NO

Gestos Expresivos: EMOCIONES POSITIVAS

Paisajes: NO

Escenas: FAMILIARES O AMIGOS

Función: REPRESENTATIVA DE MODELOS SOCIALES

\section{ASPECTOS TÉCNICOS.}

Color dominante: VARIEDAD CROMÁTICA SUPERIOR

Técnica: ÓLEO SOBRE LIENZO

Plano de la imagen: AMERICANO 


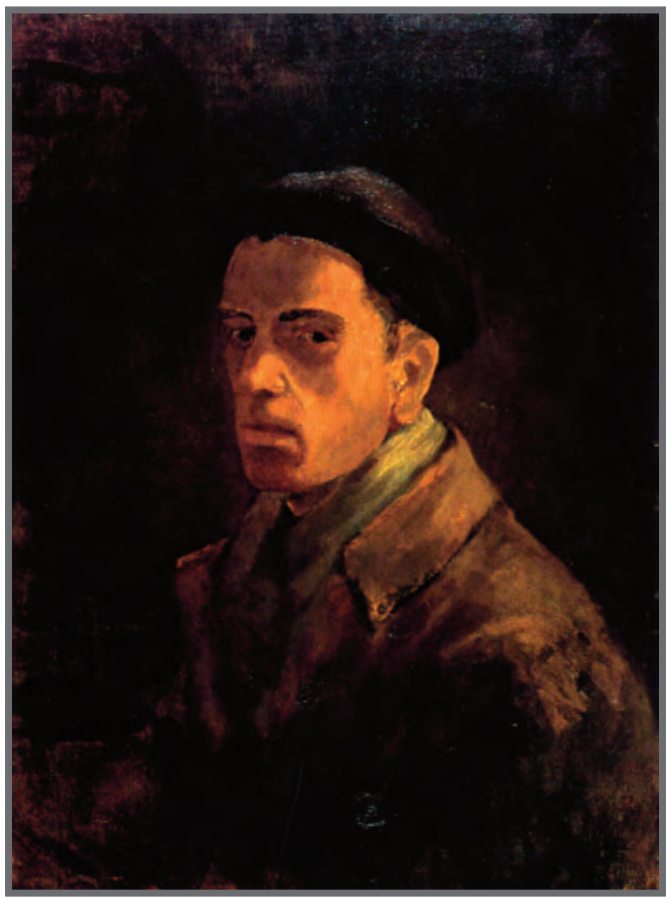

\section{VARIABLES EXTERNAS.}

Título: Autorretrato (E. Vicente)

Año: 1946

Tamaño: $65 \times 50 \mathrm{~cm}$.

\section{TIPO DE IMAGEN.}

Retrato: SI

Cartel: NO

Mural: NO

Ilustración: NO

Otras Obras: NO

\section{CONTENIDO.}

Personajes: HOMBRE

Animales: NO

Gestos Expresivos: EMOCIONES POSITIVAS

Paisajes: NO

Escenas: FAMILIARES O AMIGOS

Función: REPRESENTATIVA DE MODELOS SOCIALES

\section{ASPECTOS TÉCNICOS.}

Color dominante: VARIEDAD CROMÁTICA SUPERIOR

Técnica: ÓLEO SOBRE LIENZO

Plano de la imagen: MEDIO CORTO 
ANEXO III.

VARIABLES EXTERNAS.

Título: Pío Baroja

Año: 1949

Tamaño: $30 \times 23 \mathrm{~cm}$.

TIPO DE IMAGEN.

Retrato: SI

Cartel: NO

Mural: NO

Ilustración: NO

Otras Obras: NO

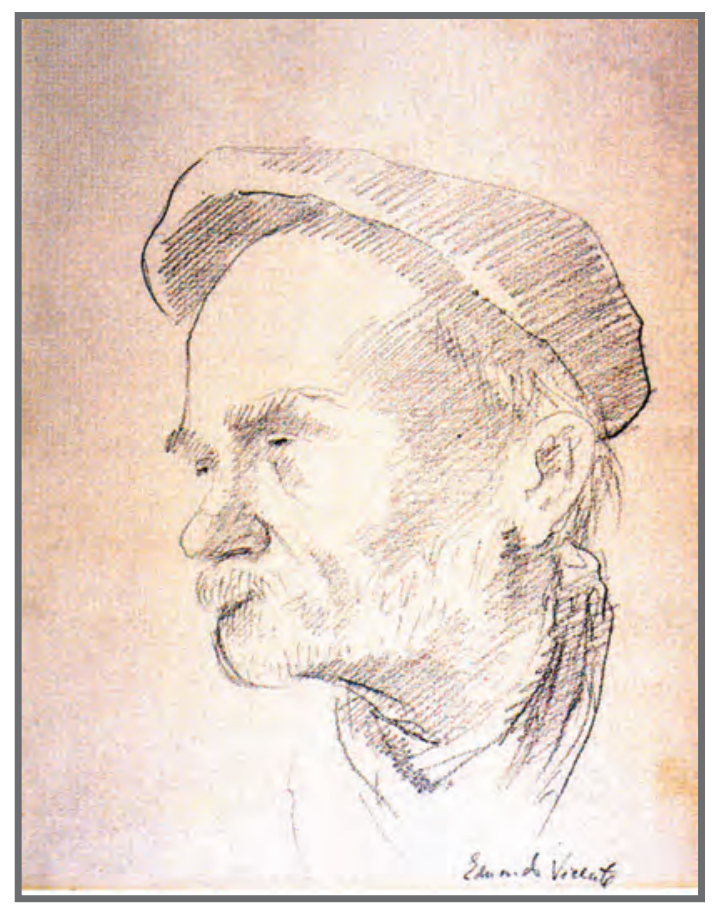

\section{CONTENIDO.}

Personajes: HOMBRE

Animales: NO

Gestos Expresivos: EMOCIONES POSITIVAS

Paisajes: NO

Escenas: FAMILIARES O AMIGOS

Función: REPRESENTATIVA DE MODELOS SOCIALES

\section{ASPECTOS TÉCNICOS.}

Color dominante: 1 TINTA

Técnica: LÁPIZ SOBRE PAPEL

Plano de la imagen: PRIMER PLANO 


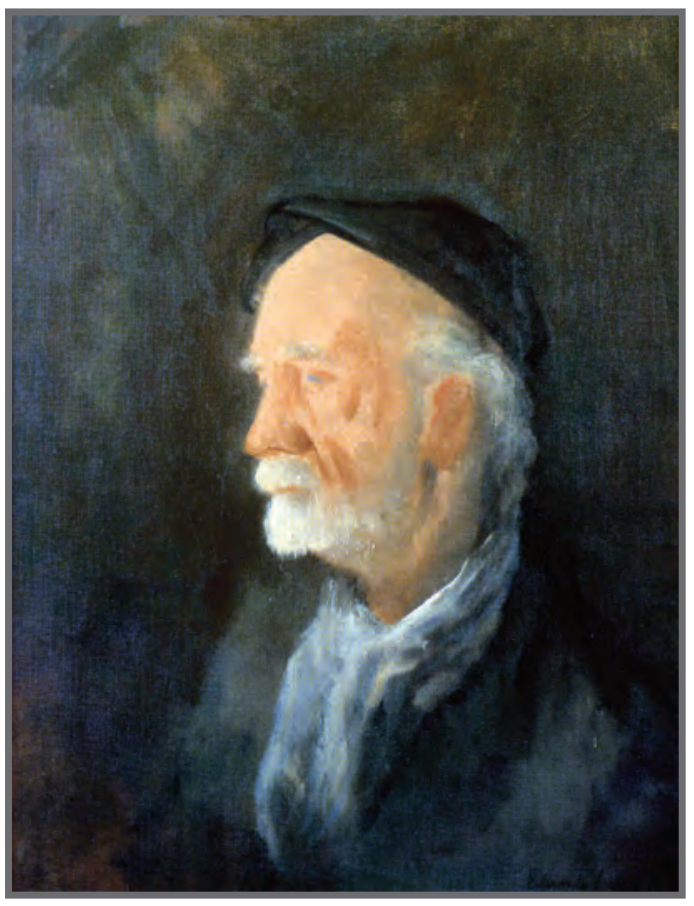

\section{VARIABLES EXTERNAS.}

Título: Pío Baroja

Año: 1950

Tamaño: 75 x $60 \mathrm{~cm}$.

\section{TIPO DE IMAGEN.}

\section{Retrato: SI}

Cartel: NO

Mural: NO

Ilustración: NO

Otras Obras: NO

\section{CONTENIDO.}

Personajes: HOMBRE

Animales: NO

Gestos Expresivos: EMOCIONES POSITIVAS

Paisajes: NO

Escenas: FAMILIARES O AMIGOS

Función: REPRESENTATIVA DE MODELOS SOCIALES

\section{ASPECTOS TÉCNICOS.}

Color dominante: VARIEDAD CROMÁTICA SUPERIOR

Técnica: ÓLEO SOBRE LIENZO

Plano de la imagen: MEDIO CORTO 


\section{[] Carteles}

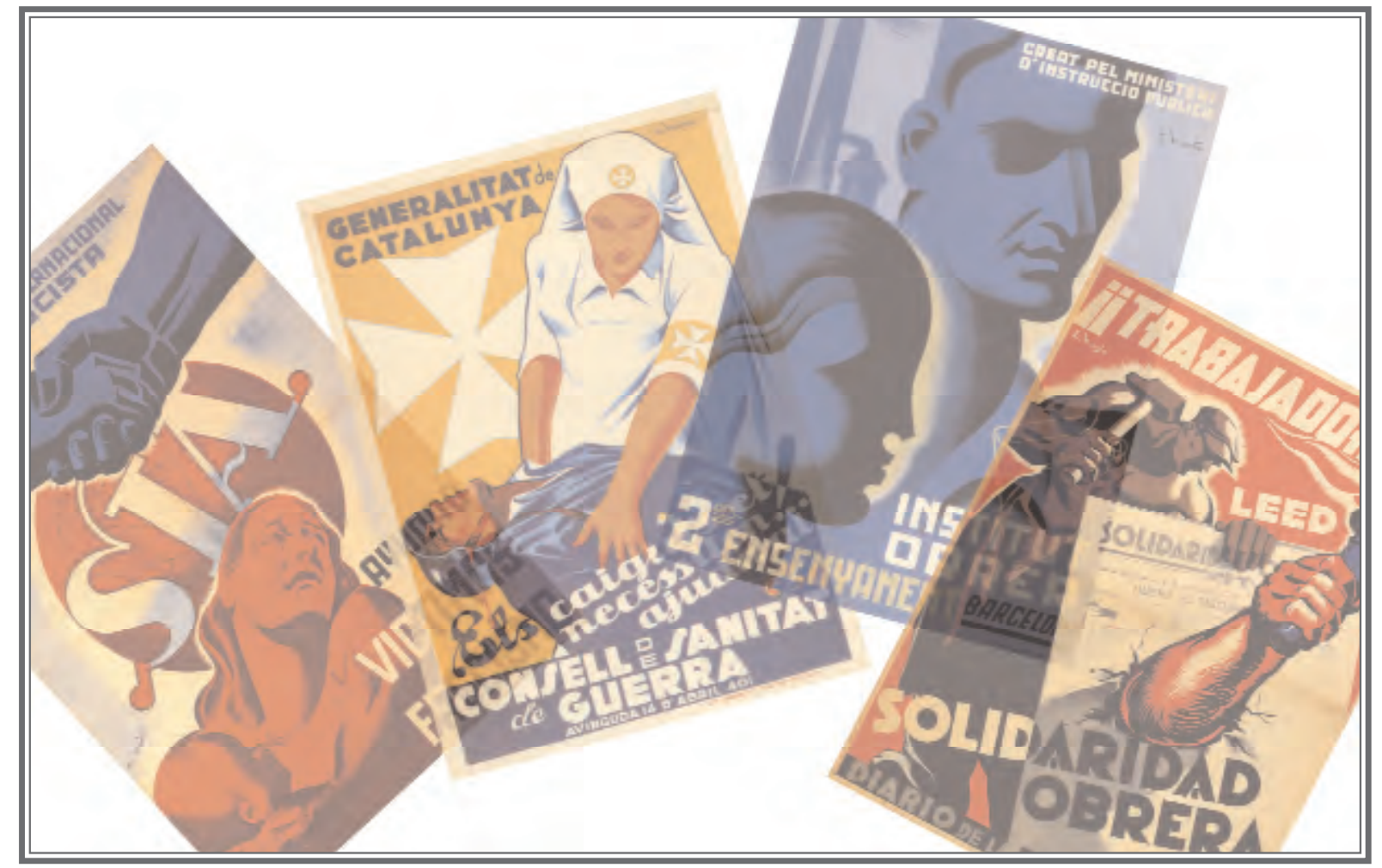





\section{VARIABLES EXTERNAS.}

Título: Institut obrer

Año: 1933

Tamaño: $120 \times 84 \mathrm{~cm}$.

TIPO DE IMAGEN.

Retrato: NO

Cartel: NO

Mural: NO

Ilustración: SI

Otras Obras: NO

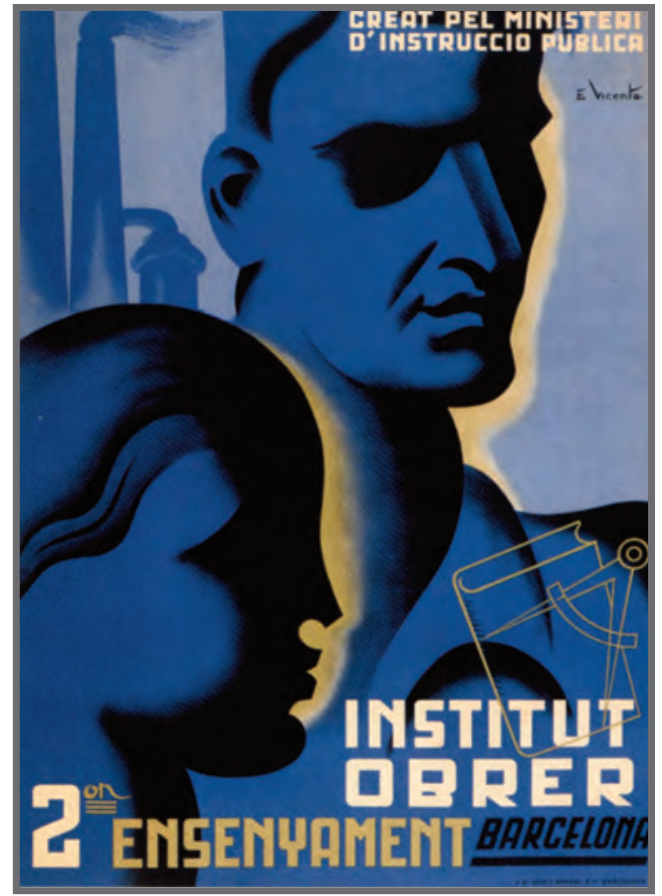

\section{CONTENIDO.}

Personajes: HOMBRE Y MUJER

Animales: NO

Gestos Expresivos: EMOCIONES POSITIVAS

Paisajes: SI

Escenas: URBANA

Función: PROPAGANDÍSTICA (IDEOLOGÍA POLÍTICA)

\section{ASPECTOS TÉCNICOS.}

Color dominante: 2 TINTAS

Técnica: LITOGRAFÍA

Plano de la imagen: PRIMER PLANO 


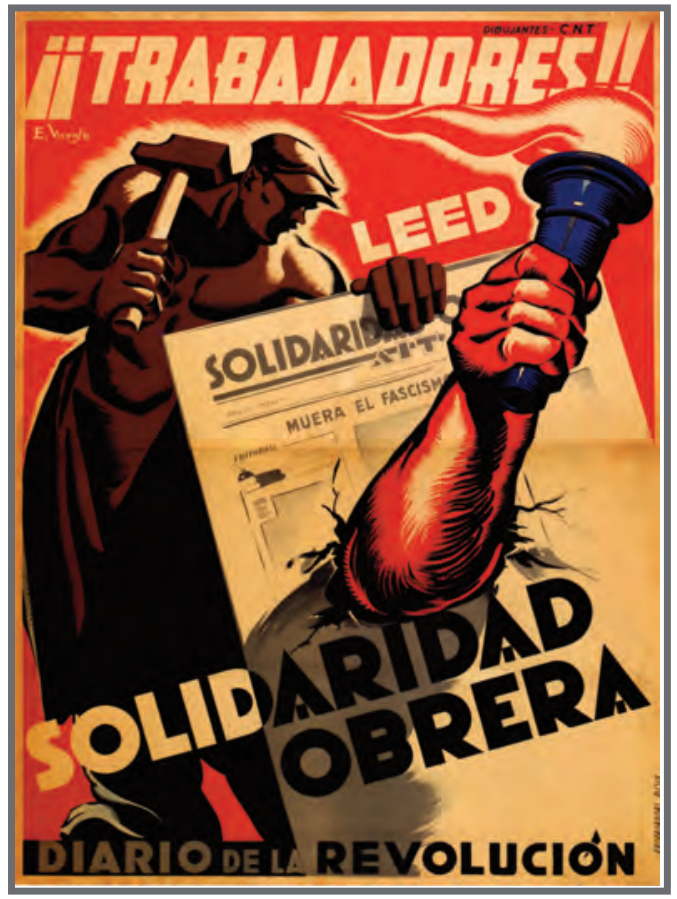

\section{VARIABLES EXTERNAS.}

Título: Solidaridad Obrera. Diario de la Revolución.

Año: 1936

Tamaño: $140 \times 100 \mathrm{~cm}$.

\section{TIPO DE IMAGEN.}

Retrato: NO

Cartel: NO

Mural: NO

Ilustración: SI

Otras Obras: NO

\section{CONTENIDO.}

Personajes: HOMBRE

Animales: NO

Gestos Expresivos: EMOCIONES POSITIVAS

Paisajes: NO

Escenas: GUERRA

Función: PROPAGANDÍSTICA (IDEOLOGÍA POLÍTICA)

\section{ASPECTOS TÉCNICOS.}

Color dominante: 3 TINTAS

Técnica: LITOGRAFÍA

Plano de la imagen: GENERAL Y DETALLE 


\section{VARIABLES EXTERNAS.}

Título: 20 noviembre 1936-1937

Año: 1937

Tamaño: $110 \times 77 \mathrm{~cm}$.

\section{TIPO DE IMAGEN.}

Retrato: NO

Cartel: NO

Mural: NO

Ilustración: SI

Otras Obras: NO

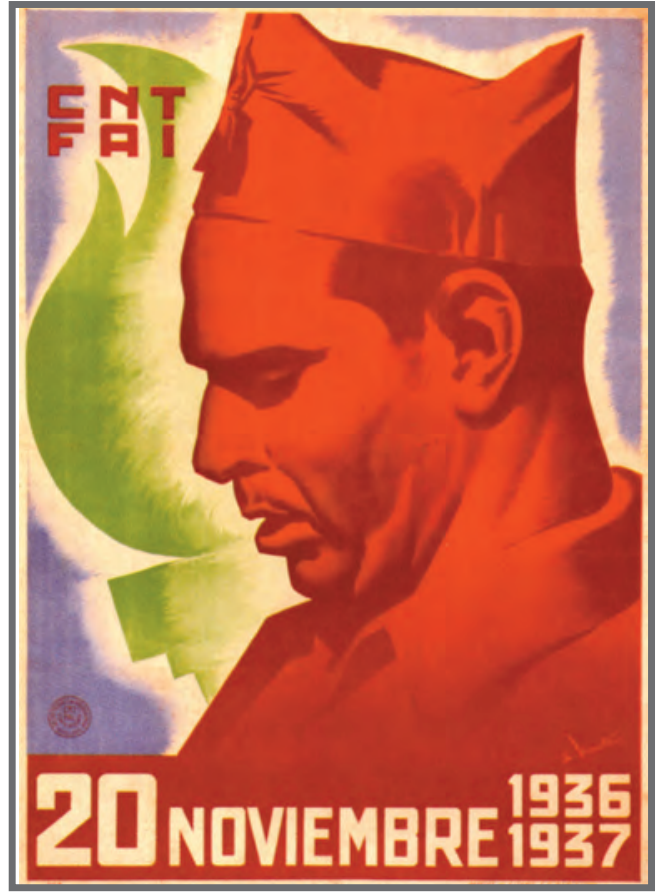

\section{CONTENIDO.}

Personajes: HOMBRE

Animales: NO

Gestos Expresivos: EMOCIONES POSITIVAS

Paisajes: NO

Escenas: GUERRA

Función: PROPAGANDÍSTICA (IDEOLOGÍA POLÍTICA)

\section{ASPECTOS TÉCNICOS.}

Color dominante: 3 TINTAS

Técnica: LITOGRAFÍA

Plano de la imagen: PRIMER PLANO 


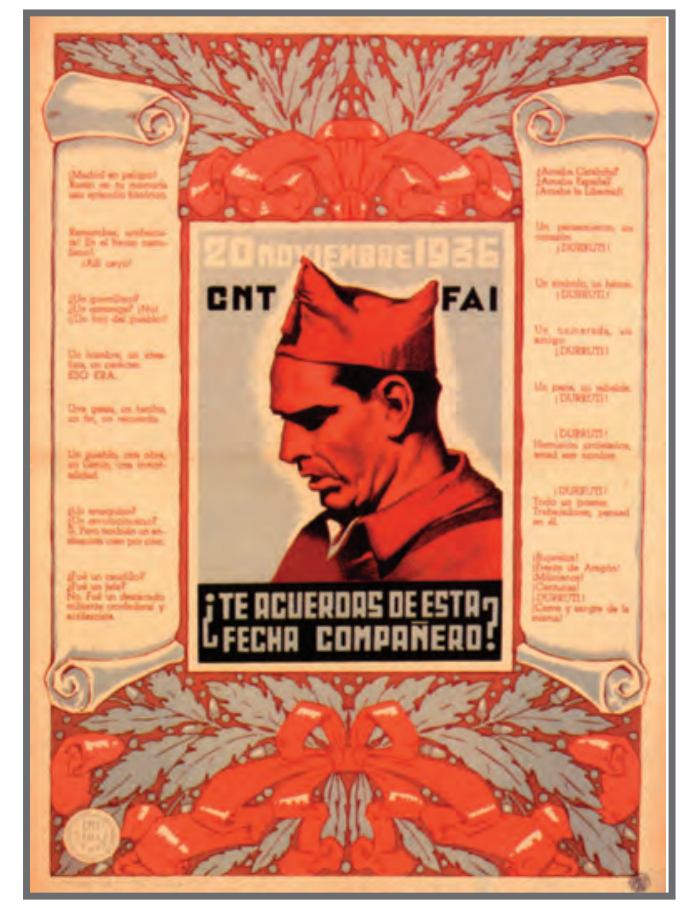

\section{VARIABLES EXTERNAS.}

Título: 20 noviembre 1936 ¿Te acuerdas de esa fecha compañero?

Año: 1937

Tamaño: $69 \times 48 \mathrm{~cm}$.

\section{TIPO DE IMAGEN.}

Retrato: NO

Cartel: NO

Mural: NO

Ilustración: SI

Otras Obras: NO

\section{CONTENIDO.}

Personajes: HOMBRE

Animales: NO

Gestos Expresivos: EMOCIONES POSITIVAS

Paisajes: NO

Escenas: GUERRA

Función: PROPAGANDÍSTICA (IDEOLOGÍA POLÍTICA)

\section{ASPECTOS TÉCNICOS.}

Color dominante: 3 TINTAS

Técnica: LITOGRAFÍA

Plano de la imagen: PRIMER PLANO 


\section{VARIABLES EXTERNAS.}

Título: Els caiguts et necessiten: ajuda al C.S.G.

Año: 1937

Tamaño: 65 × $45 \mathrm{~cm}$.

\section{TIPO DE IMAGEN.}

Retrato: NO

Cartel: NO

Mural: NO

Ilustración: SI

Otras Obras: NO

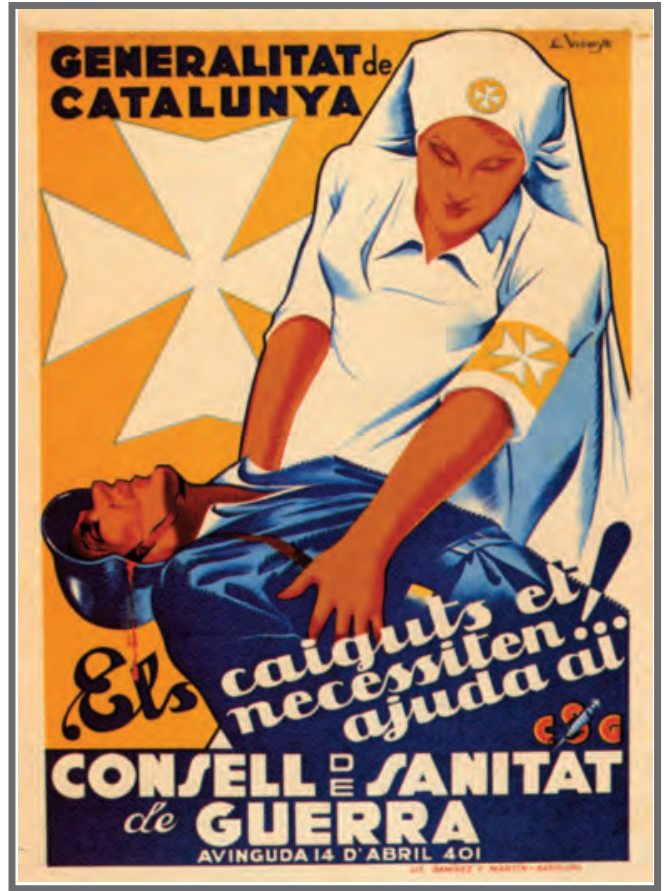

\section{CONTENIDO.}

Personajes: HOMBRE Y MUJER

Animales: NO

Gestos Expresivos: EMOCIONES POSITIVAS

Paisajes: NO

Escenas: GUERRA

Función: PROPAGANDÍSTICA (IDEOLOGÍA POLÍTICA)

\section{ASPECTOS TÉCNICOS.}

Color dominante: CUATRICROMÍA

Técnica: LITOGRAFÍA

Plano de la imagen: AMERICANO 


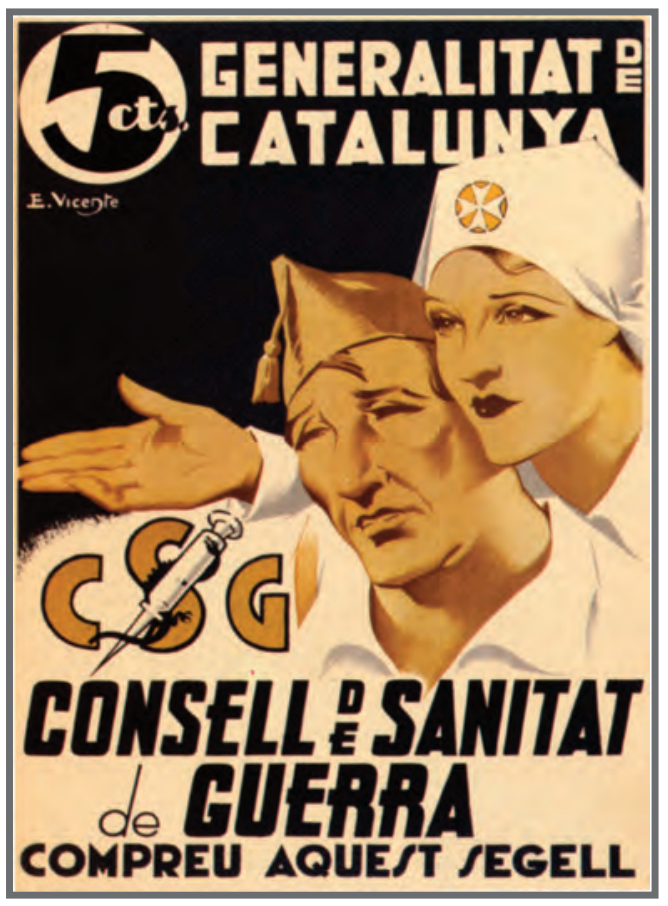

\section{VARIABLES EXTERNAS.}

Título: Compreu aquest segell

Año: 1937

Tamaño: $49 \times 34 \mathrm{~cm}$.

TIPO DE IMAGEN.

Retrato: NO

Cartel: NO

Mural: NO

Ilustración: SI

Otras Obras: NO

\section{CONTENIDO.}

Personajes: HOMBRE Y MUJER

Animales: NO

Gestos Expresivos: EMOCIONES POSITIVAS

Paisajes: NO

Escenas: GUERRA

Función: PROPAGANDÍSTICA (IDEOLOGÍA POLÍTICA)

\section{ASPECTOS TÉCNICOS.}

Color dominante: 3 TINTAS

Técnica: LITOGRAFÍA

Plano de la imagen: PRIMER PLANO 


\section{VARIABLES EXTERNAS.}

Título: Solidaridad internacional antifascista

Año: 1937

Tamaño: 49 × $34 \mathrm{~cm}$.

\section{TIPO DE IMAGEN.}

Retrato: NO

Cartel: NO

Mural: NO

Ilustración: SI

Otras Obras: NO

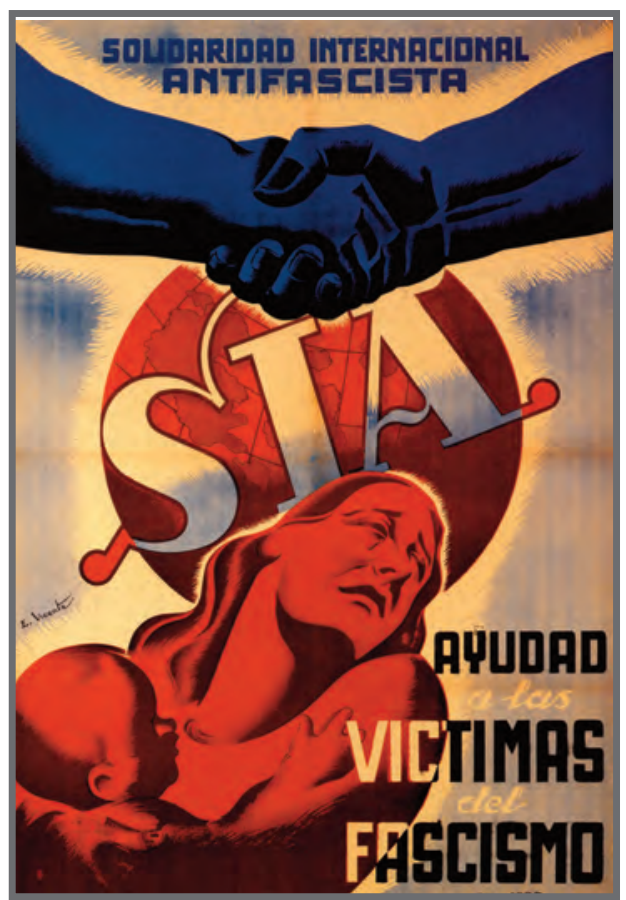

\section{CONTENIDO.}

Personajes: MUJER Y NIÑO

Animales: NO

Gestos Expresivos: EMOCIONES NEGATIVAS

Paisajes: NO

Escenas: GUERRA

Función: PROPAGANDÍSTICA (IDEOLOGÍA POLÍTICA)

\section{ASPECTOS TÉCNICOS.}

Color dominante: 3 TINTAS

Técnica: LITOGRAFÍA

Plano de la imagen: MEDIO CORTO Y DETALLE 


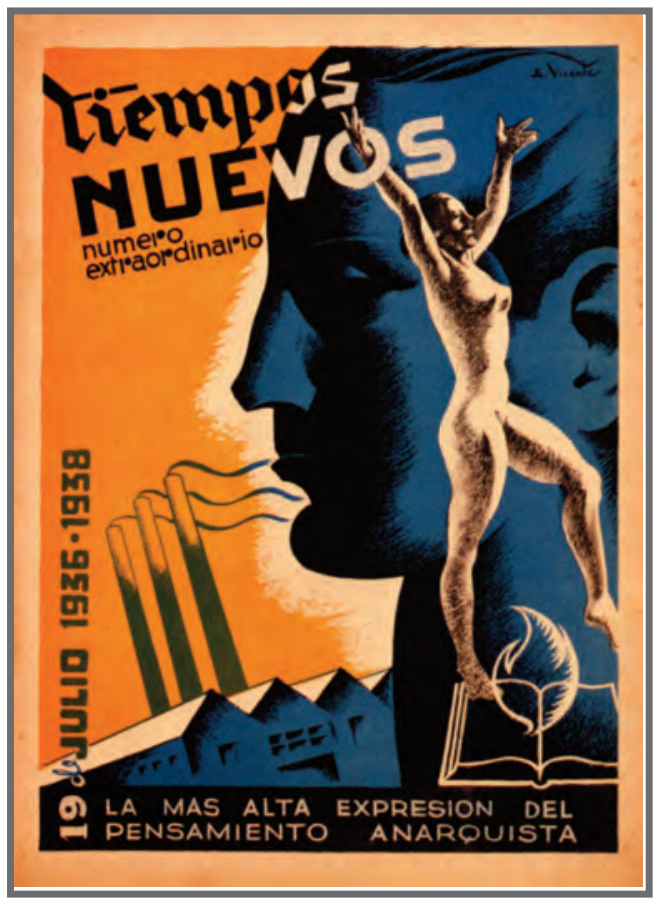

\section{VARIABLES EXTERNAS.}

Título: Tiempo nuevos

Año: 1938

Tamaño: 52 x $38 \mathrm{~cm}$.

\section{TIPO DE IMAGEN.}

Retrato: NO

Cartel: NO

Mural: NO

Ilustración: SI

Otras Obras: NO

\section{CONTENIDO.}

Personajes: MUJERES

Animales: NO

Gestos Expresivos: EMOCIONES POSITIVAS

Paisajes: SI

Escenas: URBANO

Función: PROPAGANDÍSTICA (IDEOLOGÍA POLÍTICA)

\section{ASPECTOS TÉCNICOS.}

Color dominante: 3 TINTAS

Técnica: LITOGRAFÍA

Plano de la imagen: GENERAL Y PRIMER PLANO 


\section{VARIABLES EXTERNAS.}

Título: Pro-Campaña de invierno para ropas de abrigo de nuestros combatientes

Año: 1938

Tamaño: DESCONOCIDO

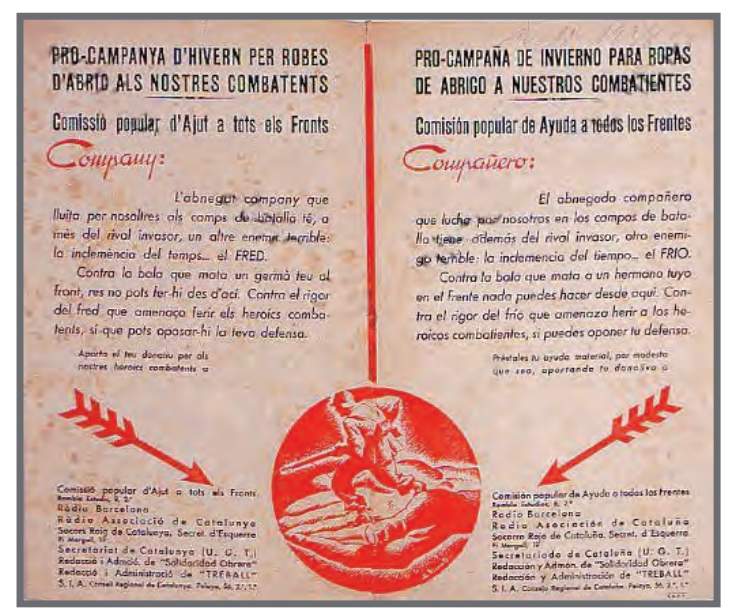

\section{TIPO DE IMAGEN.}

Retrato: NO

Cartel: NO

Mural: NO

Ilustración: SI

Otras Obras: NO

\section{CONTENIDO.}

Personajes: HOMBRE

Animales: NO

Gestos Expresivos: EMOCIONES POSITIVAS

Paisajes: NO

Escenas: GUERRA

Función: PROPAGANDÍSTICA (IDEOLOGÍA POLÍTICA)

\section{ASPECTOS TÉCNICOS.}

Color dominante: 2 TINTAS

Técnica: LITOGRAFÍA

Plano de la imagen: GENERAL 


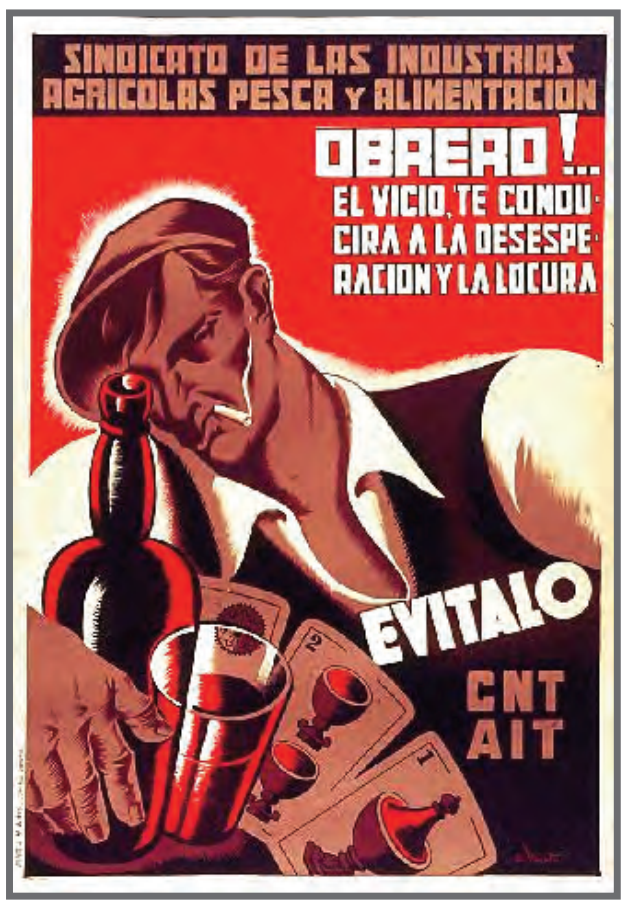

\section{VARIABLES EXTERNAS.}

Título: Obrero! El vicio te conducirá a la desesperación y a la locura: evítalo

Año: 1938

Tamaño: $100 \times 70 \mathrm{~cm}$.

\section{TIPO DE IMAGEN.}

Retrato: NO

Cartel: NO

Mural: NO

Ilustración: SI

Otras Obras: NO

\section{CONTENIDO.}

Personajes: HOMBRE

Animales: NO

Gestos Expresivos: EMOCIONES NEGATIVAS

Paisajes: NO

Escenas: INTERIOR

Función: REPRESENTATIVA DE MODELOS SOCIALES

\section{ASPECTOS TÉCNICOS.}

Color dominante: 3 TINTAS

Técnica: LITOGRAFÍA

Plano de la imagen: MEDIO CORTO 


\section{VARIABLES EXTERNAS.}

Título: Semana de México

Año: 1938

Tamaño: DESCONOCIDO

\section{TIPO DE IMAGEN.}

Retrato: NO

Cartel: NO

Mural: NO

Ilustración: SI

Otras Obras: NO

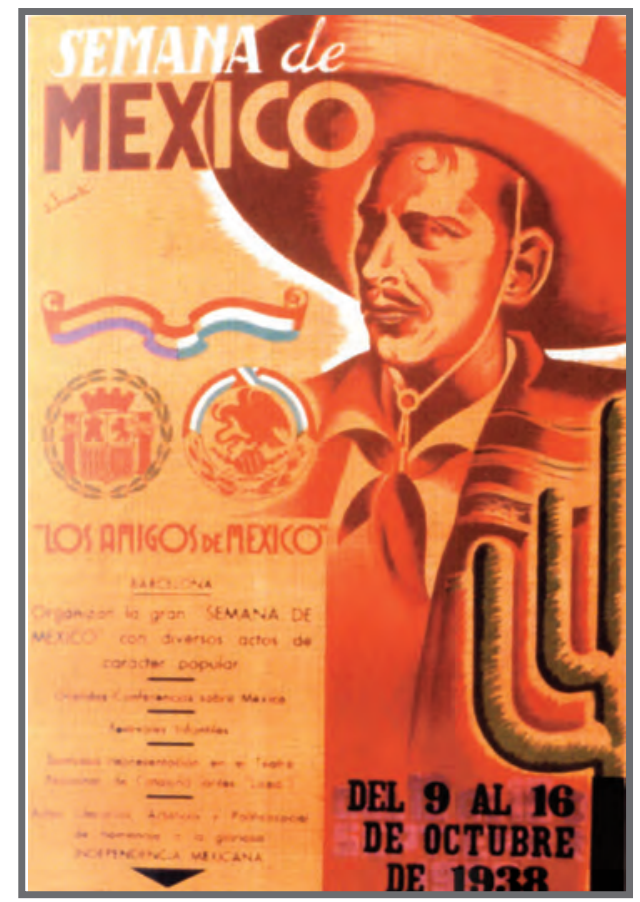

\section{CONTENIDO.}

Personajes: HOMBRE

Animales: NO

Gestos Expresivos: EMOCIONES POSITIVAS

Paisajes: NO

Escenas: FESTIVA

Función: REPRESENTATIVA DE MODELOS SOCIALES

\section{ASPECTOS TÉCNICOS.}

Color dominante: CUATRICROMIA

Técnica: LITOGRAFÍA

Plano de la imagen: MEDIO CORTO 



\section{] [I Murales}

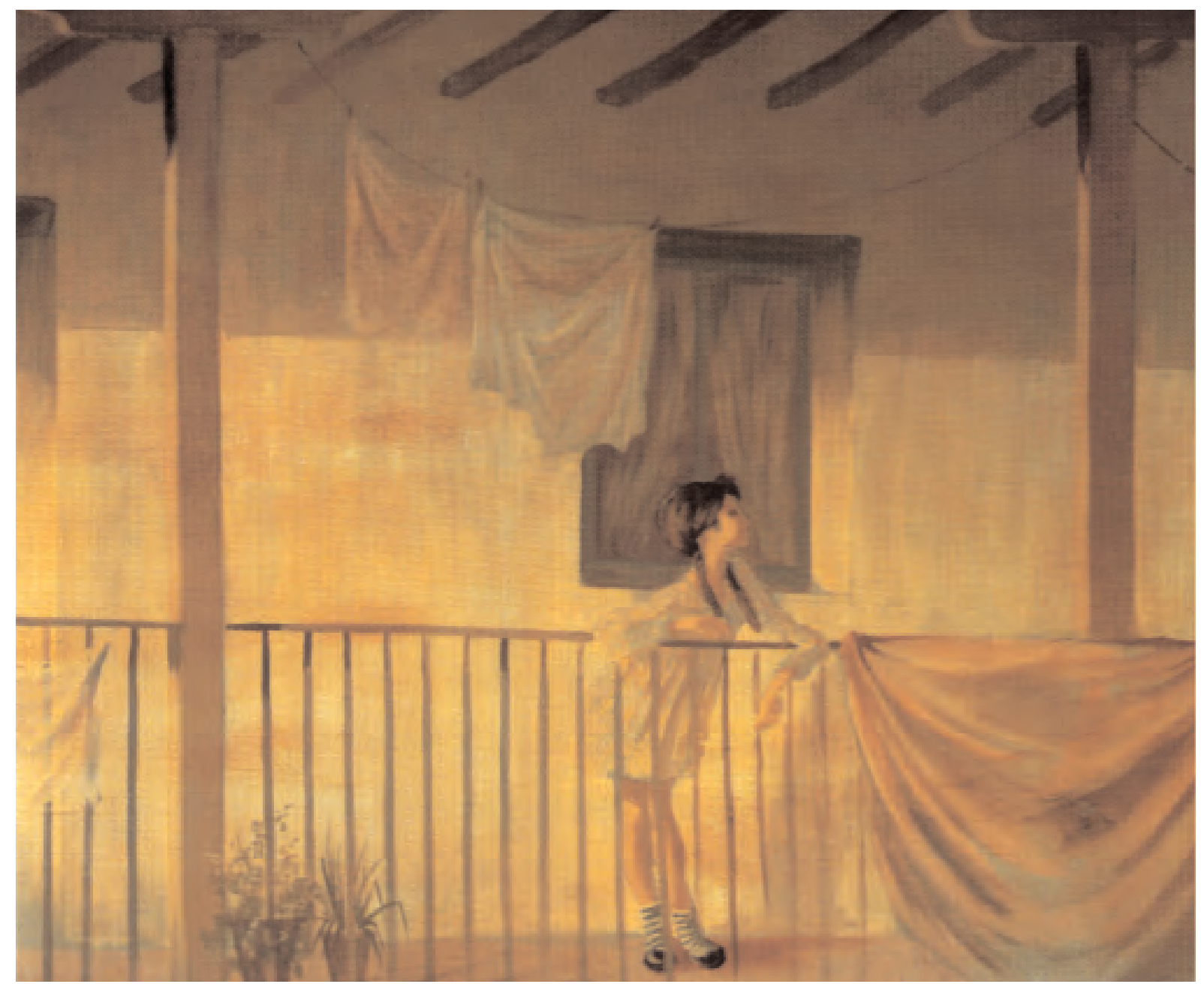

Afueras de Madrid. 1955. Madrid. Acuarela sobre papel. Colección particular. Eduardo Vicente 



\section{VARIABLES EXTERNAS.}

Título: Catedral de Orihuela. Bautismo de Cristo

Año: 1944

\section{TIPO DE IMAGEN.}

Retrato: NO

Cartel: NO

Mural: SI

Ilustración: NO

Otras Obras: NO

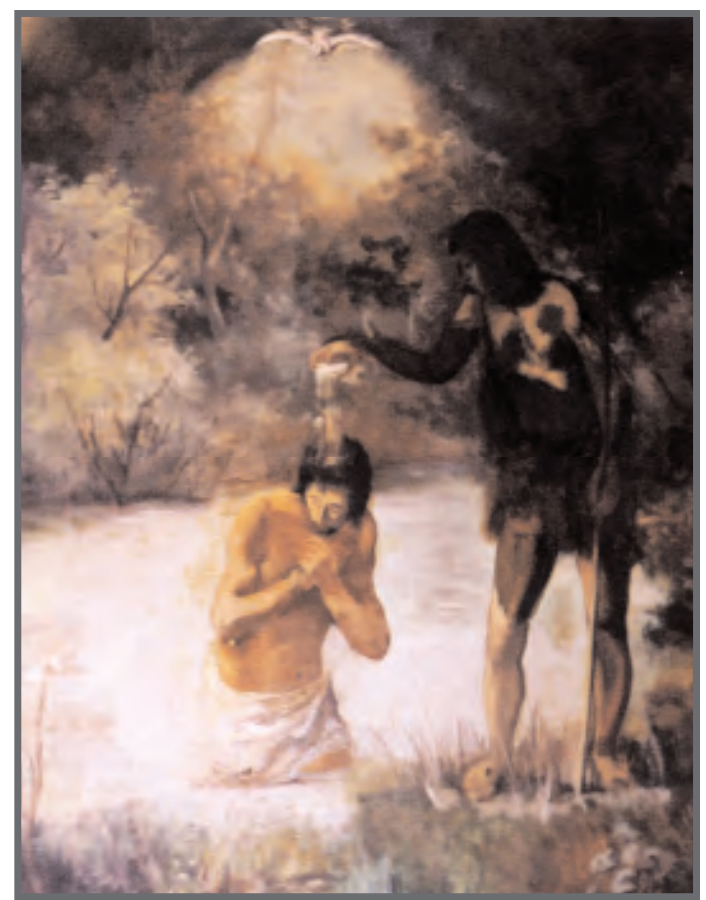

\section{CONTENIDO.}

Personajes: HOMBRES

Animales: NO

Gestos Expresivos: EMOCIONES POSITIVAS

Paisajes: si

Escenas: RELIOGIOSA

Función: PROPAGANDÍSTICA (IDEOLOGÍA RELIGIOSA)

\section{ASPECTOS TÉCNICOS.}

Color dominante: VARIEDAD CROMÁTICA SUPERIOR

Técnica: FRESCO

Plano de la imagen: GENERAL 


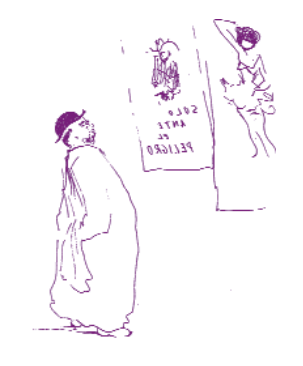

\section{VARIABLES EXTERNAS.}

Título: Restaurante El Schotis (Madrid)

Año: 1950

\section{TIPO DE IMAGEN.}

Retrato: NO

Cartel: NO

Mural: SI

Ilustración: NO

Otras Obras: NO

\section{CONTENIDO.}

Personajes: HOMBRES Y MUJERES

Animales: NO

Gestos Expresivos: EMOCIONES POSITIVAS

Paisajes: SI

Escenas: FESTIVAS Y CALLEJERAS

Función: REPRESENTATIVA DE MODELOS SOCIALES

\section{ASPECTOS TÉCNICOS.}

Color dominante: VARIEDAD CROMÁTICA SUPERIOR Técnica: FRESCO

Plano de la imagen: GENERAL 


\section{VARIABLES EXTERNAS.}

Título: Salón de Juntas de la empresa V.E.R.S.

Año: 1952

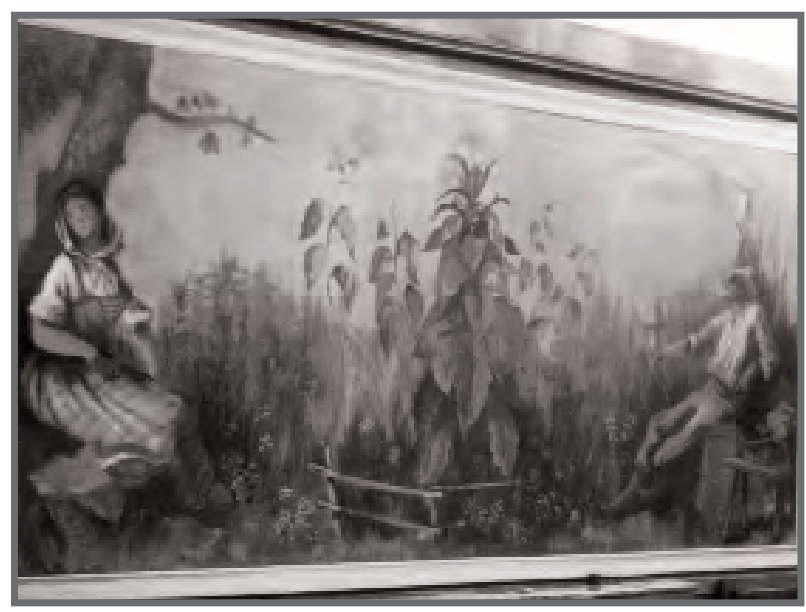

TIPO DE IMAGEN.

Retrato: NO

Cartel: NO

Mural: SI

Ilustración: NO

Otras Obras: NO

\section{CONTENIDO.}

Personajes: HOMBRE Y MUJER

Animales: NO

Gestos Expresivos: EMOCIONES POSITIVAS

Paisajes: SI

Escenas: RURAL

Función: REPRESENTATIVA DE MODELOS SOCIALES

\section{ASPECTOS TÉCNICOS.}

Color dominante: VARIEDAD CROMÁTICA SUPERIOR

Técnica: FRESCO

Plano de la imagen: GENERAL 

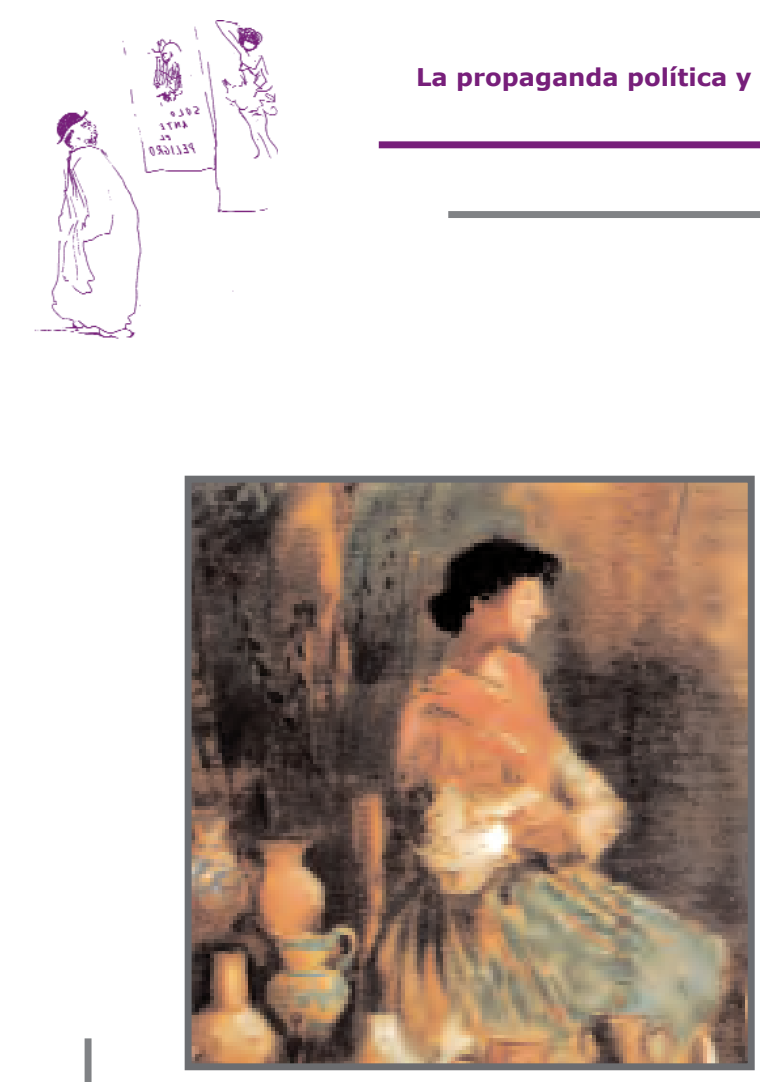

\section{VARIABLES EXTERNAS.}

Título: Hotel Emperatriz

(Madrid)

Año: 1953

\section{TIPO DE IMAGEN.}

Retrato: NO

Cartel: NO

Mural: SI

Ilustración: NO

Otras Obras: NO

\section{CONTENIDO.}

Personajes: HOMBRES Y MUJERES

Animales: NO

Gestos Expresivos: EMOCIONES POSITIVAS

Paisajes: NO

Escenas: FESTIVAS, CALLEJERAS Y PROFESIONALES

Función: REPRESENTATIVA DE MODELOS SOCIALES

\section{ASPECTOS TÉCNICOS.}

Color dominante: VARIEDAD CROMÁTICA SUPERIOR Técnica: FRESCO

Plano de la imagen: GENERAL 


\section{VARIABLES EXTERNAS.}

Título: Hotel Sirenas (Segovia)

Año: 1953

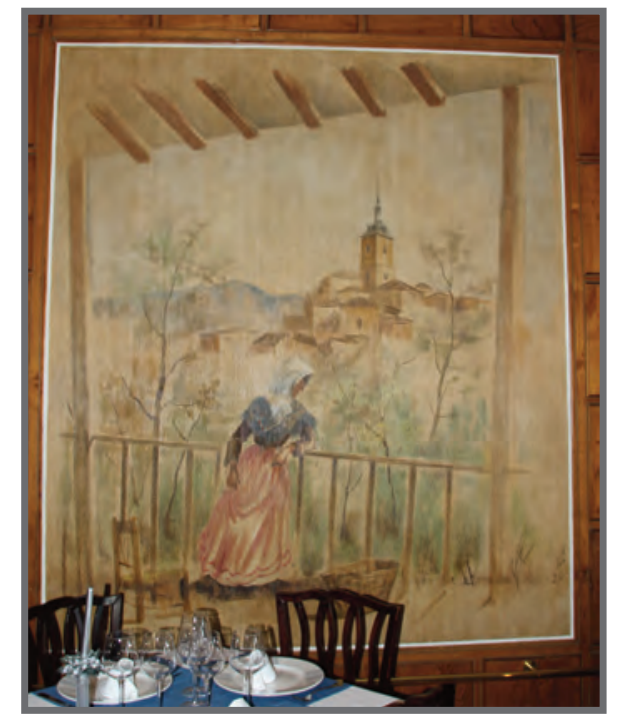

TIPO DE IMAGEN.

Retrato: NO

Cartel: NO

Mural: SI

Ilustración: NO

Otras Obras: NO

\section{CONTENIDO.}

Personajes: HOMBRES Y MUJERES

Animales: SI

Gestos Expresivos: EMOCIONES POSITIVAS

Paisajes: SI

Escenas: PROFESIONALES

Función: REPRESENTATIVA DE MODELOS SOCIALES

ASPECTOS TÉCNICOS.

Color dominante: VARIEDAD CROMÁTICA SUPERIOR

Técnica: FRESCO

Plano de la imagen: GENERAL 

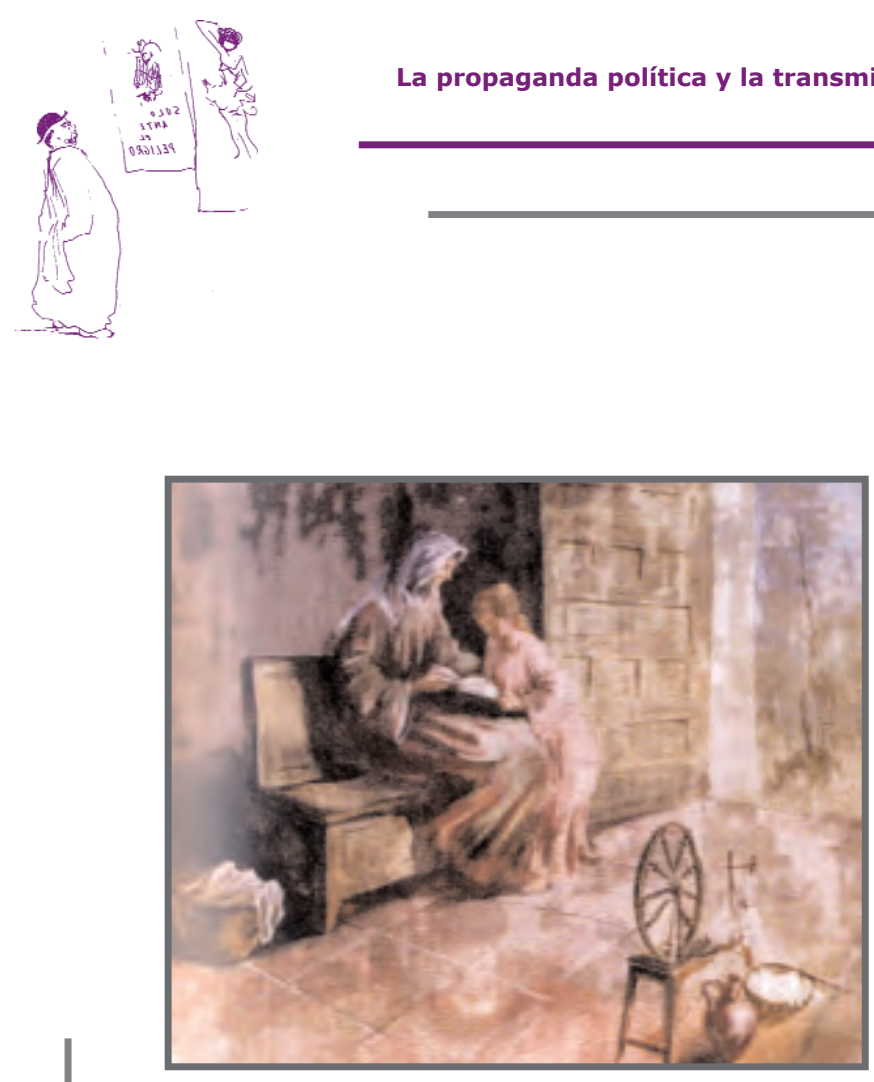

\section{VARIABLES EXTERNAS.}

Título: Iglesia de Navacerrada. Infancia de Cristo

Año: 1954

\section{TIPO DE IMAGEN.}

Retrato: NO

Cartel: NO

Mural: SI

Ilustración: NO

Otras Obras: NO

\section{CONTENIDO.}

Personajes: MUJER Y NIÑO

Animales: NO

Gestos Expresivos: EMOCIONES POSITIVAS

Paisajes: NO

Escenas: RELIGIOSAS

Función: PROPAGANDÍSTICA (IDEOLOGÍA RELIGIOSA)

\section{ASPECTOS TÉCNICOS.}

Color dominante: VARIEDAD CROMÁTICA SUPERIOR Técnica: FRESCO

Plano de la imagen: GENERAL 


\section{VARIABLES EXTERNAS.}

Título: Delegación de Hacienda de Salamanca

Año: 1957

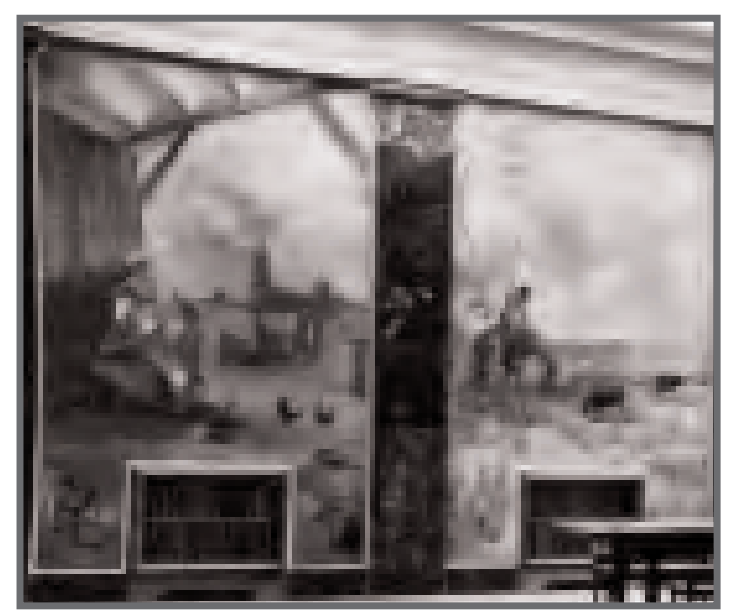

TIPO DE IMAGEN.

Retrato: NO

Cartel: NO

Mural: SI

Ilustración: NO

Otras Obras: NO

\section{CONTENIDO.}

Personajes: HOMBRES Y MUJERES

Animales: SI

Gestos Expresivos: EMOCIONES POSITIVAS

Paisajes: SI

Escenas: RURAL

Función: REPRESENTATIVA DE MODELOS SOCIALES

\section{ASPECTOS TÉCNICOS.}

Color dominante: VARIEDAD CROMÁTICA SUPERIOR

Técnica: FRESCO

Plano de la imagen: GENERAL 

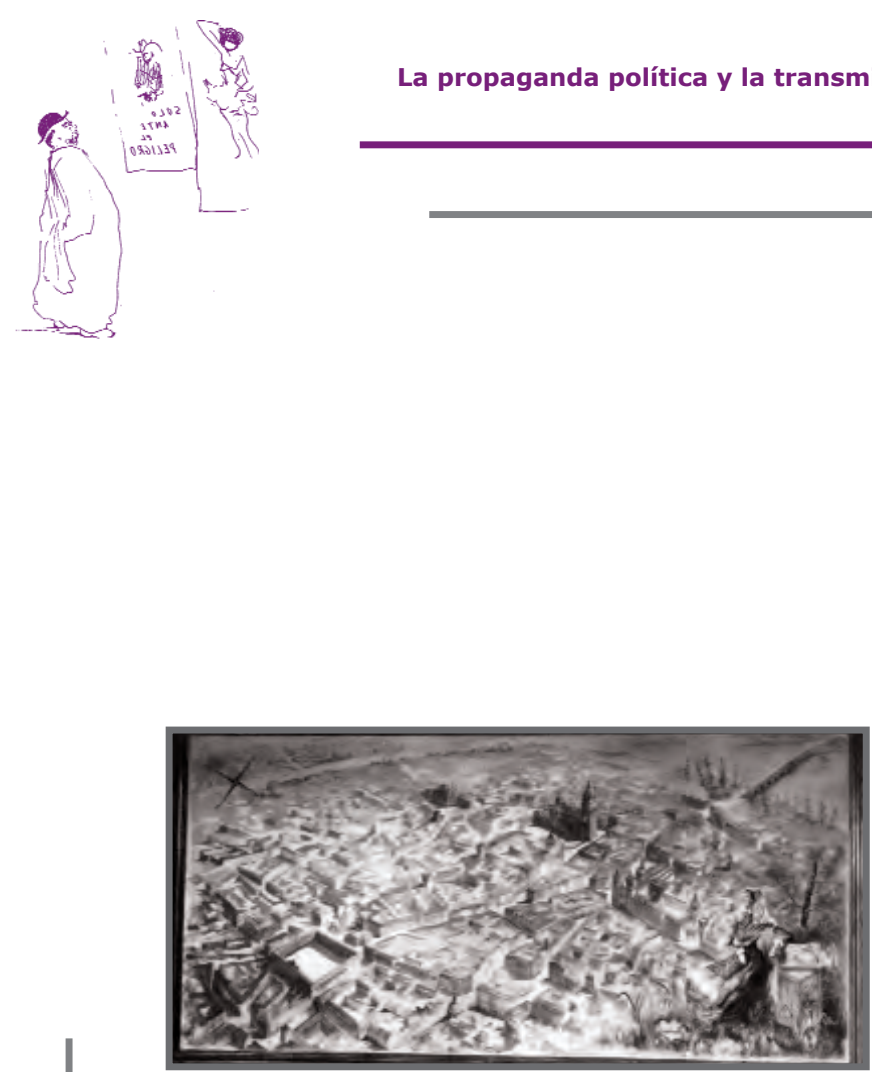

\section{VARIABLES EXTERNAS.}

Título: Ccámara de la Propiedad Urbana (Salamanca).

Vista aérea de Salamanca

Año: 1957

\section{TIPO DE IMAGEN.}

Retrato: NO

Cartel: NO

Mural: SI

Ilustración: NO

Otras Obras: NO

\section{CONTENIDO.}

Personajes: NO

Animales: NO

Gestos Expresivos: NO

Paisajes: SI

Escenas: PAISAJE AÉREO

Función: REPRESENTATIVA DE MODELOS SOCIALES

\section{ASPECTOS TÉCNICOS.}

Color dominante: VARIEDAD CROMÁTICA SUPERIOR Técnica: FRESCO

Plano de la imagen: GENERAL 


\section{VARIABLES EXTERNAS.}

Título: Café Riesgo (Madrid)

Año: 1957

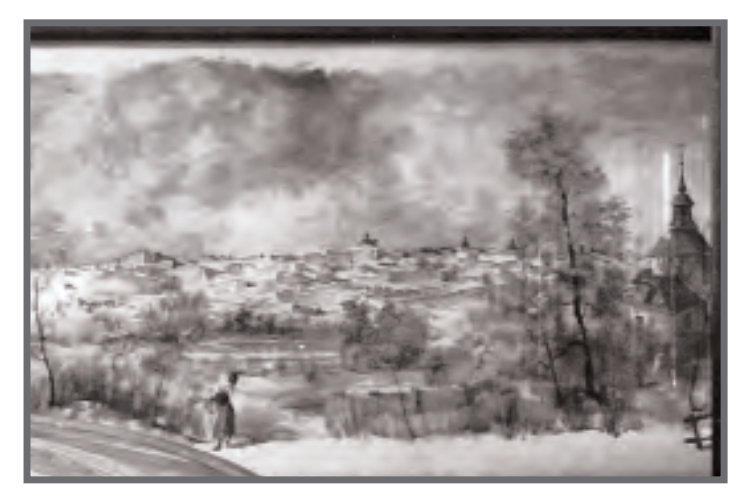

TIPO DE IMAGEN.

Retrato: NO

Cartel: NO

Mural: SI

Ilustración: NO

Otras Obras: NO

\section{CONTENIDO.}

Personajes: HOMBRES Y MUJERES

Animales: NO

Gestos Expresivos: NO

Paisajes: SI

Escenas: RURAL

Función: REPRESENTATIVA DE MODELOS SOCIALES

\section{ASPECTOS TÉCNICOS.}

Color dominante: VARIEDAD CROMÁTICA SUPERIOR

Técnica: FRESCO

Plano de la imagen: GENERAL 


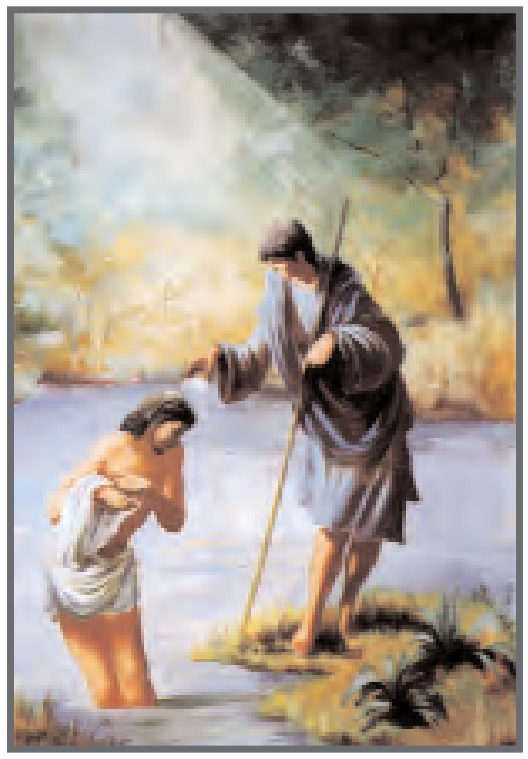

\section{VARIABLES EXTERNAS.}

Título: Iglesia de la Encarnación del Señor. Bautismo de Cristo

Año: 1960-1961

\section{TIPO DE IMAGEN.}

Retrato: NO

Cartel: NO

Mural: SI

Ilustración: NO

Otras Obras: NO

\section{CONTENIDO.}

Personajes: HOMBRES

Animales: NO

Gestos Expresivos: EMOCIONES POSITIVAS

Paisajes: SI

Escenas: RELIOGIOSA

Función: PROPAGANDÍSTICA (IDEOLOGÍA RELIGIOSA)

\section{ASPECTOS TÉCNICOS.}

Color dominante: VARIEDAD CROMÁTICA SUPERIOR

Técnica: FRESCO

Plano de la imagen: GENERAL 


\section{VARIABLES EXTERNAS.}

Título: Cafetería California (Madrid)

Año: 1960-1965

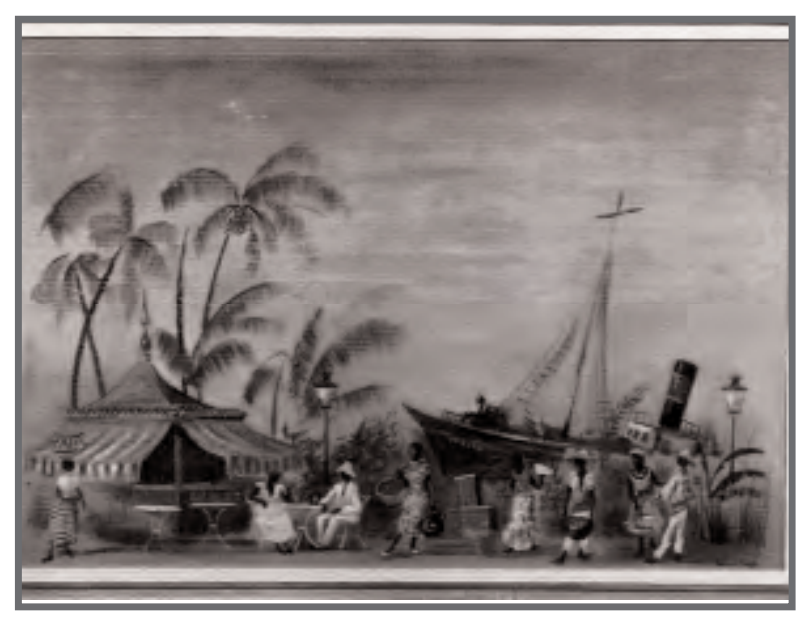

\section{TIPO DE IMAGEN.}

Retrato: NO

Cartel: NO

Mural: SI

Ilustración: NO

Otras Obras: NO

\section{CONTENIDO.}

Personajes: HOMBRES Y MUJERES

Animales: NO

Gestos Expresivos: EMOCIONES POSITIVAS

Paisajes: SI

Escenas: RURAL

Función: REPRESENTATIVA DE MODELOS SOCIALES

\section{ASPECTOS TÉCNICOS.}

Color dominante: VARIEDAD CROMÁTICA SUPERIOR

Técnica: FRESCO

Plano de la imagen: GENERAL 

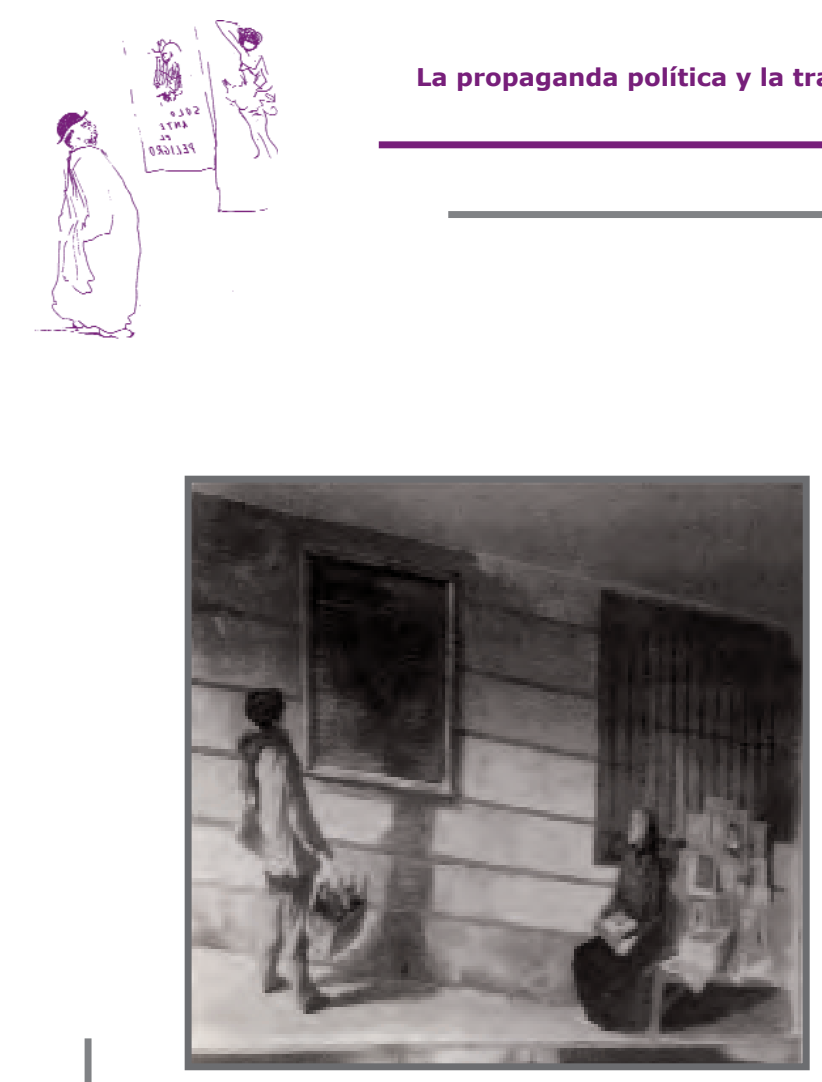

\section{VARIABLES EXTERNAS.}

Título: Antiguo Banco de Urquijo (Madrid)

Año: 1965

\section{TIPO DE IMAGEN.}

Retrato: NO

Cartel: NO

Mural: SI

Ilustración: NO

Otras Obras: NO

\section{CONTENIDO.}

Personajes: HOMBRE Y MUJER

Animales: NO

Gestos Expresivos: EMOCIONES POSITIVAS

Paisajes: NO

Escenas: CALLEJERA

Función: REPRESENTATIVA DE MODELOS SOCIALES

ASPECTOS TÉCNICOS.

Color dominante: VARIEDAD CROMÁTICA SUPERIOR Técnica: FRESCO

Plano de la imagen: GENERAL 


\section{VARIABLES EXTERNAS.}

Título: Iglesia de Brihuega

(Guadalajara)

Año: 1965

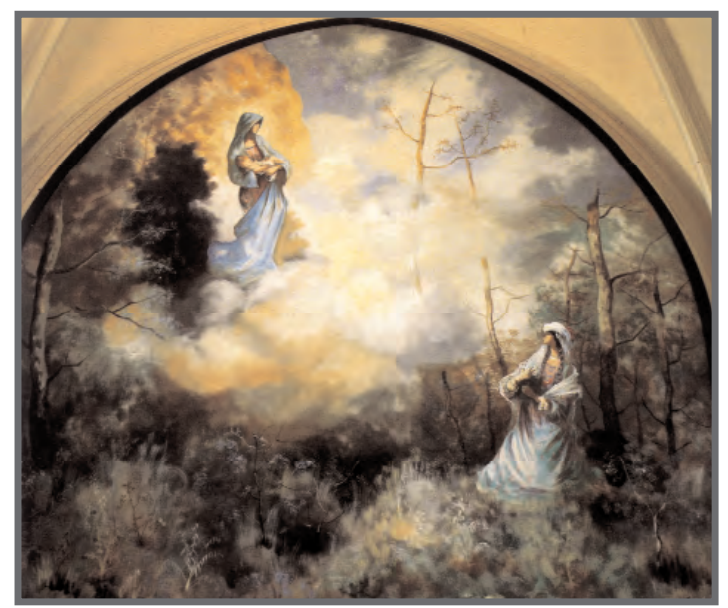

\section{TIPO DE IMAGEN.}

Retrato: NO

Cartel: NO

Mural: SI

Ilustración: NO

Otras Obras: NO

\section{CONTENIDO.}

Personajes: MUJERES

Animales: NO

Gestos Expresivos: EMOCIONES POSITIVAS

Paisajes: SI

Escenas: RELIOGIOSAS

Función: PROPAGANDÍSTICA (IDEOLOGÍA RELIGIOSA)

\section{ASPECTOS TÉCNICOS.}

Color dominante: VARIEDAD CROMÁTICA SUPERIOR

Técnica: FRESCO

Plano de la imagen: GENERAL 

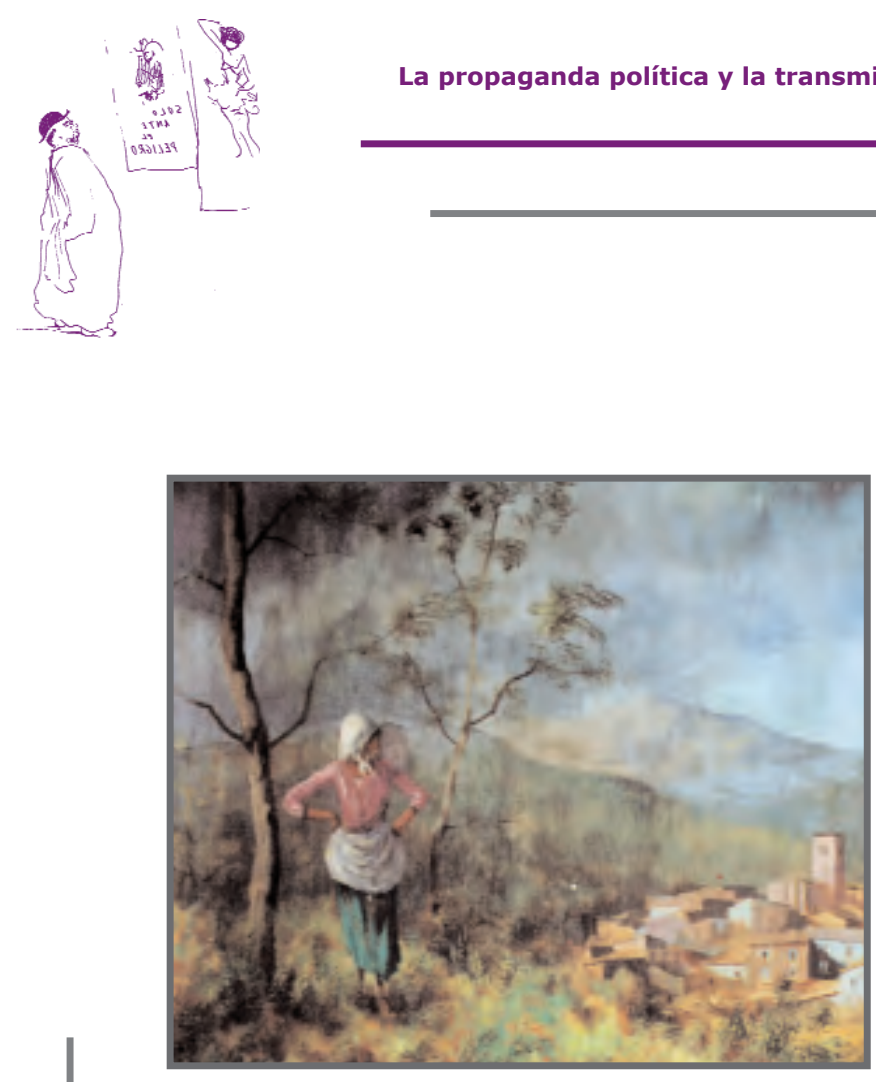

\section{VARIABLES EXTERNAS.}

Título: Portal de la calle Segre (Madrid)

Año: 1967

\section{TIPO DE IMAGEN.}

Retrato: NO

Cartel: NO

Mural: SI

Ilustración: NO

Otras Obras: NO

\section{CONTENIDO.}

Personajes: MUJER

Animales: NO

Gestos Expresivos: EMOCIONES POSITIVAS

Paisajes: SI

Escenas: RURAL

Función: REPRESENTATIVA DE MODELOS SOCIALES

ASPECTOS TÉCNICOS.

Color dominante: VARIEDAD CROMÁTICA SUPERIOR Técnica: FRESCO

Plano de la imagen: GENERAL 


\section{VARIABLES EXTERNAS.}

Título: Antigua Fábrica de Perlofil

Año: DESCONOCIDO

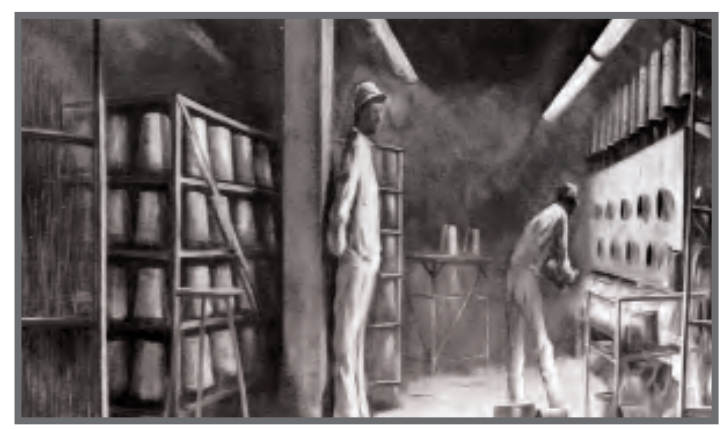

TIPO DE IMAGEN.

Retrato: NO

Cartel: NO

Mural: SI

Ilustración: NO

Otras Obras: NO

\section{CONTENIDO.}

Personajes: HOMBRES

Animales: NO

Gestos Expresivos: EMOCIONES POSITIVAS

Paisajes: NO

Escenas: PROFESIONAL

Función: REPRESENTATIVA DE MODELOS SOCIALES

\section{ASPECTOS TÉCNICOS.}

Color dominante: VARIEDAD CROMÁTICA SUPERIOR

Técnica: FRESCO

Plano de la imagen: GENERAL 



\section{[] Ilustraciones}

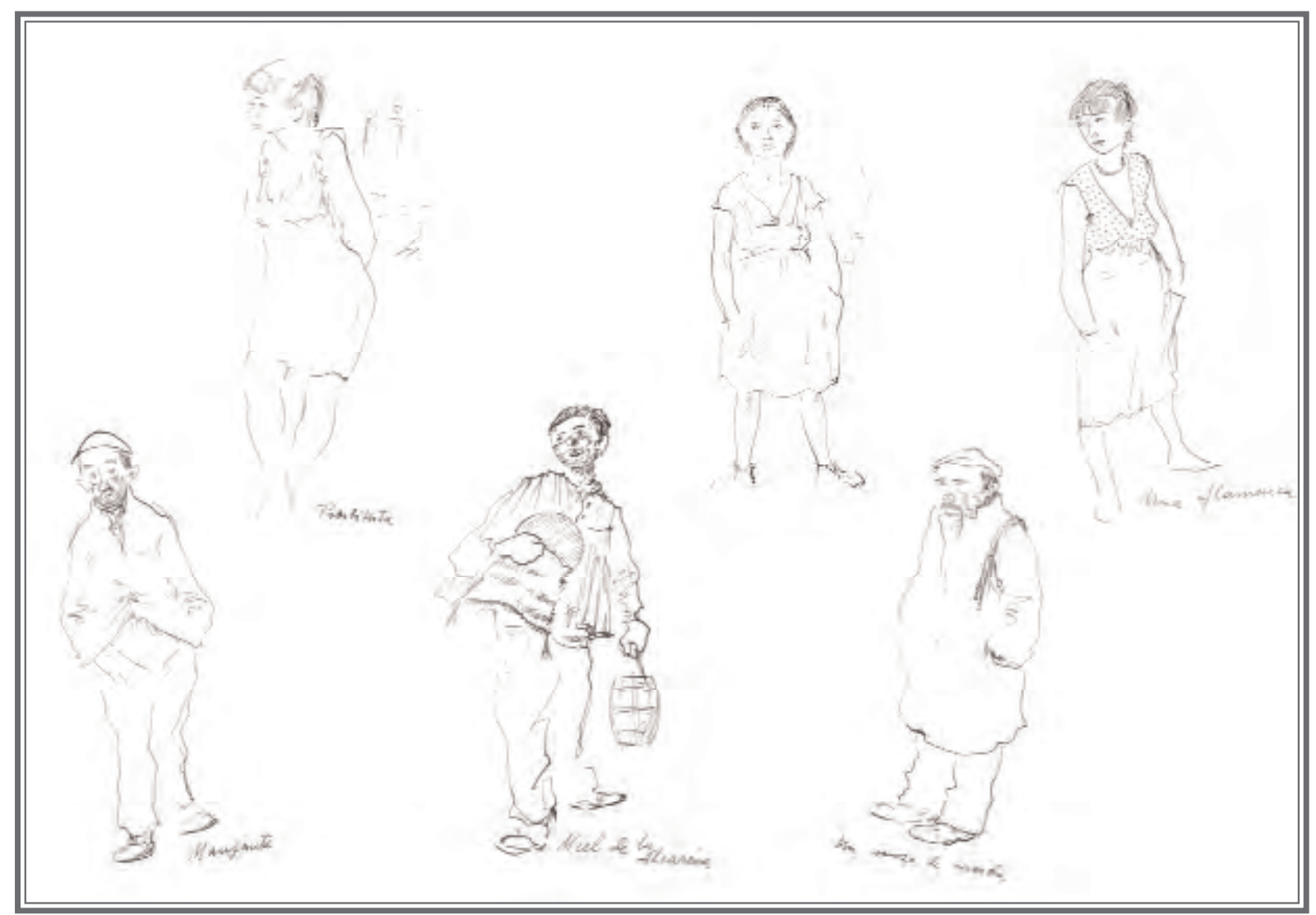

Afueras de Madrid. 1955. Madrid. Acuarela sobre papel. Colección particular. Eduardo Vicente 



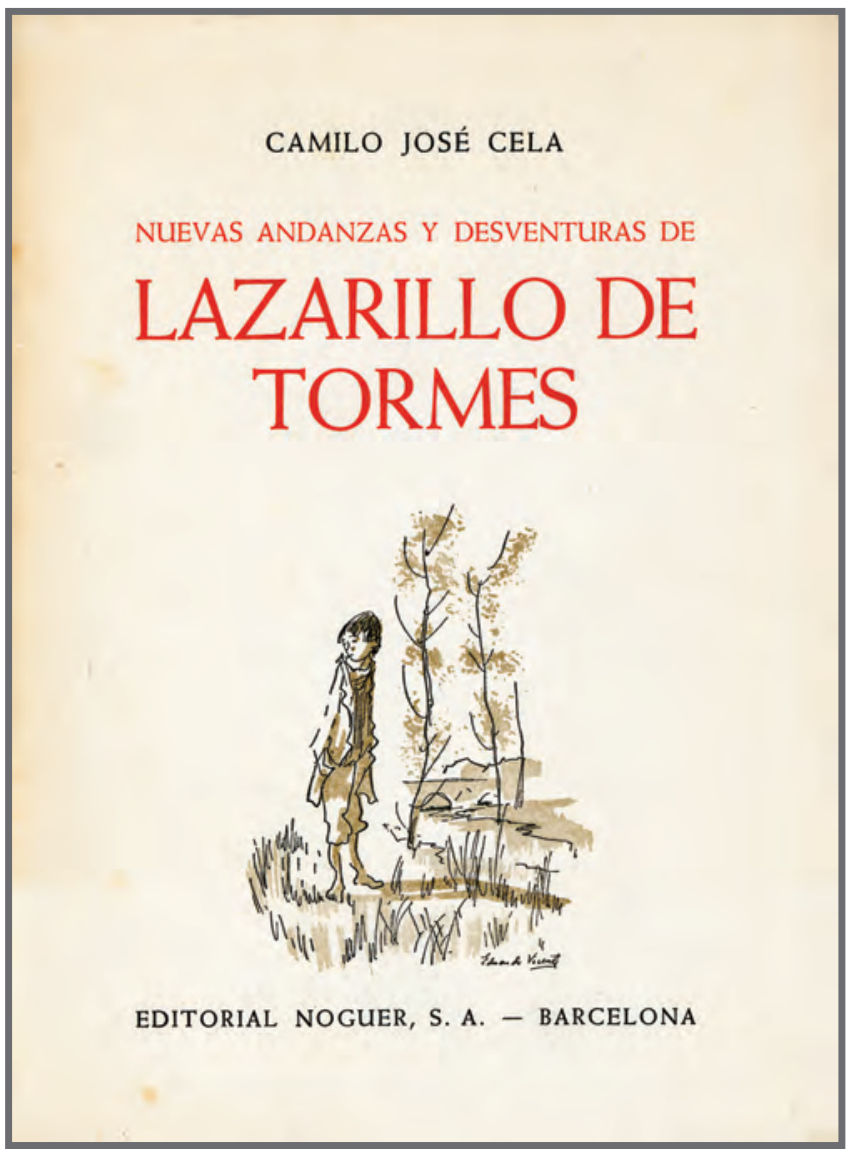

\section{FICHA TÉCNICA.}

Título: NUEVAS ANDANZAS Y DESVENTURAS DE LAZARILLLO DE TORMES Autor: CAMILO JOSÉ CELA

Editorial: NOGUER, S.A. - BARCELONA

Año: 1944

Tamaño: $19,5 \times 14,5 \mathrm{~cm}$.

Número de páginas: 239

Número de ilustraciones: 13 + (ILUSTRACIÓN EN PORTADA) 



\section{VARIABLES EXTERNAS.}

Título: Nuevas andanzas y desventuras de Lazarillo de Tormes (001)

Año: 1944

Página: PORTADA

\section{TIPO DE IMAGEN.}

Retrato: NO

Cartel: NO

Mural: NO

Ilustración: SI

Otras Obras: NO
CAMILO JOSÉ CELA

NUEVAS ANDANZAS Y DESVENTURAS DE

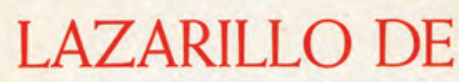
TORMES

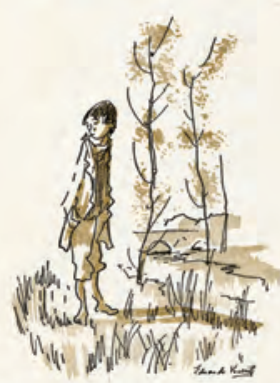

EDITORIAL NOGUER, S. A. - BARCELONA

\section{CONTENIDO.}

Personajes: NIÑO

Animales: NO

Gestos Expresivos: EMOCIONES POSITIVAS

Paisajes: SI

Escenas: RURAL

Función: REPRESENTATIVA DE MODELOS SOCIALES

\section{ASPECTOS TÉCNICOS.}

Color dominante: 2 TINTAS

Técnica: OFFSET

Plano de la imagen: GENERAL 


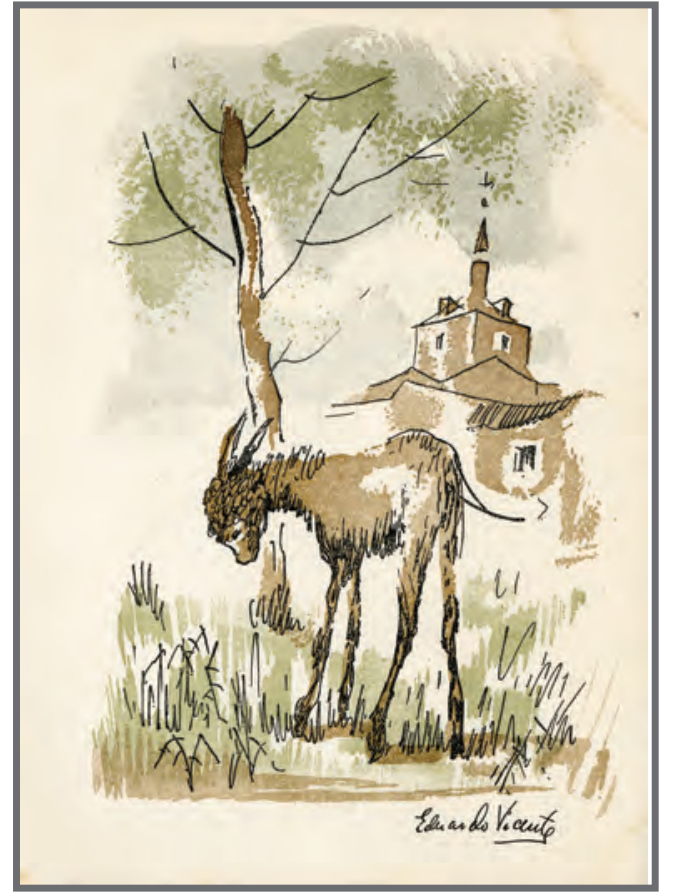

\section{VARIABLES EXTERNAS.}

Título: Nuevas andanzas y desventuras de Lazarillo de Tormes (002)

Año: 1944

Página: 4

\section{TIPO DE IMAGEN.}

Retrato: NO

Cartel: NO

Mural: NO

Ilustración: SI

Otras Obras: NO

\section{CONTENIDO.}

Personajes: NO

Animales: BURRO

Gestos Expresivos: NO

Paisajes: SI

Escenas: RURAL

Función: REPRESENTATIVA DE MODELOS SOCIALES

\section{ASPECTOS TÉCNICOS.}

Color dominante: 3 TINTAS

Técnica: OFFSET

Plano de la imagen: GENERAL 


\section{VARIABLES EXTERNAS.}

Título: Nuevas andanzas y desventuras de Lazarillo de Tormes (003)

Año: 1944

Página: 25

\section{TIPO DE IMAGEN.}

Retrato: NO

Cartel: NO

Mural: NO

Ilustración: SI

Otras Obras: NO

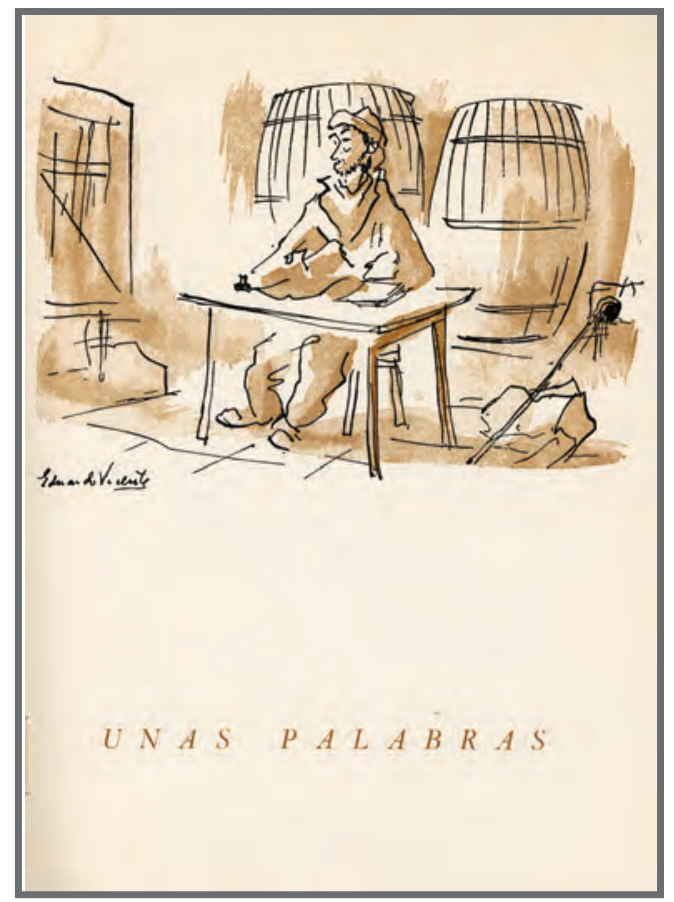

\section{CONTENIDO.}

Personajes: HOMBRE

Animales: NO

Gestos Expresivos: EMOCIONES POSITIVAS

Paisajes: NO

Escenas: INTERIOR

Función: REPRESENTATIVA DE MODELOS SOCIALES

\section{ASPECTOS TÉCNICOS.}

Color dominante: 2 TINTAS

Técnica: OFFSET

Plano de la imagen: GENERAL 


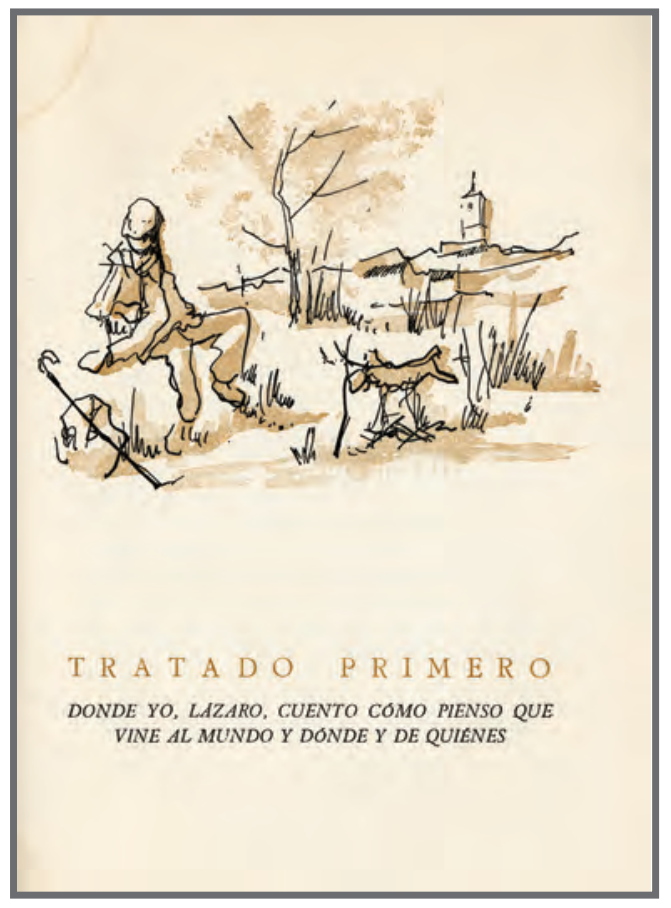

\section{VARIABLES EXTERNAS.}

Título: Nuevas andanzas y desventuras de Lazarillo de Tormes (004)

Año: 1944

Página: 29

\section{TIPO DE IMAGEN.}

Retrato: NO

Cartel: NO

Mural: NO

Ilustración: SI

Otras Obras: NO

\section{CONTENIDO.}

Personajes: HOMBRE

Animales: NO

Gestos Expresivos: EMOCIONES POSITIVAS

Paisajes: SI

Escenas: RURAL

Función: REPRESENTATIVA DE MODELOS SOCIALES

\section{ASPECTOS TÉCNICOS.}

Color dominante: 2 TINTAS

Técnica: OFFSET

Plano de la imagen: GENERAL 


\section{VARIABLES EXTERNAS.}

Título: Nuevas andanzas y desventuras de Lazarillo de Tormes (005)

Año: 1944

Página: 45

\section{TIPO DE IMAGEN.}

Retrato: NO

Cartel: NO

Mural: NO

Ilustración: SI

Otras Obras: NO

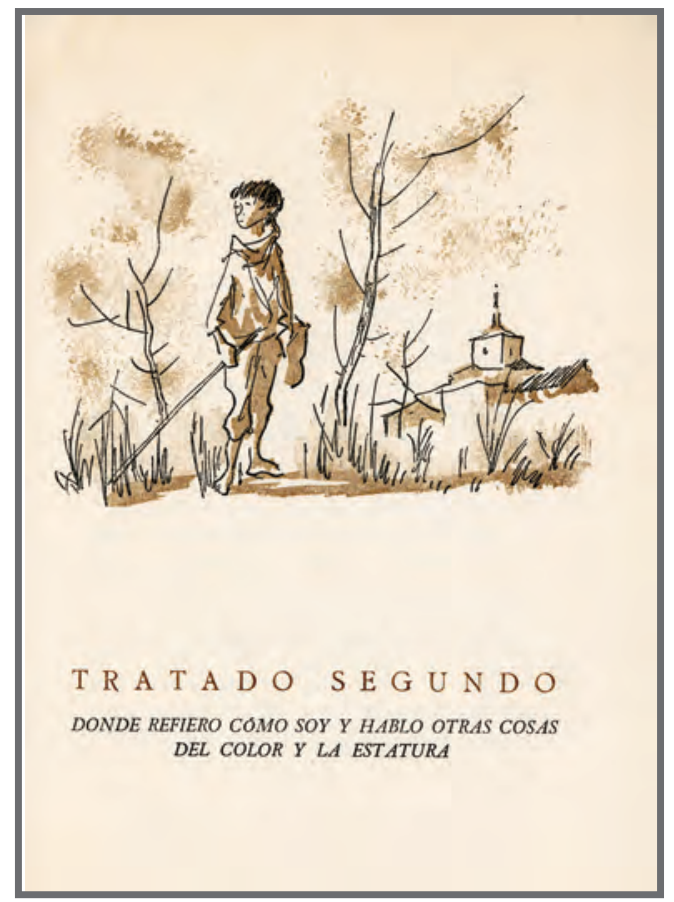

\section{CONTENIDO.}

Personajes: NIÑO

Animales: NO

Gestos Expresivos: EMOCIONES POSITIVAS

Paisajes: SI

Escenas: RURAL

Función: REPRESENTATIVA DE MODELOS SOCIALES

\section{ASPECTOS TÉCNICOS.}

Color dominante: 2 TINTAS

Técnica: OFFSET

Plano de la imagen: GENERAL 


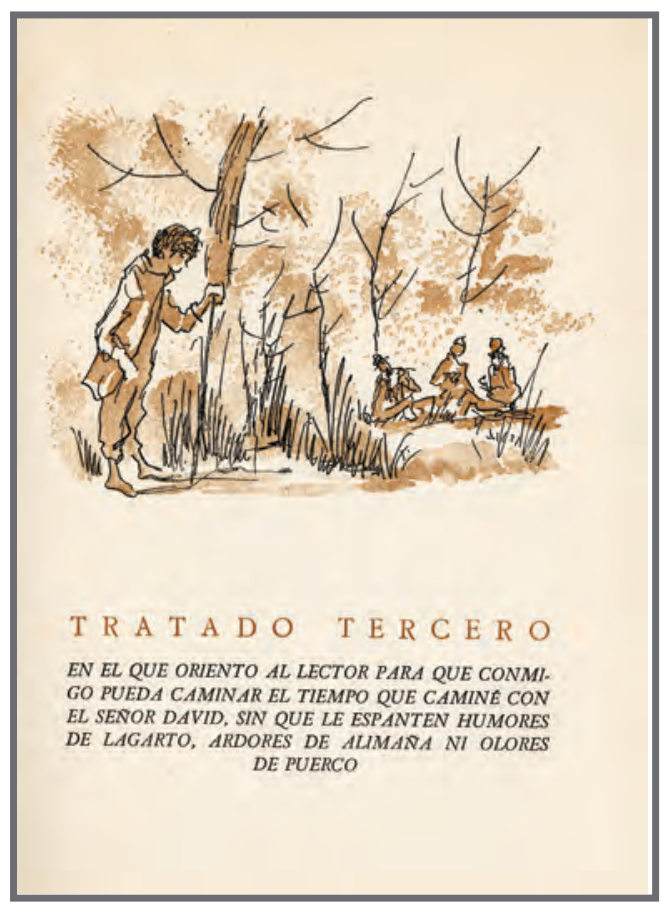

\section{VARIABLES EXTERNAS.}

Título: Nuevas andanzas y desventuras de Lazarillo de Tormes (006)

Año: 1944

Página: 51

\section{TIPO DE IMAGEN.}

Retrato: NO

Cartel: NO

Mural: NO

Ilustración: SI

Otras Obras: NO

\section{CONTENIDO.}

Personajes: HOMBRES Y NIÑO

Animales: NO

Gestos Expresivos: EMOCIONES POSITIVAS

Paisajes: SI

Escenas: RURAL

Función: REPRESENTATIVA DE MODELOS SOCIALES

\section{ASPECTOS TÉCNICOS.}

Color dominante: 2 TINTAS

Técnica: OFFSET

Plano de la imagen: GENERAL 


\section{VARIABLES EXTERNAS.}

Título: Nuevas andanzas y desventuras de Lazarillo de Tormes (007)

Año: 1944

Página: 81

\section{TIPO DE IMAGEN.}

Retrato: NO

Cartel: NO

Mural: NO

Ilustración: SI

Otras Obras: NO

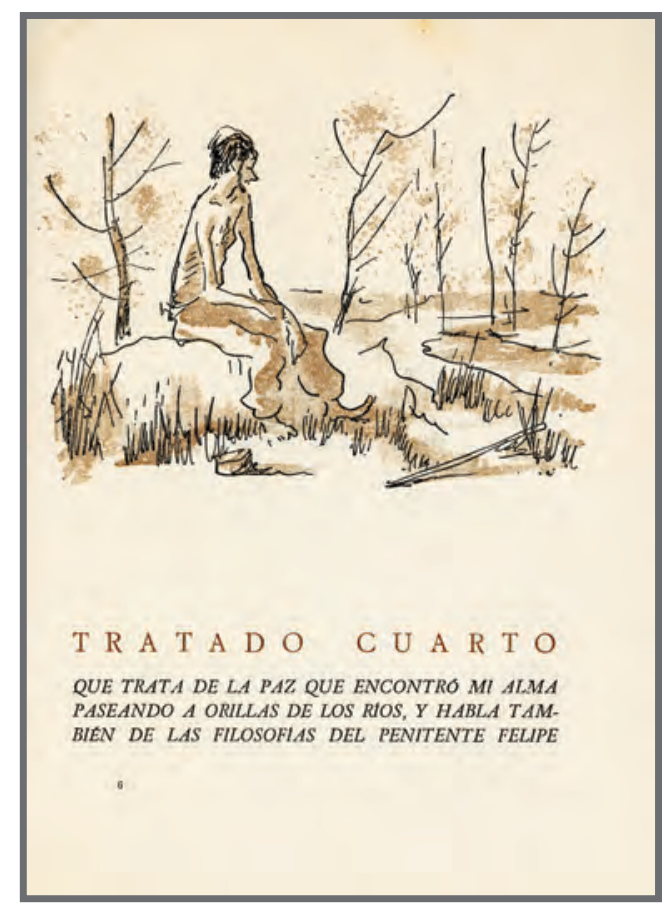

\section{CONTENIDO.}

Personajes: HOMBRE

Animales: NO

Gestos Expresivos: EMOCIONES POSITIVAS

Paisajes: SI

Escenas: RURAL

Función: REPRESENTATIVA DE MODELOS SOCIALES

\section{ASPECTOS TÉCNICOS.}

Color dominante: 2 TINTAS

Técnica: OFFSET

Plano de la imagen: GENERAL 


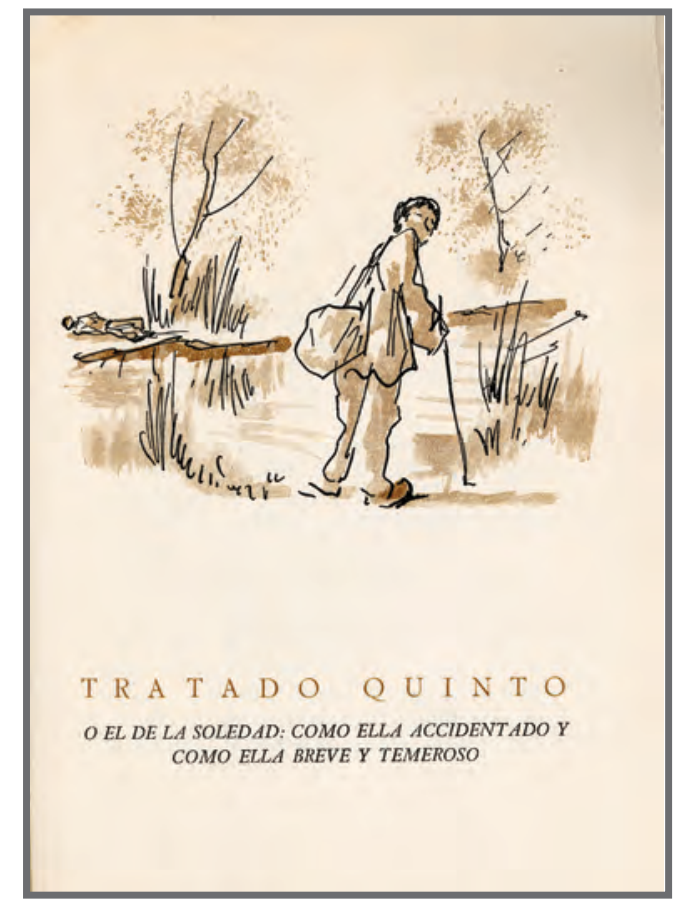

\section{VARIABLES EXTERNAS.}

Título: Nuevas andanzas y desventuras de Lazarillo de Tormes (008)

Año: 1944

Página: 111

TIPO DE IMAGEN.

Retrato: NO

Cartel: NO

Mural: NO

Ilustración: SI

Otras Obras: NO

\section{CONTENIDO.}

Personajes: NIÑO

Animales: NO

Gestos Expresivos: EMOCIONES POSITIVAS

Paisajes: SI

Escenas: RURAL

Función: REPRESENTATIVA DE MODELOS SOCIALES

\section{ASPECTOS TÉCNICOS.}

Color dominante: 2 TINTAS

Técnica: OFFSET

Plano de la imagen: GENERAL 


\section{VARIABLES EXTERNAS.}

Título: Nuevas andanzas y desventuras de Lazarillo de Tormes (009)

Año: 1944

Página: 123

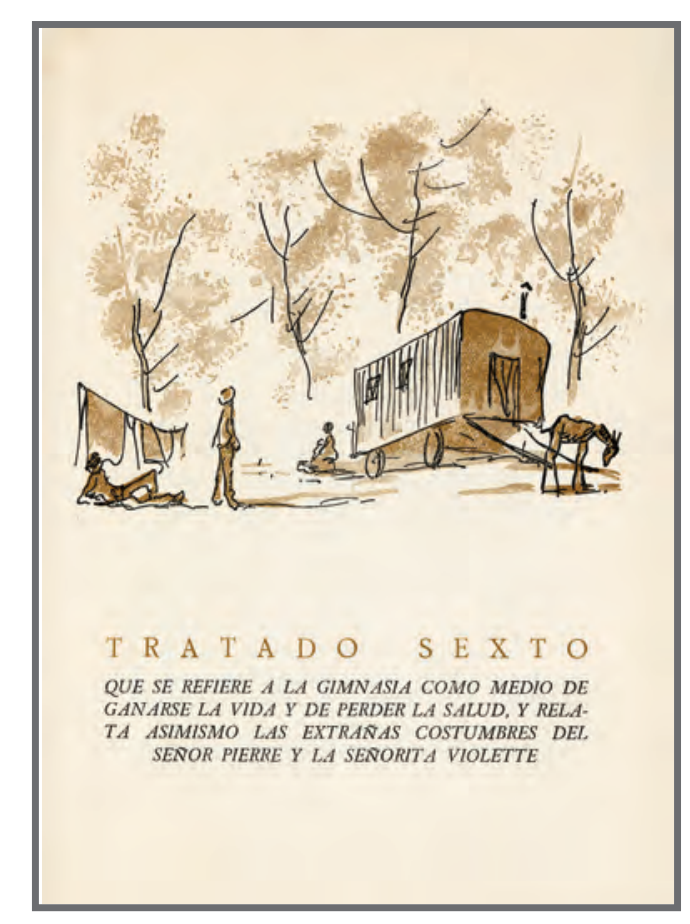

Retrato: NO

Cartel: NO

Mural: NO

Ilustración: SI

Otras Obras: NO

\section{CONTENIDO.}

Personajes: HOMBRES Y MUJER

Animales: BURRO

Gestos Expresivos: EMOCIONES POSITIVAS

Paisajes: SI

Escenas: RURAL

Función: REPRESENTATIVA DE MODELOS SOCIALES

\section{ASPECTOS TÉCNICOS.}

Color dominante: 2 TINTAS

Técnica: OFFSET

Plano de la imagen: GENERAL 


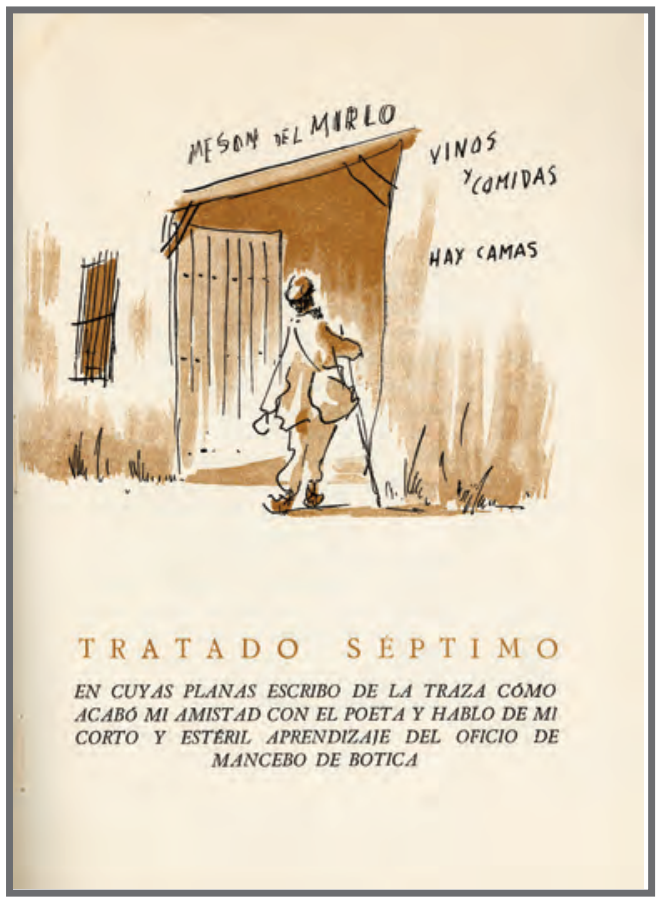

\section{VARIABLES EXTERNAS.}

Título: Nuevas andanzas y desventuras de Lazarillo de Tormes(010)

Año: 1944

Página: 153

\section{TIPO DE IMAGEN.}

Retrato: NO

Cartel: NO

Mural: NO

Ilustración: SI

Otras Obras: NO

\section{CONTENIDO.}

Personajes: NIÑO

Animales: NO

Gestos Expresivos: EMOCIONES POSITIVAS

Paisajes: NO

Escenas: CALLEJERAS

Función: REPRESENTATIVA DE MODELOS SOCIALES

\section{ASPECTOS TÉCNICOS.}

Color dominante: 2 TINTAS

Técnica: OFFSET

Plano de la imagen: GENERAL 


\section{VARIABLES EXTERNAS.}

Título: Nuevas andanzas y desventuras de Lazarillo de Tormes (011)

Año: 1944

Página: 187

\section{TIPO DE IMAGEN.}

Retrato: NO

Cartel: NO

Mural: NO

Ilustración: SI

Otras Obras: NO

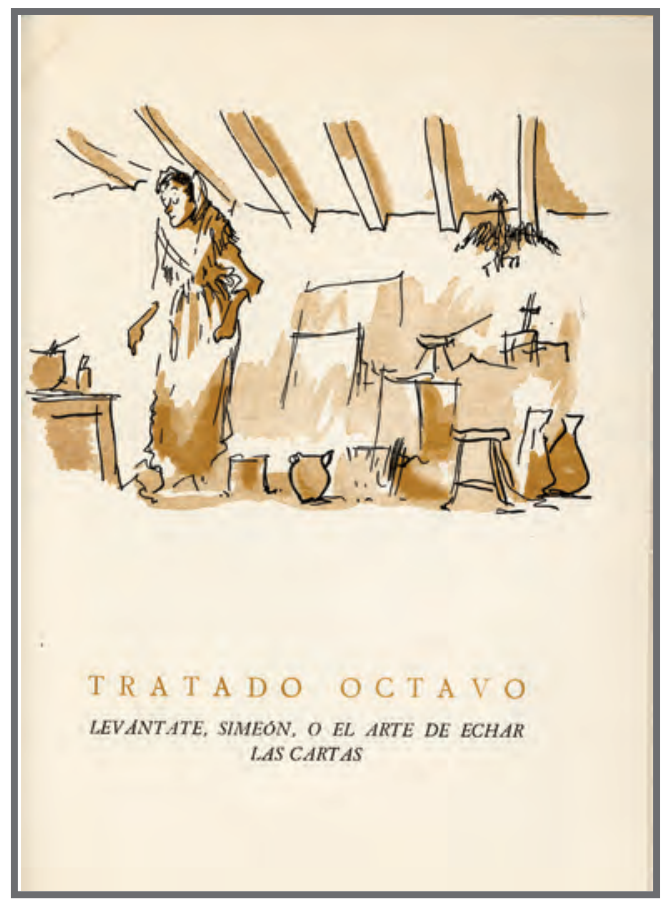

\section{CONTENIDO.}

Personajes: MUJER

Animales: GALLINA

Gestos Expresivos: EMOCIONES POSITIVAS

Paisajes: NO

Escenas: INTERIOR

Función: REPRESENTATIVA DE MODELOS SOCIALES

\section{ASPECTOS TÉCNICOS.}

Color dominante: 2 TINTAS

Técnica: OFFSET

Plano de la imagen: GENERAL 


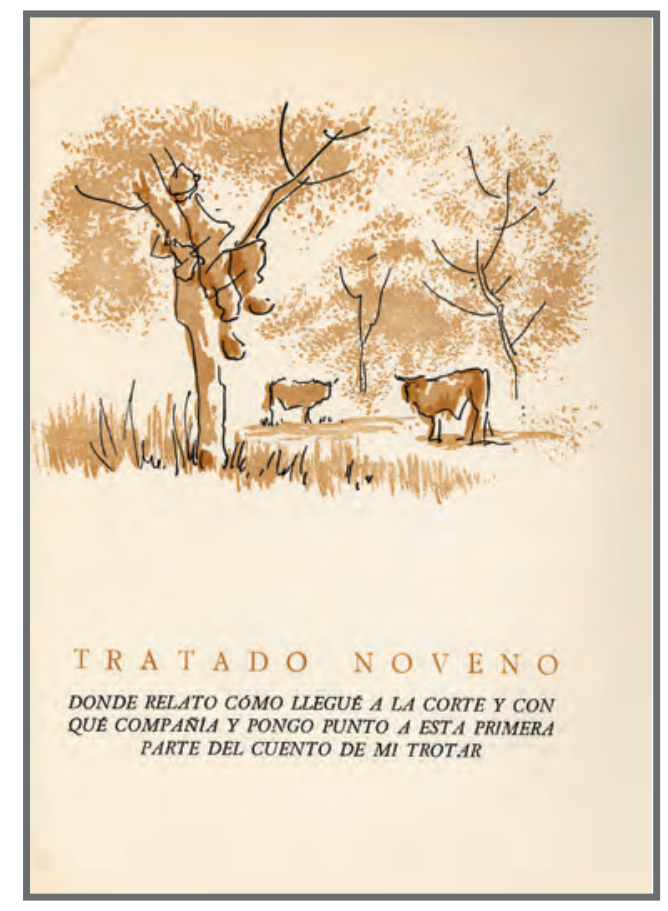

\section{VARIABLES EXTERNAS.}

Título: Nuevas andanzas y desventuras de Lazarillo de Tormes (012)

Año: 1944

Página: 217

\section{TIPO DE IMAGEN.}

Retrato: NO

Cartel: NO

Mural: NO

Ilustración: SI

Otras Obras: NO

\section{CONTENIDO.}

Personajes: NIÑO

Animales: TOROS

Gestos Expresivos: NO

Paisajes: SI

Escenas: RURAL

Función: REPRESENTATIVA DE MODELOS SOCIALES

\section{ASPECTOS TÉCNICOS.}

Color dominante: 2 TINTAS

Técnica: OFFSET

Plano de la imagen: GENERAL 


\section{VARIABLES EXTERNAS.}

Título: Nuevas andanzas y desventuras de Lazarillo de Tormes (013)

Año: 1944

Página: 229

\section{TIPO DE IMAGEN.}

Retrato: NO

Cartel: NO

Mural: NO

Ilustración: SI

Otras Obras: NO

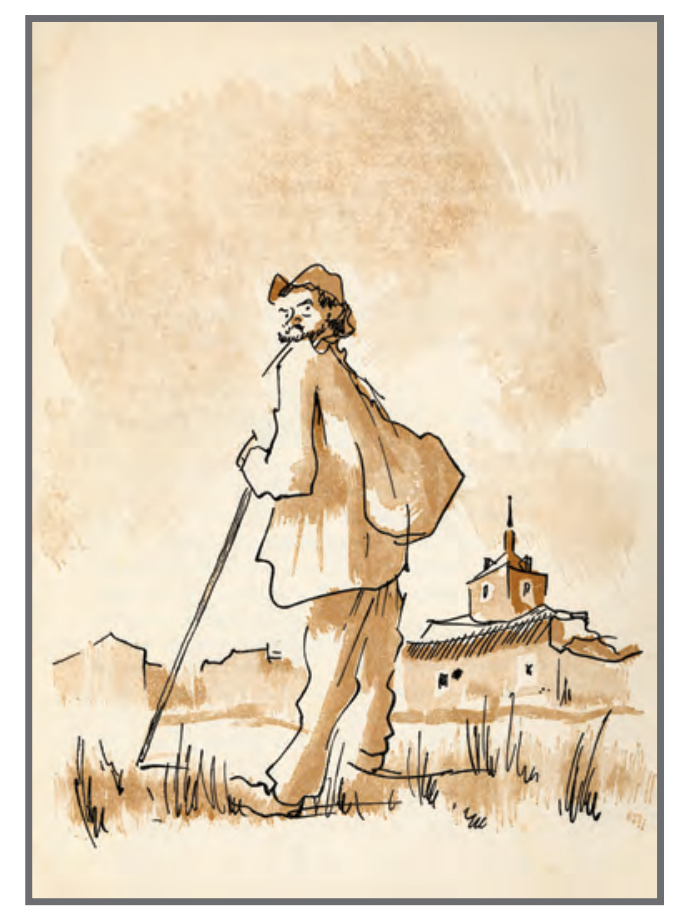

\section{CONTENIDO.}

Personajes: HOMBRE

Animales: NO

Gestos Expresivos: EMOCIONES POSITIVAS

Paisajes: SI

Escenas: RURAL

Función: REPRESENTATIVA DE MODELOS SOCIALES

\section{ASPECTOS TÉCNICOS.}

Color dominante: 2 TINTAS

Técnica: OFFSET

Plano de la imagen: GENERAL 


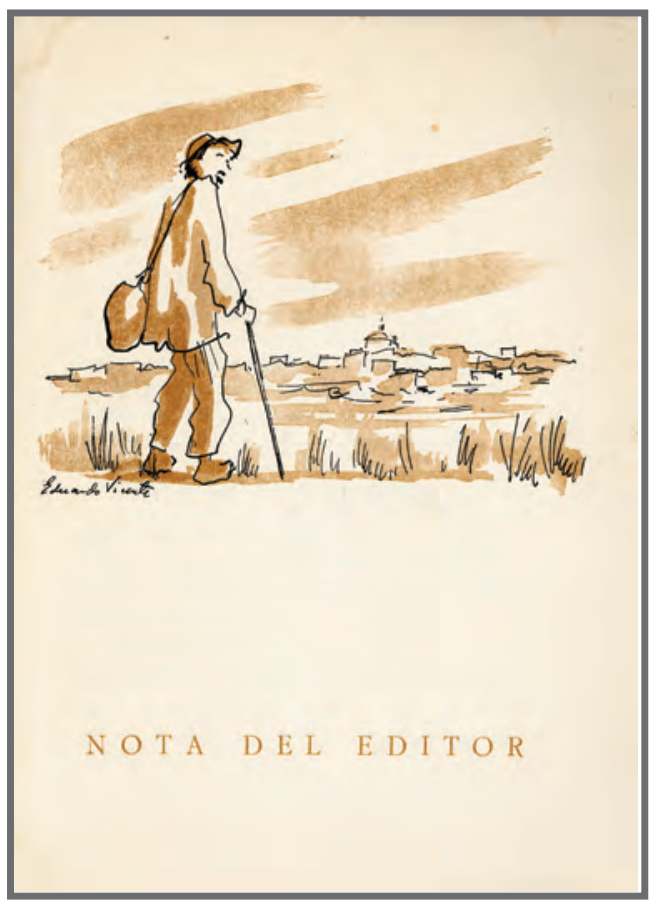

\section{VARIABLES EXTERNAS.}

Título: Nuevas andanzas y desventuras de Lazarillo de Tormes (014)

Año: 1944

Página: 23313

\section{TIPO DE IMAGEN.}

Retrato: NO

Cartel: NO

Mural: NO

Ilustración: SI

Otras Obras: NO

\section{CONTENIDO.}

Personajes: HOMBRE

Animales: NO

Gestos Expresivos: EMOCIONES POSITIVAS

Paisajes: SI

Escenas: RURAL

Función: REPRESENTATIVA DE MODELOS SOCIALES

\section{ASPECTOS TÉCNICOS.}

Color dominante: 2 TINTAS

Técnica: OFFSET

Plano de la imagen: GENERAL 


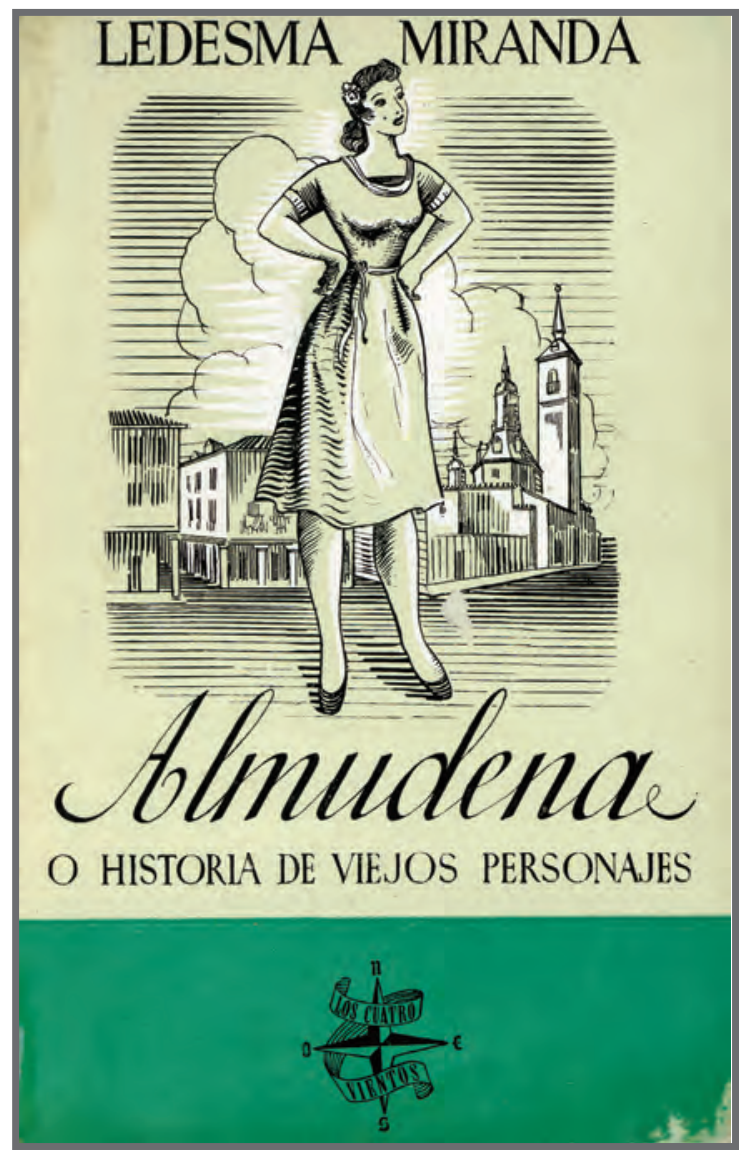

\section{FICHA TÉCNICA.}

Título: ALMUDENA O HISTORIA DE VIEJOS PERSONAJES Autor: LEDESMA MIRANDA

Editorial: AFRODISIO AGUADO

Año: 1944

Tamaño: $11 \times 17 \mathrm{~cm}$.

Número de páginas: 324

Número de ilustraciones: 18 



\section{VARIABLES EXTERNAS.}

Título: Almudena o historia de viejos personajes (001)

Año: 1944

Página: 9

\section{TIPO DE IMAGEN.}

Retrato: NO

Cartel: NO

Mural: NO

Ilustración: SI

Otras Obras: NO

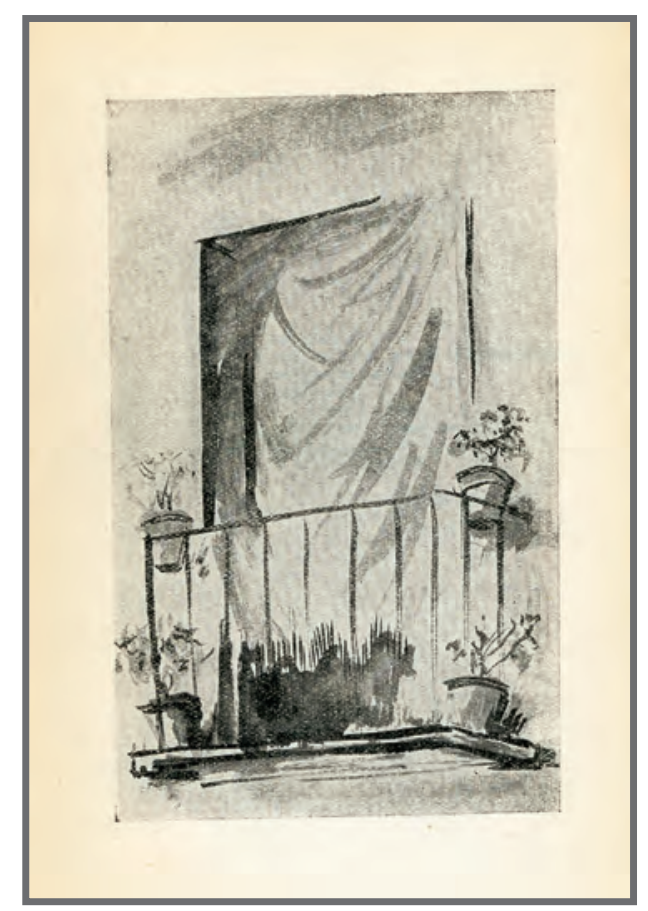

\section{CONTENIDO.}

Personajes: NO

Animales: NO

Gestos Expresivos: NO

Paisajes: NO

Escenas: URBANA

Función: REPRESENTATIVA DE MODELOS SOCIALES

\section{ASPECTOS TÉCNICOS.}

Color dominante: 1 TINTA

Técnica: OFFSET

Plano de la imagen: DETALLE 


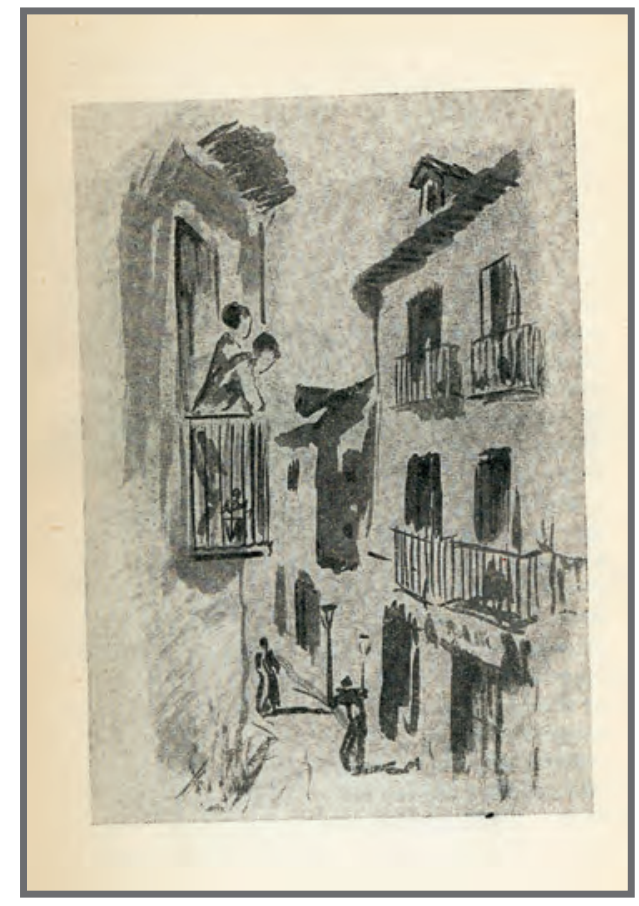

\section{VARIABLES EXTERNAS.}

Título: Almudena o historia de viejos personajes (002)

Año: 1944

Página: 15

\section{TIPO DE IMAGEN.}

Retrato: NO

Cartel: NO

Mural: NO

Ilustración: SI

Otras Obras: NO

\section{CONTENIDO.}

Personajes: HOMBRES Y MUJERES

Animales: NO

Gestos Expresivos: EMOCIONES POSITIVAS

Paisajes: SI

Escenas: CALLEJERAS

Función: REPRESENTATIVA DE MODELOS SOCIALES

\section{ASPECTOS TÉCNICOS.}

Color dominante: 1 TINTA

Técnica: OFFSET

Plano de la imagen: GENERAL 


\section{VARIABLES EXTERNAS.}

Título: Almudena o historia de viejos personajes (003)

Año: 1944

Página: 23

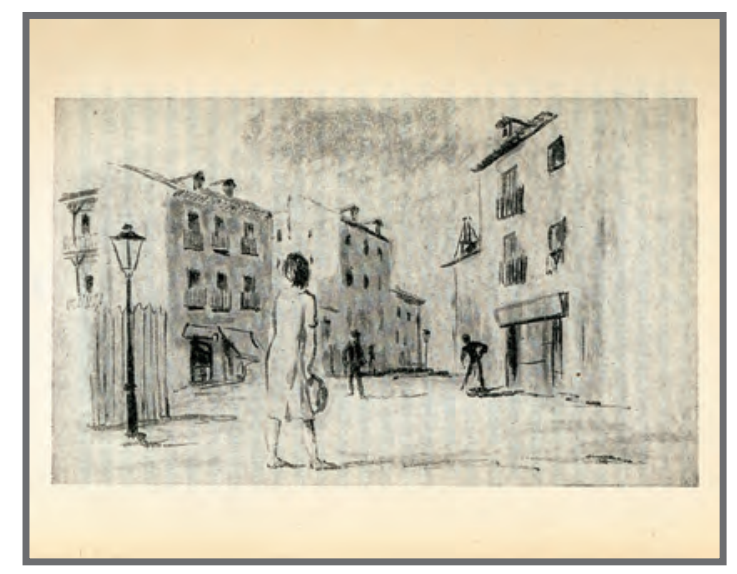

\section{TIPO DE IMAGEN.}

Retrato: NO

Cartel: NO

Mural: NO

Ilustración: SI

Otras Obras: NO

\section{CONTENIDO.}

Personajes: HOMBRES Y MUJER

Animales: NO

Gestos Expresivos: EMOCIONES POSITIVAS

Paisajes: SI

Escenas: CALLEJERA

Función: REPRESENTATIVA DE MODELOS SOCIALES

\section{ASPECTOS TÉCNICOS.}

Color dominante: 1 TINTA

Técnica: OFFSET

Plano de la imagen: GENERAL 


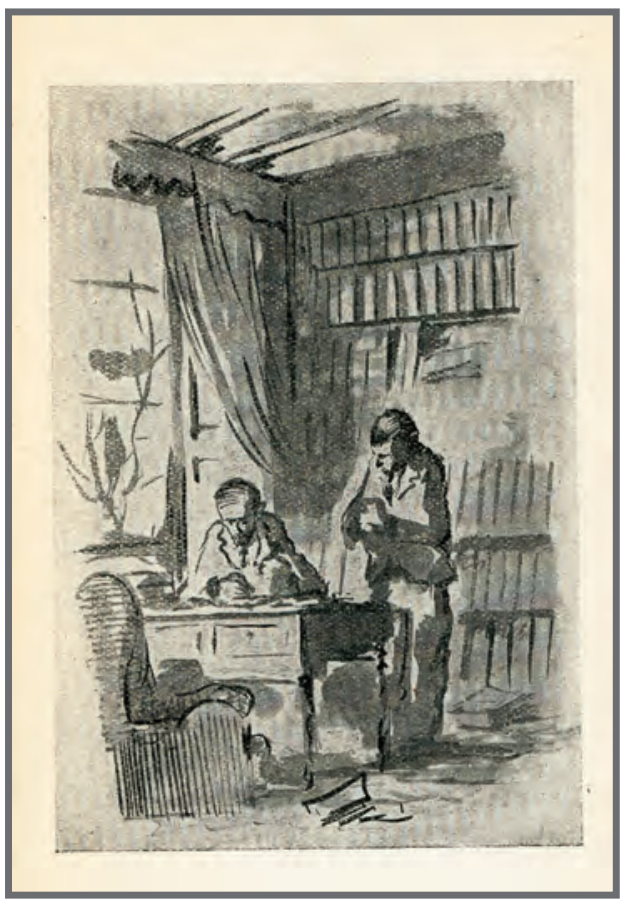

\section{VARIABLES EXTERNAS.}

Título: Almudena o historia de viejos personajes (004)

Año: 1944

Página: 61

\section{TIPO DE IMAGEN.}

Retrato: NO

Cartel: NO

Mural: NO

Ilustración: SI

Otras Obras: NO

\section{CONTENIDO.}

Personajes: HOMBRES

Animales: NO

Gestos Expresivos: EMOCIONES POSITIVAS

Paisajes: NO

Escenas: INTERIOR

Función: REPRESENTATIVA DE MODELOS SOCIALES

\section{ASPECTOS TÉCNICOS.}

Color dominante: 1 TINTA

Técnica: OFFSET

Plano de la imagen: GENERAL 


\section{VARIABLES EXTERNAS.}

Título: Almudena o historia de viejos personajes (005)

Año: 1944

Página: 77

\section{TIPO DE IMAGEN.}

Retrato: NO

Cartel: NO

Mural: NO

Ilustración: SI

Otras Obras: NO

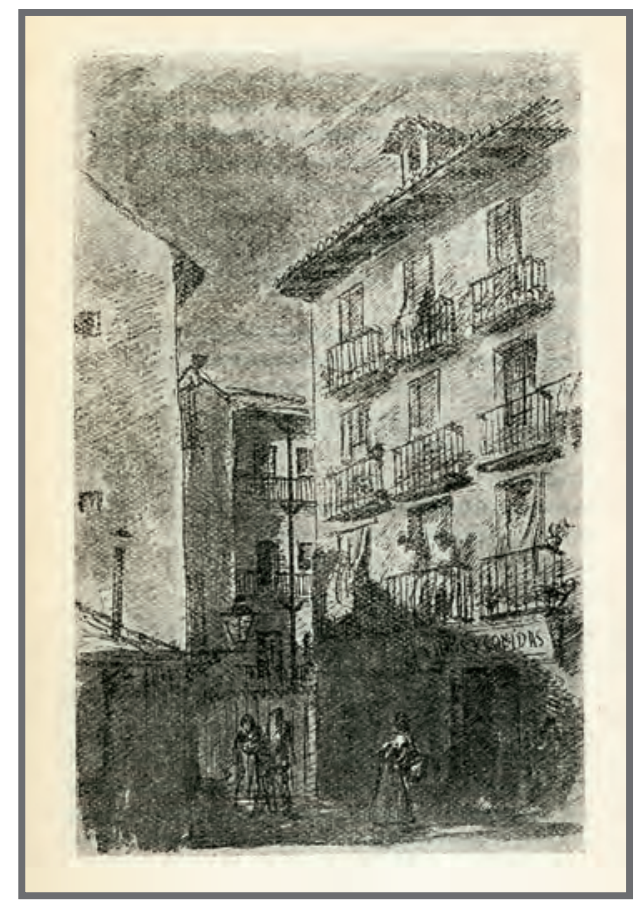

\section{CONTENIDO.}

Personajes: MUJERES

Animales: NO

Gestos Expresivos: NO

Paisajes: SI

Escenas: CALLEJERAS

Función: REPRESENTATIVA DE MODELOS SOCIALES

\section{ASPECTOS TÉCNICOS.}

Color dominante: 1 TINTA

Técnica: OFFSET

Plano de la imagen: GENERAL 

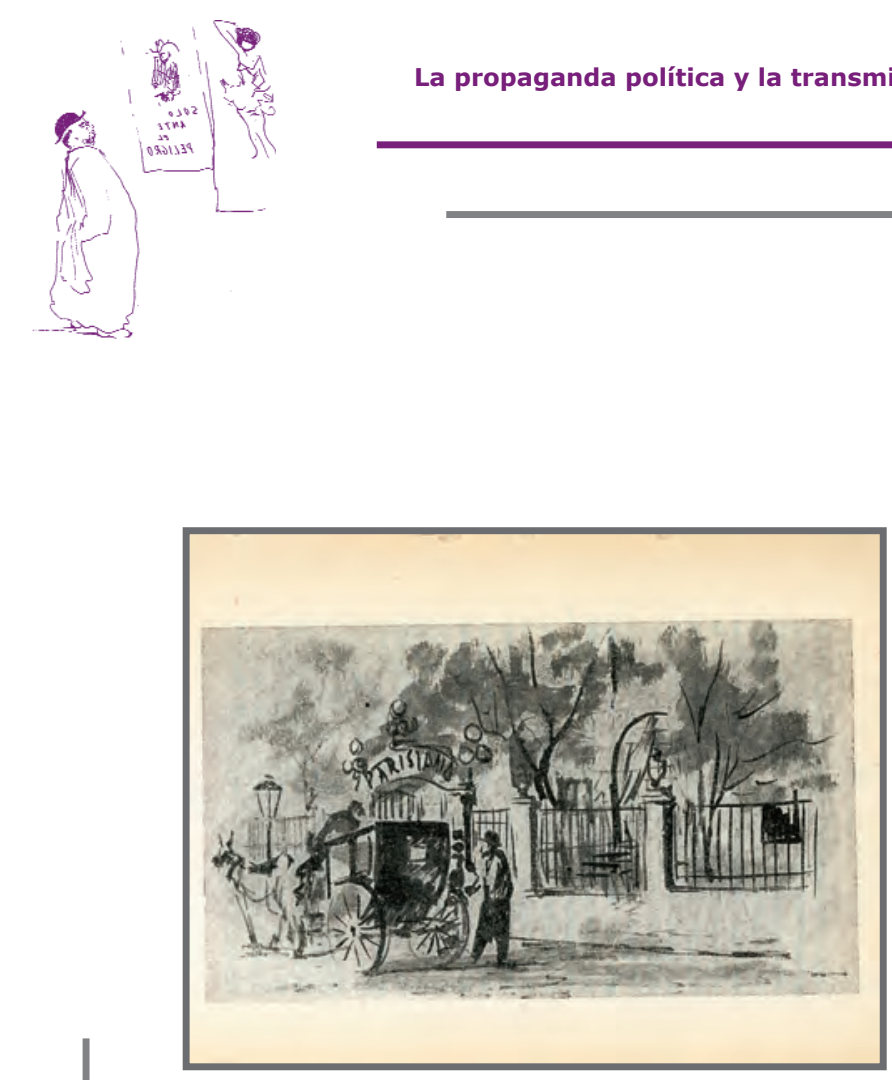

\section{VARIABLES EXTERNAS.}

Título: Almudena o historia de viejos personajes (006)

Año: 1944

Página: 105

\section{TIPO DE IMAGEN.}

Retrato: NO

Cartel: NO

Mural: NO

Ilustración: SI

Otras Obras: NO

\section{CONTENIDO.}

Personajes: HOMBRE

Animales: CABALLO

Gestos Expresivos: EMOCIONES POSITIVAS

Paisajes: SI

Escenas: URBANO

Función: REPRESENTATIVA DE MODELOS SOCIALES

\section{ASPECTOS TÉCNICOS.}

Color dominante: 1 TINTA

Técnica: OFFSET

Plano de la imagen: GENERAL 


\section{VARIABLES EXTERNAS.}

Título: Almudena o historia de viejos personajes (007)

Año: 1944

Página: 135

TIPO DE IMAGEN.

Retrato: NO

Cartel: NO

Mural: NO

Ilustración: SI

Otras Obras: NO

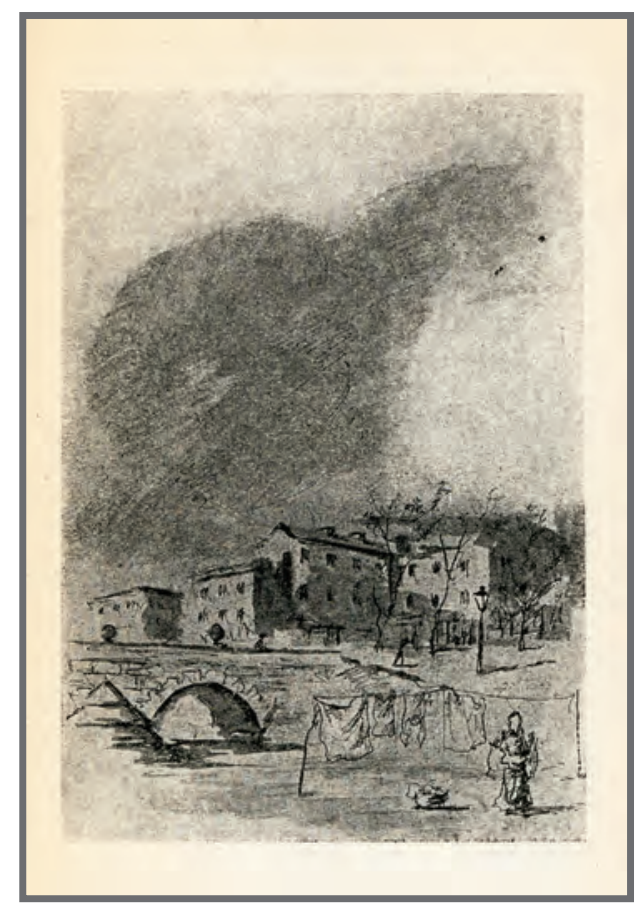

\section{CONTENIDO.}

Personajes: MUJER

Animales: NO

Gestos Expresivos: EMOCIONES POSITIVAS

Paisajes: SI

Escenas: PROFESIONAL

Función: REPRESENTATIVA DE MODELOS SOCIALES

\section{ASPECTOS TÉCNICOS.}

Color dominante: 1 TINTA

Técnica: OFFSET

Plano de la imagen: GENERAL 


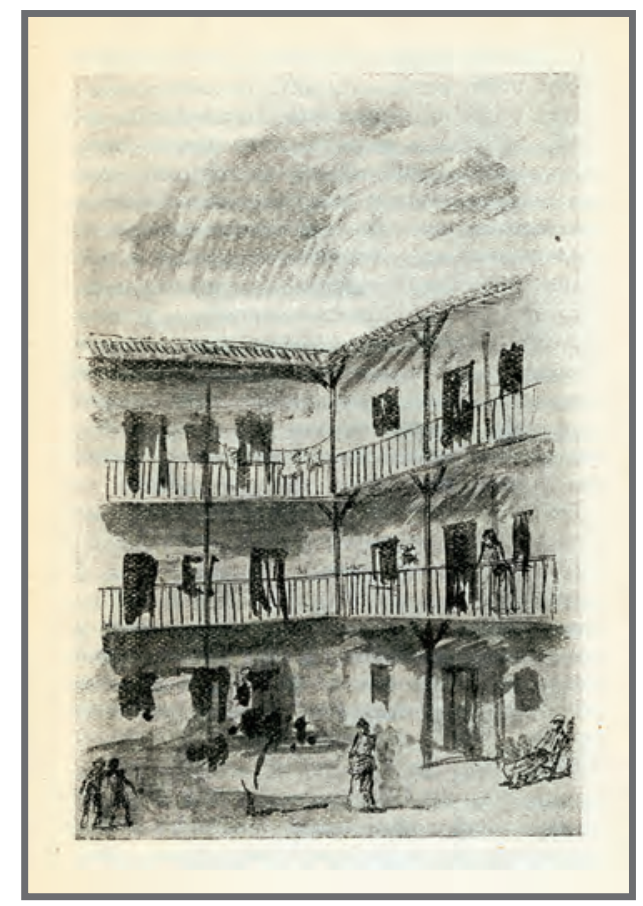

\section{VARIABLES EXTERNAS.}

Título: Almudena o historia de viejos personajes (008)

Año: 1944

Página: 141

\section{TIPO DE IMAGEN.}

Retrato: NO

Cartel: NO

Mural: NO

Ilustración: SI

Otras Obras: NO

\section{CONTENIDO.}

Personajes: HOMBRES, MUJERES Y NIÑOS

Animales: NO

Gestos Expresivos: EMOCIONES POSITIVAS

Paisajes: SI

Escenas: URBANO

Función: REPRESENTATIVA DE MODELOS SOCIALES

\section{ASPECTOS TÉCNICOS.}

Color dominante: 1 TINTA

Técnica: OFFSET

Plano de la imagen: GENERAL 


\section{VARIABLES EXTERNAS.}

Título: Almudena o historia de viejos personajes (009)

Año: 1944

Página: 159

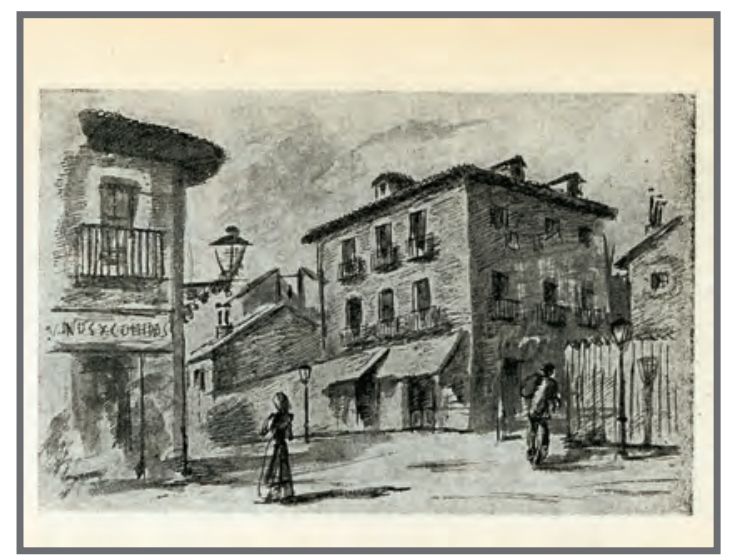

\section{TIPO DE IMAGEN.}

Retrato: NO

Cartel: NO

Mural: NO

Ilustración: SI

Otras Obras: NO

\section{CONTENIDO.}

Personajes: HOMBRE Y MUJER

Animales: NO

Gestos Expresivos: EMOCIONES POSITIVAS

Paisajes: SI

Escenas: CALLEJERA

Función: REPRESENTATIVA DE MODELOS SOCIALES

\section{ASPECTOS TÉCNICOS.}

Color dominante: 1 TINTA

Técnica: OFFSET

Plano de la imagen: GENERAL 


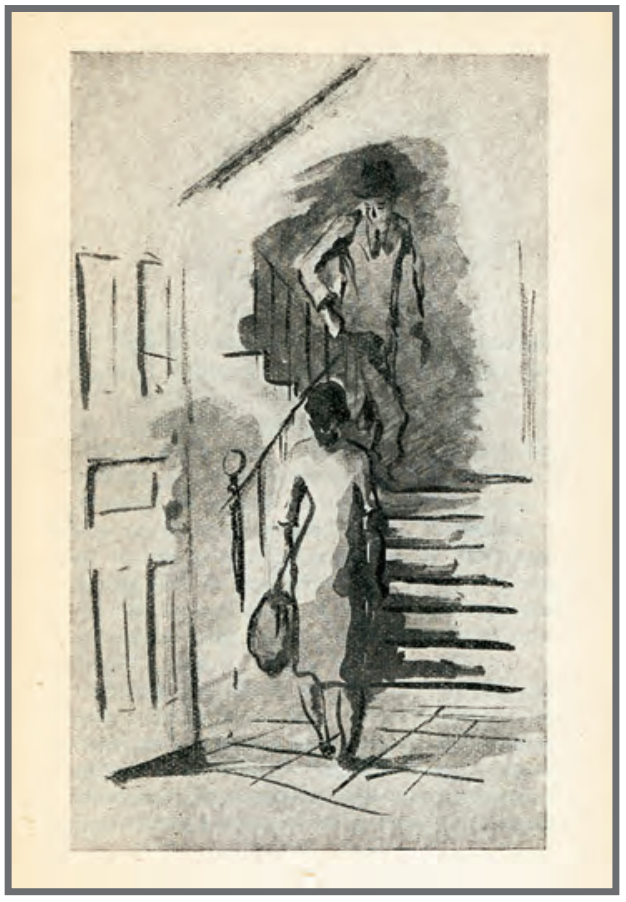

\section{VARIABLES EXTERNAS.}

Título: Almudena o historia de viejos personajes (010)

Año: 1944

Página: 181

\section{TIPO DE IMAGEN.}

Retrato: NO

Cartel: NO

Mural: NO

Ilustración: SI

Otras Obras: NO

\section{CONTENIDO.}

Personajes: HOMBRE Y MUJER

Animales: NO

Gestos Expresivos: EMOCIONES POSITIVAS

Paisajes: NO

Escenas: INTERIOR

Función: REPRESENTATIVA DE MODELOS SOCIALES

\section{ASPECTOS TÉCNICOS.}

Color dominante: 1 TINTA

Técnica: OFFSET

Plano de la imagen: GENERAL 


\section{VARIABLES EXTERNAS.}

Título: Almudena o historia de viejos personajes (011)

Año: 1944

Página: 187

\section{TIPO DE IMAGEN.}

Retrato: NO

Cartel: NO

Mural: NO

Ilustración: SI

Otras Obras: NO

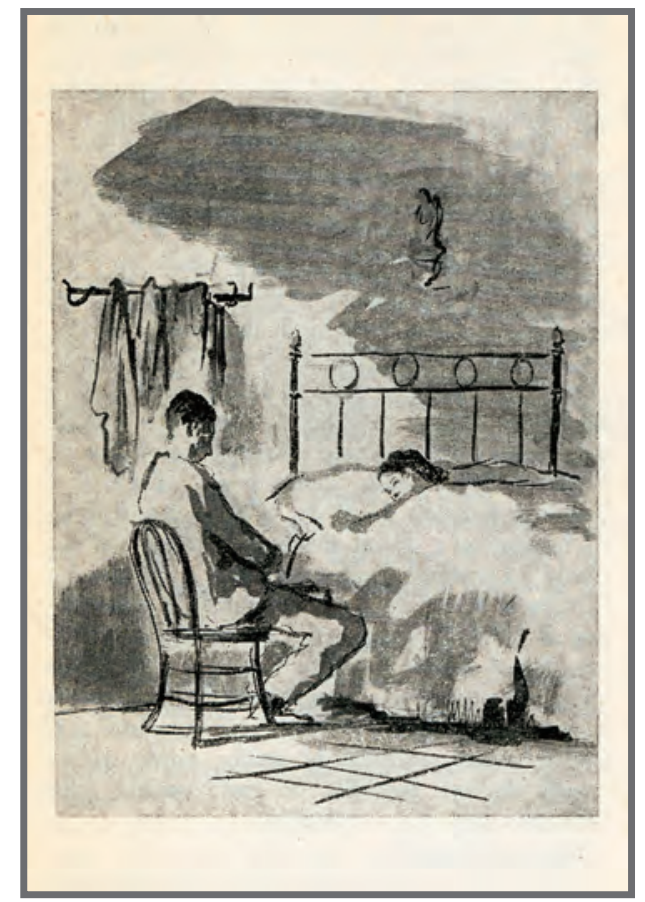

\section{CONTENIDO.}

Personajes: HOMBRE Y MUJER

Animales: NO

Gestos Expresivos: EMOCIONES NEGATIVAS

Paisajes: NO

Escenas: INTERIOR

Función: REPRESENTATIVA DE MODELOS SOCIALES

\section{ASPECTOS TÉCNICOS.}

Color dominante: 1 TINTA

Técnica: OFFSET

Plano de la imagen: GENERAL 


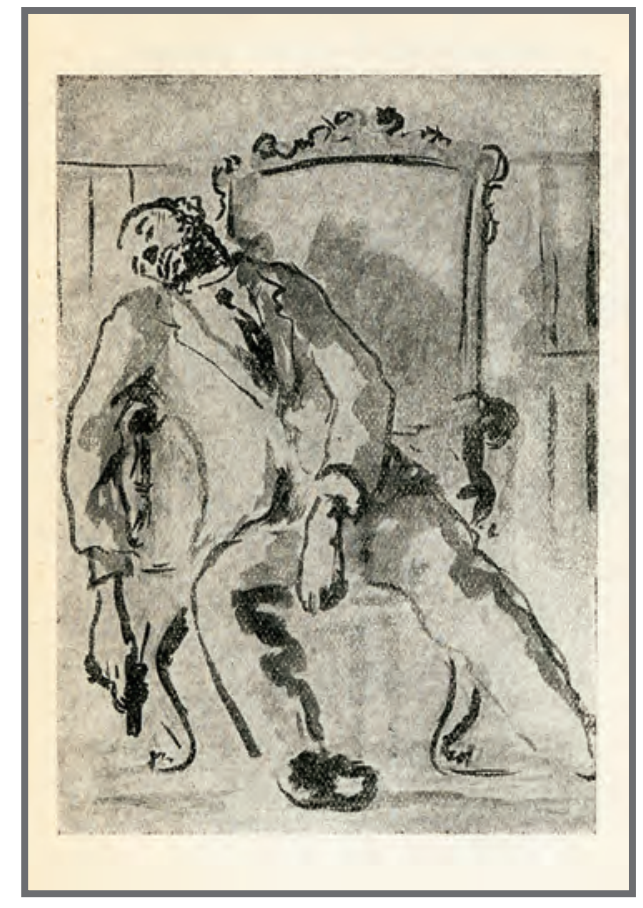

\section{VARIABLES EXTERNAS.}

Título: Almudena o historia de viejos personajes (012)

Año: 1944

Página: 197

\section{TIPO DE IMAGEN.}

Retrato: NO

Cartel: NO

Mural: NO

Ilustración: SI

Otras Obras: NO

\section{CONTENIDO.}

Personajes: HOMBRE

Animales: NO

Gestos Expresivos: EMOCIONES NEGATIVAS

Paisajes: NO

Escenas: INTERIOR

Función: REPRESENTATIVA DE MODELOS SOCIALES

\section{ASPECTOS TÉCNICOS.}

Color dominante: 1 TINTA

Técnica: OFFSET

Plano de la imagen: GENERAL 


\section{VARIABLES EXTERNAS.}

Título: Almudena o historia de viejos personajes (013)

Año: 1944

Página: 235

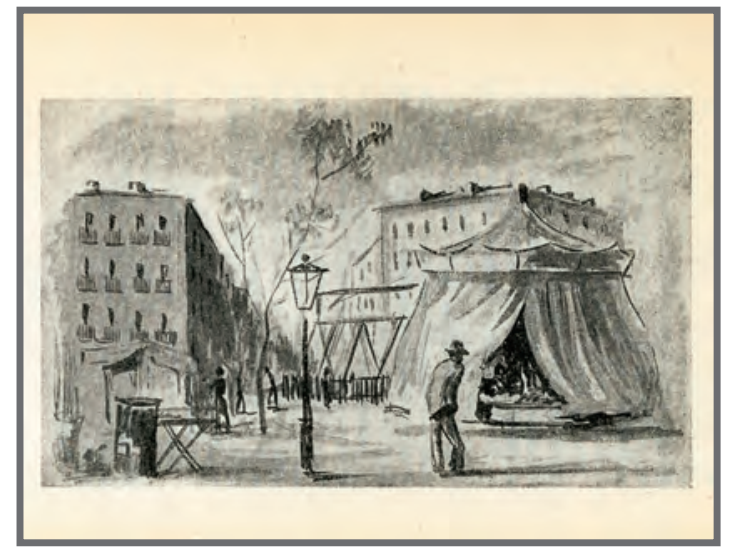

\section{TIPO DE IMAGEN.}

Retrato: NO

Cartel: NO

Mural: NO

Ilustración: SI

Otras Obras: NO

\section{CONTENIDO.}

Personajes: HOMBRES

Animales: NO

Gestos Expresivos: EMOCIONES POSITIVAS

Paisajes: SI

Escenas: CALLEJERAS

Función: REPRESENTATIVA DE MODELOS SOCIALES

\section{ASPECTOS TÉCNICOS.}

Color dominante: 1 TINTA

Técnica: OFFSET

Plano de la imagen: GENERAL 


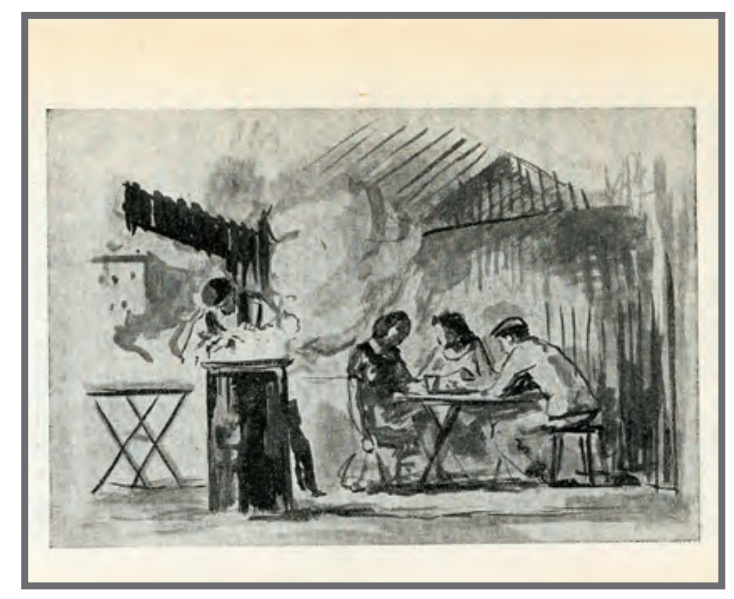

\section{VARIABLES EXTERNAS.}

Título: Almudena o historia de viejos personajes (014)

Año: 1944

Página: 241

\section{TIPO DE IMAGEN.}

Retrato: NO

Cartel: NO

Mural: NO

Ilustración: SI

Otras Obras: NO

\section{CONTENIDO.}

Personajes: HOMBRES Y MUJERES

Animales: NO

Gestos Expresivos: EMOCIONES POSITIVAS

Paisajes: NO

Escenas: INTERIOR

Función: REPRESENTATIVA DE MODELOS SOCIALES

\section{ASPECTOS TÉCNICOS.}

Color dominante: 1 TINTA

Técnica: OFFSET

Plano de la imagen: GENERAL 


\section{VARIABLES EXTERNAS.}

Título: Almudena o historia de viejos personajes (015)

Año: 1944

Página: 245

TIPO DE IMAGEN.

Retrato: NO

Cartel: NO

Mural: NO

Ilustración: SI

Otras Obras: NO

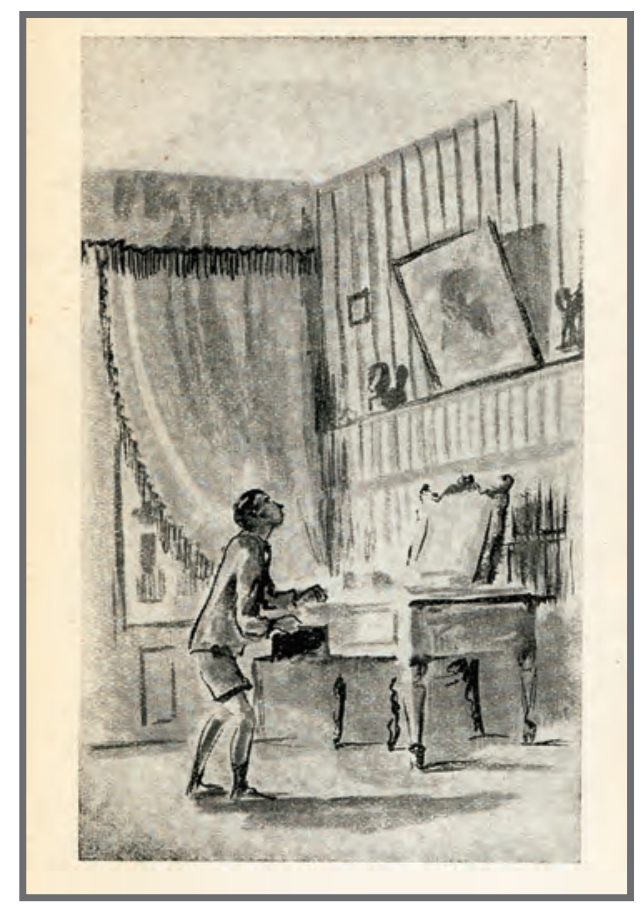

\section{CONTENIDO.}

Personajes: HOMBRE

Animales: NO

Gestos Expresivos: EMOCIONES POSITIVAS

Paisajes: NO

Escenas: INTERIOR

Función: REPRESENTATIVA DE MODELOS SOCIALES

\section{ASPECTOS TÉCNICOS.}

Color dominante: 1 TINTA

Técnica: OFFSET

Plano de la imagen: GENERAL 


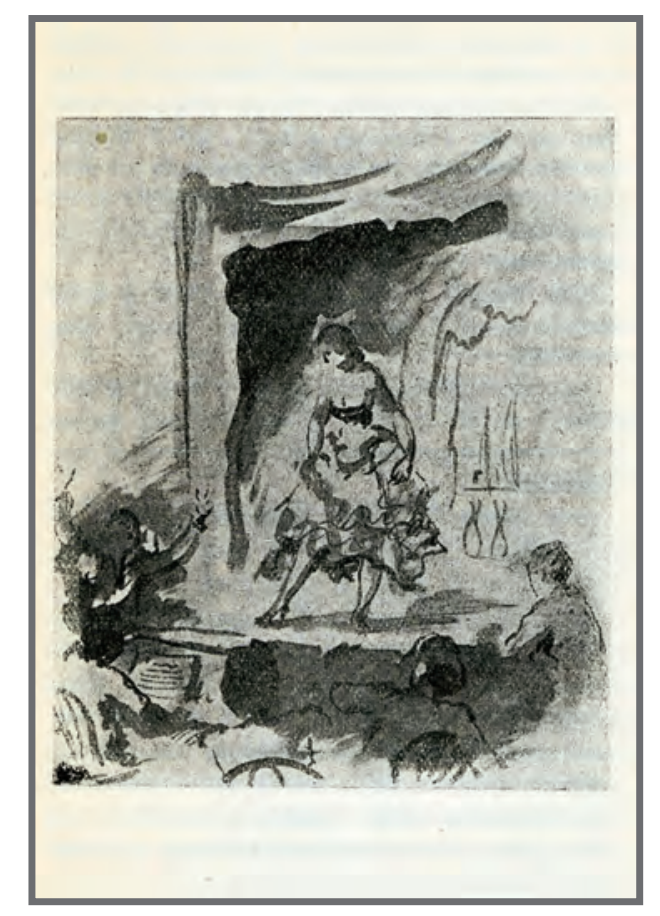

\section{VARIABLES EXTERNAS.}

Título: Almudena o historia de viejos personajes (016)

Año: 1944

Página: 269

\section{TIPO DE IMAGEN.}

Retrato: NO

Cartel: NO

Mural: NO

Ilustración: SI

Otras Obras: NO

\section{CONTENIDO.}

Personajes: HOMBRES Y MUJERES

Animales: NO

Gestos Expresivos: EMOCIONES POSITIVAS

Paisajes: NO

Escenas: PROFESIONAL

Función: REPRESENTATIVA DE MODELOS SOCIALES

\section{ASPECTOS TÉCNICOS.}

Color dominante: 1 TINTA

Técnica: OFFSET

Plano de la imagen: GENERAL 


\section{VARIABLES EXTERNAS.}

Título: Almudena o historia de viejos personajes (017)

Año: 1944

Página: 301

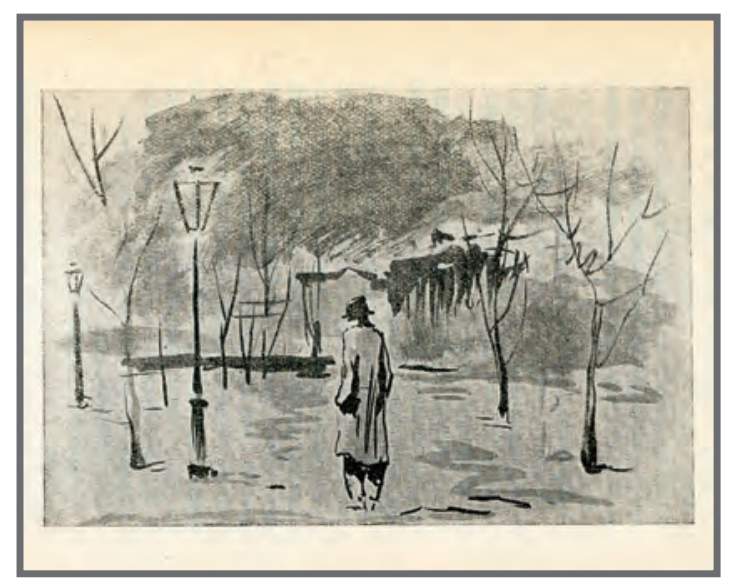

\section{TIPO DE IMAGEN.}

Retrato: NO

Cartel: NO

Mural: NO

Ilustración: SI

Otras Obras: NO

\section{CONTENIDO.}

Personajes: HOMBRE

Animales: NO

Gestos Expresivos: EMOCIONES POSITIVAS

Paisajes: SI

Escenas: URBANA

Función: REPRESENTATIVA DE MODELOS SOCIALES

\section{ASPECTOS TÉCNICOS.}

Color dominante: 1 TINTA

Técnica: OFFSET

Plano de la imagen: GENERAL 


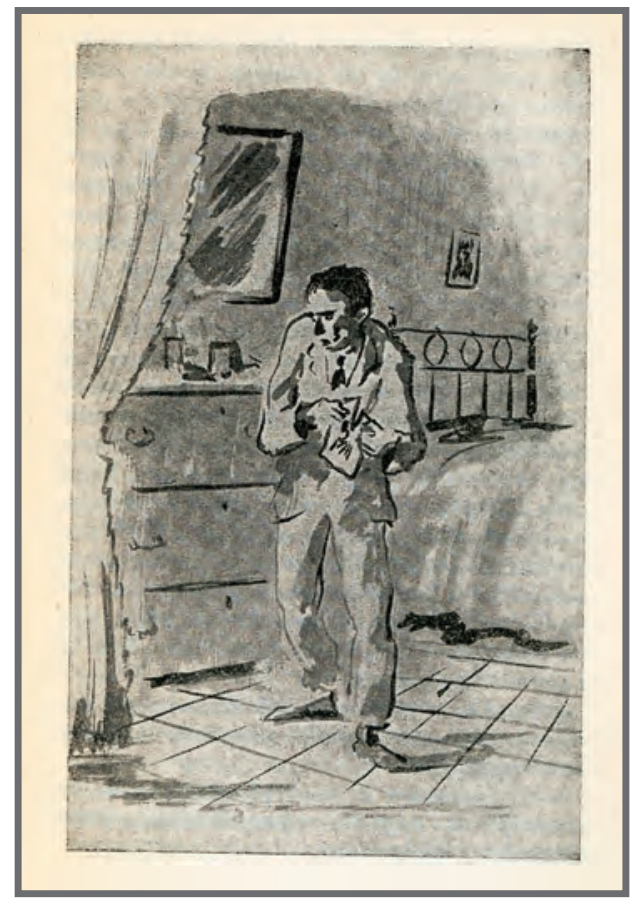

\section{VARIABLES EXTERNAS.}

Título: Almudena o historia de viejos personajes (018)

Año: 1944

Página: 217

\section{TIPO DE IMAGEN.}

Retrato: NO

Cartel: NO

Mural: NO

Ilustración: SI

Otras Obras: NO

\section{CONTENIDO.}

Personajes: HOMBRE

Animales: NO

Gestos Expresivos: EMOCIONES POSITIVAS

Paisajes: NO

Escenas: INTERIOR

Función: REPRESENTATIVA DE MODELOS SOCIALES

\section{ASPECTOS TÉCNICOS.}

Color dominante: 1 TINTA

Técnica: OFFSET

Plano de la imagen: GENERAL 


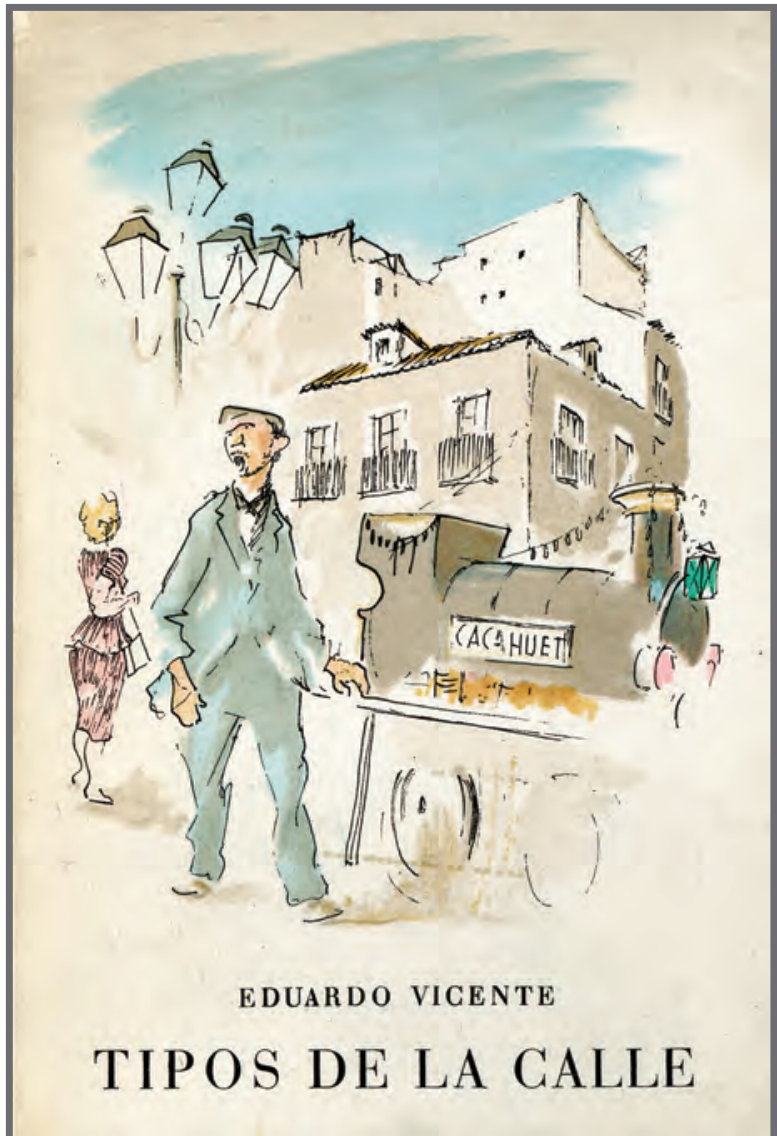

\section{FICHA TÉCNICA.}

Título: TIPOS DE LA CALLE

Autor: EDUARDO VICENTE

Editorial: AFRODISIO AGUADO, S.A. - MADRID

Año: 1950

Tamaño: $18,5 \times 12,5 \mathrm{~cm}$.

Número de páginas: 75

Número de ilustraciones: 42 (ILUSTRACIÓN EN PORTADA) 



\section{VARIABLES EXTERNAS.}

Título: Un trapero

Año: 1950

Página: 33

\section{TIPO DE IMAGEN.}

Retrato: NO

Cartel: NO

Mural: NO

Ilustración: SI

Otras Obras: NO

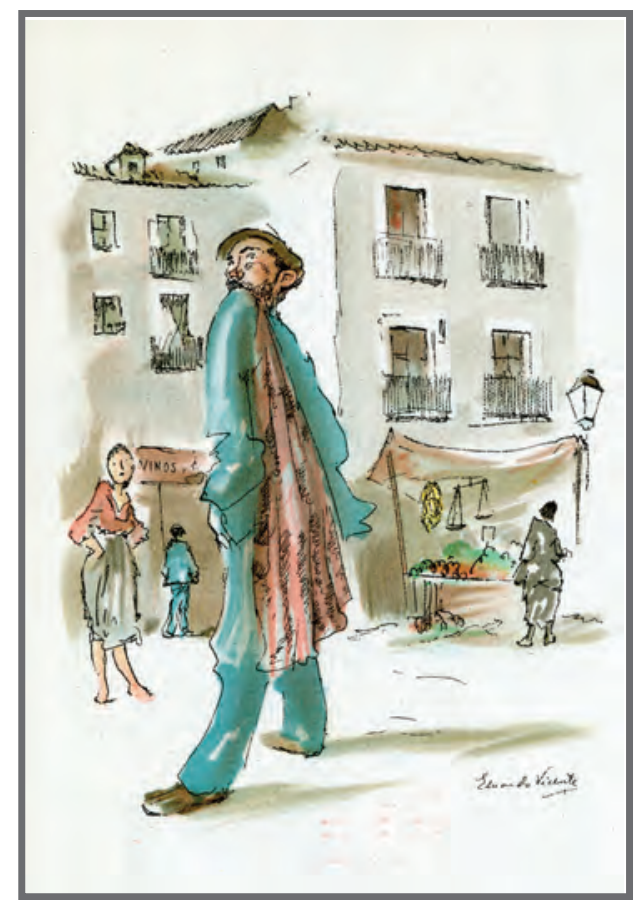

\section{CONTENIDO.}

Personajes: HOMBRES Y MUJERES

Animales: NO

Gestos Expresivos: EMOCIONES POSITIVAS

Paisajes: SI

Escenas: PROFESIONAL

Función: REPRESENTATIVA DE MODELOS SOCIALES

\section{ASPECTOS TÉCNICOS.}

Color dominante: CUATRICROMÍA

Técnica: LITOGRAFÍA

Plano de la imagen: GENERAL 


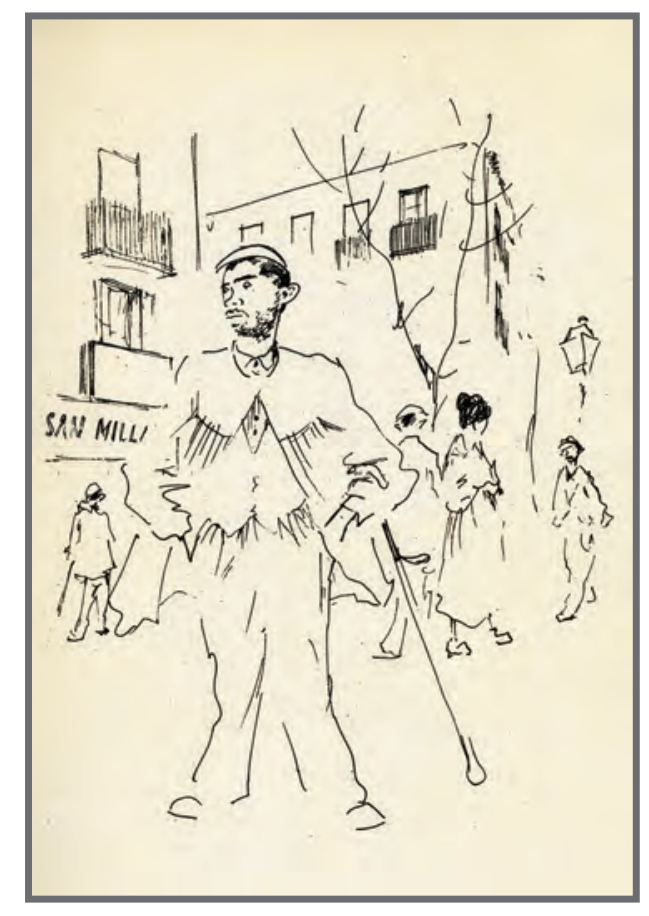

\section{VARIABLES EXTERNAS.}

Título: Un tratante

Año: 1950

Página: 35

\section{TIPO DE IMAGEN.}

Retrato: NO

Cartel: NO

Mural: NO

Ilustración: SI

Otras Obras: NO

\section{CONTENIDO.}

Personajes: HOMBRES Y MUJER

Animales: NO

Gestos Expresivos: EMOCIONES POSITIVAS

Paisajes: SI

Escenas: PROFESIONAL

Función: REPRESENTATIVA DE MODELOS SOCIALES

\section{ASPECTOS TÉCNICOS.}

Color dominante: 1 TINTA

Técnica: LITOGRAFÍA

Plano de la imagen: GENERAL 


\section{VARIABLES EXTERNAS.}

Título: Un tratante

Año: 1950

Página: 37

\section{TIPO DE IMAGEN.}

Retrato: NO

Cartel: NO

Mural: NO

Ilustración: SI

Otras Obras: NO

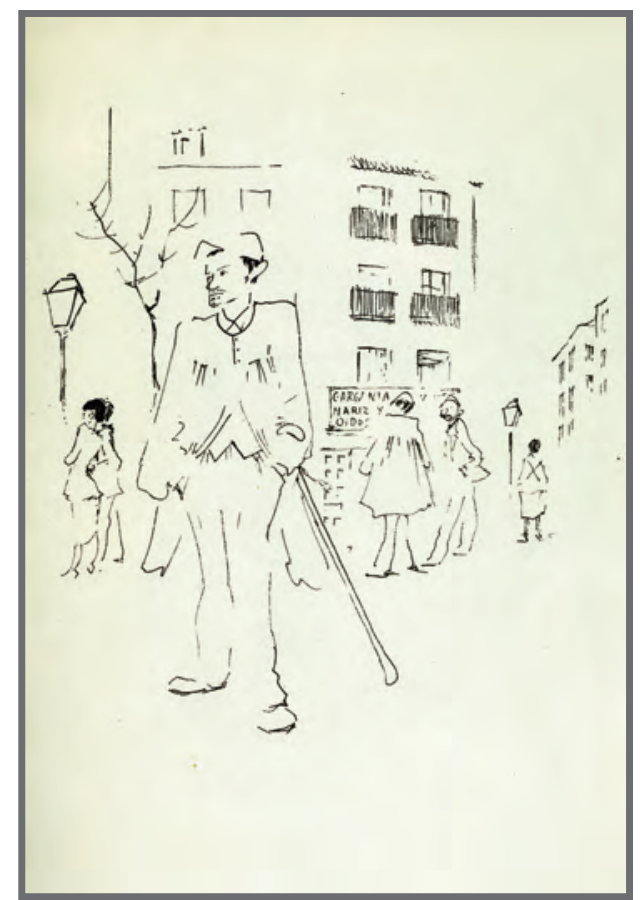

\section{CONTENIDO.}

Personajes: HOMBRES Y MUJERES

Animales: NO

Gestos Expresivos: EMOCIONES POSITIVAS

Paisajes: SI

Escenas: PROFESIONAL

Función: REPRESENTATIVA DE MODELOS SOCIALES

\section{ASPECTOS TÉCNICOS.}

Color dominante: 1 TINTA

Técnica: LITOGRAFÍA

Plano de la imagen: GENERAL 


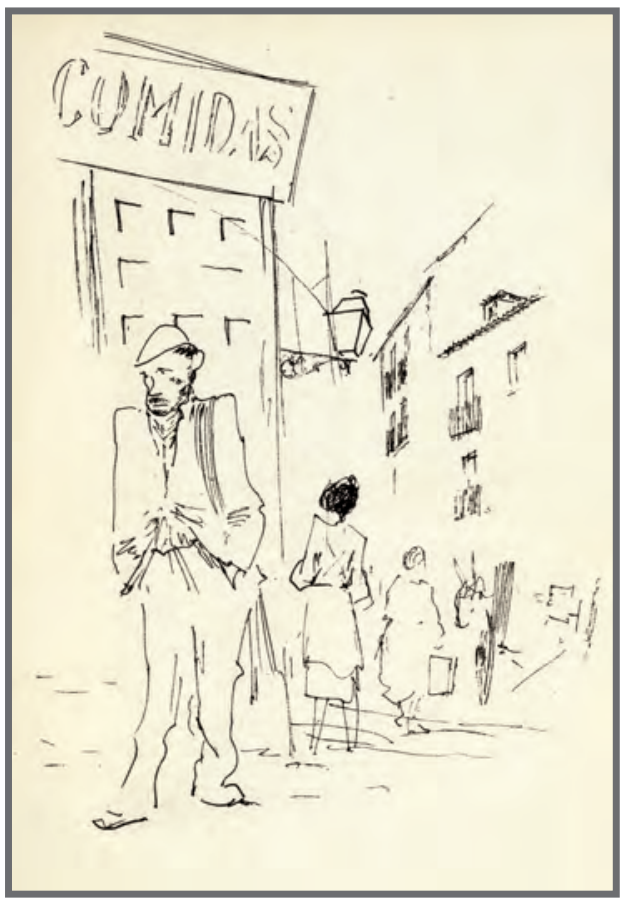

\section{VARIABLES EXTERNAS.}

Título: El mozo de cuerda

Año: 1950

Página: 39

\section{TIPO DE IMAGEN.}

Retrato: NO

Cartel: NO

Mural: NO

Ilustración: SI

Otras Obras: NO

\section{CONTENIDO.}

Personajes: HOMBRE Y MUJERES

Animales: NO

Gestos Expresivos: EMOCIONES POSITIVAS

Paisajes: SI

Escenas: CALLEJERAS

Función: REPRESENTATIVA DE MODELOS SOCIALES

\section{ASPECTOS TÉCNICOS.}

Color dominante: 1 TINTA

Técnica: LITOGRAFÍA

Plano de la imagen: GENERAL 


\section{VARIABLES EXTERNAS.}

Título: El ocioso

Año: 1950

Página: 41

\section{TIPO DE IMAGEN.}

Retrato: NO

Cartel: NO

Mural: NO

Ilustración: SI

Otras Obras: NO

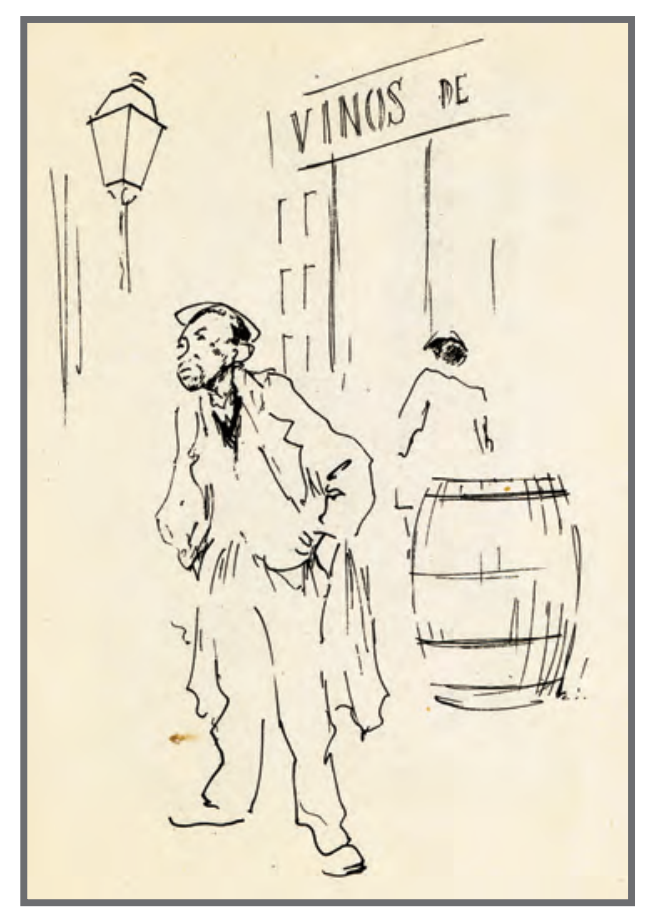

\section{CONTENIDO.}

Personajes: HOMBRES

Animales: NO

Gestos Expresivos: EMOCIONES NEGATIVAS

Paisajes: SI

Escenas: CALLEJERAS

Función: REPRESENTATIVA DE MODELOS SOCIALES

\section{ASPECTOS TÉCNICOS.}

Color dominante: 1 TINTA

Técnica: LITOGRAFÍA

Plano de la imagen: GENERAL 


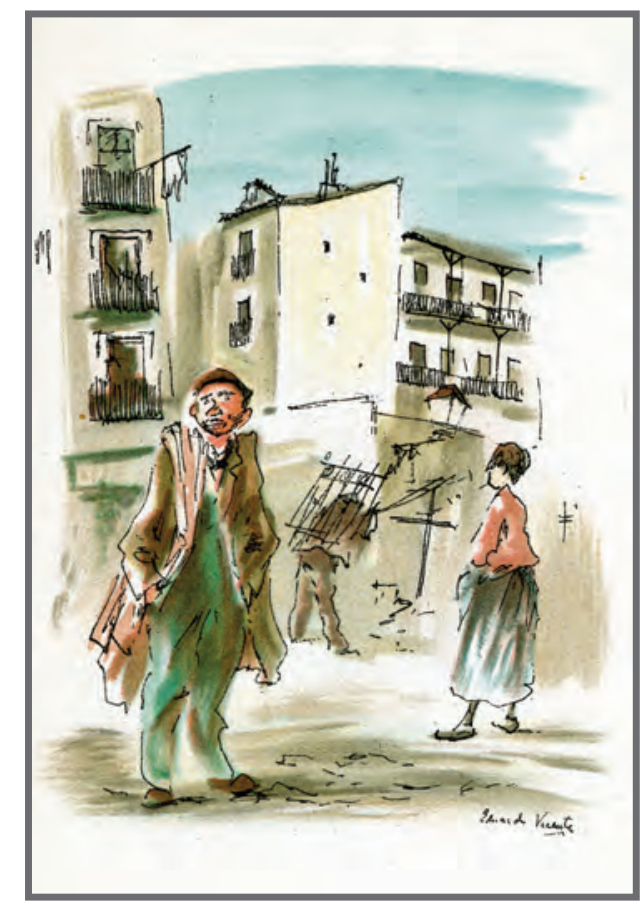

\section{VARIABLES EXTERNAS.}

Título: Un trapero

Año: 1950

Página: 43

\section{TIPO DE IMAGEN.}

Retrato: NO

Cartel: NO

Mural: NO

Ilustración: SI

Otras Obras: NO

\section{CONTENIDO.}

Personajes: HOMBRES Y MUJERES

Animales: NO

Gestos Expresivos: EMOCIONES POSITIVAS

Paisajes: SI

Escenas: PROFESIONAL

Función: REPRESENTATIVA DE MODELOS SOCIALES

\section{ASPECTOS TÉCNICOS.}

Color dominante: CUATRICROMÍA

Técnica: LITOGRAFÍA

Plano de la imagen: GENERAL 


\section{VARIABLES EXTERNAS.}

Título: Un tratante de ganado

Año: 1950

Página: 45

\section{TIPO DE IMAGEN.}

Retrato: NO

Cartel: NO

Mural: NO

Ilustración: SI

Otras Obras: NO

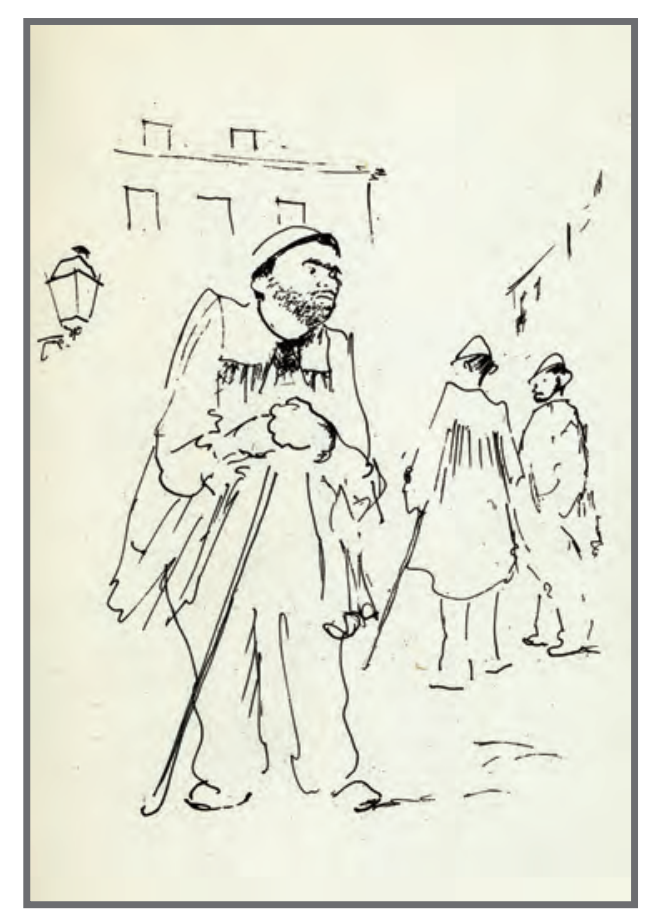

\section{CONTENIDO.}

Personajes: HOMBRES

Animales: NO

Gestos Expresivos: EMOCIONES POSITIVAS

Paisajes: SI

Escenas: PROFESIONAL

Función: REPRESENTATIVA DE MODELOS SOCIALES

\section{ASPECTOS TÉCNICOS.}

Color dominante: 1 TINTA

Técnica: LITOGRAFÍA

Plano de la imagen: GENERAL 


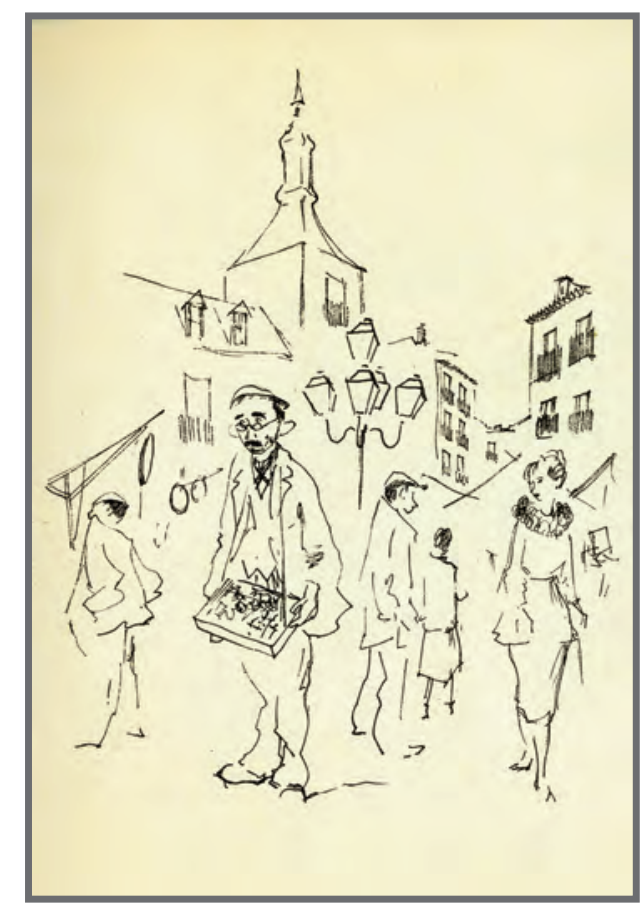

\section{VARIABLES EXTERNAS.}

Título: Plaza de Santa Cruz

Año: 1950

Página: 47

\section{TIPO DE IMAGEN.}

Retrato: NO

Cartel: NO

Mural: NO

Ilustración: SI

Otras Obras: NO

\section{CONTENIDO.}

Personajes: HOMBRES Y MUJERES

Animales: NO

Gestos Expresivos: EMOCIONES POSITIVAS

Paisajes: SI

Escenas: PROFESIONAL

Función: REPRESENTATIVA DE MODELOS SOCIALES

\section{ASPECTOS TÉCNICOS.}

Color dominante: 1 TINTA

Técnica: LITOGRAFÍA

Plano de la imagen: GENERAL 


\section{VARIABLES EXTERNAS.}

Título: Pirulís

Año: 1950

Página: 49

\section{TIPO DE IMAGEN.}

Retrato: NO

Cartel: NO

Mural: NO

Ilustración: SI

Otras Obras: NO

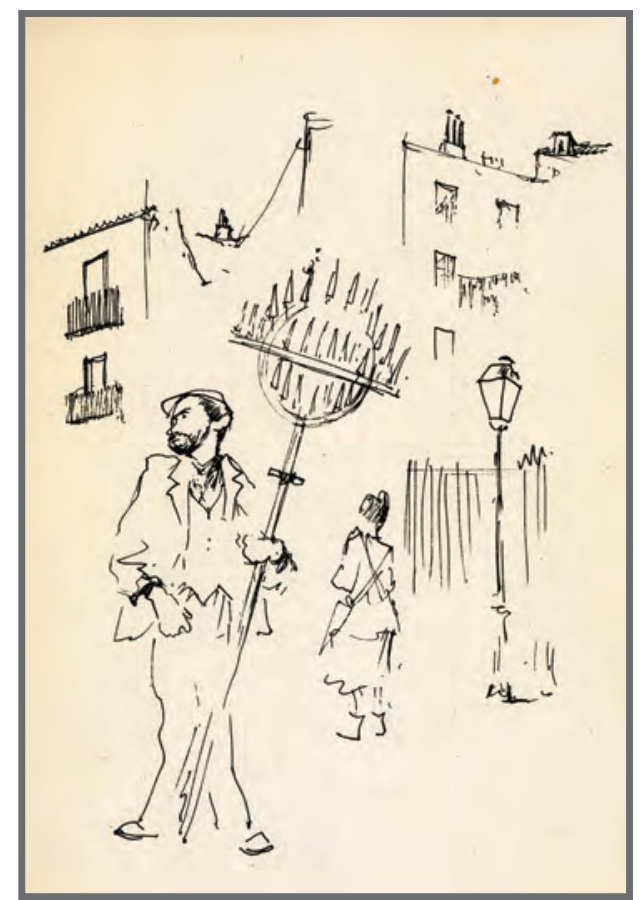

\section{CONTENIDO.}

Personajes: HOMBRE Y MUJER

Animales: NO

Gestos Expresivos: EMOCIONES POSITIVAS

Paisajes: SI

Escenas: PROFESIONAL

Función: REPRESENTATIVA DE MODELOS SOCIALES

\section{ASPECTOS TÉCNICOS.}

Color dominante: 1 TINTA

Técnica: LITOGRAFÍA

Plano de la imagen: GENERAL 


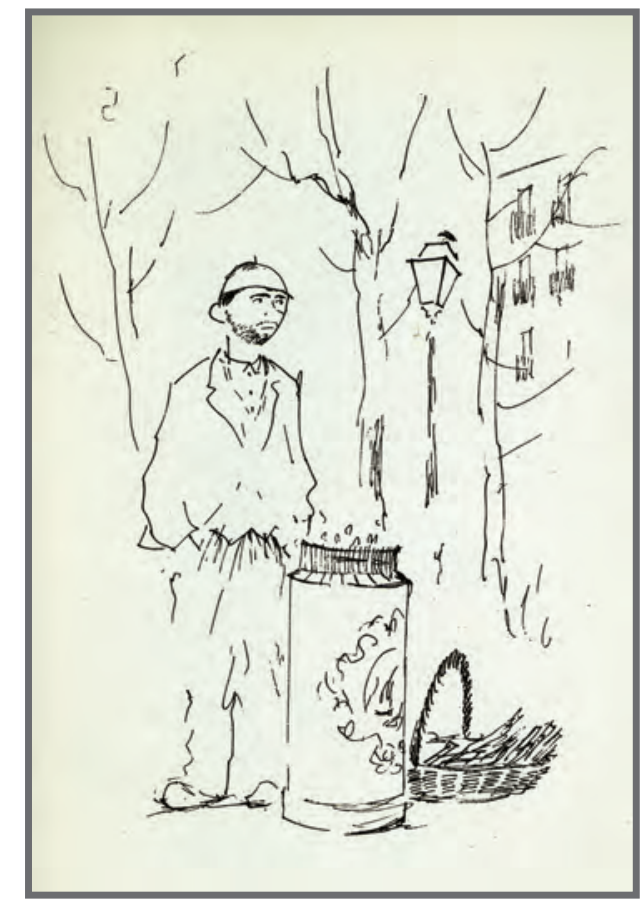

\section{VARIABLES EXTERNAS.}

Título: El barquillero

Año: 1950

Página: 51

\section{TIPO DE IMAGEN.}

Retrato: NO

Cartel: NO

Mural: NO

Ilustración: SI

Otras Obras: NO

\section{CONTENIDO.}

Personajes: HOMBRE

Animales: NO

Gestos Expresivos: EMOCIONES POSITIVAS

Paisajes: SI

Escenas: PROFESIONAL

Función: REPRESENTATIVA DE MODELOS SOCIALES

\section{ASPECTOS TÉCNICOS.}

Color dominante: 1 TINTA

Técnica: LITOGRAFÍA

Plano de la imagen: GENERAL 


\section{VARIABLES EXTERNAS.}

Título: Navidad

Año: 1950

Página: 53

\section{TIPO DE IMAGEN.}

Retrato: NO

Cartel: NO

Mural: NO

Ilustración: SI

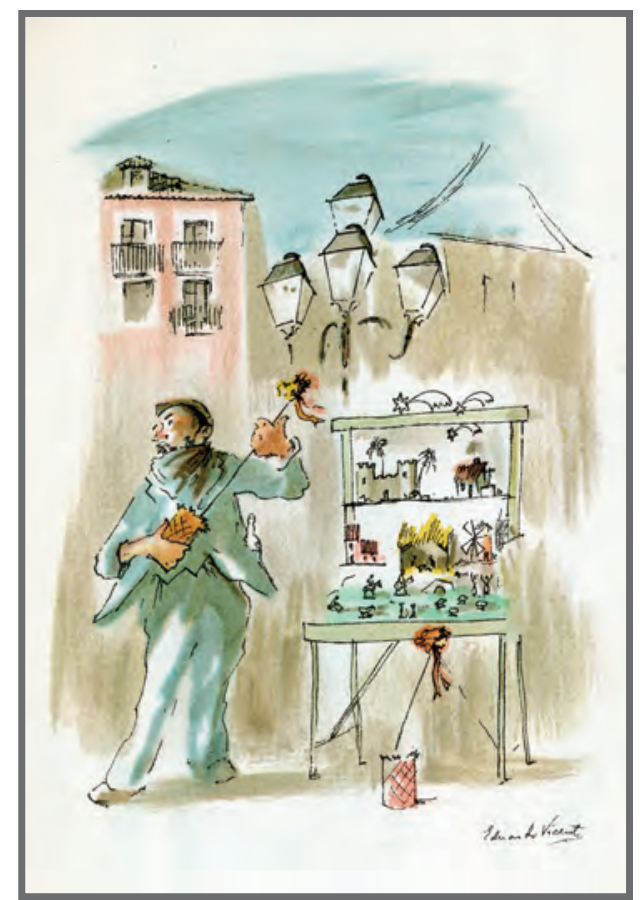

Otras Obras: NO

\section{CONTENIDO.}

Personajes: HOMBRE

Animales: NO

Gestos Expresivos: EMOCIONES POSITIVAS

Paisajes: SI

Escenas: PROFESIONAL

Función: REPRESENTATIVA DE MODELOS SOCIALES

\section{ASPECTOS TÉCNICOS.}

Color dominante: CUATRICROMÍA

Técnica: LITOGRAFÍA

Plano de la imagen: GENERAL 


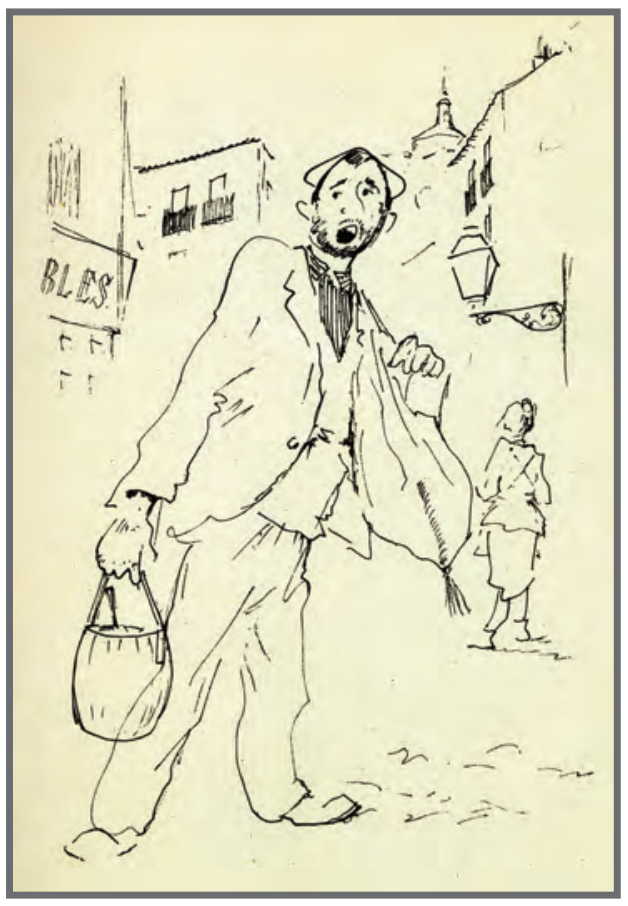

\section{VARIABLES EXTERNAS.}

Título: El mielero

Año: 1950

Página: 55

\section{TIPO DE IMAGEN.}

Retrato: NO

Cartel: NO

Mural: NO

Ilustración: SI

Otras Obras: NO

\section{CONTENIDO.}

Personajes: HOMBRE Y MUJER

Animales: NO

Gestos Expresivos: EMOCIONES POSITIVAS

Paisajes: SI

Escenas: PROFESIONAL

Función: REPRESENTATIVA DE MODELOS SOCIALES

\section{ASPECTOS TÉCNICOS.}

Color dominante: 1 TINTA

Técnica: LITOGRAFÍA

Plano de la imagen: GENERAL 


\section{VARIABLES EXTERNAS.}

Título: El quesero

Año: 1950

Página: 57

\section{TIPO DE IMAGEN.}

Retrato: NO

Cartel: NO

Mural: NO

Ilustración: SI

Otras Obras: NO

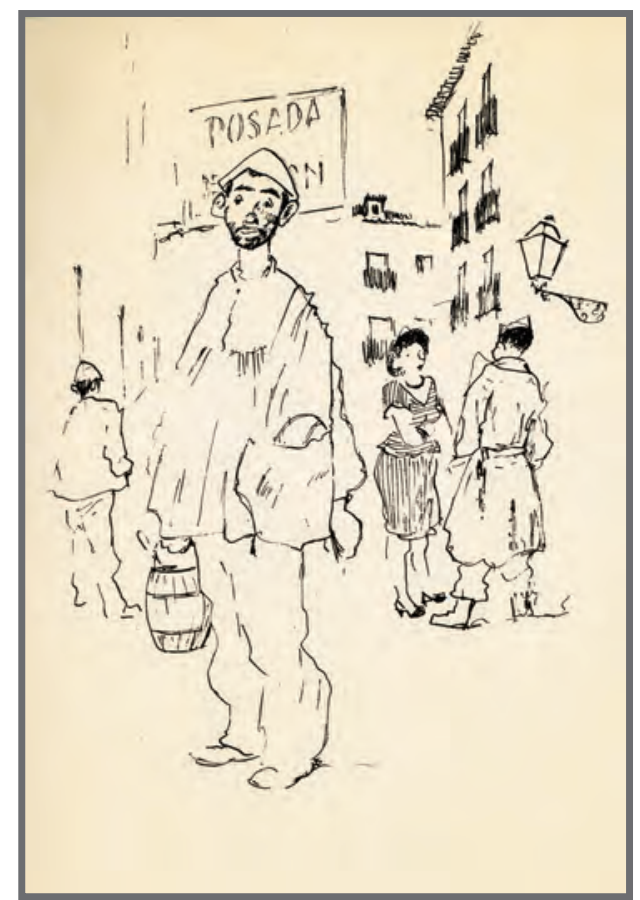

\section{CONTENIDO.}

Personajes: HOMBRES Y MUJER

Animales: NO

Gestos Expresivos: EMOCIONES POSITIVAS

Paisajes: SI

Escenas: PROFESIONAL

Función: REPRESENTATIVA DE MODELOS SOCIALES

\section{ASPECTOS TÉCNICOS.}

Color dominante: 1 TINTA

Técnica: LITOGRAFÍA

Plano de la imagen: GENERAL 


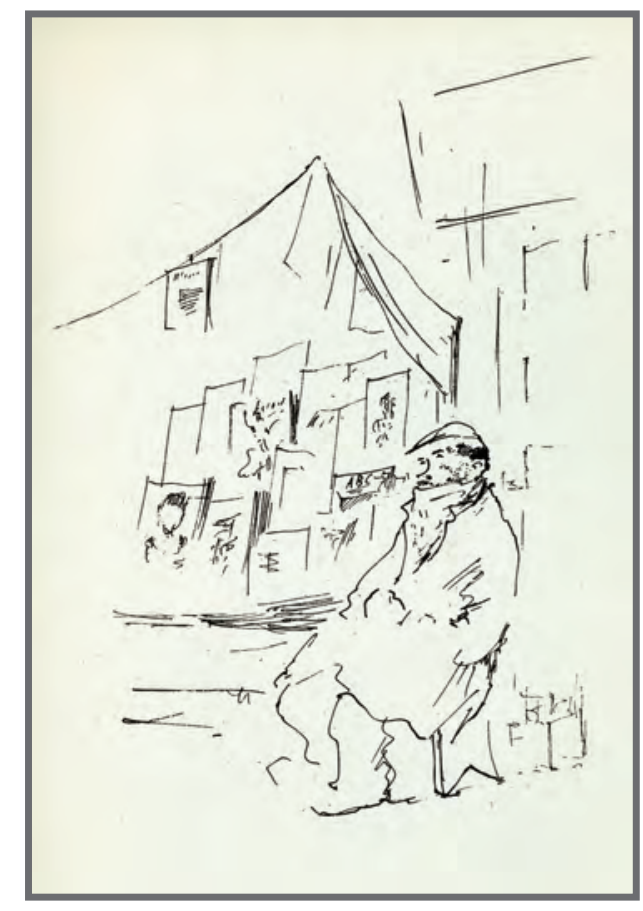

\section{VARIABLES EXTERNAS.}

Título: Novelas y cuentos

Año: 1950

Página: 59

\section{TIPO DE IMAGEN.}

Retrato: NO

Cartel: NO

Mural: NO

Ilustración: SI

Otras Obras: NO

\section{CONTENIDO.}

Personajes: HOMBRE

Animales: NO

Gestos Expresivos: EMOCIONES POSITIVAS

Paisajes: NO

Escenas: PROFESIONAL

Función: REPRESENTATIVA DE MODELOS SOCIALES

\section{ASPECTOS TÉCNICOS.}

Color dominante: 1 TINTA

Técnica: LITOGRAFÍA

Plano de la imagen: GENERAL 


\section{VARIABLES EXTERNAS.}

Título: Vendedor de coplas

Año: 1950

Página: 61

\section{TIPO DE IMAGEN.}

Retrato: NO

Cartel: NO

Mural: NO

Ilustración: SI

Otras Obras: NO

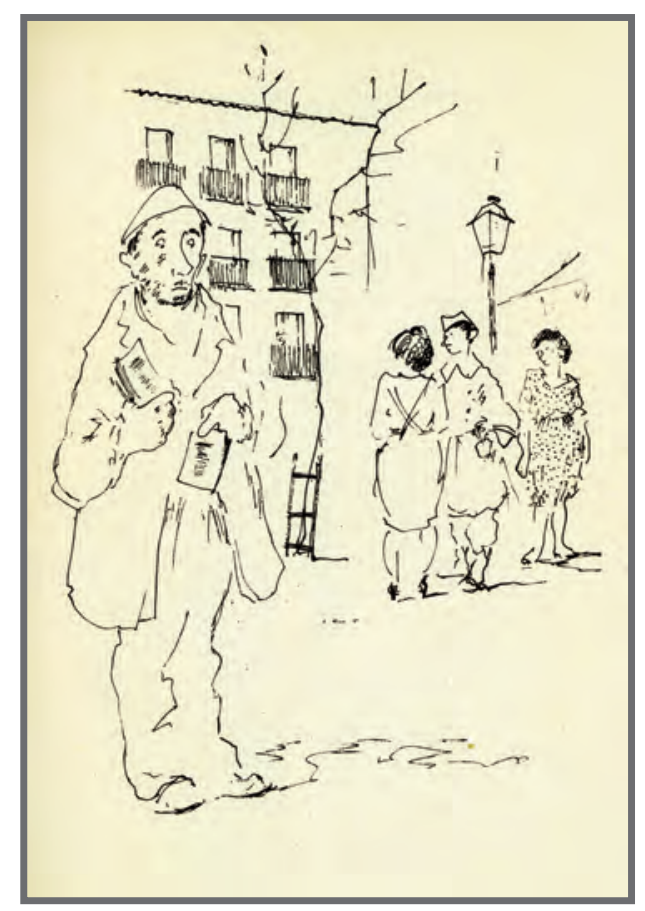

\section{CONTENIDO.}

Personajes: HOMBRE Y MUJERES

Animales: NO

Gestos Expresivos: EMOCIONES POSITIVAS

Paisajes: SI

Escenas: PROFESIONAL

Función: REPRESENTATIVA DE MODELOS SOCIALES

\section{ASPECTOS TÉCNICOS.}

Color dominante: 1 TINTA

Técnica: LITOGRAFÍA

Plano de la imagen: GENERAL 


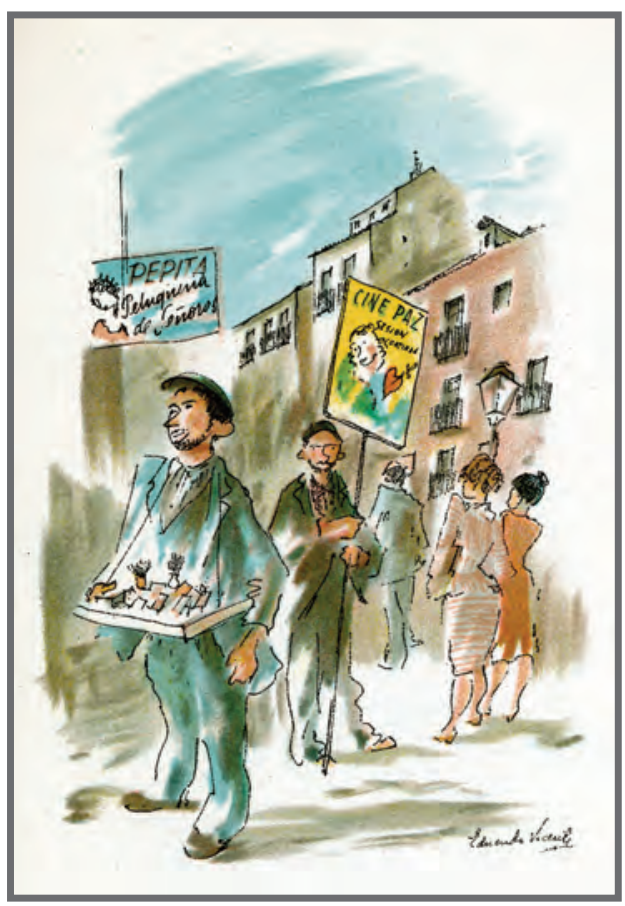

\section{VARIABLES EXTERNAS.}

Título: Vendedor ambulante

Año: 1950

Página: 63

\section{TIPO DE IMAGEN.}

Retrato: NO

Cartel: NO

Mural: NO

Ilustración: SI

Otras Obras: NO

\section{CONTENIDO.}

Personajes: HOMBRES Y MUJERES

Animales: NO

Gestos Expresivos: EMOCIONES POSITIVAS

Paisajes: SI

Escenas: PROFESIONAL

Función: REPRESENTATIVA DE MODELOS SOCIALES

\section{ASPECTOS TÉCNICOS.}

Color dominante: CUATRICROMÍA

Técnica: LITOGRAFÍA

Plano de la imagen: GENERAL 


\section{VARIABLES EXTERNAS.}

Título: Gente de la Puerta del Sol

Año: 1950

Página: 65

\section{TIPO DE IMAGEN.}

Retrato: NO

Cartel: NO

Mural: NO

Ilustración: SI

Otras Obras: NO

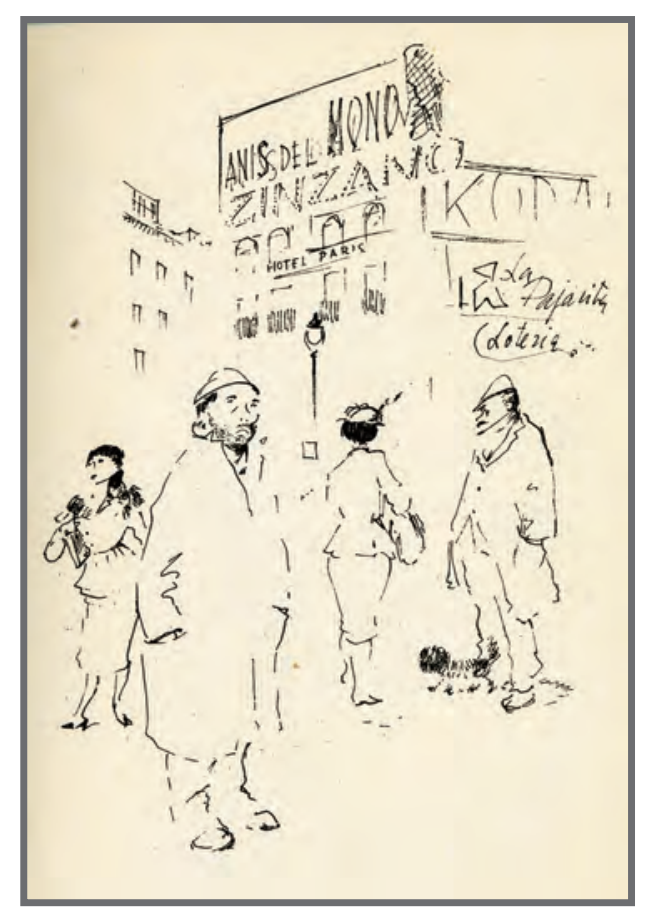

\section{CONTENIDO.}

Personajes: HOMBRES Y MUJERES

Animales: NO

Gestos Expresivos: EMOCIONES POSITIVAS

Paisajes: SI

Escenas: CALLEJERAS

Función: REPRESENTATIVA DE MODELOS SOCIALES

\section{ASPECTOS TÉCNICOS.}

Color dominante: 1 TINTA

Técnica: LITOGRAFÍA

Plano de la imagen: GENERAL 


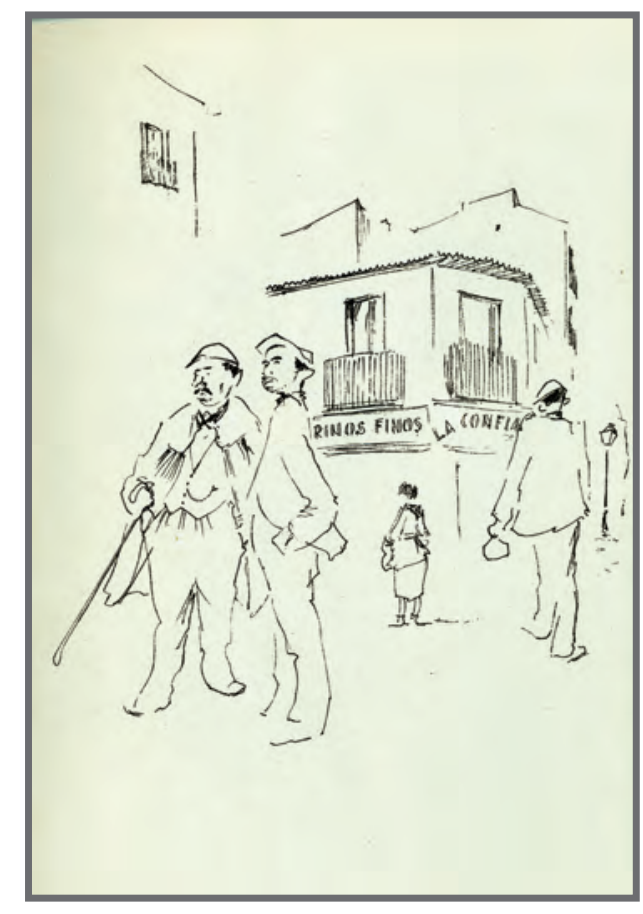

\section{VARIABLES EXTERNAS.}

Título: Vallecas

Año: 1950

Página: 67

\section{TIPO DE IMAGEN.}

Retrato: NO

Cartel: NO

Mural: NO

Ilustración: SI

Otras Obras: NO

\section{CONTENIDO.}

Personajes: HOMBRES Y MUJER

Animales: NO

Gestos Expresivos: EMOCIONES POSITIVAS

Paisajes: SI

Escenas: CALLEJERAS

Función: REPRESENTATIVA DE MODELOS SOCIALES

\section{ASPECTOS TÉCNICOS.}

Color dominante: 1 TINTA

Técnica: LITOGRAFÍA

Plano de la imagen: GENERAL 


\section{VARIABLES EXTERNAS.}

Título: El aprendiz de vidriero

Año: 1950

Página: 69

\section{TIPO DE IMAGEN.}

Retrato: NO

Cartel: NO

Mural: NO

Ilustración: SI

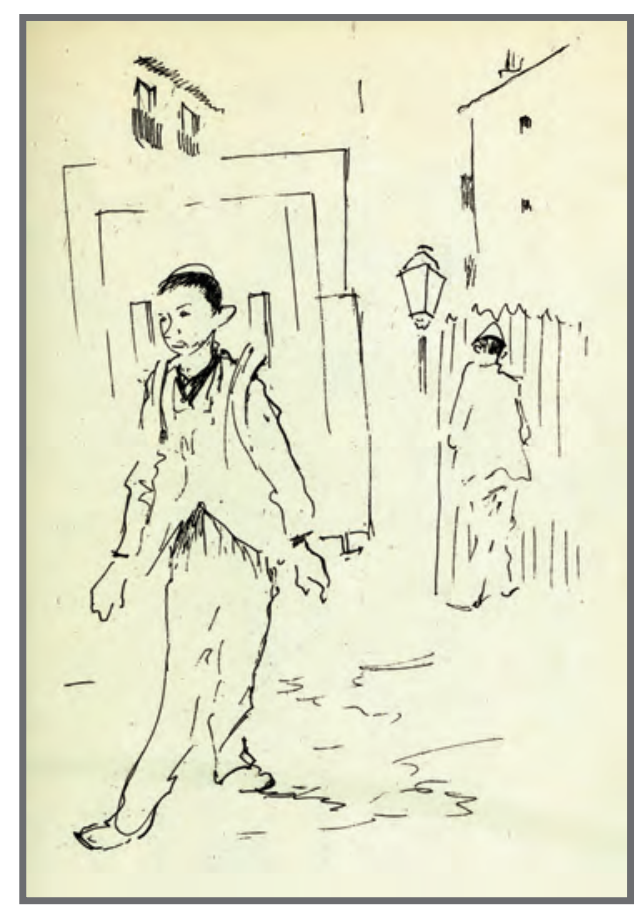

Otras Obras: NO

\section{CONTENIDO.}

Personajes: HOMBRES

Animales: NO

Gestos Expresivos: EMOCIONES POSITIVAS

Paisajes: SI

Escenas: PROFESIONAL

Función: REPRESENTATIVA DE MODELOS SOCIALES

\section{ASPECTOS TÉCNICOS.}

Color dominante: 1 TINTA

Técnica: LITOGRAFÍA

Plano de la imagen: GENERAL 


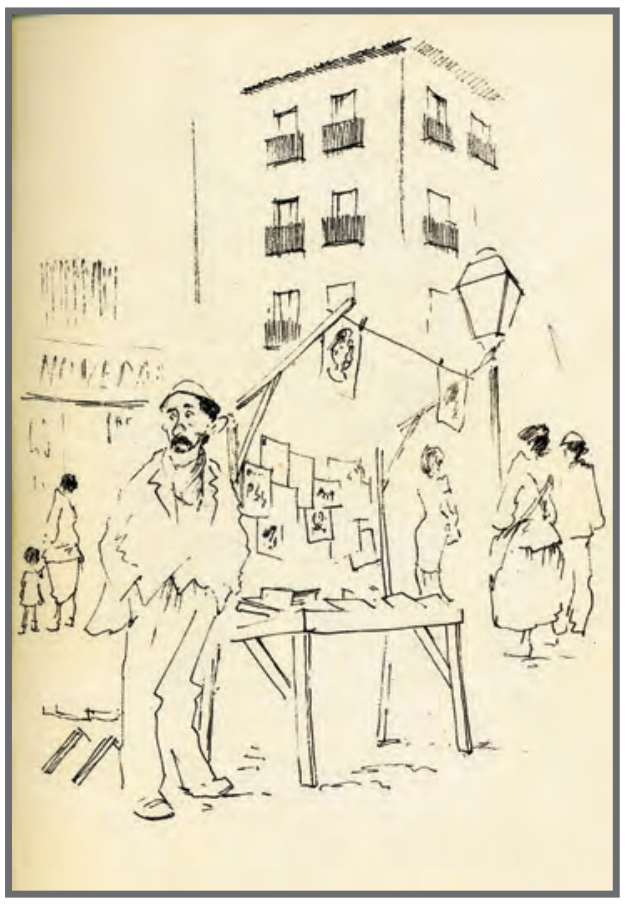

\section{VARIABLES EXTERNAS.}

Título: Novelas y cuentos

Año: 1950

Página: 71

\section{TIPO DE IMAGEN.}

Retrato: NO

Cartel: NO

Mural: NO

Ilustración: SI

Otras Obras: NO

\section{CONTENIDO.}

Personajes: HOMBRES, MUJERES Y NIÑA

Animales: NO

Gestos Expresivos: EMOCIONES POSITIVAS

Paisajes: SI

Escenas: PROFESIONAL

Función: REPRESENTATIVA DE MODELOS SOCIALES

\section{ASPECTOS TÉCNICOS.}

Color dominante: 1 TINTA

Técnica: LITOGRAFÍA

Plano de la imagen: GENERAL 


\section{VARIABLES EXTERNAS.}

Título: Gente del rastro

Año: 1950

Página: 73

TIPO DE IMAGEN.

Retrato: NO

Cartel: NO

Mural: NO

Ilustración: SI

Otras Obras: NO

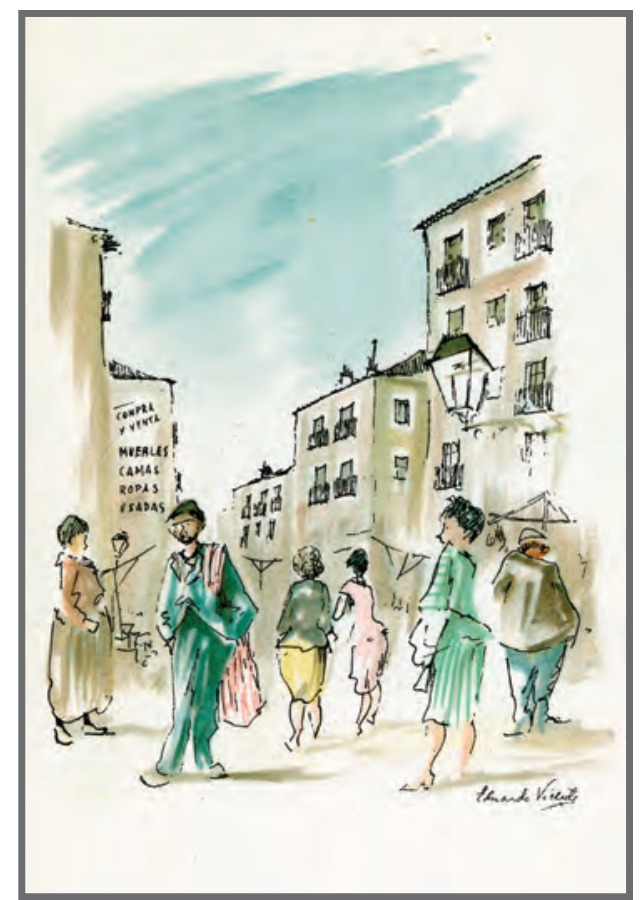

\section{CONTENIDO.}

Personajes: HOMBRES Y MUJERES

Animales: NO

Gestos Expresivos: EMOCIONES POSITIVAS

Paisajes: SI

Escenas: CALLEJERAS

Función: REPRESENTATIVA DE MODELOS SOCIALES

\section{ASPECTOS TÉCNICOS.}

Color dominante: CUATRICROMÍA

Técnica: LITOGRAFÍA

Plano de la imagen: GENERAL 


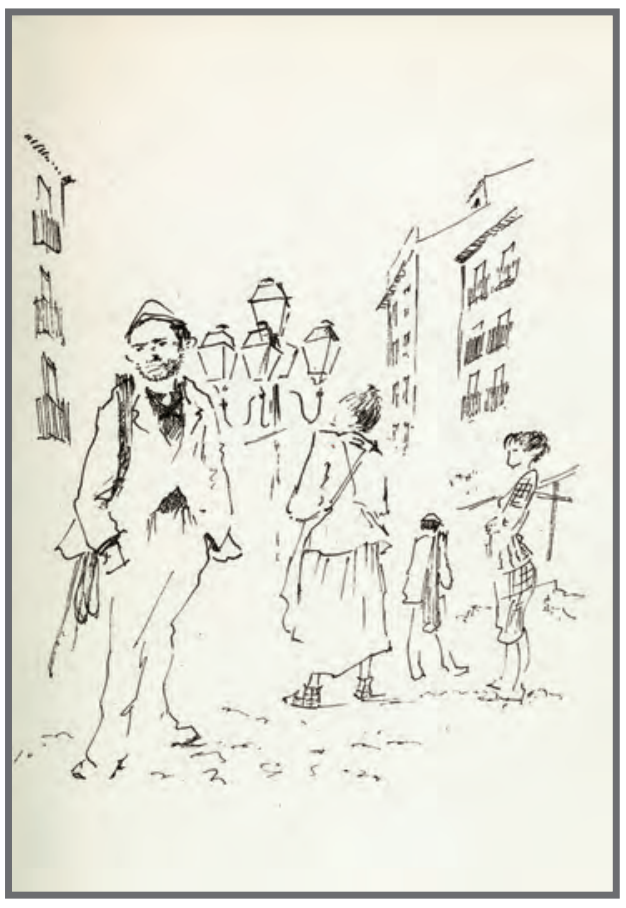

\section{VARIABLES EXTERNAS.}

Título: Cabecera del rastro

Año: 1950

Página: 75

\section{TIPO DE IMAGEN.}

Retrato: NO

Cartel: NO

Mural: NO

Ilustración: SI

Otras Obras: NO

\section{CONTENIDO.}

Personajes: HOMBRES Y MUJERES

Animales: NO

Gestos Expresivos: EMOCIONES POSITIVAS

Paisajes: SI

Escenas: CALLEJERAS

Función: REPRESENTATIVA DE MODELOS SOCIALES

\section{ASPECTOS TÉCNICOS.}

Color dominante: 1 TINTA

Técnica: LITOGRAFÍA

Plano de la imagen: GENERAL 


\section{VARIABLES EXTERNAS.}

Título: El limpia

Año: 1950

Página: 77

\section{TIPO DE IMAGEN.}

Retrato: NO

Cartel: NO

Mural: NO

Ilustración: SI

Otras Obras: NO

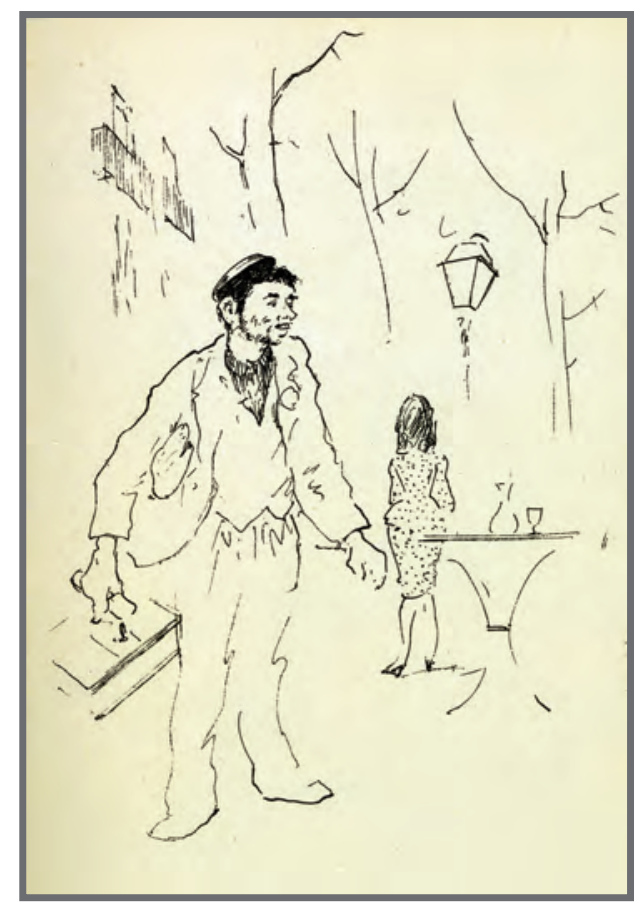

\section{CONTENIDO.}

Personajes: HOMBRE Y MUJER

Animales: NO

Gestos Expresivos: EMOCIONES POSITIVAS

Paisajes: SI

Escenas: PROFESIONAL

Función: REPRESENTATIVA DE MODELOS SOCIALES

\section{ASPECTOS TÉCNICOS.}

Color dominante: 1 TINTA

Técnica: LITOGRAFÍA

Plano de la imagen: GENERAL 


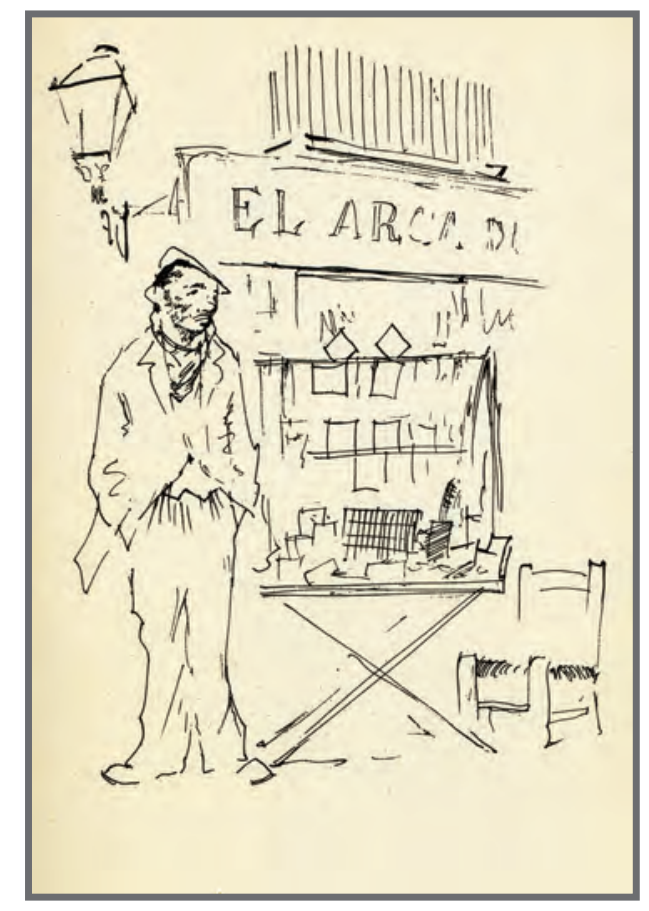

VARIABLES EXTERNAS.

Título: Un puesto en la calle Toledo

Año: 1950

Página: 79

\section{TIPO DE IMAGEN.}

Retrato: NO

Cartel: NO

Mural: NO

Ilustración: SI

Otras Obras: NO

\section{CONTENIDO.}

Personajes: HOMBRE

Animales: NO

Gestos Expresivos: EMOCIONES POSITIVAS

Paisajes: NO

Escenas: PROFESIONAL

Función: REPRESENTATIVA DE MODELOS SOCIALES

\section{ASPECTOS TÉCNICOS.}

Color dominante: 1 TINTA

Técnica: LITOGRAFÍA

Plano de la imagen: GENERAL 


\section{VARIABLES EXTERNAS.}

Título: Un puesto en el rastro

Año: 1950

Página: 81

\section{TIPO DE IMAGEN.}

Retrato: NO

Cartel: NO

Mural: NO

Ilustración: SI

Otras Obras: NO

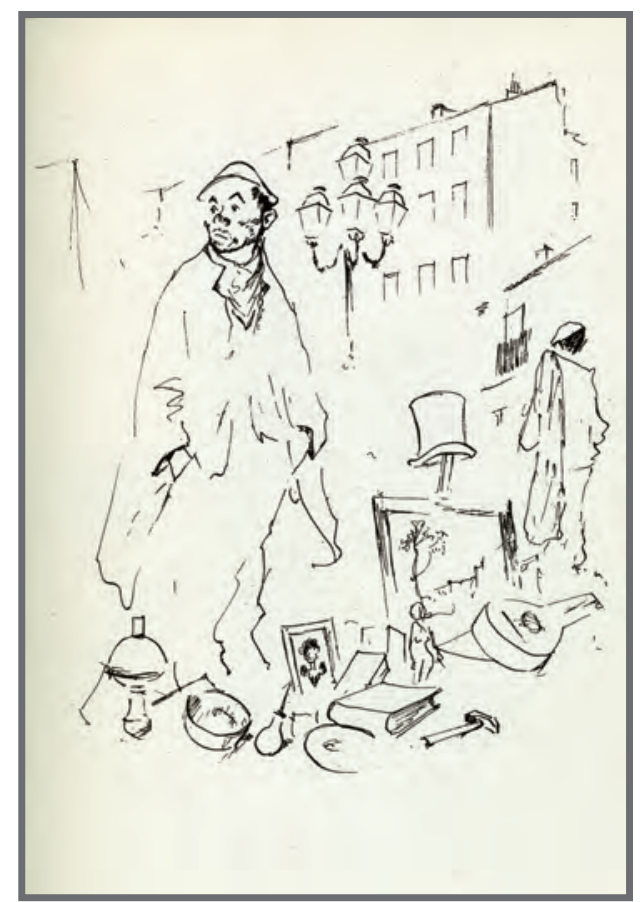

\section{CONTENIDO.}

Personajes: HOMBRES

Animales: NO

Gestos Expresivos: EMOCIONES POSITIVAS

Paisajes: SI

Escenas: PROFESIONAL

Función: REPRESENTATIVA DE MODELOS SOCIALES

\section{ASPECTOS TÉCNICOS.}

Color dominante: 1 TINTA

Técnica: LITOGRAFÍA

Plano de la imagen: GENERAL 


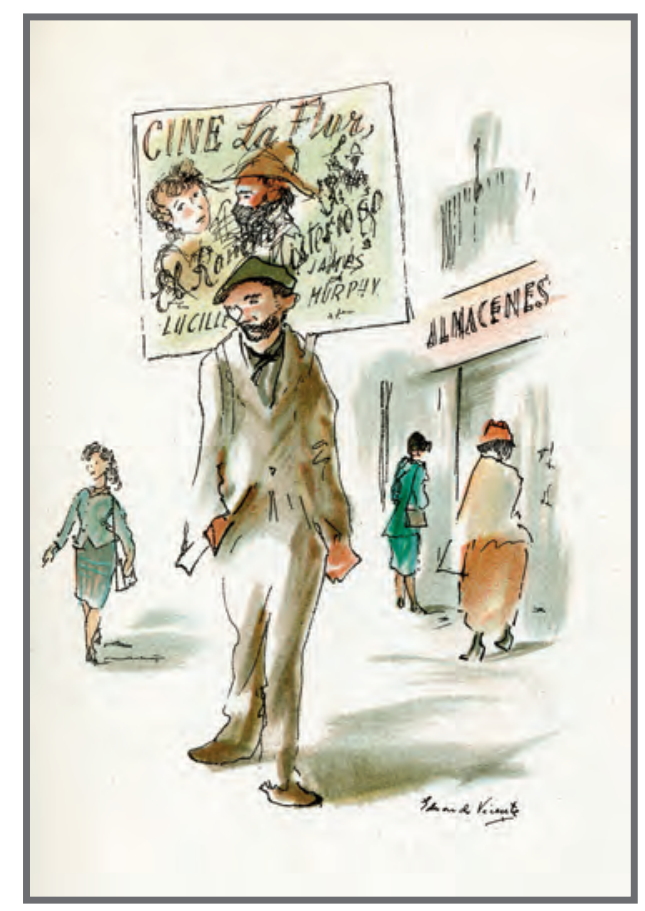

\section{VARIABLES EXTERNAS.}

Título: Hombre anuncio

Año: 1950

Página: 83

\section{TIPO DE IMAGEN.}

Retrato: NO

Cartel: NO

Mural: NO

Ilustración: SI

Otras Obras: NO

\section{CONTENIDO.}

Personajes: HOMBRE Y MUJERES

Animales: NO

Gestos Expresivos: EMOCIONES POSITIVAS

Paisajes: SI

Escenas: PROFESIONAL

Función: REPRESENTATIVA DE MODELOS SOCIALES

\section{ASPECTOS TÉCNICOS.}

Color dominante: CUATRICROMÍA

Técnica: LITOGRAFÍA

Plano de la imagen: GENERAL 


\section{VARIABLES EXTERNAS.}

Título: La prosperidad

Año: 1950

Página: 85

\section{TIPO DE IMAGEN.}

Retrato: NO

Cartel: NO

Mural: NO

Ilustración: SI

Otras Obras: NO

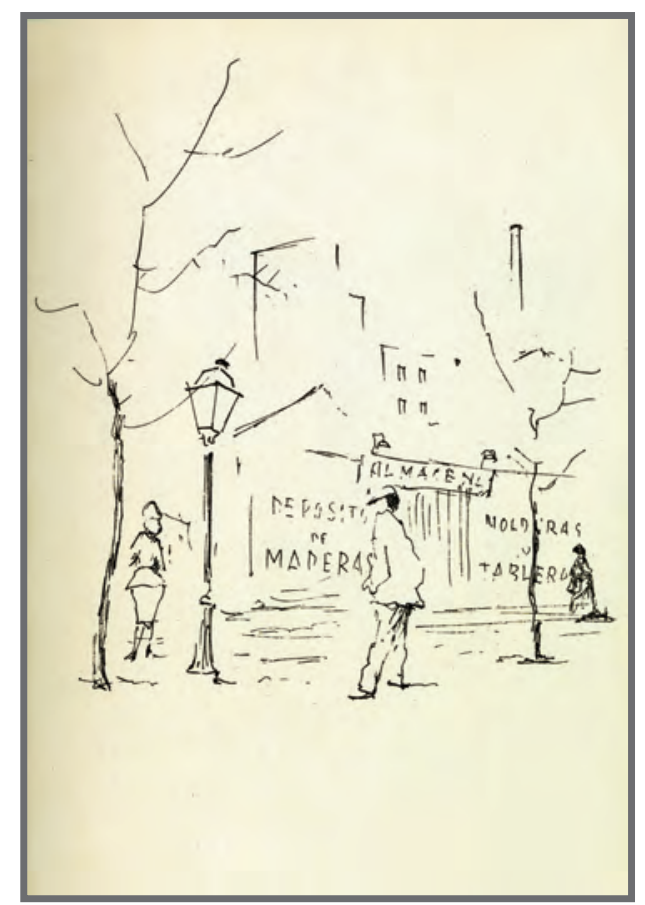

\section{CONTENIDO.}

Personajes: HOMBRE Y MUJERES

Animales: NO

Gestos Expresivos: EMOCIONES POSITIVAS

Paisajes: SI

Escenas: CALLEJERAS

Función: REPRESENTATIVA DE MODELOS SOCIALES

\section{ASPECTOS TÉCNICOS.}

Color dominante: 1 TINTA

Técnica: LITOGRAFÍA

Plano de la imagen: GENERAL 


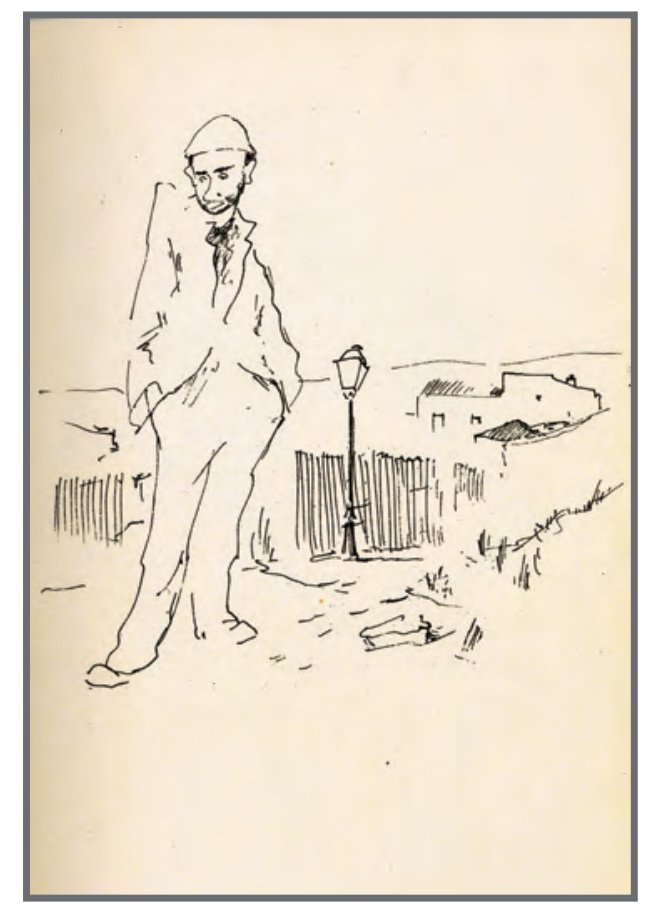

\section{VARIABLES EXTERNAS.}

Título: Un vago

Año: 1950

Página: 87

\section{TIPO DE IMAGEN.}

Retrato: NO

Cartel: NO

Mural: NO

Ilustración: SI

Otras Obras: NO

\section{CONTENIDO.}

Personajes: HOMBRE

Animales: NO

Gestos Expresivos: EMOCIONES NEGATIVAS

Paisajes: SI

Escenas: RURAL

Función: REPRESENTATIVA DE MODELOS SOCIALES

\section{ASPECTOS TÉCNICOS.}

Color dominante: 1 TINTA

Técnica: LITOGRAFÍA

Plano de la imagen: GENERAL 


\section{VARIABLES EXTERNAS.}

Título: Plaza de Lavapiés

Año: 1950

Página: 89

\section{TIPO DE IMAGEN.}

Retrato: NO

Cartel: NO

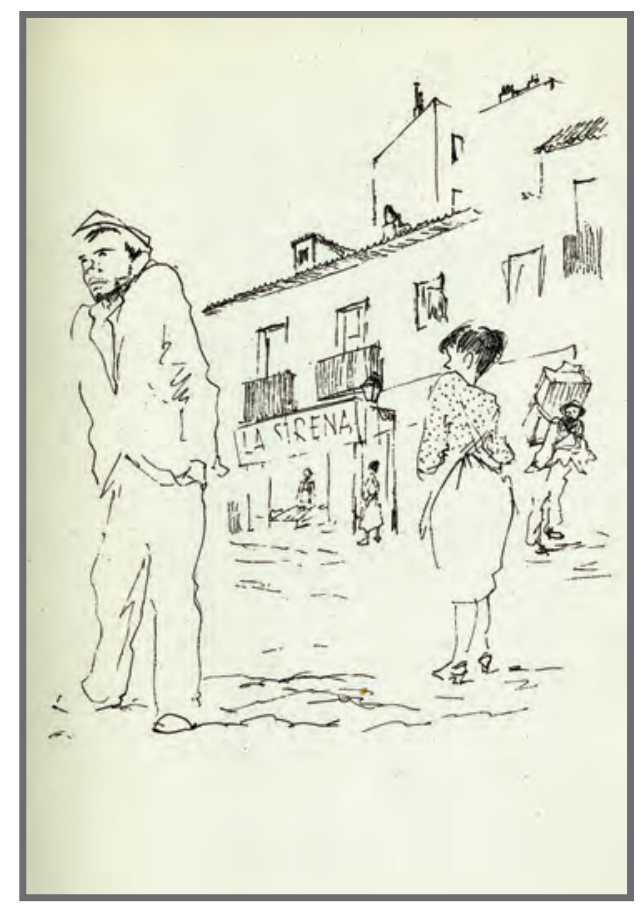

Mural: NO

Ilustración: SI

Otras Obras: NO

\section{CONTENIDO.}

Personajes: HOMBRES Y MUJERES

Animales: NO

Gestos Expresivos: EMOCIONES POSITIVAS

Paisajes: SI

Escenas: CALLEJERAS

Función: REPRESENTATIVA DE MODELOS SOCIALES

\section{ASPECTOS TÉCNICOS.}

Color dominante: 1 TINTA

Técnica: LITOGRAFÍA

Plano de la imagen: GENERAL 


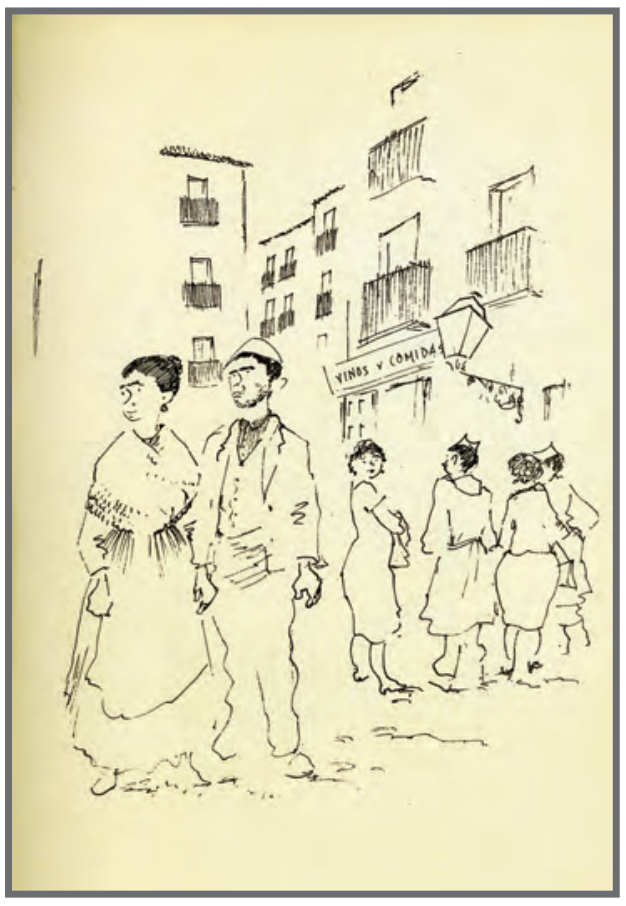

\section{VARIABLES EXTERNAS.}

Título: Caba Baja

Año: 1950

Página: 91

\section{TIPO DE IMAGEN.}

Retrato: NO

Cartel: NO

Mural: NO

Ilustración: SI

Otras Obras: NO

\section{CONTENIDO.}

Personajes: HOMBRES Y MUJERES

Animales: NO

Gestos Expresivos: EMOCIONES POSITIVAS

Paisajes: SI

Escenas: CALLEJERAS

Función: REPRESENTATIVA DE MODELOS SOCIALES

\section{ASPECTOS TÉCNICOS.}

Color dominante: 1 TINTA

Técnica: LITOGRAFÍA

Plano de la imagen: GENERAL 


\section{VARIABLES EXTERNAS.}

Título: Mujeres de aire libre

Año: 1950

Página: 93

\section{TIPO DE IMAGEN.}

Retrato: NO

Cartel: NO

Mural: NO

Ilustración: SI

Otras Obras: NO

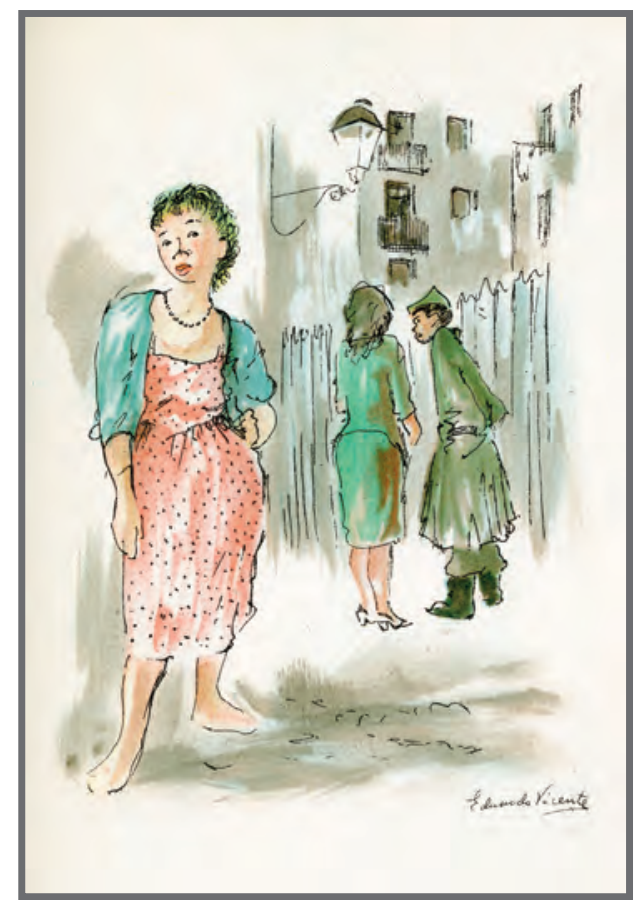

\section{CONTENIDO.}

Personajes: HOMBRE Y MUJERES

Animales: NO

Gestos Expresivos: EMOCIONES NEGATIVAS

Paisajes: SI

Escenas: CALLEJERAS

Función: REPRESENTATIVA DE MODELOS SOCIALES

\section{ASPECTOS TÉCNICOS.}

Color dominante: CUATRICROMÍA

Técnica: LITOGRAFÍA

Plano de la imagen: GENERAL 


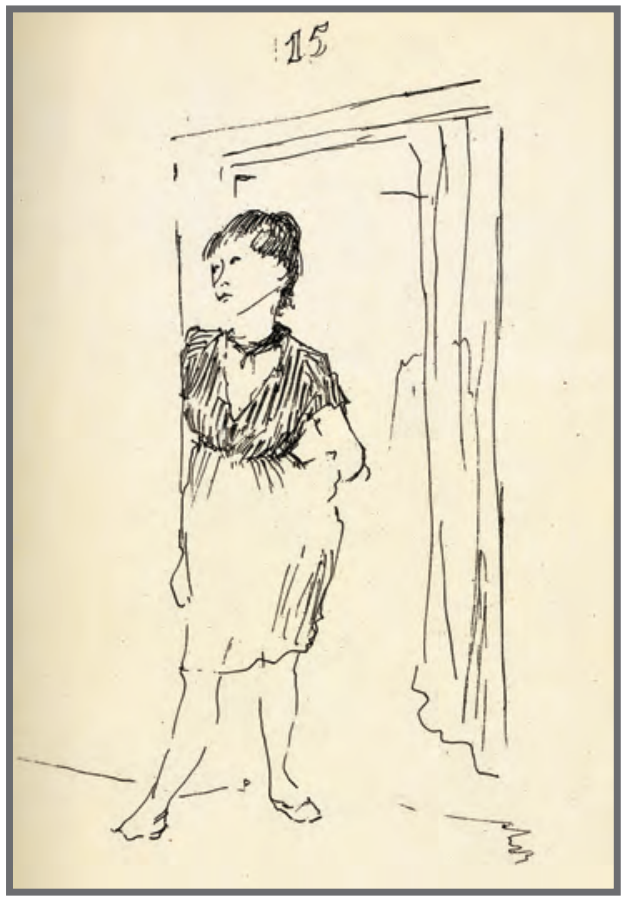

VARIABLES EXTERNAS.

Título: Esperando

Año: 1950

Página: 95

TIPO DE IMAGEN.

Retrato: NO

Cartel: NO

Mural: NO

Ilustración: SI

Otras Obras: NO

\section{CONTENIDO.}

Personajes: MUJER

Animales: NO

Gestos Expresivos: EMOCIONES NEGATIVAS

Paisajes: NO

Escenas: INTERIOR

Función: REPRESENTATIVA DE MODELOS SOCIALES

\section{ASPECTOS TÉCNICOS.}

Color dominante: 1 TINTA

Técnica: LITOGRAFÍA

Plano de la imagen: GENERAL 


\section{VARIABLES EXTERNAS.}

Título: La pipera

Año: 1950

Página: 97

\section{TIPO DE IMAGEN.}

Retrato: NO

Cartel: NO

Mural: NO

Ilustración: SI

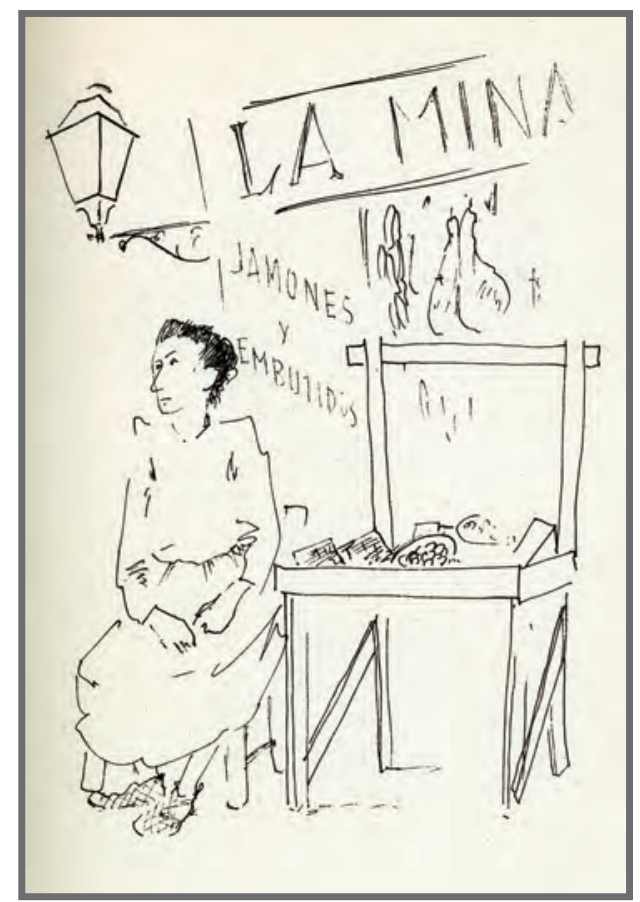

Otras Obras: NO

\section{CONTENIDO.}

Personajes: MUJER

Animales: NO

Gestos Expresivos: EMOCIONES POSITIVAS

Paisajes: NO

Escenas: PROFESIONAL

Función: REPRESENTATIVA DE MODELOS SOCIALES

\section{ASPECTOS TÉCNICOS.}

Color dominante: 1 TINTA

Técnica: LITOGRAFÍA

Plano de la imagen: GENERAL 


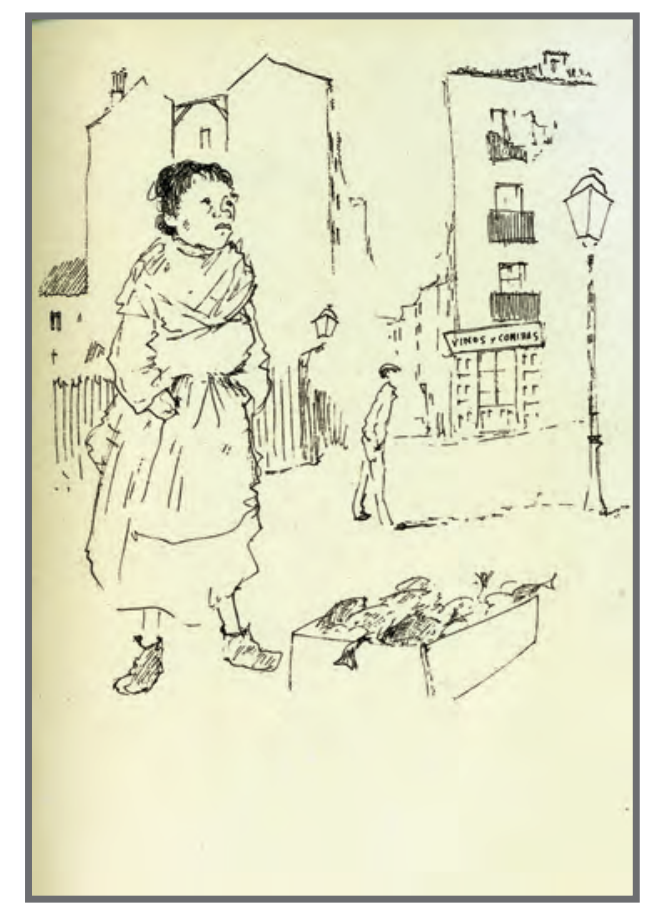

\section{VARIABLES EXTERNAS.}

Título: Puerta de Toledo

Año: 1950

Página: 99

\section{TIPO DE IMAGEN.}

Retrato: NO

Cartel: NO

Mural: NO

Ilustración: SI

Otras Obras: NO

\section{CONTENIDO.}

Personajes: HOMBRE Y MUJER

Animales: NO

Gestos Expresivos: EMOCIONES POSITIVAS

Paisajes: SI

Escenas: PROFESIONAL

Función: REPRESENTATIVA DE MODELOS SOCIALES

\section{ASPECTOS TÉCNICOS.}

Color dominante: 1 TINTA

Técnica: LITOGRAFÍA

Plano de la imagen: GENERAL 


\section{VARIABLES EXTERNAS.}

Título: Calle de la Esgrima

Año: 1950

Página: 101

\section{TIPO DE IMAGEN.}

Retrato: NO

Cartel: NO

Mural: NO

Ilustración: SI

Otras Obras: NO

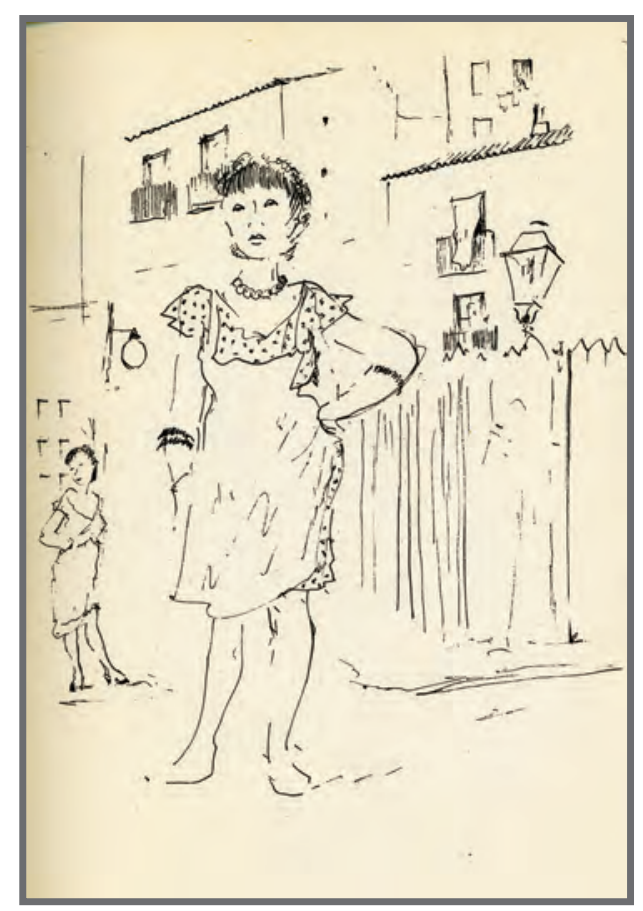

\section{CONTENIDO.}

Personajes: MUJERES

Animales: NO

Gestos Expresivos: EMOCIONES NEGATIVAS

Paisajes: SI

Escenas: CALLEJERAS

Función: REPRESENTATIVA DE MODELOS SOCIALES

\section{ASPECTOS TÉCNICOS.}

Color dominante: 1 TINTA

Técnica: LITOGRAFÍA

Plano de la imagen: GENERAL 


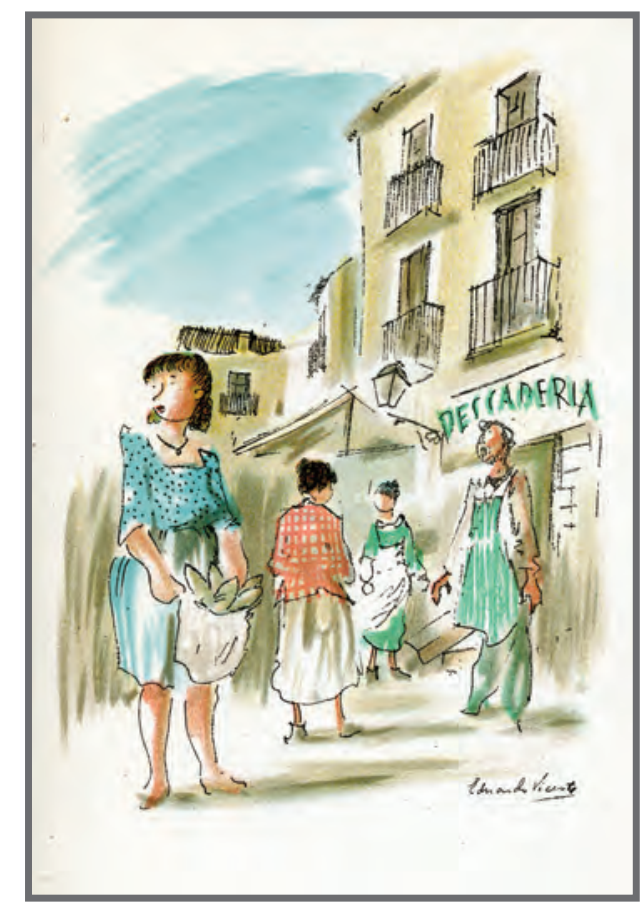

\section{VARIABLES EXTERNAS.}

Título: Pequeño mercado

Año: 1950

Página: 103

\section{TIPO DE IMAGEN.}

Retrato: NO

Cartel: NO

Mural: NO

Ilustración: SI

Otras Obras: NO

\section{CONTENIDO.}

Personajes: HOMBRE Y MUJERES

Animales: NO

Gestos Expresivos: EMOCIONES POSITIVAS

Paisajes: SI

Escenas: PROFESIONAL

Función: REPRESENTATIVA DE MODELOS SOCIALES

\section{ASPECTOS TÉCNICOS.}

Color dominante: CUATRICROMÍA

Técnica: LITOGRAFÍA

Plano de la imagen: GENERAL 


\section{VARIABLES EXTERNAS.}

Título: Hacia el puente de Toledo

Año: 1950

Página: 105

TIPO DE IMAGEN.

Retrato: NO

Cartel: NO

Mural: NO

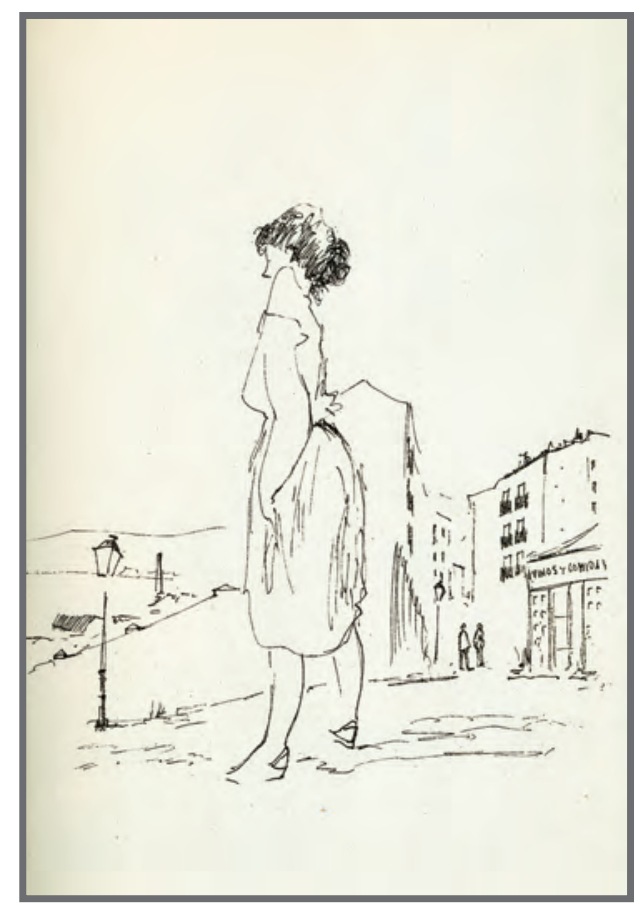

Ilustración: SI

Otras Obras: NO

\section{CONTENIDO.}

Personajes: MUJER

Animales: NO

Gestos Expresivos: EMOCIONES POSITIVAS

Paisajes: SI

Escenas: CALLEJERAS

Función: REPRESENTATIVA DE MODELOS SOCIALES

\section{ASPECTOS TÉCNICOS.}

Color dominante: 1 TINTA

Técnica: LITOGRAFÍA

Plano de la imagen: GENERAL 


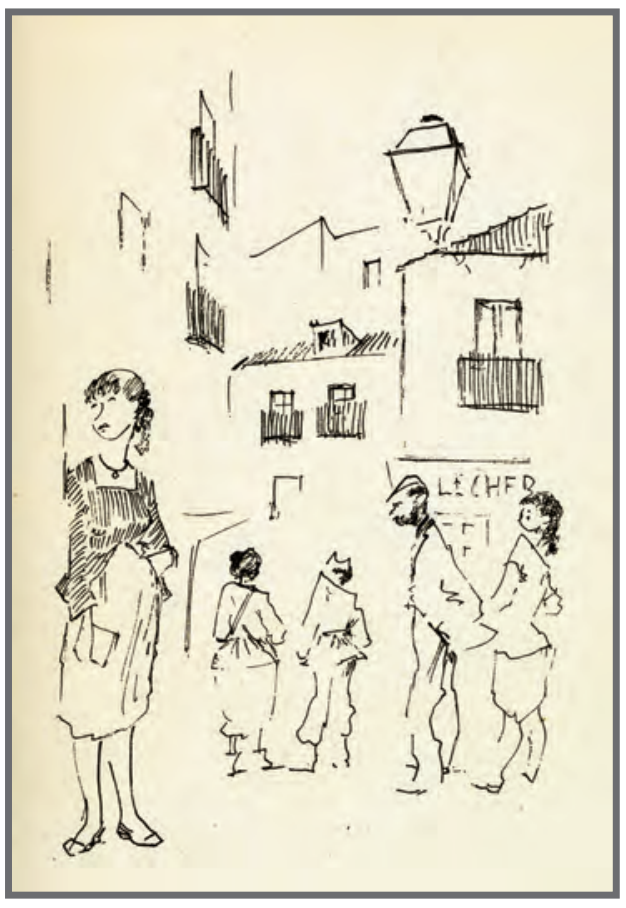

\section{VARIABLES EXTERNAS.}

Título: Barrios bajos

Año: 1950

Página: 107

\section{TIPO DE IMAGEN.}

Retrato: NO

Cartel: NO

Mural: NO

Ilustración: SI

Otras Obras: NO

\section{CONTENIDO.}

Personajes: HOMBRES Y MUJERES

Animales: NO

Gestos Expresivos: EMOCIONES NEGATIVAS

Paisajes: SI

Escenas: CALLEJERAS

Función: REPRESENTATIVA DE MODELOS SOCIALES

\section{ASPECTOS TÉCNICOS.}

Color dominante: 1 TINTA

Técnica: LITOGRAFÍA

Plano de la imagen: GENERAL 


\section{VARIABLES EXTERNAS.}

Título: Vendedores ambulantes

Año: 1950

Página: 109

\section{TIPO DE IMAGEN.}

Retrato: NO

Cartel: NO

Mural: NO

Ilustración: SI

Otras Obras: NO

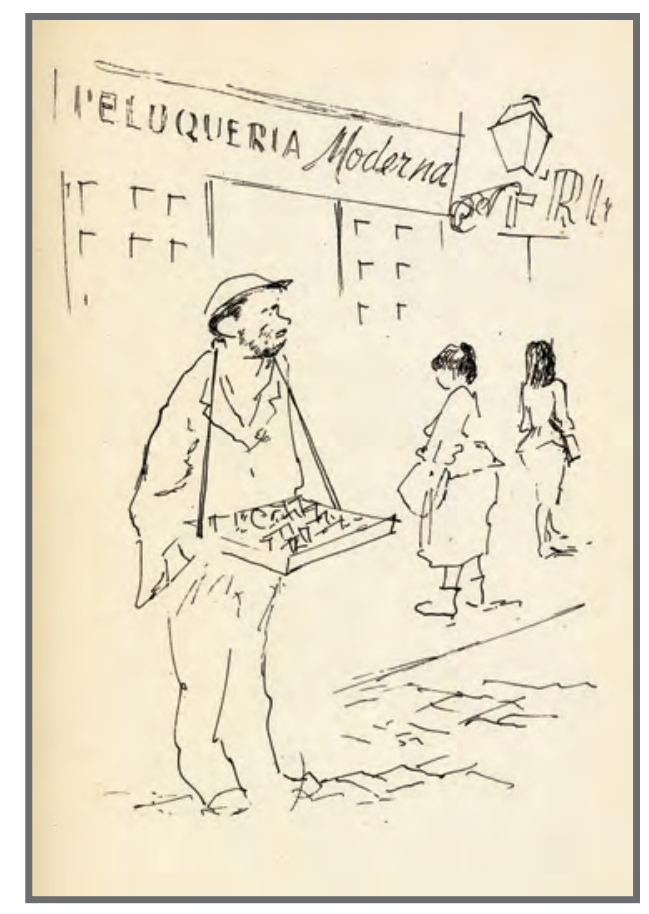

\section{CONTENIDO.}

Personajes: HOMBRE Y MUJERES

Animales: NO

Gestos Expresivos: EMOCIONES POSITIVAS

Paisajes: SI

Escenas: PROFESIONAL

Función: REPRESENTATIVA DE MODELOS SOCIALES

\section{ASPECTOS TÉCNICOS.}

Color dominante: 1 TINTA

Técnica: LITOGRAFÍA

Plano de la imagen: GENERAL 


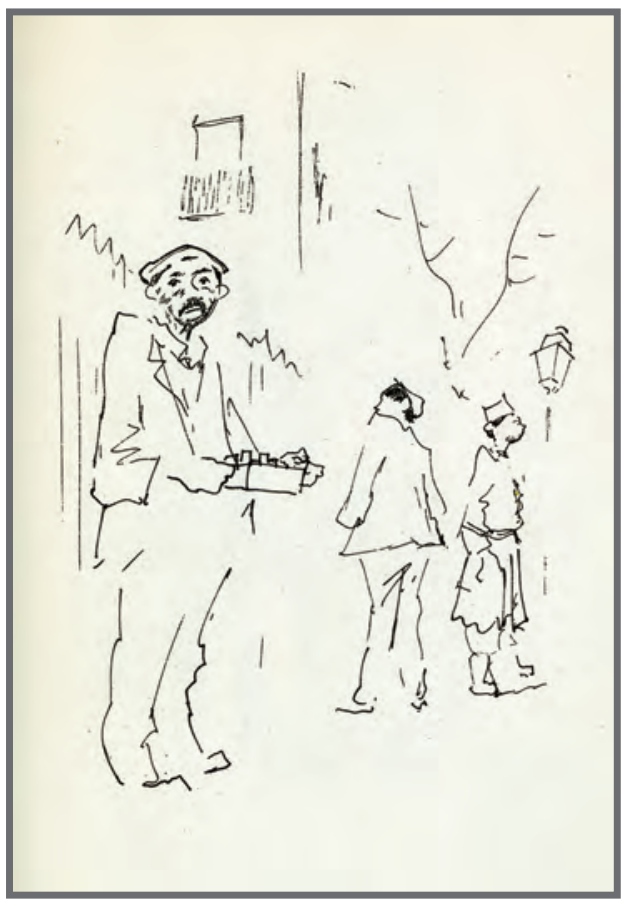

\section{VARIABLES EXTERNAS.}

Título: Gente de la Puerta de Atocha

Año: 1950

Página: 111

TIPO DE IMAGEN.

Retrato: NO

Cartel: NO

Mural: NO

Ilustración: SI

Otras Obras: NO

\section{CONTENIDO.}

Personajes: HOMBRES

Animales: NO

Gestos Expresivos: EMOCIONES POSITIVAS

Paisajes: SI

Escenas: PROFESIONAL

Función: REPRESENTATIVA DE MODELOS SOCIALES

\section{ASPECTOS TÉCNICOS.}

Color dominante: 1 TINTA

Técnica: LITOGRAFÍA

Plano de la imagen: GENERAL 


\section{VARIABLES EXTERNAS.}

Título: Vendedor (Imagen de portada)

Año: 1950

Página: 113

TIPO DE IMAGEN.

Retrato: NO

Cartel: NO

Mural: NO

Ilustración: SI

Otras Obras: NO

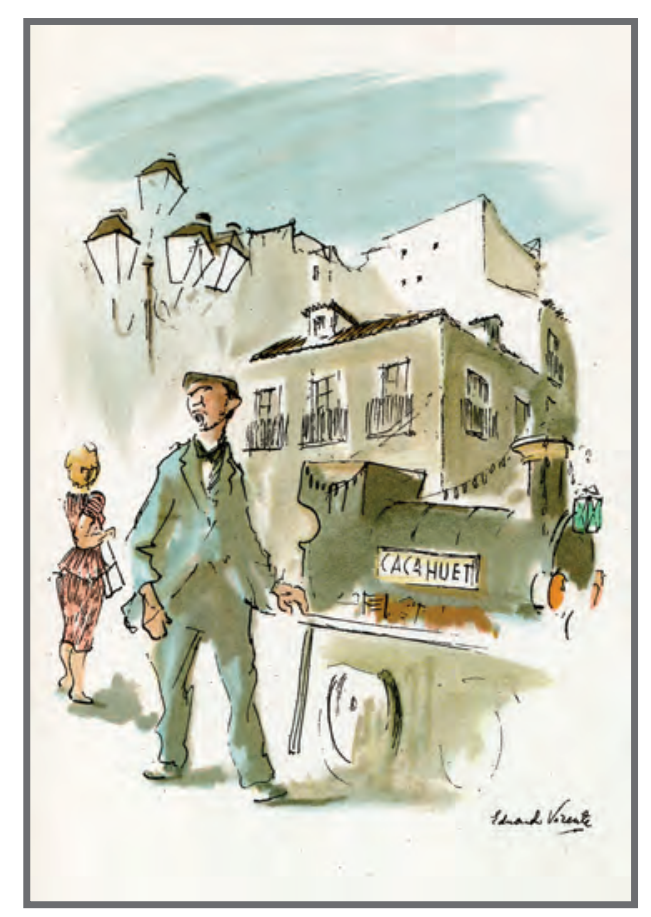

\section{CONTENIDO.}

Personajes: HOMBRE Y MUJER

Animales: NO

Gestos Expresivos: EMOCIONES POSITIVAS

Paisajes: SI

Escenas: PROFESIONAL

Función: REPRESENTATIVA DE MODELOS SOCIALES

\section{ASPECTOS TÉCNICOS.}

Color dominante: CUATRICROMÍA

Técnica: LITOGRAFÍA

Plano de la imagen: GENERAL 


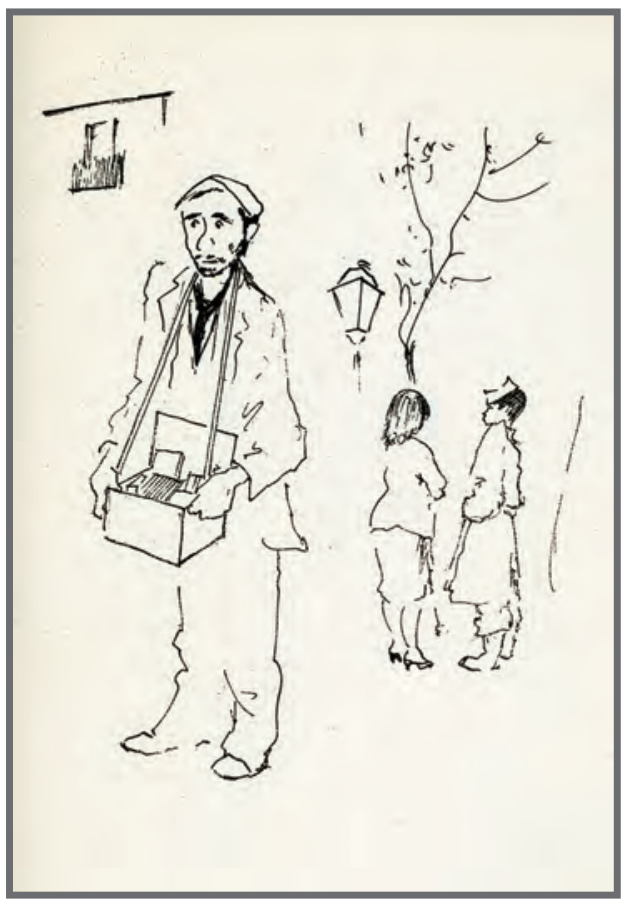

\section{VARIABLES EXTERNAS.}

Título: Gente de la Puerta de Toledo

Año: 1950

Página: 115

\section{TIPO DE IMAGEN.}

Retrato: NO

Cartel: NO

Mural: NO

Ilustración: SI

Otras Obras: NO

\section{CONTENIDO.}

Personajes: HOMBRES Y MUJER

Animales: NO

Gestos Expresivos: EMOCIONES POSITIVAS

Paisajes: SI

Escenas: PROFESIONAL

Función: REPRESENTATIVA DE MODELOS SOCIALES

\section{ASPECTOS TÉCNICOS.}

Color dominante: 1 TINTA

Técnica: LITOGRAFÍA

Plano de la imagen: GENERAL 


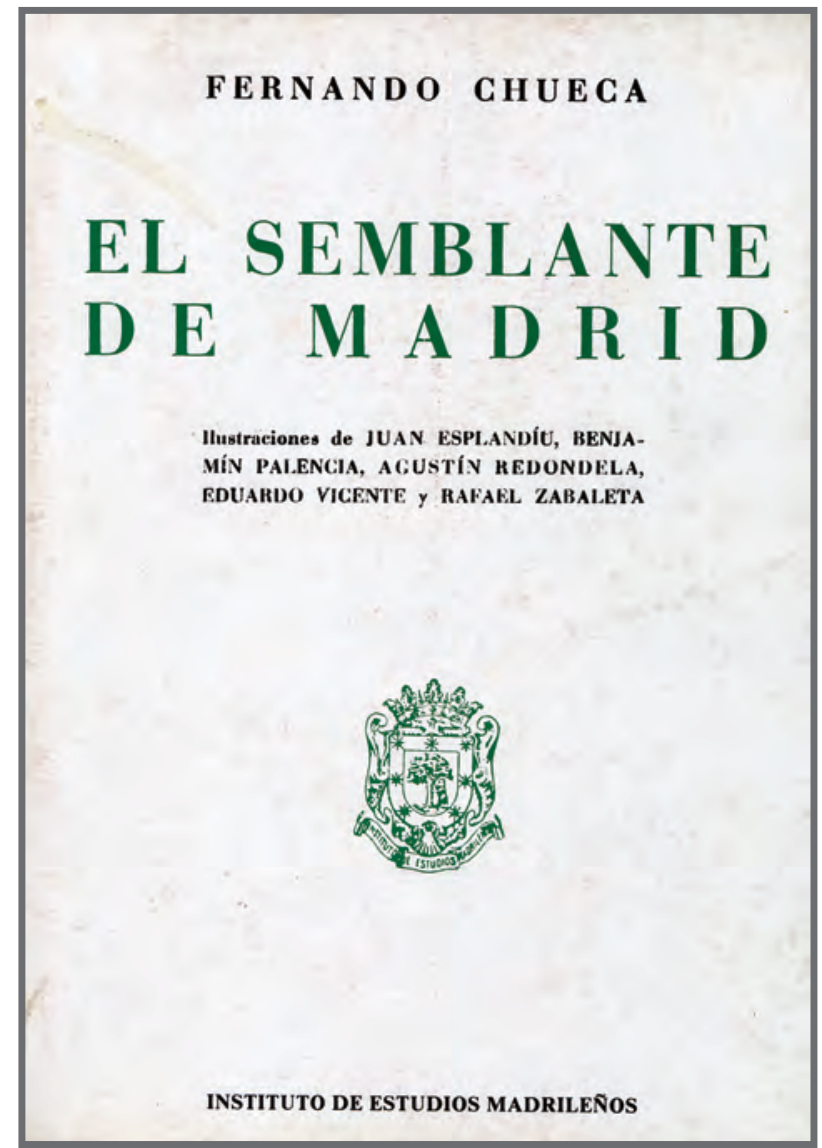

\section{FICHA TÉCNICA.}

Título: EL SEMBLANTE DE MADRID

Autor: FERNANDO CHUECA

Editorial: INSTITUTO DE ESTUDIOS MADRILEÑOS (C.S.I.C.)

Año: 1951

Tamaño: 21 x $15 \mathrm{~cm}$.

Número de páginas: 353

Número de ilustraciones: 9 



\section{VARIABLES EXTERNAS.}

Título: Literatos (001)

Año: 1951

Página: 135

\section{TIPO DE IMAGEN.}

Retrato: NO

Cartel: NO

Mural: NO

Ilustración: SI

Otras Obras: NO

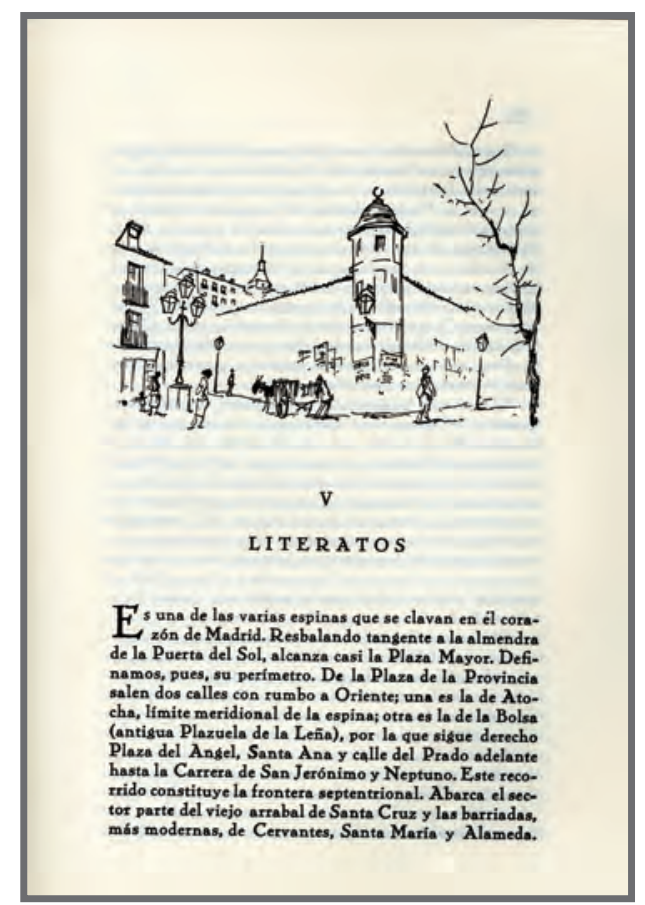

\section{CONTENIDO.}

Personajes: HOMBRES, MUJERES Y NIÑA

Animales: BURRO

Gestos Expresivos: EMOCIONES POSITIVAS

Paisajes: SI

Escenas: CALLEJERAS

Función: REPRESENTATIVA DE MODELOS SOCIALES

\section{ASPECTOS TÉCNICOS.}

Color dominante: 1 TINTA

Técnica: TIPOGRAFÍA

Plano de la imagen: GENERAL 


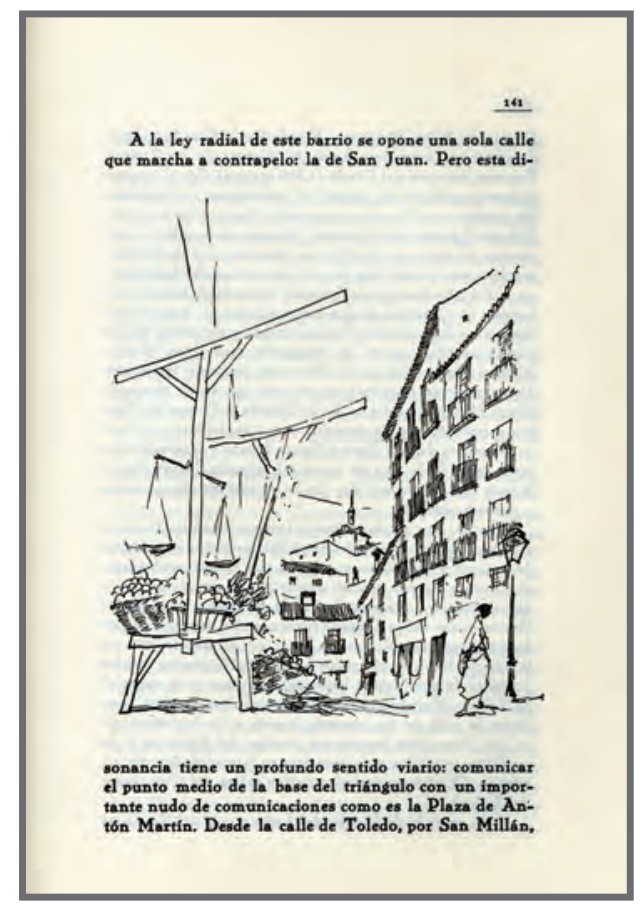

\section{VARIABLES EXTERNAS.}

Título: Literatos (002)

Año: 1951

Página: 141

TIPO DE IMAGEN.

Retrato: NO

Cartel: NO

Mural: NO

Ilustración: SI

Otras Obras: NO

\section{CONTENIDO.}

Personajes: MUJER

Animales: NO

Gestos Expresivos: EMOCIONES POSITIVAS

Paisajes: SI

Escenas: CALLEJERAS

Función: REPRESENTATIVA DE MODELOS SOCIALES

\section{ASPECTOS TÉCNICOS.}

Color dominante: 1 TINTA

Técnica: TIPOGRAFÍA

Plano de la imagen: GENERAL 


\section{VARIABLES EXTERNAS.}

Título: Literatos (003)

Año: 1951

Página: 149

\section{TIPO DE IMAGEN.}

Retrato: NO

Cartel: NO

Mural: NO

Ilustración: SI

Otras Obras: NO

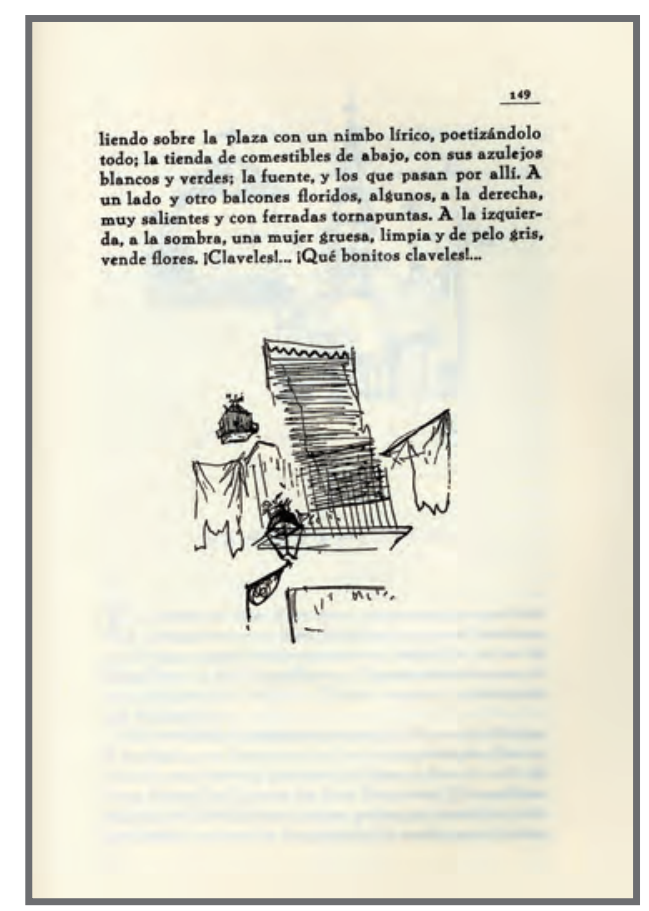

\section{CONTENIDO.}

Personajes: NO

Animales: NO

Gestos Expresivos: NO

Paisajes: NO

Escenas: CALLEJERAS

Función: REPRESENTATIVA DE MODELOS SOCIALES

\section{ASPECTOS TÉCNICOS.}

Color dominante: 1 TINTA

Técnica: TIPOGRAFÍA

Plano de la imagen: DETALLE 


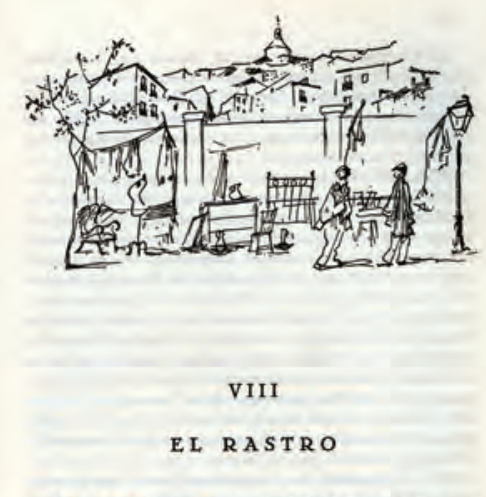

« del áltimo siro de la vidhonocimiento del despojo social, te; bazar con toques y vislumbres de basurero empujado por las escobas y recogido por manos miseras y allesadoras, que seleccionan, limpian, ordenan y clasifican los abandonados desechos, portion y vida nueva. $\mathrm{lOh}$, que estudio an provechoso, y cuánto de tales trebejos el principio de que si nada muere en le Naturaleza, nada muere tampoco en la industrial Cuando veáis que al go acaba, decid que also comienza.. (Guí Espiritual de Espeña. Madrid.)

\section{VARIABLES EXTERNAS.}

Título: El rastro (001)

Año: 1951

Página: 189

\section{TIPO DE IMAGEN.}

Retrato: NO

Cartel: NO

Mural: NO

Ilustración: SI

Otras Obras: NO

\section{CONTENIDO.}

Personajes: HOMBRES

Animales: NO

Gestos Expresivos: EMOCIONES POSITIVAS

Paisajes: SI

Escenas: CALLEJERAS

Función: REPRESENTATIVA DE MODELOS SOCIALES

\section{ASPECTOS TÉCNICOS.}

Color dominante: 1 TINTA

Técnica: TIPOGRAFÍA

Plano de la imagen: GENERAL 
VARIABLES EXTERNAS.

Título: El rastro (002)

Año: 1951

Página: 193

\section{TIPO DE IMAGEN.}

Retrato: NO

Cartel: NO

Mural: NO

Ilustración: SI

Otras Obras: NO

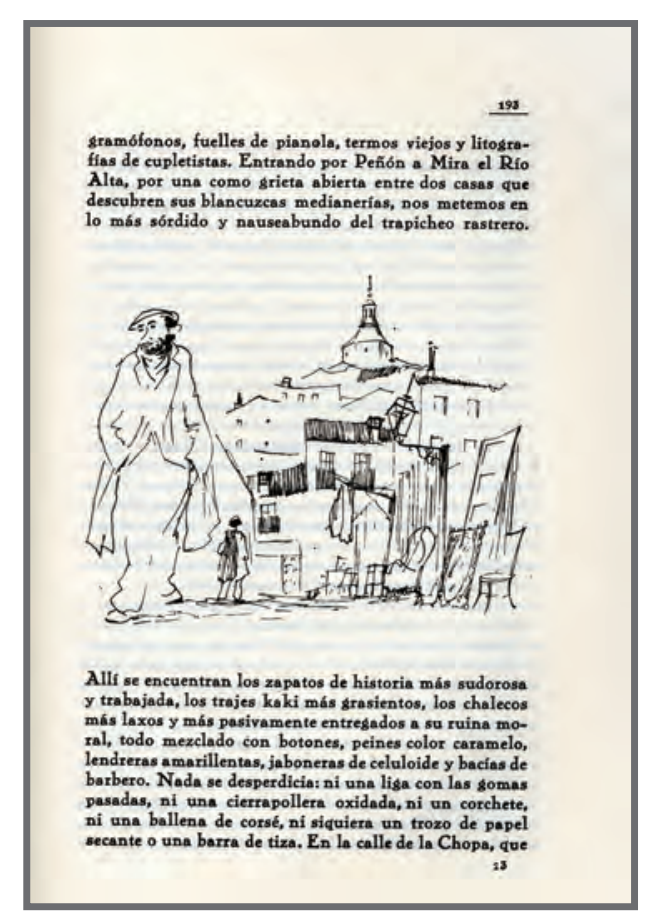

\section{CONTENIDO.}

Personajes: HOMBRES

Animales: NO

Gestos Expresivos: EMOCIONES POSITIVAS

Paisajes: SI

Escenas: CALLEJERAS

Función: REPRESENTATIVA DE MODELOS SOCIALES

\section{ASPECTOS TÉCNICOS.}

Color dominante: 1 TINTA

Técnica: TIPOGRAFÍA

Plano de la imagen: GENERAL 


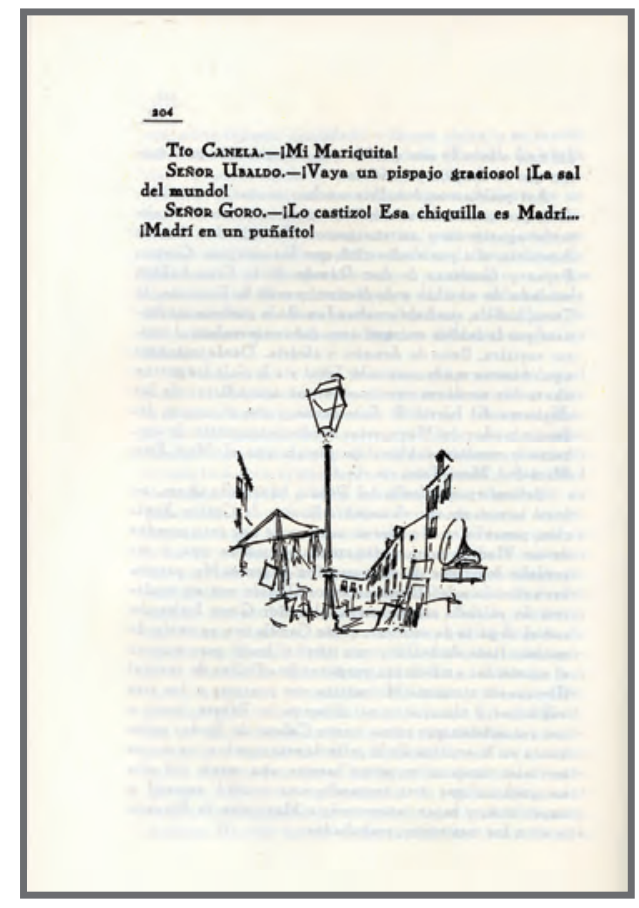

\section{VARIABLES EXTERNAS.}

Título: El rastro (003)

Año: 1951

Página: 204

\section{TIPO DE IMAGEN.}

Retrato: NO

Cartel: NO

Mural: NO

Ilustración: SI

Otras Obras: NO

\section{CONTENIDO.}

Personajes: NO

Animales: NO

Gestos Expresivos: NO

Paisajes: NO

Escenas: CALLEJERAS

Función: REPRESENTATIVA DE MODELOS SOCIALES

\section{ASPECTOS TÉCNICOS.}

Color dominante: 1 TINTA

Técnica: TIPOGRAFÍA

Plano de la imagen: DETALLE 
VARIABLES EXTERNAS.

Título: Lavapiés (001)

Año: 1951

Página: 205

\section{TIPO DE IMAGEN.}

Retrato: NO

Cartel: NO

Mural: NO

Ilustración: SI

Otras Obras: NO

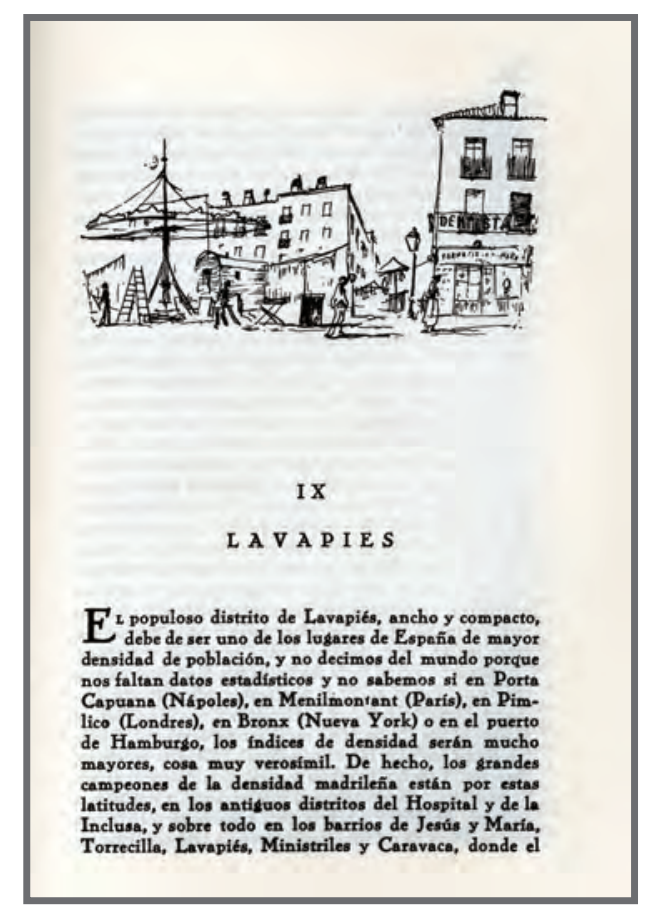

\section{CONTENIDO.}

Personajes: HOMBRES Y MUJERES

Animales: NO

Gestos Expresivos: NO

Paisajes: SI

Escenas: CALLEJERAS

Función: REPRESENTATIVA DE MODELOS SOCIALES

\section{ASPECTOS TÉCNICOS.}

Color dominante: 1 TINTA

Técnica: TIPOGRAFÍA

Plano de la imagen: GENERAL 


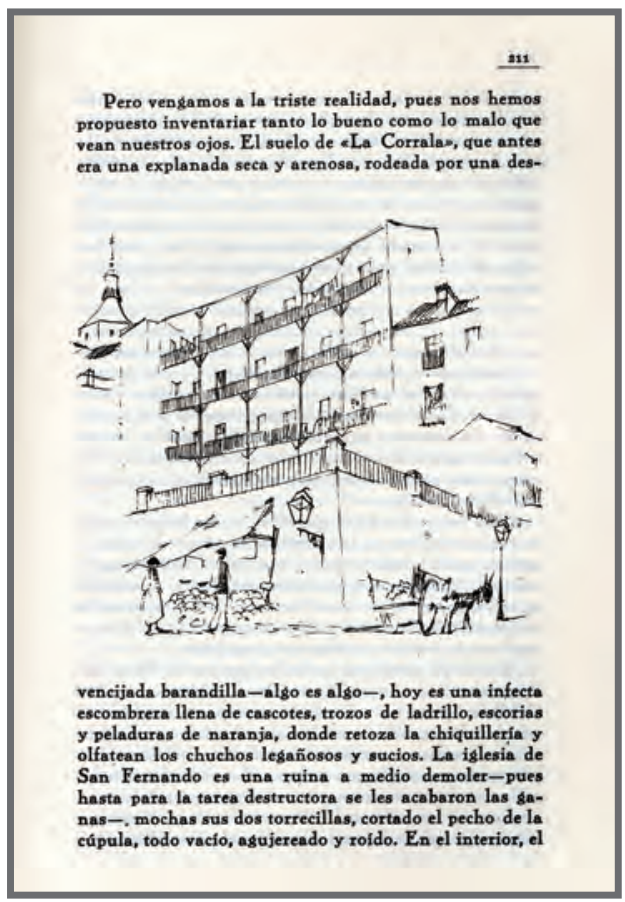

\section{VARIABLES EXTERNAS.}

Título: Lavapiés (002)

Año: 1951

Página: 211

\section{TIPO DE IMAGEN.}

Retrato: NO

Cartel: NO

Mural: NO

Ilustración: SI

Otras Obras: NO

\section{CONTENIDO.}

Personajes: HOMBRE Y MUJER

Animales: BURRO

Gestos Expresivos: EMOCIONES POSITIVAS

Paisajes: SI

Escenas: CALLEJERAS

Función: REPRESENTATIVA DE MODELOS SOCIALES

\section{ASPECTOS TÉCNICOS.}

Color dominante: 1 TINTA

Técnica: TIPOGRAFÍA

Plano de la imagen: GENERAL 


\section{VARIABLES EXTERNAS.}

34

punta Sur de Madrid; sentí una sensación indefinible hallarme, dentro de Madrid, en otra ciudad que no ere Madrid, que no era ninguna ciudad, por ser ese residuo de la ciuded moderne en indeterminedo ave podes hallar en todos pertes. Mi Madrid, el cue yo me ofano en describir, seris sólo eso, mi Madrid, existente nad más en mi conciencia subjetiva? ¿Existia otro Madrid

Título: Lavapiés (003) el real, más srande, más difuso, más inaprehensible?

Año: 1951

Página: 224

TIPO DE IMAGEN.

Retrato: NO

Cartel: NO

Mural: NO

Ilustración: SI

Otras Obras: NO

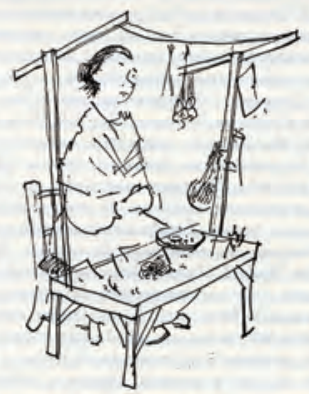

\section{CONTENIDO.}

Personajes: MUJER

Animales: NO

Gestos Expresivos: EMOCIONES POSITIVAS

Paisajes: NO

Escenas: PROFESIONAL

Función: REPRESENTATIVA DE MODELOS SOCIALES

\section{ASPECTOS TÉCNICOS.}

Color dominante: 1 TINTA

Técnica: TIPOGRAFÍA

Plano de la imagen: GENERAL 



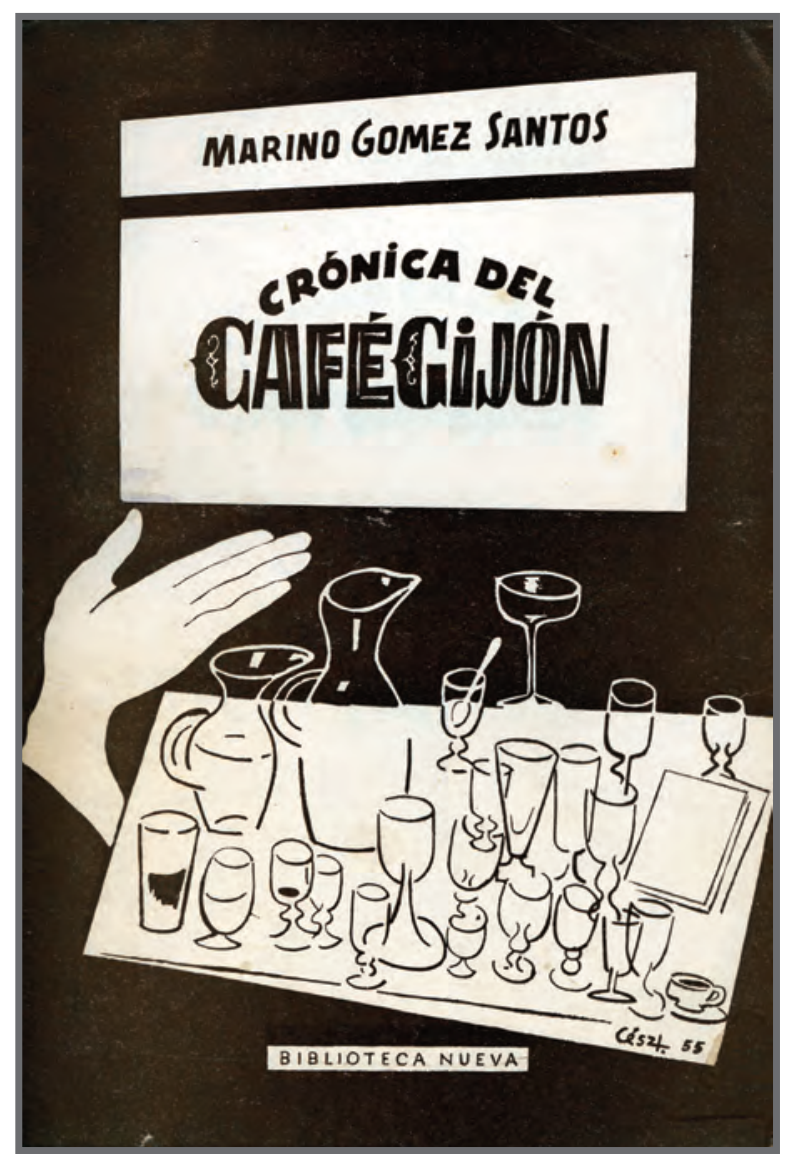

\section{FICHA TÉCNICA.}

Título: CRÓNICA DEL CAFÉ GIJÓN Autor: MARIANO GÓMEZ SANTOS Editorial: BIBLIOTECA NUEVA Año: 1955

Tamaño: $20 \times 13,5 \mathrm{~cm}$.

Número de páginas: 198

Número de ilustraciones: 17 



\section{VARIABLES EXTERNAS.}

Título: Las crónicas del Café Gijón (001)

Año: 1955

Página: 17

\section{TIPO DE IMAGEN.}

Retrato: NO

Cartel: NO

Mural: NO

Ilustración: SI

Otras Obras: NO

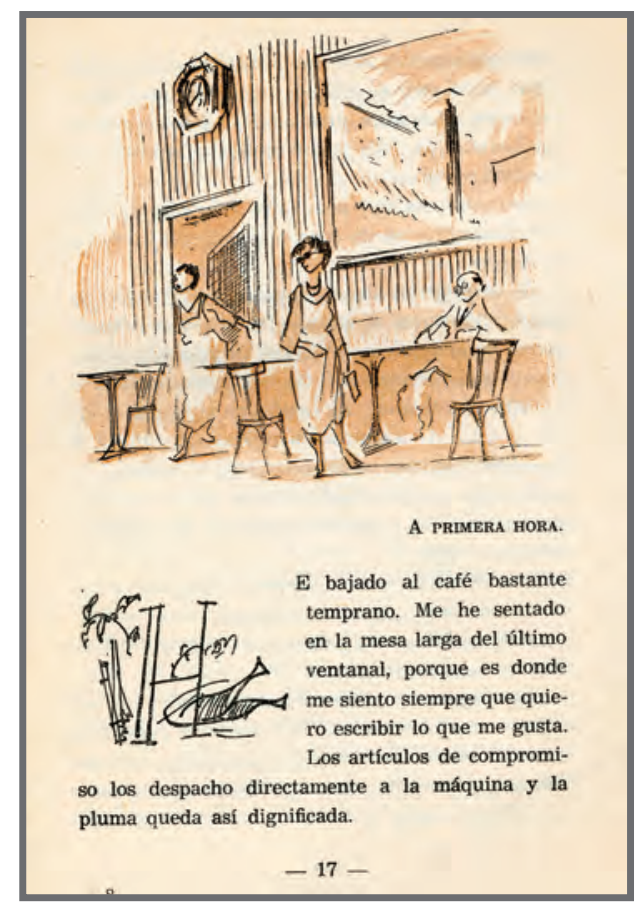

\section{CONTENIDO.}

Personajes: HOMBRE Y MUJERES

Animales: NO

Gestos Expresivos: EMOCIONES POSITIVAS

Paisajes: NO

Escenas: INTERIOR

Función: REPRESENTATIVA DE MODELOS SOCIALES

\section{ASPECTOS TÉCNICOS.}

Color dominante: 2 TINTAS

Técnica: OFFSET

Plano de la imagen: GENERAL 
EL ESCRITOR EN EL CAFE.

El café ha sido siempre lugar predilecto del escritor, porque en el café se escribe admirablemente,

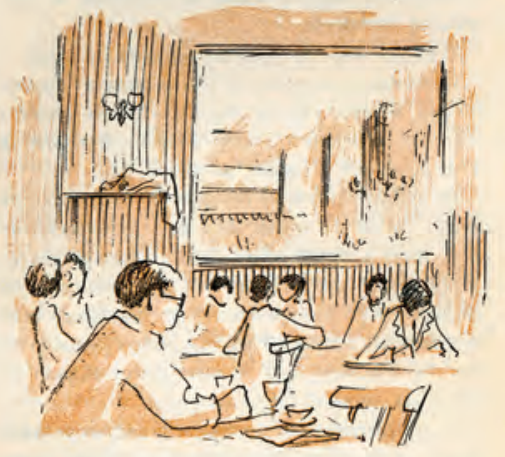

con una tranquilidad y con un aislamiento que no puede tenerse ni esperarse en ningún otro sitio.

Se explica que el escritor acuda al café y no a una biblioteca porque en el café se disfraza el trabajo de pasatiempo. Se engaña uno a sí mismo, y el $-24-$

\section{VARIABLES EXTERNAS.}

Título: Las crónicas del Café Gijón (002)

Año: 1955

Página: 24

\section{TIPO DE IMAGEN.}

Retrato: NO

Cartel: NO

Mural: NO

Ilustración: SI

Otras Obras: NO

\section{CONTENIDO.}

Personajes: HOMBRES Y MUJERES

Animales: NO

Gestos Expresivos: EMOCIONES POSITIVAS

Paisajes: NO

Escenas: INTERIOR

Función: REPRESENTATIVA DE MODELOS SOCIALES

\section{ASPECTOS TÉCNICOS.}

Color dominante: 2 TINTAS

Técnica: OFFSET

Plano de la imagen: AMERICANO 


\section{VARIABLES EXTERNAS.}

Título: Las crónicas del Café Gijón (003)

Año: 1955

Página: 31

\section{TIPO DE IMAGEN.}

Retrato: NO

Cartel: NO

Mural: NO

Ilustración: SI

Otras Obras: NO más, pero a quien todos conocen por el escándalo de sus aventuras."

LAS MUJERES EN EL CAFE.

Los cafés son lugares melancólicos hasta que aparecen en ellos las mujeres, que entran mirándose en

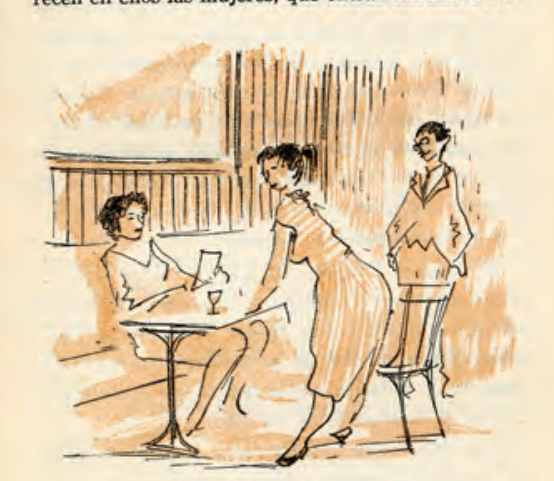

los espejos, sabiendo que las miran. Ellas dan al café aquello que le faltaba y lo humanizan, salvándole del misogismo, liberándole de esa pobreza espiritual y fisica.

\section{CONTENIDO.}

Personajes: HOMBRE Y MUJER

Animales: NO

Gestos Expresivos: EMOCIONES POSITIVAS

Paisajes: NO

Escenas: INTERIOR

Función: REPRESENTATIVA DE MODELOS SOCIALES

\section{ASPECTOS TÉCNICOS.}

Color dominante: 2 TINTAS

Técnica: OFFSET

Plano de la imagen: GENERAL 
el Premio Mariano de Cavia, titulada: Señora, ¿se le ha perdido a usted un niño?

El día 28 de marzo de 1936 "ABC" le envía de corresponsal a Roma. Se disuelve la tertulia. Ocho años después, a su regreso, vuelve a formarse. Al poco tiempo, una empresa de seguros compra el "Café de Recoletos" para instalar allí sus oficinas.

Desaparece este café y el "Gijón" cobra vida literaria inmediatamente.

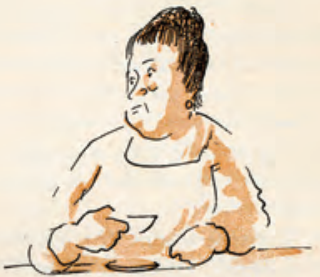

$-54-$
VARIABLES EXTERNAS.

Título: Las crónicas del Café Gijón (004)

Año: 1955

Página: 54

TIPO DE IMAGEN.

Retrato: NO

Cartel: NO

Mural: NO

Ilustración: SI

Otras Obras: NO

\section{CONTENIDO.}

Personajes: MUJER

Animales: NO

Gestos Expresivos: EMOCIONES POSITIVAS

Paisajes: NO

Escenas: INTERIOR

Función: REPRESENTATIVA DE MODELOS SOCIALES

\section{ASPECTOS TÉCNICOS.}

Color dominante: 2 TINTAS

Técnica: OFFSET

Plano de la imagen: MEDIO CORTO 


\section{VARIABLES EXTERNAS.}

Título: Las crónicas del Café Gijón (005)

Año: 1955

Página: 57

\section{TIPO DE IMAGEN.}

Retrato: NO

Cartel: NO

Mural: NO

Ilustración: SI

Otras Obras: NO

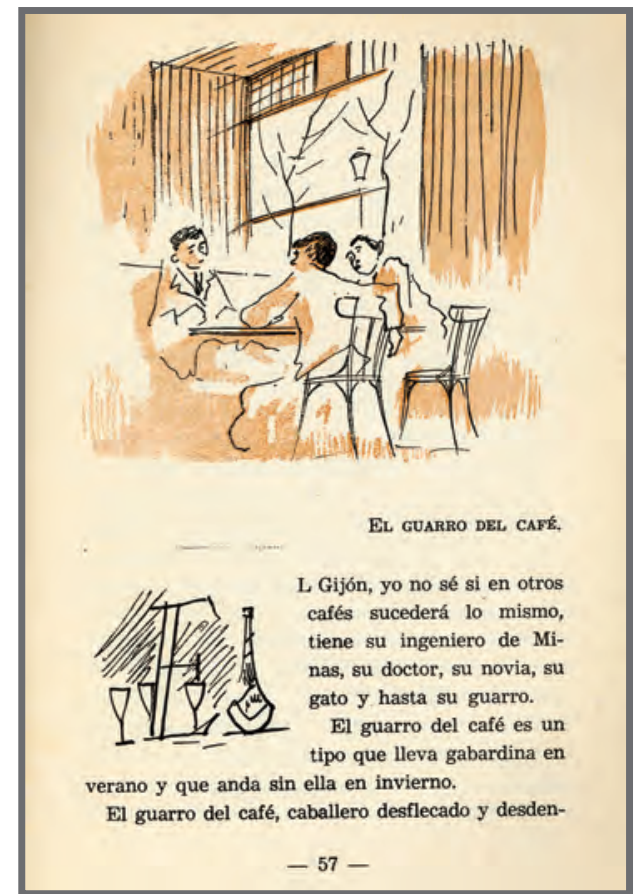

\section{CONTENIDO.}

Personajes: HOMBRES

Animales: NO

Gestos Expresivos: EMOCIONES POSITIVAS

Paisajes: NO

Escenas: INTERIOR

Función: REPRESENTATIVA DE MODELOS SOCIALES

\section{ASPECTOS TÉCNICOS.}

Color dominante: 2 TINTAS

Técnica: OFFSET

Plano de la imagen: GENERAL 
Vico el camarero un cuchillo de postre y comienza sin pérdida de tiempo a rasgar las hojas estrepito samente, declarando que nadie lee, que nadie tiene

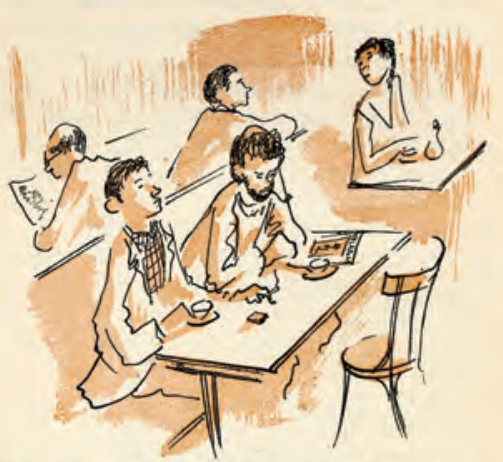

formación, que todos los que escriben son unos improvisados.

El que nunca hará nada, cuenta argumentos de comedias, de cuentos y de novelas que no escribirá nunca.

El que nunca hará nada, cree que lo sabe todo y que lo ha leído todo, sin darse cuenta que presume

$$
-74-
$$

\section{VARIABLES EXTERNAS.}

Título: Las crónicas del Café Gijón (006)

Año: 1955

Página: 74

\section{TIPO DE IMAGEN.}

Retrato: NO

Cartel: NO

Mural: NO

Ilustración: SI

Otras Obras: NO

\section{CONTENIDO.}

Personajes: HOMBRES Y MUJER

Animales: NO

Gestos Expresivos: EMOCIONES POSITIVAS

Paisajes: NO

Escenas: INTERIOR

Función: REPRESENTATIVA DE MODELOS SOCIALES

\section{ASPECTOS TÉCNICOS.}

Color dominante: 2 TINTAS

Técnica: OFFSET

Plano de la imagen: AMERICANO 


\section{VARIABLES EXTERNAS.}

Título: Las crónicas del Café Gijón (007)

Año: 1955

Página: 82

\section{TIPO DE IMAGEN.}

Retrato: NO

Cartel: NO

Mural: NO

Ilustración: SI

Otras Obras: NO entren nostálgicos como Fernando Fernán-Gómez, Fernando Rey, José Suárez y Enrique Diosdado.

Un joven actor, es, como todo lo joven, una birria inconsolable, porque cuando tiene figura no tiene experiencia y cuando le llega la madurez la figura

le obliga a retirarse.

\section{CONTENIDO.}

Personajes: HOMBRE

Animales: NO

Gestos Expresivos: EMOCIONES POSITIVAS

Paisajes: NO

Escenas: INTERIOR

Función: REPRESENTATIVA DE MODELOS SOCIALES

\section{ASPECTOS TÉCNICOS.}

Color dominante: 2 TINTAS

Técnica: OFFSET

Plano de la imagen: GENERAL 


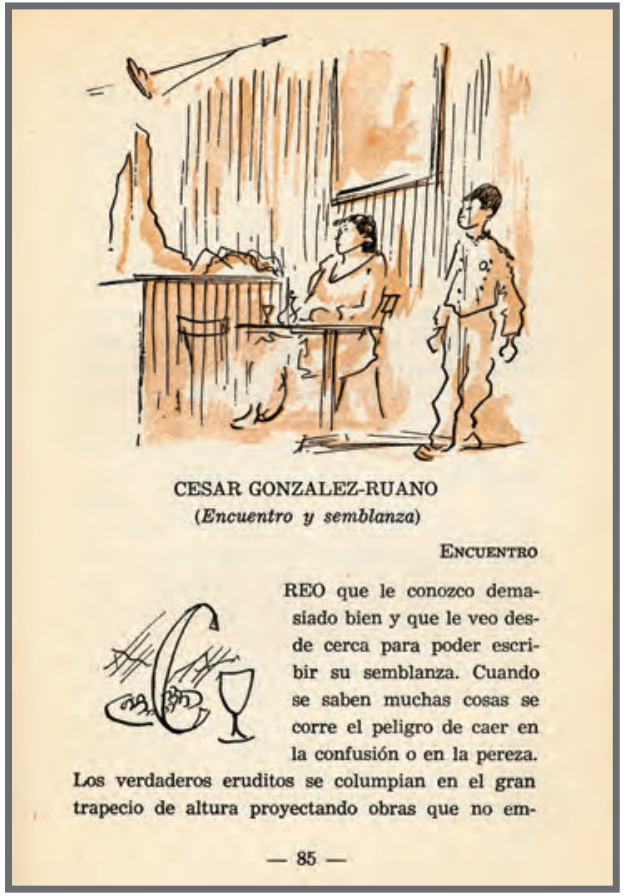

\section{VARIABLES EXTERNAS.}

Título: Las crónicas del Café Gijón (008)

Año: 1955

Página: 85

\section{TIPO DE IMAGEN.}

Retrato: NO

Cartel: NO

Mural: NO

Ilustración: SI

Otras Obras: NO

\section{CONTENIDO.}

Personajes: HOMBRE Y MUJER

Animales: NO

Gestos Expresivos: EMOCIONES POSITIVAS

Paisajes: NO

Escenas: INTERIOR

Función: REPRESENTATIVA DE MODELOS SOCIALES

\section{ASPECTOS TÉCNICOS.}

Color dominante: 2 TINTAS

Técnica: OFFSET

Plano de la imagen: GENERAL 


\section{VARIABLES EXTERNAS.}

Título: Las crónicas del Café Gijón (009)

Año: 1955

Página: 116

TIPO DE IMAGEN.

Retrato: NO

Cartel: NO

Mural: NO

Ilustración: SI

Otras Obras: NO

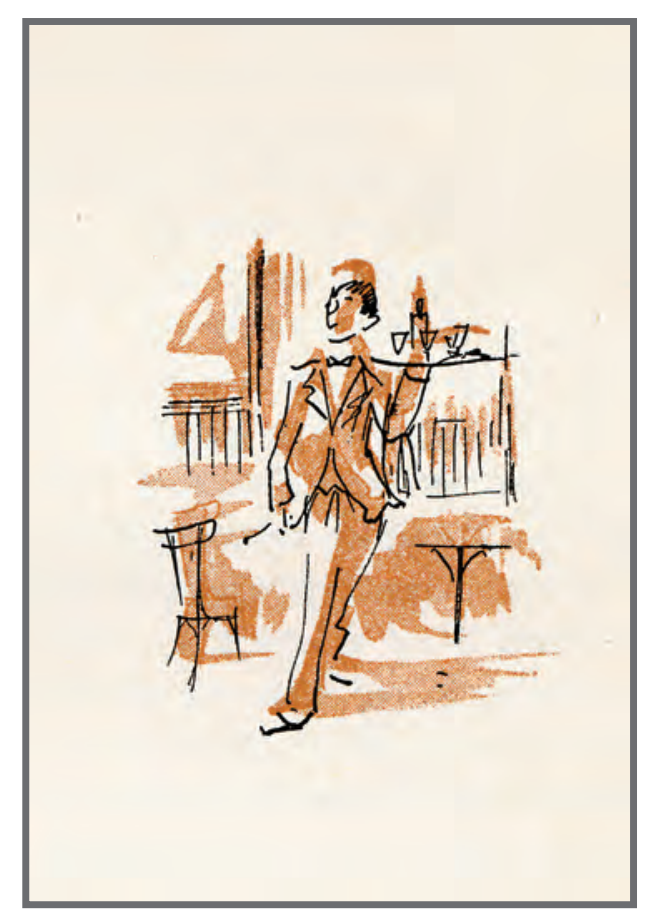

\section{CONTENIDO.}

Personajes: HOMBRE

Animales: NO

Gestos Expresivos: EMOCIONES POSITIVAS

Paisajes: NO

Escenas: PROFESIONAL

Función: REPRESENTATIVA DE MODELOS SOCIALES

\section{ASPECTOS TÉCNICOS.}

Color dominante: 2 TINTAS

Técnica: OFFSET

Plano de la imagen: GENERAL 


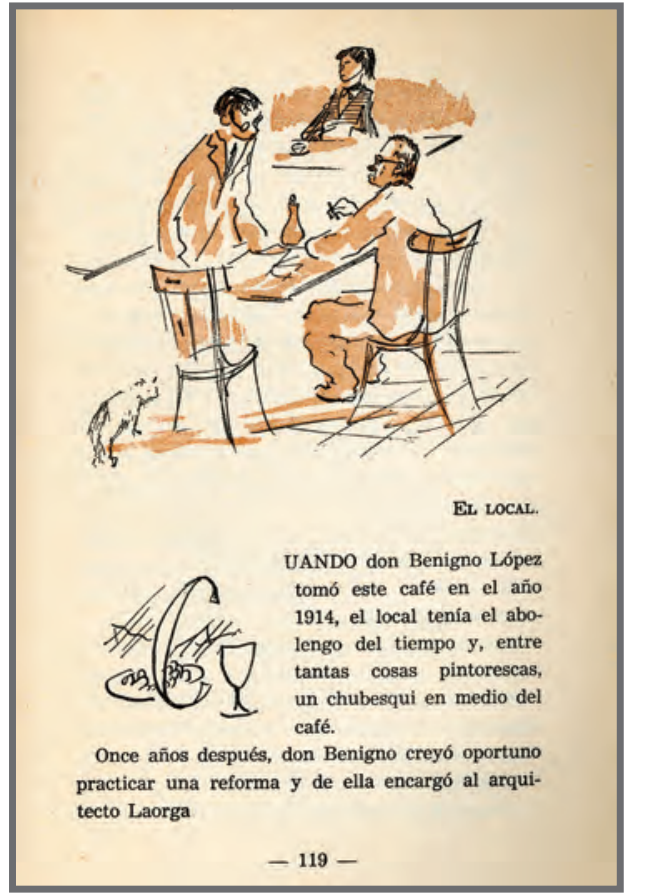

\section{VARIABLES EXTERNAS.}

Título: Las crónicas del Café Gijón (010)

Año: 1955

Página: 119

\section{TIPO DE IMAGEN.}

Retrato: NO

Cartel: NO

Mural: NO

Ilustración: SI

Otras Obras: NO

\section{CONTENIDO.}

Personajes: HOMBRES Y MUJER

Animales: GATO

Gestos Expresivos: EMOCIONES POSITIVAS

Paisajes: NO

Escenas: INTERIOR

Función: REPRESENTATIVA DE MODELOS SOCIALES

\section{ASPECTOS TÉCNICOS.}

Color dominante: 2 TINTAS

Técnica: OFFSET

Plano de la imagen: GENERAL 


\section{VARIABLES EXTERNAS.}

Título: Las crónicas del Café Gijón (011)

Año: 1955

Página: 123

\section{TIPO DE IMAGEN.}

Retrato: NO

Cartel: NO

Mural: NO

Ilustración: SI

Otras Obras: NO
De la reforma se encargó el arquitecto Carlos Arniches.

Este arquitecto puso en la reforma del café resonancias oportunas. Al arte de creación agregó

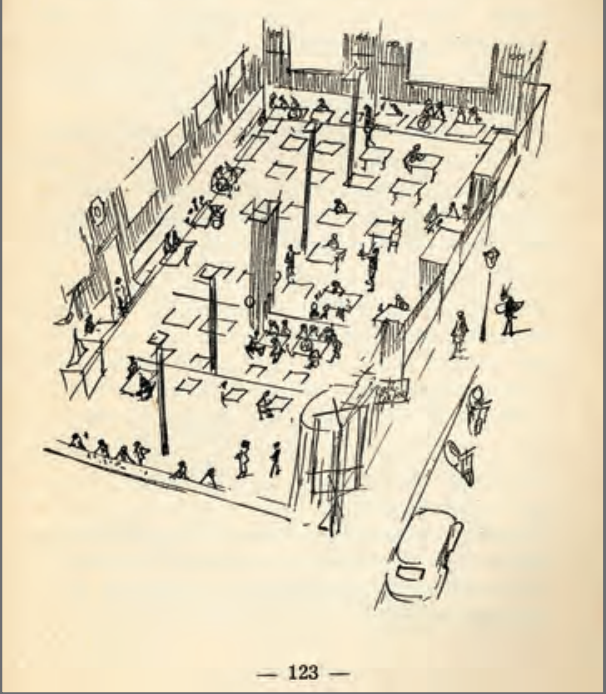

\section{CONTENIDO.}

Personajes: HOMBRES Y MUJERES

Animales: NO

Gestos Expresivos: NO

Paisajes: NO

Escenas: AÉREA

Función: REPRESENTATIVA DE MODELOS SOCIALES

\section{ASPECTOS TÉCNICOS.}

Color dominante: 2 TINTAS

Técnica: OFFSET

Plano de la imagen: GENERAL 
instalar en su biblioteca de la calle de Arapiles, una biblioteca muy ordenada en la que está todo lo principal, muy encuadernado, muy por orden de tama-

ños, muy dispuesto para trabajar.

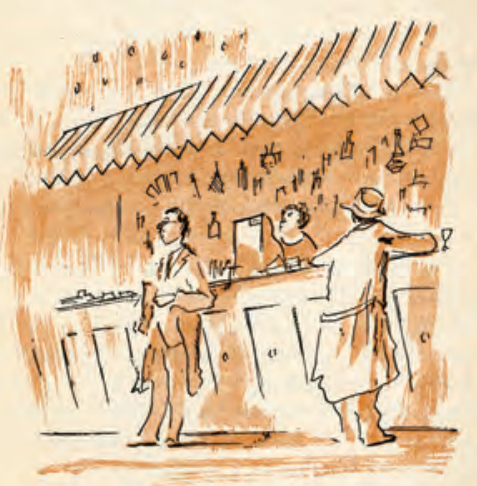

A última hora aparece Mariano Rodríguez de Rivas, trayendo la tarjeta para el último banquete de "Los Amigos de don Juan Tenorio", o de alguna otra broma parecida.

Mariano Rodríguez de Rivas es el ser más amigo $-133-$
VARIABLES EXTERNAS.

Título: Las crónicas del Café Gijón (012)

Año: 1955

Página: 133

TIPO DE IMAGEN.

Retrato: NO

Cartel: NO

Mural: NO

Ilustración: SI

Otras Obras: NO

\section{CONTENIDO.}

Personajes: HOMBRES Y MUJER

Animales: NO

Gestos Expresivos: EMOCIONES POSITIVAS

Paisajes: NO

Escenas: PROFESIONAL

Función: REPRESENTATIVA DE MODELOS SOCIALES

\section{ASPECTOS TÉCNICOS.}

Color dominante: 2 TINTAS

Técnica: OFFSET

Plano de la imagen: GENERAL 


\section{VARIABLES EXTERNAS.}

Título: Las crónicas del Café Gijón (013)

Año: 1955

Página: 161

\section{TIPO DE IMAGEN.}

Retrato: NO

Cartel: NO

Mural: NO

Ilustración: SI

Otras Obras: NO formada por el Marqués de Villanova, don Rafael Lasso de la Vega, uno de los poetas excepcionales que tenemos, hombre que llevó una vida de bohe-

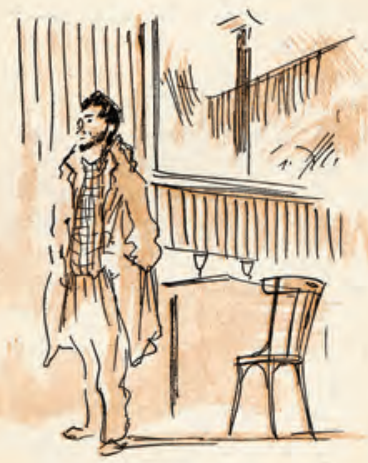

mio entrañable en el Madrid del año veinte más o menos.

Según cuentan, el Marqués de Villanova iba a la

"Posada del Peine", en la cual había como un pasillo largo y estrecho que tenía una soga de un extremo a otro, con bancos de pino arrimados a la pared. $-161-$

\section{CONTENIDO.}

Personajes: HOMBRE

Animales: NO

Gestos Expresivos: EMOCIONES POSITIVAS

Paisajes: NO

Escenas: INTERIOR

Función: REPRESENTATIVA DE MODELOS SOCIALES

\section{ASPECTOS TÉCNICOS.}

Color dominante: 2 TINTAS

Técnica: OFFSET

Plano de la imagen: GENERAL 
Yo he trabajado mucho en este café y también he dejado pasar muchas horas en la conversación y en el diálogo. Creo que entré en la literatura y en el periodismo por este agujerito del café, como un gato curioso cuando menos se lo espera nadie. Porque la literatura y la prensa están al otro lado de este café y el "Gijón" es como un gran "hall", como un andén inevitable en el que hay que sentarse a esperar.

Cerrado "Pombo", no queda otro café literario que éste, y por eso hay que apresurarse a hacerle fotografías y pequeños apuntes impresionistas para el futuro.

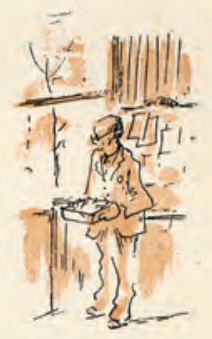

$-166-$

\section{VARIABLES EXTERNAS.}

Título: Las crónicas del Café Gijón (014)

Año: 1955

Página: 166

TIPO DE IMAGEN.

Retrato: NO

Cartel: NO

Mural: NO

Ilustración: SI

Otras Obras: NO

\section{CONTENIDO.}

Personajes: HOMBRE

Animales: NO

Gestos Expresivos: EMOCIONES POSITIVAS

Paisajes: NO

Escenas: PROFESIONAL

Función: REPRESENTATIVA DE MODELOS SOCIALES

\section{ASPECTOS TÉCNICOS.}

Color dominante: 2 TINTAS

Técnica: OFFSET

Plano de la imagen: GENERAL 


\section{VARIABLES EXTERNAS.}

Título: Las crónicas del Café Gijón (015)

Año: 1955

Página: 169

\section{TIPO DE IMAGEN.}

Retrato: NO

Cartel: NO

Mural: NO

Ilustración: SI

Otras Obras: NO

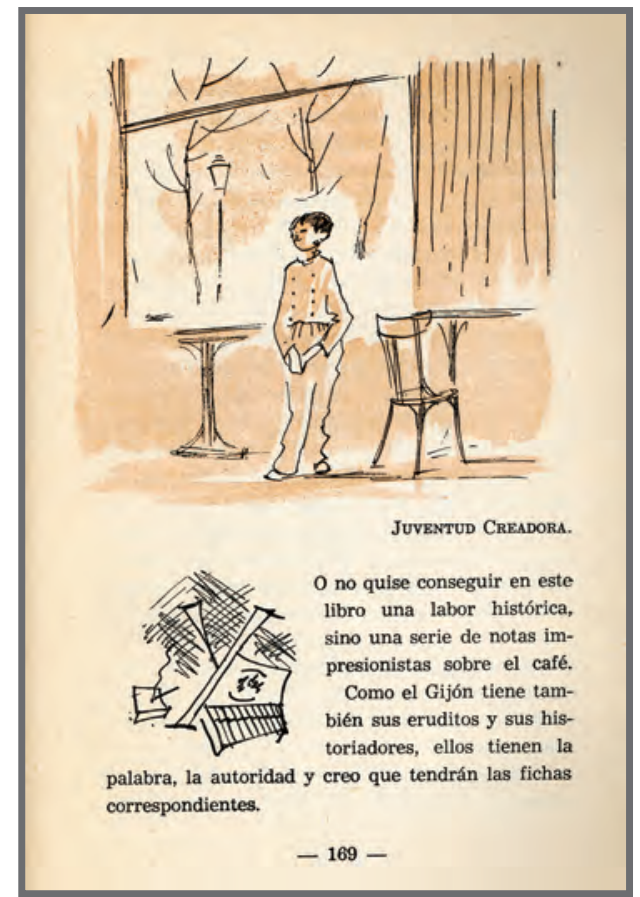

\section{CONTENIDO.}

Personajes: NIÑO

Animales: NO

Gestos Expresivos: EMOCIONES POSITIVAS

Paisajes: NO

Escenas: PROFESIONAL

Función: REPRESENTATIVA DE MODELOS SOCIALES

\section{ASPECTOS TÉCNICOS.}

Color dominante: 2 TINTAS

Técnica: OFFSET

Plano de la imagen: GENERAL 
Más o menos, todos hemos hecho de chicos una revista, y yo conservo aún algún ejemplar de las muchas que hice en colaboracion y solo.

En 1943 se funda la revista "Garcilaso", con el subtítulo de "Juventud Creadora", que dirige primero Pedro de Lorenzo y luego José García Nieto.

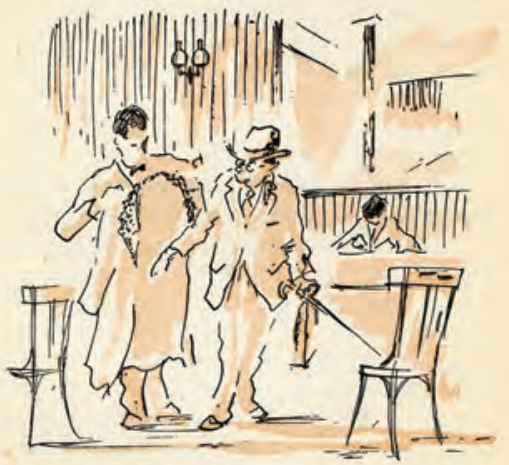

Se publicaron en total treinta y seis números. La revista, preferentemente poética, era una buena revista, en la que colaboraron, entre otros, José Ma$-172-$

\section{VARIABLES EXTERNAS.}

Título: Las crónicas del Café Gijón (016)

Año: 1955

Página: 172

TIPO DE IMAGEN.

Retrato: NO

Cartel: NO

Mural: NO

Ilustración: SI

Otras Obras: NO

\section{CONTENIDO.}

Personajes: HOMBRES

Animales: NO

Gestos Expresivos: EMOCIONES POSITIVAS

Paisajes: NO

Escenas: INTERIOR

Función: REPRESENTATIVA DE MODELOS SOCIALES

\section{ASPECTOS TÉCNICOS.}

Color dominante: 2 TINTAS

Técnica: OFFSET

Plano de la imagen: GENERAL 


\section{VARIABLES EXTERNAS.}

Título: Las crónicas del Café Gijón (017)

Año: 1955

Página: 180

\section{TIPO DE IMAGEN.}

Retrato: NO

Cartel: NO

Mural: NO

Ilustración: SI

Otras Obras: NO más generosos, porque estoy convencido de que el ambiente influye de una manera considerable.

En resumidas cuentas, el libro está terminado. Ya veremos qué suerte corre.

Sé que no está escrito a gusto de todos y que alguien tomará a mal alguna cosa que de seguro no tendrá mala intención; pero qué se le va a hacer. Cuando lo escribí dije de cada cual lo que me parecía justo. Escrito está, y como no tengo pensado tomarme la molestia de volverlo a leer, escrito queda.

"Café Gijón".

Primavera de 1955.

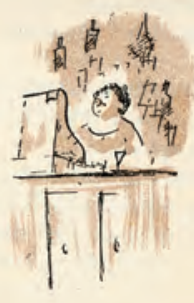

$-180-$

\section{CONTENIDO.}

Personajes: MUJER

Animales: NO

Gestos Expresivos: EMOCIONES POSITIVAS

Paisajes: NO

Escenas: PROFESIONAL

Función: REPRESENTATIVA DE MODELOS SOCIALES

\section{ASPECTOS TÉCNICOS.}

Color dominante: 2 TINTAS

Técnica: OFFSET

Plano de la imagen: MEDIO CORTO 



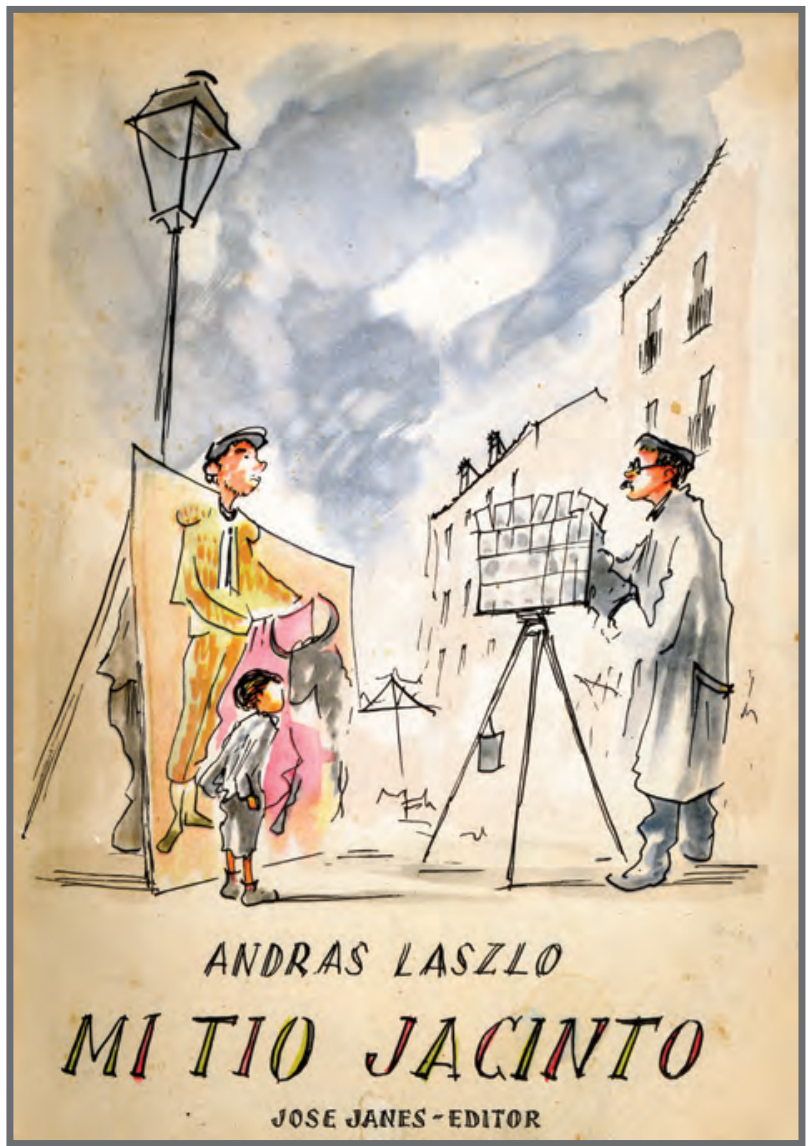

\section{FICHA TÉCNICA.}

Título: MI TÍO JACINTO

Autor: ANDRAS LASZLO

Editorial: JOSÉ JANÉS - BARCELONA

Año: 1956

Tamaño: 23,5 x $17 \mathrm{~cm}$.

Número de páginas: 109 + (ILUSTRACIÓN EN PORTADA)

Número de ilustraciones: 43 



\section{VARIABLES EXTERNAS.}

Título: Mi tío Jacinto (001)

Año: 1956

Página: PORTADA

\section{TIPO DE IMAGEN.}

Retrato: NO

Cartel: NO

Mural: NO

Ilustración: SI

Otras Obras: NO

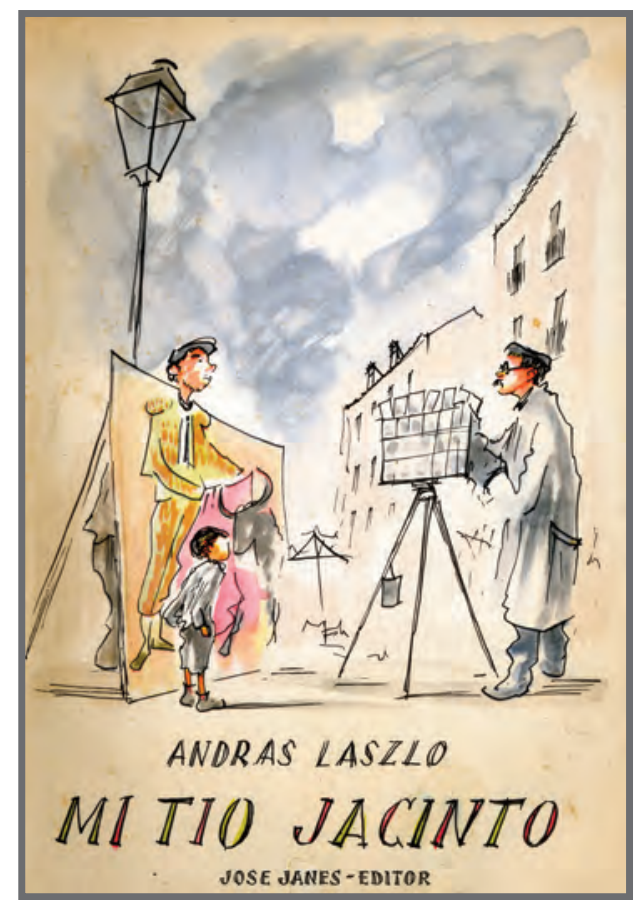

\section{CONTENIDO.}

Personajes: HOMBRES Y NIÑO

Animales: NO

Gestos Expresivos: EMOCIONES POSITIVAS

Paisajes: SI

Escenas: PROFESIONAL

Función: REPRESENTATIVA DE MODELOS SOCIALES

\section{ASPECTOS TÉCNICOS.}

Color dominante: CUATRICROMÍA

Técnica: OFFSET

Plano de la imagen: GENERAL 


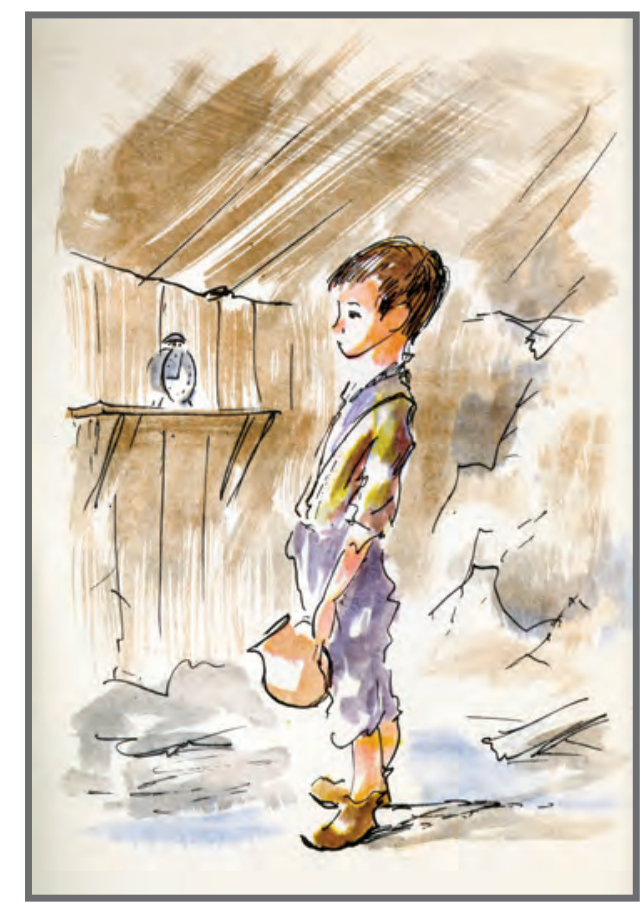

\section{VARIABLES EXTERNAS.}

Título: Mi tío Jacinto (002)

Año: 1956

Página: 4

\section{TIPO DE IMAGEN.}

Retrato: NO

Cartel: NO

Mural: NO

Ilustración: SI

Otras Obras: NO

\section{CONTENIDO.}

Personajes: NIÑO

Animales: NO

Gestos Expresivos: EMOCIONES POSITIVAS

Paisajes: NO

Escenas: INTERIOR

Función: REPRESENTATIVA DE MODELOS SOCIALES

\section{ASPECTOS TÉCNICOS.}

Color dominante: CUATRICROMÍA

Técnica: OFFSET

Plano de la imagen: GENERAL 


\section{VARIABLES EXTERNAS.}

Título: Mi tío Jacinto (003)

Año: 1956

Página: 9

\section{TIPO DE IMAGEN.}

Retrato: NO

Cartel: NO

Mural: NO

Ilustración: SI

Otras Obras: NO

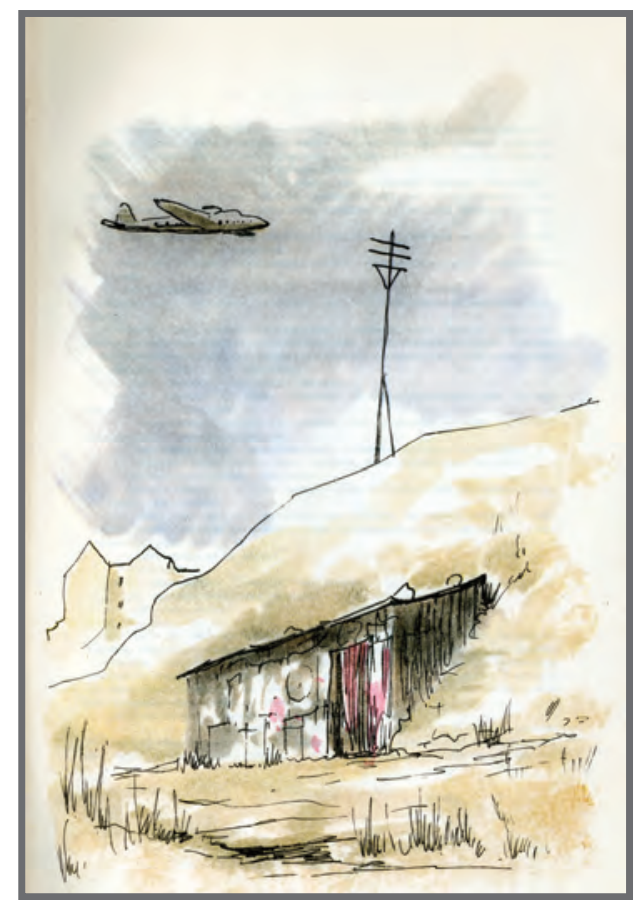

\section{CONTENIDO.}

Personajes: NO

Animales: NO

Gestos Expresivos: NO

Paisajes: SI

Escenas: URBANA

Función: REPRESENTATIVA DE MODELOS SOCIALES

\section{ASPECTOS TÉCNICOS.}

Color dominante: CUATRICROMÍA

Técnica: OFFSET

Plano de la imagen: GENERAL 


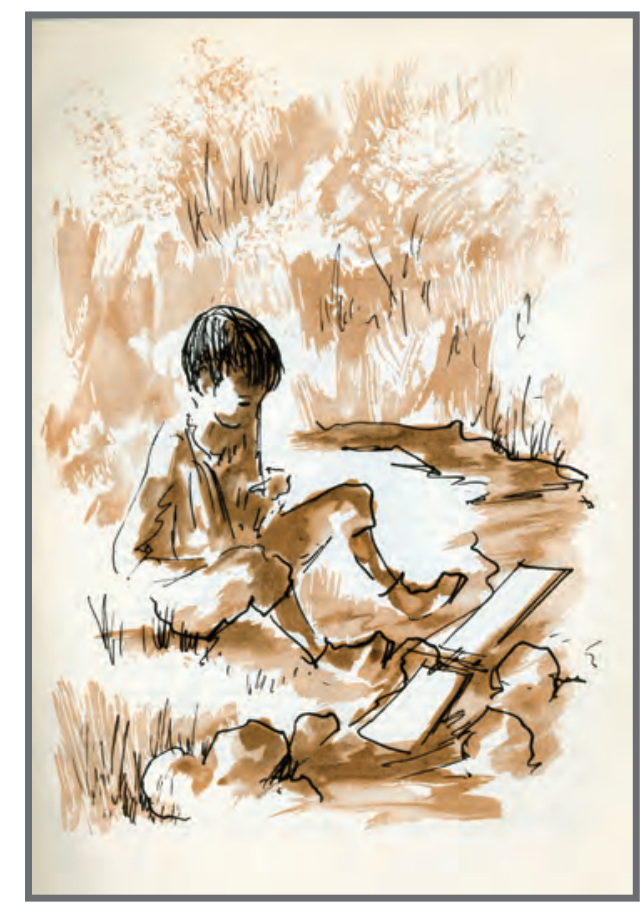

\section{VARIABLES EXTERNAS.}

Título: Mi tío Jacinto (004)

Año: 1956

Página: 13

\section{TIPO DE IMAGEN.}

Retrato: NO

Cartel: NO

Mural: NO

Ilustración: SI

Otras Obras: NO

\section{CONTENIDO.}

Personajes: NIÑO

Animales: NO

Gestos Expresivos: EMOCIONES POSITIVAS

Paisajes: NO

Escenas: RURAL

Función: REPRESENTATIVA DE MODELOS SOCIALES

\section{ASPECTOS TÉCNICOS.}

Color dominante: 2 TINTAS

Técnica: OFFSET

Plano de la imagen: GENERAL 


\section{VARIABLES EXTERNAS.}

Título: Mi tío Jacinto (005)

Año: 1956

Página: 15

\section{TIPO DE IMAGEN.}

Retrato: NO

Cartel: NO

Mural: NO

Ilustración: SI

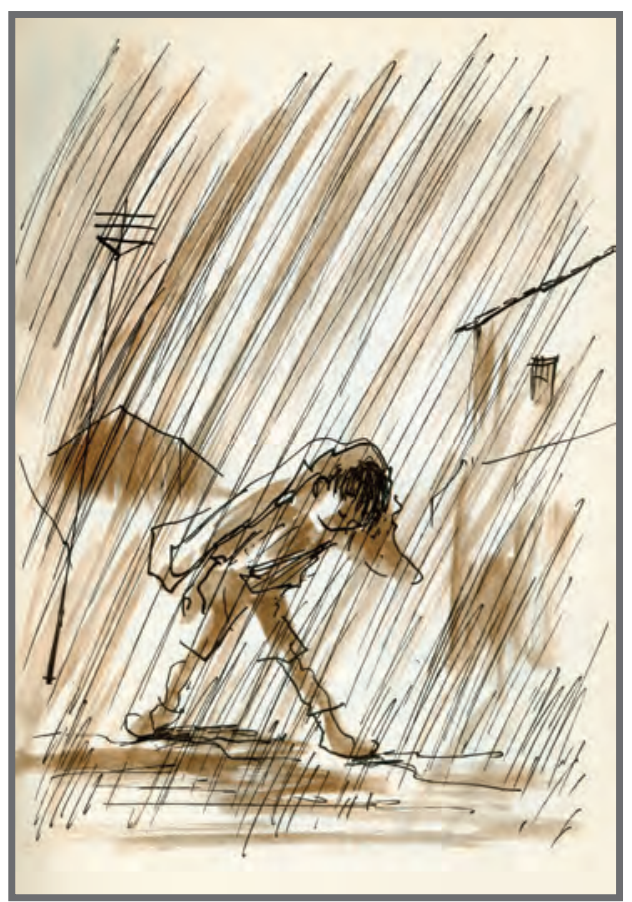

Otras Obras: NO

\section{CONTENIDO.}

Personajes: NIÑO

Animales: NO

Gestos Expresivos: EMOCIONES NEGATIVAS

Paisajes: SI

Escenas: CALLEJERAS

Función: REPRESENTATIVA DE MODELOS SOCIALES

\section{ASPECTOS TÉCNICOS.}

Color dominante: 2 TINTAS

Técnica: OFFSET

Plano de la imagen: GENERAL 


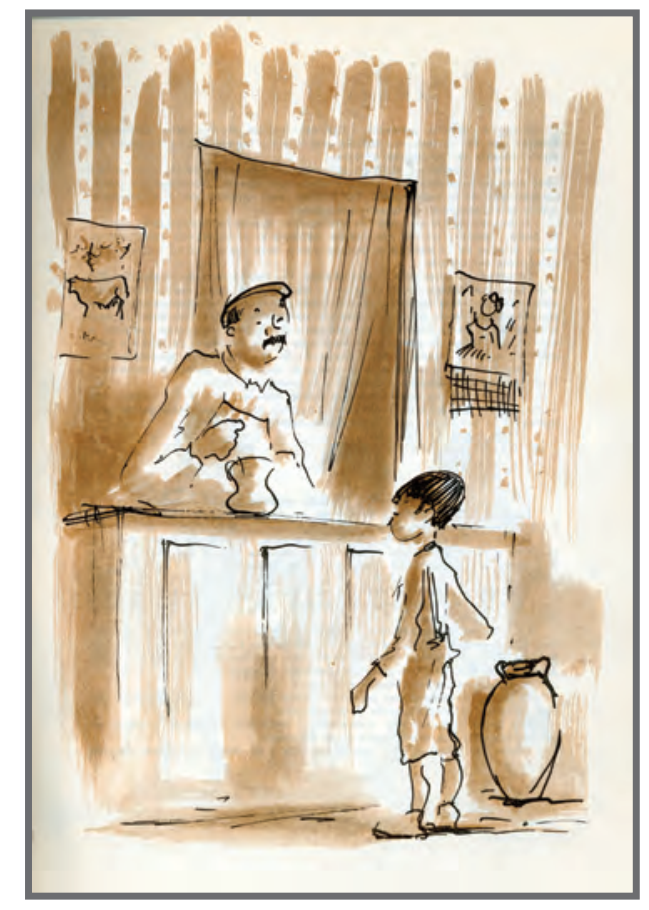

\section{VARIABLES EXTERNAS.}

Título: Mi tío Jacinto (006)

Año: 1956

Página: 17

\section{TIPO DE IMAGEN.}

Retrato: NO

Cartel: NO

Mural: NO

Ilustración: SI

Otras Obras: NO

\section{CONTENIDO.}

Personajes: HOMBRE Y NIÑO

Animales: NO

Gestos Expresivos: EMOCIONES POSITIVAS

Paisajes: NO

Escenas: PROFESIONAL

Función: REPRESENTATIVA DE MODELOS SOCIALES

\section{ASPECTOS TÉCNICOS.}

Color dominante: 2 TINTAS

Técnica: OFFSET

Plano de la imagen: GENERAL 


\section{VARIABLES EXTERNAS.}

Título: Mi tío Jacinto (007)

Año: 1956

Página: 19

\section{TIPO DE IMAGEN.}

Retrato: NO

Cartel: NO

Mural: NO

Ilustración: SI

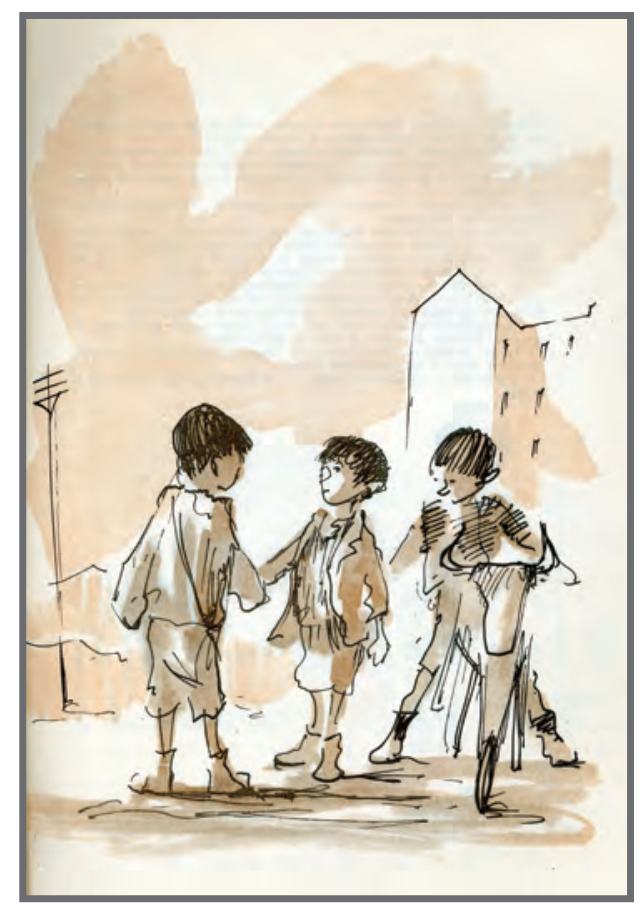

Otras Obras: NO

\section{CONTENIDO.}

Personajes: NIÑOS

Animales: TOTO (JUGUETE)

Gestos Expresivos: EMOCIONES POSITIVAS

Paisajes: SI

Escenas: CALLEJERAS

Función: REPRESENTATIVA DE MODELOS SOCIALES

\section{ASPECTOS TÉCNICOS.}

Color dominante: 2 TINTAS

Técnica: OFFSET

Plano de la imagen: GENERAL 


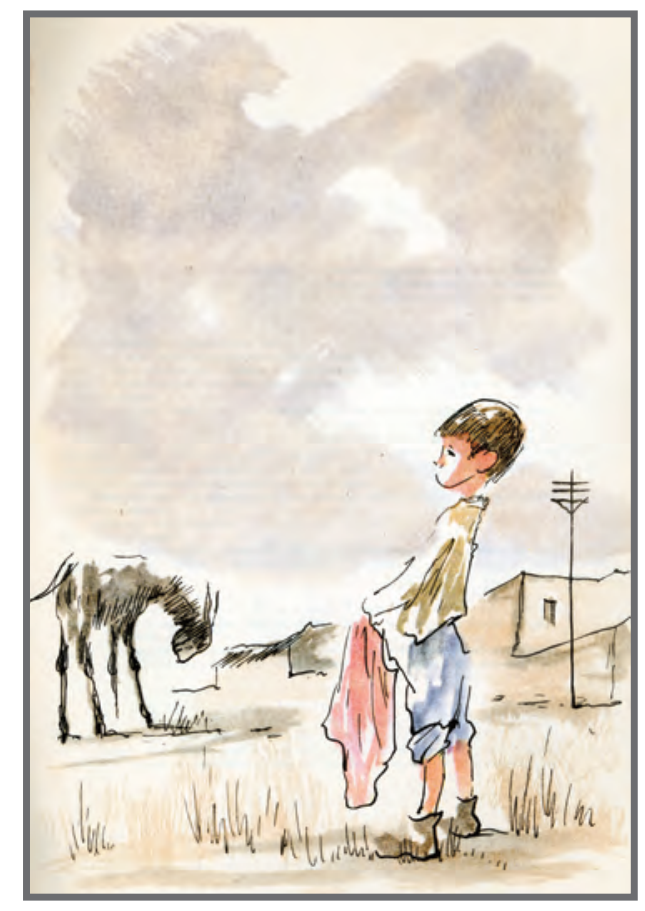

\section{VARIABLES EXTERNAS.}

Título: Mi tío Jacinto (008)

Año: 1956

Página: 21

\section{TIPO DE IMAGEN.}

Retrato: NO

Cartel: NO

Mural: NO

Ilustración: SI

Otras Obras: NO

\section{CONTENIDO.}

Personajes: NIÑO

Animales: BURRO

Gestos Expresivos: EMOCIONES POSITIVAS

Paisajes: SI

Escenas: RURAL

Función: REPRESENTATIVA DE MODELOS SOCIALES

\section{ASPECTOS TÉCNICOS.}

Color dominante: CUATRICROMÍA

Técnica: OFFSET

Plano de la imagen: GENERAL 


\section{VARIABLES EXTERNAS.}

Título: Mi tío Jacinto (009)

Año: 1956

Página: 25

\section{TIPO DE IMAGEN.}

Retrato: NO

Cartel: NO

Mural: NO

Ilustración: SI

Otras Obras: NO

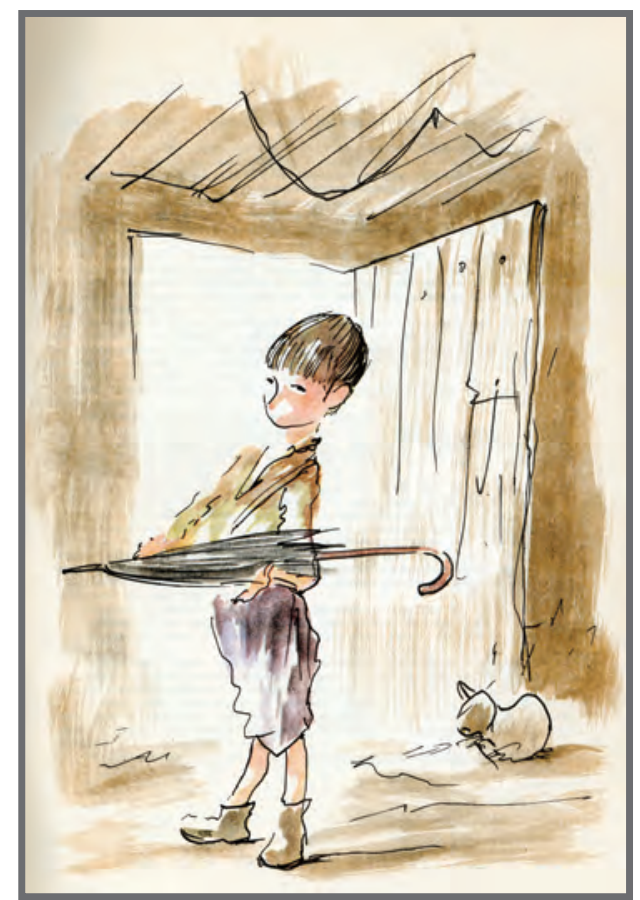

\section{CONTENIDO.}

Personajes: NIÑO

Animales: NO

Gestos Expresivos: EMOCIONES POSITIVAS

Paisajes: NO

Escenas: INTERIOR

Función: REPRESENTATIVA DE MODELOS SOCIALES

\section{ASPECTOS TÉCNICOS.}

Color dominante: CUATRICROMÍA

Técnica: OFFSET

Plano de la imagen: GENERAL 


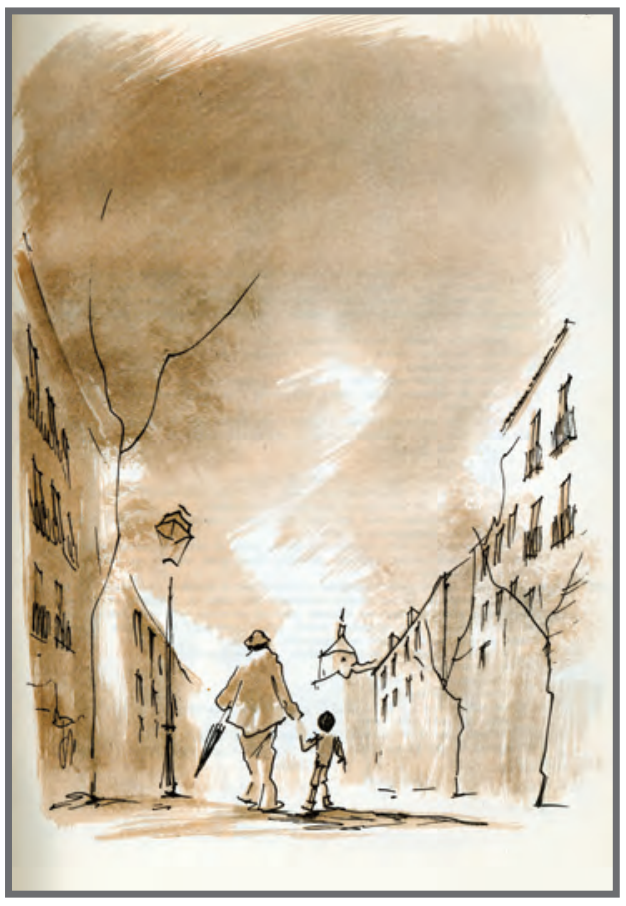

\section{VARIABLES EXTERNAS.}

Título: Mi tío Jacinto (010)

Año: 1956

Página: 29

\section{TIPO DE IMAGEN.}

Retrato: NO

Cartel: NO

Mural: NO

Ilustración: SI

Otras Obras: NO

\section{CONTENIDO.}

Personajes: HOMBRE Y NIÑO

Animales: NO

Gestos Expresivos: EMOCIONES POSITIVAS

Paisajes: SI

Escenas: CALLEJERAS

Función: REPRESENTATIVA DE MODELOS SOCIALES

\section{ASPECTOS TÉCNICOS.}

Color dominante: 2 TINTAS

Técnica: OFFSET

Plano de la imagen: GENERAL 


\section{VARIABLES EXTERNAS.}

Título: Mi tío Jacinto (011)

Año: 1956

Página: 31

\section{TIPO DE IMAGEN.}

Retrato: NO

Cartel: NO

Mural: NO

Ilustración: SI

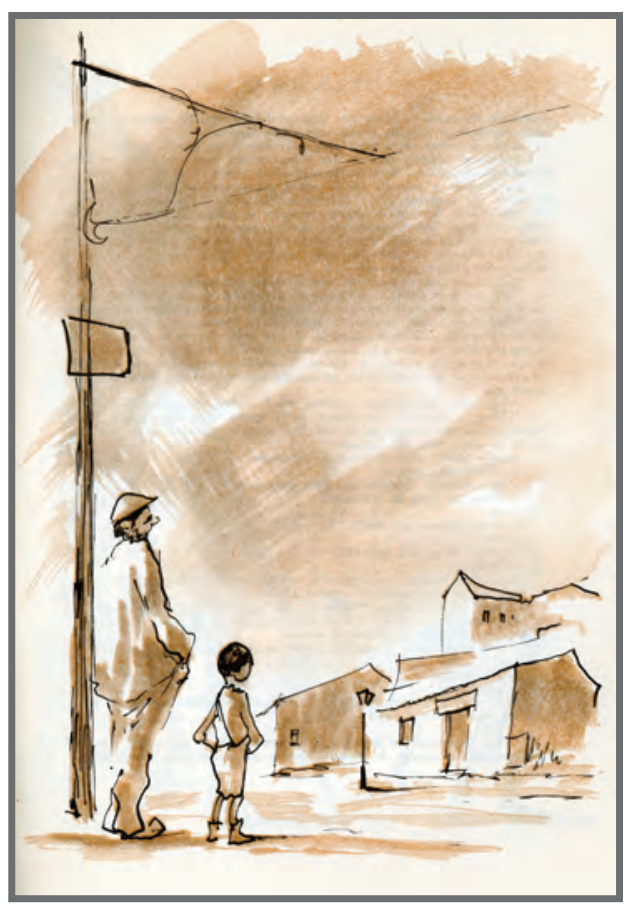

Otras Obras: NO

\section{CONTENIDO.}

Personajes: HOMBRE Y NIÑO

Animales: NO

Gestos Expresivos: EMOCIONES POSITIVAS

Paisajes: SI

Escenas: CALLEJERAS

Función: REPRESENTATIVA DE MODELOS SOCIALES

\section{ASPECTOS TÉCNICOS.}

Color dominante: 2 TINTAS

Técnica: OFFSET

Plano de la imagen: GENERAL 


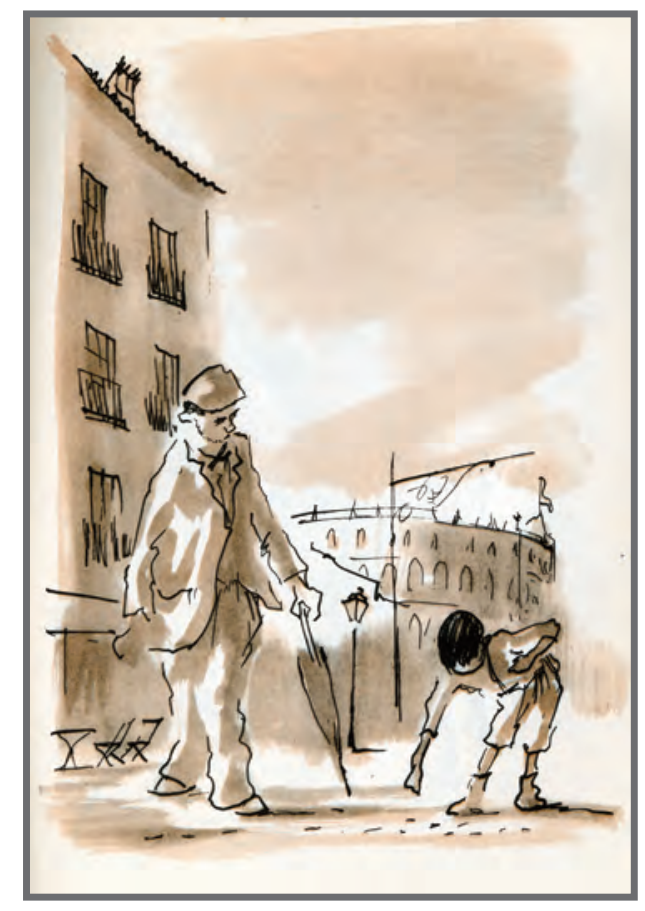

\section{VARIABLES EXTERNAS.}

Título: Mi tío Jacinto (012)

Año: 1956

Página: 33

\section{TIPO DE IMAGEN.}

Retrato: NO

Cartel: NO

Mural: NO

Ilustración: SI

Otras Obras: NO

\section{CONTENIDO.}

Personajes: HOMBRE Y NIÑO

Animales: NO

Gestos Expresivos: EMOCIONES POSITIVAS

Paisajes: SI

Escenas: CALLEJERAS

Función: REPRESENTATIVA DE MODELOS SOCIALES

\section{ASPECTOS TÉCNICOS.}

Color dominante: 2 TINTAS

Técnica: OFFSET

Plano de la imagen: GENERAL 


\section{VARIABLES EXTERNAS.}

Título: Mi tío Jacinto (013)

Año: 1956

Página: 35

\section{TIPO DE IMAGEN.}

Retrato: NO

Cartel: NO

Mural: NO

Ilustración: SI

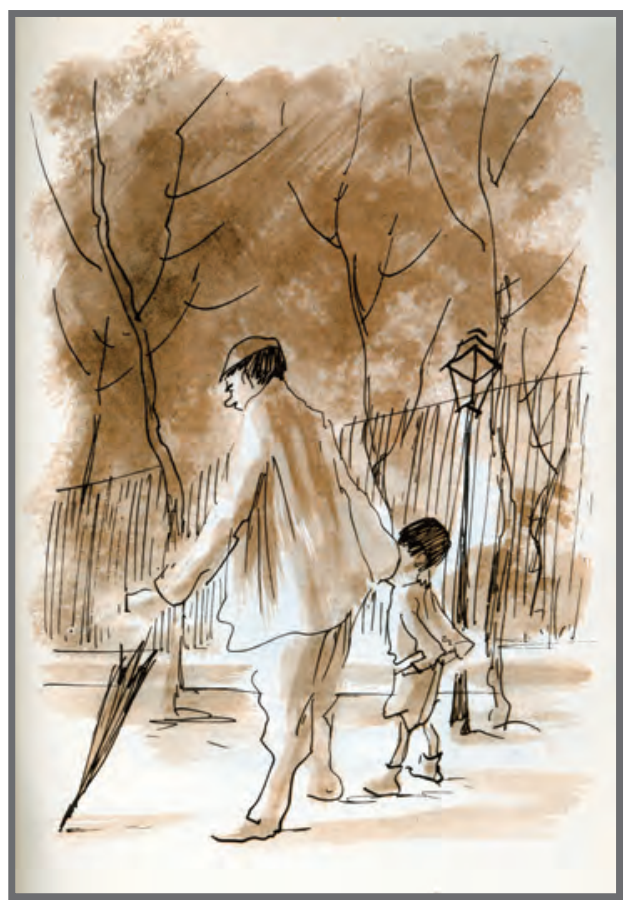

Otras Obras: NO

\section{CONTENIDO.}

Personajes: HOMBRE Y NIÑO

Animales: NO

Gestos Expresivos: EMOCIONES POSITIVAS

Paisajes: SI

Escenas: URBANA

Función: REPRESENTATIVA DE MODELOS SOCIALES

\section{ASPECTOS TÉCNICOS.}

Color dominante: 2 TINTAS

Técnica: OFFSET

Plano de la imagen: GENERAL 


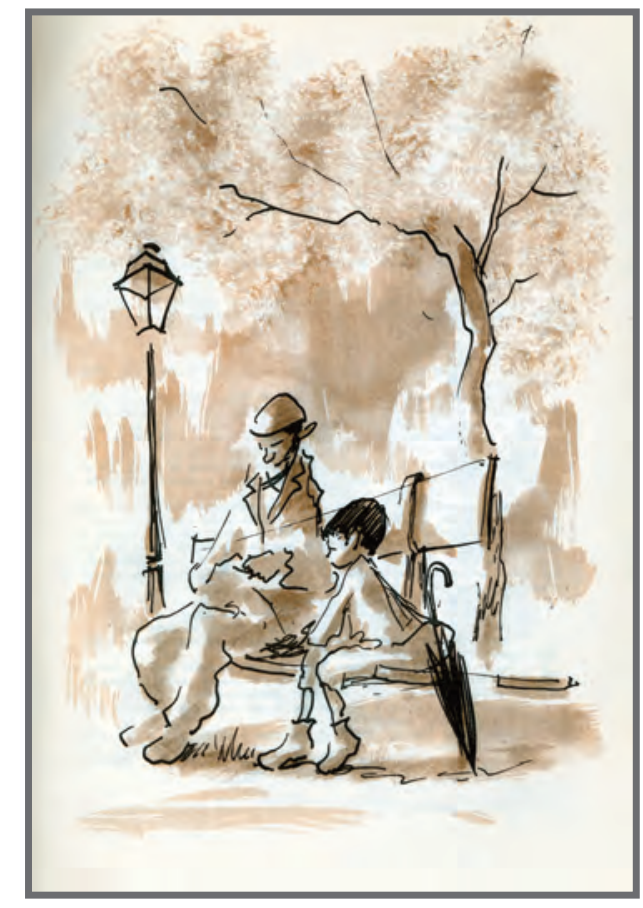

\section{VARIABLES EXTERNAS.}

Título: Mi tío Jacinto (014)

Año: 1956

Página: 37

\section{TIPO DE IMAGEN.}

Retrato: NO

Cartel: NO

Mural: NO

Ilustración: SI

Otras Obras: NO

\section{CONTENIDO.}

Personajes: HOMBRE Y NIÑO

Animales: NO

Gestos Expresivos: EMOCIONES POSITIVAS

Paisajes: SI

Escenas: URBANA

Función: REPRESENTATIVA DE MODELOS SOCIALES

\section{ASPECTOS TÉCNICOS.}

Color dominante: 2 TINTAS

Técnica: OFFSET

Plano de la imagen: GENERAL 


\section{VARIABLES EXTERNAS.}

Título: Mi tío Jacinto (015)

Año: 1956

Página: 39

\section{TIPO DE IMAGEN.}

Retrato: NO

Cartel: NO

Mural: NO

Ilustración: SI

Otras Obras: NO

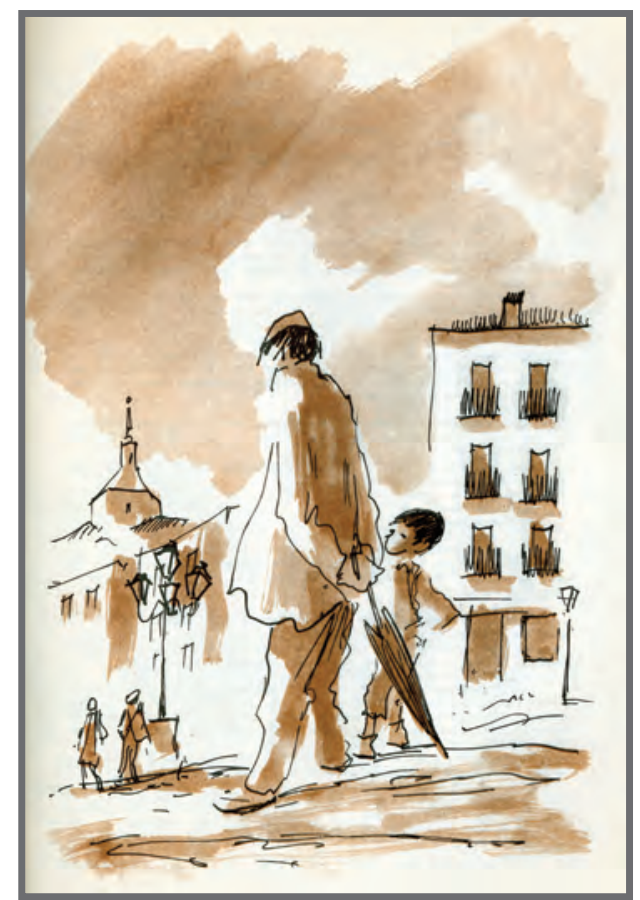

\section{CONTENIDO.}

Personajes: HOMBRES, MUJER Y NIÑO

Animales: NO

Gestos Expresivos: EMOCIONES POSITIVAS

Paisajes: SI

Escenas: CALLEJERAS

Función: REPRESENTATIVA DE MODELOS SOCIALES

\section{ASPECTOS TÉCNICOS.}

Color dominante: 2 TINTAS

Técnica: OFFSET

Plano de la imagen: GENERAL 


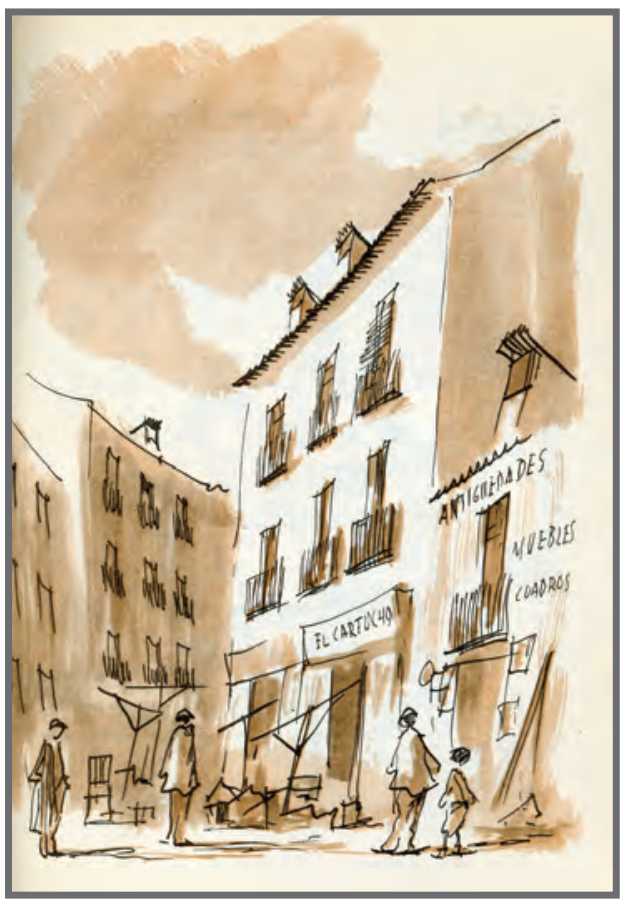

\section{VARIABLES EXTERNAS.}

Título: Mi tío Jacinto (016)

Año: 1956

Página: 41

\section{TIPO DE IMAGEN.}

Retrato: NO

Cartel: NO

Mural: NO

Ilustración: SI

Otras Obras: NO

\section{CONTENIDO.}

Personajes: HOMBRES Y NIÑO

Animales: NO

Gestos Expresivos: EMOCIONES POSITIVAS

Paisajes: SI

Escenas: CALLEJERAS

Función: REPRESENTATIVA DE MODELOS SOCIALES

\section{ASPECTOS TÉCNICOS.}

Color dominante: 2 TINTAS

Técnica: OFFSET

Plano de la imagen: GENERAL 


\section{VARIABLES EXTERNAS.}

Título: Mi tío Jacinto (017)

Año: 1956

Página: 43

\section{TIPO DE IMAGEN.}

Retrato: NO

Cartel: NO

Mural: NO

Ilustración: SI

Otras Obras: NO

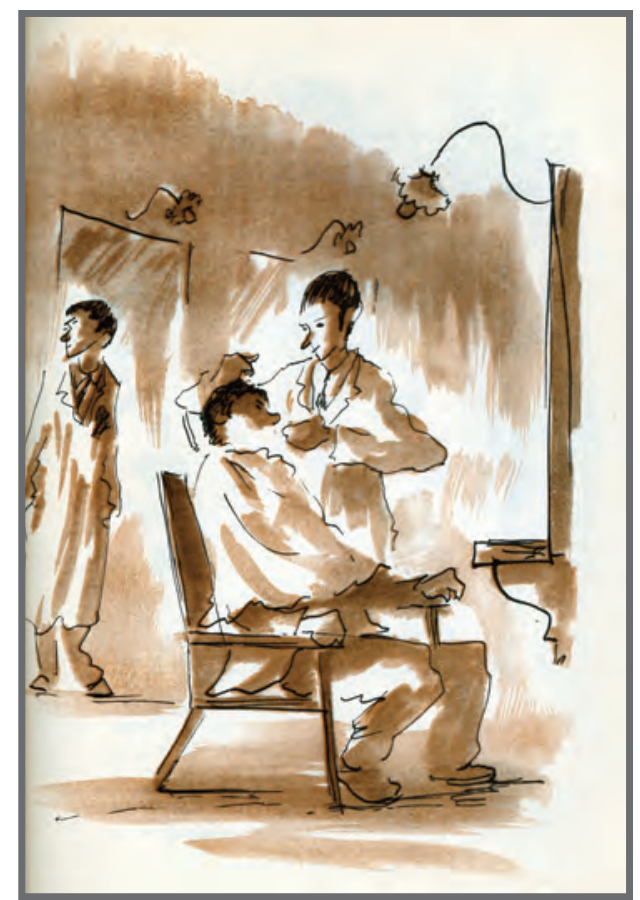

\section{CONTENIDO.}

Personajes: HOMBRES

Animales: NO

Gestos Expresivos: EMOCIONES POSITIVAS

Paisajes: NO

Escenas: PROFESIONAL

Función: REPRESENTATIVA DE MODELOS SOCIALES

\section{ASPECTOS TÉCNICOS.}

Color dominante: 2 TINTAS

Técnica: OFFSET

Plano de la imagen: GENERAL 


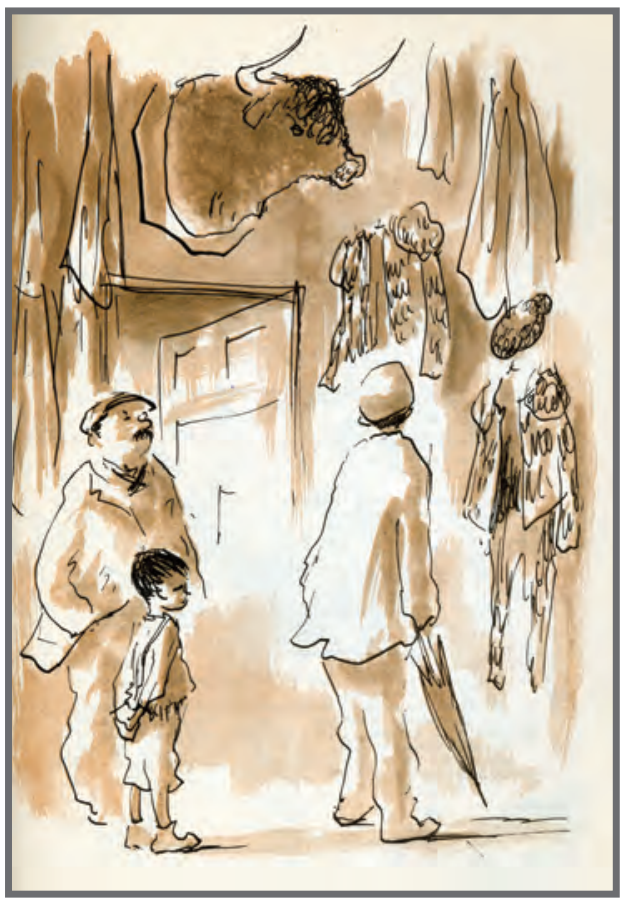

\section{VARIABLES EXTERNAS.}

Título: Mi tío Jacinto (018)

Año: 1956

Página: 45

\section{TIPO DE IMAGEN.}

Retrato: NO

Cartel: NO

Mural: NO

Ilustración: SI

Otras Obras: NO

\section{CONTENIDO.}

Personajes: HOMBRES Y NIÑO

Animales: NO

Gestos Expresivos: EMOCIONES POSITIVAS

Paisajes: NO

Escenas: INTERIOR

Función: REPRESENTATIVA DE MODELOS SOCIALES

\section{ASPECTOS TÉCNICOS.}

Color dominante: 2 TINTAS

Técnica: OFFSET

Plano de la imagen: GENERAL 


\section{VARIABLES EXTERNAS.}

Título: Mi tío Jacinto (019)

Año: 1956

Página: 47

TIPO DE IMAGEN.

Retrato: NO

Cartel: NO

Mural: NO

Ilustración: SI

Otras Obras: NO

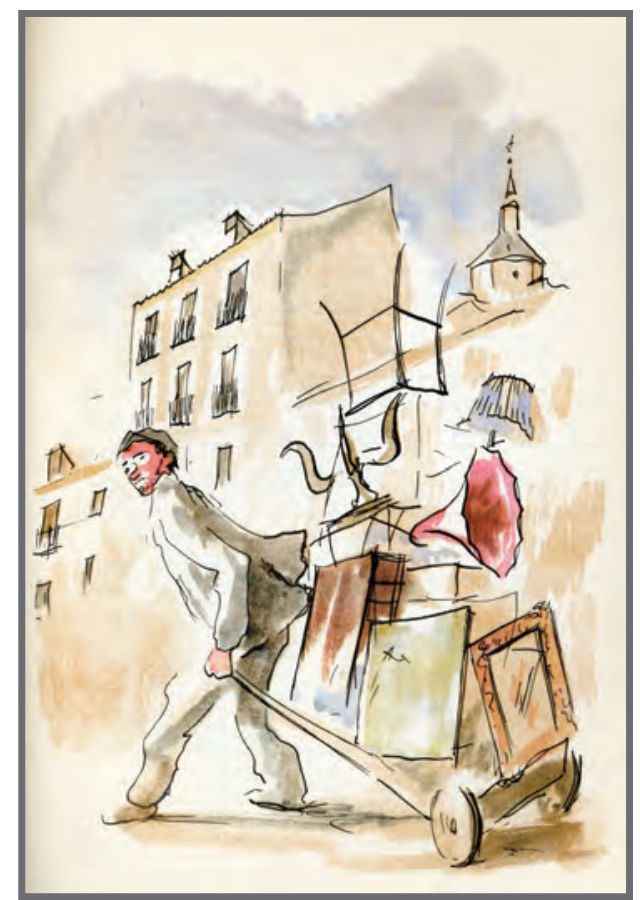

\section{CONTENIDO.}

Personajes: HOMBRE

Animales: NO

Gestos Expresivos: EMOCIONES POSITIVAS

Paisajes: SI

Escenas: PROFESIONAL

Función: REPRESENTATIVA DE MODELOS SOCIALES

\section{ASPECTOS TÉCNICOS.}

Color dominante: CUATRICROMÍA

Técnica: OFFSET

Plano de la imagen: GENERAL 


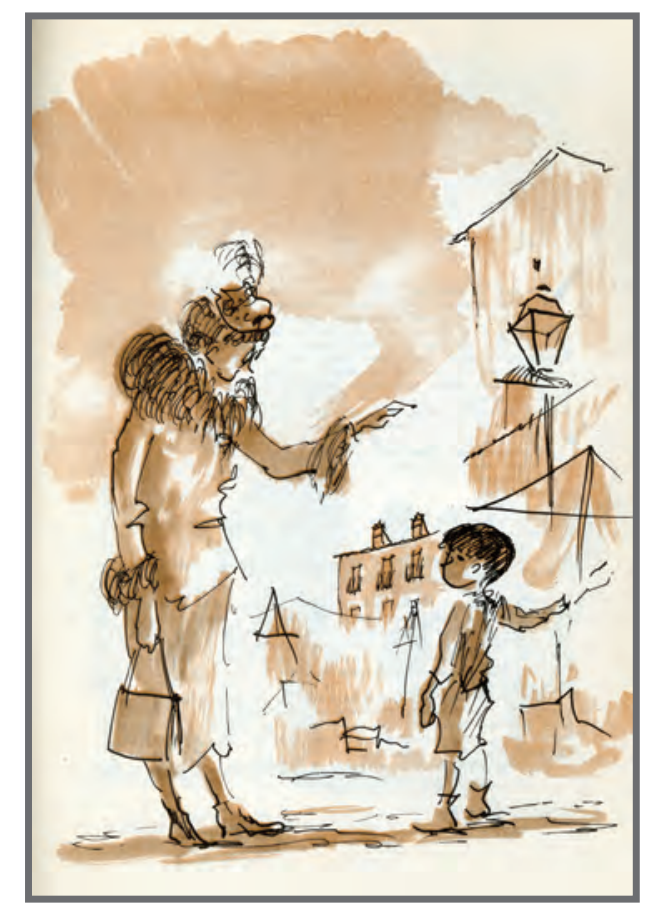

\section{VARIABLES EXTERNAS.}

Título: Mi tío Jacinto (020)

Año: 1956

Página: 51

\section{TIPO DE IMAGEN.}

Retrato: NO

Cartel: NO

Mural: NO

Ilustración: SI

Otras Obras: NO

\section{CONTENIDO.}

Personajes: MUJER Y NIÑO

Animales: NO

Gestos Expresivos: EMOCIONES NEGATIVAS

Paisajes: SI

Escenas: CALLEJERAS

Función: REPRESENTATIVA DE MODELOS SOCIALES

\section{ASPECTOS TÉCNICOS.}

Color dominante: 2 TINTAS

Técnica: OFFSET

Plano de la imagen: GENERAL 


\section{VARIABLES EXTERNAS.}

Título: Mi tío Jacinto (021)

Año: 1956

Página: 53

\section{TIPO DE IMAGEN.}

Retrato: NO

Cartel: NO

Mural: NO

Ilustración: SI

Otras Obras: NO

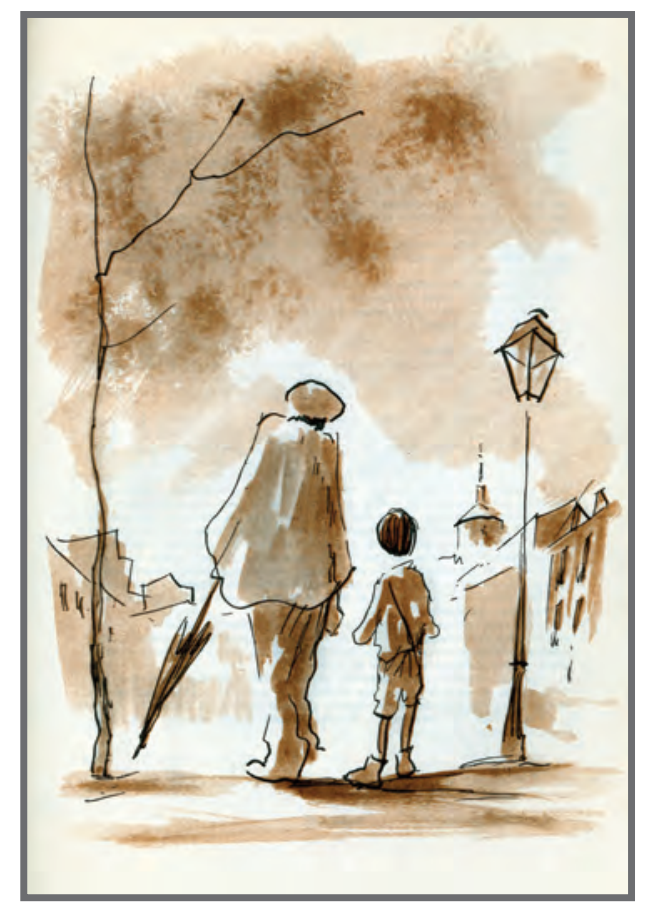

\section{CONTENIDO.}

Personajes: HOMBRE Y NIÑO

Animales: NO

Gestos Expresivos: EMOCIONES POSITIVAS

Paisajes: SI

Escenas: CALLEJERAS

Función: REPRESENTATIVA DE MODELOS SOCIALES

\section{ASPECTOS TÉCNICOS.}

Color dominante: 2 TINTAS

Técnica: OFFSET

Plano de la imagen: GENERAL 


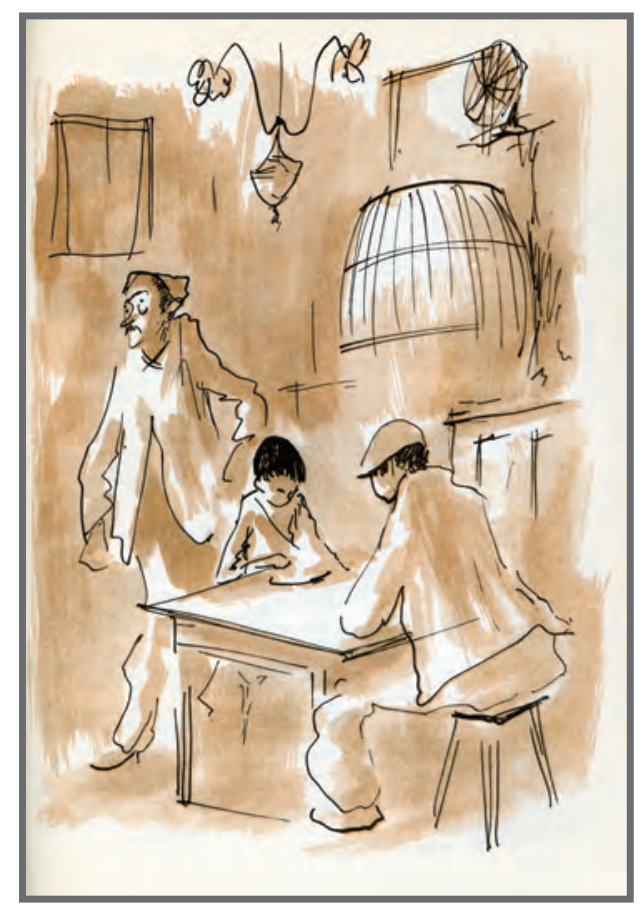

\section{VARIABLES EXTERNAS.}

Título: Mi tío Jacinto (022)

Año: 1956

Página: 55

\section{TIPO DE IMAGEN.}

Retrato: NO

Cartel: NO

Mural: NO

Ilustración: SI

Otras Obras: NO

\section{CONTENIDO.}

Personajes: HOMBRES Y NIÑO

Animales: NO

Gestos Expresivos: EMOCIONES POSITIVAS

Paisajes: NO

Escenas: INTERIOR

Función: REPRESENTATIVA DE MODELOS SOCIALES

\section{ASPECTOS TÉCNICOS.}

Color dominante: 2 TINTAS

Técnica: OFFSET

Plano de la imagen: GENERAL 


\section{VARIABLES EXTERNAS.}

Título: Mi tío Jacinto (023)

Año: 1956

Página: 57

\section{TIPO DE IMAGEN.}

Retrato: NO

Cartel: NO

Mural: NO

Ilustración: SI

Otras Obras: NO

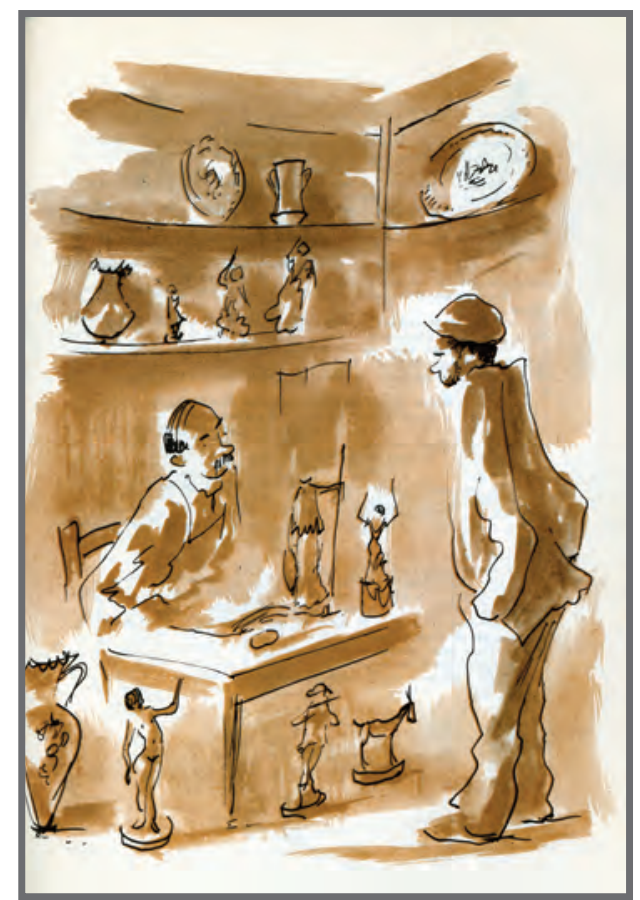

\section{CONTENIDO.}

Personajes: HOMBRES

Animales: NO

Gestos Expresivos: EMOCIONES POSITIVAS

Paisajes: NO

Escenas: PROFESIONAL

Función: REPRESENTATIVA DE MODELOS SOCIALES

\section{ASPECTOS TÉCNICOS.}

Color dominante: 2 TINTAS

Técnica: OFFSET

Plano de la imagen: GENERAL 


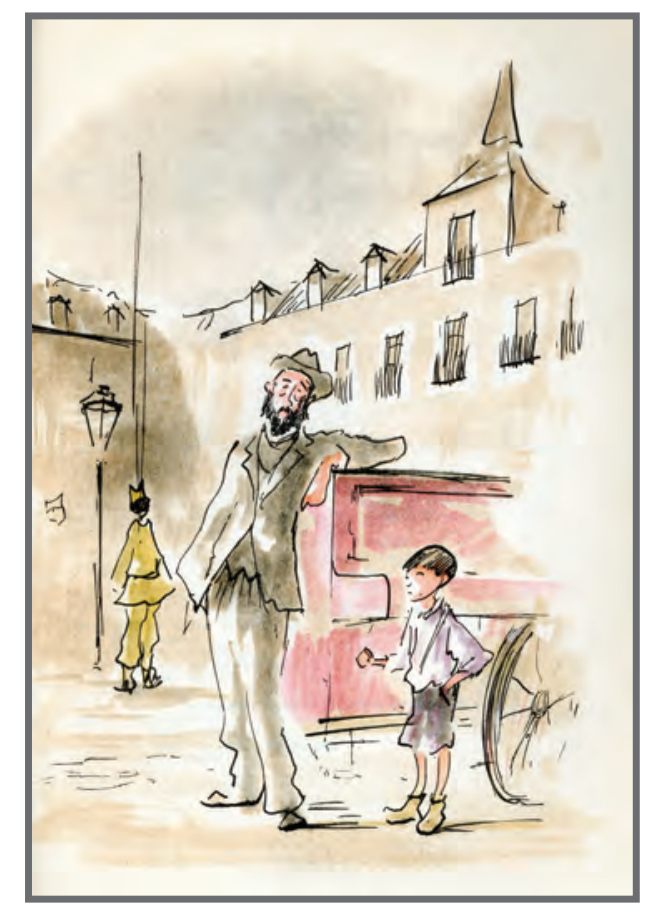

\section{VARIABLES EXTERNAS.}

Título: Mi tío Jacinto (024)

Año: 1956

Página: 59

\section{TIPO DE IMAGEN.}

Retrato: NO

Cartel: NO

Mural: NO

Ilustración: SI

Otras Obras: NO

\section{CONTENIDO.}

Personajes: HOMBRES Y NIÑO

Animales: NO

Gestos Expresivos: EMOCIONES POSITIVAS

Paisajes: SI

Escenas: PROFESIONAL

Función: REPRESENTATIVA DE MODELOS SOCIALES

\section{ASPECTOS TÉCNICOS.}

Color dominante: CUATRICROMÍA

Técnica: OFFSET

Plano de la imagen: GENERAL 


\section{VARIABLES EXTERNAS.}

Título: Mi tío Jacinto (025)

Año: 1956

Página: 63

TIPO DE IMAGEN.

Retrato: NO

Cartel: NO

Mural: NO

Ilustración: SI

Otras Obras: NO

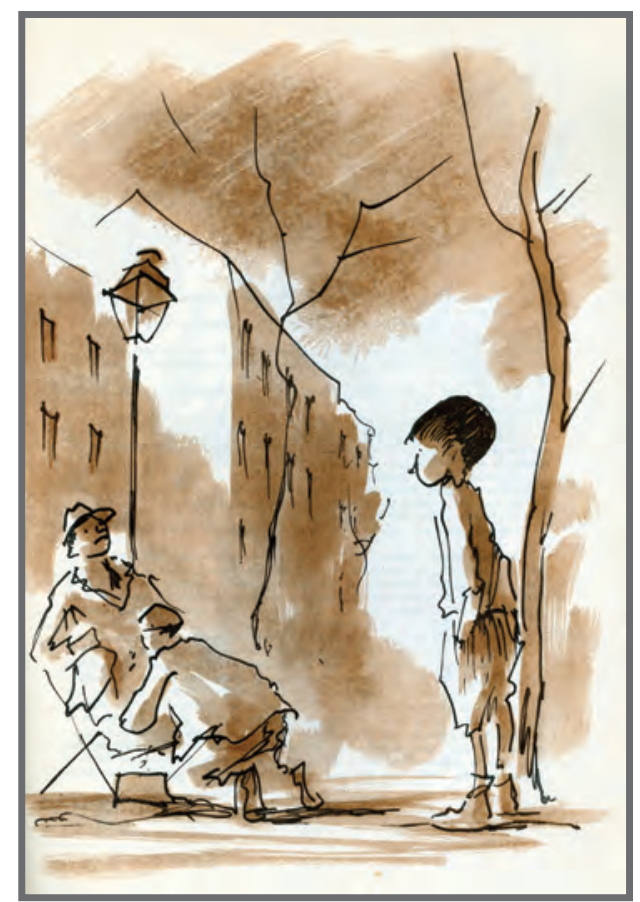

\section{CONTENIDO.}

Personajes: HOMBRES Y NIÑO

Animales: NO

Gestos Expresivos: EMOCIONES POSITIVAS

Paisajes: SI

Escenas: PROFESIONAL

Función: REPRESENTATIVA DE MODELOS SOCIALES

\section{ASPECTOS TÉCNICOS.}

Color dominante: 2 TINTAS

Técnica: OFFSET

Plano de la imagen: GENERAL 


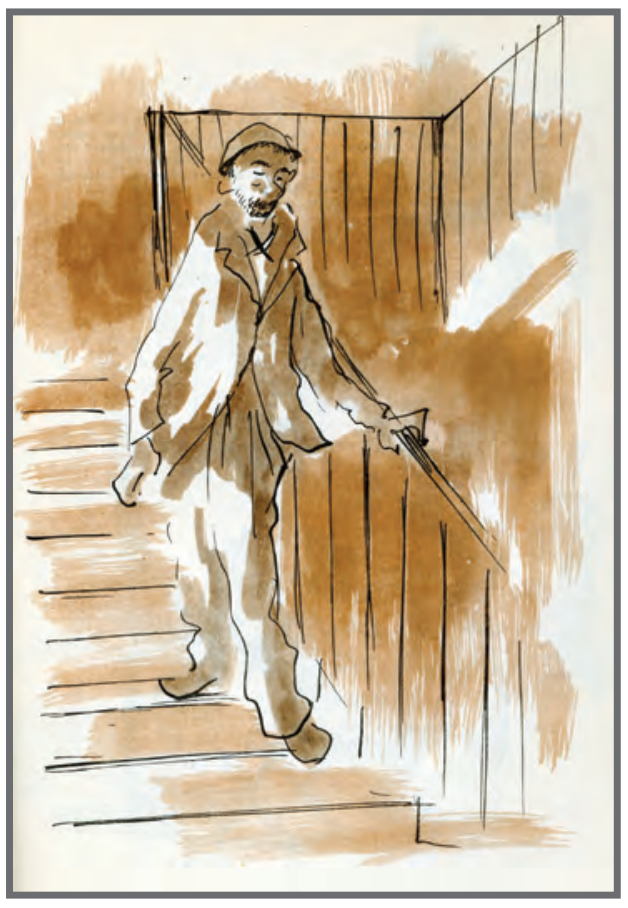

\section{VARIABLES EXTERNAS.}

Título: Mi tío Jacinto (026)

Año: 1956

Página: 65

\section{TIPO DE IMAGEN.}

Retrato: NO

Cartel: NO

Mural: NO

Ilustración: SI

Otras Obras: NO

\section{CONTENIDO.}

Personajes: HOMBRE

Animales: NO

Gestos Expresivos: EMOCIONES POSITIVAS

Paisajes: NO

Escenas: INTERIOR

Función: REPRESENTATIVA DE MODELOS SOCIALES

\section{ASPECTOS TÉCNICOS.}

Color dominante: 2 TINTAS

Técnica: OFFSET

Plano de la imagen: GENERAL 


\section{VARIABLES EXTERNAS.}

Título: Mi tío Jacinto (027)

Año: 1956

Página: 67

\section{TIPO DE IMAGEN.}

Retrato: NO

Cartel: NO

Mural: NO

Ilustración: SI

Otras Obras: NO

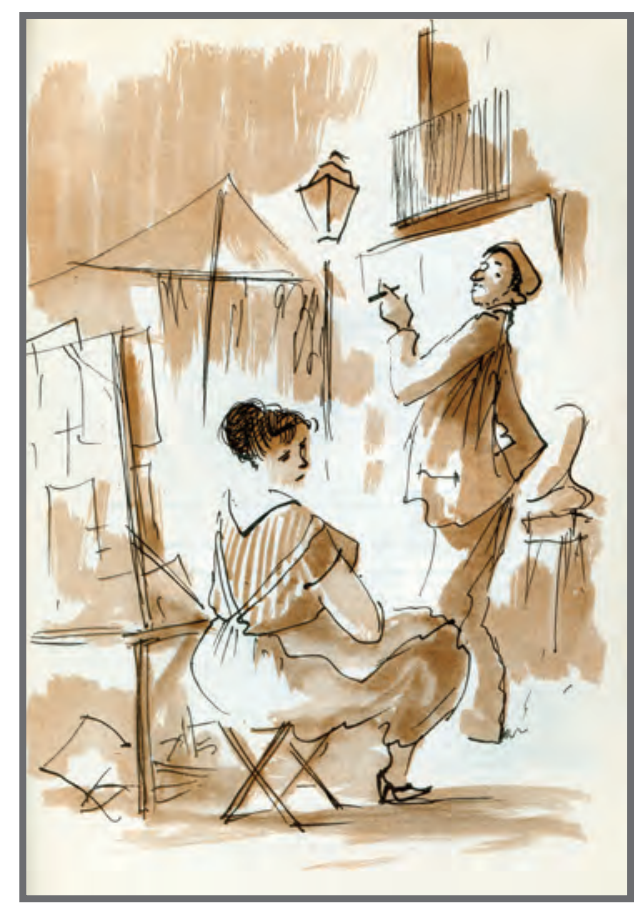

\section{CONTENIDO.}

Personajes: HOMBRE Y MUJER

Animales: NO

Gestos Expresivos: EMOCIONES POSITIVAS

Paisajes: SI

Escenas: PROFESIONAL

Función: REPRESENTATIVA DE MODELOS SOCIALES

\section{ASPECTOS TÉCNICOS.}

Color dominante: 2 TINTAS

Técnica: OFFSET

Plano de la imagen: GENERAL 


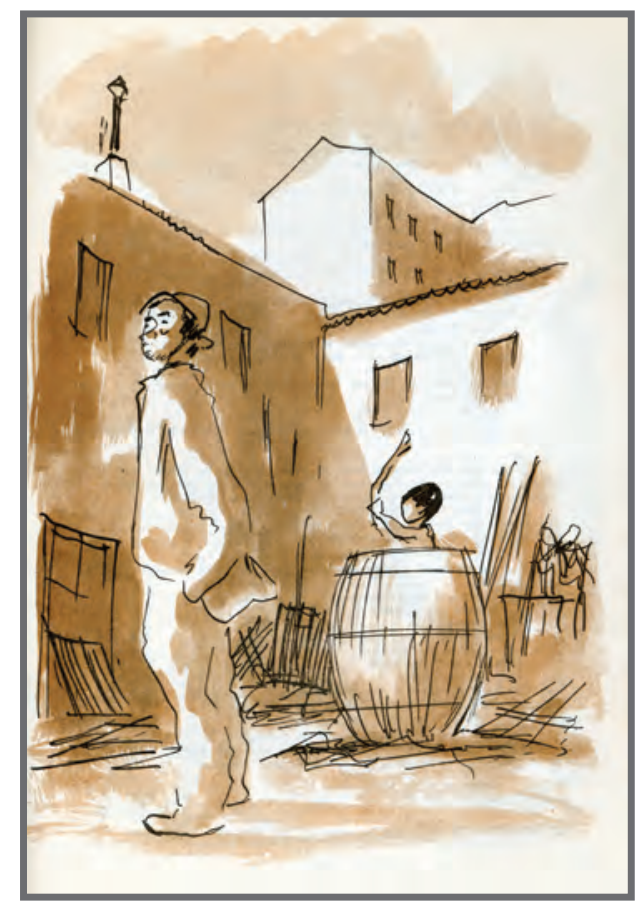

\section{VARIABLES EXTERNAS.}

Título: Mi tío Jacinto (028)

Año: 1956

Página: 69

\section{TIPO DE IMAGEN.}

Retrato: NO

Cartel: NO

Mural: NO

Ilustración: SI

Otras Obras: NO

\section{CONTENIDO.}

Personajes: HOMBRE Y NIÑO

Animales: NO

Gestos Expresivos: EMOCIONES POSITIVAS

Paisajes: SI

Escenas: CALLEJERAS

Función: REPRESENTATIVA DE MODELOS SOCIALES

\section{ASPECTOS TÉCNICOS.}

Color dominante: 2 TINTAS

Técnica: OFFSET

Plano de la imagen: GENERAL 


\section{VARIABLES EXTERNAS.}

Título: Mi tío Jacinto (029)

Año: 1956

Página: 71

\section{TIPO DE IMAGEN.}

Retrato: NO

Cartel: NO

Mural: NO

Ilustración: SI

Otras Obras: NO

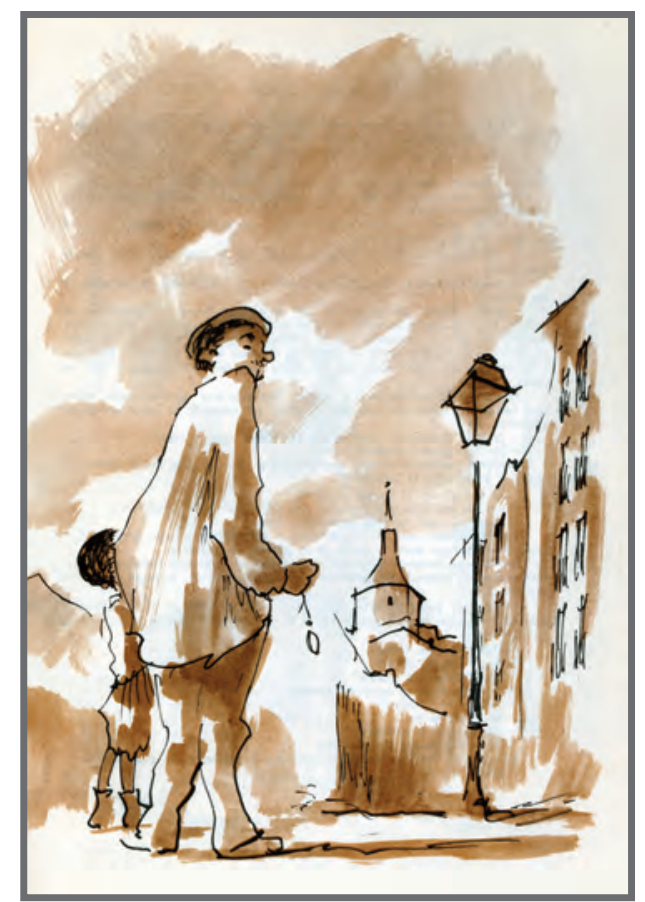

\section{CONTENIDO.}

Personajes: HOMBRE Y NIÑO

Animales: NO

Gestos Expresivos: EMOCIONES POSITIVAS

Paisajes: SI

Escenas: CALLEJERAS

Función: REPRESENTATIVA DE MODELOS SOCIALES

\section{ASPECTOS TÉCNICOS.}

Color dominante: 2 TINTAS

Técnica: OFFSET

Plano de la imagen: GENERAL 


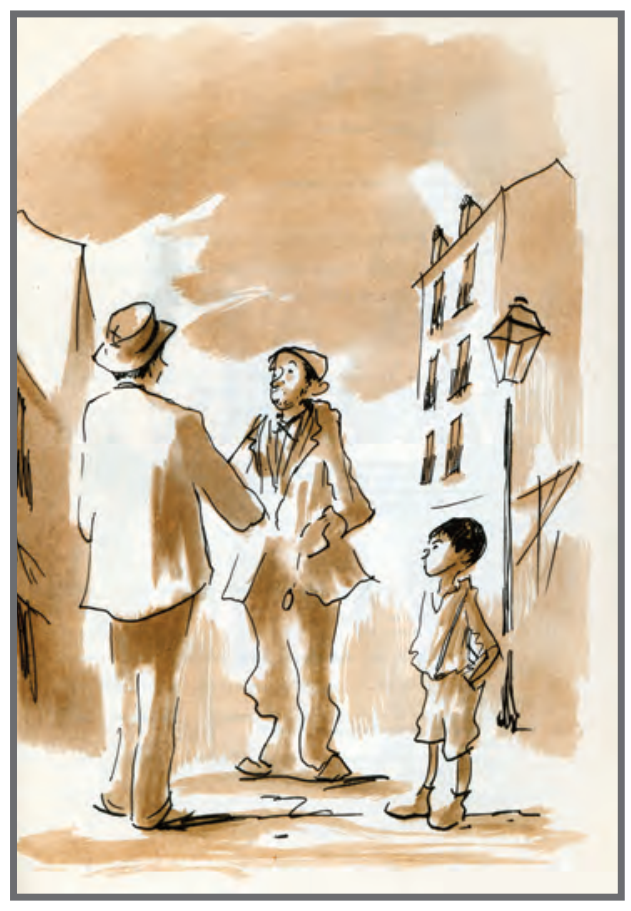

\section{VARIABLES EXTERNAS.}

Título: Mi tío Jacinto (030)

Año: 1956

Página: 73

\section{TIPO DE IMAGEN.}

Retrato: NO

Cartel: NO

Mural: NO

Ilustración: SI

Otras Obras: NO

\section{CONTENIDO.}

Personajes: HOMBRES Y NIÑO

Animales: NO

Gestos Expresivos: EMOCIONES POSITIVAS

Paisajes: SI

Escenas: CALLEJERAS

Función: REPRESENTATIVA DE MODELOS SOCIALES

\section{ASPECTOS TÉCNICOS.}

Color dominante: 2 TINTAS

Técnica: OFFSET

Plano de la imagen: GENERAL 


\section{VARIABLES EXTERNAS.}

Título: Mi tío Jacinto (031)

Año: 1956

Página: 75

TIPO DE IMAGEN.

Retrato: NO

Cartel: NO

Mural: NO

Ilustración: SI

Otras Obras: NO

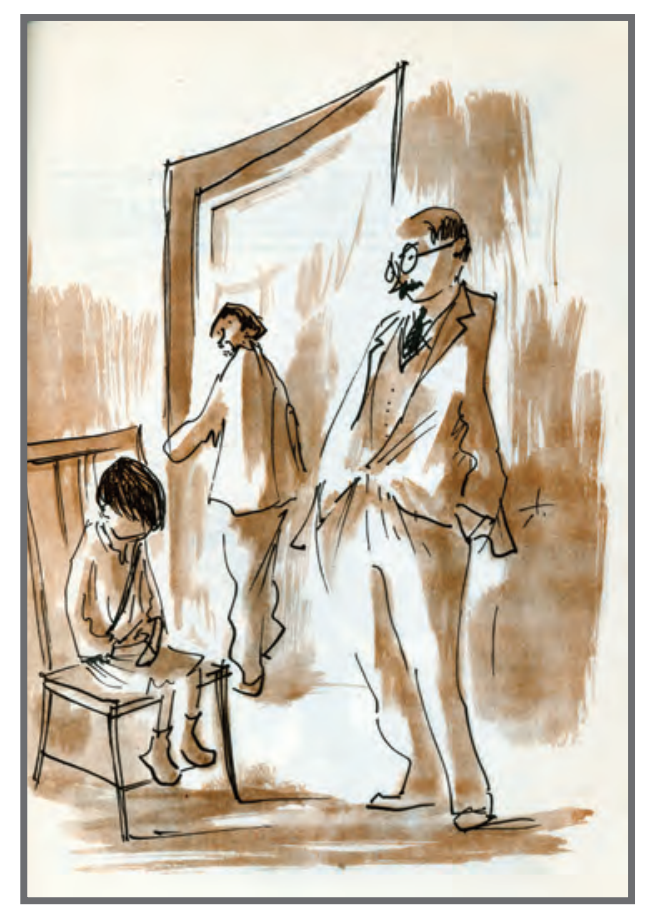

\section{CONTENIDO.}

Personajes: HOMBRES Y NIÑO

Animales: NO

Gestos Expresivos: EMOCIONES NEGATIVAS

Paisajes: NO

Escenas: INTERIOR

Función: REPRESENTATIVA DE MODELOS SOCIALES

\section{ASPECTOS TÉCNICOS.}

Color dominante: 2 TINTAS

Técnica: OFFSET

Plano de la imagen: GENERAL 


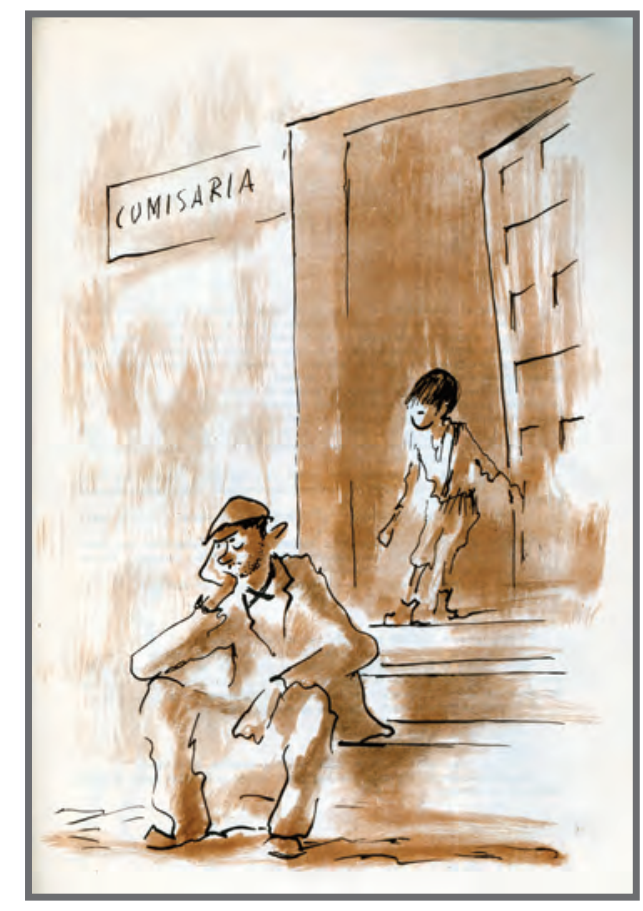

\section{VARIABLES EXTERNAS.}

Título: Mi tío Jacinto (032)

Año: 1956

Página: 77

\section{TIPO DE IMAGEN.}

Retrato: NO

Cartel: NO

Mural: NO

Ilustración: SI

Otras Obras: NO

\section{CONTENIDO.}

Personajes: HOMBRE Y NIÑO

Animales: NO

Gestos Expresivos: EMOCIONES NEGATIVAS

Paisajes: NO

Escenas: URBANA

Función: REPRESENTATIVA DE MODELOS SOCIALES

\section{ASPECTOS TÉCNICOS.}

Color dominante: 2 TINTAS

Técnica: OFFSET

Plano de la imagen: GENERAL 


\section{VARIABLES EXTERNAS.}

Título: Mi tío Jacinto (033)

Año: 1956

Página: 79

\section{TIPO DE IMAGEN.}

Retrato: NO

Cartel: NO

Mural: NO

Ilustración: SI

Otras Obras: NO

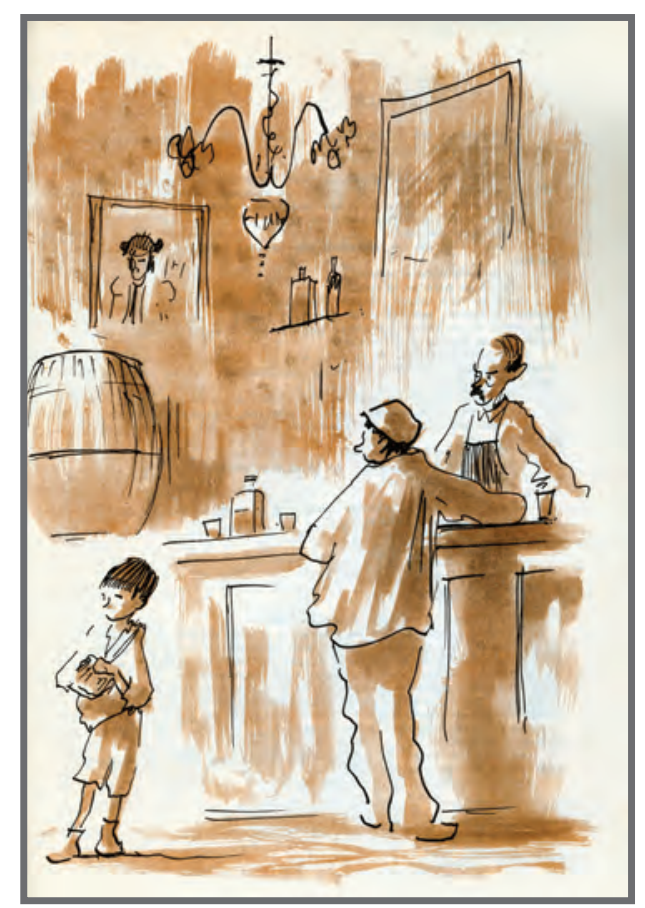

\section{CONTENIDO.}

Personajes: HOMBRES Y NIÑO

Animales: NO

Gestos Expresivos: EMOCIONES POSITIVAS

Paisajes: NO

Escenas: PROFESIONAL

Función: REPRESENTATIVA DE MODELOS SOCIALES

\section{ASPECTOS TÉCNICOS.}

Color dominante: 2 TINTAS

Técnica: OFFSET

Plano de la imagen: GENERAL 


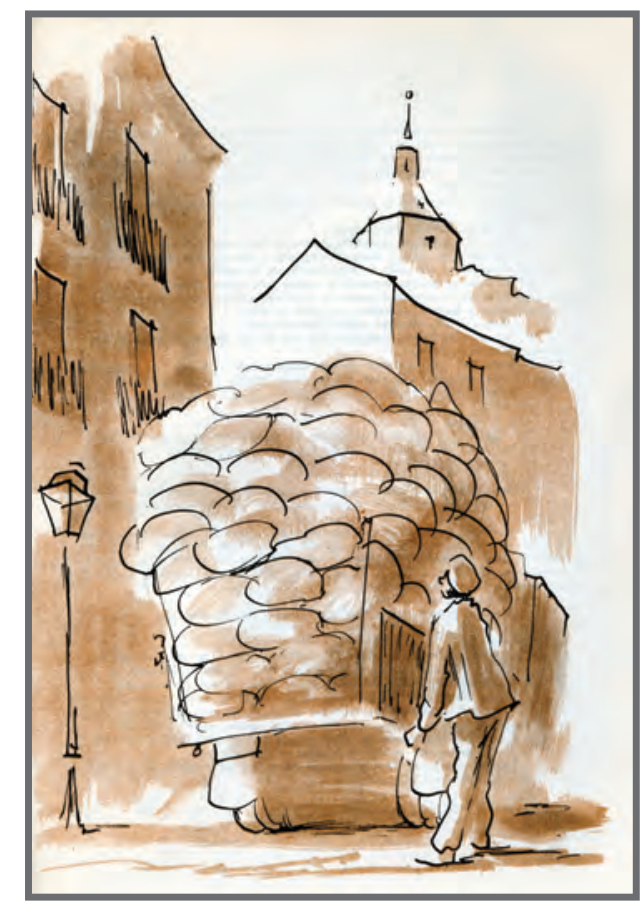

\section{VARIABLES EXTERNAS.}

Título: Mi tío Jacinto (034)

Año: 1956

Página: 81

\section{TIPO DE IMAGEN.}

Retrato: NO

Cartel: NO

Mural: NO

Ilustración: SI

Otras Obras: NO

\section{CONTENIDO.}

Personajes: HOMBRE

Animales: NO

Gestos Expresivos: EMOCIONES POSITIVAS

Paisajes: SI

Escenas: PROFESIONAL

Función: REPRESENTATIVA DE MODELOS SOCIALES

\section{ASPECTOS TÉCNICOS.}

Color dominante: 2 TINTAS

Técnica: OFFSET

Plano de la imagen: GENERAL 


\section{VARIABLES EXTERNAS.}

Título: Mi tío Jacinto (035)

Año: 1956

Página: 83

\section{TIPO DE IMAGEN.}

Retrato: NO

Cartel: NO

Mural: NO

Ilustración: SI

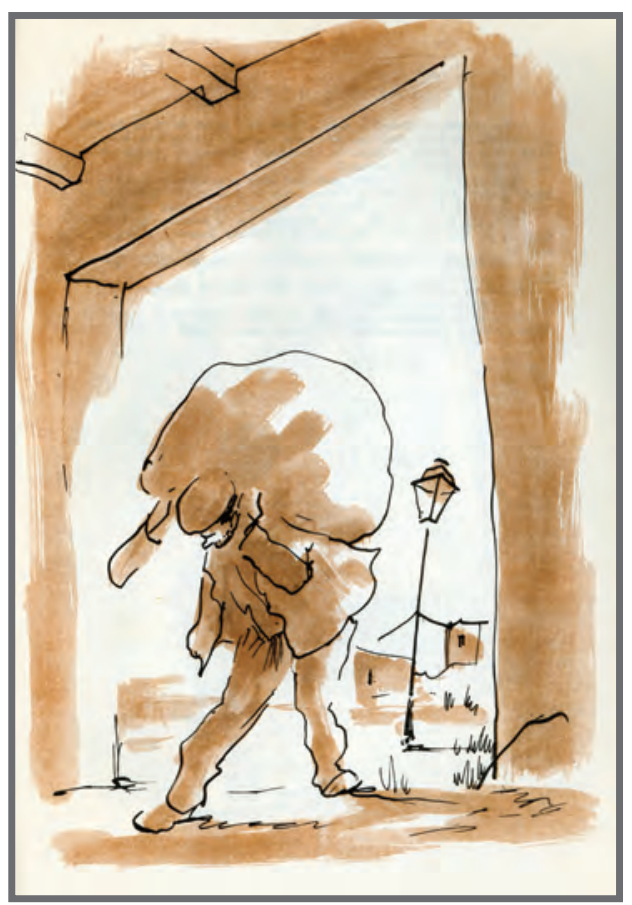

Otras Obras: NO

\section{CONTENIDO.}

Personajes: HOMBRE

Animales: NO

Gestos Expresivos: EMOCIONES POSITIVAS

Paisajes: SI

Escenas: PROFESIONAL

Función: REPRESENTATIVA DE MODELOS SOCIALES

\section{ASPECTOS TÉCNICOS.}

Color dominante: 2 TINTAS

Técnica: OFFSET

Plano de la imagen: GENERAL 


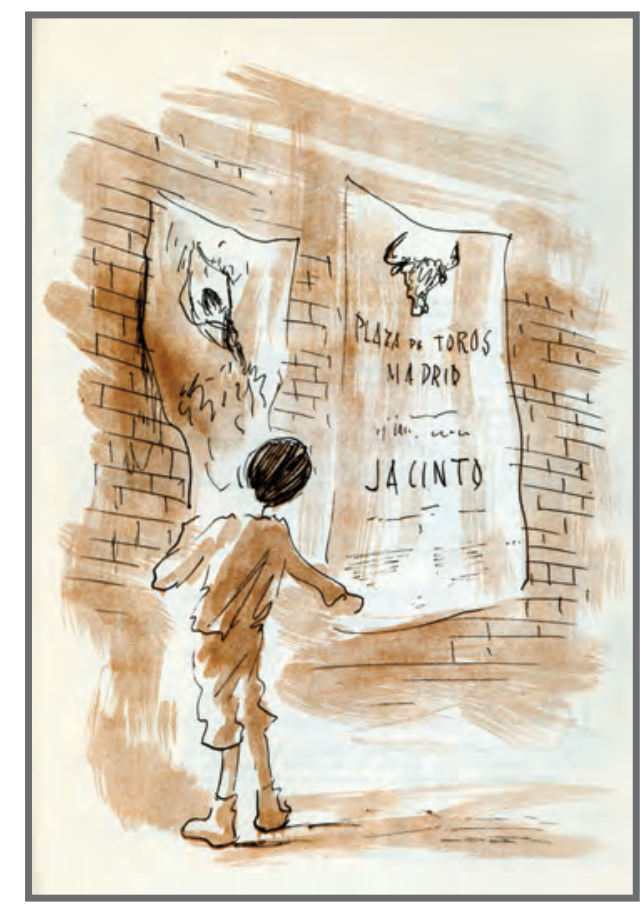

\section{VARIABLES EXTERNAS.}

Título: Mi tío Jacinto (036)

Año: 1956

Página: 85

\section{TIPO DE IMAGEN.}

Retrato: NO

Cartel: NO

Mural: NO

Ilustración: SI

Otras Obras: NO

\section{CONTENIDO.}

Personajes: NIÑO

Animales: NO

Gestos Expresivos: EMOCIONES POSITIVAS

Paisajes: NO

Escenas: URBANA

Función: REPRESENTATIVA DE MODELOS SOCIALES

\section{ASPECTOS TÉCNICOS.}

Color dominante: 2 TINTAS

Técnica: OFFSET

Plano de la imagen: GENERAL 


\section{VARIABLES EXTERNAS.}

Título: Mi tío Jacinto (037)

Año: 1956

Página: 87

\section{TIPO DE IMAGEN.}

Retrato: NO

Cartel: NO

Mural: NO

Ilustración: SI

Otras Obras: NO

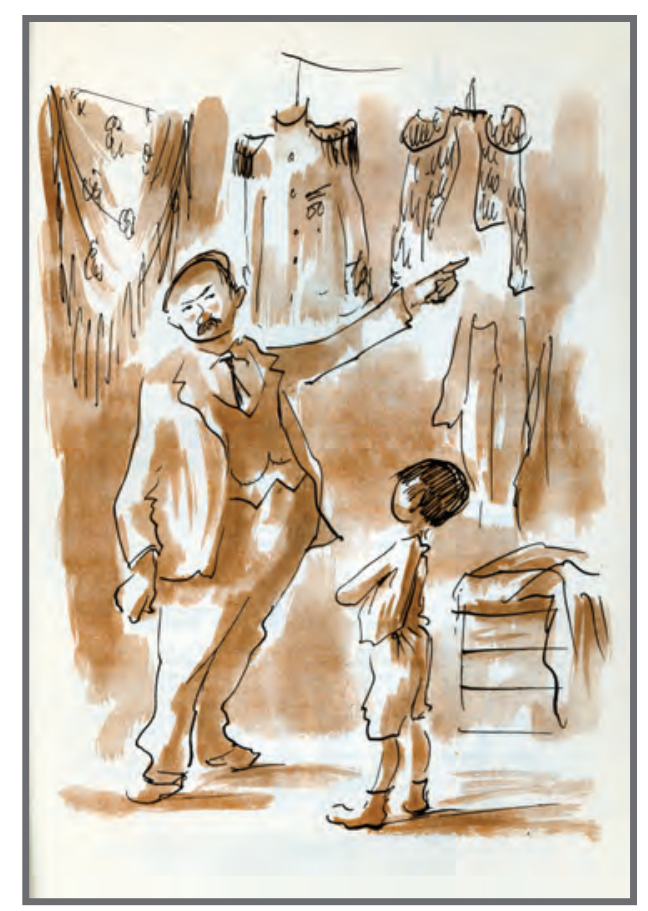

\section{CONTENIDO.}

Personajes: HOMBRE Y NIÑO

Animales: NO

Gestos Expresivos: EMOCIONES NEGATIVAS

Paisajes: NO

Escenas: INTERIOR

Función: REPRESENTATIVA DE MODELOS SOCIALES

\section{ASPECTOS TÉCNICOS.}

Color dominante: 2 TINTAS

Técnica: OFFSET

Plano de la imagen: GENERAL 


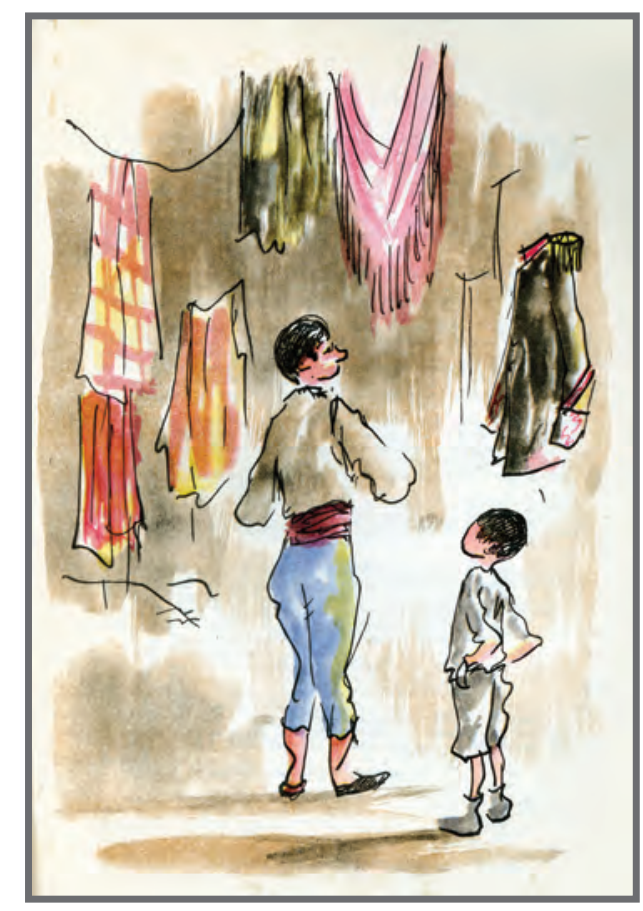

\section{VARIABLES EXTERNAS.}

Título: Mi tío Jacinto (038)

Año: 1956

Página: 89

\section{TIPO DE IMAGEN.}

Retrato: NO

Cartel: NO

Mural: NO

Ilustración: SI

Otras Obras: NO

\section{CONTENIDO.}

Personajes: HOMBRE Y NIÑO

Animales: NO

Gestos Expresivos: EMOCIONES POSITIVAS

Paisajes: NO

Escenas: INTERIOR

Función: REPRESENTATIVA DE MODELOS SOCIALES

\section{ASPECTOS TÉCNICOS.}

Color dominante: CUATRICROMÍA

Técnica: OFFSET

Plano de la imagen: GENERAL 


\section{VARIABLES EXTERNAS.}

Título: Mi tío Jacinto (039)

Año: 1956

Página: 93

\section{TIPO DE IMAGEN.}

Retrato: NO

Cartel: NO

Mural: NO

Ilustración: SI

Otras Obras: NO

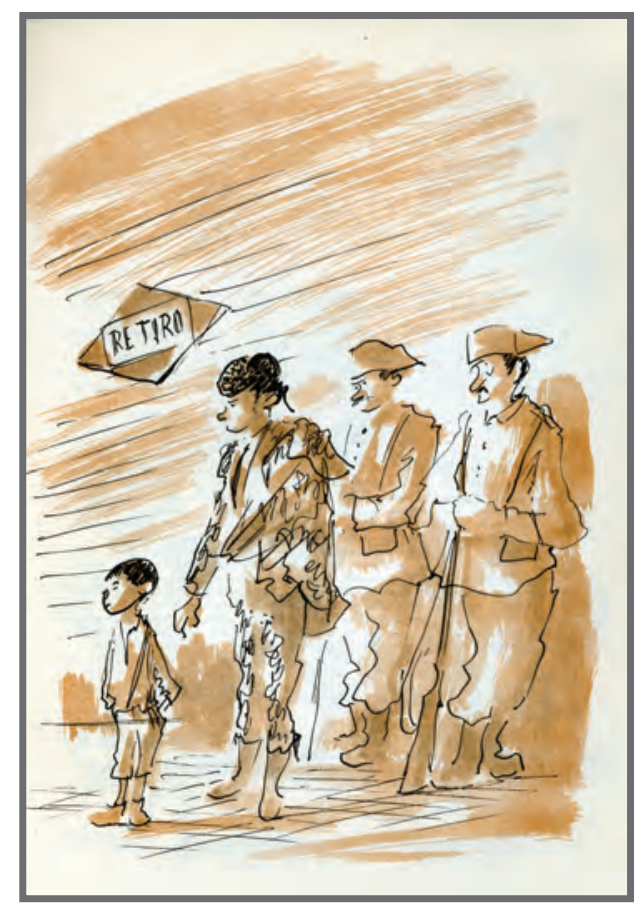

\section{CONTENIDO.}

Personajes: HOMBRES Y NIÑO

Animales: NO

Gestos Expresivos: EMOCIONES POSITIVAS

Paisajes: NO

Escenas: FESTIVA

Función: REPRESENTATIVA DE MODELOS SOCIALES

\section{ASPECTOS TÉCNICOS.}

Color dominante: 2 TINTAS

Técnica: OFFSET

Plano de la imagen: GENERAL 


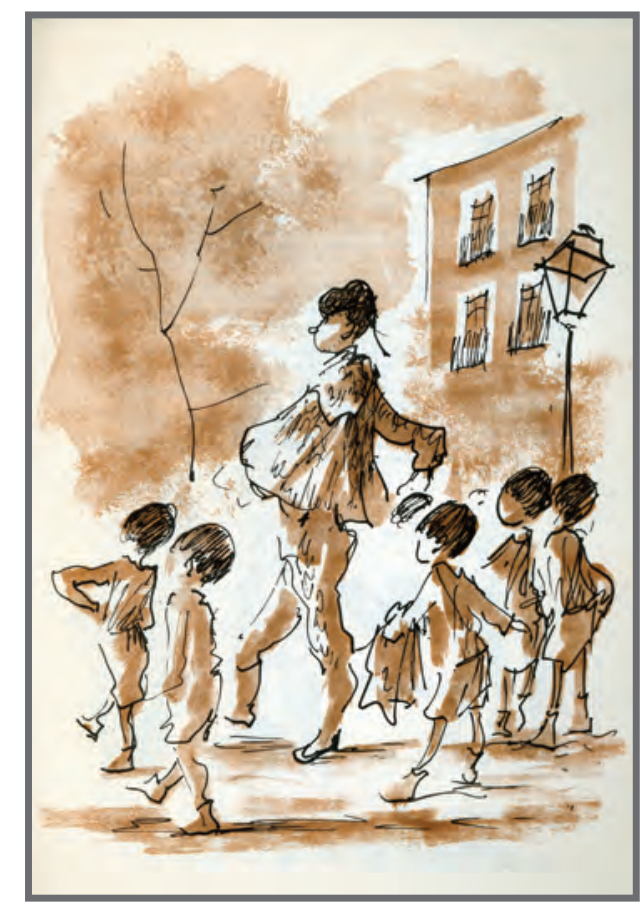

\section{VARIABLES EXTERNAS.}

Título: Mi tío Jacinto (040)

Año: 1956

Página: 95

\section{TIPO DE IMAGEN.}

Retrato: NO

Cartel: NO

Mural: NO

Ilustración: SI

Otras Obras: NO

\section{CONTENIDO.}

Personajes: HOMBRE Y NIÑOS

Animales: NO

Gestos Expresivos: EMOCIONES POSITIVAS

Paisajes: SI

Escenas: FESTIVA

Función: REPRESENTATIVA DE MODELOS SOCIALES

\section{ASPECTOS TÉCNICOS.}

Color dominante: 2 TINTAS

Técnica: OFFSET

Plano de la imagen: GENERAL 


\section{VARIABLES EXTERNAS.}

Título: Mi tío Jacinto (041)

Año: 1956

Página: 97

\section{TIPO DE IMAGEN.}

Retrato: NO

Cartel: NO

Mural: NO

Ilustración: SI

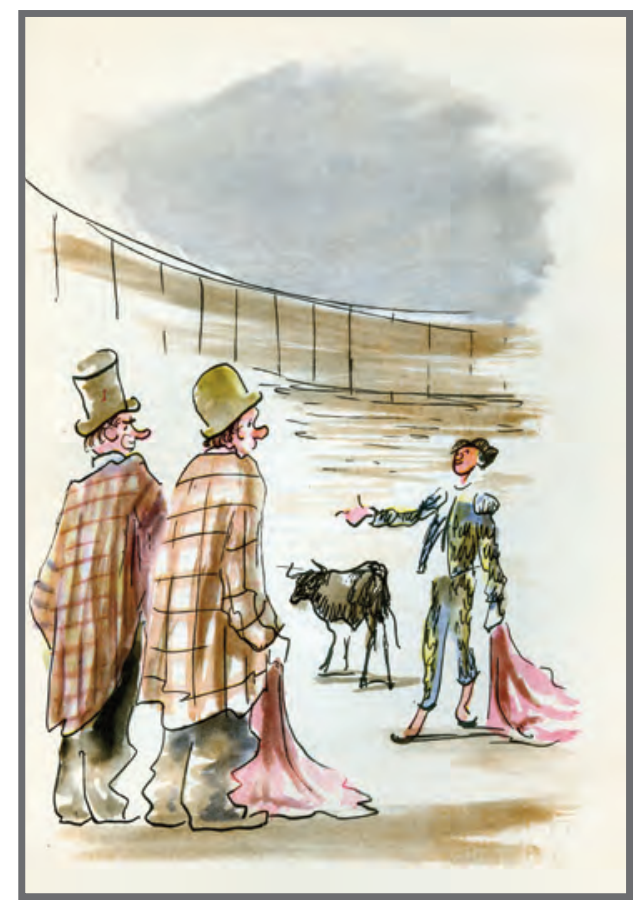

Otras Obras: NO

\section{CONTENIDO.}

Personajes: HOMBRES

Animales: TORO

Gestos Expresivos: EMOCIONES POSITIVAS

Paisajes: NO

Escenas: FESTIVA

Función: REPRESENTATIVA DE MODELOS SOCIALES

\section{ASPECTOS TÉCNICOS.}

Color dominante: CUATRICROMÍA

Técnica: OFFSET

Plano de la imagen: GENERAL 


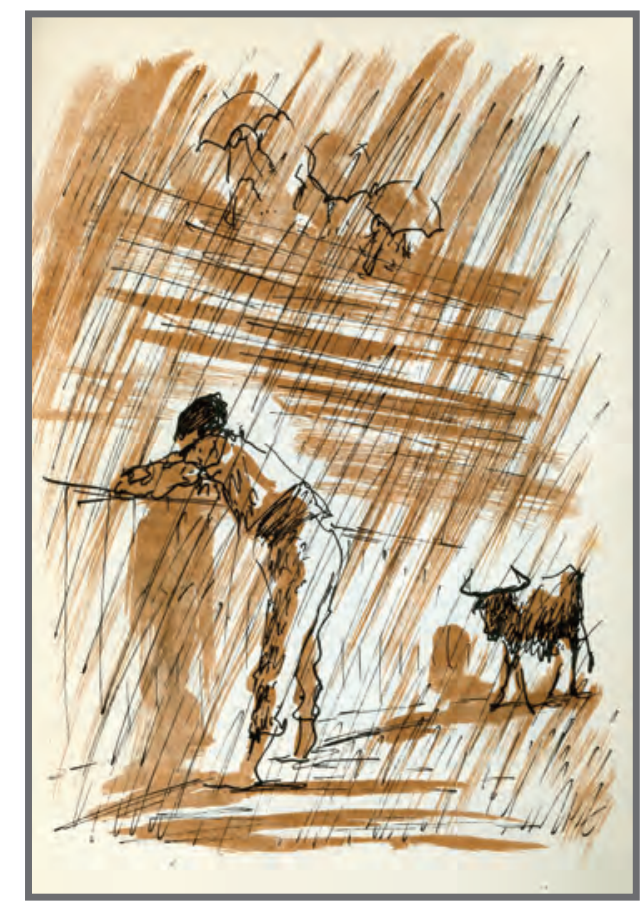

\section{VARIABLES EXTERNAS.}

Título: Mi tío Jacinto (042)

Año: 1956

Página: 101

\section{TIPO DE IMAGEN.}

Retrato: NO

Cartel: NO

Mural: NO

Ilustración: SI

Otras Obras: NO

\section{CONTENIDO.}

Personajes: HOMBRE

Animales: TORO

Gestos Expresivos: EMOCIONES NEGATIVAS

Paisajes: NO

Escenas: FESTIVA

Función: REPRESENTATIVA DE MODELOS SOCIALES

\section{ASPECTOS TÉCNICOS.}

Color dominante: 2 TINTAS

Técnica: OFFSET

Plano de la imagen: GENERAL 


\section{VARIABLES EXTERNAS.}

Título: Mi tío Jacinto (043)

Año: 1956

Página: 103

\section{TIPO DE IMAGEN.}

Retrato: NO

Cartel: NO

Mural: NO

Ilustración: SI

Otras Obras: NO

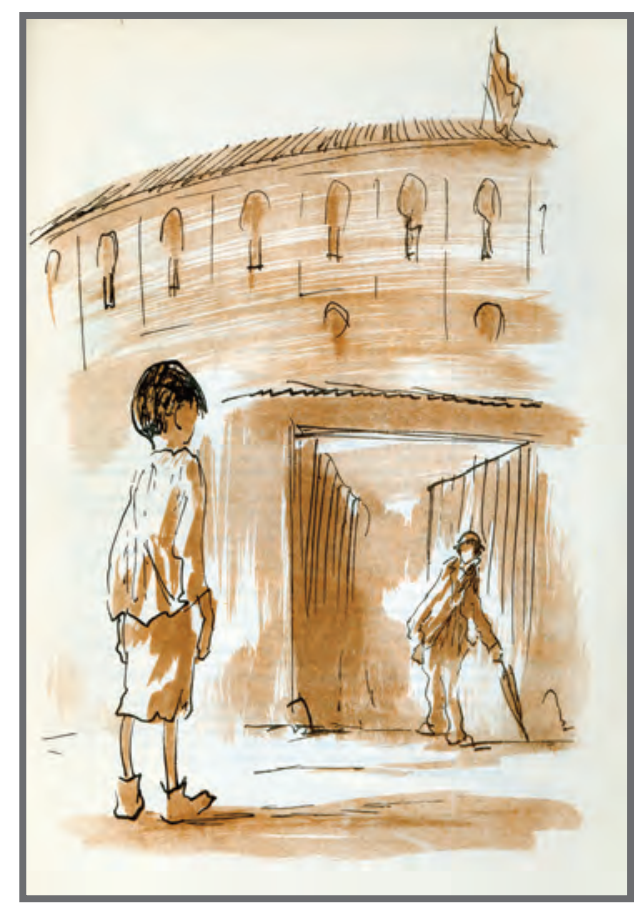

\section{CONTENIDO.}

Personajes: HOMBRE Y NIÑO

Animales: NO

Gestos Expresivos: EMOCIONES POSITIVAS

Paisajes: NO

Escenas: FESTIVA

Función: REPRESENTATIVA DE MODELOS SOCIALES

\section{ASPECTOS TÉCNICOS.}

Color dominante: 2 TINTAS

Técnica: OFFSET

Plano de la imagen: GENERAL 


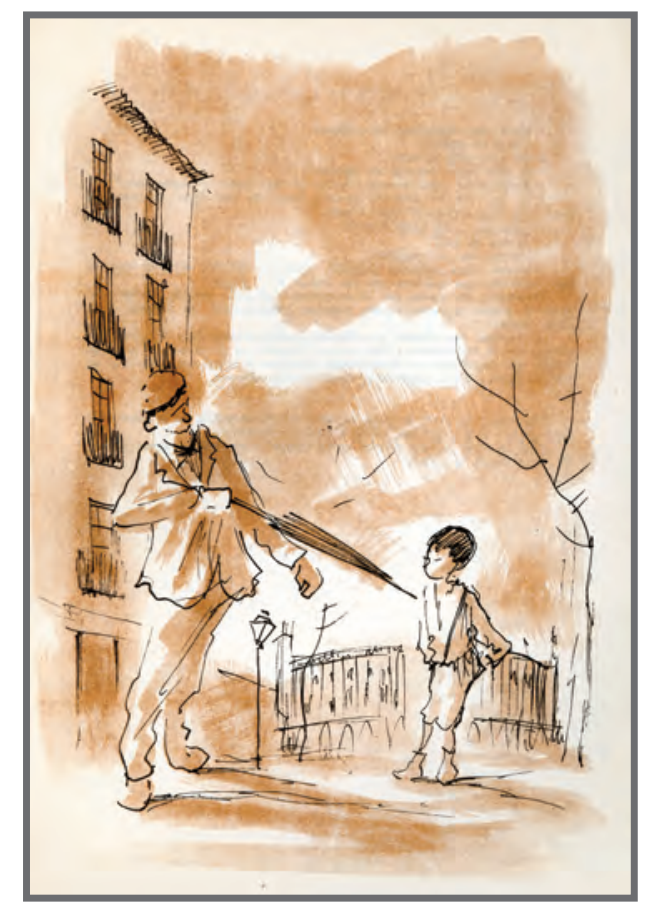

\section{VARIABLES EXTERNAS.}

Título: Mi tío Jacinto (044)

Año: 1956

Página: 105

\section{TIPO DE IMAGEN.}

Retrato: NO

Cartel: NO

Mural: NO

Ilustración: SI

Otras Obras: NO

\section{CONTENIDO.}

Personajes: HOMBRE Y NIÑO

Animales: NO

Gestos Expresivos: EMOCIONES POSITIVAS

Paisajes: SI

Escenas: CALLEJERAS

Función: REPRESENTATIVA DE MODELOS SOCIALES

\section{ASPECTOS TÉCNICOS.}

Color dominante: 2 TINTAS

Técnica: OFFSET

Plano de la imagen: GENERAL 


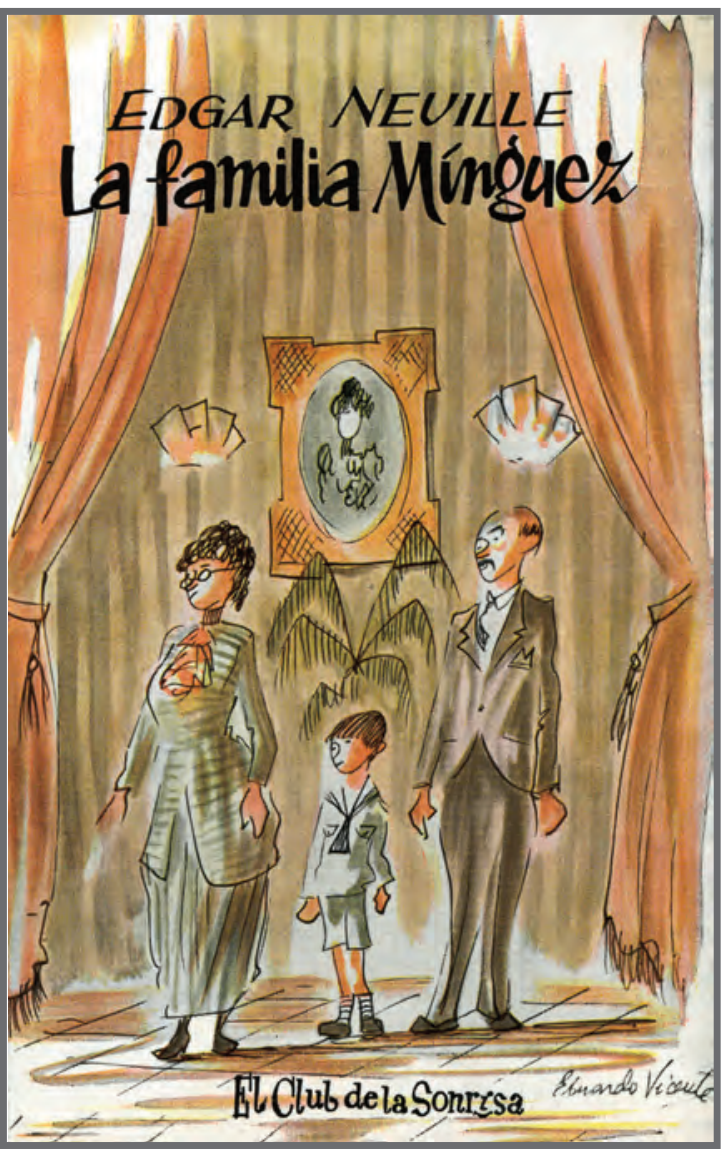

\section{FICHA TÉCNICA.}

Título: LA FAMILIA MÍNGUEZ

Autor: EDGAR NEVILLE

Editorial: TAURUS - MADRID

Año: 1956

Tamaño: 19 x $12 \mathrm{~cm}$.

Número de páginas: 113

Número de ilustraciones: 8 + (ILUSTRACIÓN EN PORTADA)

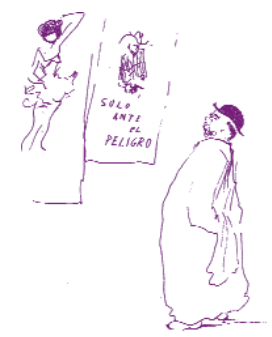



VARIABLES EXTERNAS.

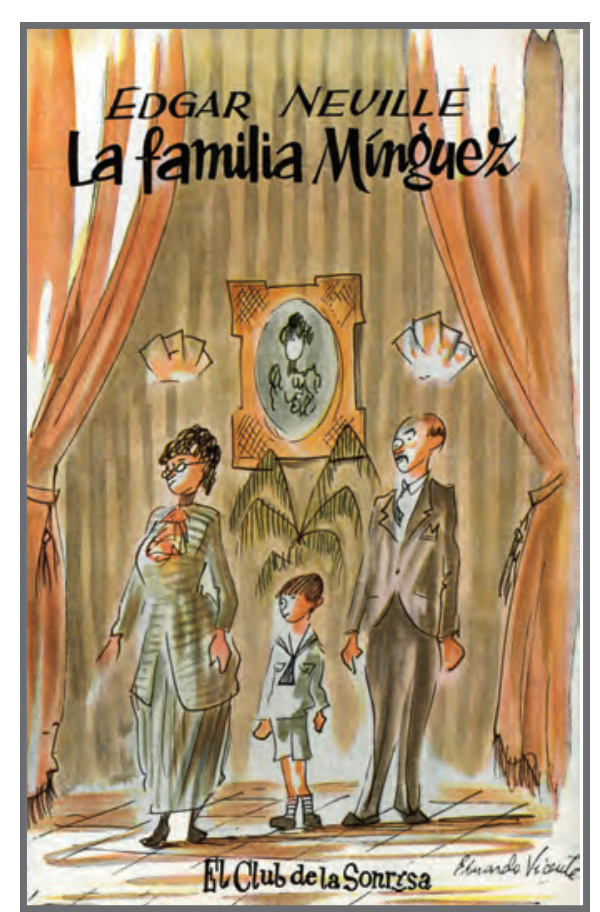

Título: La familia Mínguez (001)

Año: 1956

Página: PORTADA

TIPO DE IMAGEN.

Retrato: NO

Cartel: NO

Mural: NO

Ilustración: SI

Otras Obras: NO

\section{CONTENIDO.}

Personajes: HOMBRE, MUJER Y NIÑO

Animales: NO

Gestos Expresivos: EMOCIONES POSITIVAS

Paisajes: NO

Escenas: INTERIOR

Función: REPRESENTATIVA DE MODELOS SOCIALES

\section{ASPECTOS TÉCNICOS.}

Color dominante: CUATRICROMÍA

Técnica: OFFSET

Plano de la imagen: GENERAL 


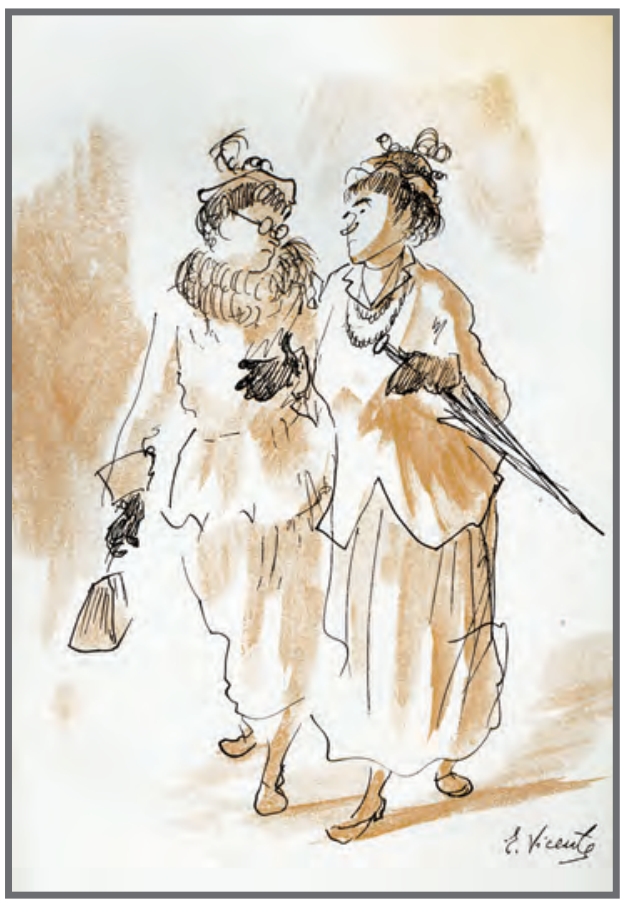

\section{VARIABLES EXTERNAS.}

Título: La familia Mínguez (002)

Año: 1956

Página: 17

\section{TIPO DE IMAGEN.}

Retrato: NO

Cartel: NO

Mural: NO

Ilustración: SI

Otras Obras: NO

\section{CONTENIDO.}

Personajes: MUJERES

Animales: NO

Gestos Expresivos: EMOCIONES POSITIVAS

Paisajes: NO

Escenas: URBANA

Función: REPRESENTATIVA DE MODELOS SOCIALES

\section{ASPECTOS TÉCNICOS.}

Color dominante: 2 TINTAS

Técnica: OFFSET

Plano de la imagen: GENERAL 


\section{VARIABLES EXTERNAS.}

Título: La familia Mínguez (003)

Año: 1956

Página: 33

TIPO DE IMAGEN.

Retrato: NO

Cartel: NO

Mural: NO

Ilustración: SI

Otras Obras: NO

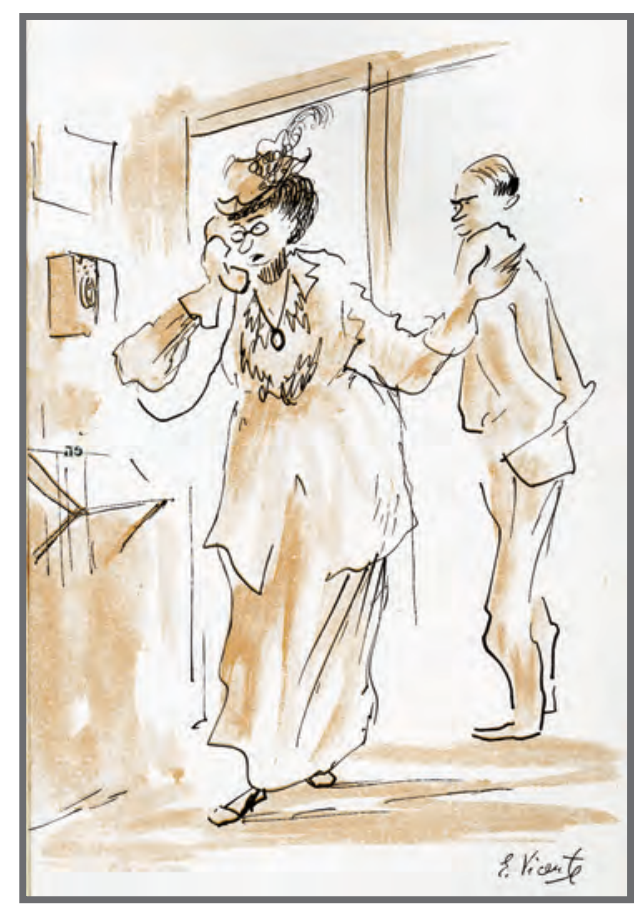

\section{CONTENIDO.}

Personajes: HOMBRE Y MUJER

Animales: NO

Gestos Expresivos: EMOCIONES POSITIVAS

Paisajes: NO

Escenas: INTERIOR

Función: REPRESENTATIVA DE MODELOS SOCIALES

\section{ASPECTOS TÉCNICOS.}

Color dominante: 2 TINTAS

Técnica: OFFSET

Plano de la imagen: GENERAL 


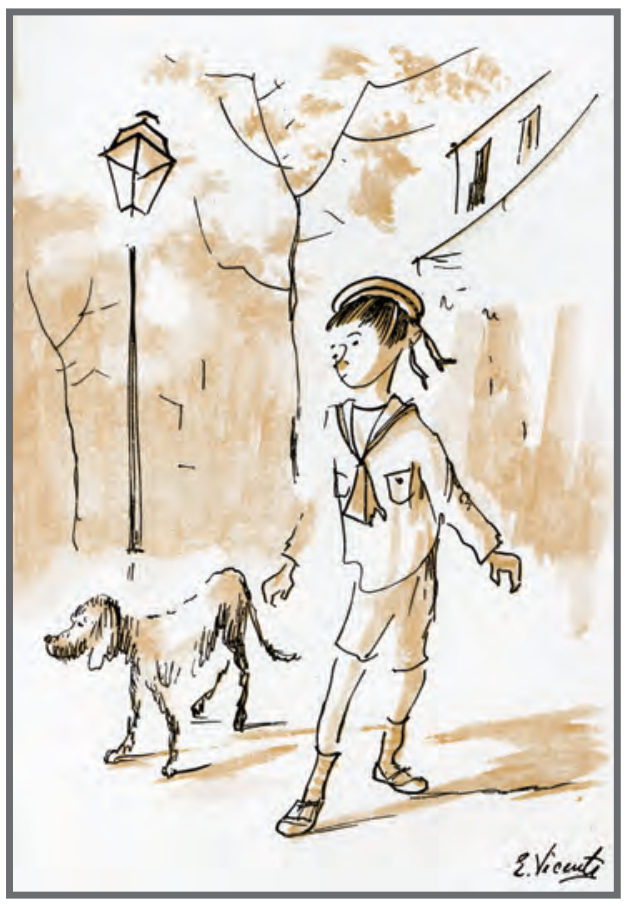

\section{VARIABLES EXTERNAS.}

Título: La familia Mínguez (004)

Año: 1956

Página: 97

\section{TIPO DE IMAGEN.}

Retrato: NO

Cartel: NO

Mural: NO

Ilustración: SI

Otras Obras: NO

\section{CONTENIDO.}

Personajes: NIÑO

Animales: PERRO

Gestos Expresivos: EMOCIONES POSITIVAS

Paisajes: SI

Escenas: URBANA

Función: REPRESENTATIVA DE MODELOS SOCIALES

\section{ASPECTOS TÉCNICOS.}

Color dominante: 2 TINTAS

Técnica: OFFSET

Plano de la imagen: GENERAL 


\section{VARIABLES EXTERNAS.}

Título: La familia Mínguez (005)

Año: 1956

Página: 105

\section{TIPO DE IMAGEN.}

Retrato: NO

Cartel: NO

Mural: NO

Ilustración: SI

Otras Obras: NO

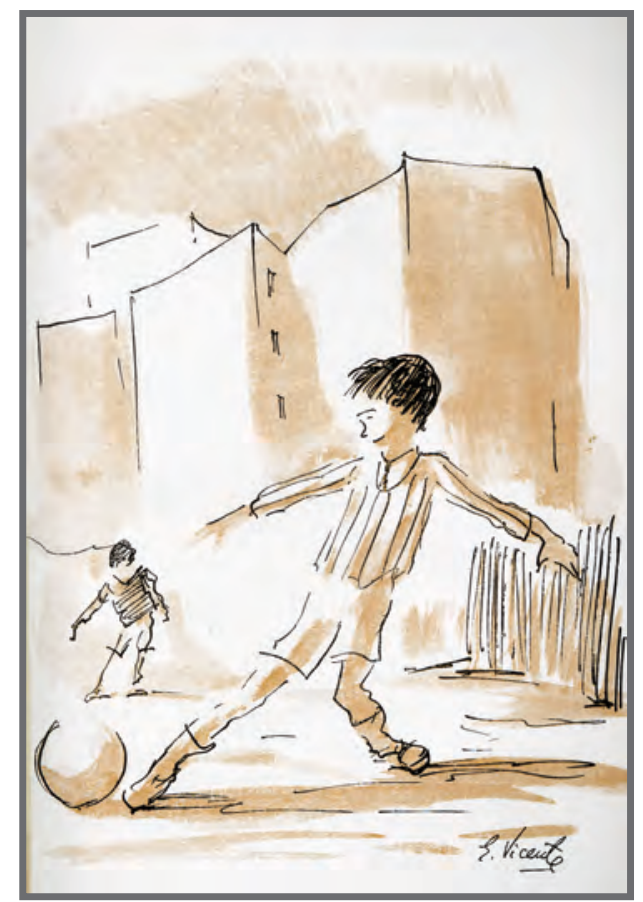

\section{CONTENIDO.}

Personajes: NIÑOS

Animales: NO

Gestos Expresivos: EMOCIONES POSITIVAS

Paisajes: NO

Escenas: FESTIVA

Función: REPRESENTATIVA DE MODELOS SOCIALES

\section{ASPECTOS TÉCNICOS.}

Color dominante: 2 TINTAS

Técnica: OFFSET

Plano de la imagen: GENERAL 


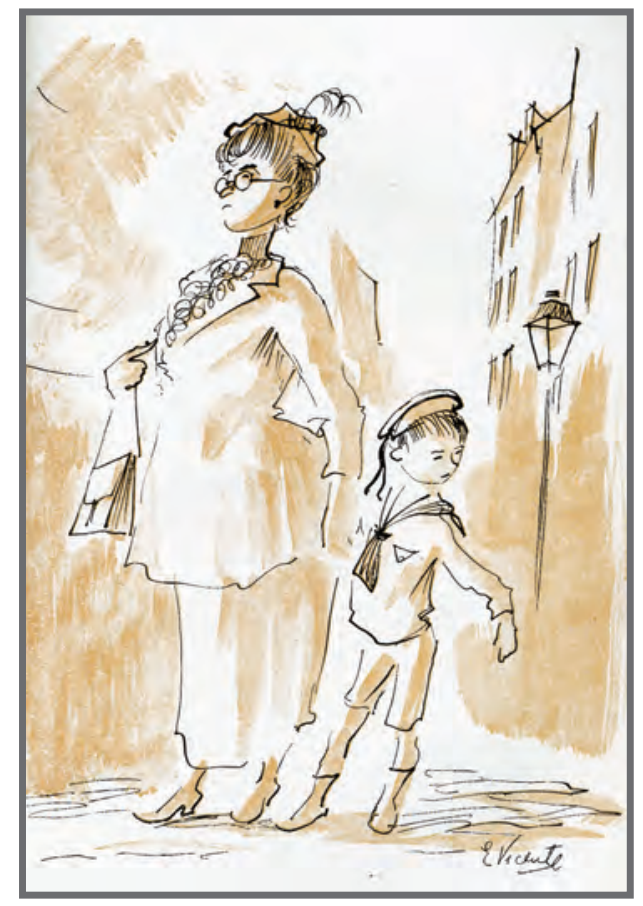

\section{VARIABLES EXTERNAS.}

Título: La familia Mínguez (006)

Año: 1956

Página: 145

\section{TIPO DE IMAGEN.}

Retrato: NO

Cartel: NO

Mural: NO

Ilustración: SI

Otras Obras: NO

\section{CONTENIDO.}

Personajes: MUJERE Y NIÑO

Animales: NO

Gestos Expresivos: EMOCIONES POSITIVAS

Paisajes: SI

Escenas: CALLEJERA

Función: REPRESENTATIVA DE MODELOS SOCIALES

\section{ASPECTOS TÉCNICOS.}

Color dominante: 2 TINTAS

Técnica: OFFSET

Plano de la imagen: GENERAL 


\section{VARIABLES EXTERNAS.}

Título: La familia Mínguez (007)

Año: 1956

Página: 153

\section{TIPO DE IMAGEN.}

Retrato: NO

Cartel: NO

Mural: NO

Ilustración: SI

Otras Obras: NO

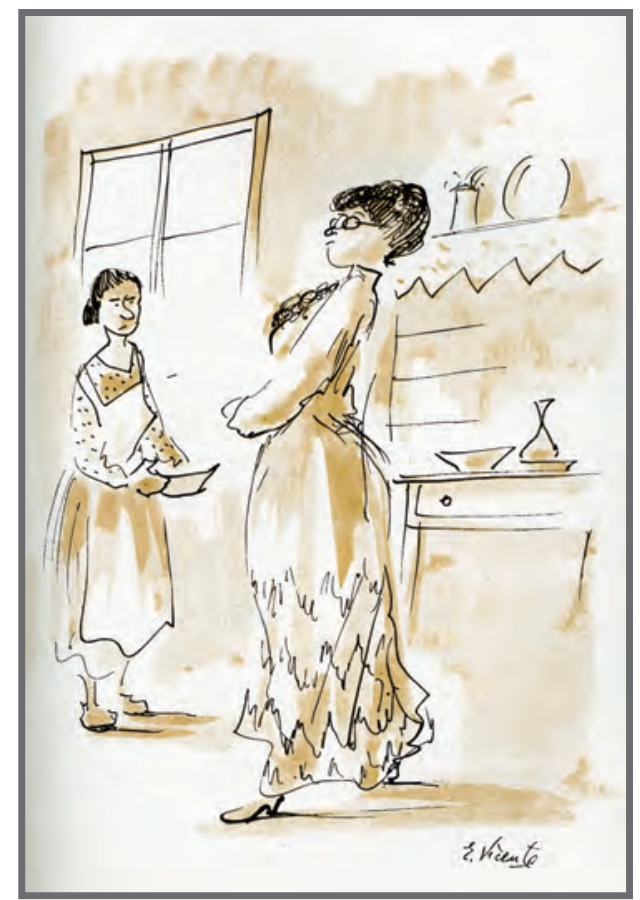

\section{CONTENIDO.}

Personajes: MUJERES

Animales: NO

Gestos Expresivos: EMOCIONES POSITIVAS

Paisajes: NO

Escenas: PROFESIONAL

Función: REPRESENTATIVA DE MODELOS SOCIALES

\section{ASPECTOS TÉCNICOS.}

Color dominante: 2 TINTAS

Técnica: OFFSET

Plano de la imagen: GENERAL 


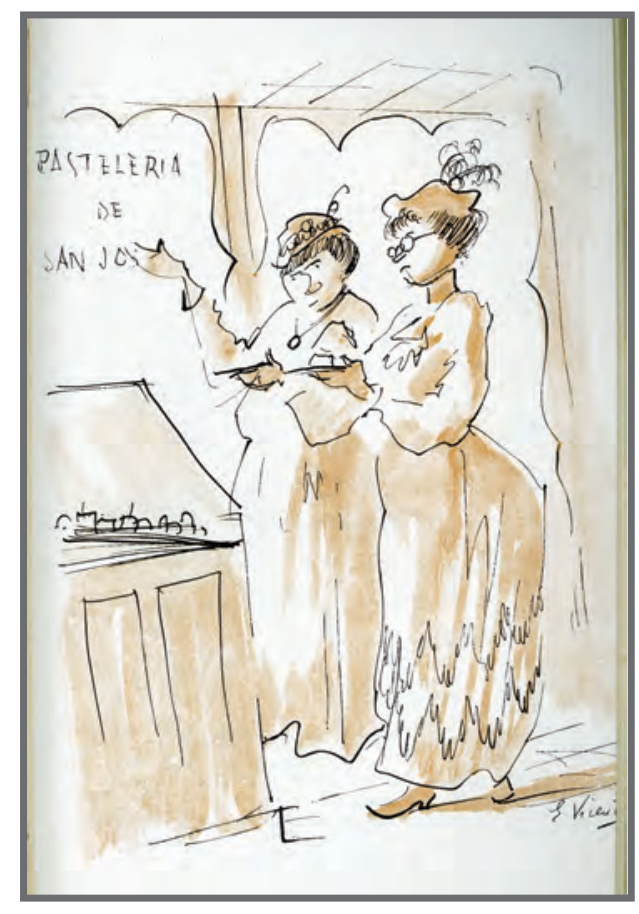

\section{VARIABLES EXTERNAS.}

Título: La familia Mínguez (008)

Año: 1956

Página: 185

\section{TIPO DE IMAGEN.}

Retrato: NO

Cartel: NO

Mural: NO

Ilustración: SI

Otras Obras: NO

\section{CONTENIDO.}

Personajes: MUJERES

Animales: NO

Gestos Expresivos: EMOCIONES POSITIVAS

Paisajes: NO

Escenas: INTERIOR

Función: REPRESENTATIVA DE MODELOS SOCIALES

\section{ASPECTOS TÉCNICOS.}

Color dominante: 2 TINTAS

Técnica: OFFSET

Plano de la imagen: GENERAL 


\section{VARIABLES EXTERNAS.}

Título: La familia Mínguez (009)

Año: 1956

Página: 201

\section{TIPO DE IMAGEN.}

Retrato: NO

Cartel: NO

Mural: NO

Ilustración: SI

Otras Obras: NO

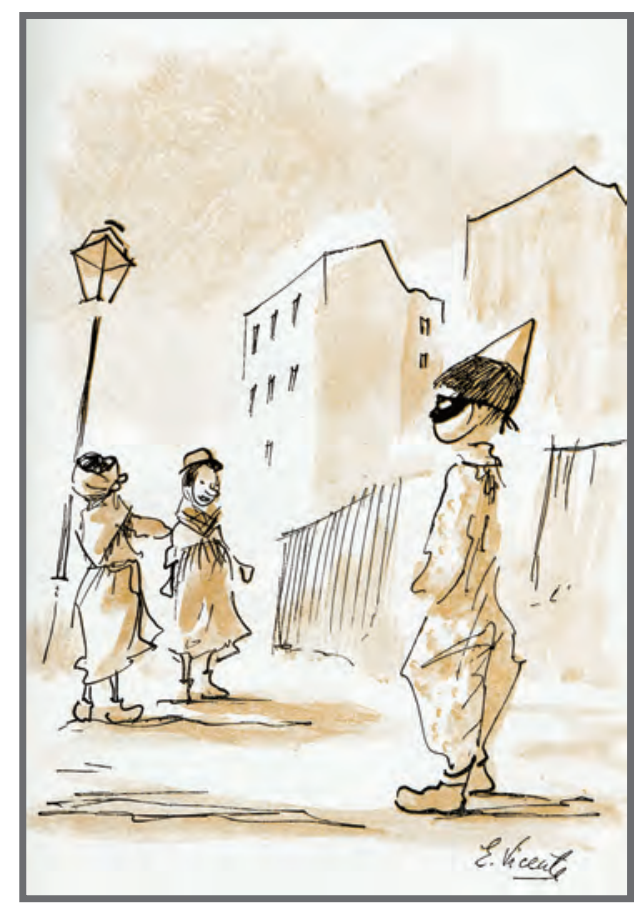

\section{CONTENIDO.}

Personajes: NIÑOS

Animales: NO

Gestos Expresivos: EMOCIONES POSITIVAS

Paisajes: NO

Escenas: FESTIVA

Función: REPRESENTATIVA DE MODELOS SOCIALES

\section{ASPECTOS TÉCNICOS.}

Color dominante: 2 TINTAS

Técnica: OFFSET

Plano de la imagen: GENERAL 



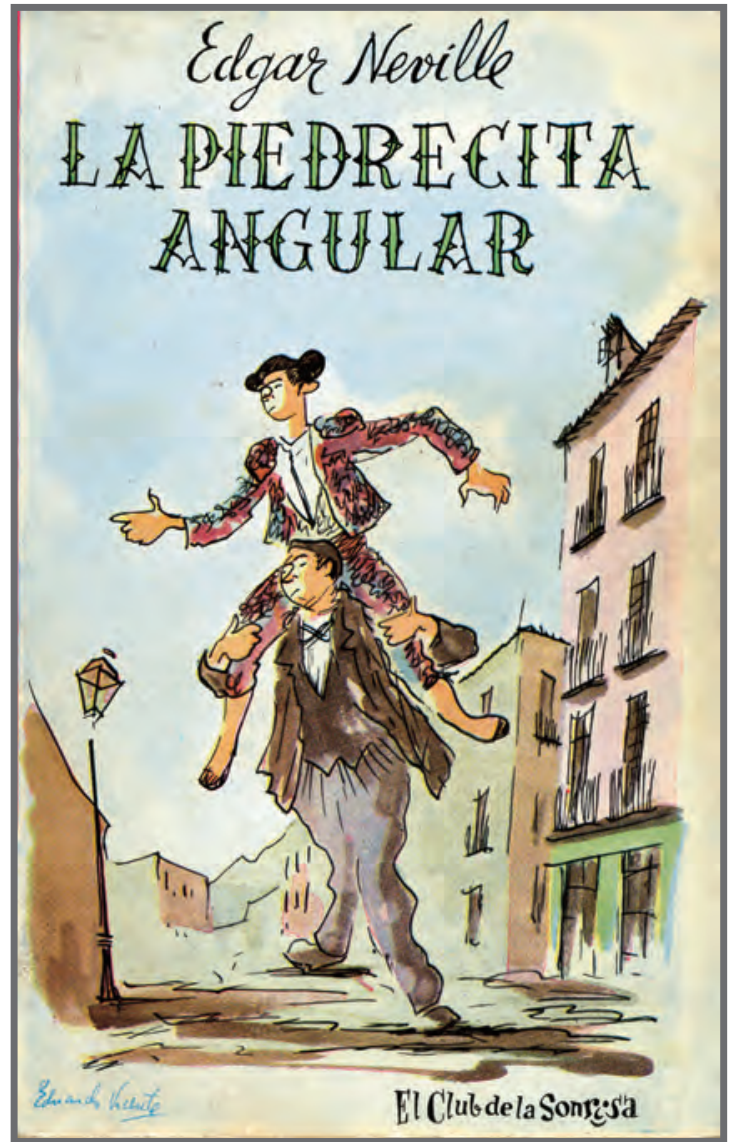

\section{FICHA TÉCNICA.}

Título: LA PIEDRECITA ANGULAR

Autor: EDGAR NEVILLE

Editorial: TAURUS

Año: 1957

Tamaño: $19,5 \times 12,5 \mathrm{~cm}$.

Número de páginas: 135

Número de ilustraciones: 7 + (ILUSTRACIÓN EN PORTADA)

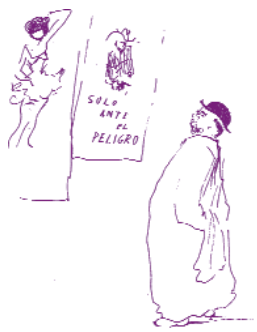





\section{VARIABLES EXTERNAS.}

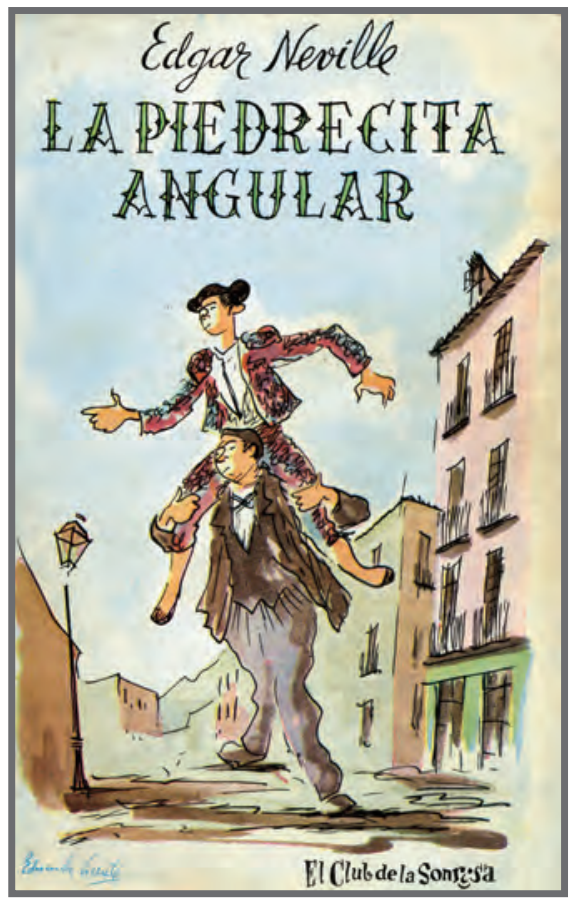

Título: La piedrecita angular (001)

Año: 1957

Página: PORTADA

TIPO DE IMAGEN.

Retrato: NO

Cartel: NO

Mural: NO

Ilustración: SI

Otras Obras: NO

\section{CONTENIDO.}

Personajes: HOMBRES

Animales: NO

Gestos Expresivos: EMOCIONES POSITIVAS

Paisajes: SI

Escenas: FESTIVA

Función: REPRESENTATIVA DE MODELOS SOCIALES

\section{ASPECTOS TÉCNICOS.}

Color dominante: CUATRICROMÍA

Técnica: OFFSET

Plano de la imagen: GENERAL 


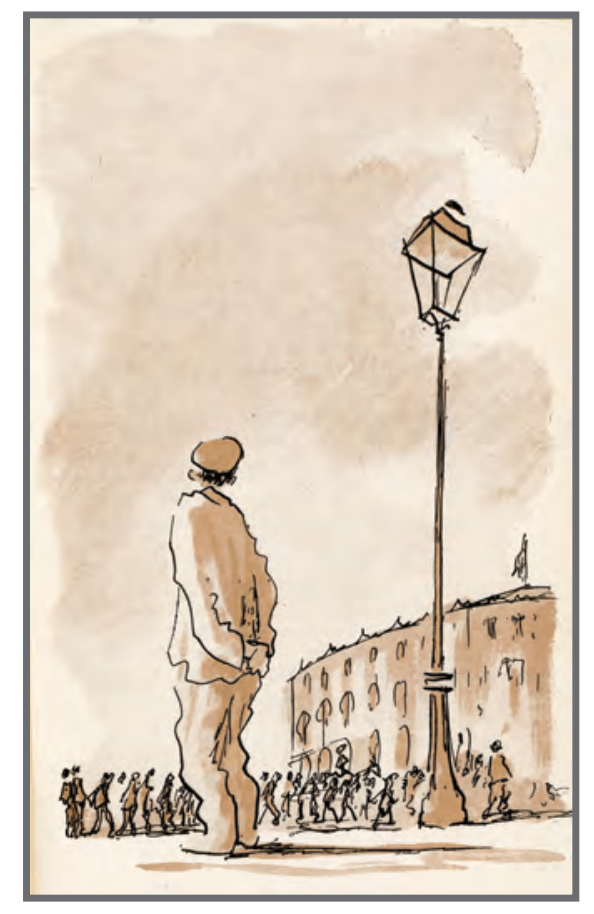

\section{VARIABLES EXTERNAS.}

Título: La piedrecita angular (002)

Año: 1957

Página: 25

\section{TIPO DE IMAGEN.}

Retrato: NO

Cartel: NO

Mural: NO

Ilustración: SI

Otras Obras: NO

\section{CONTENIDO.}

Personajes: HOMBRE

Animales: NO

Gestos Expresivos: EMOCIONES POSITIVAS

Paisajes: SI

Escenas: FESTIVA

Función: REPRESENTATIVA DE MODELOS SOCIALES

\section{ASPECTOS TÉCNICOS.}

Color dominante: 2 TINTAS

Técnica: OFFSET

Plano de la imagen: GENERAL 


\section{VARIABLES EXTERNAS.}

Título: La piedrecita angular (003)

Año: 1957

Página: 79

\section{TIPO DE IMAGEN.}

Retrato: NO

Cartel: NO

Mural: NO

Ilustración: SI

Otras Obras: NO

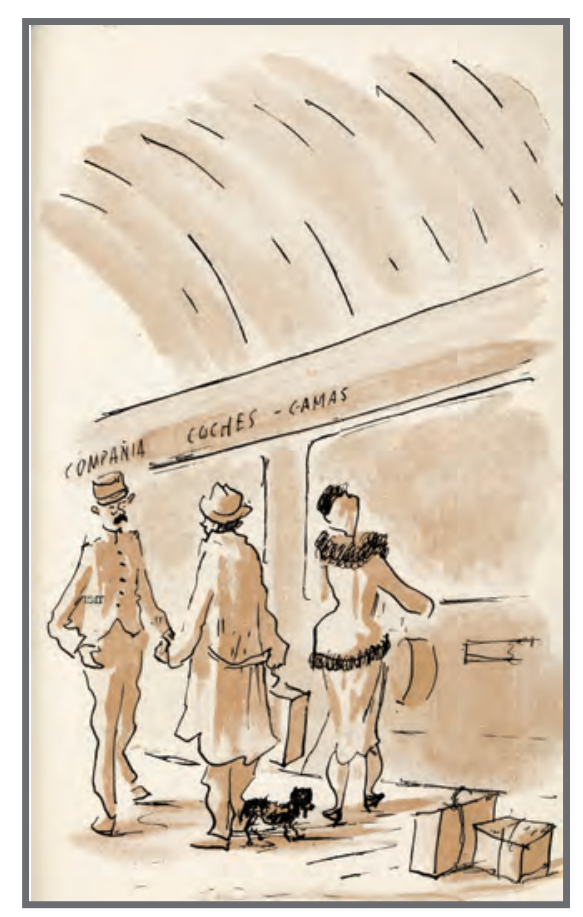

\section{CONTENIDO.}

Personajes: HOMBRES Y MUJER

Animales: PERRO

Gestos Expresivos: EMOCIONES POSITIVAS

Paisajes: NO

Escenas: PROFESIONAL

Función: REPRESENTATIVA DE MODELOS SOCIALES

\section{ASPECTOS TÉCNICOS.}

Color dominante: 2 TINTAS

Técnica: OFFSET

Plano de la imagen: GENERAL 


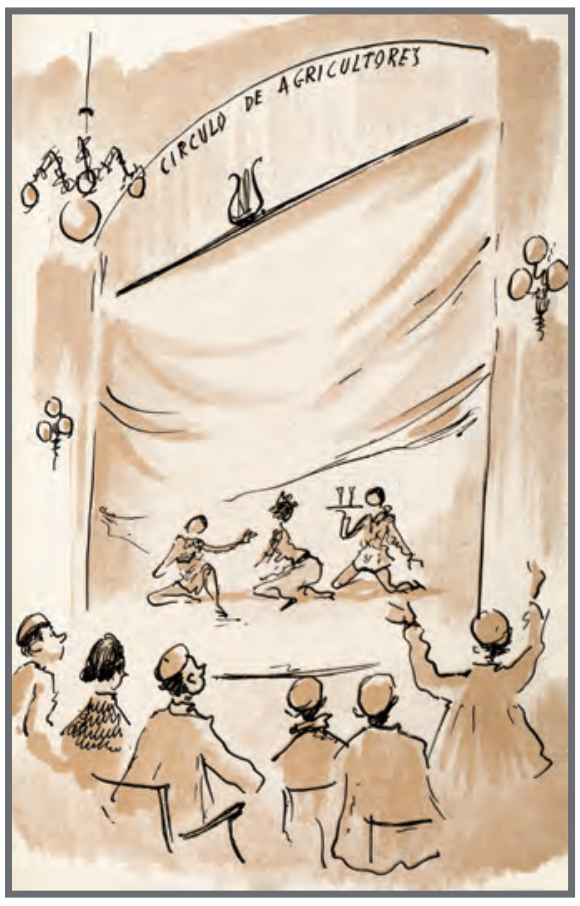

\section{VARIABLES EXTERNAS.}

Título: La piedrecita angular (004)

Año: 1957

Página: 99

\section{TIPO DE IMAGEN.}

Retrato: NO

Cartel: NO

Mural: NO

Ilustración: SI

Otras Obras: NO

\section{CONTENIDO.}

Personajes: HOMBRES Y MUJERES

Animales: NO

Gestos Expresivos: EMOCIONES POSITIVAS

Paisajes: NO

Escenas: FESTIVA

Función: REPRESENTATIVA DE MODELOS SOCIALES

\section{ASPECTOS TÉCNICOS.}

Color dominante: 2 TINTAS

Técnica: OFFSET

Plano de la imagen: GENERAL 


\section{VARIABLES EXTERNAS.}

Título: La piedrecita angular (005)

Año: 1957

Página: 101

\section{TIPO DE IMAGEN.}

Retrato: NO

Cartel: NO

Mural: NO

Ilustración: SI

Otras Obras: NO

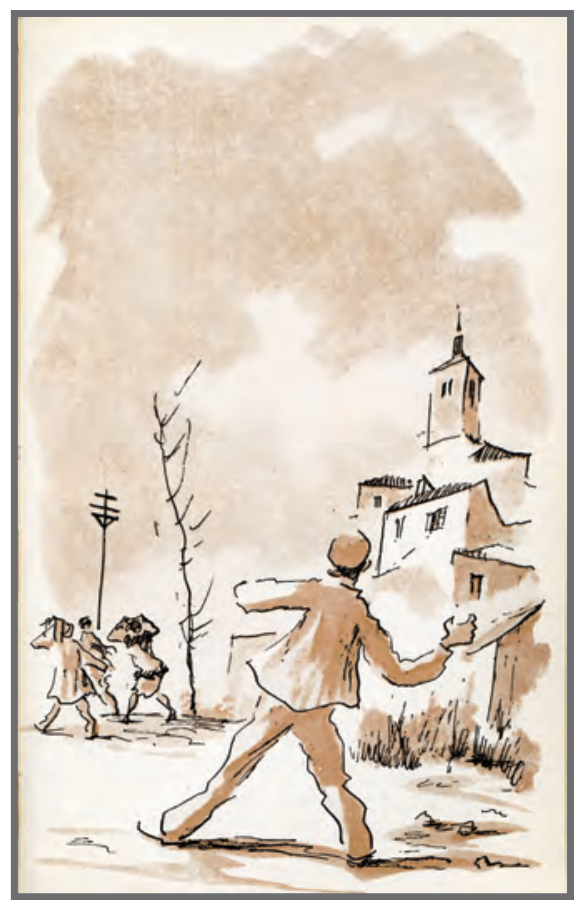

\section{CONTENIDO.}

Personajes: HOMBRES Y MUJER

Animales: NO

Gestos Expresivos: EMOCIONES NEGATIVAS

Paisajes: SI

Escenas: RURAL

Función: REPRESENTATIVA DE MODELOS SOCIALES

\section{ASPECTOS TÉCNICOS.}

Color dominante: 2 TINTAS

Técnica: OFFSET

Plano de la imagen: GENERAL 


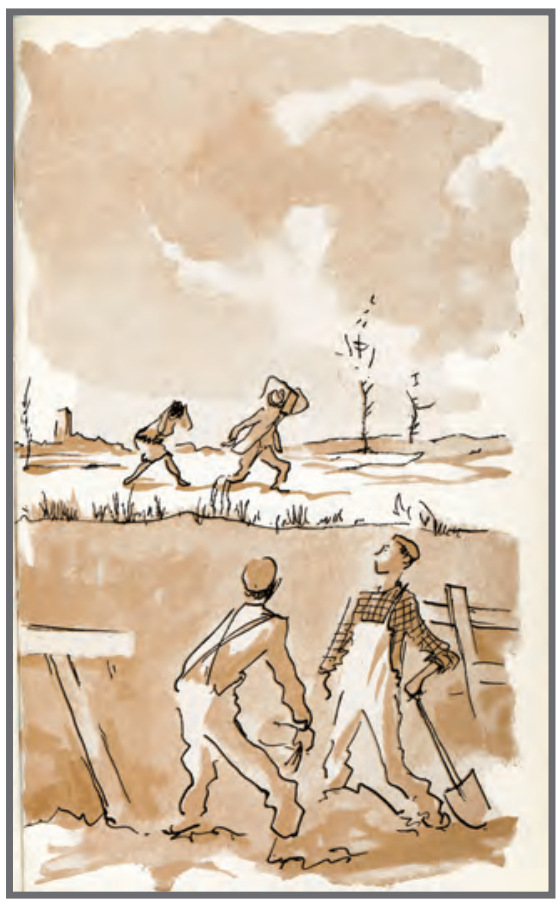

\section{VARIABLES EXTERNAS.}

Título: La piedrecita angular (006)

Año: 1957

Página: 103

\section{TIPO DE IMAGEN.}

Retrato: NO

Cartel: NO

Mural: NO

Ilustración: SI

Otras Obras: NO

\section{CONTENIDO.}

Personajes: HOMBRES Y MUJER

Animales: NO

Gestos Expresivos: EMOCIONES POSITIVAS

Paisajes: SI

Escenas: PROFESIONAL

Función: REPRESENTATIVA DE MODELOS SOCIALES

\section{ASPECTOS TÉCNICOS.}

Color dominante: 2 TINTAS

Técnica: OFFSET

Plano de la imagen: GENERAL 


\section{VARIABLES EXTERNAS.}

Título: La piedrecita angular (007)

Año: 1957

Página: 119

\section{TIPO DE IMAGEN.}

Retrato: NO

Cartel: NO

Mural: NO

Ilustración: SI

Otras Obras: NO

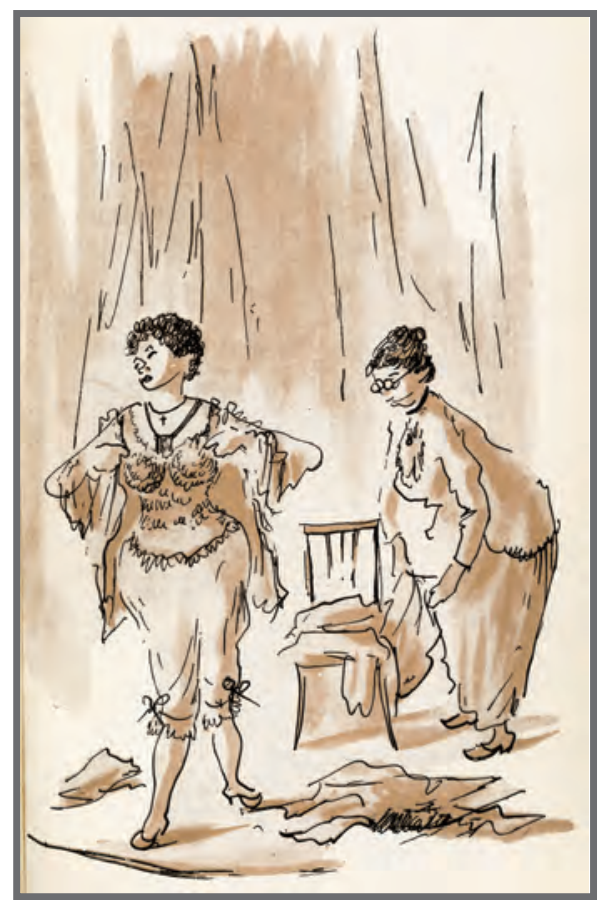

\section{CONTENIDO.}

Personajes: MUJERES

Animales: NO

Gestos Expresivos: EMOCIONES POSITIVAS

Paisajes: NO

Escenas: PROFESIONAL

Función: REPRESENTATIVA DE MODELOS SOCIALES

\section{ASPECTOS TÉCNICOS.}

Color dominante: 2 TINTAS

Técnica: OFFSET

Plano de la imagen: GENERAL 


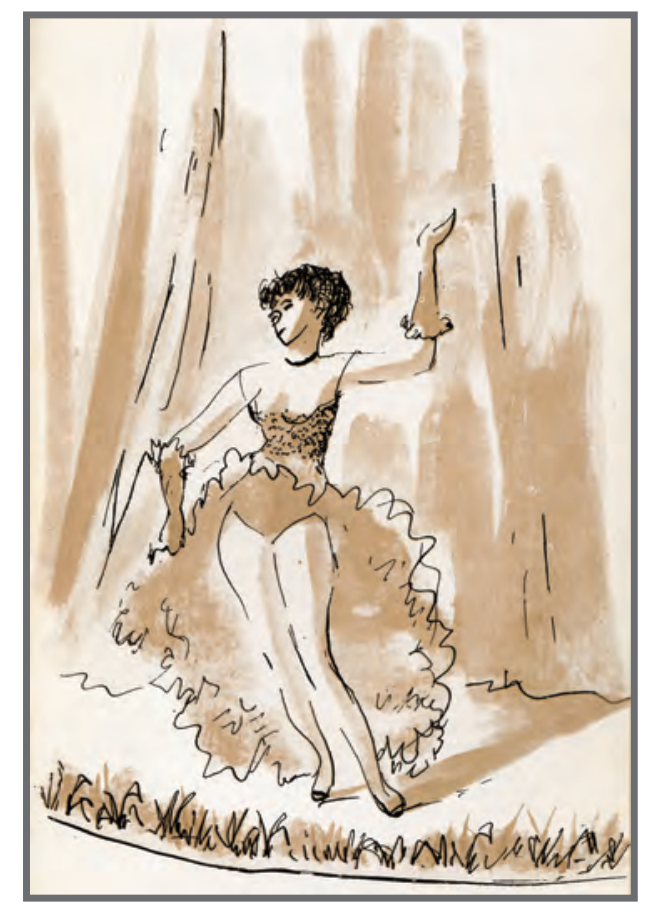

\section{VARIABLES EXTERNAS.}

Título: La piedrecita angular (008)

Año: 1957

Página: 121

\section{TIPO DE IMAGEN.}

Retrato: NO

Cartel: NO

Mural: NO

Ilustración: SI

Otras Obras: NO

\section{CONTENIDO.}

Personajes: MUJER

Animales: NO

Gestos Expresivos: EMOCIONES POSITIVAS

Paisajes: NO

Escenas: PROFESIONAL

Función: REPRESENTATIVA DE MODELOS SOCIALES

\section{ASPECTOS TÉCNICOS.}

Color dominante: 2 TINTAS

Técnica: OFFSET

Plano de la imagen: GENERAL 


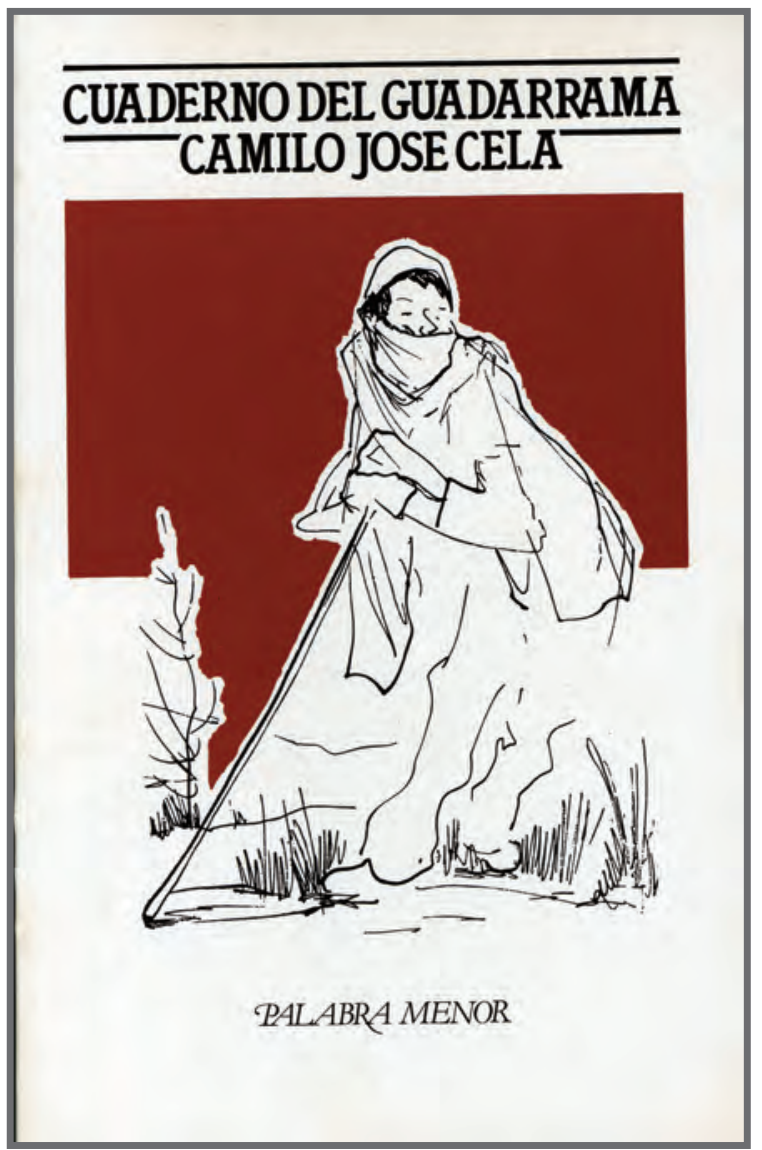

\section{FICHA TÉCNICA.}

Título: CUADERNOS DE GUADARRAMA

Autor: CAMILO JOSÉ CELA

Editorial: LUMEN S.A. - BARCELONA

Año: 1959

Tamaño: $18 \times 12 \mathrm{~cm}$.

Número de páginas: 94

Número de illustraciones: 20 + (ILUSTRACIÓN EN PORTADA) 



\section{VARIABLES EXTERNAS.}

Título: Cuadernos del Guadarrama (001)

Año: 1959

Página: PORTADA

TIPO DE IMAGEN.

Retrato: NO

Cartel: NO

Mural: NO

Ilustración: SI

Otras Obras: NO

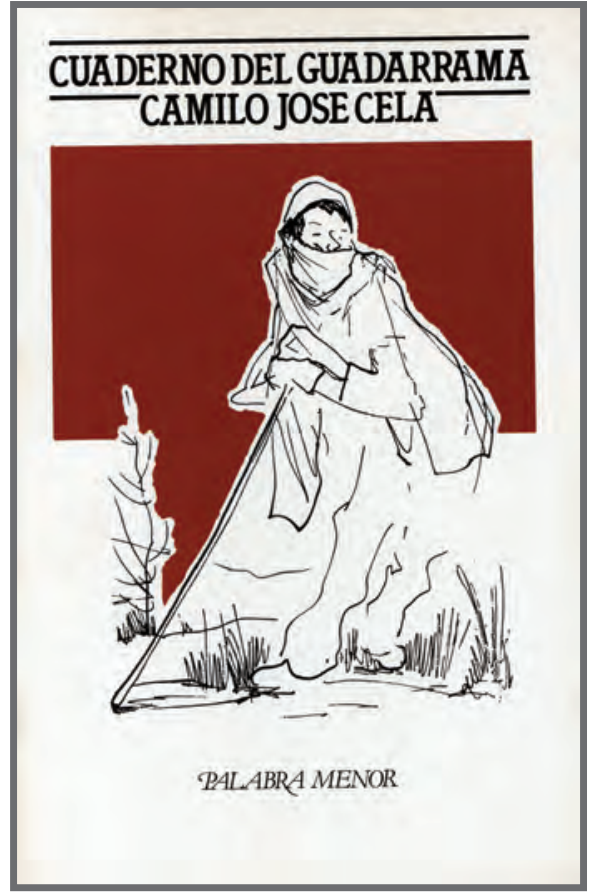

\section{CONTENIDO.}

Personajes: HOMBRE

Animales: NO

Gestos Expresivos: EMOCIONES NEGATIVAS

Paisajes: NO

Escenas: RURAL

Función: REPRESENTATIVA DE MODELOS SOCIALES

\section{ASPECTOS TÉCNICOS.}

Color dominante: 2 TINTAS

Técnica: OFFSET

Plano de la imagen: GENERAL 


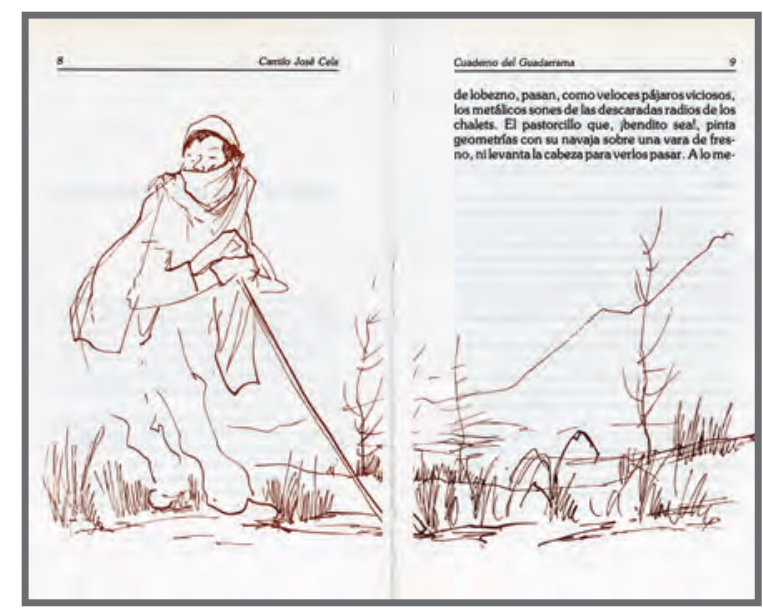

\section{VARIABLES EXTERNAS.}

Título: Cuadernos del Guadarrama (002)

Año: 1959

Página: 8-9

\section{TIPO DE IMAGEN.}

Retrato: NO

Cartel: NO

Mural: NO

Ilustración: SI

Otras Obras: NO

\section{CONTENIDO.}

Personajes: HOMBRE

Animales: NO

Gestos Expresivos: EMOCIONES NEGATIVAS

Paisajes: SI

Escenas: RURAL

Función: REPRESENTATIVA DE MODELOS SOCIALES

\section{ASPECTOS TÉCNICOS.}

Color dominante: 1 TINTA

Técnica: OFFSET

Plano de la imagen: GENERAL 


\section{VARIABLES EXTERNAS.}

Título: Cuadernos del Guadarrama (003)

Año: 1959

Página: 12-13

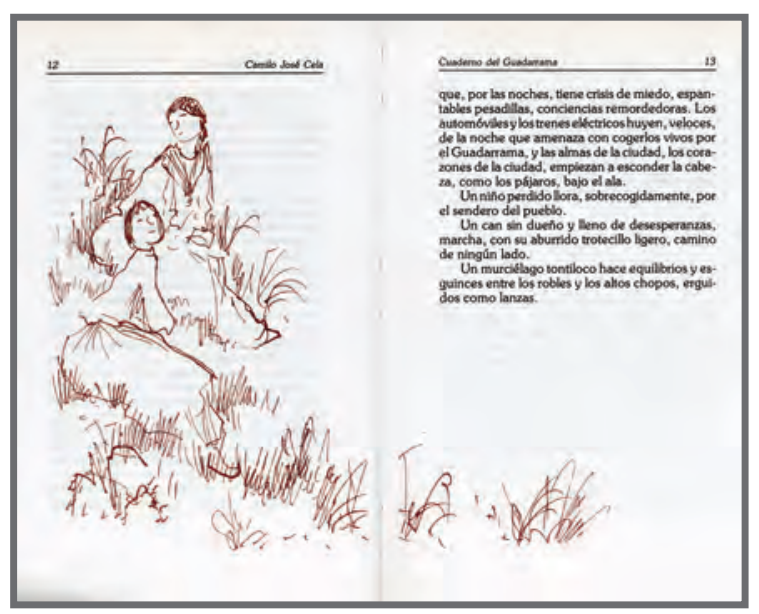

\section{TIPO DE IMAGEN.}

Retrato: NO

Cartel: NO

Mural: NO

Ilustración: SI

Otras Obras: NO

\section{CONTENIDO.}

Personajes: MUJERES

Animales: NO

Gestos Expresivos: EMOCIONES POSITIVAS

Paisajes: SI

Escenas: RURAL

Función: REPRESENTATIVA DE MODELOS SOCIALES

\section{ASPECTOS TÉCNICOS.}

Color dominante: 1 TINTA

Técnica: OFFSET

Plano de la imagen: GENERAL 


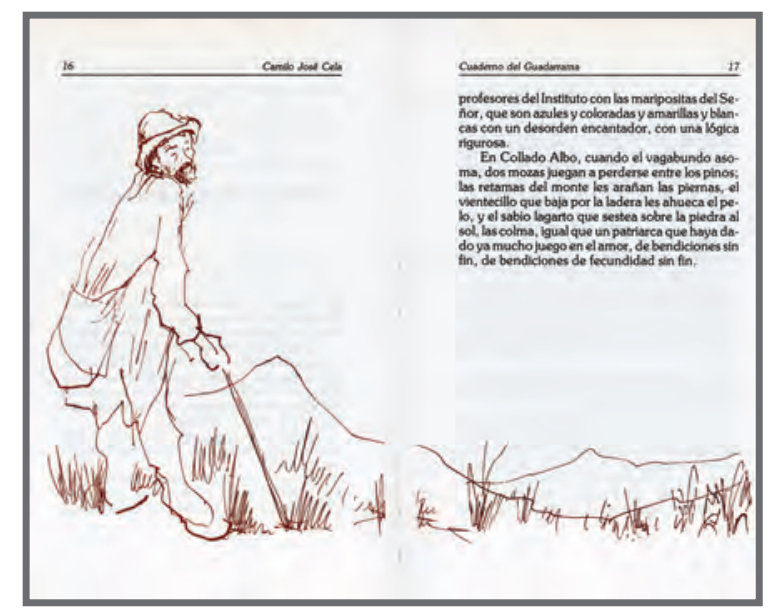

VARIABLES EXTERNAS.

Título: Cuadernos del Guadarrama (004)

Año: 1959

Página: 16-17

\section{TIPO DE IMAGEN.}

Retrato: NO

Cartel: NO

Mural: NO

Ilustración: SI

Otras Obras: NO

\section{CONTENIDO.}

Personajes: HOMBRE

Animales: NO

Gestos Expresivos: EMOCIONES NEGATIVAS

Paisajes: SI

Escenas: RURAL

Función: REPRESENTATIVA DE MODELOS SOCIALES

\section{ASPECTOS TÉCNICOS.}

Color dominante: 1 TINTA

Técnica: OFFSET

Plano de la imagen: GENERAL 


\section{VARIABLES EXTERNAS.}

Título: Cuadernos del Guadarrama (005)

Año: 1959

Página: 22-23

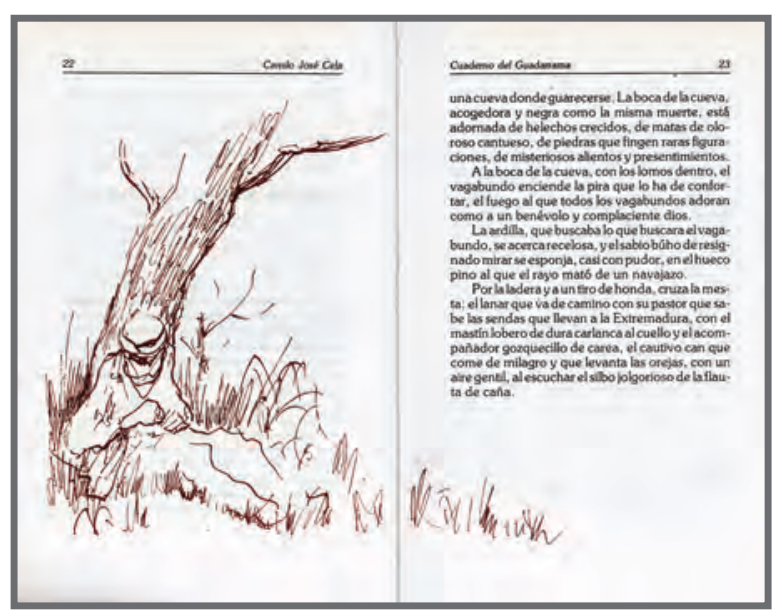

\section{TIPO DE IMAGEN.}

Retrato: NO

Cartel: NO

Mural: NO

Ilustración: SI

Otras Obras: NO

\section{CONTENIDO.}

Personajes: HOMBRE

Animales: NO

Gestos Expresivos: EMOCIONES NEGATIVAS

Paisajes: NO

Escenas: RURAL

Función: REPRESENTATIVA DE MODELOS SOCIALES

\section{ASPECTOS TÉCNICOS.}

Color dominante: 1 TINTA

Técnica: OFFSET

Plano de la imagen: GENERAL 


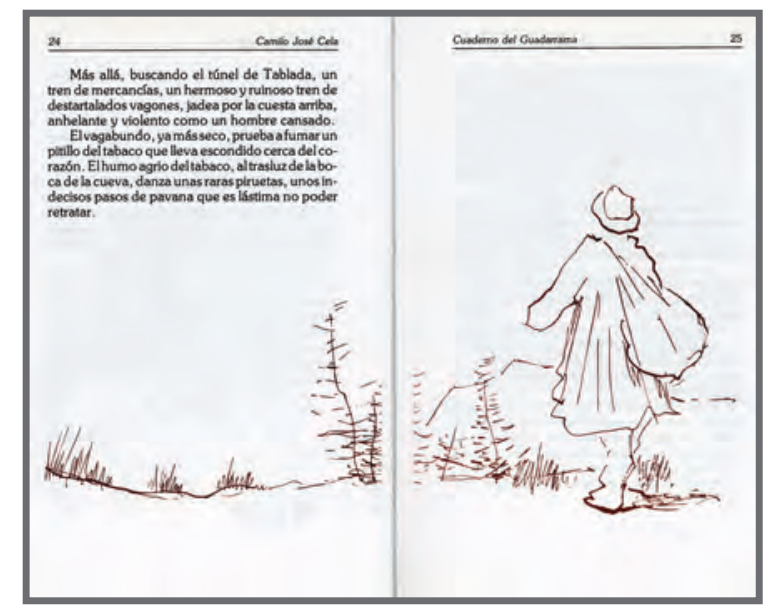

VARIABLES EXTERNAS.

Título: Cuadernos del Guadarrama (006)

Año: 1959

Página: 24-25

\section{TIPO DE IMAGEN.}

Retrato: NO

Cartel: NO

Mural: NO

Ilustración: SI

Otras Obras: NO

\section{CONTENIDO.}

Personajes: HOMBRE

Animales: NO

Gestos Expresivos: EMOCIONES NEGATIVAS

Paisajes: SI

Escenas: RURAL

Función: REPRESENTATIVA DE MODELOS SOCIALES

\section{ASPECTOS TÉCNICOS.}

Color dominante: 1 TINTA

Técnica: OFFSET

Plano de la imagen: GENERAL 


\section{VARIABLES EXTERNAS.}

Título: Cuadernos del Guadarrama (007)

Año: 1959

Página: 34-35

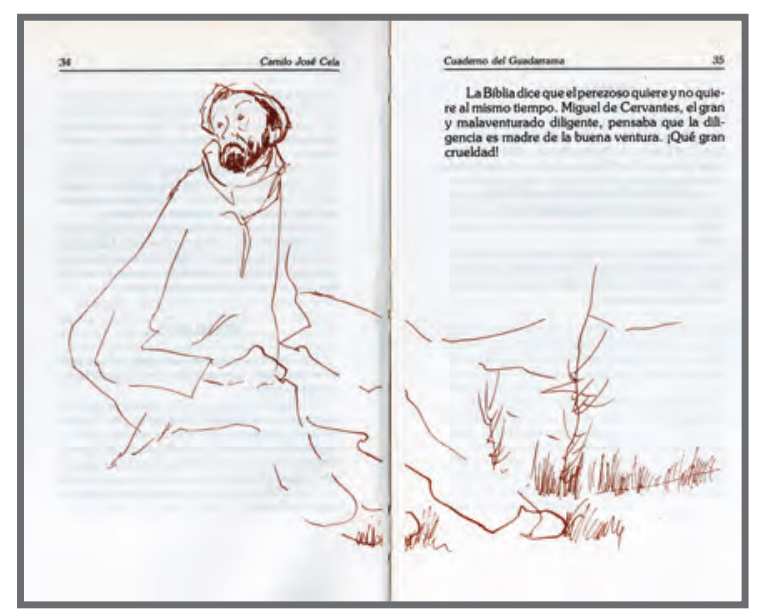

\section{TIPO DE IMAGEN.}

Retrato: NO

Cartel: NO

Mural: NO

Ilustración: SI

Otras Obras: NO

\section{CONTENIDO.}

Personajes: HOMBRE

Animales: NO

Gestos Expresivos: EMOCIONES NEGATIVAS

Paisajes: SI

Escenas: RURAL

Función: REPRESENTATIVA DE MODELOS SOCIALES

\section{ASPECTOS TÉCNICOS.}

Color dominante: 1 TINTA

Técnica: OFFSET

Plano de la imagen: GENERAL 


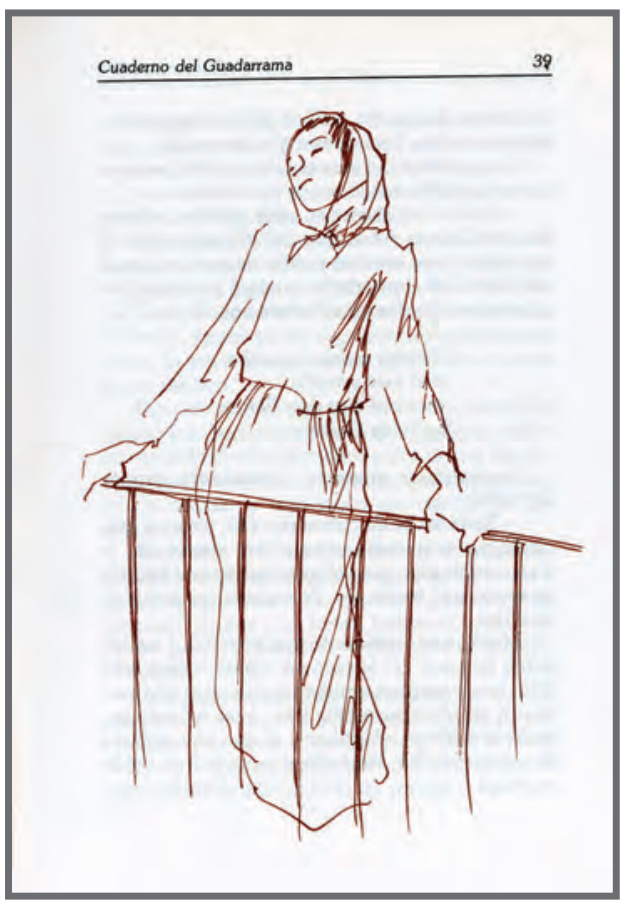

\section{VARIABLES EXTERNAS.}

Título: Cuadernos del Guadarrama (008)

Año: 1959

Página: 39

TIPO DE IMAGEN.

Retrato: NO

Cartel: NO

Mural: NO

Ilustración: SI

Otras Obras: NO

\section{CONTENIDO.}

Personajes: MUJER

Animales: NO

Gestos Expresivos: EMOCIONES POSITIVAS

Paisajes: NO

Escenas: URBANA

Función: REPRESENTATIVA DE MODELOS SOCIALES

\section{ASPECTOS TÉCNICOS.}

Color dominante: 1 TINTA

Técnica: OFFSET

Plano de la imagen: GENERAL 


\section{VARIABLES EXTERNAS.}

Título: Cuadernos del Guadarrama (009)

Año: 1959

Página: 42-43

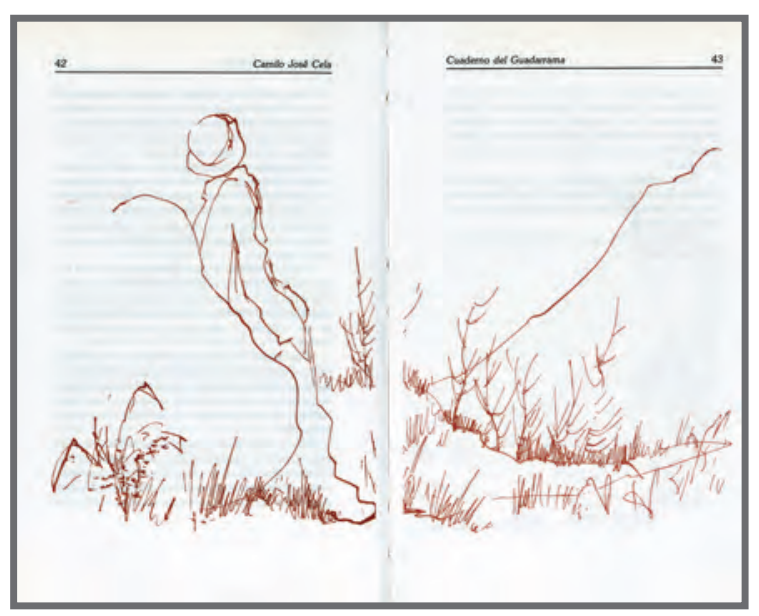

\section{TIPO DE IMAGEN.}

Retrato: NO

Cartel: NO

Mural: NO

Ilustración: SI

Otras Obras: NO

\section{CONTENIDO.}

Personajes: HOMBRE

Animales: NO

Gestos Expresivos: EMOCIONES NEGATIVAS

Paisajes: SI

Escenas: RURAL

Función: REPRESENTATIVA DE MODELOS SOCIALES

\section{ASPECTOS TÉCNICOS.}

Color dominante: 1 TINTA

Técnica: OFFSET

Plano de la imagen: GENERAL 


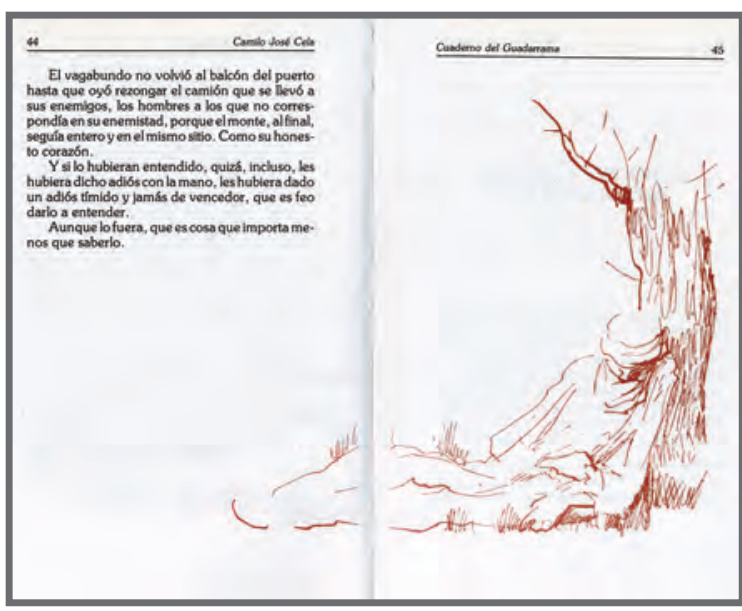

\section{VARIABLES EXTERNAS.}

Título: Cuadernos del Guadarrama (010)

Año: 1959

Página: 44-45

\section{TIPO DE IMAGEN.}

Retrato: NO

Cartel: NO

Mural: NO

Ilustración: SI

Otras Obras: NO

\section{CONTENIDO.}

Personajes: HOMBRE

Animales: NO

Gestos Expresivos: EMOCIONES NEGATIVAS

Paisajes: SI

Escenas: RURAL

Función: REPRESENTATIVA DE MODELOS SOCIALES

\section{ASPECTOS TÉCNICOS.}

Color dominante: 1 TINTA

Técnica: OFFSET

Plano de la imagen: GENERAL 


\section{VARIABLES EXTERNAS.}

Título: Cuadernos del Guadarrama (011)

Año: 1959

Página: 48-49

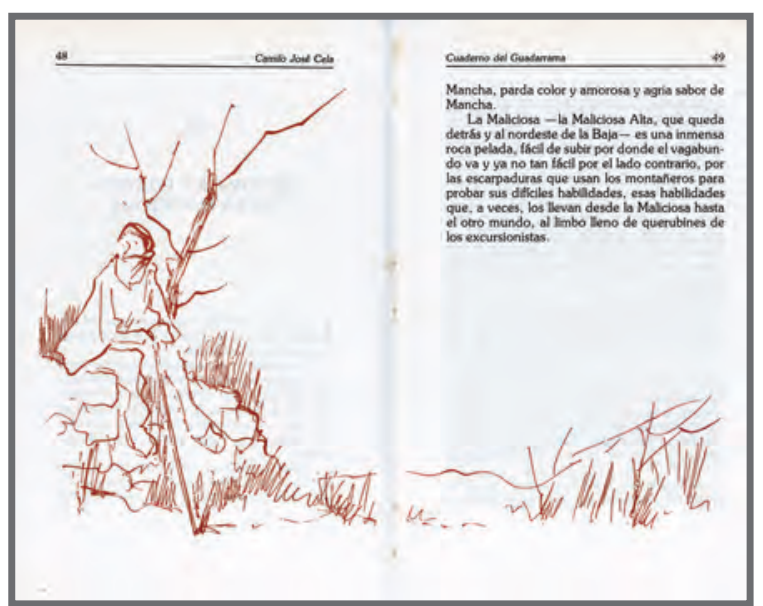

\section{TIPO DE IMAGEN.}

Retrato: NO

Cartel: NO

Mural: NO

Ilustración: SI

Otras Obras: NO

\section{CONTENIDO.}

Personajes: HOMBRE

Animales: NO

Gestos Expresivos: EMOCIONES NEGATIVAS

Paisajes: SI

Escenas: RURAL

Función: REPRESENTATIVA DE MODELOS SOCIALES

\section{ASPECTOS TÉCNICOS.}

Color dominante: 1 TINTA

Técnica: OFFSET

Plano de la imagen: GENERAL 


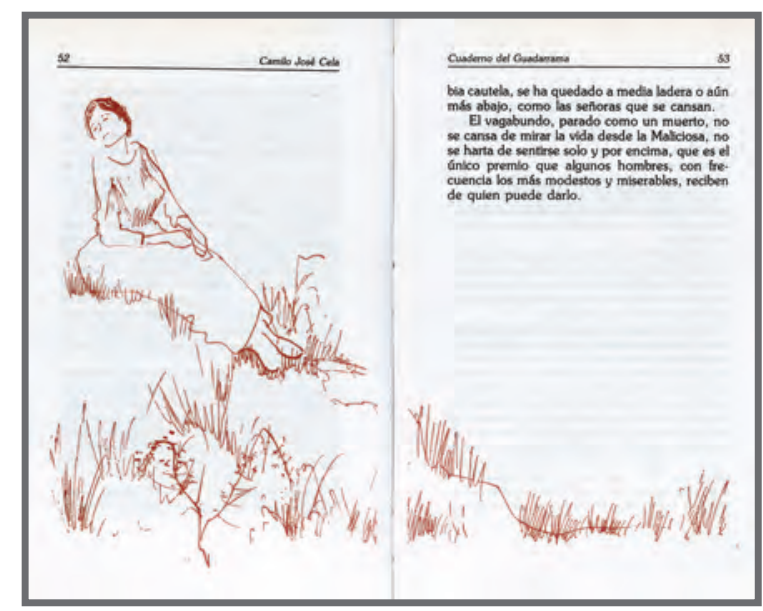

VARIABLES EXTERNAS.

Título: Cuadernos del Guadarrama (012)

Año: 1959

Página: 52-53

\section{TIPO DE IMAGEN.}

Retrato: NO

Cartel: NO

Mural: NO

Ilustración: SI

Otras Obras: NO

\section{CONTENIDO.}

Personajes: MUJER

Animales: NO

Gestos Expresivos: EMOCIONES POSITIVAS

Paisajes: NO

Escenas: RURAL

Función: REPRESENTATIVA DE MODELOS SOCIALES

\section{ASPECTOS TÉCNICOS.}

Color dominante: 1 TINTA

Técnica: OFFSET

Plano de la imagen: GENERAL 


\section{VARIABLES EXTERNAS.}

Título: Cuadernos del Guadarrama (013)

Año: 1959

Página: 56-57

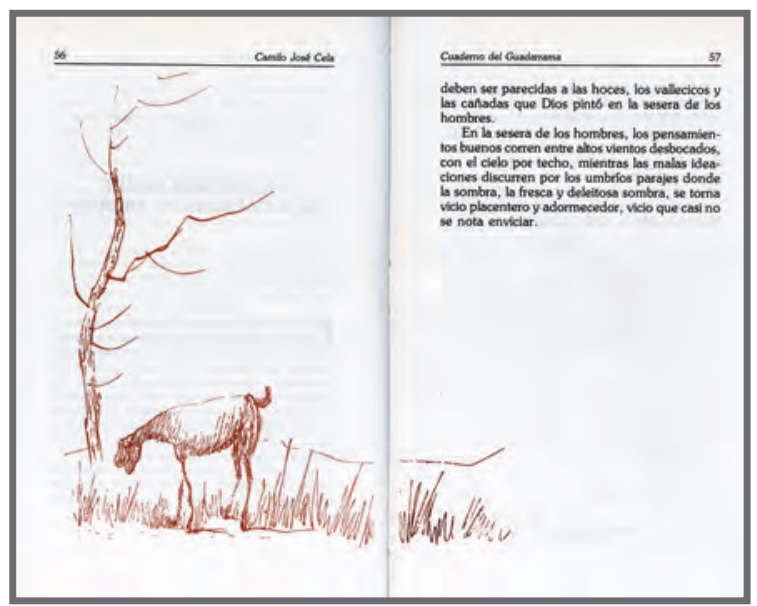

\section{TIPO DE IMAGEN.}

Retrato: NO

Cartel: NO

Mural: NO

Ilustración: SI

Otras Obras: NO

\section{CONTENIDO.}

Personajes: NO

Animales: OVEJA

Gestos Expresivos: NO

Paisajes: NO

Escenas: RURAL

Función: REPRESENTATIVA DE MODELOS SOCIALES

\section{ASPECTOS TÉCNICOS.}

Color dominante: 1 TINTA

Técnica: OFFSET

Plano de la imagen: GENERAL 


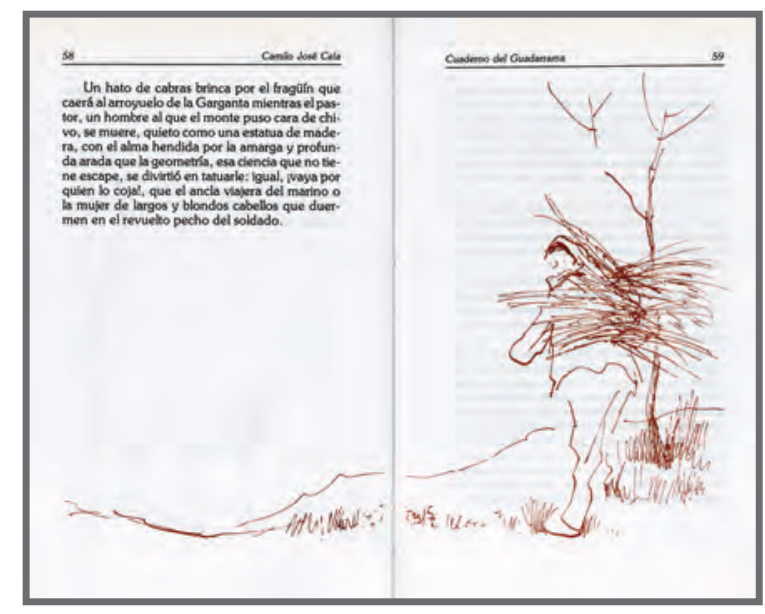

VARIABLES EXTERNAS.

Título: Cuadernos del Guadarrama (014)

Año: 1959

Página: 58-59

\section{TIPO DE IMAGEN.}

Retrato: NO

Cartel: NO

Mural: NO

Ilustración: SI

Otras Obras: NO

\section{CONTENIDO.}

Personajes: HOMBRE

Animales: NO

Gestos Expresivos: EMOCIONES POSITIVAS

Paisajes: SI

Escenas: RURAL

Función: REPRESENTATIVA DE MODELOS SOCIALES

\section{ASPECTOS TÉCNICOS.}

Color dominante: 1 TINTA

Técnica: OFFSET

Plano de la imagen: GENERAL 


\section{VARIABLES EXTERNAS.}

Título: Cuadernos del Guadarrama (015)

Año: 1959

Página: 62-63

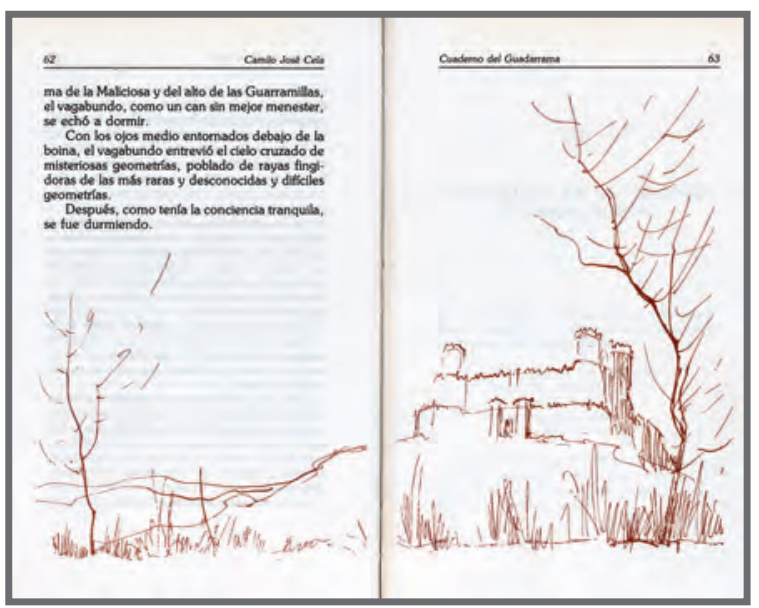

\section{TIPO DE IMAGEN.}

Retrato: NO

Cartel: NO

Mural: NO

Ilustración: SI

Otras Obras: NO

\section{CONTENIDO.}

Personajes: NO

Animales: NO

Gestos Expresivos: NO

Paisajes: SI

Escenas: ARQUITECTÓNICO

Función: REPRESENTATIVA DE MODELOS SOCIALES

\section{ASPECTOS TÉCNICOS.}

Color dominante: 1 TINTA

Técnica: OFFSET

Plano de la imagen: GENERAL 


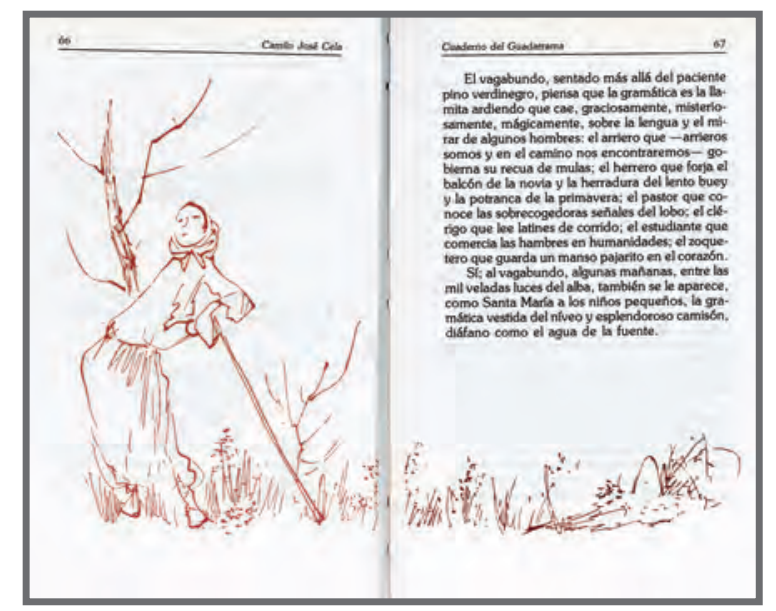

\section{VARIABLES EXTERNAS.}

Título: Cuadernos del Guadarrama (016)

Año: 1959

Página: 66-67

\section{TIPO DE IMAGEN.}

Retrato: NO

Cartel: NO

Mural: NO

Ilustración: SI

Otras Obras: NO

\section{CONTENIDO.}

Personajes: MUJER

Animales: NO

Gestos Expresivos: EMOCIONES POSITIVAS

Paisajes: NO

Escenas: RURAL

Función: REPRESENTATIVA DE MODELOS SOCIALES

\section{ASPECTOS TÉCNICOS.}

Color dominante: 1 TINTA

Técnica: OFFSET

Plano de la imagen: GENERAL 


\section{VARIABLES EXTERNAS.}

Título: Cuadernos del Guadarrama (017)

Año: 1959

Página: 70-71

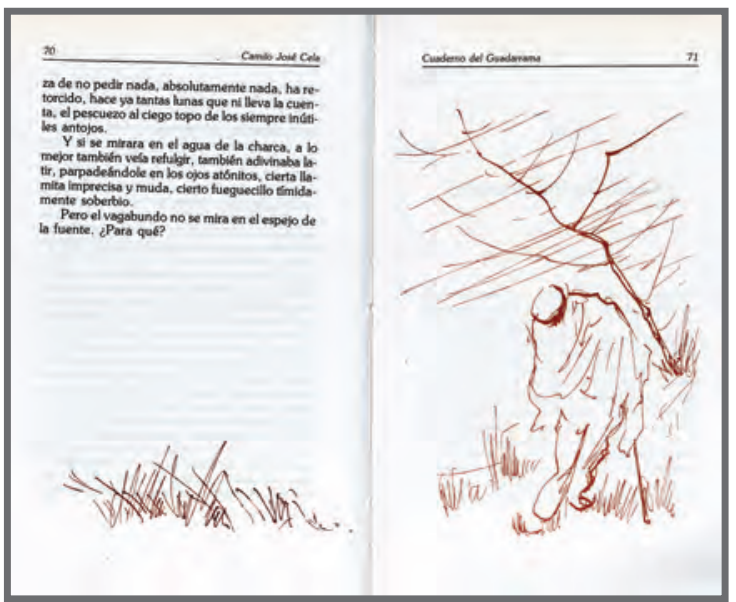

\section{TIPO DE IMAGEN.}

Retrato: NO

Cartel: NO

Mural: NO

Ilustración: SI

Otras Obras: NO

\section{CONTENIDO.}

Personajes: HOMBRE

Animales: NO

Gestos Expresivos: EMOCIONES NEGATIVAS

Paisajes: NO

Escenas: RURAL

Función: REPRESENTATIVA DE MODELOS SOCIALES

\section{ASPECTOS TÉCNICOS.}

Color dominante: 1 TINTA

Técnica: OFFSET

Plano de la imagen: GENERAL 


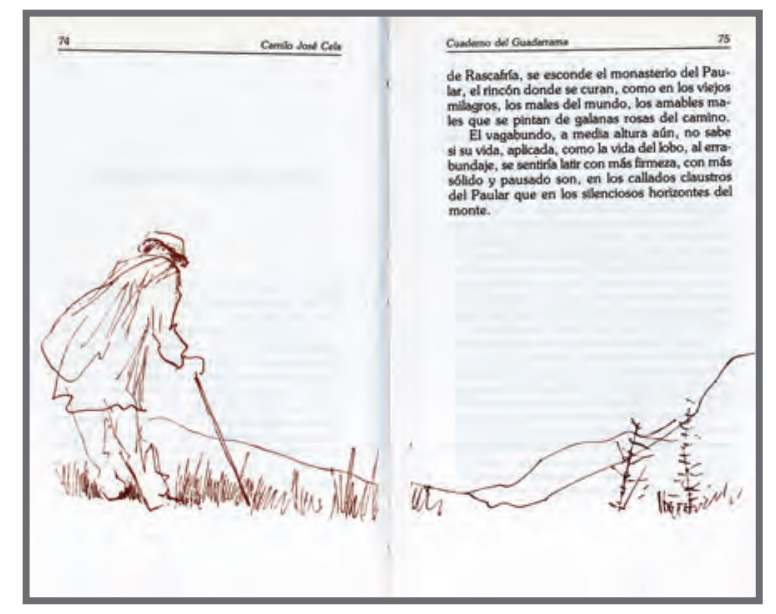

VARIABLES EXTERNAS.

Título: Cuadernos del Guadarrama (018)

Año: 1959

Página: 74-75

\section{TIPO DE IMAGEN.}

Retrato: NO

Cartel: NO

Mural: NO

Ilustración: SI

Otras Obras: NO

\section{CONTENIDO.}

Personajes: HOMBRE

Animales: NO

Gestos Expresivos: EMOCIONES NEGATIVAS

Paisajes: SI

Escenas: RURAL

Función: REPRESENTATIVA DE MODELOS SOCIALES

\section{ASPECTOS TÉCNICOS.}

Color dominante: 1 TINTA

Técnica: OFFSET

Plano de la imagen: GENERAL 


\section{VARIABLES EXTERNAS.}

Título: Cuadernos del Guadarrama (019)

Año: 1959

Página: 78-79

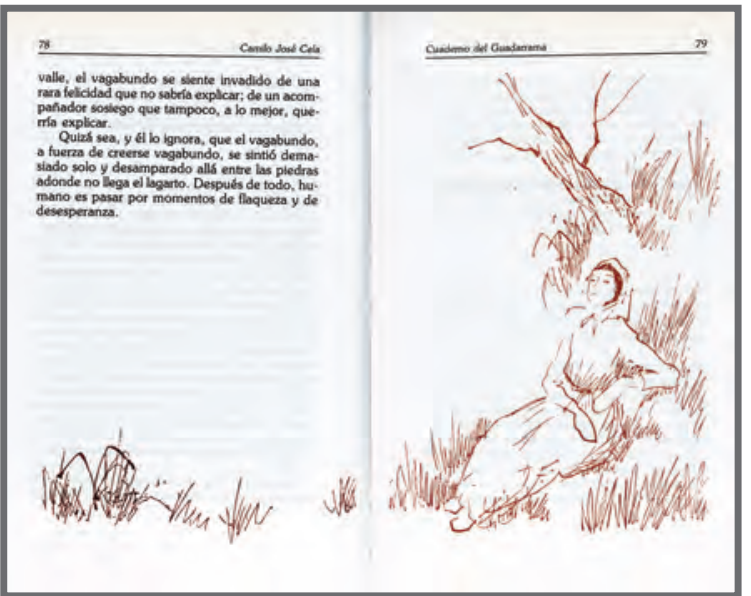

\section{TIPO DE IMAGEN.}

Retrato: NO

Cartel: NO

Mural: NO

Ilustración: SI

Otras Obras: NO

\section{CONTENIDO.}

Personajes: MUJER

Animales: NO

Gestos Expresivos: EMOCIONES POSITIVAS

Paisajes: NO

Escenas: RURAL

Función: REPRESENTATIVA DE MODELOS SOCIALES

\section{ASPECTOS TÉCNICOS.}

Color dominante: 1 TINTA

Técnica: OFFSET

Plano de la imagen: GENERAL 


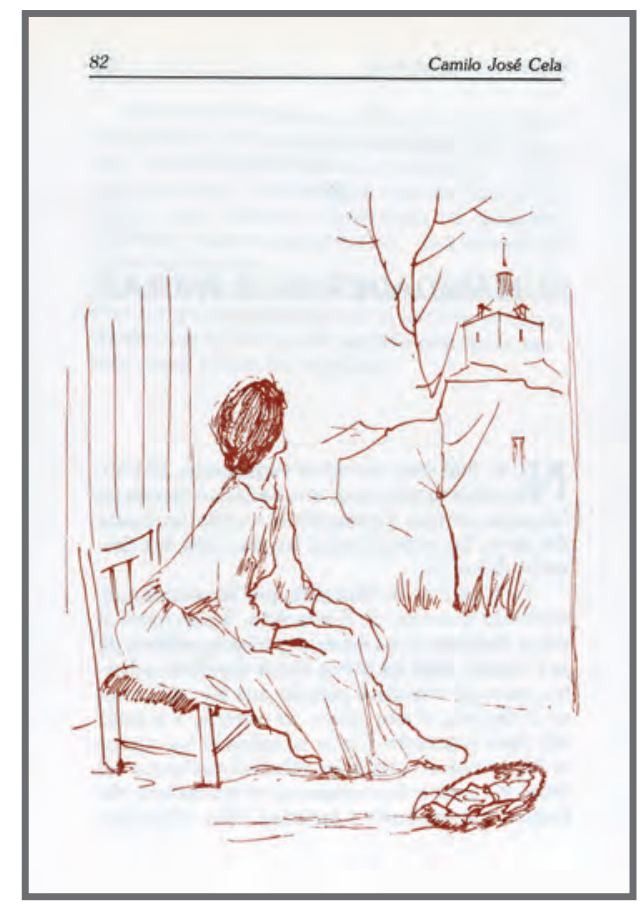

\section{VARIABLES EXTERNAS.}

Título: Cuadernos del Guadarrama (020)

Año: 1959

Página: 82

TIPO DE IMAGEN.

Retrato: NO

Cartel: NO

Mural: NO

Ilustración: SI

Otras Obras: NO

\section{CONTENIDO.}

Personajes: MUJER

Animales: NO

Gestos Expresivos: EMOCIONES POSITIVAS

Paisajes: SI

Escenas: RURAL

Función: REPRESENTATIVA DE MODELOS SOCIALES

\section{ASPECTOS TÉCNICOS.}

Color dominante: 1 TINTA

Técnica: OFFSET

Plano de la imagen: GENERAL 


\section{VARIABLES EXTERNAS.}

Título: Cuadernos del Guadarrama (021)

Año: 1959

Página: 84-85

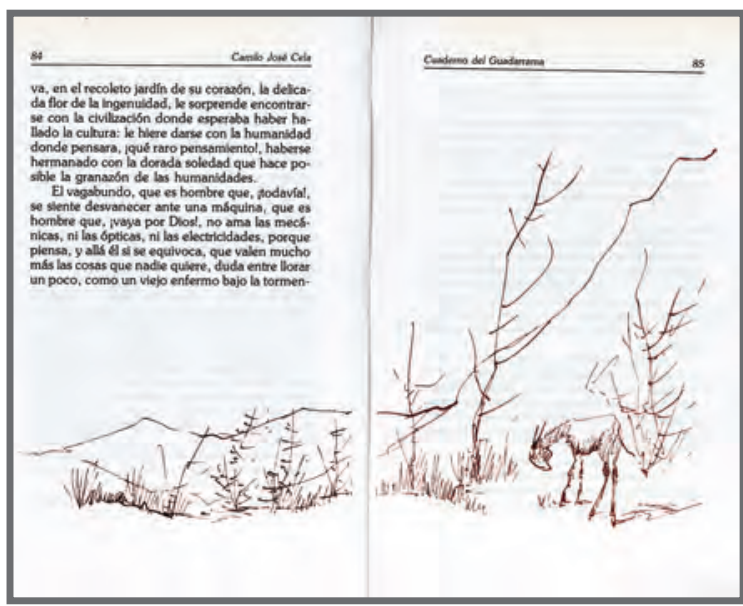

TIPO DE IMAGEN.

Retrato: NO

Cartel: NO

Mural: NO

Ilustración: SI

Otras Obras: NO

\section{CONTENIDO.}

Personajes: NO

Animales: BURRO

Gestos Expresivos: NO

Paisajes: SI

Escenas: RURAL

Función: REPRESENTATIVA DE MODELOS SOCIALES

\section{ASPECTOS TÉCNICOS.}

Color dominante: 1 TINTA

Técnica: OFFSET

Plano de la imagen: GENERAL 



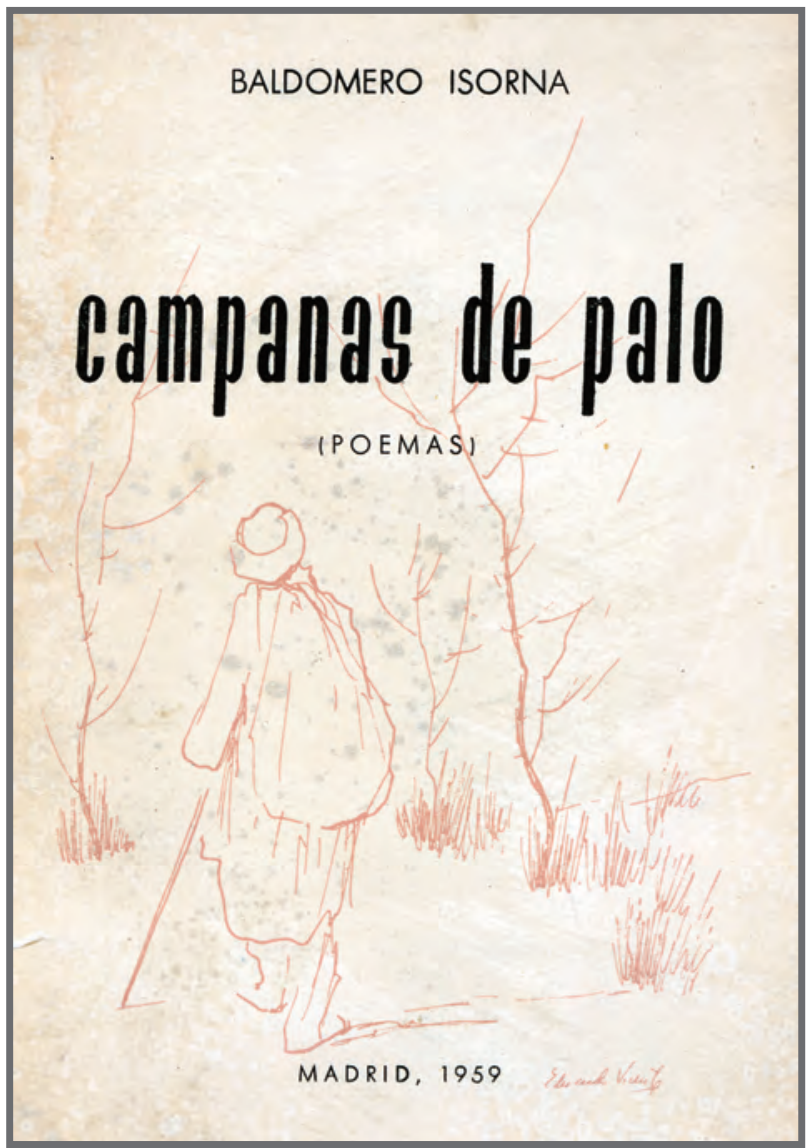

\section{FICHA TÉCNICA.}

Título: CAMPANAS DE PALO (POEMAS)

Autor: BALDOMERO ISORNA

Editorial: MARIBEL, ARTES GRÁFICAS

Año: 1959

Tamaño: $21,5 \times 16 \mathrm{~cm}$.

Número de páginas: 48

Número de ilustraciones: 1 + (ILUSTRACIÓN EN PORTADA) 



\section{VARIABLES EXTERNAS.}

Título: Campanas de palo (001)

Año: 1959

Página: PORTADA

\section{TIPO DE IMAGEN.}

Retrato: NO

Cartel: NO

Mural: NO

Ilustración: SI

Otras Obras: NO

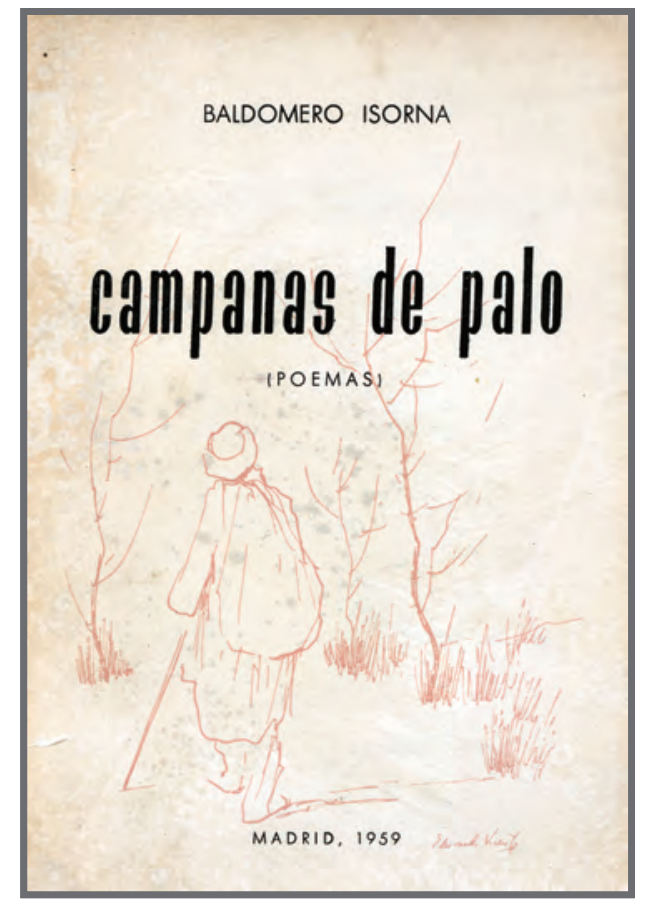

\section{CONTENIDO.}

Personajes: HOMBRE

Animales: NO

Gestos Expresivos: EMOCIONES POSITIVAS

Paisajes: NO

Escenas: RURAL

Función: REPRESENTATIVA DE MODELOS SOCIALES

\section{ASPECTOS TÉCNICOS.}

Color dominante: 1 TINTA

Técnica: OFFSET

Plano de la imagen: GENERAL 


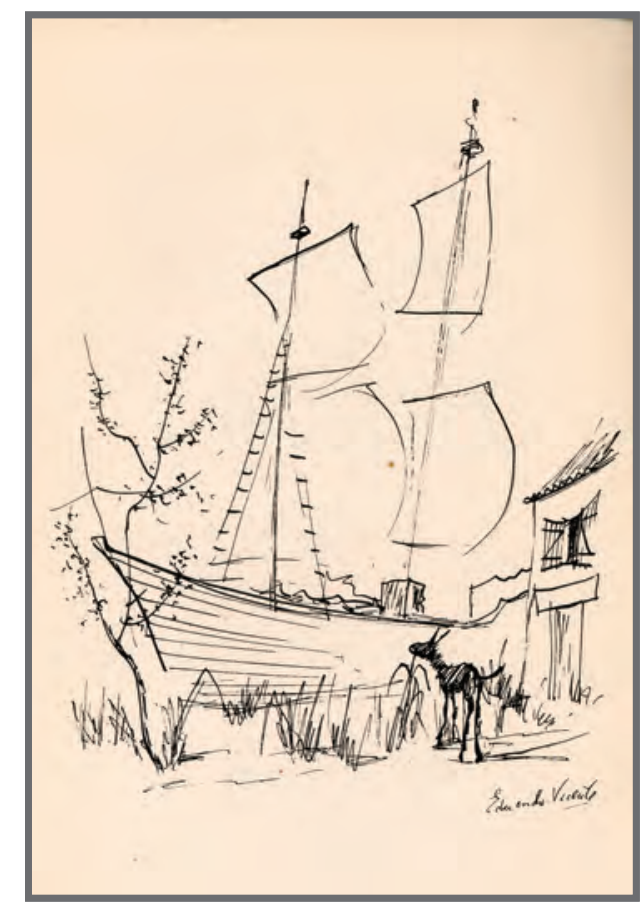

\section{VARIABLES EXTERNAS.}

Título: Campanas de palo (002)

Año: 1959

Página: 42

\section{TIPO DE IMAGEN.}

Retrato: NO

Cartel: NO

Mural: NO

Ilustración: SI

Otras Obras: NO

\section{CONTENIDO.}

Personajes: NO

Animales: BURRO

Gestos Expresivos: NO

Paisajes: SI

Escenas: RURAL

Función: REPRESENTATIVA DE MODELOS SOCIALES

\section{ASPECTOS TÉCNICOS.}

Color dominante: 1 TINTA

Técnica: OFFSET

Plano de la imagen: GENERAL 


\section{Otras obras}

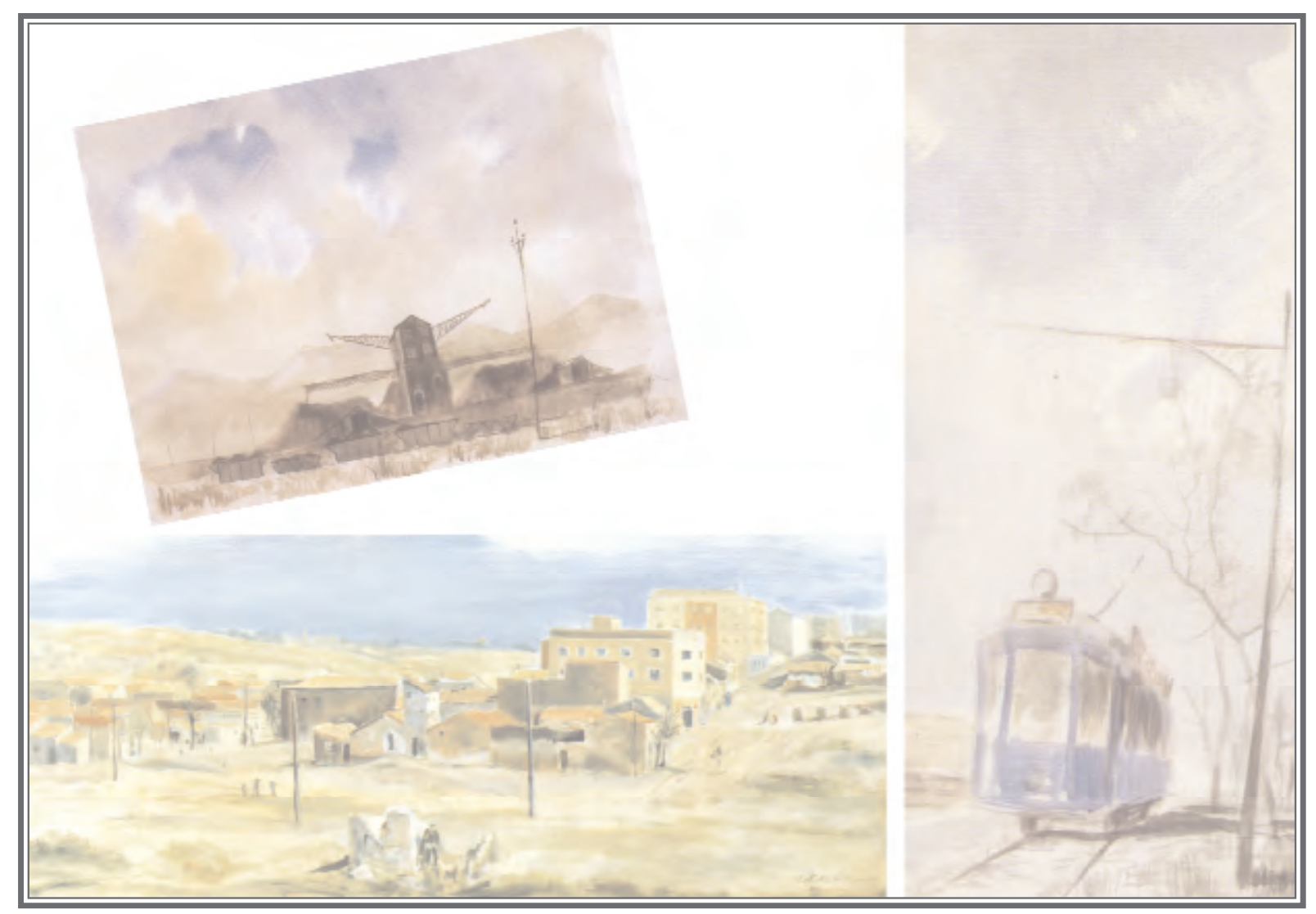

Afueras de Madrid. 1955. Madrid. Acuarela sobre papel. Colección particular. Eduardo Vicente 



\section{VARIABLES EXTERNAS.}

Título: Bodegón

Año: 11928

Tamaño: DESCONOCIDO

TIPO DE IMAGEN.

Retrato: NO

Cartel: NO

Mural: NO

Ilustración: NO

Otras Obras: SI

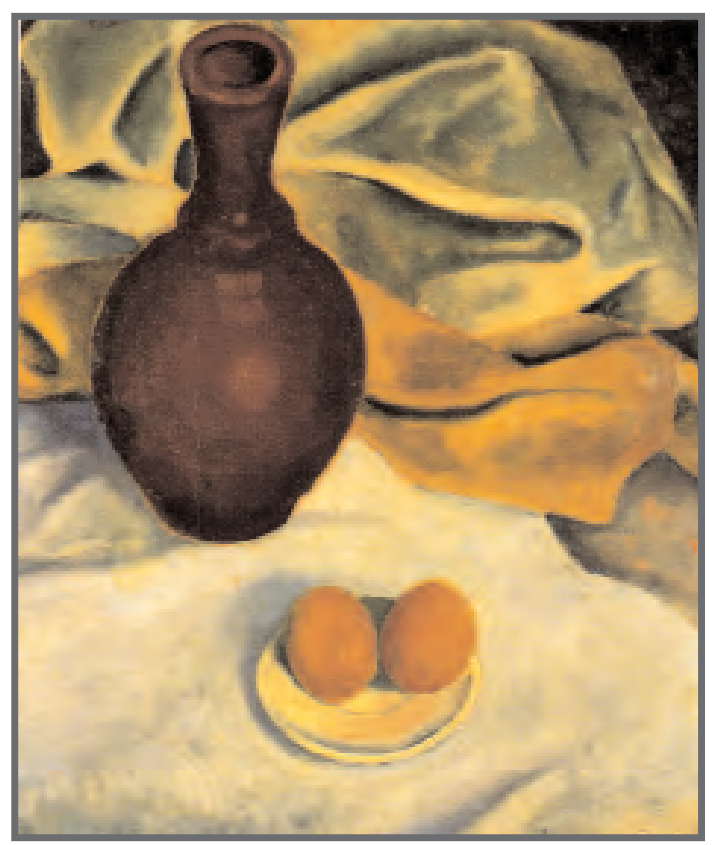

\section{CONTENIDO.}

Personajes: NO

Animales: NO

Gestos Expresivos: NO

Paisajes: NO

Escenas: BODEGÓN

Función: REPRESENTATIVA DE MODELOS SOCIALES

\section{ASPECTOS TÉCNICOS.}

Color dominante: VARIEDAD CROMÁTICA SUPERIOR

Técnica: ÓLEO SOBRE LIENZO

Plano de la imagen: GENERAL 

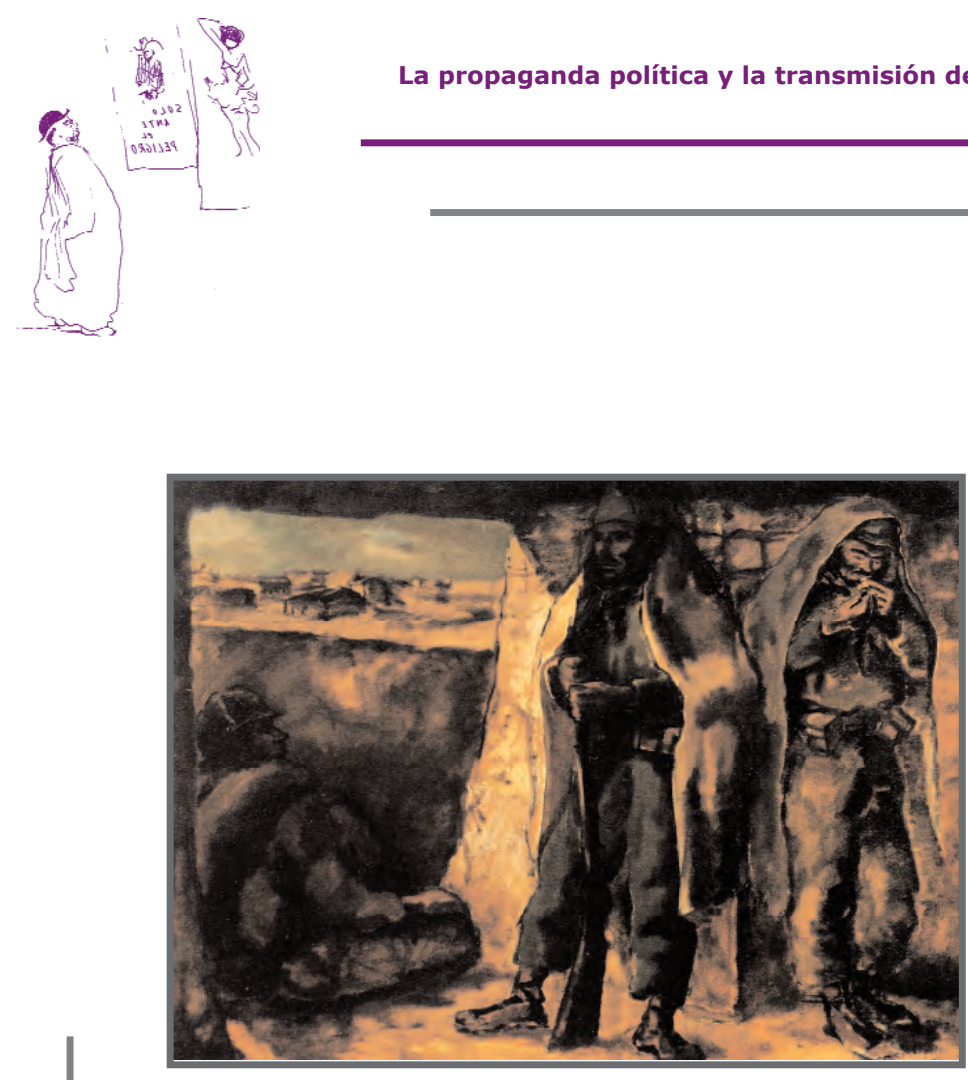

\section{VARIABLES EXTERNAS.}

Título: Milicianos de guerra

Año: 1937

Tamaño: $124,5 \times 170,5 \mathrm{~cm}$.

\section{TIPO DE IMAGEN.}

Retrato: NO

Cartel: NO

Mural: NO

Ilustración: NO

Otras Obras: SI

\section{CONTENIDO.}

Personajes: HOMBRES

Animales: NO

Gestos Expresivos: EMOCIONES NEGATIVAS

Paisajes: SI

Escenas: GUERRA

Función: PROPAGANDÍSTICA (IDEOLOGÍA POLÍTICA)

\section{ASPECTOS TÉCNICOS.}

Color dominante: VARIEDAD CROMÁTICA SUPERIOR

Técnica: ÓLEO SOBRE LIENZO

Plano de la imagen: GENERAL 


\section{VARIABLES EXTERNAS.}

Título: Guardia durante el descanso

Año: 1937

Tamaño: DESCONOCIDO

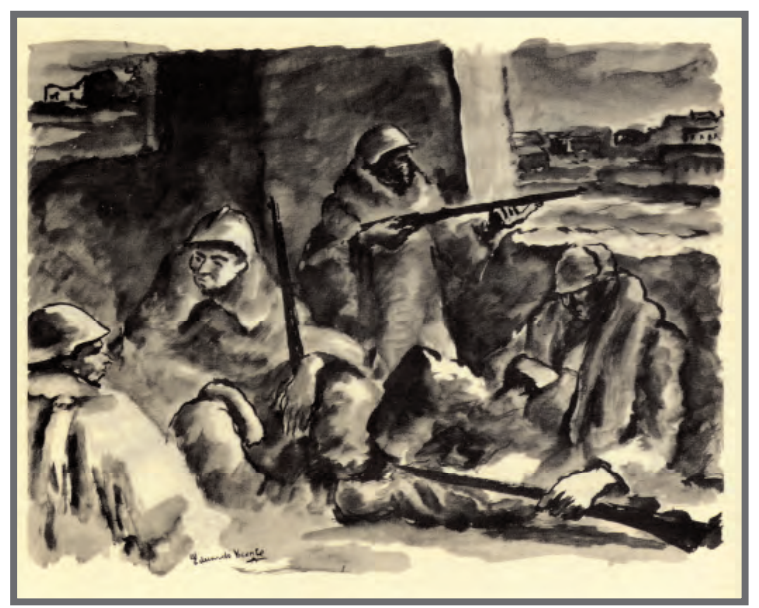

\section{TIPO DE IMAGEN.}

Retrato: NO

Cartel: NO

Mural: NO

Ilustración: NO

Otras Obras: SI

\section{CONTENIDO.}

Personajes: HOMBRES

Animales: NO

Gestos Expresivos: EMOCIONES NEGATIVAS

Paisajes: SI

Escenas: GUERRA

Función: PROPAGANDÍSTICA (IDEOLOGÍA POLÍTICA)

\section{ASPECTOS TÉCNICOS.}

Color dominante: 1 TINTA

Técnica: GRABADO

Plano de la imagen: GENERAL 


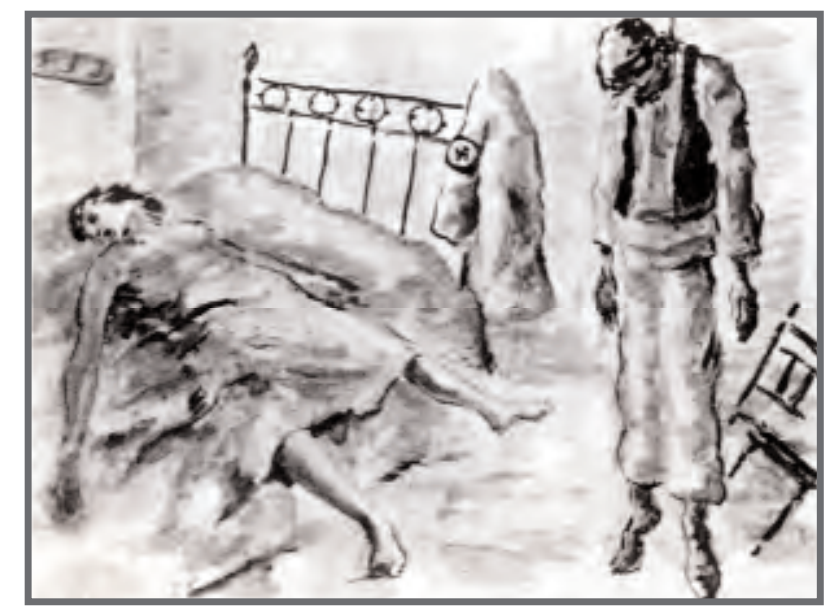

VARIABLES EXTERNAS.

Título: Pasaron los fascistas

Año: 1937

Tamaño: DESCONOCIDO

\section{TIPO DE IMAGEN.}

Retrato: NO

Cartel: NO

Mural: NO

Ilustración: NO

Otras Obras: SI

\section{CONTENIDO.}

Personajes: HOMBRE Y MUJER

Animales: NO

Gestos Expresivos: EMOCIONES NEGATIVAS

Paisajes: NO

Escenas: GUERRA

Función: PROPAGANDÍSTICA (IDEOLOGÍA POLÍTICA)

\section{ASPECTOS TÉCNICOS.}

Color dominante: 1 TINTA

Técnica: CARBONCILLO

Plano de la imagen: GENERAL 


\section{VARIABLES EXTERNAS.}

Título: Miliciano de guardia

Año: 1944

Tamaño: $19,5 \times 14,5 \mathrm{~cm}$.

\section{TIPO DE IMAGEN.}

Retrato: NO

Cartel: NO

Mural: NO

Ilustración: NO

Otras Obras: SI

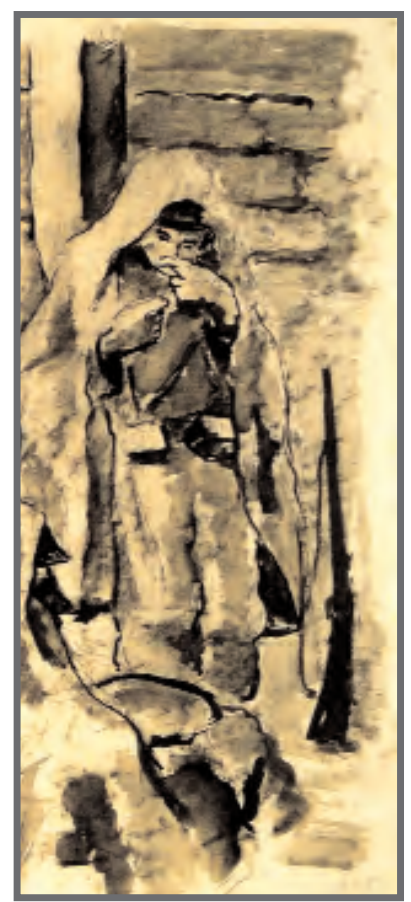

\section{CONTENIDO.}

Personajes: HOMBRE

Animales: NO

Gestos Expresivos: EMOCIONES NEGATIVAS

Paisajes: NO

Escenas: GUERRA

Función: PROPAGANDÍSTICA (IDEOLOGÍA POLÍTICA)

\section{ASPECTOS TÉCNICOS.}

Color dominante: 1 TINTA

Técnica: DIBUJO A CARBÓN, TINTA CHINA Y AGUATINTA

Plano de la imagen: GENERAL 

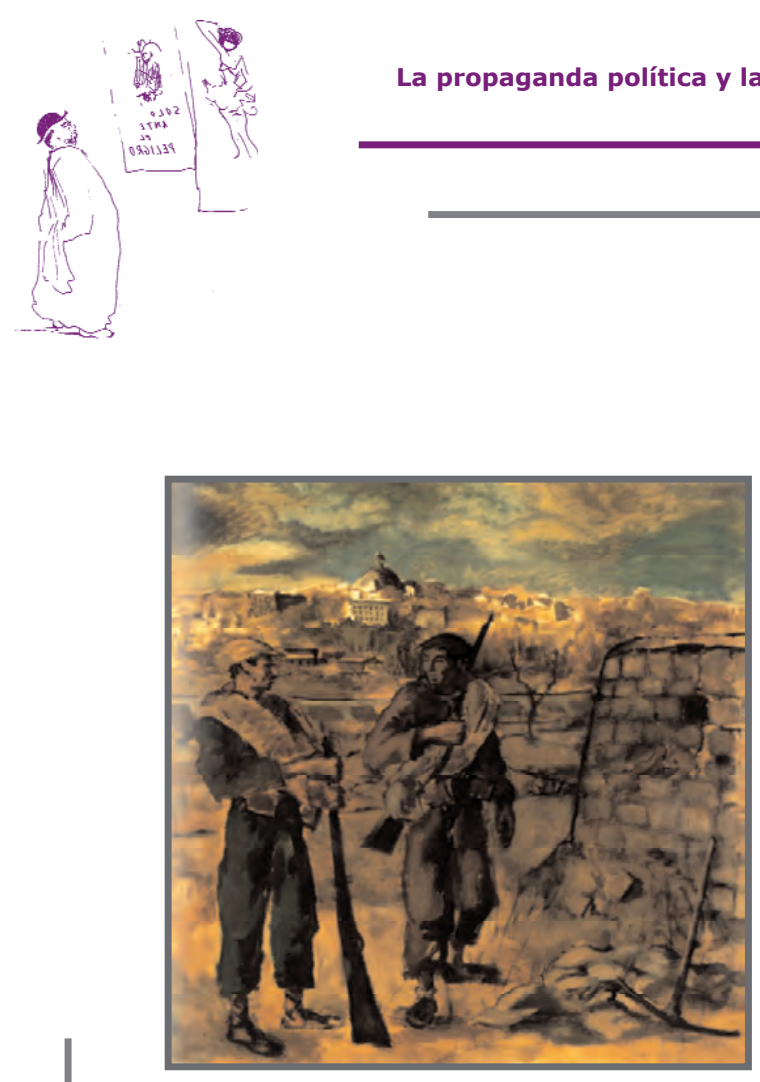

\section{VARIABLES EXTERNAS.}

Título: Milicianos haciendo guardia

Año: 1937

Tamaño: $139 \times 140 \mathrm{~cm}$.

\section{TIPO DE IMAGEN.}

Retrato: NO

Cartel: NO

Mural: NO

Ilustración: NO

Otras Obras: SI

\section{CONTENIDO.}

Personajes: HOMBRES

Animales: NO

Gestos Expresivos: EMOCIONES NEGATIVAS

Paisajes: SI

Escenas: GUERRA

Función: PROPAGANDÍSTICA (IDEOLOGÍA POLÍTICA)

\section{ASPECTOS TÉCNICOS.}

Color dominante: VARIEDAD CROMÁTICA SUPERIOR

Técnica: ÓLEO SOBRE LIENZO

Plano de la imagen: GENERAL 


\section{VARIABLES EXTERNAS.}

Título: Madrid

Año: 1937

Tamaño: 115 x $200 \mathrm{~cm}$.

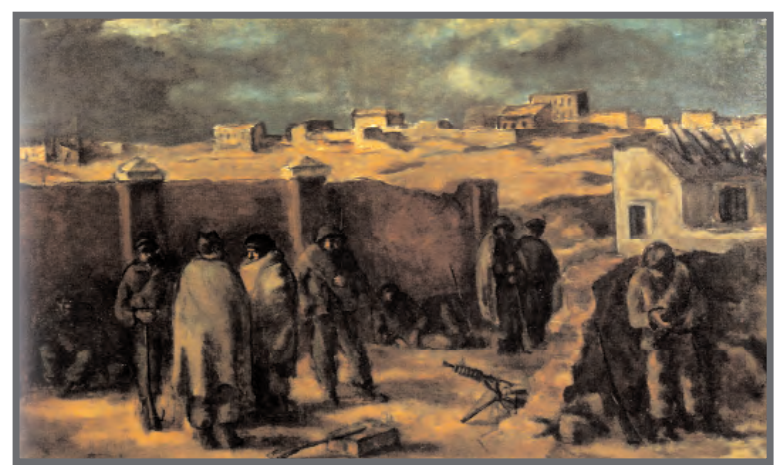

\section{TIPO DE IMAGEN.}

Retrato: NO

Cartel: NO

Mural: NO

Ilustración: NO

Otras Obras: SI

\section{CONTENIDO.}

Personajes: HOMBRES

Animales: NO

Gestos Expresivos: EMOCIONES NEGATIVAS

Paisajes: SI

Escenas: GUERRA

Función: PROPAGANDÍSTICA (IDEOLOGÍA POLÍTICA)

\section{ASPECTOS TÉCNICOS.}

Color dominante: VARIEDAD CROMÁTICA SUPERIOR Técnica: ÓLEO SOBRE LIENZO

Plano de la imagen: GENERAL 

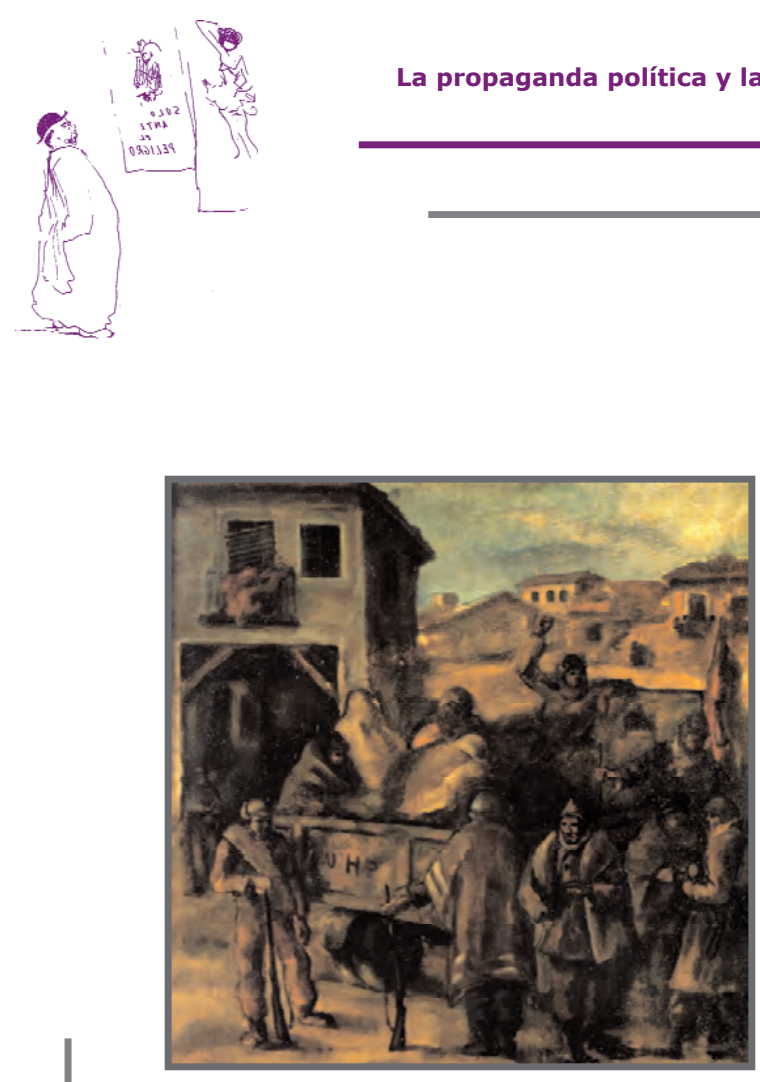

\section{VARIABLES EXTERNAS.}

Título: Camión de milicianos

Año: 1937

Tamaño: $100 \times 100 \mathrm{~cm}$.

\section{TIPO DE IMAGEN.}

Retrato: NO

Cartel: NO

Mural: NO

Ilustración: NO

Otras Obras: SI

\section{CONTENIDO.}

Personajes: HOMBRES

Animales: NO

Gestos Expresivos: EMOCIONES NEGATIVAS

Paisajes: SI

Escenas: GUERRA

Función: PROPAGANDÍSTICA (IDEOLOGÍA POLÍTICA)

\section{ASPECTOS TÉCNICOS.}

Color dominante: VARIEDAD CROMÁTICA SUPERIOR

Técnica: ÓLEO SOBRE LIENZO

Plano de la imagen: GENERAL 


\section{VARIABLES EXTERNAS.}

Título: Barrio bombardeado

Año: 1937

Tamaño: $100 \times 150 \mathrm{~cm}$.

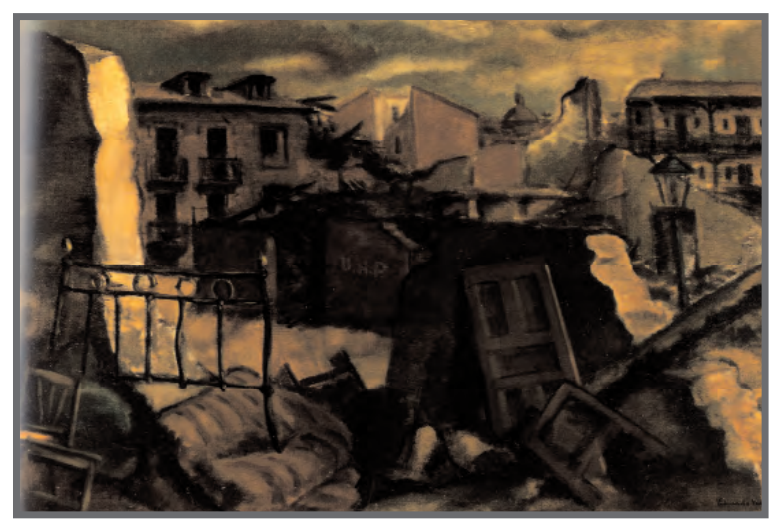

\section{TIPO DE IMAGEN.}

Retrato: NO

Cartel: NO

Mural: NO

Ilustración: NO

Otras Obras: SI

\section{CONTENIDO.}

Personajes: NO

Animales: NO

Gestos Expresivos: NO

Paisajes: SI

Escenas: GUERRA

Función: PROPAGANDÍSTICA (IDEOLOGÍA POLÍTICA)

\section{ASPECTOS TÉCNICOS.}

Color dominante: VARIEDAD CROMÁTICA SUPERIOR Técnica: ÓLEO SOBRE LIENZO

Plano de la imagen: GENERAL 


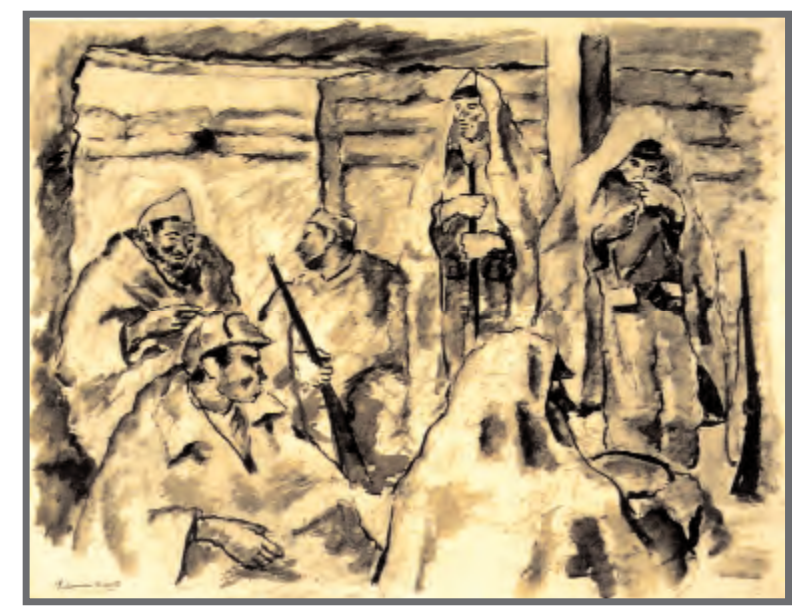

\section{VARIABLES EXTERNAS.}

Título: Seis soldados haciendo guardia

Año: 1937

Tamaño: 48 x $64 \mathrm{~cm}$.

\section{TIPO DE IMAGEN.}

Retrato: NO

Cartel: NO

Mural: NO

Ilustración: NO

Otras Obras: SI

\section{CONTENIDO.}

Personajes: HOMBRES

Animales: NO

Gestos Expresivos: EMOCIONES NEGATIVAS

Paisajes: SI

Escenas: GUERRA

Función: PROPAGANDÍSTICA (IDEOLOGÍA POLÍTICA)

\section{ASPECTOS TÉCNICOS.}

Color dominante: 1 TINTA

Técnica: DIBUJO A CARBÓN, TINTA CHINA Y AGUATINTA

Plano de la imagen: GENERAL 


\section{VARIABLES EXTERNAS.}

Título: Tres soldados vigilando desde una trinchera

Año: 1937

Tamaño: 48 x $64 \mathrm{~cm}$.

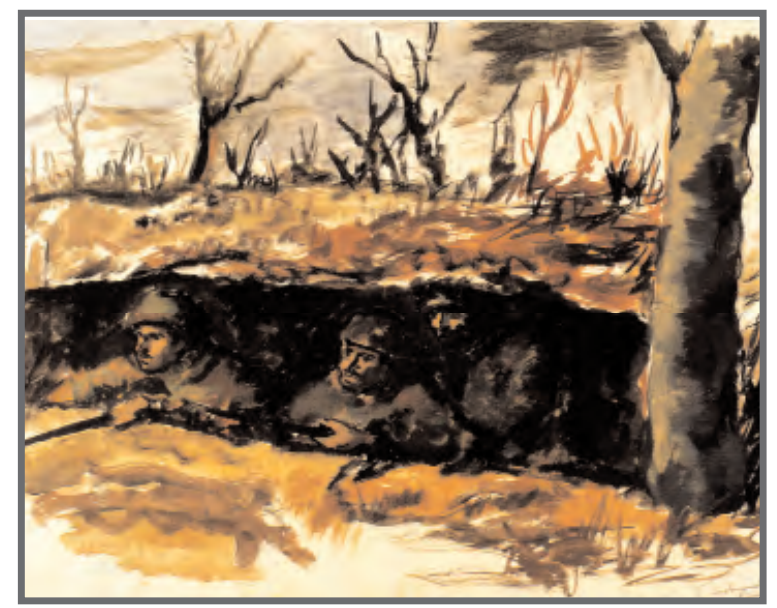

TIPO DE IMAGEN.

Retrato: NO

Cartel: NO

Mural: NO

Ilustración: NO

Otras Obras: SI

\section{CONTENIDO.}

Personajes: HOMBRES

Animales: NO

Gestos Expresivos: EMOCIONES NEGATIVAS

Paisajes: SI

Escenas: GUERRA

Función: PROPAGANDÍSTICA (IDEOLOGÍA POLÍTICA)

\section{ASPECTOS TÉCNICOS.}

Color dominante: VARIEDAD CROMÁTICA SUPERIOR Técnica: ACUARELA SOBRE PAPEL

Plano de la imagen: GENERAL 

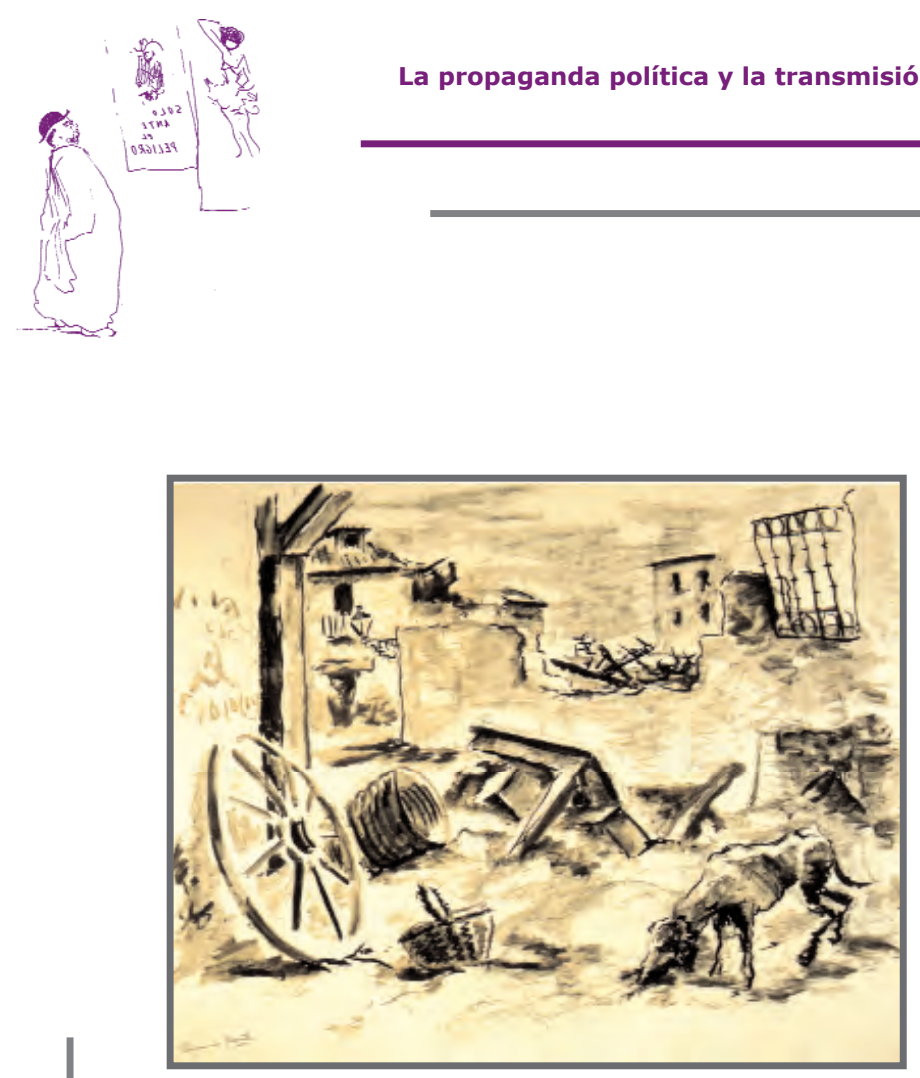

\section{VARIABLES EXTERNAS.}

Título: Pueblo destruido por un bombardeo

Año: 1937

Tamaño: 48 x $64 \mathrm{~cm}$.

\section{TIPO DE IMAGEN.}

Retrato: NO

Cartel: NO

Mural: NO

Ilustración: NO

Otras Obras: SI

\section{CONTENIDO.}

\section{Personajes: NO}

Animales: PERRO

Gestos Expresivos: NO

Paisajes: SI

Escenas: GUERRA

Función: PROPAGANDÍSTICA (IDEOLOGÍA POLÍTICA)

\section{ASPECTOS TÉCNICOS.}

Color dominante: 1 TINTA

Técnica: DIBUJO A CARBÓN, TINTA CHINA Y AGUATINTA

Plano de la imagen: GENERAL 


\section{VARIABLES EXTERNAS.}

Título: Habitación destruida por un bombardeo

\section{Año: 1937}

Tamaño: $48 \times 64 \mathrm{~cm}$.

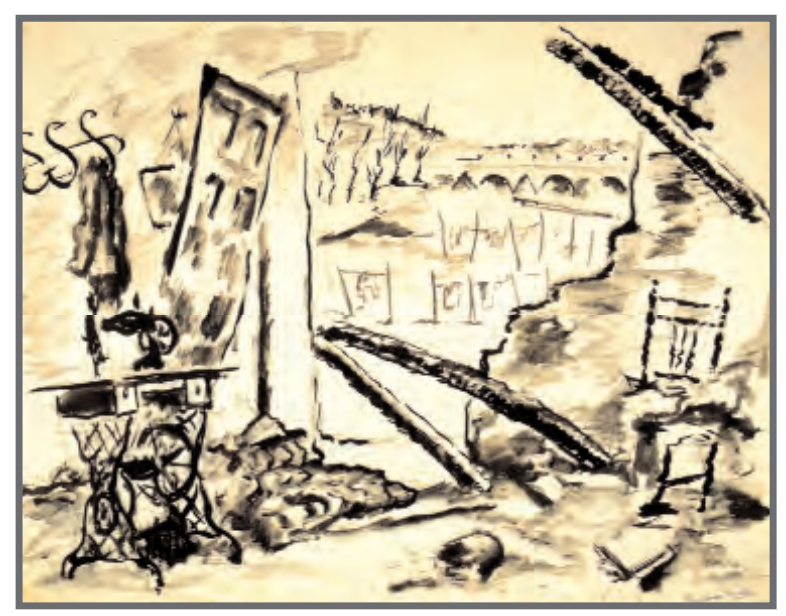

\section{TIPO DE IMAGEN.}

Retrato: NO

Cartel: NO

Mural: NO

Ilustración: NO

Otras Obras: SI

\section{CONTENIDO.}

Personajes: NO

Animales: NO

Gestos Expresivos: NO

Paisajes: SI

Escenas: GUERRA

Función: PROPAGANDÍSTICA (IDEOLOGÍA POLÍTICA)

\section{ASPECTOS TÉCNICOS.}

Color dominante: 1 TINTA

Técnica: DIBUJO A CARBÓN, TINTA CHINA Y AGUATINTA

Plano de la imagen: GENERAL 

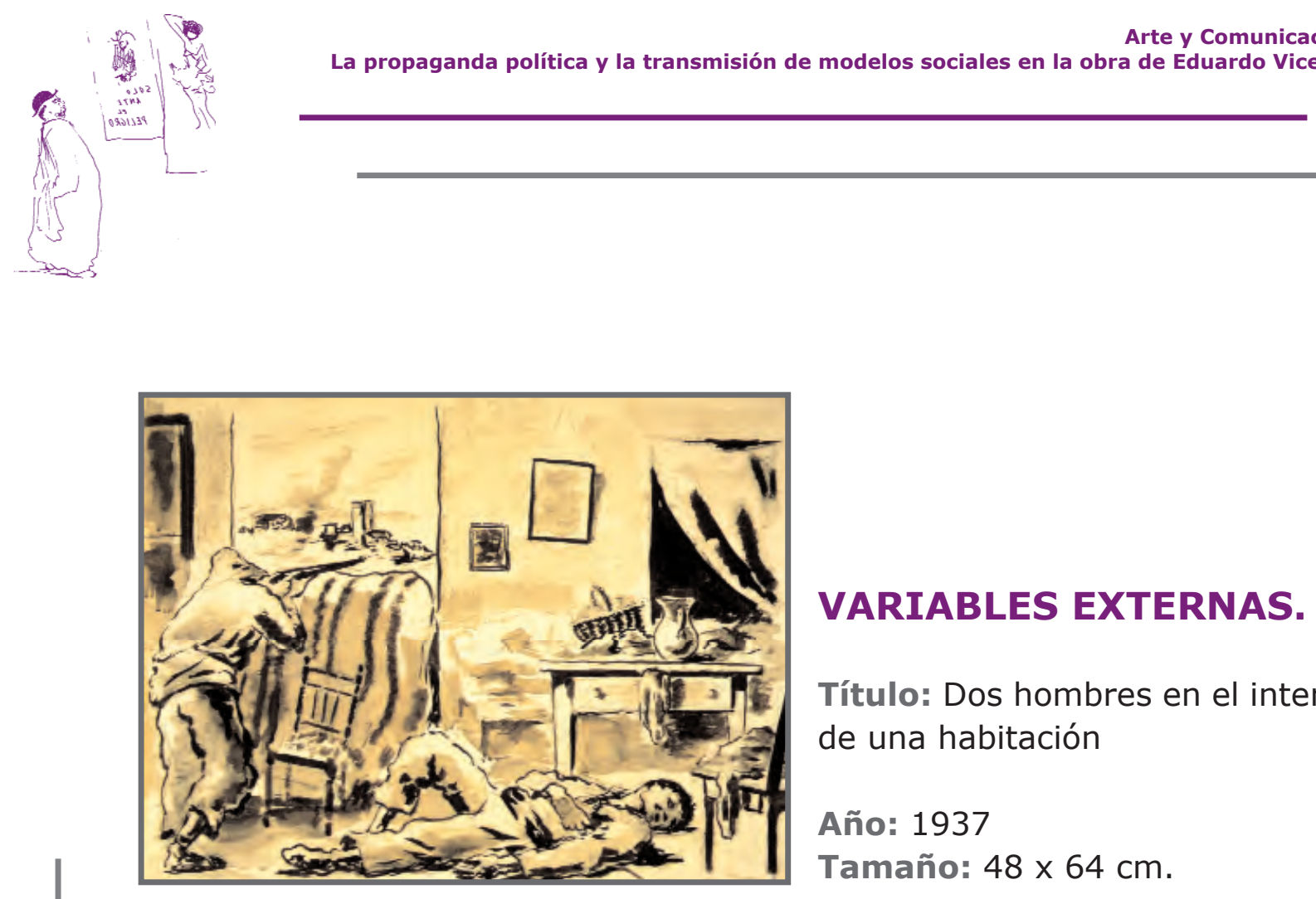

\section{VARIABLES EXTERNAS.}

Título: Dos hombres en el interior de una habitación

Año: 1937

Tamaño: 48 x $64 \mathrm{~cm}$.

\section{TIPO DE IMAGEN.}

Retrato: NO

Cartel: NO

Mural: NO

Ilustración: NO

Otras Obras: SI

\section{CONTENIDO.}

Personajes: HOMBRES

Animales: NO

Gestos Expresivos: EMOCIONES NEGATIVAS

Paisajes: SI

Escenas: GUERRA

Función: PROPAGANDÍSTICA (IDEOLOGÍA POLÍTICA)

\section{ASPECTOS TÉCNICOS.}

Color dominante: 1 TINTA

Técnica: DIBUJO A CARBÓN, TINTA CHINA Y AGUATINTA

Plano de la imagen: GENERAL 
VARIABLES EXTERNAS.

Título: Tres cadáveres en la plaza de un pueblo

\section{Año: 1937}

Tamaño: 46,6 x $63 \mathrm{~cm}$.

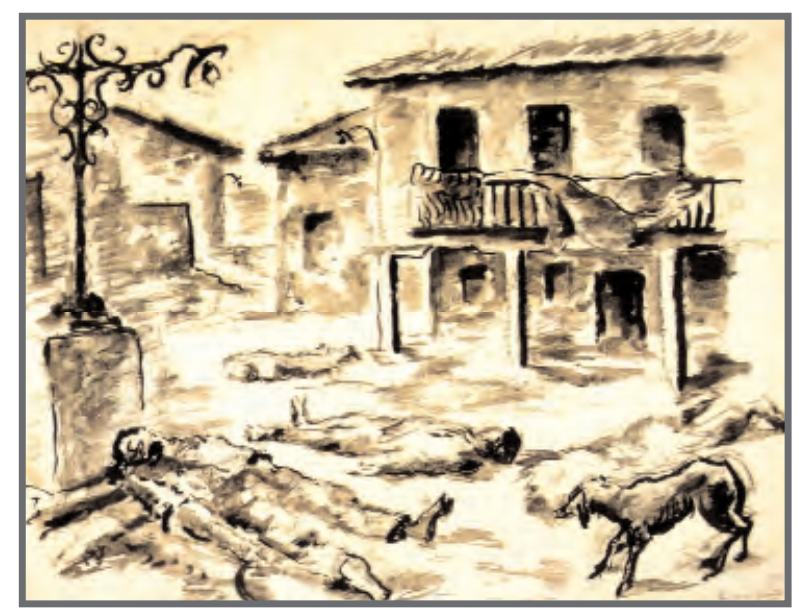

\section{TIPO DE IMAGEN.}

Retrato: NO

Cartel: NO

Mural: NO

Ilustración: NO

Otras Obras: SI

\section{CONTENIDO.}

Personajes: HOMBRES

Animales: PERRO

Gestos Expresivos: EMOCIONES NEGATIVAS

Paisajes: SI

Escenas: GUERRA

Función: PROPAGANDÍSTICA (IDEOLOGÍA POLÍTICA)

\section{ASPECTOS TÉCNICOS.}

Color dominante: 1 TINTA

Técnica: DIBUJO A CARBÓN, TINTA CHINA Y AGUATINTA

Plano de la imagen: GENERAL 

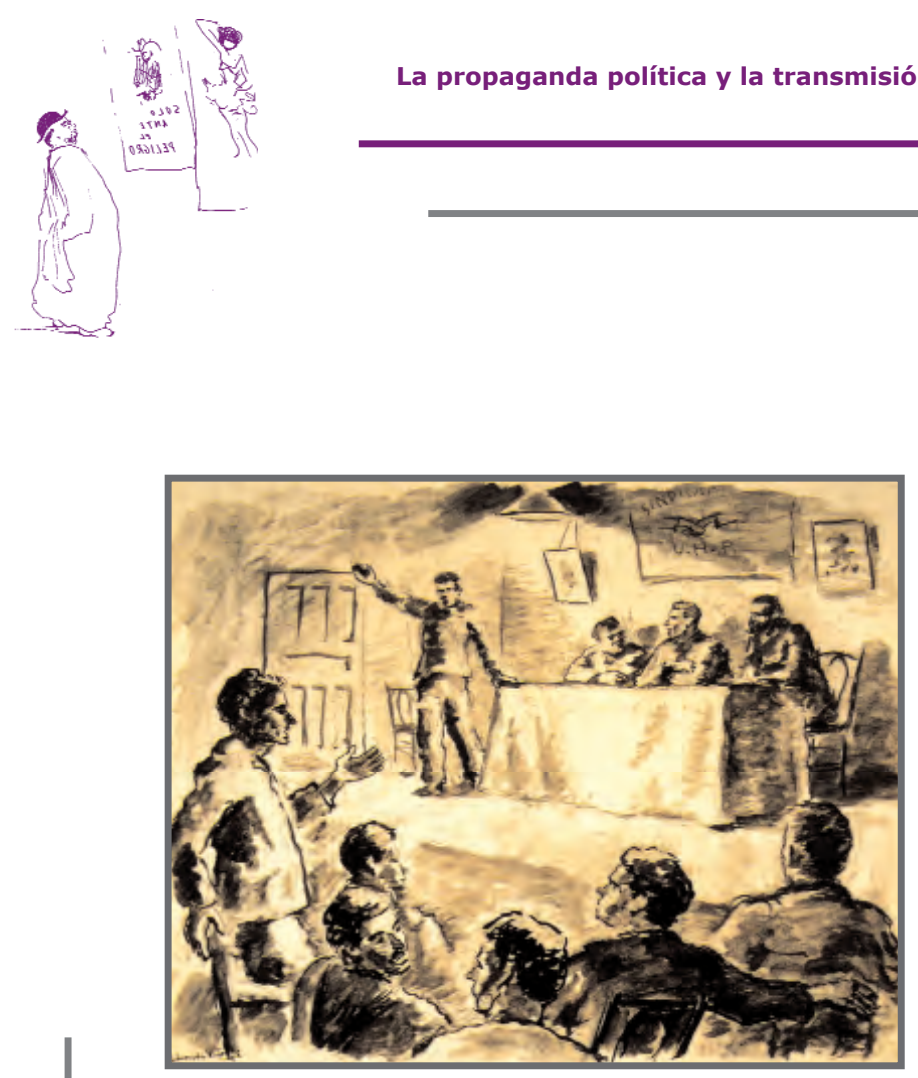

\section{VARIABLES EXTERNAS.}

Título: Grupo de hombres en una asamblea

Año: 1937

Tamaño: 48 x $64 \mathrm{~cm}$.

\section{TIPO DE IMAGEN.}

Retrato: NO

Cartel: NO

Mural: NO

Ilustración: NO

Otras Obras: SI

\section{CONTENIDO.}

Personajes: HOMBRES

Animales: NO

Gestos Expresivos: EMOCIONES NEGATIVAS

Paisajes: NO

Escenas: GUERRA

Función: PROPAGANDÍSTICA (IDEOLOGÍA POLÍTICA)

\section{ASPECTOS TÉCNICOS.}

Color dominante: 1 TINTA

Técnica: DIBUJO A CARBÓN, TINTA CHINA Y AGUATINTA

Plano de la imagen: GENERAL 


\section{VARIABLES EXTERNAS.}

Título: Busto de soldado

Año: 1944

Tamaño: $64 \times 48 \mathrm{~cm}$.

\section{TIPO DE IMAGEN.}

Retrato: NO

Cartel: NO

Mural: NO

Ilustración: NO

Otras Obras: SI

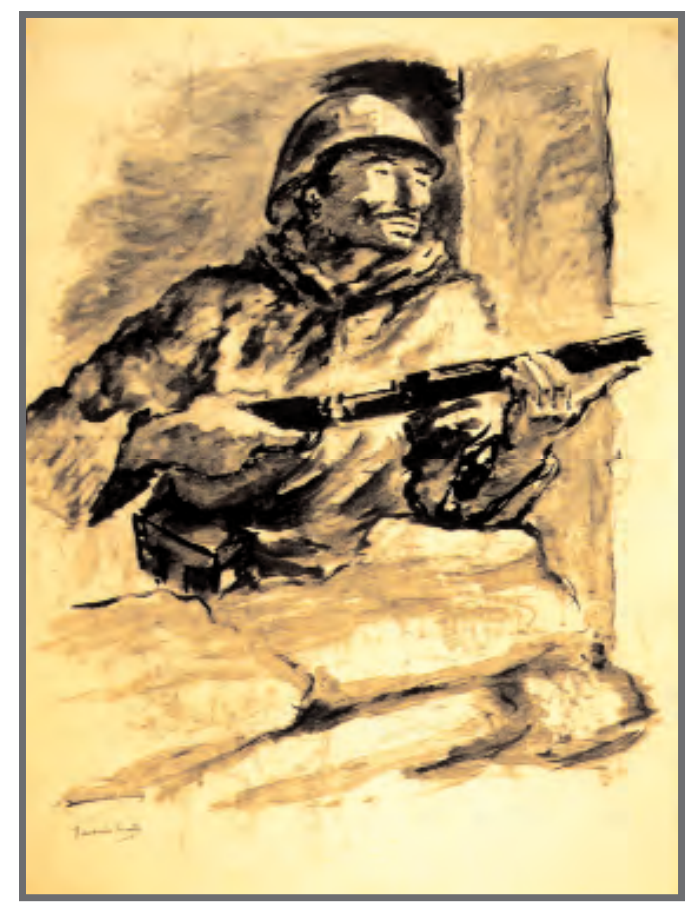

\section{CONTENIDO.}

Personajes: HOMBRES

Animales: NO

Gestos Expresivos: EMOCIONES NEGATIVAS

Paisajes: NO

Escenas: GUERRA

Función: PROPAGANDÍSTICA (IDEOLOGÍA POLÍTICA)

\section{ASPECTOS TÉCNICOS.}

Color dominante: 1 TINTA

Técnica: DIBUJO A CARBÓN, TINTA CHINA Y AGUATINTA

Plano de la imagen: GENERAL 

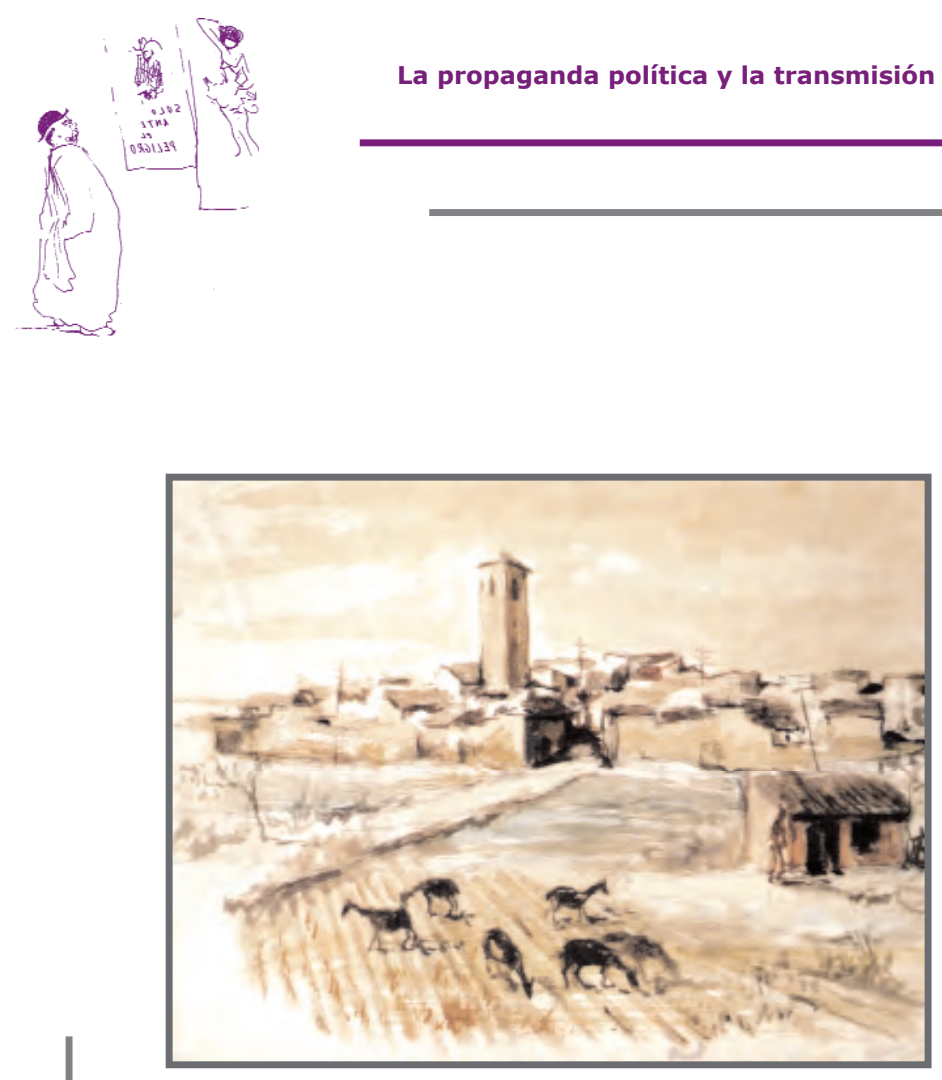

\section{VARIABLES EXTERNAS.}

Título: Pueblo de Barajas

Año: 1940

Tamaño: 48,5 x 64,5 cm.

\section{TIPO DE IMAGEN.}

Retrato: NO

Cartel: NO

Mural: NO

Ilustración: NO

Otras Obras: SI

\section{CONTENIDO.}

Personajes: NO

Animales: BURROS

Gestos Expresivos: NO

Paisajes: SI

Escenas: RURAL

Función: REPRESENTATIVA DE MODELOS SOCIALES

\section{ASPECTOS TÉCNICOS.}

Color dominante: VARIEDAD CROMÁTICA SUPERIOR

Técnica: ACUARELA SOBRE PAPEL

Plano de la imagen: GENERAL 


\section{VARIABLES EXTERNAS.}

Título: La taberna

Año: $1940-45$

Tamaño: $88 \times 126 \mathrm{~cm}$.

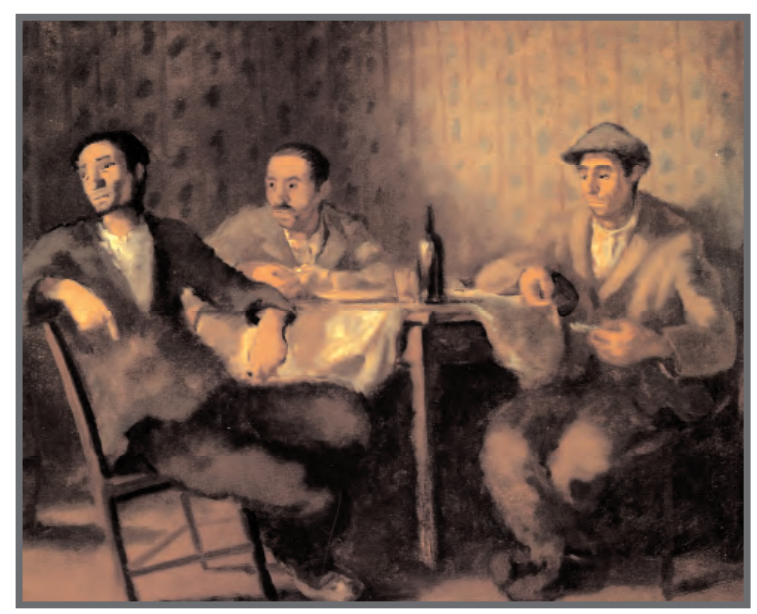

\section{TIPO DE IMAGEN.}

Retrato: NO

Cartel: NO

Mural: NO

Ilustración: NO

Otras Obras: SI

\section{CONTENIDO.}

Personajes: HOMBRES

Animales: NO

Gestos Expresivos: EMOCIONES POSITIVAS

Paisajes: NO

Escenas: INTERIOR

Función: REPRESENTATIVA DE MODELOS SOCIALES

\section{ASPECTOS TÉCNICOS.}

Color dominante: VARIEDAD CROMÁTICA SUPERIOR

Técnica: ÓLEO SOBRE LIENZO

Plano de la imagen: GENERAL 


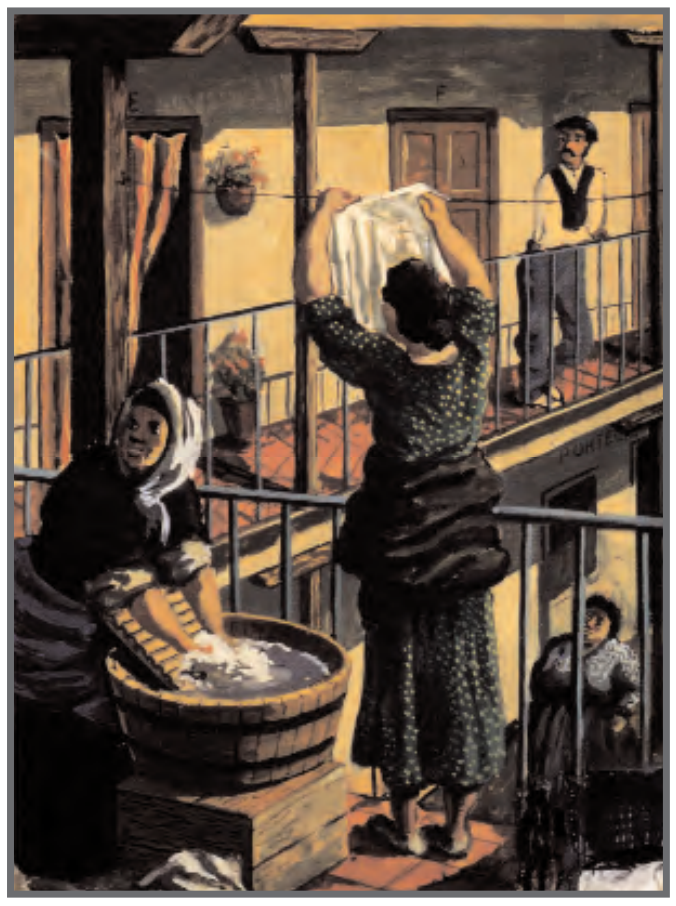

\section{VARIABLES EXTERNAS.}

Título: Corrala

Año: 1944

Tamaño: 33,5 x 25 cm.

\section{TIPO DE IMAGEN.}

Retrato: NO

Cartel: NO

Mural: NO

Ilustración: NO

Otras Obras: SI

\section{CONTENIDO.}

Personajes: HOMBRE Y MUJERES

Animales: NO

Gestos Expresivos: EMOCIONES POSITIVAS

Paisajes: NO

Escenas: PROFESIONAL

Función: REPRESENTATIVA DE MODELOS SOCIALES

\section{ASPECTOS TÉCNICOS.}

Color dominante: VARIEDAD CROMÁTICA SUPERIOR

Técnica: ÓLEO SOBRE LIENZO

Plano de la imagen: GENERAL 


\section{VARIABLES EXTERNAS.}

Título: El vagabundo

Año: $1944-45$

Tamaño: $90 \times 73 \mathrm{~cm}$.

TIPO DE IMAGEN.

Retrato: NO

Cartel: NO

Mural: NO

Ilustración: NO

Otras Obras: SI

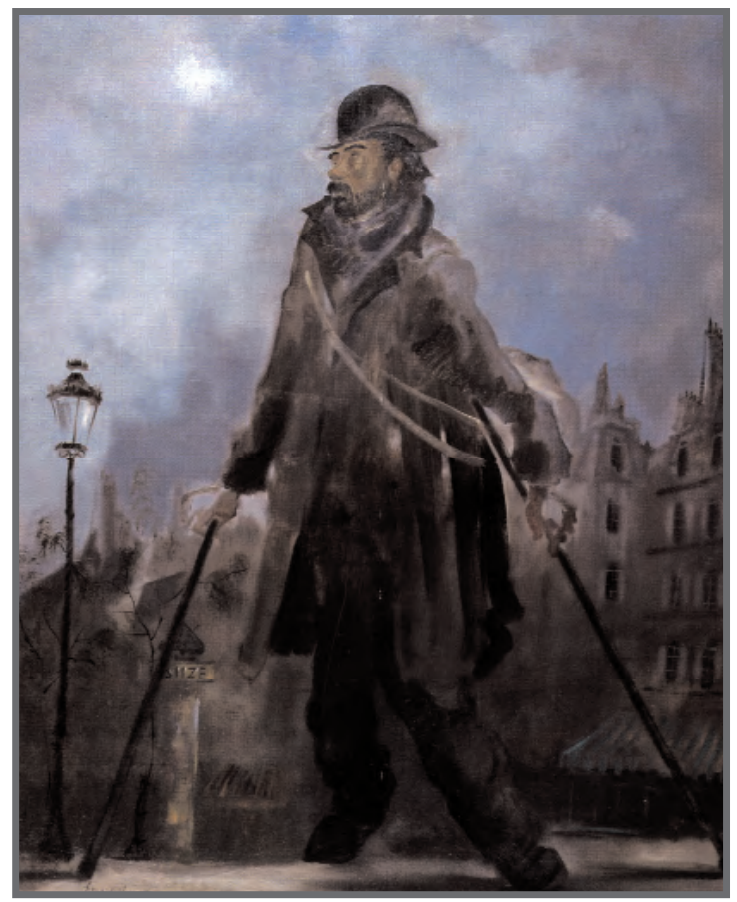

\section{CONTENIDO.}

Personajes: HOMBRE

Animales: NO

Gestos Expresivos: EMOCIONES NEGATIVAS

Paisajes: SI

Escenas: CALLEJERA

Función: REPRESENTATIVA DE MODELOS SOCIALES

\section{ASPECTOS TÉCNICOS.}

Color dominante: VARIEDAD CROMÁTICA SUPERIOR

Técnica: ÓLEO SOBRE LIENZO

Plano de la imagen: GENERAL 

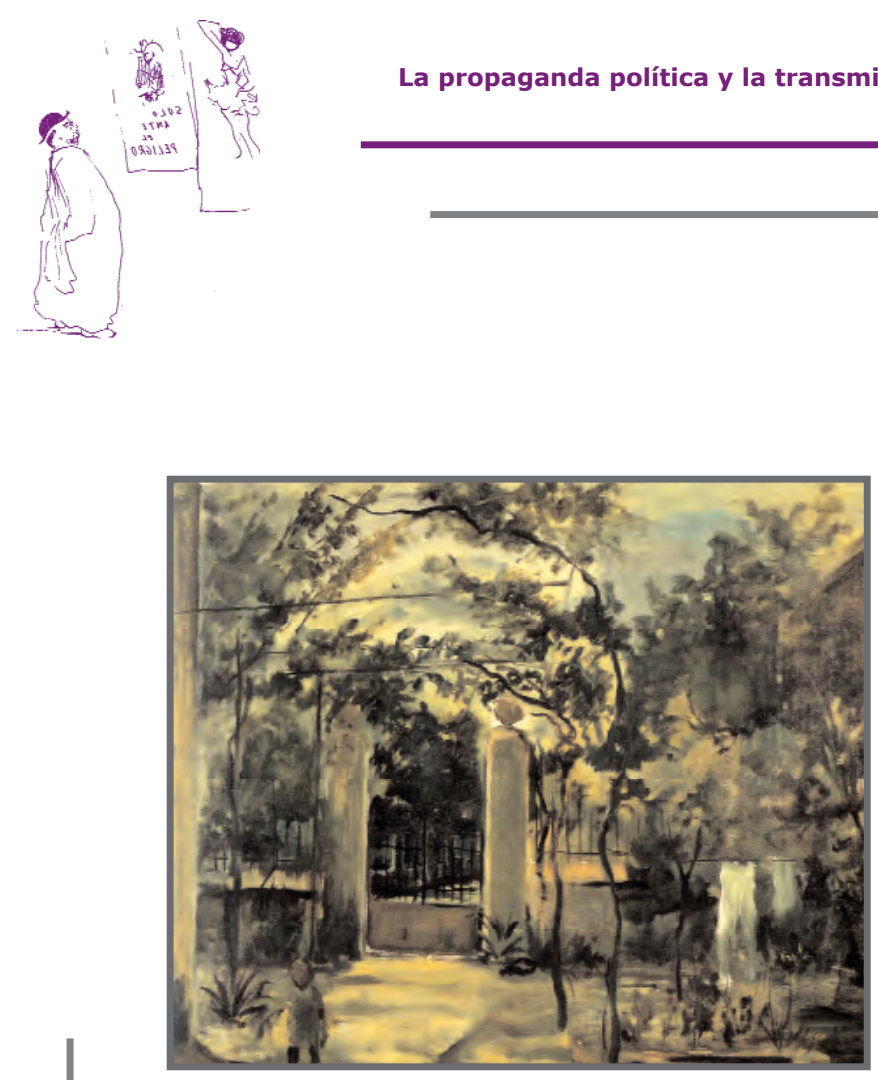

\section{VARIABLES EXTERNAS.}

Título: Casa del pintor en Ciudad Jardín

Año: 1943

Tamaño: 59 x $69 \mathrm{~cm}$.

\section{TIPO DE IMAGEN.}

Retrato: NO

Cartel: NO

Mural: NO

Ilustración: NO

Otras Obras: SI

\section{CONTENIDO.}

Personajes: NIÑA

Animales: NO

Gestos Expresivos: EMOCIONES POSITIVAS

Paisajes: SI

Escenas: RURAL

Función: REPRESENTATIVA DE MODELOS SOCIALES

\section{ASPECTOS TÉCNICOS.}

Color dominante: VARIEDAD CROMÁTICA SUPERIOR

Técnica: ÓLEO SOBRE LIENZO

Plano de la imagen: GENERAL 


\section{VARIABLES EXTERNAS.}

Título: Retrato de familia en un jardín

Año: 1937

Tamaño: 124,5 x 170,5 cm.

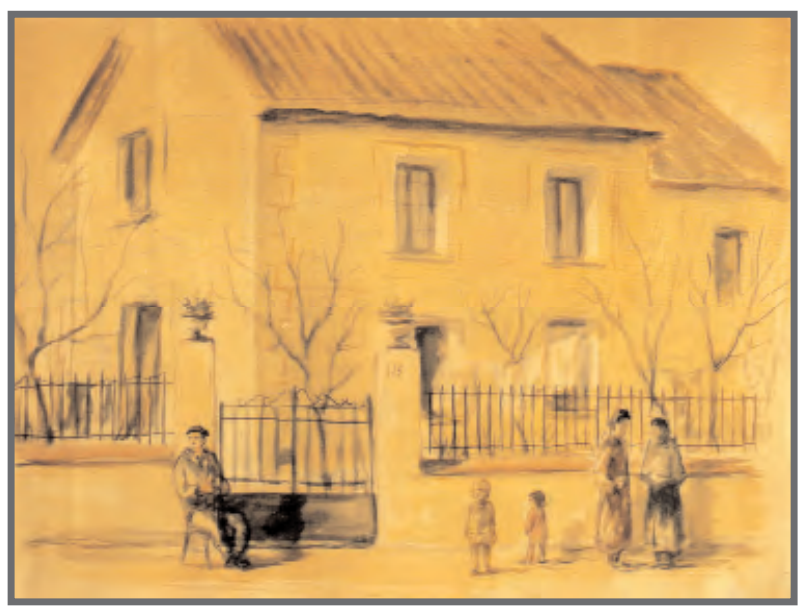

\section{TIPO DE IMAGEN.}

Retrato: NO

Cartel: NO

Mural: NO

Ilustración: NO

Otras Obras: SI

\section{CONTENIDO.}

Personajes: HOMBRE, MUJERES Y NIÑAS

Animales: NO

Gestos Expresivos: EMOCIONES POSITIVAS

Paisajes: SI

Escenas: RURAL

Función: REPRESENTATIVA DE MODELOS SOCIALES

\section{ASPECTOS TÉCNICOS.}

Color dominante: VARIEDAD CROMÁTICA SUPERIOR Técnica: ACUARELA SOBRE PAPEL

Plano de la imagen: GENERAL 

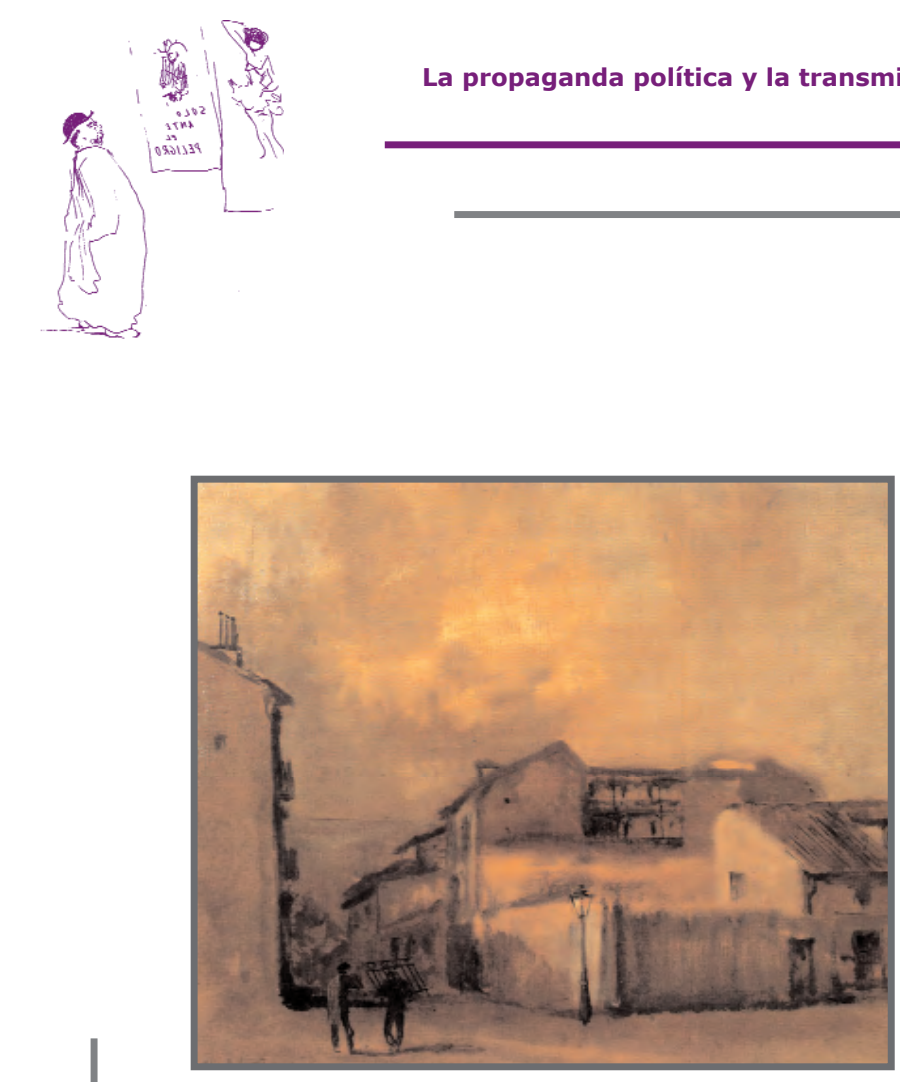

\section{VARIABLES EXTERNAS.}

Título: Barrios Bajos

Año: 1945- 50

Tamaño: 54 x $65 \mathrm{~cm}$.

\section{TIPO DE IMAGEN.}

Retrato: NO

Cartel: NO

Mural: NO

Ilustración: NO

Otras Obras: SI

\section{CONTENIDO.}

Personajes: HOMBRES

Animales: NO

Gestos Expresivos: EMOCIONES NEGATIVAS

Paisajes: SI

Escenas: CALLEJERA

Función: REPRESENTATIVA DE MODELOS SOCIALES

\section{ASPECTOS TÉCNICOS.}

Color dominante: VARIEDAD CROMÁTICA SUPERIOR

Técnica: ÓLEO SOBRE LIENZO

Plano de la imagen: GENERAL 


\section{VARIABLES EXTERNAS.}

Título: Fuente de Apolo. Paseo de Recoletos

Año: $1945-50$

Tamaño: $124,5 \times 170,5 \mathrm{~cm}$.

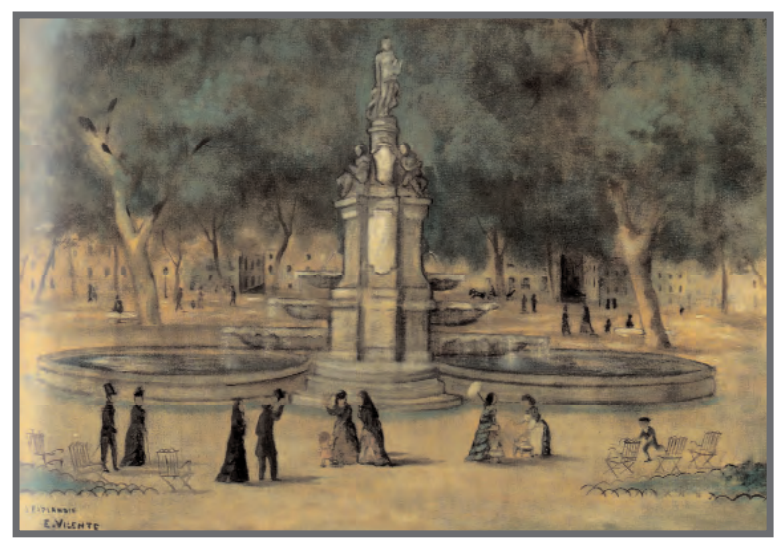

\section{TIPO DE IMAGEN.}

Retrato: NO

Cartel: NO

Mural: NO

Ilustración: NO

Otras Obras: SI

\section{CONTENIDO.}

Personajes: HOMBRES, MUJERES Y NIÑOS

Animales: NO

Gestos Expresivos: EMOCIONES POSITIVAS

Paisajes: SI

Escenas: URBANA

Función: REPRESENTATIVA DE MODELOS SOCIALES

\section{ASPECTOS TÉCNICOS.}

Color dominante: VARIEDAD CROMÁTICA SUPERIOR

Técnica: ÓLEO SOBRE LIENZO

Plano de la imagen: GENERAL 

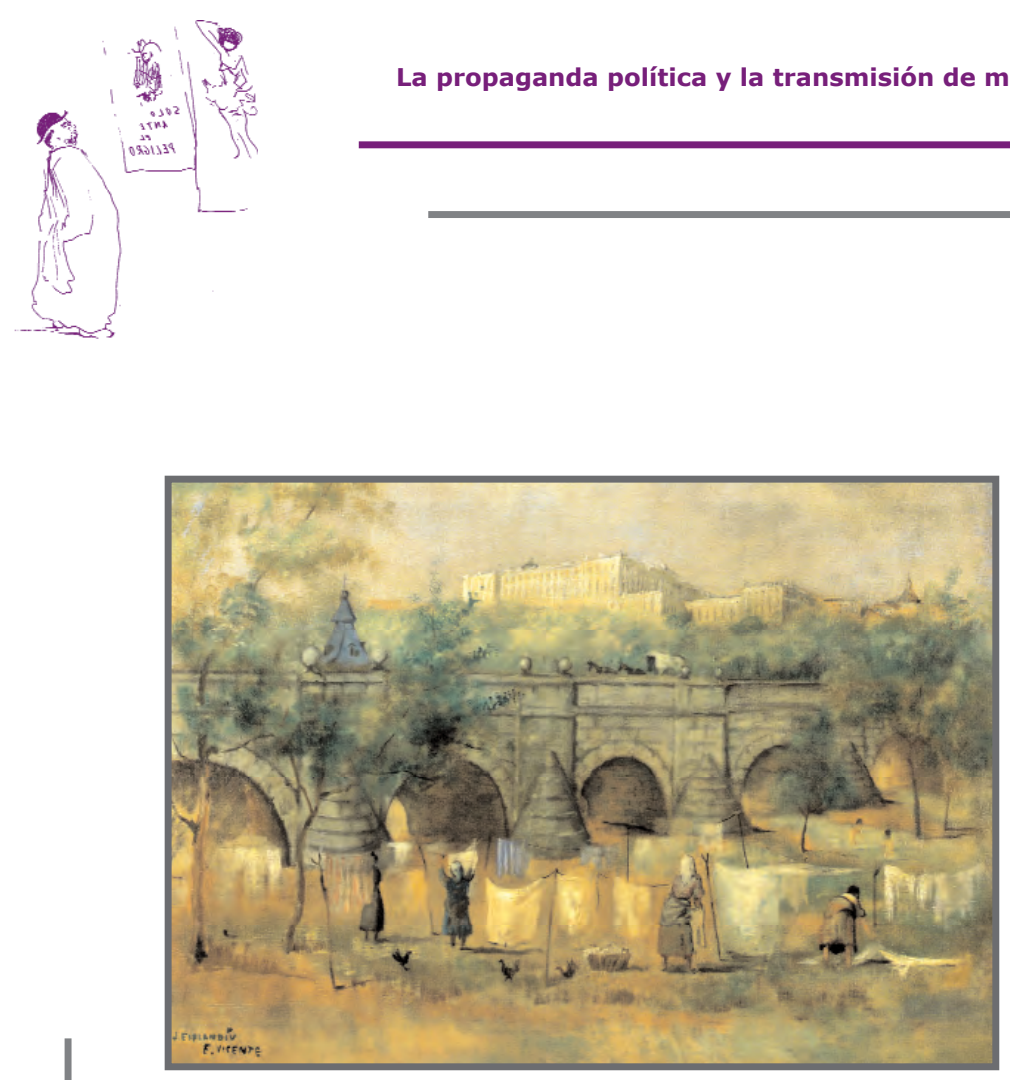

\section{VARIABLES EXTERNAS.}

Título: Puente de Segovia

Año: 1945 - 50

Tamaño: $79 \times 113 \mathrm{~cm}$.

\section{TIPO DE IMAGEN.}

Retrato: NO

Cartel: NO

Mural: NO

Ilustración: NO

Otras Obras: SI

\section{CONTENIDO.}

Personajes: MUJERES

Animales: CABALLOS Y GALLINAS

Gestos Expresivos: EMOCIONES POSITIVAS

Paisajes: SI

Escenas: PROFESIONAL

Función: REPRESENTATIVA DE MODELOS SOCIALES

\section{ASPECTOS TÉCNICOS.}

Color dominante: VARIEDAD CROMÁTICA SUPERIOR Técnica: ÓLEO SOBRE LIENZO

Plano de la imagen: GENERAL 


\section{VARIABLES EXTERNAS.}

Título: Tapia del Retiro

Año: 1945-50

Tamaño: 36,5 x $35 \mathrm{~cm}$.

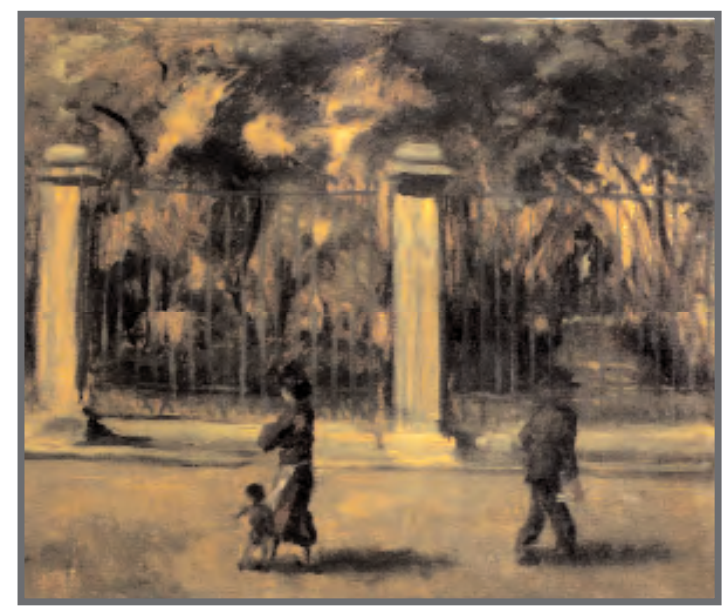

\section{TIPO DE IMAGEN.}

Retrato: NO

Cartel: NO

Mural: NO

Ilustración: NO

Otras Obras: SI

\section{CONTENIDO.}

Personajes: HOMBRE, MUJER Y NIÑO

Animales: NO

Gestos Expresivos: EMOCIONES POSITIVAS

Paisajes: NO

Escenas: URBANA

Función: REPRESENTATIVA DE MODELOS SOCIALES

\section{ASPECTOS TÉCNICOS.}

Color dominante: VARIEDAD CROMÁTICA SUPERIOR

Técnica: ÓLEO SOBRE LIENZO

Plano de la imagen: GENERAL 


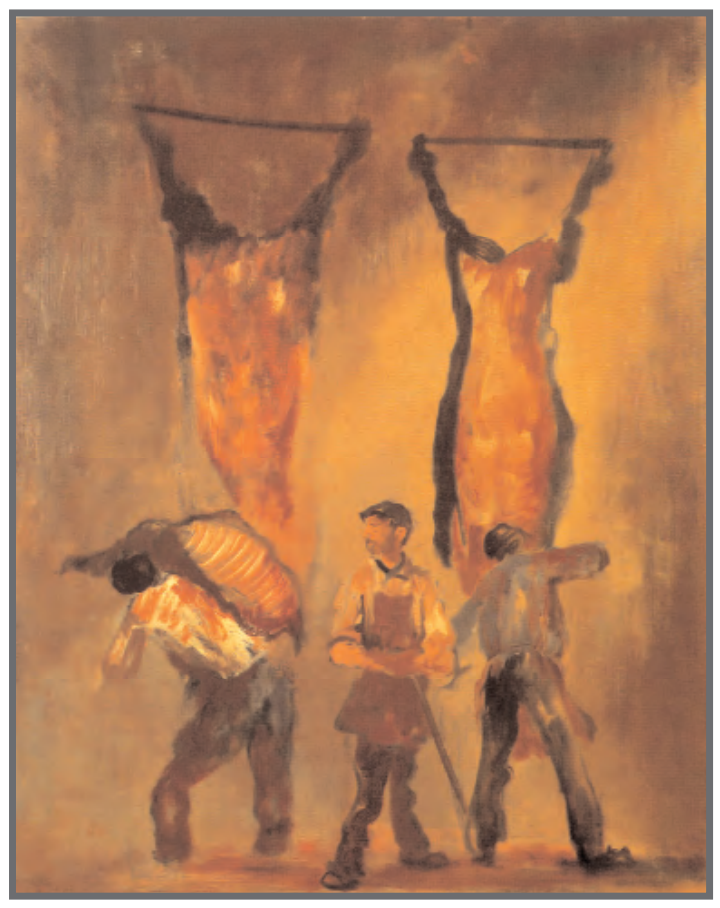

\section{VARIABLES EXTERNAS.}

Título: El matadero

Año: $1945-50$

Tamaño: $83 \times 67 \mathrm{~cm}$.

\section{TIPO DE IMAGEN.}

Retrato: NO

Cartel: NO

Mural: NO

Ilustración: NO

Otras Obras: SI

\section{CONTENIDO.}

Personajes: HOMBRES

Animales: NO

Gestos Expresivos: EMOCIONES POSITIVAS

Paisajes: NO

Escenas: PROFESIONAL

Función: REPRESENTATIVA DE MODELOS SOCIALES

\section{ASPECTOS TÉCNICOS.}

Color dominante: VARIEDAD CROMÁTICA SUPERIOR

Técnica: ÓLEO SOBRE LIENZO

Plano de la imagen: GENERAL 


\section{VARIABLES EXTERNAS.}

Título: Arganda

Año: 1948

Tamaño: $37 \times 87 \mathrm{~cm}$.

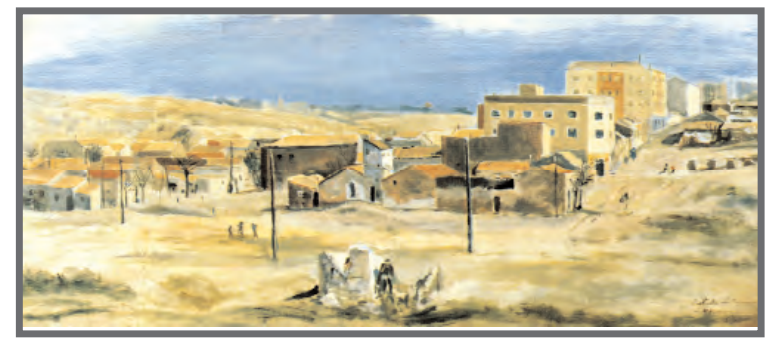

\section{TIPO DE IMAGEN.}

Retrato: NO

Cartel: NO

Mural: NO

Ilustración: NO

Otras Obras: SI

\section{CONTENIDO.}

Personajes: NO

Animales: NO

Gestos Expresivos: NO

Paisajes: SI

Escenas: RURAL

Función: REPRESENTATIVA DE MODELOS SOCIALES

\section{ASPECTOS TÉCNICOS.}

Color dominante: VARIEDAD CROMÁTICA SUPERIOR Técnica: ÓLEO SOBRE TÁBLEX

Plano de la imagen: GENERAL 


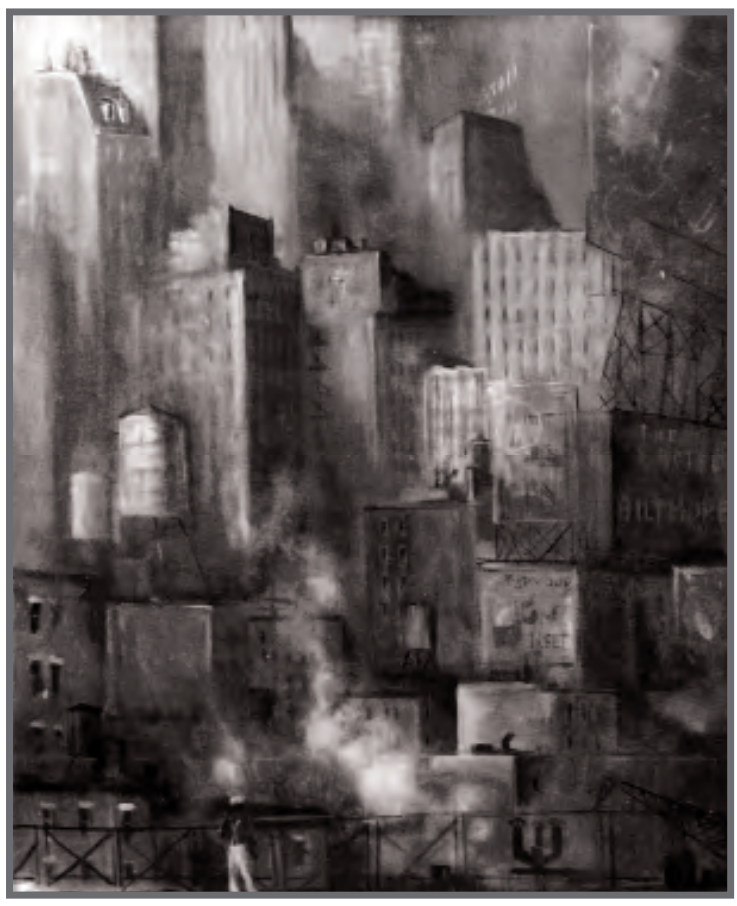

\section{VARIABLES EXTERNAS.}

Título: Nueva York

Año: 1948

Tamaño: DESCONOCIDO

TIPO DE IMAGEN.

Retrato: NO

Cartel: NO

Mural: NO

Ilustración: NO

Otras Obras: SI

\section{CONTENIDO.}

Personajes: NO

Animales: NO

Gestos Expresivos: NO

Paisajes: SI

Escenas: URBANA

Función: REPRESENTATIVA DE MODELOS SOCIALES

ASPECTOS TÉCNICOS.

Color dominante: VARIEDAD CROMÁTICA SUPERIOR

Técnica: ÓLEO SOBRE LIENZO

Plano de la imagen: GENERAL 


\section{VARIABLES EXTERNAS.}

Título: Nueva York

Año: 1948

Tamaño: DESCONOCIDO

\section{TIPO DE IMAGEN.}

Retrato: NO

Cartel: NO

Mural: NO

Ilustración: NO

Otras Obras: SI

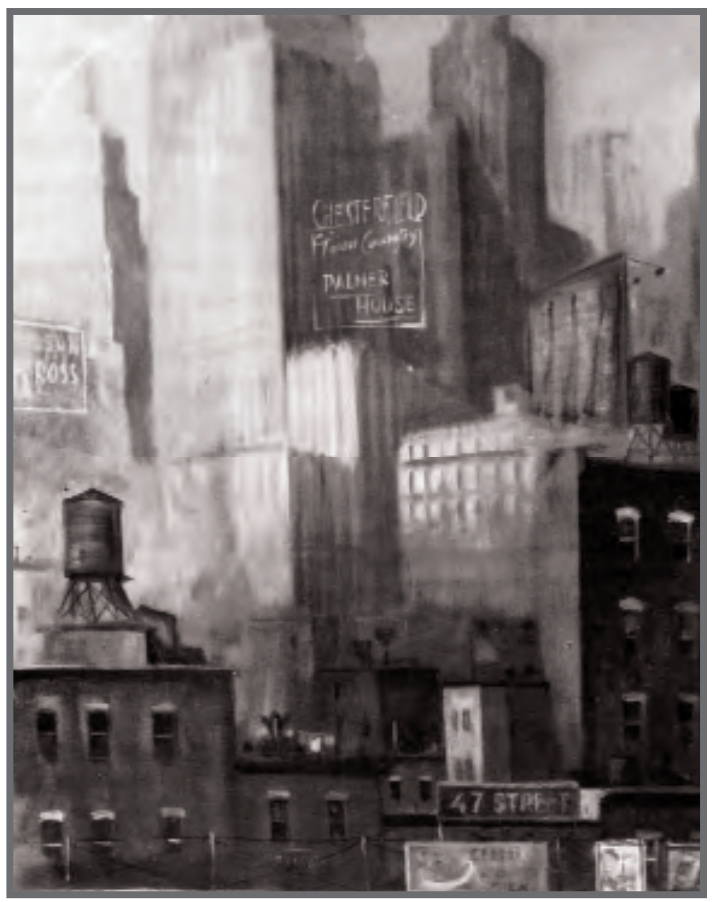

\section{CONTENIDO.}

Personajes: NO

Animales: NO

Gestos Expresivos: NO

Paisajes: SI

Escenas: URBANA

Función: REPRESENTATIVA DE MODELOS SOCIALES

\section{ASPECTOS TÉCNICOS.}

Color dominante: VARIEDAD CROMÁTICA SUPERIOR

Técnica: ÓLEO SOBRE LIENZO

Plano de la imagen: GENERAL 


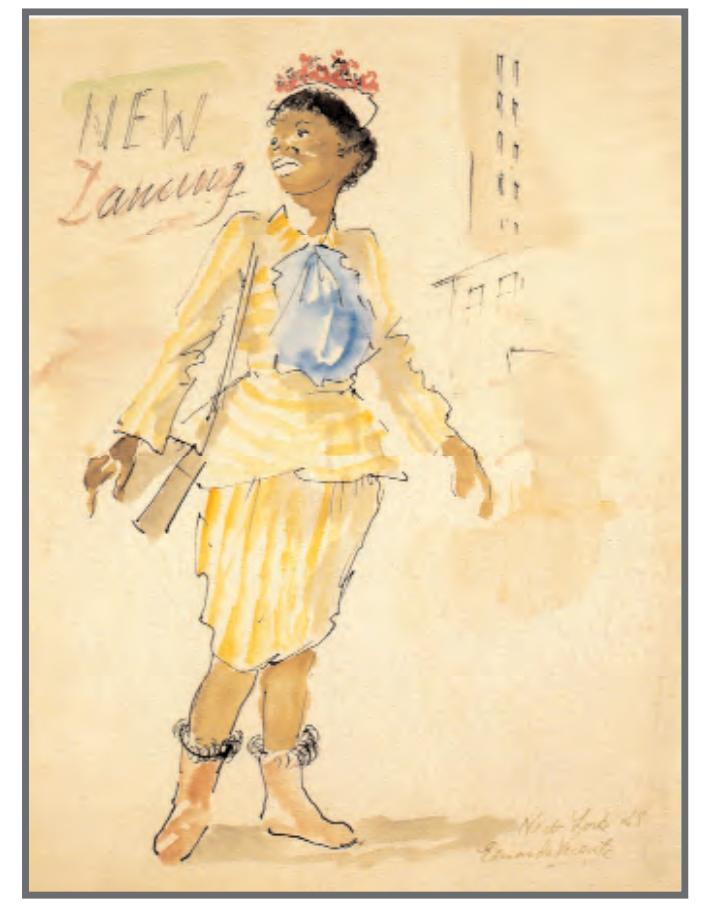

\section{VARIABLES EXTERNAS.}

Título: Mujer negra de Nueva York

Año: 1948

Tamaño: $31 \times 39 \mathrm{~cm}$.

\section{TIPO DE IMAGEN.}

Retrato: NO

Cartel: NO

Mural: NO

Ilustración: NO

Otras Obras: SI

\section{CONTENIDO.}

Personajes: MUJER

Animales: NO

Gestos Expresivos: EMOCIONES POSITIVAS

Paisajes: NO

Escenas: URBANA

Función: REPRESENTATIVA DE MODELOS SOCIALES

\section{ASPECTOS TÉCNICOS.}

Color dominante: VARIEDAD CROMÁTICA SUPERIOR

Técnica: ACUARELA Y TINTA SOBRE PAPEL

Plano de la imagen: GENERAL 


\section{VARIABLES EXTERNAS.}

Título: Harlem

Año: 1944

Tamaño: $35 \times 28 \mathrm{~cm}$.

\section{TIPO DE IMAGEN.}

Retrato: NO

Cartel: NO

Mural: NO

Ilustración: NO

Otras Obras: SI

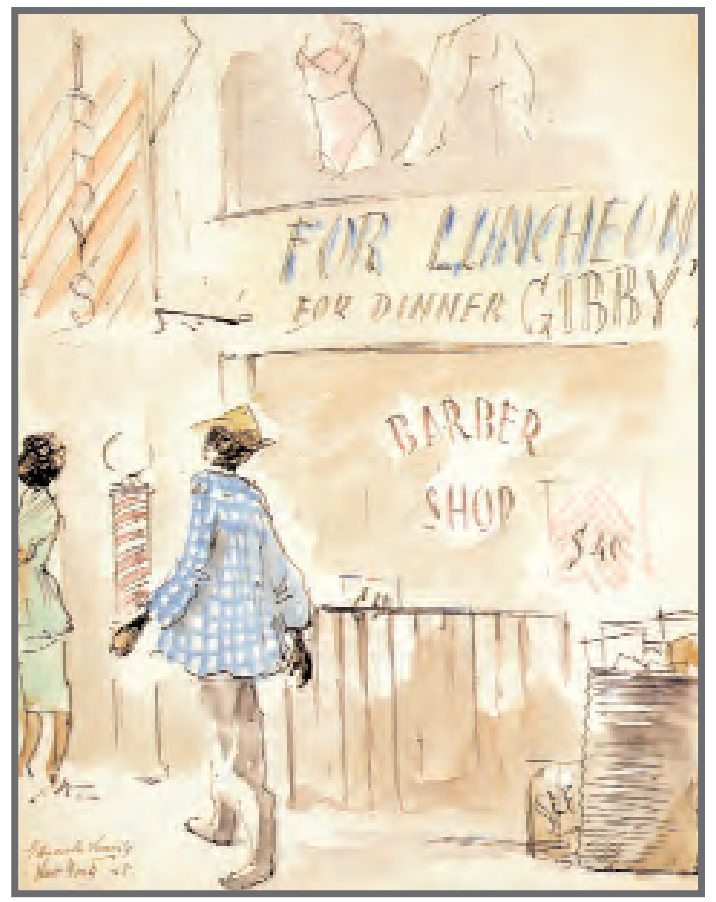

\section{CONTENIDO.}

Personajes: HOMBRE Y MUJER

Animales: NO

Gestos Expresivos: EMOCIONES POSITIVAS

Paisajes: SI

Escenas: CALLEJERA

Función: REPRESENTATIVA DE MODELOS SOCIALES

\section{ASPECTOS TÉCNICOS.}

Color dominante: VARIEDAD CROMÁTICA SUPERIOR Técnica: ACUARELA Y TINTA SOBRE PAPEL

Plano de la imagen: GENERAL 


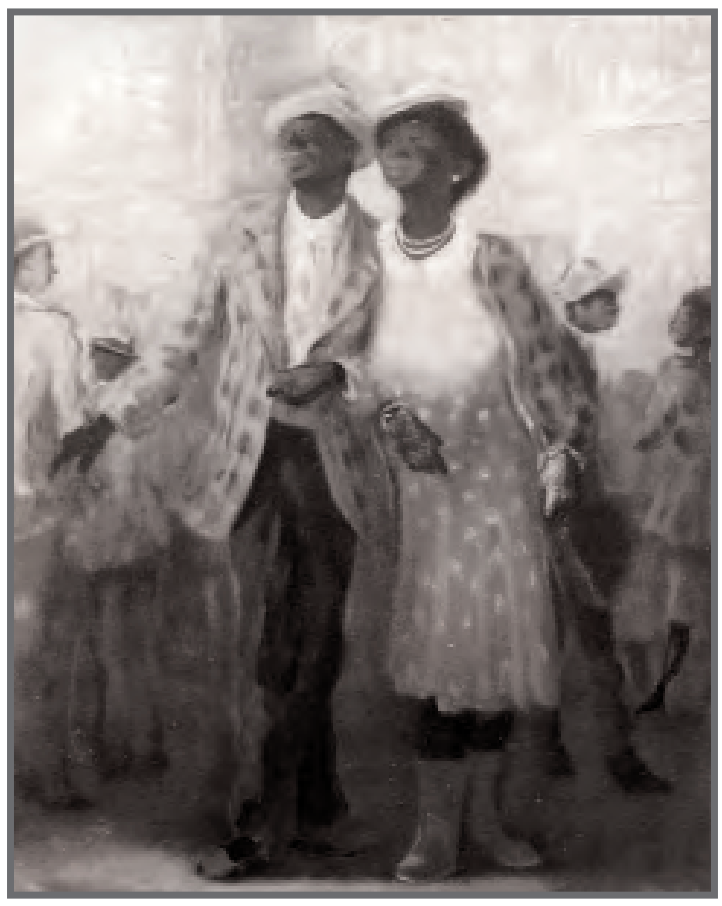

\section{VARIABLES EXTERNAS.}

Título: Negros de Harlem

Año: 1948

Tamaño: $100 \times 80 \mathrm{~cm}$.

\section{TIPO DE IMAGEN.}

Retrato: NO

Cartel: NO

Mural: NO

Ilustración: NO

Otras Obras: SI

\section{CONTENIDO.}

Personajes: HOMBRES Y MUJERES

Animales: NO

Gestos Expresivos: EMOCIONES POSITIVAS

Paisajes: NO

Escenas: URBANA

Función: REPRESENTATIVA DE MODELOS SOCIALES

\section{ASPECTOS TÉCNICOS.}

Color dominante: VARIEDAD CROMÁTICA SUPERIOR

Técnica: ÓLEO SOBRE LIENZO

Plano de la imagen: GENERAL 


\section{VARIABLES EXTERNAS.}

Título: Niña

Año: 1948

Tamaño: $100 \times 80 \mathrm{~cm}$.

\section{TIPO DE IMAGEN.}

Retrato: NO

Cartel: NO

Mural: NO

Ilustración: NO

Otras Obras: SI

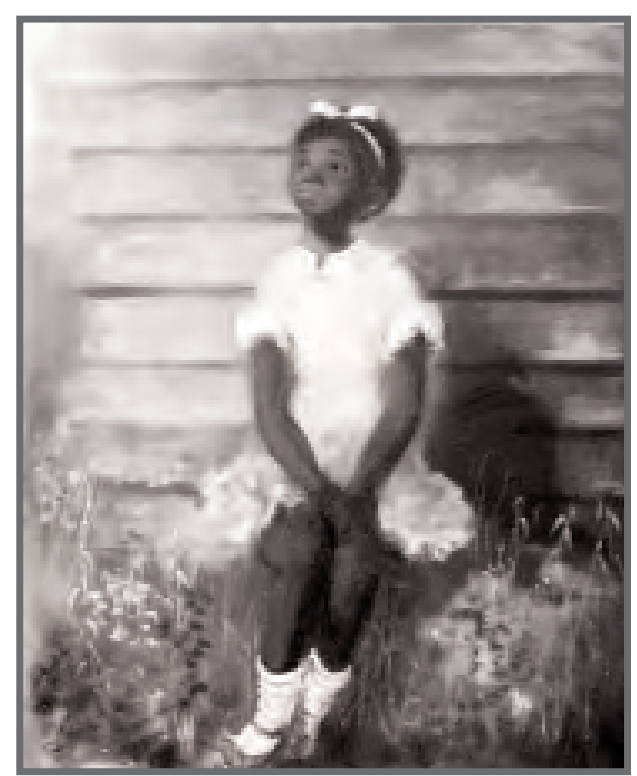

\section{CONTENIDO.}

Personajes: NIÑA

Animales: NO

Gestos Expresivos: EMOCIONES POSITIVAS

Paisajes: NO

Escenas: RURAL

Función: REPRESENTATIVA DE MODELOS SOCIALES

\section{ASPECTOS TÉCNICOS.}

Color dominante: VARIEDAD CROMÁTICA SUPERIOR

Técnica: ÓLEO SOBRE LIENZO

Plano de la imagen: GENERAL 


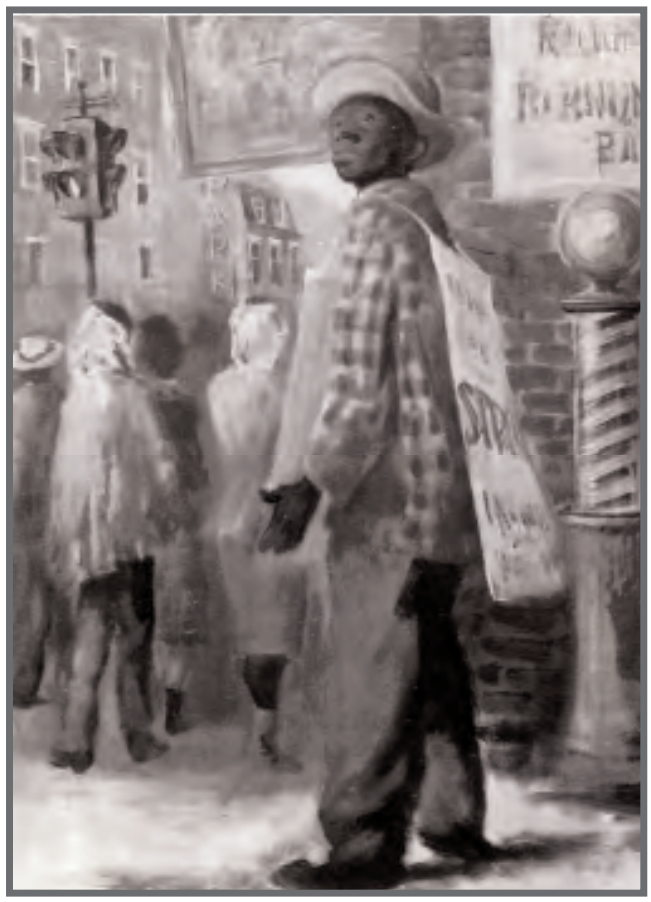

\section{VARIABLES EXTERNAS.}

Título: Hombre anuncio

Año: 1948

Tamaño: $100 \times 80 \mathrm{~cm}$.

\section{TIPO DE IMAGEN.}

Retrato: NO

Cartel: NO

Mural: NO

Ilustración: NO

Otras Obras: SI

\section{CONTENIDO.}

Personajes: HOMBRES Y MUJERES

Animales: NO

Gestos Expresivos: EMOCIONES POSITIVAS

Paisajes: SI

Escenas: PROFESIONAL

Función: REPRESENTATIVA DE MODELOS SOCIALES

\section{ASPECTOS TÉCNICOS.}

Color dominante: VARIEDAD CROMÁTICA SUPERIOR

Técnica: ÓLEO SOBRE LIENZO

Plano de la imagen: GENERAL 


\section{VARIABLES EXTERNAS.}

Título: Vista de las Vistillas

Año: 1949

Tamaño: 65 x $57 \mathrm{~cm}$.

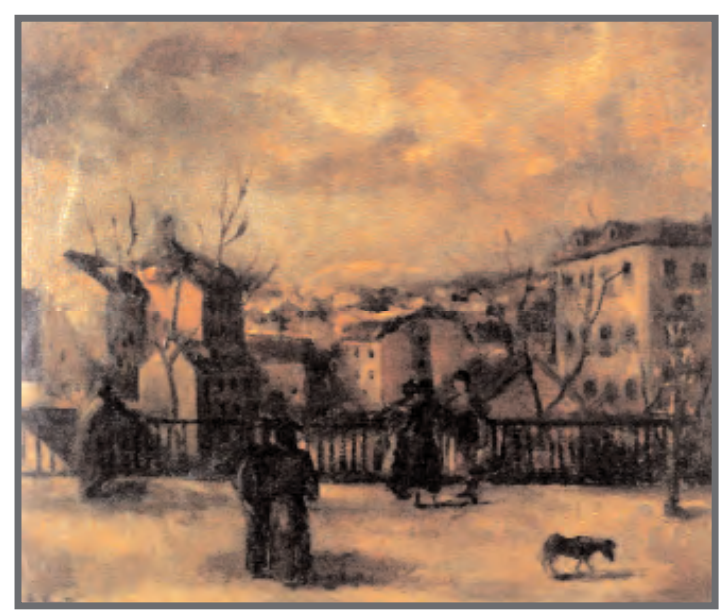

\section{TIPO DE IMAGEN.}

Retrato: NO

Cartel: NO

Mural: NO

Ilustración: NO

Otras Obras: SI

\section{CONTENIDO.}

Personajes: HOMBRES Y MUJERES

Animales: PERRO

Gestos Expresivos: EMOCIONES POSITIVAS

Paisajes: SI

Escenas: URBANA

Función: REPRESENTATIVA DE MODELOS SOCIALES

\section{ASPECTOS TÉCNICOS.}

Color dominante: VARIEDAD CROMÁTICA SUPERIOR Técnica: ÓLEO SOBRE LIENZO

Plano de la imagen: GENERAL 


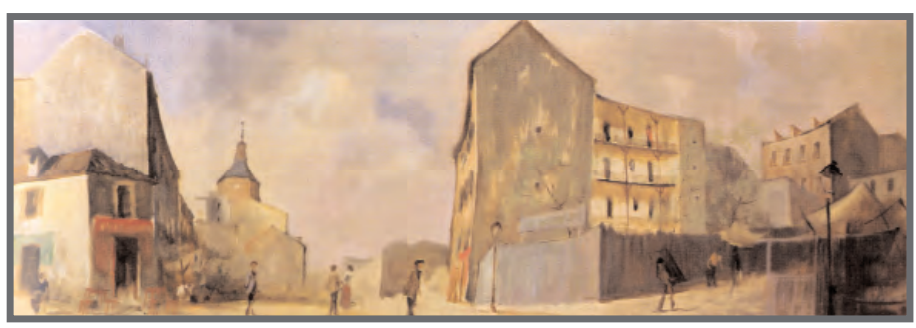

\section{VARIABLES EXTERNAS.}

Título: Barrio madrileño

Año: $1950-55$

Tamaño: $47 \times 147 \mathrm{~cm}$.

\section{TIPO DE IMAGEN.}

Retrato: NO

Cartel: NO

Mural: NO

Ilustración: NO

Otras Obras: SI

\section{CONTENIDO.}

Personajes: HOMBRES Y MUJERES

Animales: NO

Gestos Expresivos: NO

Paisajes: SI

Escenas: CALLEJERA

Función: REPRESENTATIVA DE MODELOS SOCIALES

\section{ASPECTOS TÉCNICOS.}

Color dominante: VARIEDAD CROMÁTICA SUPERIOR

Técnica: ÓLEO SOBRE LIENZO

Plano de la imagen: GENERAL 


\section{VARIABLES EXTERNAS.}

Título: Barrio de la Morería

Año: 1950

Tamaño: $98 \times 98 \mathrm{~cm}$.

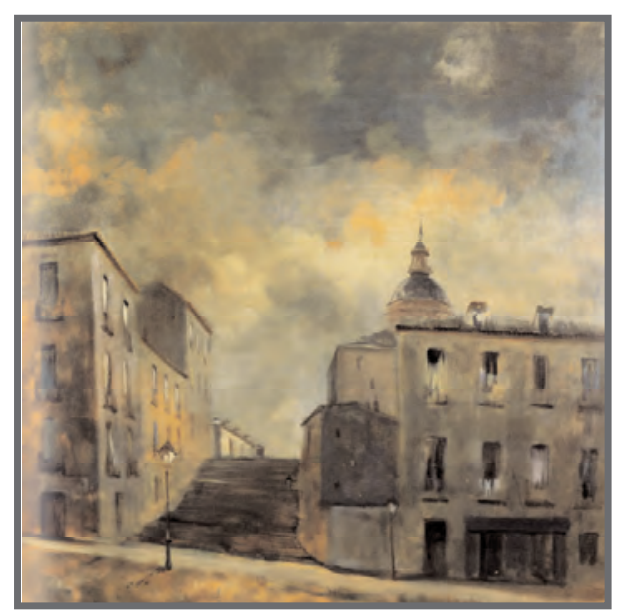

\section{TIPO DE IMAGEN.}

Retrato: NO

Cartel: NO

Mural: NO

Ilustración: NO

Otras Obras: SI

\section{CONTENIDO.}

Personajes: NO

Animales: NO

Gestos Expresivos: NO

Paisajes: SI

Escenas: CALLEJERA

Función: REPRESENTATIVA DE MODELOS SOCIALES

\section{ASPECTOS TÉCNICOS.}

Color dominante: VARIEDAD CROMÁTICA SUPERIOR Técnica: ÓLEO SOBRE LIENZO

Plano de la imagen: GENERAL 

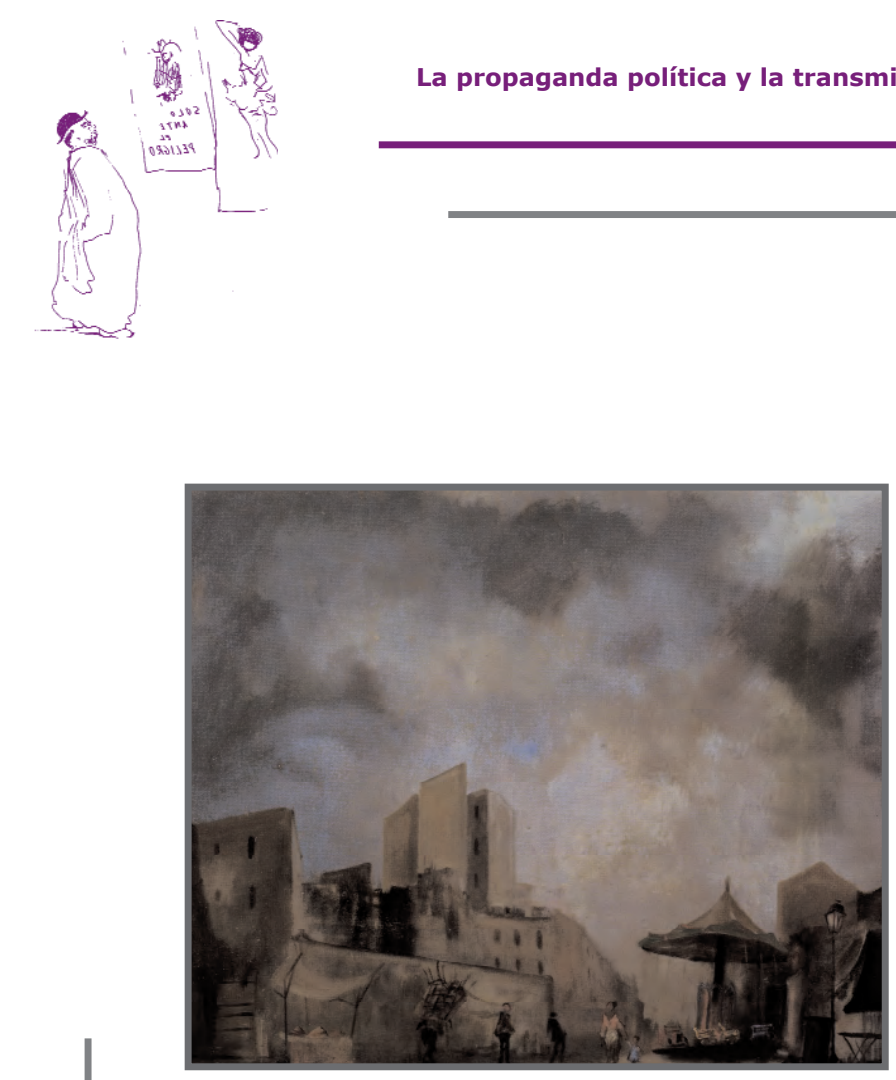

\section{VARIABLES EXTERNAS.}

Título: El tiovivo

Año: 1950 - 65

Tamaño: $74 \times 93 \mathrm{~cm}$.

\section{TIPO DE IMAGEN.}

Retrato: NO

Cartel: NO

Mural: NO

Ilustración: NO

Otras Obras: SI

\section{CONTENIDO.}

Personajes: HOMBRES, MUJER Y NIÑA

Animales: NO

Gestos Expresivos: NO

Paisajes: SI

Escenas: CALLEJERA

Función: REPRESENTATIVA DE MODELOS SOCIALES

\section{ASPECTOS TÉCNICOS.}

Color dominante: VARIEDAD CROMÁTICA SUPERIOR

Técnica: ÓLEO SOBRE LIENZO

Plano de la imagen: GENERAL 


\section{VARIABLES EXTERNAS.}

Título: Casino de la Reina. Ronda de Toledo

Año: 1950 - 55

Tamaño: 50 x 61,5 cm.

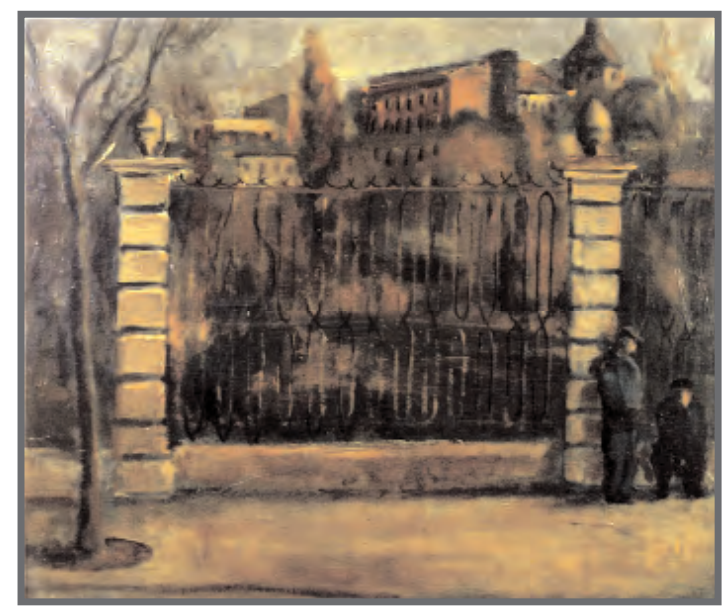

TIPO DE IMAGEN.

Retrato: NO

Cartel: NO

Mural: NO

Ilustración: NO

Otras Obras: SI

\section{CONTENIDO.}

Personajes: HOMBRES

Animales: NO

Gestos Expresivos: EMOCIONES POSITIVAS

Paisajes: SI

Escenas: URBANA

Función: REPRESENTATIVA DE MODELOS SOCIALES

\section{ASPECTOS TÉCNICOS.}

Color dominante: VARIEDAD CROMÁTICA SUPERIOR

Técnica: ÓLEO SOBRE LIENZO

Plano de la imagen: GENERAL 


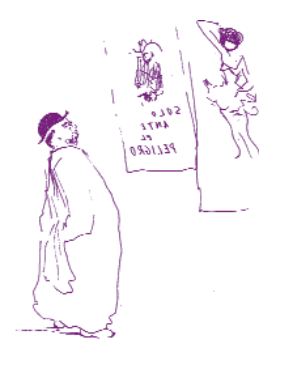

(1)

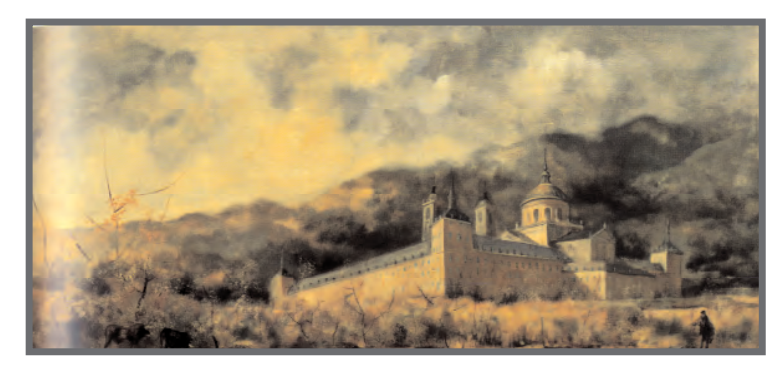

\section{VARIABLES EXTERNAS.}

Título: Vista de El Escorial

Año: 1950 - 55

Tamaño: $70 \times 148 \mathrm{~cm}$.

\section{TIPO DE IMAGEN.}

Retrato: NO

Cartel: NO

Mural: NO

Ilustración: NO

Otras Obras: SI

\section{CONTENIDO.}

Personajes: HOMBRE

Animales: NO

Gestos Expresivos: NO

Paisajes: SI

Escenas: ARQUITECTÓNICA

Función: REPRESENTATIVA DE MODELOS SOCIALES

\section{ASPECTOS TÉCNICOS.}

Color dominante: VARIEDAD CROMÁTICA SUPERIOR

Técnica: ÓLEO SOBRE LIENZO

Plano de la imagen: GENERAL 


\section{VARIABLES EXTERNAS.}

Título: Madrid a lo lejos

Año: 1950

Tamaño: 88 x 105 cm.

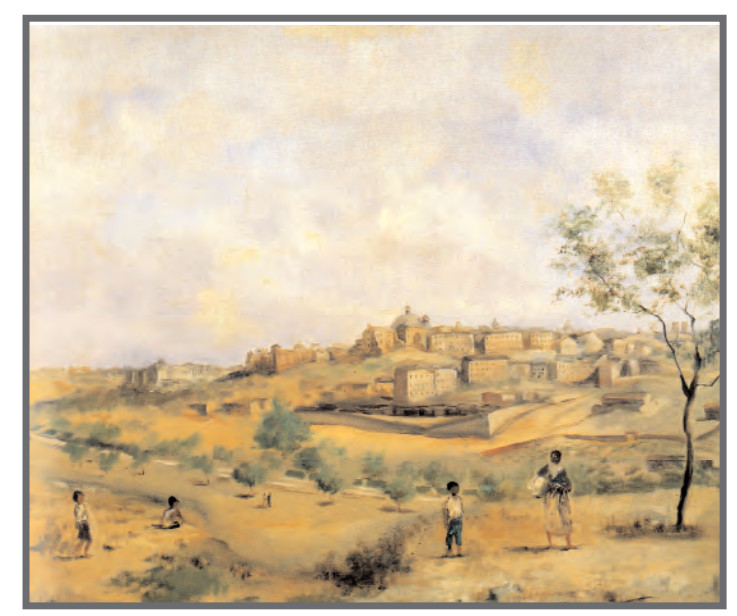

\section{TIPO DE IMAGEN.}

Retrato: NO

Cartel: NO

Mural: NO

Ilustración: NO

Otras Obras: SI

\section{CONTENIDO.}

Personajes: MUJER Y NIÑOS

Animales: NO

Gestos Expresivos: NO

Paisajes: SI

Escenas: RURAL

Función: REPRESENTATIVA DE MODELOS SOCIALES

\section{ASPECTOS TÉCNICOS.}

Color dominante: VARIEDAD CROMÁTICA SUPERIOR Técnica: ÓLEO SOBRE LIENZO

Plano de la imagen: GENERAL 

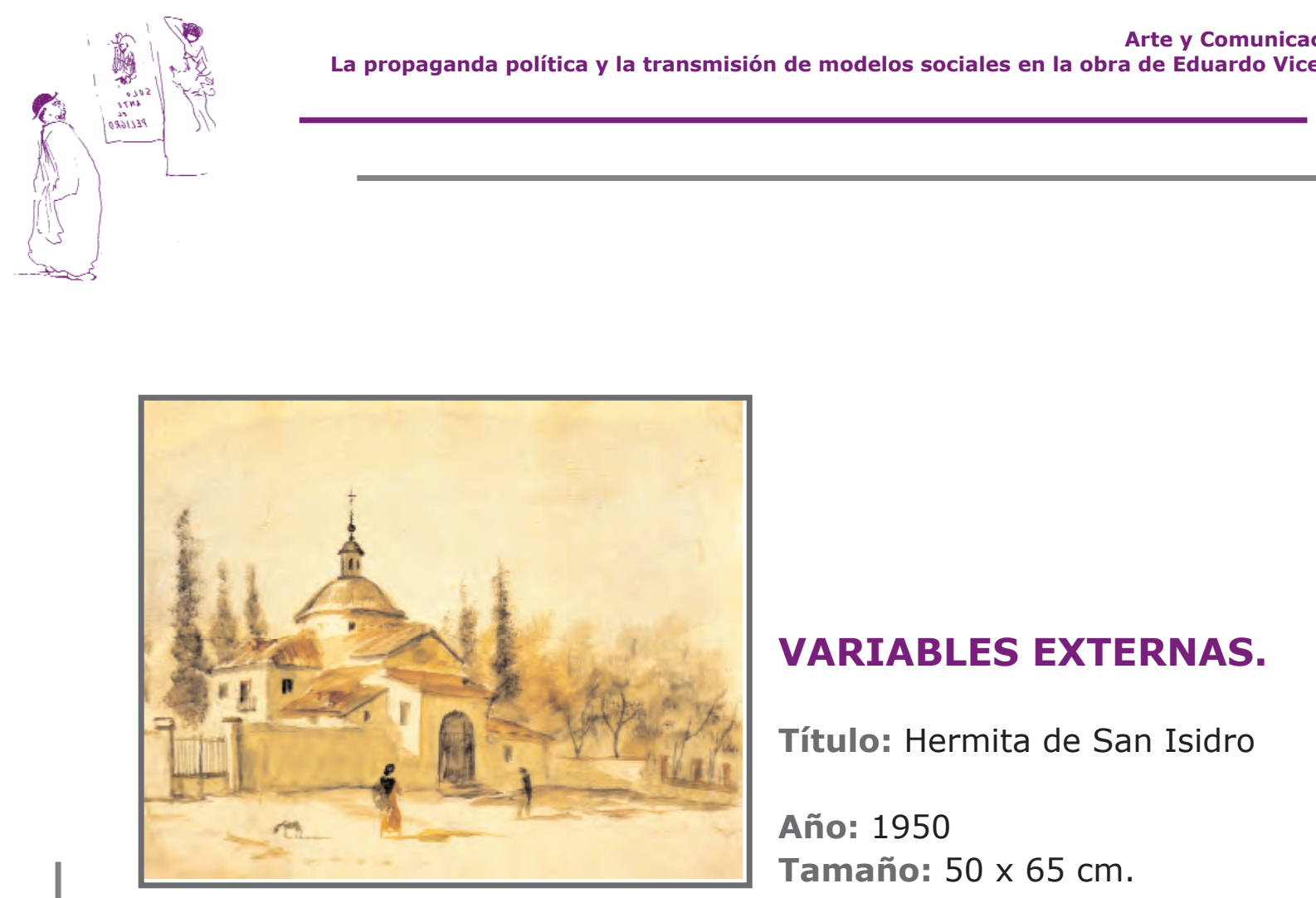

\section{VARIABLES EXTERNAS.}

Título: Hermita de San Isidro

Año: 1950

Tamaño: $50 \times 65 \mathrm{~cm}$.

\section{TIPO DE IMAGEN.}

Retrato: NO

Cartel: NO

Mural: NO

Ilustración: NO

Otras Obras: SI

\section{CONTENIDO.}

Personajes: HOMBRE Y MUJER

Animales: PERRO

Gestos Expresivos: NO

Paisajes: SI

Escenas: ARQUITECTÓNICA

Función: REPRESENTATIVA DE MODELOS SOCIALES

\section{ASPECTOS TÉCNICOS.}

Color dominante: VARIEDAD CROMÁTICA SUPERIOR

Técnica: ACUARELA SOBRE PAPEL

Plano de la imagen: GENERAL 


\section{VARIABLES EXTERNAS.}

Título: Madrid desde el Manzanares

Año: 1950

Tamaño: 48 x $56 \mathrm{~cm}$.

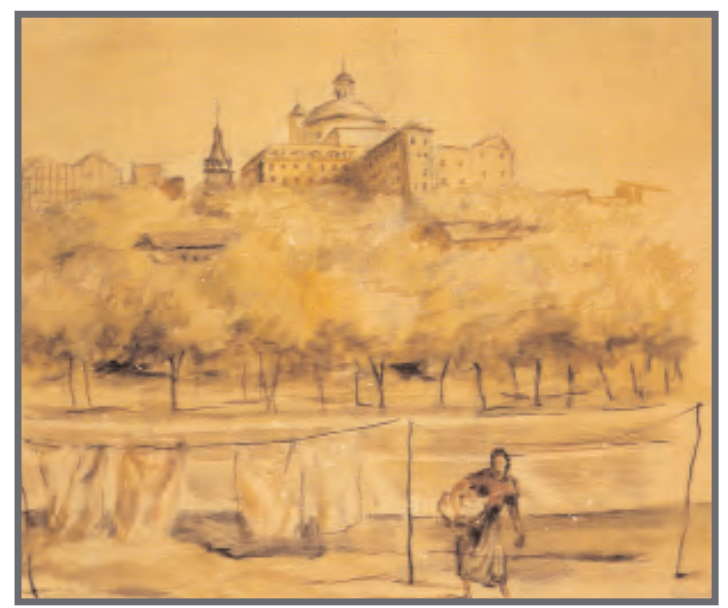

TIPO DE IMAGEN.

Retrato: NO

Cartel: NO

Mural: NO

Ilustración: NO

Otras Obras: SI

\section{CONTENIDO.}

Personajes: MUJER

Animales: NO

Gestos Expresivos: EMOCIONES POSITIVAS

Paisajes: SI

Escenas: PROFESIONAL

Función: REPRESENTATIVA DE MODELOS SOCIALES

\section{ASPECTOS TÉCNICOS.}

Color dominante: VARIEDAD CROMÁTICA SUPERIOR Técnica: ACUARELA SOBRE PAPEL

Plano de la imagen: GENERAL 

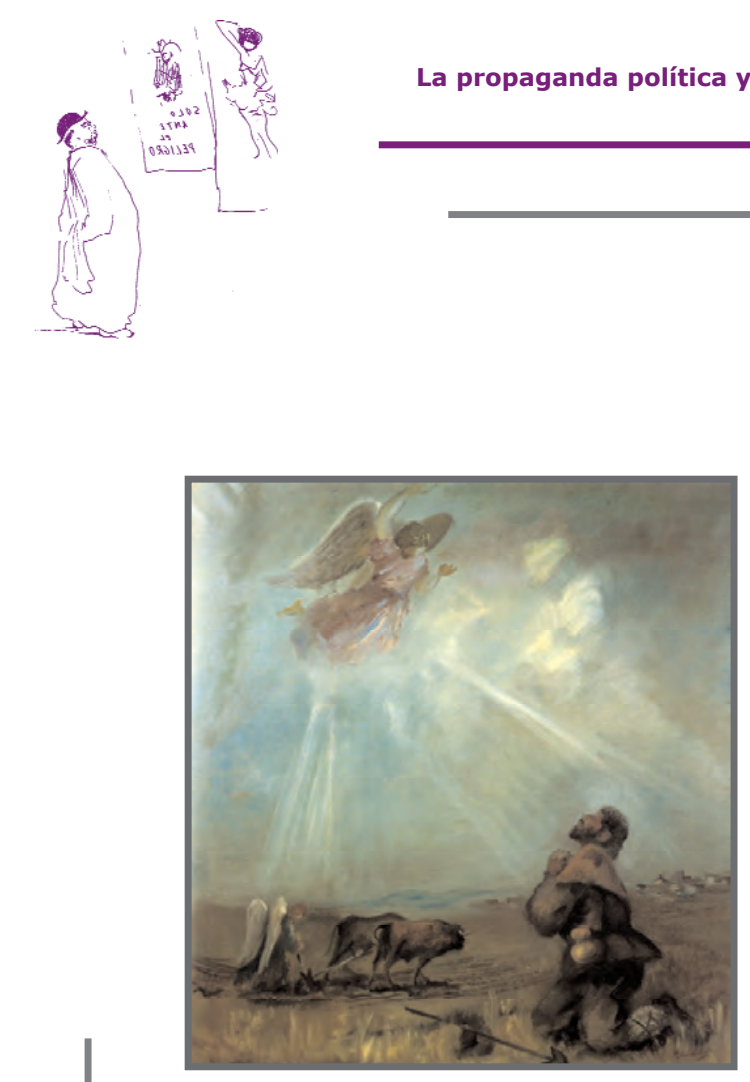

\section{VARIABLES EXTERNAS.}

Título: San Isidro Labrador

Año: 1950-60

Tamaño: 105 x $100 \mathrm{~cm}$.

\section{TIPO DE IMAGEN.}

Retrato: NO

Cartel: NO

Mural: NO

Ilustración: NO

Otras Obras: SI

\section{CONTENIDO.}

Personajes: HOMBRE

Animales: BUEYES

Gestos Expresivos: EMOCIONES POSITIVAS

Paisajes: SI

Escenas: RELIGIOSA

Función: PROPAGANDÍSTICA (IDEOLOGÍA RELIGIOSA)

\section{ASPECTOS TÉCNICOS.}

Color dominante: VARIEDAD CROMÁTICA SUPERIOR

Técnica: ÓLEO SOBRE LIENZO

Plano de la imagen: GENERAL 


\section{VARIABLES EXTERNAS.}

Título: San Isidro Labrador

Año: $1950-60$

Tamaño: 105 x $100 \mathrm{~cm}$.

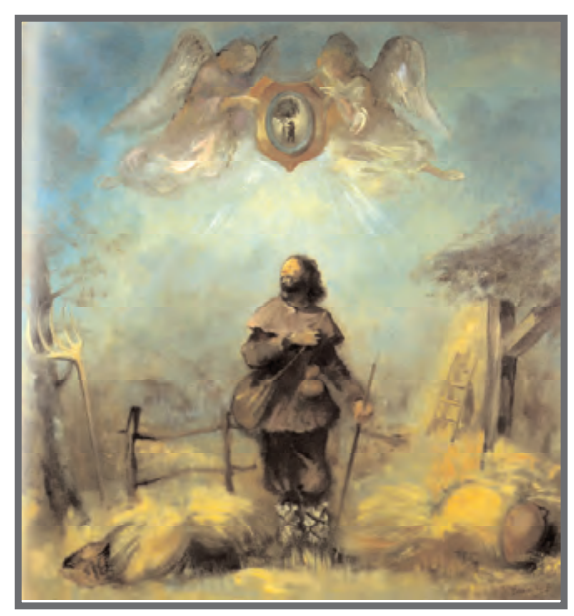

\section{TIPO DE IMAGEN.}

Retrato: NO

Cartel: NO

Mural: NO

Ilustración: NO

Otras Obras: SI

\section{CONTENIDO.}

Personajes: HOMBRE

Animales: NO

Gestos Expresivos: EMOCIONES POSITIVAS

Paisajes: NO

Escenas: RELIGIOSA

Función: PROPAGANDÍSTICA (IDEOLOGÍA RELIGIOSA)

\section{ASPECTOS TÉCNICOS.}

Color dominante: VARIEDAD CROMÁTICA SUPERIOR

Técnica: ÓLEO SOBRE LIENZO

Plano de la imagen: GENERAL 

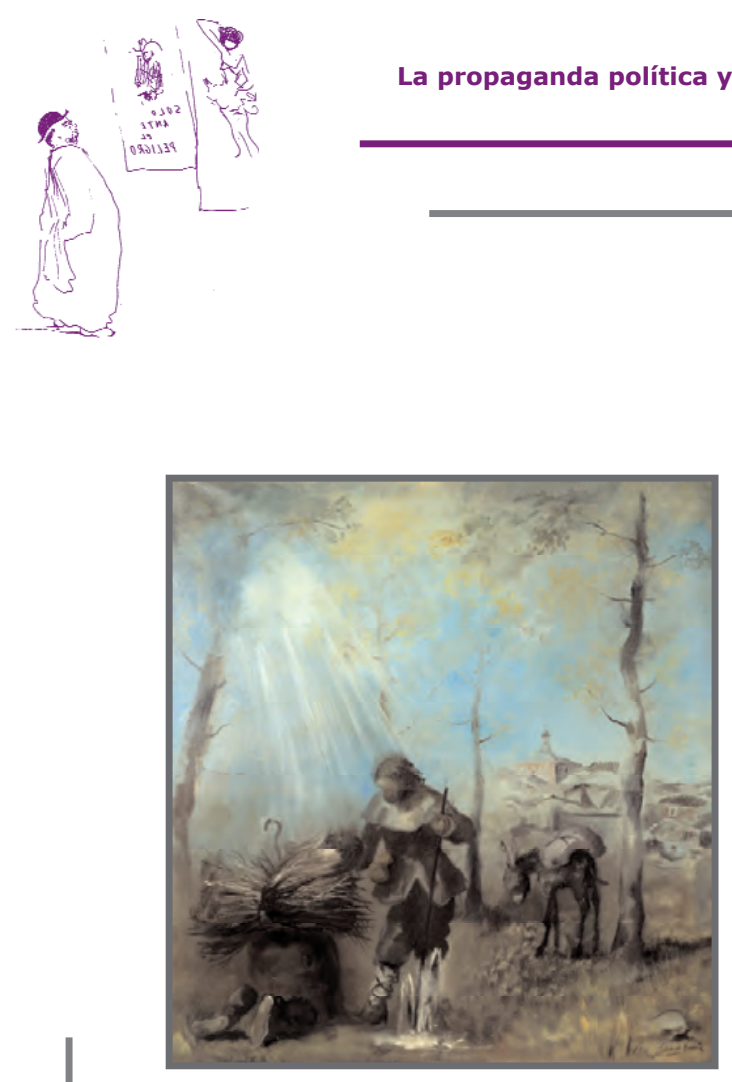

\section{VARIABLES EXTERNAS.}

Título: San Isidro Labrador

Año: 1950-60

Tamaño: 105 x $100 \mathrm{~cm}$.

\section{TIPO DE IMAGEN.}

Retrato: NO

Cartel: NO

Mural: NO

Ilustración: NO

Otras Obras: SI

\section{CONTENIDO.}

Personajes: HOMBRES

Animales: BURRO

Gestos Expresivos: EMOCIONES POSITIVAS

Paisajes: SI

Escenas: RELIGIOSA

Función: PROPAGANDÍSTICA (IDEOLOGÍA RELIGIOSA)

\section{ASPECTOS TÉCNICOS.}

Color dominante: VARIEDAD CROMÁTICA SUPERIOR Técnica: ÓLEO SOBRE LIENZO

Plano de la imagen: GENERAL 


\section{VARIABLES EXTERNAS.}

Título: Paisaje al anochecer

Año: 1950

Tamaño: $67 \times 91 \mathrm{~cm}$.

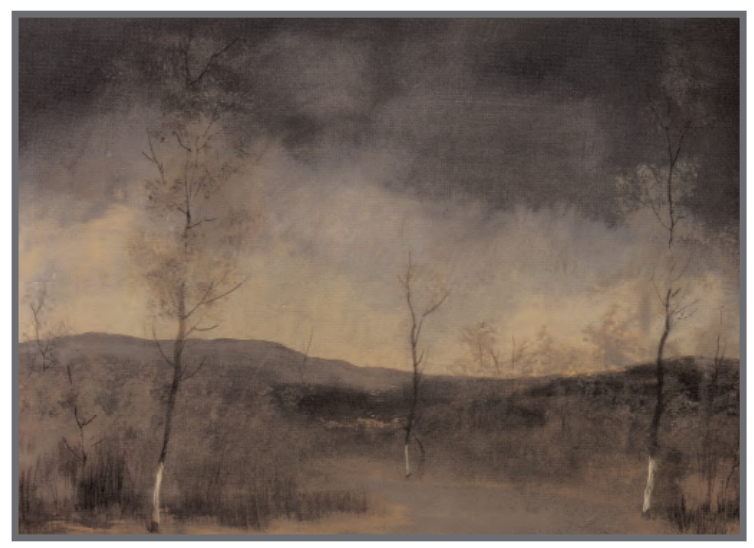

\section{TIPO DE IMAGEN.}

Retrato: NO

Cartel: NO

Mural: NO

Ilustración: NO

Otras Obras: SI

\section{CONTENIDO.}

Personajes: NO

Animales: NO

Gestos Expresivos: NO

Paisajes: SI

Escenas: RURAL

Función: REPRESENTATIVA DE MODELOS SOCIALES

\section{ASPECTOS TÉCNICOS.}

Color dominante: VARIEDAD CROMÁTICA SUPERIOR Técnica: TEMPLE

Plano de la imagen: GENERAL 

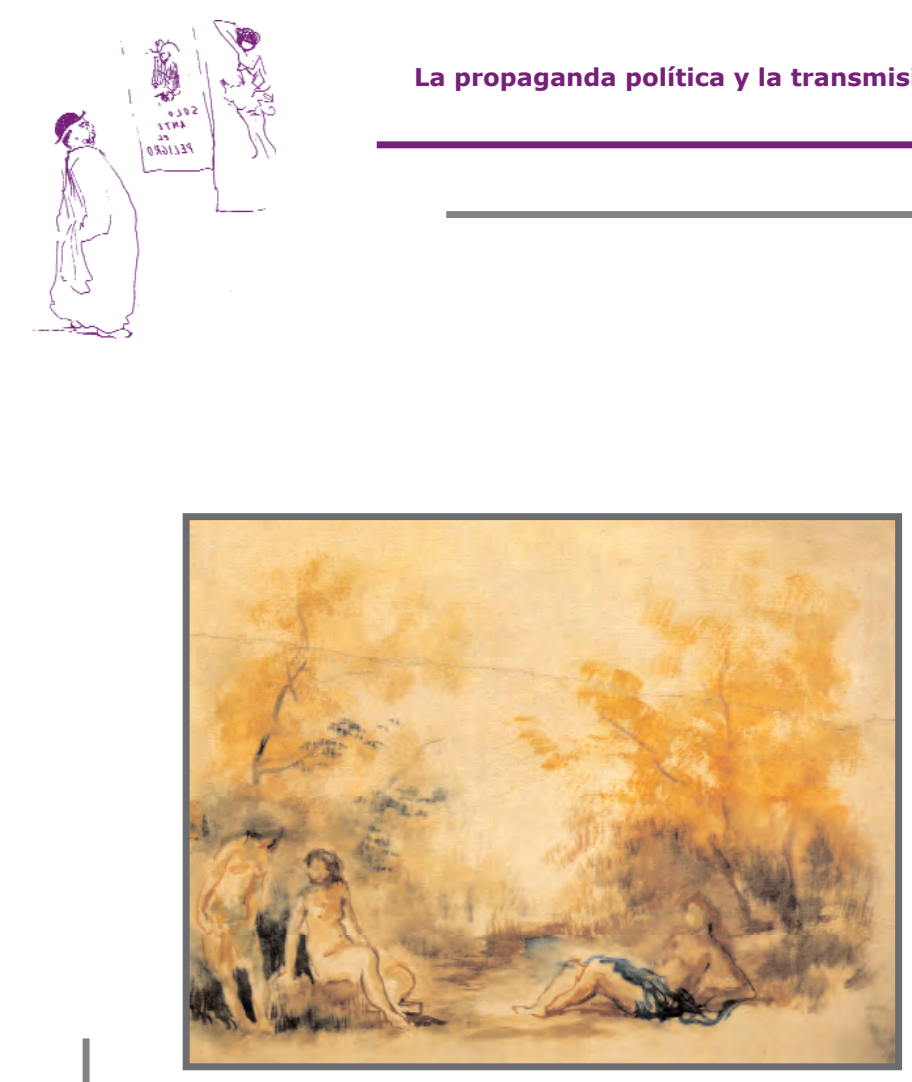

\section{VARIABLES EXTERNAS.}

Título: Tema mitológico

Año: 1950

Tamaño: $60 \times 80 \mathrm{~cm}$.

\section{TIPO DE IMAGEN.}

Retrato: NO

Cartel: NO

Mural: NO

Ilustración: NO

Otras Obras: SI

\section{CONTENIDO.}

Personajes: MUJERES

Animales: NO

Gestos Expresivos: EMOCIONES POSITIVAS

Paisajes: SI

Escenas: MITOLÓGICA

Función: PROPAGANDÍSTICA (IDEOLOGÍA RELIGIOSA)

\section{ASPECTOS TÉCNICOS.}

Color dominante: VARIEDAD CROMÁTICA SUPERIOR Técnica: ACUARELA SOBRE PAPEL Plano de la imagen: GENERAL 


\section{VARIABLES EXTERNAS.}

Título: Plaza de la Cebada

Año: 1950

Tamaño: $110 \times 86 \mathrm{~cm}$.

\section{TIPO DE IMAGEN.}

Retrato: NO

Cartel: NO

Mural: NO

Ilustración: NO

Otras Obras: SI

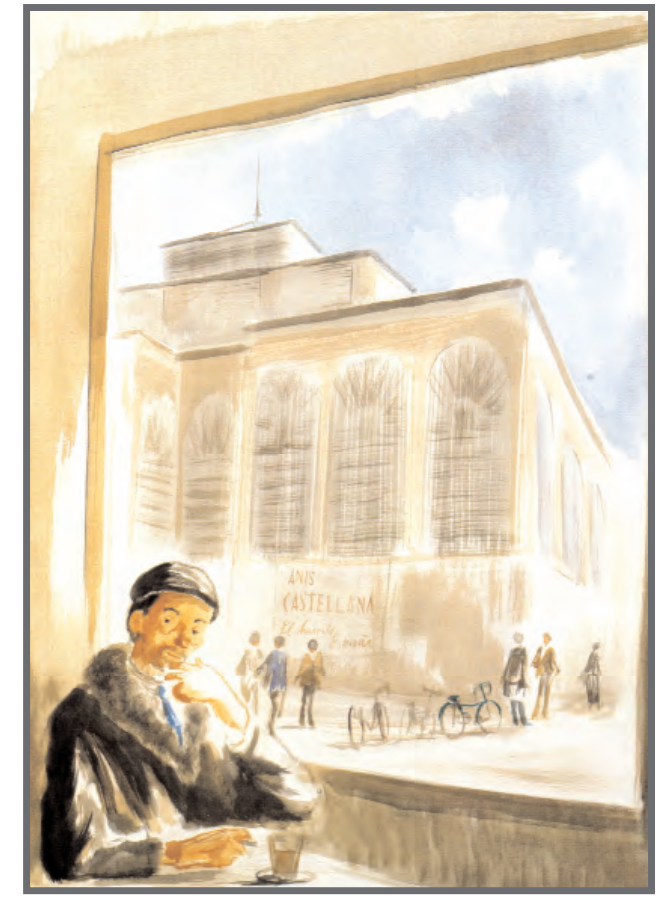

\section{CONTENIDO.}

Personajes: HOMBRES Y MUJERES

Animales: NO

Gestos Expresivos: EMOCIONES POSITIVAS

Paisajes: SI

Escenas: INTERIOR

Función: REPRESENTATIVA DE MODELOS SOCIALES

\section{ASPECTOS TÉCNICOS.}

Color dominante: VARIEDAD CROMÁTICA SUPERIOR Técnica: ACUARELA SOBRE PAPEL

Plano de la imagen: MEDIO CORTO 


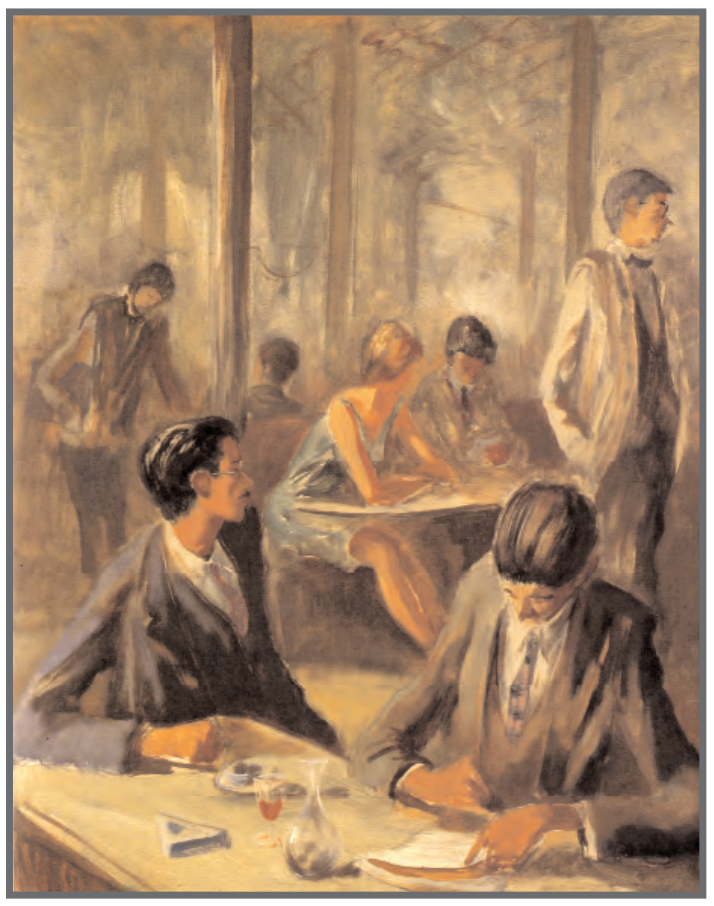

\section{VARIABLES EXTERNAS.}

Título: El Café Gijón

Año: 1950

Tamaño: $100 \times 81 \mathrm{~cm}$.

\section{TIPO DE IMAGEN.}

Retrato: NO

Cartel: NO

Mural: NO

Ilustración: NO

Otras Obras: SI

\section{CONTENIDO.}

Personajes: HOMBRES Y MUJER

Animales: NO

Gestos Expresivos: EMOCIONES POSITIVAS

Paisajes: NO

Escenas: INTERIOR

Función: REPRESENTATIVA DE MODELOS SOCIALES

\section{ASPECTOS TÉCNICOS.}

Color dominante: VARIEDAD CROMÁTICA SUPERIOR

Técnica: ÓLEO SOBRE LIENZO

Plano de la imagen: GENERAL 


\section{VARIABLES EXTERNAS.}

Título: La florista

Año: $1950-55$

Tamaño: $100 \times 80 \mathrm{~cm}$.

TIPO DE IMAGEN.

Retrato: NO

Cartel: NO

Mural: NO

Ilustración: NO

Otras Obras: SI

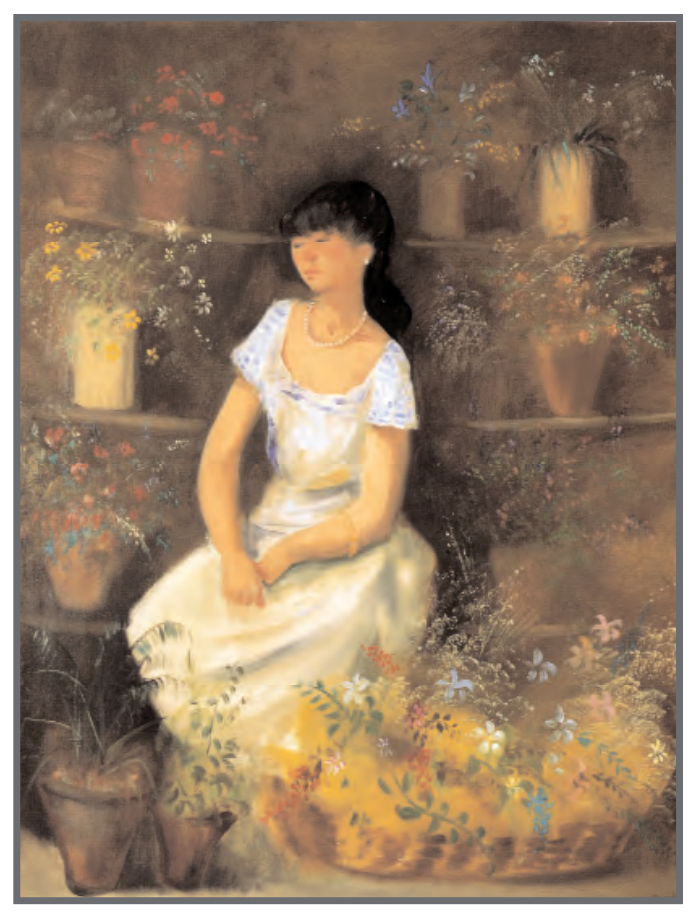

\section{CONTENIDO.}

Personajes: MUJER

Animales: NO

Gestos Expresivos: EMOCIONES POSITIVAS

Paisajes: NO

Escenas: PROFESIONAL

Función: REPRESENTATIVA DE MODELOS SOCIALES

\section{ASPECTOS TÉCNICOS.}

Color dominante: VARIEDAD CROMÁTICA SUPERIOR

Técnica: ÓLEO SOBRE LIENZO

Plano de la imagen: GENERAL 


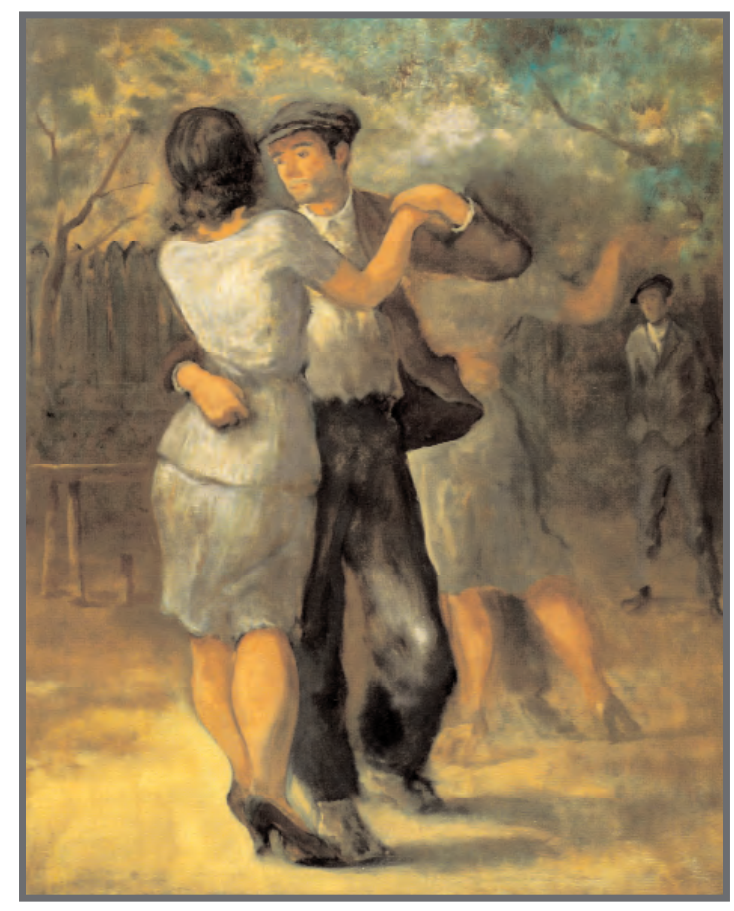

\section{VARIABLES EXTERNAS.}

Título: El baile

Año: $1950-55$

Tamaño: $100 \times 81 \mathrm{~cm}$.

\section{TIPO DE IMAGEN.}

Retrato: NO

Cartel: NO

Mural: NO

Ilustración: NO

Otras Obras: SI

\section{CONTENIDO.}

Personajes: HOMBRES Y MUJERES

Animales: NO

Gestos Expresivos: EMOCIONES POSITIVAS

Paisajes: NO

Escenas: FESTIVA

Función: REPRESENTATIVA DE MODELOS SOCIALES

\section{ASPECTOS TÉCNICOS.}

Color dominante: VARIEDAD CROMÁTICA SUPERIOR

Técnica: ÓLEO SOBRE LIENZO

Plano de la imagen: GENERAL 


\section{VARIABLES EXTERNAS.}

Título: Mujer

Año: 1950

Tamaño: $30 \times 23 \mathrm{~cm}$.

TIPO DE IMAGEN.

Retrato: NO

Cartel: NO

Mural: NO

Ilustración: NO

Otras Obras: SI

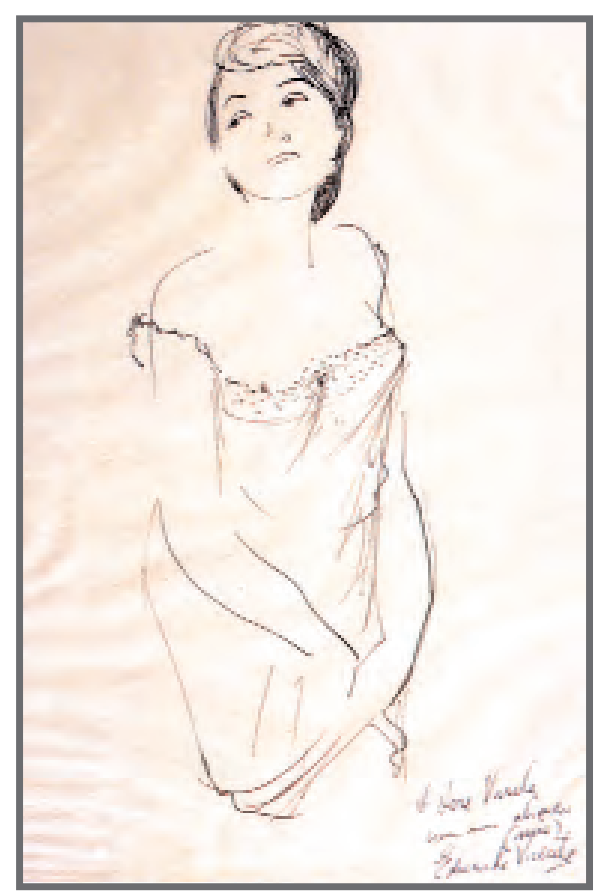

\section{CONTENIDO.}

Personajes: MUJER

Animales: NO

Gestos Expresivos: EMOCIONES NEGATIVAS

Paisajes: NO

Escenas: FAMILIARES O AMIGOS

Función: REPRESENTATIVA DE MODELOS SOCIALES

\section{ASPECTOS TÉCNICOS.}

Color dominante: 1 TINTA

Técnica: CARBONCILLO SOBRE PAPEL

Plano de la imagen: AMERICANO 


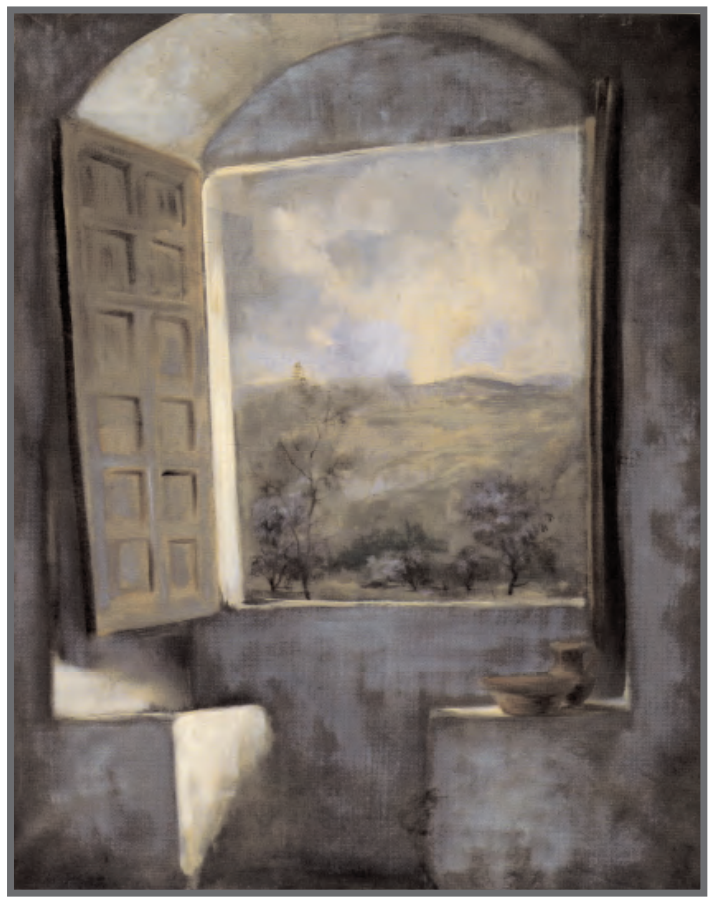

\section{VARIABLES EXTERNAS.}

Título: La ventana

Año: 1950

Tamaño: $91 \times 73 \mathrm{~cm}$.

\section{TIPO DE IMAGEN.}

Retrato: NO

Cartel: NO

Mural: NO

Ilustración: NO

Otras Obras: SI

\section{CONTENIDO.}

Personajes: NO

Animales: NO

Gestos Expresivos: NO

Paisajes: SI

Escenas: INTERIOR

Función: REPRESENTATIVA DE MODELOS SOCIALES

\section{ASPECTOS TÉCNICOS.}

Color dominante: VARIEDAD CROMÁTICA SUPERIOR

Técnica: ÓLEO SOBRE LIENZO

Plano de la imagen: GENERAL 


\section{VARIABLES EXTERNAS.}

Título: París, en el café

Año: $1950-55$

Tamaño: $100 \times 80 \mathrm{~cm}$.

TIPO DE IMAGEN.

Retrato: NO

Cartel: NO

Mural: NO

Ilustración: NO

Otras Obras: SI

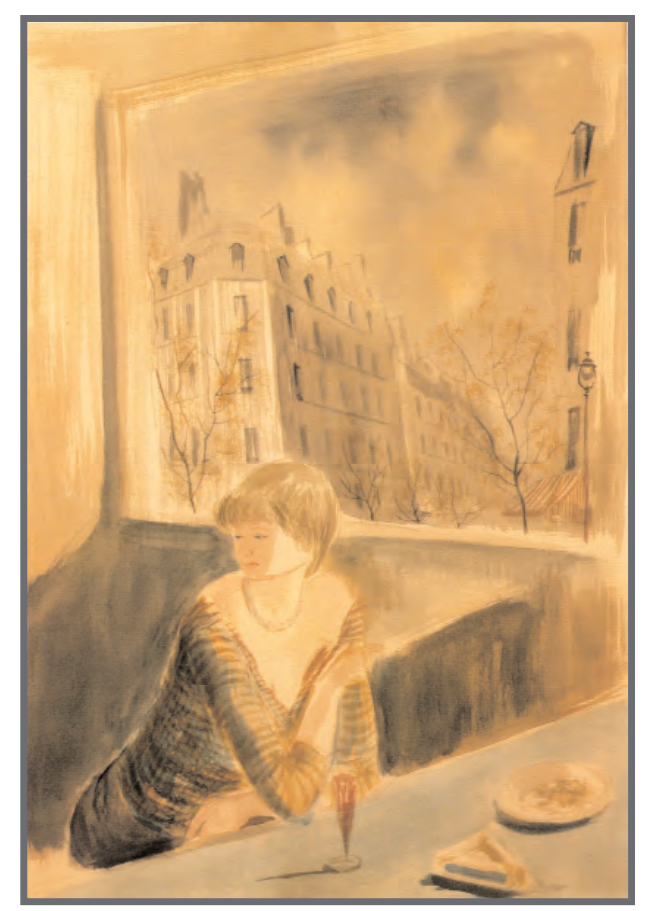

\section{CONTENIDO.}

Personajes: MUJER

Animales: NO

Gestos Expresivos: EMOCIONES POSITIVAS

Paisajes: SI

Escenas: INTERIOR

Función: REPRESENTATIVA DE MODELOS SOCIALES

\section{ASPECTOS TÉCNICOS.}

Color dominante: VARIEDAD CROMÁTICA SUPERIOR Técnica: ACUARELA SOBRE PAPEL

Plano de la imagen: AMERICANO 


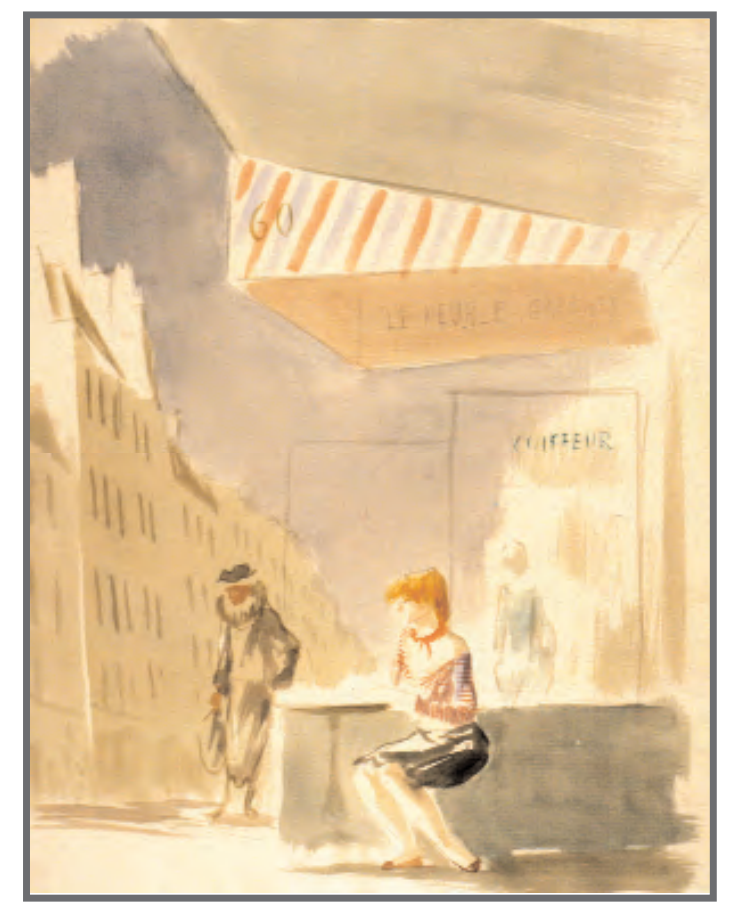

\section{VARIABLES EXTERNAS.}

Título: Escena de París

Año: 1950 - 55

Tamaño: $63 \times 50 \mathrm{~cm}$.

\section{TIPO DE IMAGEN.}

Retrato: NO

Cartel: NO

Mural: NO

Ilustración: NO

Otras Obras: SI

\section{CONTENIDO.}

Personajes: MUJERES

Animales: NO

Gestos Expresivos: EMOCIONES POSITIVAS

Paisajes: SI

Escenas: CALLEJERA

Función: REPRESENTATIVA DE MODELOS SOCIALES

\section{ASPECTOS TÉCNICOS.}

Color dominante: VARIEDAD CROMÁTICA SUPERIOR

Técnica: ACUARELA SOBRE PAPEL

Plano de la imagen: GENERAL 


\section{VARIABLES EXTERNAS.}

Título: Café de París

Año: $1950-55$

Tamaño: 65 x $52 \mathrm{~cm}$.

\section{TIPO DE IMAGEN.}

Retrato: NO

Cartel: NO

Mural: NO

Ilustración: NO

Otras Obras: SI

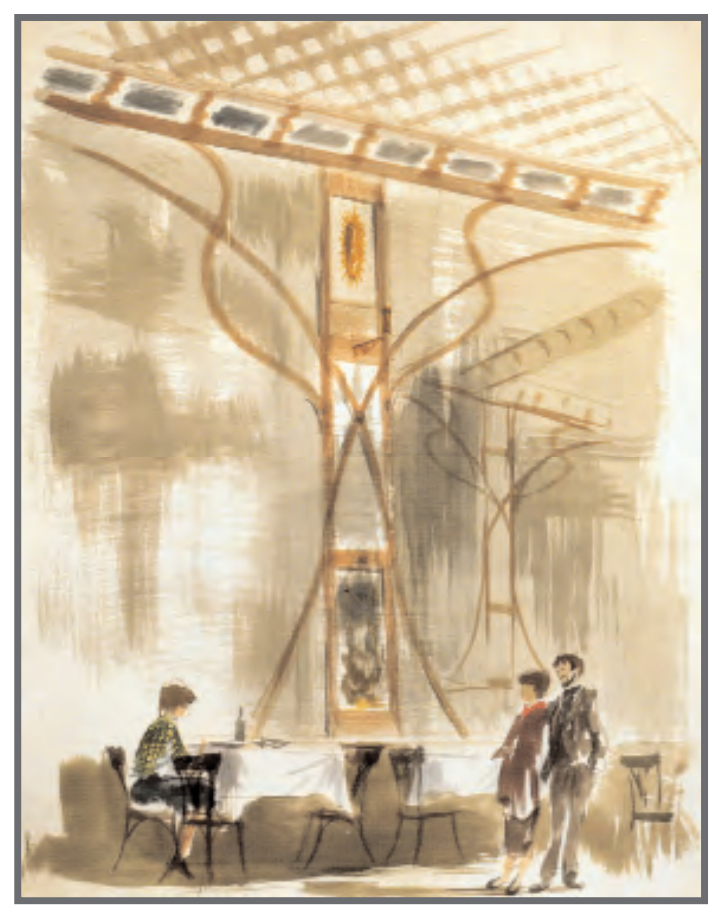

\section{CONTENIDO.}

Personajes: HOMBRE Y MUJERES

Animales: NO

Gestos Expresivos: EMOCIONES POSITIVAS

Paisajes: NO

Escenas: INTERIOR

Función: REPRESENTATIVA DE MODELOS SOCIALES

\section{ASPECTOS TÉCNICOS.}

Color dominante: VARIEDAD CROMÁTICA SUPERIOR Técnica: ACUARELA SOBRE PAPEL

Plano de la imagen: GENERAL 

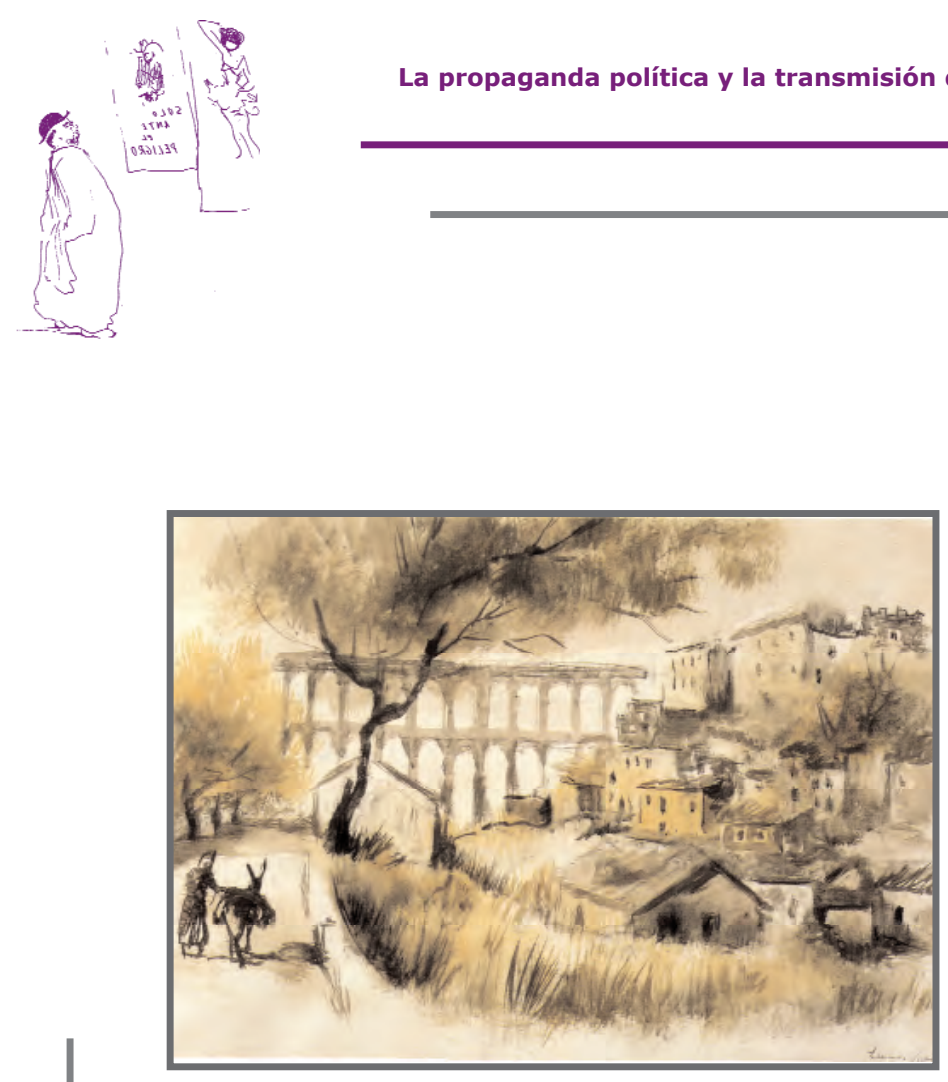

\section{VARIABLES EXTERNAS.}

Título: Vista de Segovia

Año: 1952

Tamaño: 43 x $63 \mathrm{~cm}$.

\section{TIPO DE IMAGEN.}

Retrato: NO

Cartel: NO

Mural: NO

Ilustración: NO

Otras Obras: SI

\section{CONTENIDO.}

Personajes: HOMBRE

Animales: BURRO

Gestos Expresivos: EMOCIONES POSITIVAS

Paisajes: SI

Escenas: ARQUITECTÓNICA

Función: REPRESENTATIVA DE MODELOS SOCIALES

\section{ASPECTOS TÉCNICOS.}

Color dominante: VARIEDAD CROMÁTICA SUPERIOR Técnica: ACUARELA SOBRE PAPEL

Plano de la imagen: GENERAL 


\section{VARIABLES EXTERNAS.}

Título: La Veracruz de Segovia

Año: 1952

Tamaño: $63 \times 43 \mathrm{~cm}$.

\section{TIPO DE IMAGEN.}

Retrato: NO

Cartel: NO

Mural: NO

Ilustración: NO

Otras Obras: SI

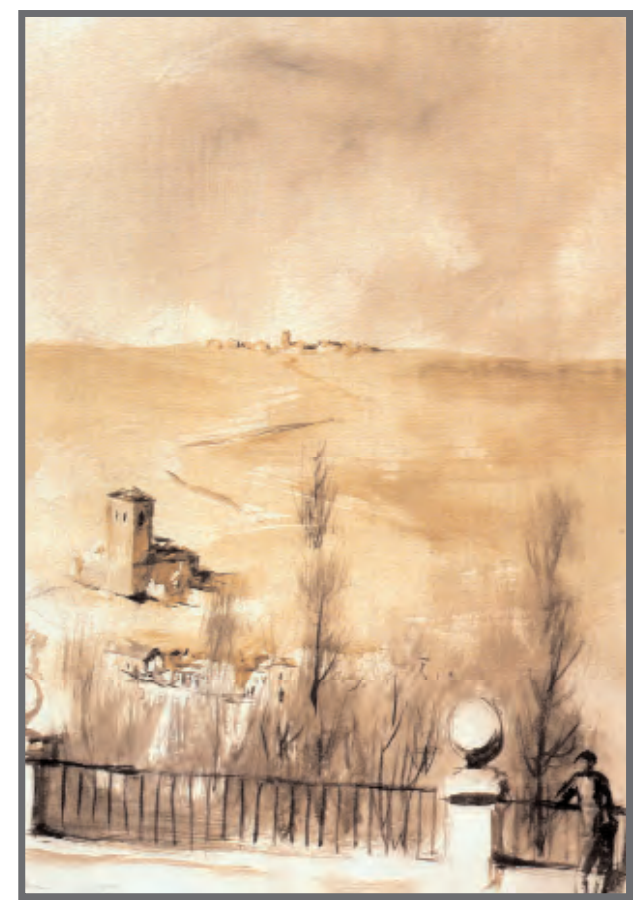

\section{CONTENIDO.}

Personajes: HOMBRE

Animales: NO

Gestos Expresivos: EMOCIONES POSITIVAS

Paisajes: SI

Escenas: ARQUITECTÓNICA

Función: REPRESENTATIVA DE MODELOS SOCIALES

\section{ASPECTOS TÉCNICOS.}

Color dominante: VARIEDAD CROMÁTICA SUPERIOR Técnica: ACUARELA SOBRE PAPEL

Plano de la imagen: GENERAL 

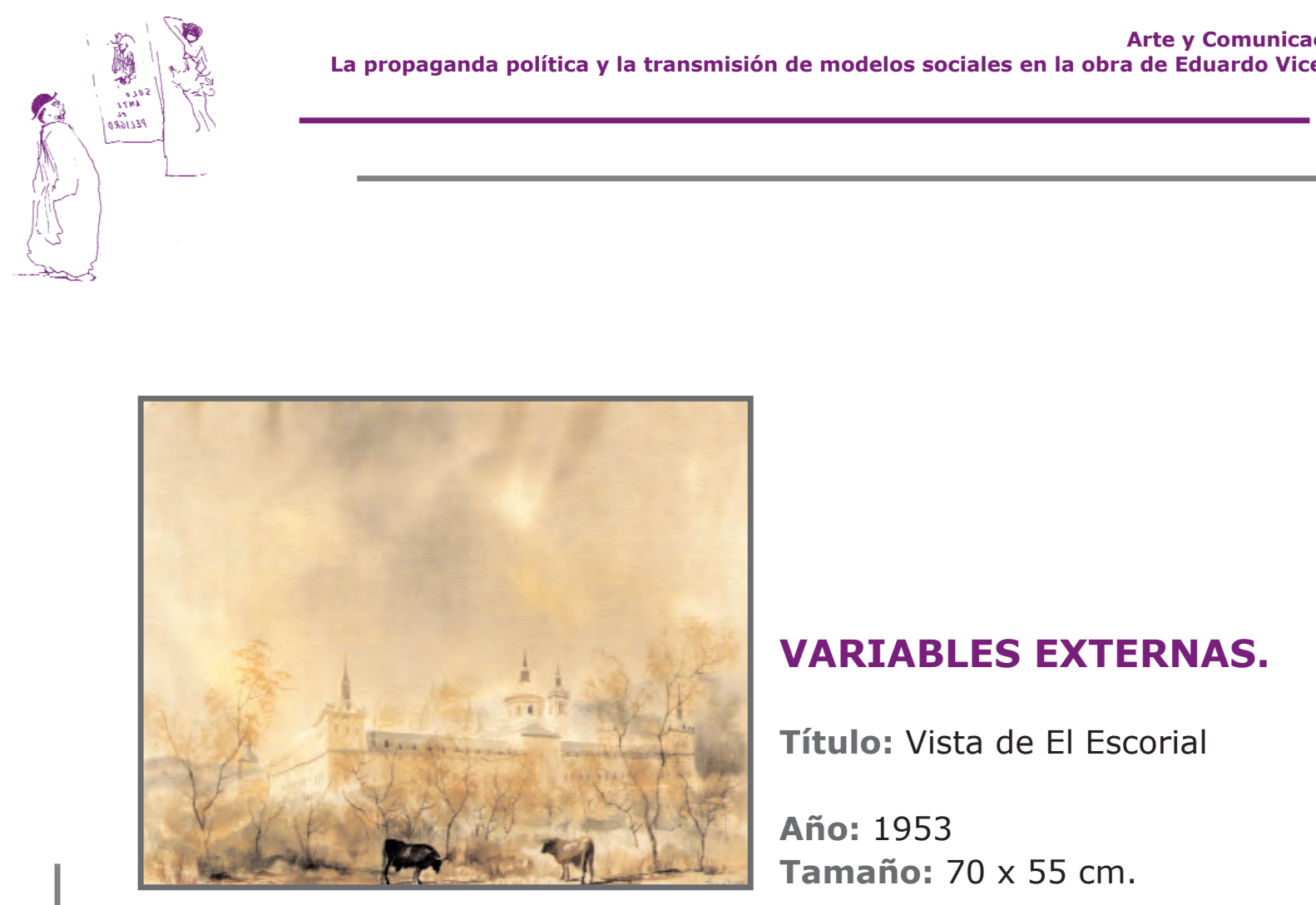

\section{VARIABLES EXTERNAS.}

Título: Vista de El Escorial

Año: 1953

Tamaño: $70 \times 55 \mathrm{~cm}$.

\section{TIPO DE IMAGEN.}

Retrato: NO

Cartel: NO

Mural: NO

Ilustración: NO

Otras Obras: SI

\section{CONTENIDO.}

Personajes: NO

Animales: TOROS

Gestos Expresivos: NO

Paisajes: SI

Escenas: ARQUITECTÓNICA

Función: REPRESENTATIVA DE MODELOS SOCIALES

\section{ASPECTOS TÉCNICOS.}

Color dominante: VARIEDAD CROMÁTICA SUPERIOR

Técnica: ACUARELA SOBRE PAPEL

Plano de la imagen: GENERAL 


\section{VARIABLES EXTERNAS.}

Título: Tranvía de las afueras

Año: 1953

Tamaño: 65 x $54 \mathrm{~cm}$.

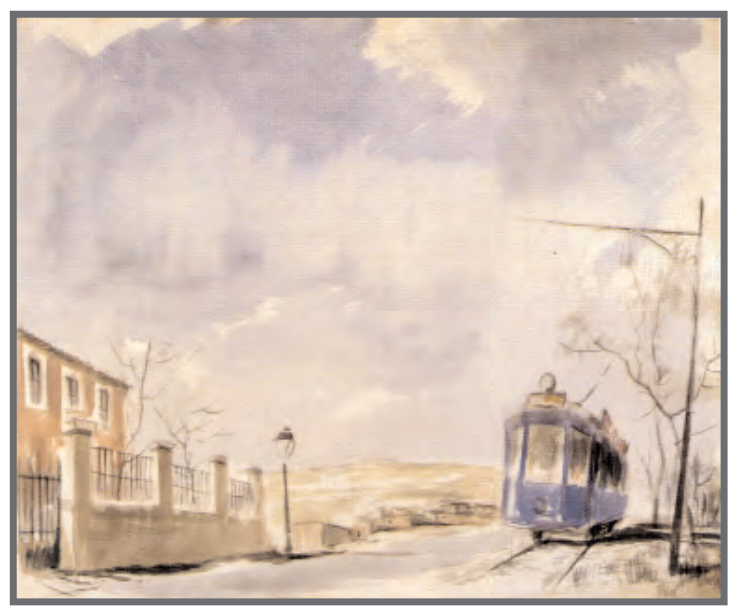

\section{TIPO DE IMAGEN.}

Retrato: NO

Cartel: NO

Mural: NO

Ilustración: NO

Otras Obras: SI

\section{CONTENIDO.}

Personajes: NO

Animales: NO

Gestos Expresivos: NO

Paisajes: SI

Escenas: URBANA

Función: REPRESENTATIVA DE MODELOS SOCIALES

\section{ASPECTOS TÉCNICOS.}

Color dominante: VARIEDAD CROMÁTICA SUPERIOR Técnica: ACUARELA SOBRE PAPEL

Plano de la imagen: GENERAL 


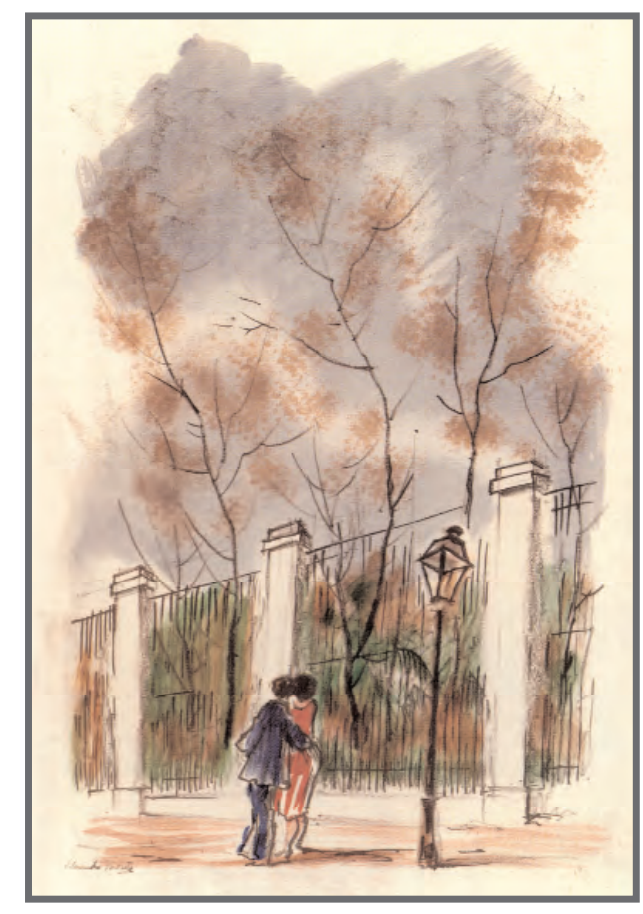

\section{VARIABLES EXTERNAS.}

Título: La tapia del Botánico

Año: 1954

Tamaño: 35 x 49,5 cm.

\section{TIPO DE IMAGEN.}

Retrato: NO

Cartel: NO

Mural: NO

Ilustración: NO

Otras Obras: SI

\section{CONTENIDO.}

Personajes: HOMBRE Y MUJER

Animales: NO

Gestos Expresivos: EMOCIONES POSITIVAS

Paisajes: SI

Escenas: URBANA

Función: REPRESENTATIVA DE MODELOS SOCIALES

\section{ASPECTOS TÉCNICOS.}

Color dominante: VARIEDAD CROMÁTICA SUPERIOR

Técnica: LITOGRAFÍA

Plano de la imagen: GENERAL 


\section{VARIABLES EXTERNAS.}

Título: Plaza de Madrid

Año: 1955

Tamaño: DESCONOCIDO

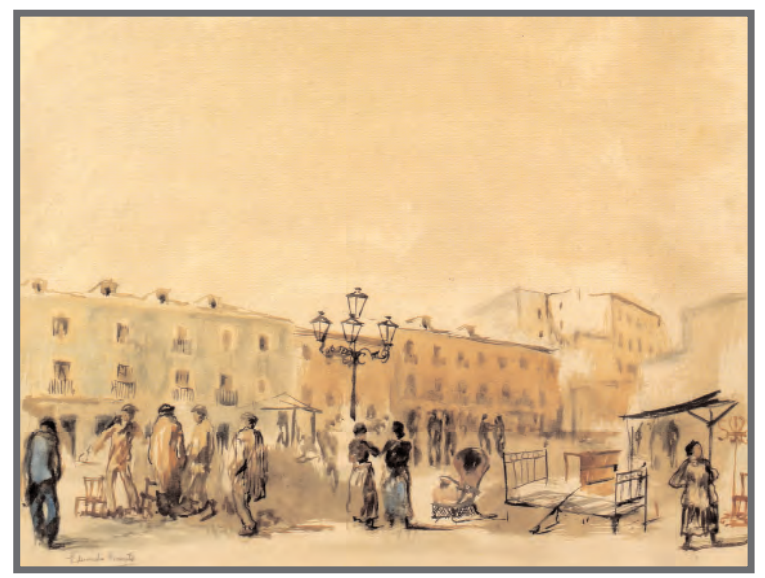

\section{TIPO DE IMAGEN.}

Retrato: NO

Cartel: NO

Mural: NO

Ilustración: NO

Otras Obras: SI

\section{CONTENIDO.}

Personajes: HOMBRES Y MUJERES

Animales: NO

Gestos Expresivos: EMOCIONES POSITIVAS

Paisajes: SI

Escenas: CALLEJERA

Función: REPRESENTATIVA DE MODELOS SOCIALES

\section{ASPECTOS TÉCNICOS.}

Color dominante: VARIEDAD CROMÁTICA SUPERIOR Técnica: ACUARELA SOBRE PAPEL

Plano de la imagen: GENERAL 


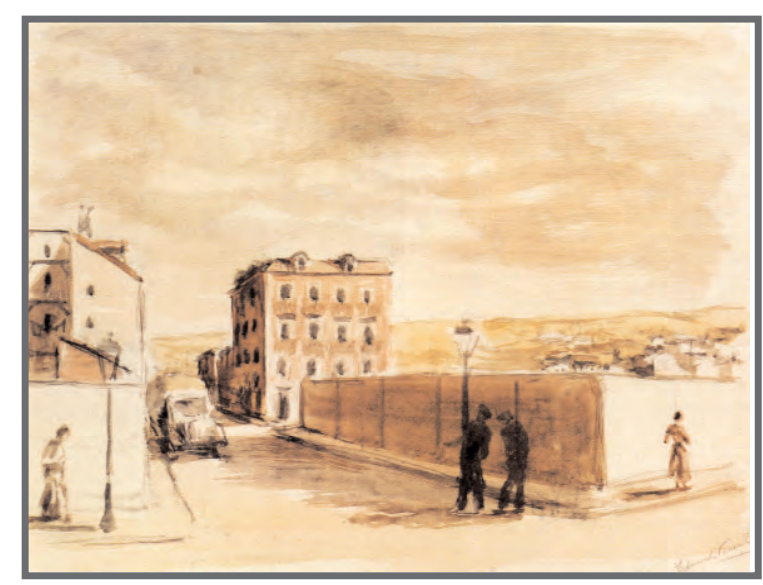

VARIABLES EXTERNAS.

Título: Afueras de Madrid

Año: 1955

Tamaño: DESCONOCIDO

\section{TIPO DE IMAGEN.}

Retrato: NO

Cartel: NO

Mural: NO

Ilustración: NO

Otras Obras: SI

\section{CONTENIDO.}

Personajes: HOMBRES Y MUJERES

Animales: NO

Gestos Expresivos: EMOCIONES POSITIVAS

Paisajes: SI

Escenas: CALLEJERA

Función: REPRESENTATIVA DE MODELOS SOCIALES

\section{ASPECTOS TÉCNICOS.}

Color dominante: VARIEDAD CROMÁTICA SUPERIOR Técnica: ACUARELA SOBRE PAPEL

Plano de la imagen: GENERAL 


\section{VARIABLES EXTERNAS.}

Título: Ermita de la Virgen del Puerto con figuras

\section{Año: 1955}

Tamaño: $110 \times 91 \mathrm{~cm}$.

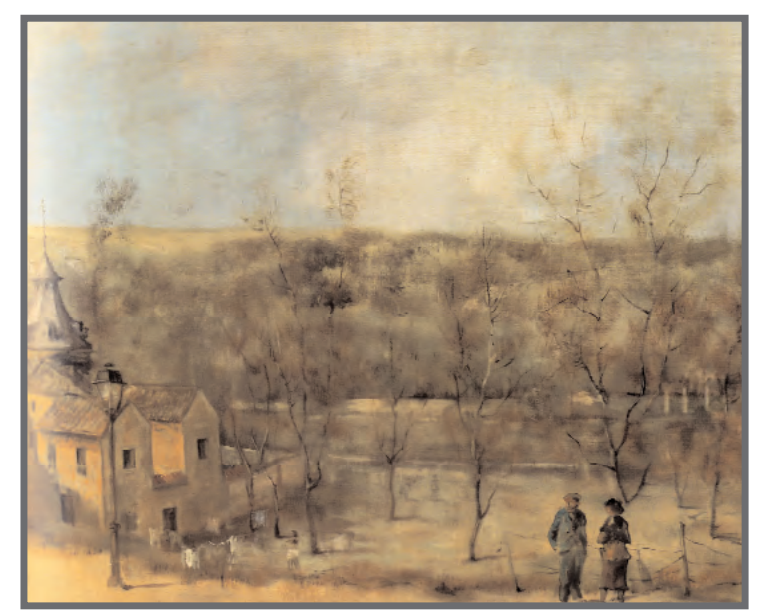

\section{TIPO DE IMAGEN.}

Retrato: NO

Cartel: NO

Mural: NO

Ilustración: NO

Otras Obras: SI

\section{CONTENIDO.}

Personajes: HOMBRE Y MUJERES

Animales: NO

Gestos Expresivos: EMOCIONES POSITIVAS

Paisajes: SI

Escenas: RURAL

Función: REPRESENTATIVA DE MODELOS SOCIALES

\section{ASPECTOS TÉCNICOS.}

Color dominante: VARIEDAD CROMÁTICA SUPERIOR Técnica: ÓLEO SOBRE LIENZO

Plano de la imagen: GENERAL 

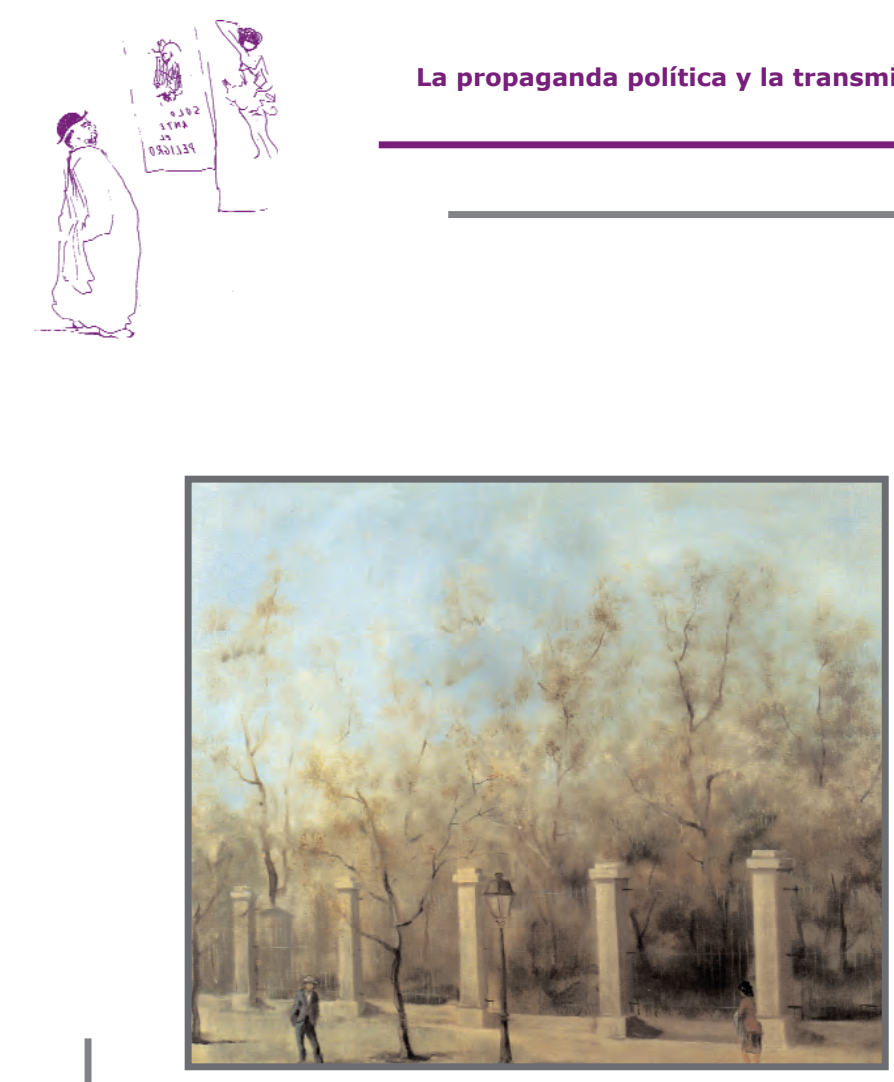

\section{VARIABLES EXTERNAS.}

Título: Vista del Jardín Botánico

Año: 1955

Tamaño: $110 \times 91 \mathrm{~cm}$.

\section{TIPO DE IMAGEN.}

Retrato: NO

Cartel: NO

Mural: NO

Ilustración: NO

Otras Obras: SI

\section{CONTENIDO.}

Personajes: HOMBRE Y MUJER

Animales: NO

Gestos Expresivos: EMOCIONES POSITIVAS

Paisajes: SI

Escenas: URBANA

Función: REPRESENTATIVA DE MODELOS SOCIALES

\section{ASPECTOS TÉCNICOS.}

Color dominante: VARIEDAD CROMÁTICA SUPERIOR

Técnica: ÓLEO SOBRE LIENZO

Plano de la imagen: GENERAL 


\section{VARIABLES EXTERNAS.}

Título: Escena taurina

Año: $1955-65$

Tamaño: $67 \times 83 \mathrm{~cm}$.

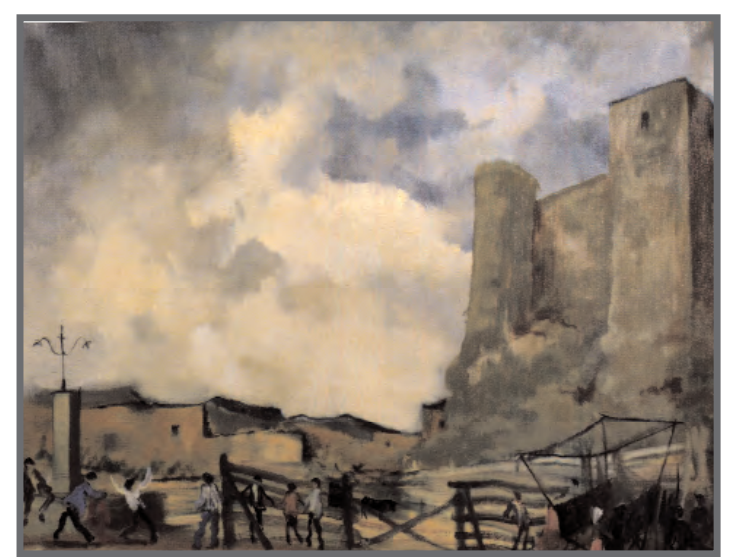

TIPO DE IMAGEN.

Retrato: NO

Cartel: NO

Mural: NO

Ilustración: NO

Otras Obras: SI

\section{CONTENIDO.}

Personajes: HOMBRES Y MUJERES

Animales: TOROS

Gestos Expresivos: EMOCIONES POSITIVAS

Paisajes: SI

Escenas: FESTIVA

Función: REPRESENTATIVA DE MODELOS SOCIALES

\section{ASPECTOS TÉCNICOS.}

Color dominante: VARIEDAD CROMÁTICA SUPERIOR

Técnica: ÓLEO SOBRE LIENZO

Plano de la imagen: GENERAL 

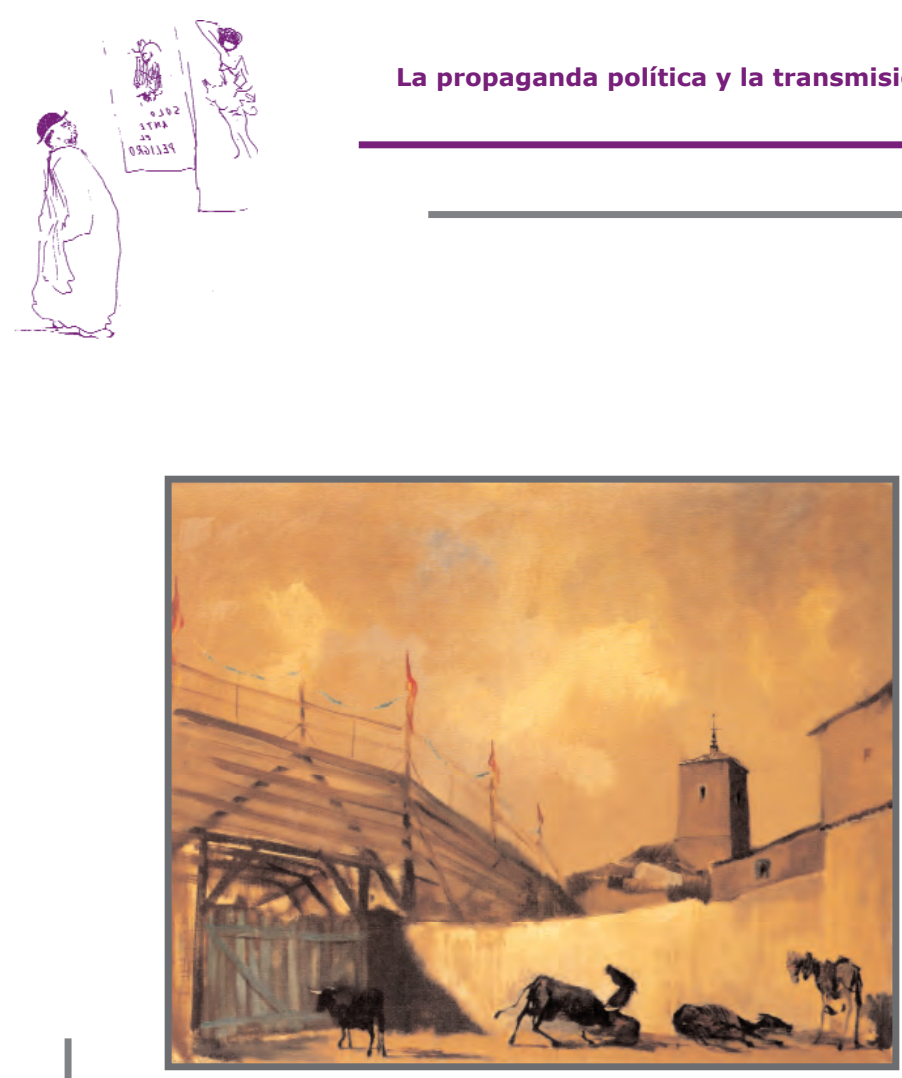

\section{VARIABLES EXTERNAS.}

Título: Escena taurina

Año: 1955 - 65

Tamaño: $67 \times 83 \mathrm{~cm}$.

\section{TIPO DE IMAGEN.}

Retrato: NO

Cartel: NO

Mural: NO

Ilustración: NO

Otras Obras: SI

\section{CONTENIDO.}

Personajes: NO

Animales: CABALLOS Y TOROS

Gestos Expresivos: NO

Paisajes: SI

Escenas: FESTIVA

Función: REPRESENTATIVA DE MODELOS SOCIALES

\section{ASPECTOS TÉCNICOS.}

Color dominante: VARIEDAD CROMÁTICA SUPERIOR

Técnica: ÓLEO SOBRE LIENZO

Plano de la imagen: GENERAL 


\section{VARIABLES EXTERNAS.}

Título: Sin título

Año: 1955

Tamaño: DESCONOCIDO

\section{TIPO DE IMAGEN.}

Retrato: NO

Cartel: NO

Mural: NO

Ilustración: NO

Otras Obras: SI

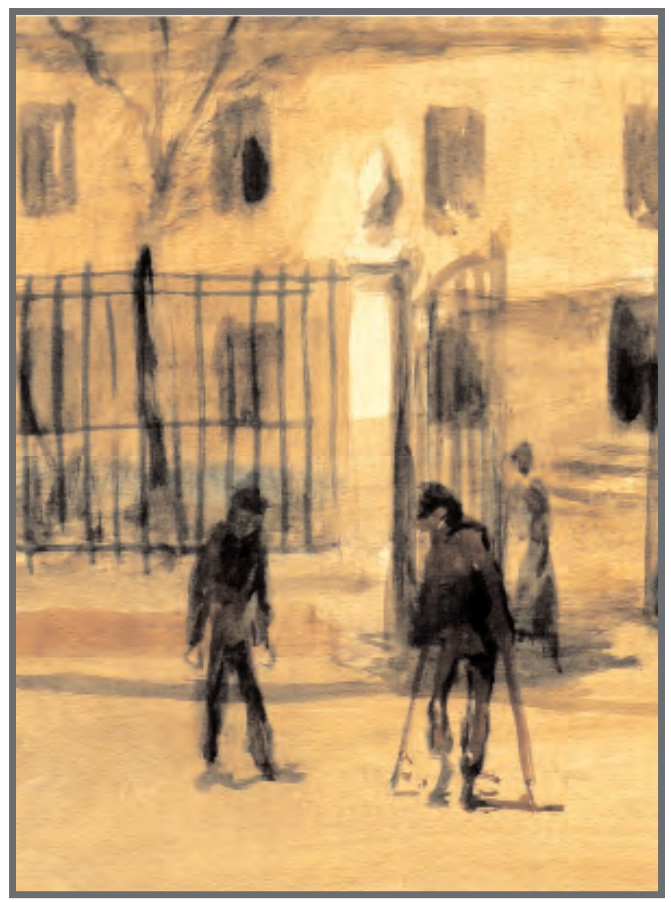

\section{CONTENIDO.}

Personajes: HOMBRES Y MUJER

Animales: NO

Gestos Expresivos: EMOCIONES POSITIVAS

Paisajes: SI

Escenas: CALLEJERA

Función: REPRESENTATIVA DE MODELOS SOCIALES

\section{ASPECTOS TÉCNICOS.}

Color dominante: VARIEDAD CROMÁTICA SUPERIOR

Técnica: ÓLEO SOBRE LIENZO

Plano de la imagen: GENERAL 


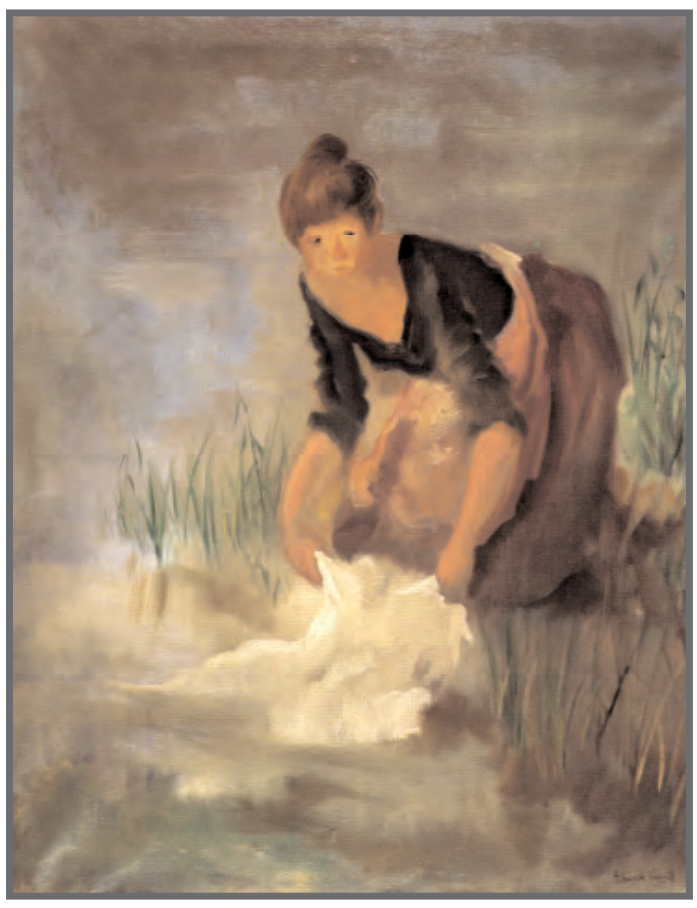

\section{VARIABLES EXTERNAS.}

Título: Lavando en el río

Año: 1955 - 60

Tamaño: 80 x $65 \mathrm{~cm}$.

\section{TIPO DE IMAGEN.}

Retrato: NO

Cartel: NO

Mural: NO

Ilustración: NO

Otras Obras: SI

\section{CONTENIDO.}

Personajes: MUJER

Animales: NO

Gestos Expresivos: EMOCIONES POSITIVAS

Paisajes: NO

Escenas: PROFESIONAL

Función: REPRESENTATIVA DE MODELOS SOCIALES

\section{ASPECTOS TÉCNICOS.}

Color dominante: VARIEDAD CROMÁTICA SUPERIOR

Técnica: ÓLEO SOBRE LIENZO

Plano de la imagen: GENERAL 


\section{VARIABLES EXTERNAS.}

Título: Mujer al aire libre

Año: $1955-60$

Tamaño: $104 \times 94 \mathrm{~cm}$.

\section{TIPO DE IMAGEN.}

Retrato: NO

Cartel: NO

Mural: NO

Ilustración: NO

Otras Obras: SI

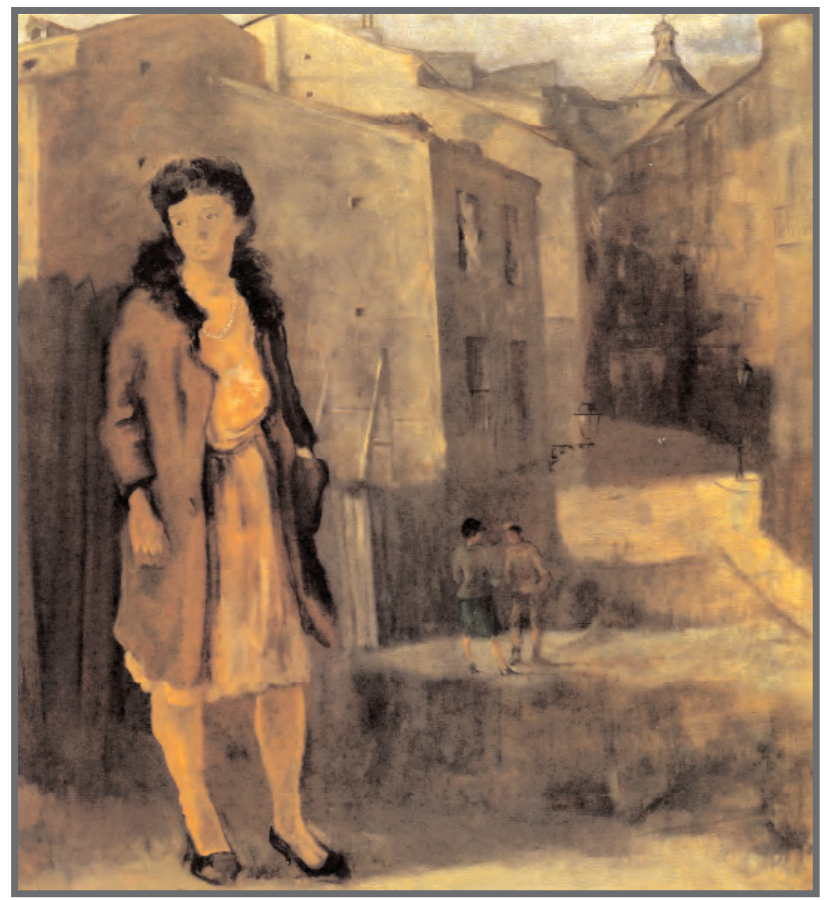

\section{CONTENIDO.}

Personajes: HOMBRE Y MUJERES

Animales: NO

Gestos Expresivos: EMOCIONES NEGATIVAS

Paisajes: SI

Escenas: CALLEJERA

Función: REPRESENTATIVA DE MODELOS SOCIALES

\section{ASPECTOS TÉCNICOS.}

Color dominante: VARIEDAD CROMÁTICA SUPERIOR

Técnica: ÓLEO SOBRE LIENZO

Plano de la imagen: GENERAL 


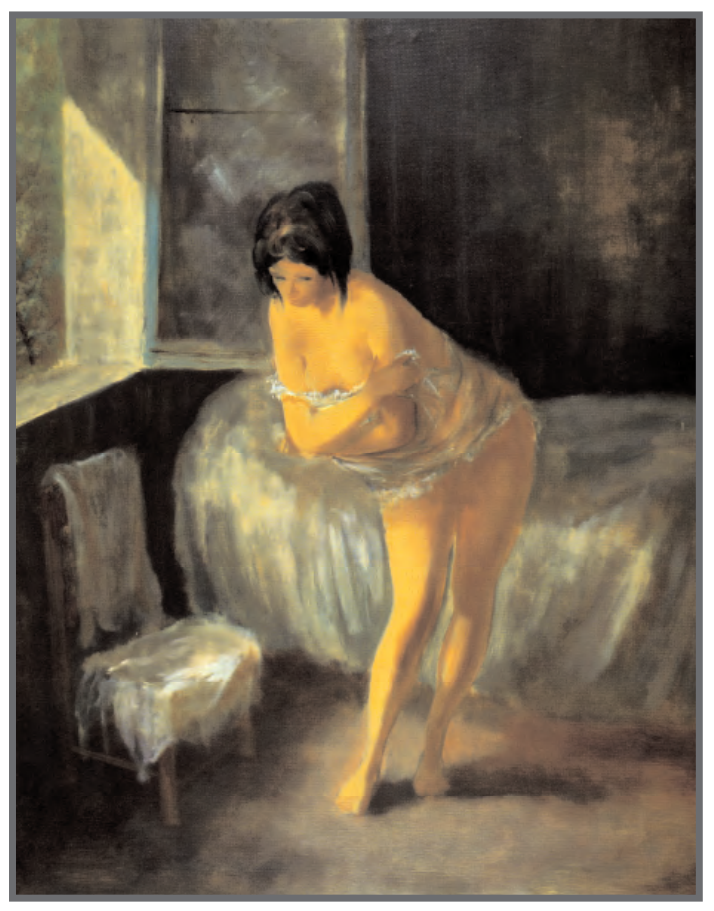

\section{VARIABLES EXTERNAS.}

Título: Mujer desnudándose

Año: $1955-65$

Tamaño: $100 \times 84 \mathrm{~cm}$.

\section{TIPO DE IMAGEN.}

Retrato: NO

Cartel: NO

Mural: NO

Ilustración: NO

Otras Obras: SI

\section{CONTENIDO.}

Personajes: MUJER

Animales: NO

Gestos Expresivos: EMOCIONES NEGATIVAS

Paisajes: NO

Escenas: INTERIOR

Función: REPRESENTATIVA DE MODELOS SOCIALES

\section{ASPECTOS TÉCNICOS.}

Color dominante: VARIEDAD CROMÁTICA SUPERIOR

Técnica: ÓLEO SOBRE LIENZO

Plano de la imagen: GENERAL 


\section{VARIABLES EXTERNAS.}

Título: Mujer sentada en la cama

Año: $1955-60$

Tamaño: $80 \times 65 \mathrm{~cm}$.

\section{TIPO DE IMAGEN.}

Retrato: NO

Cartel: NO

Mural: NO

Ilustración: NO

Otras Obras: SI

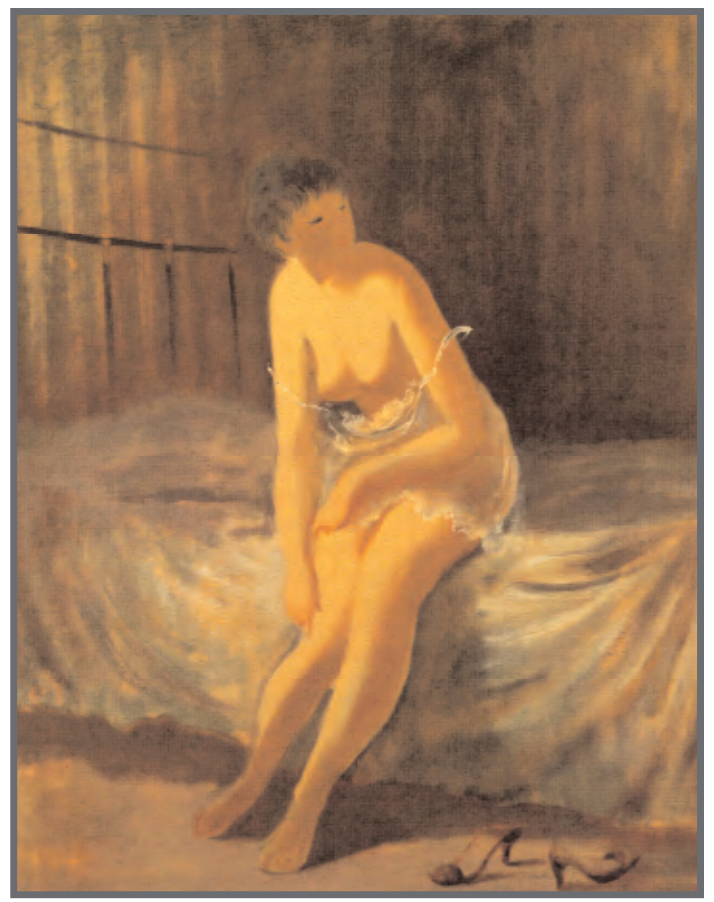

\section{CONTENIDO.}

Personajes: MUJER

Animales: NO

Gestos Expresivos: EMOCIONES NEGATIVAS

Paisajes: NO

Escenas: INTERIOR

Función: REPRESENTATIVA DE MODELOS SOCIALES

\section{ASPECTOS TÉCNICOS.}

Color dominante: VARIEDAD CROMÁTICA SUPERIOR

Técnica: ÓLEO SOBRE LIENZO

Plano de la imagen: GENERAL 


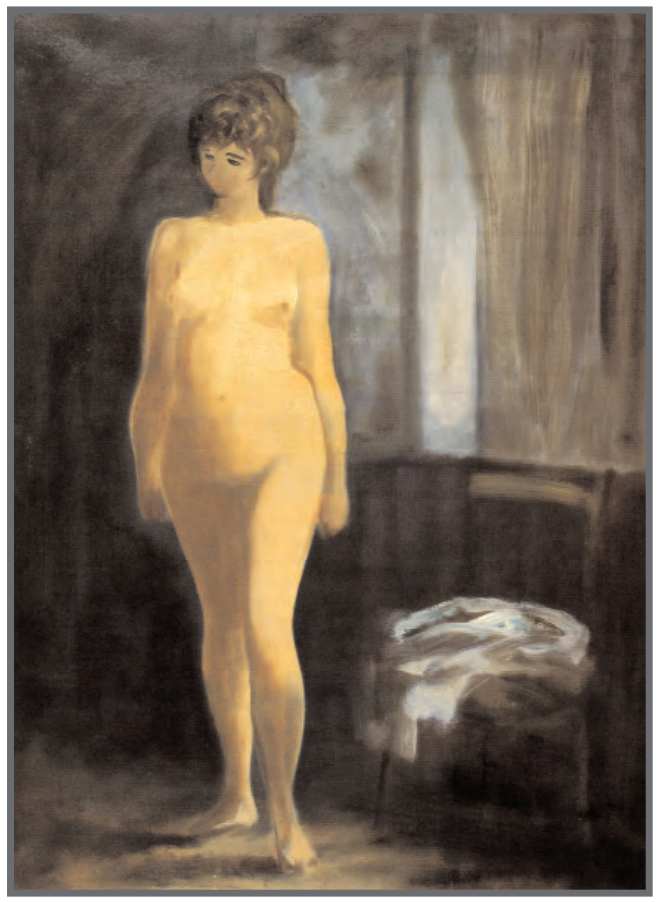

\section{VARIABLES EXTERNAS.}

Título: Desnudo

Año: 195560

Tamaño: $95 \times 80 \mathrm{~cm}$.

\section{TIPO DE IMAGEN.}

Retrato: NO

Cartel: NO

Mural: NO

Ilustración: NO

Otras Obras: SI

\section{CONTENIDO.}

Personajes: MUJER

Animales: NO

Gestos Expresivos: EMOCIONES NEGATIVAS

Paisajes: NO

Escenas: INTERIOR

Función: REPRESENTATIVA DE MODELOS SOCIALES

\section{ASPECTOS TÉCNICOS.}

Color dominante: VARIEDAD CROMÁTICA SUPERIOR

Técnica: ÓLEO SOBRE LIENZO

Plano de la imagen: GENERAL 


\section{VARIABLES EXTERNAS.}

Título: Mujer en la esquina

Año: $1955-65$

Tamaño: $87 \times 63 \mathrm{~cm}$.

TIPO DE IMAGEN.

Retrato: NO

Cartel: NO

Mural: NO

Ilustración: NO

Otras Obras: SI

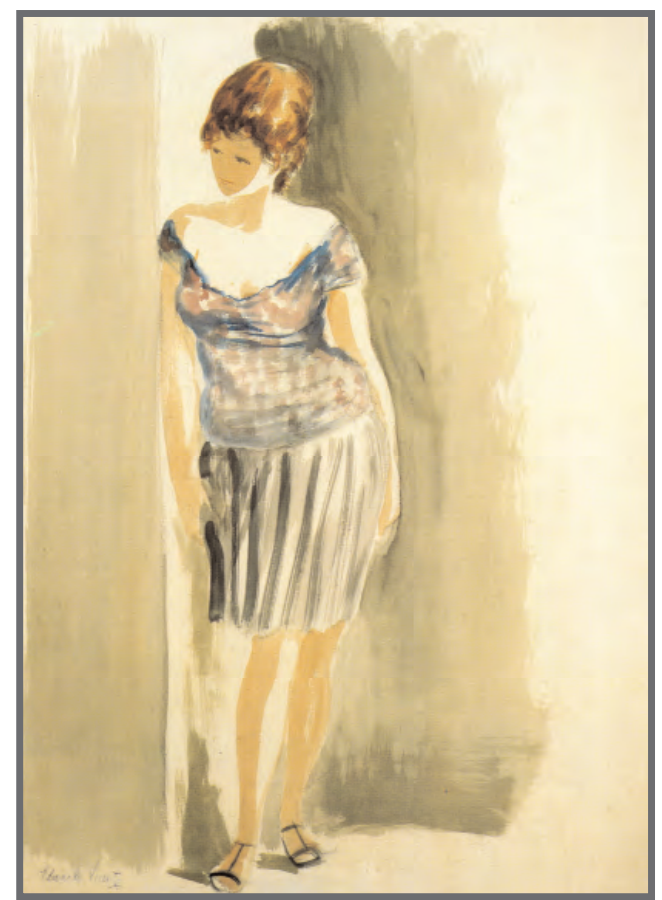

\section{CONTENIDO.}

Personajes: MUJER

Animales: NO

Gestos Expresivos: EMOCIONES NEGATIVAS

Paisajes: NO

Escenas: INTERIOR

Función: REPRESENTATIVA DE MODELOS SOCIALES

\section{ASPECTOS TÉCNICOS.}

Color dominante: VARIEDAD CROMÁTICA SUPERIOR Técnica: ACUARELA SOBRE PAPEL

Plano de la imagen: GENERAL 


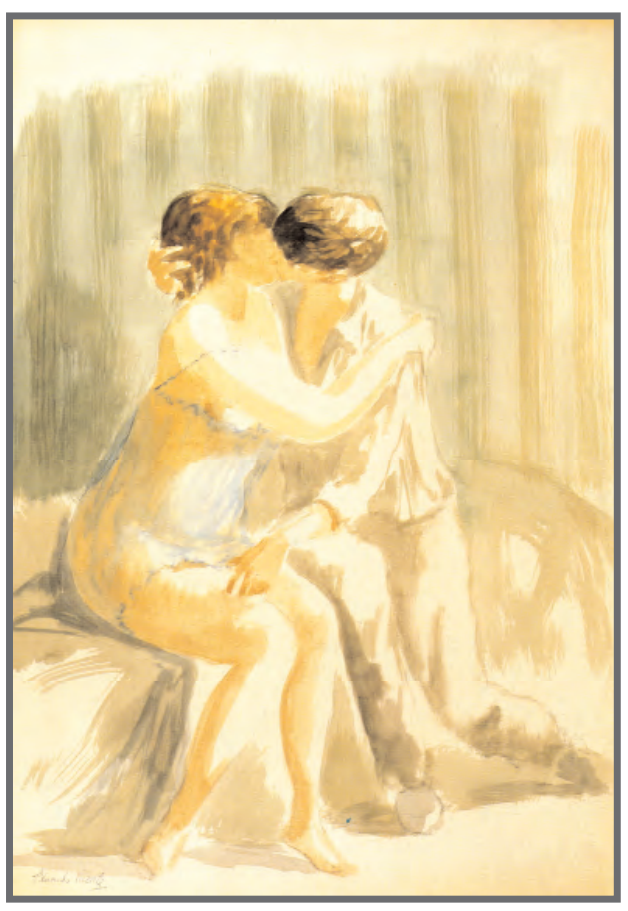

\section{VARIABLES EXTERNAS.}

Título: El beso

Año: $1955-60$

Tamaño: $101 \times 72 \mathrm{~cm}$.

\section{TIPO DE IMAGEN.}

Retrato: NO

Cartel: NO

Mural: NO

Ilustración: NO

Otras Obras: SI

\section{CONTENIDO.}

Personajes: HOMBRE Y MUJER

Animales: NO

Gestos Expresivos: EMOCIONES POSITIVAS

Paisajes: NO

Escenas: INTERIOR

Función: REPRESENTATIVA DE MODELOS SOCIALES

\section{ASPECTOS TÉCNICOS.}

Color dominante: VARIEDAD CROMÁTICA SUPERIOR

Técnica: ACUARELA SOBRE PAPEL

Plano de la imagen: GENERAL 


\section{VARIABLES EXTERNAS.}

Título: La Nardo

Año: $1955-65$

Tamaño: $84 \times 73 \mathrm{~cm}$.

\section{TIPO DE IMAGEN.}

Retrato: NO

Cartel: NO

Mural: NO

Ilustración: NO

Otras Obras: SI

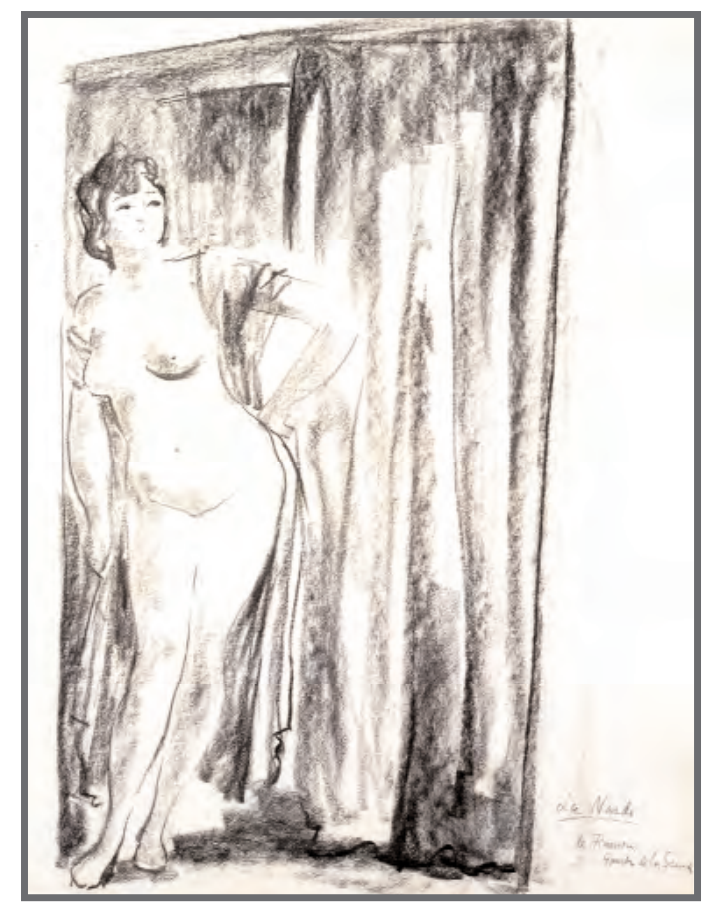

\section{CONTENIDO.}

Personajes: MUJER

Animales: NO

Gestos Expresivos: EMOCIONES NEGATIVAS

Paisajes: NO

Escenas: INTERIOR

Función: REPRESENTATIVA DE MODELOS SOCIALES

\section{ASPECTOS TÉCNICOS.}

Color dominante: 1 TINTA

Técnica: CARBONCILLO SOBRE PAPEL

Plano de la imagen: GENERAL 


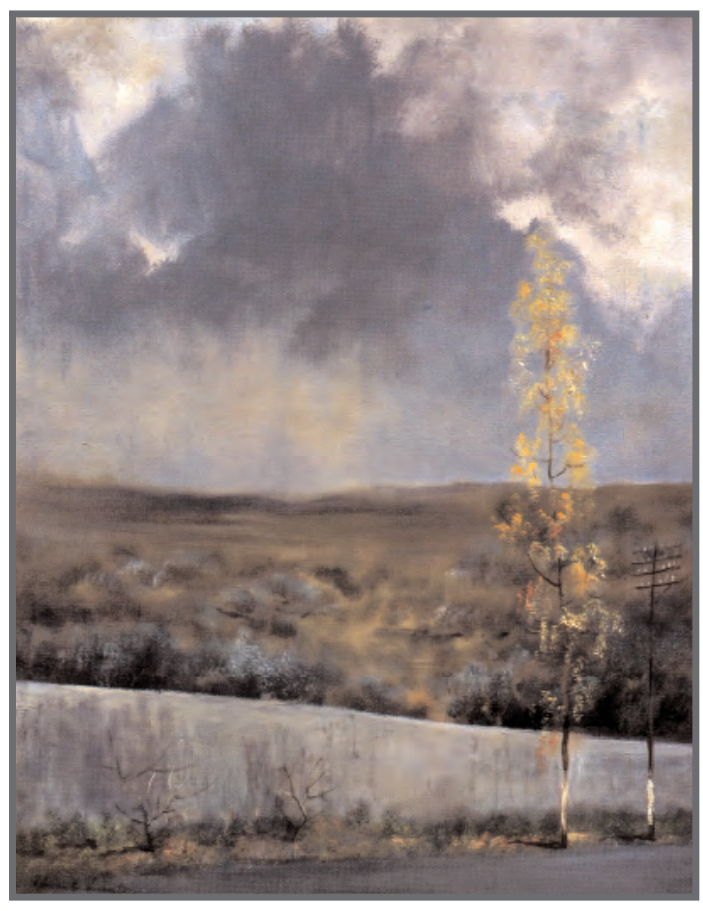

\section{VARIABLES EXTERNAS.}

Título: Paisaje

Año: 1955 - 60

Tamaño: $87 \times 63 \mathrm{~cm}$.

\section{TIPO DE IMAGEN.}

Retrato: NO

Cartel: NO

Mural: NO

Ilustración: NO

Otras Obras: SI

\section{CONTENIDO.}

Personajes: NO

Animales: NO

Gestos Expresivos: NO

Paisajes: SI

Escenas: RURAL

Función: REPRESENTATIVA DE MODELOS SOCIALES

\section{ASPECTOS TÉCNICOS.}

Color dominante: VARIEDAD CROMÁTICA SUPERIOR

Técnica: ÓLEO SOBRE LIENZO

Plano de la imagen: GENERAL 


\section{VARIABLES EXTERNAS.}

Título: Capea en la Posada de San Antonio

Año: $1955-60$

Tamaño: $92 \times 73 \mathrm{~cm}$.

TIPO DE IMAGEN.

Retrato: NO

Cartel: NO

Mural: NO

Ilustración: NO

Otras Obras: SI

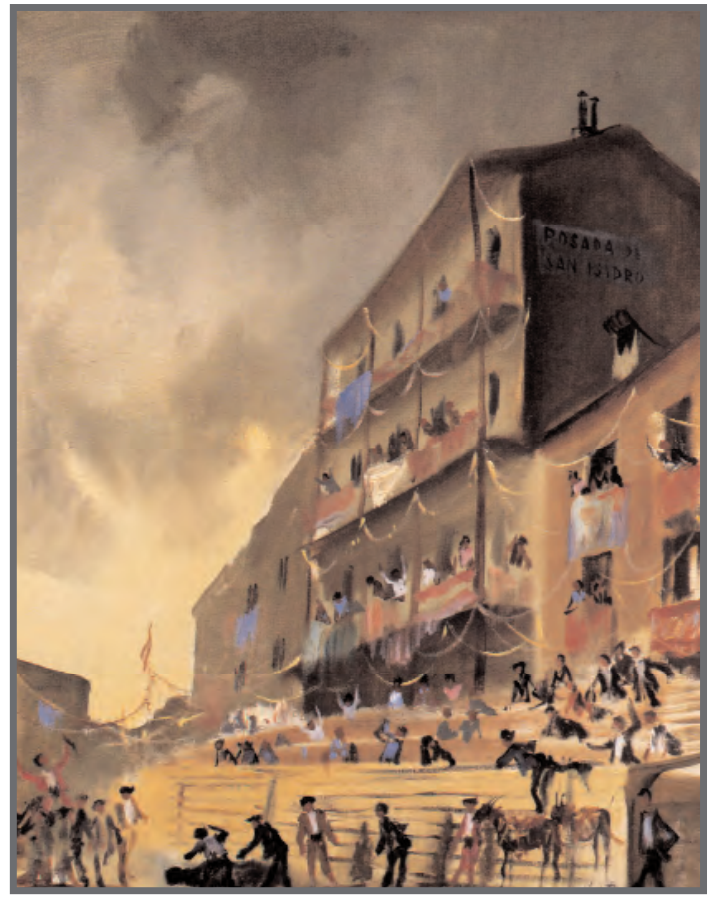

\section{CONTENIDO.}

Personajes: HOMBRES Y MUJERES

Animales: CABALLOS Y TORO

Gestos Expresivos: EMOCIONES POSITIVAS

Paisajes: SI

Escenas: FESTIVA

Función: REPRESENTATIVA DE MODELOS SOCIALES

\section{ASPECTOS TÉCNICOS.}

Color dominante: VARIEDAD CROMÁTICA SUPERIOR

Técnica: ÓLEO SOBRE LIENZO

Plano de la imagen: GENERAL 


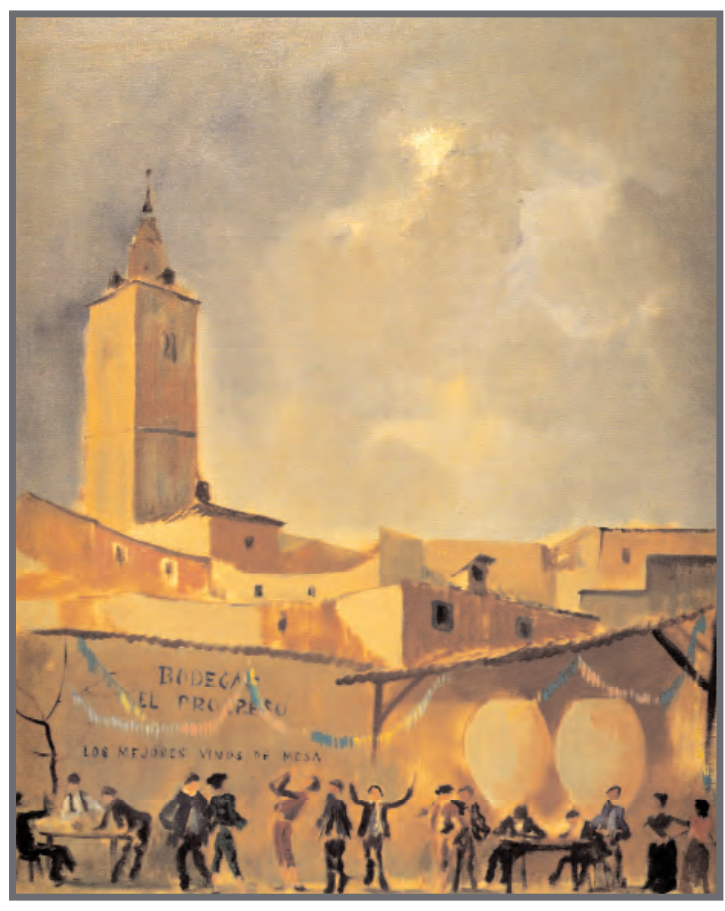

\section{VARIABLES EXTERNAS.}

Título: Fiesta en un pueblo

Año: $1955-65$

Tamaño: $117 \times 97 \mathrm{~cm}$.

\section{TIPO DE IMAGEN.}

Retrato: NO

Cartel: NO

Mural: NO

Ilustración: NO

Otras Obras: SI

\section{CONTENIDO.}

Personajes: HOMBRES Y MUJERES

Animales: NO

Gestos Expresivos: EMOCIONES POSITIVAS

Paisajes: SI

Escenas: FESTIVA

Función: REPRESENTATIVA DE MODELOS SOCIALES

\section{ASPECTOS TÉCNICOS.}

Color dominante: VARIEDAD CROMÁTICA SUPERIOR

Técnica: ÓLEO SOBRE LIENZO

Plano de la imagen: GENERAL 


\section{VARIABLES EXTERNAS.}

Título: Toros en el campo

Año: $1955-65$

Tamaño: $19,5 \times 14,5 \mathrm{~cm}$.

TIPO DE IMAGEN.

Retrato: NO

Cartel: NO

Mural: NO

Ilustración: NO

Otras Obras: SI

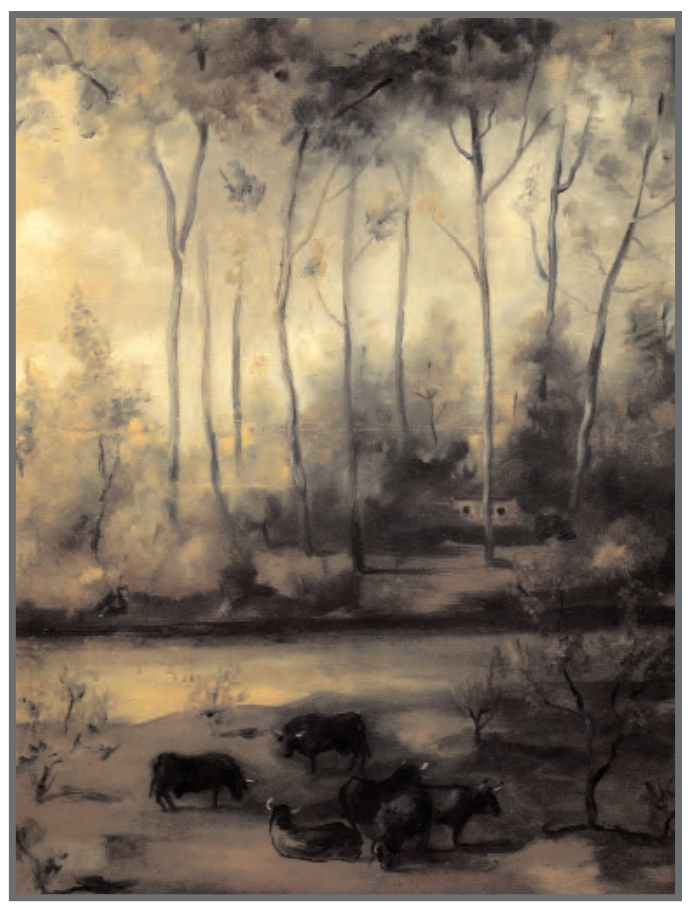

\section{CONTENIDO.}

Personajes: NO

Animales: TOROS

Gestos Expresivos: NO

Paisajes: SI

Escenas: RURAL

Función: REPRESENTATIVA DE MODELOS SOCIALES

\section{ASPECTOS TÉCNICOS.}

Color dominante: VARIEDAD CROMÁTICA SUPERIOR

Técnica: ÓLEO SOBRE LIENZO

Plano de la imagen: GENERAL 


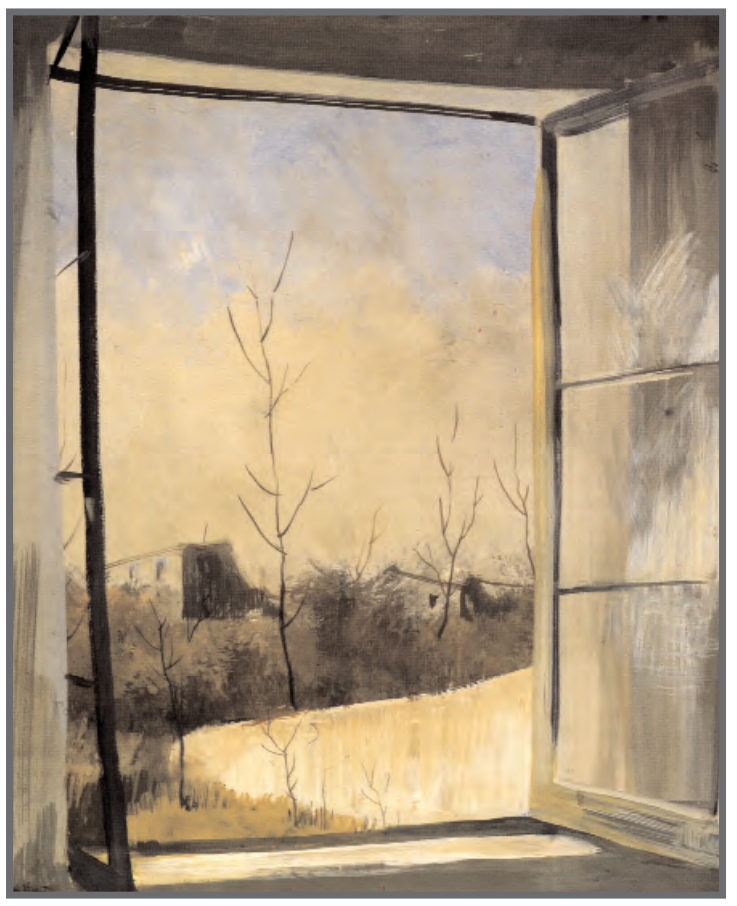

\section{VARIABLES EXTERNAS.}

Título: Ventana abierta

Año: 1957

Tamaño: $95 \times 80 \mathrm{~cm}$.

\section{TIPO DE IMAGEN.}

Retrato: NO

Cartel: NO

Mural: NO

Ilustración: NO

Otras Obras: SI

\section{CONTENIDO.}

Personajes: NO

Animales: NO

Gestos Expresivos: NO

Paisajes: SI

Escenas: RURAL

Función: REPRESENTATIVA DE MODELOS SOCIALES

ASPECTOS TÉCNICOS.

Color dominante: VARIEDAD CROMÁTICA SUPERIOR

Técnica: GOUACHE SOBRE PAPEL

Plano de la imagen: GENERAL 


\section{VARIABLES EXTERNAS.}

Título: Pareja en el Café Gijón

Año: 1958

Tamaño: 80 x $100 \mathrm{~cm}$.

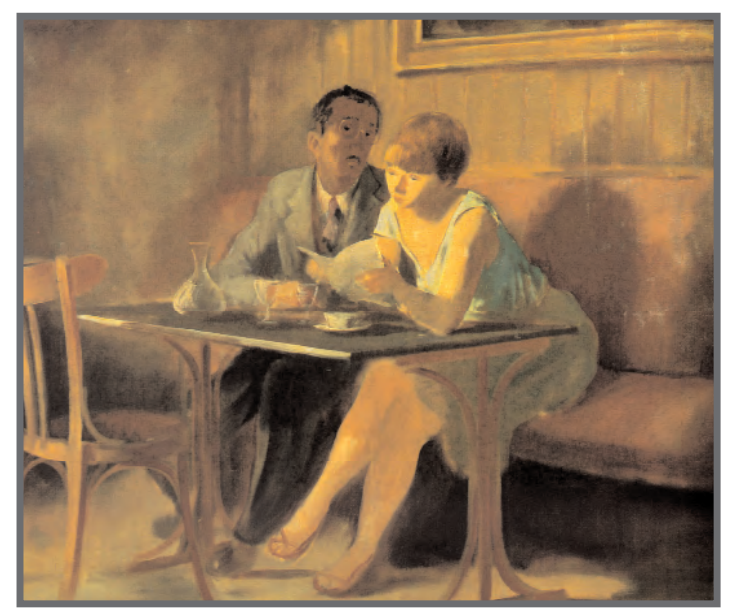

\section{TIPO DE IMAGEN.}

Retrato: NO

Cartel: NO

Mural: NO

Ilustración: NO

Otras Obras: SI

\section{CONTENIDO.}

Personajes: HOMBRE Y MUJER

Animales: NO

Gestos Expresivos: EMOCIONES POSITIVAS

Paisajes: NO

Escenas: INTERIOR

Función: REPRESENTATIVA DE MODELOS SOCIALES

\section{ASPECTOS TÉCNICOS.}

Color dominante: VARIEDAD CROMÁTICA SUPERIOR

Técnica: ÓLEO SOBRE LIENZO

Plano de la imagen: GENERAL 

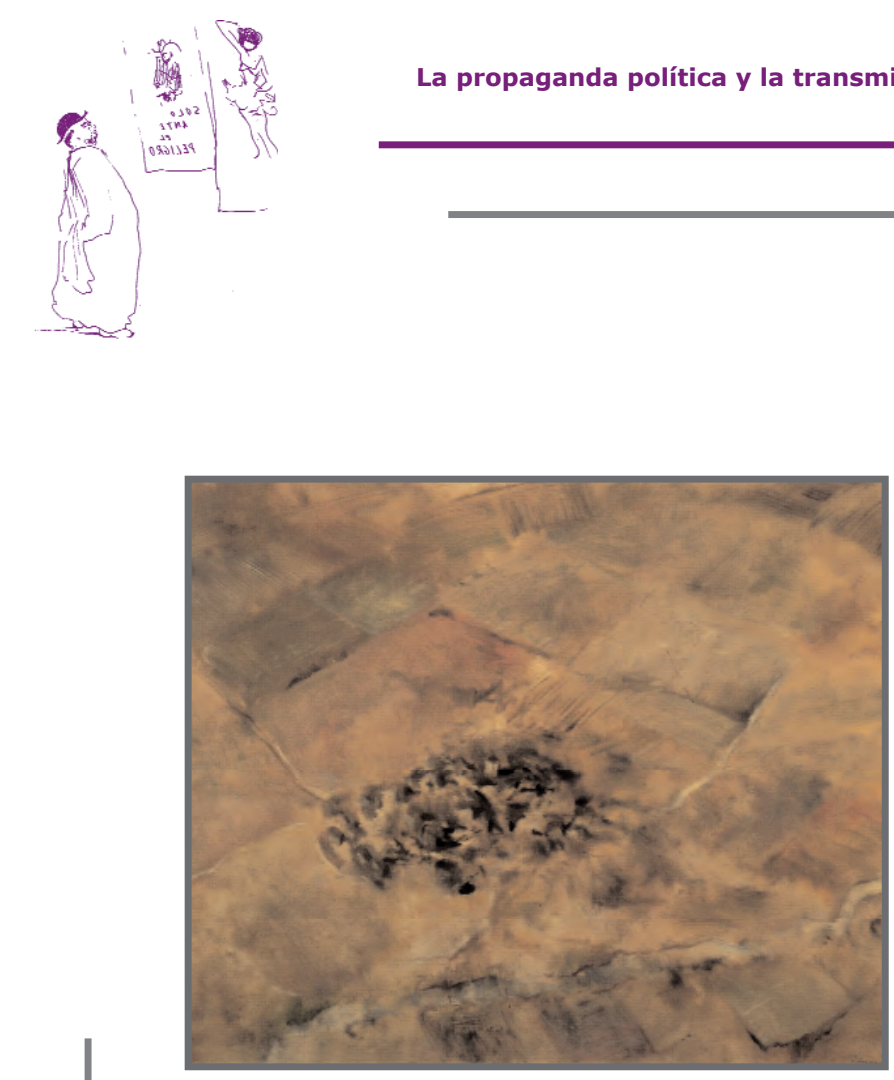

\section{VARIABLES EXTERNAS.}

Título: Paisaje castellano desde el aire

Año: 1958

Tamaño: $158,5 \times 78,5 \mathrm{~cm}$.

\section{TIPO DE IMAGEN.}

Retrato: NO

Cartel: NO

Mural: NO

Ilustración: NO

Otras Obras: SI

\section{CONTENIDO.}

Personajes: NO

Animales: NO

Gestos Expresivos: NO

Paisajes: SI

Escenas: AÉREA

Función: REPRESENTATIVA DE MODELOS SOCIALES

ASPECTOS TÉCNICOS.

Color dominante: VARIEDAD CROMÁTICA SUPERIOR

Técnica: ÓLEO SOBRE LIENZO

Plano de la imagen: GENERAL 


\section{VARIABLES EXTERNAS.}

Título: La taberna

Año: 1959

Tamaño: $140 \times 128 \mathrm{~cm}$.

\section{TIPO DE IMAGEN.}

Retrato: NO

Cartel: NO

Mural: NO

Ilustración: NO

Otras Obras: SI

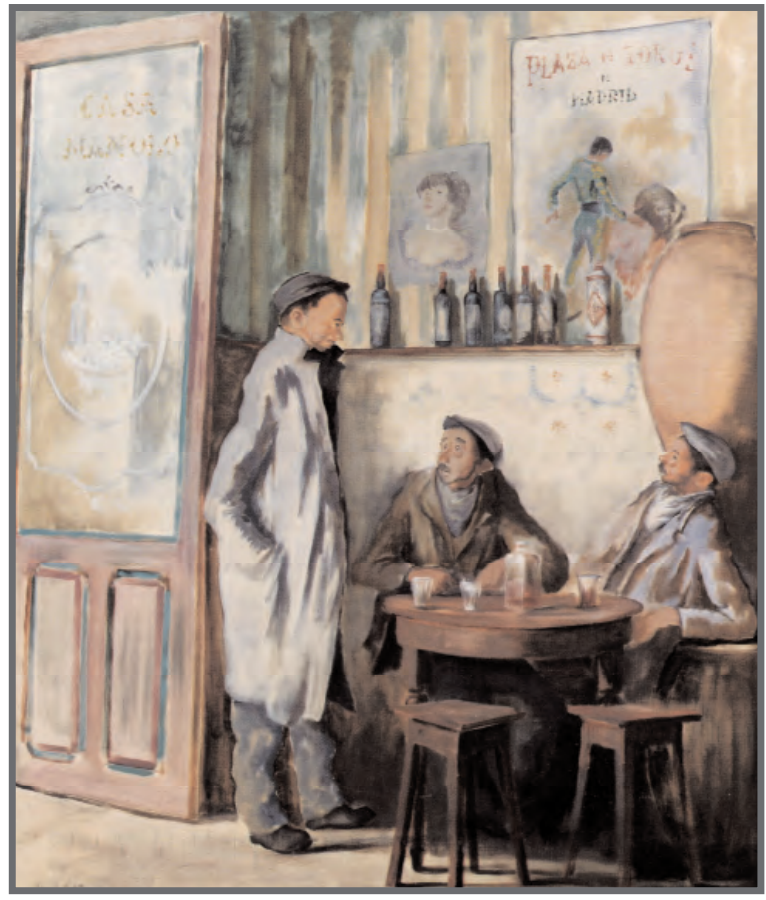

\section{CONTENIDO.}

Personajes: HOMBRES

Animales: NO

Gestos Expresivos: EMOCIONES POSITIVAS

Paisajes: NO

Escenas: INTERIOR

Función: REPRESENTATIVA DE MODELOS SOCIALES

\section{ASPECTOS TÉCNICOS.}

Color dominante: VARIEDAD CROMÁTICA SUPERIOR

Técnica: ÓLEO SOBRE LIENZO

Plano de la imagen: GENERAL 

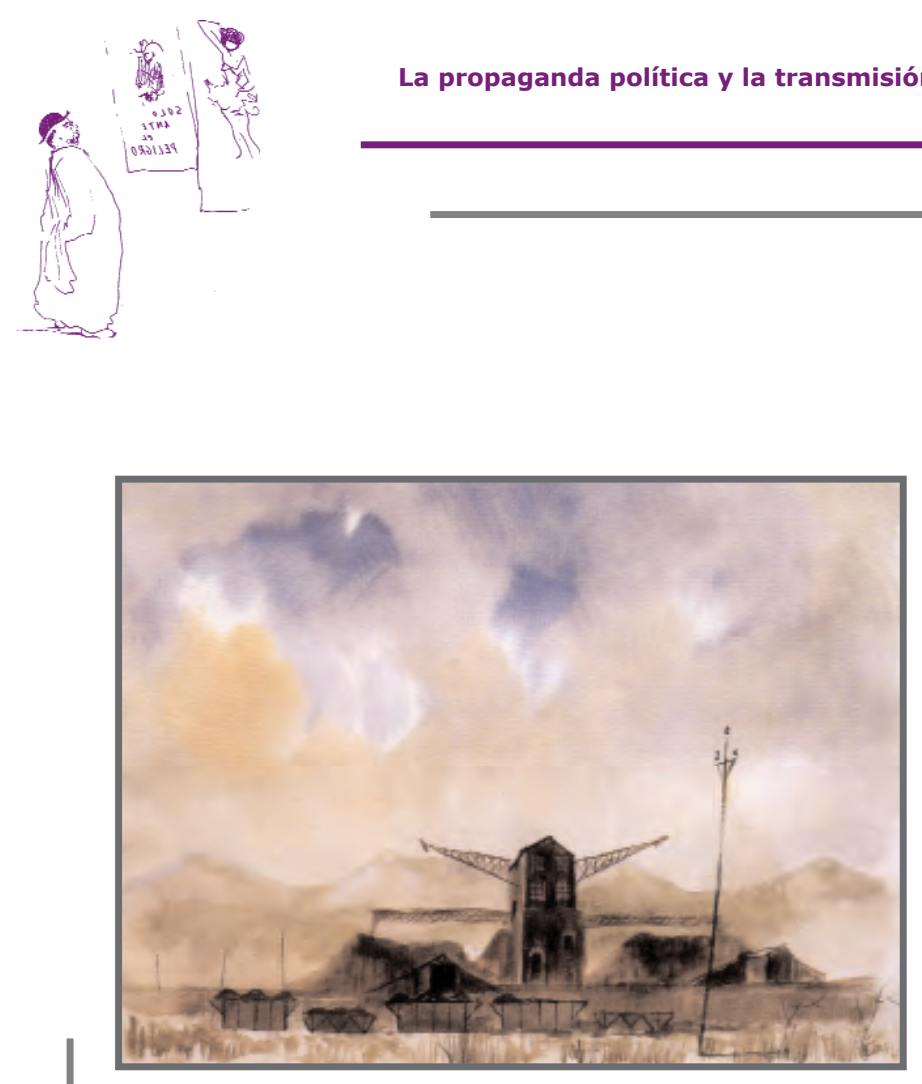

\section{VARIABLES EXTERNAS.}

Título: Mina del Marquesado

(Guadix. Granada)

Año: 1960

Tamaño: $48 \times 60 \mathrm{~cm}$.

\section{TIPO DE IMAGEN.}

Retrato: NO

Cartel: NO

Mural: NO

Ilustración: NO

Otras Obras: SI

\section{CONTENIDO.}

Personajes: NO

Animales: NO

Gestos Expresivos: NO

Paisajes: SI

Escenas: ARQUITECTÓNICA

Función: REPRESENTATIVA DE MODELOS SOCIALES

ASPECTOS TÉCNICOS.

Color dominante: VARIEDAD CROMÁTICA SUPERIOR

Técnica: ACUARELA SOBRE PAPEL

Plano de la imagen: GENERAL 


\section{VARIABLES EXTERNAS.}

Título: Metro de París

Año: 1960

Tamaño: $90 \times 64 \mathrm{~cm}$.

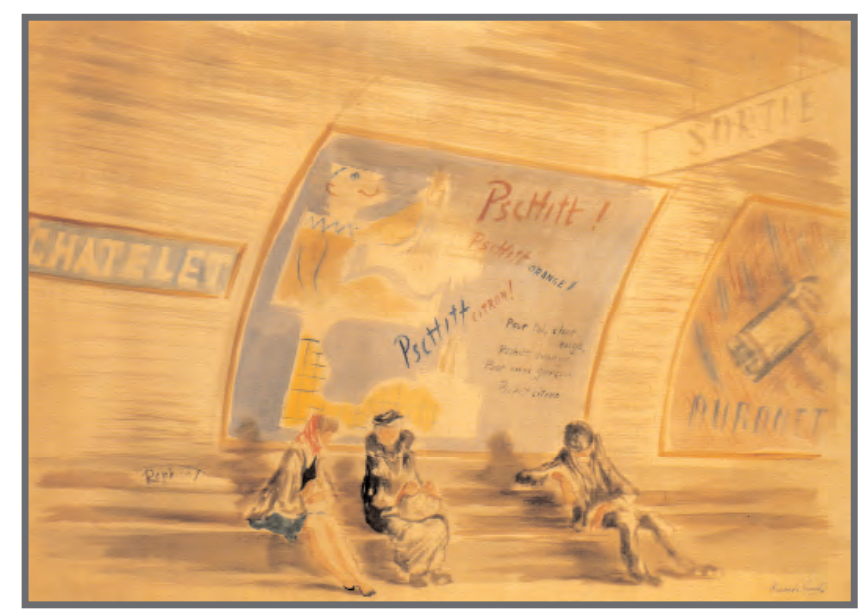

\section{TIPO DE IMAGEN.}

Retrato: NO

Cartel: NO

Mural: NO

Ilustración: NO

Otras Obras: SI

\section{CONTENIDO.}

Personajes: HOMBRE Y MUJERES

Animales: NO

Gestos Expresivos: EMOCIONES POSITIVAS

Paisajes: NO

Escenas: INTERIOR

Función: REPRESENTATIVA DE MODELOS SOCIALES

\section{ASPECTOS TÉCNICOS.}

Color dominante: VARIEDAD CROMÁTICA SUPERIOR Técnica: ACUARELA SOBRE PAPEL

Plano de la imagen: GENERAL 


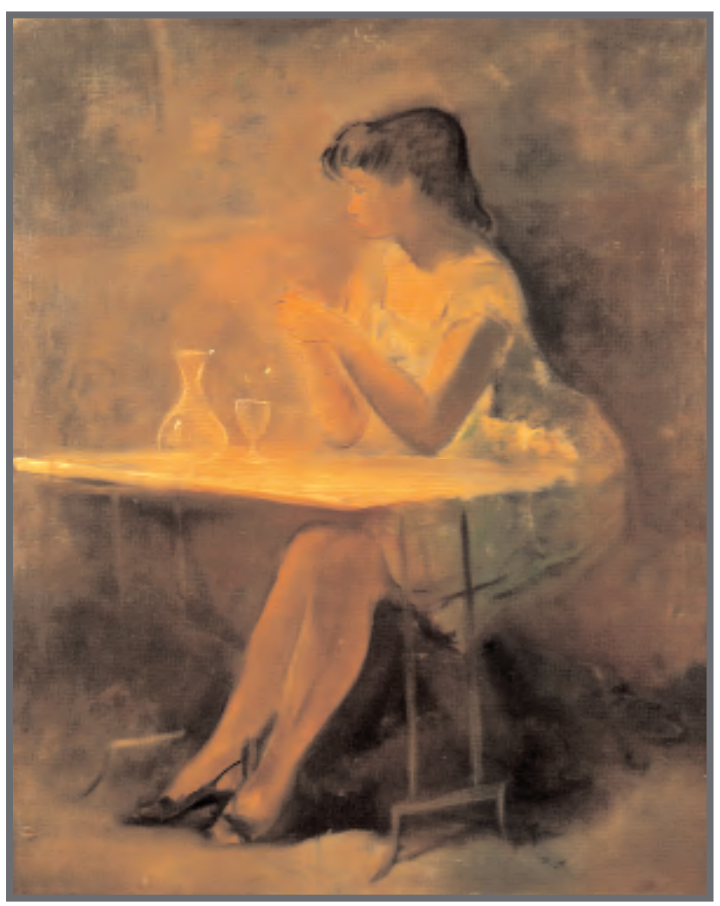

\section{VARIABLES EXTERNAS.}

Título: En el café

Año: 1960

Tamaño: DESCONOCIDO

\section{TIPO DE IMAGEN.}

Retrato: NO

Cartel: NO

Mural: NO

Ilustración: NO

Otras Obras: SI

\section{CONTENIDO.}

Personajes: MUJER

Animales: NO

Gestos Expresivos: EMOCIONES POSITIVAS

Paisajes: NO

Escenas: INTERIOR

Función: REPRESENTATIVA DE MODELOS SOCIALES

\section{ASPECTOS TÉCNICOS.}

Color dominante: VARIEDAD CROMÁTICA SUPERIOR

Técnica: ÓLEO SOBRE LIENZO

Plano de la imagen: GENERAL 


\section{VARIABLES EXTERNAS.}

Título: Bebedores en la Plaza Mayor

Año: $1960-65$

Tamaño: $91 \times 71 \mathrm{~cm}$.

TIPO DE IMAGEN.

Retrato: NO

Cartel: NO

Mural: NO

Ilustración: NO

Otras Obras: SI

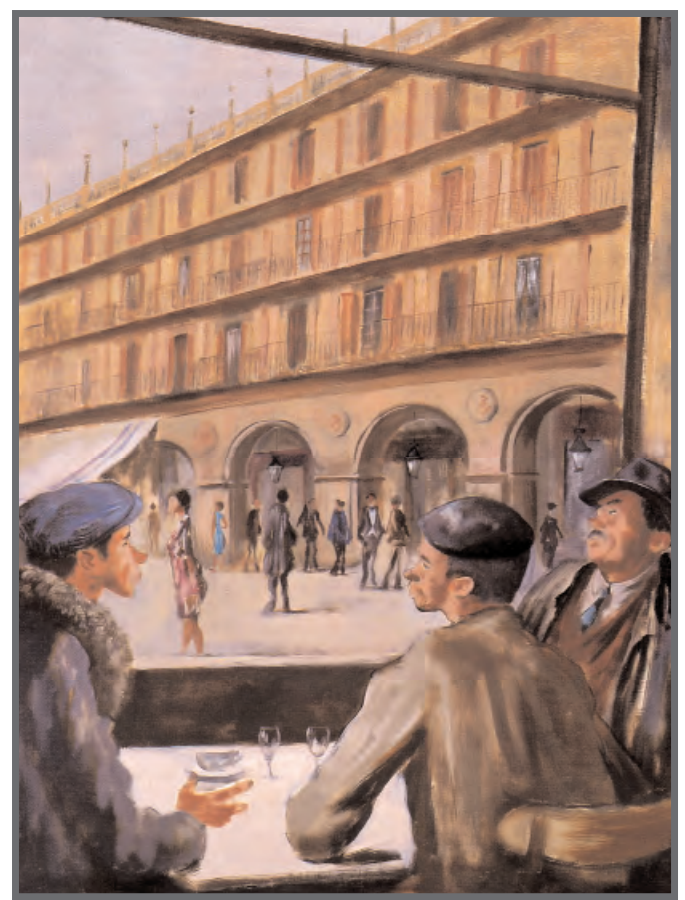

\section{CONTENIDO.}

Personajes: HOMBRES Y MUJERES

Animales: NO

Gestos Expresivos: EMOCIONES POSITIVAS

Paisajes: SI

Escenas: CALLEJERA

Función: REPRESENTATIVA DE MODELOS SOCIALES

\section{ASPECTOS TÉCNICOS.}

Color dominante: VARIEDAD CROMÁTICA SUPERIOR

Técnica: ÓLEO SOBRE LIENZO

Plano de la imagen: MEDIO CORTO Y GENERAL 


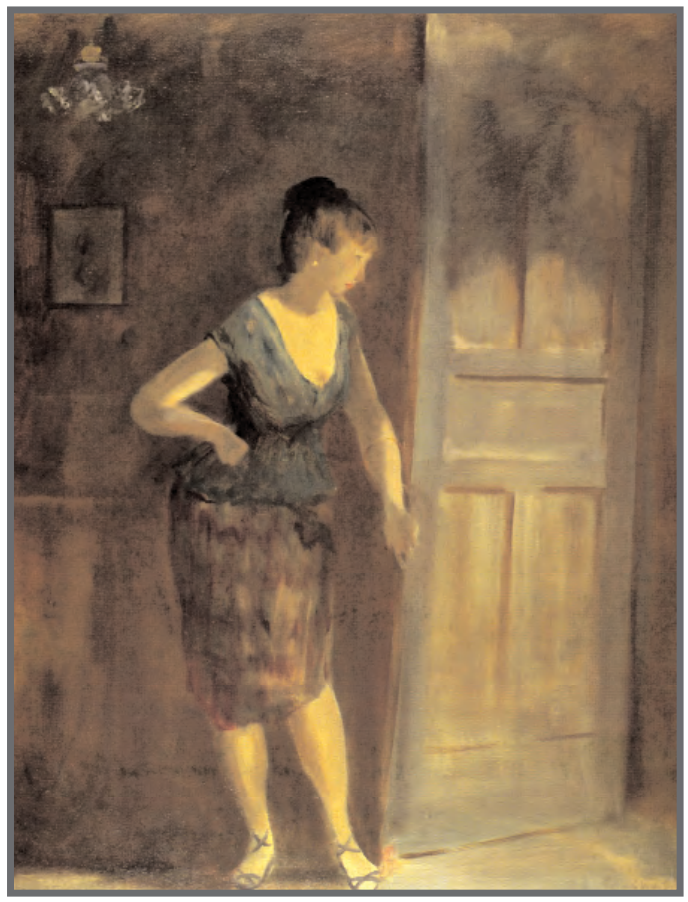

\section{VARIABLES EXTERNAS.}

Título: Figura en la puerta

Año: 1960

Tamaño: $100 \times 81 \mathrm{~cm}$.

\section{TIPO DE IMAGEN.}

Retrato: NO

Cartel: NO

Mural: NO

Ilustración: NO

Otras Obras: SI

\section{CONTENIDO.}

Personajes: MUJER

Animales: NO

Gestos Expresivos: EMOCIONES NEGATIVAS

Paisajes: NO

Escenas: INTERIOR

Función: REPRESENTATIVA DE MODELOS SOCIALES

\section{ASPECTOS TÉCNICOS.}

Color dominante: VARIEDAD CROMÁTICA SUPERIOR

Técnica: ÓLEO SOBRE LIENZO

Plano de la imagen: GENERAL 


\section{VARIABLES EXTERNAS.}

Título: Mujer con camisón

Año: $1960-68$

Tamaño: $62 \times 45 \mathrm{~cm}$.

TIPO DE IMAGEN.

Retrato: NO

Cartel: NO

Mural: NO

Ilustración: NO

Otras Obras: SI

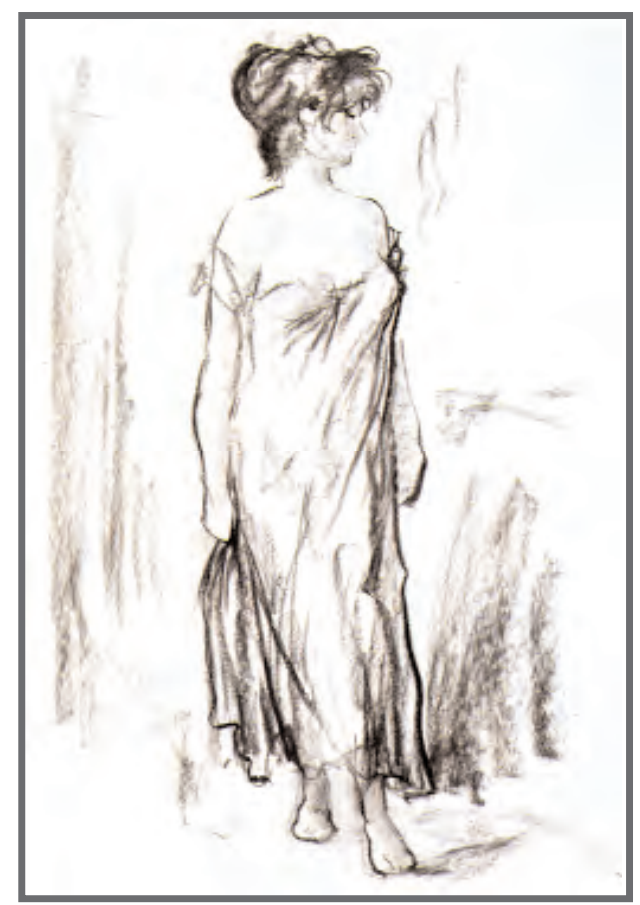

\section{CONTENIDO.}

Personajes: MUJER

Animales: NO

Gestos Expresivos: EMOCIONES NEGATIVAS

Paisajes: NO

Escenas: INTERIOR

Función: REPRESENTATIVA DE MODELOS SOCIALES

\section{ASPECTOS TÉCNICOS.}

Color dominante: 1 TINTA

Técnica: CARBONCILLO SOBRE PAPEL

Plano de la imagen: GENERAL 


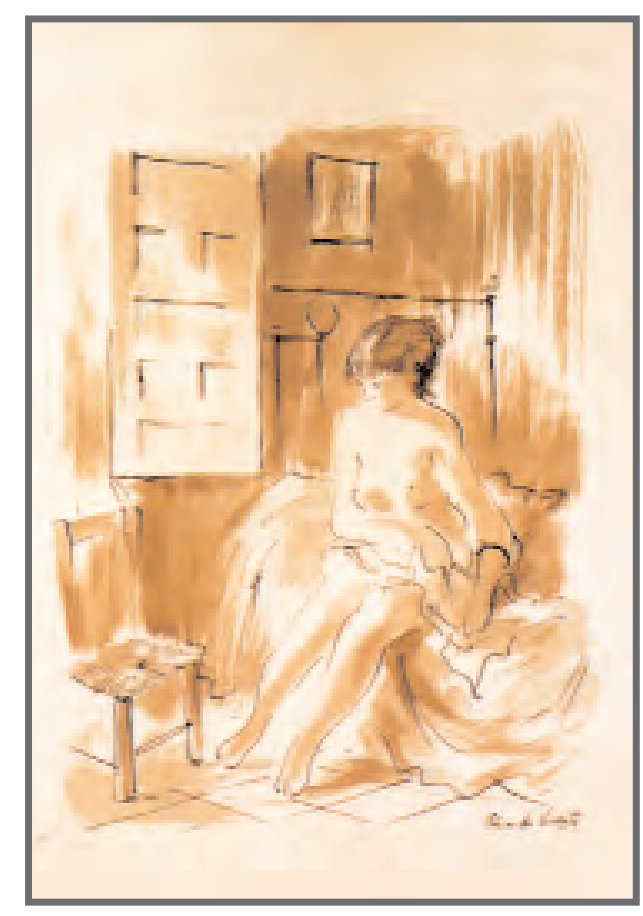

\section{VARIABLES EXTERNAS.}

Título: Interior

Año: $1960-67$

Tamaño: $34 \times 25 \mathrm{~cm}$.

\section{TIPO DE IMAGEN.}

Retrato: NO

Cartel: NO

Mural: NO

Ilustración: NO

Otras Obras: SI

\section{CONTENIDO.}

Personajes: MUJER

Animales: NO

Gestos Expresivos: EMOCIONES NEGATIVAS

Paisajes: NO

Escenas: INTERIOR

Función: REPRESENTATIVA DE MODELOS SOCIALES

\section{ASPECTOS TÉCNICOS.}

Color dominante: 2 TINTAS

Técnica: ACUARELA Y TINTA SOBRE PAPEL Plano de la imagen: GENERAL 


\section{VARIABLES EXTERNAS.}

Título: Paisaje

Año: 1960

Tamaño: $92 \times 73 \mathrm{~cm}$.

TIPO DE IMAGEN.

Retrato: NO

Cartel: NO

Mural: NO

Ilustración: NO

Otras Obras: SI

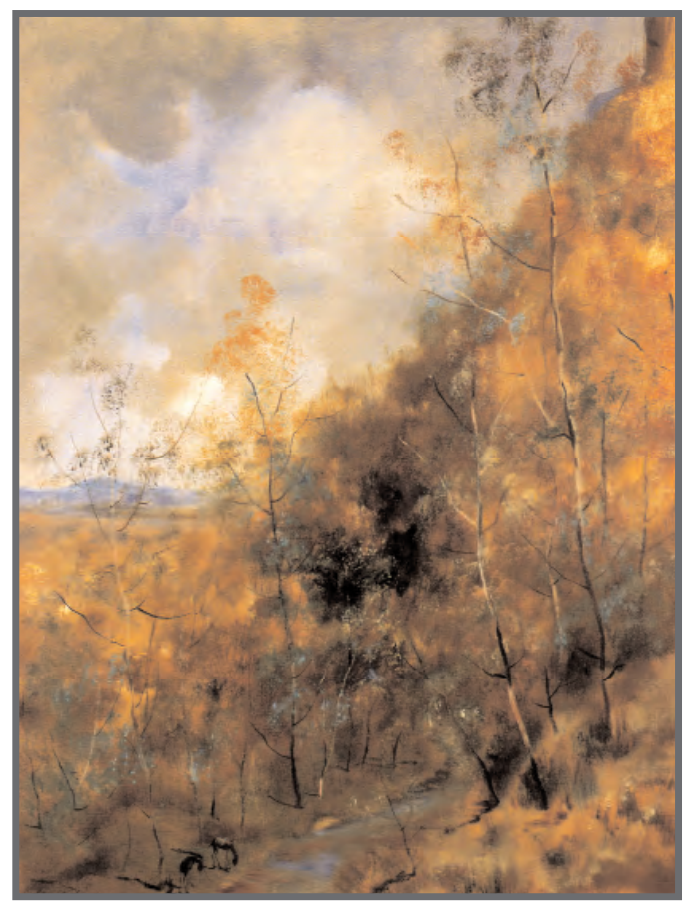

\section{CONTENIDO.}

Personajes: NO

Animales: CABALLOS

Gestos Expresivos: NO

Paisajes: SI

Escenas: RURAL

Función: REPRESENTATIVA DE MODELOS SOCIALES

\section{ASPECTOS TÉCNICOS.}

Color dominante: VARIEDAD CROMÁTICA SUPERIOR

Técnica: ÓLEO SOBRE LIENZO

Plano de la imagen: GENERAL 


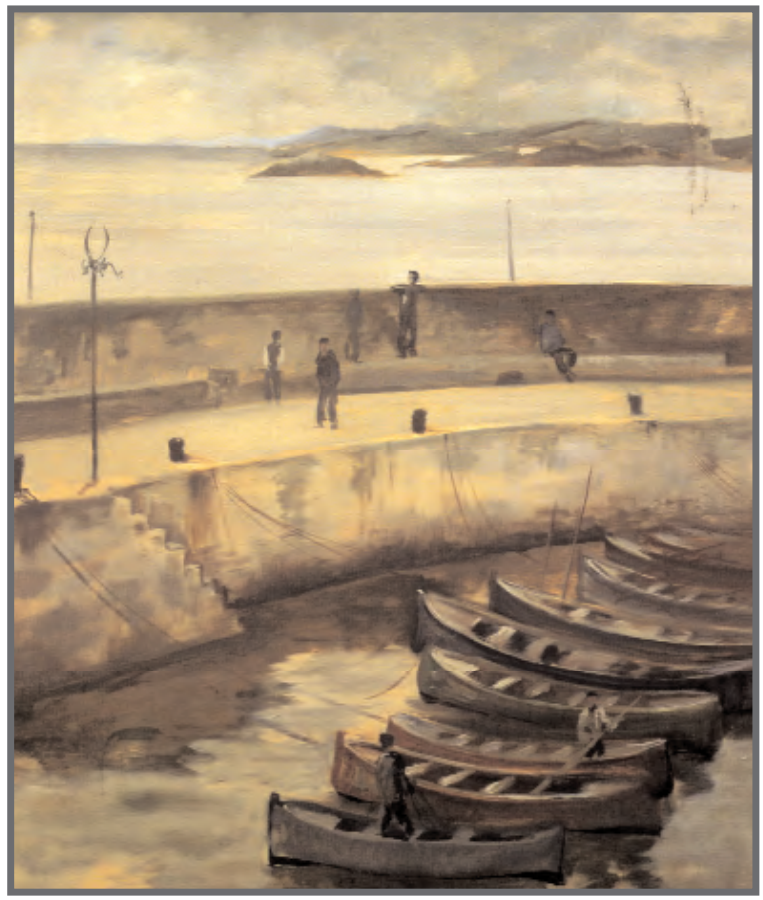

\section{VARIABLES EXTERNAS.}

Título: Puerto de Luanco

Año: 1960

Tamaño: 73 x 64,5 cm.

\section{TIPO DE IMAGEN.}

Retrato: NO

Cartel: NO

Mural: NO

Ilustración: NO

Otras Obras: SI

\section{CONTENIDO.}

Personajes: HOMBRES

Animales: NO

Gestos Expresivos: NO

Paisajes: NO

Escenas: MARINA

Función: REPRESENTATIVA DE MODELOS SOCIALES

\section{ASPECTOS TÉCNICOS.}

Color dominante: VARIEDAD CROMÁTICA SUPERIOR

Técnica: ÓLEO SOBRE LIENZO

Plano de la imagen: GENERAL 


\section{VARIABLES EXTERNAS.}

Título: Amsterdam

Año: 1960

Tamaño: 110 x $86 \mathrm{~cm}$.

\section{TIPO DE IMAGEN.}

Retrato: NO

Cartel: NO

Mural: NO

Ilustración: NO

Otras Obras: SI

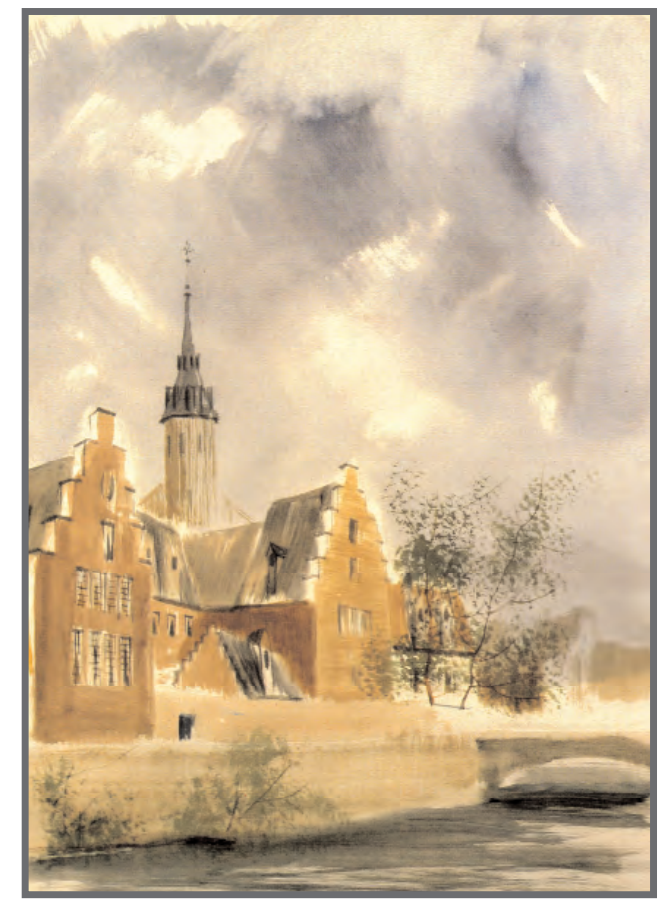

\section{CONTENIDO.}

Personajes: NO

Animales: NO

Gestos Expresivos: NO

Paisajes: SI

Escenas: ARQUITECTÓNICA

Función: REPRESENTATIVA DE MODELOS SOCIALES

\section{ASPECTOS TÉCNICOS.}

Color dominante: VARIEDAD CROMÁTICA SUPERIOR Técnica: ACUARELA SOBRE PAPEL

Plano de la imagen: GENERAL 


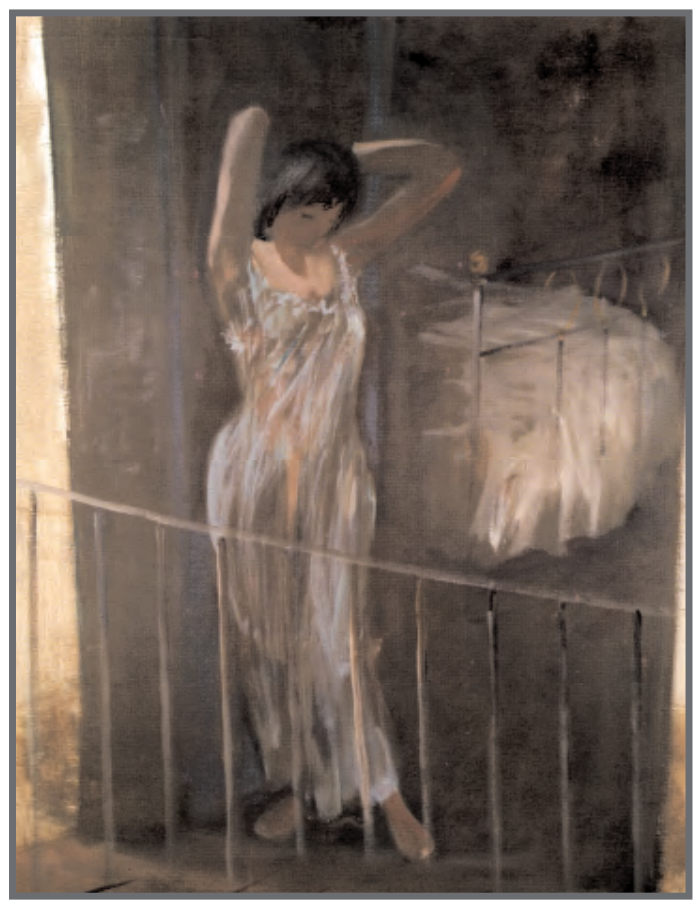

\section{VARIABLES EXTERNAS.}

Título: Mujer en el Balcón

Año: 1962

Tamaño: $80 \times 64 \mathrm{~cm}$.

\section{TIPO DE IMAGEN.}

Retrato: NO

Cartel: NO

Mural: NO

Ilustración: NO

Otras Obras: SI

\section{CONTENIDO.}

Personajes: MUJER

Animales: NO

Gestos Expresivos: EMOCIONES NEGATIVAS

Paisajes: NO

Escenas: INTERIOR

Función: REPRESENTATIVA DE MODELOS SOCIALES

\section{ASPECTOS TÉCNICOS.}

Color dominante: VARIEDAD CROMÁTICA SUPERIOR

Técnica: ÓLEO SOBRE LIENZO

Plano de la imagen: GENERAL 


\section{VARIABLES EXTERNAS.}

Título: Encierro

Año: 1963

Tamaño: 81 x $65 \mathrm{~cm}$.

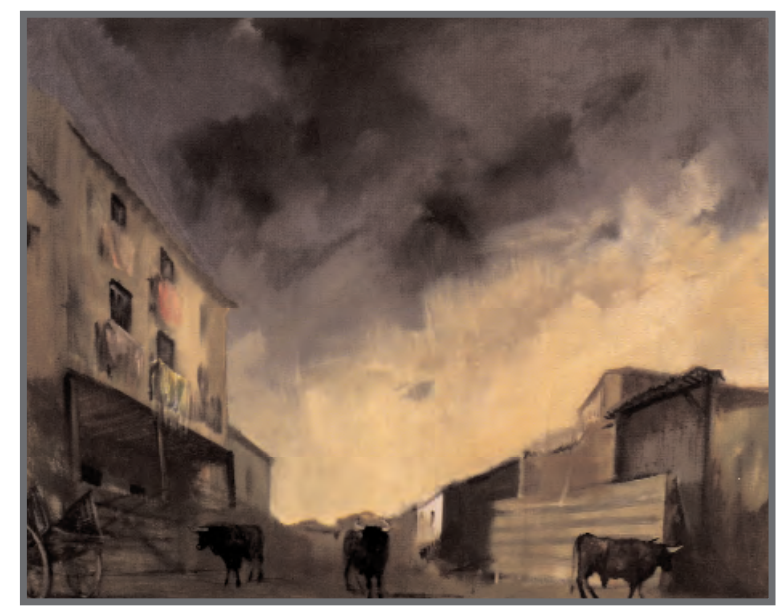

TIPO DE IMAGEN.

Retrato: NO

Cartel: NO

Mural: NO

Ilustración: NO

Otras Obras: SI

\section{CONTENIDO.}

Personajes: NO

Animales: TOROS

Gestos Expresivos: NO

Paisajes: SI

Escenas: FESTIVA

Función: REPRESENTATIVA DE MODELOS SOCIALES

\section{ASPECTOS TÉCNICOS.}

Color dominante: VARIEDAD CROMÁTICA SUPERIOR Técnica: ÓLEO SOBRE LIENZO

Plano de la imagen: GENERAL 


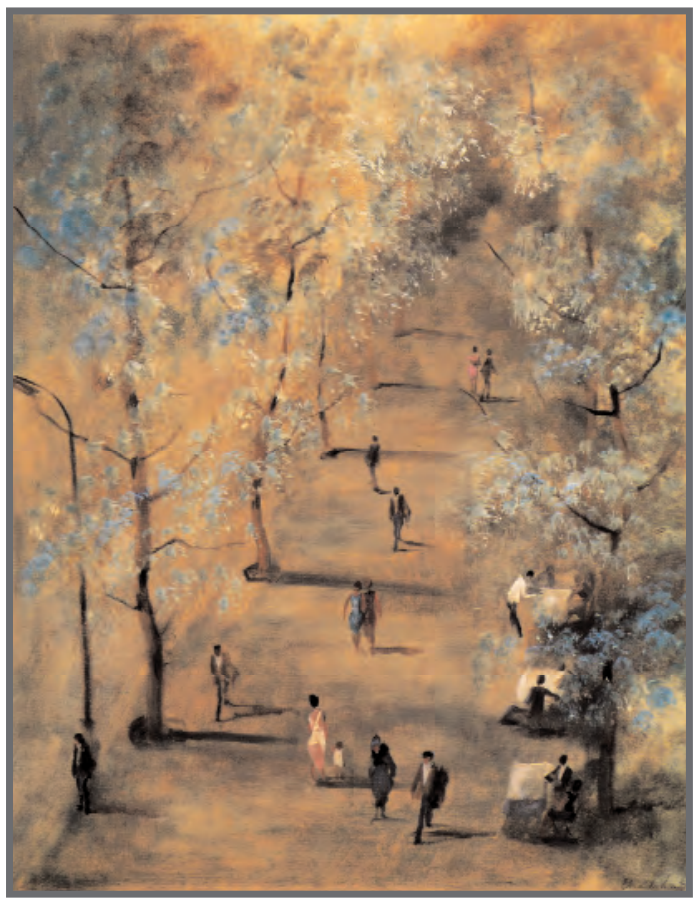

\section{VARIABLES EXTERNAS.}

Título: Paseo bajo los árboles

Año: 1965

Tamaño: $92 \times 73 \mathrm{~cm}$.

\section{TIPO DE IMAGEN.}

Retrato: NO

Cartel: NO

Mural: NO

Ilustración: NO

Otras Obras: SI

\section{CONTENIDO.}

Personajes: HOMBRES, MUJERES Y NIÑA

Animales: NO

Gestos Expresivos: EMOCIONES POSITIVAS

Paisajes: SI

Escenas: AÉREA

Función: REPRESENTATIVA DE MODELOS SOCIALES

\section{ASPECTOS TÉCNICOS.}

Color dominante: VARIEDAD CROMÁTICA SUPERIOR

Técnica: ÓLEO SOBRE LIENZO

Plano de la imagen: GENERAL 


\section{VARIABLES EXTERNAS.}

Título: Grupo de jóvenes

Año: 1965

Tamaño: $90 \times 151 \mathrm{~cm}$.

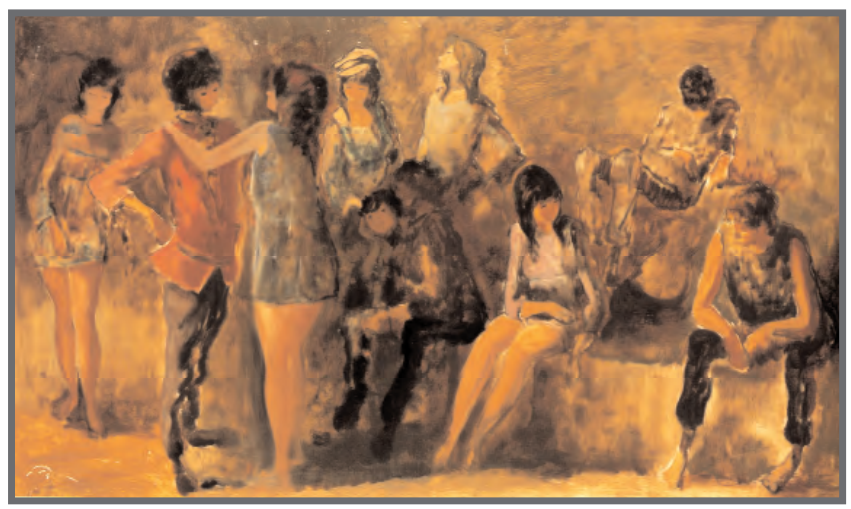

\section{TIPO DE IMAGEN.}

Retrato: NO

Cartel: NO

Mural: NO

Ilustración: NO

Otras Obras: SI

\section{CONTENIDO.}

Personajes: HOMBRES Y MUJERES

Animales: NO

Gestos Expresivos: EMOCIONES POSITIVAS

Paisajes: SI

Escenas: FESTIVA

Función: REPRESENTATIVA DE MODELOS SOCIALES

\section{ASPECTOS TÉCNICOS.}

Color dominante: VARIEDAD CROMÁTICA SUPERIOR

Técnica: ÓLEO SOBRE LIENZO

Plano de la imagen: GENERAL 


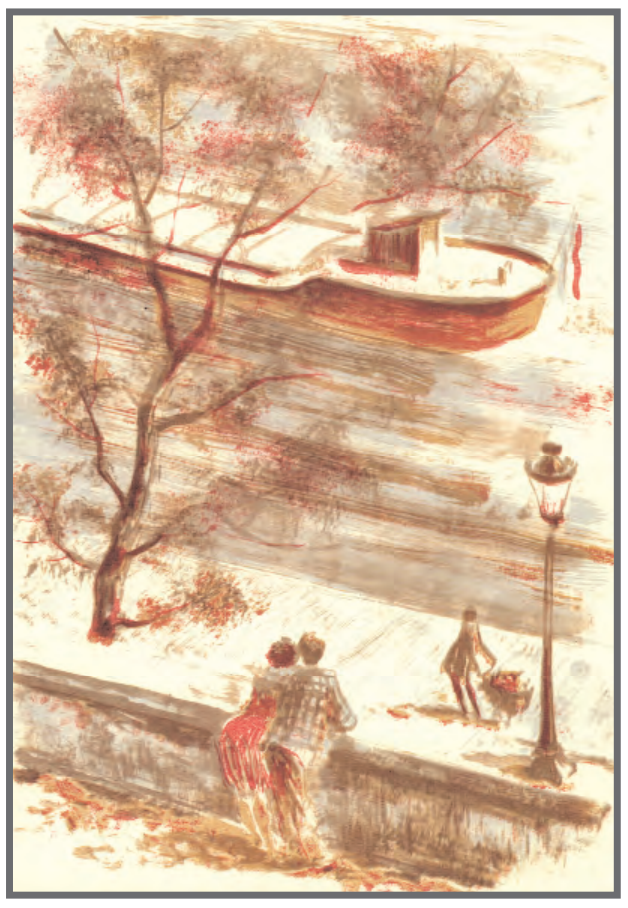

\section{VARIABLES EXTERNAS.}

Título: Sobre el Sena

Año: 1968

Tamaño: DESCONOCIDO

\section{TIPO DE IMAGEN.}

Retrato: NO

Cartel: NO

Mural: NO

Ilustración: NO

Otras Obras: SI

\section{CONTENIDO.}

Personajes: HOMBRES Y MUJER

Animales: NO

Gestos Expresivos: EMOCIONES POSITIVAS

Paisajes: SI

Escenas: URBANA

Función: REPRESENTATIVA DE MODELOS SOCIALES

\section{ASPECTOS TÉCNICOS.}

Color dominante: VARIEDAD CROMÁTICA SUPERIOR

Técnica: LITOGRAFÍA

Plano de la imagen: GENERAL 


\section{VARIABLES EXTERNAS.}

Título: La dama del Boulevard

Año: 1968

Tamaño: DESCONOCIDO

\section{TIPO DE IMAGEN.}

Retrato: NO

Cartel: NO

Mural: NO

Ilustración: NO

Otras Obras: SI

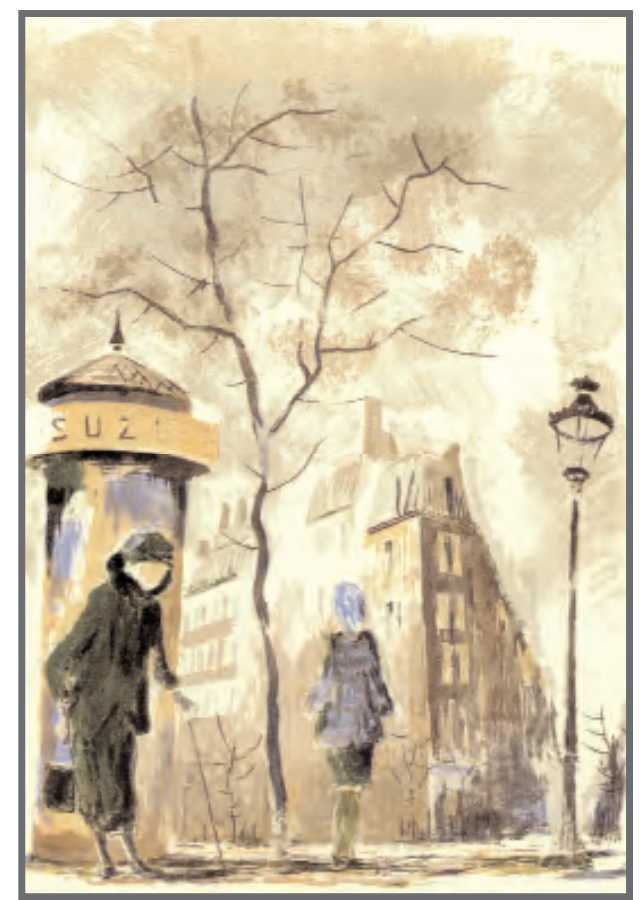

\section{CONTENIDO.}

Personajes: MUJERES

Animales: NO

Gestos Expresivos: EMOCIONES POSITIVAS

Paisajes: SI

Escenas: URBANA

Función: REPRESENTATIVA DE MODELOS SOCIALES

\section{ASPECTOS TÉCNICOS.}

Color dominante: VARIEDAD CROMÁTICA SUPERIOR

Técnica: LITOGRAFÍA

Plano de la imagen: GENERAL 


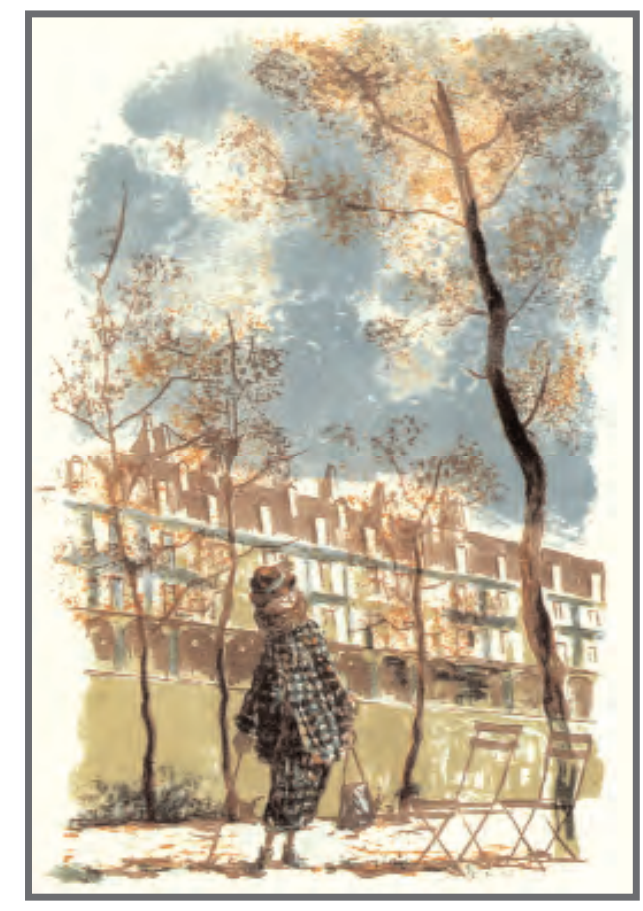

\section{VARIABLES EXTERNAS.}

Título: Disfraz de otoño

Año: 1968

Tamaño: DESCONOCIDO

\section{TIPO DE IMAGEN.}

Retrato: NO

Cartel: NO

Mural: NO

Ilustración: NO

Otras Obras: SI

\section{CONTENIDO.}

Personajes: MUJER

Animales: NO

Gestos Expresivos: EMOCIONES POSITIVAS

Paisajes: SI

Escenas: URBANA

Función: REPRESENTATIVA DE MODELOS SOCIALES

\section{ASPECTOS TÉCNICOS.}

Color dominante: VARIEDAD CROMÁTICA SUPERIOR

Técnica: LITOGRAFÍA

Plano de la imagen: GENERAL 


\section{VARIABLES EXTERNAS.}

Título: Enamorados

Año: 1968

Tamaño: DESCONOCIDO

\section{TIPO DE IMAGEN.}

Retrato: NO

Cartel: NO

Mural: NO

Ilustración: NO

Otras Obras: SI

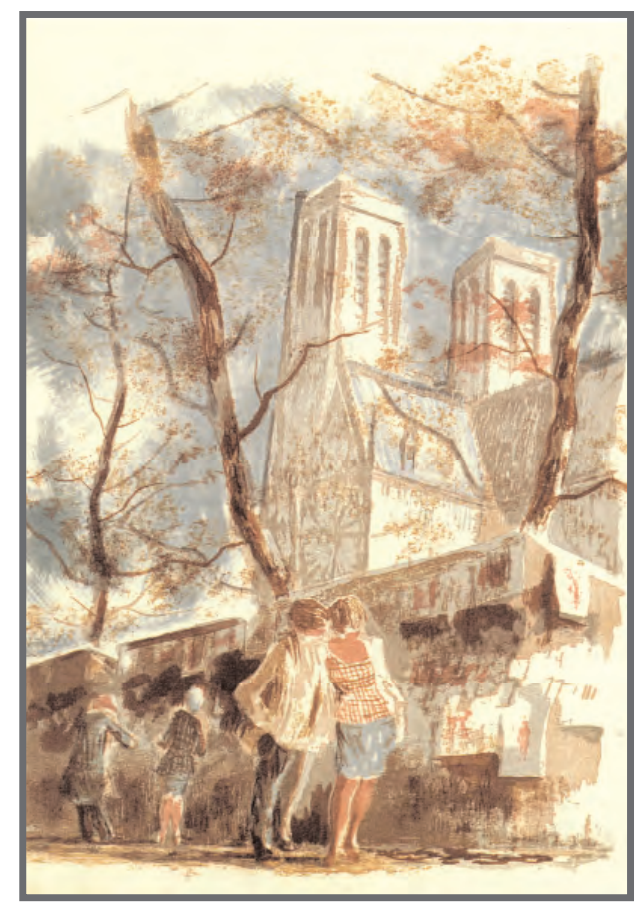

\section{CONTENIDO.}

Personajes: HOMBRES Y MUJERES

Animales: NO

Gestos Expresivos: EMOCIONES POSITIVAS

Paisajes: SI

Escenas: URBANA

Función: REPRESENTATIVA DE MODELOS SOCIALES

\section{ASPECTOS TÉCNICOS.}

Color dominante: VARIEDAD CROMÁTICA SUPERIOR

Técnica: LITOGRAFÍA

Plano de la imagen: GENERAL 


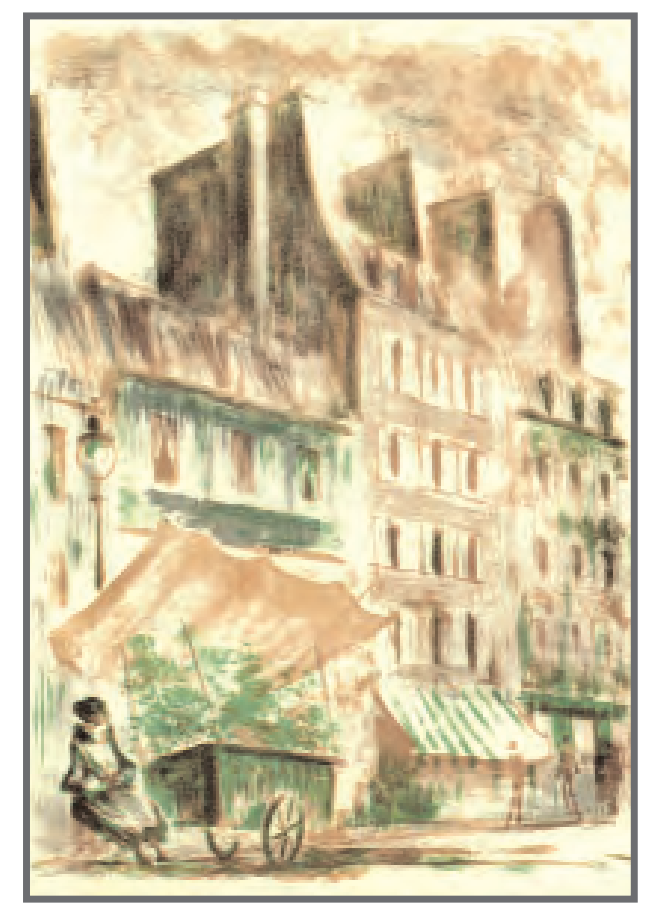

\section{VARIABLES EXTERNAS.}

Título: Florista

Año: 1968

Tamaño: DESCONOCIDO

\section{TIPO DE IMAGEN.}

Retrato: NO

Cartel: NO

Mural: NO

Ilustración: NO

Otras Obras: SI

\section{CONTENIDO.}

Personajes: MUJER

Animales: NO

Gestos Expresivos: EMOCIONES POSITIVAS

Paisajes: SI

Escenas: PROFESIONAL

Función: REPRESENTATIVA DE MODELOS SOCIALES

\section{ASPECTOS TÉCNICOS.}

Color dominante: VARIEDAD CROMÁTICA SUPERIOR

Técnica: LITOGRAFÍA

Plano de la imagen: GENERAL 


\section{VARIABLES EXTERNAS.}

Título: La pasarela

Año: 1968

Tamaño: DESCONOCIDO

\section{TIPO DE IMAGEN.}

Retrato: NO

Cartel: NO

Mural: NO

Ilustración: NO

Otras Obras: SI

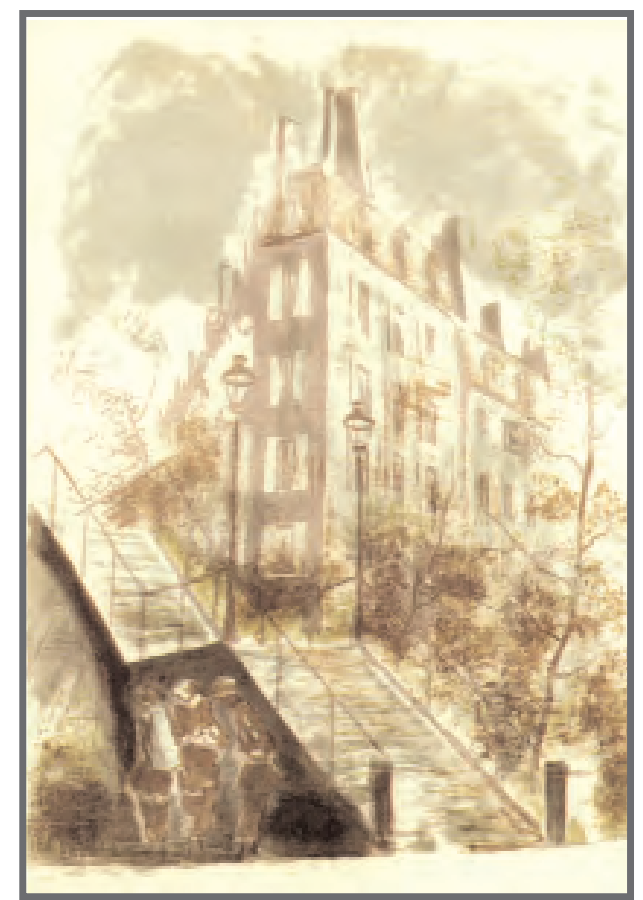

\section{CONTENIDO.}

Personajes: MUJERES

Animales: NO

Gestos Expresivos: NO

Paisajes: SI

Escenas: URBANA

Función: REPRESENTATIVA DE MODELOS SOCIALES

\section{ASPECTOS TÉCNICOS.}

Color dominante: VARIEDAD CROMÁTICA SUPERIOR

Técnica: LITOGRAFÍA

Plano de la imagen: GENERAL 


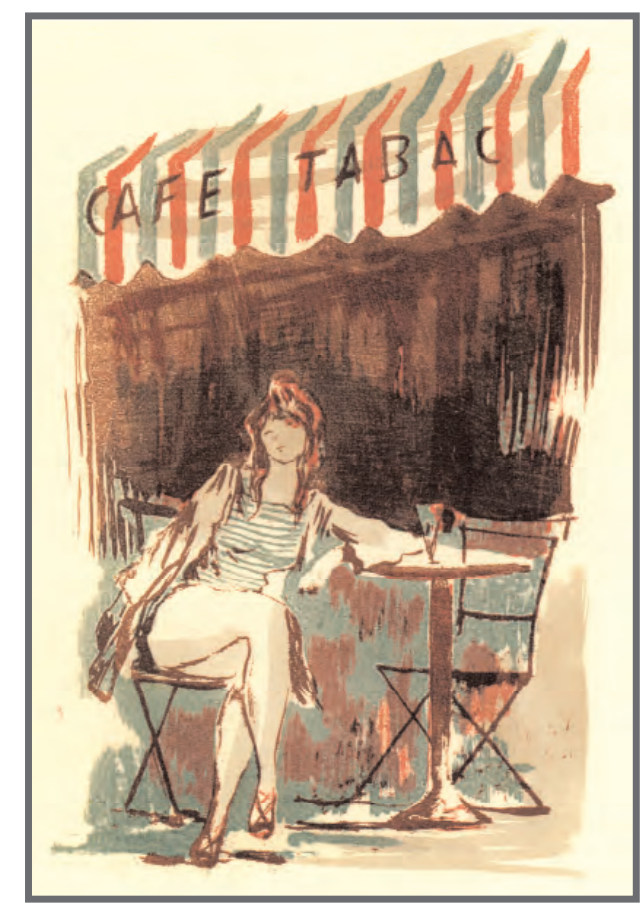

\section{VARIABLES EXTERNAS.}

Título: Café Tabac

Año: 1968

Tamaño: DESCONOCIDO

\section{TIPO DE IMAGEN.}

Retrato: NO

Cartel: NO

Mural: NO

Ilustración: NO

Otras Obras: SI

\section{CONTENIDO.}

Personajes: MUJER

Animales: NO

Gestos Expresivos: EMOCIONES POSITIVAS

Paisajes: NO

Escenas: URBANA

Función: REPRESENTATIVA DE MODELOS SOCIALES

\section{ASPECTOS TÉCNICOS.}

Color dominante: VARIEDAD CROMÁTICA SUPERIOR

Técnica: LITOGRAFÍA

Plano de la imagen: GENERAL 


\section{VARIABLES EXTERNAS.}

Título: MANSARDES SOBRE EL RÍO

Año: 1968

Tamaño: DESCONOCIDO

\section{TIPO DE IMAGEN.}

Retrato: NO

Cartel: NO

Mural: NO

Ilustración: NO

Otras Obras: SI

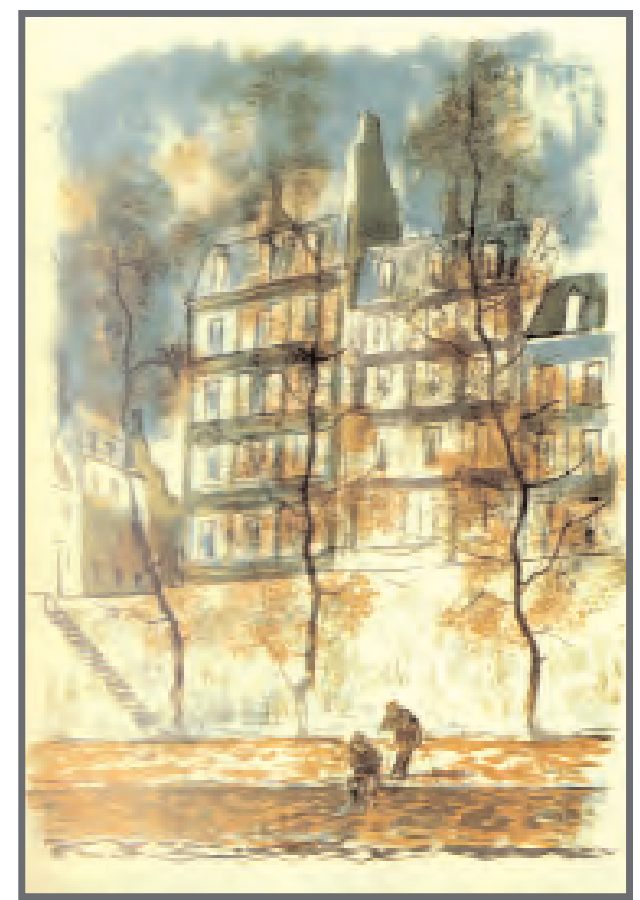

\section{CONTENIDO.}

Personajes: HOMBRES

Animales: NO

Gestos Expresivos: NO

Paisajes: SI

Escenas: URBANA

Función: REPRESENTATIVA DE MODELOS SOCIALES

\section{ASPECTOS TÉCNICOS.}

Color dominante: VARIEDAD CROMÁTICA SUPERIOR

Técnica: LITOGRAFÍA

Plano de la imagen: GENERAL 


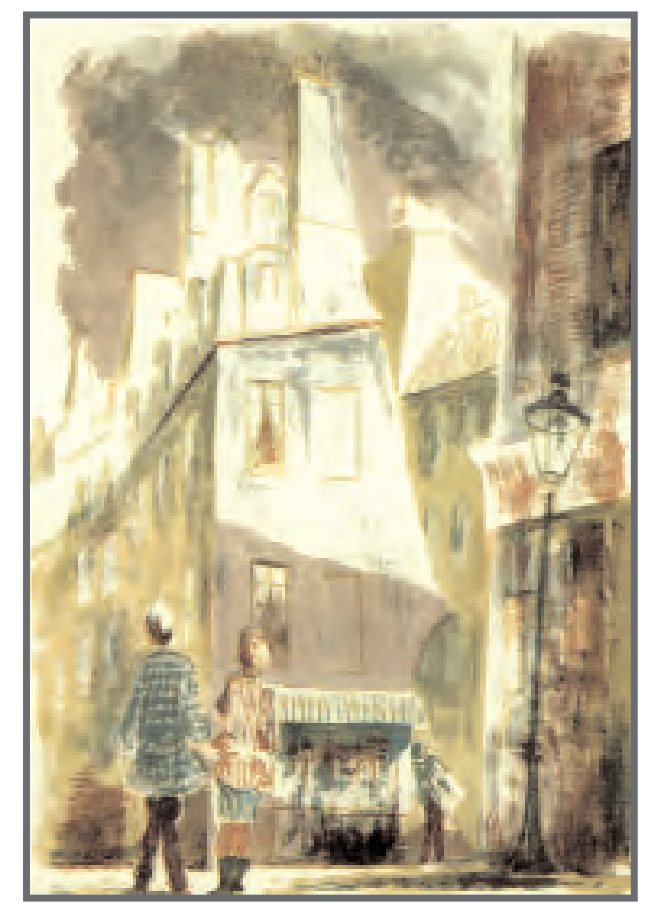

\section{VARIABLES EXTERNAS.}

Título: Rincón de Menilmontant

Año: 1968

Tamaño: DESCONOCIDO

\section{TIPO DE IMAGEN.}

Retrato: NO

Cartel: NO

Mural: NO

Ilustración: NO

Otras Obras: SI

\section{CONTENIDO.}

Personajes: HOMBRES Y MUJER

Animales: NO

Gestos Expresivos: EMOCIONES POSITIVAS

Paisajes: SI

Escenas: URBANA

Función: REPRESENTATIVA DE MODELOS SOCIALES

\section{ASPECTOS TÉCNICOS.}

Color dominante: VARIEDAD CROMÁTICA SUPERIOR

Técnica: LITOGRAFÍA

Plano de la imagen: GENERAL 


\section{VARIABLES EXTERNAS.}

Título: Interior del Café

Año: 1968

Tamaño: DESCONOCIDO

\section{TIPO DE IMAGEN.}

Retrato: NO

Cartel: NO

Mural: NO

Ilustración: NO

Otras Obras: SI

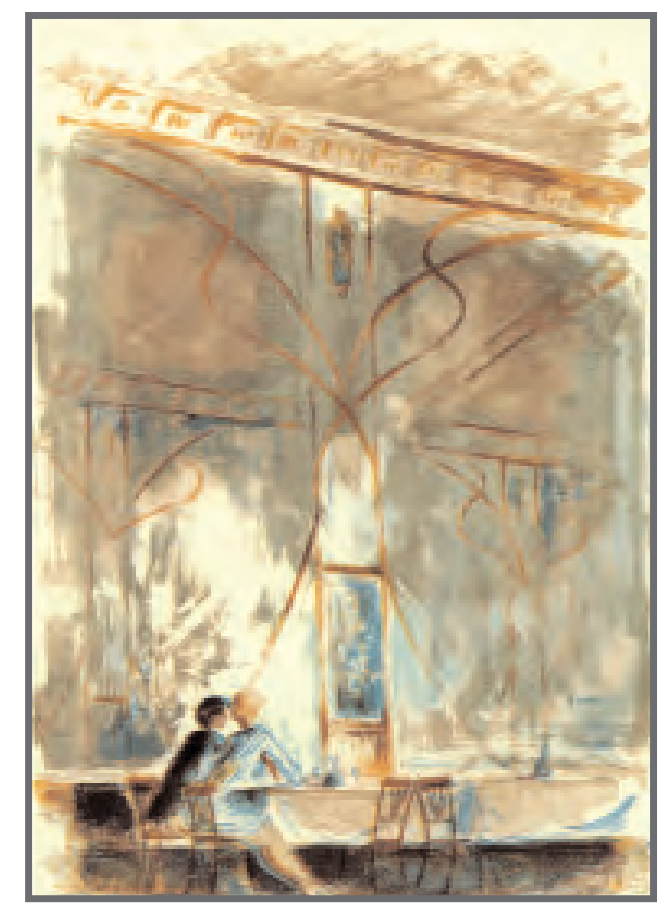

\section{CONTENIDO.}

Personajes: MUJER

Animales: NO

Gestos Expresivos: EMOCIONES POSITIVAS

Paisajes: NO

Escenas: INTERIOR

Función: REPRESENTATIVA DE MODELOS SOCIALES

\section{ASPECTOS TÉCNICOS.}

Color dominante: VARIEDAD CROMÁTICA SUPERIOR

Técnica: LITOGRAFÍA

Plano de la imagen: GENERAL 


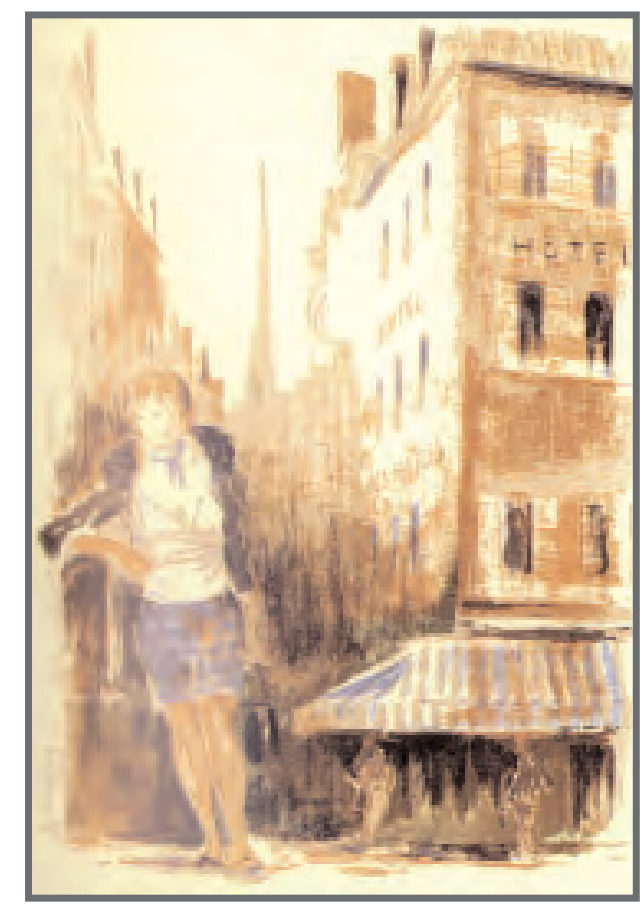

\section{VARIABLES EXTERNAS.}

Título: Esperando

Año: 1968

Tamaño: DESCONOCIDO

\section{TIPO DE IMAGEN.}

Retrato: NO

Cartel: NO

Mural: NO

Ilustración: NO

Otras Obras: SI

\section{CONTENIDO.}

Personajes: MUJER

Animales: NO

Gestos Expresivos: EMOCIONES NEGATIVAS

Paisajes: SI

Escenas: URBANA

Función: REPRESENTATIVA DE MODELOS SOCIALES

\section{ASPECTOS TÉCNICOS.}

Color dominante: VARIEDAD CROMÁTICA SUPERIOR

Técnica: LITOGRAFÍA

Plano de la imagen: GENERAL 


\section{VARIABLES EXTERNAS.}

Título: Paisaje

Año: 1968

Tamaño: DESCONOCIDO

TIPO DE IMAGEN.

Retrato: NO

Cartel: NO

Mural: NO

Ilustración: NO

Otras Obras: SI

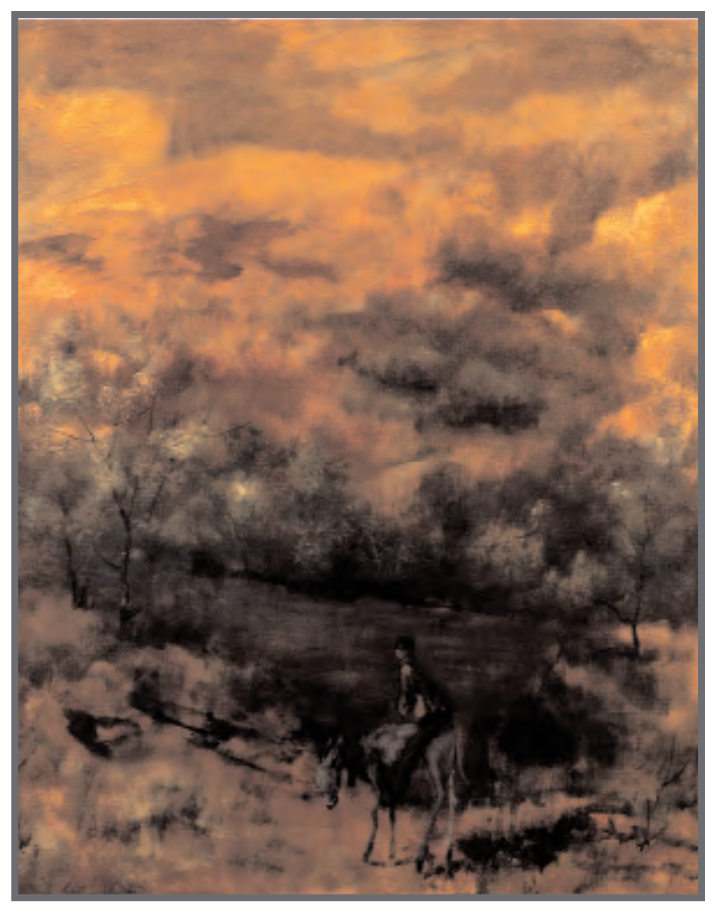

\section{CONTENIDO.}

Personajes: HOMBRE

Animales: BURRO

Gestos Expresivos: NO

Paisajes: SI

Escenas: RURAL

Función: REPRESENTATIVA DE MODELOS SOCIALES

\section{ASPECTOS TÉCNICOS.}

Color dominante: VARIEDAD CROMÁTICA SUPERIOR

Técnica: ÓLEO SOBRE LIENZO

Plano de la imagen: GENERAL 


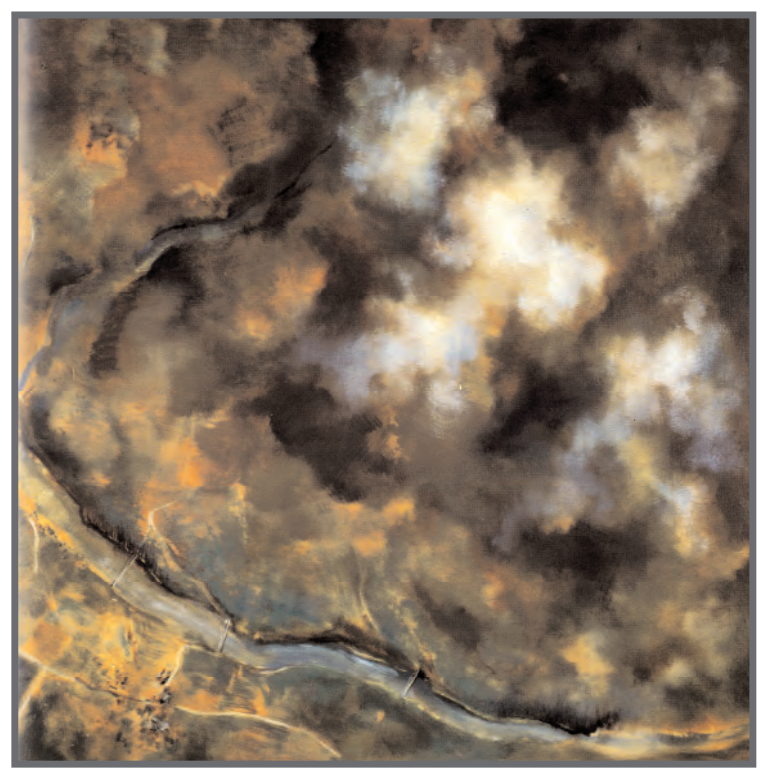

\section{VARIABLES EXTERNAS.}

Título: Desde el aire

Año: 1968

Tamaño: 100 x $100 \mathrm{~cm}$.

\section{TIPO DE IMAGEN.}

Retrato: NO

Cartel: NO

Mural: NO

Ilustración: NO

Otras Obras: SI

\section{CONTENIDO.}

Personajes: NO

Animales: NO

Gestos Expresivos: NO

Paisajes: SI

Escenas: AÉREA

Función: REPRESENTATIVA DE MODELOS SOCIALES

\section{ASPECTOS TÉCNICOS.}

Color dominante: VARIEDAD CROMÁTICA SUPERIOR

Técnica: ÓLEO SOBRE LIENZO

Plano de la imagen: GENERAL 
Anexo III.

Notas

1.- Vicente, E (1968) en Camón Aznar, J. ABC. Madrid. 21 de mayo de 1968. pp. 45. 
